\title{
Conceptual Models for Migration of Key Groundwater Contaminants Through the Vadose Zone and Into the Unconfined Aquifer Below the B-Complex
}
RJ Serne
PD Thorne
GS Thomas ${ }^{(\mathrm{c})}$
BN Bjornstad
DC Lanigan
JM Keller ${ }^{(a)}$
JN Christensen ${ }^{(\mathrm{b})}$
(a) GeoSystems Analysis, Inc Hood River, OR
(b) Center for Isotope Geochemistry, Lawrence Berkeley National Laboratory, Berkeley, CA
(c) $\mathrm{CH} 2 \mathrm{M}$-Hill Central Plateau Remediation Company, Richland, WA

July 2010

Pacific Northwest NATIONAL LABORATORY

Proudly Operated by Battelle Since 1965 


\title{
DISCLAIMER
}

This report was prepared as an account of work sponsored by an agency of the United States Government. Neither the United States Government nor any agency thereof, nor Battelle Memorial Institute, nor any of their employees, makes any warranty, express or implied, or assumes any legal liability or responsibility for the accuracy, completeness, or usefulness of any information, apparatus, product, or process disclosed, or represents that its use would not infringe privately owned rights. Reference herein to any specific commercial product, process, or service by trade name, trademark, manufacturer, or otherwise does not necessarily constitute or imply its endorsement, recommendation, or favoring by the United States Government or any agency thereof, or Battelle Memorial Institute. The views and opinions of authors expressed herein do not necessarily state or reflect those of the United States Government or any agency thereof.

\author{
PACIFIC NORTHWEST NATIONAL LABORATORY \\ operated by \\ BATTELLE \\ for the \\ UNITED STATES DEPARTMENT OF ENERGY \\ under Contract DE-ACO5-76RL01830
}

Printed in the United States of America

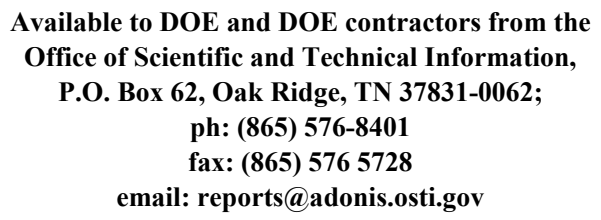

Available to the public from the National Technical Information Service,

U.S. Department of Commerce, 5285 Port Royal Rd., Springfield, VA 22161

ph: (800) 553-6847

fax: (703) 605-6900

email: orders@nits.fedworld.gov

online ordering: http://www.ntis.gov/ordering.htm 


\title{
Conceptual Models for Migration of Key Groundwater Contaminants Through the Vadose Zone and Into the Unconfined Aquifer Below the B-Complex
}

\author{
RJ Serne \\ PD Thorne \\ GS Thomas ${ }^{(\mathrm{c})}$ \\ BN Bjornstad \\ DC Lanigan \\ JM Keller $^{(a)}$ \\ JN Christensen ${ }^{(b)}$ \\ (a) GeoSystems Analysis, Inc Hood River, OR
(b) Center for Isotope Geochemistry, Lawrence Berkeley National Laboratory, Berkeley, CA
(c) CH2M-Hill Central Plateau Remediation Company, Richland, WA
}

July 2010

Prepared for

the U.S. Department of Energy

under Contract DE-AC05-76RL01830

Pacific Northwest National Laboratory

Richland, Washington 99352 

PNNL-19277

\section{Abstract}

The B-Complex contains three major crib and trench disposal sites and three single-shell tank farms that have released nearly 346 million-liters of waste liquids containing the following groundwater contaminants: $\sim 14,000 \mathrm{~kg}$ of cyanide, $29,000 \mathrm{~kg}$ of chromium, $12,000 \mathrm{~kg}$ of uranium and $145 \mathrm{Ci}$ of technetium-99. After a thorough review of available vadose zone sediment and pore water data, groundwater plume information, field gamma logging results, and field electrical resistivity information, conceptual models were developed for which waste sites have been the significant sources of the contaminants in the groundwater. This included estimating the masses of these contaminants remaining in the vadose zone and currently present in the groundwater in comparison to the totals released. This allowed mass balance calculations to be made on how consistent our knowledge is on the deep vadose zone and groundwater distribution of contaminants. Strengths and weaknesses of the conceptual models are discussed as well as implications on future groundwater and deep vadose zone remediation alternatives. The hypothesized conceptual models attribute the source of all of the cyanide and most of the technetium-99 currently in the groundwater to the BY Cribs. The source of the uranium is the 1951 BX-102 tank overfill event and the source of most of the chromium is the B-7-A\&B Cribs and B-8 Crib and Tile Field. Our mass-balance estimates suggest that there are much larger masses of uranium, and technetium-99 remaining in the deep vadose zone within $\sim 20 \mathrm{ft}$ of the water table than is currently in the groundwater plumes below the B-Complex. This hypothesis needs to be carefully considered before future remediation efforts are chosen. The masses of these contaminants in the groundwater plumes have been increasing over the last decade, and the groundwater plumes are migrating to the northwest towards the Gable Gap. The groundwater flow rate appears to fluctuate in response to seasonal changes in hydraulic gradient. The flux of contaminants out of the deep vadose zone from the three proposed sources also appears to be transient such that the evolution of the contaminant plumes is transient. 



\section{Executive Summary}

This report offers detailed conceptual models for the distribution of two key groundwater contaminants, technetium-99 and uranium, and in less detail addresses cyanide, nitrate, and chromium within the B-Complex region. The current distribution of technetium-99, uranium, and cyanide in the vadose zone are evaluated. The conceptual models identify the most likely sources (disposal facilities or single-shell tanks) and hypothesize the migration pathways that the contaminants took to reach the water table at evaluated locations. In addition, the report provides estimates for the activity of technetium-99 and mass of uranium that still remain in the vadose zone (from ground surface to the water table; with the deep vadose zone portion highlighted) and within the current groundwater plumes. The mass of cyanide in groundwater was also estimated, but the cyanide remaining in the vadose zone could not be quantitatively evaluated because the vadose zone data are too sparse. The estimated masses of contaminants remaining in the vadose zone and currently present in the groundwater plumes originating below the B-Complex are compared to the estimates of the total masses disposed or released to the subsurface since the beginning of waste disposal activities. These mass-balance estimates provide baseline information on two key issues:

1) How well has the mass (and thus distribution in the vadose zone and aquifer) of the contaminant been identified?

2) Can the contaminant mass distribution in the deep vadose zone and aquifer be used to project future risks and guide the selection of remediation alternatives?

In addition, a current geologic stratigraphy conceptual model and hydrologic and geochemical input parameters to support fate and transport predictive modeling are provided. The hydrologic and geochemical values (most plausible and min/max ranges) can be used as input to various fate and transport codes.

The methodology used to create the conceptual models started with review and assembly of pertinent background information on the B-Complex facilities that received the wastes. Key background information includes location of the facilities, period of operation, volumes of waste disposed, types of waste streams disposed, and total masses of constituents released to the vadose zone sediments. The second step was to assemble the available data on the distribution (vertical and lateral) of the key contaminants and species that control the mobility of the contaminants in the vadose zone sediments. Emphasis was placed on evaluating the distribution of technetium-99, and uranium. Distributions of chromium, cyanide, and nitrate were also evaluated. Plots of the available data for five subregions below the B-Complex were superimposed on cross sections of the stratigraphy, and available field surveys (gamma logs and soil resistivity) were used to aid in constructing models of the lateral and vertical extent of the key contaminants within the vadose zone. A similar effort was performed using the available groundwater monitoring data, with emphasis on the last decade, to develop time-series contaminant plume maps. Using a three-dimensional aquifer conceptual model with $10 \mathrm{~m}$ by $10 \mathrm{~m}$ grid cells and the aquifer thicknesses for each year from the geologic conceptual model, the mass of selected contaminants was calculated for the years 2000, 2003, 2006, and 2009. The masses within the annually averaged groundwater plumes could then be calculated and compared to evaluate whether mass was increasing or decreasing over the last decade and where the mass appears to be entering the water table. The shapes of the groundwater plumes revealed the net direction of flow of the groundwater. The vadose zone 
contaminant distribution data and groundwater data were then combined to create integrated conceptual models on where the bulk of the contaminants remain, where they enter the water table, and how the plumes have migrated over the last decade.

The available vadose zone sediment characterization data show that high concentrations of technetium-99 reside deep in the vadose zone below the BY Cribs within both the Hanford formation $\mathrm{H} 2$ and the Cold Creek unit sediments. In the region of the BY Cribs, the fine-grained Cold Creek Unit $\left(\mathrm{CCU}_{\mathrm{z}}\right)$ subunit is absent to very thin (1 to $1.5 \mathrm{ft}$ thick). It appears that water (steady-state natural recharge or transient natural or man-induced) that is fluxing through these deep sediments is carrying the technetium-99, nitrate, cyanide, sodium, and perhaps others down to the water table. Concentrations of technetium-99 in the sediments below the BY Cribs range from 120 to $200 \mathrm{pCi} / \mathrm{g}$ within 90 feet of the water table. Residual technetium-99 concentrations in deep vadose zone sediments at all other boreholes within or proximal to other inactive disposal facilities in the B-Complex in the same geologic units are at least one order of magnitude lower. However, at two new boreholes (299-E33-343 and E33-345) far from the footprints of waste disposal facilities, water extractable technetium-99 also reaches concentrations of $230 \mathrm{pCi} / \mathrm{g}$ in the $\mathrm{CCU}_{\mathrm{z}}$ unit. Based on the available deep vadose zone sediment samples from below the BY Cribs' footprint and the assumption that the areas under all eight BY Cribs have similar concentrations of technetium-99, the deep vadose zone inventory below the BY Cribs is estimated to be up to 55 curies. No other deep vadose zone region, for which sediment data are available, calculates to have technetium-99 activity greater than 4 curies. Based on the high volume of waste disposed of at the BY Cribs compared to any other facility, the lack of or thin manifestation of the $\mathrm{CCU}_{z}$ lateral spreading layer, and the observed high concentrations of technetium-99 in the deep vadose zone, the BY Cribs are considered to be the most important source for the technetium-99 currently within the groundwater plume below the B-Complex and the plumes extension out north of Gable Gap.

Time series groundwater plumes also show that the BY Cribs are the location where the high groundwater concentrations for technetium-99, nitrate, and cyanide originate. The recent time series groundwater plume maps also show a second location near the new borehole 299-E33-343 where a small technetium-99 "hot spot" has formed. This coincides with the occurrence of high concentrations of both technetium-99 and uranium in the $\mathrm{CCU}_{\mathrm{z}}$ sediments, which are only $\sim 16 \mathrm{ft}$ above the water table at this location. The source of this secondary elevated technetium-99 mass has not been absolutely determined. The simplest hypothesis is that the technetium- 99 originated from the Tank BX-102 overfill event. The BX-102 fluids then spread laterally with a vertical component driven by gravity. Gravity and the stratigraphic dip of the vadose zone sediments have managed to transport the technetium into the very moist $\mathrm{CCU}_{\mathrm{z}}$ sediments where it and uranium from BX-102 migrate east all the way to 299-E33-345.

Once the technetium-99 enters the water table at the two designated locations, it appears to be migrating towards the northwest and out of the B-Complex into the Gable Gap region. Given the fact that technetium-99 exhibits little to no sorptive tendencies with all Hanford Site sediments, its ultimate fate will be continued migration with the regional groundwater to the northwest out of the B-Complex with little to no retardation. The leading edge of the technetium-99 $900 \mathrm{pCi} / \mathrm{L}$ isopleth is moving towards the northwest and near the Gable Gap has advanced 920 feet between 2000 and 2009. However, the technetium-99 secondary plume farther north and east of Gable Gap, likely a remnant from earlier times, is moving more slowly ( $900 \mathrm{pCi} / \mathrm{L}$ isopleth has advanced to north only $\sim 350 \mathrm{ft}$ in the same time period) suggesting that dispersion and dilution to concentrations well below the drinking water standard is occurring far inland from the Columbia River. 
The available sediment characterization data from borehole 299-E33-45 and spectral gamma logs from nearby dry wells show that high concentrations of uranium reside in the Hanford formation $\mathrm{H} 2$ unit from about 70 to $140 \mathrm{ft}$ to the east and northeast of the BX-102 tank. The vertical and horizontal distribution of uranium south, east, and northeast of the tank was delineated with gamma logging surveys on about 20 boreholes, most drilled in the 1970s. Farther to the north and northeast, a combination of new boreholes with multiple sediment analyses versus depth and field gamma logs show that high concentrations of uranium reside in the thick $\mathrm{CCU}_{z}$ unit. The progression of the uranium down through the Hanford formation sediments to the $\mathrm{CCU}_{\mathrm{z}}$ unit follows the dip of the vadose zone sediments. Many of the sediment water extracts, one perched water sample, and about a dozen groundwater samples taken from wells as a function of time have been analyzed for uranium isotopic signatures. Using similar samples obtained from near several other B-Complex facilities, it has been determined that the uranium-236/238 and uranium-234/238 ratios for samples representing each facility's "source" or fingerprint are unique and distinguishable from each other. Assuming that other waste streams from other facilities for which no samples are available would have unique uranium isotope signatures, just as the four facilities that have been studied, one can hypothesize that the available data have conclusively identified the source of the deep vadose zone uranium, the 1951 Tank BX-102 overfill event. The fact that the highest concentrations of water-extractable uranium in the $\mathrm{CCU}_{\mathrm{z}}$ sediments occurs at borehole 299-E33-343 and that groundwater at this well has the highest concentration of uranium found below the entire B-Complex, the location of entry of the uranium into the aquifer is close by. It is hypothesized that the $\mathrm{CCU}_{\mathrm{z}}$ sediments in this region have become saturated and thus diminishing the capillary break feature that generally would otherwise hold water in the finer-grained unsaturated sediments and prevent movement into underlying much drier coarse-grained sediments. Once the finer grained sediments saturate, water from them can descend into the coarser sediments $\left(\mathrm{CCU}_{\mathrm{g}}\right)$ below. The descending water can then easily reach the water table that resides $\sim 16 \mathrm{ft}$ below. Therefore, the pathway followed by the highly uranium-laden waste from Tank BX-102 was to travel laterally along fine-grained layers in the Hanford formation sediments with vertical descent by gravity and the natural stratigraphic dip to the northeast until the fluids reached the $\mathrm{CCU}_{z}$ unit. Once within the $\mathrm{CCU}_{\mathrm{z}}$ unit, moisture content lead to lateral spreading towards the east. With the installation of well 299-E33-343, it appears that some of the high-uranium waste fluids have broken through the bottom of the $\mathrm{CCU}_{\mathrm{z}}$ unit or exited out the edge on the northern flank, to quickly travel to the water table. Once in the unconfined aquifer, the uranium is moving to the northwest at a speed slightly slower than the groundwater itself. Using the uranium isotopic signature measurements on several groundwater samples taken over several years from wells in the uranium plume, Christensen et al. (2004) estimated the uranium migration rate at $\sim 0.7$ to $0.8 \mathrm{~m} /$ day compared to the apparent groundwater flow rate of $\sim 1 \mathrm{~m} /$ day.

The conceptual model for both technetium-99 and uranium suggests that significant amounts continue to migrate through the deep vadose zone into the groundwater. The total activity of technetium-99 currently in the groundwater plume is estimated at $6.06 \mathrm{Ci}$, which represents no more than $5 \%$ of the total activity of technetium-99 released to the subsurface below the B-Complex. The comparable statistic for uranium mass in the groundwater plume is $22.3 \mathrm{~kg}$ or $<1 \%$ of the uranium released to the subsurface below the B-Complex. The conceptual models cannot assess how much of the technetium-99 may have migrated out of the B-Complex region before regular groundwater monitoring was performed (i.e., in time periods before the early 1990s). Thus, some of the difference between the mass balance estimates ( $\sim 65$ out of $145 \mathrm{Ci}$ have been accounted for in the proposed technetium-99 conceptual model) may have "escaped" the region in past groundwater. The conceptual model for the BX-102 sourced fluid estimates that the uranium did not reach the water table below the B-Complex until the early 1990s so that all the 
disposed uranium should remain in the B-Complex domain included in the mass balance calculations. The conceptual model proffered accounts for 7970 to $8830 \mathrm{~kg}$ out of the $10,100 \mathrm{~kg}$ of uranium lost in the 1951 overfill event at Tank BX-102 or out of the 12,100 kg disposed of to the entire B-Complex.

The mass balance estimates show that the sum of technetium-99 activity deep below the BY Cribs and in the $\mathrm{CCU}_{\mathrm{z}}$ sediments below E33-343 over to E33-345 are much larger (3.4 to 20.9 Ci) than the estimated activity of technetium-99 currently in the groundwater plume directly below B-Complex $(0.76 \mathrm{Ci})$ and similar to somewhat larger than the entire technetium-99 plume that extends out towards and beyond Gable Gap $(6.06 \mathrm{Ci})$. The same can be stated for the mass of water extractable (mobile) uranium in the deep vadose zone below the region northeast of Tank BX-102. The estimate of mobile uranium deep in the vadose zone in this region is 1520 to $1600 \mathrm{~kg}$ versus $22.3 \mathrm{~kg}$ currently in the BComplex groundwater plume. Succinctly, Section 6 and summary Table 9.2 show that there is from 8 to 30 times more technetium-99 in the deep vadose sediments than is currently present in the technetium-99 groundwater plume directly below the B-Complex and $\sim 75$ times as much mobile uranium in the deep vadose zone than is present in the current uranium groundwater plume. The technetium-99 estimates is more speculative because of the sparser data for the deep vadose zone sediments' concentrations and uncertainty in the lateral spreading area with high concentrations below BY Crib footprints. Fate and transport modeling can be used to assess the quantity of these and other contaminants, currently in the deep vadose zone that will reach the water table and the timing of their arrival at the water table. 
PNNL-19277

\section{Acronyms and Abbreviations}

3D

bgs

CCU

CH2M-Hill

CHPRC

CRBG

DOE

EDA

EPA

ERC

FGG

FHI

GD

GEA

GPS

HASQARD

HDW

HEIS

HGI

HMS

HRR

IC

IC

ICP-MS

ICP-OES

ID

IDF

ISSD

ITS

IX

MSL

NIST

NM

OU three-dimensional

below ground surface

Cold Creek Unit

CH2M-Hill Hanford Group, Inc.

CH2M-Hill Central Plateau Remediation Company

Columbia River Basalt Group

U.S. Department of Energy

Environmental Data Access

U.S. Environmental Protection Agency

Electrical Resistivity Characterization

Fluor Government Group

Fluor Hanford, Inc.

gravel-dominated

Gamma Energy Analysis

global positioning System

Hanford Analytical Services Quality Assurance Requirements Document

(DOE/RL-96-68)

Hanford Defined Waste

Hanford Environmental Information System

HydroGEOPHYSICS, Inc.

Hanford Meteorological Station

High Resolution Resistivity

Ion Chromatograph - used to measure anions concentrations

inorganic carbon

Inductively Coupled Plasma-Mass Spectroscopy

Inductively Coupled Plasma Optical Emission Spectroscopy

identification number

Integrated Disposal Facility

Interbedded sand- and silt-dominated

In-Tank Solidification

ion exchange

mean sea level

National Institute of Standards and Technology

neutron moisture

Operable Unit (a geographical area of Hanford generally with inactive facilities administratively lumped together for remediation and clean-up activities 


\begin{tabular}{|c|c|}
\hline PAS & PUREX acidified sludge \\
\hline PNNL & Pacific Northwest National Laboratory \\
\hline PSD & particle size distribution \\
\hline PUREX & Plutonium-Uranium Extraction \\
\hline REDOX & Reduction Oxidation \\
\hline $\mathrm{RI} / \mathrm{FS}$ & Remedial Investigation/Feasibility Study \\
\hline RL & (DOE's) Richland Operations Office \\
\hline SD & sand-dominated \\
\hline SGLS & spectral gamma logging system \\
\hline SGE & Surface Geophysical Exploration \\
\hline SFOPT & $\begin{array}{l}\text { Single fluid optimization computer program (Tuli et al. 2001) to optimize } \\
\text { hydraulic parameters from multistep experimental data. Available at } \\
\text { http://researchers.lawr.ucdavis.edu/tuli/PUBLICATIONS.html. }\end{array}$ \\
\hline SIM & Soil Inventory Model \\
\hline SST & single-shell tank \\
\hline STS & surface-to-surface \\
\hline TBP & tri-butyl phosphate \\
\hline TG & Total gamma \\
\hline UFA & Unsaturated Flow Apparatus - used to extract pore fluids out of moist sediments \\
\hline UPR & unplanned release \\
\hline USDA & U.S. Department of Agriculture \\
\hline USGS & United States Geological Society \\
\hline WESF & Waste Encapsulation Storage Facility \\
\hline WIDS & Waste Information Data System \\
\hline WMA & $\begin{array}{l}\text { Waste Management Area- similar to operable units but for Tank Farm clean up } \\
\text { and remediation }\end{array}$ \\
\hline WSCF & Waste Sampling and Characterization Facility \\
\hline WRPS & $\begin{array}{l}\text { Washington River Protection Solutions -Hanford contractor in charge of tank } \\
\text { farm operations }\end{array}$ \\
\hline WSCF & Waste Sampling and Characterization Facility \\
\hline WTW & well-to-well \\
\hline XANES & synchrotron X-ray adsorption near edge spectroscopy \\
\hline
\end{tabular}




\section{Acknowledgments}

The following persons are acknowledged for their cited contributions: Chris Brown and Mike Lindberg (Pacific Northwest National Laboratory [PNNL]) for coordinating the analyses of sediments and waters obtained from the recent boreholes emplaced in the 200-BP-5 Operable Unit and managing the data (producing the electronic data packages and required quality assurance/quality control documentation). The following analysts from the Applied Geology and Geochemistry Group's Environmental Sciences Laboratory at PNNL are acknowledged for performing the diverse geologic, geochemical, and hydrologic measurements on the recently acquired sediments and subsurface waters: Steve Baum (inductively coupled plasma [ICP]), Eric Clayton (ICP-mass spectrometry [ICP-MS]), Ray Clayton (hydraulic conductivity), Keith Geislzer (ICP-MS, data review), Christian Iovin (ion chromatography[IC]), Igor Kutnyakov (radiocounting, carbon analysis), Kevin Miller (sediment preparation, sample inventory management), Deneese Smith (sediment preparation, alkalinity and electrical conductivity analyses), and Michelle Valenta (sediment preparation, geologic interpretation, analytical measurement scheduling). Without all of their efforts, the large amount of data and quality checks would not have been accomplished.

Numerous scientists and engineers from 1) the Hanford Operating contractors, 2) the Department of Ecology and the U.S. Environmental Protection Agency, 3) stakeholder organizations, and 4) the two local U.S. Department of Energy branches are acknowledged for their suggestions, questions, comments, and discussions that helped formulate the conceptual models described in this report. In particular, Susan Narbutovski (CH2M-Hill Central Plateau Remediation Company [CHPRC]) provided valuable information and resources on the historical operations and groundwater status at the B-Complex, Theresa Larsen (CHPRC) generated the spring and fall groundwater time series plume plots, and Stan Sobczyk (Nez Perce Indian Tribe) provided annual groundwater summary Excel tables and Rockware ${ }^{\circledR}$ graphics, citation information to locate key historical documents, and critiqued data and interpretations on the geology, borehole logging, and historical groundwater contaminant plume evolution.

The following persons performed formal reviews of this draft document. Chris Martin (FGG), and Dave Myers, Jim Field, and Mike Connelly (WRPS) reviewed the draft report. Curt Wittreich and Marc Wood (CHPRC), Mark Triplett, Chris Brown, and Evan Dresel from PNNL provided useful comments on various sections of the draft report. Doug Hildebrand and John Morse from the Department of EnergyRichland Operations also provided comments on selected sections of the draft. Each of the reviewers provided comments that led to significant additions and improvements to this technical report. The technical report was edited and produced by Wayne Cosby (PNNL). Wayne also coordinated the PNNL word processing and document production staff that generated the draft and final document promptly to meet short deadlines. The authors are greatly indebted to their efforts. 



\section{Contents}

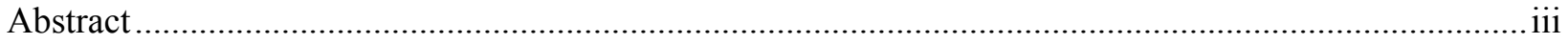

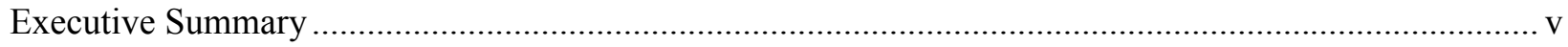

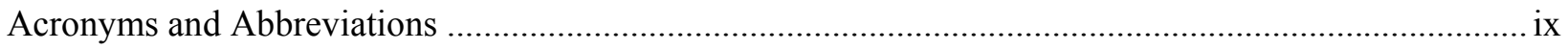

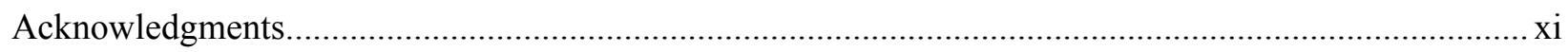

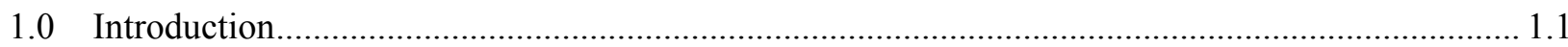

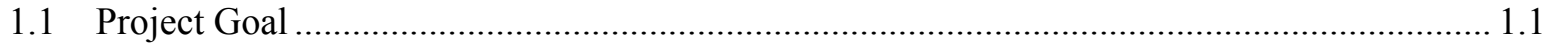

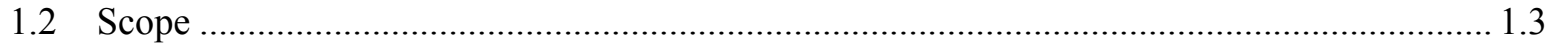

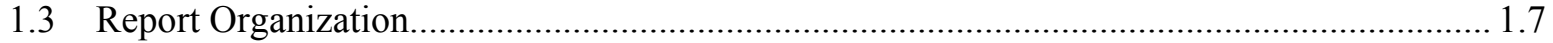

1.4 Sources and Rationale Used to Select Facility Information ............................................... 1.8

1.4.1 Cribs, Trenches, French Drains, Tile Fields, and Settling Tanks ................................ 1.8

1.4.2 Source of Single-Shell Tank Information and Rationale ......................................... 1.10

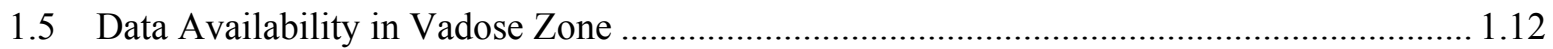

1.6 Data Availability for Unconfined Aquifer (Site-wide Groundwater Monitoring Reports) ... 1.14

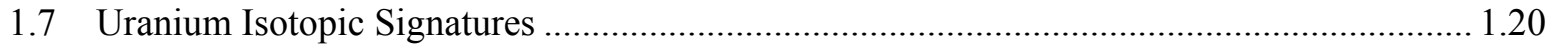

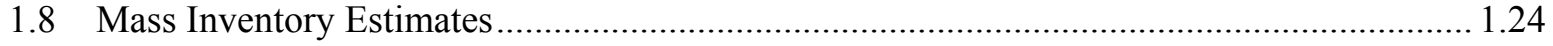

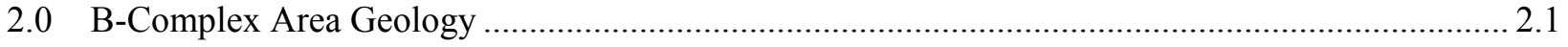

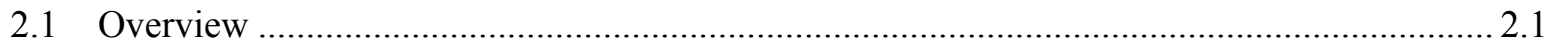

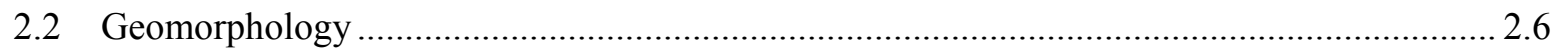

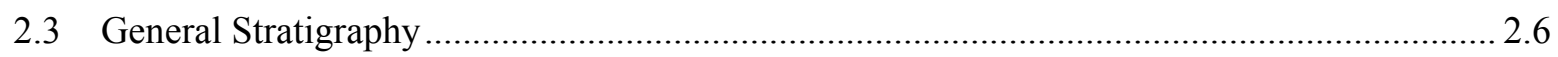

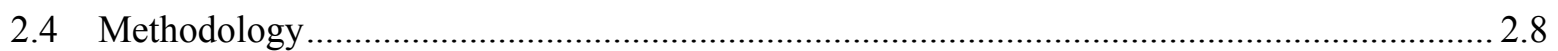

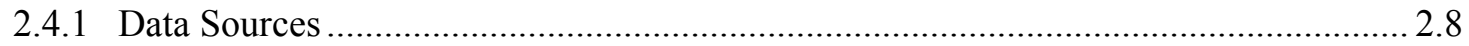

2.4.2 Development of Geology Model ........................................................................... 2.13

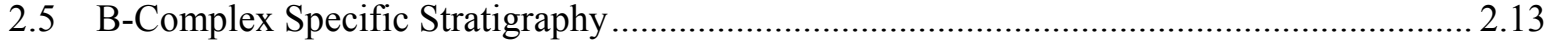

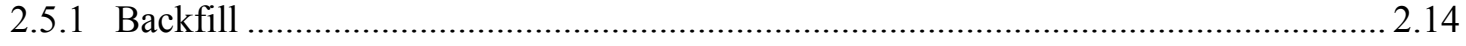

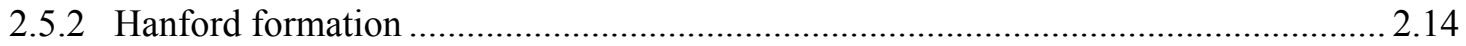

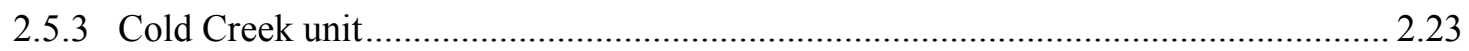

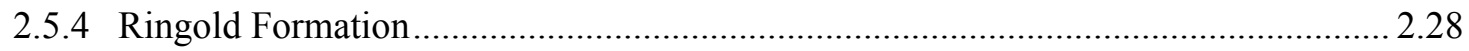

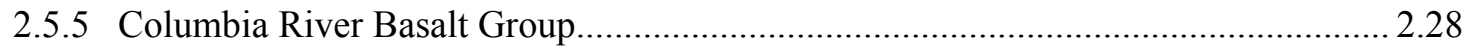

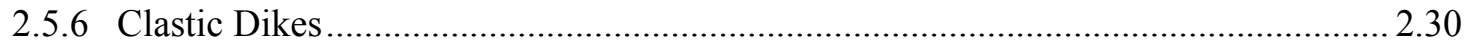

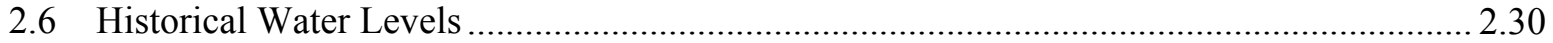

3.0 Conceptual Models for Vadose Zone and Groundwater Contamination ...................................... 3.1

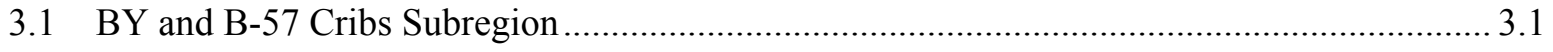

3.1.1 B-43 through B-50 Cribs Facility Description and Inventory Released ....................... 3.1 


\section{Contents}

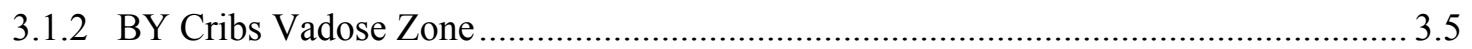

3.1.3 Uranium Isotopic Ratio Results for BY Cribs Vadose Zone Sediments ..................... 3.26

3.1.4 B-57 Crib Facilities and Inventory Released .............................................................. 3.26

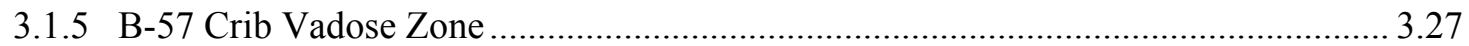

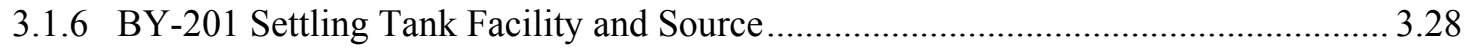

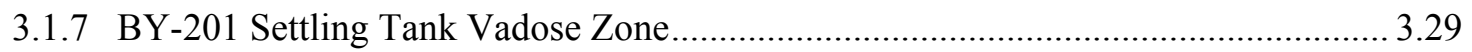

3.1.8 BY Crib Vadose Zone Conceptual Model ................................................................. 3.29

3.1.9 BY Cribs Vadose Zone Sediment Inventory Estimates............................................ 3.35

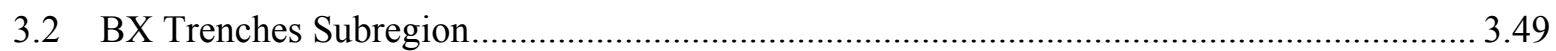

3.2.1 BX Trenches Facilities and Source Details ................................................................ 3.49

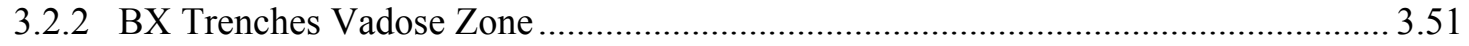

3.2.3 BX Trenches Vadose Zone Conceptual Model .......................................................... 3.57

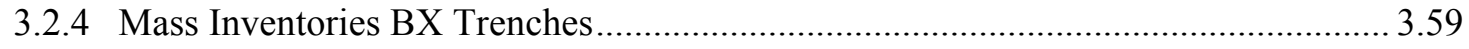

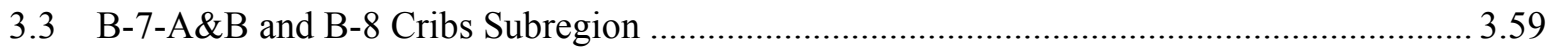

3.3.1 B-7-A\&B Cribs Facilities Description and Inventory Released................................ 3.59

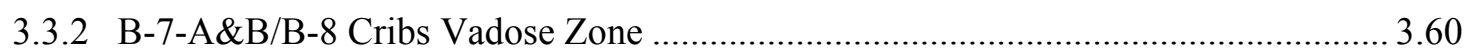

3.3.3 Uranium Isotope Signature Results Related to B-7-A Crib ....................................... 3.74

3.3.4 B-8 Crib and Tile Field Description and Inventory Released................................... 3.77

3.3.5 B-8 Crib and Tile Field Vadose Zone ...................................................................... 3.78

3.3.6 B-51 French Drain Description and Inventory Released ........................................ 3.80

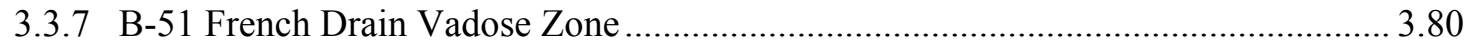

3.3.8 B-11-A\&B French Drains (Dry Wells) Description and Inventory Released ............ 3.81

3.3.9 B-11-A\&B French Drains (Dry Wells) Vadose Zone ................................................ 3.81

3.3.10 Vadose Zone Inventory Calculations for B-7-A Crib ............................................... 3.82

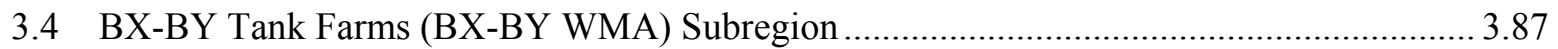

3.4.1 BX Tank Farm Description and Inventory Released ............................................... 3.89

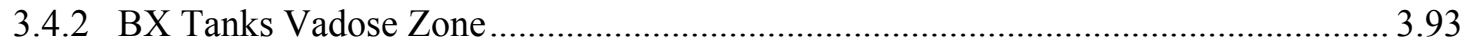

3.4.3 U Isotope Signature Measurements for New Boreholes 299-E33-205 and 299-E33-3433.1

3.4.4 Vadose Zone Mass Inventory from the BX-102 Overfill Event ............................... 3.115

3.4.5 BY Tank Farm Description and Inventory Released ............................................. 3.119

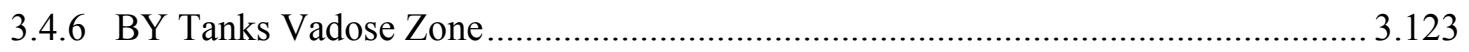

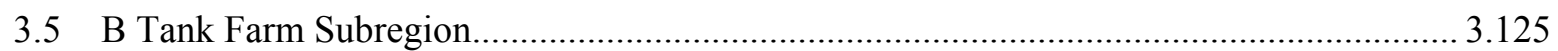

3.5.1 B Tank Farm Description and Inventory Released ............................................... 3.127

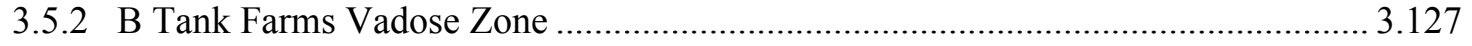




\section{Contents}

3.5.3 Mass Inventory Calculation of B Tank Farm

3.6 B-Complex Total Mass of Chemicals and Key Radionuclides Released to the Vadose Zone3.13:

4.0 Hydraulic Properties of the Vadose Zone and Unconfined Aquifer

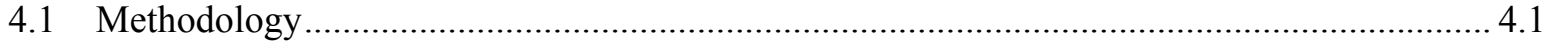

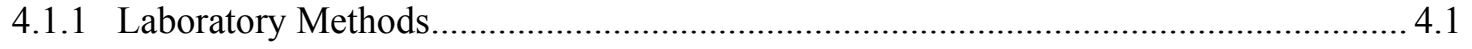

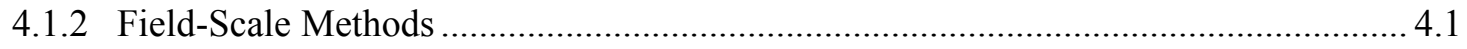

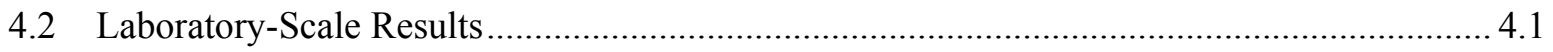

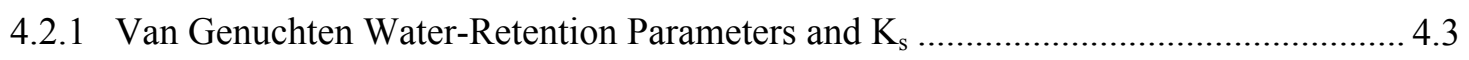

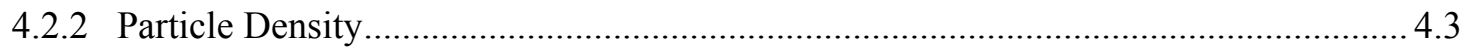

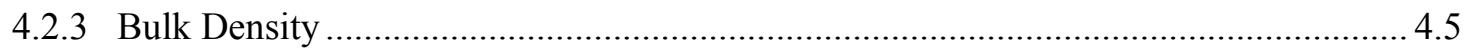

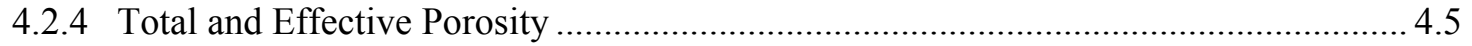

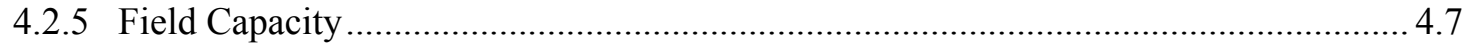

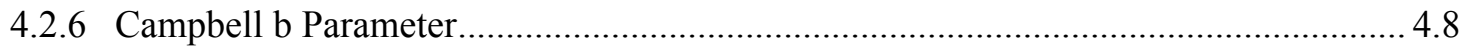

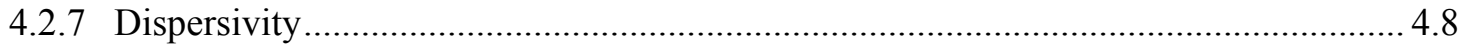

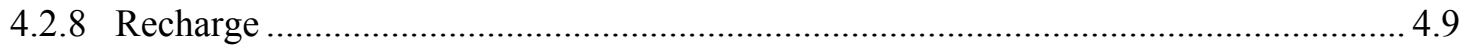

4.3 Field Scale Results (Aquifer Hydraulic Properties from In Situ Tests).............................. 4.10

4.4 Additional Remarks Pertinent to the B-Complex Hydrogeologic Model............................. 4.16

5.0 Status of Selected Mobile Contaminants in Groundwater Below the B Complex ........................ 5.1

5.1 Status of Groundwater Plumes in the B-Complex ................................................................ 5.1

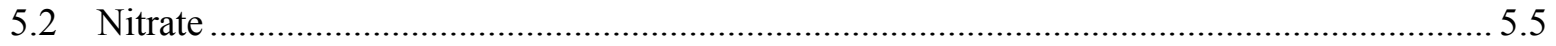

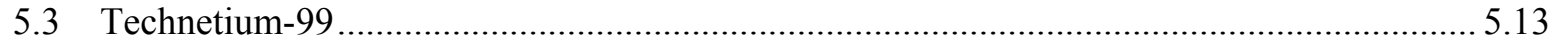

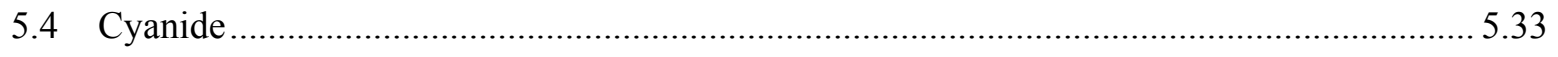

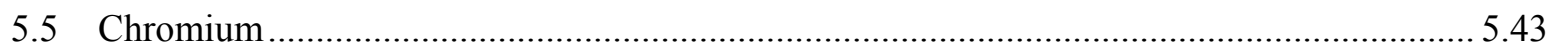

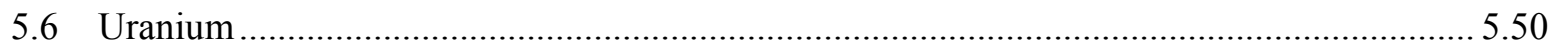

5.7 Uranium Isotopic Signatures in B-Complex Groundwater................................................ 5.64

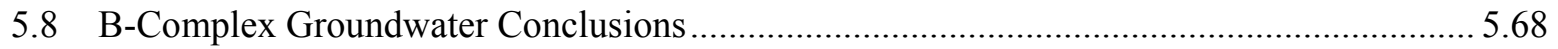

5.8.1 Groundwater Contaminant Concentration Trends (Masses Increasing) ..................... 5.68

5.8.2 Direction of Groundwater Plume Migration............................................................. 5.68

6.0 Integrated Conceptual Models for Key Contaminants................................................................ 6.1

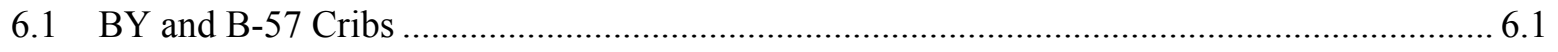

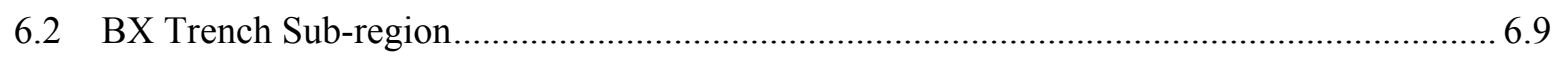

6.3 B-7-A\&B/B-8 Cribs Subregion (includes B-8 Tile Field, B-11-A\&B and B-51

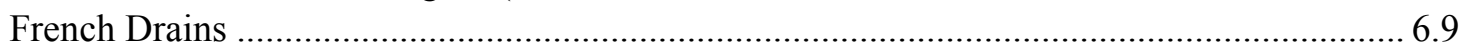

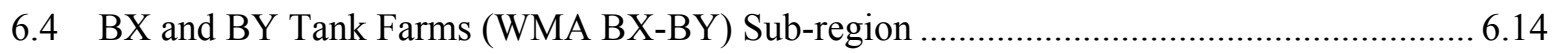




\section{Contents}

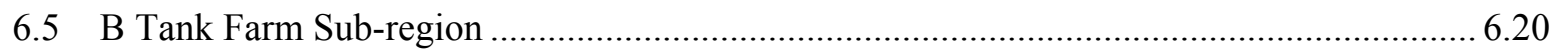

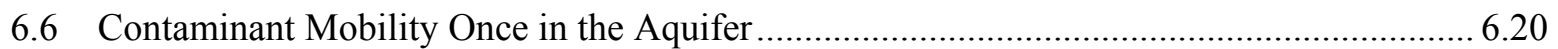

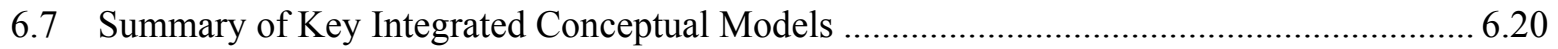

7.0 Description of Potential for Future Groundwater Impacts...................................................... 7.1

8.0 Tables Listing Recommended Values and Ranges .................................................................. 8.1

8.1 Geology (thicknesses and areal extent of each layer) ..................................................... 8.1

8.2 Hydrologic Parameters (by Geologic Layer) and Recharge ............................................... 8.2

$8.3 \mathrm{~K}_{\mathrm{d}}$ Values and Ranges (by Geologic Layer) ................................................................. 8.3

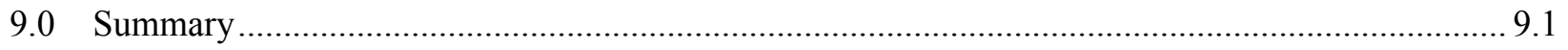

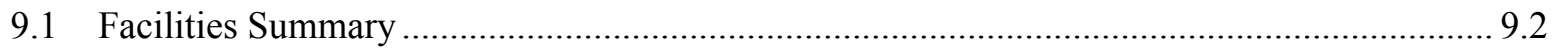

9.2 Conceptual Model for Technetium-99 in the B-Complex .................................................. 9.3

9.3 Conceptual Model for the Uranium in the B-Complex ...................................................... 9.4

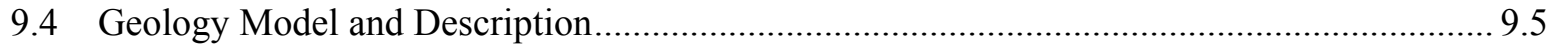

9.5 Hydraulic and Recharge Parameters.................................................................................. 9.7

9.6 Nature and Extent of Contaminants in Vadose Zone Sediments ........................................ 9.7

9.7 Vadose Zone Residual Inventories for Technetium-99 and Uranium ................................ 9.12

9.8 Uranium Isotopic Ratio Signature Results.................................................................. 9.13

9.9 Groundwater Plume Inventories for Technetium-99 and Uranium and Groundwater Flow .9.14

10.0 Recommendations Based on B-Complex Conceptual Model Findings ....................................... 10.1

10.1 Vadose Zone Sediment Sampling Protocol …............................................................... 10.1

10.2 Vadose Zone Sediment Characterization Protocol ........................................................... 10.3

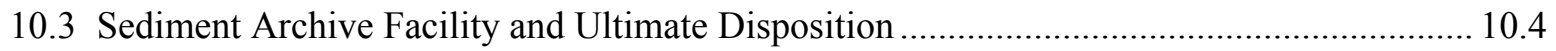

10.4 Synergistic Ties to Other Basic and Applied Research Opportunities ................................ 10.5

10.5 Highest Priority Boreholes to Address Deep Vadose Zone Technetium-99 and

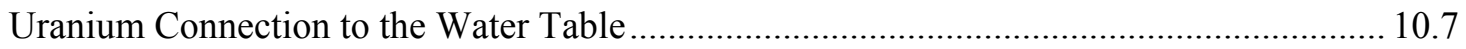

10.6 Other Locations Where Additional Vadose Zone Boreholes or Direct Push with

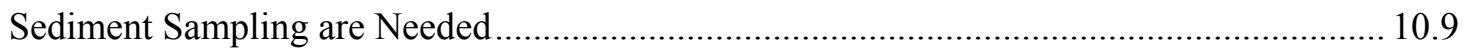

10.7 Improvement Needed in Cyanide Method for Sediments.............................................. 10.10

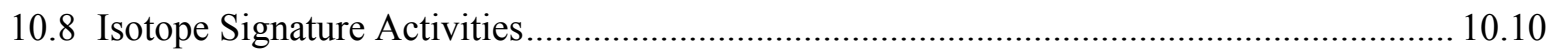

10.9 Deep Vadose Zone Uranium Remediation .................................................................... 10.11

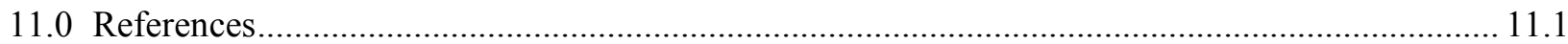

Appendix A: Waste Facility Dimensions, Waste Stream Definitions, Major Chemical Inventories Disposed by Year for Each Facility

Appendix B: Geology Details (cross sections, fence diagrams, contact isopachs, thicknesses of each stratum). 
PNNL-19277

\section{Contents}

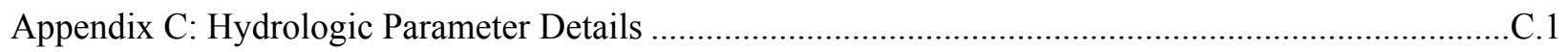

Appendix D: Electronic Files for New Boreholes (Excel Data Dumps, Digital Photos, Logs)............... D.1

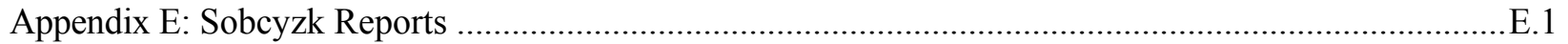

Appendix F: Spectral Gamma Logging System Logs for Key Boreholes ...........................................F.1

Appendix G: Additional Groundwater Fall and Spring Plume Maps ................................................... G.1

Appendix H: Uranium Isotope Signatures ................................................................................. H.

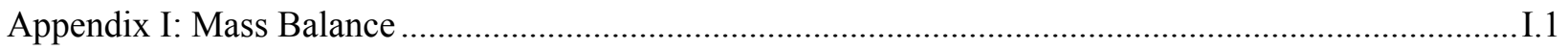




\section{Figures}

1.1. Map of B-Complex Area Showing Facilities and Key Boreholes and Wells ................................ 1.2

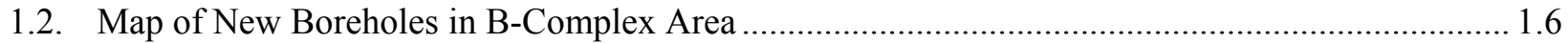

1.3. Atom Ratio of Uranium-236/238 to Uranium-235/238 for all B-Complex Vadose Zone Water Extracts and Groundwater from New Wells..... 1.22

1.4. Uranium-236/238 vs. Uranium-234/238 Ratios for Four Sources (Disposal Facilities) ............... 1.24

2.1. Location of Boreholes Used to Generate Geology Conceptual Model ......................................... 2.3

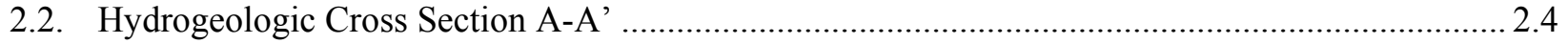

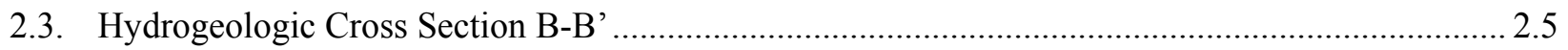

2.4. B-Complex Area in Relation to Ice Age Flood Features Within the Central Pasco Basin ..............2.7

2.5. Generalized Stratigraphy for the B-Complex Area ................................................................... 2.8

2.6. Generalized Borehole Log for Well 299-E33-45 ........................................................................ 2.12

2.7. All Three Facies of the Hanford formation are Represented in this Photo at the

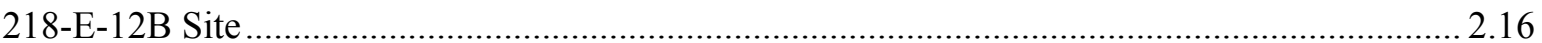

2.8. Close-Up Photo of the Silt Dominated Facies Similar to Facies Shown in 2.7 ......................... 2.17

2.9. Example of the Gravel Dominated Hanford H1 unit from Sample S01014-6A Collected at a Depth of 6.3 to $6.4 \mathrm{~m}$ (20.6 to $21.1 \mathrm{ft}$ ) from Borehole 299-E33-45

2.10. Example of the H2 Sand Sequence in Sample S01014-16C, Collected at a Depth of 12.6 to $12.7 \mathrm{~m}(41.3-41.8 \mathrm{ft})$ from Borehole 299-E33-45

2.11. Coarse to Very Coarse Sand of the Middle of the H2 Sand Sequence from Sample S101014-35B at a Depth of 23.6 to $23.7 \mathrm{~m}$ (77.4 to $77.9 \mathrm{ft})$ in Borehole 299-E33-45

2.12. Contact Between Coarse Sand and Medium Sand Strata in the H2 Sand Sequence from Sample S01014-44C (Borehole 299-E33-45) at a Depth of 30.1 to $30.2 \mathrm{~m}$ (98.8 to $99.3 \mathrm{ft}$ ) ....... 2.20

2.13. Gravelly (Mostly Fine to Very Fine Pebble) Coarse H2 unit Sand Representative of the Very Bottom of the unit (Sample S01014-88A from 299-E33-45) at a Depth of 55.3 to $55.4 \mathrm{~m}(181.4$ to $181.9 \mathrm{ft})$

2.14. Contact Between H2 Upper Sand Sequence and the Thin H2F1 Finer-Grained Lens Observed in Sample S01014-34C (Borehole 299-E33-45), Collected at a Depth of 22.7 to $22.8 \mathrm{~m}(74.4$ to $74.9 \mathrm{ft})$

2.15. Lower Contact of the H2F1 Muddy Very Fine to Fine Sand Layer in Sample S01014-34A (299-E33-45) at a Depth of 23 to $23.1 \mathrm{~m}(75.4$ to $75.9 \mathrm{ft})$

2.16. Thin Fine Grained Lens Representative of H2F2 Observed in Sample S01014-54C (Borehole 299-E33-45) at a Depth of 36.5 to $36.6 \mathrm{~m}$ (119.6 to $120.1 \mathrm{ft}$ ).

2.17. Poorly Sorted H2 Sand Contact with the Silty Very Fine Sand Layer H2F3 in Sample S01014-83D (299-E33-45) at a Depth of 51.6 to $51.7 \mathrm{~m}$ (169.3 to $169.8 \mathrm{ft})$.

2.18. Contact Beneath $\mathrm{H} 2$ Sand (left) and $\mathrm{CCU}_{z}$ Silt (right) Strata in Sample S01014-110C (299-E33-45) at a Depth of 66.5 to $66.6 \mathrm{~m}(218.2$ to $218.7 \mathrm{ft})$ 


\section{Figures}

2.19. Mud (Silt) from the $\mathrm{CCU}_{z}$ Facies in Sample S01014-111A (299-E33-45) at a Depth of

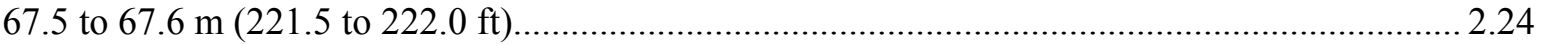

2.20. Areal Extent of the $\mathrm{CCU}_{z}$ Facies Within the B-Complex Area .................................................2.25

2.21. Top of the $\mathrm{CCU}_{z}$ Fine Grained Facies (Brown Color) B Tank Farm in Foreground and BX-BY Tank Farms in Background (yellow dots are wells that intercepted $\mathrm{CCU}_{\mathrm{z}}$ sediment) ..... 2.26

2.22. Muddy Sandy Gravel ( $\left.\mathrm{CCU}_{\mathrm{g}}\right)$ in Sample S01014-122 D (299-E33-45) at a Depth of 73.5 to $73.6 \mathrm{~m} \mathrm{(240.1} \mathrm{to} 240.6 \mathrm{ft})$.

2.23. Sandy Gravel $\left(\mathrm{CCU}_{\mathrm{g}}\right)$ from Sample S01014-129B (299-E33-45) at a Depth of 77.1 to $77.2 \mathrm{~m}(252.9$ to $253.4 \mathrm{ft})$

2.24. Top of the Basalt (looking from SE to NW) with B Tank Farm in Foreground and BX-BY Tank Farms in Background (yellow dots are wells that tagged top of basalt) ............................. 2.29

2.25. Discharge History for the B Pond and the Gable Mountain Pond Systems ................................ 2.31

2.26. Hydrographs of Selected Wells in the Area of Waste Management Area BX-BY..................... 2.33

2.27. Saturated Thickness for Unconfined Aquifer Below the B-Complex for Year 1987................... 2.34

2.28. Saturated Thickness for Unconfined Aquifer Below the B-Complex for Year 2009................... 2.35

3.1. Map Showing the BY Cribs Subregion Facilities and Key Boreholes/Monitoring Wells ............... 3.2

3.2. BY Crib Construction Details and Excavation Dimensions.......................................................... 3.4

3.3. 3D Visualization of Cobalt-60 Distribution Below the BY Cribs-from DOE/GJO (2003)......... 3.11

3.4. Inverted Field Resistivity Data Based on 2D Data Collection on 3-m Resolution ....................... 3.12

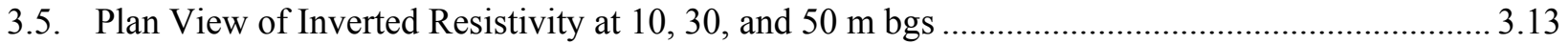

3.6. Cross Sectional View of Inverted Field Resistivity Data Below BY Cribs ................................. 3.14

3.7. Technetium-99 in Sediments as a Function of Depth In and West of B-49 Crib ........................ 3.16

3.8. Nitrate in Sediments as a Function of Depth In and West of B-49 Crib .................................... 3.17

3.9. Water-Extractable Sulfate in Sediments as a Function of Depth In and West of B-49 Crib.......... 3.18

3.10. Cyanide in Sediments as a Function of Depth In and West of B-49 Crib ................................... 3.19

3.11. Water- and Acid Extractable Uranium in Sediments as a Function of Depth In and West

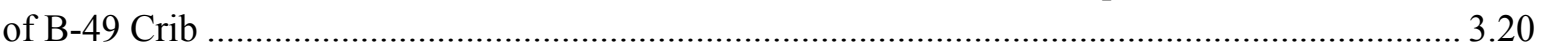

3.12. Technetium-99 in the Sediments as a Function of Depth In and South of B-43 Crib.................. 3.21

3.13. Nitrate in the Sediments as a Function of Depth In and South of B-43 Crib ............................... 3.22

3.14. Sulfate in the Sediments as a Function of Depth in and South of B-43 Crib .............................. 3.23

3.15. Cyanide in Sediments as a Function of Depth in and South of B-43 Crib ................................... 3.23

3.16. Water and Acid Extractable Uranium in the Sediments as a Function of Depth In and South of B-43 Crib

3.17. BY Crib Stratigraphy and Technetium-99 in Sediments as a Function of Depth Cross-Section ... 3.30

3.18. BY Crib Stratigraphy and Nitrate in Sediments as a Function of Depth Cross-Section ................ 3.31

3.19. BY Crib Stratigraphy and Total Uranium in Sediments as a Function of Depth Cross-Section.... 3.32 


\section{Figures}

3.20. BY Crib Stratigraphy and Water Extractable Uranium in Sediments as a Function of Depth Cross-Section

3.21. Areas Chosen to Calculate Vadose Zone Inventory for BY Crib Red Line Delineates Areal Extent of $\mathrm{CCU}_{z}$ Unit and Blue Lines Represent Thickness.....

3.22. Cross Section and Estimated Concentrations of Technetium-99 and Uranium Used in BY Cribs Mass Inventory Conceptual Model \#1

3.23. Cross Section and Estimated Concentrations of Technetium-99 and Uranium Used in BY Cribs Mass Inventory Conceptual Model \#2

3.24. Cross Section and Estimated Concentrations of Technetium-99 and Uranium Used in BY Cribs Mass Inventory Conceptual Model \#3

3.25. BX Trench Subregion Map with Facilities and Key Boreholes and Wells Highlighted 3.50

3.26. Visualization of Cobalt-60 Distribution Below and Proximal to the BX Trenches 3.53

3.27. Inverted Soil Resistivity Data for BX Trenches (from Rucker et al. 2007) ................................ 3.55

3.28. Vertical Distribution on Nitrate in Sediments Within Footprint of B-38 Trench ........................ 3.56

3.29. Vertical Distribution on Fluoride in Sediments Within Footprint of B-38 Trench ....................... 3.56

3.30. Location Map for B-7-A\&B/B-8 Cribs Subregion Facilities and Boreholes/Wells..................... 3.61

3.31. Spectral Gamma 3D Visualization of Cobalt-60 Vadose Zone Contamination Around B-7A\&B Cribs and B-11A\&B French Drains (from DOE/GJO 2002a) .......................................63

3.32. Isometric View of Soil Resistivity Data Below the B-7-A\&B and B-8 Crib and Tile Field ......... 3.64

3.33. Plan View Soil Resistivity Data Below the B-8 Crib and Tile Field at Three Depths .................. 3.66

3.34. Cross Section View of Soil Resistivity Below the B-8 Crib and Tile Field Showing Low Resistivity Plume Extending Below Water Table Under the Tile Field

3.35. Sediment Concentrations of Nitrate in B-7-A Footprint (Borehole C3103) .................................. 3.69

3.36. Sediment Concentrations of Fluoride in B-7-A Footprint (Borehole C3103) ............................... 3.70

3.37. Acid and Water Extractable Uranium vs. Depth in C3103 Borehole (Inside Footprint) .............. 3.70

3.38. Vertical Distribution of Nitrate in Sediments In and Near B-7-A Crib....................................... 3.73

3.39. Vertical Distribution of Fluoride in Sediments In and Near B-7-A Crib ..................................... 3.73

3.40. Vertical Distribution of WE Chromium in Sediments In and Near B-7-A Crib .......................... 3.73

3.41. Vertical Distribution of Technetium-99 in Sediments In and Near B-7-A Crib .......................... 3.74

3.42. Vertical Distribution of Total Uranium in Sediments in and near B-7-A Crib. ........................... 3.74

3.43. Uranium Signature for Borehole 299-E33-344 and -345 Pore and Perched Water Samples......... 3.75

3.44. Boreholes and Monitoring Wells Within and Surrounding B-8 Crib and Tile Field .................... 3.79

3.45. 3D Visualization of ${ }^{137}$ Cs Distribution in Vadose Zone Below the B-7-A\&B and

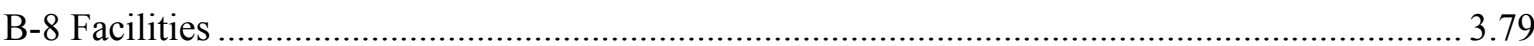

3.46. Conceptual Inventory Model Areas for B-7A\&B Cribs........................................................... 3.84

3.47. BX-BY Waste Management Subregion—Tanks and Key Dry wells Highlighted in Green.......... 3.88 


\section{Figures}

3.48. Locations of E33-45 Borehole, Direct Pushes and Dry Wells with Suspect Gamma ................... 3.89

3.49. Lateral Spread of U from BX-102 Overfill Event Based on Gamma Logs ................................ 3.96

3.50. Lateral Spread of U from BX-102 Overfill Event Based on Gamma Logs ................................ 3.97

3.51. Year 2002 SGLS Log Data for Borehole 299-E33-41 (converted from activity to mass concentrations)

3.52. Photograph of the Fine-Grained Thin Lens on Top of Sand Found in Direct Push Hole South of BX-102 Tank at $\sim 77 \mathrm{ft}$ bgs

3.53. Water-Extractable $\mathrm{Na}$ and $\mathrm{Ca}$ in Vadose Zone Sediments at 299-E33-45

3.54. Vertical Distribution of Nitrate in Sediments South and East of BX-102 Tank 3.103

3.55. Vertical Distribution of Technetium-99 in Sediments South and East of Tank BX-102 3.103

3.56. Vertical Distribution of Water-Extractable Uranium in Sediments South and East of Tank BX-102.

3.57. Vertical Distribution of Acid-Extractable Uranium in Sediments South and East of Tank BX-102. 3.104

3.58. Uranium Isotopic Signature Data for Samples from Borehole 299-E33-205

3.59. Uranium Isotopic Signature Results for Pore Waters and Groundwater from 299-E33-343 ....... 3.111

3.60. Cross Section of Boreholes That Contain Elevated Hanford Processed Uranium (total or acid extractable)

3.61. Cross Section of Boreholes That Contain Elevated Hanford Processed Uranium (water extractable or "mobile")

3.62. Cross Section Showing Distribution of Technetium-99 in Boreholes Associated with the Hanford Processed Uranium Plume

3.63. Close Up Map for the Near Tank BX-102 Region.

3.64. Location of Dry Wells and Groundwater Wells in BY Tank Farm.

3.65. Location of Boreholes and Direct Pushes and Leak Status for B Tank Farm 3.126

4.1. Mean van Genuchten Parameter Soil-Water Retention Characteristics for each Stratigraphic Unit

4.2. Predicted Unsaturated Hydraulic Conductivity Relationships Calculated from the Mean Water-Retention Parameters

4.3. Hydraulic Conductivity (m/d) Determined from Constant-Rate Pumping and Slug Tests in Vicinity of the B-Complex.

4.4. Specific Capacity (gal/min/ft) from Development Pumping of Wells in the Vicinity of the 200-BP-5 Source Area.

5.1. Location of Groundwater Monitoring Wells in B-Complex Area .....

5.2. Nitrate Groundwater Plumes below the Entire 200-E Area (based on much fewer wells

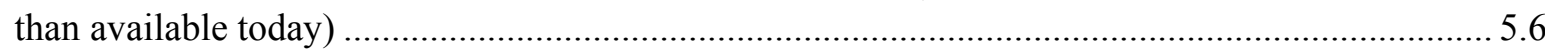

5.3. Time Series (1995 to 2007) Plume Maps for Nitrate in the B-Complex Region ........................... 5.7 


\section{Figures}

5.4. Groundwater Nitrate Plume Map for Samples Collected in Spring 2008 ....................................5.9

5.5. Groundwater Nitrate Plume Map for Samples Collected in Fall 2008....................................... 5.10

5.6. Groundwater Nitrate Plume Map for Samples Collected in Spring 2009 .................................... 5.11

5.7. Groundwater Nitrate Plume Map for Samples Collected in Fall 2009........................................ 5.12

5.8. Times Series Technetium-99 Groundwater Plume Maps for 200-E Area.................................... 5.14

5.9. Time Series (2002 to 2007) Plume Maps for Technetium-99 in the B-Complex Region.............. 5.15

5.10. Groundwater Technetium-99 Plume Map for Samples Collected in Spring 2008 ….................. 5.17

5.11. Groundwater Technetium-99 Plume Map for Samples Collected in Fall 2008 ........................... 5.18

5.12. Groundwater Nitrate Plume Map for Samples Collected in Spring 2009 .................................. 5.19

5.13. Groundwater Technetium-99 Plume Map for Samples Collected in Fall 2009 ........................... 5.20

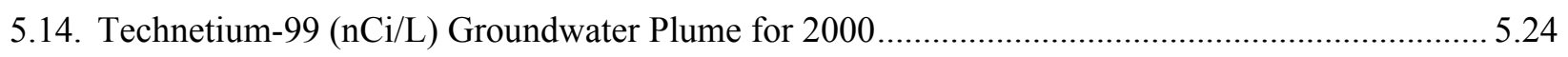

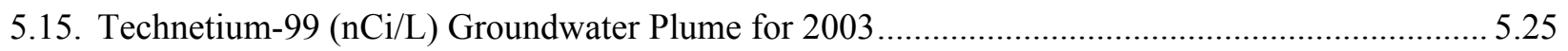

5.16. Technetium-99 (nCi/L) Groundwater Plume for 2006 …........................................................... 5.26

5.17. Technetium-99 (nCi/L) Groundwater Plume for 2009 ….......................................................... 5.27

5.18. Technetium-99 (nCi/L) Groundwater Plume Below B-Complex for 2000 ................................ 5.28

5.19. Technetium-99 (nCi/L) Groundwater Plume Below B-Complex for 2003 ................................ 5.29

5.20. Technetium-99 (nCi/L) Groundwater Plume Below B-Complex for 2006 ................................. 5.30

5.21. Technetium-99 (nCi/L) Groundwater Plume Below B-Complex for 2009 ................................. 5.31

5.22. Cyanide $(\mu \mathrm{g} / \mathrm{L})$ Groundwater Plume Time Series for 200-E Area (1992-1999).......................... 5.35

5.23. Cyanide $(\mu \mathrm{g} / \mathrm{L})$ Groundwater Plume Time Series for 200-E Area (2001-2008)......................... 5.36

5.24. Cyanide Groundwater Plume Map for the B-Complex for 2007 (from DOE/RL-2007c) ............ 5.38

5.25. Cyanide $(\mu \mathrm{g} / \mathrm{L})$ Groundwater Plume for B-Complex and to the North for Year 2000 ................. 5.39

5.26. Cyanide $(\mu \mathrm{g} / \mathrm{L})$ Groundwater Plume for B-Complex and to the North for Year 2003 .................. 5.40

5.27. Cyanide $(\mu \mathrm{g} / \mathrm{L})$ Groundwater Plume for B-Complex and to the North for Year 2006 ................. 5.41

5.28. Cyanide $(\mu \mathrm{g} / \mathrm{L})$ Groundwater Plume for B-Complex and to the North for Year 2009 ................. 5.42

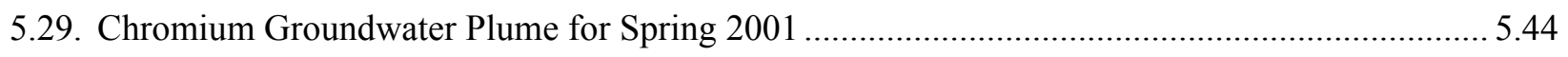

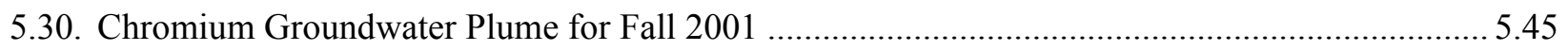

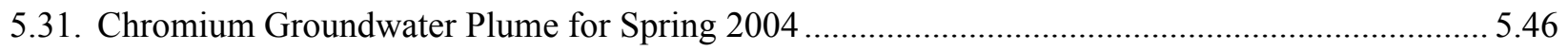

5.32. Chromium Groundwater Plume for Fall 2004 ............................................................................... 5.47

5.33. Chromium Groundwater Plume for Spring 2008 .................................................................... 5.48

5.34. Chromium Groundwater Plume for Fall 2008 ............................................................................ 5.49

5.35. Uranium Groundwater Plume Maps for Entire 200-East Area for Early Years........................... 5.52

5.36. Time Series Groundwater Plume Maps for U in B-Complex (2003, 2006, and 2007) ................. 5.53

5.37. Uranium Groundwater Plume for Fall 2007........................................................................... 5.54 
PNNL-19277

\section{Figures}

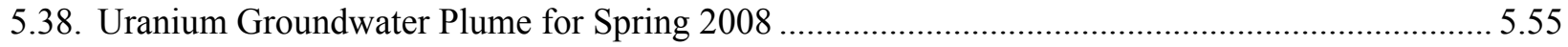

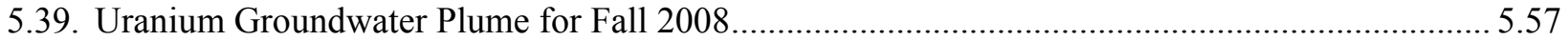

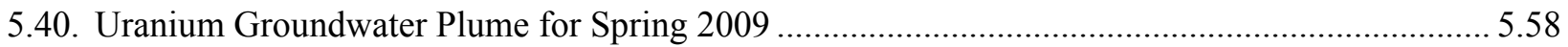

5.41. Groundwater Uranium ( $\mu \mathrm{g} / \mathrm{L}$ ) Plume Map for Year 2000 ........................................................... 5.60

5.42. Groundwater Uranium $(\mu \mathrm{g} / \mathrm{L})$ Plume Map for Year 2003 ........................................................ 5.61

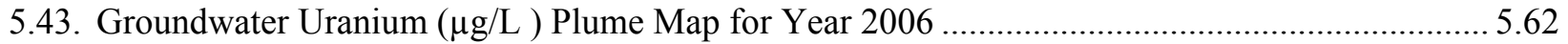

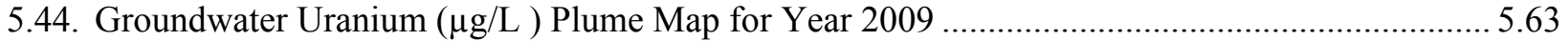

5.45. Uranium Signature for Groundwater and Perched Water from Wells 299-E33-205,

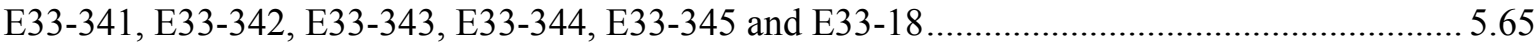

5.46. Expanded Scale Uranium Signatures for Groundwater from Wells 299-E33-205, E33-341, E33-342, E33-343, E33-344, E33-345 and E33-18

6.1. Groundwater Nitrate (black symbols) and Technetium-99 (green symbols) at E33-7 Over the Last 10 Years

6.2. Erosional Feature Formed after Heavy Rain Event Between East Side of B-57 Crib Barrier and Southwest Corner of BY Tank Farm.....

9.1. Conceptual Model for U Descent and Lateral Spreading from BX-102 (based on SGLS) 9.11

9.2. Uranium Isotope Signature Results for all Recent Vadose Zone Pore Waters. 9.15

10.1. Location Map for Extent of $\mathrm{CCU}_{z}$ Below B-Complex 10.2 


\section{Tables}

1.1. New 200-BP5 OU Boreholes Used to Augment Historical Information ...................................... 1.5

1.2. Listing of Historical groundwater Monitoring Reports............................................................ 1.15

1.3. Available Data to Estimate Vadose Zone Inventory for Technetium-99 and Uranium ................ 1.26

2.1. Boreholes Used to Generate Geology Conceptual Model.............................................................. 2.1

2.2. Drilling Methods, Data Quality Ranking and Other Information on Boreholes Used to Generate the Geology Conceptual Model ............................................................................... 2.9

2.3. Lithostratigraphic Terminology Used in this Report for the Vadose Zone Beneath the

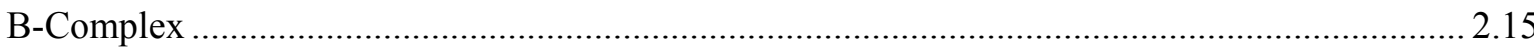

2.4. Maximum and Minimum Water Levels for 200-BP-5 Wells.................................................... 2.32

3.1. BY and B-57 Cribs Subregion Facility Details (includes BY-201 Settling Tank).......................3.3

3.2. Vadose Zone Sediment Extract Data for Boreholes In or Near B-49 Crib ................................... 3.7

3.3. Vadose Zone Sediment Extract Data for Boreholes In or Near B-43 Crib ................................... 3.9

3.4. Vadose Zone Sediment Extract Data for Borehole 299-E33-304 In the Footprint of B-57 Crib ... 3.28

3.5. Inventory Estimates for Technetium and Uranium in Vadose Zone Below BY Cribs Facility Conceptual Model \#1

3.6. Inventory Estimates for Technetium and Uranium in Vadose Zone Below BY Cribs Facility Conceptual Model \#2

3.7. Inventory Estimates for Technetium and Uranium in Vadose Zone Below BY Cribs Facility Conceptual Model \#3

3.8. Estimates of Masses of Technetium-99 and Uranium Remaining in Vadose Zone Sediment

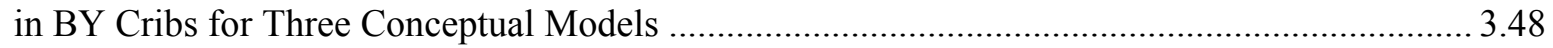

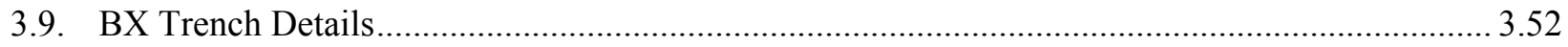

3.10. Vertical Distribution of Selected Constituents in Sediments from C3104 (B-38 Trench) ............ 3.58

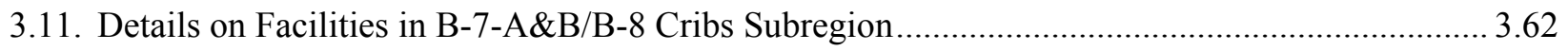

3.12. Selected Sediment Data vs. Depth for Borehole C3103 Through B-7-A Footprint...................... 3.68

3.13. Vertical Distribution of Potentially Mobile Constituents in Sediments at Two New BP-5

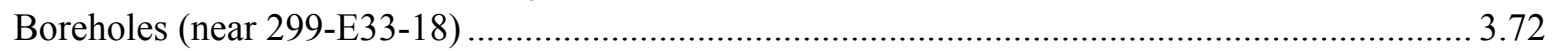

3.14. Mass Estimates for Technetium-99 and Total and Water-Leachable Uranium in Vadose

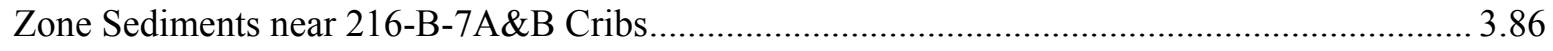

3.15. BX Tank Farm Waste Release Status and Estimates of Inventory Released ............................... 3.90

3.16. Vertical Distribution of Selected Mobile Constituents in Sediments South and Southeast of Tank BX-102.

3.17. SGLS Field Observations on Hanford Processed Uranium Increases in Deep Vadose Zone at $299-E 33-18$

3.18. Vertical Distribution of Selected Constituents in Sediments from 299-E33-205 (north of BX-106). 


\section{Tables}

3.19. Vertical Distribution of Selected Constituents in Sediments from 299-E33-343 3.108

3.20. Inventory Calculations for 3 Hypothetical Regions Hypothesized to Contain BX-102 Waste Fluids

3.21. BY Tank Integrity Status, Volumes Released and Masses Released

3.22. B Tank Farm Leak Status and Leak Inventories 3.128

3.23. Vertical Distribution of Selected Chemicals and Radionuclides in Sediments Within B Tank Farm

3.24. Total Mass/Activity of Constituents Released from Each Facility to the Subsurface by Localized Regions

3.25. Summary Information on Volumes Disposed of and Masses/Activities Released to the Vadose Zone for Subregions of B-Complex

4.1. B-Complex Mean and Maximum/Minimum Ranges for van Genuchten Parameters and $\mathrm{K}_{\mathrm{s}}$

4.2. B-Complex Mean and Maximum/Minimum Ranges of Bulk Density $\left(\rho_{b}\right)$ 4.6

4.3. B-Complex Mean and Maximum/Minimum Ranges of Total Porosity $\left(\mathrm{p}_{\mathrm{t}}\right)$ and Effective Porosity $\left(\mathrm{p}_{\mathrm{e}}\right)$

4.4. B-Complex Mean and Maximum/Minimum Ranges of Field Capacity $\left(\theta_{\mathrm{fc}}\right)$ and Campbell b Parameter.

4.5. Longitudinal $\left(\mathrm{A}_{\mathrm{L}}\right)$ and Transverse $\left(\mathrm{A}_{\mathrm{T}}\right)$ Dispersivity Estimates.

4.6. B-Complex Estimated Mean and Maximum/Minimum Ranges of Recharge 4.10

4.7. Aquifer Field Test with $\mathrm{K}_{\mathrm{sat}}$ Results in the Vicinity of the B-Complex Area 4.11

4.8. Transmissivity Estimated from Development Pumping of Wells in the Vicinity of the B-Complex Area 4.15

5.1. Details for B-Complex Groundwater Monitoring Wells.

5.2. Estimates of Mass of Technetium-99 in Aquifer for Selected Years and \% Change Between Successive Time Periods by Plume Subregion ....

5.3. Estimates of Cyanide $(\mathrm{CN})$ Mass $(\mathrm{kg})$ in Groundwater Plume Below B-Complex

5.4. Estimated Mass ( $\mathrm{kg}$ ) of Uranium Contained in Groundwater Plume for Selected Years

6.1. Mass Balance for Technetium-99 in the BY Cribs Sub-Region

6.2. Estimated Mass of Uranium Below BY Cribs and Comparison to Current Mass of Uranium in Groundwater and Mass Disposed to BY Cribs

6.3. Mass Balance Estimates for Tc-99 Below B-7-A\&B Cribs in Comparison to Current Groundwater Plume and Mass Disposed to B-7-A\&B/B-8 Cribs Subregion

6.4. Mass Balance Estimates for Uranium Below B-7-A\&B Cribs in Comparison to Current Groundwater Plume and Mass Disposed to B-7-A Sub-Region

6.5. Mass Balance Estimates for Uranium Below BX-102 Subregion in Comparison to Current Groundwater Plume and Mass Lost from BX-102.... 
PNNL-19277

\section{Tables}

6.6. Mass Balance Estimates for Technetium-99 Below BX-102 Subregion in Comparison to Current Groundwater Plume and Mass Lost from BX-102..

6.7. Qualitative Description of Strength and Weakness of Integrated VZ/groundwater Models Used to Identify Sources of groundwater Contamination

8.1. Details on Geologic Contacts .

8.2. Hydrologic Parameters for RESRAD.

8.3. Recommended Values and Ranges for Mobile Contaminants in Vadose Zone for B-Complex .....

9.1. Summary by Region of the Percentage Volume and Mass of Contaminants Disposed of.

9.2. Summary Estimates of Mass in Vadose Zone, Deep Vadose, and groundwater by Subregion for Most Realistic Conceptual Models and Comparison to Entire B-Complex Masses Released. 
PNNL-19277

\subsection{Introduction}

\subsection{Project Goal}

The overall goal of the project documented in this report was to develop a single primary conceptual model, and if appropriate, alternative conceptual models, to describe the migration of key groundwater risk-driver contaminants and the mechanisms that control the fate of these contaminants as they travel from the near-ground surface disposal facilities to the upper unconfined aquifer. Both the intentional and unintentional releases (pipeline leaks, surface spills, and tank overfills) are considered in these conceptual models. The conceptual models support the overall Remedial Investigation/Feasibility Study (RI/FS) for the 200-BP-5 Operable Unit (OU). In support of the RI/FS, this report focuses on describing the strengths and weaknesses of the conceptual models for two key risk drivers, technetium-99 and uranium. After critically analyzing the available data on disposal history, current vadose nature and extent, and the location and concentrations of these two contaminants currently in the groundwater, it was decided that only one conceptual model for each contaminant for individual facility subregions could account for the vast majority of the mass found in the current groundwater plume.

This report focuses on the area below the inactive crib and trench facilities known as BY Cribs, BX Trenches, B-7-A\&B Crib, B-8 Crib and Tile Field, B-11A\&B French Drains, B-51 French Drain, and B$57 \mathrm{Crib}$ as well as the three single-shell tank (SST) farms contained within Waste Management Area (WMA) B: B (16 tanks), WMA BX-BY: BX (12 tanks), and WMA BY: BY (12 tanks). This aggregated region is known as the B-Complex in some of the historical Hanford reports. A map of the B-Complex region and the facilities within is found in Figure 1.1.

For ease of discussion of the B-Complex region is divided into five subregions: 1) BY and B-57 Cribs, 2) BX Trenches, 3) B-7-A\&B and B-8 Cribs and B-11-A\&B and B-51 French Drains, 4) BX and BY Tank Farms (WMA BX-BY), and 5) B Tank Farm (WMA B). The subregion discussions include descriptions of the disposal facilities, the volume of waste disposed of, the masses and activities of key chemicals and radionuclides disposed of, the current distribution of key constituents in the vadose zone, historical and current groundwater concentrations below and proximal to the facilities, and the conceptual models for how key constituents migrate from the disposal facility to the water table, including subsequent migration in the groundwater. In addition, sections on the B-Complex geology and physical, hydrologic, and geochemical properties of the various strata below the B-Complex are provided.

The most supported conceptual model for the current, and apparently growing, technetium-99 groundwater plume below the B-Complex and beyond to the north and northwest assigns the major source as the BY Cribs. Minor amounts of technetium-99 from another inactive facility or tank farm, in comparison to the amounts descending out of the deep vadose zone below the BY cribs area, appear to be reaching the groundwater near borehole 299-E33-343, but this contribution is dwarfed by the BY cribs' source. The conceptual model for the vast majority of the uranium found in the current and growing groundwater plume below the B-Complex is the 1951 overfill event at BX-102. Fluids from this event have contaminated the Hanford formation H2 unit sediments northeast of tank BX-102. The point of entry of the uranium to the aquifer again appears to be near borehole 299-E33-343, also to the northeast of $\mathrm{BX}-102$. At this location the $\mathrm{CCU}_{\mathrm{z}}$ unit is very moist and in places saturated with water. 


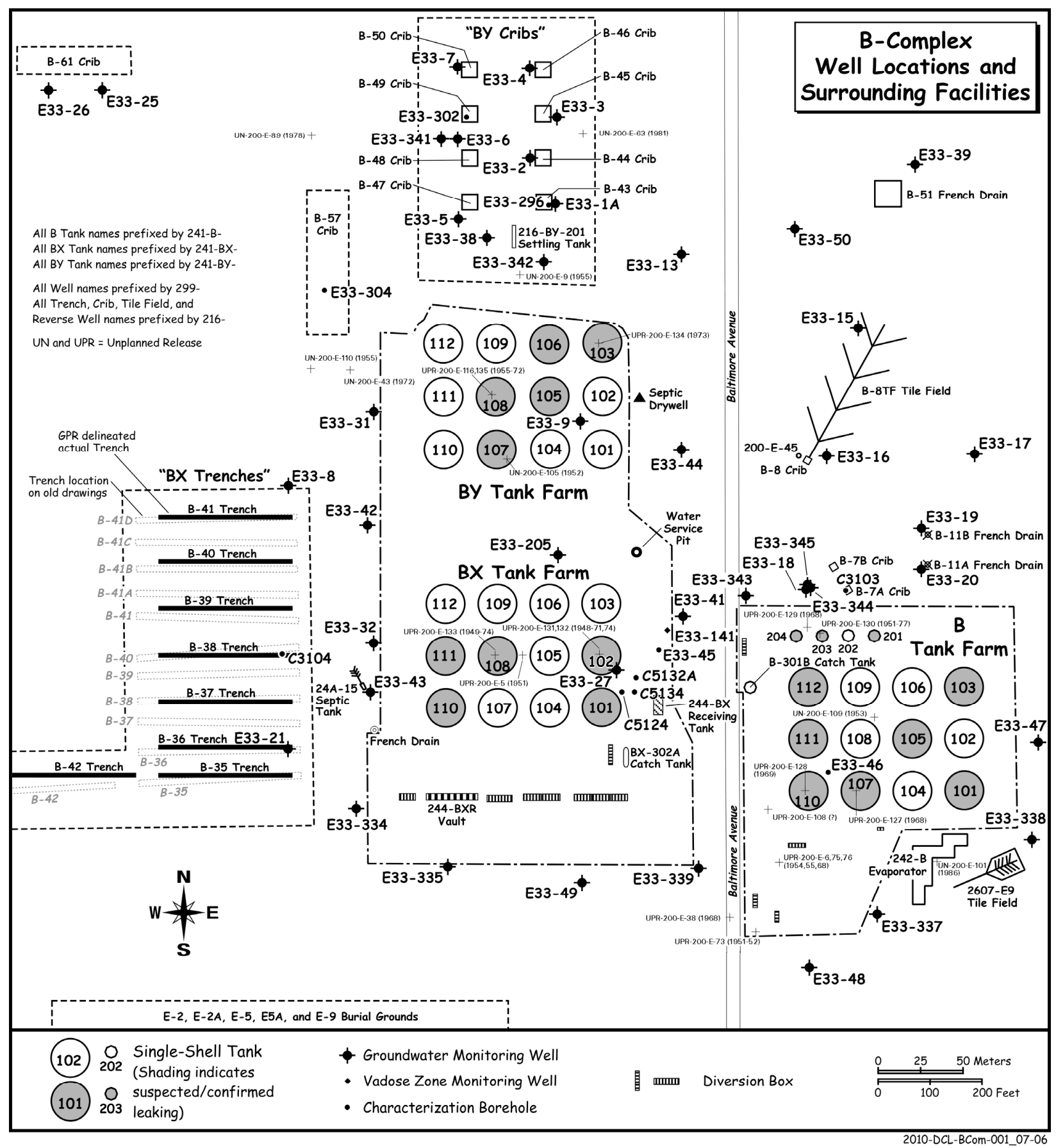

Figure 1.1. Map of B-Complex Area Showing Facilities and Key Boreholes and Wells 
At some point, fluids are descending through the capillary break between the overlying fine-grained $\mathrm{CCU}_{\mathrm{z}}$ sediments into the $\mathrm{CCU}_{\mathrm{g}}$ coarser grained sediments in which the water table resides. The uranium is then migrating with the regional groundwater to the northwest. Very small amounts of uranium from other inactive facilities and tank farms, in comparison to the amounts descending out of the $\mathrm{CCU}_{\mathrm{z}}$ unit near borehole 299-E33-343 area, may be reaching the groundwater at other locations, but their contributions are minor to the amount entering near borehole 299-E33-343. Numerical vadose zone flow and transport modeling predictions should be performed to aid in determining why the uranium residing within the $\mathrm{CCU}_{\mathrm{z}}$ in the deep vadose zone has been descending into the aquifer at increasing rates over the past 3 to 5 years. Such predictions will benefit from the availability of the new and collated historical data provided in this report.

The bulk of this report tabulates the available data on the facilities with emphasis on timing of disposal, volumes disposed of, the mass of constituents disposed of, and the horizontal and vertical extent of key mobile contaminants within the vadose sediments directly below the inactive facilities. The vadose zone data were then paired with historical and current groundwater monitoring data to determine probable locations for the contaminant entry into the aquifer. The plausible pathways were then compared with the B-Complex geology conceptual model that was generated from a critical analysis of borehole data on stratigraphic contacts that allowed a detailed three-dimensional (3D) visualization to be generated using EarthVision ${ }^{\circledR}$ software. A key to pathway comparison was to identify whether the strata dip in the same direction as the observed vadose zone contaminant distributions would imply. The authors also provide a review of and recommend values for the parameters needed to perform fate and transport predictions. This is so that numerical modeling of the conceptual models can be performed to investigate whether the hypothesized pathways from the sources to the water table and subsequent migration with the regional groundwater are realistic. Such numerical modeling efforts were not part of the scope of this project.

The data values (most plausible and min-max ranges) that are provided can be used to guide selection of and as input to various fate and transport codes. It is anticipated that fate and transport models will be used to predict current and future groundwater risks and the efficacy of potential remediation alternatives. The selection of the key parameter values used both historical data and data from the new BP-5 OU wells that have been drilled over the last 4 years. Details on the rationale for the drilling and sediment and subsurface water characterization objectives can be found in the 200-BP-5 groundwater Operable Unit Work Plan (DOE/RL 2008a) and the Data Quality Objective Summary Report (Thomas 2008).

\subsection{Scope}

The scope of this report is limited to the B-Complex region of the overall 200-BP-5 OU. Should additional 200-BP-5 wells be drilled that provide new data, either supporting or refuting the proffered conceptual models, it is anticipated that this report would eventually be revised to encompass the new data. Other BP-5 characterization wells outside the B-Complex region have been drilled over the past 4 years, and a few more are planned. The data from these other wells could also be incorporated into a revision of this report, or a separate report could be prepared to address the larger BP-5 groundwater OU. The conceptual models for the pathway from the sources to the groundwater for key contaminants discussed herein provide 1) an interpretation of the historical and newly acquired data in the context of determining an appropriate conceptual model, 2) the vertical extent, and to a more limited extent the 
horizontal distribution, of contamination in the vadose zone, 3) the migration potential of the contaminants that still reside in the vadose zone, and 4) the correspondence of the contaminant distributions in the borehole sediment samples to groundwater plumes in the unconfined aquifer proximate and down-gradient from the B-Complex area.

This report does not include discussions on the low-level solid waste burial grounds or WMA C facilities within the 200-BP-5 OU that also contain chemical and radiological wastes that could potentially or may have impacted the vadose zone and groundwater in the B-Complex and overall BP-5 OU, respectively. Further, contamination that exists in the Gable Mountain/Gable Butte gap area north of the 200 East Area as well as in the confined aquifers under the BP-5 OU have not been discussed in any detail in this report. The issues of existing and future groundwater contamination in the confined aquifers and the current and future for groundwater flow to the north through the Gable Mountain/Gable Butte gap are not addressed in this report. The key concern about northerly flow of groundwater through the Gable Mountain/Gable Butte gap area towards the Columbia River is that such flow may provide a shorter travel time to the Columbia River than flow out of the 200 East Area to the east. However, with the receding water table and relatively shallow occurrence of basalt bedrock in the Gable Mountain/Gable Butte gap area, the basalt may form a barrier to northerly groundwater flow if the lowering trend for the unconfined aquifer continues. The authors propose that the possibility of contaminated groundwater flowing through fractures or erosional channels in the basalt bedrock or in confined aquifers in the Gable Mountain/Gable Butte gap area that might allow continued "short-circuiting" to the Columbia River should be studied in future years. The subsurface surrounding WMA $\mathrm{C}$ is also actively being investigated, and more vadose zone boreholes and groundwater monitoring wells are planned by both the Hanford operations contractors (CH2M-Hill Central Plateau Remediation Company/Washington River Protection Solutions [CHPRC and WRPS]) that will significantly add to the available WMA C data set.

Secondary goals for this report are to publish the analytical data produced by the characterization efforts on the subsurface sediments (vadose zone and aquifer) and fluids (1:1 sediment to de-ionized water extracts, ultracentrifuge directly extracted vadose zone pore waters, and groundwater) obtained for the 200-BP-5 OU boreholes emplaced over the last 4 years. Most of the data collected on the sediments from the BP-5 boreholes were used (along with available historical data) to generate the conceptual models discussed herein for the two key mobile contaminants (technetium-99 and uranium) in the subsurface so that future mobility and groundwater impacts can be evaluated. From the conceptual models presented herein and the available sediment characterization data, baseline risk assessments and guidance on choosing remedial-action alternatives are possible. Finally, the newly acquired data and analyses can aid in the future decisions that must be made by the U.S. Department of Energy (DOE) regarding the near-term operations, future waste site remediation, and final closure activities for the inactive disposal facilities.

The appendices of this report contain the salient geologic, hydrological, geophysical, geochemical and selected physical characterization data collected on sediments and waters recovered from eight boreholes placed within the BP5 OU (see Table 1.1 for a listing of the boreholes). The locations of these new wells are shown in Figure 1.2. The appendices also provide support to the interpretation of the appropriate hydro-geologic model, the vertical extent of contamination, the migration potential of the contaminants that still reside in the vadose zone, and the correspondence of the contaminant distribution in the borehole sediment to groundwater plumes in the unconfined aquifer proximate and down-gradient from the B-Complex. 
This report focuses on the conceptual model discussion on key contaminants that are currently impacting the groundwater below the B-Complex. Specifically, this report addresses uranium and technetium-99 in detail and nitrate/nitrite, cyanide, chromium (VI), cobalt-60, and other major constituents that impact the fate of the selected contaminants (common divalent cations [calcium and magnesium], sodium, sulfate, alkalinity, fluoride, and $\mathrm{pH}$ and specific electrical conductivity) in less detail. There is a much larger list of potential contaminants of concern listed in WMP-28945, Rev. 1, Section 1.8 (Thomas 2008), where Tables 1-7 and 1-10 show the final list of contaminants of potential concern for the vadose zone and groundwater, respectively. The list reported herein has been shortened to those contaminants that have been measured frequently in the groundwater below the B-Complex and are present over a significant enough area to merit being described as a "plume." Using known reviews of contaminant interactions with sediments (see, for example, EPA 1999a, 1999b, and 2004; Cantrell et al. 2003, 2008), many potential contaminants of concern listed in Table 1-7 of WMP-28945 Rev. 1 (Thomas 2008) are found solely in the shallow sediments below the inactive disposal sites and are not expected to reach the groundwater in significant concentrations.

Table 1.1. New 200-BP5 OU Boreholes Used to Augment Historical Information

\begin{tabular}{ccc}
\hline Well Letter & Borehole \# & Well \# \\
\hline A & C5858 & 299-E33-343 \\
B & C5859 & 299-E33-344 \\
B' & C6226 & 299-E33-345 \\
C & C5989 & 299-E33-205 \\
D & C5856 & 299-E33-341 \\
E & C5857 & $299-E 33-342$ \\
F & C5195 & $299-E 33-50$ \\
G & C5853 & 299-E33-340 \\
\hline
\end{tabular}




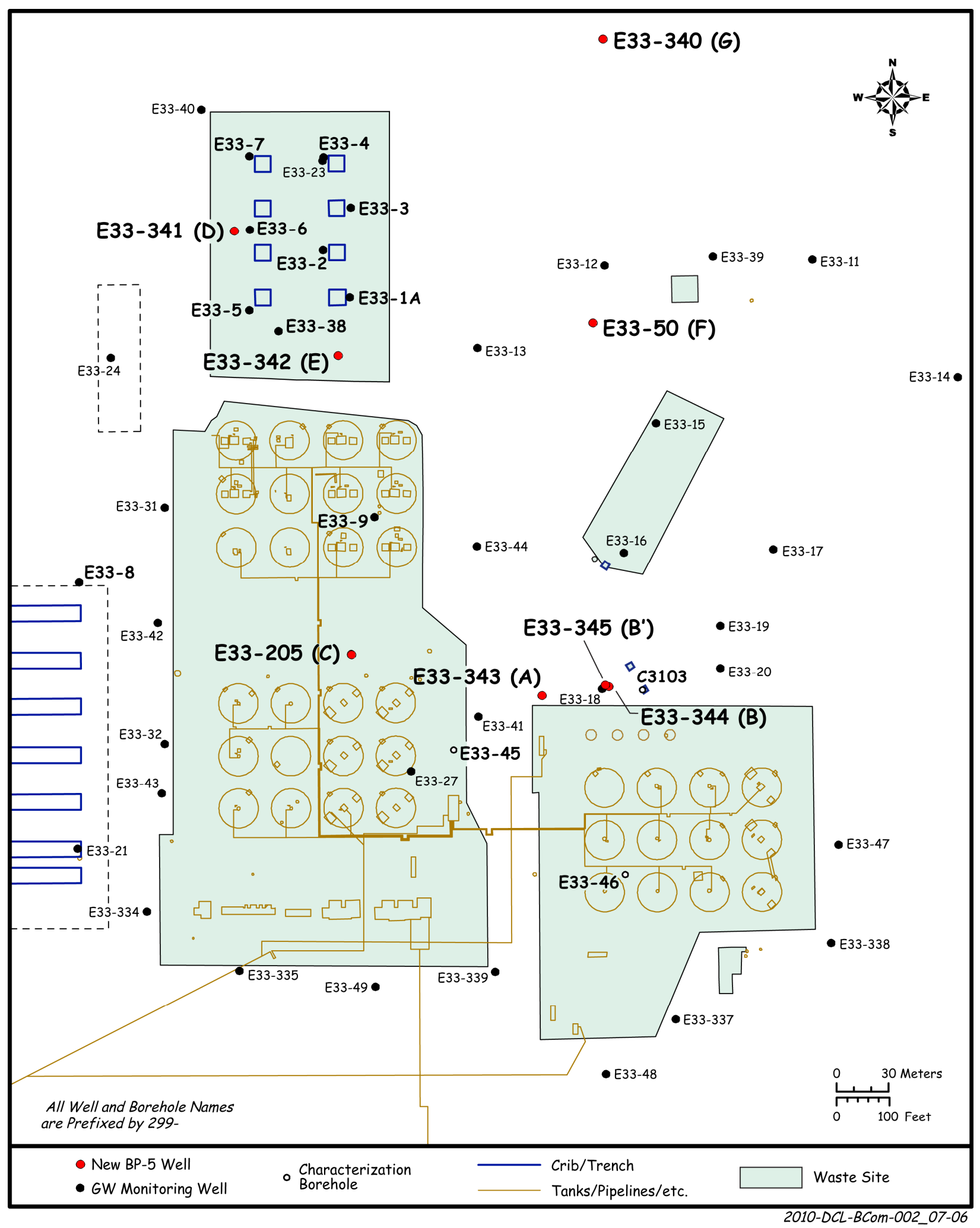

Figure 1.2. Map of New Boreholes in B-Complex Area 


\subsection{Report Organization}

Within the introduction, the authors delineate the objectives and scope of the report and present background information on where the details for the facility's descriptions, the operation time lines, and the volumes of waste disposed of and chemical and radionuclide inventories were obtained. A listing of the historical groundwater monitoring reports that were reviewed to aid in determining the locations where and the timing when contaminants entered the groundwater are found in Table 1.2.

This report continues with a description of the geology below the B-Complex and then presents all the background information and the conceptual models for the vadose zone contaminant distributions and groundwater plumes for each of the five subregions identified in the introduction. The background information for each major facility in each subregion provides details on the disposal/storage facilities from whence the wastes were intentionally or accidently released followed by a summary of the types of contaminants and their current vertical and horizontal extent in the B-Complex area in both the vadose zone and aquifer. After these background sections, the subregion discussion presents the most robust conceptual model(s) for the vadose zone and unconfined aquifer for technetium-99 and uranium, followed by a summary of each conceptual model's strengths and weaknesses. After the subregional conceptual models are discussed, they are melded together where they overlap to present a B-Complex wide groundwater conceptual model that discusses regional groundwater flow and the changes in mass of technetium-99 and uranium found over the last decade. The report also contains a section (Section 4) on hydrologic properties of the various sedimentary strata found below the B-Complex, a brief discussion of the potential for future groundwater impacts (Section 7), and a section (Section 8) with tables listing recommended values and ranges for the parameters that most fate and transport codes require to project future migration of contaminants. Finally, the report ends with a summary (Section 9), a recommendations section (Section 10), and a reference section (Section 11). There are also several appendices with supporting details for many of the sections found in the main report.

The appendices provide more details and tables for 1) the waste source inventories, 2) the recommended geologic model (the elevation of the geologic contacts between the various sediment units at many boreholes), 3) the hydrologic system (details on how new hydraulic conductivity data were collected, interpreted, and merged with historical data), 4) electronic files with the analytical data from the eight new boreholes, the uranium isotopic signature raw data, digital photographs of the grab samples from each borehole, and geologic details obtained by visual inspection of the grab samples in the laboratory during processing to provide representative aliquots for the various measurements, 5) the uranium isotopic signature raw data, 6) detailed spreadsheets for the mass estimates for vadose zone sediment inventory and overall mass balances, and 7) geophysical logs for gamma activities and neutron moisture for key boreholes. The values for the total or strong acid-extractable and waterextractable concentrations of selected constituents found in Appendix D have also been uploaded into the Hanford Environmental Information System (HEIS) and newly created Environmental Data Access (EDA) databases. 
PNNL-19277

\subsection{Sources and Rationale Used to Select Facility Information}

\subsubsection{Cribs, Trenches, French Drains, Tile Fields, and Settling Tanks}

Key data for determining the sources of vadose zone and groundwater contamination include the volumes of waste disposed of, the total inventory of major constituents and contaminants of interest associated with the disposed wastes, and the time of disposal or accidental leak event. Short descriptions of the chemical processes that led to the waste streams disposed of to cribs, trenches, and reverse wells in the B-Complex are found in Appendices A and B of the Data Quality Objectives (DQO) Summary Document (Thomas 2008) and the references cited therein. For readers who want more detail, there is the Hanford Defined Waste technical report series (current Version 5; Higley and Place 2004) that categorizes the major waste streams and offers brief descriptions of the various processes. Higley and Place (2004) relied heavily on technical manuals for each of the three main reprocessing procedures used at Hanford: Bismuth Phosphate Precipitation, Reduction Oxidation (REDOX), and Plutonium-Uranium Extraction (PUREX) solvent extractions to define the major wastes produced. Further, the Hanford Defined Waste (HDW) report used technical manuals/flow sheets for the uranium recovery and strontium-90 and cesium137 removal processes to provide additional estimates of the chemical composition of the wastes generated and sent to the cribs, trenches, and SST. References to most of the technical manuals and some of the early documents on waste characterization are found in Appendices A and B in Thomas (2008) and in the reference section of Higley and Place (2004).

The HDW Model is a spreadsheet-based engineering estimate of the chemical and radionuclide contents of Hanford Site waste streams. HDW calculations are based on process knowledge, which includes, but is not limited to, reactor fuel irradiation records, irradiated fuel plant dissolver charging records, plutonium/uranium separation plant and tank farm process flow sheets, and tank farm waste receipt and transfer records. The constituent inventory calculations were made using Microsoft ${ }^{\circledR}$ Excel software and conventionally available personal computers. The formation of primary waste stream compositions, such as sludges and saltcakes (e.g., evaporator concentrates), is estimated by applying waste-stream-specific analyte solubility limits to each of the plant waste streams. A macro-driven subroutine within the HDW Model calculates the fraction of each waste stream that precipitates as sludge or saltcake and enters the fractions into the waste stream composition calculation such that two distinct compositions (solids and solution) are generated for each waste stream. Using this information, SST tank compositions can be calculated as a function of time using additional subroutines within the HDW Model by calculating the cross-product of the waste stream compositions and their respective contributing volumes (both solid and liquid phases) at various points within a tank's operating lifetime.

In addition to estimating the composition of the primary separation process wastes discharged from the Bismuth Phosphate, REDOX, and PUREX process facilities, HDW calculations also simulate the various re-processing efforts that occurred and their corresponding waste streams as well. Reprocessing campaigns include tributyl phosphate (TBP) Plant (uranium recovery), Hot Semiworks Plant, B Plant (cesium and strontium recovery), and various tank farm evaporations (including tank waste selfconcentration). The waste streams from these second-tier processes are calculated using the principal waste streams discharged from the Bismuth Phosphate, REDOX, and PUREX process facilities as the starting composition. A selected subset of radionuclide concentrations for each waste stream is also 
calculated from the ORIGEN2 radionuclide inventory for irradiated fuel processed through each separations plant and assigned using a set of radionuclide distribution factors and solubilities specific to the particular separation process.

Another useful resource for estimating waste stream inventories is Appendix B in the Resource Conservation and Recovery Act Facility Investigation (RFI) Report for Hanford Single-Shell Tank Waste Management Areas, DOE/ORP-2008-01 (DOE/ORP 2008), co-coordinated by the tank farm contractor, which can be accessed at

\section{http://wrpstoc.com.s59537.gridserver.com/uploads/files/tier2/Appendix_B_Inventory.pdf.}

It is beyond the scope of this report to critically review the waste stream compositions and total inventories disposed of to the facilities found in the B-Complex area. Instead, the authors deferred to the most recent version the Soil Inventory Model (SIM) (Corbin et al. 2005), which relies heavily on the HDW Model, Version 5 (Higley and Place 2004) to select the inventory values in the tables that follow in Section 3. These include each of the five subregions discussed and individual waste stream chemical compositions when needed in the interpretation of contaminant mobility. In SIM, the HDW waste stream compositions are used as a basis to calculate the inventories associated with liquid waste disposal sites and unplanned releases (UPRs). The HDW feature that calculates SST compositions as a function of time is also used by SIM to develop tank farm leak descriptions specific to any given loss event.

A principal assumption of the HDW Model is that a limited set of waste streams can be used to represent all the wastes that emanated from the plutonium separation processes used at the Hanford Site despite the fact that the processes evolved and changed over time. Appendix A in this report lists the set of waste streams that HDW (and thus SIM) uses, and the electronic Appendix D of the SIM model contains the chemical composition of the solution and solid phases for each of these "basis" waste streams.

A second key assumption of particular importance to the SIM model calculations for the various cribs and trenches is that very few waste streams disposed of to the past-practice waste sites (e.g., cribs and trenches) possessed solids. Thus, only the solution portion of the HDW calculations and not the solids portion of each basis waste stream are generally used in the SIM estimates, which were used in this report. Solids are ignored, in general, because of the waste management and surveillance practices employed during production operations and the general physical constraints of the system with regard to particulate entrainment (e.g., radiation monitors, settling tanks, no agitation, passive filtration, etc. in the tank-canyon systems). This entrainment precluded solids from being piped to the cribs and trenches. Therefore, the default condition for SIM is not to incorporate entrained solids. However, for certain waste streams and waste sites, the inclusion of entrained solids is reasonable from a physical and waste management operations perspective; for example, SIM documentation suggests that laboratory wastes, decontamination wastes, cold start wastes, and fuel cladding were all likely to have solids, and in certain instances, the surveillance data suggest that solids were present. In addition, there were selected process excursions (piping failures, overflow conditions, or poor settling) where the conventional waste management practices were inadequate to maintain particulate containment. Thus, the presence of solids in the disposal site's description of operations was allowed when such information was noted. Solids inclusion in the waste stream was tracked for each site on a yearly basis; that is, if solids were noted at any time during any given year, the entire year's volume discharged was calculated with a certain percentage of solids. The SIM documentation in Corbin et al. (2005) suggests that $\sim 21 \%$ of the disposal sites received solids at some point in their operating history. 
Besides SIM values used in this report, the authors looked at the current electronic version of the Waste Information Data System (WIDS) and Stenner et al. (1988) to see if the references were in general agreement on facility operating periods, types of waste disposed of, and volumes discharged. When data from these three sources differed significantly, the authors have noted/compared it with SIM. Again, it is stressed that the SIM data were used exclusively to populate the volumes disposed of and chemical and radionuclide inventories released to the subsurface unless supporting evidence from another source was more defensible. When a different source was chosen for the key information, it is noted in the tables found in Section 3.

\subsubsection{Source of Single-Shell Tank Information and Rationale}

The current reference that tabulates the status of SST integrity, the timing of past releases of fluids, and the estimated release volumes is a series of status reports generally called the Hanlon reports (e.g., Hanlon 2006) that is updated when significant new evaluations have been made. A second resource is Field and Jones (2006) that revisited the timing of past releases and the estimated release volumes. Field and Jones (2006) release volume estimates are identical to those used in the current version of the SIM model, which are the values used in this report.

A formal process was established several years ago wherein the tank farm contractor (WRPS) and the state regulator (Department of Ecology) review historical and any new information that is obtained for the SST status (see Field et al. 2007 for details). However, the B, BX, and BY tank farms have not yet been re-evaluated using this process. Formerly, these were relied upon to be the best resource. Another resource that describes the status of SSTs is the WIDS database, which can be accessed for persons inside the Hanford firewall at URL $:<$ http://www2.rl.gov/phmc/cp/wids/>.

The authors reviewed all of these resources but used the tank leak status found in Hanlon (2006) and the release volume and waste types found in SIM, Rev 1 (Corbin et al. 2005) in this report. Based on the complicated operations history of inputs and exports of fluids to most of the SSTs, it is a challenge to determine 1) when fluids were released to the subsurface, 2) the volumes of fluid released, and 3) the chemical composition of the released fluids. In many cases, a release was assumed when the operating contractor noticed an unexplained drop in liquid level measured inside a tank. However, chemical reactions, and sludge consolidation confound using drops in liquid levels as a definitive sign of lost fluids. The liquid-level gauges also have a short operating lifetime in the highly corrosive and high-radiation environment inside the SSTs. A second monitoring method is to measure the gamma activity in the subsurface around the SSTs through dry wells drilled around the tanks. The areal coverage of dry monitoring wells around individual tanks varies such that small volume leaks might not be detected. The highly heterogeneous subsurface lithology can also cause released fluids to channel along discrete flow paths as opposed to spreading uniformly through the vadose zone porosity, perhaps allowing fluids to travel undetected past the discrete monitoring dry well locations. Further, most gamma-emitting radionuclides interact moderately to strongly with the sediments (adsorption) such that they do not migrate as far as the released fluids. Surface spills and leaks from the shallow pipe lines that are present between the SSTs also confound interpretation of the gamma log results, especially since many of the dry wells were drilled after fluids were released to the sediments, and drag-down of contaminated sediments to deeper depths was common. Thus, only the largest volume releases have a high probability of being discovered by gamma-logging through dry wells. 
Field and Jones (2006) categorize the tanks into four groups as follows. Group 1 tanks have well documented leaks based on vadose zone investigations (both dry well gamma logging and sediment collection). The vadose zone data for Group 1 tanks generally indicate contamination from a combination of positive hits of gamma activity in several dry wells and direct measurement of contamination in sediment samples. That is, a contiguous subsurface plume is observed. However, the leak volume and exact time of the release can be highly uncertain for some of the Group 1 tanks. Group 2 tanks are those that have had no new vadose zone studies since the original Hanlon-assumed leak designations were assigned. Therefore, the original Hanlon designations for the time of the leak and the volume of the leak have been retained. Group 3 tanks have had new vadose zone studies that are inconsistent with the original Hanlon designations. In general, the newer data suggest that leak volumes are lower than the Hanlon estimates. Actual leak volumes are generally highly uncertain for many of the Group 3 tanks. Group 4 tanks have no new vadose zone data collected, and a thorough review of the operations records shows no definitive sign of unexplainable liquid level drops, thus making confirmation of the original Hanlon designation as a potential leaker questionable. However, for conservatism, the original Hanlon designation as a potential leaker and the assumed time and volume of the leaks are retained for Group 4 tanks.

The SIM, Rev 1 analysis relies on the key assumption that the HDW Model, which couples chemical processing flow sheet information with the historical waste transfer records to estimate tank waste composition over time, provides a defensible waste composition estimate at the time chosen for the release event. At present, despite the limitations discussed above, the SIM, Rev 1 is the best source of information. The drywell gross and spectral gamma logs through the dry well casings is a qualitative tool to aid in confirming leak events and leak volumes. As mentioned, sediment contamination from surface and shallow pipeline losses often was dragged down while many of the drywells were emplaced in the 1970s. Leaks that occurred before the dry wells were drilled have this potential confounding factor that needs to be acknowledged. When the gamma monitoring shows rapid increases in gamma radioactivity and a decrease in in-tank liquid levels, a tank-leak event was most likely captured.

Tank leaks and UPRs are mostly assumed to have no particulates; therefore, the inventory contribution from these solids losses for many analytes is very small on a volumetric basis. However, there are particular site-analyte combinations for which the losses attributable to solids represent a relatively large source term because there are fewer (or no) constraints associated with the loss (e.g., minimal settling in the BX-102 overfill). Alternatively, the wastes may have simply been discarded without regard to the amounts of solids present (e.g., cold start wastes from REDOX and PUREX). Because of the vast difference in concentration for several analytes between their concentration in solution and when they are present as a solid, where entrained solids are present, they can often provide the majority (greater than 50\%) of the inventory for several analytes.

A key assumption for each tank farm leak in all the cited references is that the release event was confined to the year specified and does not occur over multiple years. This assumption attempts to ease the identification of the waste type involved in a release to the sediment because waste type is more important than knowing the release volume to develop the estimate for the mass or activity inventory. For some wastes, the concentration of key contaminants can vary by over four orders of magnitude whereas the release volume generally varies by much lower amounts. For SST releases, inventories are especially difficult to estimate accurately because the liquids in the tanks were blended to a much greater extent than wastes disposed of to cribs and trenches. Therefore, a certain amount of technical judgment and assumptions are needed to define the composition of a tank leak. 
This report uses the letter " $R$ " to represent tanks (and their ancillary equipment) that released fluids and "I" to represent tanks deemed intact. The values in blue and red type in the tables come from a combination of WIDS and the Hanlon periodic reports. In general, WIDS has the same values as reported in the most current version of the Hanlon status report (Hanlon 2006). All of the most recent entries to WIDS for the B-BX-BY Tank Farms are dated 1996.

\subsection{Data Availability in Vadose Zone}

The most relevant geochemical characterization data were collected on sediment (grab and core samples) from boreholes within facility footprints or close to the facilities. Next in relevancy are data from gamma and neutron logging activities that provide information on gamma-emitting radionuclides and sediment moisture content, respectively. Spectral gamma logging through borehole casings can be used to develop a vertical profile of gamma-emitting radionuclides. When several boreholes are available at different distances from disposal facilities, it is possible to track lateral spreading of the gamma emitters. However, most of the mobile constituents of concern are not gamma emitters so that knowledge of the more commonly observed gamma emitters such as cesium-137 and several europium isotopes (all are relatively strong adsorbers to Hanford sediments) may underestimate the migration of mobile waste constituents. In the 1950s through 1970s, gross gamma and spectral gamma logging was useful in delineating the vertical distribution and horizontal spread of two mobile gamma emitters, ruthenium-106 and cobalt-60. In the 1980s through today, gross gamma and spectral gamma logging are of lesser value because ruthenium-106 (half life $\sim 1$ yr) has decayed below practical detection limits and cobalt-60 (half life $5.7 \mathrm{yr}$ ) has decayed in most cases to near background values. The historical gross and spectral gamma-logging activities in the B-Complex for the B-7-A\&B and B-8 Cribs, BX Trenches, BY Cribs, and the B-BX-BY Tank Farms subregions have been well reviewed in the following documents (DOE/GJO 2002a, 2002b, and 2003) and Sobczyk (2004a, b), respectively. Both of the Sobczyk references are provided in Appendix E. The spectral gamma logging technique has proven useful in delineating vadose regions that contain significant levels of Hanford processed uranium in the B-complex area (see Sobczyk 2004a, b, and DOE/GJO 1998).

In the recent past, it has been more evident that spectral gamma field logs, especially in older steel casings, can give inflated estimates of the activities of radionuclides such as cobalt-60 and Hanford processed uranium. This is because these and other metal-like radionuclides concentrate on the casing walls by either adsorption to corrosion (rust) material, which exhibits very high sorption tendencies, or by redox-mediated co-precipitation into the corrosion products. The spectral gamma-logging results do indicate where these two mobile contaminants are in the subsurface but do not necessarily yield accurate concentrations for the surrounding sediments. During comparison of direct vadose zone sediment analysis from new boreholes 299-E33-344 and 299-E33-345, which are within $10 \mathrm{ft}$ of the older borehole 299-E33-18, it was found that uranium in the pore waters within the $\mathrm{CCU}_{z}$ strata has been adsorbing/precipitating onto the metal casings of older boreholes. The adsorbed/precipitated uranium gets interpreted by the spectral gamma-logging results as evidence of high concentrations of uranium in the surrounding formation. Because of the assumptions used in the processing of the spectral gamma raw-counting data, the sediments and extant pore water around the casing are assigned much higher concentrations than are actually present. The newer installed casings will eventually start to corrode (albeit at a slower rate than the older carbon steel casings), and uranium and other metallic solutes will start to concentrate on the corroded surfaces. As mentioned, the same casing-concentrating mechanisms apply to cobalt-60 also. 
To make good estimates of mass or activity in the vadose zone sediments, one needs accurate measurements of the concentrations in the sediments. Thus, a main use of historical gross gamma and spectral gamma-logging data was to aid in selecting lateral spreading distances using the cobalt-60 (especially in the BY cribs subregion) and for delineating locations where Hanford processed uranium was found.

Neutron logging results have been best correlated with the presence of fine-grained sediments, which naturally retain higher moisture contents through capillary forces than coarser sediments. Because Hanford sediments are generally dominated by sand and gravel, they drain back to near their natural field capacities quite rapidly. Therefore, elevated neutron logging results in profiles below or near inactive disposal sites rarely are indications of excess remnant water from the active disposal. Rather, elevated neutron-logging values are indicative of the presence of finer grained sediments, such as the thin silt-fine sand lenses found in the Hanford $\mathrm{H} 2$ unit and the often several to a few tens of feet thick silt-dominated $\mathrm{CCU}$ named $\mathrm{CCU}_{z}$. Thus, this report uses neutron logging data solely to aid in identifying the location and thickness of these finer grained strata.

Earth resistivity techniques were applied in the B-Complex in an attempt to extrapolate the information gathered through more standard approaches to site characterization (drilling, sampling, geophysical logging, etc.). Surface geophysical techniques provide a means of assessing subsurface conditions over a large area in a cost effective manner. Interpreted results are then used to guide the placement of boreholes or wells to assess those identified anomalies. Identifying contaminated zones in the vadose zone requires that there be a contrast in electrical properties between zones impacted by contaminants and those not impacted. If that contrast does not exist, or is masked by infrastructure, an anomaly may not be identified.

There are known challenges to resistivity techniques as they were applied in the B-Complex. These challenges include extensive infrastructure and the non-specific causes of interpreted resistivity anomalies. Even with these challenges taken into consideration, the value of the surveys far exceeds the incremental cost. It is unlikely that SGE will ever replace drilling and sampling as the means to characterize the environmental insult due to Hanford's past practices; it does, however, lend itself to more appropriate application of drilling and sampling.

Field electrical resistivity surveys yield only qualitative to at best semi-quantitative estimates of the concentrations of high conductivity present in the subsurface. Electrical resistivity measurements respond to total conductivity (related to inorganic salt content) in the sediments' pore water, which at the Hanford site is generally dominated by nitrate, sodium, sulfate, calcium, and bicarbonate. Because technetium-99 generally migrates with the same tendencies as nitrate, when nitrate dominates the pore-water salt content, more specifically pore-water ionic strength, then the electrical resistivity has merit in identifying where technetium-99 may be located in the sub-surface (see Serne et al. 2009 for more discussion). The results of the soil electrical resistivity field survey in the B-Complex (see Rucker et al. 2007) were useful in a qualitative sense to delineate the lateral extent of high conductivity areas within the vadose zone sediments. However, as caveated in Rucker et al. (2007) and Rucker and Fink (2007) and more quantitatively described in a comprehensive "ground truthing" effort for surface-based soil electrical resistivity field surveys at BC Cribs (same waste type disposed of to the BY cribs), Serne et al. (2009) show that the soil resistivity technique may not accurately delineate the vertical extent of subsurface plumes. Analysis of surface-based soil electrical resistivity surveys tends to smear the vertical 
distribution of high conductivity plumes when the vertical distribution of conductivity consists of several lobes of alternating high and low conductivity, which is very common within the heterogeneous Hanford subsurface. Although the vertical distribution is smeared, high-conductivity signatures apparently representing remnant waste fluids released to the Hanford subsurface show significant lateral spreading, most likely at several thin fine-grained lenses within the Hanford formation (H2F1, H2F2, H2F3, and other more localized lenses; see discussion in Section 2.4) and when present, within the fine-grained $\mathrm{CCU}_{z}$, discussed in detail in Section 2.4.2. A key implication of the lateral spreading is that past estimations of the depth of penetration of waste fluids based on the concept that flow was strictly vertical down through the facility footprint likely over predict the depth to which fluids reached in the vadose zone.

The extent of contamination in the subsurface below each of the inactive disposal and tank farm regions is used to develop conceptual models of the current nature and extent of contamination for each facility or localized subregion in Section 3. The conceptual models of the distribution of contaminants in the vadose zone can then be used to perform baseline risk predictions for the groundwater pathway and to aid in selecting appropriate remedial alternatives for final site cleanup.

\subsection{Data Availability for Unconfined Aquifer (Site-wide Groundwater Monitoring Reports)}

The earliest B-Complex reports describing groundwater contamination plumes reviewed are periodic (quarterly evolving into semi-annual) monitoring reports that cover the time period July 1956 through June 1965. Table 1.2 lists the identification numbers and titles of these early reports. A large groundwater contamination plume of gross beta was present from the first monitoring report covering July to September 1956, extending at least $1000 \mathrm{ft}$ in a southeasterly direction from the BY cribs area, which received on average nearly 2.5-million liters of liquid wastes per month from November 1954 through December 1955. To the southeast of the BY Cribs, the B7A\&B and B8 Crib and Tile Field as well as the B-11A\&B French Drains actively received similar volumes of waste from 1946 to 1954, 1948 to 1953 , and 1952 to 1954 , respectively. Thus, it is not surprising that a large gross beta plume was observed to the southeast of the BY Cribs. In all of the periodic monitoring reports, the BY Cribs and B cribs (B-7A\&B Crib, B-8 Crib and Tile Field, B-11A\&B French Drains, and B-51 Crib) are not differentiated as distinct regions in the discussions. It is therefore difficult to determine whether the authors attempted to differentiate contributions from these two different subregions as done in this report. By the fourth quarter of 1956, the periodic monitoring reports suggest that groundwater mounding in the B-Complex region, caused by both disposal to the A Cribs and the B Ponds, was causing the groundwater plume to migrate in a westerly direction until the water reached the western edge of the 200-East Area where high permeability channels in the aquifer sediment caused both northerly and southerly flow.

Over the quarter of January to March 1959, the vadose zone under both crib regions was still draining fluids. Three wells right next to BY cribs (299-E33-3, -E33-4 and -E33-7) were re-perforated at the water table on December 31, 1958, and gross beta concentrations of the water withdrawn was lower than previous samples. This suggested that water was not freely flowing in these wells for some time period before the maintenance activities. Early groundwater sampling relied upon bailers that in general only gathered water from the uppermost portion of the aquifer. If the water table rose above the perforated or 
screened portion of the casing, then the uppermost portion of the aquifer could become stagnant. ${ }^{(a)}$ This might explain some of the highly variable gross beta concentrations reported in the HEIS database for wells in the BY cribs region around this time period. In the April to June 1959 report, the authors state that a distinct "2-pronged" shape was developing for the gross beta plume in the B-Complex. They attribute this shape to the presence of "fine-grained Ringold sediments" above the water table just southeast of the BY cribs. It appears that the scientists monitoring the groundwater in fact were aware of what is now called the Cold Creek silt dominated unit, $\mathrm{CCU}_{z}$, which is presently hypothesized as the key to the current deep vadose zone contamination distribution.

By the end of September 1959, the authors state that cobalt-60 concentrations in wells near the BY cribs were about as high as when the cribs were receiving wastes ( $\sim$ years earlier, excluding B-50). Between October 1959 and June 1963, the gross beta and cobalt-60 plumes slowly evolved, and average concentrations at most wells slowly dropped. The periodic monitoring reports covering the period from June 1963 through June 1965 suggested there was little movement of the gross beta plume, and concentrations of gross beta and cobalt-60 were decreasing in most well waters within the B-Complex.

Table 1.2. Listing of Historical groundwater Monitoring Reports

\begin{tabular}{|c|c|c|}
\hline Document \# & Time Period & \\
\hline HW-49465 & July to Sept 1956 & $\begin{array}{l}\text { Brown DJ (editor). 1957a. Chemical Effluents } \\
\text { Technology Waste Disposal Investigations July, August, } \\
\text { September 1956. HW-49465, Hanford Atomic Products } \\
\text { Operation, Richland, Washington. }\end{array}$ \\
\hline HW-50186 & Oct to Dec 1956 & $\begin{array}{l}\text { Brown DJ (editor). 1957b. Chemical Effluents } \\
\text { Technology Waste Disposal Investigations October, } \\
\text { November December 1956. HW-50186, Hanford } \\
\text { Atomic Products Operation, Richland, Washington. }\end{array}$ \\
\hline HW-51095 & Jan to Mar 1957 & $\begin{array}{l}\text { Brown DJ (editor). 1957c. Chemical Effluents } \\
\text { Technology Waste Disposal Investigations January, } \\
\text { February, March 1957. HW-51095, Hanford Atomic } \\
\text { Products Operation, Richland, Washington. }\end{array}$ \\
\hline HW-53225 & Apr to June 1957 & $\begin{array}{l}\text { Brown DJ (editor). 1957d. Chemical Effluents } \\
\text { Technology Waste Disposal Investigations April, May, } \\
\text { June 1957. HW-53225, Hanford Atomic Products } \\
\text { Operation, Richland, Washington. }\end{array}$ \\
\hline HW-54655 & July to Sept 1957 & $\begin{array}{l}\text { Brown DJ (editor). 1957e. Chemical Effluents } \\
\text { Technology Waste Disposal Investigations July, August, } \\
\text { September 1957. HW-54655, Hanford Atomic Products } \\
\text { Operation, Richland, Washington. }\end{array}$ \\
\hline HW-54848 & Oct to Dec 1957 & $\begin{array}{l}\text { Bierschenk WH (editor). 1958a. Chemical Effluents } \\
\text { Technology Waste Disposal Investigations October, } \\
\text { November December 1976. HW-54848, Hanford } \\
\text { Atomic Products Operation, Richland, Washington. }\end{array}$ \\
\hline
\end{tabular}

(a) Groundwater sampling using downhole pumps was not common before 1978 to 1979. Personal communication from Dave Myers (WRPS) in September 2009. 
PNNL-19277

Table 1.2. Listing of Historical groundwater Monitoring Reports

\begin{tabular}{|c|c|c|}
\hline Document \# & Time Period & \\
\hline HW-55841 & Jan to Mar 1958 & $\begin{array}{l}\text { Bierschenk WH (editor). 1958b. Chemical Effluents } \\
\text { Technology Waste Disposal Investigations January, } \\
\text { February, March 1958. HW-55841 RD, Hanford } \\
\text { Atomic Products Operation, Richland, Washington. }\end{array}$ \\
\hline HW-57002 RD & Apr to Jun 1958 & $\begin{array}{l}\text { Bierschenk WH (editor). 1958c. Chemical Effluents } \\
\text { Technology Waste Disposal Investigations April, May, } \\
\text { June 1958. HW-57002 RD, Hanford Atomic Products } \\
\text { Operation, Richland, Washington. }\end{array}$ \\
\hline HW-58023 & Jul to Sept 1958 & $\begin{array}{l}\text { Bierschenk WH (editor). 1958d. Chemical Effluents } \\
\text { Technology Waste Disposal Investigations July, August, } \\
\text { September 1958. HW-58023, Hanford Atomic Products } \\
\text { Operation, Richland, Washington. }\end{array}$ \\
\hline HW-58811 RD & Oct to Dec 1958 & $\begin{array}{l}\text { Bierschenk WH (editor). 1959a. Chemical Effluents } \\
\text { Technology Waste Disposal Investigations October, } \\
\text { November December 1958. HW-58811 RD, Hanford } \\
\text { Atomic Products Operation, Richland, Washington. }\end{array}$ \\
\hline HW-60163 & Jan to Mar 1959 & $\begin{array}{l}\text { Bierschenk WH (editor). 1959b. Chemical Effluents } \\
\text { Technology Waste Disposal Investigations January, } \\
\text { February, March 1959. HW-60163, Hanford Atomic } \\
\text { Products Operation, Richland, Washington. }\end{array}$ \\
\hline HW-61197 RD & Apr to June 1959 & $\begin{array}{l}\text { Bierschenk WH (editor). 1959c. Chemical Effluents } \\
\text { Technology Waste Disposal Investigations April, May, } \\
\text { June 1959. HW-61197 RD, Hanford Atomic Products } \\
\text { Operation, Richland, Washington. }\end{array}$ \\
\hline HW-62692 & Jul to Sept 1959 & $\begin{array}{l}\text { Haney WA (editor). 1959. Chemical Effluents } \\
\text { Technology Waste Disposal Investigations July, August, } \\
\text { September 1959. HW-62692 RD, Hanford Atomic } \\
\text { Products Operation, Richland, Washington. }\end{array}$ \\
\hline HW-64094 RD & Oct to Dec 1959 & $\begin{array}{l}\text { Haney WA (editor). 1960a. Chemical Effluents } \\
\text { Technology Waste Disposal Investigations October, } \\
\text { November December 1959. HW-64094-RD, Hanford } \\
\text { Atomic Products Operation, Richland, Washington. }\end{array}$ \\
\hline HW-65464 RD & Jan to Mar 1960 & $\begin{array}{l}\text { Haney WA (editor). 1960b. Chemical Effluents } \\
\text { Technology Waste Disposal Investigations January, } \\
\text { February, March 1960. HW-65464-RD, Hanford } \\
\text { Atomic Products Operation, Richland, Washington. }\end{array}$ \\
\hline HW-66859 RD & Apr to Jun 1960 & $\begin{array}{l}\text { Haney WA (editor). 1960c. Chemical Effluents } \\
\text { Technology Waste Disposal Investigations April, May, } \\
\text { June 1960. HW-66859-RD, Hanford Atomic Products } \\
\text { Operation, Richland, Washington. }\end{array}$ \\
\hline
\end{tabular}


PNNL-19277

Table 1.2. Listing of Historical groundwater Monitoring Reports

\begin{tabular}{|c|c|c|}
\hline Document \# & Time Period & \\
\hline HW-67753 RD & Jul to Sept 1960 & $\begin{array}{l}\text { Haney WA (editor). 1960d. Chemical Effluents } \\
\text { Technology Waste Disposal Investigations July, August, } \\
\text { September 1960. HW-67753- RD, Hanford Atomic } \\
\text { Products Operation, Richland, Washington. }\end{array}$ \\
\hline HW 68543 & Oct to Dec 1960 & $\begin{array}{l}\text { Haney WA (editor). 1961a. Chemical Effluents } \\
\text { Technology Waste Disposal Investigations October, } \\
\text { November December 1960. HW-68543-RD, Hanford } \\
\text { Atomic Products Operation, Richland, Washington. }\end{array}$ \\
\hline HW-70806 RD & Jan to Jun 1961 & $\begin{array}{l}\text { Haney WA (editor). 1961b. Chemical Effluents } \\
\text { Technology Waste Disposal Investigations-January- } \\
\text { June, 1961. HW-70806-RD, Hanford Atomic Products } \\
\text { Operation, Richland, Washington. }\end{array}$ \\
\hline HW-72645 RD & Jul to Dec 1961 & $\begin{array}{l}\text { Brown DJ (editor). 1962a. Chemical Effluents } \\
\text { Technology Waste Disposal Investigations-July- } \\
\text { December, 1961. HW-72645-RD, Hanford Atomic } \\
\text { Products Operation, Richland, Washington. }\end{array}$ \\
\hline HW-74915 RD & Jan to Jun 1962 & $\begin{array}{l}\text { Brown DJ (editor). 1962b. Chemical Effluents } \\
\text { Technology Waste Disposal Investigations_January- } \\
\text { June 1962. HW-74915-RD, Hanford Atomic Products } \\
\text { Operation, Richland, Washington. }\end{array}$ \\
\hline HW-76120 RD & Jul to Dec 1962 & $\begin{array}{l}\text { Brown DJ (editor). 1963. Chemical Effluents } \\
\text { Technology Waste Disposal Investigations-July - } \\
\text { December 1962. HW-76120-RD, Hanford Atomic } \\
\text { Products Operation, Richland, Washington. }\end{array}$ \\
\hline HW-78951 & Jan to Jun 1963 & $\begin{array}{l}\text { Haney WA (editor). 1963. Chemical Effluents } \\
\text { Technology Waste Disposal Investigations—January- } \\
\text { June, 1963. HW-78951, Hanford Atomic Products } \\
\text { Operation, Richland, Washington. }\end{array}$ \\
\hline HW-80909 & Jul to Dec 1963 & $\begin{array}{l}\text { Brown DJ and WA Haney. 1964. Chemical Effluents } \\
\text { Technology Waste Disposal Investigations-July- } \\
\text { December, 1963. HW-80909, Hanford Atomic } \\
\text { Products Operation, Richland, Washington. }\end{array}$ \\
\hline HW-84549 & Jan to Dec 1964 & $\begin{array}{l}\text { Brown DJ (editor). 1964. Chemical Effluents } \\
\text { Technology Waste Disposal Investigations - January - } \\
\text { December 1964. HW-84549, Hanford Atomic Products } \\
\text { Operation, Richland, Washington. }\end{array}$ \\
\hline BNWL-CC-285 & Jan to Jun 1965 & $\begin{array}{l}\text { Brown DJ (editor). 1965. Chemical Effluents } \\
\text { Technology Waste Disposal Investigation, January - } \\
\text { June 1965. BNWL-CC-285, Battelle-Northwest } \\
\text { Laboratory, Richland, Washington. }\end{array}$ \\
\hline BNWL-CC-574 & Jul to Dec 1965 & $\begin{array}{l}\text { Eliason JR. 1966a. Earth Sciences Waste Disposal } \\
\text { Investigations July - December, 1965. BNWL-CC-574, } \\
\text { Battelle-Northwest Laboratory, Richland, Washington. }\end{array}$ \\
\hline
\end{tabular}


Table 1.2. Listing of Historical groundwater Monitoring Reports

\begin{tabular}{ccc}
\hline Document \# & Time Period & \\
\hline BNWL-CC-887 & Jan to Jun 1966 & $\begin{array}{l}\text { Eliason JR. 1966b. Earth Sciences Waste Disposal } \\
\text { Investigations January-June, 1966. BNWL-CC-887, } \\
\text { Battelle-Northwest Laboratory, Richland, Washington. }\end{array}$ \\
Myers DA, JJ Fix, and JR Raymond. 1977. Environmental Monitoring Report on Radiological \\
$\begin{array}{l}\text { Status of the Groundwater Beneath the Hanford Site, January-December 1976. BNWL-2199, } \\
\text { Battelle, Pacific Northwest Laboratory, Richland, Washington (Myers et al. 1977). }\end{array}$
\end{tabular}

Myers DA. 1978. Environmental Monitoring Report on Radiological Status of the Groundwater Beneath the Hanford Site, January-December 1977. PNL-2624, Pacific Northwest Laboratory, Richland, Washington (Myers et al. 1978).

Evans JC, RW Bryce, and DR Sherwood. 1989. Hanford Site Ground-Water Monitoring for January Through June 1988. PNL-6886, Pacific Northwest Laboratory, Richland, Washington (Evans et al. 1989).

Johnson VG. 1993. Westinghouse Hanford Company Operational Groundwater Status Report 1990-1992. WHC-EP-0595, Westinghouse Hanford Company, Richland, Washington (Johnson 1993.

DOE/RL. 1996b. Annual Report for RCRA Groundwater Monitoring Projects at Hanford Site Facilities for 1995. DOE/RL-96-01, Rev. 0, U.S. Department of Energy, Richland, Washington (DOE-RL 1996b).

Hanford Site Groundwater Monitoring for Fiscal Year 1996 (PNNL-11470) (PNNL 1996): http://www2.hanford.gov/arpir/?content=findpage\&AKey=D199132964

Hanford Site Groundwater Monitoring for Fiscal Year 1997 (PNNL-11793) (PNNL 1997): http://www2.hanford.gov/arpir/?content=findpage\&AKey=D199132962

Hanford Site Groundwater Monitoring for Fiscal Year 1998 (PNNL-12086) (PNNL 1998): http://www2.hanford.gov/arpir/?content=findpage\&AKey=D199091099

Hanford Site Groundwater Monitoring for Fiscal Year 1999 (PNNL-13116) (PNNL 1999b): http://www2.hanford.gov/arpir/?content=findpage\&AKey $=\mathrm{D} 2736610$ and http://www2.hanford.gov/arpir/?content=findpage\&AKey=D2736978

Hanford Site Groundwater Monitoring for Fiscal Year 2000 (PNNL-13404) (PNNL 2000): http://www.pnl.gov/main/publications/external/technical_reports/PNNL-13404.pdf

Hanford Site Groundwater Monitoring for Fiscal Year 2001 (PNNL-13788) (PNNL 2001): http://www.pnl.gov/main/publications/external/technical_reports/PNNL-13788.pdf 
Table 1.2. Listing of Historical groundwater Monitoring Reports

\section{Document \# Time Period}

Hanford Site Groundwater Monitoring for Fiscal Year 2002 (PNNL-14187) (PNNL 2002):

http://www.pnl.gov/main/publications/external/technical reports/PNNL-14187.pdf

Hanford Site Groundwater Monitoring for Fiscal Year 2003 (PNNL-14548) (PNNL 2003): http://www.pnl.gov/main/publications/external/technical_reports/PNNL-14548.pdf

Hanford Site Groundwater Monitoring for Fiscal Year 2004 (PNNL-15070) (PNNL 2004): http://www.pnl.gov/main/publications/external/technical_reports/PNNL-15070.pdf

Hanford Site Groundwater Monitoring for Fiscal Year 2005 (PNNL-15670) (PNNL 2005): http://www.pnl.gov/main/publications/external/technical reports/PNNL-15670.pdf

Hanford Site Groundwater Monitoring for Fiscal Year 2006 (PNNL-16346) (PNNL 2006): http://www.pnl.gov/main/publications/external/technical_reports/PNNL-16346.pdf

Hanford Site Groundwater Monitoring for Fiscal Year 2007d (DOE/RL-2008-01) (DOE/RL 2007c):

http:/www.hanford.gov/cp/gpp/library/gwrep07/html/start07.htm

Hanford Site Groundwater Monitoring for Fiscal Year 2008 (DOE/RL-2008-66) (DOE/RL 2008b):

http:/www.hanford.gov/cp/gpp/library/gwrep08/html/start08.htm

Unfortunately, a full suite of groundwater reports that cover the time between 1965 and early 1996 when annual site-wide groundwater reports are available (see URLs in Table 1.2) could not be found. References to a few other reports with titles that appear to be groundwater-monitoring status reports were found, but they were not critically assessed for coverage for every year between 1965 and 1996. In addition, the HEIS database or its newer publicly available version, Environmental Dashboard Application, http://environmet.hanford.gov/eda/, was used to assess the concentration trends for specific potentially mobile contaminants, which are discussed in Section 3 for each subregion and for the entire B-Complex in the end of Section 3 over the last decade at wells in the entire B-Complex. It is clear from studying the EDA database that there was a gap when very little groundwater data were reported. This occurred right after the mid 1960s, which was covered in the cited periodic groundwater monitoring reports, and before 1987 for some constituents and early to middle 1990s for many other constituents. This presents a difficult challenge to understanding the time evolution of key contaminants in the groundwater below the B-Complex. The pre-1987 data set consisted of mainly gross beta and cobalt-60 for most monitoring wells, with some nitrate and uranium for a few wells. Uranium data before 1987 are available for only a short time period between 1955 and 1957. This early uranium groundwater data covers just a handful of wells. From 1987 to 1991, a few additional wells had uranium measured. The uranium in the late 1950 s time period was measured by liquid scintillation radio counting. For most wells, the measurement of uranium mass (using first a fluorescence technique [KPA] and more recently inductively coupled plasma-mass spectrometry [ICP-MS]) began in 1991 or later with more consistent 
quarterly to annual sampling and analyses. In general, since the early to mid 1990s, many more monitoring wells were drilled, and a much wider suite of contaminants was measured.

Therefore, it is not possible to present a year-by-year time series of all the key potentially mobile contaminants selected for this report for the B-Complex region. Time-series plots for individual species for many individual wells are already assembled in the "Pre-calculated Reports" menu and "groundwater Quality for Wells" submenu (drill down) in the EDA database. The authors of this report encourage interested readers to obtain a password and to investigate these data summary graphics. However, looking at the time series data for key constituents for each well does not yield a good overall impression of the evolution of the overall groundwater plume in the B-Complex area. More useful time series groundwater plume maps for a few key contaminants for specific regions have been constructed by both the groundwater annual report staff and outside stakeholders. Some of the plume maps are reproduced in Section 3 to aid in discussions on three main topics. The main topics are 1) whether constituent plumes seem to be increasing or decreasing in the recent past, 2) the migration direction of the groundwater plume in the recent past and currently, and 3) what facility(ies) might be the dominant source of each key contaminant in the B-Complex groundwater plume.

The sparseness of the data in time and areal extent (especially inside SST tank farm boundaries) and the close proximity of the numerous deep vadose zone sources identified within inactive disposal facility footprints and nearby sediments (see subsections named Vadose Zone Distribution in Section 3) makes it difficult to identify unequivocally all the locations where contaminants are entering the unconfined aquifer. However, this report presents plausible locations for the major migration pathways from the inactive disposal facilities through the vadose zone sediments to the groundwater for some of the mobile contaminants.

\subsection{Uranium Isotopic Signatures}

Selected vadose zone sediment water extracts, actual pore waters obtained by high-speed centrifugation of vadose zone sediments, and groundwater samples collected at specific depths in the aquifer during the drilling of many of the new boreholes/wells listed in Table 1.1 were precisely measured for ratios of uranium isotopes. These new uranium isotope ratio data were merged with existing data on similar samples collected from 2001 to 2007 at boreholes 299-E33-45 (near BX-102 tank), 299-E33-46 (near B-110 tank), C3103 (in B-7A Crib), and several groundwater samples from the B-Complex. Figure 1.3 shows a plot of the atom ratio of $(\mathrm{U}-236 / \mathrm{U}-238)$ multiplied by $10^{+6}$ on the Y-axis and the atom ratio of (U-235/U-238) on the X-axis. Almost all the data fall on a line that represents fuels that started with natural abundances of uranium-235 and uranium-238, in other words, un-enriched uranium fuel. Before irradiation in nuclear reactors to form plutonium, the natural fuel had no uranium-236 atoms, and the ratio of uranium-235 to uranium-238 was 0.00725 . As fuel was irradiated in the reactor, uranium-236 started to build up and uranium-235 decreased such that these two isotopes' ratios versus uranium-238 changes, and the resultant fuel when reprocessed yields uranium isotopic ratios that move from the bottom right-hand corner of Figure 1.3 towards the upper left-hand corner of the figure. The groundwater available from the new groundwater well 299-E33-345 that falls off the natural fuel line in Figure 1.3 is one sample. The deviation is small, but because the uranium isotopic measurements are so precise, the deviation appears to be statistically real. This groundwater sample includes a small fraction of uranium from a fuel that was enriched (contained more than the natural abundance of uranium-235). The slight deviation from the natural abundance fuel line indicates that some waste stream with residual enriched 
uranium was disposed of in the B-Complex, likely near this new groundwater monitoring well. Based on the history of the B-Complex, waste disposals as tabulated in Section 3, it was confirmed that the B-7A\&B cribs received about 1.13 million liters of PUREX decontamination waste in 1966-67. This type of waste contained enriched uranium from PUREX fuels reprocessing. Well 299-E33-345 is $\sim 70 \mathrm{ft}$ west of the B-7-A Crib and $\sim 60 \mathrm{ft}$ southwest of B-7-B Crib. As discussed in Section 6 , it is hypothesized that the regional groundwater flow now and in the recent past is towards the northwest, so water that percolated down through the vadose zone below the B-7-A crib would migrate past the new well. Thus, there is a plausible explanation for observing a trace of enriched uranium in this groundwater, which has a low concentration of total uranium. It is easier to see traces of elevated uranium-235 isotope when the total uranium concentration from natural fuel is low. In most of the water samples near the BX-102 overfill event, the total uranium concentration is very high, and the natural fuel uranium signature for the uranium-235/238 ratio dominates, making it difficult to observe enriched uranium fuel uranium-235/238 signals. The fact that there was low total uranium and not much contribution from natural uranium fuel allowed the identification of trace amounts of enriched uranium-235/238 in the one groundwater sample at 299-E33-345.

Because all of the uranium in wastes disposed of to the BY Cribs, BX Trenches, B-8 Crib and Tile Field, and many of the B-BX-BY tanks at the time of their leaks came from un-enriched natural abundance fuel, the two uranium isotope ratios, as plotted in Figure 1.3, do not provide a great deal of source discrimination potential. However, the isotope signatures that use the uranium-236/238 and uranium-234/238 ratios do offer a method to discriminate between some of the sources (disposal facilities) in the B-Complex. As discussed in Christensen et al. (2004) and Maher et al. (2006), the ratio of uranium-234 to uranium-238 for vadose zone water extracts and groundwater in general are not in secular equilibrium because of alpha recoil reactions that allow uranium-234 to escape from the surfaces of solids containing uranium and enter the surrounding solution (either vadose zone pore water or groundwater).

Based on precise measurements of dozens of Hanford pore water and groundwater samples in the B-Complex, it has been found that groundwaters contain a larger excess of uranium-234 than vadose zone pore waters, likely because of the longer time frame groundwater has to react with aquifer sediments when compared to the vadose zone pore water interactions with its surrounding sediments.

Figure 1.4 shows a plot with the atom ratio (uranium-236/238) multiplied by $10^{+6}$ on the $\mathrm{Y}$ axis and the atom ratio (uranium-234/238) multiplied by $10^{+6}$ on the $\mathrm{X}$ axis. This plot is used in later discussions in Section 3 and 5 for subregions where Hanford-processed uranium was found. The isotope ratios for uncontaminated pore waters from vadose zone H2 unit sediments from borehole 299-E33-46 and 299W22-48 were grouped (four data and three data, respectively) and designated as "clean H2 >100 ft bgs" in the plots. Only one porewater sample from the CCU unit in the B-Complex was found to be uncontaminated (sample from 299-E33-205), and its signature was combined with five pore waters from 200-West Area and designated as "clean CCU." The same uranium isotope ratios for three groundwaters just north of the B-Complex were grouped with adjusted uranium isotope ratio signatures for nine groundwater samples from 2001 sampling and designated "clean groundwater" in the plots. The details on the specific samples chosen are found in Appendix H. A water sample is declared to be clean if the total uranium concentration is close to the regional background (several $\mu \mathrm{g} / \mathrm{L}$ ) and the uranium-236 content is essentially zero. On the plots, clean samples will plot along the $\mathrm{Y}=0$ axis. Because the authors suspect that the source of much of the elevated uranium in the groundwater below the B-Complex 


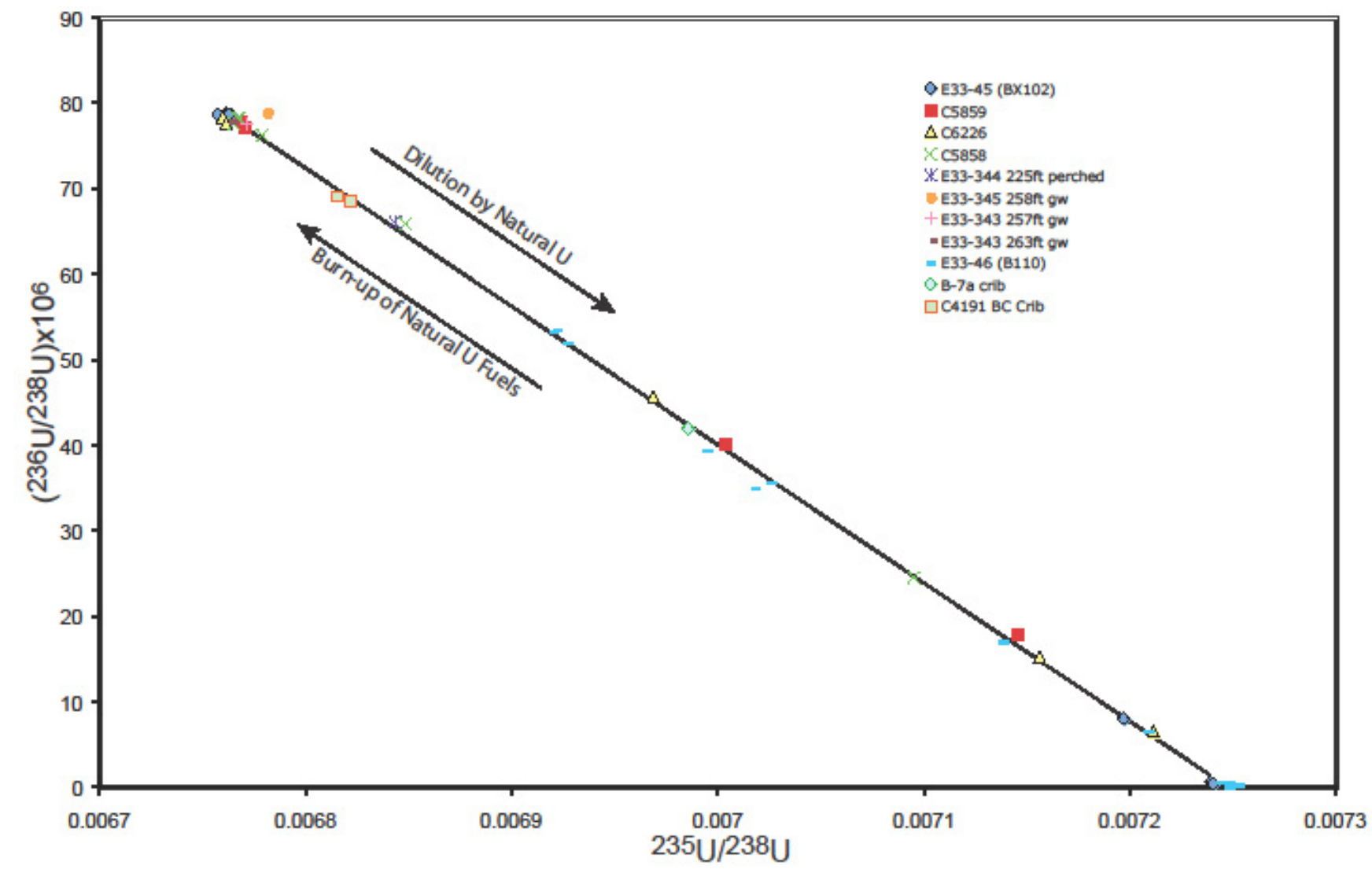

Figure 1.3. Atom Ratio of Uranium-236/238 to Uranium-235/238 for all B-Complex Vadose Zone Water Extracts and Groundwater from New Wells 
came from the Tank BX-102 overfill event in 1951, the plot also contains the cluster of the nine water extracts in the Hanford formation of borehole 299-E33-45 that were contaminated solely by the Tank BX102 overfill event. As described in Christensen et al. (2004), the uranium isotopic measurements of these nine separate samples cluster very tightly together for all three uranium ratios measured (uranium-234, uranium-235, and uranium-236 versus uranium-238), which further corroborates the assumption that the uranium in the 299-E33-45 borehole pore water is from one source. Further, as described in Christensen et al. (2004), the contaminated pore water from borehole 299-E33-46 (near B-110 tank) has a strikingly different uranium-236/238 ratio than the pore waters from 299-E33-45. Christensen et al. (2004) concluded that the slightly elevated uranium below tank B-110 is not contributing to the B-Complex groundwater plume. This was based on the limited depth of the elevated total uranium concentration at 299-E33-46, the low volume estimate for the B-110 tank leak, and its pore-water showing a significantly different uranium-236/238 atom ratio than groundwater samples below the B-Complex, The authors of this report concur and do not plot the 299-E33-46 contaminated pore-water isotope ratio data on most of the plots to be discussed in Section 3.

Figure 1.4 shows the uranium isotope ratios that differentiate the various B-Complex disposal sites from each other. The data set for the B-7-A Crib consists of one pore water sample from borehole C3103 at $70 \mathrm{ft}$ bgs (in the $\mathrm{H} 2$ unit) with a total uranium concentration of $18.7 \mathrm{mg} / \mathrm{L}$. It is assumed that this high uranium concentration and its resultant isotope ratios represent the uranium isotopic ratio signature for the bulk of the wastes disposed of to this crib and its companion B-7-B Crib. For the BY Cribs, the data set is even more tenuous in that there is only one pore water sample from borehole 299-E33-341 from a depth of $20 \mathrm{ft} \mathrm{bgs} \mathrm{(in} \mathrm{the} \mathrm{H} 1 \mathrm{unit}$ ) with a total uranium concentration of $2.3 \mathrm{mg} / \mathrm{L}$. This borehole is $\sim 50 \mathrm{ft}$ west and equidistant from the western edges of the B-48 and B-49 cribs. At 299-E33-45 (BX-102), there were nine pore waters from different depths that exhibited very tightly clustered uranium isotopic ratios. At 299-E33-46, there were eight pore waters. Two clustered tightly to define the B-110 tank source, and six plotted tightly along the mixing line between the B-110 tank source and uncontaminated vadose zone pore water, thus forming an adequate database to feel confident on the B-110 tank source uranium isotopic signature. There is only one sample each for the B-7-A and BY cribs because the available sediment samples in regions where high concentrations of total uranium might have been present were limited. To get precise uranium isotope ratio data, one must have high concentrations of total uranium in the pore water or large volumes of pore water available to collect an adequate mass of uranium (30 to $100 \mathrm{ng}$ ) to process. The very dry vadose zone sediments do not contain large volumes of pore water so that the authors were stymied from gathering more uranium isotope ratios for the B-7-A and BY crib facilities. Despite the sparseness of uranium isotope signature data on water extracts from around the BY cribs and within the B-7-A crib and lack of any data for vadose zone water extracts for the B-8 Crib and Tile Field and BX Trenches, Figure 1.4 does show distinctions between the four sources for which data are available. It would seem logical that differences would be present in the uranium-236/238 and uranium-234/238 ratios for other facilities that disposed of natural uranium fuel wastes. The BY Cribs signature is differentiable from the Tank BX-102 and Tank B-110 signatures. There are significant differences between the B-7A Crib and the other three facilities (Tank B-110, Tank BX-102 and BY Cribs). Thus, all four sources have adequately unique signatures to use in evaluating and assigning sources to contaminated pore waters and groundwaters in the B-Complex region. 


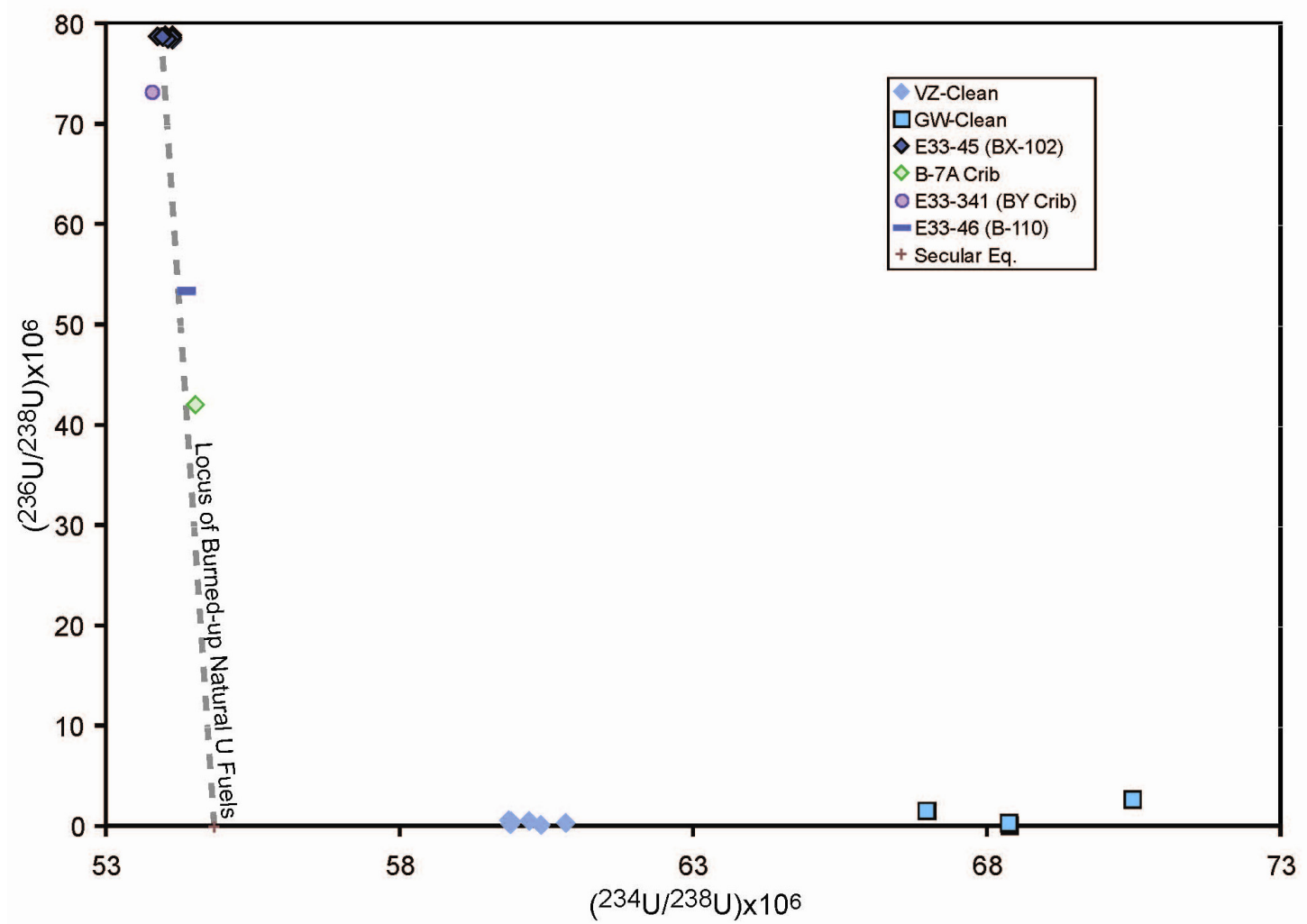

Figure 1.4. Uranium-236/238 vs. Uranium-234/238 Ratios for Four Sources (Disposal Facilities)

\subsection{Mass Inventory Estimates}

As part of the conceptual models developed for the two key contaminants discussed in detail, uranium and technetium-99, this report assembles the available data for their distribution in the vadose zone sediments within and proximal to the B-Complex disposal facility footprints and estimates their mass in the groundwater plumes for 4 years $(2000,2003,2006$, and 2009). Analytical data for the vadose zone sediment distribution for key mobile constituents, such as technetium-99, nitrate, uranium, chromium, and cyanide, remains sparse at and proximal to the most well characterized inactive disposal facilities and non-existent at some of the inactive disposal facilities and many SSTs. Until recently, gross and spectral gamma logs have been useful to track cobalt-60 and ruthenium-106, two generally mobile radionuclides, but now these short-lived isotopes have decayed in most locations to activities that are barely detectable and thus less useful for quantifying current vadose zone sediment inventories. The subsurface electrical resistivity field surveys available at many of the inactive sites of interest also do not yield quantitative information on specific analytes; rather, they indicate qualitatively the lateral extent and in some locations, without much metallic infrastructure, an indication of the vertical extent of highconductivity plumes within the vadose zone sediments.

Generally, one to at best five boreholes that penetrate down to the water table are available to quantify the horizontal and vertical distribution of contaminants in the vadose zone for each of the designated subregions (BY Cribs, B-7A\&B/B8 Cribs and Tile Field area, BX Trenches, BX and BY WMA, and B WMA). Because of the importance of lateral spreading, especially on top of or within the 
numerous thin fine-grained layers in the Hanford $\mathrm{H} 2$ unit and the $\mathrm{CCU}_{z}$ unit below the B-Complex, it is now realized that more effort needs to be placed on characterizing samples from these strata in the future. The available sediment characterization data sets for each sub-region, which identify the state of knowledge on the vertical and horizontal distribution of uranium and technetium-99, are summarized in Table 1.3. Direct measurement of strong acid-extractable concentrations of metal-like constituents such as technetium-99, uranium, and chromium should represent their maximum masses that could be available for transport to the water table over long times. For cyanide, an alkaline extraction is used to measure total sediment concentrations. For anions, water-extractable concentrations are used to estimate total sediment concentrations because total digestion or strong acid extractions of sediments generally require the use of nitric, sulfuric, hydrochloric, and hydrofluoric acids. Water-extractable concentrations of the metal-like constituents should represent a minimum mass that would reach the water table, given adequate recharge water (from any source) and "reasonable" time. A determination of the time required to move labile contaminants from their location in the vadose zone sediments to the water table is predicted most often using computer-based transport models. The transport models require choosing values for key hydraulic parameters (e.g., recharge rate, unsaturated hydraulic conductivity, moisture content) and contaminant-sediment retardation factors (e.g., $\mathrm{K}_{\mathrm{d}} \mathrm{S}$ and solubility constants) and boundary conditions (e.g., stratigraphy, depth to water table, current distribution of contaminants in the sediments and their pore waters). Section 6 includes tables with recommended values for each geologic stratum for many of the input parameters needed for such transport codes.

Given the geologic heterogeneity caused by the catastrophic Ice Age floods and the wide range of chemical waste types disposed of in the B-Complex, there exists great potential for wide-ranging variations in contaminant distribution, both vertically and horizontally, in the vadose zone below the B-Complex. The authors request that the reader keep this admonition in mind while processing the discussions that follow in Section 3 on the mass of uranium and technetium-99 estimates within the vadose zone. There is little "statistical" justification for assigning uncertainties to the masses projected to be present in the vadose zone. The only justification for the estimates of mass found in Section 3 are the sediment characterization data presented in the subsections named Vadose Zone Distribution and "expert judgment" supported by tens of years of critical analysis of the Hanford site's subsurface by the team of multi-disciplined earth scientists contributing to this report. It is difficult to offer anything but qualitative discussion on uncertainty in the masses proposed. This report attempts to err on the side of overestimating concentrations (especially in vertical extent) of technetium-99 and uranium in the various geologic layers or "boxes." On the other hand, it is unclear whether the horizontal spreading of the contaminants outside the facility footprints (e.g., BY Cribs, BX Trenches, B-7-A\&B Cribs, and the BX102 "near-field") in the vadose zone has been fully captured. The approach used in this report was to emphasize the direct measurements on vadose zone sediment total concentrations, and the water extract's and pore water's (obtained using ultra-centrifugation) concentrations to estimate the distribution of total and mobile uranium and technetium-99, respectively, in the vadose zone. Where noted in the mass estimate sections in Section 3, the authors did consider the more qualitative gamma logging and soil electrical resistivity field surveys to guide their estimates of the volume of sediment impacted. 
Table 1.3. Available Data to Estimate Vadose Zone Inventory for Technetium-99 and Uranium

\begin{tabular}{|c|c|c|c|c|}
\hline Region & Type & Number & Details & Comments \\
\hline BY Cribs & $\begin{array}{c}\text { Boreholes, SGLS } \\
\operatorname{logs}\end{array}$ & 5 boreholes & $\begin{array}{c}3 \text { inside footprints } \\
\text { (B-43, B-49, B-57) } \\
\text { and } 2 \text { proximal to } \\
\text { cribs }\end{array}$ & $\begin{array}{l}\text { SGLS did not identify } \\
\text { the presence of } \\
\text { Hanford processed } \\
\text { uranium and cannot } \\
\text { measure technetium. }\end{array}$ \\
\hline B-7A/B \& B-8 Cribs & $\begin{array}{c}\text { Boreholes, SGLS } \\
\operatorname{logs}\end{array}$ & 4 boreholes & $\begin{array}{c}1 \text { inside } \mathrm{B}-7 \mathrm{~A} \text { crib, } 3 \\
\text { proximal to } \mathrm{B}-7 \mathrm{~A}\end{array}$ & $\begin{array}{l}\text { SGLS did not identify } \\
\text { the presence of } \\
\text { Hanford processed } \\
\text { uranium in C3103, } \\
\text { but did in the CCU } \\
\text { unit at E33-18, E33- } \\
\text { 344, and 345. }\end{array}$ \\
\hline BX Trenches & $\begin{array}{c}\text { Boreholes, SGLS } \\
\log \end{array}$ & 1 borehole & Inside B-38 & $\begin{array}{l}\text { SGLS did not identify } \\
\text { the presence of } \\
\text { Hanford processed } \\
\text { uranium in C3104. }\end{array}$ \\
\hline BX Tank Farm & $\begin{array}{l}\text { Boreholes, shallow } \\
\text { direct push, SGLS } \\
\text { logs }\end{array}$ & $\begin{array}{l}2 \text { boreholes, } 3 \text { direct } \\
\text { push, } \sim 20 \text { SGLS logs }\end{array}$ & $\begin{array}{l}\text { 299-E33-45 borehole } \\
70 \mathrm{ft} \text { east of BX-102, } \\
\text { direct pushes south of } \\
\text { tank, SGLS focused } \\
\text { NE of tank; E33-343 } \\
\sim 250 \mathrm{ft} \text { NE of tank }\end{array}$ & $\begin{array}{l}\text { SGLS logs of } 13 \\
\text { boreholes NE of BX- } \\
102 \text { detected Hanford } \\
\text { processed uranium in } \\
\text { VZ; gamma logs } \\
\text { from six shallow } \\
\text { direct pushes south- } \\
\text { east of BX-102 show } \\
\text { the presence of } \\
\text { Hanford processed } \\
\text { uranium also. }\end{array}$ \\
\hline B Tank Farm & $\begin{array}{l}\text { Boreholes, very } \\
\text { shallow direct push, } \\
\text { SGLS logs }\end{array}$ & $\begin{array}{c}1 \text { borehole, } 3 \text { very } \\
\text { shallow direct pushes, } \\
\text { SGLS }\end{array}$ & $\begin{array}{l}\text { E33-46 borehole } 15 \mathrm{ft} \\
\text { NE of B-110, direct } \\
\text { pushes (only to } \\
\sim 25 \mathrm{ft} \text { bgs) near } \\
\text { B-153 diversion box }\end{array}$ & $\begin{array}{l}\text { None of the SGLS } \\
\text { logs in the region } \\
\text { show Hanford- } \\
\text { processed uranium. }\end{array}$ \\
\hline BY Tank Farm & $\begin{array}{c}\text { Boreholes, SGLS } \\
\operatorname{logs}\end{array}$ & $\begin{array}{c}1 \text { borehole, SGLS for } \\
299-E 33-9 \text { and E33- } \\
205\end{array}$ & $\begin{array}{l}\text { E33-205 is 200 ft } \\
\text { south of BY farm and } \\
\text { "up-dip" from VZ } \\
\text { beds' dip (better } \\
\text { suited to monitor the } \\
\text { BX tank farm VZ) }\end{array}$ & $\begin{array}{l}\text { No SGLS logs show } \\
\text { consistent signs of } \\
\text { Hanford processed } \\
\text { uranium. }\end{array}$ \\
\hline
\end{tabular}

A "box" model of representative volumes of sediment both within disposal facility footprints and outside the footprints was created. Separate sediment concentration values were chosen for "total" uranium, water extractable-uranium, and -technetium for the various geologic strata to represent 1) inside facility footprints and 2) outside the footprints. Data from within facility footprints were used to develop a vertical distribution of contamination from the bottom of the disposal facility to the water table whenever chemical data within the footprints were available. The concentration values came from the data presented in Section 3 subsections on vadose zone contaminant distributions and are summarized in the tables (see Table 3.3, and Table 3.4 ) and cross-section figures that accompany the text in the 
inventory estimate subsections (see Figure 3.22 and Figure 3.23 for examples). The directly measured sediment data from boreholes outside the facility footprints combined with estimates of lateral spreading distances from SGLS logging information, (mostly cobalt-60 or Hanford-processed uranium in the BX Tank Farm region; see Figure 3.49 top panel and Figure 3.50) were used for the shallow vadose zone where the Hanford-processed uranium can be identified with fair certainty to estimate the extent of lateral spreading. ${ }^{\text {(a) }}$ The vertical distribution of these two contaminants was guided by the geologic stratigraphy model described in Section 2 and more specifically the stratigraphic thickness plots in Appendix B. Where present, emphasis was placed on the three thin fine-grained lenses in the $\mathrm{H} 2$ formation and the $\mathrm{CCU}_{\mathrm{z}}$ unit as key locations where significant lateral spreading should have occurred. Vadose zone sediment data from the new boreholes 299-E33-343, -344, -345 and historical SGLS logs at 299-E33-18 and -41 conclusively show that the $\mathrm{CCU}_{\mathrm{z}}$ unit, where present under the B-Complex, contains significant masses of water, technetium-99, and uranium (as well as other constituents: nitrate, chromium, fluoride, sodium etc).

For the facility footprint cross-sectional area, either the literal cross sectional area of the facilities or the entire contiguous area of the perimeter around the base of the cribs or trenches was used. When the facility footprint calculations were parsed into "literal" cross sections versus contiguous cross sections, both calculations are presented as shown in Table 3.8 and Figure 3.21 for the BY Cribs. For a few calculations, two lateral spreading areas were chosen to see how much mass would be estimated to reside in the vadose zone under lesser and greater lateral spreading scenarios. The mass of the contaminant is calculated as the product of concentration in the sediment $\times$ area $\times$ thickness $\times$ bulk density (taken from Table 4.2 for each stratum such as $1.65 \mathrm{~g} / \mathrm{cm}^{3}\left[1650 \mathrm{~kg} / \mathrm{m}^{3}\right]$ for the $\mathrm{CCU}_{\mathrm{z}}$ unit). The masses for inside the footprint and the laterally spread masses were then summed and compared to the total mass disposed of to each sub-region (found in Table 3.25 presented at the end of Section 3).

(a) Cobalt-60 deep in the vadose zone cannot be directly attributed to any single source because it was present in almost all the waste disposals and releases from tank farms and horizontal spreading may have commingled vadose zone plumes. The authors placed the most emphasis on the shallow vadose zone portion of gamma log, where source attribution is better constrained, to estimate lateral spreading distances. Unless other data types were available that confirmed greater distances of lateral spreading, the deep vadose zone gamma logging information was not used. 



\subsection{B-Complex Area Geology}

This section summarizes the geologic setting and presents an updated conceptual geohydrologic model for the B-Complex.

\subsection{Overview}

The B-Complex conceptual model is based on a select 64 boreholes (Table 2.1) out of hundreds drilled in the B Complex. The analysis focused on the deeper and most recently drilled boreholes within $1000 \mathrm{ft}(300 \mathrm{~m})$ of the B-Complex as shown in Figure 2.1. Most of the available geophysical logs for the key boreholes are found in Appendix F. The selected boreholes provide the most complete information available on the suprabasalt stratigraphy and lithology of the site. Most of the hundreds of shallow, vadose zone boreholes drilled around the tank farms (e.g., DOE-GJO 1997, 1998, and 1999) were not considered as important in the development of the updated conceptual geohydrologic model. The information in this section provides the framework for subsequent consideration of general stratigraphic and structural controls on moisture and waste fluid movement through the vadose zone to groundwater. Stratigraphic cross sections based on the two transects shown in Figure 2.1 are illustrated in Figure 2.2 and Figure 2.3. Isopach (thickness of units) and structure contour maps (elevations of the tops of each unit) of the suprabasalt units are included in Appendix B.

Table 2.1. Boreholes Used to Generate Geology Conceptual Model

\begin{tabular}{|c|c|c|c|}
\hline Well Name & $\begin{array}{c}\text { Ground Surface } \\
\text { Elev. at Time of Drilling }(\mathrm{ft})\end{array}$ & $\begin{array}{l}\text { Easting } \\
(\mathrm{m})\end{array}$ & $\begin{array}{l}\text { Northing } \\
(\mathrm{m})\end{array}$ \\
\hline 299-E27-16 & 652.8 & 574179.24 & 137164.86 \\
\hline 299-E28-8 & 670.5 & 573698.10 & 137074.30 \\
\hline 299-E33-1A & 632.9 & 573632.34 & 137614.03 \\
\hline 299-E33-2 & 631.9 & 573617.01 & 137641.27 \\
\hline 299-E33-3 & 631.4 & 573633.13 & 137666.04 \\
\hline 299-E33-4 & 630.5 & 573616.75 & 137693.11 \\
\hline 299-E33-5 & 635.5 & 573574.23 & 137606.42 \\
\hline 299-E33-6 & 631.3 & 573574.40 & 137652.87 \\
\hline 299-E33-7 & 628.6 & 573574.03 & 137695.97 \\
\hline 299-E33-8 & 654.3 & 573475.30 & 137447.93 \\
\hline 299-E33-9 & 654.2 & 573646.83 & 137485.88 \\
\hline 299-E33-10 & 677 & 573255.50 & 137258.19 \\
\hline 299-E33-11 & 621.2 & 573901.32 & 137635.81 \\
\hline 299-E33-12 & 624.3 & 573780.54 & 137632.23 \\
\hline 299-E33-13 & 629.3 & 573706.49 & 137584.39 \\
\hline 299-E33-14 & 622.9 & 573985.61 & 137567.22 \\
\hline 299-E33-15 & 628.1 & 573810.29 & 137540.70 \\
\hline 299-E33-16 & 642.1 & 573791.69 & 137465.30 \\
\hline 299-E33-17 & 635.1 & 573878.52 & 137467.18 \\
\hline 299-E33-18 & 652.7 & 573779.17 & 137386.06 \\
\hline 299-E33-19 & 654 & 573847.63 & 137422.66 \\
\hline 299-E33-20 & 653.4 & 573847.60 & 137397.91 \\
\hline 299-E33-21 & 669.4 & 573474.47 & 137293.21 \\
\hline 299-E33-22 & 634.5 & 573624.75 & 137660.79 \\
\hline
\end{tabular}


Table 2.1. Boreholes Used to Generate Geology Conceptual Model

\begin{tabular}{|c|c|c|c|}
\hline Well Name & $\begin{array}{c}\text { Ground Surface } \\
\text { Elev. at Time of Drilling }(\mathrm{ft})\end{array}$ & $\begin{array}{c}\text { Easting } \\
(\mathrm{m})\end{array}$ & $\begin{array}{l}\text { Northing } \\
\text { (m) }\end{array}$ \\
\hline 299-E33-23 & 632.6 & 573617.06 & 137695.14 \\
\hline 299-E33-24 & 639.3 & 573493.54 & 137578.53 \\
\hline 299-E33-25 & 634.3 & 573365.23 & 137681.63 \\
\hline 299-E33-26 & 633.7 & 573333.35 & 137681.47 \\
\hline 299-E33-27 & 659.4 & 573668.07 & 137338.19 \\
\hline 299-E33-31 & 647.7 & 573524.98 & 137491.44 \\
\hline 299-E33-32 & 660.2 & 573524.83 & 137354.02 \\
\hline 299-E33-33 & 640.7 & 574080.14 & 137301.93 \\
\hline 299-E33-36 & 647.2 & 574068.54 & 137239.98 \\
\hline 299-E33-37 & 653.5 & 574091.48 & 137185.42 \\
\hline 299-E33-38 & 633.3 & 573591.16 & 137594.49 \\
\hline 299-E33-39 & 623.8 & 573843.52 & 137637.37 \\
\hline 299-E33-40 & 624.6 & 573546.23 & 137723.10 \\
\hline 299-E33-41 & 654.8 & 573707.19 & 137369.94 \\
\hline 299-E33-42 & 654.2 & 573520.99 & 137424.38 \\
\hline 299-E33-43 & 662.5 & 573523.19 & 137325.43 \\
\hline 299-E33-44 & 643.1 & 573706.41 & 137469.16 \\
\hline 299-E33-45 & 656.8 & 573693.10 & 137350.60 \\
\hline 299-E33-46 & 657.3 & 573792.55 & 137278.37 \\
\hline 299-E33-47 & 648.8 & 573916.48 & 137295.46 \\
\hline 299-E33-48 & 664.7 & 573781.45 & 137162.07 \\
\hline 299-E33-49 & 666.8 & 573647.48 & 137212.80 \\
\hline 299-E33-50 & 625.8 & 573773.61 & 137599.30 \\
\hline 299-E33-205 (C) & 657.2 & 573633.38 & 137406.22 \\
\hline 299-E33-296 & 632.4 & 573628.12 & 137613.85 \\
\hline 299-E33-302 & 629 & 573579.94 & 137665.73 \\
\hline 299-E33-304 & 640.3 & 573496.64 & 137563.32 \\
\hline 299-E33-333 & 653.4 & 574086.41 & 137181.28 \\
\hline 299-E33-334 & 667 & 573514.72 & 137256.37 \\
\hline 299-E33-335 & 667.4 & 573568.44 & 137222.23 \\
\hline 299-E33-337 & 662.7 & 573821.80 & 137193.87 \\
\hline 299-E33-338 & 657 & 573912.07 & 137238.24 \\
\hline 299-E33-339 & 663.7 & 573716.86 & 137221.51 \\
\hline 299-E33-340 (G) ${ }^{1}$ & 617.9 & 573779.64 & 137763.84 \\
\hline 299-E33-341 (D) & 627.5 & 573565.21 & 137652.50 \\
\hline 299-E33-342 (E) & 636.9 & 573625.68 & 137579.96 \\
\hline 299-E33-343 (A) & 652.3 & 573743.98 & 137382.25 \\
\hline 299-E33-345 (Br) & 653.2 & 573780.87 & 137388.24 \\
\hline C3103 & 652.8 & 573802.55 & 137385.58 \\
\hline C3104 & 662.7 & 573471.18 & 137347.64 \\
\hline $\begin{array}{l}=\text { Disc_Z value in Han } \\
=\text { Calculated using late } \\
\text { Calculated from casing } \\
=\text { Coordinates from } \mathrm{RP} \\
1=\text { Letter designation } \mathrm{f} \\
\mathrm{Br}=\text { replacement borel }\end{array}$ & $\begin{array}{l}\text { System } \\
\text { ng stick-up adjustments since time } \\
\text { omas (2008) }\end{array}$ & & \\
\hline
\end{tabular}




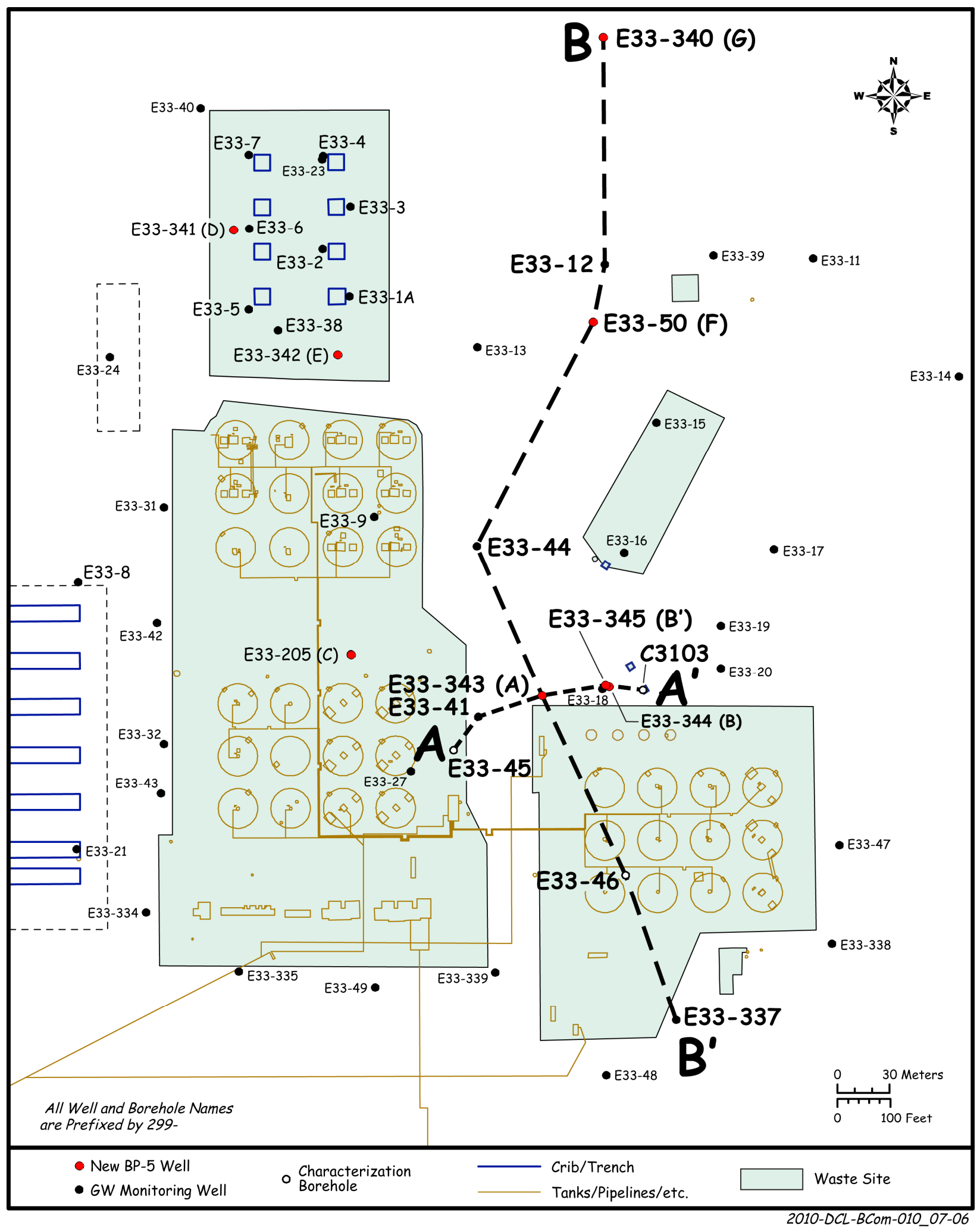

Figure 2.1. Location of Boreholes Used to Generate Geology Conceptual Model 


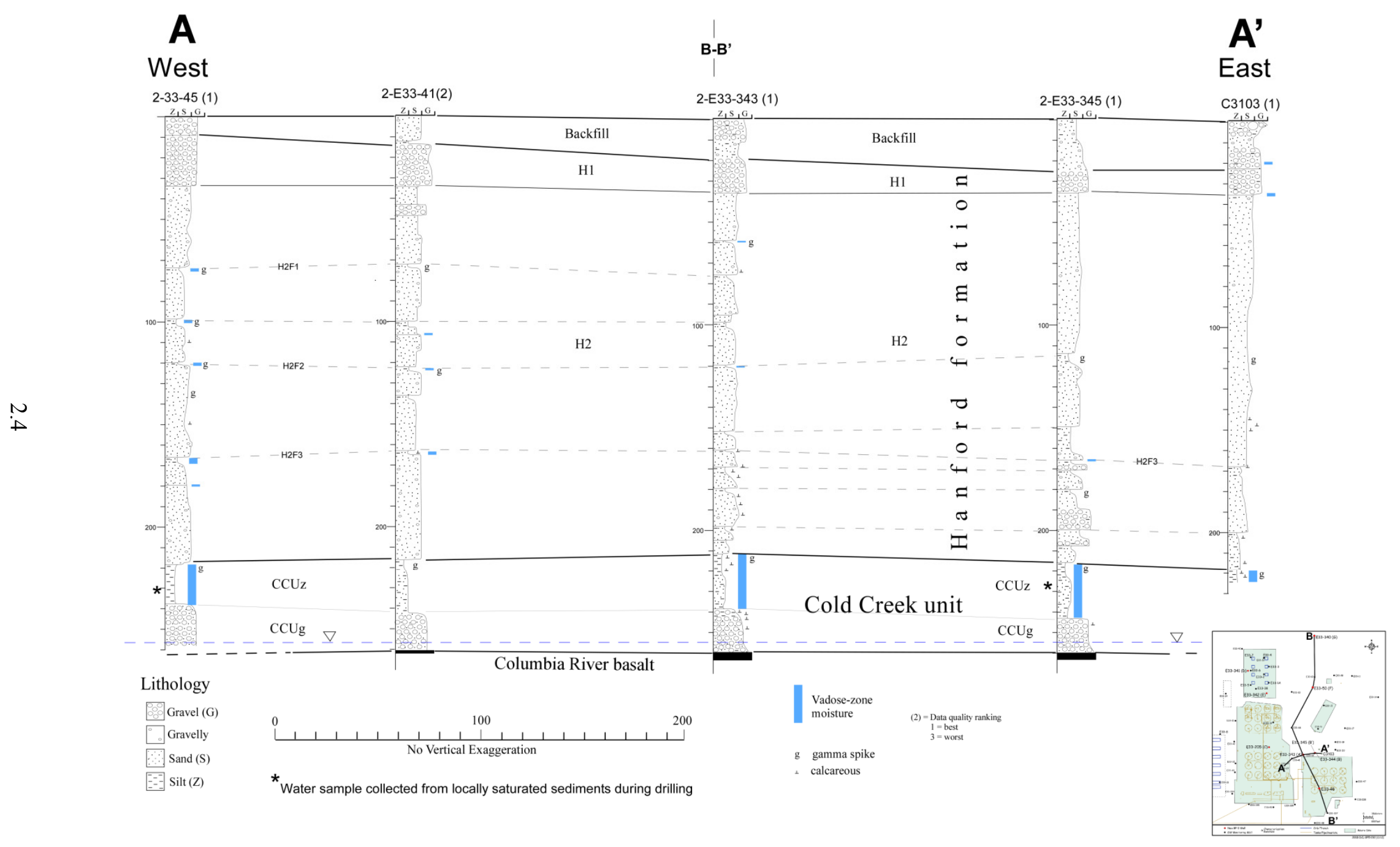

Figure 2.2. Hydrogeologic Cross Section A-A' 


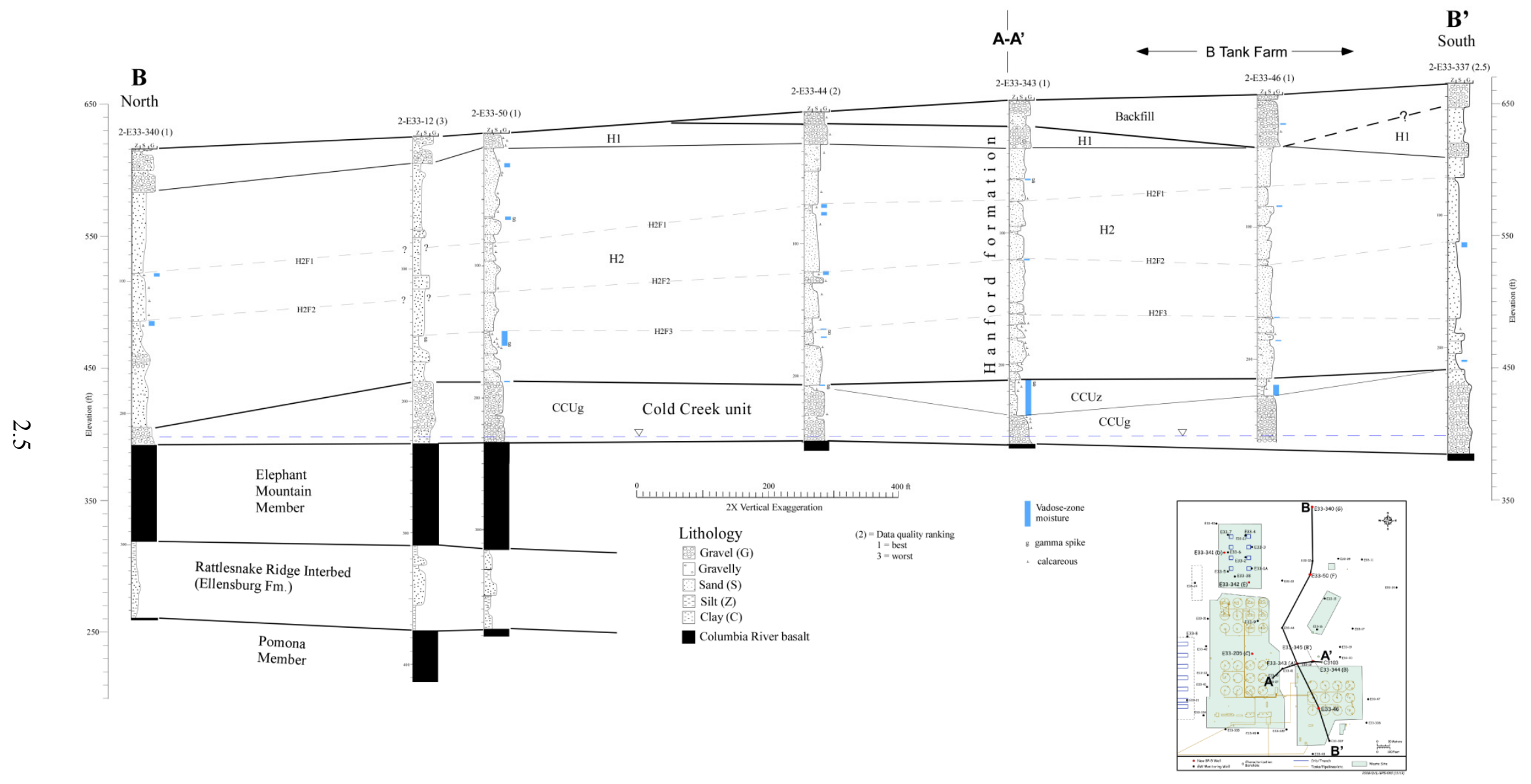

Figure 2.3. Hydrogeologic Cross Section B-B' 


\subsection{Geomorphology}

The B-Complex lies along the northern flank of Cold Creek bar, a large compound flood bar formed during Pleistocene Ice-Age floods (Figure 2.4). The upper surface of the bar in the 200 East Area forms a broad plain at about $700-\mathrm{ft}(210-\mathrm{m})$ elevation. The bar extends westward for several miles; the northern boundary of the bar is defined by a series of northwest-southeast trending flood channels (Bjornstad 2006). The B-Complex is located on the grade that slopes gently $(\sim 0.026 \mathrm{ft} / \mathrm{ft}[0.085 \mathrm{~m} / \mathrm{m}])$ to the northeast from Cold Creek bar into the uppermost flood channel south of Gable Mountain (see Figure 2.4).

\subsection{General Stratigraphy}

A total of six stratigraphic units are recognized in the B-Complex area, and three rather continuous thin fine-grained lenses have been designated within the Hanford H2 unit (Figure 2.5).

- Recent backfill material

- Hanford formation-gravel-dominated sequence (H1 unit)

- Hanford formation-sand-dominated sequence (H2 unit)

- Cold Creek unit silt-fine grained $\left(\mathrm{CCU}_{\mathrm{z}}\right)$

- Cold Creek unit gravel—coarse grained $\left(\mathrm{CCU}_{\mathrm{g}}\right)$

- CRBG.

The B-Complex trenches and cribs and B-BX-BY SSTs were constructed in the near-surface sediments that overlie the CRBG (i.e., bedrock) Plio-Pleistocene age fluvial and perhaps some eolian deposits lay between Columbia River basalt and the overlying cataclysmic ice-age flood deposits (i.e., Hanford formation). Suprabasalt sediments in the vicinity are unconsolidated and include two facies of the CCU: the deeper facies is coarse grained (gravel dominated), and the shallower one is generally fine-grained mud with sand. Sand, gravel, and lesser amounts of silt-dominated deposits from Pleistocene cataclysmic floods are collectively referred to as the Hanford formation (see Figure 2.5). In the vicinity of the B-Complex, the Hanford formation is subdivided into a gravel sequence (H1 unit) and an underlying sequence composed of predominantly sand (H2 unit), which contains several thin, fine-grained silty lenses. Three thin, finegrained lenses may correlate across the region of interest. These fine-grained lenses play a significant role in horizontal spreading of waste liquids disposed of or accidently leaked at the various facilities.

The fluvial-lacustrine Ringold Formation, which overlies basalt over most of the Hanford Site, does not appear to be present beneath in the B-Complex, having been completely eroded away by later cataclysmic flooding. The vadose zone beneath the B-Complex is as much as $83 \mathrm{~m}(273 \mathrm{ft})$ thick and consists of the Pleistocene-aged Hanford formation and the Cold Creek unit. The unconfined aquifer beneath the B-Complex ranges from 0 to about 18 feet thick. In a few places, the top of the basalt bedrock extends above the water table. The saturated zone above the basalt lies mostly within the coarse-grained CCUg unit. In section 2.6 (see Figure 2.27 and Figure 2.28 the reader will find maps showing the saturated thickness of the aquifer for the historical high water table and the relatively low current water table. 


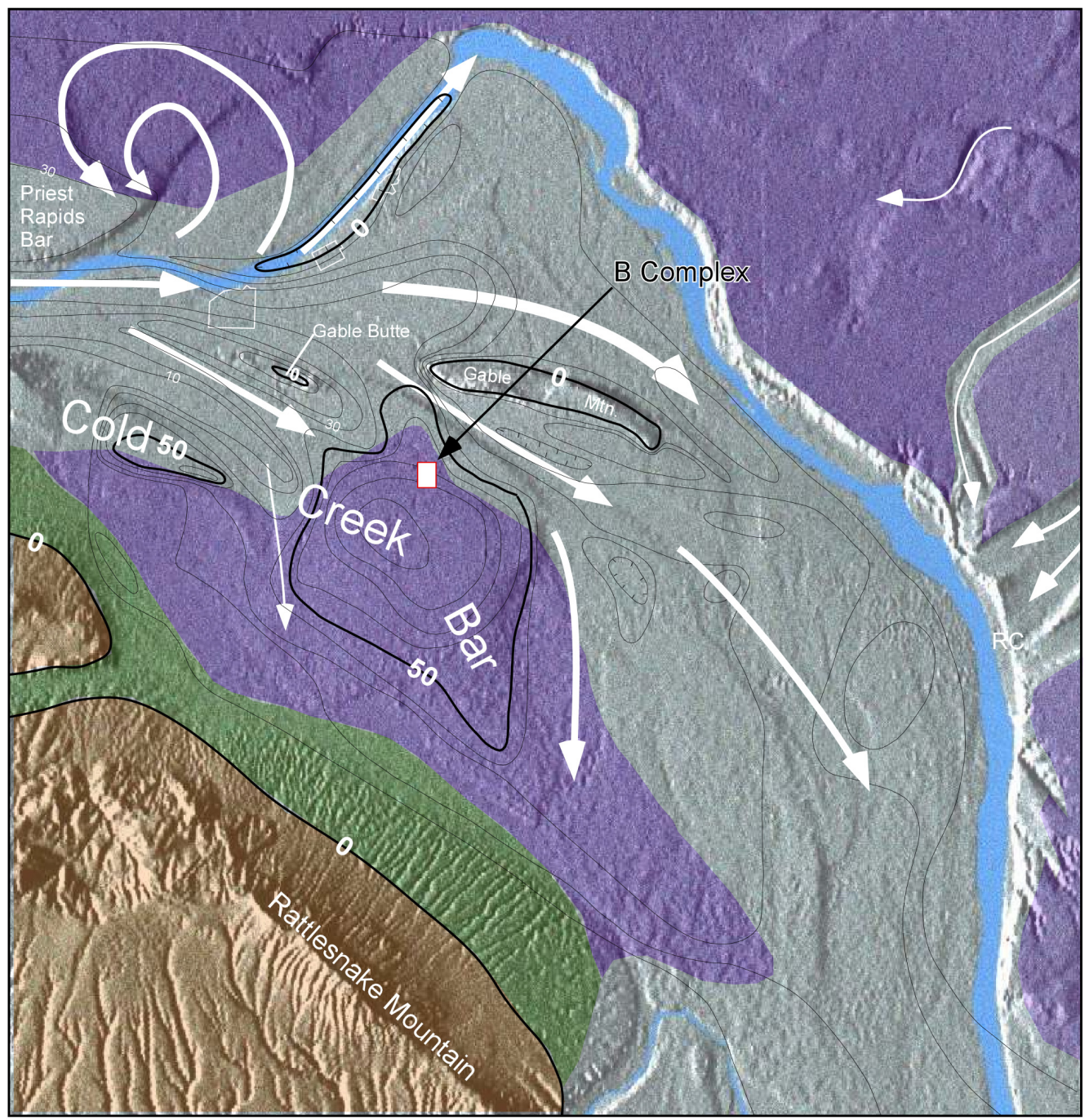

\section{Hanford Formation}

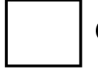

Gravel-Dominated Flood Deposits

Sand-Dominated Flood Deposits

Interbedded Sand- and

Silt-Dominated Flood Deposits

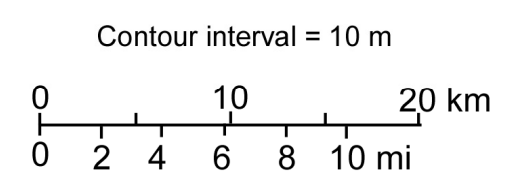

Above flood level (>380 m elev.)

\section{Flood Channel}

Figure 2.4. B-Complex Area in Relation to Ice Age Flood Features Within the Central Pasco Basin Contours are isopach thicknesses (in meters) for the Ice Age flood deposits (Hanford formation). Also shown is the distribution for the three dominant flood facies. 


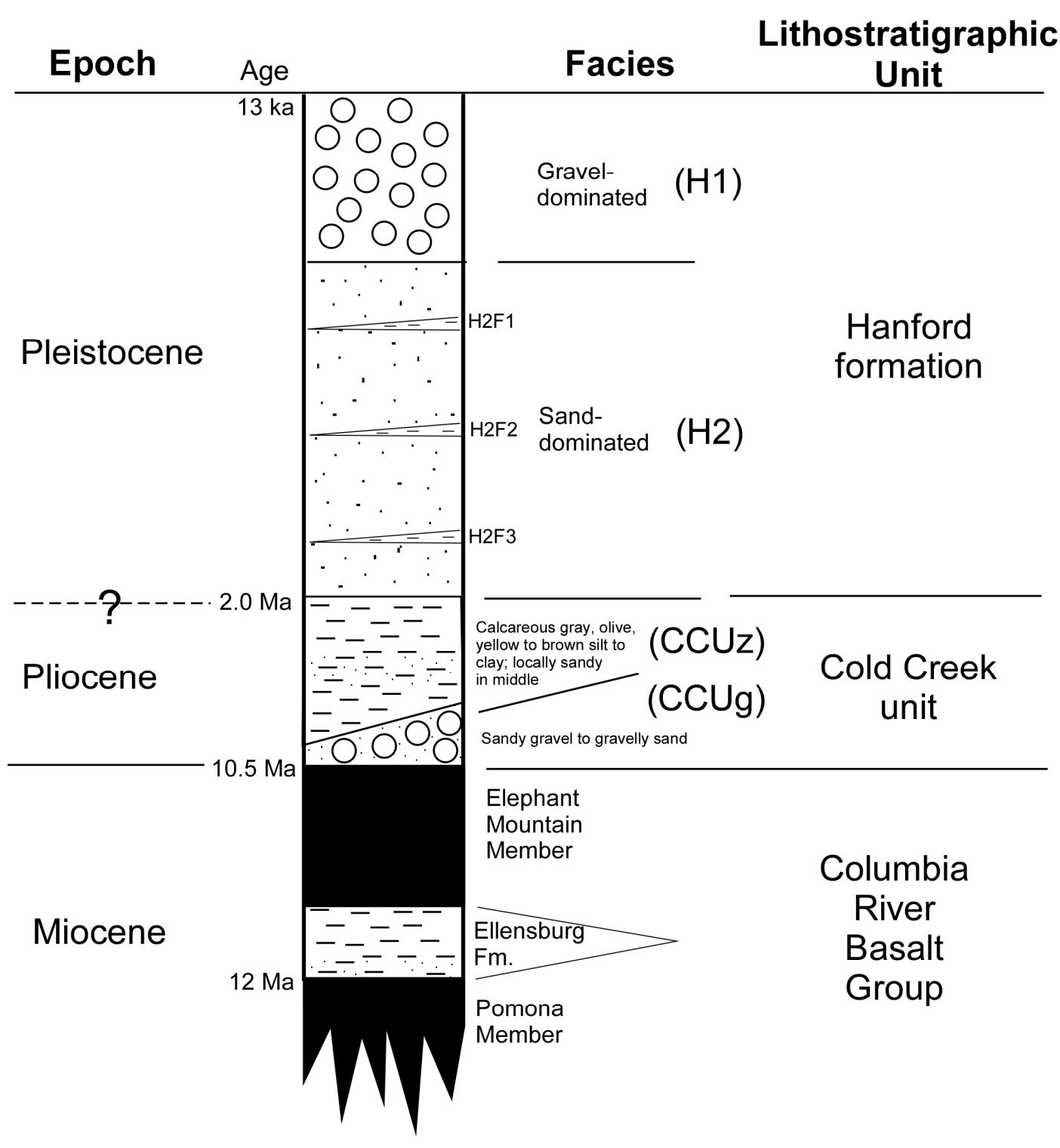

Figure 2.5. Generalized Stratigraphy for the B-Complex Area

\subsection{Methodology}

The sources of available geologic data, the quality of these data, and how they are used to develop the conceptual geohydrologic model for the B-Complex area are described in the following paragraphs.

\subsubsection{Data Sources}

Borehole data consisting of driller's logs, geologist's logs, actual sediment samples (archived for older boreholes), and geophysical logs obtained through the borehole casings, as well as limited characterization data (grain-size distribution, calcium carbonate $\left(\mathrm{CaCO}_{3}\right)$, and moisture content), are the principal data sets used to interpret the subsurface hydrogeology at the B-Complex. In addition, numerous reports describing 
the geology of the area create the foundation from which the model has evolved (e.g., Tallman et al. 1979; DOE 1988; Last et al. 1989; Lindsey 1991, 1995; Wood et al. 2000; Serne et al 2002a,b; and Reidel and Chamness 2007). A summary of the types of data available for boreholes within the B-Complex region is presented in Table 2.2.

Table 2.2. Drilling Methods, Data Quality Ranking and Other Information on Boreholes Used to Generate the Geology Conceptual Model

\begin{tabular}{|c|c|c|c|c|c|}
\hline & & Total Depth & & Data Quality & \\
\hline Well Name & Well ID & $(\mathrm{ft})$ & Drill Method & Ranking* & Completed \\
\hline 299-E27-16 & A4814 & 269 & $\mathrm{DB} / \mathrm{HT}$ & 3 & 1990 \\
\hline 299-E28-008 & A6788 & 315 & HT & 4 & 1957 \\
\hline 299-E33-001A & A4838 & 235 & $\mathrm{DB} / \mathrm{HT}$ & 3 & 1954 \\
\hline 299-E33-002 & A4846 & 243 & HT & 4 & 1954 \\
\hline 299-E33-003 & A4854 & 236 & HT & 4 & 1954 \\
\hline 299-E33-004 & A4865 & 231 & HT & 4 & 1954 \\
\hline 299-E33-005 & A4870 & 242 & HT & 4 & 1955 \\
\hline 299-E33-006 & A6852 & 238 & HT & 4 & 1955 \\
\hline 299-E33-007 & A4871 & 233 & HT & 4 & 1955 \\
\hline 299-E33-008 & A4872 & 257 & HT & 3 & 1953 \\
\hline 299-E33-009 & A4873 & 275 & HT & 4 & 1949 \\
\hline 299-E33-010 & A6853 & 290 & HT & 3 & 1955 \\
\hline 299-E33-011 & A6854 & 230 & HT & 4 & 1954 \\
\hline 299-E33-012 & A4839 & 415 & HT & 3 & 1953 \\
\hline 299-E33-013 & A4840 & 235 & HT & 3 & 1953 \\
\hline 299-E33-014 & A4841 & 230 & HT & 3 & 1953 \\
\hline 299-E33-015 & A4842 & 251 & HT & 3 & 1953 \\
\hline 299-E33-016 & A6855 & 258 & HT & 3 & 1953 \\
\hline 299-E33-017 & A4843 & 244 & HT & 3 & 1953 \\
\hline 299-E33-018 & A4844 & 278 & HT & 4 & 1947 \\
\hline 299-E33-019 & A4845 & 252 & HT & 4 & 1956 \\
\hline 299-E33-020 & A4847 & 254 & HT & 3 & 1956 \\
\hline 299-E33-021 & A4848 & 282 & HT & 4 & 1957 \\
\hline 299-E33-022 & A6856 & 233 & DB & 3 & 1965 \\
\hline 299-E33-023 & A6857 & 230 & DB & 3 & 1965 \\
\hline 299-E33-024 & A4849 & 256 & $\mathrm{DB} / \mathrm{HT}$ & 4 & 1967 \\
\hline 299-E33-025 & A6858 & 240 & HT/DB & 4 & 1969 \\
\hline 299-E33-026 & A4850 & 240 & HT/DB & & 1969 \\
\hline 299-E33-027 & A4851 & 255 & $?$ & 5 & 1970 \\
\hline 299-E33-031 & A4856 & 255.9 & $\mathrm{DB} / \mathrm{HT}$ & 3 & 1989 \\
\hline 299-E33-032 & A4857 & 270.3 & $\mathrm{DB} / \mathrm{HT}$ & 3 & 1989 \\
\hline 299-E33-033 & A4858 & 252 & $\mathrm{DB} / \mathrm{HT}$ & 3 & 1989 \\
\hline 299-E33-036 & A4861 & 263.8 & $\mathrm{DB} / \mathrm{HT}$ & 3 & 1990 \\
\hline 299-E33-037 & A4862 & 267.5 & $\mathrm{DB} / \mathrm{HT}$ & 3 & 1990 \\
\hline 299-E33-038 & A4863 & 239.6 & $\mathrm{DB} / \mathrm{HT}$ & 3 & 1990 \\
\hline 299-E33-039 & A4864 & 230.1 & $\mathrm{DB} / \mathrm{HT}$ & 3 & 1991 \\
\hline
\end{tabular}


Table 2.2. Drilling Methods, Data Quality Ranking and Other Information on Boreholes Used to Generate the Geology Conceptual Model

\begin{tabular}{|c|c|c|c|c|c|}
\hline Well Name & Well ID & $\begin{array}{l}\text { Total Depth } \\
\text { (ft) }\end{array}$ & Drill Method & $\begin{array}{c}\text { Data Quality } \\
\text { Ranking* }\end{array}$ & Completed \\
\hline 299-E33-040 & A4866 & 318 & $\mathrm{DB} / \mathrm{SS}$ & 3 & 1991 \\
\hline 299-E33-041 & A4867 & 263 & DB & 2 & 1991 \\
\hline 299-E33-042 & A4868 & 260.2 & DB & 3 & 1991 \\
\hline 299-E33-043 & A4869 & 273.7 & $\mathrm{DB} / \mathrm{HT}$ & 4 & 1991 \\
\hline 299-E33-044 & B8554 & 255 & DB & 2 & 1998 \\
\hline 299-E33-045 & C3269 & 261 & $\mathrm{DB} / \mathrm{SS}$ & 1 & 2001 \\
\hline 299-E33-046 & C3360 & 264.2 & $\mathrm{DB} / \mathrm{SS}$ & 1 & 2000 \\
\hline 299-E33-047 & C4259 & 268.9 & DB & 2 & 2004 \\
\hline 299-E33-048 & C4260 & 290.9 & DB & 2 & 2004 \\
\hline 299-E33-049 & C4261 & 288.8 & $\mathrm{DB} / \mathrm{SS}$ & 1 & 2004 \\
\hline 299-E33-050 (F) & C5195 & 381 & $\mathrm{DB} / \mathrm{SS}$ & 1 & 2006 \\
\hline 299-E33-205 (C) & C5989 & 270.6 & DB & 1 & 2008 \\
\hline 299-E33-296 & A7092 & 227 & $\mathrm{DB} / \mathrm{SS}$ & 2 & 1992 \\
\hline 299-E33-302 & A7098 & 223 & $\mathrm{DB} / \mathrm{SS}$ & 2 & 1992 \\
\hline 299-E33-304 & A7100 & 235.5 & $\mathrm{DB} / \mathrm{SS}$ & 2 & 1991 \\
\hline 299-E33-333 & B8079 & 254 & $\mathrm{DB} / \mathrm{SS}$ & 2 & 1998 \\
\hline 299-E33-334 & B8810 & 285 & $\mathrm{DB} / \mathrm{HT}$ & 2 & 1999 \\
\hline 299-E33-335 & B8811 & 286 & Sonic/AR & 2.5 & 2000 \\
\hline 299-E33-337 & C3390 & 286 & $\mathrm{AR}$ & 2.5 & 2001 \\
\hline 299-E33-338 & C3391 & 275.8 & SS & 1 & 2001 \\
\hline 299-E33-339 & C3392 & 285.4 & $\mathrm{DB} / \mathrm{AR}$ & 2.5 & 2001 \\
\hline 299-E33-340 (G) & C5853 & 325.7 & DB & 1 & 2008 \\
\hline 299-E33-341 (D) & C5856 & 237 & $\mathrm{DB} / \mathrm{SS}$ & 1 & 2008 \\
\hline 299-E33-342 (E) & C5857 & 245.5 & DBSS & 1 & 2008 \\
\hline 299-E33-343 (A) & C5858 & 268.8 & $\mathrm{DB} / \mathrm{SS}$ & 1 & 2008 \\
\hline 299-E33-345 (Br) & C6226 & 263.8 & DB & 1 & 2008 \\
\hline C3103 & C3103 & 222.5 & $\mathrm{DB} / \mathrm{SS}$ & 1 & 2001 \\
\hline C3104 & C3104 & 263.5 & $\mathrm{DB} / \mathrm{SS}$ & 2 & 2001 \\
\hline
\end{tabular}

New BP5 well names include alternate letter designation

Drilling method $\mathrm{DB}=$ drive barrel, $\mathrm{SS}=$ split-spoon, $\mathrm{HT}=$ hard tool, $\mathrm{AR}=$ air rotary, Sonic $=$ Sonic drilling Data Quality Ranking $1=$ highest quality; $5=$ poorest quality

Initially, well-site geologist's logs or driller's logs were examined and compared to geophysical logs from the boreholes. The quality of drilling logs varies because many wells and boreholes were drilled without a geologist present at the site; this is generally true for all boreholes drilled before the mid-1980s. Up until that time, driller's would collect sediment samples every $5 \mathrm{ft}(1.5 \mathrm{~m})$ and provide general descriptions of the formation materials and problems encountered onto drilling-summary forms. Most of the archived sediment samples from these early (pre-1980) wells were subsequently analyzed in the laboratory for grain-size distribution and $\mathrm{CaCO}_{3}$ content; these results reside in an old database called ROCSAN, found in the Virtual Library for the Hanford Site:

$<$ http://vlprod.rl.gov/vlib/app/index.cfm?TID=AF407230BF39F4E842AEE06730B6621D1865AD9FBF1B 344849E045CDDCDA896D\&ChangeModule $=$ Yes\&ModID $=$ ROCSAN $>$. 
The quality of the grain-size distribution data is largely dependent on the drilling method used. Those intervals drilled with a hard tool tend to produce more fines because of the pulverizing action of the hardtool bit. An alternative method is the drive-barrel, which preserves the original grain-size distribution, but can also result in some pulverization. A third method of collecting sediment samples is the split-spoon method, a small-diameter core barrel that is used to collect and preserve the sediment core within a metal or plastic sleeve. The split-spoon method also provides the best quality sample for geologic description and laboratory analysis. Unlike grain-size distribution data, the quality of the $\mathrm{CaCO}_{3}$ data is believed to be representative irrespective of the drill method since there is nothing to suggest that the drill method affects the bulk chemistry of the sample.

Beginning in the mid-1980s, recovered sediment samples were no longer routinely analyzed in the laboratory because more reliance was placed on using trained and experienced geologists to make detailed field observations on geologic properties such as grain size. Therefore, quantitative grain-size distribution and $\mathrm{CaCO}_{3}$ data are not available for many of the boreholes drilled between the mid-1980s and late 1990s; however, these parameters were provided qualitatively in geologists' logs. Geologists visually inspected the sediments and estimated grain size and qualitatively determined calcium carbonate content through contacting a small aliquot of sediment with hydrochloric acid. In most cases, there are archived sediment samples available should quantitative measurements be deemed important. Since the late 1990s, vadose zone sediment characterization in the laboratory has increased, and quantitative measurements of particle size and carbonate content using combination sieving-hydrometer and total carbon analyzer methods, respectively, have resumed on sediment samples deemed important to understanding the subsurface conditions. Other uncontaminated sediment samples continue to be archived should additional characterization be required. However, radiologically contaminated sediments, which are often of most interest, are not generally archived for future needs. This is an important shortcoming of the vadose zone sediment activities occurring over the entire Hanford Site.

Grain size distributions, $\mathrm{CaCO}_{3}$ contents and other characterization data are available for many of the sediments from the newer boreholes listed in Table 2.1. These data were assimilated into the process used to create the conceptual model of the B-Complex geology.

Geophysical logs (e.g., gross-gamma ray and more recently, spectral gamma ray), available for most of the boreholes, vary in quality, but are useful for identifying some, but not all, stratigraphic features. Geophysical logs sometimes show lithologic differences because of differing amounts of natural gamma-ray emitters (most commonly potassium-40 $\left[{ }^{40} \mathrm{~K}\right]$ ). The proportion of ${ }^{40} \mathrm{~K}$ generally increases with decreasing grain size because finer grained fractions are enriched in potassium-bearing felsic minerals such as micas and feldspars. Sample retrieval is sometimes difficult and often does not permit a determination of the exact depth of contacts. The gamma log is useful for accurately determining depths of fine-grained layers containing clay minerals, especially those a meter or more thick. However, thin $(<2 \mathrm{ft})$ layers or those with very little clay often still go undetected on gamma logs. Figure 2.6 is an example of geophysical logs for the 299-E33-45 borehole near SST BX-102.

Another data source useful for interpreting the lithology is moisture content. Within the vadose zone, moisture content generally increases along interfaces between materials with highly contrasting grain size. This is particularly true where high-permeability material (gravel and/or sand) overlies lower-permeability material (fine sand and/or silt). However, moisture may also concentrate along interfaces where a finegrained unit overlies a coarse sand or gravel. Using neutron-moisture logs in combination with gross gamma logs further aids in the lithologic interpretation. For example, a sudden moderate increase in gamma 
PNNL-19277

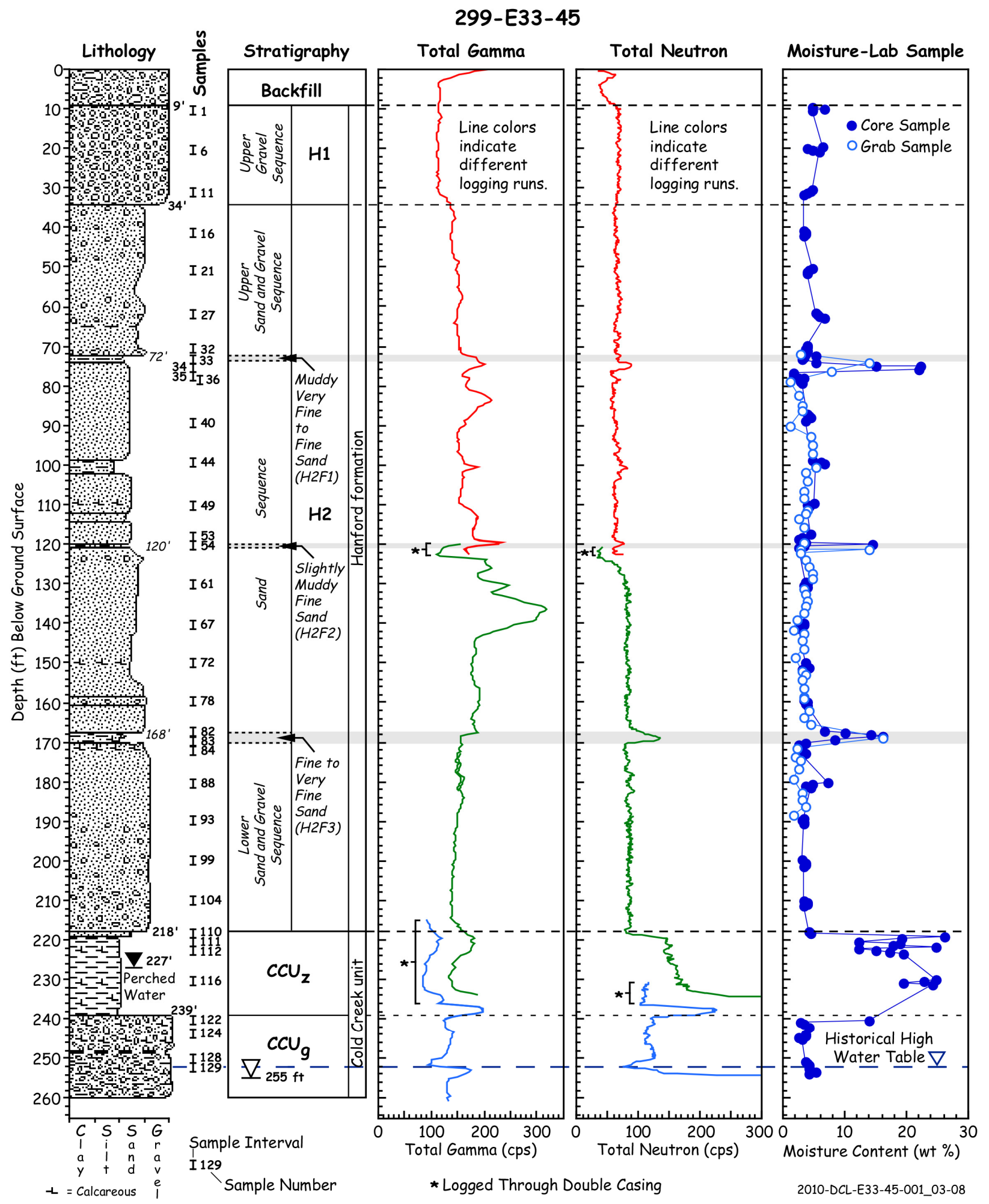

Figure 2.6. Generalized Borehole Log for Well 299-E33-45 
activity coincident with an increase in moisture is supports the indication of a fine-grained bed. However, an anomalous increase in moisture without an increase in the gross-gamma log may indicate either a fine-grained layer lacking in clay minerals or an elevated moisture interval not related to a change in sediment texture. It could instead indicate liquid moving through the vadose zone. Moisture may also concentrate along bed interfaces without displaying a contrast in gamma activity. Sediment sample data should (or is) being used to corroborate this assumption. Since the late 1990s, the gravimetric moisture content has been measured on sediment samples sent to the PNNL Applied Geology and Geochemistry Group's Environmental Sciences Laboratory analytical laboratory to aid in verifying the neutron moisture logs.

\subsubsection{Development of Geology Model}

The conceptual geology model presented herein used the driller's logs, geologist's logs, geophysical logs, and characterization data as well as visual inspection of sediment samples. All available data for each of the boreholes within and surrounding the B-Complex were compiled and summarized onto borehole summary sheets; a separate summary sheet was compiled for each borehole. Boreholes and the quality of their information are ranked in Table 2.2 (second column from the right) vis a vis the degree of uncertainty in the interpretation of the stratigraphy and lithology of the borehole. Each borehole is ranked from 1 to 5, with 1 having the highest confidence and least uncertainty in the geologic interpretation. Those boreholes ranked 5 (least confidence and highest uncertainty) had only a driller's log available. In contrast, boreholes ranked 1 (highest confidence and least uncertainty) have geologist's logs, and gamma and moisture logs as well as grain-size, $\mathrm{CaCO}_{3}$, and/or other characterization data.

The process of building the geologic conceptual model followed a series of investigative steps that were designed to honor the data and give preferential treatment to the higher ranked boreholes. First, the main stratigraphic units and contacts were identified in boreholes ranked with high quality (1 or 2$)$. This was done by comparing available data and picking depths to major lithologic contacts (i.e., units with roughly uniform grain size). Elevations and thicknesses of the major stratigraphic contacts were then calculated from the depths. Next, the same procedure was performed on lower-ranked boreholes. The next step was to plot the elevations and thicknesses of these major units onto structure-contour and isopach maps, respectively, as a way to determine if the contacts are realistic and make sense geologically. If the contacts are chosen correctly, the data should plot as relatively smooth surfaces transitioning from one borehole to another. Isolated, large, steep-gradient "bull eyes" on contour maps indicate that the contact may be miscalculated; in these cases, borehole information was reevaluated and the contact adjusted as necessary. Structure contour and isopach maps are presented in Appendix B.

Included in building a geologic conceptual model of the subsurface is constructing scaled cross sections linking boreholes together. Ideally, cross sections should trend at roughly right angles to one another to obtain a representative $3 \mathrm{D}$ view of the subsurface.

\subsection{B-Complex Specific Stratigraphy}

This section describes the stratigraphy in the B-Complex area. Table 2.3 describes the stratigraphy, and several photographs of sediments from each identified facies are provided to give the reader more help in conceptualizing the proposed geologic model. 


\subsubsection{Backfill}

Up to $10 \mathrm{~m}(35 \mathrm{ft})$ of backfill material is present above the undisturbed portions of the Hanford formation in many of the boreholes drilled in the WMA B-BX-BY, and up to $6 \mathrm{~m}(\sim 20 \mathrm{ft})$ of backfill is present within and proximal to the cribs and trenches in the B-Complex. The backfill is the native Hanford formation H1 unit material that was stockpiled nearby during disposal facility construction. Some of the coarsest gravel was removed before backfilling, and all natural layering/stratification was disrupted such that the backfill is rather homogeneous and featureless compared to the undisturbed H1 unit.

\subsubsection{Hanford formation}

The Hanford formation is the informal name given to all glacio-fluvial deposits from cataclysmic IceAge floods. Sources for floodwaters included glacial Lake Missoula, pluvial Lake Bonneville, and icemargin lakes that formed around the margins of the Columbia Plateau (Baker et al. 1991). The last Ice Age floods were about 15,000 calendar years ago; the earliest may have been 1 to 2 million years ago (Bjornstad 2006). The Hanford formation consists of mostly unconsolidated sediments that cover a wide range in grain size from pebble- to boulder-gravel, fine- to coarse-grained sand, silty sand, and silt. The Hanford formation is further subdivided into gravel-, sand-, and silt-dominated facies, which transition into one another vertically, as well as laterally with distance from the main, high-energy flood currents. Subunits ( $\mathrm{H} 1, \mathrm{H} 2$ and $\mathrm{H} 3$ ) of the Hanford formation have been defined by delineating contiguous sediments that are predominately composed of one of the facies types described below:

1) GRAVEL-DOMINATED FACIES. This facies sometimes consists of coarse-grained basaltic sand and granule to boulder gravel. These deposits display an open framework texture, massive bedding, plane to low-angle bedding, and large-scale planar cross bedding in outcrop. Gravel-dominated beds sometimes grade upward into the sand- and silt-dominated facies. Gravel clasts are dominantly basalt with lesser amounts of Ringold Formation clasts, granite, quartzite, and gneiss (Lindsey et al. 1992). The graveldominated facies was deposited by high-energy floodwaters in or immediately adjacent to the main cataclysmic flood channel ways.

2) SAND-DOMINATED FACIES. This facies consists of fine- to coarse-grained sand and granule gravel. The sands typically have high basalt content and are commonly referred to as black, gray, or "salt-andpepper" sands. They may contain small pebbles and rip-up clasts and pebble-gravel interbeds, and they often grade upward into thin $(<1 \mathrm{~m})$ zones of silt-dominated facies. This facies commonly displays plane lamination and bedding and less commonly channel cut-and-fill sequences. The sand-dominated facies was deposited adjacent to the main flood channel ways during the waning stages of flooding. The facies is transitional between the gravel-dominated facies and the silt-dominated facies.

3) SILT-DOMINATED FACIES. This facies consists of thin-bedded, plane-laminated, and ripple crosslaminated silt and fine- to coarse-grained sand. Beds are typically a few inches to several tens of inches thick and commonly display normally graded-bedding (Lindsey et al. 1992). Sediments of this facies were deposited under slack water conditions and in back-flooded areas (DOE 1988, Baker et al. 1991). 
PNNL-19277

Table 2.3. Lithostratigraphic Terminology Used in this Report for the Vadose Zone Beneath the B-Complex (Updated from Wood et al. 2000)

\begin{tabular}{|c|c|c|c|c|}
\hline $\begin{array}{l}\text { Stratigraphic } \\
\text { Symbol }\end{array}$ & $\begin{array}{l}\text { Lithostratigraphic } \\
\text { Unit }\end{array}$ & $\begin{array}{l}\text { Facies/ } \\
\text { Subunit }\end{array}$ & Description & Genesis \\
\hline Holocene/Fill & NA & backfill & $\begin{array}{l}\text { Poorly sorted cobbles, pebbles, and coarse to } \\
\text { medium sand with some silt derived from the } \\
\text { Hanford formation (Price and Fecht 1976) }\end{array}$ & Anthropogenic \\
\hline H1 & $\begin{array}{l}\text { Hanford } \\
\text { formation }\end{array}$ & H1 unit & $\begin{array}{l}\text { An upper gravel sequence consisting of high- } \\
\text { energy, gravel-dominated facies interbedded } \\
\text { with lenticular and discontinuous layers of } \\
\text { sand-dominated facies. }\end{array}$ & \multirow[b]{2}{*}{$\begin{array}{l}\text { Cataclysmic Flood } \\
\text { Deposits }\end{array}$} \\
\hline $\mathrm{H} 2$ & & $\mathrm{H} 2$ unit & $\begin{array}{l}\text { Sand sequence consisting predominantly of } \\
\text { sand-dominated facies, with multiple graded } \\
\text { beds of plane to foreset-bedded sand or } \\
\text { gravelly sand, which sometimes grades } \\
\text { upward to silty sand or silt. }\end{array}$ & \\
\hline $\mathrm{CCU}_{\mathrm{z}}$ & \multirow[t]{2}{*}{ Cold Creek Unit } & silt facies & $\begin{array}{l}\text { Silt sequence consisting of interstratified well } \\
\text { sorted calcareous silt and fine sand. }\end{array}$ & $\begin{array}{l}\text { Fluvial overbank } \\
\text { and/or Eolian } \\
\text { Deposits (with } \\
\text { some weakly } \\
\text { developed } \\
\text { paleosols) }\end{array}$ \\
\hline $\mathrm{CCU}_{\mathrm{g}}$ & & $\begin{array}{l}\text { Sandy } \\
\text { Gravel to } \\
\text { Gravelly } \\
\text { sand facies }\end{array}$ & $\begin{array}{l}\text { Sandy gravel to gravelly sand sequence } \\
\text { consisting predominantly of unconsolidated } \\
\text { moderately basaltic sands and gravels. }\end{array}$ & $\begin{array}{l}\text { Post-Ringold } \\
\text { coarse-grained } \\
\text { fluvial gravel and } \\
\text { sand. }\end{array}$ \\
\hline
\end{tabular}

The sand and gravel fractions of the Hanford formation generally consist of about $50 \%$ basalt and $50 \%$ felsic material (Tallman et al. 1979). This mineral assemblage gives the Hanford formation its characteristic "salt and pepper" appearance, often noted in driller's and geologist's logs. The felsic component is composed of quartz, feldspar and mica with some samples containing greater than $10 \%$ pyroxene, amphibole, mica, chlorite, ilmenite, and magnetite. The silt- and clay-sized fractions consist of quartz, feldspar, mica, and smectite.

The Hanford formation makes up the majority of the suprabasalt sedimentary sequence beneath the B-Complex, ranging in thickness from 43 to $73 \mathrm{~m}$ (140 to $240 \mathrm{ft}$ ). Based on lithologies observed at the B-Complex, the Hanford formation can be divided into two informal units (H1 and H2). It is important to note that $\mathrm{H} 1$ and $\mathrm{H} 2$, units are purely lithostratigraphic units and NOT time-stratigraphic units - in other words they are flood facies that may have been deposited simultaneously. From one place to another the type of flood sediment deposited was strongly dependent on its location relative to the changing energy level of the floods, which transitioned laterally across the B-Complex site. The H1 unit consists of mostly coarse-grained gravel or sandy gravel; the $\mathrm{H} 2$ unit is predominantly sand or gravelly sand, with occasional beds of sandy gravel. The sand-dominated $\mathrm{H} 2$ unit was deposited under less-energetic currents, perhaps farther away from the main channel way. The third facies of the Hanford formation, the silt-dominated facies, is occasionally present at the tops of some beds, but it is a minor component in these overall higher energy flood deposits. Three of these silt-dominated beds (H2F1, H2F2, and H2F3) appear to correlate at least over a portion of the B-Complex (see Figure 2.2 and Figure 2.3 cross sections). 
Because of the scale and dynamics of ice-age floods, the characteristics of the Hanford formation are unique compared to almost any other type of sedimentary deposit. For this reason, a complete assessment of the Hanford formation cannot be realized from boreholes alone; only through the study of outcrops can the actual stratigraphic relationships between Ice-Age flood deposits be fully evaluated. Fortunately, an excellent exposure of what is considered typical of the Hanford formation exists just to the east of the B-Complex at the 218-E-12B Burial Ground, which was excavated for the disposal of U.S Navy nuclearreactor cores (Rhoads et al. 1994).

A composite photograph and facies analysis of a portion of the 218-E-12B Burial Ground is shown in Figure 2.7. The walls of this large, 15-m-deep open pit, photographed and surveyed soon after excavation, expose a sequence of flood gravels, sands, and silts deposited during the last late-Pleistocene cataclysmic floods (Lewis et al. 1993). Within the excavation, the upper gravel sequence (H1 unit) and the uppermost portion of the sand sequence (H2 unit) appear to be represented. The complexity and heterogeneity inherent in these coarse-grained (i.e., high energy) flood deposits are illustrated in the upper half of Figure 2.7 and the accompanying close-up photograph (Figure 2.8). Of particular note is a series of six buried giant current ripples, $10 \mathrm{~m}$ below ground surface (bgs), that developed near the top of the sand sequence (H2 unit). The ripples, which display an amplitude of $1.8 \mathrm{~m}$, are asymmetric and about $60 \mathrm{~m}$ apart. Current ripples of this magnitude are a characteristic feature of the cataclysmic ice-age floods (Baker 1978). Paleocurrent

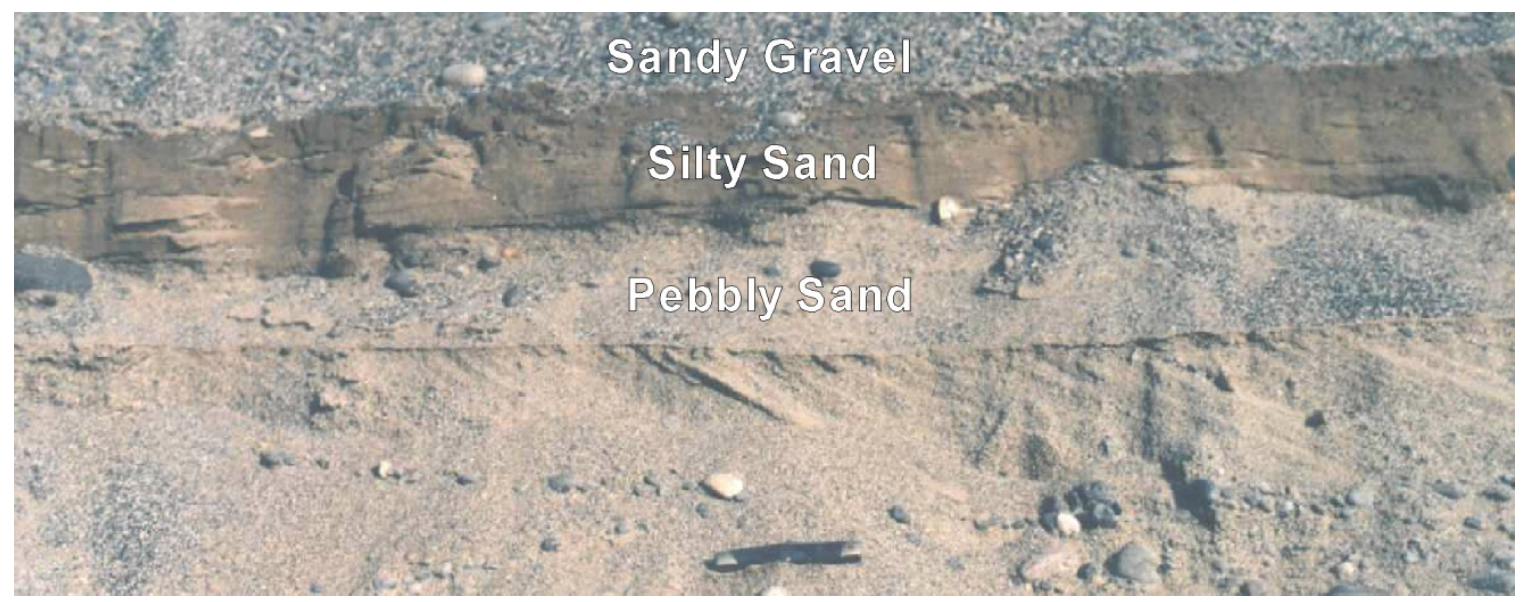

Figure 2.7. All Three Facies of the Hanford formation are Represented in this Photo at the 218-E-12B Site

Tabular cross bedding in the pebbly sand facies indicates a paleoflood direction from left (west) to right (east). Stratigraphically, the pebbly sand (i.e., sand-dominated facies) lies directly beneath and grades upward into the upper silty sand layer (sand-dominated facies). The silty sand is overlain in sharp contact by sandy gravel (i.e., gravel-dominated facies) along an erosional unconformity. An unknown amount of the silty sand was probably removed before being deposition of the overlying sandy gravel during a subsequent cataclysmic flood. Note the pocket knife in the center/bottom of the photo for scale. The Hanford coarse sand and Hanford fine sand, two samples characterized in detail for this report, came from the pebbly sand and silty sand layers, respectively. Note that the silty sand layer is darker due to its higher moisture content resulting from preferential absorption of meteoric water. 
PNNL-19277

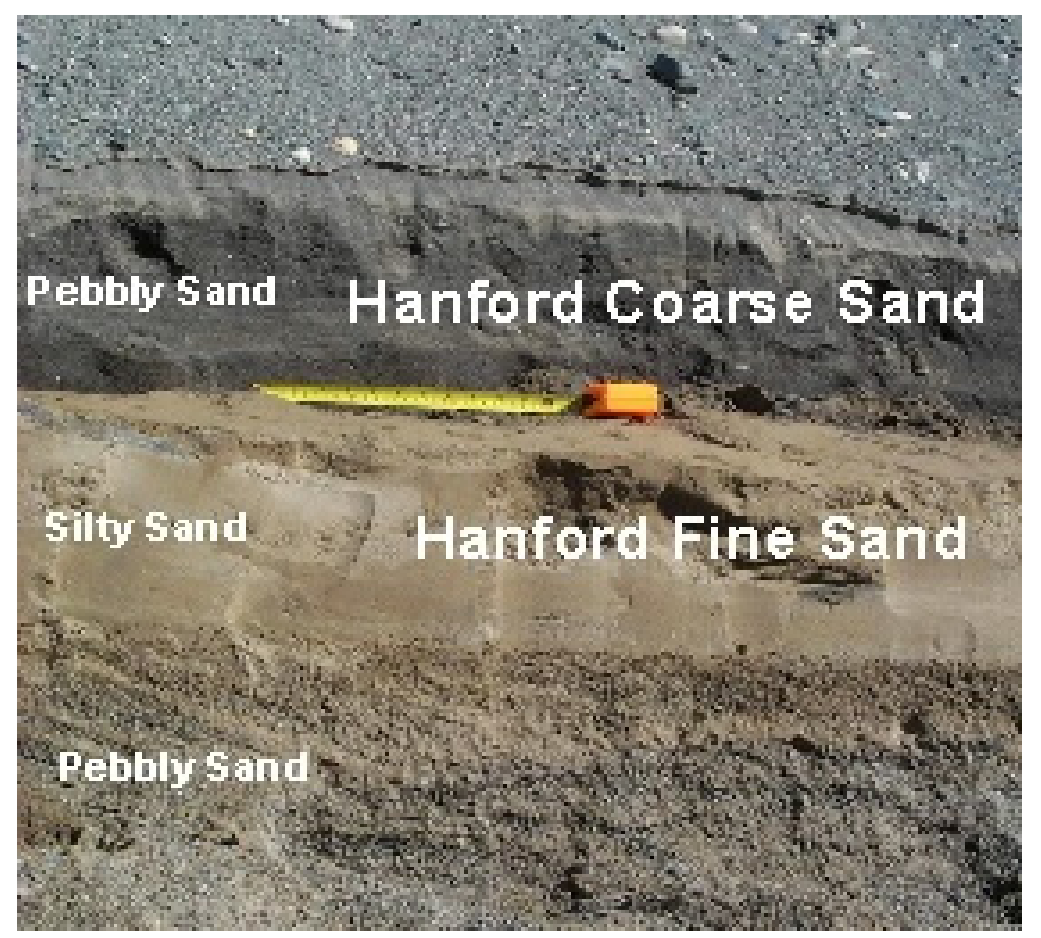

Figure 2.8. Close-Up Photo of the Silt Dominated Facies Similar to Facies Shown in Figure 2.7

indicators suggest the ripples were laid down by high-energy flood currents moving from west to east along the northern edge of Cold Creek Bar in a depositional environment similar to that of the B-Complex. Two separate layers of lower permeability, fine sand, and silt are present within the $15-\mathrm{m}$ sequence and partially fill troughs between ripple crests (these same finer grained layers thin to only a few centimeters over the ripple crests). It is significant that these fine-grained layers are continuous across the entire 140-m by 450$\mathrm{m}$ excavation, even though the thickness varies considerably. Because these fine-grained layers have lower permeability and retain more moisture, they have been implicated as intercepting waste-water moving downward through the vadose zone below the disposal facilities, the SSTs, and the infrastructure that have released waste fluids.

\subsubsection{Hanford formation gravel-dominated sequence (H1 unit)}

The Hanford formation gravel-dominated sequence overlies the Hanford formation sand-dominated sequence. Based on observations of outcrop and intact core samples, the Hanford formation gravel sequence is interpreted to consist of the high-energy, gravel-dominated facies interbedded with lenticular and discontinuous layers of the sand-dominated facies. Silt-dominated facies may also be present, although they probably constitute a relatively small percentage of the total. A photograph of what H1 sediment typically looks like is shown in Figure 2.9. The maximum thickness of the H1 unit reflects a north-south trending trough (i.e., channel) that trends beneath the BX and BY Tank Farms; the maximum thickness of the $\mathrm{H} 1$ unit in this trough is about $15 \mathrm{~m}(50 \mathrm{ft})$ (see Appendix B, Figure B.7).

\subsubsection{Hanford formation sand-dominated sequence (H2 unit)}

The Hanford formation sand sequence overlies the Cold Creek unit in the B-Complex area. The Hanford formation sand sequence (H2 unit) is ubiquitous beneath the B-Complex. The $\mathrm{H} 2$ unit consists 
of predominantly sand-dominated facies of the Hanford formation (see Figure 2.10 through Figure 2.17). Internally, this sequence probably contains multiple graded beds of plane- to foreset-bedded sand or gravelly sand several meters or more thick, which sometimes grades upward into silty sand or silt similar to that observed at the 218-E-12B Burial Ground (Figure 2.7). Many more silt layers are probably present in the subsurface than are reported in driller's and geologist's logs and appear in the cross sections shown in Figure 2.2 and Figure 2.3. This is because the drill method and/or the sampling interval (normally every $5 \mathrm{ft}$ ) often cannot distinguish layers less than a few feet thick. Cementation is very minor or absent in the $\mathrm{H} 2$ unit, and total $\mathrm{CaCO}_{3}$ content is generally a few weight percent or less. Three rather continuous thin fine-grained lens have been identified across the B-Complex region within the $\mathrm{H} 2$ unit that have been identified as H2F1 (at $\sim 70 \mathrm{ft}$ bgs), H2F2 (at $\sim 120 \mathrm{ft}$ bgs), and H2F3 (at about $\sim 170 \mathrm{ft} \mathrm{bgs}$ ). Example photographs of the fine-grained thin layers in the $\mathrm{H} 2$ sand-dominated unit are shown in Figure 2.17. The base of the Hanford formation sand sequence in the geology conceptual model overlies the Cold Creek unit.

A structure contour map of the top of the Hanford formation $\mathrm{H} 2$ sand sequence is shown in Appendix B, Figure B.8. The map shows about $20 \mathrm{~m}(60 \mathrm{ft})$ of relief on the surface of the sand sequence

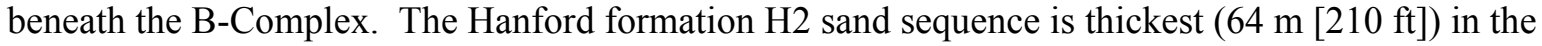

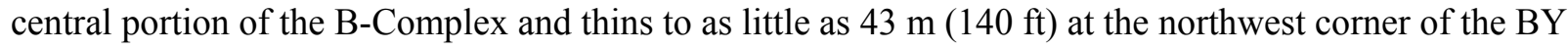
Cribs (Figure B.12).

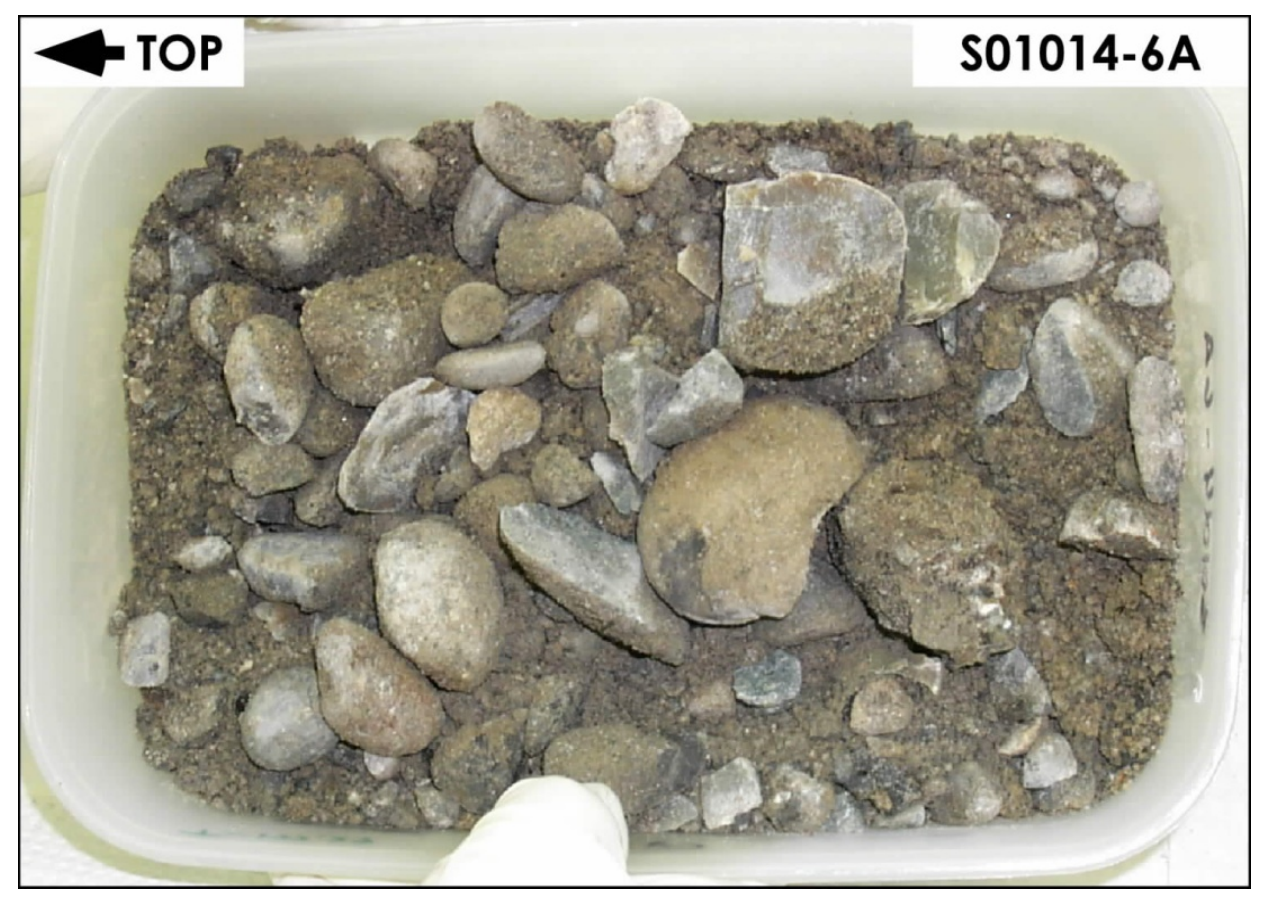

Figure 2.9. Example of the Gravel Dominated Hanford H1 unit from Sample S01014-6A Collected at a Depth of 6.3 to $6.4 \mathrm{~m}$ (20.6 to $21.1 \mathrm{ft})$ from Borehole 299-E33-45 
PNNL-19277

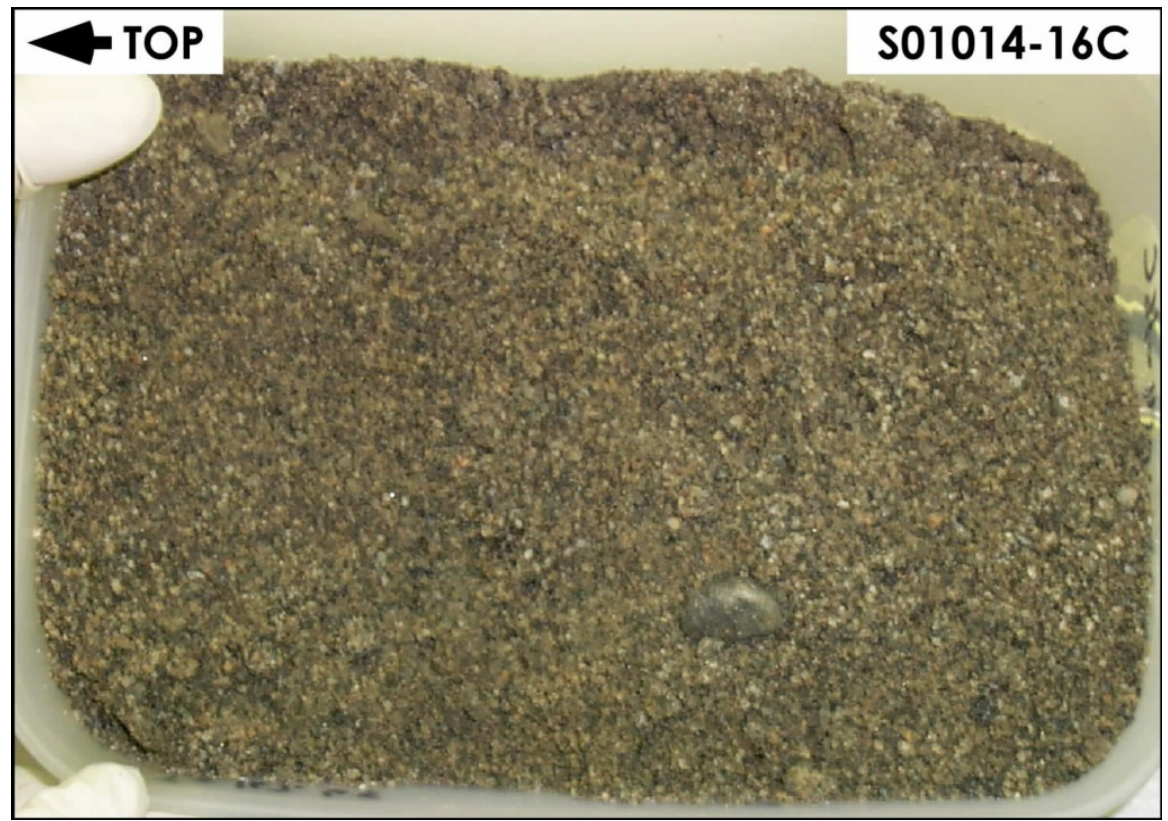

Figure 2.10. Example of the H2 Sand Sequence in Sample S01014-16C, Collected at a Depth of 12.6 to $12.7 \mathrm{~m}(41.3-41.8 \mathrm{ft})$ from Borehole 299-E33-45

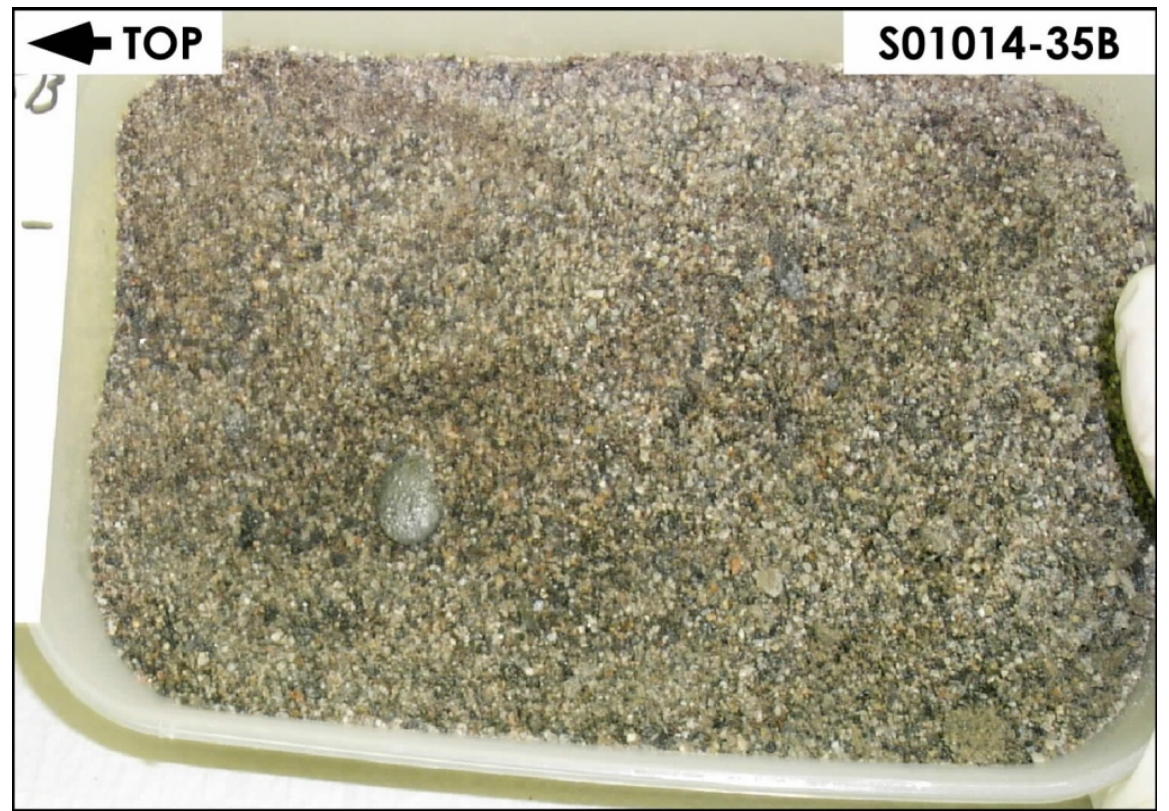

Figure 2.11. Coarse to Very Coarse Sand of the Middle of the H2 Sand Sequence from Sample S101014-35B at a Depth of 23.6 to $23.7 \mathrm{~m}$ (77.4 to $77.9 \mathrm{ft}$ ) in Borehole 299-E33-45 


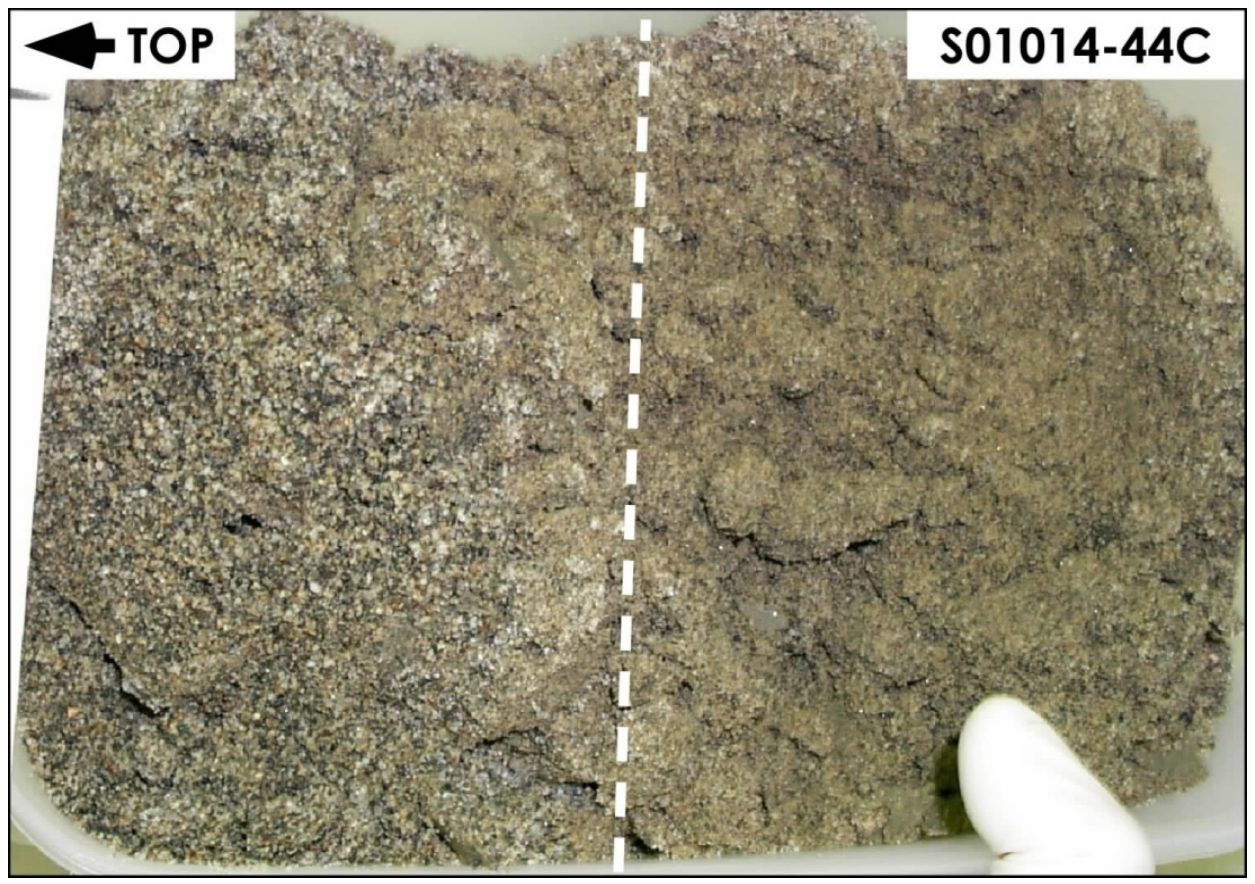

Figure 2.12. Contact Between Coarse Sand and Medium Sand Strata in the H2 Sand Sequence from Sample S01014-44C (Borehole 299-E33-45) at a Depth of 30.1 to $30.2 \mathrm{~m}$ (98.8 to $99.3 \mathrm{ft}$ )

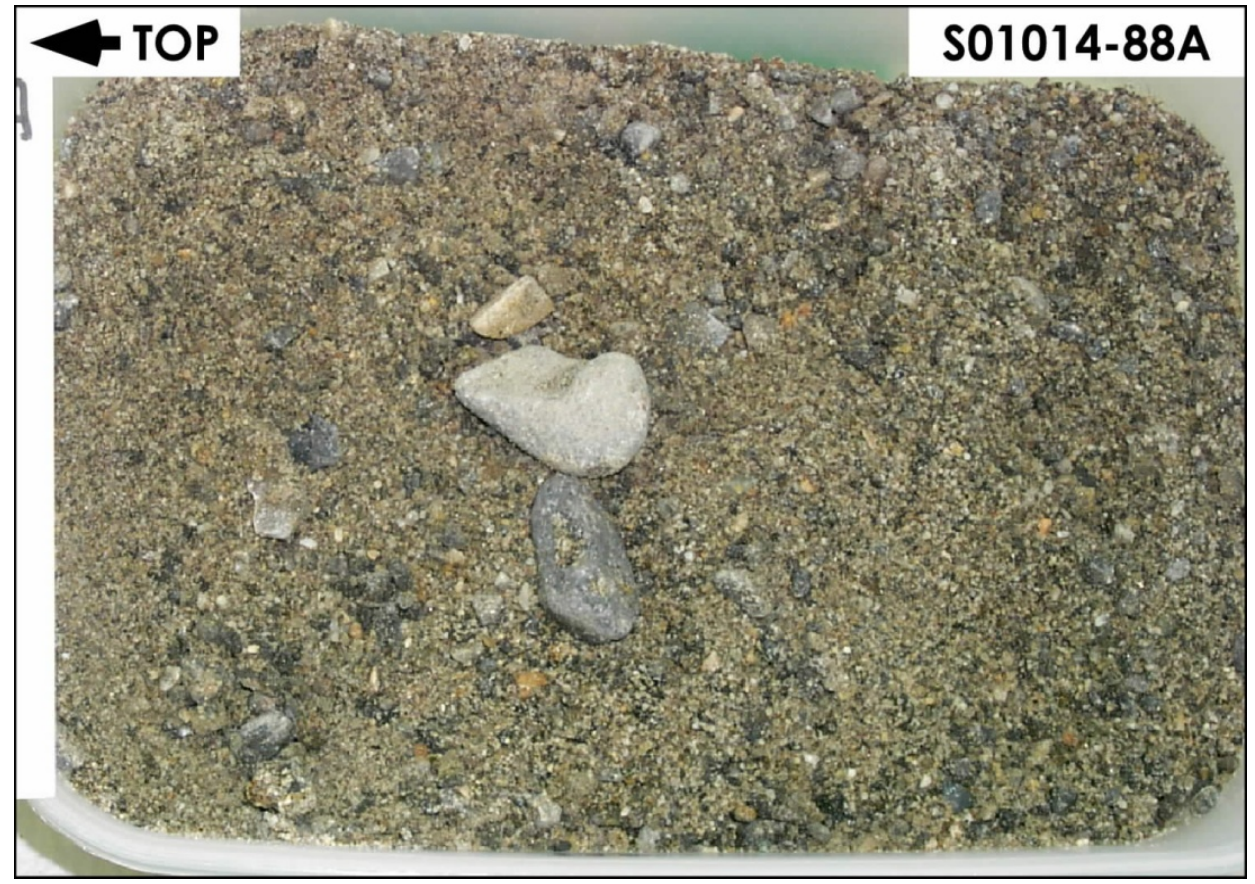

Figure 2.13. Gravelly (Mostly Fine to Very Fine Pebble) Coarse H2 unit Sand Representative of the Very Bottom of the unit (Sample S01014-88A from 299-E33-45) at a Depth of 55.3 to $55.4 \mathrm{~m}(181.4$ to $181.9 \mathrm{ft})$ 


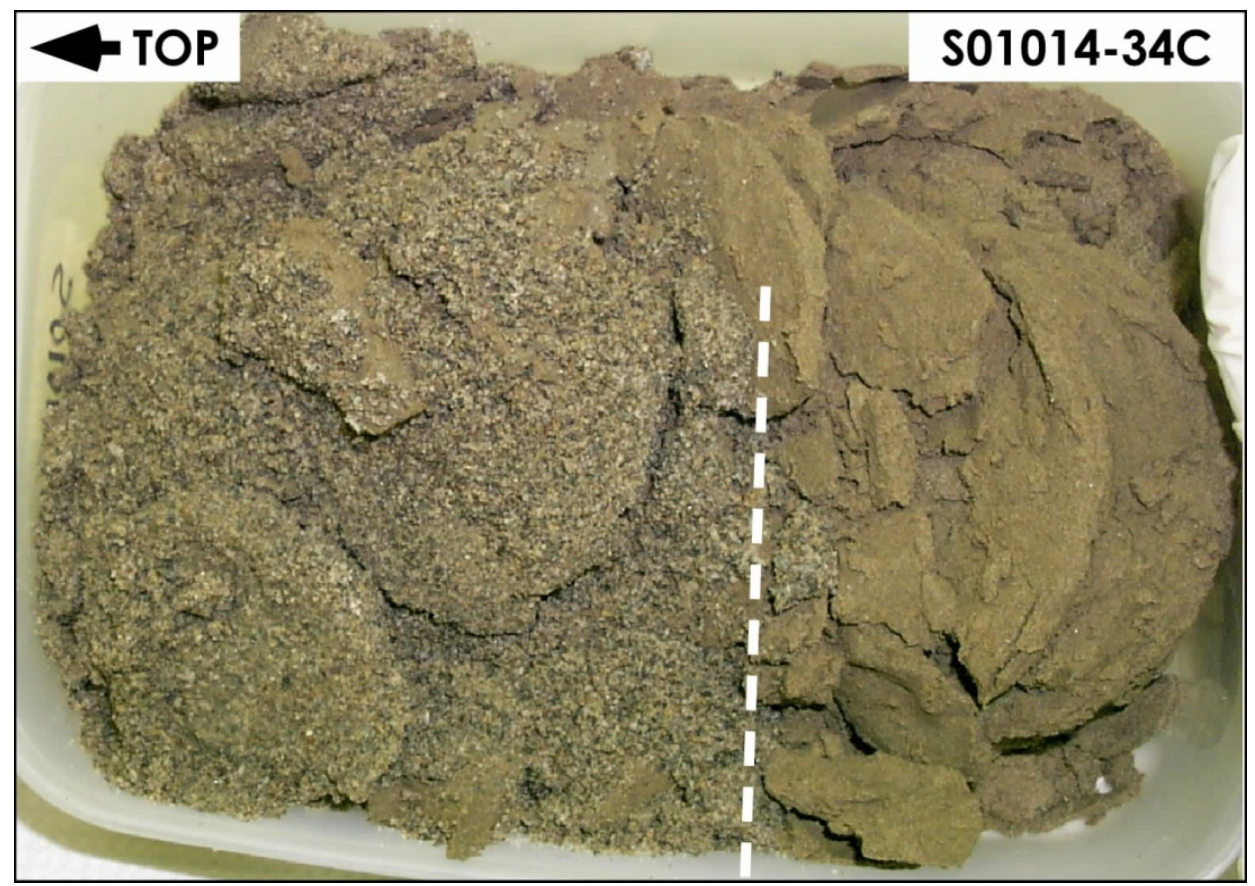

Figure 2.14. Contact Between H2 Upper Sand Sequence and the Thin H2F1 Finer-Grained Lens Observed in Sample S01014-34C (Borehole 299-E33-45), Collected at a Depth of 22.7 to $22.8 \mathrm{~m}$ (74.4 to $74.9 \mathrm{ft})$

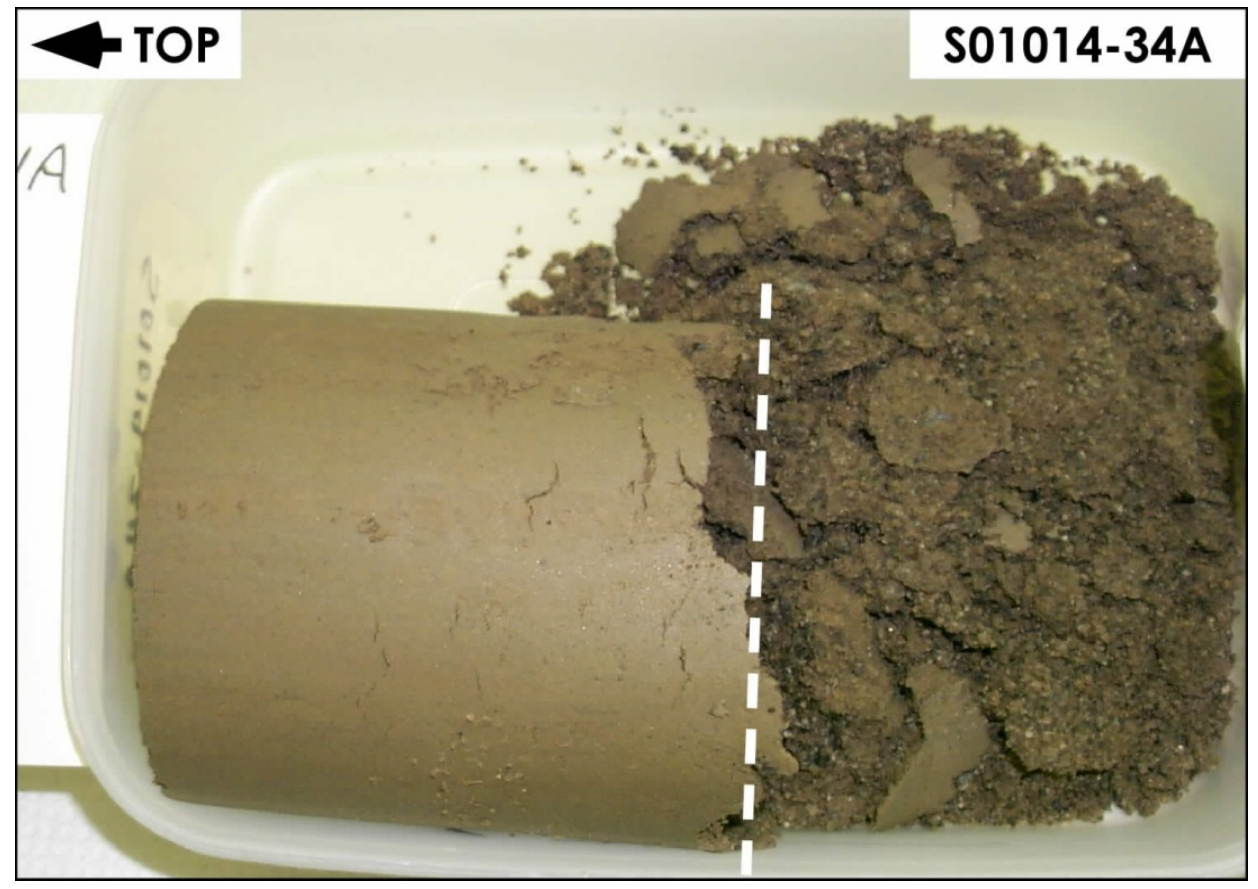

Figure 2.15. Lower Contact of the H2F1 Muddy Very Fine to Fine Sand Layer in Sample S01014-34A (299-E33-45) at a Depth of 23 to $23.1 \mathrm{~m}(75.4$ to $75.9 \mathrm{ft})$. Contact occurs at the break between the cohesive muddy sand on the left and the loose coarse sand on the right. 


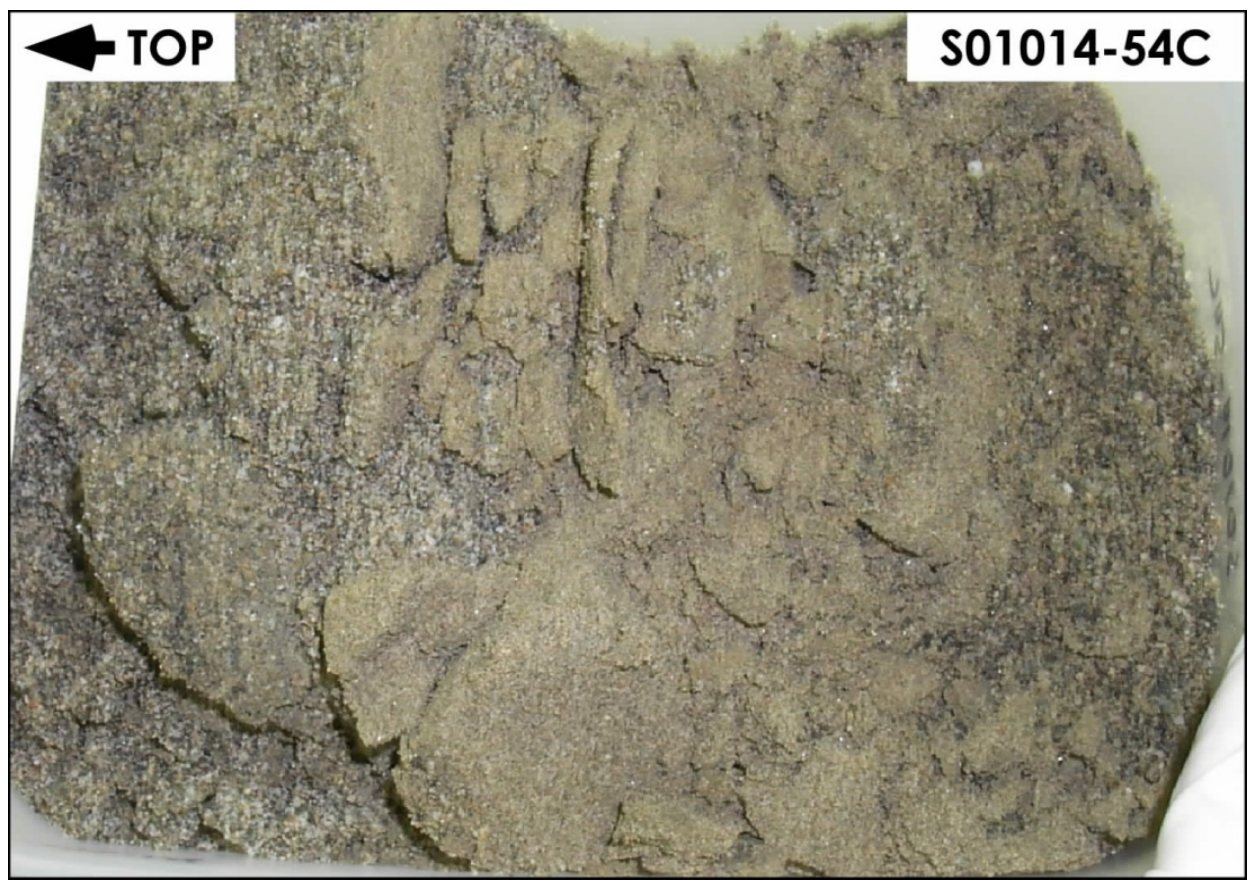

Figure 2.16. Thin Fine Grained Lens Representative of H2F2 Observed in Sample S01014-54C (Borehole 299-E33-45) at a Depth of 36.5 to $36.6 \mathrm{~m}$ (119.6 to $120.1 \mathrm{ft}$ )

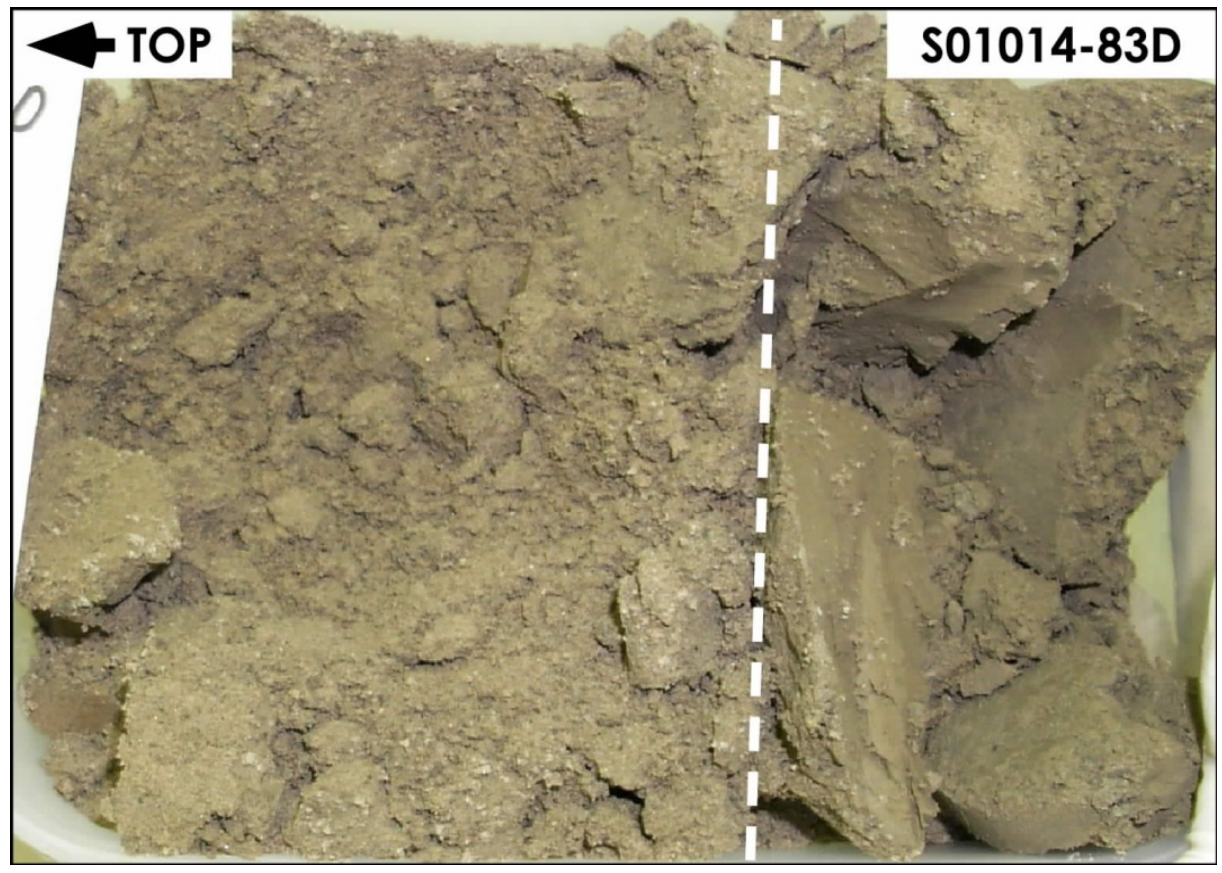

Figure 2.17. Poorly Sorted H2 Sand Contact with the Silty Very Fine Sand Layer H2F3 in Sample S01014-83D (299-E33-45) at a Depth of 51.6 to $51.7 \mathrm{~m}$ (169.3 to $169.8 \mathrm{ft})$ 
PNNL-19277

\subsubsection{Cold Creek unit}

A geologic unit of late Pliocene to early Pleistocene age, the Cold Creek unit (DOE/RL 2002), appears to be present beneath the B-Complex area. The Cold Creek unit was formerly referred to as the PlioPleistocene unit. This is indicated by a thick (up to 25 to $27 \mathrm{ft}$ in wells 299-E33-16, E33-18, E33-343, and E33-345-see Figure B.14) layer of well-sorted silt and/or fine sand that lies several tens of feet above the top of basalt. Cataclysmic-flood deposits of the Hanford formation typically do not contain silt beds more than a few feet thick; therefore, this silt layer is believed to be a pre-Missoula flood deposit, an overbankflood plain alluvium from the ancestral Columbia River. The $\mathrm{CCU}_{z}$ silt layer could be equivalent or partially equivalent to the early "Palouse" soil, a distinctive fine-grained unit beneath the 200-West Area (DOE 1988). Slate (1996) has included the early "Palouse" soil in with the Plio-Pleistocene Unit. If the silt layer is of Plio-Pleistocene age, then it follows that the sediments between the top of basalt and the silt layer must also be of Plio-Pleistocene age. Figure 2.18 and Figure 2.19 are example photographs of the Cold Creek silt sediments $\left(\mathrm{CCU}_{\mathrm{z}}\right)$.

The silt layer is localized over the northwestern portion of the B Tank Farm as shown in Figure 2.20. Elsewhere, in the B-Complex localized region it was either subsequently eroded or not deposited. Recently it has been discovered that the $\mathrm{CCU}_{\mathrm{z}}$ reappears to the northwest toward Gable Gap where it is up to $55 \mathrm{ft}$ thick (Bjornstad et al., in prep). The top of the $\mathrm{CCU}_{\mathrm{z}}$ silt layer dips slightly toward the northeast (Figure 2.21). Where the silt layer is missing, which is over most of the northern, western, and eastern edges of the B-Complex area, it is often difficult to distinguish between the Cold Creek gravel dominated unit $\left(\mathrm{CCU}_{\mathrm{g}}\right)$ and the overlying Hanford formation $\mathrm{H} 2$ unit. Contour maps showing the elevation of the tops of the $\mathrm{CCU}_{\mathrm{z}}$ silt and $\mathrm{CCU}_{\mathrm{g}}$ gravel units are shown in Appendix B, Figures B.14 and B.15.

Beneath the $\mathrm{CCU}_{z}$ silt layer (where it exists) is a sequence of moderately felsic sand and gravel that are being designated as the $\mathrm{CCU}_{\mathrm{g}}$ unit (Figure 2.22 and Figure 2.23). This layer is very similar to the Ringold Formation, except it often caves and heaves during drilling and contains a higher concentration of basaltic rock fragments. The loose, unconsolidated nature of these sediments suggests that they are post-Ringold in age and belong to a mainstream gravel facies of the Cold Creek unit. Most likely these represent fluvial deposits from the ancestral Columbia River, perhaps equivalent to the pre-Missoula Gravels (PSPL 1982) identified east of the study area. The upper surface of the gravel facies of the $\mathrm{CCU}_{\mathrm{g}}$ shows about $10 \mathrm{~m}$ $(30 \mathrm{ft})$ of relief.

A depression exists at the top of this unit centered over the northwest corner of the B Tank Farm, which appears to be filled with the overlying $\mathrm{CCU}_{z}$ layer (Figure B.15). The thickness of the gravel ranges from 5 to $18 \mathrm{~m}$ (20 to $60 \mathrm{ft}$ ) (Figure B.16). The $\mathrm{CCU}_{\mathrm{g}}$ unit is thinnest and structurally low near the same point, suggesting that channeling of the gravel took place before being backfilled with silt.

Within this sand and gravel sequence, there is a distinctive sudden shift in the $\mathrm{CaCO}_{3}$ content from $0 \%$ below to 2 to $3 \% \mathrm{CaCO}_{3}$ above over a short distance. This $\mathrm{CaCO}_{3}$ marker horizon is only apparent in a string of wells located in the northern portion of the B-Complex. The cause and significance of this marker horizon is not clear, but may represent a transition in climate to more arid conditions that promote higher $\mathrm{CaCO}_{3}$ content, and which are known to have occurred during Pliocene to Pleistocene times. 


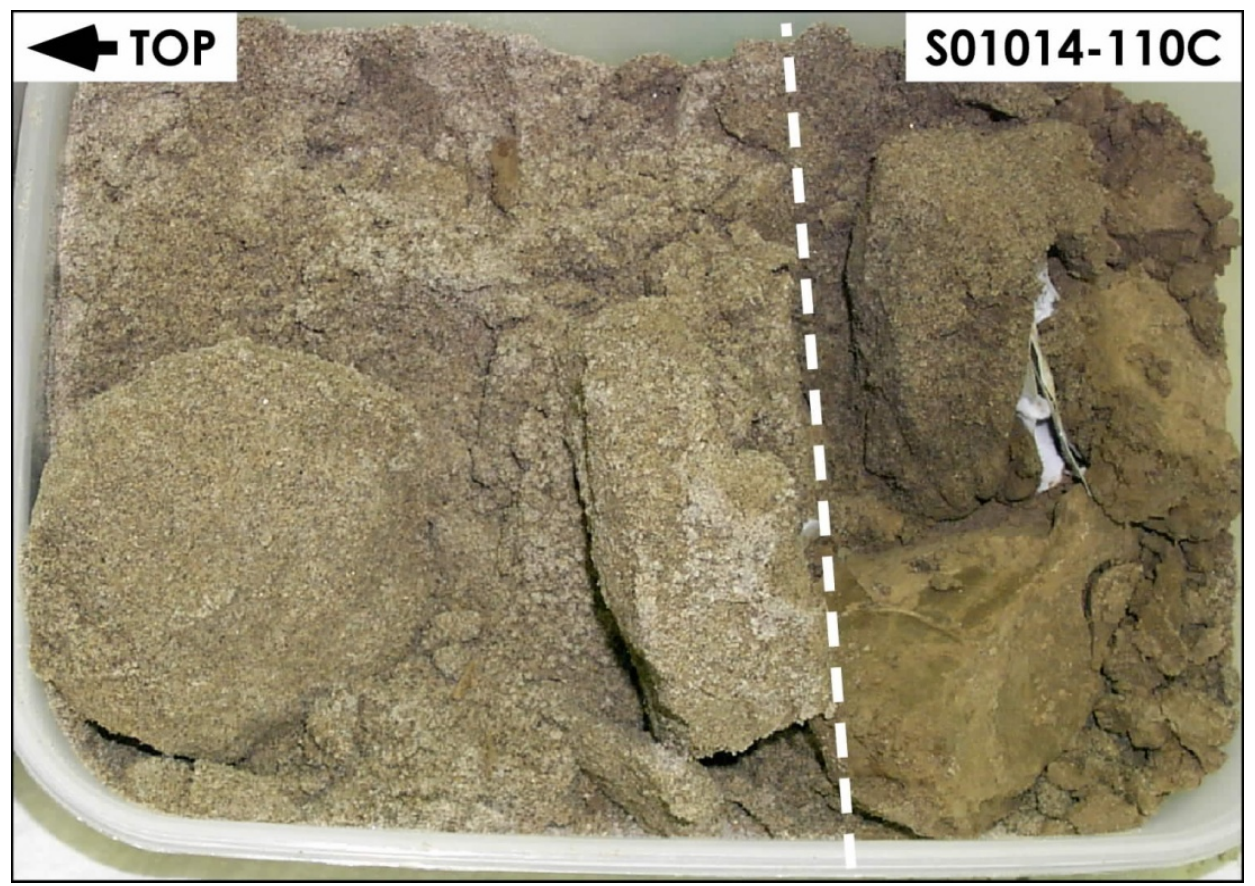

Figure 2.18. Contact Beneath $\mathrm{H} 2$ Sand (left) and $\mathrm{CCU}_{\mathrm{z}}$ Silt (right) Strata in Sample S01014-110C (299-E33-45) at a Depth of 66.5 to $66.6 \mathrm{~m}(218.2$ to $218.7 \mathrm{ft})$

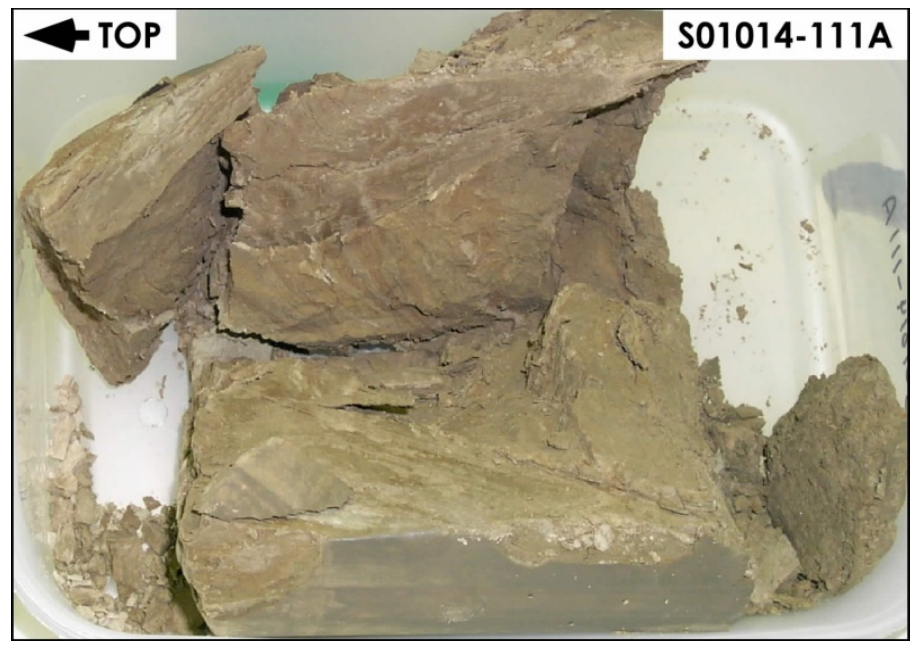

Figure 2.19. Mud (Silt) from the $\mathrm{CCU}_{\mathrm{z}}$ Facies in Sample S01014-111A (299-E33-45) at a Depth of 67.5 to $67.6 \mathrm{~m}(221.5$ to $222.0 \mathrm{ft})$ 
PNNL-19277

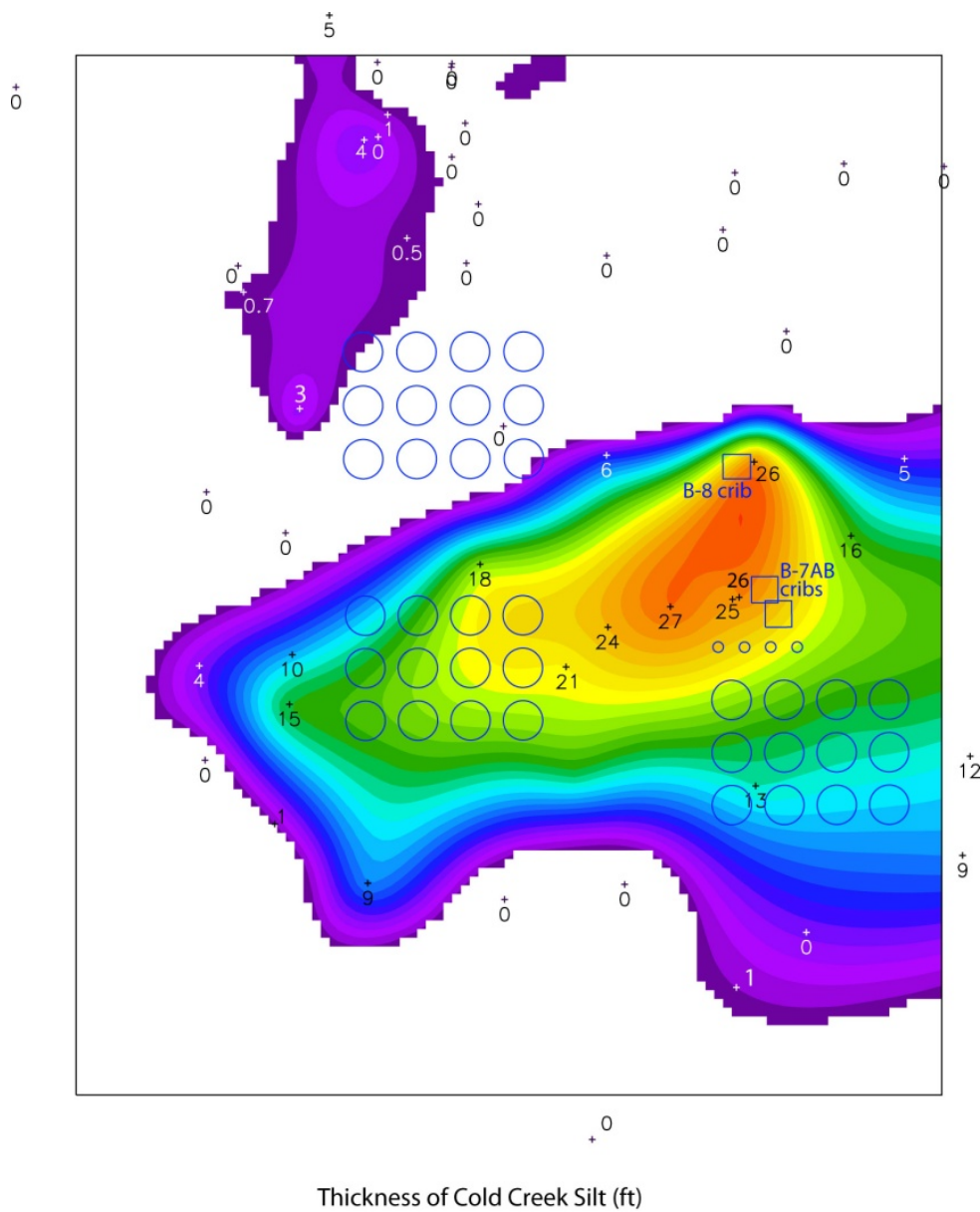

Figure 2.20. Areal Extent of the $\mathrm{CCU}_{z}$ Facies Within the B-Complex Area Colors represent thickness of the facies with purple being the thinnest (0-2 ft) and red being the thickest ( $\geq 26 \mathrm{ft}$ ) See more detailed isopach in Appendix B. 


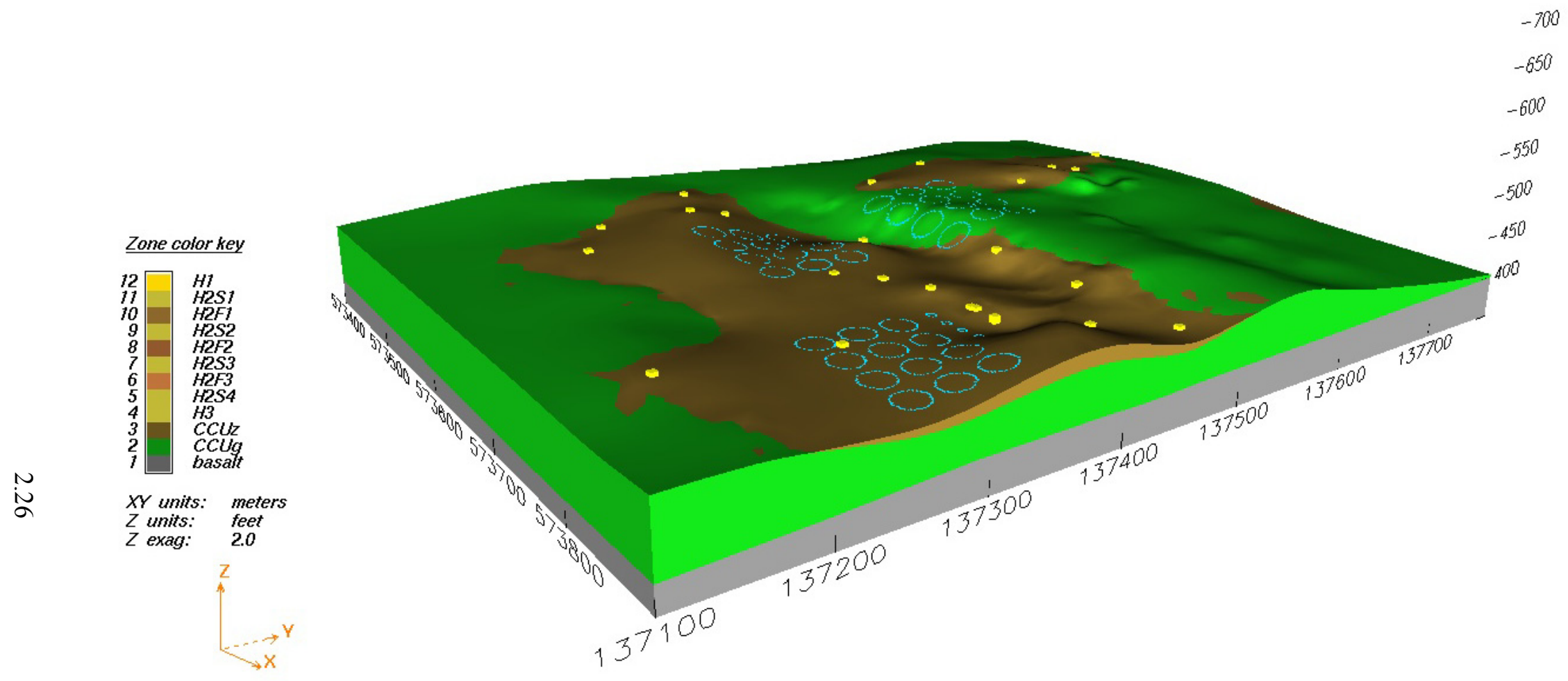

Figure 2.21. Top of the $\mathrm{CCU}_{z}$ Fine Grained Facies (Brown Color) B Tank Farm in Foreground and BX-BY Tank Farms in Background (yellow dots are wells that intercepted $\mathrm{CCU}_{\mathrm{z}}$ sediment) 


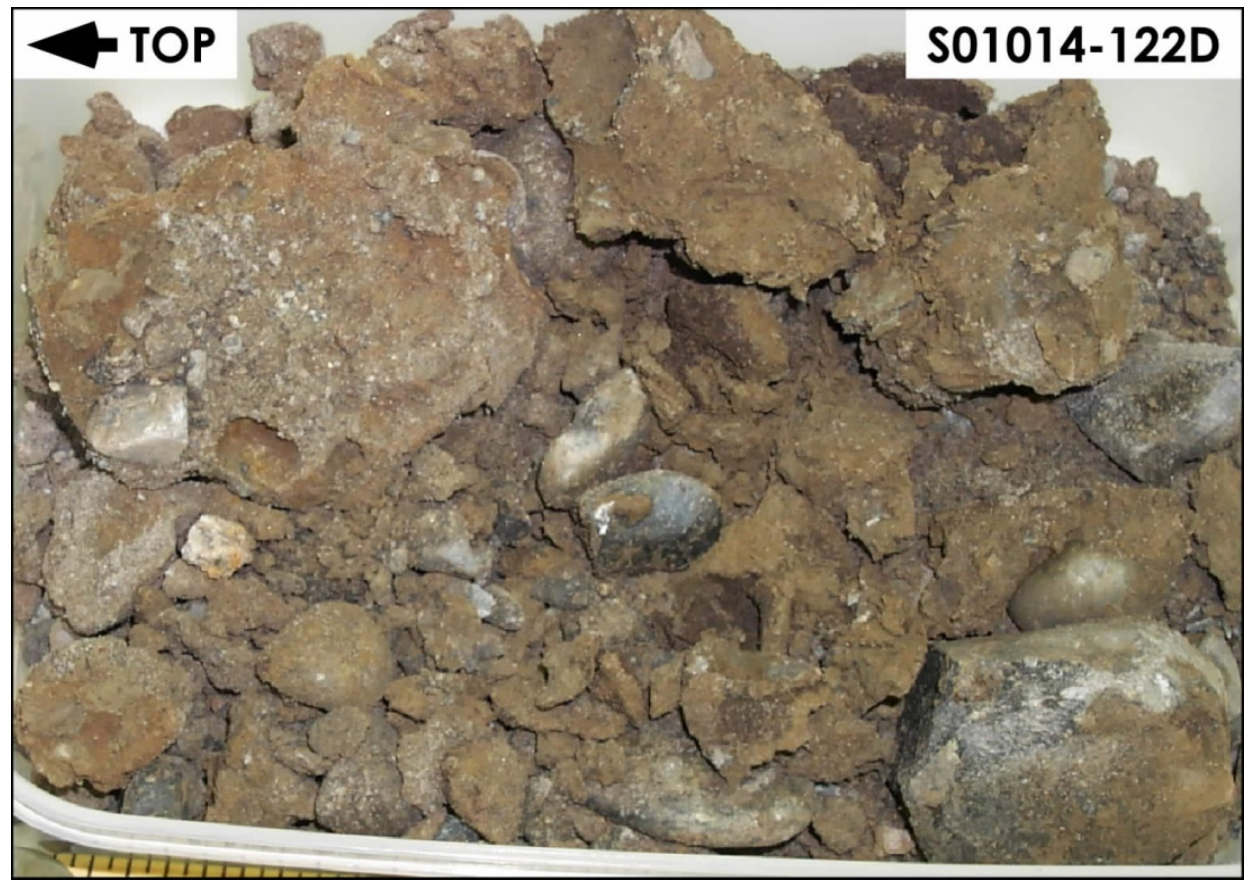

Figure 2.22. Muddy Sandy Gravel ( $\left.\mathrm{CCU}_{\mathrm{g}}\right)$ in Sample S01014-122 D (299-E33-45) at a Depth of 73.5 to $73.6 \mathrm{~m}$ (240.1 to $240.6 \mathrm{ft})$

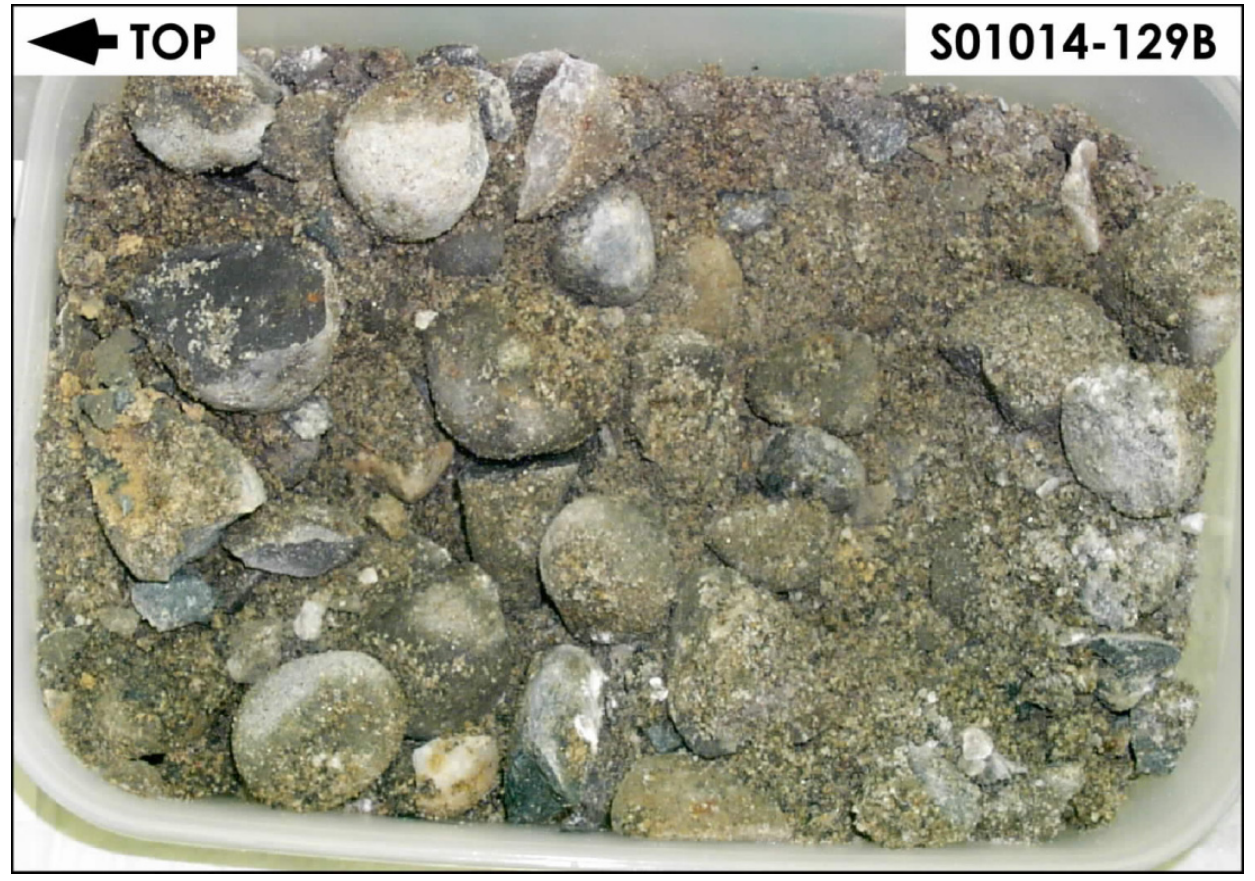

Figure 2.23. Sandy Gravel $\left(\mathrm{CCU}_{\mathrm{g}}\right)$ from Sample S01014-129B (299-E33-45) at a Depth of 77.1 to $77.2 \mathrm{~m}$ (252.9 to $253.4 \mathrm{ft})$.

Note the moderate amount of basalt in the sand fraction, characteristic of the CCUg. 
PNNL-19277

\subsubsection{Ringold Formation}

The fluvial-lacustrine Ringold Formation (Lindsey 1995), which overlies basalt over most of central the Pasco Basin, is not present beneath the B-Complex. The Ringold Formation was present and probably filled the basin with sediments to at least $900 \mathrm{ft}$ elevation (Lindsey 1996) during the late Miocene to Pliocene time (10.5-3.4 Ma). Since that time, however, the Ringold Formation was effectively removed by erosion in the vicinity of the B-Complex, by fluvial down cutting of the ancestral Columbia River and cataclysmic IceAge flooding.

\subsubsection{Columbia River Basalt Group}

The surface of the Columbia River Basalt Group (CRBG) forms the bedrock base of the unconfined aquifer under the B-Complex. The Elephant Mountain Member of the Saddle Mountains Basalt formation is the youngest flow and ranges from 230 to $320 \mathrm{ft}$ below land surface. Up to $6 \mathrm{~m}$ of topographic relief exists on the basalt surface as a result of tectonic deformation and/or erosion that occurred in this area before or during cataclysmic flooding. The top of basalt dips east and northeast in the eastern half of the B-Complex area. There is a relative low in the basalt surface just north of the B and BX Tank Farms, as shown in the EarthVision 3D graphic shown Figure 2.24. A northwest-southeast trending basalt high lies north of the B Tank Farm and extends westward through the BY Tanks Farm. A contour map of the basalt surface elevation is shown in Appendix B, Figure B.17. The region between the BX and BY Tank Farms is consistent with the trend of other eroded and/or deformed basalt highs in the region. In general, lavas of the Saddle Mountains Basalt and the overlying suprabasalt sediments thicken to the south toward the axis of the Cold Creek syncline.

The Elephant Mountain Member is a medium to fine-grained tholeiitic basalt with abundant microphenocrysts of plagioclase (DOE 1988). The Elephant Mountain Member has been dated by the $\mathrm{K} / \mathrm{Ar}$ method to be about $10.5 \mathrm{Ma}$ (McKee et al. 1977) and consists of two flows beneath the 200 East Area. Because the water table is near the top of the basalt bedrock, most boreholes beneath the B-Complex were drilled until they intersected basalt. Before the recent 200-BP-5 OU borehole characterization effort, only two boreholes penetrated the Elephant Mountain Member; one (299-E33-40) terminated within the first interbed (Rattlesnake Ridge Interbed of the Ellensburg Formation), and the other (299-E33-12) advanced through the first interbed into the underlying Pomona Member of the CRBG. Recently, other boreholes were drilled into the basalt to investigate contamination in the confined aquifer (e.g., 299-E33-50, 299-E33-340, and 699-52-55B), but only the upper portions of 299-E33-50 and 299-E33-340 were used in creating the geologic conceptual model presented herein. The deeper portions of the boreholes that penetrated deep into the basalt bedrock will be important in addressing the gap between Gable Mountain and Gable Butte and confined aquifer issues at a later date. 


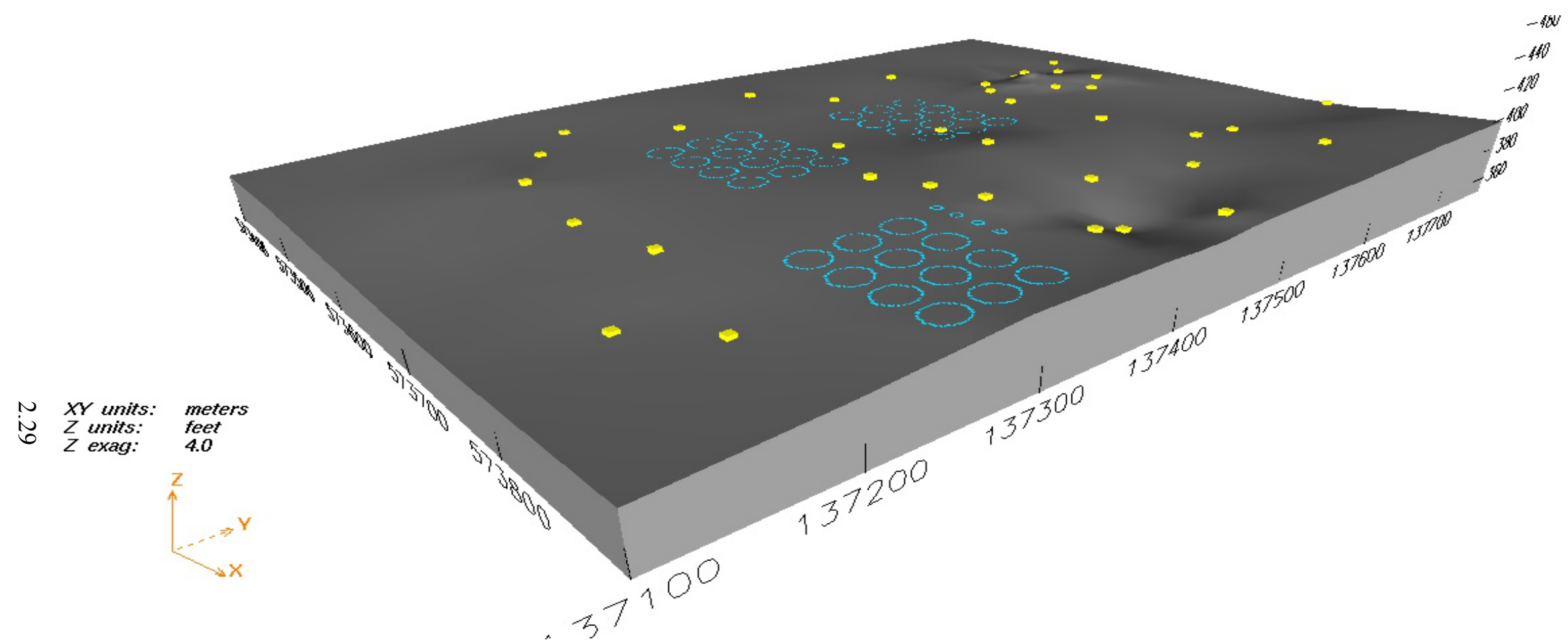

Figure 2.24. Top of the Basalt (looking from SE to NW) with B Tank Farm in Foreground and BX-BY Tank Farms in Background (yellow dots are wells that tagged top of basalt)

Graphics with elevations above mean sea level are found in Appendix B. 
PNNL-19277

\subsubsection{Clastic Dikes}

Clastic dikes are vertical to subvertical sedimentary structures that crosscut normal sedimentary layering. Clastic dikes are a common geologic feature of the Hanford formation in the 200 Areas, especially in the sand- and silt-dominated facies. Clastic dikes are much less common in the graveldominated facies of the Hanford formation. No clastic dikes were observed in the excavated walls of the 218-E-12B burial ground (Figure 2.7), located about 1000 m east of the B-BX-BY Tank Farm or in any of the new 200-BP-5 boreholes. However, they are occasionally observed elsewhere within the graveldominated facies of the Hanford formation.

Clastic dikes occur in swarms and form four types of networks (Fecht et al. 1999): 1) regular-shaped polygonal-patterns, 2) irregular-shaped, polygonal-patterns, 3) pre-existing fissure fillings, and 4) random occurrences. In outcrop, regular clastic dikes are fairly common in the sand-dominated Hanford formation facies, but relatively rare in the gravel-dominated facies. In the B-Complex area clastic dikes are most likely to occur in the sand-dominated facies (Hanford formation unit H2). Regular polygonal networks resemble 4- to 8-sided polygons and typically range from $3 \mathrm{~cm}$ to $1 \mathrm{~m}$ in width, from $2 \mathrm{~m}$ to greater than $20 \mathrm{~m}$ in depth, and from 1.5 to $100 \mathrm{~m}$ along the strike. Smaller dikelets, sills, and small-scale faults and shears are commonly associated with master dikes that form the polygons.

In general, a clastic dike has an outer skin of silt-clay with coarser infilling material. Silt-clay linings are commonly $0.03 \mathrm{~mm}$ to $1.0 \mathrm{~mm}$ in thickness, but linings up to about $10 \mathrm{~mm}$ are known. The width of individual infilling layers ranges from as little as $0.01 \mathrm{~mm}$ to more than $30 \mathrm{~cm}$, and their length can vary from about $0.2 \mathrm{~m}$ to more than $20 \mathrm{~m}$. Infilling sediments are typically poor- to well-sorted sand, but may contain clay, silt, and gravel (Wood et al. 1999). The importance of clastic dikes in determining the migration potential of contaminants from the near-surface disposal facilities to the water table is still being debated, but those that question their importance appear to be correct. Over the B-Complex's entire vadose zone and the area covered by groundwater plumes in the upper unconfined aquifer, it is felt that clastic dikes are not a significant contributor to the evolution of the groundwater plumes.

\subsection{Historical Water Levels}

Water levels beneath the 200 East Area rose as much as $9 \mathrm{~m}$ (well 699-45-42, located near B Pond) because of artificial recharge from liquid waste disposal operations. The largest volumes of discharge were to the B pond system east of the 200 East Area, the A-25 (Gable Mountain) pond system north of the 200 East Area, and several of the PUREX Plant cribs east and south of WMA A-AX and WMA C. Figure 2.25 shows the liquid discharge history for the two pond systems. The Gable Mountain pond system is estimated to have received approximately 307 billion $\mathrm{L}$ of effluent, and the B pond received about 240 billion L of effluent (DOE/RL 1993b). These large volumes disposed of to the ponds (and, lesser volumes to cribs and ditches) artificially recharged the unconfined aquifer, creating large watertable mounds. The increase in water-table elevation was most rapid from 1954 to 1963, increasing as much as $0.6 \mathrm{~m}$ per year at times. The water table declined somewhat in the late $1960 \mathrm{~s}$ and early $1970 \mathrm{~s}$ and then increased again in the early 1980s before the latest decline beginning in 1988. The decline continued throughout the 1990s when wastewater discharges in the 200 East Area were reduced. 
PNNL-19277

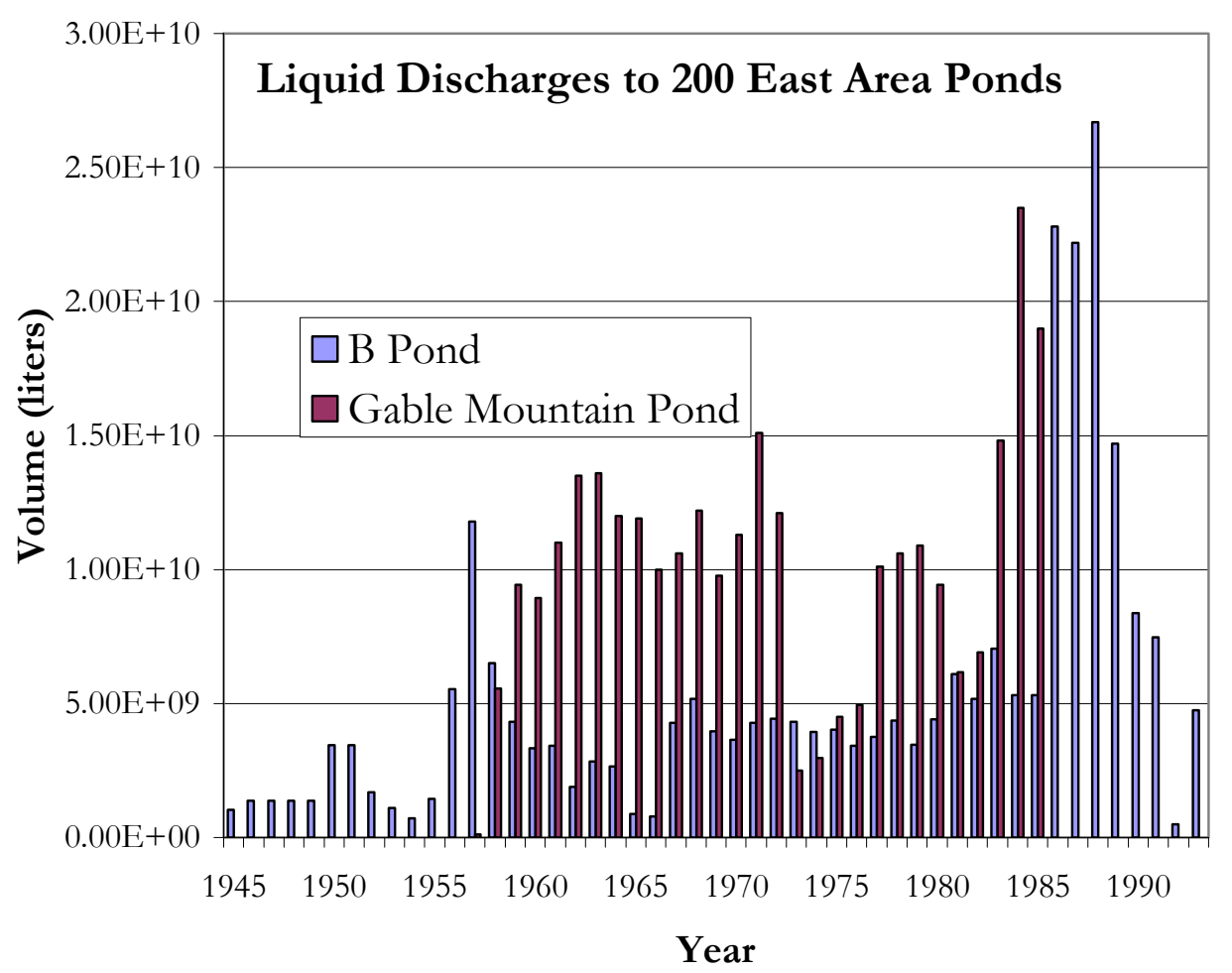

Figure 2.25. Discharge History for the B Pond and the Gable Mountain Pond Systems

Wood et al. (2000) reported that this discharge of large volumes of wastewater raised the water table in the vicinity of the B-Complex to over $4.9 \mathrm{~m} \mathrm{(16} \mathrm{ft)} \mathrm{above} \mathrm{pre-Hanford} \mathrm{conditions.} \mathrm{They} \mathrm{indicated}$

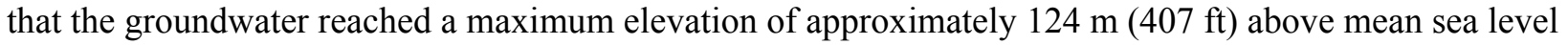
(AMSL) in the 1967 to 1968 time frame, with a secondary maximum just below this in the 1986 to 1989 time frame. Water levels have declined approximately 7 to $8 \mathrm{ft}$ since 1989 at an average rate of approximately $20 \mathrm{~cm} / \mathrm{yr}(0.7 \mathrm{ft} / \mathrm{yr})$.

A second analysis performed by us for the highest water levels for the unconfined aquifer suggests that water rose to near $410 \mathrm{ft}(125 \mathrm{~m})$ elevation in the vicinity of the B-Complex area (see Table 2.4). This height is 6 to $10 \mathrm{ft}$ above the present water level and up to $17 \mathrm{ft}$ above pre-Hanford levels. Since early wells (e.g., 299-E33-14 in 1953) were installed in the vicinity of the northern portion of 200-BP-5, the water table there has fluctuated as much as $15 \mathrm{ft}$. Because the aquifer sediments in this area have relatively high permeability, the hydraulic gradient at the top of the unconfined aquifer is low. This means that the maximum water level of $410 \mathrm{ft}$ probably extended across most of the B-Complex area.

Historical fluctuations in water levels are recorded in hydrographs shown in Figure 2.26 for the areas around each of the 200 East Area SST WMAs. The hydrographs illustrate the changes in watertable elevations that have occurred since at least the mid 1950s. All data used to make the hydrographs were obtained from the HydroDat database (see data files on CD included in Hartman et al. 2006). 
Table 2.4. Maximum and Minimum Water Levels for 200-BP-5 Wells

\begin{tabular}{|c|c|c|c|c|c|c|c|c|}
\hline Well & $\begin{array}{c}\text { Date } \\
\text { Completed }\end{array}$ & $\begin{array}{l}\text { Water } \\
\text { level }\end{array}$ & $\begin{array}{l}\text { Elev. Water } \\
\text { level }(\mathrm{ft})^{\# 1}\end{array}$ & $\begin{array}{c}\text { Date of } \\
\text { Max-Min }\end{array}$ & $\begin{array}{c}\text { Elev. } \\
\text { difference (ft) }\end{array}$ & $\begin{array}{l}\text { Screen Elev. } \\
\text { (ft AMSL) }\end{array}$ & Aquifer & Comments \\
\hline \multirow[t]{2}{*}{$699-50-53 \mathrm{~A}$} & 1995 & Max & 410.3 & $4 / 24 / 1969$ & 12.2 & $416.3-401.8^{(\mathrm{a})}$ & Unconfined & Dry in 2004; Decommissioned. in 2005 \\
\hline & & Min & 398.1 & $8 / 22 / 1955$ & & & & \\
\hline \multirow[t]{2}{*}{ 699-50-53B } & 1991 & $\operatorname{Max}$ & 407 & $6 / 18 / 1991$ & 6.2 & 344.4-334.4 & Confined & \\
\hline & & Min & 400.8 & $11 / 2 / 2006$ & & & & \\
\hline \multirow[t]{2}{*}{ 299-E33-14 } & 1953 & Max & 410.4 & $12 / 8 / 1987$ & 14.8 & $410.9-395.9^{(a)}$ & Unconfined & \\
\hline & & Min & 395.6 & $4 / 22 / 1954$ & & & & \\
\hline \multirow[t]{2}{*}{ 299-E33-34 } & 1990 & $\operatorname{Max}$ & 407.6 & 4/24/1990 & 7.3 & 415-395 & Confined & \\
\hline & & Min & 400.3 & $8 / 29 / 2006$ & & & & \\
\hline \multirow[t]{2}{*}{ 699-49-55A } & 1961 & Max & 410.1 & $8 / 27 / 1987$ & 11.5 & $407.8-392.8$ & Unconfined & \\
\hline & & Min & 398.6 & $5 / 1 / 2007$ & & & & \\
\hline \multirow[t]{2}{*}{ 699-49-55B } & 1982 & Max & 408.6 & $12 / 9 / 1986$ & 7.8 & $356.8-305.8$ & Unconfined + confined & \\
\hline & & Min & 400.8 & $3 / 29 / 2005$ & & & & \\
\hline \multirow{2}{*}{ 699-49-57A } & 1956 & $\operatorname{Max}$ & 410.1 & $4 / 24 / 1969$ & 10 & $410.3-393.3^{(\mathrm{a})}$ & Unconfined & \\
\hline & & Min & 400.1 & $3 / 13 / 2006$ & & & & \\
\hline \multirow[t]{2}{*}{ 699-49-57B } & 1991 & Max & 409.3 & 2/9/1993 & 8.9 & $336.5-326.5$ & Confined & \\
\hline & & Min & 400.4 & $3 / 13 / 2006$ & & & & \\
\hline \multirow[t]{2}{*}{$699-52-54$} & 1991 & $\operatorname{Max}$ & 406.4 & 4/23/1991 & 4.2 & 411.9-401.9 & Unconfined & Dry 2001; Decommissioned in 2004 \\
\hline & & Min & 402.2 & $3 / 23 / 2001$ & & & & \\
\hline
\end{tabular}


All three hydrographs show similar changes in water levels with a maximum in water-table elevation about 1968-69 that corresponds to a time of high discharge to Gable Mountain pond (Figure 2.26). This maximum is followed by a minimum in about $1978-79$, that corresponds to a minimum in the discharges to both pond systems. Finally, a second maximum is seen in 1986 to 1987 corresponding to the peak discharge to the B Pond system. Maximum water levels measured in some wells are less than $410 \mathrm{ft}$ (125 $\mathrm{m}$ ) elevation (Figure 2.26); however, this is because they were completed as wells much later (after the termination of the larger discharges to ground) than the first wells installed at Hanford so that the complete time series hydrograph is not available.

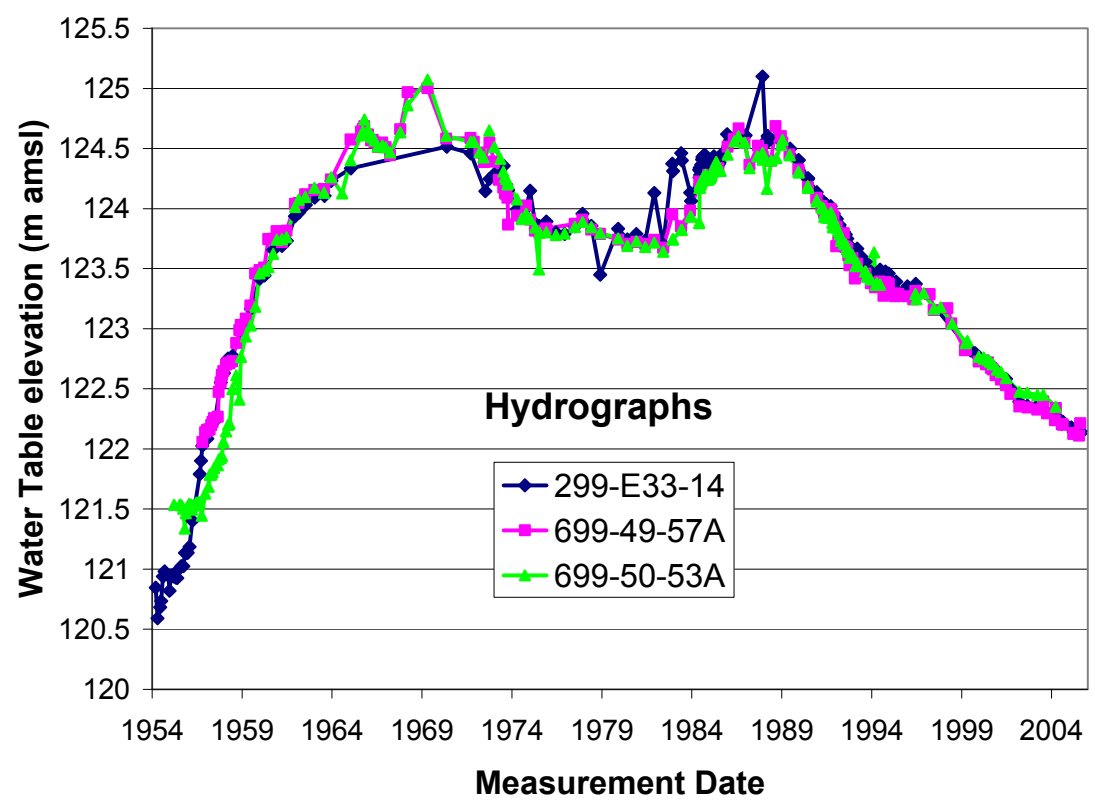

Figure 2.26. Hydrographs of Selected Wells in the Area of Waste Management Area BX-BY.

(Well 299-E33-14 is located about 250 m east of the northeast corner of the BY Tank Farm; well 699-49-57A is located about $1.5 \mathrm{~km}$ northwest of the BY Tank Farm; well 699-50-53A is located about $1.5 \mathrm{~km}$ north of the BY Tank Farm.)

With the termination of manmade discharges to ground starting in 1990, the water level in the unconfined aquifer in the vicinity of the B-Complex area has steadily dropped at an average rate of about $0.5 \mathrm{ft} / \mathrm{y}(0.14 \mathrm{~m} / \mathrm{y})$ according to Horton (2007). Due to a prolonged period of decreasing water levels, at least two wells (699-52-54 and 699-50-53A) have gone dry (comment column in Table 2.4) and have since been decommissioned. As water levels continue to drop, other wells with shallow screens (e.g., 299-E33-34 and 699-49-57A) will also likely go dry. Figure 2.27 and Figure 2.28 show the saturated aquifer thickness based on 1987 and 2009 water table elevations, respectively. These aquifer thickness maps are based on an updated interpretation of the top of basalt surface shown in Appendix B. 


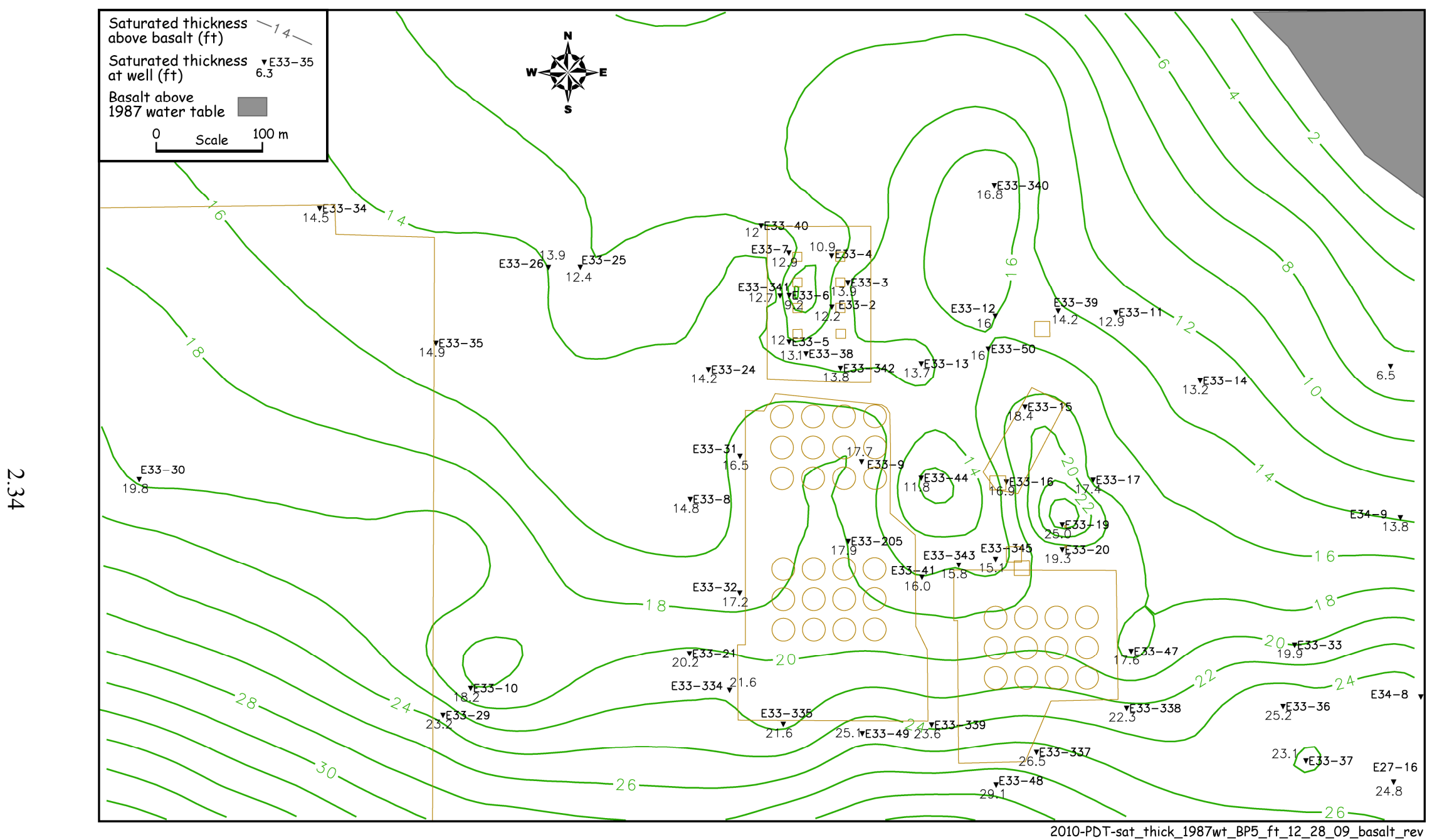

Figure 2.27. Saturated Thickness for Unconfined Aquifer Below the B-Complex for Year 1987 


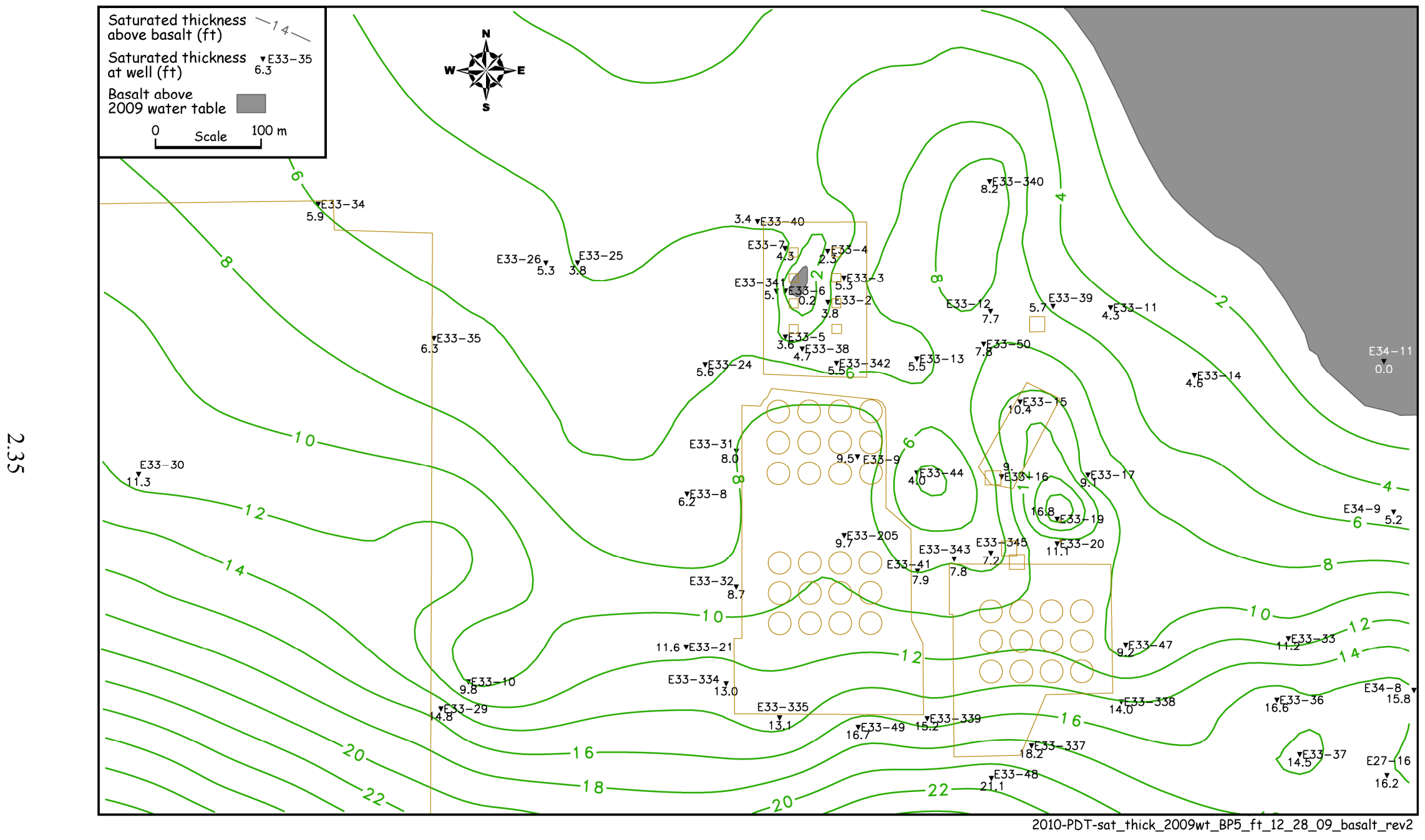

Figure 2.28. Saturated Thickness for Unconfined Aquifer Below the B-Complex for Year 2009 



\subsection{Conceptual Models for Vadose Zone and Groundwater Contamination}

In this section, conceptual models will be presented for mobile contaminants in the vadose zone and groundwater by subregions. The data used to support the conceptual models are discussed before or in concert with the delineation of the conceptual model(s). The subregions chosen are 1) BY and B-57 Cribs, 2) BX Trenches, 3) B-7-A\&B and B-8 Cribs, 4) BX and BY Tank Farms (WMA BX-BY), and 5) B Tank Farm (WMA B). Quantitative estimates of the mass of technetium-99 and uranium are provided in both the vadose zone and unconfined aquifer for several of the subregions where significant amounts of the key mobile contaminants are believed to be present in the deep vadose zone that is currently releasing significant mass to the unconfined aquifer.

\subsection{BY and B-57 Cribs Subregion}

In this subsection, the available borehole sediment characterization data, field gamma logging and soil electrical resistivity data are tabulated and compared with the known volumes and masses of waste chemicals and radionuclides released to the subsurface. Subsequently, a conceptual model is constructed for key waste constituents remaining in the vadose zone sediments.

The key facilities and key boreholes that were evaluated for the BY and B-57 Cribs subregion are shown in red in Figure 3.1. The reader should refer back to this figure to aid in understanding the following the discussion.

\subsubsection{B-43 through B-50 Cribs Facility Description and Inventory Released}

The BY Cribs consist of an excavated area containing eight square facilities (cribs) each $75 \mathrm{ft}$ on a side with bottoms $\sim 15 \mathrm{ft}$ below the original ground surface. The BY crib layout is two north-south trending rows with four cribs in each row. From 1952 through 1958, bismuth phosphate process waste stored in T, TX, B, BX, BY, C, and U tank farms was transferred to 221-U to recover the uranium from the waste after the tank sludge had been thinned with nitric acid. The waste from the uranium recovery process was neutralized and transferred to the BY tank farm. In addition to uranium recovery, additional activities included the use of potassium ferrocyanide, sodium hydroxide, and nickel sulfate to precipitate cesium-137 and strontium-90 from the liquid waste. It was necessary to remove cesium-137 and strontium-90 to meet cribbing criteria requirements in place at the time. Later, the cesium-137 and strontium-90 removal process included the use of sodium ferrocyanide and calcium nitrate. An important element of the cesium and strontium sequestration process was maintaining a $\mathrm{pH}$ between 8 and 10 . After a settling period, the scavenged wastes in the BY tanks were sampled, and if cribbing criteria were met, the supernate was disposed of to the BY cribs. The supernate from the tanks was decanted first to the B-43 through 49 cribs and later to the BC Cribs and Trenches south of the 200-East Area. Crib B-50 reportedly was not used for treated TBP waste and instead received condensate from the BY Tank Farm In-Tank Solidification (ITS) system. The other seven BY cribs received treated TBP process waste from 1954-55. Effluent release to the BY Cribs was discontinued in December 1955 when beta activity was detected in a groundwater monitoring well and later confirmed as being sourced from the BY Cribs. The 




Figure 3.1. Map Showing the BY Cribs Subregion Facilities and Key Boreholes/Monitoring Wells

decision to use the B-50 Crib for ITS condensate was made about 8 or 9 years later when monitoring showed that the groundwater radioactivity levels beneath the BY cribs were decreasing. Summary information of the waste types, disposal volumes, and active disposal time period for each BY crib is shown in Table 3.1. 
Table 3.1. BY and B-57 Cribs Subregion Facility Details (includes BY-201 Settling Tank)

\begin{tabular}{|c|c|c|c|c|c|c|c|}
\hline & & $\begin{array}{c}\text { Dimensions } \\
(\mathrm{ft})\end{array}$ & $\begin{array}{l}\text { Depth of } \\
\text { Bottom }\end{array}$ & Type of Waste & $\begin{array}{c}\text { SIM } \\
\text { ML } \\
\text { (mega liters) }\end{array}$ & $\begin{array}{c}\text { WIDS } \\
\text { ML } \\
\text { (mega liters) }\end{array}$ & $\begin{array}{c}\text { Stenner } \\
\text { ML } \\
\text { (mega liters) }\end{array}$ \\
\hline Facility & Date of Disposal & $\begin{array}{c}\mathrm{L} \times \mathrm{W} X \\
\text { Depth }\end{array}$ & $\begin{array}{c}\mathrm{ft} \text { bgs of } \\
\text { original ground } \\
\text { surface }\end{array}$ & HDW definitions & Vol Disposed & Vol Disposed & Vol Disposed \\
\hline B-43 & Nov-54 & $75 \times 75 \times 8$ & 15 & PFeCN1 (BT1) & $2.12 \mathrm{E}+00$ & $2.10 \mathrm{E}+00$ & $2.10 \mathrm{E}+00$ \\
\hline B-44 & $\begin{array}{c}\text { Dec } 1954 \text { to } \\
\text { Mar } 1955\end{array}$ & $75 \times 75 \times 8$ & 15 & PFeCN1 (BT1) & $5.60 \mathrm{E}+00$ & $5.60 \mathrm{E}+00$ & $5.60 \mathrm{E}+00$ \\
\hline B-45 & Apr-Jun-1955 & $75 \times 75 \times 8$ & 15 & PFeCN1 (BT1) & $4.92 \mathrm{E}+00$ & $4.90 \mathrm{E}+00$ & $4.90 \mathrm{E}+00$ \\
\hline B-46 & Sep-Dec 1955 & $75 \times 75 \times 8$ & 15 & PFeCN1 (BT1) & $6.70 \mathrm{E}+00$ & $6.70 \mathrm{E}+00$ & $6.70 \mathrm{E}+00$ \\
\hline B-47 & Sep-55 & $75 \times 75 \times 8$ & 15 & PFeCN1 (BT1), PFeCN2 (BT2) & $3.68 \mathrm{E}+00$ & $3.70 \mathrm{E}+00$ & $3.70 \mathrm{E}+00$ \\
\hline B-48 & Nov-55 & $75 \times 75 \times 8$ & 15 & PFeCN1 (BT1) & $4.09 \mathrm{E}+00$ & $4.10 \mathrm{E}+00$ & $4.10 \mathrm{E}+00$ \\
\hline B-49 & Nov-Dec-1955 & $75 \times 75 \times 8$ & 15 & PFeCN1 (BT1) & $6.70 \mathrm{E}+00$ & $6.70 \mathrm{E}+00$ & $6.70 \mathrm{E}+00$ \\
\hline B-50 & Jan 1965 to Jan 1974 & $75 \times 75 \times 8$ & 15 & ITS Cool Wtr-Cond (BT2) & $5.47 \mathrm{E}+01$ & $5.48 \mathrm{E}+01$ & $5.48 \mathrm{E}+01$ \\
\hline B-57 & Feb 1968 to Jun 1973 & $200 \times 15 \times 10$ & Barrier on top now & ITS Cool Wtr-Cond (BT2) & $8.43 \mathrm{E}+01$ & $8.44 \mathrm{E}+01$ & $8.44 \mathrm{E}+01$ \\
\hline $\begin{array}{c}\text { BY-201 } \\
\text { Settling Tank }\end{array}$ & $1954-1955$ & $41.33 \times 6.33 \times 9.1$ & 14.1 & PFeCN1 (BT1) & 4.16E-02 & 4.16E-02 (leak) & 4.16E-02 (leak) \\
\hline
\end{tabular}

HDW definitions (Waste types) are defined in Appendix A, Table A.2.

Inventory (kg) Inventory (Ci)

\begin{tabular}{|c|c|c|c|c|c|c|c|c|c|c|c|c|c|c|c|}
\hline Facility & $\mathrm{Na}$ & $\mathrm{Ca}$ & $\mathrm{NO}_{3}$ & $\mathrm{NO}_{2}$ & $\mathrm{SO}_{4}$ & $\mathrm{CO}_{3}$ & $\mathrm{PO}_{4}$ & $\mathrm{~F}$ & $\mathrm{Fe}(\mathrm{CN})_{6}$ & $\mathrm{U}$ & $\mathrm{Cr}$ & Co-60 & I-129 & Tc-99 & $\mathrm{H}-3$ \\
\hline \multicolumn{16}{|c|}{ BY Cribs \& Vicinity } \\
\hline B-43 & $1.89 \mathrm{E}+05$ & $3.13 \mathrm{E}+02$ & $4.21 \mathrm{E}+05$ & $2.01 \mathrm{E}+02$ & $2.49 \mathrm{E}+04$ & $4.68 \mathrm{E}+02$ & $1.42 \mathrm{E}+04$ & $8.59 \mathrm{E}+03$ & $1.10 \mathrm{E}+03$ & $6.58 \mathrm{E}+01$ & $3.65 \mathrm{E}+02$ & $3.98 \mathrm{E}-01$ & $1.03 \mathrm{E}-02$ & $8.05 \mathrm{E}+00$ & $1.32 \mathrm{E}+01$ \\
\hline B44 & $4.99 \mathrm{E}+05$ & $8.27 \mathrm{E}+02$ & $1.11 \mathrm{E}+06$ & $5.30 \mathrm{E}+02$ & $6.59 \mathrm{E}+04$ & $1.24 \mathrm{E}+03$ & $3.75 \mathrm{E}+04$ & $2.27 \mathrm{E}+04$ & $1.22 \mathrm{E}+03$ & $1.74 \mathrm{E}+02$ & $9.63 \mathrm{E}+02$ & $1.05 \mathrm{E}+00$ & 2.73E-02 & $2.13 \mathrm{E}+01$ & $3.49 \mathrm{E}+01$ \\
\hline B-45 & $4.39 \mathrm{E}+05$ & $7.48 \mathrm{E}+02$ & $9.77 \mathrm{E}+05$ & $5.13 \mathrm{E}+02$ & $5.81 \mathrm{E}+04$ & $1.12 \mathrm{E}+03$ & $3.32 \mathrm{E}+04$ & $1.99 \mathrm{E}+04$ & $1.78 \mathrm{E}+03$ & $1.65 \mathrm{E}+02$ & $8.46 \mathrm{E}+02$ & $9.24 \mathrm{E}-01$ & 2.40E-02 & $1.87 \mathrm{E}+01$ & $3.07 E+01$ \\
\hline B-46 & $5.97 \mathrm{E}+05$ & $9.89 E+02$ & $1.33 E+06$ & $6.34 \mathrm{E}+02$ & $7.88 E+04$ & $1.48 E+03$ & $4.49 \mathrm{E}+04$ & $2.71 \mathrm{E}+04$ & $2.60 \mathrm{E}+03$ & $2.08 \mathrm{E}+02$ & $1.15 \mathrm{E}+03$ & $1.26 \mathrm{E}+00$ & $3.26 \mathrm{E}-02$ & $2.55 \mathrm{E}+01$ & $4.18 \mathrm{E}+01$ \\
\hline B-47 & $3.30 \mathrm{E}+05$ & $5.43 \mathrm{E}+02$ & $7.32 \mathrm{E}+05$ & $2.53 \mathrm{E}+02$ & $4.33 \mathrm{E}+04$ & $8.13 \mathrm{E}+02$ & $2.47 \mathrm{E}+04$ & $1.49 \mathrm{E}+04$ & $4.00 \mathrm{E}+03$ & $1.14 \mathrm{E}+02$ & $6.33 \mathrm{E}+02$ & $6.92 \mathrm{E}-01$ & $1.79 \mathrm{E}-02$ & $1.40 \mathrm{E}+01$ & $2.29 \mathrm{E}+01$ \\
\hline B-48 & $3.65 \mathrm{E}+05$ & $6.03 \mathrm{E}+02$ & $8.12 \mathrm{E}+05$ & $3.87 \mathrm{E}+02$ & $4.81 \mathrm{E}+04$ & $9.04 \mathrm{E}+02$ & $2.74 \mathrm{E}+04$ & $1.66 \mathrm{E}+04$ & $2.00 \mathrm{E}+03$ & $1.27 \mathrm{E}+02$ & $7.03 E+02$ & $7.69 \mathrm{E}-01$ & 1.99E-02 & $1.55 E+01$ & $2.55 E+01$ \\
\hline B-49 & $5.98 E+05$ & $9.89 E+02$ & $1.33 E+06$ & $6.35 \mathrm{E}+02$ & $7.88 E+04$ & $1.48 E+03$ & $4.49 \mathrm{E}+04$ & $2.71 E+04$ & $2.20 \mathrm{E}+03$ & $2.08 \mathrm{E}+02$ & $1.15 \mathrm{E}+03$ & $1.26 \mathrm{E}+00$ & $3.27 \mathrm{E}-02$ & $2.55 \mathrm{E}+01$ & $4.18 \mathrm{E}+01$ \\
\hline B50 & $1.57 \mathrm{E}+02$ & $7.22 \mathrm{E}+02$ & $1.11 \mathrm{E}+02$ & $3.90 \mathrm{E}+01$ & $4.20 \mathrm{E}+02$ & $1.05 \mathrm{E}+01$ & $1.97 \mathrm{E}+00$ & $7.59 \mathrm{E}+00$ & $4.00 \mathrm{E}+03$ & $2.88 \mathrm{E}-02$ & $1.48 \mathrm{E}+01$ & 8.01E-03 & $9.34 \mathrm{E}-05$ & $6.60 \mathrm{E}-02$ & $1.26 \mathrm{E}+02$ \\
\hline B-57 & $3.66 \mathrm{E}+02$ & $1.11 \mathrm{E}+03$ & $2.76 \mathrm{E}+02$ & $1.17 \mathrm{E}+02$ & $6.53 \mathrm{E}+02$ & $3.16 \mathrm{E}+01$ & $5.91 \mathrm{E}+00$ & $1.27 \mathrm{E}+01$ & 0 & $5.94 \mathrm{E}-02$ & $2.42 \mathrm{E}+01$ & $2.40 \mathrm{E}-02$ & $2.80 \mathrm{E}-04$ & $1.97 \mathrm{E}-01$ & $1.95 \mathrm{E}+02$ \\
\hline BY-201 Settling Tank & $3.71 \mathrm{E}+03$ & $6.14 \mathrm{E}+00$ & $8.27 \mathrm{E}+03$ & $3.94 \mathrm{E}+00$ & $4.90 \mathrm{E}+02$ & $9.19 \mathrm{E}+00$ & $2.79 \mathrm{E}+02$ & $1.69 \mathrm{E}+02$ & 0 & $1.29 \mathrm{E}+00$ & $7.16 \mathrm{E}+00$ & 7.83E-03 & 2.03E-04 & $1.58 \mathrm{E}-01$ & $2.59 \mathrm{E}-01$ \\
\hline Sum & $3.02 \mathrm{E}+06$ & $6.85 \mathrm{E}+03$ & $6.72 \mathrm{E}+06$ & $3.31 \mathrm{E}+03$ & $3.99 \mathrm{E}+05$ & $7.56 \mathrm{E}+03$ & $2.27 \mathrm{E}+05$ & $1.37 \mathrm{E}+05$ & $1.89 \mathrm{E}+04$ & $1.06 \mathrm{E}+03$ & $5.86 \mathrm{E}+03$ & $6.39 \mathrm{E}+00$ & $1.65 \mathrm{E}-01$ & $1.29 \mathrm{E}+02$ & $5.32 \mathrm{E}+02$ \\
\hline
\end{tabular}


Each of the eight cribs (B-43 through B-50) was constructed of four 1.22-m (4-ft) diameter by $1.22-\mathrm{m}$ (4-ft) long concrete culverts buried vertically, 2.14 meters $(7 \mathrm{ft})$ below grade, on a $1.53-\mathrm{m}(5-\mathrm{ft})$ bed of 7.62-cm (3-in.) gravel $\left(291 \mathrm{~m}^{3}\left[380 \mathrm{yd}^{3}\right]\right)$. The culverts are arranged in a square with the centers spaced 4.58 meters ( $15 \mathrm{ft}$ ) apart in a 9.15 by 9.15 by $4.58-\mathrm{m}$ ( 30 by 30 by $15-\mathrm{ft})$ deep excavation. Each culvert was fed by a $20.3-\mathrm{cm}$ (8-in.) steel pipe coming from a main line and forming a chevron pattern. Each culvert has a concrete cover (DOE/RL 1993a). Figure 3.2 shows the details on the BY crib construction. A key point to consider in developing the conceptual model for the flow of the liquid waste into the underlying vadose zone is the degree of horizontal spreading that likely occurred within the gravel below the culverts and along the bottom of the entire excavation.

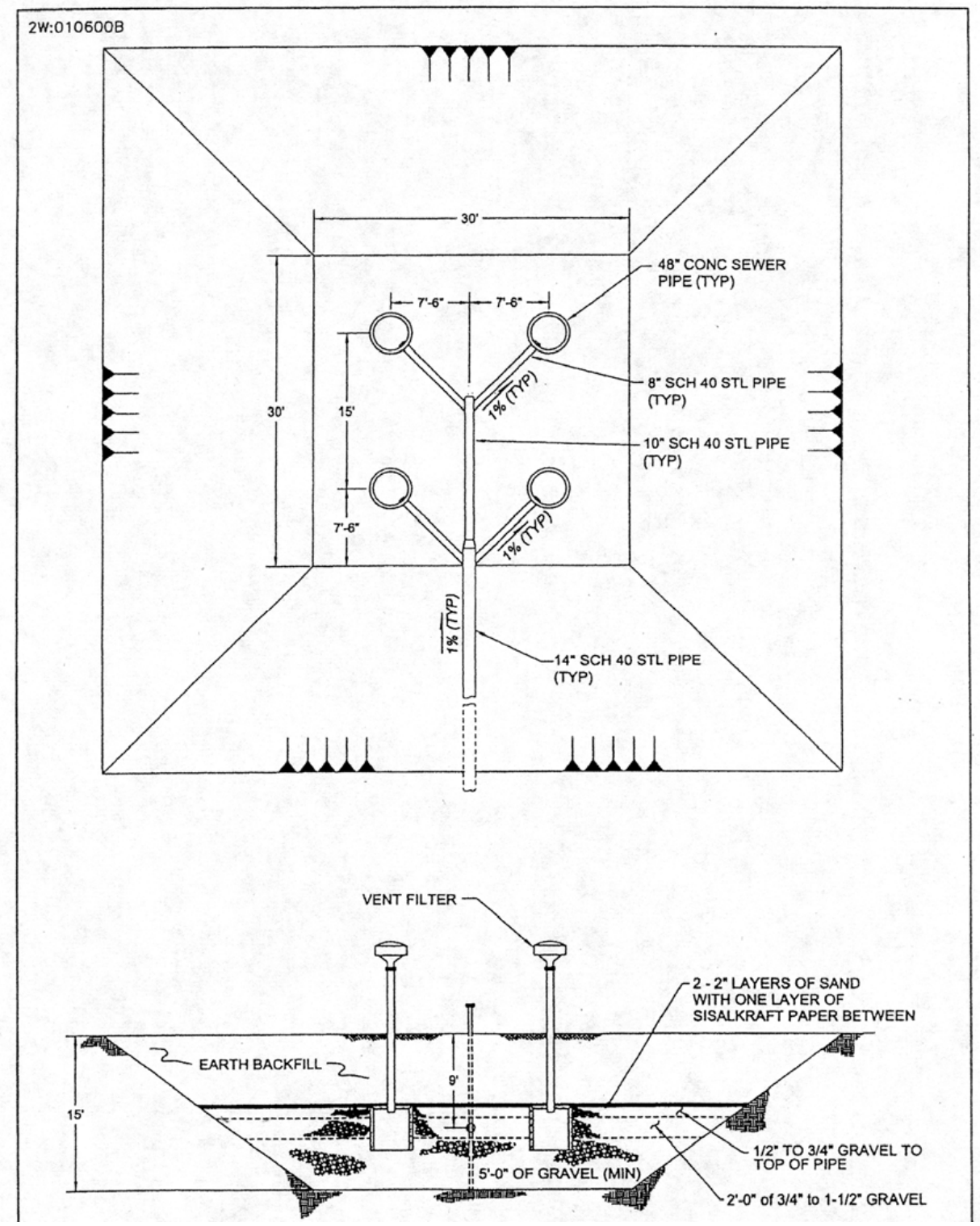

Figure 3.2. BY Crib Construction Details and Excavation Dimensions 
PNNL-19277

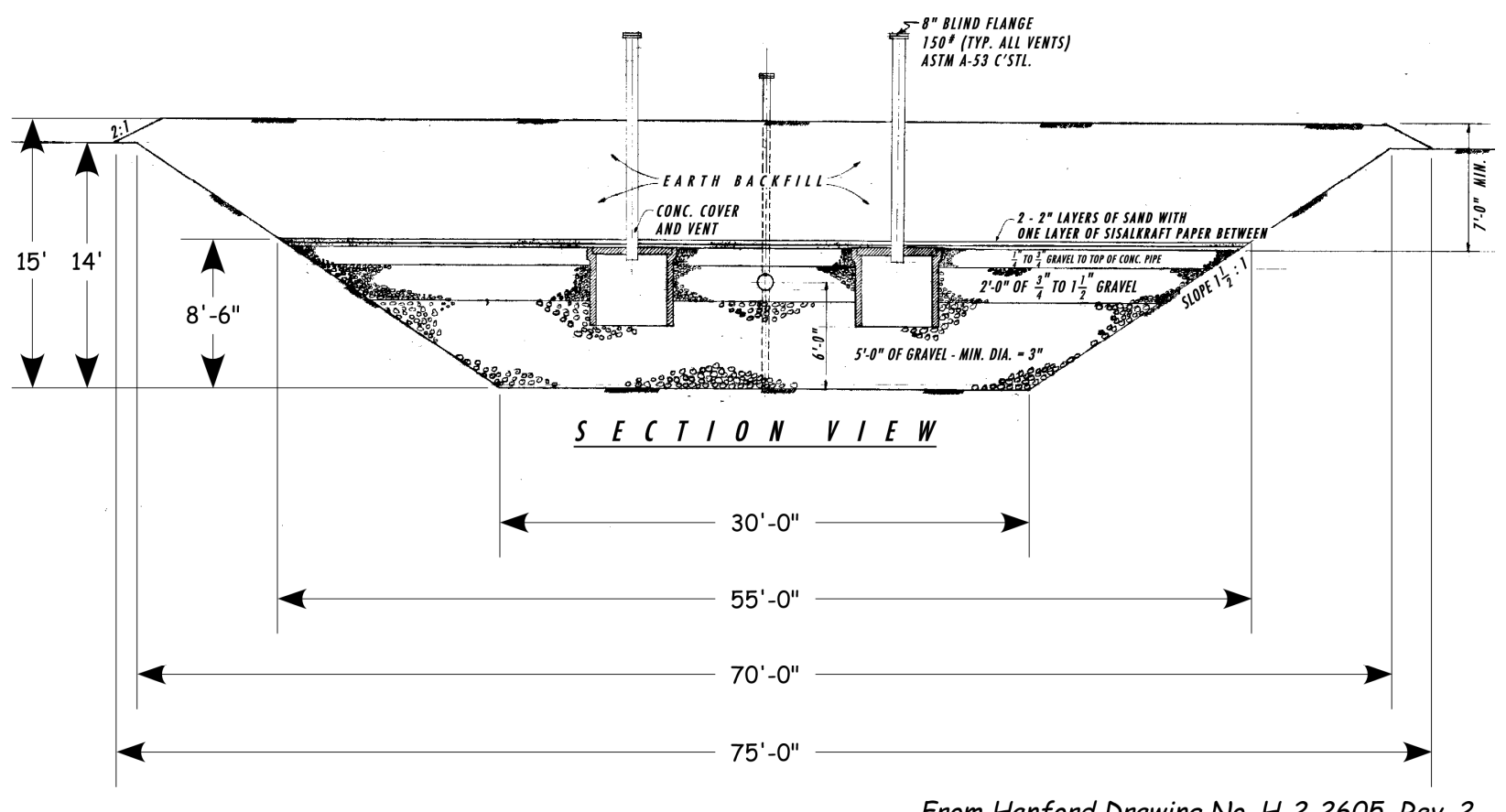

Figure 3.2 (contd)

Based on an assumed large horizontal spreading of the liquid waste at the base of the culverts within the coarse gravel, each crib has been assigned footprint dimensions as follows: length $22.9 \mathrm{~m} \mathrm{(75} \mathrm{ft),}$ width $22.9 \mathrm{~m}(75 \mathrm{ft})$, and height $2.4 \mathrm{~m}(8 \mathrm{ft})$, and the cribs are covered by $2.1 \mathrm{~m}(7 \mathrm{ft})$ of overburden. Thus, the areal footprint of ground surface above each crib is $522.6 \mathrm{~m}^{2}\left(5625 \mathrm{ft}^{2}\right)$. That is, there is a large area $\left(\sim 5570 \mathrm{ft}^{2}\right)$ and volume of sediment between each of the four concrete culverts that constitute the assumed footprint for purposes of developing one of the vadose zone conceptual models for estimating the inventory of contaminants within the BY Cribs region. Based on the large fluxes of liquid disposed of to each crib, there likely was ponding when the disposed fluids hit the contact with the native sediments (if not within the 5-ft thick bed of gravel directly below the culverts). This ponding likely led to significant lateral flow of the waste fluids into the sediments between the concrete culverts and in the native sediments outside the original excavation. Three conceptual models that use different BY Crib areal footprints are discussed in Section 3.1.8 where vadose residual inventories for technetium-99 and

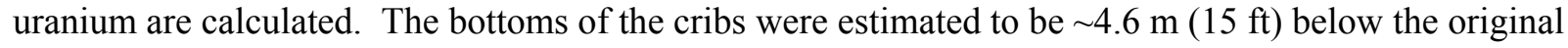

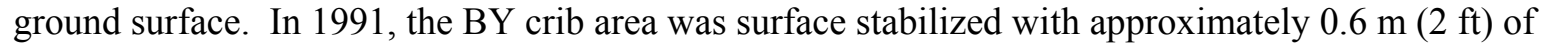
additional uncontaminated sediment.

\subsubsection{BY Cribs Vadose Zone}

Recent BY crib field investigations were performed as part of the 200-BP-5 Operable Unit remedial investigation because concentrations of technetium- 99 and other co-contaminants in the groundwater beneath this waste disposal unit have recently been increasing. The recent field investigations included a soil electrical resistivity survey, geophysical logging, and sediment collection and analyses associated with two new groundwater wells (299-E33-341 and 299-E33-342). In addition, previous field investigations and sediment contaminant distribution results at the BY cribs and adjacent sites were 
reviewed and compared with the new investigations' data to develop conclusions on the distribution of selected contaminants and whether they have the potential for continued transport to the water table.

In 1993, a detailed report on sediment sampling and analysis in the BY Cribs area was published (DOE/RL 1993a). Three shallow boreholes were drilled from ground surface to $\sim 30 \mathrm{ft}$ bgs in each of the eight BY cribs as well as in the nearby B-57 crib. In three of the cribs, B-43, B-49, and B-57, one of the three boreholes was extended down to $\sim 230 \mathrm{ft}$ bgs, nearly to the water table. Also, one shallow borehole was drilled in the B-61 facility, which records suggested was never used. The analytical results confirmed that the shallow sediments from near the inlet of B-61 were not contaminated. Chemical and radionuclide analyses of 11 to 13 selected sediment intervals at each borehole within the BY cribs and B57 crib were completed. In general, only total sediment concentrations (e.g., determined by strong acid digestion) analyses were completed except for anions, which were extracted using a water leach.

Therefore, the data generated in most cases do not allow the percentage that is water leachable to be predicted. They are also not readily used to predict the future mobility of contaminants subjected to recharge water pushing the constituents through the vadose zone towards the water table. However, for highly contaminated sediments, the strong acid digestion is an acceptable, albeit conservative (i.e., over estimates), method of determining the fraction of potentially mobile constituents. In addition, some sitespecific sorption studies for the radionuclides cobalt-60, strontium-90, cesium-137, technetium-99, and plutonium as well as the chemical cyanide were also performed on uncontaminated sediments from boreholes (699-52-57 and 699-55-55) using groundwater from 699-50-53 that was spiked with the species of interest. The results of the BY crib site-specific $\mathrm{K}_{\mathrm{d}}$ values are used in Section 8, Table 8.3 where BComplex sorption values are recommended.

During the recent 200-BP-5 characterization activities, two additional boreholes/groundwater monitoring wells were drilled outside the BY crib footprints from ground surface to the water table and then down to the top of the basalt. The two new wells are 299-E33-341 and 299-E33-342 (see Figure 3.1 for locations). Well 299-E33-341 was drilled $\sim 35 \mathrm{ft}$ west of existing well 299-E33-6, which is just west and in between the western edges of BY cribs B-49 and 216-B-48. New well 299-E33-342 is $\sim 75 \mathrm{ft}$ directly south of the southern edge of BY Crib B-43 and also $220 \mathrm{ft}$ southeast of existing well 299-E3338. During the drilling of these two new wells, both grab and core samples, over 160 samples at each borehole, were retrieved, and selected samples were used for geochemical, hydrologic, and physical characterization. Vadose zone sediment analyses included both acid extraction and 1:1 water to sediment extractions used to better estimate the portion of key constituents that are readily mobilized by waters such as natural recharge. By comparing the results of water and acid extracts an in situ desorption $\mathrm{Kd}$ value can be calculated to compare with the more traditional Kd determined in laboratory-batch Kd tests (see Serne et al. 2002a,b and 2004a,b for details). Chemical characterization results from the sediments of the two new wells were compared with the results from the three deep boreholes found in DOE/RL (1993a). All the sediment data were used to develop the vertical and horizontal distribution of selected species in the subsurface sediments. The merged data sets from the new 200-BP-5 boreholes/wells, 299-E33-341 and 299-E33-342, and two of the deep boreholes drilled in the early 1990s (299-E33-296 inside BY crib B-43 and 299-E33-302 inside BY crib B-49) are shown in Table 3.2 and Table 3.3. The data sets are comparable, even though different extraction protocols were used to create the extracts submitted for analyte analyses. 
Table 3.2. Vadose Zone Sediment Extract Data for Boreholes In or Near B-49 Crib

\begin{tabular}{|c|c|c|c|c|c|c|c|c|c|}
\hline $\begin{array}{c}\text { 299-E33-341 (near) } \\
\text { WATER EXTRACT }\end{array}$ & $\begin{array}{l}\text { Depth } \\
\mathrm{ft} \text { bgs }\end{array}$ & $\begin{array}{l}\mu \mathrm{g} / \mathrm{g} \text { soil } \\
\text { Sulfate }\end{array}$ & $\begin{array}{l}\mu g / g \text { soil } \\
\text { Nitrate }\end{array}$ & $\begin{array}{l}\mu \mathrm{g} / \mathrm{g} \text { soil } \\
\text { Cyanide }\end{array}$ & $\begin{array}{c}\mathrm{pCi} / \mathrm{g} \text { soil } \\
\text { Tc } 99\end{array}$ & $\begin{array}{l}\mu \mathrm{g} / \mathrm{g} \text { soil } \\
\mathrm{U}(\mathrm{WE})\end{array}$ & $\begin{array}{c}\mu \mathrm{g} / \mathrm{g} \text { soil } \\
\mathrm{U}(\mathrm{AE})\end{array}$ & $\mathrm{pH}$ & $\begin{array}{c}\mathrm{mS} / \mathrm{cm} \\
\text { Pore water Cond }\end{array}$ \\
\hline B1TP22 & 15 & 55.8 & 7.54 & NA & $<0.399$ & $2.90 \mathrm{E}-03$ & 0.45 & 8.62 & 6.52 \\
\hline В1ТР24 & 20 & 48.3 & 14.7 & $<0.212$ & $<0.416$ & 1.39E-01 & 22.40 & 9.71 & 8.73 \\
\hline B1TP26 & 25 & 21.6 & 5.57 & NA & $<0.395$ & $2.61 \mathrm{E}-03$ & 0.33 & 10.2 & 22.3 \\
\hline В1ТР28 & 30 & 31.1 & 17.1 & NA & 0.438 & $3.49 \mathrm{E}-03$ & 0.35 & 10.2 & 16.7 \\
\hline В1ТР29 & 32.5 & 31 & 18.9 & NA & 0.905 & $5.90 \mathrm{E}-03$ & 0.34 & 9.99 & 13.9 \\
\hline B1TP30 & 35 & 68.4 & 40.1 & NA & 2.53 & $6.80 \mathrm{E}-03$ & 0.35 & 10.1 & 20.6 \\
\hline B1TNV9 & 37.5 & 1070 & 532 & NA & 10 & $2.59 \mathrm{E}-03$ & 0.33 & 9.26 & 101 \\
\hline B1TNW0 & 40 & 461 & 4120 & NA & 74.6 & $<5.60 \mathrm{E}-04$ & 0.30 & 7.89 & 274 \\
\hline B1TNW1 & 42.5 & 166 & 6970 & 0.58 & 198 & $<5.58 \mathrm{E}-04$ & 0.37 & 7.51 & 296 \\
\hline B1TNW3 & 47.5 & $<150$ & 864 & NA & 17.8 & $7.18 \mathrm{E}-04$ & 0.36 & 7.41 & 70.0 \\
\hline B1TNW5 & 52.5 & 58.3 & 14.5 & NA & 44 & $8.28 \mathrm{E}-04$ & 0.37 & 7.47 & 58.6 \\
\hline B1TP35 & 65 & 55.3 & 13.2 & NA & $<0.424$ & $<5.60 \mathrm{E}-04$ & 0.39 & 7.95 & 9.76 \\
\hline B1TP40 & 77.5 & 46.2 & 15.9 & NA & $<0.393$ & $<5.60 \mathrm{E}-04$ & 0.34 & 7.82 & 7.26 \\
\hline B1TP42 & 82.5 & 74.6 & 256 & NA & 5.17 & 7.29E-04 & 0.32 & 7.77 & 22.2 \\
\hline В1ТР43 & 85 & 747 & 36.1 & 2.22 & 106 & $1.51 \mathrm{E}-03$ & 0.36 & 7.65 & 58.0 \\
\hline B1TP45 & 90 & 328 & 1060 & 0.39 & 18.5 & 7.27E-04 & 0.32 & 8.97 & 82.5 \\
\hline B1TP47 & 95 & 36.3 & 20 & NA & 49.3 & $6.90 \mathrm{E}-04$ & 0.35 & 7.18 & 149 \\
\hline В1TP49 & 100 & 210 & 1590 & NA & 44.7 & 8.04E-04 & 0.33 & 7.18 & 102 \\
\hline B1TP51 & 105 & 163 & 6360 & 1.66 & 181 & $1.54 \mathrm{E}-03$ & 0.40 & 7.29 & 151 \\
\hline B1TP52 & 107.5 & 73 & 1160 & NA & 27.4 & $1.68 \mathrm{E}-03$ & 0.31 & 7.67 & 90.5 \\
\hline В1TP53 & 110 & 26.3 & 1680 & NA & 36.4 & $<5.59 \mathrm{E}-04$ & 0.35 & 7.05 & 154 \\
\hline B1TP55 & 115 & 34 & 188 & NA & 3.39 & $5.89 \mathrm{E}-04$ & 0.36 & 7.56 & 20.8 \\
\hline B1TP59 & 125 & 40.6 & 7.84 & NA & $<0.399$ & $<5.58 \mathrm{E}-04$ & 0.30 & 7.52 & 8.40 \\
\hline B1TP61 & 130 & 39.3 & 10.3 & NA & 0.979 & $<5.61 \mathrm{E}-04$ & 0.40 & 7.68 & 7.13 \\
\hline В1TP62 & 132.5 & 44.6 & 817 & NA & 19.2 & $<5.58 \mathrm{E}-04$ & 0.34 & 7.34 & 45.7 \\
\hline В1TP64 & 137.5 & $<150$ & 1030 & NA & 24.1 & $5.89 \mathrm{E}-04$ & 0.35 & 7.43 & 61.3 \\
\hline В1ТР67 & 145 & 40.5 & 48.2 & NA & 0.698 & $<5.57 \mathrm{E}-04$ & 0.32 & 7.51 & 7.93 \\
\hline В1ТР69 & 150 & 39.4 & $<1$ & NA & 0.922 & $5.68 \mathrm{E}-04$ & 0.39 & 8.04 & 7.09 \\
\hline B1TP71 & 155 & 34.2 & $<0.997$ & NA & $<0.392$ & $<5.58 \mathrm{E}-04$ & NA & 7.74 & 6.12 \\
\hline В1ТР77 & 170 & 26.9 & $<0.999$ & NA & $<0.393$ & $<5.57 \mathrm{E}-04$ & NA & 7.99 & 5.12 \\
\hline В1TP78 & 180 & 34.5 & 6.16 & NA & $<0.393$ & $<5.61 \mathrm{E}-04$ & NA & 7.7 & 6.16 \\
\hline B1TP82 & 190 & 170 & 27.6 & NA & $<0.392$ & $5.36 \mathrm{E}-04$ & 0.32 & 7.41 & 12.1 \\
\hline
\end{tabular}


Table 3.2. Vadose Zone Sediment Extract Data for Boreholes In or Near B-49 Crib

\begin{tabular}{|c|c|c|c|c|c|c|c|c|c|}
\hline $\begin{array}{c}\text { 299-E33-341 (near) } \\
\text { WATER EXTRACT }\end{array}$ & $\begin{array}{l}\text { Depth } \\
\text { ft bgs }\end{array}$ & $\begin{array}{l}\mu \mathrm{g} / \mathrm{g} \text { soil } \\
\text { Sulfate }\end{array}$ & $\begin{array}{l}\mu \mathrm{g} / \mathrm{g} \text { soil } \\
\text { Nitrate }\end{array}$ & $\begin{array}{l}\mu \mathrm{g} / \mathrm{g} \text { soil } \\
\text { Cyanide }\end{array}$ & $\begin{array}{l}\mathrm{pCi} / \mathrm{g} \text { soil } \\
\text { Tc } 99\end{array}$ & $\begin{array}{l}\mu \mathrm{g} / \mathrm{g} \text { soil } \\
\mathrm{U}(\mathrm{WE})\end{array}$ & $\begin{array}{c}\mu \mathrm{g} / \mathrm{g} \text { soil } \\
\mathrm{U}(\mathrm{AE})\end{array}$ & $\mathrm{pH}$ & $\begin{array}{c}\mathrm{mS} / \mathrm{cm} \\
\text { Pore water Cond }\end{array}$ \\
\hline B1TP84 & 195 & 98.2 & 18.2 & NA & $<0.393$ & $7.30 \mathrm{E}-04$ & NA & 7.9 & 8.71 \\
\hline B1TNX1 & 202.5 & 76.4 & 6.12 & NA & $<0.397$ & $<5.59 \mathrm{E}-04$ & NA & 7.67 & 5.95 \\
\hline В1TP86 & 212.5 & 33.6 & 2.01 & NA & $<0.393$ & $<5.57 \mathrm{E}-04$ & NA & 7.91 & 4.44 \\
\hline B1TP89 & 220 & 46.5 & 1.97 & NA & $<0.395$ & $<5.61 \mathrm{E}-04$ & NA & 6.77 & 4.43 \\
\hline B1TP91 & 225 & 29.1 & $<1$ & $<0.214$ & $<0.395$ & $<5.59 \mathrm{E}-04$ & NA & 7.87 & 6.93 \\
\hline \multicolumn{10}{|c|}{ B-49 Borehole 299-E33-302 (in crib) } \\
\hline \multirow[t]{2}{*}{ Sample ID } & Depth & $\begin{array}{l}\text { Sulfate } \\
\text { (WE) }\end{array}$ & $\begin{array}{l}\text { Nitrate } \\
\text { (WE) }\end{array}$ & $\begin{array}{l}\text { Cyanide } \\
\text { (PNL) }\end{array}$ & Cyanide & Tc & $\mathrm{U}(\mathrm{AE})$ & & \\
\hline & (ft bgs) & $\mu \mathrm{g} / \mathrm{g}$ & $\mu \mathrm{g} / \mathrm{g}$ & $\mu \mathrm{g} / \mathrm{g}$ & $\mu \mathrm{g} / \mathrm{g}$ & $\mathrm{pCi} / \mathrm{g}$ & $\mu \mathrm{g} / \mathrm{g}$ & & \\
\hline B00X67 & 4.25 & NA & 56.5 & $<0.6$ & $<1.00$ & NA & $<0.5$ & & \\
\hline B00X69 & 9.75 & NA & 23.1 & $<0.6$ & $<1.03$ & NA & $<0.5$ & & \\
\hline B00X75 & 18.5 & 162 & 887 & 1.6 & NA & 48 & 41 & & \\
\hline B00XB7 & 26.25 & 67.3 & 444 & 0.8 & $<1.03$ & NA & 6.7 & & \\
\hline BD0X76 & 47.75 & 1080 & 4040 & 4.4 & 3.18 & 100 & $<1$ & & \\
\hline B00XD5 & 76.25 & 362 & 5470 & $<0.6$ & $<1.00$ & 160 & $<0.6$ & & \\
\hline B015G3 & 105.75 & 822 & 3380 & 0.8 & $<1.00$ & 110 & $<1.4$ & & \\
\hline В015H5 & 136.25 & 152 & 3490 & 1.5 & 1.5 & 120 & 2.4 & & \\
\hline B015K1 & 163.25 & 121 & 2220 & 0.8 & $<1.03$ & 65 & $<0.4$ & & \\
\hline B015K7 & 191.75 & 722 & 3760 & 1.2 & $<1.10$ & 100 & $<0.6$ & & \\
\hline B015K9 & 218.25 & 53.8 & 3710 & 0.7 & $<1.00$ & 140 & $<0.4$ & & \\
\hline
\end{tabular}


Table 3.3. Vadose Zone Sediment Extract Data for Boreholes In or Near B-43 Crib

\begin{tabular}{|c|c|c|c|c|c|c|c|c|c|}
\hline \multicolumn{10}{|c|}{ 299-E33-342 (near crib) } \\
\hline HEIS Number & $\begin{array}{l}\text { Depth } \\
\mathrm{ft} \text { bgs }\end{array}$ & $\begin{array}{c}\mu \mathrm{g} / \mathrm{g} \\
\text { Sulfate }\end{array}$ & $\begin{array}{c}\mu \mathrm{g} / \mathrm{g} \\
\text { Nitrate }\end{array}$ & $\begin{array}{l}\mu \mathrm{g} / \mathrm{g} \text { soil } \\
\text { Cyanide }\end{array}$ & $\begin{array}{l}\mathrm{pCi} / \mathrm{g} \text { soil } \\
\text { Tc } 99\end{array}$ & $\begin{array}{c}\mu \mathrm{g} / \mathrm{g} \text { soil } \\
\mathrm{U}-238(\mathrm{WE})\end{array}$ & $\begin{array}{c}\mu \mathrm{g} / \mathrm{g} \text { soil } \\
\mathrm{U}-238(\mathrm{AE})\end{array}$ & $\mathrm{pH}$ & $\begin{array}{c}\mathrm{mS} / \mathrm{cm} \\
\text { Pore water Cond }\end{array}$ \\
\hline B1TMT2 & 20.1 & 3.6 & 3.53 & NA & $<0.388$ & 0.001 & 0.32 & 8.75 & 2.88 \\
\hline B1TMT7 & 32 & 5.85 & 5.73 & NA & $<0.387$ & 0.001 & 0.39 & 9.2 & 3.04 \\
\hline B1TMV1 & 42.5 & 8.98 & 3.86 & NA & $<0.390$ & 0.002 & 0.37 & 8.87 & 3.21 \\
\hline B1TMV6 & 55 & 13.2 & 7.39 & NA & $<0.390$ & 0.001 & 0.34 & 8.32 & 3 \\
\hline B1TMV9 & 62.5 & 9.51 & 6.45 & NA & $<0.387$ & 0.008 & 0.40 & 9.6 & 6.02 \\
\hline B1TMW2 & 70 & 17.3 & 7.36 & NA & $<0.395$ & 0.001 & 0.31 & 8.8 & 3.67 \\
\hline B1TMW7 & 82.5 & 18.0 & 16.6 & $<0.21$ & $<0.387$ & 0.009 & 0.51 & 9.82 & 7.93 \\
\hline B1TMX1 & 90 & 22.4 & 6.5 & NA & $<0.390$ & 0.001 & 0.40 & 9.4 & 5.55 \\
\hline B1TMX5 & 102.5 & 42.0 & 30.3 & NA & $<0.390$ & 0.001 & 0.28 & 9.23 & 4.64 \\
\hline B1TMX8 & 109.5 & 30.5 & 11.4 & NA & $<0.390$ & 0.001 & 0.35 & 8.57 & 4.49 \\
\hline B1TMY1 & 117 & 149 & 75.2 & $<0.23$ & 0.621 & 0.001 & 0.38 & 7.89 & 4.28 \\
\hline B1TMY2 & 120 & 93.9 & 50.8 & NA & $<0.390$ & 0.001 & 0.36 & 7.81 & 2.74 \\
\hline B1TMY6 & 130 & 30.5 & 16.4 & NA & $<0.387$ & $<0.001$ & 0.29 & 7.95 & 4.64 \\
\hline B1TMY9 & 137.2 & 33.9 & 16 & NA & $<0.394$ & $<0.001$ & 0.29 & 7.93 & 4.9 \\
\hline B1TN03 & 147 & 36.2 & 413 & $<0.21$ & 6.97 & 0.001 & 0.24 & 7.75 & 18.9 \\
\hline B1TN08 & 160 & 42.2 & 904 & $<0.21$ & 2.05 & 0.001 & 0.34 & 7.81 & 8.88 \\
\hline B1TN11 & 167.5 & 34.6 & 149 & NA & 1.59 & $<0.001$ & 0.32 & 7.85 & 14.8 \\
\hline B1TN15 & 177.5 & 22.6 & 216 & NA & 3.41 & $<0.001$ & 0.36 & 7.41 & 13.1 \\
\hline B1TN37 & 190 & 66.2 & 288 & 0.25 & 4.68 & 0.001 & 0.31 & 7.48 & 13.4 \\
\hline B1TN22 & 199 & 62.4 & 188 & NA & 0.497 & $<0.001$ & 0.37 & 7.75 & 11.2 \\
\hline B1TN27 & 210 & 40.8 & 215 & NA & 2.04 & $<0.001$ & 0.42 & 7.47 & 13.6 \\
\hline B1TN31 & 220 & 44.8 & 152 & NA & 0.787 & $<0.001$ & 0.31 & 7.71 & 15.9 \\
\hline B1TN34 & 228 & 54.0 & 278 & $<0.22$ & 2.77 & $<0.001$ & 0.30 & 7.44 & 16.4 \\
\hline \multicolumn{10}{|c|}{ B-43, BOREHOLE 299-E33-296 (in crib) } \\
\hline Sample ID & $\begin{array}{c}\text { Depth } \\
\text { (ft bgs) }\end{array}$ & $\begin{array}{c}\text { Sulfate } \\
\mu \mathrm{g} / \mathrm{g}\end{array}$ & $\begin{array}{c}\text { Nitrate } \\
\mu \mathrm{g} / \mathrm{g}\end{array}$ & $\begin{array}{l}\text { Cyanide } \\
\mu \mathrm{g} / \mathrm{g}\end{array}$ & $\begin{array}{c}\text { Cyanide (PNL) } \\
\mu \mathrm{g} / \mathrm{g}\end{array}$ & $\begin{array}{c}\mathrm{Tc} \\
\mathrm{pCi} / \mathrm{g}\end{array}$ & $\begin{array}{c}\mathrm{U}(\mathrm{AE}) \\
\mu \mathrm{g} / \mathrm{g}\end{array}$ & & \\
\hline B015L7 & 3.5 & 28.5 & 73.7 & $<1.05$ & $<0.6$ & 2 & $<0.5$ & & \\
\hline B015M3 & 11.65 & 517 & 36.5 & $<1.05$ & $<0.6$ & 1.1 & $<0.4$ & & \\
\hline B015P9 & 19.25 & 283 & 1140 & NA & 4.2 & 80 & 30.8 & & \\
\hline $\mathrm{B} 015 \mathrm{P} 1$ & 27.25 & 108 & 440 & NA & 1.1 & $<70$ & 18.7 & & \\
\hline B015Q3 & 57.25 & 197 & 2740 & $<1.03$ & 0.2 & 35 & 2.2 & & \\
\hline B015R1 & 84.75 & 66.1 & 1500 & $<1.06$ & $<0.2$ & 18 & $<0.7$ & & \\
\hline B015R3 & 109.75 & 53.3 & 4.7 & $<1.02$ & $<0.2$ & $<0.7$ & NA & & \\
\hline 5015R9 & 131.75 & 44.2 & 458 & $<1.03$ & 0.4 & 24 & 2 & & \\
\hline B015J6 & 158.75 & 210 & 4620 & 2.86 & 3.4 & 210 & $<1$ & & \\
\hline B01S79 & 189.75 & 30 & 1550 & 1.7 & 2.8 & 96 & 1.4 & & \\
\hline B01S81 & 215.25 & 70.3 & 3090 & $<1.00$ & 1.3 & 130 & $<0.5$ & & \\
\hline B01S87 & 225.25 & 32.1 & 2970 & 1.2 & 2.3 & 140 & $<1$ & & \\
\hline
\end{tabular}

Bold values are highly elevated concentrations compared to uncontaminated sediments.

$\mathrm{NA}=$ not analyzed or not reported

Historical field gamma and neutron moisture logs from the boreholes in the BY Cribs region provide another mechanism for establishing the vertical and horizontal distribution of selected species as well as evaluating the migration of the waste fluids in the vadose zone since active disposal stopped. Cobalt-60 is the main contaminant used in evaluating contaminant movement with time. Because cobalt- 60 was found to be as mobile as ruthenium-106 below the BY Cribs in 1956, most likely because of strong complexing between the cobalt-60 and ferrocyanide anion, the gross- and spectral-gamma logs for boreholes around 
the BY cribs were very useful for delineating the vertical and to some extent (dependent on borehole availability) the horizontal spreading of the fluids disposed of to the BY cribs. Further, by comparing historical gross gamma logs with the spectral gamma logs obtained since 2002, it is possible to determine whether the waste fluids have migrated in the vadose zone between the times that logging activities at each borehole were performed. The gamma and neutron moisture logs for many or the boreholes around the BY cribs region can be found through the "Geophysical Reports" menu tab at (URL:

http://environet.hanford.gov/eda) and in DOE/GJO (2003). Gross gamma logs versus time are found in Price (1992).

Summary findings from DOE/GJO (2003) confirm that lateral spreading of cobalt-60 appears to be extensive. According to DOE/GJO (2003), using spectral gamma logging cobalt-60 was detected as far as $220 \mathrm{ft}$ northwest of the B-50 Crib and $286 \mathrm{ft}$ southeast of the B-43 Crib. A 3D geostatistically based visualization of the spread of the mobile contaminant cobalt-60 is shown in Figure 3.3. Contaminant distributions in regions north, west, and south of the cribs could not be assessed because these regions have few boreholes. On the basis of a vadose zone stratigraphic dip to the north at one degree, it is likely that extensive contamination would be detected north of the cribs. A comparison of borehole logs acquired in 1992 and 2002 indicates continuing migration of cobalt-60 in the area of the cribs in either vertical, lateral or both directions depending on the borehole. Figure 3.3 shows that the higher cobalt-60 activities are found quite close to the footprints of the cribs, but that low concentrations have spread over nearly the entire area delineated by the dashed fenceline in Figure 3.1 around the cribs.

Although technetium-99, cobalt-60, and uranium-238 were detected in groundwater in the vicinity of the BY Cribs, no uranium-238 above background concentrations was detected in the vadose zone below a $\log$ depth of approximately $60 \mathrm{ft}$. Cobalt- 60 and cesium-137 contamination was not continuously detected throughout the vadose zone, but occasionally were found just above and within the groundwater. This sporadic contamination is believed to be residual activity bound to the metal borehole casings from contaminated groundwater that invaded this area during the active disposal of waste in the B-43 to -49 Cribs in 1954 to 1955 . DOE/GJO (2003) recommends that boreholes should be drilled in all compass directions from the B-43 to -50 Cribs to determine the lateral extent of contamination. Also, sediment samples should be obtained from the vadose zone and vadose zone/aquifer interface to determine the distribution of non-gamma-emitting radionuclides, and the relationship of cobalt-60 to technetium-99 should be evaluated.

The soil electrical resistivity field survey (Rucker et al. 2007) was used to help locate where the two new combined vadose zone characterization and groundwater monitoring wells (299-E33-341 and E33342 ) were drilled. Based on a localized low resistivity region to the west of the center line between cribs B-49 and B-48, the location of 299-E33-341 was moved from the north side of the BY cribs to its current location. In addition E33-342 was moved slightly to a location where an apparent low resistivity signature was dissipating to assess whether soil resistivity measurements could identify the leading edge of a vadose zone salt plume. 
PNNL-19277
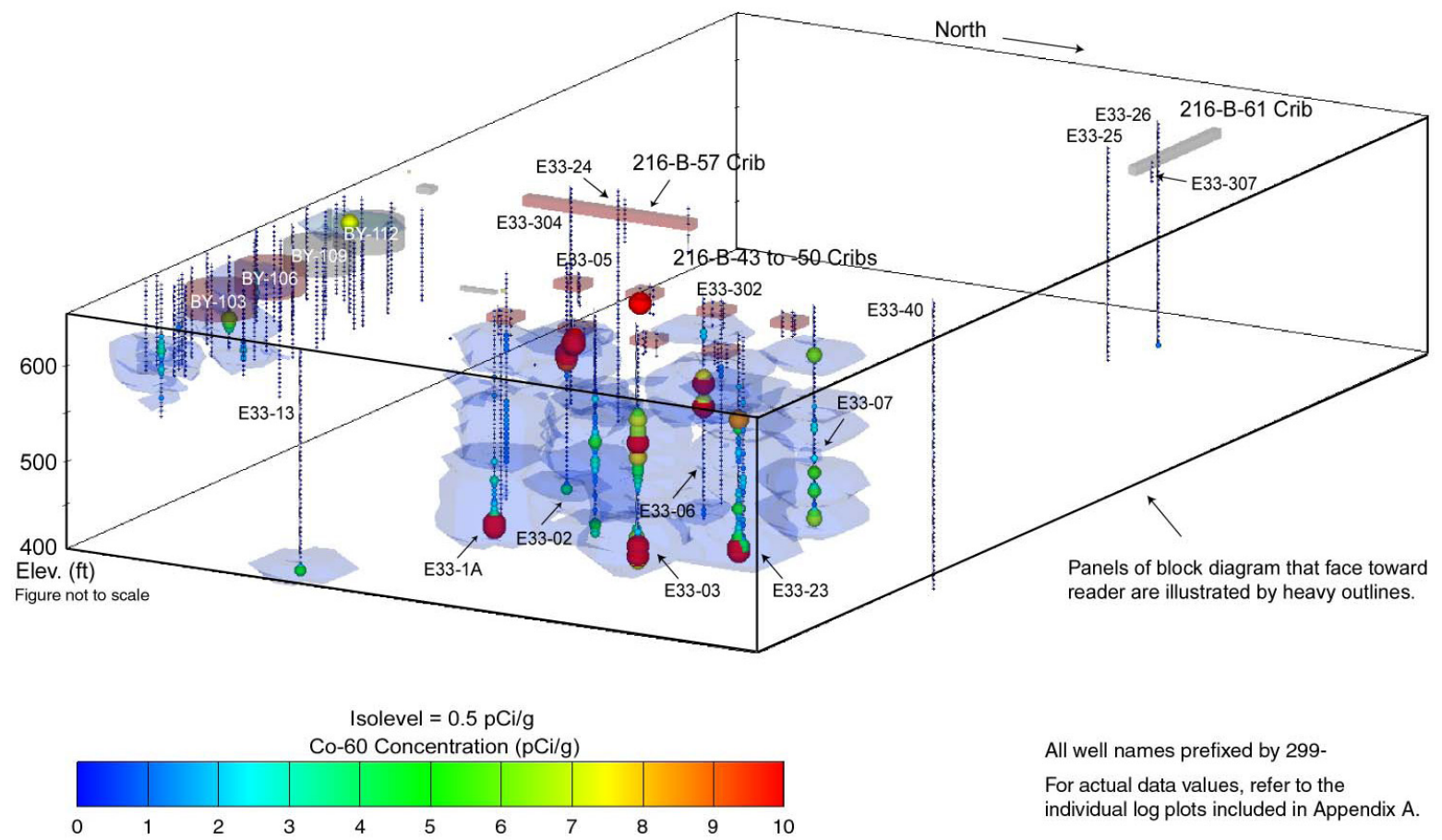

All well names prefixed by 299-

For actual data values, refer to the individual log plots included in Appendix A.

Figure 3.3. 3D Visualization of Cobalt-60 Distribution Below the BY Cribs-from DOE/GJO (2003)

Overall, the soil electrical resistivity field survey results of essentially the entire B-Complex region (see Rucker et al. 2007) were useful in a qualitative sense to delineate the lateral extent of high conductivity pore fluids (residual waste) within the vadose zone sediments. Vertical resolution was difficult to attain with surface, well-to-well, and well-to-surface resistivity methods and approaches. Key conclusions offered by the HGI staff who conducted the field work and data inversion/interpretation follow. The BY Cribs area received a significant quantity of liquid waste, and values of low resistivity relative to the background appear directly beneath the cribs and correlate spatially to disposal activities. The field survey is not definitive on whether any of the BY Crib wastes reached the water table. However, comparing the depth of the low-resistivity anomalies to those at the BX Trenches and the BBX-BY tank farms, the low resistivity anomaly beneath the BY Cribs appears much deeper and closer to the water table. In addition, evaluation of plan view sections through the distribution of estimated resistivity seems to suggest the occurrence of the low resistivity anomaly extending outwards beyond the northeast boundary from the BY Cribs area. Analysis of results also suggests that the conductive anomaly does not extend southward all the way to the BY Tank Farm. However, given the vertical smearing issue of estimated resistivity during the inversion process, this observation should be followed up with direct field confirmation of results from geochemical analyses on soils collected from a borehole. Rucker et al. (2007) recommended that results of the soil resistivity data analysis efforts be used to help define locations for additional confirmational drilling and borehole analysis. In particular, Rucker et al. (2007) identified three focus areas on the periphery of the tank farms; the B Trenches (BX Trenches), the BY Cribs, and the B-8 Crib and Tile Field. They recommended confirmatory boreholes where sediment samples would be collected every $6.5 \mathrm{ft}$ ( 2 meters) from the surface to the water table. The inverted field data for the BY Cribs region copied directly from Rucker et al. (2007) are shown in Figure 3.4 through Figure 3.6. 
PNNL-19277

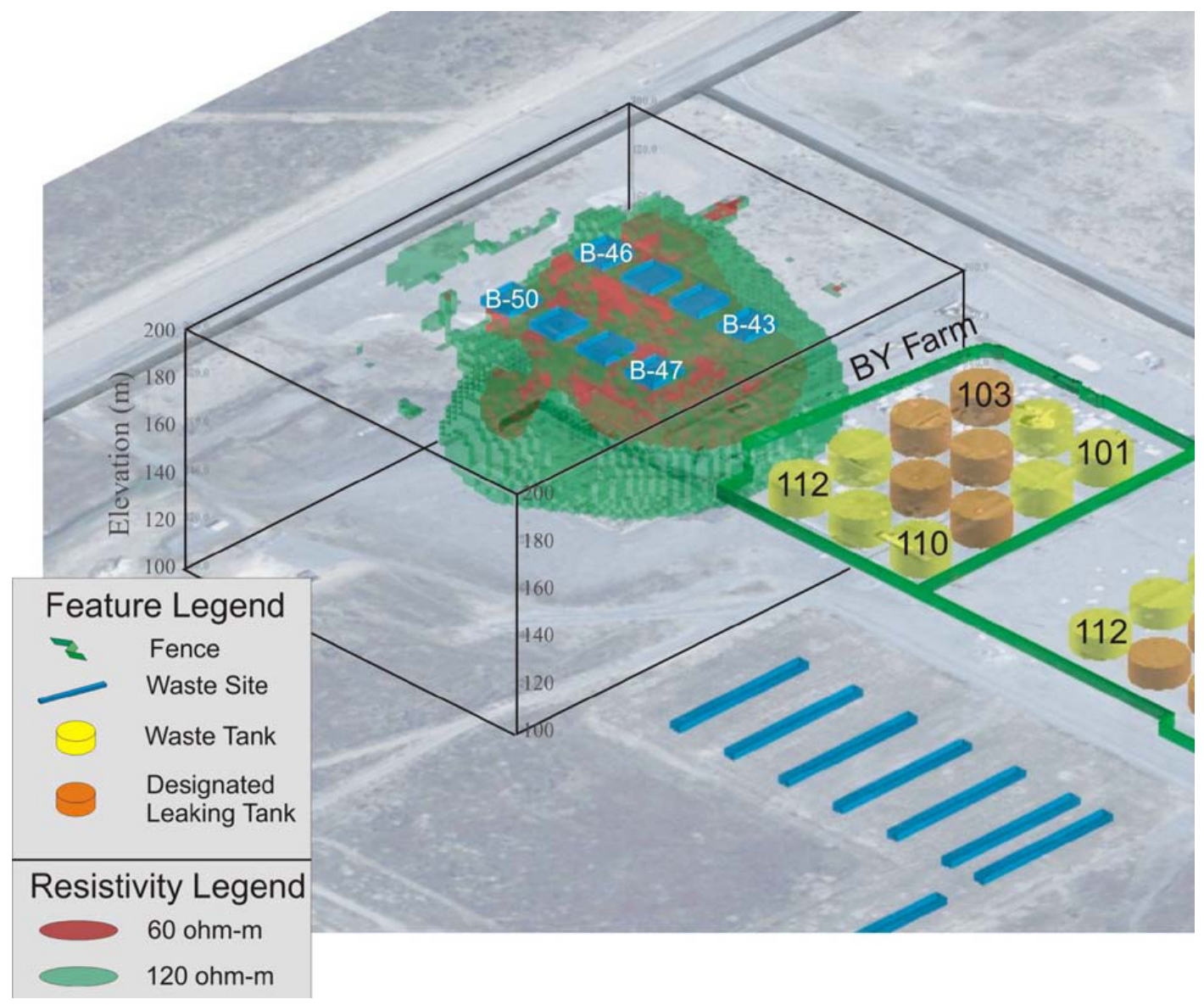

Figure 3.4. Inverted Field Resistivity Data Based on 2D Data Collection on 3-m Resolution 
PNNL-19277

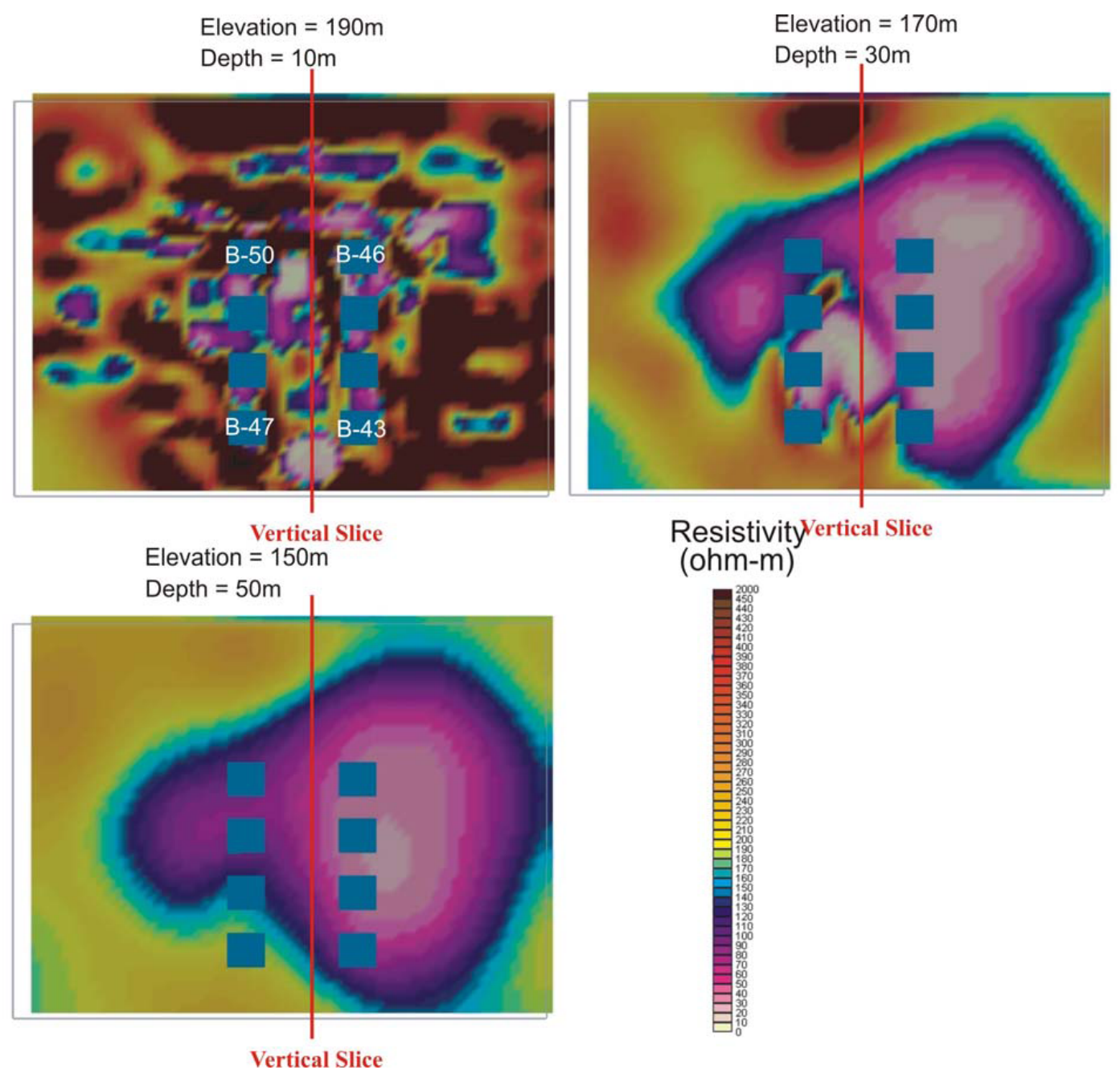

Figure 3.5. Plan View of Inverted Resistivity at 10, 30, and $50 \mathrm{~m}$ bgs (Eight BY cribs are blue squares; $N$ is to top of each figure) 

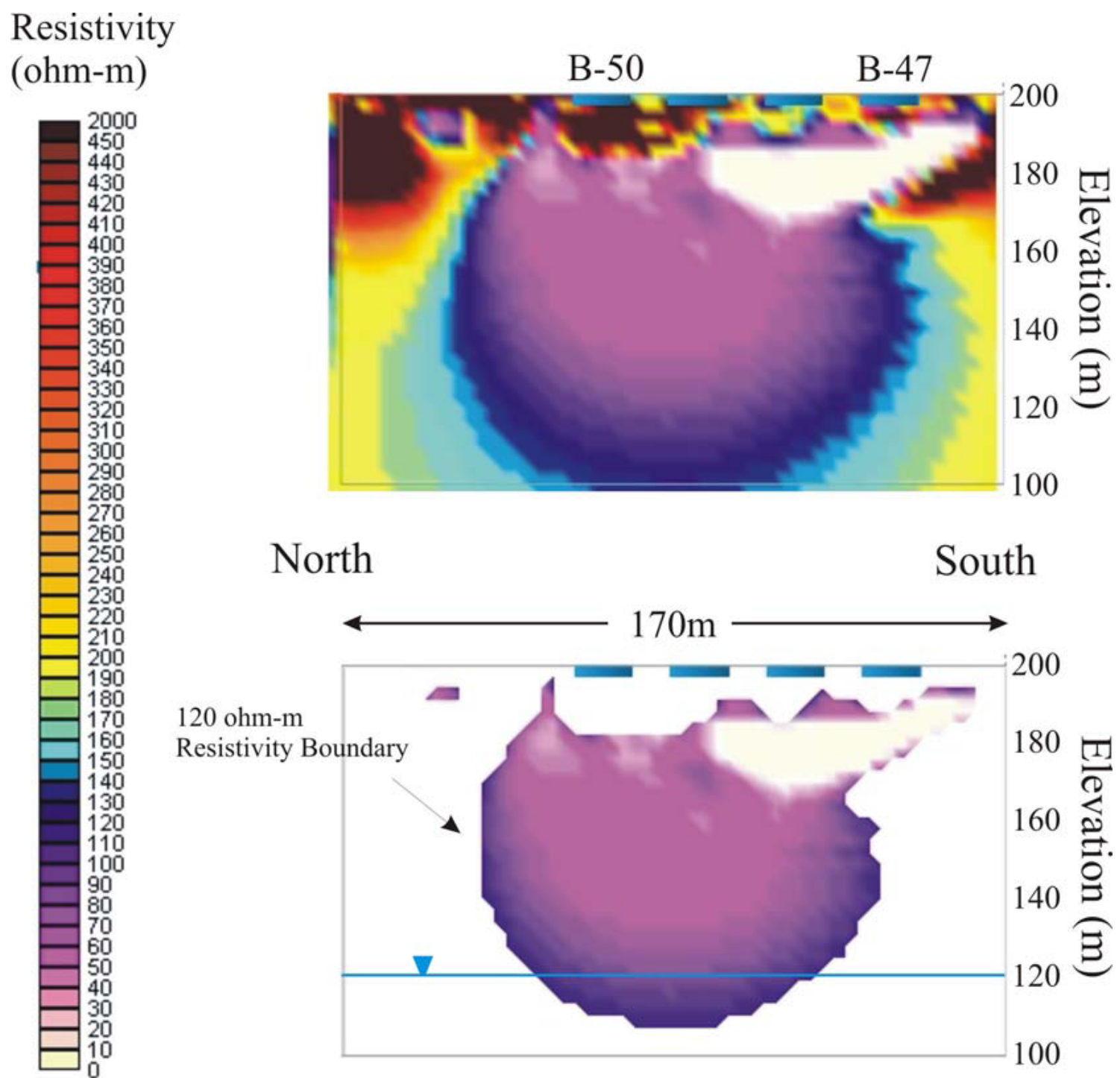

Figure 3.6. Cross Sectional View of Inverted Field Resistivity Data Below BY Cribs (Suggests low resistivity plume reaches the water table.)

However, as caveated in Rucker and Fink (2007) and more quantitatively described in a comprehensive "ground truthing" effort for surface-based soil electrical resistivity field surveys at the BC Cribs (same waste type disposed of to the BY cribs), Serne et al. (2009) show that the soil resistivity technique may not accurately delineate the vertical extent of subsurface plumes. Analysis of surfacebased soil electrical resistivity surveys tends to smear the vertical distribution of high conductivity plumes when the vertical distribution of salt consists of several lobes of alternating high and low conductivity, which is very common within the heterogeneous Hanford subsurface. Although the vertical distribution is smeared, high-conductivity signatures, apparently representing the remaining waste fluids released to the Hanford subsurface, show significant lateral spreading, most likely at several thin fine-grained lenses within the Hanford formation (H2F1, H2F2, and H2F3) and other more localized lenses (see discussion in Section 2.4). Lateral spreading would also be expected within the Cold Creek fine-grained unit $\left(\mathrm{CCU}_{\mathrm{z}}\right)$ when it is present; however, as shown in Figure 2.20, the CCUz unit is not continuously present below the 
entire BY cribs footprint. A key implication of the lateral spreading is that past estimations of the depth of penetration of waste fluids based on the concept that flow was strictly vertical down through the facility footprint likely over predict the depth to which fluids reached in the vadose zone and the mass of contaminants that still reside in the vadose zone sediments. Later in this section (see Figure 3.17 through Figure 3.20) a conceptualization of the stratigraphy below the BY cribs is presented based on direct examination of the sediments and driller's logs from boreholes 299-E33-296, E33-302, E33-341, and E33-342. These two figures can be used to aid in assimilating the following information.

Table 3.2 and Figure 3.7 through Figure 3.9 present the distribution of key constituents throughout the vadose zone using the depth-discrete sediment samples at borehole/wells 299-E33-302 and 299-E33341 below and near the B-49 crib, respectively. The data at borehole 299-E33-302 provides evidence that mobile contaminants such as technetium-99, nitrate, sulfate, cyanide, and sodium (not plotted) from the waste fluids disposed of to the B-49 crib reached the groundwater. Further, to this day, the deep vadose zone pore waters below the footprint of B-49 from $\sim 50 \mathrm{ft}$ bgs to the water table at $\sim 230 \mathrm{ft}$ bgs contain elevated concentrations of these mobile species. To the west of the B-49 crib, the new borehole/well 299E33-341 shows that lateral spreading of the fluids disposed of to the BY cribs has occurred.

At the new borehole, 299-E33-341, elevated concentrations (max $\sim 200 \mathrm{pCi} / \mathrm{g}$ ) of technetium-99 are found at the top of a fine-grained lens at $42.5 \mathrm{ft} \mathrm{bgs}$, and lower concentrations are found deeper from 85 to $110 \mathrm{ft}$ bgs (see Figure 3.7). The technetium-99 concentration again reaches $\sim 200 \mathrm{pCi} / \mathrm{g}$ at another finegrained lens at $105 \mathrm{ft}$ bgs (H2F2; see Section 2.4) in borehole 299-E33-341. There is a faint sign of a third deeper lobe of technetium-99 at about $132.5 \mathrm{ft}$ bgs again associated with a fine-grained lens (H2F3) within the $\mathrm{H} 2$ formation sands. The technetium- 99 sediment concentrations below the B- 49 crib footprint in borehole 299-E33-302 over the depth range from 48 to $218 \mathrm{ft}$ bgs were in the range from $\sim 65$ to 160 $\mathrm{pCi} / \mathrm{g}$. The range of technetium-99 concentrations and peak at $160 \mathrm{pCi} / \mathrm{g}$ are similar to the range and peak concentrations in sediments at the nearby 299-E33-341 borehole. Given the fact that technetium-99 does not adsorb to any significant degree and thus remains in the pore water, finding similar concentrations in the sediment about a hundred feet laterally from the crib footprint supports the conclusion that waste fluids disposed of in the BY cribs spread horizontally, especially along fine-grained lenses in the sanddominated $\mathrm{H} 2$ formation. In contrast, there is little indication of technetium-99 spreading laterally between the Hanford formation and the Cold Creek units beneath B-49 likely because the fine-grained $\mathrm{CCU}_{\mathrm{z}}$ strata are very thin or non-existent. In general, the $\mathrm{CCU}_{\mathrm{z}}$ lens is very thin or absent below the entire northern half of the western row of BY cribs (see discussion in Section 2.4.2 and Appendix B regarding the areal extent of the $\mathrm{CCU}_{\mathrm{z}}$ strata below the B-Complex).

Elevated nitrate concentrations (Figure 3.8) are found at about the same sediment horizons as the technetium-99. That is, where the technetium-99 sediment concentrations are approaching $\sim 200 \mathrm{pCi} / \mathrm{g}$, the nitrate concentrations are $\sim 7000 \mu \mathrm{g} / \mathrm{g}$. As found at most other Hanford subsurface contamination sites, nitrate and technetium-99 appear to migrate coincident with each other as waste fluid percolates from the disposal facilities towards the water table. 


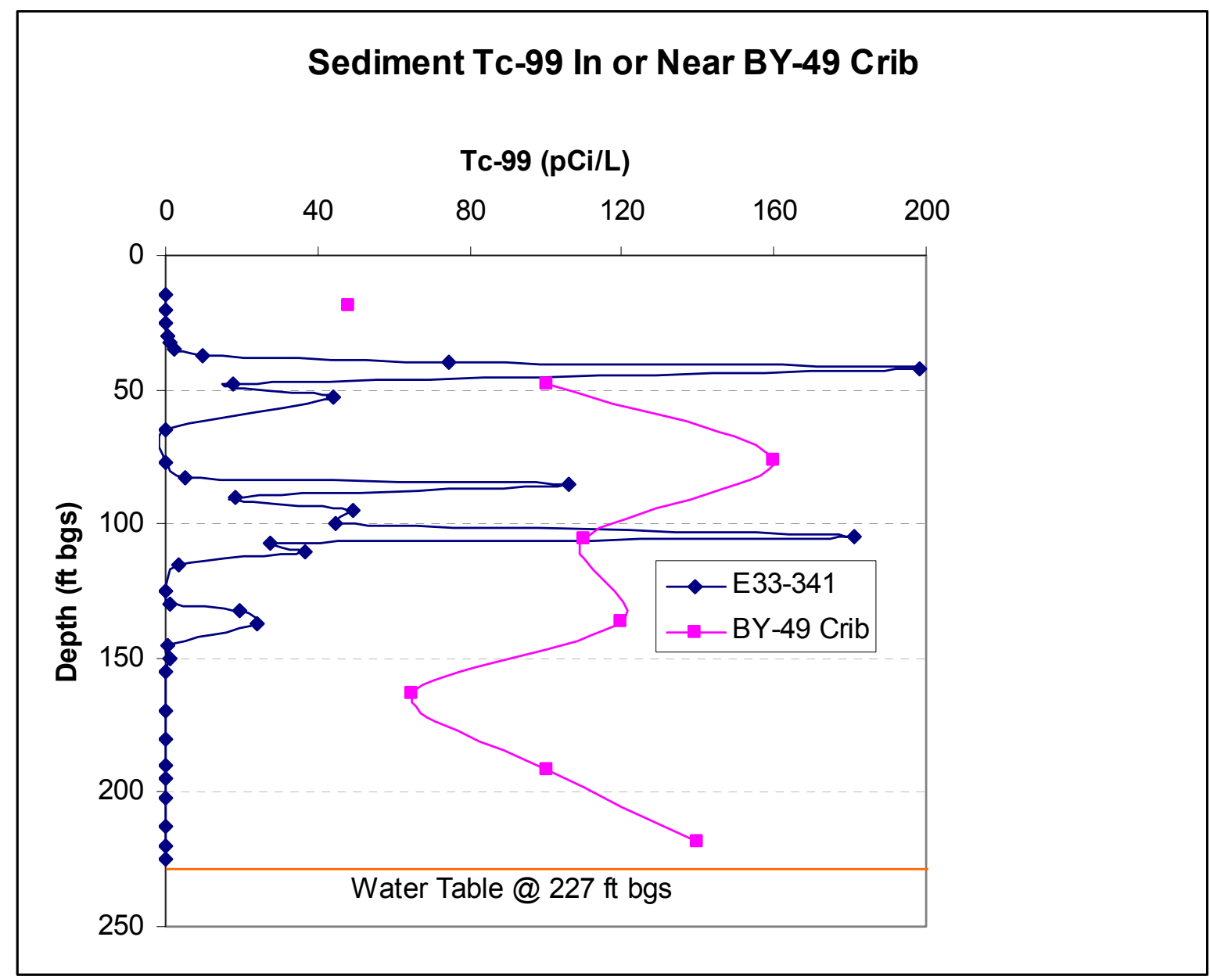

Figure 3.7. Technetium-99 in Sediments as a Function of Depth In and West of B-49 Crib Based on depth-discrete sediment analyses from the two available boreholes.

Elevated water-extractable sulfate values in borehole 299-E33-302 sediments occur at $\sim 48, \sim 106$, and $\sim 192 \mathrm{ft}$ bgs (see Figure 3.9). The shallowest region has the highest concentration with $1080 \mu \mathrm{g} / \mathrm{g}$ while the two deeper peaks are $\sim 820$ and $\sim 720 \mu \mathrm{g} / \mathrm{g}$. The peak at $106 \mathrm{ft}$ bgs is associated with the H2F2 finegrained lens, and the deepest peak at $\sim 192 \mathrm{ft}$ bgs is near the top of the $\mathrm{CCU}_{\mathrm{z}}$, lens which is quite thin at this location. At the nearby 299-E33-341 borehole, the water-extractable sulfate concentrations are also elevated at 37.5 to $40 \mathrm{ft}$ bgs and 85-90 ft bgs. Although the concentrations at 105 and $190 \mathrm{ft}$ bgs are below the 95\% LCL site background concentrations provided in DOE/RL (1992), the concentrations may also reflect lateral spreading along the associated fine grain low permeability sediment layer. Note that the maximum concentrations occur near the tops or within finer-grained lenses. The sulfate distributions below BY-49, in contrast to the technetium-99 distribution, suggest that sulfate has spread laterally at the contact between the $\mathrm{H} 2$ formation and the thin $\mathrm{CCU}_{\mathrm{z}}$ unit near $192 \mathrm{ft}$ bgs. Below the BY-43 Crib the deep vadose zone sediments do not show highly elevated sulfate concentrations in the vicinity of the contact between the $\mathrm{H} 2$ and $\mathrm{CCU}_{z}$ strata. 


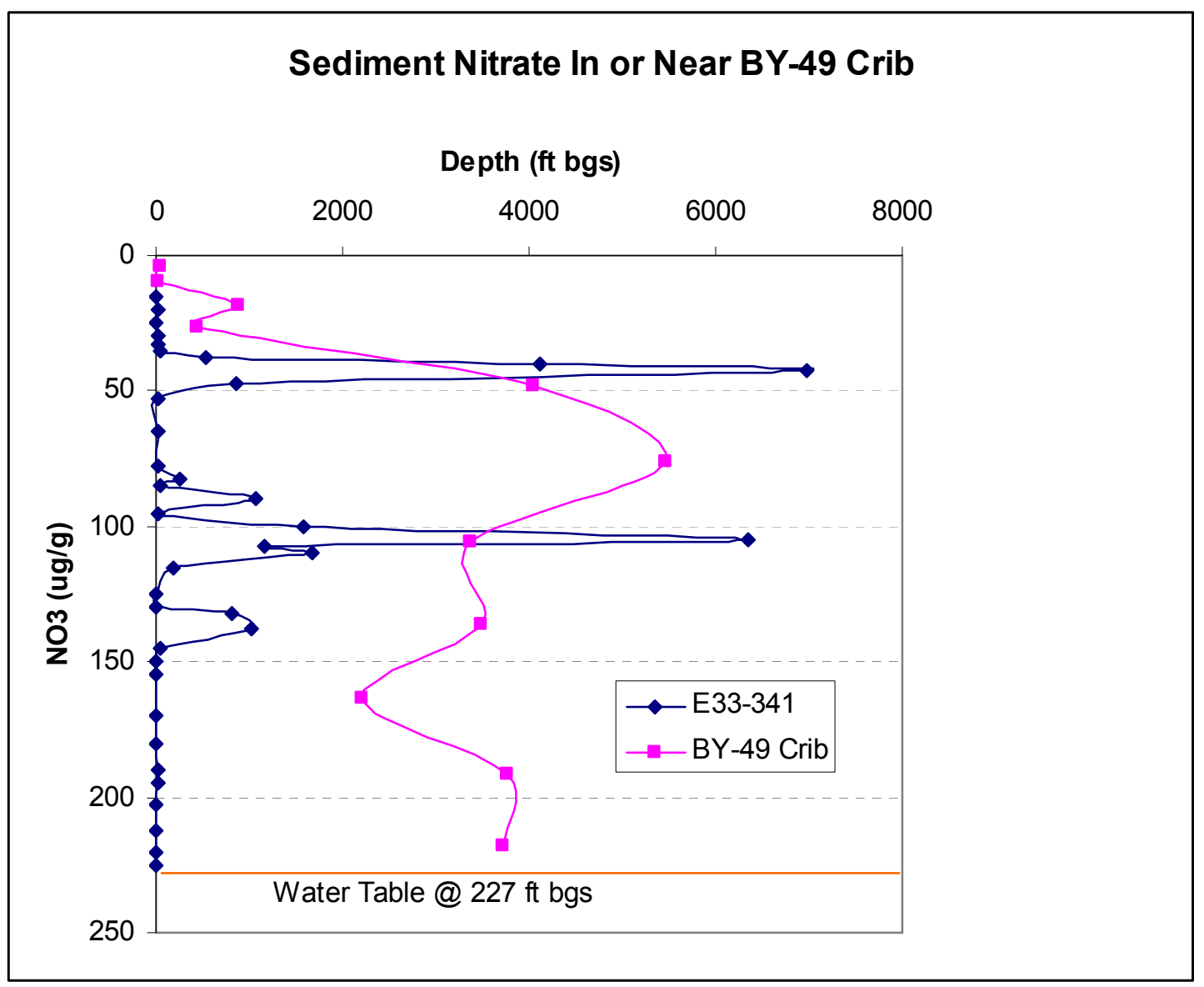

Figure 3.8. Nitrate in Sediments as a Function of Depth In and West of B-49 Crib Based on depth-discrete sediment analyses from the two available boreholes. 
PNNL-19277

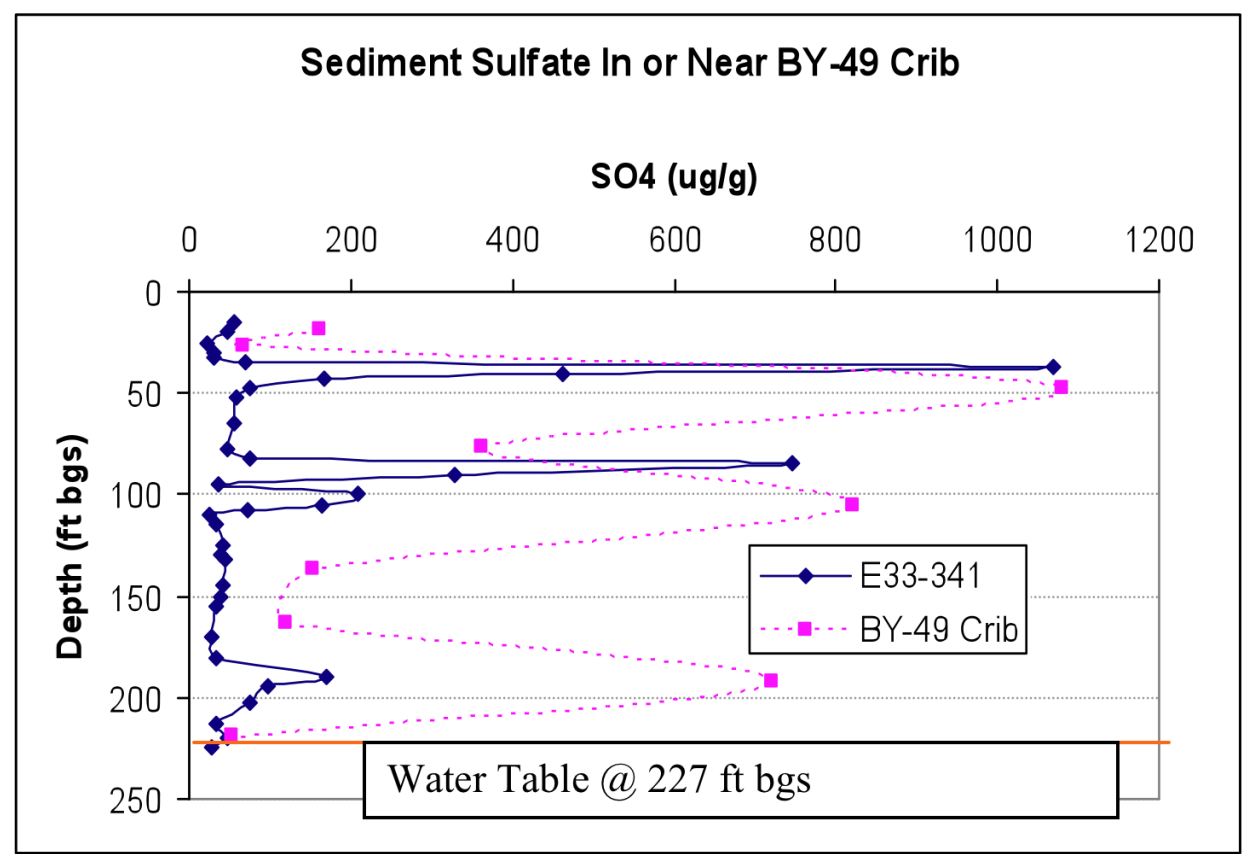

Figure 3.9. Water-Extractable Sulfate in Sediments as a Function of Depth In and West of B-49 Crib Based on depth-discrete sediment analyses from the two available boreholes.

Measureable cyanide is found in the 299-E33-302 sediments below the B-49 crib and to the west in borehole 299-E33-341 sediments (see Figure 3.10). The number of sediment samples measured is rather limited such that it is not prudent to state that there are distinct peaks in the vertical distribution of cyanide. Samples between $\sim 48$ and $136 \mathrm{ft}$ bgs show measurable cyanide with higher values found near $48,85,105$, and $136 \mathrm{ft}$ bgs. The latter three depths are coincident with the three most areally extensive fine-grained lenses noted in the geologic cross-sections of the area as H2F1, H2F2 and H2F3, although not all three lenses have been positively identified in the available sediment samples at these two boreholes.

Because the detection limit for cyanide in Hanford vadose zone sediments has ranged from 0.2 to 1 $\mu \mathrm{g} / \mathrm{g}$ over the last 20 years, it is difficult to show where cyanide is present and not present at environmentally important concentrations in sediments. That is, if one assumes that all the cyanide extracted from the sediment was present in the pore water, then at the typical moisture contents of Hanford formation $\mathrm{H} 2$ sand ( 3 to $5 \% \mathrm{wt}$ ), the detection limit is equivalent to pore-water concentrations of between 4,000 and 33,000 $\mu \mathrm{g} / \mathrm{L}$ cyanide. These pore-water detection limits are much too insensitive to be very useful at discerning the presence or absence of cyanide in vadose zone pore water excepting in situations with very high cyanide concentrations. Cyanide concentrations found in Hanford Site groundwater plumes rarely exceed $1,000 \mu \mathrm{g} / \mathrm{L}$ such that relying on the current analytical procedures for determining cyanide concentrations in moist vadose zone sediments is a rather insensitive protocol that is likely only identifying the most highly cyanide-contaminated locations. Albeit, there appears to be measurable cyanide present in sediments below and adjacent to the B- 49 and as will be discussed next below the B-43 crib. 
PNNL-19277

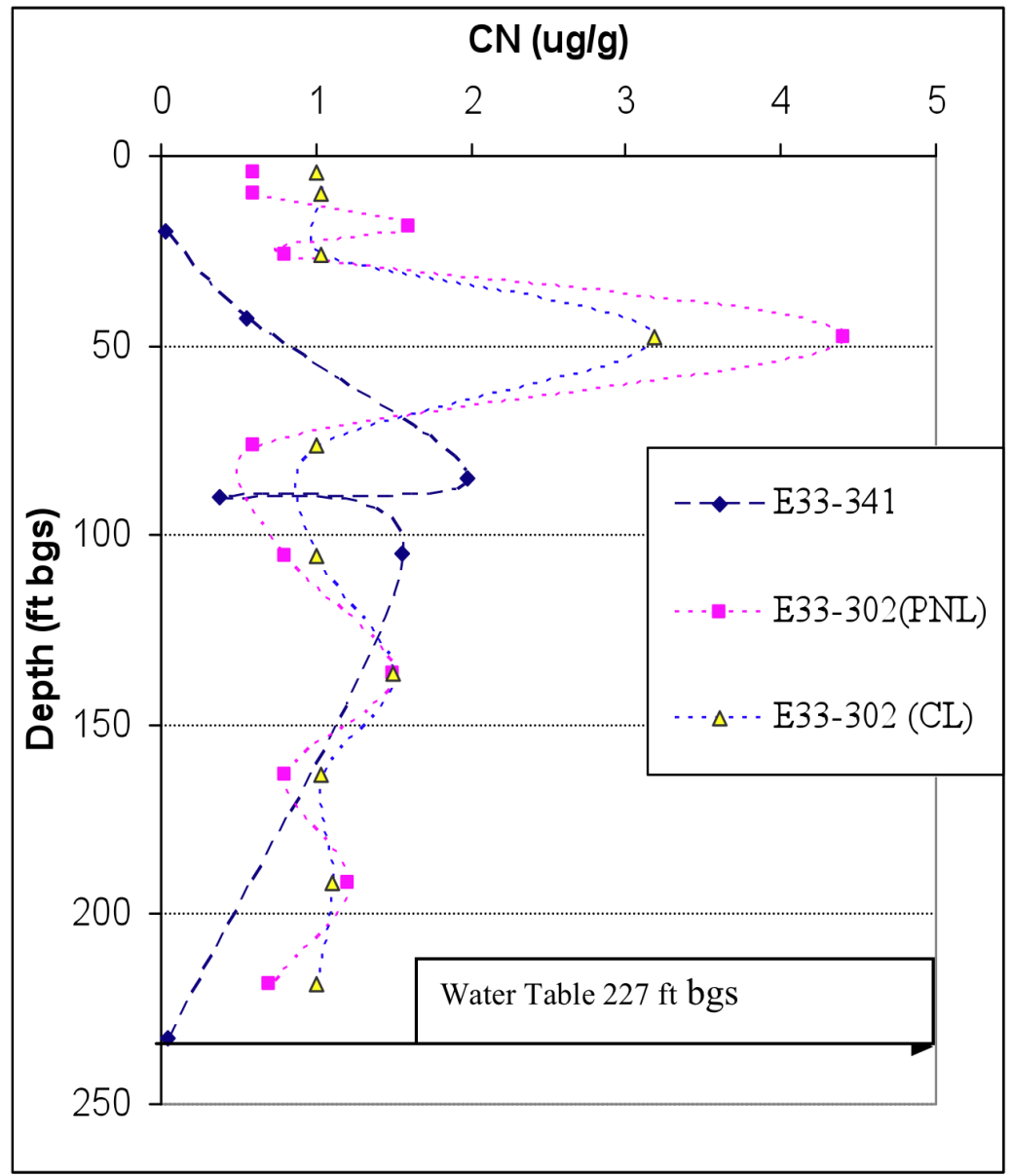

Figure 3.10. Cyanide in Sediments as a Function of Depth In and West of B-49 Crib Based on depth-discrete sediment analyses from the two available borehole. Both PNL and a contract laboratory analyzed sediment samples from borehole E33-302, and agreement was good.

The cobalt-60 activities in the sediments from 299-E33-302 (measured in 1993) and in 299-E33-341 (measured in 2008) were very low and not detectable, respectively. Given the long time period between the active disposal in the mid 1950s and the dates when sediments were collected and analyzed, it is not surprising that the cobalt- 60 had decayed to barely or not-detectable status. However, historical detailed spectral gamma logging found in DOE/GJO (2003) and summarized above concluded that lateral migration of cobalt- 60 appeared to be extensive in the BY cribs region in the past. Further, comparison of borehole logs acquired in 1992 and 2002 indicated continuing migration of cobalt-60 in the vadose zone in the area of the BY cribs' over this time period.

The water extract of only one shallow sediment sample (Figure 3.11), taken at about $20 \mathrm{ft}$ bgs from borehole 299-E33-341, shows mildly elevated uranium $(22.4 \mu \mathrm{g} / \mathrm{g})$ indicative of Hanford processed uranium. Sensitive and extremely precise uranium isotope ratios (see discussion later in Section 3.1.3) show that the uranium was irradiated natural fuel (not enriched in uranium-235), with uranium-236/238 and uranium-234/238 ratios different from the BX-102 tank overfill fluid's uranium signature (see Figure 1.4). 
PNNL-19277

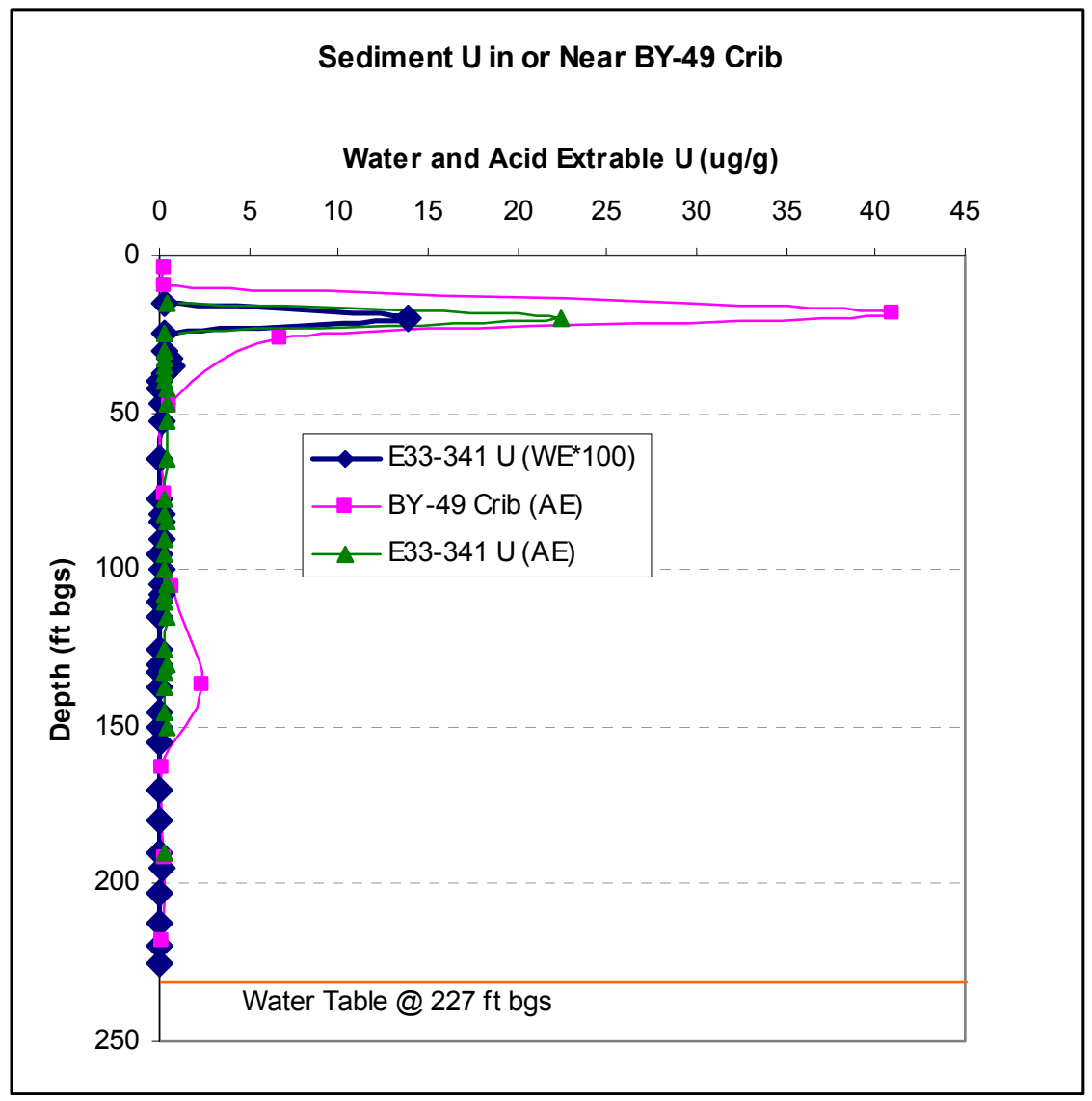

Figure 3.11. Water- and Acid Extractable Uranium in Sediments as a Function of Depth In and West of B-49 Crib

Based on depth-discrete sediment analyses from the two available boreholes.

Both the 299-E33-341 sediment acid extracts and water extracts (a proxy for pore-water analyses) suggest that uranium concentrations from $\sim 40 \mathrm{ft}$ bgs to the water table are similar to natural background levels. The acid extractable uranium in the sediment profile at 299-E33-302, right through the BY-49 Crib footprint shows elevated uranium at 18.5 and $26.25 \mathrm{ft}$ bgs $(41$ and $6.7 \mu \mathrm{g} / \mathrm{g})$ and perhaps an isolated mildly elevated value of $2.4 \mu \mathrm{g} / \mathrm{g}$ at $136 \mathrm{ft}$ bgs near the depth of the H2F3 fine grained layer.

Table 3.3 and Figure 3.12 through Figure 3.16 show the combined data sets for sediments from directly below the B-43 Crib (based on borehole 299-E33-296) and the sediments to the south at new borehole 299-E-33-342. The sediment data from borehole 299-E33-296, collected directly below the footprint of B-43 crib, show elevated concentrations of technetium-99, nitrate, sodium, and to a lesser extent cyanide in the deep vadose zone. One sediment sample from 299-E33-296 at $159 \mathrm{ft}$ bgs also appears to contain elevated sulfate. Quite likely, the elevated concentrations in the deep vadose zone sediments at 299-E33-296 are an indication that mobile contaminants in the waste fluids reached the water table in the past and are continuing to be a source today. The sediment concentrations deeper than $\sim 150 \mathrm{ft}$ bgs for technetium-99 and nitrate below B-43 are in the same range (but the average concentrations may be slightly lower) as those below B-49. The concentrations of cyanide and uranium deep and below B-43 are lower than those below B-49. The similar ranges would be expected given that the same waste type was disposed of to both cribs. However, B-49 received about three times the volume 
of waste as the B-43 crib (see Table 3.1) thus higher concentrations in the deep vadose zone below B-49 Crib reflects the larger volume disposed. The concentrations of these mobile constituents in the sediments at the new borehole, 299-E33-342, south of B-43 crib are much lower than those within the footprint of the crib and also lower than in the sediments from borehole 299-E33-341, which was drilled closer to the B-49 crib. The lower concentrations in the sediments at 299-E33-342 reflect that this well is placed more distant from the BY cribs, less waste volumes were disposed of, and less fluids likely spread to the location of 299-E33-342.

There are slight indications (see Figure 3.12) that technetium-99 has migrated into the deep vadose zone at 299-E33-342 to the thin fine-grained lens at $\sim 147 \mathrm{ft}$ bgs and again at the contact between the Hanford formation and $\mathrm{CCU}$ at $190 \mathrm{ft}$ bgs, although there was no obvious indication that the $\mathrm{CCU}_{Z}$ finegrained sediment exists at this borehole. Rather, the Hanford formation contacts directly with the $\mathrm{CCU}_{\mathrm{g}}$ unit at this location. Below the slightly elevated technetium-99 concentrations at $\sim 147$ and $190 \mathrm{ft}$ bgs, the sediments contain a few $\mathrm{pCi} / \mathrm{g}$ of technetium-99. These relatively low but measurable technetium-99 sediment concentrations are found in the deep vadose zone all the way to the water table.

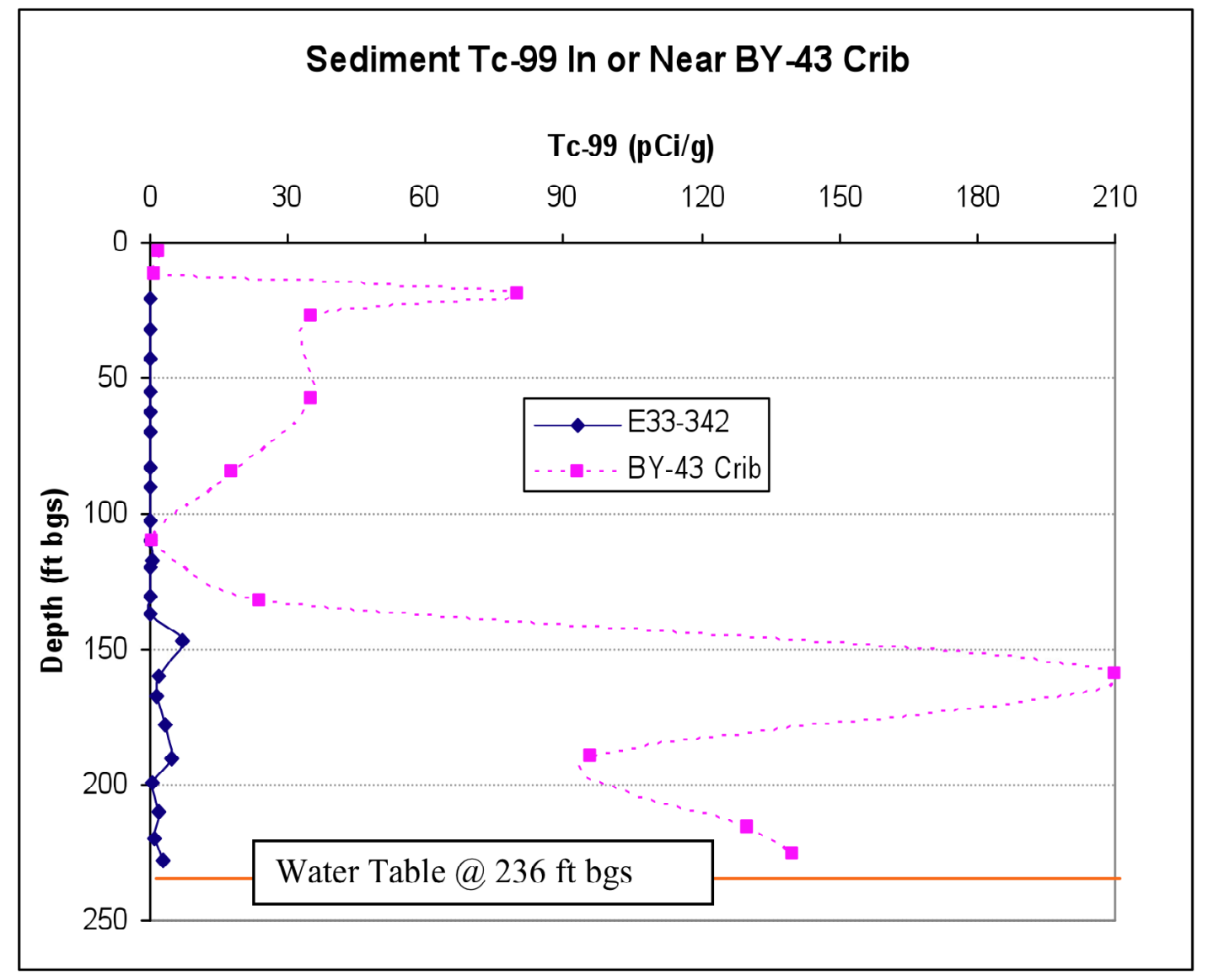

Figure 3.12. Technetium- 99 in the Sediments as a Function of Depth In and South of B- 43 Crib Based on depth-discrete sediment analyses from the two available boreholes. 


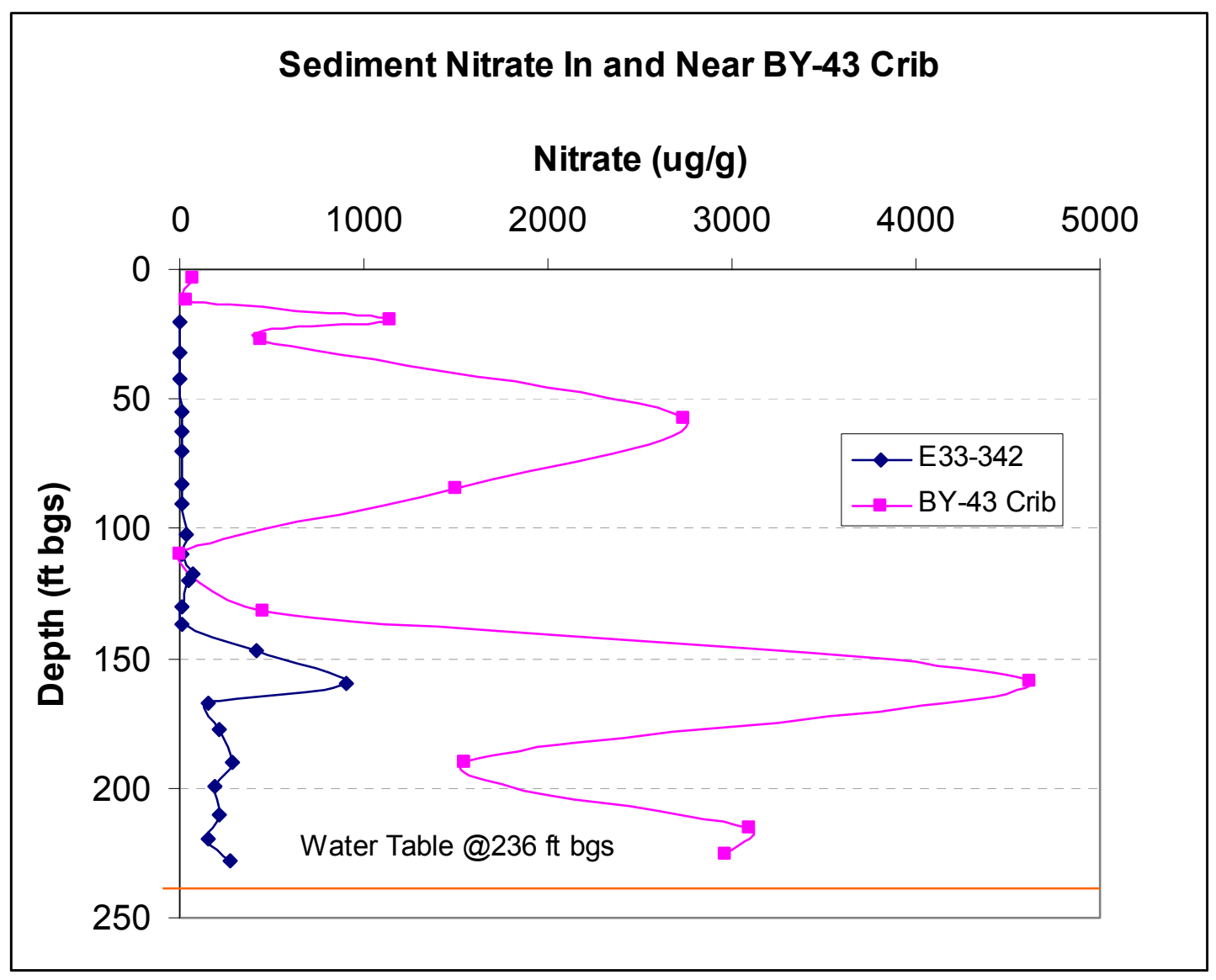

Figure 3.13. Nitrate in the Sediments as a Function of Depth In and South of B-43 Crib Based on depth-discrete sediment analyses from the two available boreholes. 
PNNL-19277

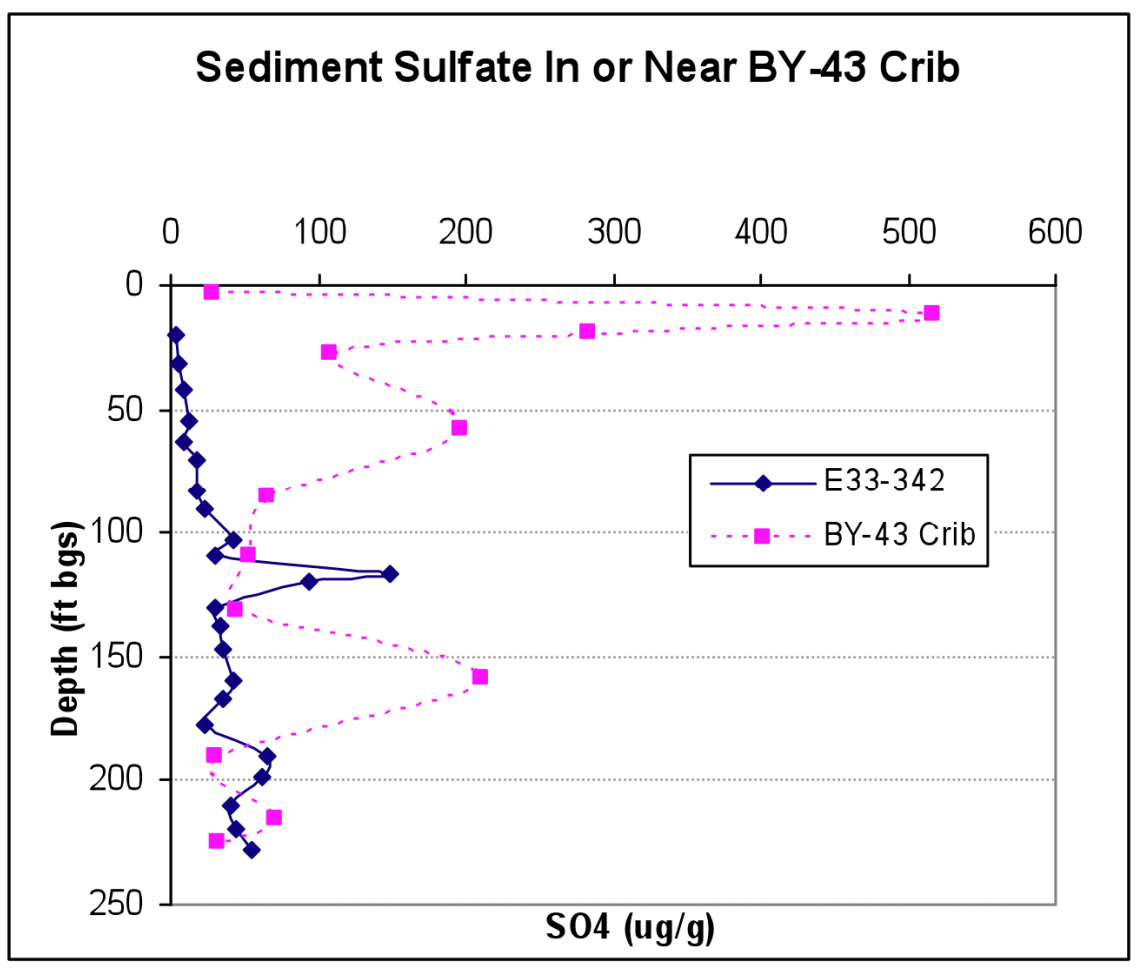

Figure 3.14. Sulfate in the Sediments as a Function of Depth in and South of B-43 Crib Based on depth-discrete sediment analyses from the two available boreholes.

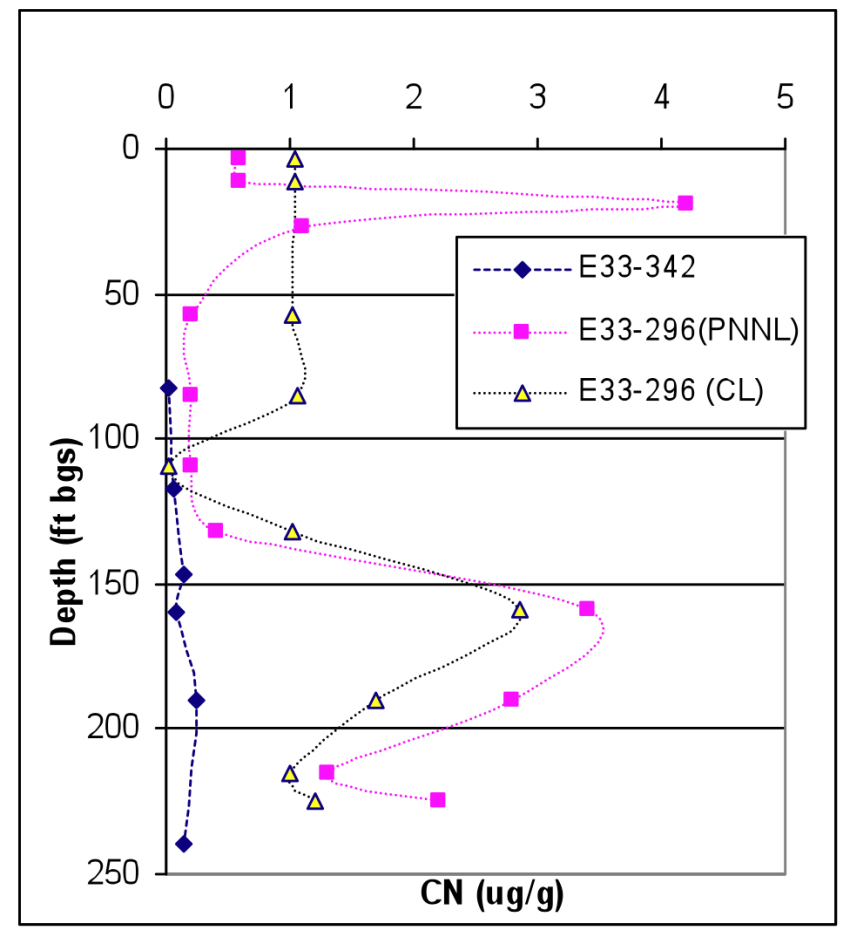

Figure 3.15. Cyanide in Sediments as a Function of Depth in and South of B-43 Crib Based on depth-discrete sediment analyses from the two available boreholes; $C L=$ contract lab. 


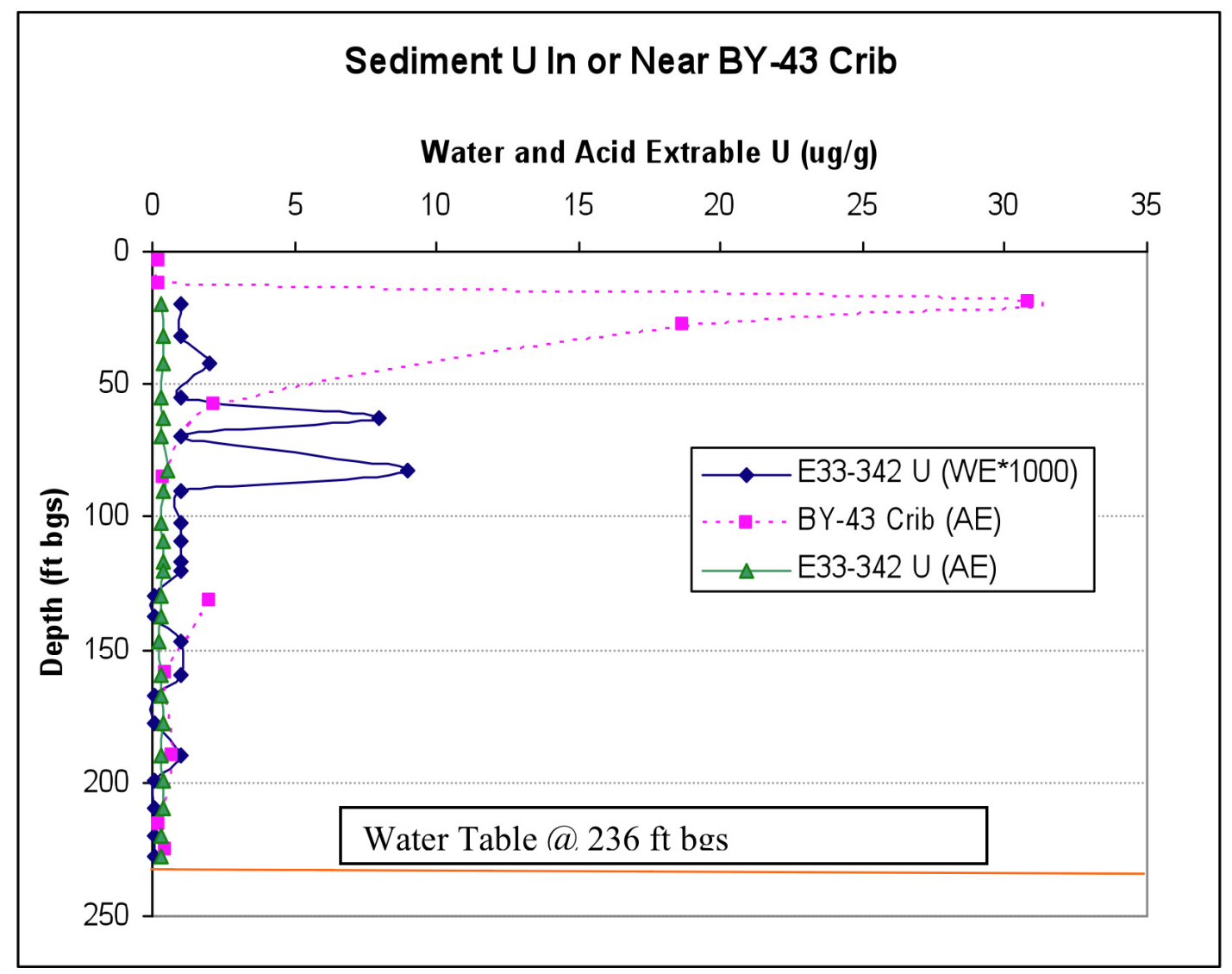

Figure 3.16. Water and Acid Extractable Uranium in the Sediments as a Function of Depth In and South of B-43 Crib

Based on depth-discrete sediment analyses from the two available boreholes.

The sediment nitrate data (see Figure 3.13) show a slightly different vertical distribution than the technetium-99 distribution at borehole 299-E33-342. The nitrate is most elevated in a sediment sample right above an apparent very localized fine-grained lens at $160 \mathrm{ft}$ bgs. The sediment nitrate elevated concentrations start at the very thin lens at $147 \mathrm{ft}$ (H2F3 lens) but increase to the peak at $160 \mathrm{ft}$ bgs. There is a second smaller peak in nitrate concentration at the contact between the Hanford formation and $\mathrm{CCU}$ at $190 \mathrm{ft}$ bgs. The peak nitrate concentrations range from 300 to $900 \mu \mathrm{g} / \mathrm{g}$ in the deep vadose zone at borehole 299-E33-342, which is about an order of magnitude lower than the nitrate concentrations found in sediments below the BY crib footprints, based on the assumption that the two available boreholes through the B-43 and B-49 cribs are representative of all the BY cribs that received the TBPscavenged waste. The fact that the technetium-99 and nitrate vertical distributions at borehole 299-E33342 are not as similar as usually found at other Hanford contamination sites is not currently understood.

The sulfate (see Figure 3.14) and cyanide (see Figure 3.15) sediment concentrations in borehole 299-E33-342 are significantly lower than found directly under the B-43 crib as would be expected for a borehole that is capturing only the leading edge of fluids that migrated laterally away from the majority of the fluids that likely migrated vertically down the crib excavation footprint. The only indication of wasteinduced sulfate in borehole 299-E33-342 sediments occurs between 117 and $120 \mathrm{ft}$ bgs, which has been 
identified as the regionally extensive H2F2 fine-grained lens. The rest of the sulfate profile in the Hanford formation may reflect natural background sulfate. There is a slight secondary peak of sulfate $(\sim 65 \mu \mathrm{g} / \mathrm{g}$ ) down near 190 to $199 \mathrm{ft}$ bgs in the top of the Cold Creek gravel-dominated unit that might reflect deep and lateral migration of waste fluids from the BY cribs; however, water extractable sulfate is often higher in Cold Creek sediments than Hanford formation sediments and these values are within the sulfate range for uncontaminated sediments (DOE/RL 1995).

The cyanide concentrations in the sediments at borehole $299-\mathrm{E} 33-342$ are no greater than $0.24 \mu \mathrm{g} / \mathrm{g}$, which is very close to the quantification limit for the analysis. There was no measurable cobalt-60 in the sediments from 299-E33-342 and very low cobalt-60 in the entire sediment profile below B-43 when measured in 1993, a reflection of the radioactive decay of this relatively short-lived nuclide to low levels since active disposal in the mid 1950s.

The acid-extractable uranium content in the sediment below the B-43 crib footprint is significantly elevated above natural background only in the zone between 19 and $27 \mathrm{ft}$ bgs (see Table 3.3 bolded values and Figure 3.16). The acid-extractable and water-extractable uranium concentrations in sediments from borehole 299-E33-342 are very low and not significantly elevated above natural background values. The total water-extractable uranium in sediments from borehole 299-E33-342 is barely elevated at only a few discrete depths (62 and $82 \mathrm{ft}$ bgs). These sediments also show elevated $\mathrm{pH}$ values, which suggest waste fluid influences, compared to uncontaminated sediments in the Hanford formation. However, highly sensitive and precise $U$ isotopic signature measurements on one of the slightly elevated uranium water extracts from 299-E33-342 are barely distinguishable from natural (uncontaminated) uranium waters. The slight hint of the anthropomorphic uranium-236 isotope appears to be contamination from sample preparations in the PNNL laboratory. Hundreds of highly uranium-contaminated sediments have been processed over the last 10 years in the PNNL laboratory. It would require clean-room techniques or processing the very low-level uranium-bearing sediments in another facility to make sure that there is no possibility of slight inadvertent cross contamination.

In summary, the vadose zone sediments below and proximal to the BY cribs still contain elevated concentrations of technetium-99, nitrate, sulfate, and cyanide deep in the vadose zone as well as shallower in or right above thin fine-grained layers in the Hanford $\mathrm{H} 2$ unit. There are indications of lateral spreading and residual elevated concentrations of mobile contaminants in the deep vadose zone sediments based on the direct measurement of mobile contaminants in the two new boreholes near B-43 and -49 . Extensive lateral spreading is also confirmed by the spectral gamma logging activities that show cobalt- 60 lateral migration over several hundred feet. Although uranium is present in the groundwater beneath the BY cribs, it does not appear to be associated with waste fluids disposed of to the BY cribs. This conclusion is based on the lack of significantly elevated sediment uranium concentrations in the sediments from the four deep boreholes below and adjacent to the BY cribs footprints at depths deeper than $40 \mathrm{ft}$ bgs. The lack of mobile uranium deep in the vadose zone below the BY Cribs region is strongly supported by the water extractable uranium concentrations in boreholes 299-E33-341 and 299E33-342.

However, the areal coverage of information to allow a good mass balance of the residual mass of the mobile constituents in the vadose zone below the BY Cribs region is rather sparse. Therefore, residual vadose zone mass balances estimates will only be performed for technetium-99 and uranium in the final subsection 3.1.9. 
PNNL-19277

\subsubsection{Uranium Isotopic Ratio Results for BY Cribs Vadose Zone Sediments}

Additional information that is available to interpret the vadose zone sediment distribution of contaminants below and proximal to the B-7-A crib is the precise uranium isotopic ratio measurements on vadose zone sediment water extracts and the direct measurement of the perched water sample. Appendix E lists all the available uranium isotopic ratio data collected, identifies which samples represent the various waste sources and which samples were used to create the clean end members for vadose zone pore waters and groundwater.

There were only two sediment-water extracts from the two new boreholes (299-E33-341 and 299E33-342) that contained adequate masses of total uranium to yield accurate and precise uranium isotopic measurements. The sample from the 20-ft bgs depth in borehole 299-E33-341 contained elevated water and acid-extractable uranium at values of 0.131 and $22.4 \mu \mathrm{g} \mathrm{U} / \mathrm{g}$ of sediment, respectively. The depth of this sample is very close to the bottom of the excavation in which the BY Cribs were constructed, and it is assumed that the fluids released to the BY cribs would have spread horizontally along the base of the excavation after release into the concrete culverts and gravel base. This sediment and water-extract sample has been used to create the unique uranium isotopic signature to represent the scavenged waste stream disposed of to seven of the eight BY cribs. The data point is shown on Figure 1.4. As discussed in Section 1.7, the BY crib waste uranium isotope signature is distinct from the signatures for the other BComplex sources for which samples have been obtained, (the BX-102, B-110, and B-7A crib sources) and analyzed. Further, the BC-Crib (far to the south outside the B-Complex) source uranium signature is most similar to the BY crib uranium signature as might be expected based on these two crib sites having received the same waste stream. The slight differences might reflect a combination of small differences in the uranium fuel that was processed over time and the slight differences in vadose zone sediment weathering and infiltration rates.

The only other vadose zone sediment water extract that was processed was from borehole 299-E33341 from $35 \mathrm{ft} \mathrm{bgs.} \mathrm{The} \mathrm{water} \mathrm{extract} \mathrm{for} \mathrm{this} \mathrm{sample} \mathrm{had} \mathrm{an} \mathrm{elevated} \mathrm{pH}$, a slight hint of elevated nitrate, sulfate, and technetium-99, and a uranium concentration of $6.8 \mathrm{E}-03 \mu \mathrm{g} \mathrm{U} / \mathrm{g}$. The acid extractable uranium concentration was $0.345 \mu \mathrm{g} \mathrm{U} / \mathrm{g}$, indistinguishable from background. The uranium isotopic-signature measurements were indistinguishable from the uranium ratios for uncontaminated Hanford formation sediments, so this datum was added to other data points used to generate the clean $\mathrm{H} 2$ end member signature that is shown on figures to be discussed in other subregion subsections discussing results of uranium isotope signatures. As shown in Table 3.3, none of the water extracts or acid extracts contained elevated uranium concentrations to warrant accurate and precise uranium isotopic ratios to be performed in search of Hanford-processed uranium from BY Crib waste streams. groundwater samples from both new boreholes did contain elevated total uranium concentrations, and the results of uranium isotopic signature measurements will be discussed in Section 5.7.

\subsubsection{B-57 Crib Facilities and Inventory Released}

The B-57 Crib is located west of the southernmost BY Cribs (see Figure 3.1) and received wastes from the In Tank Solidification Unit \#2 (ITS \#2) and the BY Tank Farm activities. It received liquid wastes from 1968 to 1973 . The total volume of liquid disposed of is estimated at 84.3 million liters in SIM, Rev. 1 (Corbin et al. 2005) and 84.4 million liters in WIDS and Stenner et al. (1988) as shown in the bottom of Table 3.1. The original bottom dimensions of the crib were 61 meters ( $200 \mathrm{ft})$ by 4.5 meters $(15 \mathrm{ft})$ and 3 meters $(10 \mathrm{ft})$ deep. During construction, the crib was filled with gravel to 1.2 meters $(4 \mathrm{ft})$ 
above the bottom (approximately 474 cubic meters [620 cubic yards]). A perforated, 30.5 -cm (12-in.) corrugated pipe runs the length of the crib. This crib has been covered with the Hanford Prototype Barrier since 1994. The barrier is 105 meters (340 ft) long, 64 meters (210 ft) wide, and 15 meters (49 ft) tall. Details on the years of operation, types of waste disposed of, and total volumes disposed of are found in Table 3.1 .

\subsubsection{B-57 Crib Vadose Zone}

Three shallow boreholes were drilled from ground surface to $\sim 30 \mathrm{ft} \mathrm{bgs} \mathrm{in} \mathrm{the} \mathrm{B-57} \mathrm{crib} \mathrm{as} \mathrm{part} \mathrm{of} \mathrm{the}$ investigation detailed in DOE/RL (1993a). One of the boreholes, with the highest shallow gamma activity, was continued down to $\sim 230 \mathrm{ft}$ bgs. Selected sediments from the two shallow boreholes and the deep borehole were analyzed for selected chemicals and radionuclides. In general, only total concentrations in the sediments were sought, and aside from the fact that anions are extracted using a water leach, the other constituent's data are not readily useable to predict future mobility of contaminants subjected to recharge water mobilization, because they were determined using a strong acid extraction. There were no new boreholes emplaced proximal to the B-57 trench during the recent 200-BP-5 field activities because the inventory of wastes disposed of to the facility was relatively small compared to the eight BY cribs. Further, the crib has been covered with a surface barrier designed to reduce infiltration since 1994. Thus, it is unlikely that B-57 is a significant current contributor to groundwater plumes except for tritium and possibly small amounts of nitrate and Tc-99 which are indistinguishable from contributions associated with the BY Cribs.

The results of the chemical analyses on the sediments for the borehole through the footprint of B-57 are found in Table 3.4. As can be seen with comparison to data in Table 3.2 and Table 3.3, the concentrations in deep vadose zone sediments from B-57 are much lower. There was no cyanide or significantly elevated uranium concentrations observed in any of the sediments analyzed. Technetium-99 at concentrations of 60 and $160 \mathrm{pCi} / \mathrm{g}$ were found at depths of $\sim 31$ and $57 \mathrm{ft} \mathrm{bgs}$, suggesting either that this mobile contaminant descended $\sim 30 \mathrm{ft}$ below the crib bottom. Note that the barrier was installed before the sampling event so the bottom of the crib now is much deeper than when originally constructed. "The B-57 Crib site has a Hanford barrier that is up to $7.9 \mathrm{~m}$ (26-ft) thick that was constructed as noted in DOE/RL 2003 (p. 2-63). "The B-57 Crib site has a Hanford barrier that is up to $7.9 \mathrm{~m}$ (26-ft) thick that was constructed as a treatability test to gain information on the cost and performance of the barrier".

A summary of the gamma logging results from boreholes within and around B-57 crib, DOE/GJO (2003), follows. The B-57 Crib exhibits cesium-137 contamination down to a maximum elevation of 550 $\mathrm{ft}$ (90-ft $\log$ depth) in the southern portion of the crib near the influent point of the waste stream. The waste stream, ITS condensate, is much different than the uranium recovery/scavenged waste disposed of in the BY Cribs. Soil sample analytical results indicate that the contaminants plutonium-239/240, strontium-90, technetium-99, total uranium, and tritium are either nonexistent or at very low levels relative to the BY Cribs. Breakthrough of contaminants to the groundwater is not indicated by historical or current gamma measurements. However, soil sample analytical results available from the one deep borehole in the crib indicate tritium and technetium- 99 at concentrations less than $1 \mathrm{pCi} / \mathrm{g}$ just above the depth of the current groundwater level. Cobalt-60 and cesium-137 contamination, not continuously detected throughout the vadose zone, is also identified just above and within the groundwater. This contamination is believed to be residual from contaminated groundwater that invaded this area during the disposal of waste in the B-43 to -49 cribs in 1955 and that interacted over time with corrosion products formed on the carbon steel casings of the deep vadose zone well. 
Table 3.4. Vadose Zone Sediment Extract Data for Borehole 299-E33-304 In the Footprint of B-57 Crib

\begin{tabular}{ccccccccccc}
\hline Sample ID & $\begin{array}{c}\text { Depth } \\
(\mathrm{ft} \mathrm{bgs})\end{array}$ & $\begin{array}{c}\mathrm{Na} \\
\mu \mathrm{g} / \mathrm{g}\end{array}$ & $\begin{array}{c}\text { Cyanide } \\
\mu \mathrm{g} / \mathrm{g}\end{array}$ & $\begin{array}{c}\text { Cyanide (PNL) } \\
\mu \mathrm{g} / \mathrm{g}\end{array}$ & $\begin{array}{c}\mathrm{F} \\
\mu \mathrm{g} / \mathrm{g}\end{array}$ & $\begin{array}{c}\text { Nitrate } \\
\mu \mathrm{g} / \mathrm{g}\end{array}$ & $\begin{array}{c}\text { Nitrite } \\
\mu \mathrm{g} / \mathrm{g}\end{array}$ & $\begin{array}{c}\text { Sulfate } \\
\mu \mathrm{g} / \mathrm{g}\end{array}$ & $\begin{array}{c}\text { Tc-99 } \\
\mathrm{pCi} / \mathrm{g}\end{array}$ & $\begin{array}{c}\mathrm{U} \\
\mu \mathrm{g} / \mathrm{g}\end{array}$ \\
\hline B00X37 & 2.25 & $<105$ & $<0.52$ & $<0.6$ & $\mathrm{NA}$ & 5.3 & $<1.2$ & NA & NA & NA \\
B00X57 & 8.75 & 117 & $<0.52$ & $<0.6$ & NA & NA & NA & NA & NA & 1.05 \\
B00X61 & 16.25 & $<216$ & $<0.52$ & $<0.6$ & NA & 125 & 8.3 & NA & NA & $<0.4$ \\
B00X59 & 27.75 & 90 & $<1.03$ & $<0.6$ & NA & 4.7 & $<1.3$ & NA & NA & $<1$ \\
BD0X77 & 31.5 & 113 & NA & 1 & NA & 23.6 & $<1.0$ & 23.6 & 60 & $<0.7$ \\
B00X65 & 56.75 & 85.1 & $<1.02$ & $<1$ & NA & 1190 & NA & 3.9 & 160 & $<0.5$ \\
B00X71 & 83.25 & 71.3 & $<1.03$ & $<0.6$ & NA & 206 & NA & 6 & NA & $<0.4$ \\
B00X73 & 110.75 & 105 & $<1.02$ & $<0.6$ & NA & 13.8 & NA & $<1.3$ & $<0.09$ & $<0.5$ \\
B00X89 & 140.25 & 68.2 & $<1.02$ & $<0.6$ & NA & 31.7 & NA & $<1.5$ & 0.69 & $<0.2$ \\
B00X91 & 167.75 & 90.4 & $<1.03$ & $<0.6$ & NA & 47.2 & NA & 9.4 & $<0.6$ & 0.4 \\
B00X93 & 196.25 & 105 & $<1.03$ & $<0.6$ & NA & 19.5 & NA & 10.7 & $<0.1$ & $<0.5$ \\
B00X65 & 226.25 & 198 & $<1.02$ & $<0.6$ & NA & 22 & NA & 26.2 & $<0.1$ & $<5$ \\
B00X97 & 234.25 & 212 & $<1.06$ & $<0.6$ & NA & 15.5 & NA & 23.8 & 0.32 & $<0.5$ \\
\hline NA= not analyzed & & & & & & & \\
\hline
\end{tabular}

Based on the inventory estimates for the B-57 Crib, shown in Table 3.1, and the fact that sediments under the -B-57 Crib footprint do not contain cyanide, contain only minor amounts of uranium and only about $0.1 \%$ of the total technetium-99 mass in the BY crib region, the authors agree with the gamma logging conclusion that this facility has not contaminated groundwater. It is also unlikely that the B-57 Crib will be a significant contributor to groundwater contamination in the future because it has a surface barrier in place, and mobile contaminants do not appear to have descended more than $\sim 60 \mathrm{ft}$ below the ground surface.

\subsubsection{BY-201 Settling Tank Facility and Source}

The BY-201 Settling Tank is located north of the BY Tank Farm and south of the B-43 and B-47 cribs (see Figure 3.1). It is south of $12^{\text {th }}$ Street and west of Baltimore Ave. The tank is a rectangular, reinforced concrete disposal structure with dimensions $12.6 \mathrm{~m}(41.33 \mathrm{ft})$ long by $1.9 \mathrm{~m}(6.33 \mathrm{ft})$ wide by $2.8 \mathrm{~m}(9.1 \mathrm{ft})$ tall. The top of the concrete structure is $\sim 1.5 \mathrm{~m}(5 \mathrm{ft})$ bgs. This tank received waste from the BY Tank Farm. The unit was designed to settle and collect the uranium recovery waste and discharge the supernatant to the B-43 through B-49 cribs. The B-50 Crib supposedly was the only BY Crib that did not receive uranium recovery waste via the BY-201 Tank.

Drawing H-2-2604 shows a vent pipe $15 \mathrm{~cm}$ (6 in.) in diameter by 2.7 meters ( $9 \mathrm{ft}$ ) long that extends from the top of the tank to 1.2 meters $(4 \mathrm{ft}$ ) above grade. A manhole is located at each end of the tank. A 10-cm (4-in.) diameter pipe from the B and BY Tank Farms enters near the top of the tank. A "Miller Siphon" is located at the bottom of the tank, and it drains Tank BX-102 through a 35-cm (14-in.) line to the B-43 through B-49 cribs. An overflow pipe was also connected to this line.

On September 15, 1955, approximately 41,635 L (11,000 gal) of supernate waste overflowed from the BY-201 Settling Tank, bubbled to the surface, and spread towards the B-43 crib. Most of the contamination was pushed into a shallow area southeast of the B-43 crib and was covered with 0.6 meters $(2 \mathrm{ft})$ of clean sediment. The contamination left near the settling tank was covered with 3 meters $(10 \mathrm{ft})$ 
of clean soil. Details on the settling tank's operational history, types of waste transferred into and out of the tank, and tank dimensions are found in Table 3.1. In 1991, a large Surface Contamination Area (UPR-200-E-89), located north of BY Tank Farm, was stabilized. The stabilization activity scraped most of the contaminated soil on top of the B-43 through B-50 cribs and then covered the cribs with clean sediment. The area was re-posted as Underground Radioactive Material.

Most of the contamination was pushed into a shallow area southeast of the B-43 crib and was covered with 0.6 meters $(2 \mathrm{ft})$ of clean sediment. The contamination left near the settling tank was covered with 3 meters (10 ft) of clean soil. Details on the settling tank's operational history, types of waste transferred into and out of the tanks, and tank dimensions are found in Table 3.1. In 1991, a large Surface Contamination Area (UPR-200-E-89), located north of BY tank farm, was stabilized. The stabilization activity scraped most of the contaminated soil on top of the B-43 through B-50 Cribs and then covered the cribs with clean sediment. The area was re-posted as Underground Radioactive Material.

\subsubsection{BY-201 Settling Tank Vadose Zone}

There have been no direct measurements performed on sediments proximal to this tank, but as shown in Table 3.1, the volume of waste spilled from the tank and its inventory is small compared to the eight nearby BY Cribs. Spectral gamma logging results in the BY crib region found the following. Borehole 299-E33-22, located approximately $16 \mathrm{ft}$ south of the B-45 crib, showed relatively high cesium-137 concentrations between elevations 625 and $611 \mathrm{ft}, 8$ to $10 \mathrm{ft}$ shallower than the cribs bottom. This contamination may have been placed at this location from removal of contaminated soil from the spill from the BY-201 Flush Tank. However, there are no boreholes in close proximity to BY-201, and the impact of this site cannot be completely evaluated. However, it seems reasonable to dismiss this facility as a significant contributor to past and future groundwater contamination based on its low volume released and the fact that the contamination appears to have remained near the ground surface where it was scraped up and placed over the tops of the already contaminated cribs.

No further consideration was given to these two facilities as potential contributors to groundwater contamination below the B-Complex because the volumes and masses of waste disposed of and the masses of key contaminants were very low at both the B-57 Crib and the BY-201 Settling Tank. Also, the sediment samples from the borehole through the B-57 Crib footprint showed no deep vadose zone contamination.

\subsubsection{BY Crib Vadose Zone Conceptual Model}

The volumes of liquid waste, the mass of contaminants disposed of, and the direct measurements of sediment samples for the BY Crib subregion indicate the eight BY Cribs (B-43 through B-50) have and continue to impact the groundwater. Contrarily, there is no evidence of contamination deep below the BY-201 Settling Tank or the B-61 Crib. Lastly, although there are no significantly elevated concentrations of contaminants in the deep vadose zone at the B-57 Crib, it is difficult to determine if infiltration maybe occurring from this site based on the vadose zone data alone. The groundwater data below the BY Crib subregion suggest that tritium is infiltrating from this source, however, technetium-99 and nitrate contributions if any are masked by their more dominant infiltration associated with the BY Cribs. Thus, the only facility within the BY Cribs sub region warranting further discussion is the BY Cribs themselves. 
Based on the direct measurement of the vertical distribution of key constituents in the vadose zone sediment from the four boreholes that were drilled down to the water table, the spectral gamma logging information for cobalt-60, and the qualitative field electrical resistivity data, the following vadose zone conceptual model was developed for the BY Cribs subregion.

Based on the vadose zone sediment distribution of mobile constituents in the four boreholes discussed, there must have been a strong vertical component to vadose zone liquid flow with some fluid being diverted horizontally along/within the fine-grained lenses in the Hanford formation and at the Hanford formation-CCU contact. Cross sections, which rely on the four boreholes, showing the stratigraphy and the vertical distribution of key contaminants are shown in Figure 3.17 through Figure 3.20 for technetium-99, nitrate, total uranium, and water-extractable uranium, respectively.

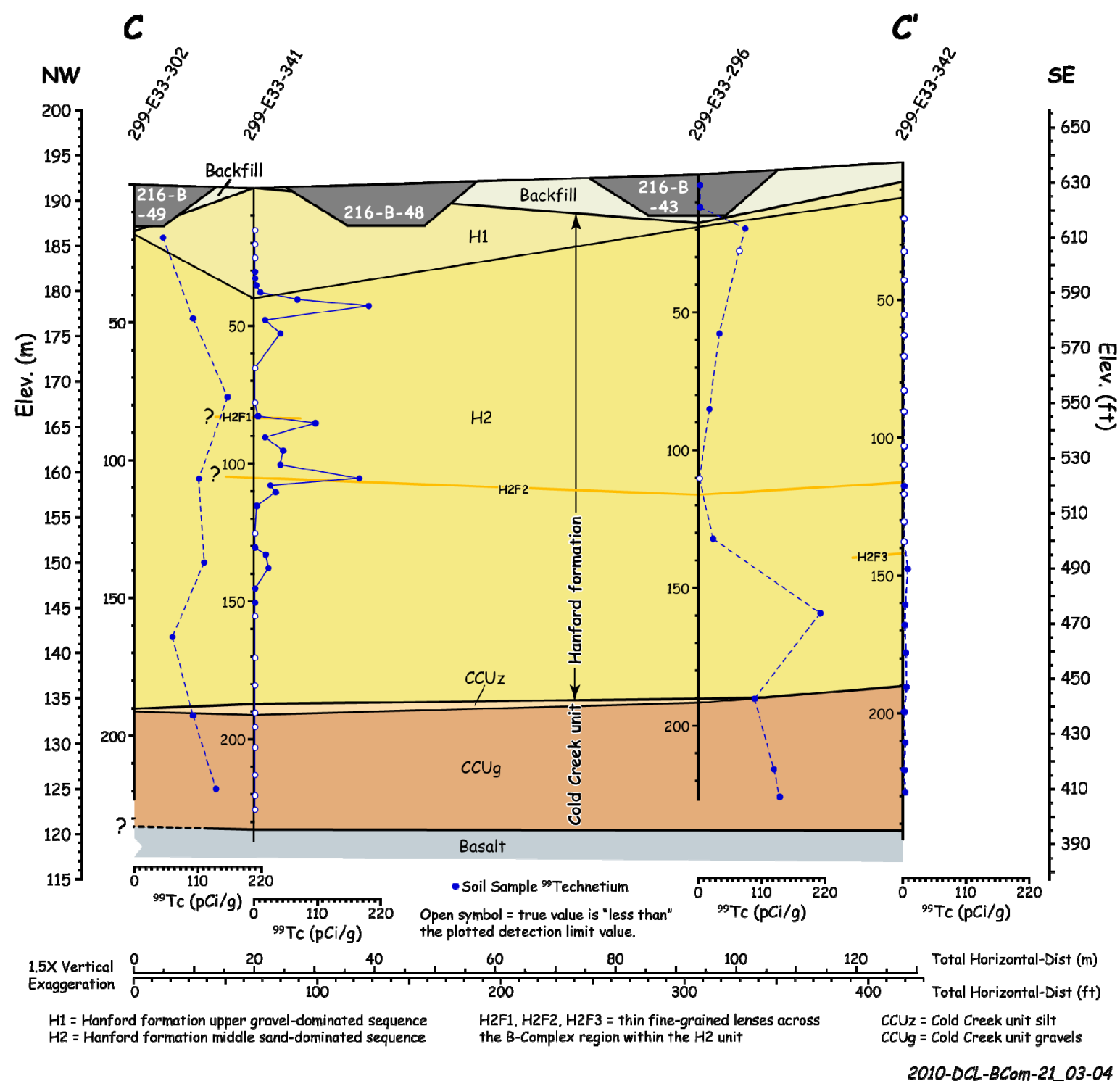

Figure 3.17. BY Crib Stratigraphy and Technetium- 99 in Sediments as a Function of Depth Cross-Section

Based on depth-discrete sediment analyses from the four boreholes 
PNNL-19277

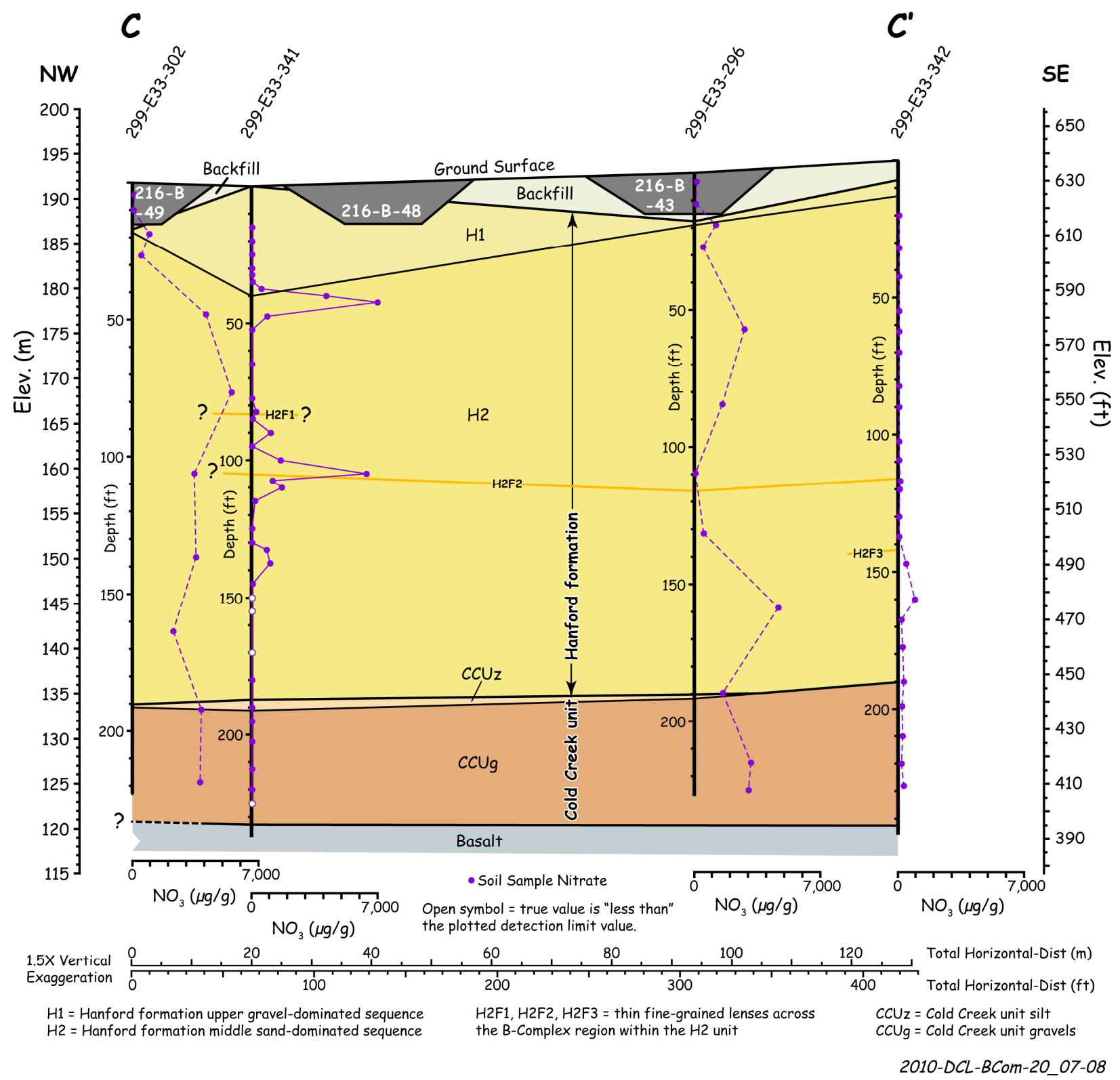

Figure 3.18. BY Crib Stratigraphy and Nitrate in Sediments as a Function of Depth Cross-Section Based on depth-discrete sediment analyses from the four boreholes 
PNNL-19277

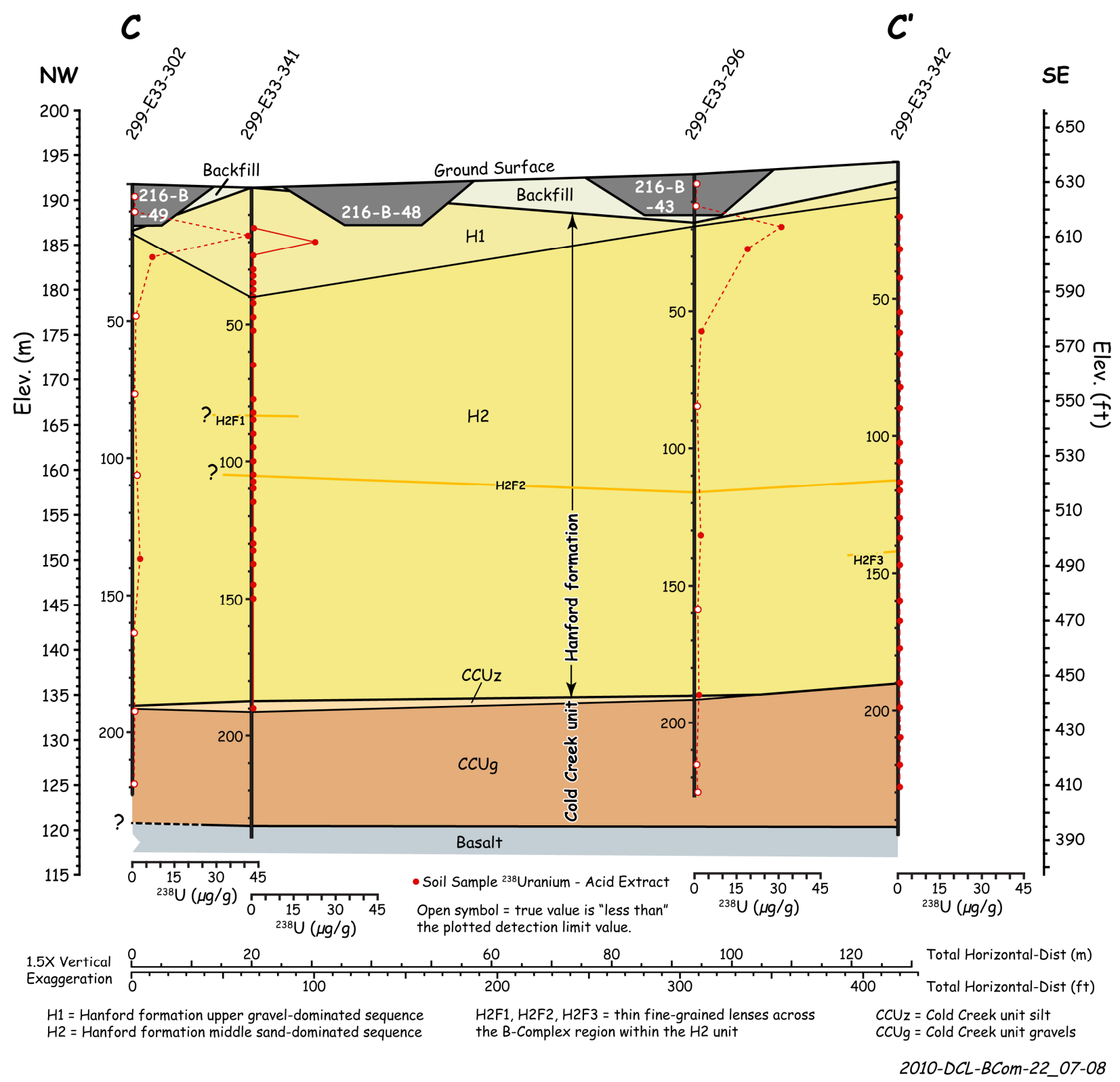

Figure 3.19. BY Crib Stratigraphy and Total Uranium in Sediments as a Function of Depth CrossSection

Based on depth-discrete sediment analyses from the four boreholes 


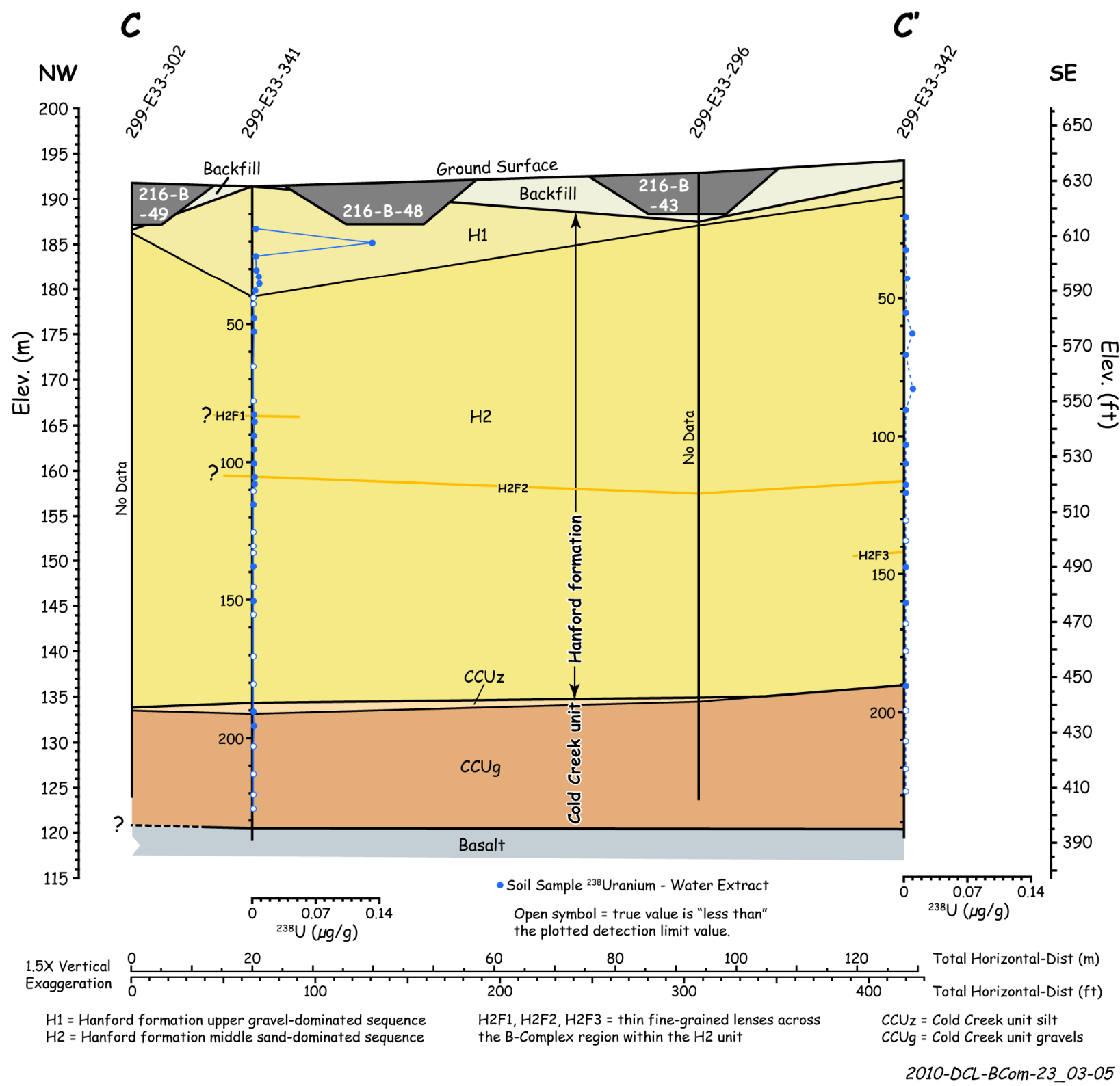

Figure 3.20. BY Crib Stratigraphy and Water Extractable Uranium in Sediments as a Function of Depth Cross-Section

Based on depth-discrete sediment analyses from the four boreholes

The spectral gamma field logs also suggest that the highest concentrations of cobalt-60 are found right below the crib footprints but that low concentrations of cobalt- 60 have spread laterally (see Figure 3.3) throughout the contiguous area represented by the fence-line (dotted rectangle in Figure 3.1). The direct sediment measurements and field logs also suggest that mobile contaminants have reached the water table, but that considerable concentrations of mobile contaminants still reside in the deep vadose zone sediments. The inverted field electrical resistivity data also imply deep penetration of high conductivity fluids and horizontal spreading to the northeast well beyond the BY Crib "fence line" as 
depicted in Figure 3.6. Further, comparison of borehole logs acquired in 1992 and 2002 indicated continuing migration of cobalt-60 in the vadose zone in the area of the BY cribs over this time period. By analogy, it is hypothesized that other mobile contaminants (e.g., technetium-99, nitrate, cyanide, sulfate, etc.) in the deep vadose zone below the BY cribs continue to migrate towards the water table.

The diminished concentrations of mobile constituents found in the sediments at 299-E33-342 in relation to those in borehole 299-E33-341 and those below the BY crib footprints also imply that less waste fluids have reached borehole 299-E33-342 along these horizontal spreading planes than have reached the sediments at 299-E33-341. This is understandable considering that borehole 299-E33-341 is closer to BY crib footprints than borehole 299-E33-342 by about $40 \mathrm{ft}$. Further, the volumes of fluids disposed of to the two cribs nearest to each of the boreholes (299-E33-341 and 299-E33-342) were 10.7 vs. 5.8 mega-liters, respectively. Therefore, the greater distance and lower disposal volumes to the cribs closest to the 299-E33-342 borehole explain the lower vadose zone concentrations for mobile contaminants in the vertical profile. At borehole 299-E33-342, the first sign of horizontal spreading occurred deeper in the profile than at borehole 299-E33-341. The deeper occurrence of the first sign of horizontal spreading at borehole 299-E33-342 (i.e., $~ 147 \mathrm{ft} \mathrm{bgs)} \mathrm{appears} \mathrm{to} \mathrm{be} \mathrm{associated} \mathrm{with} \mathrm{the} \mathrm{fact} \mathrm{that}$ there are no shallow ( $<100 \mathrm{ft}$ bgs) thin fine-grained layers at 299-E33-342 in comparison to 299-E33-341 and 299-E33-296, where shallow thin fine grained layers were observed. Because the fine-grained layers of lenses are intermittent and very localized in areal extent, the depth at which the BY Crib wastes are intercepted at boreholes drilled away from the crib footprints can be quite variable. However, as the waste fluids reached the finer grained sediment layers lateral spreading of contaminants is observed in all four boreholes. Because the sediment concentrations of mobile contaminants at 299-E33-342 were significantly less than at 299-E33-341, the waste volume disposed to cribs near 299-E33-342 was also less and the vadose zone strata all dip towards the northeast, it appears that the leading edge of the lateral spreading did not extend significantly beyond 299-E33-342, which is up dip from the location where wastes were disposed. The soil electrical resistivity results indicate that high conductivity fluids are contiguous throughout most of the area represented by the fence-line (dotted rectangle in Figure 3.1) but dissipating near the location of 299-E33-342. Also spectral gamma field logs suggest that the highest concentrations of cobalt- 60 are found right below the crib footprints but that low concentrations of cobalt-60 have spread laterally (see Figure 3.3) throughout the area represented by the fence-line (dotted rectangle in Figure 3.1). The direct sediment measurements and field logs also suggest that mobile contaminants have reached the water table and that considerable concentrations of mobile contaminants still reside in the deep vadose zone sediments. The inverted field electrical resistivity data also imply deep penetration of high conductivity fluids and horizontal spreading to the northeast well beyond the BY Crib "fence line" as depicted in Figure 3.6. Further, comparison of borehole logs acquired in 1992 and 2002 indicated continuing migration of cobalt-60 in the vadose zone in the area of the BY cribs over this time period. By analogy, it is hypothesized that other mobile contaminants (e.g., technetium-99, nitrate, cyanide, sulfate, etc.) in the deep vadose zone below the BY cribs continue to migrate towards the water table.

It is therefore concluded that the deep vadose zone sediments below the contiguous BY cribs "fence line" area contain relatively high concentrations of nitrate, sulfate, cyanide, technetium-99, sodium, and perhaps other constituents. The deep vadose zone below the BY cribs is contributing technetium-99, nitrate, cyanide, and perhaps sulfate to the water table as corroborated by groundwater trend plots found in Section 5. A further observation is that the cyanide sediment concentrations are approximately three orders of magnitude lower than those for nitrate (cyanide $\sim$ a few $\mu \mathrm{g} / \mathrm{g}$ and nitrate $\sim 3000 \mu \mathrm{g} / \mathrm{g}$ ). 
Currently, cyanide groundwater concentrations beneath the BY cribs are also approximately three orders less than the nitrate concentrations. Therefore, it is concluded that the cyanide currently and previously reported in the groundwater plume in the B Complex is from the BY cribs based on the inventory disposed of, the presence of cyanide and nitrate in the vadose zone at relatively the same ratios as found in the groundwater plume, and the significant groundwater presence of cyanide beneath the BY cribs.

However, the uranium disposed of to the BY cribs is not as mobile as technetium-99, nitrate, sulfate, or cyanide. The only significantly elevated uranium concentrations are found shallow in the BY crib footprint profiles near the crib bottoms. In the boreholes outside the crib footprints in the sediments in the upper $50 \mathrm{ft}$, there may be some slightly elevated water extractable uranium above the range found in uncontaminated sediments. In borehole 299-E33-341, only two sediment samples had adequate concentrations of water-extractable uranium to warrant accurate and precise uranium isotope signature measurements. The sample from $20 \mathrm{ft}$ bgs did contain Hanford processed uranium consistent with the waste disposed, but the sample at $35 \mathrm{ft}$ bgs contained only natural background uranium. All the measurements of water and acid-extractable uranium and the uranium isotopic ratio measurements suggest that the deep vadose zone below the BY Cribs is not contributing uranium to the groundwater. Thus, recent increases in the uranium groundwater concentrations in the B-Complex plume (see discussion in Section 5.6) is likely from another source besides the deep vadose zone below the BY cribs region.

\subsubsection{BY Cribs Vadose Zone Sediment Inventory Estimates}

This section focuses on the mass inventory estimates for two contaminants, technetium-99 and uranium. Sediment data from boreholes 299-E33-296, 299-E33-302 and 299-E33-341 were used to determine the remaining mass inventory in the vadose zone. The following paragraphs provide the process in which the mass inventory remaining in the vadose zone was derived. The localized cross sections with the depth-discrete concentrations of key mobile contaminants, shown in Figure 3.17 through Figure 3.20, and qualitative field visualizations of cobalt-60 (Figure 3.3) and the area of the high conductivity plume (Figure 3.6) are used to determine the distribution of technetium-99 and uranium in the vadose zone below the BY cribs. To account for horizontal spreading, three areas depicted in Figure 3.21 were chosen to represent the estimate of the maximum masses still residing in the vadose zone. The three areas are 1) the sum of the literal bases of the crib excavations of each of the eight BY cribs, which are $30 \mathrm{ft}$ by $30 \mathrm{ft}$ and shown as the eight brown squares, 2) the area shown as the black rectangle in Figure 3.21, which is essentially a "continuous perimeter" around the eight cribs (estimated to be $170 \mathrm{ft}$ by $280 \mathrm{ft}$ ), and finally, 3) an area, shown as a green rectangular border, based on an assumed 20-m lateral spread of contaminants in all four directions beyond the BY Cribs continuous perimeter.

Based on Hanford site geochemical observations governing the interactions of these two contaminants with sediments vertical distributions of sediment concentrations were constructed. Two vertical sediment concentration distributions were chosen for the BY Cribs literal footprints (the brown squares) and for the BY Cribs continuous perimeter (black rectangle). One vertical distribution (based on the borehole 299-E33-341 sediment results) was chosen to represent the 20-m lateral spread (green border) around all four sides of the black rectangle. Then three conceptual models were developed that sum the estimated masses for the three designated areas to bound the estimates for the residual mass of technetium-99 and uranium in the vadose zone. The three bounding calculations are shown in Figure 3.22 
through Figure 3.24. Table 3.5 through Table 3.7 present the detailed calculations for each of the three conceptual models for residual mass.

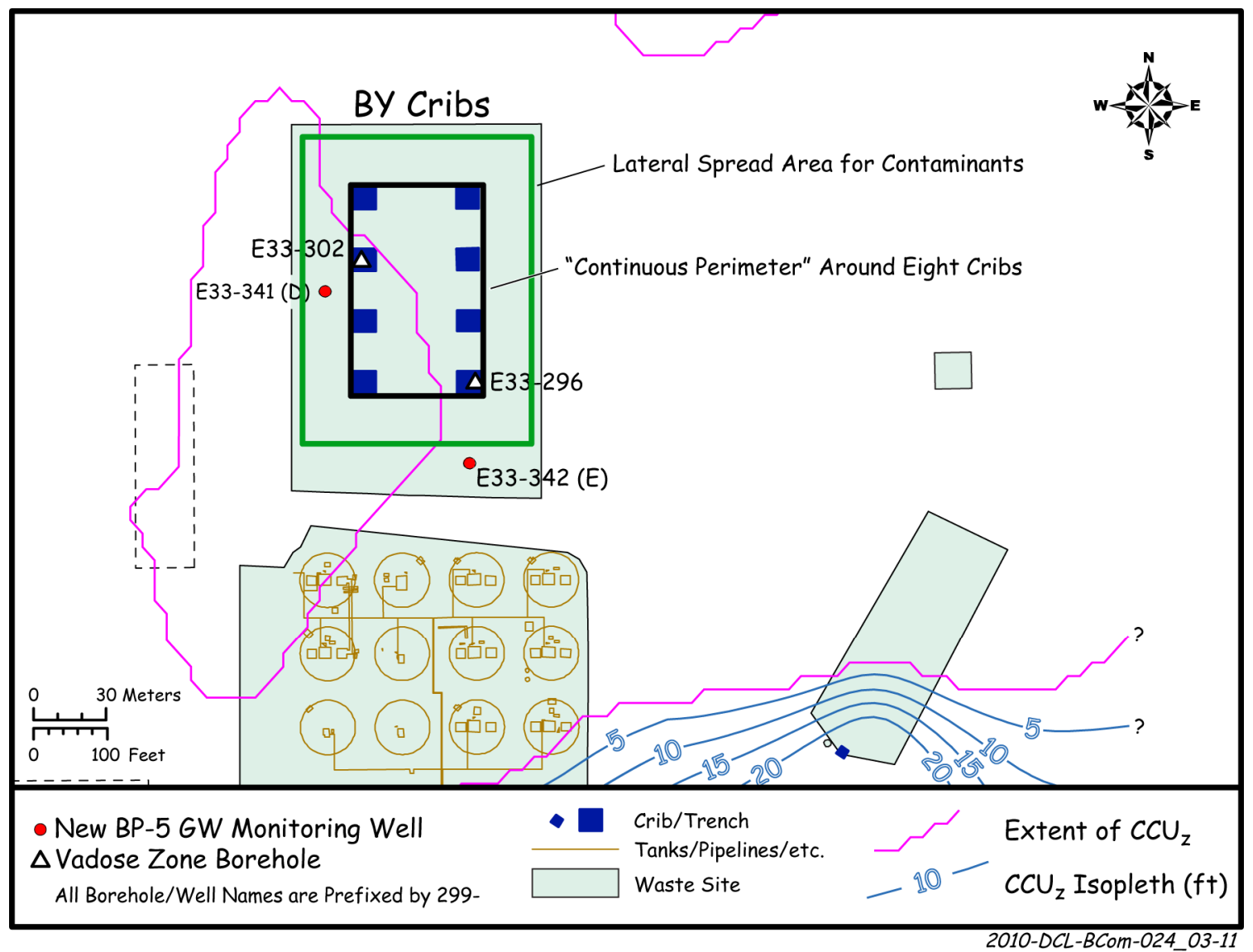

Figure 3.21. Areas Chosen to Calculate Vadose Zone Inventory for BY Crib Red Line Delineates Areal Extent of $\mathrm{CCU}_{\mathrm{z}}$ Unit and Blue Lines Represent Thickness

Brown lines outline the facility and tank farm fence boundaries 
PNNL-19277
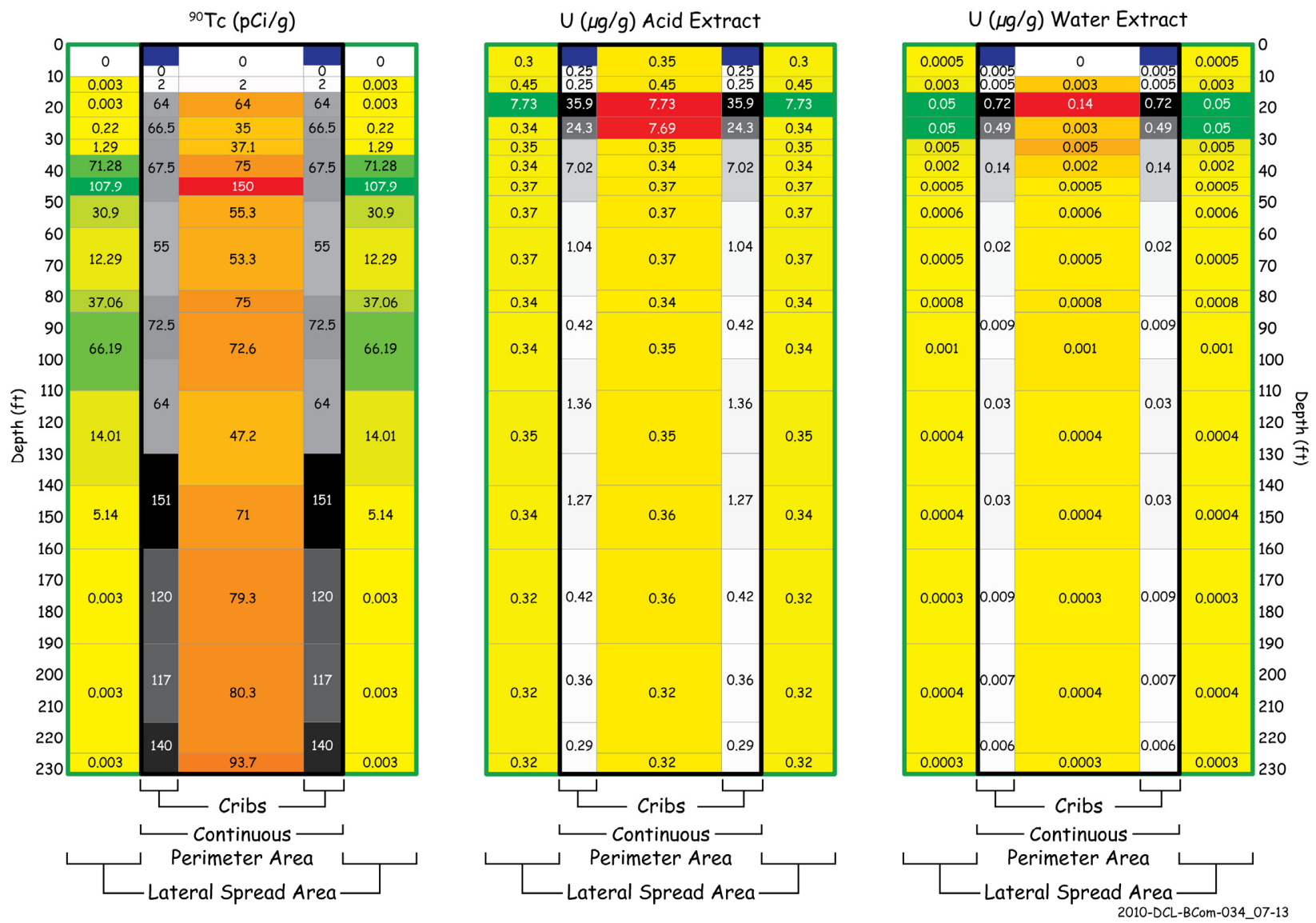

Figure 3.22. Cross Section and Estimated Concentrations of Technetium-99 and Uranium Used in BY Cribs Mass Inventory Conceptual Model \#1 
PNNL-19277
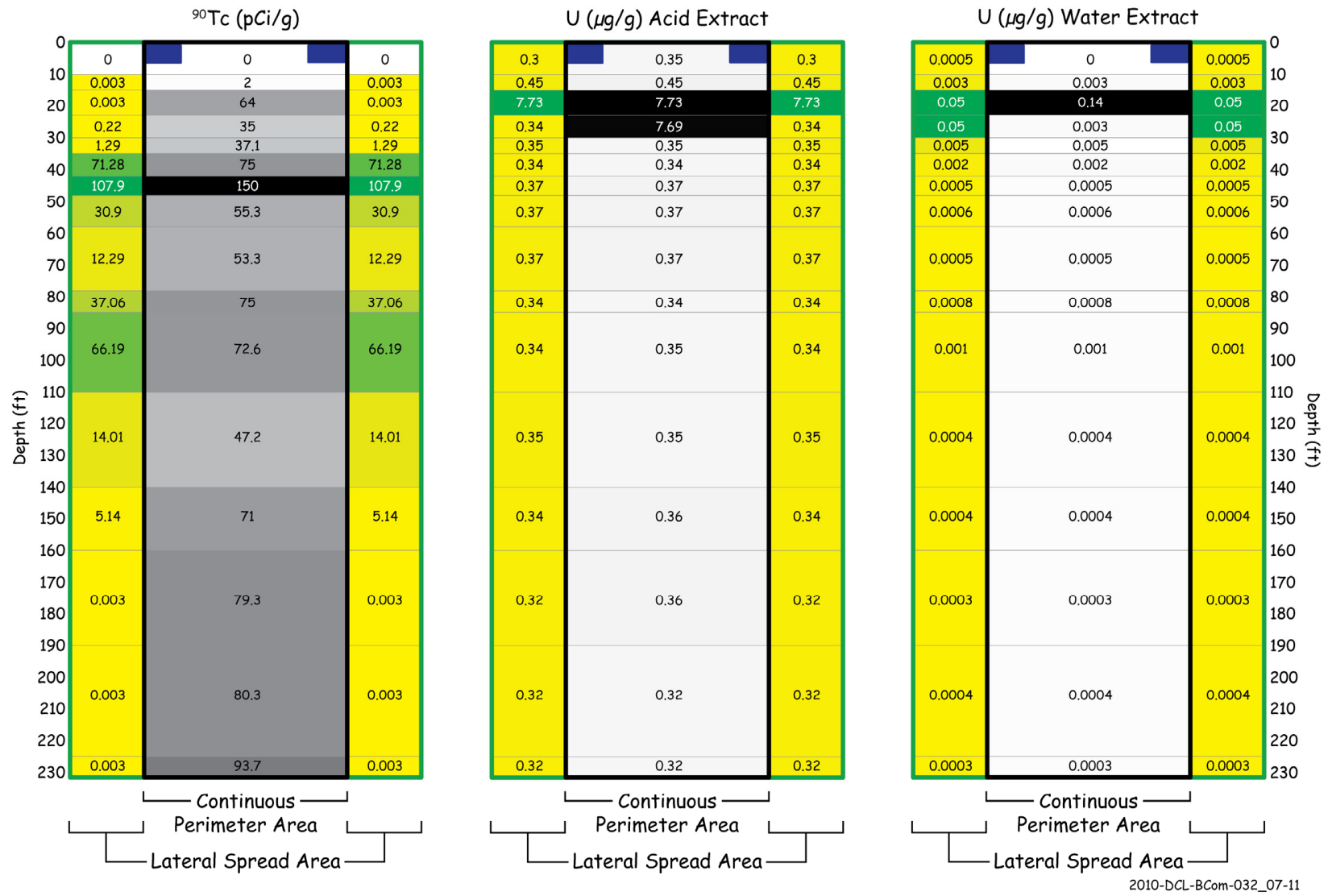

Figure 3.23. Cross Section and Estimated Concentrations of Technetium-99 and Uranium Used in BY Cribs Mass Inventory Conceptual Model \#2 
PNNL-19277
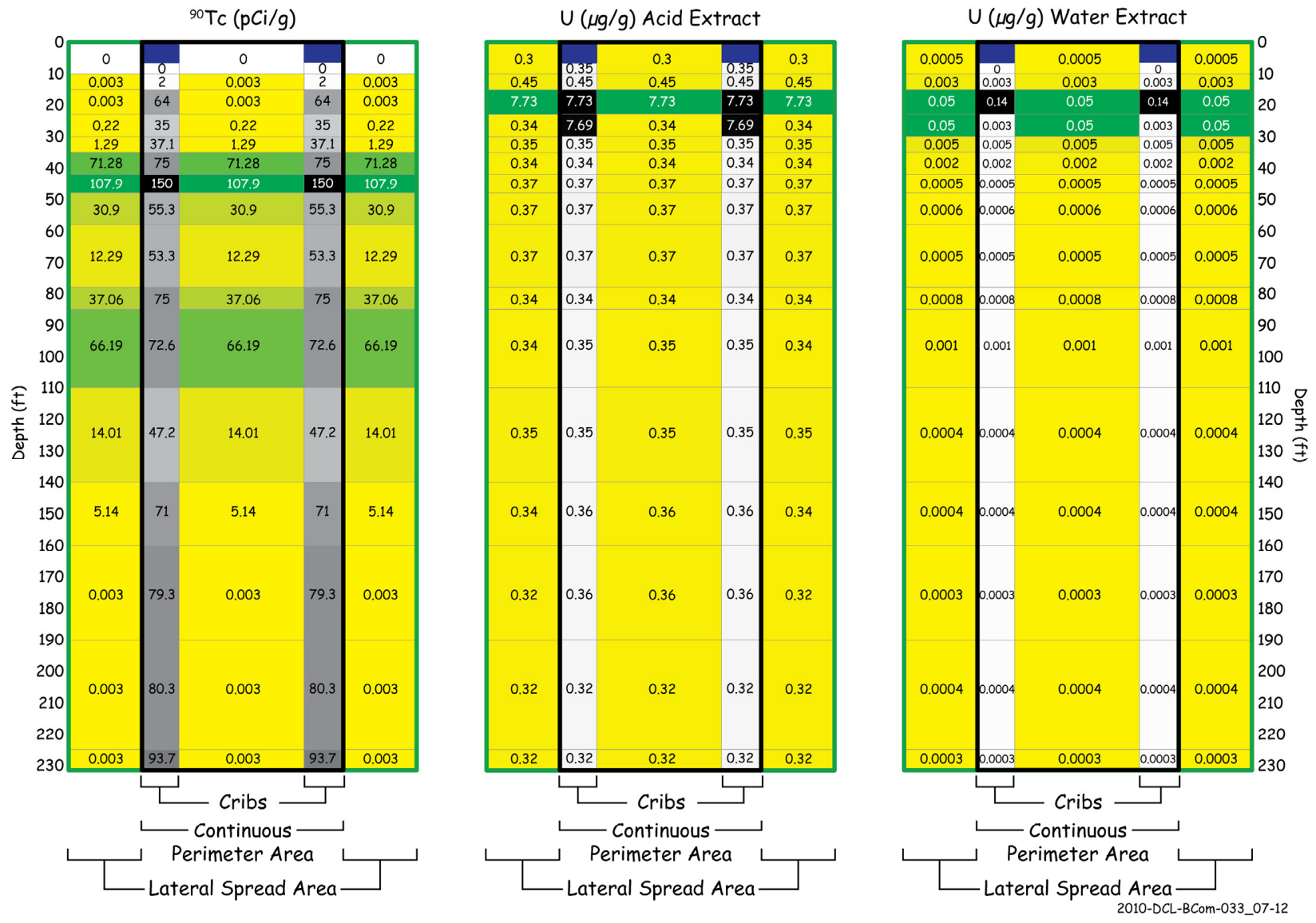

Figure 3.24. Cross Section and Estimated Concentrations of Technetium-99 and Uranium Used in BY Cribs Mass Inventory Conceptual Model \#3 
Table 3.5. Inventory Estimates for Technetium and Uranium in Vadose Zone Below BY Cribs Facility Conceptual Model \#1

\begin{tabular}{|c|c|c|c|c|c|c|c|c|c|c|c|}
\hline $\begin{array}{c}\text { Area }=8 \text { Crib Footprints } \\
\text { Layer }\end{array}$ & $\begin{array}{c}669 \mathrm{~m}^{2} \\
\text { Depth Interval }\end{array}$ & $\begin{array}{c}\mathrm{pCi} / \mathrm{g} \\
\mathrm{Tc} \\
\end{array}$ & $\begin{array}{c}\mathrm{ug} / \mathrm{g} \\
\mathrm{U}(\mathrm{AE}) \\
\end{array}$ & $\begin{array}{c}\mathrm{ug} / \mathrm{g} \\
\mathrm{U}(\mathrm{WE}) \\
\end{array}$ & $\begin{array}{c}\text { thickness } \\
\mathrm{ft}\end{array}$ & $\begin{array}{c}\rho b \\
\mathrm{~g} / \mathrm{cm} 3 \\
\end{array}$ & $\begin{array}{c}\text { Volume } \\
\text { m3 } \\
\end{array}$ & $\begin{array}{c}\text { Sed Mass } \\
\mathrm{g} \\
\end{array}$ & $\begin{array}{l}\mathrm{Tc} \\
\mathrm{Ci} \\
\end{array}$ & $\begin{array}{c}\mathrm{U}(\mathrm{AE}) \\
\mathrm{kg} \\
\end{array}$ & $\begin{array}{c}\mathrm{U}(\mathrm{WE}) \\
\mathrm{kg} \\
\end{array}$ \\
\hline Overburden & 0 to 10 & 0 & 0.25 & 0.005 & 10 & 2.15 & $2.04 \mathrm{E}+03$ & $4.38 \mathrm{E}+09$ & $0.00 \mathrm{E}+00$ & $1.10 \mathrm{E}+00$ & $2.19 \mathrm{E}-02$ \\
\hline Backfill & 10 to 15 & 2 & 0.25 & 0.005 & 5 & 2.15 & $1.02 \mathrm{E}+03$ & $2.19 \mathrm{E}+09$ & $4.38 \mathrm{E}-03$ & $5.48 \mathrm{E}-01$ & $1.10 \mathrm{E}-02$ \\
\hline Crib Base & 15 to 23 & 64 & 35.9 & 0.718 & 8 & 1.77 & $1.63 \mathrm{E}+03$ & $2.89 \mathrm{E}+09$ & $1.85 \mathrm{E}-01$ & $1.04 \mathrm{E}+02$ & $2.07 \mathrm{E}+00$ \\
\hline $\mathrm{H} 2$ & 23 to 30 & 66.5 & 24.3 & 0.486 & 7 & 1.77 & $1.43 \mathrm{E}+03$ & $2.53 \mathrm{E}+09$ & $1.68 \mathrm{E}-01$ & $6.14 \mathrm{E}+01$ & $1.23 \mathrm{E}+00$ \\
\hline $\mathrm{H} 2$ & 30 to 50 & 67.5 & 7.025 & 0.141 & 20 & 1.77 & $4.08 \mathrm{E}+03$ & $7.22 \mathrm{E}+09$ & 4.87E-01 & $5.07 \mathrm{E}+01$ & $1.01 \mathrm{E}+00$ \\
\hline $\mathrm{H} 2$ & 50 to 80 & 55 & 1.0375 & 0.021 & 30 & 1.77 & $6.12 \mathrm{E}+03$ & $1.08 \mathrm{E}+10$ & $5.96 \mathrm{E}-01$ & $1.12 \mathrm{E}+01$ & $2.25 \mathrm{E}-01$ \\
\hline $\mathrm{H} 2$ & 80 to 100 & 72.5 & 0.425 & 0.009 & 20 & 1.77 & $4.08 \mathrm{E}+03$ & $7.22 \mathrm{E}+09$ & $5.23 \mathrm{E}-01$ & $3.07 \mathrm{E}+00$ & $6.14 \mathrm{E}-02$ \\
\hline $\mathrm{H} 2$ & 100 to 130 & 64 & 1.3625 & 0.027 & 30 & 1.77 & $6.12 \mathrm{E}+03$ & $1.08 \mathrm{E}+10$ & $6.93 \mathrm{E}-01$ & $1.48 \mathrm{E}+01$ & $2.95 \mathrm{E}-01$ \\
\hline $\mathrm{H} 2$ with fines & 130 to 160 & 151 & 1.275 & 0.026 & 30 & 1.77 & $6.12 \mathrm{E}+03$ & $1.08 \mathrm{E}+10$ & $1.63 \mathrm{E}+00$ & $1.38 \mathrm{E}+01$ & $2.76 \mathrm{E}-01$ \\
\hline H2 deep & 160 to 190 & 120 & 0.425 & 0.009 & 30 & 1.77 & $6.12 \mathrm{E}+03$ & $1.08 \mathrm{E}+10$ & $1.30 \mathrm{E}+00$ & $4.60 \mathrm{E}+00$ & $9.20 \mathrm{E}-02$ \\
\hline CCUz and CCUg & 190 to 215 & 117 & 0.3625 & 0.007 & 25 & 2.15 & $5.10 \mathrm{E}+03$ & $1.10 \mathrm{E}+10$ & $1.28 \mathrm{E}+00$ & $3.97 \mathrm{E}+00$ & 7.95E-02 \\
\hline \multirow[t]{2}{*}{ CCUg } & 215 to 231.5 & 140 & 0.2875 & 0.006 & 16.5 & 2.15 & $3.36 \mathrm{E}+03$ & $7.23 \mathrm{E}+09$ & $1.01 \mathrm{E}+00$ & $2.08 \mathrm{E}+00$ & 4.16E-02 \\
\hline & & & & total $\mathrm{ft}$ & 231.5 & & & $\begin{array}{c}\text { sum } \\
\text { deen }(90 \mathrm{ft}\end{array}$ & $\begin{array}{l}7.89 \mathrm{E}+00 \\
4.60 \mathrm{E}+00\end{array}$ & $\begin{array}{l}2.71 \mathrm{E}+02 \\
1.92 \mathrm{E}+01\end{array}$ & $\begin{array}{l}5.42 \mathrm{E}+00 \\
3.83 \mathrm{E}-01\end{array}$ \\
\hline
\end{tabular}

Area_Black-8 Footprints $\quad 3753.3 \mathrm{~m} 2 \quad$ pCi/g $\quad$ ug/g $\quad$ ug/g $\quad$ thickness $\quad \rho b \quad$ Volume $\quad$ Sed Mass $\quad$ Tc $\quad$ U(AE) $\quad$ U(WE)

\begin{tabular}{lccccccccccc} 
& Layer & Depth Interval & Tc & $\mathrm{U}(\mathrm{AE})$ & $\mathrm{U}(\mathrm{WE})$ & $\mathrm{ft}$ & $\mathrm{g} / \mathrm{cm} 3$ & $\mathrm{~m} 3$ & $\mathrm{~g}$ & $\mathrm{Ci}$ & $\mathrm{kg}$ \\
\hline Overburden & 0 to 10 & 0 & 0.35 & 0 & 10 & 2.15 & $1.14 \mathrm{E}+04$ & $2.46 \mathrm{E}+10$ & $0.00 \mathrm{E}+00$ & $8.61 \mathrm{E}+00$ & $0.00 \mathrm{E}+00$ \\
Backfill & 10 to 15 & 2 & 0.45 & $2.90 \mathrm{E}-03$ & 5 & 2.15 & $5.72 \mathrm{E}+03$ & $1.23 \mathrm{E}+10$ & $2.46 \mathrm{E}-02$ & $5.53 \mathrm{E}+00$ & $3.57 \mathrm{E}-02$ \\
Crib Base & 15 to 23 & 64 & 7.73 & $1.39 \mathrm{E}-01$ & 8 & 1.77 & $9.15 \mathrm{E}+03$ & $1.62 \mathrm{E}+10$ & $1.04 \mathrm{E}+00$ & $1.25 \mathrm{E}+02$ & $2.25 \mathrm{E}+00$ \\
H2 (shallow contam) & 23 to 30 & 35 & 7.69 & $3.05 \mathrm{E}-03$ & 7 & 1.77 & $8.01 \mathrm{E}+03$ & $1.42 \mathrm{E}+10$ & $4.96 \mathrm{E}-01$ & $1.09 \mathrm{E}+02$ & $4.32 \mathrm{E}-02$ \\
H2 (mid 1 contam) & 30 to 35 & 37.1 & 0.35 & $5.40 \mathrm{E}-03$ & 5 & 1.77 & $5.72 \mathrm{E}+03$ & $1.01 \mathrm{E}+10$ & $3.76 \mathrm{E}-01$ & $3.51 \mathrm{E}+00$ & $5.46 \mathrm{E}-02$ \\
H2 (mid 2 contam) & 35 to 42 & 75 & 0.34 & $2.49 \mathrm{E}-03$ & 7 & 1.77 & $8.01 \mathrm{E}+03$ & $1.42 \mathrm{E}+10$ & $1.06 \mathrm{E}+00$ & $4.78 \mathrm{E}+00$ & $3.53 \mathrm{E}-02$ \\
H2 (high contam) & 42 to 48 & 150 & 0.37 & $4.99 \mathrm{E}-04$ & 6 & 1.77 & $6.86 \mathrm{E}+03$ & $1.21 \mathrm{E}+10$ & $1.82 \mathrm{E}+00$ & $4.53 \mathrm{E}+00$ & $6.06 \mathrm{E}-03$ \\
H2 & 48 to 58 & 55.3 & 0.37 & $6.09 \mathrm{E}-04$ & 10 & 1.77 & $1.14 \mathrm{E}+04$ & $2.02 \mathrm{E}+10$ & $1.12 \mathrm{E}+00$ & $7.56 \mathrm{E}+00$ & $1.23 \mathrm{E}-02$ \\
H2 & 58 to 78 & 53.3 & 0.37 & $4.63 \mathrm{E}-04$ & 20 & 1.77 & $2.29 \mathrm{E}+04$ & $4.05 \mathrm{E}+10$ & $2.16 \mathrm{E}+00$ & $1.48 \mathrm{E}+01$ & $1.87 \mathrm{E}-02$ \\
H2 fine grain-1 & 78 to 85 & 75 & 0.34 & $8.40 \mathrm{E}-04$ & 7 & 1.77 & $8.01 \mathrm{E}+03$ & $1.42 \mathrm{E}+10$ & $1.06 \mathrm{E}+00$ & $4.82 \mathrm{E}+00$ & $1.19 \mathrm{E}-02$ \\
H2 fine grain-2 & 85 to 110 & 72.6 & 0.35 & $1.03 \mathrm{E}-03$ & 25 & 1.77 & $2.86 \mathrm{E}+04$ & $5.06 \mathrm{E}+10$ & $3.67 \mathrm{E}+00$ & $1.78 \mathrm{E}+01$ & $5.23 \mathrm{E}-02$ \\
H2 deep & 110 to 140 & 47.2 & 0.35 & $3.83 \mathrm{E}-04$ & 30 & 1.77 & $3.43 \mathrm{E}+04$ & $6.07 \mathrm{E}+10$ & $2.87 \mathrm{E}+00$ & $2.13 \mathrm{E}+01$ & $2.33 \mathrm{E}-02$ \\
H2-fine grain-3 & 140 to 160 & 71 & 0.36 & $3.51 \mathrm{E}-04$ & 20 & 1.77 & $2.29 \mathrm{E}+04$ & $4.05 \mathrm{E}+10$ & $2.88 \mathrm{E}+00$ & $1.44 \mathrm{E}+01$ & $1.42 \mathrm{E}-02$ \\
H2 \&CCUz & 160 to 190 & 79.3 & 0.36 & $3.44 \mathrm{E}-04$ & 30 & 1.77 & $3.43 \mathrm{E}+04$ & $6.07 \mathrm{E}+10$ & $4.82 \mathrm{E}+00$ & $2.16 \mathrm{E}+01$ & $2.09 \mathrm{E}-02$
\end{tabular}


Table 3.5 (cont). Inventory Estimates for Technetium and Uranium in Vadose Zone Below BY Cribs Facility Conceptual Model \#1

\begin{tabular}{|c|c|c|c|c|c|c|c|c|c|c|c|}
\hline Area_Black-8 Footprints & $3753.3 \mathrm{~m}^{2}$ & $\mathrm{pCi} / \mathrm{g}$ & $\mathrm{ug} / \mathrm{g}$ & $\mathrm{ug} / \mathrm{g}$ & thickness & $\rho b$ & Volume & Sed Mass & Tc & $\mathrm{U}(\mathrm{AE})$ & $\mathrm{U}(\mathrm{WE})$ \\
\hline Layer & Depth Interval & Tc & $\mathrm{U}(\mathrm{AE})$ & $\mathrm{U}(\mathrm{WE})$ & $\mathrm{ft}$ & $\mathrm{g} / \mathrm{cm} 3$ & $\mathrm{~m} 3$ & $\mathrm{~g}$ & $\mathrm{Ci}$ & $\mathrm{kg}$ & $\mathrm{kg}$ \\
\hline $\mathrm{CCUz}$ and $\mathrm{CCUg}$ & 190 to 225 & 80.3 & 0.32 & $4.45 \mathrm{E}-04$ & 35 & 2.15 & $4.00 \mathrm{E}+04$ & $8.61 \mathrm{E}+10$ & $6.92 \mathrm{E}+00$ & $2.75 \mathrm{E}+01$ & $3.83 \mathrm{E}-02$ \\
\hline CCUg & 225 to 231.5 & 93.7 & 0.32 & $2.80 \mathrm{E}-04$ & 6.5 & 2.15 & $7.44 \mathrm{E}+03$ & $1.60 \mathrm{E}+10$ & $1.50 \mathrm{E}+00$ & $5.12 \mathrm{E}+00$ & $4.48 \mathrm{E}-03$ \\
\hline & & & & total $\mathrm{ft}$ & 231.5 & & & $\begin{array}{l}\text { sum } \\
\text { leep } 90\end{array}$ & $\begin{array}{c}3.18 \mathrm{E}+01 \\
1.59 \mathrm{E}+01\end{array}$ & $\begin{array}{c}3.96 \mathrm{E}+02 \\
6.75 \mathrm{E}+01\end{array}$ & $\begin{array}{l}2.62 \mathrm{E}+00 \\
7.68 \mathrm{E}-02\end{array}$ \\
\hline
\end{tabular}

Area $=$ Green Lateral Spread Border $\quad 7086.4 \mathrm{~m} 2 \quad \mathrm{pCi} / \mathrm{g} \quad \mathrm{ug} / \mathrm{g} \quad \mathrm{ug} / \mathrm{g} \quad$ thickness $\quad \mathrm{\rho b} \quad$ Volume Sed Mass $\quad$ Tc U(AE) U(WE)

\begin{tabular}{|c|c|c|c|c|c|c|c|c|c|c|c|}
\hline Layer & & $\mathrm{Tc}$ & $\mathrm{U}(\mathrm{AE})$ & $\mathrm{U}(\mathrm{WE})$ & $\mathrm{ft}$ & $\mathrm{g} / \mathrm{cm} 3$ & $\mathrm{~m} 3$ & g & $\mathrm{Ci}$ & $\mathrm{kg}$ & $\mathrm{kg}$ \\
\hline Overburden & 0 to 10 & 0 & 0.3 & $5.00 \mathrm{E}-04$ & 10 & 2.15 & $2.16 \mathrm{E}+04$ & $4.64 \mathrm{E}+10$ & $0.00 \mathrm{E}+00$ & $1.39 \mathrm{E}+01$ & $2.32 \mathrm{E}-02$ \\
\hline Backfill & 10 to 15 & 0.003 & 0.45 & $2.90 \mathrm{E}-03$ & 5 & 2.15 & $1.08 \mathrm{E}+04$ & $2.32 \mathrm{E}+10$ & $6.97 \mathrm{E}-05$ & $1.04 \mathrm{E}+01$ & $6.73 \mathrm{E}-02$ \\
\hline Crib Base & 15 to 23 & 0.003 & 7.73 & 4.82E-02 & 8 & 1.77 & $1.73 \mathrm{E}+04$ & $3.06 \mathrm{E}+10$ & $9.18 \mathrm{E}-05$ & $2.36 \mathrm{E}+02$ & $1.47 \mathrm{E}+00$ \\
\hline H2 (shallow contam) & 23 to 30 & 0.22 & 0.34 & $4.84 \mathrm{E}-02$ & 7 & 1.77 & $1.51 \mathrm{E}+04$ & $2.68 \mathrm{E}+10$ & $5.90 \mathrm{E}-03$ & $9.10 \mathrm{E}+00$ & $1.29 \mathrm{E}+00$ \\
\hline H2 (mid 1 contam) & 30 to 35 & 1.29 & 0.35 & $5.40 \mathrm{E}-03$ & 5 & 1.77 & $1.08 \mathrm{E}+04$ & $1.91 \mathrm{E}+10$ & $2.47 \mathrm{E}-02$ & $6.69 \mathrm{E}+00$ & $1.03 \mathrm{E}-01$ \\
\hline H2 (mid 2 contam) & 35 to 42 & 71.28 & 0.34 & 2.49E-03 & 7 & 1.77 & $1.51 \mathrm{E}+04$ & $2.68 \mathrm{E}+10$ & $1.91 \mathrm{E}+00$ & $9.10 \mathrm{E}+00$ & $6.66 \mathrm{E}-02$ \\
\hline H2 (high contam) & 42 to 48 & 107.9 & 0.37 & 4.99E-04 & 6 & 1.77 & $1.30 \mathrm{E}+04$ & $2.29 \mathrm{E}+10$ & $2.48 \mathrm{E}+00$ & $8.49 \mathrm{E}+00$ & $1.14 \mathrm{E}-02$ \\
\hline $\mathrm{H} 2$ & 48 to 58 & 30.9 & 0.37 & $6.09 \mathrm{E}-04$ & 10 & 1.77 & $2.16 \mathrm{E}+04$ & $3.82 \mathrm{E}+10$ & $1.18 \mathrm{E}+00$ & $1.41 \mathrm{E}+01$ & 2.33E-02 \\
\hline $\mathrm{H} 2$ & 58 to 78 & 12.29 & 0.37 & 4.63E-04 & 20 & 1.77 & $4.32 \mathrm{E}+04$ & $7.65 \mathrm{E}+10$ & $9.40 \mathrm{E}-01$ & $2.83 \mathrm{E}+01$ & $3.54 \mathrm{E}-02$ \\
\hline H2 fine grain-1 & 78 to 85 & 37.06 & 0.34 & $8.40 \mathrm{E}-04$ & 7 & 1.77 & $1.51 \mathrm{E}+04$ & $2.68 \mathrm{E}+10$ & $9.92 \mathrm{E}-01$ & $9.10 \mathrm{E}+00$ & $2.25 \mathrm{E}-02$ \\
\hline H2 fine grain-2 & 85 to 110 & 66.19 & 0.34 & $1.03 \mathrm{E}-03$ & 25 & 1.77 & $5.40 \mathrm{E}+04$ & $9.56 \mathrm{E}+10$ & $6.33 \mathrm{E}+00$ & $3.25 \mathrm{E}+01$ & $9.87 \mathrm{E}-02$ \\
\hline H2 deep & 110 to 140 & 14.01 & 0.35 & $3.80 \mathrm{E}-04$ & 30 & 1.77 & $6.48 \mathrm{E}+04$ & $1.15 \mathrm{E}+11$ & $1.61 \mathrm{E}+00$ & $4.01 \mathrm{E}+01$ & $4.36 \mathrm{E}-02$ \\
\hline H2-fine grain-3 & 140 to 160 & 5.15 & 0.34 & 4.29E-04 & 20 & 1.77 & $4.32 \mathrm{E}+04$ & $7.65 \mathrm{E}+10$ & $3.93 \mathrm{E}-01$ & $2.60 \mathrm{E}+01$ & $3.28 \mathrm{E}-02$ \\
\hline $\mathrm{H} 2 \& \mathrm{CCUz}$ & 160 to 190 & 0.003 & 0.32 & $3.44 \mathrm{E}-04$ & 30 & 1.77 & $6.48 \mathrm{E}+04$ & $1.15 \mathrm{E}+11$ & $3.44 \mathrm{E}-04$ & $3.67 \mathrm{E}+01$ & $3.94 \mathrm{E}-02$ \\
\hline CCUz and CCUg & 190 to 225 & 0.003 & 0.32 & 3.98E-04 & 35 & 2.15 & $7.56 \mathrm{E}+04$ & $1.63 \mathrm{E}+11$ & 4.88E-04 & $5.20 \mathrm{E}+01$ & $6.46 \mathrm{E}-02$ \\
\hline CCUg & 225 to 231.5 & 0.003 & 0.32 & $2.80 \mathrm{E}-04$ & 6.5 & 2.15 & $1.40 \mathrm{E}+04$ & $3.02 \mathrm{E}+10$ & $9.06 \mathrm{E}-05$ & $9.66 \mathrm{E}+00$ & $8.45 \mathrm{E}-03$ \\
\hline & & & & total $\mathrm{ft}$ & 231.5 & & & $\begin{array}{c}\text { sum } \\
\text { deep } 90\end{array}$ & $\begin{array}{l}1.59 \mathrm{E}+01 \\
3.65 \mathrm{E}-01 \\
\end{array}$ & $\begin{array}{l}5.43 \mathrm{E}+02 \\
1.22 \mathrm{E}+02 \\
\end{array}$ & $\begin{array}{c}3.41 \mathrm{E}+00 \\
1.43 \mathrm{E}-01\end{array}$ \\
\hline
\end{tabular}


Table 3.6. Inventory Estimates for Technetium and Uranium in Vadose Zone Below BY Cribs Facility Conceptual Model \#2

\begin{tabular}{|c|c|c|c|c|c|c|c|c|c|c|c|}
\hline Area $=8$ Crib Footprints & $\begin{array}{c}669 \mathrm{~m}^{2} \\
\text { Depth Interval }\end{array}$ & $\begin{array}{c}\mathrm{pCi} / \mathrm{g} \\
\mathrm{Tc}\end{array}$ & $\begin{array}{c}\mathrm{ug} / \mathrm{g} \\
\mathrm{U}(\mathrm{AE})\end{array}$ & $\begin{array}{c}\mathrm{ug} / \mathrm{g} \\
\mathrm{U}(\mathrm{WE})\end{array}$ & $\begin{array}{c}\text { thickness } \\
\mathrm{ft}\end{array}$ & $\begin{array}{c}\rho b \\
g / \mathrm{cm}^{3}\end{array}$ & $\begin{array}{l}\text { Volume } \\
\text { m3 }\end{array}$ & $\begin{array}{c}\text { Sed Mass } \\
\mathrm{g}\end{array}$ & $\begin{array}{l}\mathrm{Tc} \\
\mathrm{Ci}\end{array}$ & $\begin{array}{c}\mathrm{U}(\mathrm{AE}) \\
\mathrm{kg}\end{array}$ & $\begin{array}{c}\mathrm{U}(\mathrm{WE}) \\
\mathrm{kg}\end{array}$ \\
\hline Overburden & 0 to 10 & 0 & 0.35 & 0 & 10 & 2.15 & $2.04 \mathrm{E}+03$ & $4.38 \mathrm{E}+09$ & $0.00 \mathrm{E}+00$ & $1.53 \mathrm{E}+00$ & $0.00 \mathrm{E}+00$ \\
\hline Crib Base & 15 to 23 & 64 & 7.73 & $1.39 \mathrm{E}-01$ & 8 & 1.77 & $1.63 \mathrm{E}+03$ & $2.89 \mathrm{E}+09$ & $1.85 \mathrm{E}-01$ & $2.23 \mathrm{E}+01$ & $4.01 \mathrm{E}-01$ \\
\hline H2 (shallow contam) & 23 to 30 & 35 & 7.69 & $3.05 \mathrm{E}-03$ & 7 & 1.77 & $1.43 \mathrm{E}+03$ & $2.53 \mathrm{E}+09$ & $8.84 \mathrm{E}-02$ & $1.94 \mathrm{E}+01$ & $7.71 \mathrm{E}-03$ \\
\hline H2 (mid 1 contam) & 30 to 35 & 37.1 & 0.35 & $5.40 \mathrm{E}-03$ & 5 & 1.77 & $1.02 \mathrm{E}+03$ & $1.80 \mathrm{E}+09$ & $6.69 \mathrm{E}-02$ & $6.26 \mathrm{E}-01$ & $9.74 \mathrm{E}-03$ \\
\hline $\mathrm{H} 2$ & 48 to 58 & 55.3 & 0.37 & $6.09 \mathrm{E}-04$ & 10 & 1.77 & $2.04 \mathrm{E}+03$ & $3.61 \mathrm{E}+09$ & $2.00 \mathrm{E}-01$ & $1.35 \mathrm{E}+00$ & $2.20 \mathrm{E}-03$ \\
\hline $\mathrm{H} 2$ & 58 to 78 & 53.3 & 0.37 & 4.63E-04 & 20 & 1.77 & $4.08 \mathrm{E}+03$ & $7.22 \mathrm{E}+09$ & $3.85 \mathrm{E}-01$ & $2.65 \mathrm{E}+00$ & $3.34 \mathrm{E}-03$ \\
\hline H2 fine grain-1 & 78 to 85 & 75 & 0.34 & 8.40E-04 & 7 & 1.77 & $1.43 \mathrm{E}+03$ & $2.53 \mathrm{E}+09$ & $1.89 \mathrm{E}-01$ & $8.59 \mathrm{E}-01$ & $2.12 \mathrm{E}-03$ \\
\hline H2 fine grain-2 & 85 to 110 & 72.6 & 0.35 & $1.03 \mathrm{E}-03$ & 25 & 1.77 & $5.10 \mathrm{E}+03$ & $9.02 \mathrm{E}+09$ & $6.55 \mathrm{E}-01$ & $3.17 \mathrm{E}+00$ & $9.32 \mathrm{E}-03$ \\
\hline H2 deep & 110 to 140 & 47.2 & 0.35 & $3.83 \mathrm{E}-04$ & 30 & 1.77 & $6.12 \mathrm{E}+03$ & $1.08 \mathrm{E}+10$ & $5.11 \mathrm{E}-01$ & $3.79 \mathrm{E}+00$ & 4.15E-03 \\
\hline $\mathrm{H} 2$-fine grain-3 & 140 to 160 & 71 & 0.36 & $3.51 \mathrm{E}-04$ & 20 & 1.77 & $4.08 \mathrm{E}+03$ & $7.22 \mathrm{E}+09$ & $5.13 \mathrm{E}-01$ & $2.56 \mathrm{E}+00$ & $2.54 \mathrm{E}-03$ \\
\hline $\mathrm{H} 2 \& \mathrm{CCUz}$ & 160 to 190 & 79.3 & 0.36 & $3.44 \mathrm{E}-04$ & 30 & 1.77 & $6.12 \mathrm{E}+03$ & $1.08 \mathrm{E}+10$ & $8.59 \mathrm{E}-01$ & $3.84 \mathrm{E}+00$ & $3.72 \mathrm{E}-03$ \\
\hline
\end{tabular}

Area_Black-8 Footprints $3753.3 \mathrm{~m} 2 \quad \mathrm{pCi} / \mathrm{g} \quad \mathrm{ug} / \mathrm{g} \quad \mathrm{ug} / \mathrm{g} \quad$ thickness $\quad \rho b \quad$ Volume $\quad$ Sed Mass $\quad$ Tc $\quad$ U(AE) $\quad$ U(WE)

\begin{tabular}{lcccccccccccc} 
Layer & Depth Interval & $\mathrm{Tc}$ & $\mathrm{U}(\mathrm{AE})$ & $\mathrm{U}(\mathrm{WE})$ & $\mathrm{ft}$ & $\mathrm{g} / \mathrm{cm} 3$ & $\mathrm{~m} 3$ & $\mathrm{~g}$ & $\mathrm{Ci}$ & $\mathrm{kg}$ & $\mathrm{kg}$ \\
\hline Overburden & 0 to 10 & 0 & 0.35 & 0 & 10 & 2.15 & $1.14 \mathrm{E}+04$ & $2.46 \mathrm{E}+10$ & $0.00 \mathrm{E}+00$ & $8.61 \mathrm{E}+00$ & $0.00 \mathrm{E}+00$ \\
Backfill & 10 to 15 & 2 & 0.45 & $2.90 \mathrm{E}-03$ & 5 & 2.15 & $5.72 \mathrm{E}+03$ & $1.23 \mathrm{E}+10$ & $2.46 \mathrm{E}-02$ & $5.53 \mathrm{E}+00$ & $3.57 \mathrm{E}-02$ \\
Crib Base & 15 to 23 & 64 & 7.73 & $1.39 \mathrm{E}-01$ & 8 & 1.77 & $9.15 \mathrm{E}+03$ & $1.62 \mathrm{E}+10$ & $1.04 \mathrm{E}+00$ & $1.25 \mathrm{E}+02$ & $2.25 \mathrm{E}+00$ \\
H2 (shallow contam) & 23 to 30 & 35 & 7.69 & $3.05 \mathrm{E}-03$ & 7 & 1.77 & $8.01 \mathrm{E}+03$ & $1.42 \mathrm{E}+10$ & $4.96 \mathrm{E}-01$ & $1.09 \mathrm{E}+02$ & $4.32 \mathrm{E}-02$ \\
H2 (mid 1 contam) & 30 to 35 & 37.1 & 0.35 & $5.40 \mathrm{E}-03$ & 5 & 1.77 & $5.72 \mathrm{E}+03$ & $1.01 \mathrm{E}+10$ & $3.76 \mathrm{E}-01$ & $3.51 \mathrm{E}+00$ & $5.46 \mathrm{E}-02$ \\
H2 (mid 2 contam) & 35 to 42 & 75 & 0.34 & $2.49 \mathrm{E}-03$ & 7 & 1.77 & $8.01 \mathrm{E}+03$ & $1.42 \mathrm{E}+10$ & $1.06 \mathrm{E}+00$ & $4.78 \mathrm{E}+00$ & $3.53 \mathrm{E}-02$ \\
H2 (high contam) & 42 to 48 & 150 & 0.37 & $4.99 \mathrm{E}-04$ & 6 & 1.77 & $6.86 \mathrm{E}+03$ & $1.21 \mathrm{E}+10$ & $1.82 \mathrm{E}+00$ & $4.53 \mathrm{E}+00$ & $6.06 \mathrm{E}-03$
\end{tabular}


Table 3.6 (cont). Inventory Estimates for Technetium and Uranium in Vadose Zone Below BY Cribs Facility Conceptual Model \#2

\begin{tabular}{|c|c|c|c|c|c|c|c|c|c|c|c|}
\hline$\overline{\text { Area_Black-8 Footprints }}$ & $3753.3 \mathrm{~m}^{2}$ & $\mathrm{pCi} / \mathrm{g}$ & $\mathrm{ug} / \mathrm{g}$ & $\mathrm{ug} / \mathrm{g}$ & thickness & $\rho \mathrm{\rho b}$ & Volume & Sed Mass & $\overline{\mathrm{Tc}}$ & $\mathrm{U}(\mathrm{AE})$ & $\mathrm{U}(\mathrm{WE})$ \\
\hline Layer & Depth Interval & Tc & $\mathrm{U}(\mathrm{AE})$ & $\mathrm{U}(\mathrm{WE})$ & $\mathrm{ft}$ & $\mathrm{g} / \mathrm{cm} 3$ & $\mathrm{~m} 3$ & $\mathrm{~g}$ & $\mathrm{Ci}$ & $\mathrm{kg}$ & $\mathrm{kg}$ \\
\hline $\mathrm{H} 2$ & 48 to 58 & 55.3 & 0.37 & $6.09 \mathrm{E}-04$ & 10 & 1.77 & $1.14 \mathrm{E}+04$ & $2.02 \mathrm{E}+10$ & $1.12 \mathrm{E}+00$ & $7.56 \mathrm{E}+00$ & $1.23 \mathrm{E}-02$ \\
\hline $\mathrm{H} 2$ & 58 to 78 & 53.3 & 0.37 & 4.63E-04 & 20 & 1.77 & $2.29 \mathrm{E}+04$ & $4.05 \mathrm{E}+10$ & $2.16 \mathrm{E}+00$ & $1.48 \mathrm{E}+01$ & $1.87 \mathrm{E}-02$ \\
\hline H2 fine grain-1 & 78 to 85 & 75 & 0.34 & $8.40 \mathrm{E}-04$ & 7 & 1.77 & $8.01 \mathrm{E}+03$ & $1.42 \mathrm{E}+10$ & $1.06 \mathrm{E}+00$ & $4.82 \mathrm{E}+00$ & $1.19 \mathrm{E}-02$ \\
\hline H2 fine grain-2 & 85 to 110 & 72.6 & 0.35 & $1.03 \mathrm{E}-03$ & 25 & 1.77 & $2.86 \mathrm{E}+04$ & $5.06 \mathrm{E}+10$ & $3.67 \mathrm{E}+00$ & $1.78 \mathrm{E}+01$ & $5.23 \mathrm{E}-02$ \\
\hline H2 deep & 110 to 140 & 47.2 & 0.35 & $3.83 \mathrm{E}-04$ & 30 & 1.77 & $3.43 \mathrm{E}+04$ & $6.07 E+10$ & $2.87 \mathrm{E}+00$ & $2.13 \mathrm{E}+01$ & $2.33 \mathrm{E}-02$ \\
\hline H2-fine grain-3 & 140 to 160 & 71 & 0.36 & $3.51 \mathrm{E}-04$ & 20 & 1.77 & $2.29 \mathrm{E}+04$ & $4.05 E+10$ & $2.88 \mathrm{E}+00$ & $1.44 \mathrm{E}+01$ & $1.42 \mathrm{E}-02$ \\
\hline $\mathrm{H} 2 \& \mathrm{CCUz}$ & 160 to 190 & 79.3 & 0.36 & $3.44 \mathrm{E}-04$ & 30 & 1.77 & $3.43 \mathrm{E}+04$ & $6.07 \mathrm{E}+10$ & $4.82 \mathrm{E}+00$ & $2.16 \mathrm{E}+01$ & 2.09E-02 \\
\hline CCUz and CCUg & 190 to 225 & 80.3 & 0.32 & $4.45 \mathrm{E}-04$ & 35 & 2.15 & $4.00 \mathrm{E}+04$ & $8.61 E+10$ & $6.92 \mathrm{E}+00$ & $2.75 \mathrm{E}+01$ & $3.83 \mathrm{E}-02$ \\
\hline \multirow[t]{2}{*}{ CCUg } & 225 to 231.5 & 93.7 & 0.32 & $2.80 \mathrm{E}-04$ & 6.5 & 2.15 & $7.44 \mathrm{E}+03$ & $1.60 \mathrm{E}+10$ & $1.50 \mathrm{E}+00$ & $5.12 \mathrm{E}+00$ & $4.48 \mathrm{E}-03$ \\
\hline & & & & total $\mathrm{ft}$ & 231.5 & & & $\begin{array}{c}\text { sum } \\
\text { deep } 90\end{array}$ & $\begin{array}{l}3.18 \mathrm{E}+01 \\
1.59 \mathrm{E}+01\end{array}$ & $\begin{array}{l}3.96 \mathrm{E}+02 \\
6.75 \mathrm{E}+01\end{array}$ & $\begin{array}{c}2.62 \mathrm{E}+00 \\
7.68 \mathrm{E}-02\end{array}$ \\
\hline $\begin{array}{l}\text { Area }=\text { Green Lateral } \\
\text { Spread Border }\end{array}$ & $7086.4 \mathrm{~m} 2$ & $\mathrm{pCi} / \mathrm{g}$ & $\mathrm{ug} / \mathrm{g}$ & $\mathrm{ug} / \mathrm{g}$ & thickness & $\rho b$ & Volume & Sed Mass & Tc & $\mathrm{U}(\mathrm{AE})$ & $\mathrm{U}(\mathrm{WE})$ \\
\hline Layer & & $\mathrm{Tc}$ & $\mathrm{U}(\mathrm{AE})$ & $\mathrm{U}(\mathrm{WE})$ & $\mathrm{ft}$ & $\mathrm{g} / \mathrm{cm} 3$ & $\mathrm{~m} 3$ & $\mathrm{~g}$ & $\mathrm{Ci}$ & $\mathrm{kg}$ & $\mathrm{kg}$ \\
\hline Overburden & 0 to 10 & 0 & 0.3 & $5.00 \mathrm{E}-04$ & 10 & 2.15 & $2.16 \mathrm{E}+04$ & $4.64 \mathrm{E}+10$ & $0.00 \mathrm{E}+00$ & $1.39 \mathrm{E}+01$ & $2.32 \mathrm{E}-02$ \\
\hline Backfill & 10 to 15 & 0.003 & 0.45 & $2.90 \mathrm{E}-03$ & 5 & 2.15 & $1.08 \mathrm{E}+04$ & $2.32 \mathrm{E}+10$ & $6.97 \mathrm{E}-05$ & $1.04 \mathrm{E}+01$ & $6.73 \mathrm{E}-02$ \\
\hline Crib Base & 15 to 23 & 0.003 & 7.73 & 4.82E-02 & 8 & 1.77 & $1.73 \mathrm{E}+04$ & $3.06 \mathrm{E}+10$ & $9.18 \mathrm{E}-05$ & $2.36 \mathrm{E}+02$ & $1.47 \mathrm{E}+00$ \\
\hline H2 (shallow contam) & 23 to 30 & 0.221 & 0.34 & 4.84E-02 & 7 & 1.77 & $1.51 \mathrm{E}+04$ & $2.68 \mathrm{E}+10$ & $5.90 \mathrm{E}-03$ & $9.10 \mathrm{E}+00$ & $1.29 \mathrm{E}+00$ \\
\hline H2 (mid 1 contam) & 30 to 35 & 1.291 & 0.35 & $5.40 \mathrm{E}-03$ & 5 & 1.77 & $1.08 \mathrm{E}+04$ & $1.91 \mathrm{E}+10$ & $2.47 \mathrm{E}-02$ & $6.69 \mathrm{E}+00$ & $1.03 \mathrm{E}-01$ \\
\hline H2 (mid 2 contam) & 35 to 42 & 71.283 & 0.34 & $2.49 \mathrm{E}-03$ & 7 & 1.77 & $1.51 \mathrm{E}+04$ & $2.68 \mathrm{E}+10$ & $1.91 \mathrm{E}+00$ & $9.10 \mathrm{E}+00$ & $6.66 \mathrm{E}-02$ \\
\hline H2 (high contam) & 42 to 48 & 107.9 & 0.37 & 4.99E-04 & 6 & 1.77 & $1.30 \mathrm{E}+04$ & $2.29 \mathrm{E}+10$ & $2.48 \mathrm{E}+00$ & $8.49 \mathrm{E}+00$ & $1.14 \mathrm{E}-02$ \\
\hline $\mathrm{H} 2$ & 48 to 58 & 30.9 & 0.37 & $6.09 \mathrm{E}-04$ & 10 & 1.77 & $2.16 \mathrm{E}+04$ & $3.82 \mathrm{E}+10$ & $1.18 \mathrm{E}+00$ & $1.41 \mathrm{E}+01$ & $2.33 \mathrm{E}-02$ \\
\hline $\mathrm{H} 2$ & 58 to 78 & 12.294 & 0.37 & 4.63E-04 & 20 & 1.77 & $4.32 \mathrm{E}+04$ & $7.65 \mathrm{E}+10$ & $9.40 \mathrm{E}-01$ & $2.83 \mathrm{E}+01$ & $3.54 \mathrm{E}-02$ \\
\hline H2 fine grain-1 & 78 to 85 & 37.058 & 0.34 & $8.40 \mathrm{E}-04$ & 7 & 1.77 & $1.51 \mathrm{E}+04$ & $2.68 \mathrm{E}+10$ & $9.92 \mathrm{E}-01$ & $9.10 \mathrm{E}+00$ & $2.25 \mathrm{E}-02$ \\
\hline H2 fine grain-2 & 85 to 110 & 66.186 & 0.34 & $1.03 \mathrm{E}-03$ & 25 & 1.77 & $5.40 \mathrm{E}+04$ & $9.56 \mathrm{E}+10$ & $6.33 \mathrm{E}+00$ & $3.25 \mathrm{E}+01$ & $9.87 \mathrm{E}-02$ \\
\hline H2 deep & 110 to 140 & 14.012 & 0.35 & $3.80 \mathrm{E}-04$ & 30 & 1.77 & $6.48 \mathrm{E}+04$ & $1.15 \mathrm{E}+11$ & $1.61 \mathrm{E}+00$ & $4.01 \mathrm{E}+01$ & $4.36 \mathrm{E}-02$ \\
\hline $\mathrm{H} 2$-fine grain-3 & 140 to 160 & 5.145 & 0.34 & $4.29 \mathrm{E}-04$ & 20 & 1.77 & $4.32 \mathrm{E}+04$ & $7.65 \mathrm{E}+10$ & $3.93 \mathrm{E}-01$ & $2.60 \mathrm{E}+01$ & $3.28 \mathrm{E}-02$ \\
\hline H2 \&CCUz & 160 to 190 & 0.003 & 0.32 & $3.44 \mathrm{E}-04$ & 30 & 1.77 & $6.48 \mathrm{E}+04$ & $1.15 \mathrm{E}+11$ & $3.44 \mathrm{E}-04$ & $3.67 \mathrm{E}+01$ & $3.94 \mathrm{E}-02$ \\
\hline $\mathrm{CCUz}$ and $\mathrm{CCUg}$ & 190 to 225 & 0.003 & 0.32 & $3.98 \mathrm{E}-04$ & 35 & 2.15 & $7.56 \mathrm{E}+04$ & $1.63 \mathrm{E}+11$ & $4.88 \mathrm{E}-04$ & $5.20 \mathrm{E}+01$ & $6.46 \mathrm{E}-02$ \\
\hline \multirow[t]{2}{*}{ CCUg } & 225 to 231.5 & 0.003 & 0.32 & $2.80 \mathrm{E}-04$ & 6.5 & 2.15 & $1.40 \mathrm{E}+04$ & $3.02 \mathrm{E}+10$ & $9.06 \mathrm{E}-05$ & $9.66 \mathrm{E}+00$ & $8.45 \mathrm{E}-03$ \\
\hline & & & & total $\mathrm{ft}$ & 231.5 & & & $\begin{array}{c}\text { sum } \\
\text { deep } 90\end{array}$ & $\begin{array}{l}1.59 \mathrm{E}+01 \\
3.65 \mathrm{E}-01\end{array}$ & $\begin{array}{l}5.43 \mathrm{E}+02 \\
1.22 \mathrm{E}+02\end{array}$ & $\begin{array}{l}3.41 \mathrm{E}+00 \\
1.43 \mathrm{E}-01\end{array}$ \\
\hline
\end{tabular}


Table 3.7. Inventory Estimates for Technetium and Uranium in Vadose Zone Below BY Cribs Facility Conceptual Model \#3

\begin{tabular}{|c|c|c|c|c|c|c|c|c|c|c|c|}
\hline Overburden & 0 to 10 & 0 & 0.35 & 0 & 10 & 2.15 & $2.04 \mathrm{E}+03$ & $4.38 \mathrm{E}+09$ & $0.00 \mathrm{E}+00$ & $1.53 \mathrm{E}+00$ & $0.00 \mathrm{E}+00$ \\
\hline Crib Base & 15 to 23 & 64 & 7.73 & $1.39 \mathrm{E}-01$ & 8 & 1.77 & $1.63 \mathrm{E}+03$ & $2.89 \mathrm{E}+09$ & $1.85 \mathrm{E}-01$ & $2.23 \mathrm{E}+01$ & 4.01E-01 \\
\hline H2 (shallow contam) & 23 to 30 & 35 & 7.69 & $3.05 \mathrm{E}-03$ & 7 & 1.77 & $1.43 \mathrm{E}+03$ & $2.53 \mathrm{E}+09$ & 8.84E-02 & $1.94 \mathrm{E}+01$ & $7.71 \mathrm{E}-03$ \\
\hline H2 (mid 1 contam) & 30 to 35 & 37.1 & 0.35 & $5.40 \mathrm{E}-03$ & 5 & 1.77 & $1.02 \mathrm{E}+03$ & $1.80 \mathrm{E}+09$ & $6.69 \mathrm{E}-02$ & $6.26 \mathrm{E}-01$ & $9.74 \mathrm{E}-03$ \\
\hline $\mathrm{H} 2$ & 48 to 58 & 55.3 & 0.37 & $6.09 \mathrm{E}-04$ & 10 & 1.77 & $2.04 \mathrm{E}+03$ & $3.61 \mathrm{E}+09$ & $2.00 \mathrm{E}-01$ & $1.35 \mathrm{E}+00$ & $2.20 \mathrm{E}-03$ \\
\hline $\mathrm{H} 2$ & 58 to 78 & 53.3 & 0.37 & 4.63E-04 & 20 & 1.77 & $4.08 \mathrm{E}+03$ & $7.22 \mathrm{E}+09$ & $3.85 \mathrm{E}-01$ & $2.65 \mathrm{E}+00$ & $3.34 \mathrm{E}-03$ \\
\hline H2 fine grain-1 & 78 to 85 & 75 & 0.34 & $8.40 \mathrm{E}-04$ & 7 & 1.77 & $1.43 \mathrm{E}+03$ & $2.53 \mathrm{E}+09$ & $1.89 \mathrm{E}-01$ & $8.59 \mathrm{E}-01$ & $2.12 \mathrm{E}-03$ \\
\hline $\mathrm{H} 2$ fine grain-2 & 85 to 110 & 72.6 & 0.35 & $1.03 \mathrm{E}-03$ & 25 & 1.77 & $5.10 \mathrm{E}+03$ & $9.02 \mathrm{E}+09$ & $6.55 \mathrm{E}-01$ & $3.17 \mathrm{E}+00$ & $9.32 \mathrm{E}-03$ \\
\hline H2 deep & 110 to 140 & 47.2 & 0.35 & $3.83 \mathrm{E}-04$ & 30 & 1.77 & $6.12 \mathrm{E}+03$ & $1.08 \mathrm{E}+10$ & $5.11 \mathrm{E}-01$ & $3.79 \mathrm{E}+00$ & $4.15 \mathrm{E}-03$ \\
\hline $\mathrm{H} 2$-fine grain-3 & 140 to 160 & 71 & 0.36 & $3.51 \mathrm{E}-04$ & 20 & 1.77 & $4.08 \mathrm{E}+03$ & $7.22 \mathrm{E}+09$ & $5.13 \mathrm{E}-01$ & $2.56 \mathrm{E}+00$ & $2.54 \mathrm{E}-03$ \\
\hline $\mathrm{CCUg}$ & & & & & & & & deep 90 & $2.83 \mathrm{E}+00$ & $1.20 \mathrm{E}+01$ & $1.37 \mathrm{E}-02$ \\
\hline Area=Black-8 Footprints & $3753.3 \mathrm{~m}^{2}$ & $\mathrm{pCi} / \mathrm{g}$ & $\mathrm{ug} / \mathrm{g}$ & $\mathrm{ug} / \mathrm{g}$ & thickness & $\rho_{\mathrm{b}}$ & Volume & Sed Mass & $\mathrm{Tc}$ & $\mathrm{U}(\mathrm{AE})$ & $\mathrm{U}(\mathrm{WE})$ \\
\hline Layer & Depth Interval & $\mathrm{Tc}$ & $\mathrm{U}(\mathrm{AE})$ & $\mathrm{U}(\mathrm{WE})$ & $\mathrm{ft}$ & $\mathrm{g} / \mathrm{cm}^{3}$ & $\mathrm{~m}^{3}$ & $\mathrm{~g}$ & $\mathrm{Ci}$ & $\mathrm{kg}$ & $\mathrm{kg}$ \\
\hline Overburden & 0 to 10 & 0 & 0.3 & $5.00 \mathrm{E}-04$ & 10 & 2.15 & $1.14 \mathrm{E}+04$ & $2.46 \mathrm{E}+10$ & $0.00 \mathrm{E}+00$ & $7.38 \mathrm{E}+00$ & $1.23 \mathrm{E}-02$ \\
\hline Backfill & 10 to 15 & 0.003 & 0.45 & $2.90 \mathrm{E}-03$ & 5 & 2.15 & $5.72 \mathrm{E}+03$ & $1.23 \mathrm{E}+10$ & 3.69E-05 & $5.53 \mathrm{E}+00$ & $3.57 \mathrm{E}-02$ \\
\hline Crib Base & 15 to 23 & 0.003 & 7.73 & 4.82E-02 & 8 & 1.77 & $9.15 \mathrm{E}+03$ & $1.62 \mathrm{E}+10$ & $4.86 \mathrm{E}-05$ & $1.25 \mathrm{E}+02$ & 7.80E-01 \\
\hline H2 (shallow contam) & 23 to 30 & 0.221 & 0.34 & 4.84E-02 & 7 & 1.77 & $8.01 \mathrm{E}+03$ & $1.42 \mathrm{E}+10$ & $3.13 \mathrm{E}-03$ & $4.82 \mathrm{E}+00$ & $6.86 \mathrm{E}-01$ \\
\hline H2 (mid 1 contam) & 30 to 35 & 1.291 & 0.35 & $5.40 \mathrm{E}-03$ & 5 & 1.77 & $5.72 \mathrm{E}+03$ & $1.01 \mathrm{E}+10$ & $1.31 \mathrm{E}-02$ & $3.54 \mathrm{E}+00$ & $5.46 \mathrm{E}-02$ \\
\hline $\mathrm{H} 2$ (mid 2 contam) & 35 to 42 & 71.283 & 0.34 & $2.49 \mathrm{E}-03$ & 7 & 1.77 & $8.01 \mathrm{E}+03$ & $1.42 \mathrm{E}+10$ & $1.01 \mathrm{E}+00$ & $4.82 \mathrm{E}+00$ & $3.53 \mathrm{E}-02$ \\
\hline H2 (high contam) & 42 to 48 & 107.9 & 0.37 & 4.99E-04 & 6 & 1.77 & $6.86 \mathrm{E}+03$ & $1.21 \mathrm{E}+10$ & $1.31 \mathrm{E}+00$ & $4.50 \mathrm{E}+00$ & $6.06 \mathrm{E}-03$ \\
\hline $\mathrm{H} 2$ & 48 to 58 & 30.9 & 0.37 & $6.09 \mathrm{E}-04$ & 10 & 1.77 & $1.14 \mathrm{E}+04$ & $2.02 \mathrm{E}+10$ & $6.26 \mathrm{E}-01$ & $7.49 \mathrm{E}+00$ & $1.23 \mathrm{E}-02$ \\
\hline $\mathrm{H} 2$ & 58 to 78 & 12.294 & 0.37 & 4.63E-04 & 20 & 1.77 & $2.29 \mathrm{E}+04$ & $4.05 \mathrm{E}+10$ & $4.98 \mathrm{E}-01$ & $1.50 \mathrm{E}+01$ & $1.87 \mathrm{E}-02$ \\
\hline
\end{tabular}


Table 3.7 (cont). Inventory Estimates for Technetium and Uranium in Vadose Zone Below BY Cribs Facility Conceptual Model \#3

\begin{tabular}{|c|c|c|c|c|c|c|c|c|c|c|c|}
\hline $\begin{array}{l}\text { Area }=\text { Black- } 8 \text { Footprints } \\
\text { Layer }\end{array}$ & $\begin{array}{c}3753.3 \mathrm{~m}^{2} \\
\text { Depth Interval }\end{array}$ & $\begin{array}{c}\mathrm{pCi} / \mathrm{g} \\
\mathrm{Tc}\end{array}$ & $\begin{array}{c}\mathrm{ug} / \mathrm{g} \\
\mathrm{U}(\mathrm{AE})\end{array}$ & $\begin{array}{c}\mathrm{ug} / \mathrm{g} \\
\mathrm{U}(\mathrm{WE})\end{array}$ & $\begin{array}{c}\text { thickness } \\
\mathrm{ft}\end{array}$ & $\begin{array}{c}\rho_{\mathrm{b}} \\
\mathrm{g} / \mathrm{cm}^{3}\end{array}$ & $\begin{array}{l}\text { Volume } \\
\mathrm{m}^{3}\end{array}$ & $\begin{array}{c}\text { Sed Mass } \\
\mathrm{g}\end{array}$ & $\mathrm{Ci}^{\mathrm{Tc}}$ & $\begin{array}{l}\mathrm{U}(\mathrm{AE}) \\
\mathrm{kg}\end{array}$ & $\begin{array}{l}\mathrm{U}(\mathrm{WE}) \\
\mathrm{kg}\end{array}$ \\
\hline $\mathrm{H} 2$ fine grain-1 & 78 to 85 & 37.058 & 0.34 & $8.40 \mathrm{E}-04$ & 7 & 1.77 & $8.01 \mathrm{E}+03$ & $1.42 \mathrm{E}+10$ & $5.25 \mathrm{E}-01$ & $4.82 \mathrm{E}+00$ & $1.19 \mathrm{E}-02$ \\
\hline H2 fine grain-2 & 85 to 110 & 66.186 & 0.34 & $1.03 \mathrm{E}-03$ & 25 & 1.77 & $2.86 \mathrm{E}+04$ & $5.06 \mathrm{E}+10$ & $3.35 \mathrm{E}+00$ & $1.72 \mathrm{E}+01$ & $5.23 \mathrm{E}-02$ \\
\hline H2 deep & 110 to 140 & 14.012 & 0.35 & $3.80 \mathrm{E}-04$ & 30 & 1.77 & $3.43 \mathrm{E}+04$ & $6.07 \mathrm{E}+10$ & $8.51 \mathrm{E}-01$ & $2.13 \mathrm{E}+01$ & $2.31 \mathrm{E}-02$ \\
\hline H2-fine grain-3 & 140 to 160 & 5.145 & 0.34 & 4.29E-04 & 20 & 1.77 & $2.29 \mathrm{E}+04$ & $4.05 \mathrm{E}+10$ & $2.08 \mathrm{E}-01$ & $1.38 \mathrm{E}+01$ & $1.74 \mathrm{E}-02$ \\
\hline $\mathrm{H} 2 \& \mathrm{CCU}_{\mathrm{z}}$ & 160 to 190 & 0.003 & 0.32 & $3.44 \mathrm{E}-04$ & 30 & 1.77 & $3.43 \mathrm{E}+04$ & $6.07 \mathrm{E}+10$ & $1.82 \mathrm{E}-04$ & $1.94 \mathrm{E}+01$ & $2.09 \mathrm{E}-02$ \\
\hline $\mathrm{CCUz}$ and $\mathrm{CCU}_{\mathrm{g}}$ & 190 to 225 & 0.003 & 0.32 & $3.98 \mathrm{E}-04$ & 35 & 2.15 & $4.00 \mathrm{E}+04$ & $8.61 \mathrm{E}+10$ & $2.58 \mathrm{E}-04$ & $2.75 \mathrm{E}+01$ & $3.42 \mathrm{E}-02$ \\
\hline \multirow[t]{2}{*}{ CCUg } & 225 to 231.5 & 0.003 & 0.32 & $2.80 \mathrm{E}-04$ & 6.5 & 2.15 & $7.44 \mathrm{E}+03$ & $1.60 \mathrm{E}+10$ & $4.80 \mathrm{E}-05$ & $5.12 \mathrm{E}+00$ & 4.48E-03 \\
\hline & & & & total $\mathrm{ft}$ & 231.5 & & & $\begin{array}{c}\text { sum } \\
\text { deep } 90\end{array}$ & $\begin{array}{r}8.40 \mathrm{E}+00 \\
1.93 \mathrm{E}-01\end{array}$ & $\begin{array}{l}2.87 \mathrm{E}+02 \\
6.48 \mathrm{E}+01\end{array}$ & $\begin{array}{r}1.81 \mathrm{E}+00 \\
7.57 \mathrm{E}-02\end{array}$ \\
\hline $\begin{array}{l}\text { Area }=\text { Green Lateral } \\
\text { Spread Border }\end{array}$ & $7086.4 \mathrm{~m}^{2}$ & $\mathrm{pCi} / \mathrm{g}$ & $\mathrm{ug} / \mathrm{g}$ & $\mathrm{ug} / \mathrm{g}$ & thickness & $\rho_{b}$ & Volume & Sed Mass & Tc & $\mathrm{U}(\mathrm{AE})$ & $\mathrm{U}(\mathrm{WE})$ \\
\hline Layer & & $\mathrm{Tc}$ & $\mathrm{U}(\mathrm{AE})$ & $\mathrm{U}(\mathrm{WE})$ & $\mathrm{ft}$ & $\mathrm{g} / \mathrm{cm} 3$ & $\mathrm{~m} 3$ & $\mathrm{~g}$ & $\mathrm{Ci}$ & $\mathrm{kg}$ & $\mathrm{kg}$ \\
\hline Overburden & 0 to 10 & 0 & 0.3 & $5.00 \mathrm{E}-04$ & 10 & 2.15 & $2.16 \mathrm{E}+04$ & $4.64 \mathrm{E}+10$ & $0.00 \mathrm{E}+00$ & $1.39 \mathrm{E}+01$ & $2.32 \mathrm{E}-02$ \\
\hline Backfill & 10 to 15 & 0.003 & 0.45 & $2.90 \mathrm{E}-03$ & 5 & 2.15 & $1.08 \mathrm{E}+04$ & $2.32 \mathrm{E}+10$ & $6.97 \mathrm{E}-05$ & $1.04 \mathrm{E}+01$ & $6.73 \mathrm{E}-02$ \\
\hline Crib Base & 15 to 23 & 0.003 & 7.73 & 4.82E-02 & 8 & 1.77 & $1.73 \mathrm{E}+04$ & $3.06 \mathrm{E}+10$ & $9.18 \mathrm{E}-05$ & $2.36 \mathrm{E}+02$ & $1.47 \mathrm{E}+00$ \\
\hline H2 (shallow contam) & 23 to 30 & 0.221 & 0.34 & 4.84E-02 & 7 & 1.77 & $1.51 \mathrm{E}+04$ & $2.68 \mathrm{E}+10$ & $5.90 \mathrm{E}-03$ & $9.10 \mathrm{E}+00$ & $1.29 \mathrm{E}+00$ \\
\hline H2 (mid 1 contam) & 30 to 35 & 1.291 & 0.35 & $5.40 \mathrm{E}-03$ & 5 & 1.77 & $1.08 \mathrm{E}+04$ & $1.91 \mathrm{E}+10$ & $2.47 \mathrm{E}-02$ & $6.69 \mathrm{E}+00$ & $1.03 \mathrm{E}-01$ \\
\hline H2 (mid 2 contam) & 35 to 42 & 71.283 & 0.34 & $2.49 \mathrm{E}-03$ & 7 & 1.77 & $1.51 \mathrm{E}+04$ & $2.68 \mathrm{E}+10$ & $1.91 \mathrm{E}+00$ & $9.10 \mathrm{E}+00$ & $6.66 \mathrm{E}-02$ \\
\hline H2 (high contam) & 42 to 48 & 107.9 & 0.37 & 4.99E-04 & 6 & 1.77 & $1.30 \mathrm{E}+04$ & $2.29 \mathrm{E}+10$ & $2.48 \mathrm{E}+00$ & $8.49 \mathrm{E}+00$ & $1.14 \mathrm{E}-02$ \\
\hline $\mathrm{H} 2$ & 48 to 58 & 30.9 & 0.37 & $6.09 \mathrm{E}-04$ & 10 & 1.77 & $2.16 \mathrm{E}+04$ & $3.82 \mathrm{E}+10$ & $1.18 \mathrm{E}+00$ & $1.41 \mathrm{E}+01$ & $2.33 \mathrm{E}-02$ \\
\hline $\mathrm{H} 2$ & 58 to 78 & 12.294 & 0.37 & 4.63E-04 & 20 & 1.77 & $4.32 \mathrm{E}+04$ & $7.65 \mathrm{E}+10$ & $9.40 \mathrm{E}-01$ & $2.83 \mathrm{E}+01$ & $3.54 \mathrm{E}-02$ \\
\hline H2 fine grain-1 & 78 to 85 & 37.058 & 0.34 & $8.40 \mathrm{E}-04$ & 7 & 1.77 & $1.51 \mathrm{E}+04$ & $2.68 \mathrm{E}+10$ & $9.92 \mathrm{E}-01$ & $9.10 \mathrm{E}+00$ & $2.25 \mathrm{E}-02$ \\
\hline H2 fine grain-2 & 85 to 110 & 66.186 & 0.34 & $1.03 \mathrm{E}-03$ & 25 & 1.77 & $5.40 \mathrm{E}+04$ & $9.56 \mathrm{E}+10$ & $6.33 \mathrm{E}+00$ & $3.25 \mathrm{E}+01$ & $9.87 \mathrm{E}-02$ \\
\hline H2 deep & 110 to 140 & 14.012 & 0.35 & $3.80 \mathrm{E}-04$ & 30 & 1.77 & $6.48 \mathrm{E}+04$ & $1.15 \mathrm{E}+11$ & $1.61 \mathrm{E}+00$ & $4.01 \mathrm{E}+01$ & 4.36E-02 \\
\hline $\mathrm{H} 2$-fine grain-3 & 140 to 160 & 5.145 & 0.34 & 4.29E-04 & 20 & 1.77 & $4.32 \mathrm{E}+04$ & $7.65 \mathrm{E}+10$ & $3.93 \mathrm{E}-01$ & $2.60 \mathrm{E}+01$ & $3.28 \mathrm{E}-02$ \\
\hline $\mathrm{H} 2 \& \mathrm{CCUz}$ & 160 to 190 & 0.003 & 0.32 & $3.44 \mathrm{E}-04$ & 30 & 1.77 & $6.48 \mathrm{E}+04$ & $1.15 \mathrm{E}+11$ & $3.44 \mathrm{E}-04$ & $3.67 \mathrm{E}+01$ & $3.94 \mathrm{E}-02$ \\
\hline CCUz and CCUg & 190 to 225 & 0.003 & 0.32 & $3.98 \mathrm{E}-04$ & 35 & 2.15 & $7.56 \mathrm{E}+04$ & $1.63 \mathrm{E}+11$ & $4.88 \mathrm{E}-04$ & $5.20 \mathrm{E}+01$ & $6.46 \mathrm{E}-02$ \\
\hline \multirow[t]{2}{*}{ CCUg } & 225 to 231.5 & 0.003 & 0.32 & $2.80 \mathrm{E}-04$ & 6.5 & 2.15 & $1.40 \mathrm{E}+04$ & $3.02 \mathrm{E}+10$ & $9.06 \mathrm{E}-05$ & $9.66 \mathrm{E}+00$ & $8.45 \mathrm{E}-03$ \\
\hline & & & & total $\mathrm{ft}$ & 231.5 & & & $\begin{array}{c}\text { sum } \\
\text { deep } 90\end{array}$ & $\begin{array}{l}1.59 \mathrm{E}+01 \\
3.65 \mathrm{E}-01\end{array}$ & $\begin{array}{l}5.43 \mathrm{E}+02 \\
1.22 \mathrm{E}+02\end{array}$ & $\begin{array}{l}3.41 \mathrm{E}+00 \\
1.43 \mathrm{E}-01\end{array}$ \\
\hline
\end{tabular}


In conceptual model \#1 the distribution of contaminants has been set within the literal footprints of the eight cribs based solely on the measured contaminant concentrations in the two boreholes 299-E33296 and -302. As seen in Table 3.2, Table 3.3 and Figure 3.7, Figure 3.11, Figure 3.12, and Figure 3.16, the depth discrete sampling for these two boreholes was not as frequent as for the new boreholes 299E33-341 and 299-E33-342. In conceptual model \#1 the sediment vertical concentration profile for technetium-99 and acid extractable uranium within the BY Crib footprints was generated for 12 sediment layers by averaging depth discrete concentration values for the two boreholes within BY Crib footprints and performing averages for each layer based on the concentration values for discrete samples within and/or close to the tops and bottoms of the chosen layers. Because there were not sediment water extract uranium measurements made on the sediments from boreholes 299-E33-296 and 299-E33-302, it was assumed that $2 \%$ of the acid extractable uranium was water extractable. This value is based on averaging the percentage of water extractable to acid extractable uranium ratio for the sediments from borehole 299E33-341 that contained elevated levels of uranium. In conceptual models \#2 and \#3, the vertical distribution of sediment technetium-99 and uranium concentrations in the BY Cribs footprints were estimated for 16 layers by averaging discrete sample concentrations from the three boreholes 299-E33296, E33-302, and E33-341. The higher density of samples in borehole E33-341 allow more layers to be delineated to better capture the irregular vertical distributions of contaminants shown in Figure 3.7 through Figure 3.16. Especially noteworthy are the thin high concentration peaks found associated with fine grained sediment layers that are not generally captured when sample density versus depth is sparse. Adding the additional layers allow for capturing the higher concentration thin peaks in a more realistic fashion. For conceptual models \#1 and \#2, the vertical distribution of contaminants below the black rectangle (space between the eight cribs out to the contiguous perimeter around the BY Cribs was developed for sixteen sediment layers assuming sediment concentrations based on averaging the data from the three boreholes 299-E33-296, E33-302, and E33-341. This estimate is equivalent to assuming lateral spreading below the contiguous BY Cribs has contaminated the sediments with the same concentrations as found below the BY Cribs footprints. For conceptual model \#3, the sediments below the black rectangle and between the eight crib footprints are assumed to be in the less contaminated with a vertical distribution the same as that created from the sediment concentrations found solely at 299-E33341. This contaminant distribution assumes less lateral spreading of the high concentrations for both technetium-99 and uranium estimated to be below the footprints. All three conceptual models add the lower concentration $20-\mathrm{m}$ lateral spreading beyond the black rectangular contiguous crib perimeter in order to honor the spectral gamma logging and soil electrical resistivity survey lateral spreading findings as well as the direct measurement of sediment concentrations at borehole 299-E33-341, which is $\sim 19.8 \mathrm{~m}$ away from borehole 299-E33-302 directly through the B-49 Crib. The green border in all three conceptual models uses the vertical distribution of sediment concentrations generated from constructing the 16 layers and values of technetium-99, acid and water extractable uranium found in borehole 299E33-341 sediments. It is assume that the 20-m lateral spreading occurs equally in all four directions outside the BY Crib perimeter. In reality, the spectral gamma logging and soil resistivity field survey suggest more lateral spreading occurred to the northeast than to the southwest of the BY cribs perimeter. The lateral spreading was also greater than the $20-\mathrm{m}$ assumed; however, no actual sediment concentration values for technetium-99 or uranium can be gleaned from the spectral gamma logging or soil resistivity field survey. Further, based on the very low technetium-99 and natural background acid extractable uranium concentrations found in the sediments at 299-E33-342, which is $34 \mathrm{~m}$ away from borehole 299-E33-296 that resides within the footprint of B-43 Crib, it was concluded that the mass of 
contaminants remaining in the vadose zone out beyond the assumed $20-\mathrm{m}$ lateral spreading zone is small in comparison to the mass within the three regions chosen.

The assumed vertical distributions of technetium-99 and uranium sediment concentrations are shown in Figure 3.22 through Figure 3.24 for BY Cribs conceptual models \#1, \#2, and \#3, respectively. These three figures show the various sediment layers and contaminant values for each of the three areas that constitute the region chosen to encompass the technetium-99 and uranium wastes disposed of to the BY Cribs. The mass estimates for each of the three conceptual models shown in Table 3.5 through Table 3.7 are found in more detail in Appendix I, which includes the logic and equations used. Table 3.8 presents the sums of the mass of technetium-99, water extractable (i.e., mobile uranium) and acid extractable uranium for all three areas chosen for each conceptual model and compares these mass estimates to the total masses disposed to the BY Cribs, based on SIM Model calculations. Recall that in the first conceptual model, it is assumed that the technetium-99 and uranium within the footprints of the BY Cribs have a vertical distribution based on average values found in sediments from boreholes 299E33-296 and E33-302. In between the cribs the sediment concentrations for the two contaminants were estimated from averaging the sediment data from three boreholes (299-E33-296, E33-302, and E33-341 and finally the lateral spreading region was allocated sediment concentrations based on averaging and interpolating values from E33-341.

For the second conceptual model, the assumption is that the concentrations below the cribs footprints and in between the cribs have the same vertical distribution derived from averaging and interpolating sediment concentrations from the three boreholes (299-E33-296, E33-302 and E33-341 are lower and the same as found in borehole 299-E33-341. The farther lateral spread region was the same as used for conceptual model \#1. The difference between conceptual models \#1 and \#2 attempts to capture differences in near crib lateral spreading with model \#2 assuming more lateral spreading that "homogenized" sediment concentrations within the entire BY Crib perimeter area. The third conceptual model assumes that more elevated sediment concentrations within the BY Cribs' footprints do not spread laterally throughout the area between crib footprints; rather the area between crib footprints is assigned sediment concentrations the same as found at borehole 299-E33-341, which is $\sim 20 \mathrm{~m}$ southwest from the center of B-49 Crib.

The key points shown the conceptual model mass estimates (Table 3.8) are that the sediments below the BY Cribs contain from $\sim 23$ to $43 \%$ of the technetium- 99 disposed of to the cribs, and about 3 to 21 curies are deep in the vadose zone within $90 \mathrm{ft}$ of the water table, depending on which conceptual model is chosen to represent lateral spreading. Most of the deeply retained technetium-99 is within the BY Cribs "perimeter" (the region within the black rectangle in Figure 3.21). The mass estimates for total uranium remaining in the vadose zone sediments range from 85 to $114 \%$ of the total mass disposed of to the BY Cribs. Elevated concentrations of uranium are found mainly within the crib footprints at between 18.5 and $21 \mathrm{ft}$ bgs (see Table 3.2 and Table 3.3 ) suggesting that uranium likely precipitated near the bottom of the cribs. The next two depths sampled were about 26 to 27 and 47 or $57 \mathrm{ft} \mathrm{bgs,} \mathrm{dependent} \mathrm{on} \mathrm{crib.} \mathrm{The}$ uranium concentrations measured between 26 and $56 \mathrm{ft}$ bgs were much lower to below the detection limit. Thus, the true vertical distribution of uranium below the BY crib footprints likely has a relatively thin zone with high concentrations with a rapid drop-off in concentrations over the next 30 to $35 \mathrm{ft}$. The three conceptual models assumed that the high concentrations of uranium was distributed over zones situated between 15 to $50 \mathrm{ft}$ (conceptual model \#1) and 15 to $30 \mathrm{ft}$ (conceptual models \#2 and \#3) The conceptual models for the vertical distribution of uranium beyond the crib footprints assume that uranium spreads 
PNNL-19277

Table 3.8. Estimates of Masses of Technetium-99 and Uranium Remaining in Vadose Zone Sediment in BY Cribs for Three Conceptual Models

\begin{tabular}{|c|c|c|c|c|c|c|c|}
\hline & & \multicolumn{3}{|c|}{ Mass in Total VZ } & \multicolumn{3}{|c|}{ Mass in Deep VZ } \\
\hline \multirow[b]{2}{*}{ Conceptual Model } & & Te $(\mathrm{Ci})$ & $\underline{\mathrm{U}}(\underline{\mathrm{AE}})-\underline{\mathrm{kg}}$ & U(WE)-kg & $\underline{\mathrm{T}} \mathrm{c}(\mathrm{Ci})$ & $\mathrm{U}(\mathrm{AE})-\mathrm{kg}$ & U(WEE)-kg \\
\hline & & i & & & i & & \\
\hline \multirow{5}{*}{$\# 1$} & Footprint & 7.89 & 270.92 & 5.42 & 4.60 & 19.17 & 0.38 \\
\hline & In Btwn Cribs & 31.81 & 396.07 & 2.62 & 15.89 & 67.53 & 0.08 \\
\hline & Lateral Spread & 15.85 & 542.62 & 3.41 & 0.36 & 122.42 & 0.14 \\
\hline & Sum & 55.55 & 1209.6 & 11.45 & 20.86 & 209.11 & 0.60 \\
\hline & Footprint & 5.67 & 70.60 & 0.47 & 2.83 & 12.04 & 0.01 \\
\hline \multirow{3}{*}{$\# 2$} & In Btwn Cribs & 31.81 & 396.07 & 2.62 & 15.89 & 67.53 & 0.08 \\
\hline & Lateral Spread & 15.85 & 542.62 & 3.41 & 0.36 & 122.42 & 0.14 \\
\hline & Sum & 53.33 & 1009.28 & 6.50 & 19.09 & 201.98 & 0.23 \\
\hline \multirow{5}{*}{$\# 3$} & & i & & & i & & \\
\hline & Footprint & 5.67 & 70.60 & 0.47 & 2.83 & 12.04 & 0.01 \\
\hline & In Btwn Cribs & 8.40 & 287.39 & 1.81 & 0.19 & 64.84 & 0.08 \\
\hline & Lateral Spread & 15.85 & 542.62 & 3.41 & 0.36 & 122.42 & 0.14 \\
\hline & Sum & 29.92 & 900.61 & 5.68 & | 3.39 & 199.29 & 0.23 \\
\hline & & \multicolumn{3}{|c|}{$\%$ in VZ vs. Total Disposed } & \multicolumn{3}{|c|}{ \% in Deep VZ vs. Total Disposed } \\
\hline \multirow{6}{*}{ Conceptual Model } & & $\mathrm{T} \mathrm{Tc}$ & $\mathrm{U}(\mathrm{AE})$ & $\mathrm{U}(\mathrm{WE})$ & T $\quad$ Tc & $\mathrm{U}(\mathrm{AE})$ & $\mathrm{U}(\mathrm{WE})$ \\
\hline & & $i$ & & & i & & \\
\hline & Footprint & $6.1 \%$ & $25.6 \%$ & $0.51 \%$ & $3.6 \%$ & $1.8 \%$ & $0.036 \%$ \\
\hline & In Btwn Cribs & $24.7 \%$ & $37.4 \%$ & $0.25 \%$ & $12.3 \%$ & $6.4 \%$ & $0.01 \%$ \\
\hline & Lateral Spread & $12.3 \%$ & $51.2 \%$ & $0.32 \%$ & $0.3 \%$ & $11.5 \%$ & $0.01 \%$ \\
\hline & Sum & $43.1 \%$ & $114.1 \%$ & $1.1 \%$ & $16.2 \%$ & $19.7 \%$ & $0.06 \%$ \\
\hline \multirow{4}{*}{$\# 2$} & Footprint & i $4.4 \%$ & $6.7 \%$ & $0.04 \%$ & $2.2 \%$ & $1.1 \%$ & $0.00 \%$ \\
\hline & In Btwn Cribs & $24.7 \%$ & $37.4 \%$ & $0.25 \%$ & $12.3 \%$ & $6.4 \%$ & $0.01 \%$ \\
\hline & Lateral Spread & $12.3 \%$ & $51.2 \%$ & $0.32 \%$ & $0.3 \%$ & $11.5 \%$ & $0.01 \%$ \\
\hline & Sum & $41.3 \%$ & $95.2 \%$ & $0.6 \%$ & $14.8 \%$ & $19.1 \%$ & $0.02 \%$ \\
\hline \multirow{4}{*}{$\# 3$} & Footprint & $4.4 \%$ & $6.7 \%$ & $0.04 \%$ & $2.2 \%$ & $1.1 \%$ & $0.00 \%$ \\
\hline & In Btwn Cribs & $6.5 \%$ & $27.1 \%$ & $0.17 \%$ & $0.1 \%$ & $6.1 \%$ & $0.01 \%$ \\
\hline & Lateral Spread & $12.3 \%$ & $51.2 \%$ & $0.32 \%$ & $0.3 \%$ & $11.5 \%$ & $0.01 \%$ \\
\hline & Sum & $23.2 \%$ & $85.0 \%$ & $0.5 \%$ & $2.6 \%$ & $18.8 \%$ & $0.02 \%$ \\
\hline
\end{tabular}


laterally only near $20 \mathrm{ft}$ bgs. The significance of the conceptual models, which are based on the measurement of depth discrete sediment samples, is that very little of the uranium disposed of to the BY cribs has migrated far below or far in a lateral direction. At borehole 299-E33-341, about $47 \mathrm{ft}$ from the northwest edge of B-48, sediment samples were measured for uranium about every $2.5 \mathrm{ft}$. The results show elevated uranium only at $20 \mathrm{ft}$ bgs, which likely represents a contact with the bottom of the excavation where compaction and the transition from gravel backfill below the crib bottoms to the undisturbed Hanford formation sediments. Borehole 299-E33-341 is beyond the crib excavation and shows no presence of backfill; however, liquids disposed of in the cribs likely spread at this depth throughout the excavation and were driven farther horizontally by the hydraulic head of the disposed fluids.

The water-extractable portion of the total uranium in sediments from the BY Cribs region is quite small, and the conceptual models lead to estimates that less than $1.1 \%$ (6 to $11.5 \mathrm{~kg}$ ) of the total disposed uranium inventory is readily mobile. Currently in the deep vadose zone, it is estimated that less than $0.05 \%(<0.5 \mathrm{~kg})$ of the total uranium disposed to BY Cribs is mobile (readily water leachable). These technetium-99 and uranium mass estimates, based on the available measurements of sediments from four boreholes (two within crib footprints and two off to the side of cribs and outside the crib excavation), suggests that all of the uranium disposed of to the cribs is still present shallow within the vadose zone sediments and areally constrained to a region predominately within the BY Crib perimeter with very little water extractable uranium present beyond the crib's "fence line" and even less deep in the vadose zone. The chemical composition of the scavenged waste does not appear to form highly mobile uranium species that would be readily leachable by water.

\subsection{BX Trenches Subregion}

In this subsection, the available borehole sediment characterization data, field gamma logging and electrical resistivity data are tabulated and compared with the known volumes and masses of waste chemicals and radionuclides released to the subsurface. Subsequently, a conceptual model is constructed for key waste constituents remaining in the vadose zone sediments.

\subsubsection{BX Trenches Facilities and Source Details}

The BX specific retention trenches are located north of the B Plant and west of the BX Tank Farm as highlighted in purple in Figure 3.25. The reader should refer back to this figure to aid in understanding the following the discussion. Several historical drawings suggest that there were as many as 11 trenches oriented in an east to west direction in a north-south row west of the BX Tank Farm. However, several of the trenches on the northern end of this row may not have been excavated or if so were not used. There is also one trench, B-42, west of the southern end of the row of BX Trenches. The main BX Trenches in the row are numbered B-35 through B-41D, going from south to north up the row. In some historical documents, the northern end of the row has five trenches numbered B-41, B-41A, B-41B, B-41C, and B41D from south to north. It is this B-41 series of trenches that appears to have never been constructed based on geophysical surveys with various ground penetrating tools and conclusions found in the most current version of the WIDS database. 


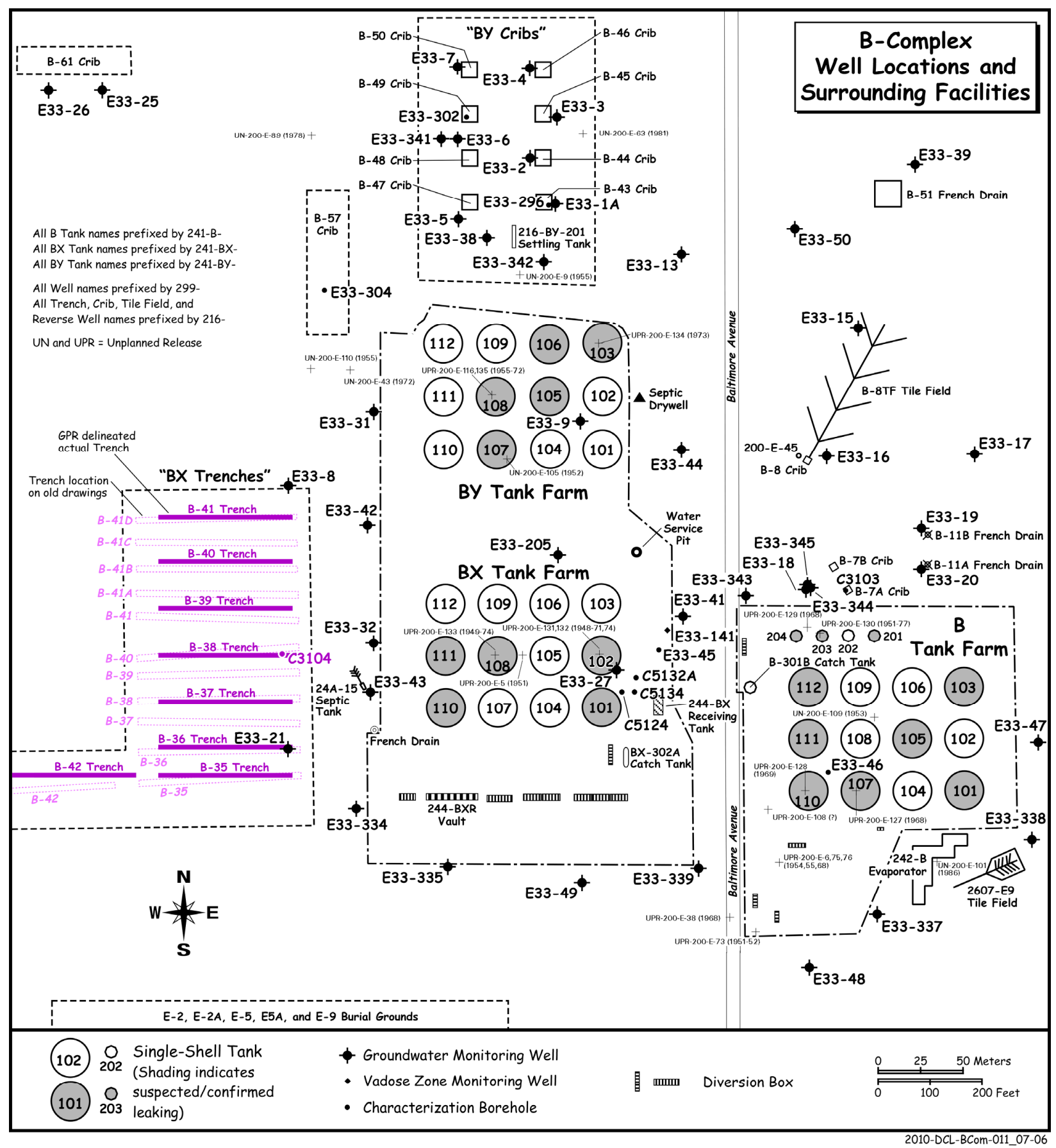

Figure 3.25. BX Trench Subregion Map with Facilities and Key Boreholes and Wells Highlighted 
Disposal to the BX trenches was active during 1954 and 1955. The disposal was necessary to provide the tank space needed to support additional fuel-separations operations in the 200 East and West Areas. The waste disposed was first-cycle supernate except B-42 Trench, which received scavenged tributyl phosphate supernatant waste. Based on the inventory and volume of waste disposed per square foot of trench area the disposal criteria for the BX Trenches was more conservative than at the BY Cribs. The BX Trenches were considered "specific retention" disposal facilities. The volume of liquid waste was limited to disposing only enough liquid waste to fill $10 \%$ of the facility's footprint from the trench bottom to the water table. This criterion was designed to limit the migration of waste fluids and to enhance the adsorption of cesium and strontium within the shallow vadose zone sediments.

The waste originated at B Plant and T Plant that used the Bismuth Phosphate process to separate plutonium from irradiated fuel collectively from 1944 through 1956. The first step in the process was to dissolve the metal coating from the fuel rods. The next step dissolved the uranium and extracted the plutonium. This step created the metal waste stream that contained the bulk of the uranium and $\sim 90 \%$ of the total beta activity, which included cesium-137 and strontium-90. The plutonium stream went through two additional decontamination cycles to purify it, producing the first- and second-cycle waste streams. The first-cycle waste stream contained $\sim 10 \%$ of the total beta activity of the long-lived fission products and a small amount of the plutonium. The liquid first- and second-cycle waste was initially stored in SSTs in tank farms. By 1948, limited space in the tank farms resulted in the decision to discharge the second-cycle waste to cribs. In 1951, the 242-B and 242-T Evaporators began to concentrate the firstcycle waste to reduce the volume of waste stored in the tank farms. By 1953, the need for additional tank space resulted in the first-cycle waste that was being stored in the SSTs to be discharged via over-ground pipelines to specific retention trenches. Some specific retention trenches received the waste from the bottoms of the 242-B and 242-T Evaporator tank or TBP waste from the uranium recovery process.

Details on the types of waste, volumes of liquid disposed of, and time period of the disposal to the BX Trenches are shown in Table 3.9. There are a few discrepancies between the SIM and WIDS information as noted.

\subsubsection{BX Trenches Vadose Zone}

The available data for the BX Trenches consists of historical geophysical logs, a soil resistivity survey and one sediment collection activity through the footprint of the B-38 Trench. The field logging data (spectral gamma and neutron) and interpretation are found in DOE/GJO (2002b). Figure 3.26, taken from DOE/GJO (2002b), shows a 3D geostatistically based visualization of the subsurface distribution of cobalt-60 under and around the BX Trenches in the early 1990s.

A brief summary of the findings from DOE/GJO (2002b) report and pertinent to the scope of this current report follows. Cobalt-60 was detected in all the boreholes drilled within the B-36 and -38 Trenches and north of the B-41 Trench in the interval from 30 to $72 \mathrm{ft}$ at activities ranging up to 0.6 $\mathrm{pCi} / \mathrm{g}$. Activities have now decayed to trace amounts $(0.1$ to $0.6 \mathrm{pCi} / \mathrm{g})$ because of the relatively short half-life of cobalt-60 (about 5.2 years). The cobalt-60 contamination detected at depths from 30 to $72 \mathrm{ft}$ resulted from discharges to the BX trenches. Unlike the visualization for the BY cribs (see Figure 3.3), the cobalt-60 is not found extensively throughout the vadose zone profile or all the way to the water table within the footprints of the BX Trenches and is not interpreted as being present in the areas between 
Table 3.9. BX Trench Details

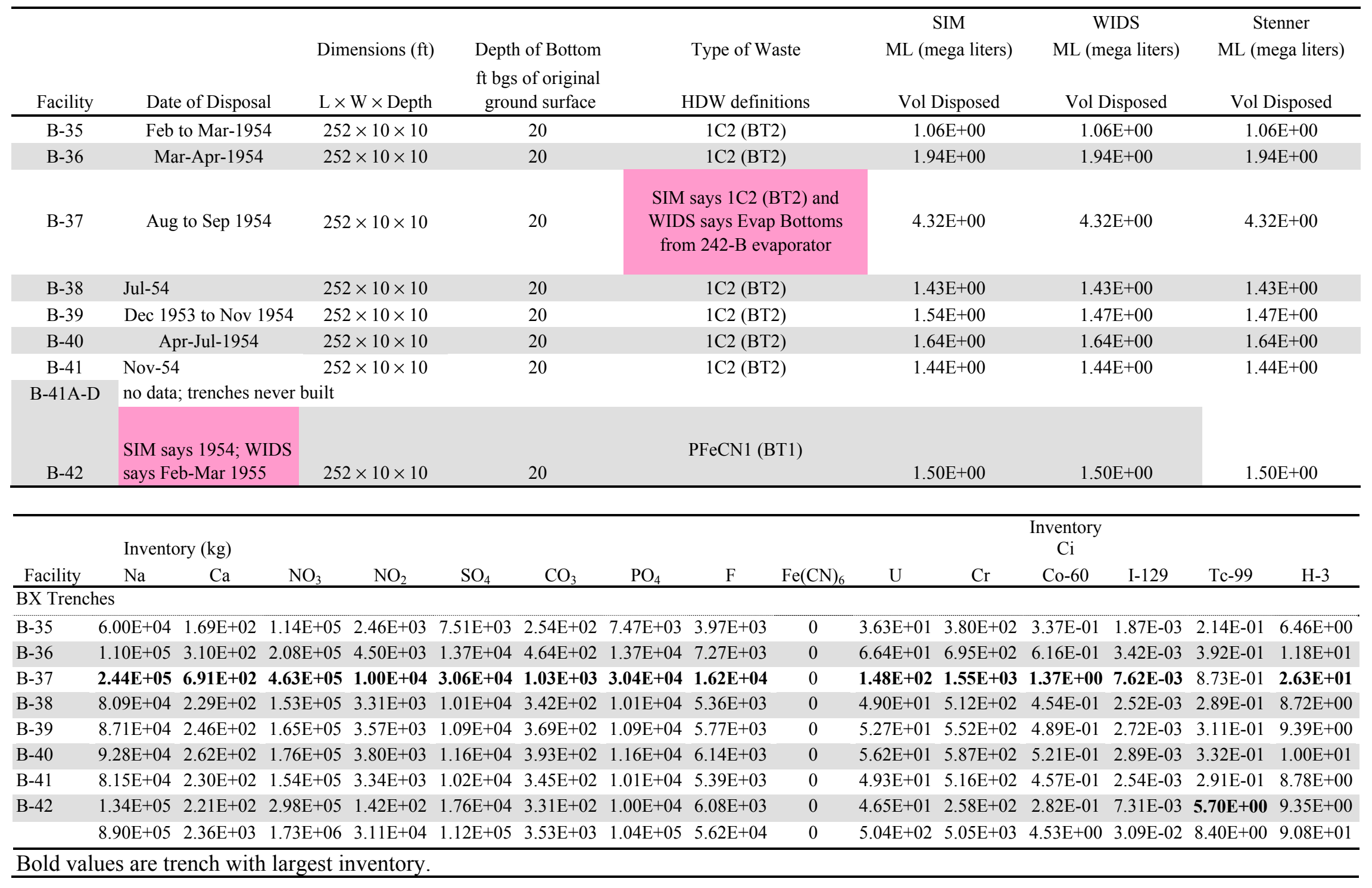


PNNL-19277
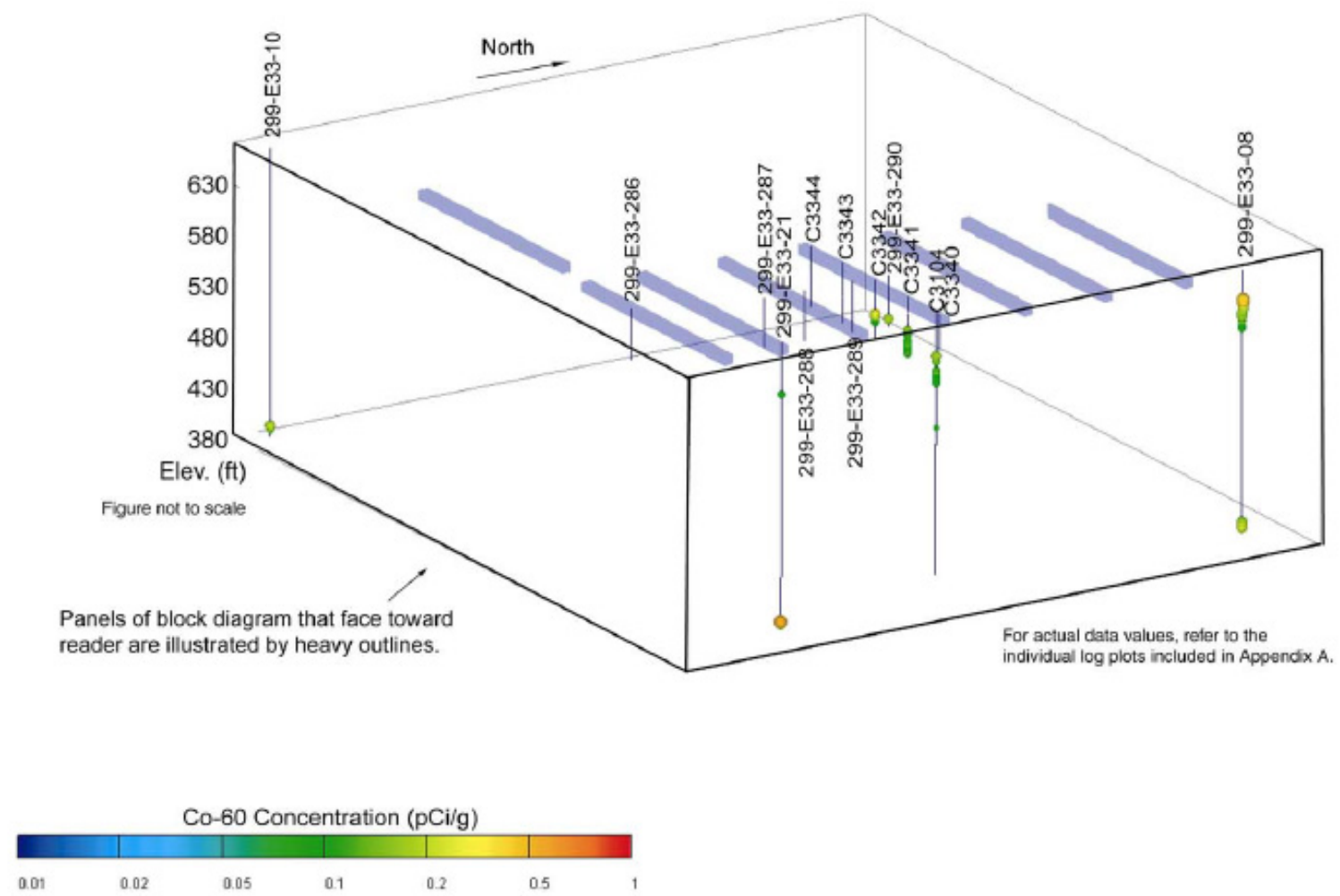

Figure 3.26. Visualization of Cobalt-60 Distribution Below and Proximal to the BX Trenches

the trenches. A small amount of cobalt-60 appears to have spread locally to the east (following the stratigraphic dip of on the dip of the $\mathrm{H} 2$ unit sediments), but the degree and amount of lateral spread is much less than under the BY Cribs. That is, the waste liquids that contained the cobalt-60 did not spread laterally throughout the entire region below the BX trenches because of the limited volume disposed in comparison to the subsurface below the BY Cribs. In addition, DOE/GJO (2002b) notes that where comparisons could be made between earlier (pre-1998) gamma logs and logs in the early 2000s, no significant changes in gamma contaminant profiles were evident. This lack of migration suggests that there has been little to no movement of contaminants in the vadose zone below the BX Trenches for a few decades.

On the other hand, cobalt-60 was detected using gamma logs through the casings in the groundwater in all of the nearby groundwater wells for several decades and currently is found at activities ranging from 0.1 to $0.3 \mathrm{pCi} / \mathrm{g}$ at the water table. This cobalt-60 signal at the groundwater table is likely activity precipitated in casing corrosion products sourced from contamination that was in the groundwater in the mid 1950s through 1960s, most likely from disposal to the BY Cribs to the northeast. Spectral gamma logging in early 2000 along the long axis of the B-38 trench in shallow boreholes suggests that waste liquids did not spread past the center of this trench and by inference other BX Trenches. This would imply that the specific retention capacity of the BX Trenches may have been overestimated during active disposal (that is the wastes percolated into the vadose zone over a smaller area than the trench footprint, thus allowing for potential breakthrough to groundwater). Trench B-37 received about 28 percent of the total liquid volume and about 96 percent of the ${ }^{137} \mathrm{Cs}$ discharged to the BX Trenches so it would be the most likely candidate for impacting groundwater. 
A review of historical gross gamma logs suggests that groundwater in the BX Trench area may have contained fission waste products as early as 1957. One review (see Brodeur et al. 1993 for more detailed discussion) of historical gross and spectral gamma logging results for groundwater monitoring well 299E33-21 (south of B-37 Trench), and the total discharge volume to each BX Trench suggest that waste fluid discharges to the B-37 Trench may have reached groundwater. However, an alternate hypothesis for the source of the groundwater contaminants below the BX Trenches is the BY Cribs or BY Tank Farm (Fecht et al. 1977). Because no boreholes have been drilled directly in or near B-37 Trench, a major data gap exists with regard to verifying the vertical extent of contamination in and around the B-37 Trench to determine which hypothesis better fits the source of contamination found in the groundwater at 299-E3321. DOE/GJO (2002b) recommended that a characterization borehole be drilled to groundwater near the eastern end of B-37 trench and that sediment samples be directly characterized. The authors of this conceptual model report would add recommendations to emphasize sediment collection and characterization at depths where elevated moisture is found, including near 110 and $220 \mathrm{ft}$ bgs. At this time the authors of this conceptual model report favor the hypothesis that liquid wastes and mobile contaminants disposed to the BX Trenches have not reached groundwater in any significant amounts.

The field electrical resistivity survey results were interpreted with several inversion models and suggest the following (see Rucker et al. 2007 for details). The results (cross sectional view) of the B-35 through B-42 western trenches are shown in Figure 3.27. As expected, a low resistivity anomaly was identified beneath the cribs and trenches where liquid wastes were discharged in the past. The electrical resistivity inverted data shown in Figure 3.27 do suggest that at depths between $\sim 60$ and $\sim 200 \mathrm{ft}$ bgs that a high conductivity plume is continuous below the entire BX Trench region and that the highest concentration (see white shaded region) is centered below the B-37 Crib, which, as noted, received the largest volume of waste. In comparison to similar inverted models at the BY Cribs region shown in Figure 3.4 through Figure 3.6, the interpreted BX Trench high conductivity plume does not extend as deep and probably does not reach the water table. It also should be noted that the surface resistivity approach tends to "smear" the bottom edge of the high conductivity anomaly, and it may not be a true approximation for the depth of the plume. It is likely that the bottom edge of the high conductivity plume is closer to the ground surface than the inverted low resistivity results would suggest. While the resistivity work associated with the BX Trenches supports and confirms the sampling data (to be discussed next) that indicate that the majority of the material disposed to these structures remains high in the vadose zone; it does not absolve these facilities as potential sources of groundwater contamination.

In the summer of 2001, five shallow-drive-point boreholes were pushed down to $60 \mathrm{ft}$ bgs inside the footprint of the B-38 trench. The five shallow boreholes were distributed along the length of the $250-\mathrm{ft}$ long trench. Each of the drive point boreholes was logged with a spectral gamma detector to determine the presence of gamma-emitting radionuclides. The gamma logging showed that the three boreholes on the eastern half of the trench contained high concentrations of gamma emitters, but the two westernmost boreholes contained no detectable manmade gamma activity excepting very near the ground surface (DOE/GJO 2002b). The inlet to the trench was on the eastern end of the trench, and most of the disposed fluids percolated into the ground before reaching the far end of the trench. Based on the shallow borehole results, one deep borehole (C3104) was drilled using cable-tool drive barrel and split-spoon sampling inside the eastern end of the B-38 Trench footprint down to $263.5 \mathrm{ft} \mathrm{bgs}$ as shown in Figure 3.25. The temporary casing was driven to $259.6 \mathrm{ft}$ bgs, and the final $4 \mathrm{ft}$ was sampled beyond the casing using a 5-in. OD split spoon sampler. Eighteen cores, each 2.5-ft long, were obtained during the drilling. Twenty homogenized sediment samples from 12 depth intervals were analyzed for total concentrations of selected 
metals, radionuclides, and anions. Several months after the drilling operation was completed, three of the drums containing drilling cuttings were opened, and one sample from each drum was collected and sent to PNNL for additional chemical analyses. The waste drums were marked as to which depths the drill cutting came from such that estimated depths for the three sediment samples could be made. Table 3.10 shows some of the chemical characterization data collected on the homogenized sediment samples. Details on the drilling of the borehole are found in Todd and Trice (2002). All the data collected are found in the HEIS database. In addition, the characterization results from three sediment samples taken from waste drums are found in Lindenmeier et al. (2002). Preliminary risk evaluations for the B-38 Trench, based on the data collected by Todd and Trice (2002), are found in DOE/RL (2003).

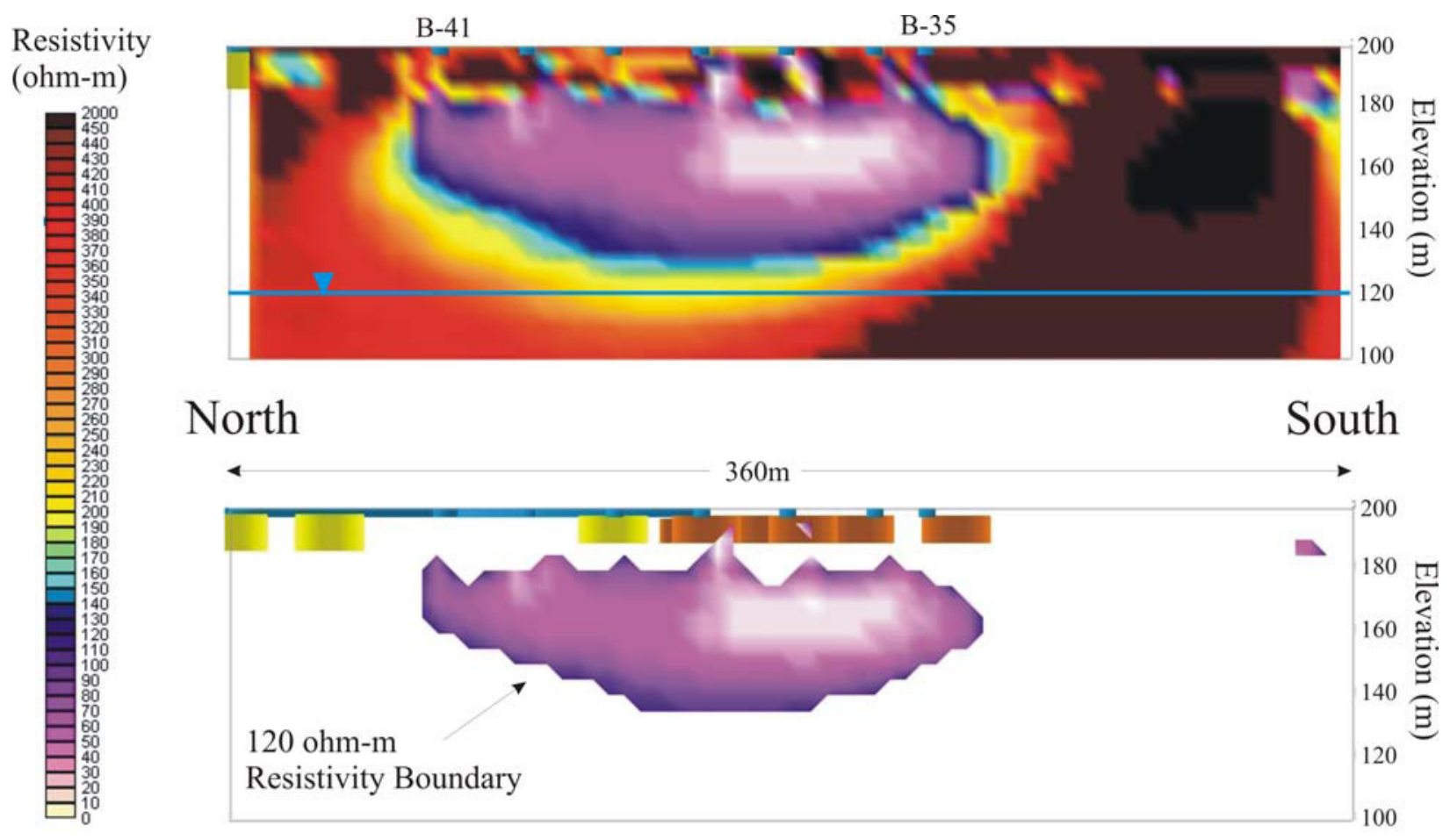

Figure 3.27. Inverted Soil Resistivity Data for BX Trenches (from Rucker et al. 2007)

The vertical distribution for nitrate in borehole C 3104 through the eastern end of the B-38 trench is shown in Figure 3.28, and although depth coverage in the deep vadose zone is not good (approximately one sample every $50 \mathrm{ft}$ ), the bulk of the nitrate and the disposed fluids is found above $150 \mathrm{ft}$ bgs. The nitrate concentration in the sample at $198.75 \mathrm{ft}$ bgs also is higher than Hanford background levels. The nitrate distribution shows its highest concentrations between 60 and $160 \mathrm{ft}$ bgs. The highest nitrate concentration is at about the depth interval for one of the fine-grained thin lenses, H2F3, at $\sim 160 \mathrm{ft}$ bgs. Unfortunately, the sediment sampling at this borehole was not frequent enough to identify the presence of other thin fine grained layers. The water table is at $\sim 265 \mathrm{ft}$ bgs.

The concentrations of other potentially mobile constituents, such as cyanide, fluoride, nitrite, and technetium-99, are so small that most of the results were below detection limits. The full data set, which includes spectral gamma logging through the casing of C3104, suggests that the bottom of the trench is currently about $18 \mathrm{ft}$ bgs and immobile contaminants such as americium-241, plutonium-239, and 
cesium-137 are detectable from about 15 to $38.75 \mathrm{ft}$ bgs and generally drop below detection by about 50 $\mathrm{ft}$ bgs. Fluoride is present at rather high concentrations ( 15 to $35 \mu \mathrm{g} / \mathrm{g}$ ) in the vadose zone sediments between the depths of 20 and $40 \mathrm{ft}$ bgs at C3104. However, as shown in Figure 3.29, the elevated fluoride concentrations are relatively shallow in the B-38 trench footprint and do not reach the water table.

Technetium-99 concentrations are $\sim 2 \mathrm{pCi} / \mathrm{g}$ at $53 \mathrm{ft}$ bgs, and had one other detection $(\sim 1 \mathrm{pCi} / \mathrm{g})$ observed at $\sim 150 \mathrm{ft}$ bgs. The strong acid-extractable uranium concentrations in the $\mathrm{C} 3104$ sediments are within the range for uncontaminated sediments, and the water-extractable uranium in the three samples sent to PNNL is also not elevated compared to uncontaminated sediments. No uranium isotopic analyses were performed on water extracts from sediments from borehole C3104 because the water extracts did not contain elevated concentrations of uranium and would not have been useful for determining an isotope signature for wastes disposed of to the BX trenches.

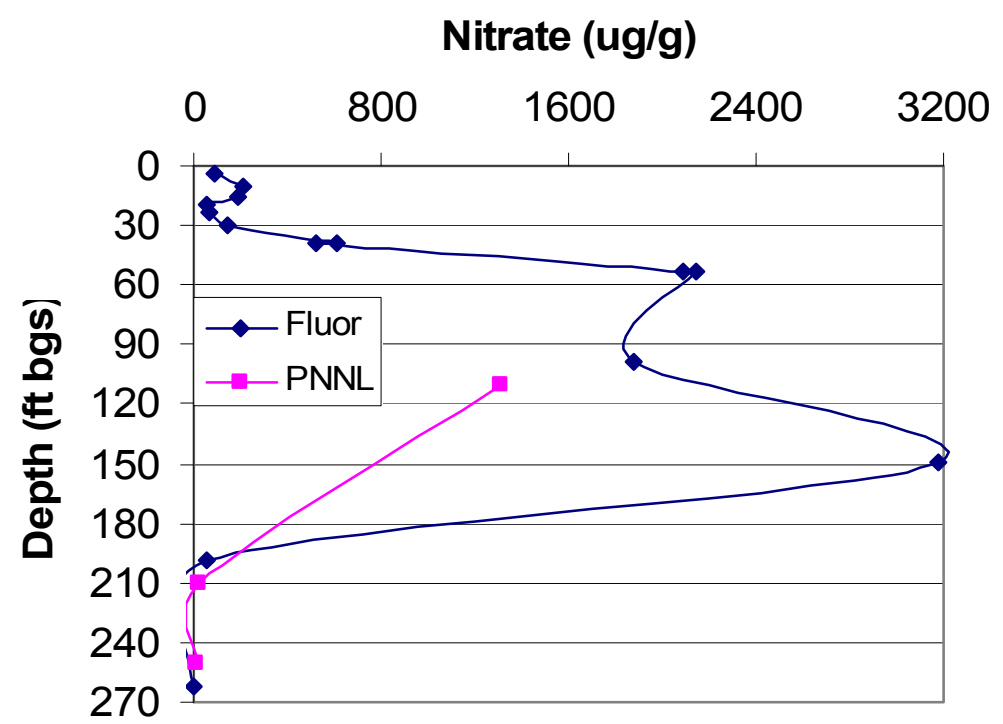

Figure 3.28. Vertical Distribution on Nitrate in Sediments Within Footprint of B-38 Trench

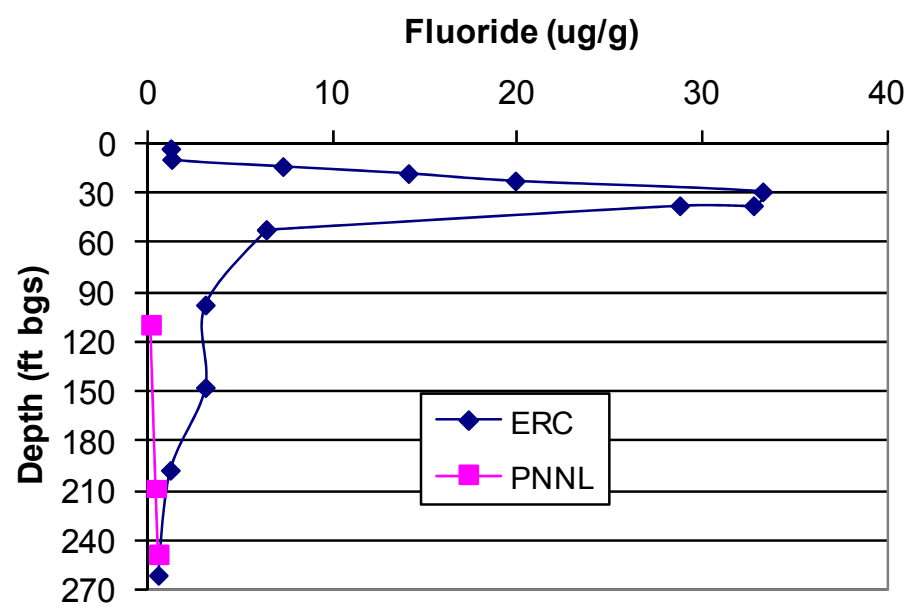

Figure 3.29. Vertical Distribution on Fluoride in Sediments Within Footprint of B-38 Trench 
PNNL-19277

\subsubsection{BX Trenches Vadose Zone Conceptual Model}

After review of the records on the types of waste, volumes of waste, time of disposal, characterization data, and geophysical surveys the following conceptual model for mobile vadose zone contaminants of concern in this subregion is proposed. Waste liquids disposed of to the B-38 Trench, the only trench with sediment samples that were directly characterized, likely have not reached the groundwater during since the active disposal in 1954.

The only mobile constituent that is present at large enough concentrations to develop a good vertical distribution is nitrate as shown in Figure 3.28; it still resides in the upper 150 to no deeper than $180 \mathrm{ft}$ bgs. The profile indicates that the majority of the nitrate inventory is in the upper portion of the vadose zone (e.g., primarily between 30 and $150 \mathrm{ft}$ bgs). In addition, historical gross gamma logs suggest that contamination was limited to the upper portion of the vadose zone based on DOE/GJO (2002b). However, groundwater wells 299-E33-8 and 299-E33-21 located adjacent the BX Trench area have detected manmade gamma-emitting radionuclides. Upon review of the groundwater reports the elevated gross gamma was probably associated with cobalt-60 from the BY Cribs. Note because there is no definitive and unique constituent associated with the BX Trench disposals in comparison to other cribs and tank farm releases in this area, it is difficult to differentiate whether the BX Trenches have contributed to groundwater contamination solely from the study of groundwater results.

Although characterization results at the B-38 Trench, the geophysical results (e.g., gross gamma and electrical resistivity) provide a direct means to evaluate these trenches the data is limited. One limit is that the characterization results are not available for all the depths where fine-grained layers are suspected. Another limitation is that the B-38 Trench only received 1.43 million liters versus B-37 that received 4.32 million liters. Finally, the B-42 Trench received a different waste stream and contaminants may migrate differently in the vadose zone sediments below B-42 than found at B-38 Trench. Thus, although the available data indicate that the BX Trench wastes have not reached groundwater, based on the B-38 Trench data there may have been groundwater contributions associated with other BX Trenches.

In summary based on the limit data set, the authors of this conceptual model report hypothesize that the BX Trench region has not and will not be a significant contributor to the groundwater plumes below the B-Complex. The hypothesis relies on the vadose zone profile of contaminants below the B-38 trench (see Table 3.10), which shows no contamination in the deep vadose zone, the spectral gamma logging not showing a continuous signal down to the water table and the relatively low inventory of contaminants in the relatively low volume of waste disposed, it appears that By comparison to the BY Cribs, the total liquid volume of waste disposed to the BX Trenches was only about $10 \%$ the volume disposed to the BY cribs, and the inventories of chemicals and radionuclides disposed to the BX trenches were about onethird to one-half the inventories disposed of to the BY cribs (data presented later in the Section 3.6. Therefore, even if the BX trenches did impact groundwater, the masses of constituents added would be masked by the masses provided by the wastes from the BY Cribs. 
Table 3.10. Vertical Distribution of Selected Constituents in Sediments from C3104 (B-38 Trench)

\begin{tabular}{|c|c|c|c|c|c|c|c|c|c|c|}
\hline C3104 & Environme & al Resto & on (ERC & ontractor & & & & & & \\
\hline $\begin{array}{c}\text { Depth } \\
\text { (ft bgs) }\end{array}$ & $\begin{array}{c}\mathrm{Na} \\
\mu \mathrm{g} / \mathrm{g}\end{array}$ & $\begin{array}{c}\mathrm{CN} \\
\mu \mathrm{g} / \mathrm{g}\end{array}$ & $\begin{array}{c}\mathrm{F} \\
\mu \mathrm{g} / \mathrm{g}\end{array}$ & $\begin{array}{c}\text { Nitrate } \\
\mu \mathrm{g} / \mathrm{g}\end{array}$ & $\begin{array}{c}\text { Nitrite } \\
\mu \mathrm{g} / \mathrm{g}\end{array}$ & $\begin{array}{c}\text { Sulfate } \\
\mu \mathrm{g} / \mathrm{g}\end{array}$ & $\begin{array}{c}\mathrm{Tc} \\
\mathrm{pCi} / \mathrm{g}\end{array}$ & $\begin{array}{c}\text { U-total } \\
\mu \mathrm{g} / \mathrm{g}\end{array}$ & $\begin{array}{c}\mathrm{U}-238 \\
\mu \mathrm{g} / \mathrm{g}\end{array}$ & $\begin{array}{c}\text { Phosphate } \\
\mu \mathrm{g} / \mathrm{g}\end{array}$ \\
\hline 4.25 & NA & $<0.43$ & $<2.66$ & 94.4 & $<2.62$ & 51.1 & $<0.3$ & 1.6 & 2.2 & 8.2 \\
\hline 10.75 & NA & $<0.44$ & $<2.75$ & 208 & $<1.34$ & 248 & $<0.3$ & 1.69 & 1.8 & 1.6 \\
\hline 15.00 & 551 & $<0.13$ & 7.4 & 193 & $<0.069$ & 114 & $<0.3$ & 11.3 & $<19.6$ & $<0.37$ \\
\hline 19.25 & 848 & $<0.13$ & 14.2 & 54.4 & $<0.069$ & 35 & $<0.3$ & 14.8 & 21.3 & 27.1 \\
\hline 23.75 & NA & 0.42 & 20 & 67.7 & $<0.069$ & 49.1 & $<0.3$ & 32.5 & $<18.9$ & 34.1 \\
\hline 30.25 & NA & 0.31 & 33.4 & 141 & $<0.069$ & 151 & $<0.3$ & 19.1 & $<24.6$ & 67.4 \\
\hline 38.75 & NA & $<0.13$ & 32.9 & 615 & $<0.069$ & 69.8 & $<0.3$ & 7.74 & 9.5 & 137 \\
\hline 38.75 & NA & $<0.13$ & 28.9 & 522 & $<0.069$ & 60.6 & $<0.3$ & 8.09 & 8.3 & 106 \\
\hline 53.25 & NA & $<0.5$ & $<12.9$ & 2090 & 34.3 & 106 & 1.9 & 2.9 & 2.6 & 149 \\
\hline 53.25 & NA & $<0.48$ & $<12.9$ & 2140 & 34.7 & 110 & 1.93 & 3.5 & 4.1 & 121 \\
\hline 98.75 & NA & $<0.47$ & $<6.4$ & 1880 & 35.2 & 131 & $<0.3$ & 0.934 & 1.5 & $<6.4$ \\
\hline 148.75 & NA & $<0.47$ & $<6.4$ & 3180 & 41.2 & 48.2 & 0.888 & 0.901 & 1.4 & $<6.4$ \\
\hline 198.75 & NA & $<0.41$ & $<2.6$ & 57.6 & $<2.56$ & 38.1 & $<0.3$ & 0.862 & 1.3 & $<2.6$ \\
\hline 262.25 & NA & $<0.45$ & $<1.3$ & 1.48 & $<1.31$ & 13.5 & $<0.3$ & 0.79 & 1.1 & $<1.3$ \\
\hline C3104 & PNNL & & & & & & & & & \\
\hline $\begin{array}{l}\text { Depth } \\
\text { (ft bgs) }\end{array}$ & $\begin{array}{c}\mathrm{Na}(\mathrm{WE}) \\
\mu \mathrm{g} / \mathrm{g}\end{array}$ & $\begin{array}{r}\mathrm{CN} \\
\mu \mathrm{g} / \mathrm{g}\end{array}$ & $\begin{array}{c}F \\
\mu \mathrm{g} / \mathrm{g}\end{array}$ & $\begin{array}{c}\text { Nitrate } \\
\mu \mathrm{g} / \mathrm{g}\end{array}$ & $\begin{array}{c}\text { Nitrite } \\
\mu \mathrm{g} / \mathrm{g}\end{array}$ & $\begin{array}{c}\text { Sulfate } \\
\mu \mathrm{g} / \mathrm{g}\end{array}$ & $\begin{array}{c}\mathrm{Tc} \\
\mathrm{pCi} / \mathrm{g}\end{array}$ & $\begin{array}{c}\mathrm{U}-238 \\
\mu \mathrm{g} / \mathrm{g}\end{array}$ & $\begin{array}{c}\mathrm{U}(\mathrm{WE}) \\
\mu \mathrm{g} / \mathrm{g}\end{array}$ & \\
\hline 110 & NA & NA & 0.187 & 1310 & 8.7 & 30 & $<0.08$ & 0.63 & $6.10 \mathrm{E}-04$ & \\
\hline 210 & NA & NA & 0.507 & 22.4 & $<0.7$ & 46.5 & $<0.08$ & 0.46 & 4.81E-04 & \\
\hline 250 & NA & NA & 0.651 & 6 & $<0.7$ & 54.4 & $<0.08$ & 0.50 & $4.71 \mathrm{E}-04$ & \\
\hline
\end{tabular}




\subsubsection{Mass Inventories BX Trenches}

Vadose zone sediment data are available from borehole C3104 in the BX Trench region such that inventory calculations similar to those in Section 3.1.9 for the BY Cribs subregion could be performed to estimate the residual mass in the vadose zone sediments; however, the total masses of technetium-99 and uranium disposed of to the BX Trenches were very low. Further, very low or undetectable concentrations of these two contaminants were observed in most of the C3104 sediments (see Table 3.10) so that this region does not warrant further attention. Also, there is only one borehole with direct measurements of sediment concentrations, so no quantitative estimate can be made for horizontal spreading within the vadose zone.

\subsection{B-7-A\&B and B-8 Cribs Subregion}

This subsection contains a discussion of the available borehole sediment, field gamma logging and electrical resistivity data in relationship with the volumes disposed of and mass of contaminants released). This information is used to construct a conceptual model of the current vadose zone distribution of key contaminants, including an estimate of masses remaining below and proximal to the B-7-A crib. This is the only facility for which there are direct measurements of the distribution of chemicals and radionuclides in the sediments (borehole $\mathrm{C} 3103$ ).

The key facilities and key boreholes that were evaluated for the B-7-A and B and B-8 Cribs subregion are shown in blue in Figure 3.30. The reader should refer back to this figure to aid in understanding the following the discussion.

\subsubsection{B-7-A\&B Cribs Facilities Description and Inventory Released}

The B-7-A\&B cribs site is located north of B Tank Farm and east of Baltimore Avenue (see blue highlighted facilities in Figure 3.30). The cribs are approximately 8.6 meters $(28.2 \mathrm{ft}$ ) apart. The northwest crib is B-7B, and the southeast crib is B-7A. The B-7A and B-7B cribs were constructed with

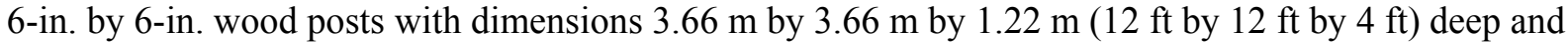
were placed side by side. Near the end of the time period available for finishing this report, there was a discrepancy in the facility construction details discovered. The WIDS description and Hanford drawings differ as to how the two cribs are connected. WIDS claims that the two cribs are connected by underground piping through a T-fitting in a pipeline from the 201-B settling tanks (B-201, B-202, B-203, and B-204) located inside the B Tank Farm. Further, WIDS claims that the T-fitting allows liquids to be disposed of simultaneously to both cribs. However Hanford drawings HW H-2-558, H-2-579, and H-22021 show that the pipeline from 201-B is connected solely to B-7-A crib and a separate pipe connects B7-A to B-7-B in a serial fashion. Process effluent from 221-B and 224-B was routed to the settling tanks from 1946 through 1967 and dispersed to the two cribs. In 1951, cell drainage from 221-B was diverted to the B-9 Crib. In 1954, the 224-B waste stream was diverted to the B-8 Crib when the B-7-A\&B cribs exceeded their liquid infiltration capacity. The B-7-A\&B cribs were reactivated and used intermittently from December 1954 through May 1967 when it was determined that they had reached their radionuclide capacity. A letter written by G.L. Hanson in September 1967 states that the cribs received approximately 49 million liters (13 million gallons) of process waste from 221-B and 224-B from 1946 through 1958. 
In 1992, a large Surface Contamination Area (UPR-200-E-144) was scraped and consolidated into a smaller area along the north side of the B Tank Farm. At its largest extent, UPR-200-E-144 encompassed approximately 10 hectares ( 25 acres) of soil contamination located north and east of the B Tank Farm. The contamination is assumed to have migrated out of the tank farm over years of operation. The contaminated soil was consolidated into a spoil pile adjacent to the north side of the B fence. The spoil pile is approximately 1.2 to 1.6 hectares ( 3 to 4 acres) in size. As a consequence of consolidating the contamination on the north side of the tank farm fence, the original ground surface at B-7A and B-7B, and B-11-A\&B French drains were covered with an additional 0.45 to 0.61 meters of clean backfill material was placed over the consolidated contamination. Summary details on these crib facilities and the others found to the north of the B Tank Farm are provided in Table 3.11. The SIM model does not list individual values for waste volumes disposed of or masses of material disposed of for B-7-A versus B-7-B. The staff who created SIM likely were under the impression that waste was sent simultaneously to both cribs as opposed to serially.

\subsubsection{B-7-A\&B/B-8 Cribs Vadose Zone}

For this analysis, the authors were under the impression that these two cribs were connected by a common waste inlet pipe, but it is now believed that all waste first entered B-7-A, and only excess volume that did not percolate into the subsurface sediments likely reached B-7-B. Regardless, the combined B-7-A\&B Crib facility received about equal masses of the major contaminants of interest, uranium and technetium-99 as the B-8 Crib (see Table 3.11). Also, the two B-7 cribs received about onethird more nitrate and almost twice as much chromium as the B-8 Crib and Tile Field. The other facilities (B-51 and B11-A\&B French Drains) in this subregion received much less mass of chemicals and radionuclides as shown in Table 3.11. In a regional comparison to the BY Cribs subregion, the B-7-A\&B and B-8 Cribs subregion received less sodium, nitrate, and nitrite, much less sulfate, uranium, technetium99, iodine-129 and tritium. Also the B-7A\&B and B-8 Cribs subregion received no cyanide. However, the B-7-A\&B and B-8 Cribs received about three times as much fluoride and chromium as the BY Cribs subregion (see Table 3.1). Thus, elevated groundwater fluoride and chromium concentrations in the vicinity of this subregion are good indicators of waste breakthrough to groundwater from the disposal facilities north of the B Tank Farm.

Nineteen vadose zone boreholes, 10 non-RCRA-compliant groundwater monitoring wells, and 3 RCRA-compliant groundwater monitoring wells in the B-7-A\&B and B-8 subregion were logged in early 2002 with the SGLS, and results and interpretation are found in DOE/GJO (2002a). The gamma contamination is generally sporadic or non-existent in the shallow vadose zone except in boreholes that are located within a contaminated waste site. Note that elevated gamma results were reported close to the B-7A Crib in May 1963, in boreholes 299-E33-58, 299-E33-59, and 299-E33-60 throughout the wells' lengths (149 ft bgs). However, in 2002 spectral gamma results did not find any cobalt-60, although over 0.3 curies were disposed. DOE/GJO (2002a) provides a 3D visualization, called "sphere plots," of the cobalt-60 logging results in the vicinity of the B-7A\&B cribs as shown in Figure 3.31. The gamma emitter observed in 1963 undoubtedly was ruthenium-106 that decayed quickly and thus was not observed in the SGLS logging in 2002. 


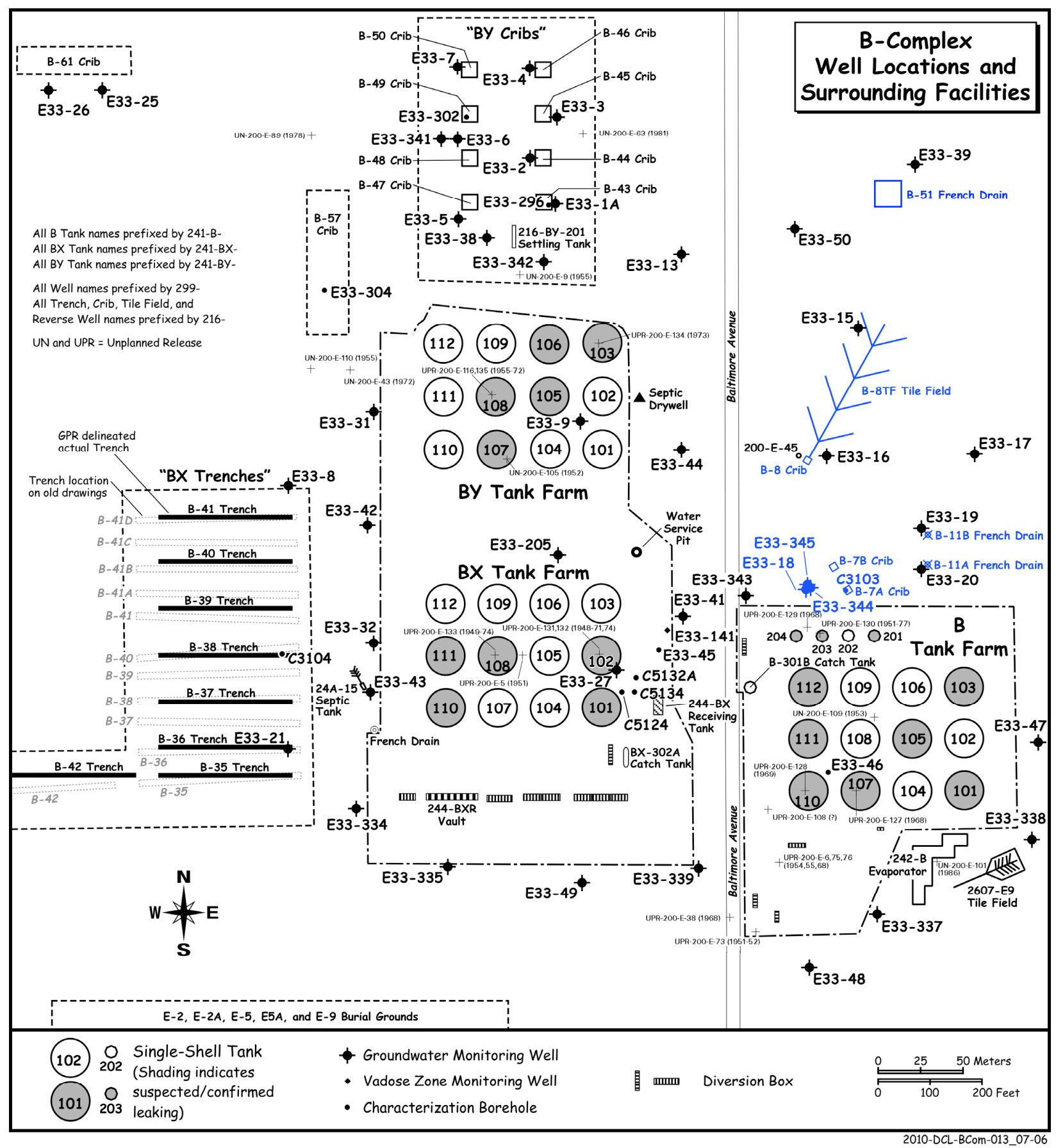

Figure 3.30. Location Map for B-7-A\&B/B-8 Cribs Subregion Facilities and Boreholes/Wells 
Table 3.11. Details on Facilities in B-7-A\&B/B-8 Cribs Subregion

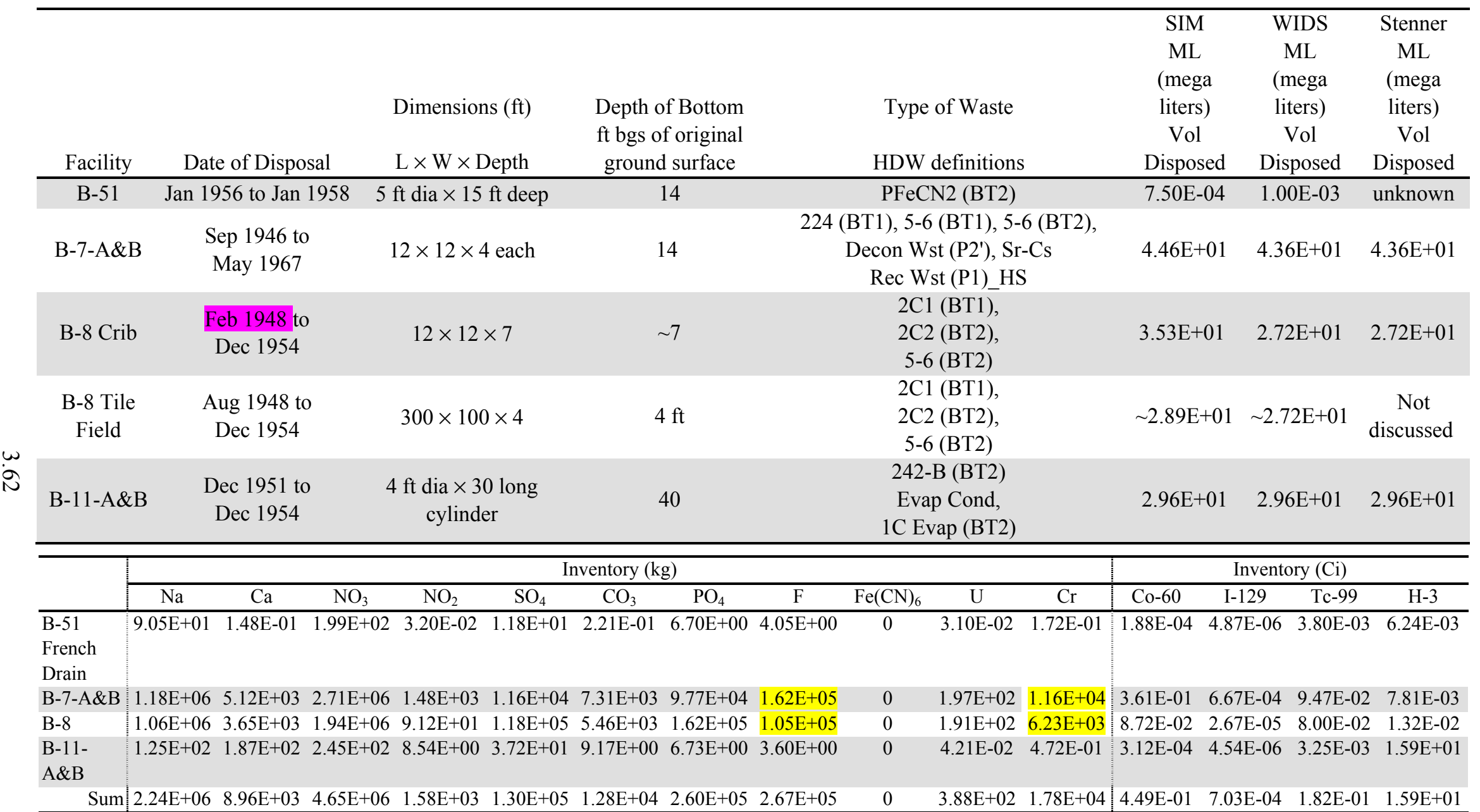

Pink highlight (one document suggests that B-8 Crib started receiving wastes in 1945).Yellow highlight = very high inventory compared to other B-Complex facilities. 
Interestingly, cobalt-60 was detected in borehole 299-E33-18, approximately 75 feet west of the B-7$\mathrm{A} \& \mathrm{~B}$ cribs within a fine grain sediment layer above the historical high groundwater level and within the groundwater. This contamination appears to be unrelated to the B-7-A\&B cribs based on the gamma logging data acquired from boreholes 299-E33-58, 299-E33-59, and 299-E33-60 within the B-7A Crib and borehole 299-E33-75, which is $60 \mathrm{ft}$ north of B-7-B Crib and down the vadose zone stratigraphic dip. The cobalt-60 also does not appear to be associated with the B-11-A French Drain based on comparison of waste inventories of cobalt-60 with the B-7A crib, which received approximately three orders of magnitude more cobalt-60 than B-11-A. An equally interesting finding related to the spectral gamma logging was the detection of Hanford processed uranium in borehole 299-E33-59 between depths of 41 to $53 \mathrm{ft}$ bgs at concentrations of $32 \mathrm{pCi} / \mathrm{g}(\sim 96 \mu \mathrm{g} / \mathrm{g})$. This dry well is located between the B-7-A and the B7-B cribs.

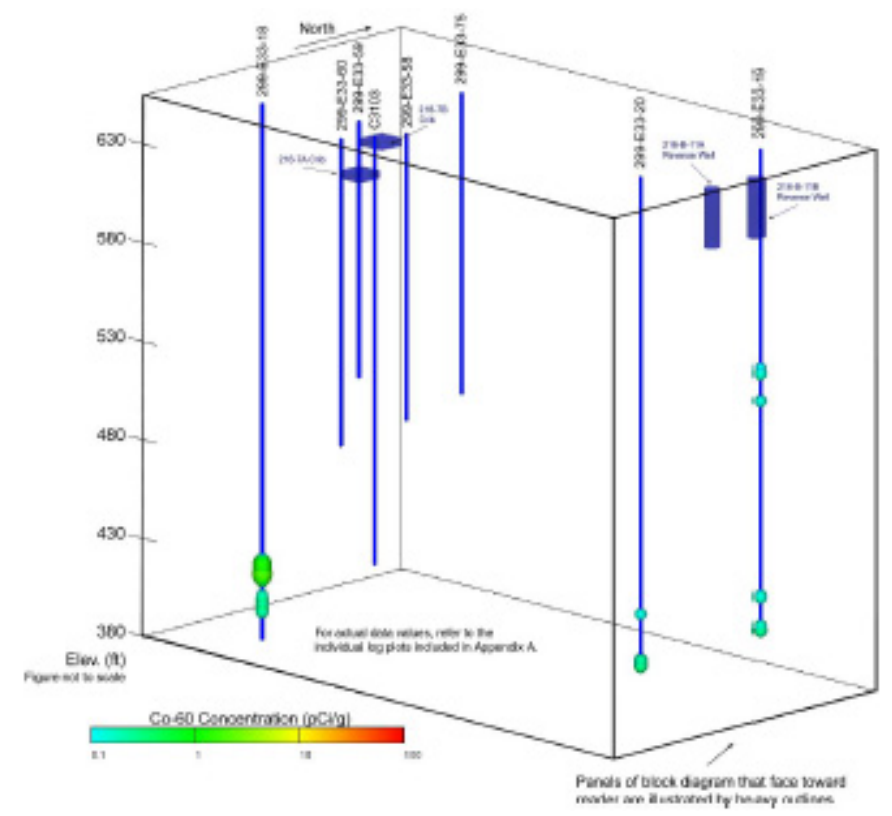

Figure 3.31. Spectral Gamma 3D Visualization of Cobalt-60 Vadose Zone Contamination Around B-7A\&B Cribs and B-11A\&B French Drains (from DOE/GJO 2002a)

Cribs are square blue boxes on left and French Drains are blue cylinders on right.

Rucker et al. (2007) describe the field electrical resistivity survey performed in the vicinity of the B-7-A\&B Cribs and B-8 Crib and Tile Field. An isometric view of soil resistivity results for the inversion model is illustrated in Figure 3.32. The black box in Figure 3.32 defines the extent of the inversion domain. The inversion made use of all resistivity data collected at the 10-ft (3-m) electrode spacing. Figure 3.32 also provides a color demarcation of the two resistivity levels in the isometric view: 60 and $120 \mathrm{ohm}-\mathrm{m}$. The $60 \mathrm{ohm}-\mathrm{m}$ value is represented in red, and the $120 \mathrm{ohm}-\mathrm{m}$ level is represented with a transparent green. 
PNNL-19277

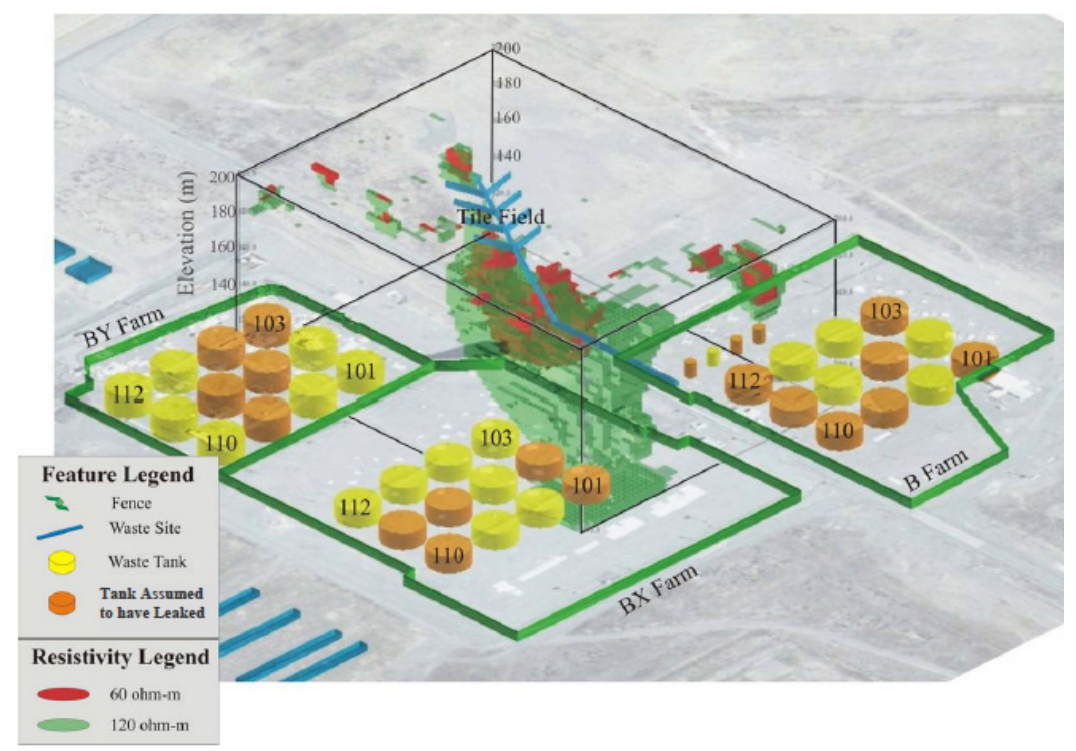

Figure 3.32. Isometric View of Soil Resistivity Data Below the B-7-A\&B and B-8 Crib and Tile Field (from Rucker et al. 2007)

Plan views of the soil resistivity inversion results at 33, 98, and $164 \mathrm{ft}(10,30$, and 50 meters) bgs are illustrated in Figure 3.33, and a cross-sectional profile through the B-8 Crib and Tile Field is shown in Figure 3.34. The footprint of the anomaly in Figure 3.34 shows a low resistivity region primarily beneath the tile-field portion of the B-8 Crib as well as below the B-7-A\&B cribs and B-11-A\&B French Drains (at the southern boundary of the inversion domain). A smaller low resistivity feature can be seen to the northeast of the B-8 crib and tile field, which coincides with the location of the B-51 Crib. Evaluating inversion modeling results at various depths (Figure 3.33 and Figure 3.34) suggests a strong possibility that the low-resistivity anomaly may extend all the way to the water table, which is found at a depth of about $260 \mathrm{ft}$ ( 80 meters). However, since vertical information from inversion is known to be smeared, especially at the bottom of a low-resistivity anomaly, the interpretation of inversion results should be confirmed separately with direct measurements of the vadose zone sediments.

In the fall of 2001, a borehole was drilled using cable-tool drive barrel and split-spoon sampling inside the footprint of the B-7A crib. Temporary casing of various diameters were pushed down to $218 \mathrm{ft}$ bgs, and an additional split-spooning sample was collected from the sediments to a total depth of $222.5 \mathrm{ft}$ bgs. Temporary casing of various diameters was pushed down to $218 \mathrm{ft} \mathrm{bgs}$, and additional split-spoon samples were obtained a total depth of $222.5 \mathrm{ft}$ bgs. Twenty-two cores, each $\sim 2.5 \mathrm{ft}$ long, were obtained during the drilling. Homogenized sediment samples from 14 depth intervals were analyzed for total concentrations of selected metals, radionuclides, and anions. During the drilling of this borehole, C3103, the field crew also collected grab samples of the sediment "cuttings" as the sediment was removed from the drive barrel. The grab samples were sent to PNNL for characterization. PNNL performed detailed characterization on the grab samples using both direct gamma counting of the sediment, strong acid extraction, and deionized water extraction of the sediments. Results of the chemical analyses on the sediments are shown in Table 3.12. Details on the drilling of the borehole can be found in Todd and Trice (2002). All the data collected are found in either the HEIS database or are in Lindenmeier et al. (2002). Preliminary risk evaluations for the B-7A/B cribs, based on the data collected by Todd and Trice (2002), are found in DOE/RL (2003). 
The C3103 sediment characterization data in Table 3.12 and Figure 3.35 and Figure 3.36 show that the mobile and partially mobile constituents nitrate and fluoride are present within the Hanford formation below the B-7-A crib footprint from 60 to 160 and 30 to $95 \mathrm{ft}$ bgs, respectively. Both constituents also show a sharp increase in concentration in the $\mathrm{CCU}_{z}$ unit, which starts at $218 \mathrm{ft}$ bgs; just where the borehole $\mathrm{C} 3103$ ended. There must be a continuous trail of these two constituents through the Hanford formation into the $\mathrm{CCU}_{\mathrm{z}}$ formation and likely down to the water table somewhere in the vadose zone proximal to borehole $\mathrm{C} 3103$. One key indicator species is fluoride, which is present at high concentrations in the wastes disposed of to B-7-A\&B and B-8 Cribs in comparison to wastes disposed of to all other facilities in the B-Complex area. It is also noteworthy that there is little to no technetium-99 in the sediments below the B-7A crib footprint (C3103 borehole; see Table 3.12) as expected based on the small inventory (i.e., $<0.095$ Curies). In addition, acid- and water-leachable uranium was found only shallow in the sediment profile (see vertical distribution in Figure 3.37). Note that uranium concentrations in the shallow C3103 profile (e.g., B-7-A Crib) were much higher than at the BY Cribs even though the inventory was very similar for each individual BY Crib. The higher concentrations are explained by the fact that approximately $192 \mathrm{~kg}$ of the uranium was disposed to the B-7-A Crib in 1966 through 1967. During this time only about 1.14 million liters of liquid waste was discharged as compared with about 6.7 million liters discharge at the B-49 crib. Thus, the uranium concentration during the last two years of disposal to the B-7-A Crib was significantly more concentrated than the waste disposed at the BY Cribs leading to the higher concentrations within the soil column are found in the shallow soils beneath the B-7A Crib.

Two new 200-BP-5 characterization boreholes, 299-E33-344 and 299-E33-345, were placed within $10 \mathrm{ft}$ of the existing groundwater monitoring well 299-E33-18, which monitors the B-7-A\&B crib facility. Vadose zone sediment samples from borehole 299-E33-344 were taken from $40 \mathrm{ft}$ bgs down to $235 \mathrm{ft}$ bgs past a perched water zone intercepted at $225 \mathrm{ft}$ bgs. Sediment samples from 299-E33-345 were obtained from $\sim 216 \mathrm{ft}$ bgs to $260 \mathrm{ft}$ bgs (several $\mathrm{ft}$ below the water table at $253.3 \mathrm{ft}$ bgs). Interestingly, both new wells show no signs of elevated concentrations of major chemical constituents or typical waste constituents from the shallowest available sample at $40 \mathrm{ft} \mathrm{bgs}$ all the way through the Hanford formation (see Table 3.13). Once the Cold Creek silt dominated unit (CCUz) is penetrated at $\sim 218.5 \mathrm{ft}$ bgs at both the two new boreholes, the sediments and accompanying pore waters show significant signs of waste impacts. Observed waste impacts on the deep sediments include elevated $\mathrm{pH}$ and elevated concentrations of water-extractable sodium, chromium, fluoride, nitrate, sulfate, carbonate, technetium-99, and uranium. The total uranium concentration in the CCUz sediments at both of the new boreholes is also elevated.

The concentrations of most of the mobile constituents remain elevated throughout the $\mathrm{CCU}_{\mathrm{z}}$ layer from $\sim 218.5$ to $246 \mathrm{ft}$ bgs. However, a few constituents show a more complicated vertical distribution within the $\mathrm{CCU}_{\mathrm{z}}$ layer. The technetium-99 is highest from $\sim 230$ to $240 \mathrm{ft} \mathrm{bgs,} \mathrm{and} \mathrm{the} \mathrm{water-extractable}$ uranium is highest from $\sim 228$ to $235 \mathrm{ft} \mathrm{bgs}$, which is in about the middle of this rather thick ( $27.5 \mathrm{ft})$ silt dominated lens. The sediments in the middle of this lens are a bit coarser (more sand than silt) such that the middle sediments likely exhibit a higher hydraulic conductivity given that the entire lens is quite moist (15 to $29 \%$ wt for 19 samples that were characterized). Data from the two new boreholes suggest that the CCUz layer is acting like an effective lateral spreading zone that has accepted waste fluids from waste facilities from both nearby (B-7-A\&B) and possibly (BX-102, B-8 Crib and Tile field) distant facilities. Figure 3.38 through Figure 3.42 show the vertical profiles of several constituents from the C3103 borehole compared with the vertical profiles for sediments from the two new boreholes, E33-344 and -E33-345. 
PNNL-19277
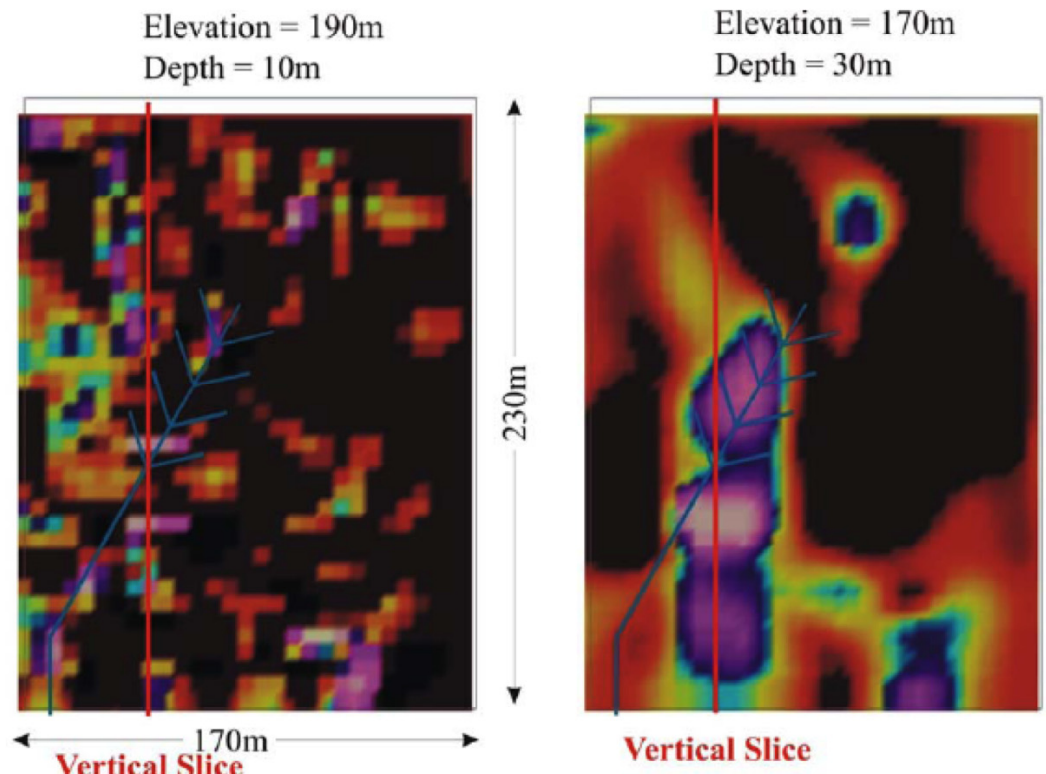

Vertical Slice

Elevation $=150 \mathrm{~m}$

Depth $=50 \mathrm{~m}$

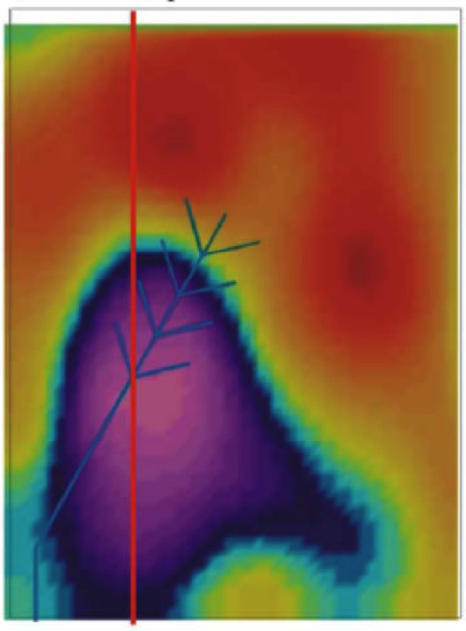

Resistivity

(ohm-m)

Vertical Slice

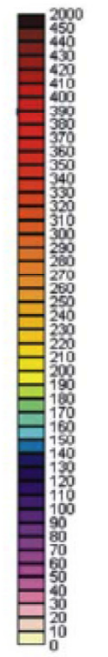

Figure 3.33. Plan View Soil Resistivity Data Below the B-8 Crib and Tile Field at Three Depths (from Rucker et al. 2007) 


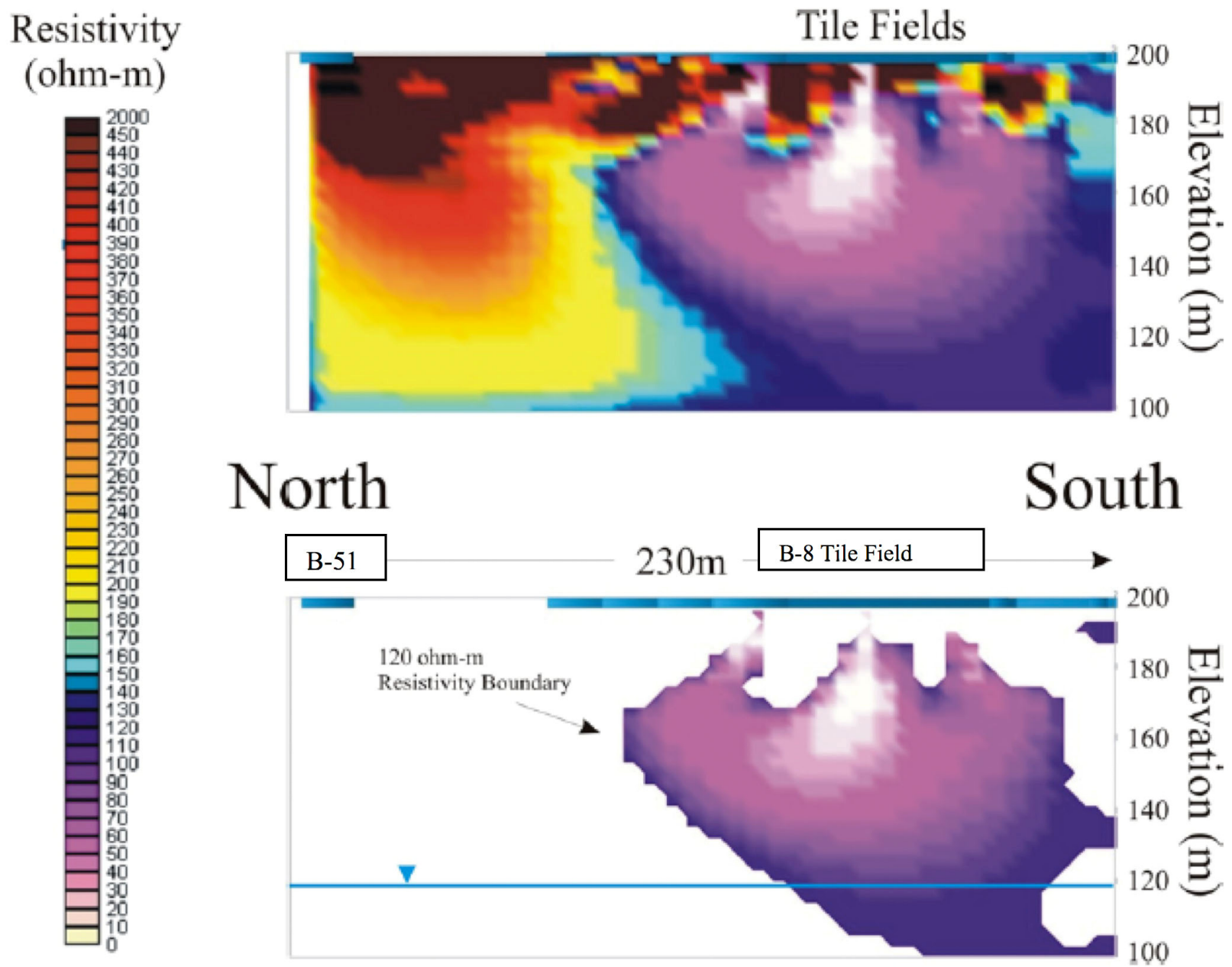

Figure 3.34. Cross Section View of Soil Resistivity Below the B-8 Crib and Tile Field Showing Low Resistivity Plume Extending Below Water Table Under the Tile Field (from Rucker et al. 2007) 
Table 3.12. Selected Sediment Data vs. Depth for Borehole C3103 Through B-7-A Footprint

\begin{tabular}{|c|c|c|c|c|c|c|c|c|c|}
\hline C3103 & \multicolumn{9}{|c|}{ ERC Contractor Data } \\
\hline $\begin{array}{l}\text { Depth } \\
\text { (ft bgs) }\end{array}$ & $\begin{array}{c}\mathrm{Na} \\
\mu \mathrm{g} / \mathrm{g}\end{array}$ & $\begin{array}{c}\text { Cyanide } \\
\mu \mathrm{g} / \mathrm{g}\end{array}$ & $\begin{array}{c}\mathrm{F} \\
\mu \mathrm{g} / \mathrm{g}\end{array}$ & $\begin{array}{c}\text { Nitrate } \\
\mu \mathrm{g} / \mathrm{g}\end{array}$ & $\begin{array}{c}\text { Nitrite } \\
\mu \mathrm{g} / \mathrm{g}\end{array}$ & $\begin{array}{c}\text { Sulfate } \\
\mu \mathrm{g} / \mathrm{g}\end{array}$ & $\begin{array}{c}\text { Tc } \\
\mathrm{pCi} / \mathrm{g}\end{array}$ & $\begin{array}{l}\mathrm{U}-238 \\
\mu \mathrm{g} / \mathrm{g}\end{array}$ & $\begin{array}{c}\text { U-total } \\
\mu \mathrm{g} / \mathrm{g}\end{array}$ \\
\hline 3.75 & $\overline{\mathrm{NA}}$ & $<0.451$ & $<2.66$ & 110 & $\overline{\mathrm{NA}}$ & 45.9 & $<0.17$ & 1.56 & 0.93 \\
\hline 6.75 & NA & $<0.476$ & $<2.75$ & 193 & NA & 185 & $<0.17$ & 1.54 & 1 \\
\hline 11.25 & NA & $<0.37$ & $<5.3$ & 77.3 & NA & 67.5 & $<0.16$ & 1.56 & 0.94 \\
\hline 13.75 & NA & $<0.44$ & $<5.3$ & 65.3 & NA & 38.3 & $<0.16$ & 1.56 & 0.96 \\
\hline 19.75 & NA & 0.8 & 23.6 & 101 & NA & 40 & 32.9 & 201.66 & 51.3 \\
\hline 23.75 & NA & 0.31 & 38.8 & 93.8 & NA & 48.2 & 4.27 & 65.54 & 147 \\
\hline 26.25 & NA & $<0.15$ & 38.6 & 97.8 & NA & 25 & 1.56 & 90.07 & 139 \\
\hline 26.25 & NA & 0.56 & 70 & 50.9 & NA & 35.4 & $<0.35$ & 362.99 & 346 \\
\hline 26.25 & NA & 0.38 & 205 & 126 & NA & 42.9 & $<0.27$ & 25.21 & 24.2 \\
\hline 49.25 & NA & 0.47 & 28.8 & 23.9 & NA & 20.4 & $<0.5$ & 2.65 & 2.02 \\
\hline 49.25 & NA & $<0.4$ & 23.4 & 21.3 & NA & 11 & $<0.089$ & 2.04 & 1.06 \\
\hline 73.76 & NA & $<0.44$ & 11.6 & 8.51 & NA & 6.1 & $<0.21$ & 3.17 & 2.39 \\
\hline 73.76 & NA & $<0.42$ & 11.8 & 7.57 & NA & 6 & $<0.26$ & 2.73 & 2.59 \\
\hline 98.76 & NA & $<0.38$ & $<5.1$ & 133 & NA & 14.2 & $<0.17$ & 1.69 & 1.21 \\
\hline 148.75 & NA & $<0.38$ & $<5.1$ & 493 & NA & 14.6 & $<0.34$ & 1.68 & 1.25 \\
\hline 220.25 & NA & $<0.58$ & 101 & 263 & NA & 121 & $<0.24$ & 2.31 & 1.8 \\
\hline C3103 & PNNL & & & & & & & & \\
\hline $\begin{array}{l}\text { Depth } \\
\text { (ft bgs) }\end{array}$ & $\begin{array}{c}\mathrm{Na}(\mathrm{WE}) \\
\mu \mathrm{g} / \mathrm{g}\end{array}$ & $\begin{array}{c}\mathrm{Cr}(\mathrm{WE}) \\
\mu \mathrm{g} / \mathrm{g}\end{array}$ & $\begin{array}{c}\mathrm{F} \\
\mu \mathrm{g} / \mathrm{g}\end{array}$ & $\begin{array}{c}\text { Nitrate } \\
\mu \mathrm{g} / \mathrm{g}\end{array}$ & $\begin{array}{l}\text { Nitrite } \\
\mu \mathrm{g} / \mathrm{g}\end{array}$ & $\begin{array}{l}\text { Sulfate } \\
\mu \mathrm{g} / \mathrm{g}\end{array}$ & $\begin{array}{c}\mathrm{Tc} \\
\mathrm{pCi} / \mathrm{g}\end{array}$ & $\begin{array}{c}\mathrm{U}-238 \\
\mu \mathrm{g} / \mathrm{g}\end{array}$ & $\begin{array}{c}\mathrm{U}(\mathrm{WE}) \\
\mu \mathrm{g} / \mathrm{g}\end{array}$ \\
\hline 22 & $4.78 \mathrm{E}+01$ & 6.79E-02 & 5.63 & 20.8 & 1.23 & 24.7 & $<1.92 \mathrm{E}+01$ & 87.5 & $6.16 \mathrm{E}-01$ \\
\hline 25 & $1.24 E+02$ & 3.79E-02 & 24.0 & 111 & $<0.08$ & 29.1 & $<1.95 \mathrm{E}+01$ & 89.6 & $9.75 E-01$ \\
\hline 30 & $1.10 \mathrm{E}+02$ & $1.54 \mathrm{E}-03$ & 23.6 & 30.7 & $<0.08$ & 22.9 & $<5.59 \mathrm{E}+01$ & 329 & $4.42 \mathrm{E}+00$ \\
\hline 35 & $2.16 E+02$ & $3.60 \mathrm{E}-03$ & 32.1 & 100 & $<0.08$ & 40.9 & $<3.73 \mathrm{E}+00$ & 24.3 & $1.77 \mathrm{E}+00$ \\
\hline 35 & $2.17 E+02$ & $4.21 \mathrm{E}-03$ & 33.3 & 115 & $<0.08$ & 48.6 & $<3.79 \mathrm{E}+00$ & 22.8 & $1.91 \mathrm{E}+00$ \\
\hline 48 & $1.93 E+02$ & $6.66 \mathrm{E}-03$ & 21.8 & 15.6 & $<0.08$ & 12.6 & $<1.15 \mathrm{E}-01$ & 0.6 & $8.41 \mathrm{E}-02$ \\
\hline 60 & $2.18 E+02$ & 2.91E-03 & 21.5 & 189 & 0.57 & 10.4 & $<4.13 \mathrm{E}-01$ & 1.91 & 4.43E-01 \\
\hline 70 & $1.29 \mathrm{E}+02$ & 1.11E-02 & 12.6 & 9.33 & $<0.08$ & 3.5 & $<8.57 \mathrm{E}-01$ & 3.95 & $7.91 \mathrm{E}-01$ \\
\hline 80 & $2.02 E+02$ & $5.74 \mathrm{E}-03$ & 42.9 & 23.9 & $<0.08$ & 6.57 & $<4.22 \mathrm{E}-01$ & 2.49 & 4.33E-01 \\
\hline 90 & $2.68 \mathrm{E}+02$ & 3.70E-02 & 16.6 & 188 & $<0.08$ & 27.0 & $<1.27 \mathrm{E}-01$ & 0.7 & $2.77 \mathrm{E}-02$ \\
\hline 90 & $2.10 \mathrm{E}+02$ & 2.03E-02 & 11.8 & 97.4 & $<0.08$ & 13.2 & $<1.38 \mathrm{E}-01$ & 0.63 & 2.13E-02 \\
\hline 100 & $1.10 \mathrm{E}+02$ & $7.05 \mathrm{E}-03$ & 2.76 & 126 & $<0.08$ & 14.8 & $<1.08 \mathrm{E}-01$ & 0.52 & $1.81 \mathrm{E}-03$ \\
\hline 110 & $1.27 \mathrm{E}+02$ & $5.99 \mathrm{E}-03$ & 0.38 & 247 & 0.1 & 17.2 & $<1.11 \mathrm{E}-01$ & 0.61 & $9.39 \mathrm{E}-04$ \\
\hline 120 & $7.45 \mathrm{E}+01$ & $1.79 \mathrm{E}-03$ & 0.25 & 248 & 0.14 & 10.8 & $<1.12 \mathrm{E}-01$ & 0.57 & $1.60 \mathrm{E}-04$ \\
\hline 130 & $1.02 E+02$ & $2.06 \mathrm{E}-03$ & 0.23 & 626 & 0.22 & 15.0 & $<1.01 \mathrm{E}-01$ & 0.51 & $3.36 \mathrm{E}-04$ \\
\hline 140 & $2.03 \mathrm{E}+01$ & $9.78 \mathrm{E}-04$ & 0.23 & 320 & $<0.08$ & 10.2 & $<1.28 \mathrm{E}-01$ & 0.64 & $3.53 \mathrm{E}-04$ \\
\hline 150 & $2.57 \mathrm{E}+01$ & $1.23 \mathrm{E}-03$ & 0.2 & 630 & $<0.08$ & 20.0 & $<1.01 \mathrm{E}-01$ & 0.5 & $6.16 \mathrm{E}-04$ \\
\hline 160 & $1.99 \mathrm{E}+01$ & 1.37E-03 & 0.21 & 207 & $<0.08$ & 17.0 & $<1.07 \mathrm{E}-01$ & 0.54 & $6.59 \mathrm{E}-04$ \\
\hline 168 & $1.91 \mathrm{E}+01$ & 7.38E-04 & 0.48 & 53.8 & $<0.08$ & 30.6 & $<1.46 \mathrm{E}-01$ & 0.7 & $6.27 \mathrm{E}-04$ \\
\hline 170 & $2.00 \mathrm{E}+01$ & $7.26 \mathrm{E}-04$ & 0.37 & 24.3 & $<0.08$ & 25.4 & $<1.03 \mathrm{E}-01$ & 0.53 & $3.69 \mathrm{E}-04$ \\
\hline 172.5 & $1.82 \mathrm{E}+01$ & $<6.01 \mathrm{E}-03$ & 0.44 & 22.8 & $<0.08$ & 25.9 & $<1.13 \mathrm{E}-01$ & 0.57 & $4.09 \mathrm{E}-04$ \\
\hline 180 & $1.61 \mathrm{E}+01$ & $<6.03 \mathrm{E}-03$ & 0.34 & 45.4 & $<0.08$ & 35.7 & $<1.09 \mathrm{E}-01$ & 0.54 & $4.41 \mathrm{E}-04$ \\
\hline 190 & $1.59 \mathrm{E}+01$ & $5.90 \mathrm{E}-04$ & 0.49 & 16.5 & $<0.08$ & 31.0 & $<1.11 \mathrm{E}-01$ & 0.55 & $6.36 \mathrm{E}-04$ \\
\hline 200 & $2.29 \mathrm{E}+01$ & 7.14E-04 & 0.57 & 19.8 & $<0.08$ & 40.0 & $<1.06 \mathrm{E}-01$ & 0.51 & $3.57 \mathrm{E}-04$ \\
\hline 210 & $1.50 \mathrm{E}+01$ & $1.51 \mathrm{E}-03$ & 0.33 & 19.6 & $<0.08$ & 29.2 & $<1.29 \mathrm{E}-01$ & 0.64 & $6.58 \mathrm{E}-04$ \\
\hline
\end{tabular}


Table 3.12 (cont)

\begin{tabular}{cccccccccc}
\hline $\begin{array}{c}\text { C3103 } \\
\text { Depth }\end{array}$ & PNNL & & & & & & & & \\
$(\mathrm{fa}(\mathrm{WE})$ & $\mathrm{Cr}(\mathrm{WE})$ & $\mathrm{F}$ & Nitrate & Nitrite & Sulfate & $\mathrm{Tc}$ & $\mathrm{U}-238$ & $\mathrm{U}(\mathrm{WE})$ \\
210 & $\mu \mathrm{g} / \mathrm{g}$ & $\mu \mathrm{g} / \mathrm{g}$ & $\mu \mathrm{g} / \mathrm{g}$ & $\mu \mathrm{g} / \mathrm{g}$ & $\mu \mathrm{g} / \mathrm{g}$ & $\mu \mathrm{g} / \mathrm{g}$ & $\mathrm{pCi} / \mathrm{g}$ & $\mu \mathrm{g} / \mathrm{g}$ & $\mu \mathrm{g} / \mathrm{g}$ \\
218 & $1.54 \mathrm{E}+01$ & $7.02 \mathrm{E}-04$ & 0.32 & 19.5 & $<0.08$ & 37.1 & $<1.05 \mathrm{E}-01$ & 0.55 & $8.02 \mathrm{E}-04$ \\
219 & $2.55 \mathrm{E}+02$ & $6.63 \mathrm{E}-03$ & $\mathbf{2 2 . 3}$ & $\mathbf{7 1 . 8}$ & $<0.08$ & 142.3 & $<1.63 \mathrm{E}-01$ & 0.85 & $6.00 \mathrm{E}-06$ \\
221.5 & $4.14 \mathrm{E}+02$ & $\mathbf{1 . 0 9 E}-02$ & $\mathbf{6 4 . 8}$ & $\mathbf{2 1 8}$ & $<0.08$ & 88.1 & $<1.73 \mathrm{E}-01$ & 1.01 & $3.20 \mathrm{E}-03$ \\
221.5 & $7.01 \mathrm{E}+02$ & $\mathbf{1 . 8 7 E}-01$ & $\mathbf{1 3 2}$ & $\mathbf{5 9 2}$ & $\mathbf{3 . 6 1}$ & 182 & $<1.59 \mathrm{E}-01$ & 0.98 & $9.97 \mathrm{E}-03$ \\
\hline
\end{tabular}

Bold Text $=$ Elevated Concentrations

$\mathrm{NA}=$ not analyzed

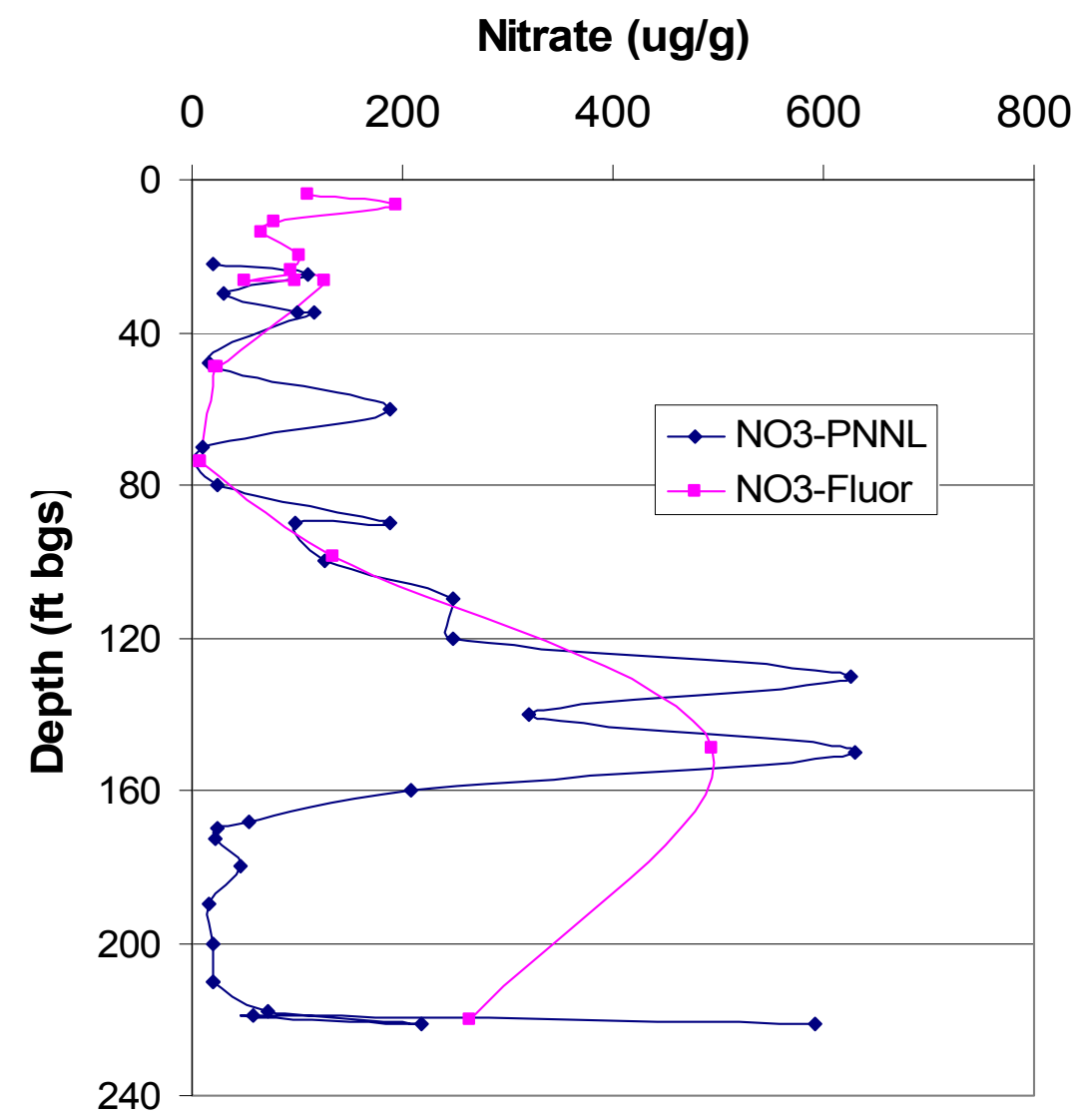

Figure 3.35. Sediment Concentrations of Nitrate in B-7-A Footprint (Borehole C3103) 
PNNL-19277

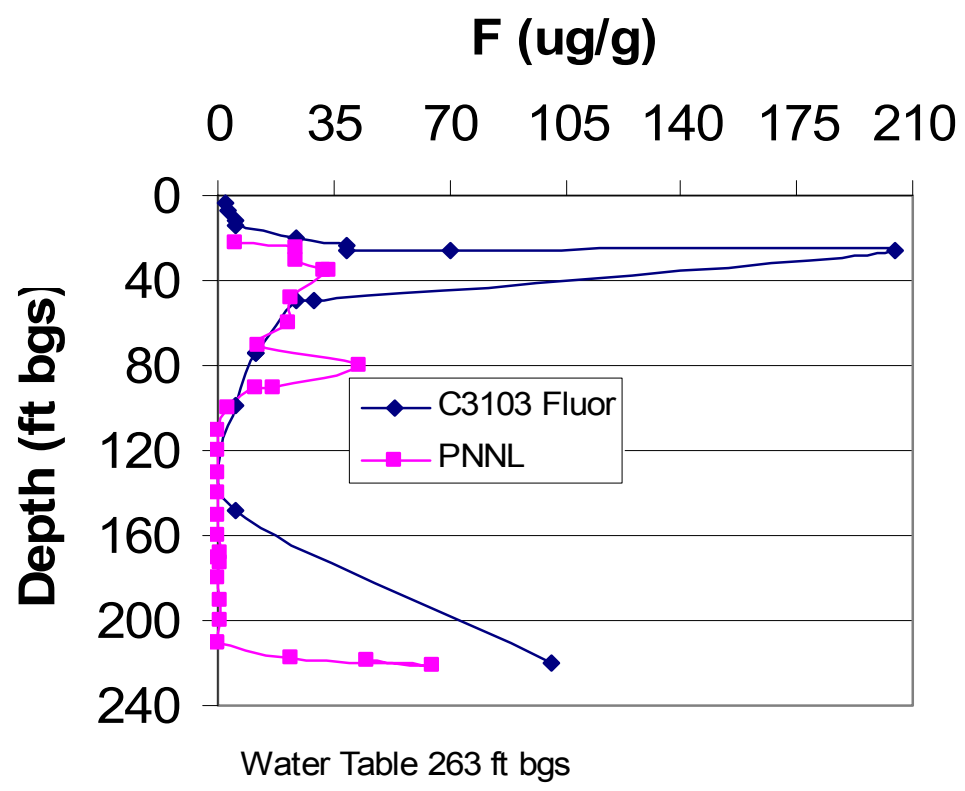

Figure 3.36. Sediment Concentrations of Fluoride in B-7-A Footprint (Borehole C3103)

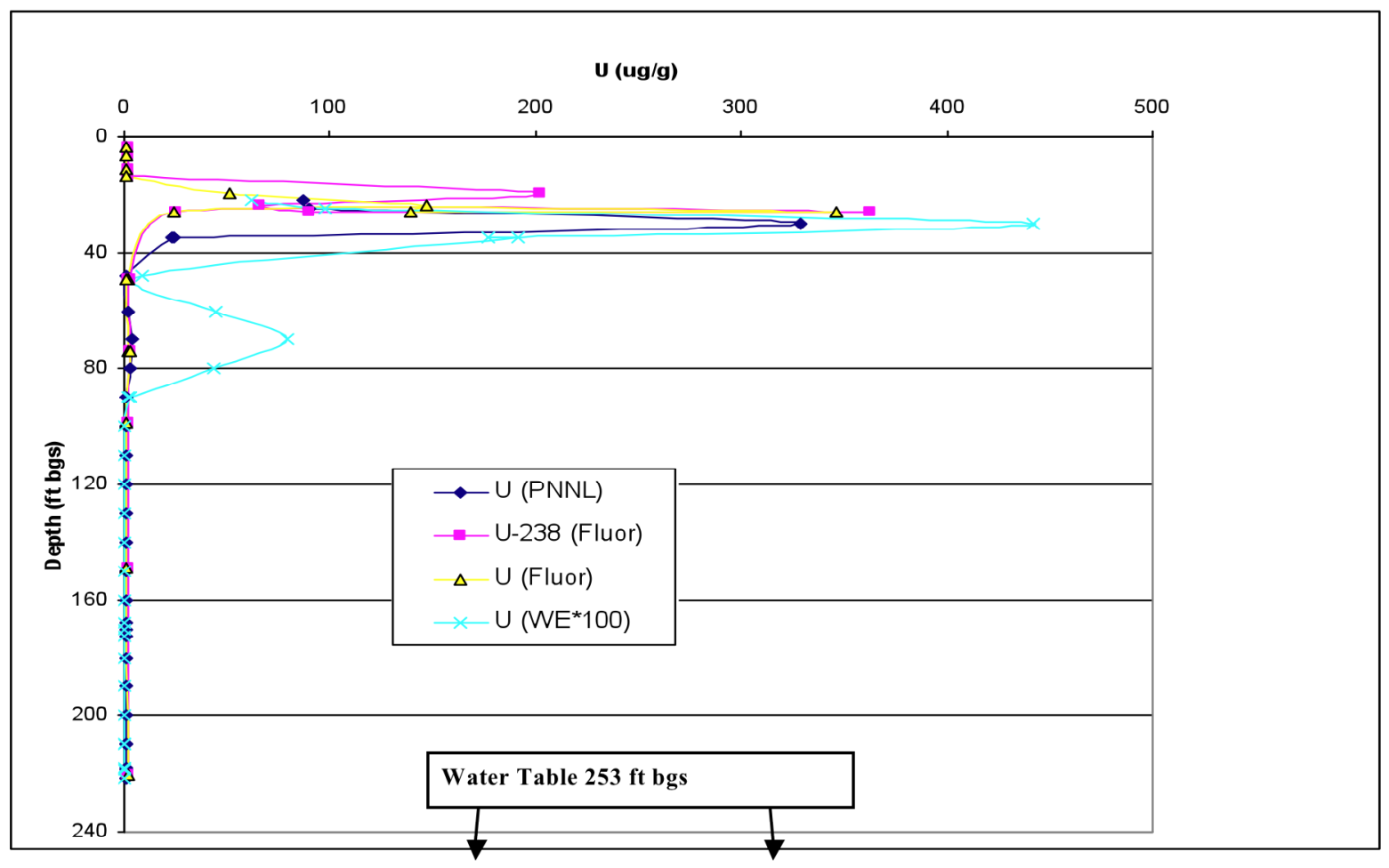

Figure 3.37. Acid and Water Extractable Uranium vs. Depth in C3103 Borehole (Inside Footprint) 
The $\mathrm{C} 3103$ borehole was stopped just below the $\mathrm{H} 2-\mathrm{CCU}_{\mathrm{z}}$ contact; therefore, there is not a full vadose zone vertical profile for the B-7-A Crib. The vertical distribution of most species in the C3103 borehole in general shows high concentrations in the shallow sediments below the crib bottom, much lower concentrations in the deeper Hanford formation sediments, and then sharp increases once the $\mathrm{CCU}_{z}$ contact is reached. Nitrate and chromium did show elevated concentrations in the deeper Hanford formation vadose zone sediments. One explanation for the differing vertical profiles for nitrate and chromium versus the technetium-99, fluoride, and uranium sediment concentrations at C3103 is possibly associated with the varying types of waste fluids disposed over time. For example, the Tc-99 profile (Figure 3.41) shows relatively high concentrations (e.g., $32.9 \mathrm{pCi} / \mathrm{g})$ at $6.02 \mathrm{~m}(19.75 \mathrm{ft}) \mathrm{bgs}$. This high concentration interval may be associated with the 1966-1967 waste disposed at the B-7A crib. Note that the waste type disposed in 1967 was estimated to contain $0.419 \mathrm{uCi} / \mathrm{L}$ technetium-99 versus only 57 $\mathrm{pCi} / \mathrm{L}$ from the waste in 1952 (see SIM Model estimates in Appendix C; Corbin et al. 2005). Since the 1967 waste was the last disposed it is conceivable that remnant inventory would still be located near the bottom of the crib. Similarly, the uranium inventory was almost completely associated with the 1966 and 1967 disposal events. By the same logic the uranium should be located in the shallow sediments beneath the crib which is what the sample results show. In contrast, nitrate concentrations were generally an order of magnitude more concentrated in the 1946-1954 disposal history compared to the 1966-1967 disposal history (e.g., $9740 \mathrm{mg} / \mathrm{L}$ in 1966 versus $85,900 \mathrm{mg} / \mathrm{L}$ in 1952) and as can be seen in the vertical profile the majority of the nitrate exists deeper in the sediment profile. Interestingly, fluoride shows significant concentration peaks beneath the crib at depths of 25 to $\sim 100 \mathrm{ft}$ bgs with near background concentrations from 100 to $210 \mathrm{ft}$ bgs and then the fluoride concentrations increase again between 218 to $221.5 \mathrm{ft}$ bgs (the bottom of the borehole. Water extractable chromium shows a vertical distribution most similar to fluoride but the concentrations are not as significantly elevated from values found in uncontaminated sediments. The 1966-1967 disposal inventories of fluoride had significantly less inventory than the 1946 to 1954 disposed wastes (no reported inventory of fluoride in the 1966-67 disposal period compared with $5140 \mathrm{mg} / \mathrm{L}$ in of fluoride in the 1946 to 1954 time period (Corbin et al. 2005). This indicates that some of the constituents in the early waste stream preferentially adsorbed to the sediments beneath the B-7-A Crib while other contaminants either migrated through the sediments to the point at which the contaminants are now found or migrated through an alternative pathway before reaching the effective lateral spreading layer $\mathrm{CCU}_{\mathrm{z}}$. A conceptual model for why the shallow sediments may not have retained significant concentrations is because of their coarse grained nature. Based on the geologic logs the sediments were described as mainly coarse sands that can be corroborated by the low natural thorium and potassium activities in the geophysical logs. Unfortunately some of depths where the thorium and potassium peaks in the geophysical logs indicate finer grained sediments are present where not sampled. Sampling these intervals may have provided an indication as to whether the contaminants migrated vertically through the B-7-A cribs footprint or preferentially found an alternative pathway to the lateral spreading layer below $218 \mathrm{ft}$ bgs. 
Table 3.13. Vertical Distribution of Potentially Mobile Constituents in Sediments at Two New BP-5 Boreholes (near 299-E33-18)

\begin{tabular}{|c|c|c|c|c|c|c|c|c|c|c|}
\hline $\begin{array}{c}\text { Depth } \\
\text { (ft bgs) }\end{array}$ & $\begin{array}{c}\mathrm{Na}(\mathrm{WE}) \\
\mu \mathrm{g} / \mathrm{g}\end{array}$ & $\begin{array}{c}\mathrm{Ca}(\mathrm{WE}) \\
\mu \mathrm{g} / \mathrm{g}\end{array}$ & $\begin{array}{c}\mathrm{F} \\
\mu \mathrm{g} / \mathrm{g}\end{array}$ & $\begin{array}{c}\text { Nitrate } \\
\mu \mathrm{g} / \mathrm{g}\end{array}$ & $\begin{array}{c}\text { Nitrite } \\
\mu \mathrm{g} / \mathrm{g}\end{array}$ & $\begin{array}{c}\text { Sulfate } \\
\mu \mathrm{g} / \mathrm{g}\end{array}$ & $\begin{array}{c}\mathrm{Tc} \\
\mathrm{pCi} / \mathrm{g}\end{array}$ & $\begin{array}{c}\mathrm{U}(\mathrm{AE}) \\
\mu \mathrm{g} / \mathrm{g}\end{array}$ & $\begin{array}{c}\mathrm{U}(\mathrm{WE}) \\
\mu \mathrm{g} / \mathrm{g}\end{array}$ & $\begin{array}{c}\mathrm{Cr}(\mathrm{WE}) \\
(\mu \mathrm{g} / \mathrm{g})\end{array}$ \\
\hline \multicolumn{11}{|c|}{ 299-E33-344 } \\
\hline 41.5 & 7.4 & 7.1 & 0.28 & 2.24 & $<1.00$ & 9.96 & $<8.51 \mathrm{E}-02$ & 0.35 & $2.53 \mathrm{E}-04$ & $<3.19 \mathrm{E}-04$ \\
\hline 55 & 10.9 & 6.7 & 0.33 & 3.39 & $<1.00$ & 13.9 & $<8.51 \mathrm{E}-02$ & 0.40 & $3.12 \mathrm{E}-04$ & $<3.00 \mathrm{E}-04$ \\
\hline 67.5 & 10.6 & 7.4 & 0.27 & 4.32 & $<1.00$ & 17.9 & $<8.49 \mathrm{E}-02$ & 0.38 & $2.11 \mathrm{E}-04$ & $<2.45 \mathrm{E}-04$ \\
\hline 85.4 & 12.9 & 10.7 & 0.28 & 8.37 & $<1.00$ & 18.2 & $<8.48 \mathrm{E}-02$ & 0.35 & 2.19E-04 & $<3.16 \mathrm{E}-04$ \\
\hline 107.5 & 10.1 & 9.5 & 0.21 & 8.12 & $<1.00$ & 11.3 & $<8.50 \mathrm{E}-02$ & 0.31 & $1.32 \mathrm{E}-04$ & $<2.96 \mathrm{E}-04$ \\
\hline 122.5 & 10.4 & 7.0 & 0.37 & 2.12 & $<1.00$ & 12.4 & $<8.48 \mathrm{E}-02$ & 0.33 & $1.05 \mathrm{E}-04$ & $<3.13 \mathrm{E}-04$ \\
\hline 137.5 & 8.2 & 7.3 & 0.21 & 1.57 & $<1.00$ & 16.8 & $<8.49 \mathrm{E}-02$ & 0.39 & 2.62E-04 & $<3.43 \mathrm{E}-04$ \\
\hline 152.5 & 13.1 & 8.9 & 0.32 & 2.09 & $<1.00$ & 27.8 & $<8.48 \mathrm{E}-02$ & 0.37 & $1.99 \mathrm{E}-04$ & $<2.61 \mathrm{E}-04$ \\
\hline 162.5 & 11.0 & 11.6 & 0.22 & 3.03 & $<1.00$ & 43.8 & $<8.48 \mathrm{E}-02$ & 0.32 & $3.60 \mathrm{E}-04$ & $<3.47 \mathrm{E}-04$ \\
\hline 172.5 & 7.3 & 5.6 & 0.21 & 1.02 & $<1.00$ & 9.04 & $<8.51 \mathrm{E}-02$ & 0.35 & $1.59 \mathrm{E}-04$ & $<2.90 \mathrm{E}-04$ \\
\hline 182.5 & 10.5 & 10.7 & $<2$ & $<10$ & $<10.00$ & 36.7 & $<8.51 \mathrm{E}-02$ & 0.36 & $3.58 \mathrm{E}-04$ & $<1.99 \mathrm{E}-04$ \\
\hline 192 & 16.6 & 12.7 & $<2$ & $<10$ & $<10.00$ & 46.9 & $<9.45 \mathrm{E}-02$ & 0.34 & $2.31 \mathrm{E}-04$ & $<3.55 \mathrm{E}-04$ \\
\hline 202.5 & 12.7 & 14.0 & $<2$ & $<10$ & $<10.00$ & 51.0 & $<8.48 \mathrm{E}-02$ & 0.40 & $2.14 \mathrm{E}-04$ & $<2.82 \mathrm{E}-04$ \\
\hline 212.3 & 14.3 & 13.7 & $<2$ & $<10$ & $<10.00$ & 50.7 & $<8.48 \mathrm{E}-02$ & 0.39 & $1.83 \mathrm{E}-04$ & $<3.26 \mathrm{E}-04$ \\
\hline 219.8 & 118 & 2.1 & 7.38 & 30.1 & $<10.00$ & 107 & $<8.48 \mathrm{E}-02$ & 1.11 & $1.05 \mathrm{E}-02$ & 0.017 \\
\hline 225 & 360 & 1.8 & 54.2 & 136 & $<10.00$ & 154 & 0.26 & 0.64 & 0.10 & 0.076 \\
\hline \multicolumn{2}{|c|}{ Perched Water } & \multicolumn{9}{|c|}{ perched } \\
\hline 227.5 & 147 & 1.0 & 21.6 & 43.0 & $<10.00$ & 82.3 & 0.34 & 1.05 & $9.48 E-03$ & 0.014 \\
\hline 230 & 232 & 2.0 & 26.0 & 97.1 & $<10.00$ & 133 & 0.64 & 9.09 & 3.93 & 0.015 \\
\hline 232.5 & 234 & 4.8 & 10.1 & 158 & $<10.00$ & 158 & 7.52 & 5.61 & 0.97 & $5.08 \mathrm{E}-03$ \\
\hline 233.25 & 259 & 9.8 & 1.43 & 290 & NR & 177 & 22.8 & 1.07 & 0.04 & NR \\
\hline 235 & 256 & 10.8 & $<2$ & 325 & $<10.00$ & 176 & 17.6 & 1.25 & 0.03 & 0.039 \\
\hline 235.25 & 223 & 7.52 & 16 & 97.4 & NR & 176 & 1.88 & 28.6 & 11.3 & $6.1 \mathrm{E}-03$ \\
\hline \multicolumn{11}{|c|}{ 299-E33-345 } \\
\hline 220 & 137 & 1.69 & 1.48 & 47.0 & $<1.00$ & 107 & 0.48 & 0.67 & 2.64E-03 & $9.53 \mathrm{E}-03$ \\
\hline 225 & 212 & 0.72 & 32.6 & 56.9 & $<1.00$ & 117 & 0.38 & 0.49 & 1.17E-02 & $9.49 \mathrm{E}-03$ \\
\hline 230 & 88.2 & 40.5 & 0.20 & 18.4 & $<1.00$ & 14.0 & 10.5 & 46.4 & 12.6 & $5.91 \mathrm{E}-03$ \\
\hline 235 & 135 & 149 & 0.20 & 58.8 & $<1.00$ & 42.2 & 90.0 & 119 & 18.2 & $<0.0014634$ \\
\hline 239.5 & 233 & 13.2 & 0.20 & 36.2 & $<1.00$ & 17.8 & 46.9 & 1.33 & 0.03 & $<0.0018224$ \\
\hline 247.25 & 83.3 & 1.19 & 0.20 & 4.57 & $<1.00$ & 4.06 & 1.87 & 0.42 & $3.23 \mathrm{E}-03$ & 0.11 \\
\hline 252.25 & 67.6 & 1.44 & 0.20 & 3.32 & $<1.00$ & 3.43 & 1.91 & 0.39 & $1.46 \mathrm{E}-03$ & 0.05 \\
\hline \multicolumn{2}{|c|}{$253.29 \mathrm{ft} \mathrm{bgs}$} & water table & & & & & & & & \\
\hline 257.5 & 12.4 & 8.84 & 0.20 & 1.26 & $<1.00$ & 1.60 & 0.24 & 0.35 & $1.12 \mathrm{E}-03$ & $2.74 \mathrm{E}-03$ \\
\hline
\end{tabular}

Tan shading $=\mathrm{CCU}_{\mathrm{z}}$ sediments; Red type $=$ very high concentrations; Bold type $=$ elevated above natural background; Blue type $=$ depleted concentrations caused by ion exchange; $\mathrm{NR}=$ not reported. 
PNNL-19277

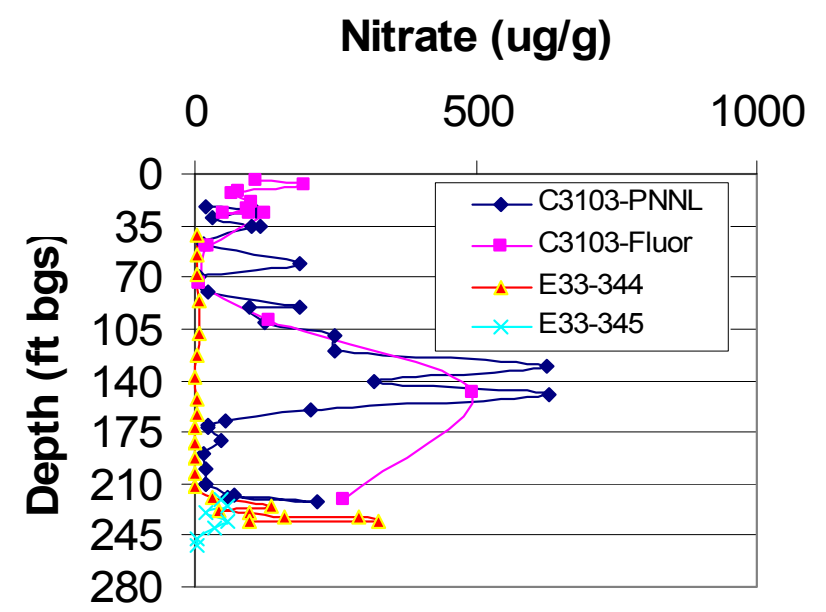

Figure 3.38. Vertical Distribution of Nitrate in Sediments In and Near B-7-A Crib

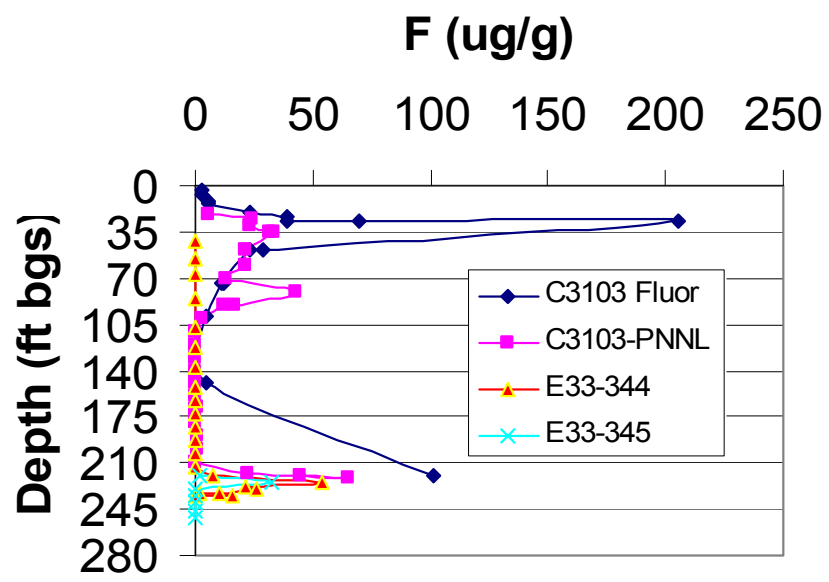

Figure 3.39. Vertical Distribution of Fluoride in Sediments In and Near B-7-A Crib

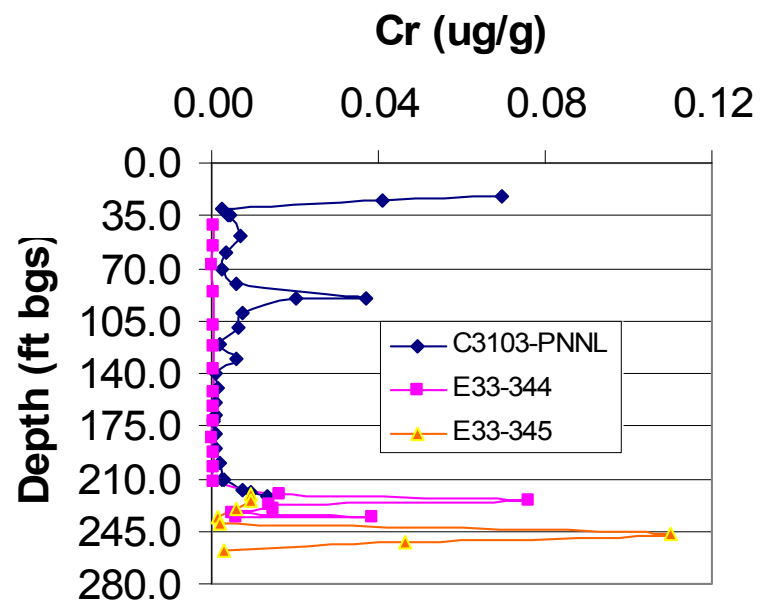

Figure 3.40. Vertical Distribution of WE Chromium in Sediments In and Near B-7-A Crib 
PNNL-19277

\section{Tc-99 (pCi/g)}

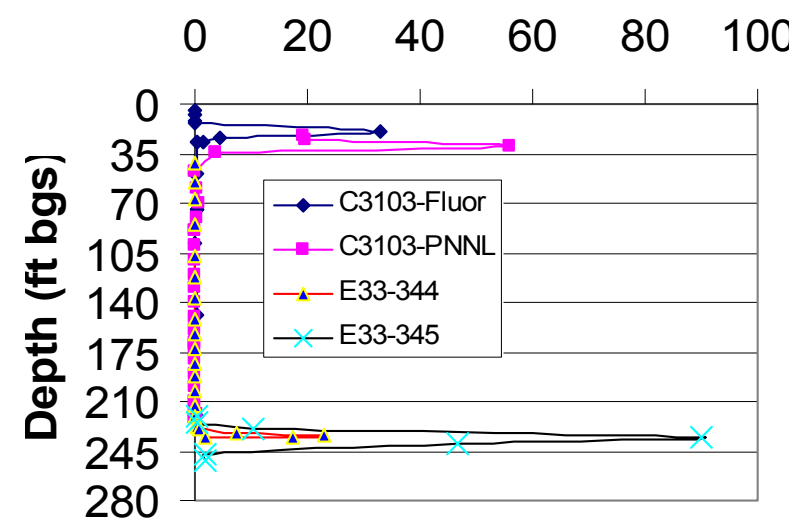

Figure 3.41. Vertical Distribution of Technetium-99 in Sediments In and Near B-7-A Crib

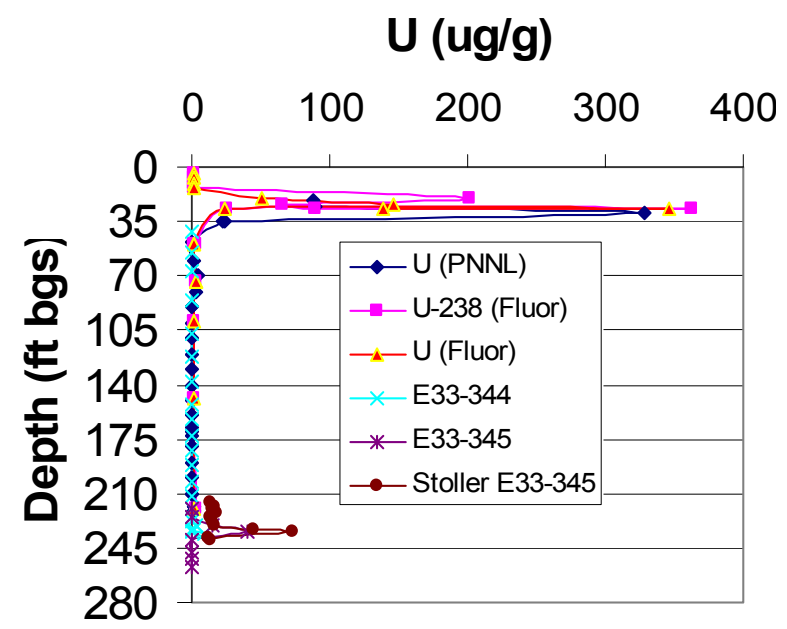

Figure 3.42. Vertical Distribution of Total Uranium in Sediments in and near B-7-A Crib.

\subsubsection{Uranium Isotope Signature Results Related to B-7-A Crib}

The final information that is available to interpret the vadose zone sediment distribution of contaminants below and proximal to the B-7-A Crib is the precise uranium isotopic ratio measurements on vadose zone sediment water extracts and the direct measurement of the perched water sample. Appendix E lists all the available uranium isotopic ratio data collected, identifies which samples represent the various waste sources and which samples were used to create the clean end members for vadose zone pore waters and groundwater.

Figure 3.43 shows the uranium isotopic ratio plots for vadose pore waters, from the two new boreholes, 299-E33-344 and 299-E33-345, and the vadose zone perched water from $225 \mathrm{ft}$ bgs from E33-344. In Figure 3.43, the three potential uranium sources (BX-102 [blue diamonds], BY Cribs [purple square] and B-7-A Crib [yellow triangle] are shown for comparison to the vadose zone water extracts and perched water sample. Three end member clean data points for the $\mathrm{CCU}_{\mathrm{z}}$ (blue bar), the Hanford $\mathrm{H} 2$ unit deeper than $100 \mathrm{ft}$ bgs (green bar), and uncontaminated groundwater (red bar) are also shown along the 
X-axis. These end member bars represent the uranium-234/238 variation in uncontaminated pore waters or groundwater. Mixing lines shown in Figure 3.43; connect the BX-102 source signature with the uncontaminated end members in either the $\mathrm{H} 2$ unit (green arrow) or $\mathrm{CCU}_{\mathrm{z}}$ unit (blue arrow). No mixing line is shown between the BX-102 source and groundwater because all but one of the samples is in the vadose zone.

If contaminated pore water is assumed to be a binary mixture of a source waste and uncontaminated pore water, the resultant contaminated pore water sample should plot along a the mixing line connecting the source signature with the uncontaminated pore water for the stratigraphy that the uncontaminated water originated from. The amount of contamination present is reflected by how close to the source signature the contaminated pore water plots. Essentially, the uranium-236 value is largest for the source signature and the uncontaminated waters contain no uranium-236. As can be seen in Figure 3.43, most of the data points for the water extracts from the contaminated sediments from 299-E33-344 and -345 either plot near the BX-102 source signature (inset) or along one of the two mixing lines.

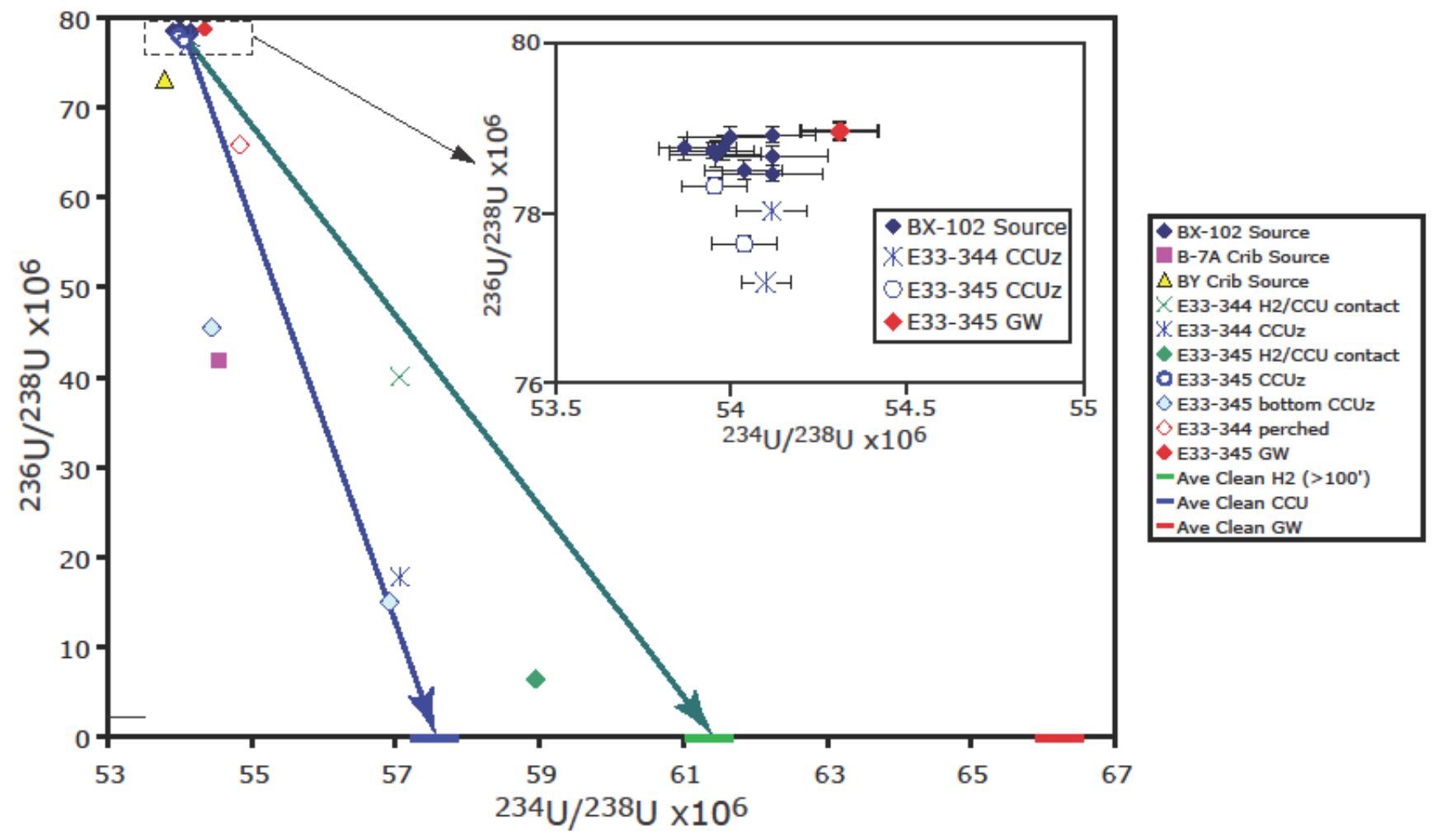

Figure 3.43. Uranium Signature for Borehole 299-E33-344 and -345 Pore and Perched Water Samples

Four contaminated pore waters from 299-E33-344 were measured. The first was at $220 \mathrm{ft}$ bgs, which is near the contact between the Hanford formation $\mathrm{H} 2$ unit and the $\mathrm{CCU}_{z}$ unit (the green $\mathrm{X}$ in Figure 3.43). It lies close to the mixing line between the BX-102 source and the clean $\mathrm{H} 2$ unit pore water in about the middle of the mixing line, suggesting about a 50/50\% mix of waste fluid with uncontaminated pore water mostly dominated by clean $\mathrm{H} 2$ pore water but with some clean $\mathrm{CCU}_{z}$ pore 
water ${ }^{\mathrm{a}}$. The other three samples from within the $\mathrm{CCU}_{\mathrm{z}}$ unit between 230 and $235.25 \mathrm{ft}$ bgs are shown as blue Ж symbols. Two samples plot within the BX-102 source signature in the upper left-hand corner of Figure 3.43, suggesting $\sim 98 \% \mathrm{BX}-102$ source. The remaining pore water sample from $235 \mathrm{ft}$ bgs plots close to the mixing line between $\mathrm{BX}-102$ waste and clean $\mathrm{CCU}_{\mathrm{z}}$ pore water with about $23 \% \mathrm{BX}-102$ waste signature. It is remarkable that two sediment samples supposedly taken within $0.25 \mathrm{ft}$ of each other in this borehole would exhibit significantly different proportions of waste and clean pore fluids (98 vs. $23 \%$ waste). Visual inspection of the various grab and core samples taken in the $\mathrm{CCU}_{\mathrm{z}}$ at the new wells has yielded knowledge that there is significant variation in the silt-clay-sand content over the 20- to 30-ftthick unit. Observations of widely varying pore water compositions and thus vertical distribution of contaminants in the $\mathrm{CCU}_{\mathrm{z}}$ unit as a function of depth were found as shown in Table 3.13. The perched water from 299-E33-344 obtained at a depth of $225 \mathrm{ft}$ bgs has a uranium isotope signature in between the two mixing lines between BX-102 waste and the clean pore waters from the $\mathrm{H} 2$ and $\mathrm{CCU}_{\mathrm{z}}$ units with about $84 \% \mathrm{BX}-102$ waste signature. It is surmised that the perched water is a mixture of waste from both BX-102 (providing the uranium and the B-7-A\&B Cribs and B-8 Crib and Tile Field providing other chemicals, such as chromium and fluoride; see Table 3.13) with clean pore waters that have equilibrated with both the $\mathrm{H} 2$ unit and the $\mathrm{CCU}_{\mathrm{z}}$ unit.

The uranium isotope signatures of five contaminated pore waters from 299-E33-345 sediments were measured, from depths 220, 230, 235, 239.5, and $252 \mathrm{ft}$ bgs. The sample from $220 \mathrm{ft}$ bgs is near the contact between the $\mathrm{H} 2$ and $\mathrm{CCU}_{z}$ units and is shown in Figure 3.43 as the green diamond. Its signature falls about midway between the two mixing lines, suggesting it is a mixture of BX-102 waste with essentially equal amounts of clean $\mathrm{H} 2$ and $\mathrm{CCU}_{\mathrm{z}}$ pore waters. This data point has the least uranium-236 content of any of the pore water sample, with $\sim 8 \%$ BX-102 waste signature. The two contaminated 299E33-345 pore waters from the middle of the $\mathrm{CCU}_{\mathrm{z}}$ strata (230 and $235 \mathrm{ft} \mathrm{bgs}$; shown as open circles) plot close to the BX-102 waste source (see insert for more detail), suggesting about $99 \%$ BX-102 waste signature. The remaining two contaminated pore waters from 239.5 and $252 \mathrm{ft}$ bgs are shown as blue diamonds in Figure 3.43. The shallower data point falls considerably to the left of the mixing line between a BX-102 waste signature and clean $\mathrm{CCU}_{z}$ with a uranium-236/238 atom ratio of $\sim 46 \times 10^{-6}$. There is no explanation for why this data point falls so far off the $\mathrm{BX}-102-\mathrm{CCU}_{\mathrm{z}}$ mixing line. It has a uranium-236/238 ratio too high to be sourced from the B-7-A crib (purple square) and does not fall between any of the mixing lines for BY Cribs with uncontaminated pore waters. Because there is only one data point each that identifies the BY Cribs and the B-7-A Crib uranium source signal, perhaps there is more variation in the signatures for these other two potential sources. The data point from the $252 \mathrm{ft}$ bgs sample falls on the mixing line between the BX-102 source and uncontaminated $\mathrm{CCU}_{\mathrm{z}}$ pore water with about $20 \%$ BX-102 waste signature.

In conclusion, the uranium in the contaminated vadose pore waters from the two new boreholes, 299-E33-344 and E33-345, appears to be either nearly full-strength BX-102 waste fluid or some mixture of BX-102 waste fluid with uncontaminated pore fluids. The uranium in the perched water from well 299-E33-344 found at $225 \mathrm{ft}$ bgs within the $\mathrm{CCU}_{\mathrm{z}}$ unit is also a mixture of BX-102 waste (84\%), a second waste containing elevated fluoride and chromium, and uncontaminated fluids that have equilibrated with both the $\mathrm{H} 2$ and $\mathrm{CCU}_{z}$ units in roughly equal proportions ( $8 \%$ of each). The

(a) An alternate description of this data point is that it could be on a mixing line with BY Cribs sourced uranium with clean $\mathrm{H} 2$ vadose zone pore water. Because all the other samples from boreholes E33-344 and E33-345 do not show any correlation with the BY Cribs uranium source signature, the distance from the BY Cribs and the demonstrated immobility of uranium disposed to BY Cribs, this alternate interpretation is less plausible. 
contaminated pore waters with a high percentage of BX-102 waste also have rather high total uranium concentrations $(17,000$ to $70,000 \mu \mathrm{g} / \mathrm{L})$ as would be expected. As examples, the pore water from $220 \mathrm{ft}$ bgs in well 299-E33-344 with a source signature that is approximately $50 \% \mathrm{BX}-102$ waste contains 80 $\mu \mathrm{g} / \mathrm{L}$ of total uranium, while the sediment sample from the same depth in well 299-E33-345 has a uranium source signature of $\sim 8 \% \mathrm{BX}-102$ waste and has a total uranium concentration of $13 \mu \mathrm{g} / \mathrm{L}$.

\subsubsection{B-8 Crib and Tile Field Description and Inventory Released}

As shown in Figure 3.30, the B-8 Crib and Tile Field is located north of the B Tank Farm and east of Baltimore Avenue. It is also north of the B-7-A\&B Cribs. The B-8 Crib has almost the same construction as the B-7-A\&B Cribs, with the exception of being 3 feet deeper (B-8 Crib is 7 feet instead of the 4 feet of the B-7-A\&B Cribs). The tile field is 91.5 meters $(300 \mathrm{ft})$ long and 30.5 meters (100 ft) wide. The main trunk of the tile field is a $30.48-\mathrm{cm}$ (12-in.) PVC pipe running northeast of the crib. Eight side pipes branch from the main trunk, each at a $45^{\circ}$ angle to the trunk and extending out $\sim 70 \mathrm{ft}$. The excavation for the tile field has a 1.22-m (4-ft) bottom dimension with a 1:1.5 side slope.

There are many service date discrepancies in the reference documents for the B- 8 crib. One document (Clukey 1956) states the B-8 Crib started receiving wastes in March 1945. Several documents agree that the B Plant began to release second-cycle waste to cribs in 1948. More than one reference states that the B-8 Crib stopped receiving effluent in December 1951. The most consistent activity appears to be the disposal to B-8 Crib starting in February 1948 of second cycle waste from the bismuth phosphate process. The B-8 Crib received this second cycle waste from B Plant via the B Tank Farm (SSTs B-110, B-111, and B-112) when tank storage space was full. The disposal of this second cycle waste appears to have ceased in July 1951. The B-8 Tile Field was built in August 1948 immediately after an inadvertent release of sludge from tank B-104 plugged the B- 8 Crib. The sludge release created a layer approximately $37.5 \mathrm{~cm}$ (15 in.) thick in the B-8 Crib. Some sludge washed to at least 6.1 meters (20 ft) below the crib bottom and was collected in the Health Instrument (HI) Shaft (labeled 200-E-45 in Figure 3.30). Citric and hydrochloric acids were added to the crib in an attempt to unplug the crib. Neither acid addition significantly improved the crib drainage, thus the B-8 Tile Field was built to receive crib overflow.

From December 1951 to December 1952, the B-8 Crib and Tile Field received decontamination and cleanup waste generated during the shutdown of the 221-B and 224-B facilities. Some documents state that the pipeline to the B-8 crib was blanked and the effluent routed to B-7-A crib in December 1954. However, Hanford drawing H-2-2928 shows that the effluent was re-routed to the B-11-A and B French Drains. The decontamination and cleanup waste was high in dissolved solids, neutral to basic in $\mathrm{pH}$, and contained transuranic waste and fission products. The details found in Table 3.11 on the time period of operation, types of wastes disposed of, and total volume of waste disposed of to B-8 Crib and B-8 Tile Field come from the WIDS data base.

The HI Shaft (WIDS Sitecode 200-E-45) is located adjacent to the west side of the B-8 Crib. The HI Shaft was originally installed to allow Health Instrument technicians to descend a ladder and collect liquid and soil samples from a depth of approximately 3 meters $(10 \mathrm{ft})$ and 6 meters $(20 \mathrm{ft})$ below the bottom of the B-8 Crib through openings in the shaft. Perforated lateral pipes extending beneath the crib allowed liquid waste from the crib to enter the pipes and collect in sample cups. Other holes were made in the side of the shaft facing the crib to collect sediment samples. According to the WIDS data base, 
samples were collected for several years ${ }^{(a)}$ and with sampling ending on December 31, 1949. In 1949, radiological readings up to $4 \mathrm{rad} /$ hour were recorded at the bottom of the HI Shaft. As of December 1949, 105 liquid samples, 4 sludge samples, and 7 sediment samples had been collected and analyzed to characterize the operation of the B-8 Crib. Liquid sample collected in the HI Shaft, before the inadvertent B-104 tank sludge discharge, contained less than 1000 disintegrations per minute per liter of alpha contamination. Liquid samples collected after the sludge release contained an average of 17,500 disintegrations per minute per liter of alpha contamination. Sediment samples collected from approximately 5.5 meters $(18 \mathrm{ft}$ ) below the crib from the HI Shaft before the sludge release contained beta-gamma activity of 0.13 microcuries per kilogram. After the sludge release, the activity increased to 0.33 microcuries per kilogram. No alpha contamination was found in the sediment samples.

The B-8 Crib and Tile Field was stabilized in 1992, along with the UPR-200-E-144 Surface Contamination Area, the B-7-A\&B Cribs and B-11-A\&B French Drains. Stabilization consisted of first scraping the surface of the tile field. The contaminated soil scraped off was consolidated on top of B-7A and B Cribs and B-11A\&B French Drains along with the soil from the UPR-200-E-144 clean-up. The B8 Crib was covered with 0.45 to 0.61 meters $(1.5$ to $2 \mathrm{ft})$ of uncontaminated backfill.

\subsubsection{B-8 Crib and Tile Field Vadose Zone}

There are no vadose zone boreholes within the footprint of the B-8 Crib, and no sediment samples have been analyzed from boreholes near or within the B-8 Tile Field area. Thus, the only data available to discuss are gross-gamma and spectral-gamma log results for nearby boreholes and the recent soil resistivity survey. A thorough review of the gamma-logging data was performed in DOE/GJO (2002a). Key points from that report have been excerpted and are presented herein. Figure 3.44 taken from DOE/GJO (2002a) shows a map of dry monitoring boreholes and groundwater wells that were placed inside the B- 8 Tile Field footprint and close to the B- 8 Crib. Figure 3.45 shows a 3D visualization of the 2002 status of cesium-137, the only gamma emitter that was found consistently throughout the vadose zone below the facility. The more mobile cobalt- 60 had decayed to such low values by the time of the 2002 study that it was not very useful in determining the vertical and horizontal spreading of waste fluids disposed to the B-8 Crib and Tile Field. The maximum gamma concentration measured was about $150,000 \mathrm{pCi} / \mathrm{g}$ of cesium-137 in borehole 299-E33-67, which is in closest proximity to the B-8 Crib of all the boreholes surveyed. Borehole 299-E33-89 exhibits a major interval of cesium-137 contamination at $\sim 20 \mathrm{ft}$ bgs that extends down to $\sim 145 \mathrm{ft}$ bgs where the borehole ends. Monitoring well 299-E33-16 is the deepest borehole in the vicinity of the B-8 Crib and exhibits almost continuous cesium-137 gamma contamination (but at very low concentrations below $105 \mathrm{ft}$ bgs) down to the water table. Boreholes northeast of the crib but within the far end of the tile field exhibit only near-surface gamma contamination. The 2002 data visualization in Figure 3.45 suggests that the vertical extent of cesium-137 was well above the water table, which occurs near an elevation of $401 \mathrm{ft}$. There does appear in the visualization to be horizontal spreading below B-8 Crib, generally following the vadose zone stratigraphic dip (northeast). The horizontal spread reaches only about two-thirds the distance of the tile field and does not reach well 299-E33-17 to the east or well 299-E33-15 to the north. The gamma contamination in boreholes in the three waste sites (B-7A\&B Crib, B-8 Crib and Tile Field, and B-11-A\&B French Drains)

(a) This statement suggests that the B-8 Crib and HI Shaft were constructed before 1948 as many documents suggest. Cluckey (1956) could have the correct date of construction of 1945. 
PNNL-19277

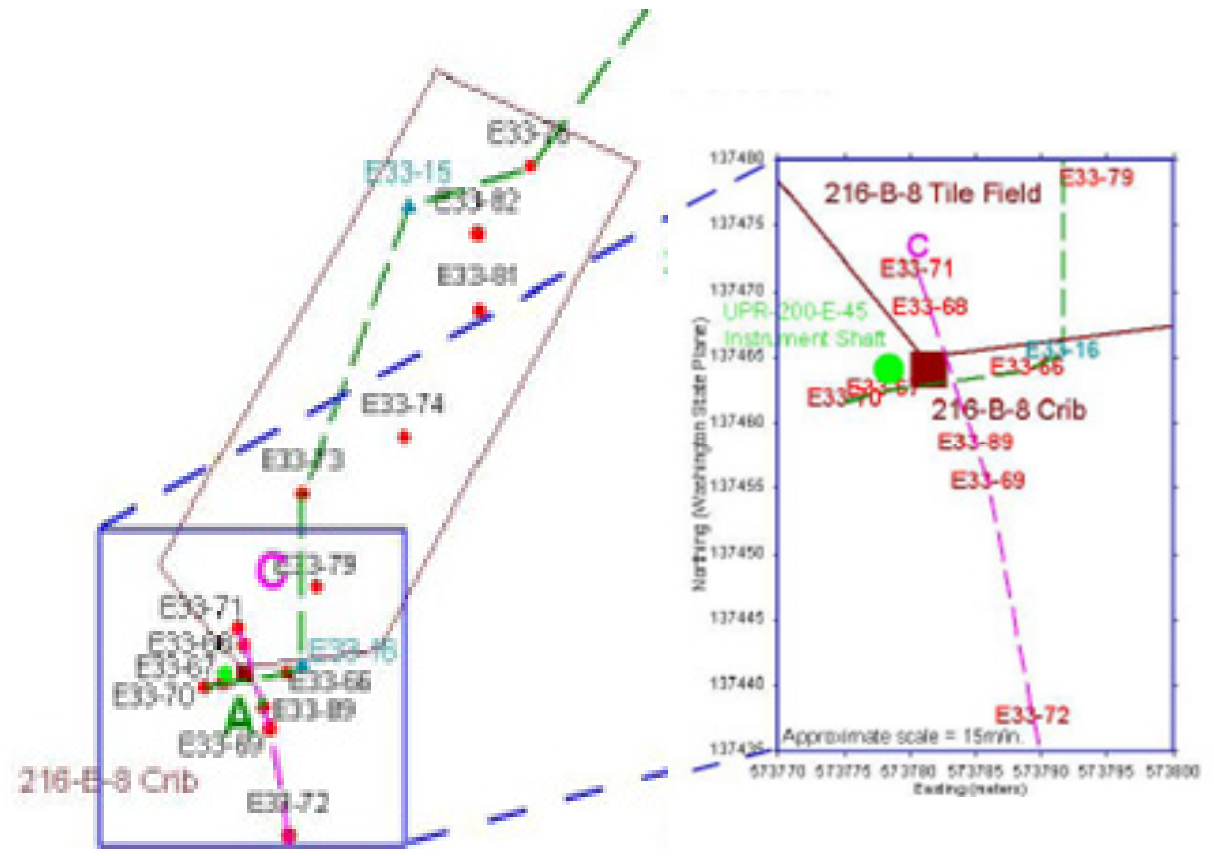

Figure 3.44. Boreholes and Monitoring Wells Within and Surrounding B-8 Crib and Tile Field (taken from DOE/GJO 2002a)

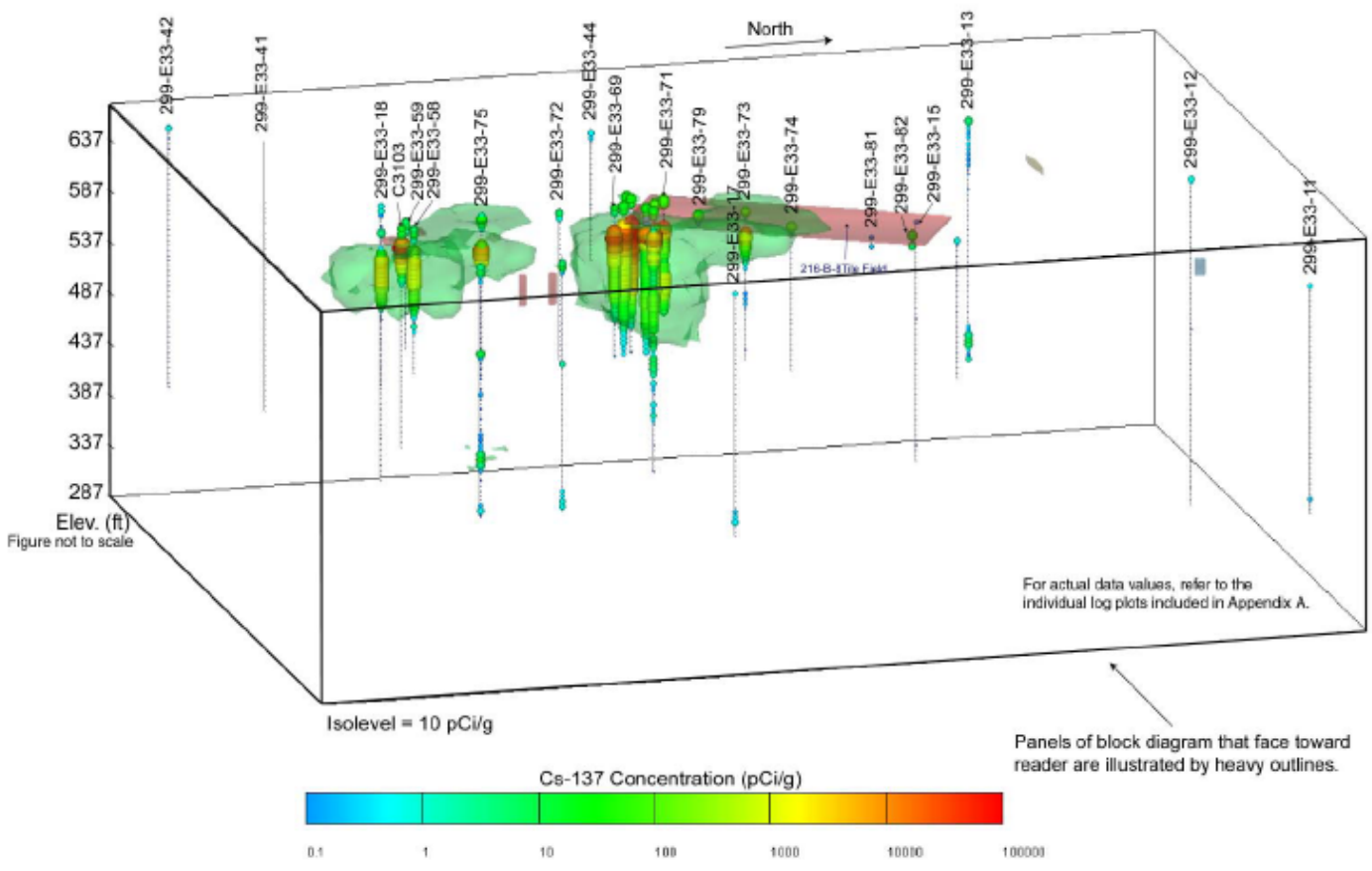

Figure 3.45. $3 \mathrm{D}$ Visualization of ${ }^{137} \mathrm{Cs}$ Distribution in Vadose Zone Below the B-7-A\&B and B-8 Facilities (taken from DOE/GJO 2002a)

$B-7 A \& B$ are the left hand region, $B-8$ is within the cluster of boreholes in the middle of the figure. The tile field area is designated by the purplish rectangle. 
does not appear to correlate depth wise; thus, it is unlikely that wastes from each facility have commingled, at least in the portion of vadose zone above the historical high water table (see the clear separation of waste plumes shown in Figure 3.45).

However, historical gross gamma logs from 1959 of borehole 299-E33-16 show that contamination was already present in groundwater (Raymond and McGhan 1964). Historical log information collected after 1959 also suggest the possibility of contaminant breakthrough to the groundwater in the vicinity of the B-8 Crib. A comparison of the profiles of historical gross gamma logs and current SGLS logs as well as a more direct comparison of more recent RLS spectral logs with the SGLS suggest that contamination profiles and concentrations at the waste sites are relatively stable over time such that further migration of gamma emitters is not evident.

Using the gamma logging, the fact that large volumes of liquids were disposed of to the B- $8 \mathrm{crib}$, and historical groundwater data, it has been concluded that liquids disposed of to the B-8 Crib likely did reach groundwater no later than 1959. The qualitative soil electrical resistivity field survey (see Rucker et al. 2007) as discussed in Section 3.3.2 and shown in Figure 3.34 also suggest that the high conductivity plume below the B-8 Crib resides in the water table today. It is interesting to note that waste fluids disposed of to the B-8 Tile Field do not appear to have travelled to the far end of the drain field before completely percolating into the subsurface.

\subsubsection{B-51 French Drain Description and Inventory Released}

The B-51 French Drain is located northeast of the B-8 Tile Field (see Figure 3.30). The B-51 French Drain is constructed of sections of $1.5-\mathrm{m}(5-\mathrm{ft})$ diameter concrete pipe stacked vertically extending $30 \mathrm{~cm}$ $(1 \mathrm{ft})$ above ground and 4.3 meters $(14 \mathrm{ft})$ below ground. The concrete pipe column was filled with 4 meters (13 ft) of gravel. The French Drain has a wood cover with vent holes. A region 3 meters by 3 meters (10 ft by $10 \mathrm{ft}$ ) around the structure has been designated as a Radiation Contamination Area.

The site received drainage from the BC Crib pipeline from January 1956 to January 1958. The pipeline carried high conductivity, neutral-to-basic $\mathrm{pH}$, scavenged waste via the BY Tank Farm to the BC Crib area. The site contains less than 10 curies total beta. More details of the B-51 French Drain waste types and volumes disposed of are found in Table 3.11 .

\subsubsection{B-51 French Drain Vadose Zone}

There has been no vadose zone sediment characterization within or close to the B-51 French Drain. Further, there is such sparse dry well and groundwater monitoring well coverage in the area that historical and spectral gamma logging data are inadequate to make any statements about the vertical extent and horizontal spreading potential of waste fluids disposed of to this facility. The latter conclusion is also made in DOE-GJO (2002a) “...the B-51 French Drain, 244-BX-DCRT, B-252 Diversion Box, and the B301 Catch Tank do not have boreholes in close proximity and thus the presence or absence of contamination in the immediate vicinity cannot be evaluated."

Based on the low volume of liquid disposed of (only 750 liters) and low total inventories (see Table 3.11$)$ of key constituents $(0.03 \mathrm{~kg}$ of uranium and $0.003 \mathrm{Ci}$ of technetium-99), this facility will be ignored as a significant contributor to deep vadose zone and upper unconfined aquifer contamination. Therefore, further evaluation of this facility will not be included in any further discussions. 
PNNL-19277

\subsubsection{B-11-A\&B French Drains (Dry Wells) Description and Inventory Released}

The B-11-A\&B French Drains are located north of the B Tank Farm and east of Baltimore Avenue, directly east of the B-7-A\&B Cribs (see Figure 3.30). WIDS refers to these facilities as French drains in its "type" categories, but much of the available literature calls these facilities dry wells or reverse wells. The WIDS "type" nomenclature will be used for subsequent discussions. B-11-A is the southern French drain; B-11-B is the northern French drain. The two French drains are 16 meters (52.5 ft) apart. Each French drain is constructed of a $9.15-\mathrm{m}$ (30-ft) long corrugated, 4-ft-diameter culvert, buried vertically 3.05 meters $(10 \mathrm{ft})$ below grade. The culverts are perforated with $1 / 2$-in. $(1.27-\mathrm{cm})$ holes, 6 in. $(15.24 \mathrm{~cm})$ on center horizontally and 12 in $(30.48 \mathrm{~cm})$ on center vertically, starting at 6 in. $(15.24 \mathrm{~cm})$ from the bottom. The culverts were placed in $2.44-\mathrm{m}(8-\mathrm{ft})$ diameter excavations that are filled with crushed rock. The culverts are connected with a 7.6-cm (3-in.) diameter steel pipe.

The site originally received condensate waste from the 242-B Evaporator. Drawing H-2-2928 shows B-8 Crib waste being re-routed to B-11-A\&B French Drains in 1954. The B-11-A\&B French Drains received waste from December 1951 to December 1954. Most of the liquid waste went to the B-11-A French Drain because of the piping arrangement. Details on the period of operation and the types and volumes of waste disposed of to the two French drains are found in Table 3.11.

In 1992, cleanup of the soil contamination area from UPR-200-E-144 was placed along the north side of the B Tank Farm. The resulting large spoil pile covered the B-11-A\&B French Drains. Wells 299E33-20 and E33-19 monitor these two French drains.

\subsubsection{B-11-A\&B French Drains (Dry Wells) Vadose Zone}

There have been no vadose zone sediment characterization studies within or close to the B-11A\&B French Drains. However, several boreholes in the region that have been gamma logged over the years can be used to assess the status of contamination below and proximal to these two French drains. Gross gamma logs were acquired in 1959 and 1963 from borehole 299-E33-20. The 1959 log indicated contamination throughout the (length of borehole) of the borehole. Based on the fact that the $1963 \log$ indicated elevated total gamma only down to $80 \mathrm{ft}$ bgs and at the bottom of the borehole, the dominant gamma-emitting radionuclide measured in 1959 was likely the short lived ruthenium-106. The 1963 profile is consistent with the 2002 SGLS log data that shows some shallow cesium-137 and deep cobalt60. Raymond and McGhan (1964) concluded "The 1959 scintillation log shows low-level contamination of the entire soil column. The sharp peak noted on the 1959 and 1963 logs at about $80 \mathrm{ft}$ bgs is probably caused by waste from the adjacent B-7-A\&B Cribs. The 1963 trace indicates that decay has reduced the radioactivity in most of the soil column to near background levels." These authors also state that the B$11-A \& B$ French Drains likely contaminated groundwater soon after disposal began.

Fecht et al. (1977) reported gamma contamination at 90 and $75 \mathrm{ft}$ bgs in wells 299-E33-19 and -20, respectively. In contrast to Raymond and McGhan (1964), they concluded that no measurable migration of radionuclides or breakthrough of contaminants to the groundwater had occurred. Borehole 299-E33-20 was logged with both a gross gamma logging system and RLS (Brodeur et al. 1993). The 1993 logs indicated three minor zones of cesium-137 contamination at about 10, 90, and $190 \mathrm{ft}$ bgs, but based on the older gross gamma-ray logs, Brodeur et al. (1993) assumed that groundwater at this site had been contaminated with cesium-137. 
SGLS logging in 2002 at well 299-E33-20 indicated intermittent cesium-137 contamination near the SGLS's Minimum Detectable Limit between 78 and $194 \mathrm{ft}$ bgs with an interval between 178.4 and 189.4 $\mathrm{ft}$ bgs measuring about $20 \mathrm{pCi} / \mathrm{g}$. Both wells, 299-E33-19 and -20, indicated cesium-137 contamination just above the groundwater table at $\sim 240 \mathrm{ft}$ bgs. Intervals of cesium-137 contamination were detected between 232.4 and $237.4 \mathrm{ft}$ bgs in well 299-E33-20 and between 219.3 and $234.3 \mathrm{ft}$ bgs in well 299-E3319. Cobalt-60 was detected in the 2002 logging event at intermittent depth intervals from 104 to $120 \mathrm{ft}$ bgs in well 299-E33-19 and at $213.4 \mathrm{ft}$ bgs in the upper vadose zone in well 299-E33-20. Both locations indicate minor amounts of cobalt-60 just above the current groundwater table. The DOE/GJO (2002a) authors concluded that:

"On the basis of historical logs in borehole 299-E33-20, contamination introduced to the B-11-A Dry Well may have entered the groundwater prior to 1959 . Current SGLS data shows ${ }^{60}$ Co and ${ }^{137} \mathrm{Cs}$ intermittently throughout the borehole below $78 \mathrm{ft}$ bgs. The contamination is not as extensive in borehole 299-E33-19. Although the contamination was distributed to both dry wells, Maxfield (1979) suggested that the majority of contamination probably entered the B-11-A Dry Well. It should also be noted that Wood et al. (2000) have concluded that breakthrough to groundwater had occurred in the vicinity, apparently only on the basis of the that was similar to a "Reverse Well" that is usually reserved for wells where fluid is directly injected to the groundwater. Waste liquids from B-7A\&B Cribs do not appear to have migrated down the vadose zone stratigraphic dip (northeast) as far as the B-11A\&B French Drains."

To better ascertain the status of the vadose zone sediments below and proximal to the B-11-A\&B French Drains, the following recommendations offered in DOE/GJO (2002a) are being endorsed:

"The locations of the existing boreholes, northwest and southeast, relative to the B-11A\&B dry wells are not well suited to intercept contamination that likely would flow to the northeast along the vadose zone stratigraphic dip. One or more boreholes drilled northeast of the B-11-A\&B dry wells would be useful to better determine the nature and extent of the contamination."

Near surface contamination observed in the 2002 SGLS survey is likely from the unplanned release mentioned in Section 3.3.4 where contaminated soil was removed, transported to the B-7A \&B Cribs and B-11-A\&B French Drains location and topped with clean fill. This contamination is composed of cesium-137 and is generally on the order of 10 to $20 \mathrm{pCi} / \mathrm{g}$ with a profile of 5 to $10 \mathrm{ft}$ in thickness. The currently observed low concentrations of cobalt-60 and cesium-137 right above the water table in borehole E33-19 are likely adsorbed contaminants inside the rusted borehole casing and not indicative of the current groundwater, itself. In conclusion, the B-11-A\&B French Drains are likely contributors to the historical groundwater plume, but based on the low inventory of key contaminants (only $0.04 \mathrm{~kg}$ of uranium and $0.003 \mathrm{Ci}$ of technetium-99; see Table 3.11), this facility is not worthy of being considered a current or future source of significant contamination to the groundwater.

\subsubsection{Vadose Zone Inventory Calculations for B-7-A Crib}

The available sediment data to determine the inventory of technetium-99 and uranium below the B7A Crib is not complete because the $\mathrm{C} 3103$ borehole was terminated well above the water table at the top of the $\mathrm{CCU}_{\mathrm{z}}$. The decision was made at the time to end drilling when unexpected wet sediment interpreted as water saturated was encountered. Much has been learned about the geology and subsurface contamination since this borehole was drilled in 2001 and it is now realized that the $\mathrm{CCU}_{z}$ unit is very 
important to understanding vadose zone contaminant distribution below the B-Complex. Unfortunately, stopping the borehole $\mathrm{C} 3103$ drilling represents a missed opportunity to explore lateral spreading in this subregion. The inventory box model calculations presented here assume that the $\mathrm{CCU}_{\mathrm{z}}$ and $\mathrm{CCU}_{\mathrm{g}}$ sediments below the $\mathrm{C} 3103$ borehole contain similar concentrations of technetium- 99 and uranium as the sediments at the two new boreholes 299-E33-344 and -E33-345. These boreholes are $\sim 70 \mathrm{ft}$ west of the B-7-A crib, and the $\mathrm{CCU}_{z}$ layer is quite thick underneath the entire region encompassing the two new boreholes and the B-7-A Crib (see Figure 3.46). It has been found that the sediments from the $\mathrm{CCU}_{\mathrm{z}}$ unit at 299-E33-344 and -E33-345 contain elevated levels of many constituents, including technetium-99 and uranium; thus, it seems appropriate to assume that similar contaminant concentrations would occur within this known lateral spreading layer below the B-7-A Crib.

A second complication is that the types of waste disposed to the B-7-A\&B Cribs differed significantly in chemical composition between their first usage between 1946 and 1954 and the second campaign in 1966-1967. There were two waste types disposed in the first campaign whose compositions were distinctly different in total dissolved solids (dominated by sodium and nitrate) content. One waste stream, from the 224 Building, contained $\sim 37 \mathrm{~g} / \mathrm{L}$ sodium, $\sim 86 \mathrm{~g} / \mathrm{L}$ nitrate, $\sim 5 \mathrm{~g} / \mathrm{L}$ fluoride, $\sim 0.4 \mathrm{~g} / \mathrm{L}$ chromium and $\sim 35 \mathrm{pCi} / \mathrm{L}$ technetium-99 while the other waste stream, from specific hot cells $5-6$, contained $\sim 2.4$ $\mathrm{g} / \mathrm{L}$ sodium, $\sim 4.7 \mathrm{~g} / \mathrm{L}$ nitrate, $\sim 0.3 \mathrm{~g} / \mathrm{L}$ fluoride, $\sim 0.01 \mathrm{~g} / \mathrm{L}$ chromium but $\sim 160 \mathrm{pCi} / \mathrm{L}$ technetium. The decontamination wastes disposed in 1966-67 were more dilute but still contained nearly $5 \mathrm{~g} / \mathrm{L}$ sodium, 10 $\mathrm{g} / \mathrm{L}$ nitrate, essentially no fluoride or uranium, $\sim 1 \mathrm{pCi} / \mathrm{L}$ technetium- 99 and $0.42 \mathrm{~g} / \mathrm{L}$ chromium. The volumes of waste disposed also differed with the 1946 to 1954 campaign totaling 43.5 mega-liters ( 4.8 mega-liters per yr) compared to 1.1 mega-liters disposed between 1966 and 1967. The differences in waste composition and volumes disposed as well as the twelve year hiatus between disposal campaigns likely complicated the distribution of contaminants in the sediment profile below the B-7-A Crib such that the incomplete sediment profile afforded by the drilling of borehole $\mathrm{C} 3103$ down to the top of the $\mathrm{CCU}_{z}$ unit makes it difficult to develop the mass estimates for residual contaminants in the vadose zone.

Despite all the caveats the mass estimates were performed as follows. It was assumed, based on the elevated fluoride and chromium in the $\mathrm{CCU}_{z}$ pore waters from the two new boreholes (299-E33-344 and E33-345) that one source for the chemical contamination must be the B-7-A\& B Cribs and/or B-8 Crib and Tile Field so that sediments at the $\mathrm{C} 3103$ borehole deeper in the sediment profile than sampled would have similar concentrations of contaminants as the sediments from 299-E33-344 and -345. Thus, sediment data results from C3103 and the two new boreholes 299-E33-344,345 have been combined to provide values to populate the inventory box model for the B-7-A\&B Cribs. The one exception is the assumption that the uranium present in the 299-E33-344 and -345 $\mathrm{CCU}_{z}$ sediments comes from the BX102 source and not the B-7-A\&B and B-8 Cribs subregion. Vadose zone inventories can only be estimated for the area surrounding B-7-A\&B Cribs because no direct sediment contaminant concentration data for the B-8 Crib and Tile Field exist. As discussed in Section 3.3.5, field gamma results do not suggest that there has been sufficient lateral spreading to commingle the vadose zone waste plumes from B-7-A\&B with either B-8 or B-11-A and B vadose zone inventories. 
PNNL-19277

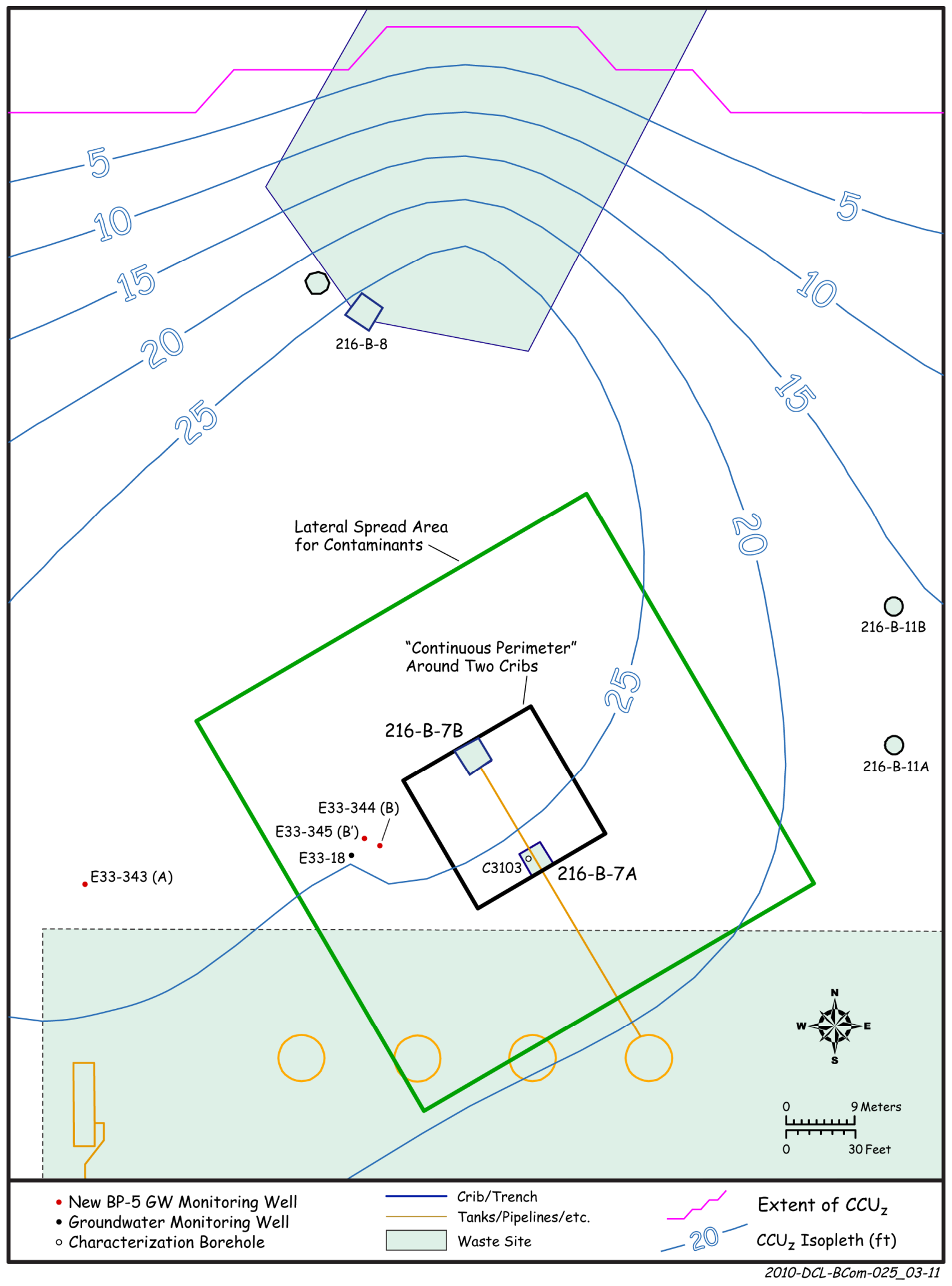

Figure 3.46. Conceptual Inventory Model Areas for B-7A\&B Cribs 
Three vadose zone contaminant distribution models are considered to estimate the masses of technetium-99 and uranium below the B-7-A\&B Cribs. The three conceptual models are portrayed in Figure 3.46. Model 1 assumes that the wastes disposed of to the relatively small footprint of these two cribs descended only straight down the footprints to the water table. Model 2 assumes limited horizontal spreading such that the footprint through which the fluids percolated vertically to the water table was the entire perimeter around both cribs as delineated by the black box, which has the dimensions of 64 by 64 $\mathrm{ft}$. Model 3 assumes that there is a $\sim 20$-m horizontal spreading zone throughout the $\mathrm{CCU}_{z}$ unit sediments below the contiguous perimeter footprint surrounding the two cribs (i.e., the black box). The conceptual model \#3 assumes vertical migration down through the perimeter footprint and then both vertical and horizontal flow through the Cold Creek Units $\left(\mathrm{CCU}_{\mathrm{z}}\right.$ and $\left.\mathrm{CCU}_{\mathrm{g}}\right)$ for $20 \mathrm{~m}$ in all directions. Model \#3 honors the assumption that fluids from the B-7-A\&B Cribs have reached the new boreholes, 299-E33344and -E33-345, based on high fluoride and chromium found in the $\mathrm{CCU}_{\mathrm{z}}$ pore waters at these two boreholes, and that no contamination is found shallower in the Hanford formation sediments at the two new boreholes.

The inventory estimates for the technetium-99 and uranium masses are shown in Table 3.14. Detailed logic and equations showing the derivation of the values found in Table 3.14 are found in Appendix I. Model \#1 estimates show that $16 \%$ of the technetium-99 disposed of to the B-7A\&B cribs is still present in the vadose zone sediments directly below the actual footprint of the two $12-\mathrm{ft} \times 12$ - $\mathrm{ft}$ square cribs with most of the mass in the $\mathrm{CCU}_{z}$ unit. The uranium inventory calculation for Model \#1 shows that $21 \%$ of the uranium disposed of to the cribs is contained in the actual footprint, with most of it between the depths of 20 to $30 \mathrm{ft}$ bgs (at the bottom of the cribs). Further, based on water extract data on the sediments from $\mathrm{C} 3103$, only $2.2 \%$ of the uranium disposed of to the cribs is readily leachable. The inventory calculations for Model 2 show that when the footprint is expanded to include the entire area encompassed by the perimeter around the two cribs, there would be unrealistically large technetium-99 (231\%) and $296 \%$ of the disposed uranium remaining in the sediments below the B-7A\&B Cribs perimeter footprint. The Model 2 estimates show 189\% of the total technetium-99 disposed of to the B$7 \mathrm{~A} \& \mathrm{~B}$ Cribs and only $18 \%$ of the total uranium is mobile and in the deep vadose zone (within $90 \mathrm{ft}$ of the water table). Model 3 mass estimates, which sum the mass under the perimeter of the B-7A\&B Cribs with the 20-m $\mathrm{CCU}_{z}$ spreading zone in all directions, leads to significantly higher masses remaining in the vadose zone than were disposed of to the two cribs. The values chosen for technetium-99 and uranium in the CCU unit sediments are measured values from the two new boreholes 299-E33-344,-345. Using these values for the contaminant concentrations in the Cold Creek unit sediments leads to unrealistic masses remaining in the region if the contaminants came solely from B-7A\&B disposal. That is, about 17 times more technetium- 99 and almost 2.5 times more uranium is predicted to be in the $\mathrm{CCU}_{\mathrm{z}}$ sediments surrounding the cribs than were disposed of. At least three possibilities exist to explain this discrepancy: either the 20-m spreading distance in each direction has been over-estimated, or there is another facility besides the B-7A\&B waste supplying waste, or the SIM estimates of waste inventory disposed of to the B-7-A\&B Cribs is biased low.

The authors of this report believe that the second possibility - another waste source - is the most plausible explanation. Based on knowledge gleaned from all the new boreholes in the B-Complex, it is clear that wastes from several facilities have spread horizontally within the $\mathrm{CCU}_{z}$ unit for distances much greater than $20 \mathrm{~m}$. The fact that fluoride and chromium are present in the pore waters at boreholes 299E33-344,-345 shows that waste fluids from B-7A\&B and/or B-8 Cribs have definitely spread laterally 
PNNL-19277

Table 3.14. Mass Estimates for Technetium- 99 and Total and Water-Leachable Uranium in Vadose Zone Sediments near 216-B-7A\&B Cribs

\begin{tabular}{|c|c|c|c|c|c|c|c|c|c|c|c|}
\hline $\begin{array}{c}\text { Model \#1 } \\
\mathrm{A}=26.8\end{array}$ & $\mathrm{pCi} / \mathrm{g}$ & $\mu \mathrm{g} / \mathrm{g}$ & $\mu \mathrm{g} / \mathrm{g}$ & thick & Volume & $\begin{array}{l}\text { Sediment } \\
\text { Mass }\end{array}$ & $\mathrm{Tc}$ & $\mathrm{U}(\mathrm{AE})$ & $\mathrm{U}(\mathrm{WE})$ & Tc-99 (Ci) & $\mathrm{U}(\mathrm{kg})$ \\
\hline $\mathrm{m}^{2}$ & $\mathrm{Tc}$ & $\mathrm{U}(\mathrm{AE})$ & $\mathrm{U}(\mathrm{WE})$ & $\mathrm{ft}$ & $\mathrm{m}^{3}$ & $\mathrm{~g}$ & $\mathrm{Ci}$ & $\mathrm{kg}$ & $\mathrm{kg}$ & \multicolumn{2}{|c|}{ disposed to B-7-A\&B } \\
\hline backfill & 0.2 & 2 & 0.001 & 20 & $1.63 \mathrm{E}+02$ & $3.51 \mathrm{E}+08$ & 7.01E-05 & $7.01 \mathrm{E}-01$ & $3.51 \mathrm{E}-04$ & $9.47 \mathrm{E}-02$ & $1.97 \mathrm{E}+02$ \\
\hline H1 & 20 & 125 & 1.5 & 5 & $4.08 \mathrm{E}+01$ & $7.22 \mathrm{E}+07$ & $1.44 \mathrm{E}-03$ & $9.02 \mathrm{E}+00$ & $1.08 \mathrm{E}-01$ & & \\
\hline $\mathrm{H} 2$ & 5 & 300 & 5 & 5 & $4.08 \mathrm{E}+01$ & $7.22 \mathrm{E}+07$ & $3.61 \mathrm{E}-04$ & $2.17 \mathrm{E}+01$ & $3.61 \mathrm{E}-01$ & \multicolumn{2}{|c|}{ literal footprint } \\
\hline $\mathrm{H} 2$ & 2 & 25 & 2 & 5 & $4.08 \mathrm{E}+01$ & $7.22 \mathrm{E}+07$ & $1.44 \mathrm{E}-04$ & $1.80 \mathrm{E}+00$ & $1.44 \mathrm{E}-01$ & & All VZ \\
\hline $\mathrm{H} 2$ & 1 & 5 & 2 & 25 & $2.04 \mathrm{E}+02$ & $3.61 \mathrm{E}+08$ & $3.61 \mathrm{E}-04$ & $1.80 \mathrm{E}+00$ & $7.22 \mathrm{E}-01$ & $16 \%$ & $\mathrm{Tc}$ \\
\hline $\mathrm{H} 2$ & 0.5 & 3 & 1 & 20 & $1.63 \mathrm{E}+02$ & $2.89 \mathrm{E}+08$ & 1.44E-04 & $8.66 \mathrm{E}-01$ & $2.89 \mathrm{E}-01$ & $2.2 \%$ & $\mathrm{U}(\mathrm{WE})$ \\
\hline $\mathrm{H} 2$ & 0.2 & 1.5 & 0.5 & 10 & $8.16 \mathrm{E}+01$ & $1.44 \mathrm{E}+08$ & $2.89 \mathrm{E}-05$ & $2.17 \mathrm{E}-01$ & $7.22 \mathrm{E}-02$ & $21 \%$ & $\mathrm{U}$ (total) \\
\hline $\mathrm{H} 2$ & 0.2 & 0.8 & 0.05 & 20 & $1.63 \mathrm{E}+02$ & $2.89 \mathrm{E}+08$ & $5.77 \mathrm{E}-05$ & $2.31 \mathrm{E}-01$ & $1.44 \mathrm{E}-02$ & & \\
\hline $\mathrm{H} 2$ & 0.2 & 0.6 & 0.005 & 53.3 & $4.35 \mathrm{E}+02$ & $7.69 \mathrm{E}+08$ & $1.54 \mathrm{E}-04$ & $4.62 \mathrm{E}-01$ & $3.85 \mathrm{E}-03$ & \multicolumn{2}{|c|}{ literal footprint } \\
\hline $\mathrm{H} 2$ & 0.2 & 0.6 & 0.005 & 56.7 & $4.62 \mathrm{E}+02$ & $8.18 \mathrm{E}+08$ & $1.64 \mathrm{E}-04$ & 4.91E-01 & 4.09E-03 & \multicolumn{2}{|r|}{ Deep VZ } \\
\hline $\mathrm{CCUz}$ & 0.5 & 1 & 0.1 & 5 & $4.08 \mathrm{E}+01$ & $6.73 \mathrm{E}+07$ & $3.36 \mathrm{E}-05$ & $6.73 \mathrm{E}-02$ & $6.73 \mathrm{E}-03$ & $13 \%$ & $\mathrm{Tc}$ \\
\hline $\mathrm{CCUz}$ & 5 & 10 & 8 & 5 & $4.08 \mathrm{E}+01$ & $6.73 \mathrm{E}+07$ & $3.36 \mathrm{E}-04$ & $6.73 \mathrm{E}-01$ & $5.38 \mathrm{E}-01$ & $1.3 \%$ & $\mathrm{U}(\mathrm{WE})$ \\
\hline $\mathrm{CCUz}$ & 75 & 20 & 15 & 10 & $8.16 \mathrm{E}+01$ & $1.35 \mathrm{E}+08$ & $1.01 \mathrm{E}-02$ & $2.69 \mathrm{E}+00$ & $2.02 \mathrm{E}+00$ & $2.1 \%$ & $\mathrm{U}$ (total) \\
\hline $\mathrm{CCUz}$ & 25 & 2 & 0.003 & 5 & $4.08 \mathrm{E}+01$ & $6.73 \mathrm{E}+07$ & $1.68 \mathrm{E}-03$ & $1.35 \mathrm{E}-01$ & $2.02 \mathrm{E}-04$ & & \\
\hline CCUg & 2 & 1 & 0.0015 & 8.3 & $6.77 \mathrm{E}+01$ & $1.46 \mathrm{E}+08$ & $2.91 \mathrm{E}-04$ & $1.46 \mathrm{E}-01$ & $2.18 \mathrm{E}-04$ & & \\
\hline \multirow[t]{2}{*}{$\begin{array}{l}\text { Water } \\
\text { Table }\end{array}$} & & & & 253.3 & & total VZ & $1.54 \mathrm{E}-02$ & $4.10 \mathrm{E}+01$ & $4.28 \mathrm{E}+00$ & & \\
\hline & & & & & & deep VZ & $1.26 \mathrm{E}-02$ & $4.20 \mathrm{E}+00$ & $2.57 \mathrm{E}+00$ & & \\
\hline Model \#2 & $\mathrm{pCi} / \mathrm{g}$ & $\mu \mathrm{g} / \mathrm{g}$ & $\mu \mathrm{g} / \mathrm{g}$ & thick & Volume & $\begin{array}{l}\text { Sediment } \\
\text { Mass }\end{array}$ & $\mathrm{Tc}$ & U(AE) & U(WE) & Tc-99 (Ci) & $\mathrm{U}(\mathrm{kg})$ \\
\hline $\begin{array}{c}\mathrm{A}=380.5 \\
\mathrm{~m}^{2}\end{array}$ & $\mathrm{Tc}$ & $\mathrm{U}(\mathrm{AE})$ & U(WE) & $\mathrm{ft}$ & $\mathrm{m}^{3}$ & $\mathrm{~g}$ & $\mathrm{Ci}$ & $\mathrm{kg}$ & $\mathrm{kg}$ & \multicolumn{2}{|c|}{ disposed to $\mathrm{B}-7-\mathrm{A} \& \mathrm{~B}$} \\
\hline backfill & 0.2 & 2 & 0.001 & 20 & $2.32 \mathrm{E}+03$ & $4.99 \mathrm{E}+09$ & $9.97 \mathrm{E}-04$ & $9.97 \mathrm{E}+00$ & $4.99 \mathrm{E}-03$ & $9.47 \mathrm{E}-02$ & $1.97 \mathrm{E}+02$ \\
\hline H1 & 20 & 125 & 1.5 & 5 & $5.80 \mathrm{E}+02$ & $1.03 \mathrm{E}+09$ & $2.05 \mathrm{E}-02$ & $1.28 \mathrm{E}+02$ & $1.54 \mathrm{E}+00$ & & \\
\hline $\mathrm{H} 2$ & 5 & 300 & 5 & 5 & $5.80 \mathrm{E}+02$ & $1.03 \mathrm{E}+09$ & $5.13 \mathrm{E}-03$ & $3.08 \mathrm{E}+02$ & $5.13 \mathrm{E}+00$ & \multicolumn{2}{|c|}{ perimeter footprint } \\
\hline $\mathrm{H} 2$ & 2 & 25 & 2 & 5 & $5.80 \mathrm{E}+02$ & $1.03 \mathrm{E}+09$ & $2.05 \mathrm{E}-03$ & $2.57 \mathrm{E}+01$ & $2.05 \mathrm{E}+00$ & & All VZ \\
\hline $\mathrm{H} 2$ & 1 & 5 & 2 & 25 & $2.90 \mathrm{E}+03$ & $5.13 \mathrm{E}+09$ & $5.13 \mathrm{E}-03$ & $2.57 \mathrm{E}+01$ & $1.03 \mathrm{E}+01$ & $231 \%$ & $\mathrm{Tc}$ \\
\hline $\mathrm{H} 2$ & 0.5 & 3 & 1 & 20 & $2.32 \mathrm{E}+03$ & $4.11 \mathrm{E}+09$ & $2.05 \mathrm{E}-03$ & $1.23 \mathrm{E}+01$ & $4.11 \mathrm{E}+00$ & $30.9 \%$ & U(WE) \\
\hline $\mathrm{H} 2$ & 0.2 & 1.5 & 0.5 & 10 & $1.16 \mathrm{E}+03$ & $2.05 \mathrm{E}+09$ & $4.11 \mathrm{E}-04$ & $3.08 \mathrm{E}+00$ & $1.03 \mathrm{E}+00$ & $296 \%$ & U(total) \\
\hline $\mathrm{H} 2$ & 0.2 & 0.8 & 0.05 & 20 & $2.32 \mathrm{E}+03$ & $4.11 \mathrm{E}+09$ & $8.21 \mathrm{E}-04$ & $3.28 \mathrm{E}+00$ & $2.05 \mathrm{E}-01$ & & \\
\hline $\mathrm{H} 2$ & 0.2 & 0.6 & 0.005 & 53.3 & $6.18 \mathrm{E}+03$ & $1.09 \mathrm{E}+10$ & $2.19 \mathrm{E}-03$ & $6.57 \mathrm{E}+00$ & $5.47 \mathrm{E}-02$ & \multicolumn{2}{|c|}{ perimeter footprint } \\
\hline $\mathrm{H} 2$ & 0.2 & 0.6 & 0.005 & 56.7 & $6.58 \mathrm{E}+03$ & $1.16 \mathrm{E}+10$ & $2.33 \mathrm{E}-03$ & $6.98 \mathrm{E}+00$ & $5.82 \mathrm{E}-02$ & \multicolumn{2}{|r|}{ Deep VZ } \\
\hline $\mathrm{CCUz}$ & 0.5 & 1 & 0.1 & 5 & $5.80 \mathrm{E}+02$ & $9.57 \mathrm{E}+08$ & $4.78 \mathrm{E}-04$ & $9.57 \mathrm{E}-01$ & $9.57 \mathrm{E}-02$ & $189 \%$ & $\mathrm{Tc}$ \\
\hline $\mathrm{CCUz}$ & 5 & 10 & 8 & 5 & $5.80 \mathrm{E}+02$ & $9.57 \mathrm{E}+08$ & $4.78 \mathrm{E}-03$ & $9.57 \mathrm{E}+00$ & $7.66 \mathrm{E}+00$ & $18.5 \%$ & $\mathrm{U}(\mathrm{WE})$ \\
\hline $\mathrm{CCUz}$ & 75 & 20 & 15 & 10 & $1.16 \mathrm{E}+03$ & $1.91 \mathrm{E}+09$ & $1.44 \mathrm{E}-01$ & $3.83 \mathrm{E}+01$ & $2.87 \mathrm{E}+01$ & $30.3 \%$ & $\mathrm{U}$ (total) \\
\hline CCUz & 25 & 2 & 0.003 & 5 & $5.80 \mathrm{E}+02$ & $9.57 \mathrm{E}+08$ & $2.39 \mathrm{E}-02$ & $1.91 \mathrm{E}+00$ & $2.87 \mathrm{E}-03$ & & \\
\hline CCUg & 2 & 1 & 0.0015 & 8.3 & $9.63 \mathrm{E}+02$ & $2.07 \mathrm{E}+09$ & $4.14 \mathrm{E}-03$ & $2.07 \mathrm{E}+00$ & $3.10 \mathrm{E}-03$ & & \\
\hline \multirow[t]{2}{*}{$\begin{array}{l}\text { Water } \\
\text { Table } \\
\end{array}$} & & & & 253.3 & & total VZ & $2.19 \mathrm{E}-01$ & $5.83 \mathrm{E}+02$ & $6.09 \mathrm{E}+01$ & & \\
\hline & & & & & & deep VZ & $1.79 \mathrm{E}-01$ & $5.98 \mathrm{E}+01$ & $3.65 \mathrm{E}+01$ & & \\
\hline Model \#3 & $\mathrm{pCi} / \mathrm{g}$ & $\mu \mathrm{g} / \mathrm{g}$ & $\mu \mathrm{g} / \mathrm{g}$ & thick & Volume & $\begin{array}{l}\text { Sediment } \\
\text { Mass }\end{array}$ & $\mathrm{Tc}$ & $\mathrm{U}(\mathrm{AE})$ & U(WE) & Tc-99 (Ci) & $\mathrm{U}(\mathrm{kg})$ \\
\hline $\begin{array}{c}\mathrm{A}=380.5 \\
\mathrm{~m}^{2} \text { for } \\
\text { Hanford } \mathrm{f} \\
\text { and } 3062 \\
\mathrm{~m}^{2} \text { for } \\
\mathrm{CCU}\end{array}$ & $\mathrm{Tc}$ & $\mathrm{U}(\mathrm{AE})$ & U(WE) & $\mathrm{ft}$ & $\mathrm{m}^{3}$ & g & $\mathrm{Ci}$ & $\mathrm{kg}$ & $\mathrm{kg}$ & \multicolumn{2}{|c|}{ disposed to B-7-A\&B } \\
\hline backfill & 0.2 & 2 & 0.001 & 20 & $2.32 \mathrm{E}+03$ & $4.99 \mathrm{E}+09$ & 9.97E-04 & $9.97 \mathrm{E}+00$ & 4.99E-03 & $9.47 \mathrm{E}-02$ & $1.97 \mathrm{E}+02$ \\
\hline H1 & 20 & 125 & 1.5 & 5 & $5.80 \mathrm{E}+02$ & $1.03 \mathrm{E}+09$ & $2.05 \mathrm{E}-02$ & $1.28 \mathrm{E}+02$ & $1.54 \mathrm{E}+00$ & & \\
\hline $\mathrm{H} 2$ & 5 & 300 & 5 & 5 & $5.80 \mathrm{E}+02$ & $1.03 \mathrm{E}+09$ & $5.13 \mathrm{E}-03$ & $3.08 \mathrm{E}+02$ & $5.13 \mathrm{E}+00$ & & \\
\hline
\end{tabular}


Table 3.14. Mass Estimates for Technetium- 99 and Total and Water-Leachable Uranium in Vadose Zone Sediments near 216-B-7A\&B Cribs

\begin{tabular}{|c|c|c|c|c|c|c|c|c|c|c|c|}
\hline $\begin{array}{l}\text { Model \#3 } \\
\text { (cont) }\end{array}$ & $\mathrm{pCi} / \mathrm{g}$ & $\mu \mathrm{g} / \mathrm{g}$ & $\mu \mathrm{g} / \mathrm{g}$ & thick & Volume & $\begin{array}{l}\text { Sediment } \\
\text { Mass }\end{array}$ & $\mathrm{Tc}$ & $\mathrm{U}(\mathrm{AE})$ & $\mathrm{U}(\mathrm{WE})$ & \multicolumn{2}{|c|}{ Tc-99 (Ci) } \\
\hline & Tc & $\mathrm{U}(\mathrm{AE})$ & U(WE) & $\mathrm{ft}$ & $\mathrm{m}^{3}$ & $\mathrm{~g}$ & $\mathrm{Ci}$ & $\mathrm{kg}$ & $\mathrm{kg}$ & \multicolumn{2}{|c|}{$\begin{array}{c}\text { Crib perimeter+ } \\
\text { spread }\end{array}$} \\
\hline $\mathrm{H} 2$ & 2 & 25 & 2 & 5 & $5.80 \mathrm{E}+02$ & $1.03 \mathrm{E}+09$ & $2.05 \mathrm{E}-03$ & $2.57 \mathrm{E}+01$ & $2.05 \mathrm{E}+00$ & & All VZ \\
\hline $\mathrm{H} 2$ & 1 & 5 & 2 & 25 & $2.90 \mathrm{E}+03$ & $5.13 \mathrm{E}+09$ & $5.13 \mathrm{E}-03$ & $2.57 \mathrm{E}+01$ & $1.03 \mathrm{E}+01$ & $1733 \%$ & Tc \\
\hline $\mathrm{H} 2$ & 0.5 & 3 & 1 & 20 & $2.32 \mathrm{E}+03$ & $4.11 \mathrm{E}+09$ & $2.05 \mathrm{E}-03$ & $1.23 \mathrm{E}+01$ & $4.11 \mathrm{E}+00$ & $179.9 \%$ & U(WE) \\
\hline $\mathrm{H} 2$ & 0.2 & 1.5 & 0.5 & 10 & $1.16 \mathrm{E}+03$ & $2.05 \mathrm{E}+09$ & $4.11 \mathrm{E}-04$ & $3.08 \mathrm{E}+00$ & $1.03 \mathrm{E}+00$ & $511 \%$ & U(total) \\
\hline $\mathrm{H} 2$ & 0.2 & 0.8 & 0.05 & 20 & $2.32 \mathrm{E}+03$ & $4.11 \mathrm{E}+09$ & $8.21 \mathrm{E}-04$ & $3.28 \mathrm{E}+00$ & $2.05 \mathrm{E}-01$ & & \\
\hline $\mathrm{H} 2$ & 0.2 & 0.6 & 0.005 & 53.3 & $6.18 \mathrm{E}+03$ & $1.09 \mathrm{E}+10$ & $2.19 \mathrm{E}-03$ & $6.57 \mathrm{E}+00$ & $5.47 \mathrm{E}-02$ & \multicolumn{2}{|c|}{$\begin{array}{c}\text { Crib perimeter+ CCU } \\
\text { spread }\end{array}$} \\
\hline $\mathrm{H} 2$ & 0.2 & 0.6 & 0.005 & 56.7 & $6.58 \mathrm{E}+03$ & $1.16 \mathrm{E}+10$ & $2.33 \mathrm{E}-03$ & $6.98 \mathrm{E}+00$ & $5.82 \mathrm{E}-02$ & \multicolumn{2}{|r|}{ Deep VZ } \\
\hline $\mathrm{CCUz}$ & 0.5 & 1 & 0.1 & 5 & $5.25 \mathrm{E}+03$ & $8.66 \mathrm{E}+09$ & $4.33 \mathrm{E}-03$ & $8.66 \mathrm{E}+00$ & $8.66 \mathrm{E}-01$ & $1691 \%$ & $\mathrm{Tc}$ \\
\hline CCUz & 5 & 10 & 8 & 5 & $5.25 \mathrm{E}+03$ & $8.66 \mathrm{E}+09$ & $4.33 \mathrm{E}-02$ & $8.66 \mathrm{E}+01$ & $6.93 \mathrm{E}+01$ & $167.5 \%$ & U(WE) \\
\hline $\mathrm{CCUz}$ & 75 & 20 & 15 & 10 & $1.05 \mathrm{E}+04$ & $1.73 \mathrm{E}+10$ & $1.30 \mathrm{E}+00$ & $3.46 \mathrm{E}+02$ & $2.60 \mathrm{E}+02$ & $245.9 \%$ & $\mathrm{U}($ total) \\
\hline $\mathrm{CCUz}$ & 25 & 2 & 0.003 & 5 & $5.25 \mathrm{E}+03$ & $8.66 \mathrm{E}+09$ & $2.16 \mathrm{E}-01$ & $1.73 \mathrm{E}+01$ & $2.60 \mathrm{E}-02$ & & \\
\hline CCUg & 2 & 1 & 0.0015 & 8.3 & $8.71 \mathrm{E}+03$ & $1.87 \mathrm{E}+10$ & $3.75 \mathrm{E}-02$ & $1.87 \mathrm{E}+01$ & $2.81 \mathrm{E}-02$ & & \\
\hline \multirow[t]{2}{*}{$\begin{array}{l}\text { Water } \\
\text { Table }\end{array}$} & & & & 253.3 & & total VZ & $1.64 \mathrm{E}+00$ & $1.01 \mathrm{E}+03$ & $3.54 \mathrm{E}+02$ & & \\
\hline & & & & & & deep VZ & $1.60 \mathrm{E}+00$ & $4.85 \mathrm{E}+02$ & $3.30 \mathrm{E}+02$ & & \\
\hline
\end{tabular}

The yellow highlight values represent the inventory estimates for each layer in the deep vadose zone (between the water table to $90 \mathrm{ft}$ above the water table).

farther than $20 \mathrm{~m}$ from these disposal locations. There also is no reason to suspect that the SIM volume and mass estimates of contaminants disposed of are incorrect by a factor of 2 for uranium or 17 for technetium-99. Also based on the spectral gamma logging and uranium isotopic signature measurements, it is clear that the pore fluids in the sediments within the $\mathrm{CCU}_{\mathrm{z}}$ unit at 299-E33-344 and E33-345 contain fluid from the BX-102 overfill event. The high concentrations of technetium-99 found in the 299-E33344 and E33-345 sediments in the $\mathrm{CCU}_{\mathrm{z}}$ unit and the mass estimate results shown in Table 3.14 seem to support the presence of additional waste from a source with high technetium-99 content. The most likely sources are BX-102 overfill, some SST release that has not been identified or very remotely fluids from the BY Cribs. This will be discussed more in Section 5 where groundwater data are interpreted. There is little doubt that the $\mathrm{CCU}_{\mathrm{z}}$ unit is present, contiguous, and relatively thick below both the B-7-A\&B Cribs and the two new boreholes (see $\mathrm{CCU}_{z}$ thickness isopachs on Figure 3.46), but the number of waste sources that have commingled to create the vadose zone pore waters is not known. Because borehole C3103 was terminated at the top of the $\mathrm{CCU}_{\mathrm{z}}$ spreading unit and no sediments B-7-B or B-8 Crib have been characterized, there is no current data set available to resolve this inconsistency.

\subsection{BX-BY Tank Farms (BX-BY WMA) Subregion}

In this subsection, the available borehole sediment characterization data, field gamma logging and electrical resistivity data are tabulated and compared with the known volumes and masses of waste chemicals and radionuclides released to the subsurface. Subsequently, a conceptual model is constructed for key waste constituents remaining in the vadose zone sediments in the BX-BY subregion.

The key facilities and key boreholes that were evaluated for the BX-BY Tank Farms subregion are shown in green in Figure 3.47. The reader should refer back to this figure to aid in understanding the following the discussion. In the following sections many dry wells (e.g. relatively shallow vadose zone boreholes used to monitor tank leaks) are discussed and Figure 3.48 is provided for identifying the dry well locations. 


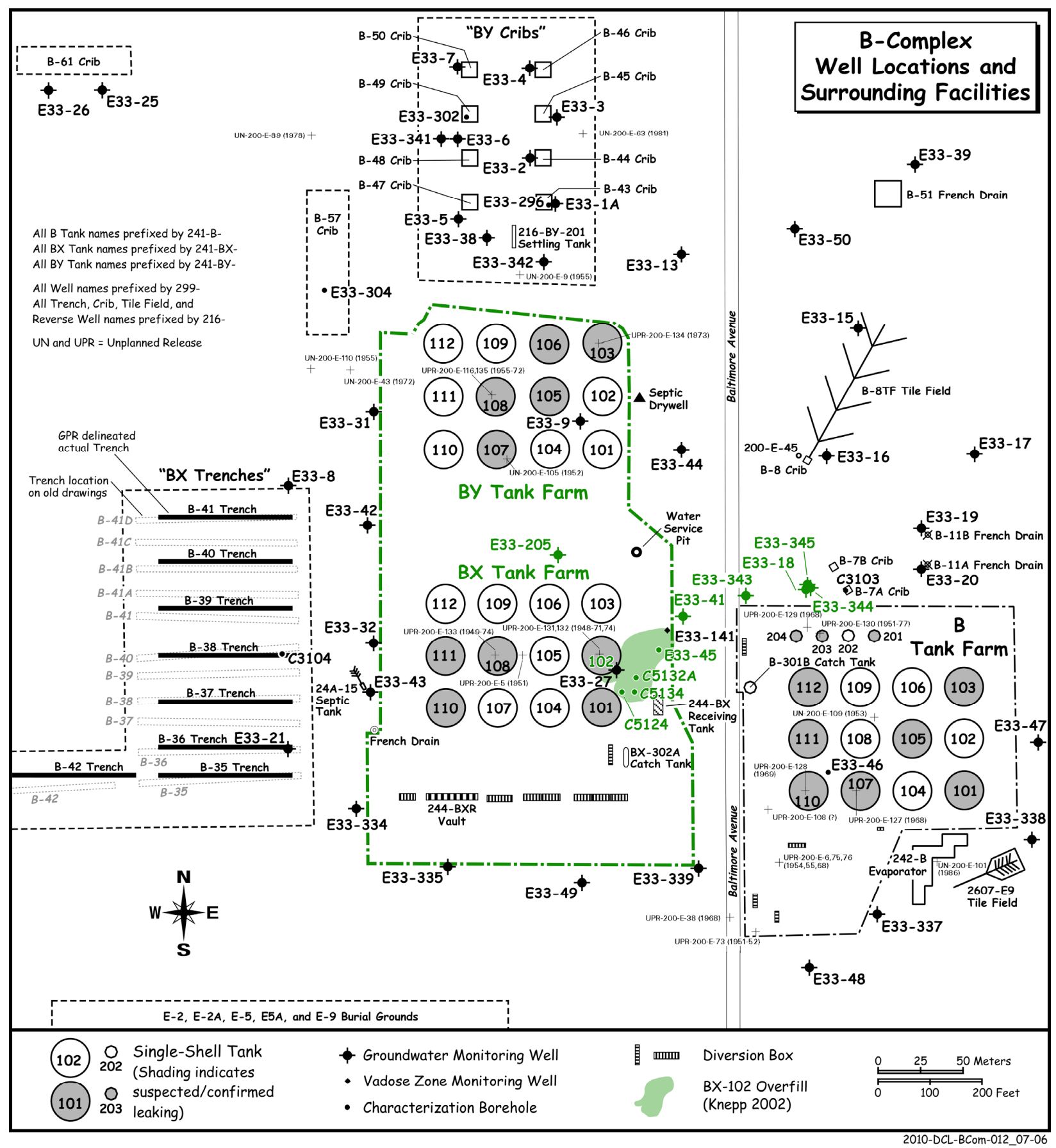

Figure 3.47. BX-BY Waste Management Subregion-Tanks and Key Dry wells Highlighted in Green 


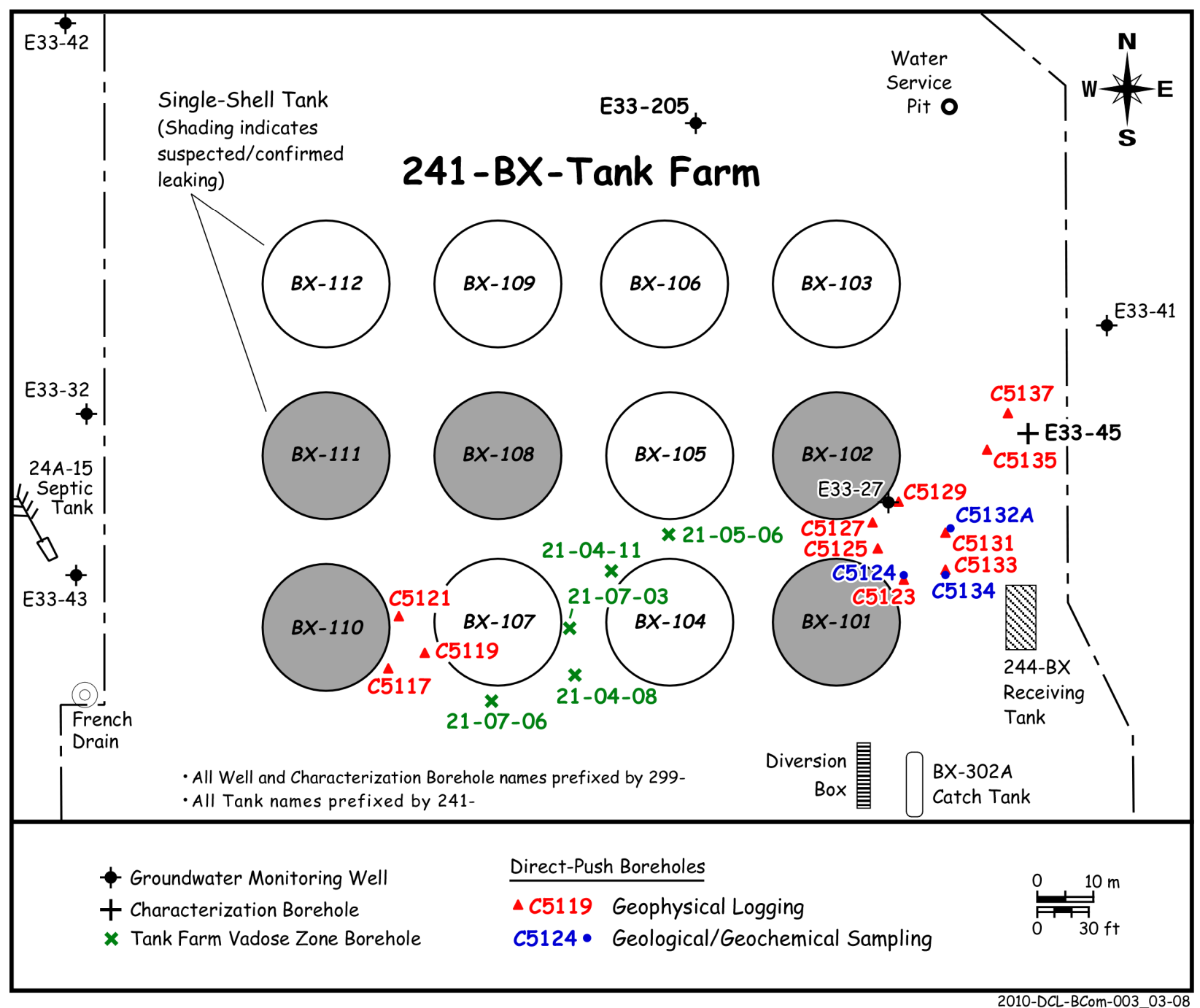

Figure 3.48. Locations of E33-45 Borehole, Direct Pushes and Dry Wells with Suspect Gamma

\subsubsection{BX Tank Farm Description and Inventory Released}

As shown in Table 3.15, three tanks in the BX Tank Farm are known to have released liquids (BX101, BX-102, and BX-108). Field and Jones (2006) indicate two other tanks (BX-110 and BX-111) that have been identified as possible "leakers" in Hanlon (2006) may not have released any waste to the subsurface. Field and Jones (2006) base their hypothesis on the lack of or low gamma activity in nearby drywells near or below the bottoms of these BX tanks.

Based on a review of all historical gross gamma and more recent spectral gamma logs for the dry wells around the BX tanks, Sobczyk (2004a, b) states that dry well 21-07-06 on the south side of tank BX-107 showed high cesium-137 concentrations that cannot be attributed to near-surface spills.

Numerous dry wells that monitor tank BX-104 show zones of cobalt-60 detected from 65 to $100 \mathrm{ft}$ bgs in dry wells 21-04-08, 21-07-03, 21-04-11, and 21-05-06 that appear to be remnants of a vadose plume that could have originated from a leak from any of the tanks in the vicinity, including Tank BX-104. Sobczyk (2004a, b) also suggests that Tank BX-106 likely also leaked, based on cesium-137 activity occurring at 
Table 3.15. BX Tank Farm Waste Release Status and Estimates of Inventory Released

\begin{tabular}{|c|c|c|c|c|c|c|}
\hline & Status & $\begin{array}{l}\text { Date of } \\
\text { Release }\end{array}$ & $\begin{array}{c}\text { Dimensions }(\mathrm{ft}) \\
\text { Dia } \times \mathrm{Ht} \times \text { Bottom } \\
(\mathrm{ft} \mathrm{bgs})\end{array}$ & $\begin{array}{c}\text { Major Waste } \\
\text { Type (for } \\
\text { Leakers) }\end{array}$ & $\begin{array}{c}\text { Volume } \\
\text { Released (ML) }\end{array}$ & Comments \\
\hline BX-101 & $\mathrm{R}$ & 1972 & $\begin{array}{c}75 \times 31.17 \\
\times 38.42\end{array}$ & $\begin{array}{l}\text { Sr-Cs Rec Org Wst aq } \\
\text { (P2)_BL }\end{array}$ & $1.51 \mathrm{E}-02$ & $\begin{array}{l}\text { Leak assigned UPR-200-E-131; WIDS suggests } \\
\text { leak was } 3.03 \text { E-02 ML; not 1.51E-02 ML }\end{array}$ \\
\hline BX-102 & $\mathrm{R}$ & 1951 & $\begin{array}{l}75 \times 31.17 \\
\times 38.42\end{array}$ & MW1 (BT1) & $3.47 \mathrm{E}-01$ & $\begin{array}{l}\text { UPR-200-E-132 (9463 L in 1974); UPR-200-E- } \\
5 \text { (1951 over-fill); leak volume estimate shown } \\
\text { only includes } 1951 \text { overfill volume } \\
\text { estimate }\end{array}$ \\
\hline BX-103 & I & & $\begin{array}{l}75 \times 31.17 \\
\times 38.42\end{array}$ & & & \\
\hline BX-104 & I & & $\begin{array}{l}75 \times 31.17 \\
\times 38.42\end{array}$ & & & \\
\hline BX-105 & I & & $\begin{array}{l}75 \times 31.17 \\
\times 38.42\end{array}$ & & & \\
\hline BX-106 & I & & $\begin{array}{l}75 \times 31.17 \\
\times 38.42\end{array}$ & & & \\
\hline BX-107 & I & & $\begin{array}{l}75 \times 31.17 \\
\times 38.42\end{array}$ & & & \\
\hline BX-108 & $\mathrm{R}$ & 1972 & $\begin{array}{l}75 \times 31.17 \\
\times 38.42\end{array}$ & $\begin{array}{c}\text { Sr-Cs Rec Org Wst } \\
\text { (P2')_CSR; } \\
\text { CWP2 (CWP2) }\end{array}$ & $9.46 \mathrm{E}-03$ & UPR-200-E-133 \\
\hline BX-109 & I & & $\begin{array}{l}75 \times 31.17 \\
\times 38.42\end{array}$ & & & \\
\hline BX-110 & $\mathrm{R}$ & 1976 & $\begin{array}{l}75 \times 31.17 \\
\times 38.42\end{array}$ & NA & $3.03 \mathrm{E}-02$ & $\begin{array}{l}\text { Leak assigned UPR-200-E-128; WIDS notes } \\
\text { rapid intrusions of water raising levels in tanks } \\
\text { Jan } 1980 \text { attributed to snow melt } \\
\text { and Jan } 1981 \text { to large rain event. Water entered } \\
\text { through riser \#9 } \\
\text { under construction during this time period. }\end{array}$ \\
\hline BX-111 & $\mathrm{R}$ & 1984 & $\begin{array}{l}75 \times 31.17 \\
\times 38.42\end{array}$ & NA & 3.03E-02 & $\begin{array}{l}\text { Occurrence report issued in } 1993 \text { noted liquid } \\
\text { level drop (WIDS). However, WIDS also states } \\
\text { that leak occurred prior to 1984. Seems like } \\
\text { inconsistent descriptions unless these were two } \\
\text { independent events. }\end{array}$ \\
\hline
\end{tabular}


Table 3.15. BX Tank Farm Waste Release Status and Estimates of Inventory Released

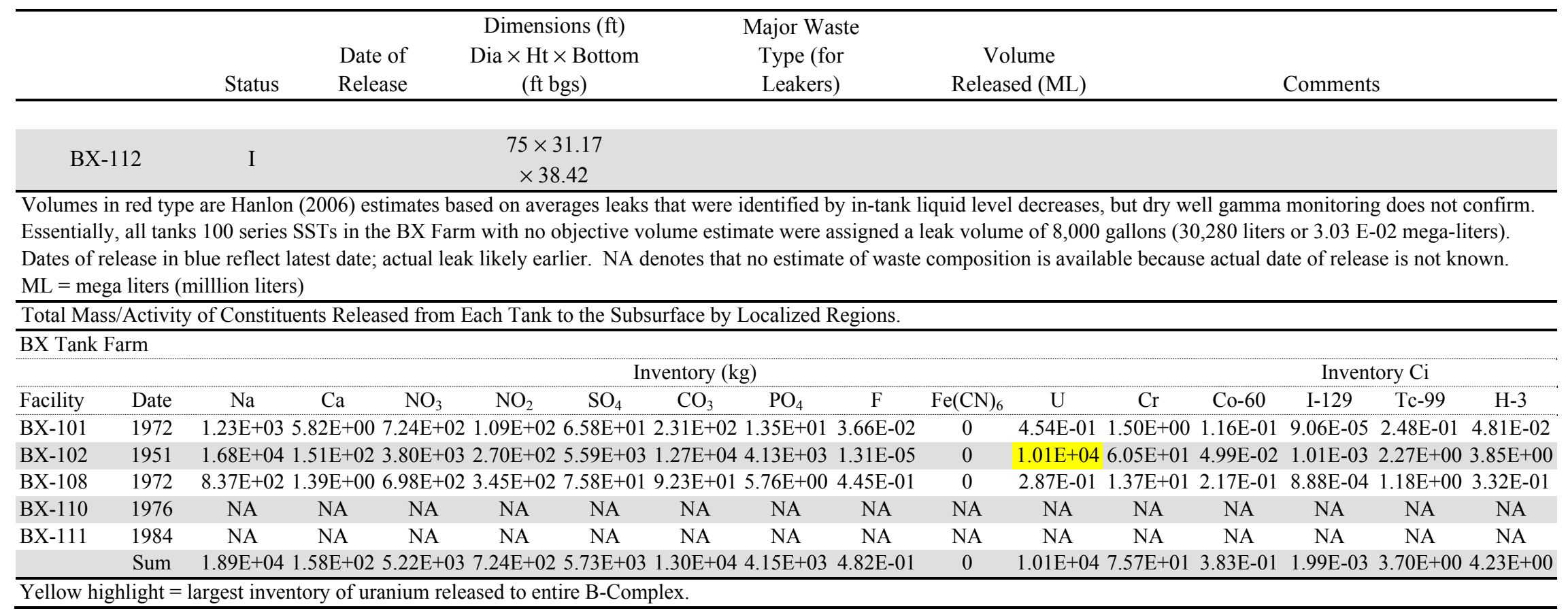

Yellow highlight $=$ largest inventory of uranium released to entire B-Complex. 
about $39 \mathrm{ft}$ bgs in dry well 21-06-05. Antimony-125 and uranium-235/238 were also detected in the gamma logs between 41 and $54 \mathrm{ft} \log$ depth and appear to be associated with the shallower cesium-137. These two more mobile elements appear to have migrated below the tank farm excavation into the undisturbed sediments of the Hanford formation. Sobczyk (2004a, b) notes the contamination distribution is not continuous in the upper portion of this dry well; therefore, it is unlikely that the plume originated from surface contamination that migrated down the side of the tank. In addition, the radionuclides have segregated below the base of the tank in a pattern that would be expected from a nearby concentrated source, and no contamination was identified in any of the dry wells between dry well 21-06-05 and adjacent tanks. These observations led Sobczyk to conclude that the contamination originated from a leak from Tank BX-106. Because uranium was identified as a principal component in the plume, if BX-106 has leaked it is likely that the leak occurred in the early years between when the tank was constructed and the mid1950 s when the uranium-laden waste was removed from the tank.

Current gamma logging reports suggest alternate sources for the observed gamma activity near tanks BX-104 and 107, and the possibility of a tank leak from BX-106. Sobczyk (2004a, b) reported that spectral gamma logs also detected contamination from 8 to $65 \mathrm{ft}$ in dry wells 21-1001, 21-10-03, and 21-10-05. This contamination suggests a leak from tank BX-110, the associated service piping, or both. This contamination is most prominent in dry well 21-10-03 and extends from 8 to $65 \mathrm{ft}$ bgs. Similar contamination occurs from 36 to $62 \mathrm{ft}$ bgs in dry well 21-10-05 and from 38 to $42 \mathrm{ft}$ in dry well 21-10-01. Historical gross gamma records show that this contamination was present before 1972. In 1976, Tank BX-111 was categorized as "questionable integrity" because of gross gamma activity increases at about $40 \mathrm{ft}$ in dry wells 21 11-03, 21-11-04, 21-11-05, and 21-11-07. (a)

Based on the above observations, Sobczyk $(2004 \mathrm{a}, \mathrm{b})$ recommends adding four more BX tanks (BX-106, BX-107, BX-110, and BX-111) to the list of "leakers. Others have interpreted the dry well gross gamma logs differently but agree that all the available data from around these BX tanks should be re-evaluated by the formal protocol described in Field et al. (2007) before adding these tanks to the "leakers" list.

Of particular note is the 1951 overfill event at tank BX-102. This event is considered the largest release of uranium from any of the SST farms and will be discussed in more detail below. This leak event was characterized in 1971 by drilling 19 vadose zone (dry) wells to the south, east, and northeast of the tank and performing borehole gross gamma logging to estimate the depth and areal extent of the overfill release (green shaded area in Figure 3.47 and Figure 3.49 top panel). Womack and Larkin (1971) did not realize that the radioactivity being monitored likely came from the 1951 overfill event as opposed to a recent 1971 release. A second field characterization effort that focused on the 1951 overfill event was performed in 2002 (Serne et al. 2002b) wherein a borehole, 299-E33-45, was drilled east of the BX-102 tank. The primary purpose of this borehole was to investigate the vertical extent of uranium, technetium-99, and other mobile contaminants in the center of the gross gamma vadose zone plume identified in 1971 by Womack and Larkin. Sediment samples were retrieved nearly continuously from the ground

(a) Walker CM. 1988. Internal Letter, Subject: "Summary of Leaker or Questionable Integrity Tanks," 13331-88-460, Westinghouse Hanford Company, Richland, Washington. 
surface to the water table. Vadose zone characterization results for borehole 299-E33-45 along with detailed geologic interpretations are found in Serne et al. (2002b). The vertical distribution of potentially mobile constituents is shown in Table 3.16. These characterization results are used extensively in Section 3.4.2 to define the vertical extent of contamination at this location.

\subsubsection{BX Tanks Vadose Zone}

Vadose zone characterization activities completed in the BX Tank Farm to determine the distribution of constituents in the vadose zone include:

- gamma logging dry wells during and after active operations at the tank farm,

- gamma logging and limited soil analyses from three shallow push holes located southeast of Tank BX-102

- spectral gamma logging and soil analyses from the near-continuously sampled E33-45 borehole to groundwater east of Tank BX-102

- soil electrical resistivity survey of the entire B-Complex during the BP-5 Remedial Investigation,

- spectral gamma logging and soil analyses from borehole E33-205 to the base of the unconfined aquifer along the northern boundary of the BX tank farm during the BP-5 Remedial Investigation, and

- spectral gamma logging and soil analyses from borehole E33-343 to the base of the unconfined aquifer north-northeast of the BX-102 release along the northwest corner of the B tank farm during the BP-5 Remedial Investigation.

The first activity, gamma logging of dry wells during and after active operations, discussed in this section occurred periodically from the 1960s through the 1990s to determine if releases associated with the tanks and or associated piping had occurred. This process was a key part in identifying the lateral spreading of the BX-102 overfill fluids and to a limited extent identifying the depth of penetration of the fluids. The results of spectral gamma logging of dry wells within and surrounding the WMA were thoroughly reviewed by Sobczyk (2004a, b). Sobczyk (2004a, b) also documented comparisons to historical gross gamma logs with the more recent spectral gamma logs. There are 74 monitoring boreholes, mostly drilled in the early to mid 1970s, in the BX Tank Farm, and most were drilled to a depth of $100 \mathrm{ft} \mathrm{bgs).} \mathrm{Many} \mathrm{of} \mathrm{these} \mathrm{boreholes} \mathrm{show}$ that Hanford-processed uranium is present in the vadose zone sediments at sufficient concentrations that a fairly detailed estimate of horizontal spreading of the fluids from the 1951 overfill event is possible in the near-field region covered by the boreholes (Figure 3.49). The upper panel in Figure 3.49 shows the lateral spread area identified in 1971 by Womack and Larkin (1971) and the lower panel shows the lateral spread in 2009 based on the most current SGLS data of boreholes including all the new BP-5 OU boreholes shown in Figure 1.2. Figure 3.50 shows the lateral extent of the Hanford processed uranium from the Tank BX-102 overfill event as indicated by SGLS logs as a function of depth as interpreted by Sobczyk (2004b). 
Table 3.16. Vertical Distribution of Selected Mobile Constituents in Sediments South and Southeast of Tank BX-102

\begin{tabular}{|c|c|c|c|c|c|c|c|c|c|c|}
\hline \multicolumn{11}{|c|}{ 299-E33-45 } \\
\hline $\begin{array}{r}\text { Depth } \\
\text { (ft bgs) }\end{array}$ & $\begin{array}{c}\mathrm{Na}(\mathrm{WE}) \\
\mu \mathrm{g} / \mathrm{g}\end{array}$ & $\begin{array}{c}\mathrm{Ca}(\mathrm{WE}) \\
\mu \mathrm{g} / \mathrm{g}\end{array}$ & $\begin{array}{c}\mathrm{F} \\
\mu \mathrm{g} / \mathrm{g} \\
\end{array}$ & $\begin{array}{c}\text { Nitrate } \\
\mu \mathrm{g} / \mathrm{g}\end{array}$ & $\begin{array}{c}\text { Nitrite } \\
\mu \mathrm{g} / \mathrm{g}\end{array}$ & $\begin{array}{c}\text { Sulfate } \\
\mu \mathrm{g} / \mathrm{g}\end{array}$ & $\begin{array}{c}\mathrm{Tc} \\
\mathrm{pCi} / \mathrm{g}\end{array}$ & $\begin{array}{c}\mathrm{U}(\mathrm{AE}) \\
\mu \mathrm{g} / \mathrm{g}\end{array}$ & $\begin{array}{c}\mathrm{U}(\mathrm{WE}) \\
\mu \mathrm{g} / \mathrm{g}\end{array}$ & $\begin{array}{c}\mathrm{Cr}(\mathrm{WE}) \\
(\mu \mathrm{g} / \mathrm{g})\end{array}$ \\
\hline 10.64 & 46.3 & 3.5 & 1.2 & 1.1 & $<0.1$ & 20.8 & $<2.12 \mathrm{E}+00$ & $\overline{\mathrm{NA}}$ & $2.09 \mathrm{E}-03$ & $1.57 \mathrm{E}-03$ \\
\hline 20.84 & 31.1 & 3.7 & 0.9 & 1.4 & $<0.1$ & 10 & $<2.12 \mathrm{E}+00$ & NA & 8.38E-04 & $4.75 \mathrm{E}-05$ \\
\hline 31.84 & 8.3 & 8.7 & 0.4 & 1.9 & $<0.1$ & 10.2 & $<2.12 \mathrm{E}+00$ & NA & $4.06 \mathrm{E}-04$ & $<1.25 \mathrm{E}-02$ \\
\hline 42.04 & 9.5 & 7.9 & 0.4 & 4.8 & $<0.1$ & 11.7 & $<2.12 \mathrm{E}+00$ & 0.53 & 4.49E-04 & $<1.25 \mathrm{E}-02$ \\
\hline 51.64 & 10.6 & 7.1 & 0.4 & 5 & $<0.1$ & 11.4 & $<2.12 \mathrm{E}+00$ & NA & $4.25 \mathrm{E}-04$ & $<1.25 \mathrm{E}-02$ \\
\hline 62.99 & 13.1 & 10.4 & 0.4 & 9.9 & $<0.1$ & 24 & $<2.12 \mathrm{E}+00$ & NA & $2.95 \mathrm{E}-04$ & (4.90E-04) \\
\hline 71.24 & 12.9 & 18.8 & 0.3 & 11.3 & $<0.1$ & 55.3 & $<2.12 \mathrm{E}+00$ & NA & 4.34E-04 & $<1.25 \mathrm{E}-02$ \\
\hline 73.39 & 13.0 & 20.3 & 0.1 & 7.8 & $<0.1$ & 62.3 & $<2.12 \mathrm{E}+00$ & NA & $9.43 \mathrm{E}-01$ & $<1.25 \mathrm{E}-02$ \\
\hline 75.65 & 24.2 & 42.2 & 0.1 & 25.8 & $<0.1$ & 85.5 & $<2.12 \mathrm{E}+00$ & 59.2 & $5.60 \mathrm{E}-01$ & (1.00E-03) \\
\hline 75.65 & 26.1 & 43.9 & 0.1 & 27.6 & $<0.1$ & 91.4 & $<2.12 \mathrm{E}+00$ & NA & $5.88 \mathrm{E}-01$ & $(1.16 \mathrm{E}-03)$ \\
\hline 78.19 & 27.3 & 2.8 & 0.3 & 1.5 & $<1$ & 12.5 & $1.27 \mathrm{E}-01$ & NA & $5.47 \mathrm{E}-01$ & $(2.90 \mathrm{E}-04)$ \\
\hline 79.34 & 98.5 & 0.5 & 0.1 & 1.9 & $<1$ & 11.9 & $(2.12 \mathrm{E}+00)$ & NA & $2.51 \mathrm{E}+00$ & $<1.25 \mathrm{E}-02$ \\
\hline 88.65 & 24.3 & 2.9 & 0.1 & 3.6 & $<0.1$ & 7.4 & $(2.12 \mathrm{E}+00)$ & 6.2 & $3.26 \mathrm{E}-01$ & $(8.83 \mathrm{E}-04)$ \\
\hline 100.09 & 111 & 1.4 & 0.5 & 9.6 & $<0.1$ & 16.8 & $<2.12 \mathrm{E}+00$ & 5.3 & $6.04 \mathrm{E}-01$ & $(8.77 \mathrm{E}-04)$ \\
\hline 111.14 & 165 & 1.2 & 0.6 & 10.1 & $<0.1$ & 11.9 & $<8.47 \mathrm{E}-02$ & NA & $3.61 \mathrm{E}+00$ & $(1.08 \mathrm{E}-03)$ \\
\hline 119.04 & 75.8 & 1.9 & 0.6 & 33.8 & $<0.1$ & 15 & $<7.20 \mathrm{E}-01$ & NA & $5.83 E+00$ & $(3.95 \mathrm{E}-04)$ \\
\hline 120.14 & 329 & 5.2 & 0 & 174 & 0.02 & 121 & $1.87 \mathrm{E}+01$ & 1470 & $9.37 E+01$ & NR \\
\hline 120.14 & 238 & 4.6 & 0 & 96 & 0.36 & 64.7 & $9.94 \mathrm{E}+00$ & NA & $7.02 E+01$ & NR \\
\hline 120.14 & 116 & 3.0 & 0.4 & 85.8 & 0.04 & 52.8 & $(6.34 \mathrm{E}+00)$ & NA & $1.79 E+01$ & NR \\
\hline 120.89 & 170 & 1.6 & 0.5 & 32 & $<0.1$ & 21.8 & $2.77 \mathrm{E}+00$ & NA & $1.68 \mathrm{E}+01$ & $(1.12 \mathrm{E}-03)$ \\
\hline 121.24 & 146 & 0.9 & 0.1 & 22 & $<0.01$ & 18.8 & $2.75 \mathrm{E}+00$ & NA & $1.75 E+01$ & NR \\
\hline 121.34 & 349 & 5.8 & 0.1 & 202 & 0.01 & 127 & $2.30 \mathrm{E}+01$ & NA & $9.28 \mathrm{E}+01$ & $\mathrm{NR}$ \\
\hline 122.32 & 136 & 0.7 & 0.1 & 12.9 & 0.01 & 9.6 & $(1.34 \mathrm{E}+00)$ & NA & $6.51 \mathrm{E}+00$ & NR \\
\hline 130.95 & 193 & 1.0 & 1.1 & 43 & 0.12 & 32.9 & $5.09 \mathrm{E}+00$ & NA & $2.28 \mathrm{E}+01$ & $(9.33 \mathrm{E}-04)$ \\
\hline 141.25 & 105 & 1.7 & 1.4 & 62 & $<0.1$ & 46.2 & $7.32 \mathrm{E}+00$ & NA & $1.01 \mathrm{E}+01$ & $(1.18 \mathrm{E}-03)$ \\
\hline 150.55 & 272 & 29.9 & 0.4 & 15 & 0.05 & 1410 & $(1.39 \mathrm{E}+00)$ & NA & $7.14 E+00$ & NR \\
\hline 151.55 & 318 & 47.2 & 0.2 & 97.4 & $<1$ & 702 & $1.01 \mathrm{E}+01$ & 48.7 & $2.81 \mathrm{E}+00$ & $<1.25 \mathrm{E}-02$ \\
\hline 152.7 & 263 & 57.5 & 0.6 & 74 & 0.17 & 767 & $4.26 \mathrm{E}+00$ & NA & $4.58 \mathrm{E}+00$ & NR \\
\hline 156.2 & 351 & 67.3 & 0.5 & 182 & 0.1 & 897 & $1.58 \mathrm{E}+01$ & NA & $7.41 E+00$ & NR \\
\hline 159.1 & 262 & 42 & 0.5 & 45.6 & 0.03 & 692 & $5.55 \mathrm{E}+00$ & NA & $5.07 E+00$ & NR \\
\hline 159.85 & 318 & 51.0 & 0.5 & 41.9 & 0.12 & 612 & $4.73 \mathrm{E}+00$ & NA & $5.25 \mathrm{E}+00$ & NR \\
\hline 160.85 & 338 & 46.4 & 0.4 & 100 & $<0.5$ & 732 & $1.33 \mathrm{E}+01$ & NA & $2.68 \mathrm{E}+00$ & $<1.25 \mathrm{E}-02$ \\
\hline 165.55 & 45.3 & 6.7 & 0.5 & 66.2 & 0.18 & 19.5 & $6.23 \mathrm{E}+00$ & NA & $4.16 \mathrm{E}+00$ & NR \\
\hline 168.65 & 33.5 & 69.2 & 0.3 & 205 & $<1$ & 111 & $1.00 \mathrm{E}+01$ & NA & $8.62 \mathrm{E}-01$ & $(1.23 \mathrm{E}-03)$ \\
\hline 168.65 & 35.2 & 76.2 & 0.3 & 229 & $<1$ & 124 & $1.21 \mathrm{E}+01$ & NA & $7.60 \mathrm{E}-01$ & $(3.27 \mathrm{E}-04)$ \\
\hline 169.1 & 32.0 & 66.6 & 0.5 & 210 & 0.04 & 13 & $3.69 \mathrm{E}+00$ & NA & 7.54E-01 & NR \\
\hline 169.55 & 308 & 21.1 & 0.6 & 249 & 0.5 & 492 & $(3.31 \mathrm{E}+01)$ & 137 & $3.78 \mathrm{E}+01$ & NR \\
\hline 171.05 & 10.8 & 12.1 & 0.4 & 15.5 & $<0.1$ & 19.7 & $<2.12 \mathrm{E}+00$ & NA & $1.36 \mathrm{E}-01$ & $(1.85 \mathrm{E}-03)$ \\
\hline 173.35 & 12.7 & 10.3 & 0.4 & 13.2 & $<0.1$ & 20 & $<2.12 \mathrm{E}+00$ & NA & $2.47 \mathrm{E}-01$ & $<1.25 \mathrm{E}-02$ \\
\hline 181.65 & 36.8 & 7.8 & 0.5 & 21.9 & $<0.1$ & 29 & $<2.12 \mathrm{E}+00$ & NA & $3.23 E+00$ & $(8.59 \mathrm{E}-04)$ \\
\hline 190.65 & 10.4 & 13.5 & 0.3 & 20.1 & 0.17 & 22.8 & $<2.12 \mathrm{E}+00$ & 19.8 & $1.62 \mathrm{E}+00$ & $<1.25 \mathrm{E}-02$ \\
\hline 201.35 & 12.0 & & 0.3 & 25.2 & $<0.1$ & 29.1 & (1.69E-01) & NA & $6.21 \mathrm{E}-04$ & $<1.25 \mathrm{E}-02$ \\
\hline 211.42 & 11.8 & 14.5 & 0.4 & 27.2 & $<0.1$ & 24.1 & $(1.02 \mathrm{E}+00)$ & NA & $2.12 \mathrm{E}-04$ & $(5.89 \mathrm{E}-04)$ \\
\hline 217.95 & 11.6 & 17.6 & 0.3 & 23.6 & 0.06 & 31 & $2.29 \mathrm{E}+00$ & 0.54 & 4.99E-04 & NR \\
\hline
\end{tabular}


PNNL-19277

Table 3.16. Vertical Distribution of Selected Mobile Constituents in Sediments South and Southeast of Tank BX-102

\begin{tabular}{|c|c|c|c|c|c|c|c|c|c|c|}
\hline \multicolumn{11}{|c|}{ 299-E33-45 } \\
\hline $\begin{array}{c}\text { Depth } \\
\text { (ft bgs) }\end{array}$ & $\begin{array}{c}\mathrm{Na}(\mathrm{WE}) \\
\mu \mathrm{g} / \mathrm{g}\end{array}$ & $\begin{array}{c}\mathrm{Ca}(\mathrm{WE}) \\
\mu \mathrm{g} / \mathrm{g}\end{array}$ & $\begin{array}{c}\mathrm{F} \\
\mu \mathrm{g} / \mathrm{g}\end{array}$ & $\begin{array}{c}\text { Nitrate } \\
\mu \mathrm{g} / \mathrm{g}\end{array}$ & $\begin{array}{c}\text { Nitrite } \\
\mu \mathrm{g} / \mathrm{g}\end{array}$ & $\begin{array}{c}\text { Sulfate } \\
\mu \mathrm{g} / \mathrm{g}\end{array}$ & $\begin{array}{c}\mathrm{Tc} \\
\mathrm{pCi} / \mathrm{g}\end{array}$ & $\begin{array}{c}\mathrm{U}(\mathrm{AE}) \\
\mu \mathrm{g} / \mathrm{g}\end{array}$ & $\begin{array}{c}\mathrm{U}(\mathrm{WE}) \\
\mu \mathrm{g} / \mathrm{g}\end{array}$ & $\begin{array}{c}\mathrm{Cr}(\mathrm{WE}) \\
(\mu \mathrm{g} / \mathrm{g})\end{array}$ \\
\hline 219.45 & 35.5 & 105 & 0.3 & 186 & $<1$ & 207 & $1.49 \mathrm{E}+01$ & NA & 5.19E-02 & $(9.55 \mathrm{E}-04)$ \\
\hline 221.75 & 41.2 & 132 & 0.3 & 324 & $<1$ & 228 & $1.27 \mathrm{E}+01$ & 2.1 & $1.77 \mathrm{E}-03$ & (1.64E-03) \\
\hline 223.65 & 25.4 & 82.1 & 0.3 & 213 & $<1$ & 109 & $1.29 \mathrm{E}+01$ & NA & $3.18 \mathrm{E}-04$ & $(4.56 \mathrm{E}-04)$ \\
\hline 231.45 & 35.6 & 99.8 & 0.5 & 331 & $<1$ & 146 & $7.17 \mathrm{E}+00$ & 1.1 & $3.03 \mathrm{E}-03$ & $(4.19 \mathrm{E}-04)$ \\
\hline 231.45 & 36.2 & 98.3 & 0.5 & 323 & $<1$ & 147 & $7.20 \mathrm{E}+00$ & NA & $4.08 \mathrm{E}-03$ & (5.29E-04) \\
\hline 241.89 & 16.2 & 10.6 & 0.4 & 20.2 & $<0.1$ & 25.4 & $(3.39 \mathrm{E}-01)$ & 2.5 & $3.60 \mathrm{E}-04$ & $<1.25 \mathrm{E}-02$ \\
\hline 245.25 & 14.8 & 9.8 & 0.4 & 3.2 & $<0.1$ & 32.5 & $<2.12 \mathrm{E}+00$ & NA & $1.45 \mathrm{E}-04$ & $<1.25 \mathrm{E}-02$ \\
\hline 251.75 & 13.9 & 14.5 & 0.4 & 27.3 & $<0.1$ & 27.4 & $(4.65 \mathrm{E}-01)$ & NA & $2.12 \mathrm{E}-04$ & $(4.40 \mathrm{E}-04)$ \\
\hline 253.65 & 7.1 & 15.1 & 0.3 & 34.3 & $<1$ & 14.1 & $(8.50 \mathrm{E}-01)$ & NA & $1.77 \mathrm{E}-03$ & $<1.25 \mathrm{E}-02$ \\
\hline C5134 & $\begin{array}{l}\text { Sodium } \\
(\mu \mathrm{g} / \mathrm{g})\end{array}$ & $\begin{array}{c}\text { Calcium } \\
(\mu \mathrm{g} / \mathrm{g})\end{array}$ & $\begin{array}{c}\text { Fluoride } \\
(\mu \mathrm{g} / \mathrm{g})\end{array}$ & $\begin{array}{l}\text { Nitrate } \\
(\mu \mathrm{g} / \mathrm{g})\end{array}$ & $\begin{array}{c}\text { Nitrite } \\
\mu \mathrm{g} / \mathrm{g}\end{array}$ & $\begin{array}{l}\text { Sulfate } \\
(\mu \mathrm{g} / \mathrm{g})\end{array}$ & $\begin{array}{c}{ }^{99} \mathrm{Tc} \\
(\mathrm{pCi} / \mathrm{g})\end{array}$ & $\begin{array}{l}\mathrm{U} A \mathrm{AE} \\
\mu \mathrm{g} / \mathrm{g})\end{array}$ & $\begin{array}{l}\text { U WE } \\
(\mu \mathrm{g} / \mathrm{g})\end{array}$ & $\begin{array}{c}\mathrm{Cr}(\mathrm{WE}) \\
(\mu \mathrm{g} / \mathrm{g})\end{array}$ \\
\hline $\begin{array}{c}77 \\
\text { (fine- } \\
\text { grained) }\end{array}$ & $7.26 \mathrm{E}+01$ & $1.68 \mathrm{E}+01$ & NA & 6.6 & NA & 46.6 & $2.45 \mathrm{E}-01$ & $2.75 E+02$ & $3.80 \mathrm{E}-02$ & $7.82 \mathrm{E}-02$ \\
\hline $\begin{array}{c}77 \\
\text { (coarse- } \\
\text { grained) }\end{array}$ & $3.77 \mathrm{E}+01$ & $5.37 \mathrm{E}+00$ & NA & 2.1 & NA & 15.5 & $(1.40 \mathrm{E}-01)$ & $5.87 \mathrm{E}+01$ & $1.77 \mathrm{E}+00$ & 7.93E-03 \\
\hline 77.5 & $4.21 \mathrm{E}+01$ & $2.09 \mathrm{E}+00$ & NA & 1.7 & NA & 9.6 & (7.63E-02) & $1.26 \mathrm{E}+02$ & $3.59 \mathrm{E}+00$ & $3.20 \mathrm{E}-03$ \\
\hline 78 & $5.89 \mathrm{E}+01$ & $1.51 \mathrm{E}+00$ & NA & 1.1 & NA & 9.1 & $(8.31 \mathrm{E}-02)$ & $5.55 \mathrm{E}+02$ & $1.85 \mathrm{E}+00$ & $3.98 \mathrm{E}-03$ \\
\hline C5132 & & & NA & & NA & & & & & \\
\hline 63.3 & $1.49 \mathrm{E}+02$ & $4.66 \mathrm{E}-01$ & NA & 2.3 & NA & 4.5 & $4.91 \mathrm{E}-01$ & $4.43 E+01$ & $4.61 E+00$ & $5.46 \mathrm{E}-04$ \\
\hline 63.8 & $1.45 E+02$ & 7.92E-01 & NA & 3.1 & NA & 5.3 & $5.25 \mathrm{E}-01$ & $2.03 E+02$ & $1.20 \mathrm{E}+01$ & $1.02 \mathrm{E}-03$ \\
\hline 64.3 & $7.96 \mathrm{E}+01$ & $5.17 \mathrm{E}-01$ & NA & 1.0 & NA & 2.5 & $(1.01 \mathrm{E}-01)$ & $1.88 \mathrm{E}+02$ & $4.12 E+00$ & $(2.45 \mathrm{E}-03)$ \\
\hline $\begin{array}{c}64.3 \\
\text { (dup) }\end{array}$ & $1.01 \mathrm{E}+02$ & $5.25 \mathrm{E}-01$ & NA & 1.1 & NA & 2.4 & $(1.02 \mathrm{E}-01)$ & $1.31 \mathrm{E}+02$ & $4.36 \mathrm{E}+00$ & $6.14 \mathrm{E}-04$ \\
\hline 64.8 & $9.80 \mathrm{E}+01$ & 4.64E-01 & NA & 0.9 & NA & 2.0 & (8.18E-02) & $2.06 \mathrm{E}+02$ & $2.75 \mathrm{E}+00$ & $3.70 \mathrm{E}-04$ \\
\hline C5124 & & & NA & & NA & & & & & \\
\hline 44.3 & $7.92 \mathrm{E}+01$ & 4.97E-01 & NA & 1.9 & NA & 5.6 & 2.40E-01 & $1.35 \mathrm{E}-01$ & 2.01E-02 & $1.06 \mathrm{E}-02$ \\
\hline 44.8 & $8.11 \mathrm{E}+01$ & $4.40 \mathrm{E}-01$ & NA & 2.4 & NA & 4.1 & $2.15 \mathrm{E}-01$ & $1.81 \mathrm{E}-01$ & $3.14 \mathrm{E}-02$ & $1.54 \mathrm{E}-02$ \\
\hline we tr & $\begin{array}{l}\text { alues } \\
\text { and } \mathrm{N}\end{array}$ & an bac & und & ta & 1) & nts- & sed by 1 & iste stri & the so & hange sit \\
\hline Red typ & $=$ values gr & & & & & & & & & \\
\hline Red and & Bold type & wes th & e extr & y hi & in & si & cant cont & & & \\
\hline $\mathrm{NA}=\mathrm{no}$ & $t$ analyzed & & & & & & & & & \\
\hline $\mathrm{NR}=\mathrm{n}$ & ported & & & & & & & & & \\
\hline
\end{tabular}



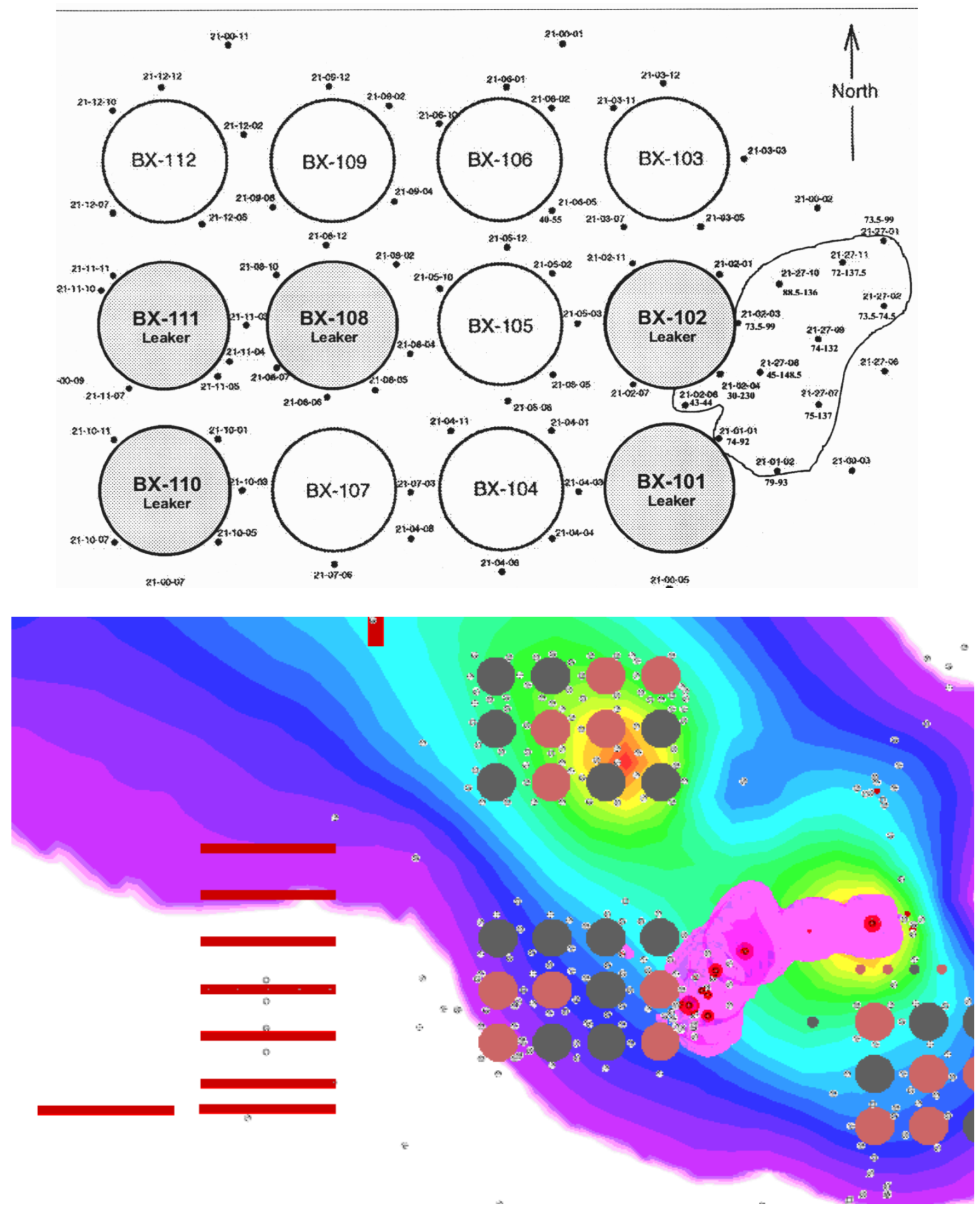

Figure 3.49. Lateral Spread of U from BX-102 Overfill Event Based on Gamma Logs (top) taken from Knepp (2002) and represents 1971 logging data and (bottom) generated by Sobczyk in 2009 and represents 2009 logging data 

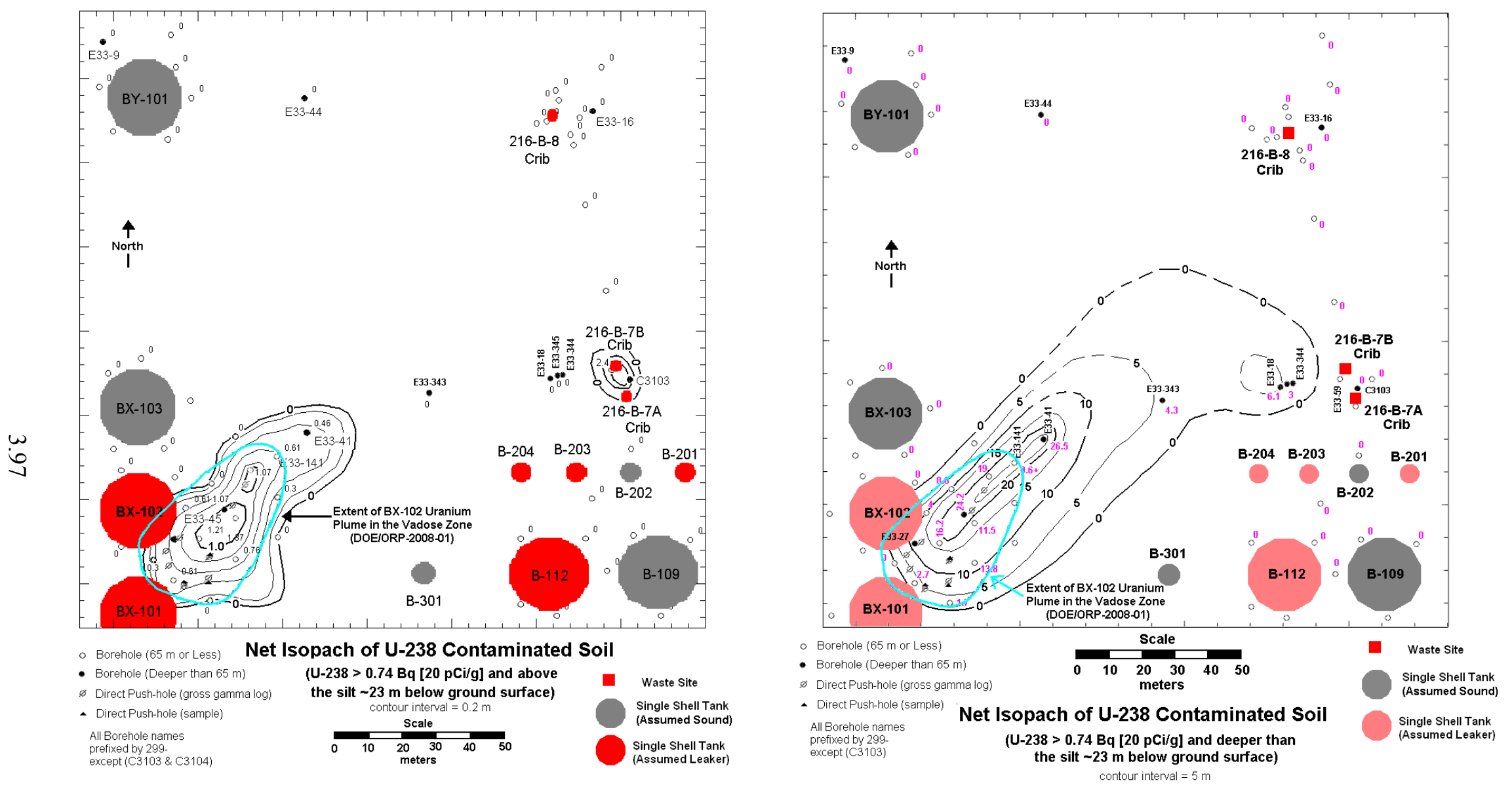

Figure 3.50. Lateral Spread of U from BX-102 Overfill Event Based on Gamma Logs taken from Sobczyk (2004b)

Left represents $U$ in Hanford formation above $H 2 F 2$ and right represents $U$ in deep Hanford \& $C C U_{z}$ unit (blue ellipse represents lateral spread interpretation by Knepp (2002) 
In terms of uranium identification in the vadose zone using gamma logging results, Sobczyk (2004a, b) found that the most extensive area of uranium-235/238 contamination is located northeast of Tank BX-102. The area northeast of Tank BX-102 contains 13 of the 17 boreholes (out of $\sim 300$ boreholes in the B-Complex region that have logging data) where Hanford-processed uranium was detected. Hanford-processed uranium concentrations reached $1,000 \mathrm{pCi} / \mathrm{g}$ in logged boreholes east of Tank BX-102. Farther away from BX-102, borehole 299-E33-18, located approximately $80 \mathrm{ft}$ west of the B-7-A\&B Cribs, exhibited Hanford-processed uranium contamination at 234 and $254 \mathrm{ft}$ bgs at concentrations exceeding $500 \mathrm{pCi} / \mathrm{g}$. Most striking was the fact that two older groundwater wells (299E33-18 and 299-E33-41) located northeast of Tank BX-102 and outside the BX Tank Farm showed by time series gamma logging an influx of uranium contamination between 1991 and 1997 (Price 1998, PNNL 1999a, and DOE/GJO 2002a). In well 299-E33-41, Hanford processed uranium-238 increased from 200 to $1,000 \mathrm{pCi} / \mathrm{g}$ between 1991 and $1997 \mathrm{in}$ a zone between 220 and $240 \mathrm{ft} \log$ depth. At the groundwater well 299-E33-41, which is about half way between Tank BX-102 and well 299-E33-18, Hanford-processed uranium-238 was detected just above the water table at 234 and $254 \mathrm{ft} \log$ depth. The maximum Hanford-processed uranium-238 concentration in this deep region of 299-E33-18 has steadily increased (as shown in Table 3.17) from not detected in 1992 to $1532 \mathrm{pCi} / \mathrm{g}$ when last logged in August 2007.

Table 3.17. SGLS Field Observations on Hanford Processed Uranium Increases in Deep Vadose Zone at 299-E33-18

\begin{tabular}{llcccc}
\hline & \multicolumn{4}{c}{ Year Maximum Concentrations Reported } \\
\cline { 2 - 5 } & 1992 & 1997 & 2001 & 2006 & 2007 \\
\hline Uranium-238 & None detected & $439 \mathrm{pCi} / \mathrm{g}$ & $623 \mathrm{pCi} / \mathrm{g}$ & $1237 \mathrm{pCi} / \mathrm{g}$ & $1532 \mathrm{pCi} / \mathrm{g}$ \\
Uranium-235 & None detected & $25 \mathrm{pCi} / \mathrm{g}$ & $51 \mathrm{pCi} / \mathrm{g}$ & $104 \mathrm{pCi} / \mathrm{g}$ & $137 \mathrm{pCi} / \mathrm{g}$ \\
\hline To convert the uranium activities $(\mathrm{pCi} / \mathrm{g})$ to uranium mass $(\mu \mathrm{g} / \mathrm{g})$, multiply by 2.975. & \\
\hline
\end{tabular}

It is now known that in both of these older boreholes (299-E33-41 and -18), the regions of high uranium are within the $\mathrm{CCU}_{\mathrm{z}}$ unit that is very moist and in places yields free-standing water (perched water). Further, it has been determined that the field SGLS logs over-estimate the actual Hanford processed uranium concentrations in the sediments surrounding the borehole casings because uranium has a tendency to adsorb/precipitate on the casing walls over time. The preferential distribution of uranium on the casings leads to an overestimation of the concentration of uranium in the vadose zone sediments (and pore waters) surrounding the boreholes.

No sediments from well 299-E33-41 (drilled in 1991) are available to characterize, but the gamma logs (Figure 3.51 and gamma log reports available from the EDA website $<$ http://environmet.hanford.gov/eda/ $>$ ) confirm the presence of elevated concentrations of Hanford processed uranium between 218 and $242 \mathrm{ft}$ bgs in the $\mathrm{CCU}_{\mathrm{z}}$ unit at this borehole. Further, there appears to be some Hanford processed uranium shallower in the Hanford formation; especially noteworthy is the presence at the location of the thin $\mathrm{H} 2 \mathrm{~F} 2$ fine-grained layer at $123 \mathrm{ft}$ bgs. There also appears to be Hanford processed uranium deep in the Hanford formation between 177 and $217 \mathrm{ft}$ bgs. Assuming that uranium is from the BX-102 overfill event, this represents significant vadose zone spreading. 299-E33-41 is approximately $165 \mathrm{ft}$ northeast of the edge of the BX-102 tank. In an effort to collect more data 
PNNL-19277

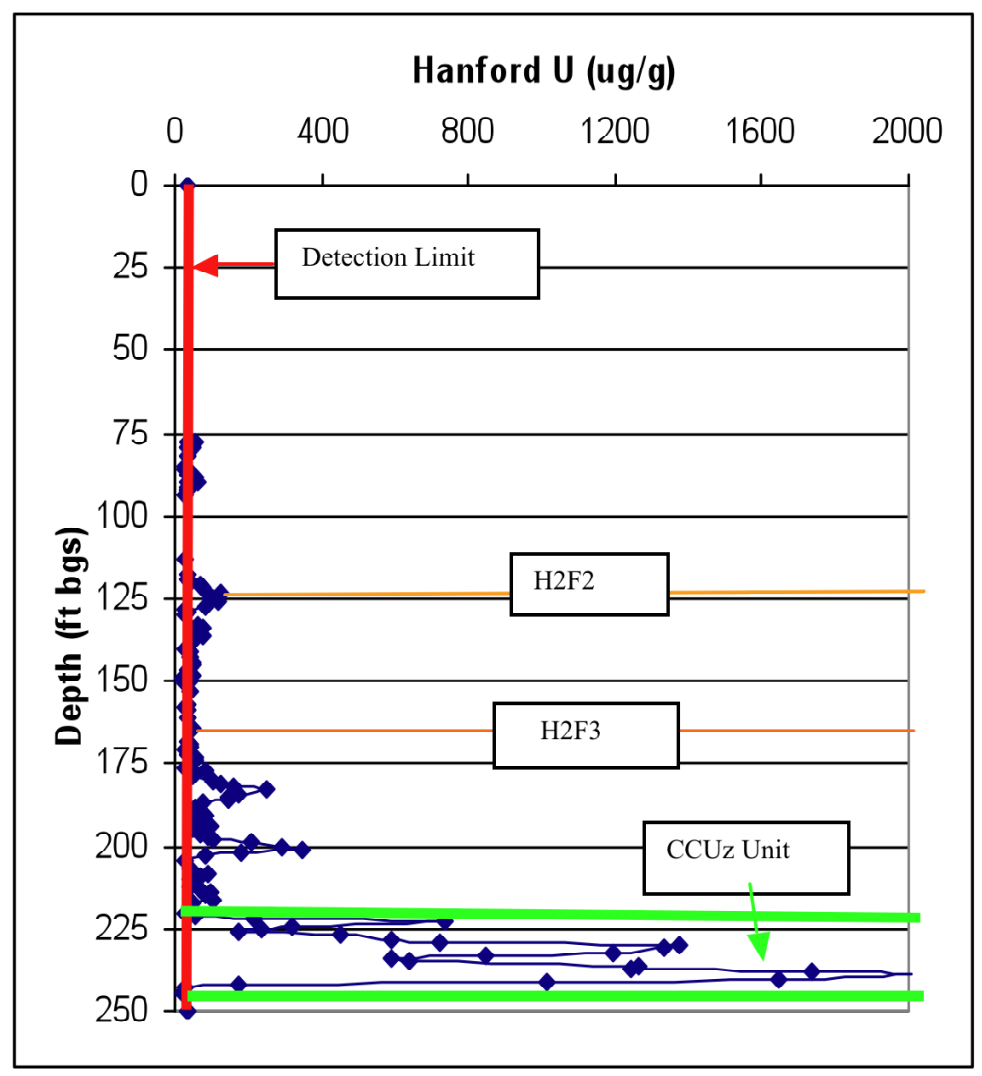

Figure 3.51. Year 2002 SGLS Log Data for Borehole 299-E33-41 (converted from activity to mass concentrations)

relevant to the deep vadose uranium concentrations in this region, the 200-BP-5 vadose characterization project drilled three new monitoring wells, 299-E33-343, approximately mid way between the older groundwater wells 299-E33-41 and 299-E33-18, and 299-E33-344 and 299-E33-345, both approximately $10 \mathrm{ft}$ from 299-E33-18. Findings from the three new boreholes are discussed below.

The results of the shallow direct push campaign to the southeast of Tank BX-102 are found in Brown et al. (2007). This characterization activity provided several 1.5-in. outer diameter (OD), 6-in.-long stainless steel liners of sediment from three shallow (no deeper than $78 \mathrm{ft} \mathrm{bgs}$ ) direct push holes (see Figure 3.48 for location). Pertinent sediment chemical concentration data are shown at the bottom of Table 3.16. A small core from direct push hole $\mathrm{C} 5134$ at $77 \mathrm{ft}$ bgs contained a contact with two distinct sediment types (Figure 3.52). The fine-grained portion of the core contained nearly four times the concentration of uranium as the coarse-grained sample (390 versus $108 \mu \mathrm{g} / \mathrm{g}$ uranium). Several tests were done on the two sediments to distinguish between mobile and immobile uranium. The first test consisted of exposing the fine and coarser grained sediments to a bicarbonate-carbonate leach solution. The second test consisted of equilibrating the uranium-contaminated sediments with a synthetic groundwater solution and then spiking the solution with a uranium isotope (uranium-233) that can easily be distinguished analytically from common uranium. This test relies on the supposition that weakly sorbed uranium (from contamination) can exchange with the doped uranium-233 such that the uptake of the tracer isotope can be quantified. The extent of uptake of uranium- 233 correlates with the amount of mobile uranium in the 
sediments. The quantities of mobile uranium in the coarse- and fine-grained sediments were, by the two test methods, similar. Test 1 yielded 51 to $67 \%$ and test 2 yielded 63 to $75 \%$ of the total uranium as being mobile, respectively. These data indicate that a sizeable fraction (from $25 \%$ to at least $33 \%$ and perhaps as much as $50 \%$ ) of uranium is immobile and in a form that is resistant to water leaching.

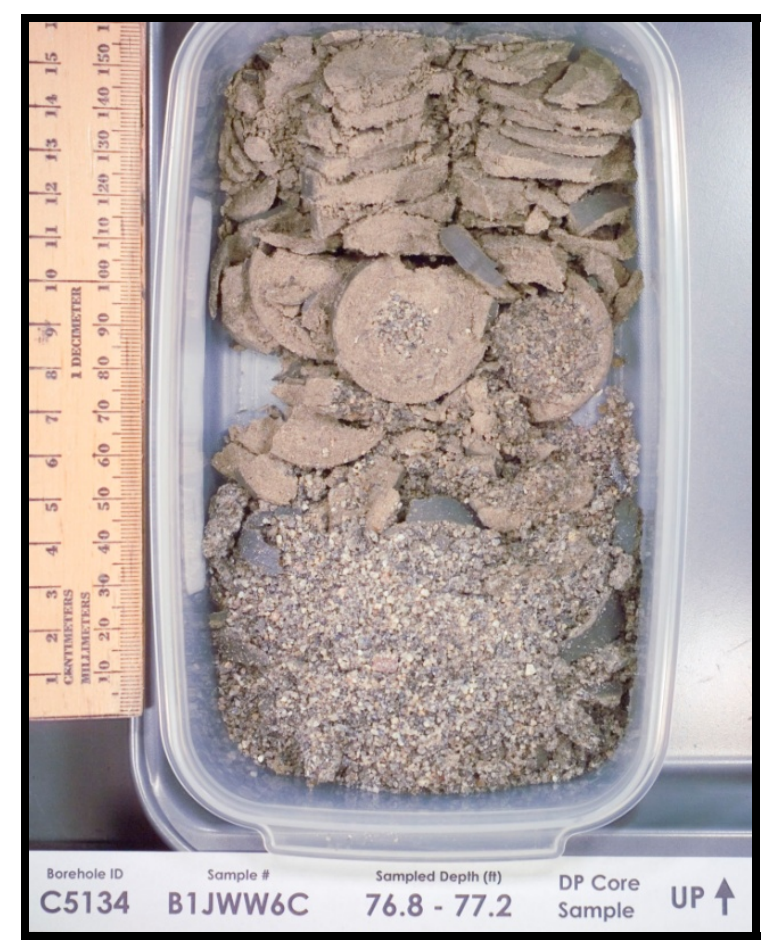

Figure 3.52. Photograph of the Fine-Grained Thin Lens on Top of Sand Found in Direct Push Hole South of BX-102 Tank at $\sim 77 \mathrm{ft}$ bgs

The significance of this detailed characterization of the more highly uranium-contaminated sediments from the shallow Hanford formation near Tank BX-102 is that some of the uranium is not readily leached by water and that the uranium associates more so with the fine-grained portions of the heterogeneous Hanford formation sediments, which are predominately sand. It is assumed that the fine-grained $\mathrm{CCU}_{z}$ sediments would also be capable of immobilizing a significant amount of uranium that migrates into this stratum.

The third activity was drilling borehole 299-E33-45 (completed in January 2001). This activity produced the most comprehensive set of contaminated sediments that allowed a detailed vertical profile

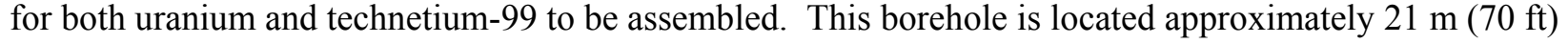
from the east edge of Tank BX-102 (see Figure 3.48). The borehole was installed in three stages using drive-barrel drilling methods to a total depth of $80 \mathrm{~m}$ (260 ft) (Reynolds 2001). A perched water zone was encountered at a depth of $69.2 \mathrm{~m}(227.1 \mathrm{ft})$ within the silty-to clayey-silt $\mathrm{CCU}_{\mathrm{z}}$ unit and groundwater was reached at a depth of $77.7 \mathrm{~m}(255 \mathrm{ft})$. A stainless steel screen was installed to complete the borehole as a groundwater monitoring well, however, the borehole was subsequently decommissioned after only one groundwater sample was taken. Thirty-five split-spoon core samples were collected approximately every $3 \mathrm{~m}(10 \mathrm{ft})$ or at pre-selected locations where hydrogeologic contacts were anticipated. Grab samples were collected between core sample intervals to yield near continuous samples to a depth of $77 \mathrm{~m}$ 
(254 ft). Ninety-six composite grab samples were collected with material composited from the core drive barrel, representing a roughly $60-\mathrm{cm}(2-\mathrm{ft})$ interval of the borehole. Additionally, 26 grab samples were taken from the shoe of the split-spoon samplers as they were disassembled.

Three different high purity germanium spectral-gamma logging events were conducted to identify the specific gamma-emitting radionuclides in the formation surrounding the borehole (Reynolds 2001). A different logging event was conducted at the end of each drilling phase through the single thickness of casing (with the exception of short overlaps between successive events) (Lindsey et al. 2001). Processing the spectral gamma log data provided plots of total gamma, naturally occurring radionuclides (potassium, uranium, and thorium [KUT]), and Hanford processed gamma emitters, such as cesium-137, uranium-235, and uranium-238. The spectral gamma log showed significant concentrations of Hanford processed uranium in the vadose zone profile that agreed remarkably well with the uranium concentrations measured directly in the sediment samples. The concentrations of select constituents in the sediment from 299-E33-45 are shown in Table 3.16.

The data in Table 3.16 and Figure 3.53 through Figure 3.57 show that sediments in 299-E33-45 contain waste fluids from the neutralized-bismuth phosphate waste overfill event in 1951. The depths at which waste fluids are found vary with constituent. Elevated sodium is found in sediment pore waters continuously between 80 and $170 \mathrm{ft}$ bgs (see Figure 3.53). Between 80 and $140 \mathrm{ft}$ bgs waterextractable native calcium is also depleted because of cation exchange (IX) reactions where highconcentration sodium wastes percolated through the sediments and stripped off native calcium from sediment exchange sites. Elevated calcium concentrations were found in the pore waters between 150 and $170 \mathrm{ft}$ bgs. A strong horizontal component to the waste fluid migration must have been established during the overfill event considering that the distance between the BX-102 tank perimeter and borehole 299-E33-45 (70 ft east). Waste fluid is found as shallow as $80 \mathrm{ft}$ bgs. If the overfill event was near the top of the steel liner at $\sim 20 \mathrm{ft}$ bgs, fluid traveled the 70 feet horizontally while descending vertically $\sim 55 \mathrm{ft}(\sim 1.3$ to 1 slope) to the location in borehole $299-\mathrm{E} 33-45$ where the top of the sodium vadose zone plume is found. It has been hypothesized that much of this lateral movement took place along a compacted zone at the base of the farm.

Elevated pore-water nitrate (Figure 3.54) is found intermittently between 120 and $170 \mathrm{ft}$ bgs with very high concentrations at $120 \mathrm{ft}$ bgs where the fine-grained H2F2 layer is located. There are other high nitrate concentrations at $\sim 156$ and 168 to $169 \mathrm{ft}$ (the depth of the H2F3 fine grain layer) and then again within the $\mathrm{CCU}_{\mathrm{z}}$ thicker silty layer between 218 and $239 \mathrm{ft}$ bgs. The nitrate concentration in the $\mathrm{CCU}_{\mathrm{z}}$ strata is the highest found in the vertical profile of $299-E 33-45$ with an average of $\sim 320 \mu \mathrm{g} / \mathrm{g}$. The vertical distribution of technetium-99 in borehole 299-E33-45 sediments (Figure 3.55) is similar to the nitrate with a sharp narrow spike in the thin fine-grained H2F2 layer at $120 \mathrm{ft}$ bgs. The technetium-99 here varies between 10 and $20 \mathrm{pCi} / \mathrm{g}$ (about one-tenth the concentration found in the deep vadose zone sediments below the BY cribs) between $130 \mathrm{ft}$ and the $\mathrm{H} 2 \mathrm{~F} 3$ fine-grained layer at $168 \mathrm{ft}$ bgs. There is technetium present in the $\mathrm{CCU}_{\mathrm{z}}$ strata at concentrations between 7 and $15 \mathrm{pCi} / \mathrm{g}$ with the higher values near the top of this unit. The shallow direct push sediments taken south and southeast of the BX-102 tank show lower concentrations of nitrate and technetium than found deeper in borehole 299-E33-45, suggesting either that the overfill fluids descended with a strong vertical component closer to than the shallow direct push holes to the tank's perimeter until they reached the three fine-grained layers at 70, 120 , and $168 \mathrm{ft}$ bgs or that natural recharge water, perhaps snow melt, and near-surface waters from potable water line leaks have driven the mobile contaminants deeper than $\sim 70 \mathrm{ft}$ bgs at the shallow direct push locations. 
PNNL-19277

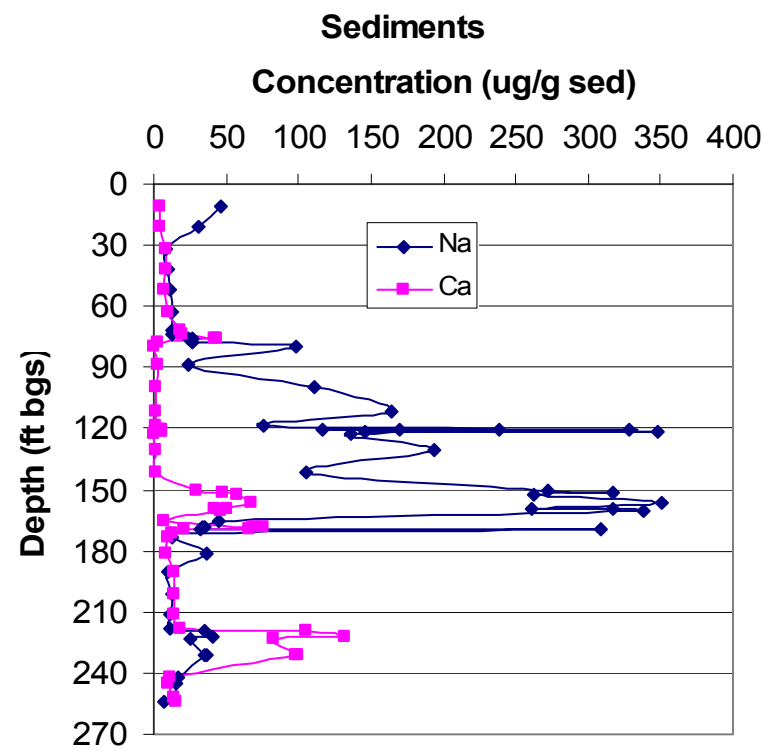

Figure 3.53. Water-Extractable $\mathrm{Na}$ and $\mathrm{Ca}$ in Vadose Zone Sediments at 299-E33-45

The water- and acid-extractable uranium (Figure 3.56 and Figure 3.57) to the east and southeast of BX-102 shows elevated values starting at about $60 \mathrm{ft}$ bgs in the three shallow direct push boreholes (see bottom of Table 3.16) and at $73 \mathrm{ft}$ bgs at 299-E33-45. At 299-E33-45 there is a narrow very high uranium concentration spike in the thin silty layer at $120 \mathrm{ft}$ bgs $(\mathrm{H} 2 \mathrm{~F} 2)$. Below the H2F2 fine-grained layer down to the next areally extensive thin fine-grained layer at 168 feet, high concentrations $(\sim 20 \mu \mathrm{g} / \mathrm{g})$ of water-extractable uranium were found. Below the thin fine-grained lens at $168 \mathrm{ft}$ bgs, the waterextractable uranium ranges from 0.2 to $3 \mu \mathrm{g} / \mathrm{g}$. Between $191 \mathrm{ft}$ bgs and the top of the $\mathrm{CCU}_{\mathrm{z}}$ at $218 \mathrm{ft}$ bgs, the water-extractable uranium is not distinguishable from uncontaminated sediments. Within the $\mathrm{CCU}_{\mathrm{z}}$ unit, the water-extractable uranium is slightly higher than uncontaminated sediments with a value 0.05 $\mu \mathrm{g} / \mathrm{g}$ versus $\leq 0.005 \mu \mathrm{g} / \mathrm{g}$ for uncontaminated sediments. The acid-extractable uranium in the direct push sediments from samples below $60 \mathrm{ft}$ bgs (see bottom of Table 3.16) and those in borehole 299-E33-45 from 75 to $200 \mathrm{ft}$ bgs are elevated compared to uncontaminated sediments from the 200 East Area. However, not as many acid extractions were performed on the 299-E33-45 sediments in comparison to water extractions; therefore, the acid extraction data set is not as robust, leading to less detail in the vertical distribution of acid-extractable uranium. The acid-extractable total uranium concentrations in the $\mathrm{CCU}_{\mathrm{z}}$ unit's sediments are not distinguishable from natural background sediments. However, more sensitive uranium isotope signature results suggest that about $10 \%$ of the water-extractable uranium in the one sample of $\mathrm{CCU}_{z}$ sediments analyzed at Lawrence Berkeley National Laboratory comes from the BX102 overfill, and 90\% is from natural background (see next subsection 3.4.3 and Christensen et al. 2004 for more details). 


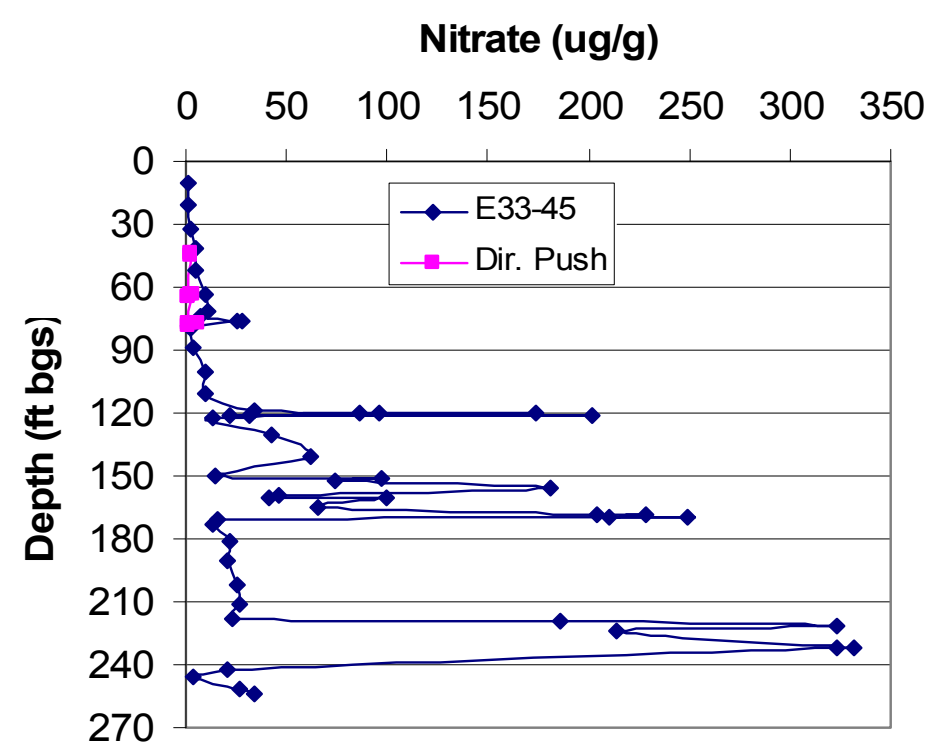

Figure 3.54. Vertical Distribution of Nitrate in Sediments South and East of BX-102 Tank

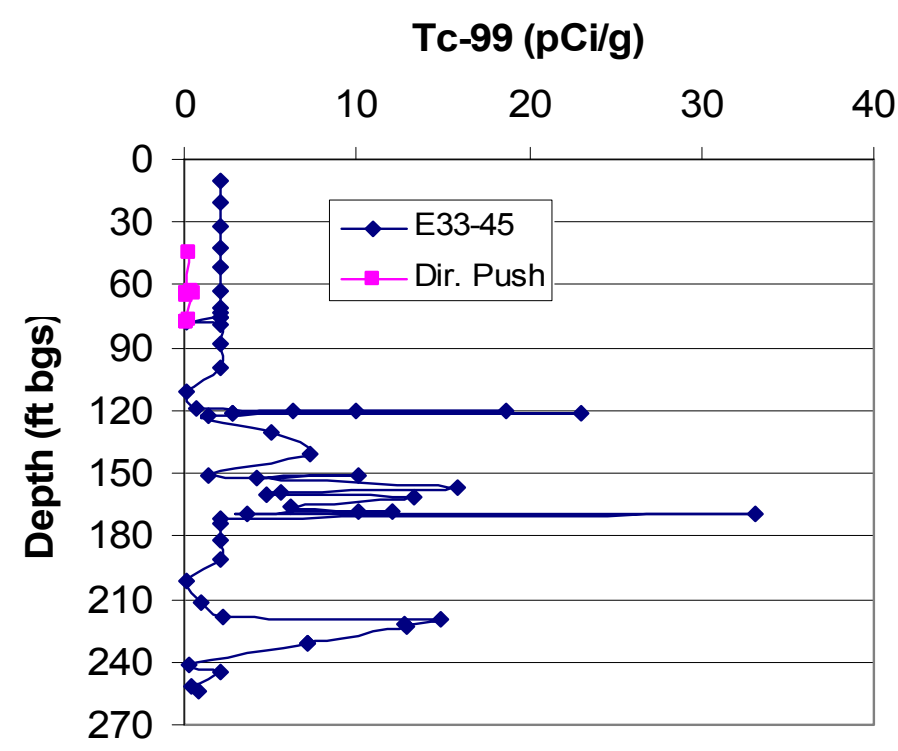

Figure 3.55. Vertical Distribution of Technetium-99 in Sediments South and East of Tank BX-102 


\section{Water Extractable U (ug/g)}

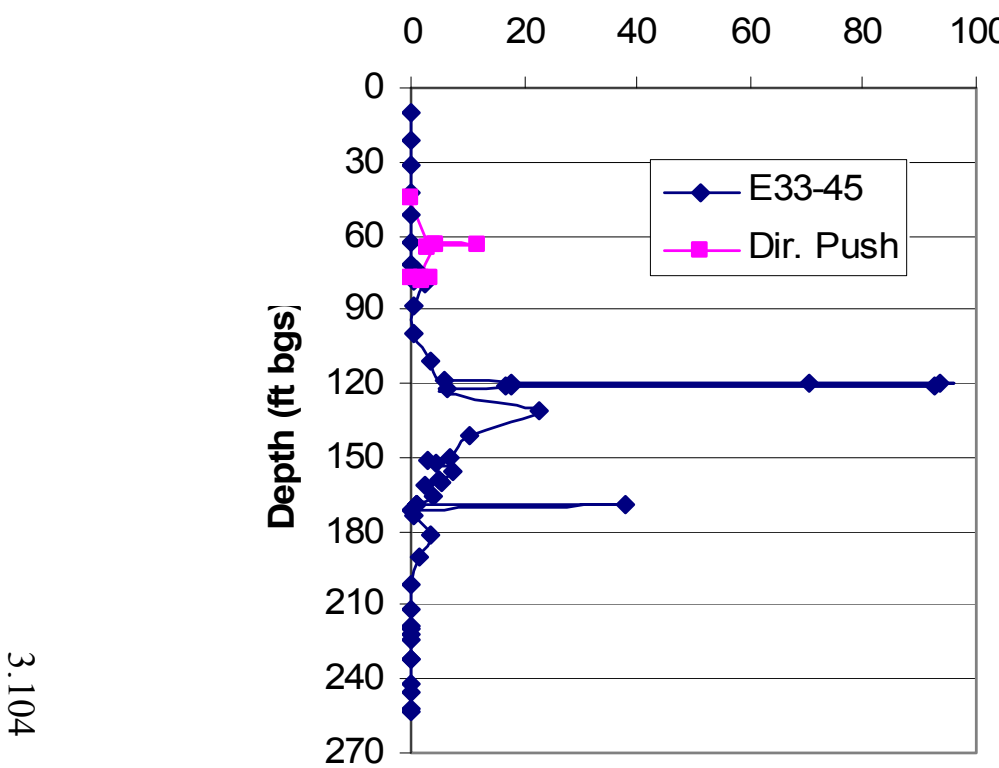

Figure 3.56. Vertical Distribution of Water-Extractable Uranium in Sediments South and East of Tank BX-102

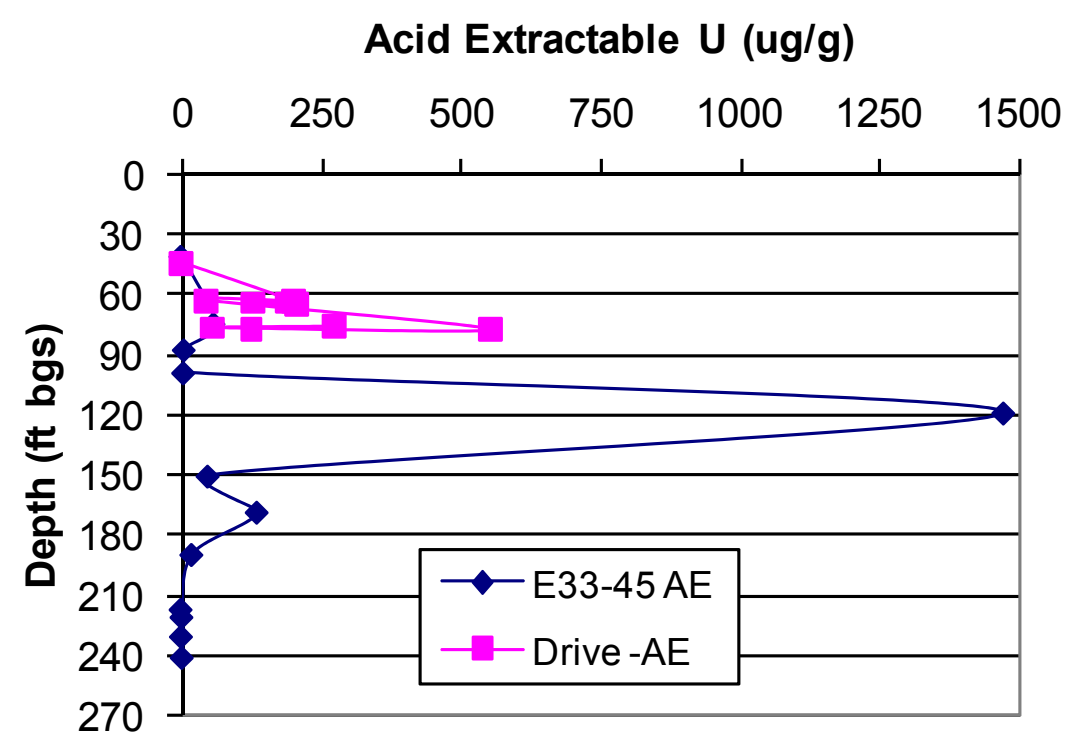

Figure 3.57. Vertical Distribution of Acid-Extractable Uranium in Sediments South and East of Tank BX-102 
Based on the available vadose zone sediment data, it appears that elevated concentrations of sodium, nitrate, technetium-99, and uranium from the overfill event have migrated throughout much of the Hanford formation H2 unit to the northeast of Tank BX-102. at least as far as 299-E33-45 and likely farther. There has been significant horizontal spreading along several of the fine-grained thin layers in the Hanford $\mathrm{H} 2$ unit, especially at the 120-ft-bgs depth, which represents the areally extensive H2F2 layer. There is also evidence of elevated nitrate and technetium-99 in the $\mathrm{CCU}_{z}$ strata found between 218 and $239 \mathrm{ft}$ bgs at borehole 299-E33-45. The nitrate in the $\mathrm{CCU}_{\mathrm{z}}$ unit is more concentrated than in any of overlying Hanford formation sediments. The $\mathrm{CCU}_{z}$ strata at 299-E33-45 show technetium-99 concentrations between 7 and $15 \mathrm{pCi} / \mathrm{g}$. The variable vertical distribution of these two contaminants at E33-45 suggest that overfill fluids migrated laterally within the $\mathrm{CCU}_{\mathrm{z}}$ after descending vertically closer to BX-102 tank in the shallower Hanford formation sediments.

The fact that the uranium observed in the $\mathrm{CCU}_{z}$ strata at 299-E33-45 borehole is at a much lower concentration than found shallower in the Hanford formation suggests that the bulk of the uranium lost during the overfill event has not descended as deep as the $\mathrm{CCU}_{z}$ unit at the 299-E33-45 borehole. The sensitive isotope signature measurements also suggest that most of the measured low concentration waterextractable uranium was natural uranium, and only $10 \%$ has come from a waste source with the isotope signature of the BX-102 waste stream (refer to Christensen et al. 2004 for more discussion.)

The fourth activity was the soil resistivity field survey documented in Rucker et al. (2007). The impacts of all the metallic infrastructure around the SSTs makes surface-to-surface electrical resistivity measurements extremely difficult to interpret. Using well to well (where existing dry wells and groundwater monitoring wells are used as the electrodes) complemented by placement of short electrodes in abandoned direct push holes near the tanks appears to offer more defensible information, but there is still wide variation between the results of different conceptual models used to process the raw soil resistivity data. Therefore, the soil resistivity information for below the BX-BY tank farms was not used in the development of the conceptual model for the vertical and horizontal distribution of contaminants below the BX-BY tank farms, especially to the northeast of Tank BX-102, where the soil electrical resistivity field survey processed data yielded widely different results based on what inversion approach was chosen.

The fifth activity performed in 2008 was installation of a groundwater monitoring well (299-E33-205) drilled as near to a low soil electrical resistivity anomaly as possible to evaluate possible vadose zone migration of contaminants. E33-205 is located about $55 \mathrm{ft}$ north of Tank BX-106 (see Figure 3.47 or Figure 3.48). Vadose zone sediments were collected and analyzed to look for contamination either migrating north from the BX Tank Farm or south from the BY Tank Farm. The vertical distribution of selected potentially mobile contaminants in the vadose zone sediments at 299-E33-205 are shown in Table 3.18. The data for the Hanford formation portion of the sediment profile, shown in Table 3.18, are indistinguishable from uncontaminated sediments in the 200 East Area except for faint signs of elevated water-extractable calcium, nitrate, and sulfate in the $\mathrm{CCU}_{\mathrm{z}}$ silt-dominated stratum, which is present from 220 to $238 \mathrm{ft}$ bgs. Unlike the $\mathrm{CCU}_{\mathrm{z}}$ strata at several of the other boreholes north and east of Tank BX102, there does not appear to be significant signs of technetium-99 or uranium contamination in this siltdominated stratum at this location. However, three sediment samples did show measurable technetium99 concentrations below $1 \mathrm{pCi} / \mathrm{g}$. The elevated calcium with no zone of elevated sodium found somewhat shallower in this formation suggests that there is high sodium waste somewhere in a lateral direction away from this borehole that at one time was migrating towards the borehole. The elevated calcium is either 
Table 3.18. Vertical Distribution of Selected Constituents in Sediments from 299-E33-205 (north of $\mathrm{BX}-106)$

\begin{tabular}{|c|c|c|c|c|c|c|c|c|c|}
\hline $\begin{array}{c}\text { Depth } \\
\text { (ft bgs) }\end{array}$ & $\begin{array}{c}\mathrm{Na}(\mathrm{WE}) \\
\mu \mathrm{g} / \mathrm{g}\end{array}$ & $\begin{array}{c}\mathrm{Ca}(\mathrm{WE}) \\
\mu \mathrm{g} / \mathrm{g}\end{array}$ & $\begin{array}{c}\mathrm{F} \\
\mu \mathrm{g} / \mathrm{g}\end{array}$ & $\begin{array}{c}\text { Nitrate } \\
\mu \mathrm{g} / \mathrm{g}\end{array}$ & $\begin{array}{c}\text { Nitrite } \\
\mu \mathrm{g} / \mathrm{g}\end{array}$ & $\begin{array}{c}\text { Sulfate } \\
\mu \mathrm{g} / \mathrm{g}\end{array}$ & $\begin{array}{c}\mathrm{Tc} \\
\mathrm{pCi} / \mathrm{g}\end{array}$ & $\begin{array}{c}\mathrm{U}(\mathrm{WE}) \\
\mu \mathrm{g} / \mathrm{g}\end{array}$ & $\begin{array}{c}\mathrm{Cr}(\mathrm{WE}) \\
(\mu \mathrm{g} / \mathrm{g})\end{array}$ \\
\hline 0 & 1.33 & 8.76 & 0.24 & 2.4 & $<1.00$ & $<1.50$ & $<0.390$ & $<5.64 \mathrm{E}-04$ & $<2.06 \mathrm{E}-03$ \\
\hline 2.5 & 6.37 & 8.48 & 1.37 & $<1$ & $<1.00$ & 1.68 & $<0.389$ & $<5.62 \mathrm{E}-04$ & $<2.05 \mathrm{E}-03$ \\
\hline 5 & 3.12 & 9.06 & 0.4 & 1.98 & $<0.99$ & $<1.49$ & $<0.387$ & $<5.59 \mathrm{E}-04$ & $<2.04 \mathrm{E}-03$ \\
\hline 7.5 & 6.36 & 9.85 & 1.05 & 1.53 & $<1.00$ & 2.72 & $<0.389$ & $7.53 \mathrm{E}-04$ & $<2.05 \mathrm{E}-03$ \\
\hline 10 & 8.03 & 8.99 & 1.01 & 1.44 & $<1.00$ & 2.02 & $<0.390$ & $7.72 \mathrm{E}-04$ & $<2.06 \mathrm{E}-03$ \\
\hline 12.6 & 24.0 & 6.13 & 1.14 & 4.6 & $<1.00$ & 2.68 & $<0.390$ & $2.82 \mathrm{E}-03$ & $<2.06 \mathrm{E}-03$ \\
\hline 15.5 & 22.9 & 5.68 & 1.01 & 4.16 & $<1.00$ & 4.78 & $<0.390$ & $2.88 \mathrm{E}-03$ & $<2.05 \mathrm{E}-03$ \\
\hline 17.5 & 21.8 & 3.40 & 0.72 & 3.59 & $<1.00$ & 8.36 & $<0.390$ & $1.16 \mathrm{E}-03$ & $<2.06 \mathrm{E}-03$ \\
\hline 20 & 20.2 & 4.13 & 0.65 & 4.26 & $<1.00$ & 10.9 & $<0.389$ & $7.74 \mathrm{E}-04$ & $<2.05 \mathrm{E}-03$ \\
\hline 23.3 & 17.4 & 5.08 & 0.37 & 4.81 & $<1.00$ & 11.9 & $<0.389$ & 7.38E-04 & $<2.05 \mathrm{E}-03$ \\
\hline 25 & 15.7 & 5.94 & 0.43 & 5.54 & $<1.00$ & 10.8 & $<0.389$ & $8.77 \mathrm{E}-04$ & $<2.05 \mathrm{E}-03$ \\
\hline 27.5 & 14.0 & 6.86 & 0.47 & 4.42 & $<1.00$ & 12.3 & $<0.390$ & $5.64 \mathrm{E}-04$ & $<2.06 \mathrm{E}-03$ \\
\hline 30.8 & 23.0 & 6.44 & 1.02 & 4 & $<1.00$ & 18.1 & $<0.390$ & $5.64 \mathrm{E}-04$ & $<2.06 \mathrm{E}-03$ \\
\hline 32.7 & 10.8 & 7.64 & 0.43 & 7.43 & $<1.00$ & 8.54 & $<0.389$ & $1.20 \mathrm{E}-03$ & $<2.05 \mathrm{E}-03$ \\
\hline 35 & 5.94 & 5.26 & 0.23 & 2.46 & $<1.00$ & 7.26 & $<0.390$ & $<5.63 \mathrm{E}-04$ & $<2.05 \mathrm{E}-03$ \\
\hline 37.5 & 7.99 & 6.42 & 0.24 & 5.69 & $<1.00$ & 14.4 & $<0.389$ & $<5.62 \mathrm{E}-04$ & $<2.05 \mathrm{E}-03$ \\
\hline 40 & 9.29 & 7.83 & $<0.20$ & 7.43 & $<1.00$ & 18.9 & $<0.390$ & $<5.63 \mathrm{E}-04$ & $<2.05 \mathrm{E}-03$ \\
\hline 42.5 & 9.63 & 7.14 & 0.21 & 5.42 & $<1.01$ & 14.5 & $<0.392$ & $<5.67 \mathrm{E}-04$ & $<2.07 \mathrm{E}-03$ \\
\hline 46 & 11.4 & 8.22 & 0.26 & 3.88 & $<1.00$ & 21.9 & $<0.388$ & $<5.61 \mathrm{E}-04$ & $<2.04 \mathrm{E}-03$ \\
\hline 48.5 & 11.5 & 9.06 & 0.22 & 3.52 & $<1.00$ & 27.6 & $<0.391$ & $<5.65 \mathrm{E}-04$ & $<2.06 \mathrm{E}-03$ \\
\hline 50 & 11. & 10.1 & 0.23 & 3.87 & $<1.00$ & 34.1 & $<0.390$ & $<5.63 \mathrm{E}-04$ & $<2.05 \mathrm{E}-03$ \\
\hline 53 & 11.6 & 11.3 & 0.25 & 8.18 & $<1.00$ & 34.2 & $<0.390$ & $<5.63 \mathrm{E}-04$ & $<2.05 \mathrm{E}-03$ \\
\hline 55 & 10.4 & 7.84 & 0.23 & 6.37 & $<1.00$ & 19.0 & $<0.389$ & $<5.61 \mathrm{E}-04$ & $<2.05 \mathrm{E}-03$ \\
\hline 58.6 & 11.0 & 8.28 & 0.28 & 5.15 & $<1.00$ & 17.4 & $<0.391$ & $<5.64 \mathrm{E}-04$ & $<2.06 \mathrm{E}-03$ \\
\hline 60.5 & 7.41 & 5.90 & 0.21 & 3.26 & $<1.00$ & 8.9 & $<0.389$ & $<5.62 \mathrm{E}-04$ & $<2.05 \mathrm{E}-03$ \\
\hline 75 & 13.1 & 7.35 & 0.3 & $<1$ & $<1.00$ & 14.8 & $<0.389$ & $1.51 \mathrm{E}-03$ & $<2.05 \mathrm{E}-03$ \\
\hline 91 & 11.3 & 8.26 & 0.33 & 7.33 & $<1.00$ & 22.3 & $<0.388$ & $<5.61 \mathrm{E}-04$ & $<2.04 \mathrm{E}-03$ \\
\hline 112.8 & 13.5 & 17.5 & 0.24 & 9.87 & $<1.00$ & 50.4 & $<0.389$ & $<5.61 \mathrm{E}-04$ & $<2.05 \mathrm{E}-03$ \\
\hline 125.6 & 18.2 & 31.4 & 0.27 & 12.7 & $<1.00$ & 91.8 & $<0.388$ & $<5.61 \mathrm{E}-04$ & $<2.05 \mathrm{E}-03$ \\
\hline 135.8 & 9.33 & 10.4 & 0.21 & 3.99 & $<0.99$ & 32.1 & $<0.388$ & $<5.60 \mathrm{E}-04$ & $<2.04 \mathrm{E}-03$ \\
\hline 145.5 & 11.9 & 18.5 & 0.25 & 4.45 & $<1.00$ & 65.4 & $<0.391$ & $<5.65 \mathrm{E}-04$ & $<2.06 \mathrm{E}-03$ \\
\hline 158 & 13.3 & 13.7 & 0.25 & 4.92 & $<1.09$ & 46.9 & $<0.427$ & $<6.17 \mathrm{E}-04$ & $<2.25 \mathrm{E}-03$ \\
\hline 160.75 & NA & NA & $<0.294$ & 6.99 & NA & 50 & $<0.339$ & NA & NA \\
\hline 167.7 & 19.2 & 35.0 & 0.35 & 14.2 & $<1.00$ & 126.6 & $<0.390$ & $1.22 \mathrm{E}-03$ & $<2.06 \mathrm{E}-03$ \\
\hline 170 & 21.4 & 29.0 & 0.34 & 15.3 & $<1.00$ & 102 & $<0.389$ & $6.37 \mathrm{E}-04$ & $<2.05 \mathrm{E}-03$ \\
\hline 173.5 & 39.3 & 37.8 & $<0.20$ & 1.09 & $<1.00$ & 7.03 & 0.543 & $1.42 \mathrm{E}-03$ & $<2.04 \mathrm{E}-03$ \\
\hline 187.5 & 28.3 & 8.89 & 0.35 & 30.9 & $<1.00$ & 29.3 & $<0.391$ & $<5.64 \mathrm{E}-04$ & $<2.06 \mathrm{E}-03$ \\
\hline 200 & 9.52 & 9.88 & 0.3 & 10.1 & $<1.00$ & 20.7 & $<0.389$ & $<5.63 \mathrm{E}-04$ & $<2.05 \mathrm{E}-03$ \\
\hline 210 & 13.9 & 12.7 & 0.39 & 10.2 & $<1.00$ & 35.3 & $<0.389$ & $<5.63 \mathrm{E}-04$ & $<2.05 \mathrm{E}-03$ \\
\hline 217.75 & NA & NA & $<0.3$ & 8.01 & NA & 34.6 & 0.666 & NA & NA \\
\hline 217.75 & NA & NA & $<0.3$ & 22.3 & NA & 31.3 & 0.867 & NA & NA \\
\hline 221 & 18.6 & 20.4 & 0.42 & 45.5 & $<1.00$ & 44.1 & $<0.390$ & $<5.64 \mathrm{E}-04$ & $<2.06 \mathrm{E}-03$ \\
\hline 222.5 & 35.8 & 113 & $<2.00$ & 112 & $<9.99$ & 335 & 0.976 & 7.71E-04 & $<2.05 \mathrm{E}-03$ \\
\hline 225 & 30.8 & 80.7 & $<2.00$ & 88.5 & $<9.98$ & 223 & $<0.389$ & $1.49 \mathrm{E}-03$ & $<2.05 \mathrm{E}-03$ \\
\hline
\end{tabular}


Table 3.18. Vertical Distribution of Selected Constituents in Sediments from 299-E33-205 (north of BX-106)

\begin{tabular}{|c|c|c|c|c|c|c|c|c|c|}
\hline $\begin{array}{l}\text { Depth } \\
(\mathrm{ft} \text { bgs) }\end{array}$ & $\begin{array}{c}\mathrm{Na}(\mathrm{WE}) \\
\mu \mathrm{g} / \mathrm{g}\end{array}$ & $\begin{array}{c}\mathrm{Ca}(\mathrm{WE}) \\
\mu \mathrm{g} / \mathrm{g}\end{array}$ & $\begin{array}{c}\mathrm{F} \\
\mu \mathrm{g} / \mathrm{g}\end{array}$ & $\begin{array}{c}\text { Nitrate } \\
\mu \mathrm{g} / \mathrm{g}\end{array}$ & $\begin{array}{c}\text { Nitrite } \\
\mu \mathrm{g} / \mathrm{g}\end{array}$ & $\begin{array}{c}\text { Sulfate } \\
\mu \mathrm{g} / \mathrm{g}\end{array}$ & $\begin{array}{c}\mathrm{Tc} \\
\mathrm{pCi} / \mathrm{g}\end{array}$ & $\begin{array}{c}\text { U (WE) } \\
\mu \mathrm{g} / \mathrm{g}\end{array}$ & $\begin{array}{c}\text { Cr (WE) } \\
(\mu \mathrm{g} / \mathrm{g})\end{array}$ \\
\hline 227.5 & 27.8 & 55.8 & 0.3 & 74.3 & $<1.00$ & 159 & $<0.389$ & $1.11 \mathrm{E}-03$ & $<2.05 \mathrm{E}-03$ \\
\hline 230.65 & NA & NA & $<0.3$ & 34.4 & NA & 37.8 & $<0.389$ & NA & NA \\
\hline 255.74 & NA & NA & $<0.3$ & 7.13 & NA & 19.5 & $<0.381$ & NA & NA \\
\hline 255.74 & NA & NA & $<0.3$ & 6.11 & NA & 22.4 & $<0.394$ & NA & NA \\
\hline water table & & & $259.7 \mathrm{ft} \mathrm{bg}$ & & & water tab & & & \\
\hline 260.75 & NA & NA & $<0.3$ & 15.7 & NA & 11.7 & 1.14 & NA & NA \\
\hline 262.5 & 8.02 & 12.0 & 0.27 & 18.1 & $<1.00$ & 13.9 & $<0.389$ & $5.96 \mathrm{E}-03$ & $<2.05 \mathrm{E}-03$ \\
\hline 267.5 & 9.95 & 11.1 & 0.38 & 13.3 & $<1.12$ & 13.4 & $<0.435$ & 7.01E-03 & $<2.29 \mathrm{E}-03$ \\
\hline 267.25 & NA & NA & $<0.3$ & 2.18 & NA & 22.4 & 4.74 & NA & NA \\
\hline
\end{tabular}

the leading edge of a laterally moving ion exchange front or might be the sign of elevated concentrations of calcium carbonate in the sediment within the $\mathrm{CCU}_{z}$ unit at this location. The presence of elevated sulfate in conjunction with elevated calcium is often indicative of the presence of calcium carbonate in the sediments. Field geologic descriptive logs and laboratory qualitative hydrochloric acid testing suggest that the $\mathrm{CCU}_{\mathrm{z}}$ unit at this borehole does contain more calcium carbonate than found in the overlying Hanford $\mathrm{H} 2$ unit. The presence of slightly elevated nitrate and a few measurable technetium-99 values does allow for concluding that some minor proportion of Hanford liquid wastes could be present in the $\mathrm{CCU}_{\mathrm{z}}$ stratum at 299-E33-205.

Based solely on the data found in Table 3.18, it is concluded that the vadose zone at 299-E33-205 has been slightly impacted by horizontal spreading of waste fluids in the CCUz. Sediment samples at 218 and $222.5 \mathrm{ft}$ bgs contain measureable technetium-99. Sensitive uranium isotope ratio data to be discussed in Section 3.4.3 also confirm the presence of some Hanford-processed uranium within the $\mathrm{CCU}_{\mathrm{z}}$ sediments that have a BX-102 source signature mixed with uncontaminated pore water. The concentrations of Hanford-processed uranium in the 299-E33-205 sediments in the $\mathrm{CCU}_{z}$ stratum are lower than boreholes/wells farther east that are located along the northeasterly dipping proposed path for fluids lost at BX-102. Interestingly, groundwater samples at 299-E33-205 taken at the end of drilling and since the quarterly monitoring has been underway does contain elevated uranium (700 to $1000 \mu \mathrm{g} / \mathrm{L}$ ) and elevated technetium ( $\sim 9000 \mathrm{pCi} / \mathrm{L})$. The vadose zone above the water table at 299-E33-205 is not the source of the groundwater contamination. More discussion of groundwater and contaminant migration dynamics is found in Section 5.

The final activity that yields valuable data on the fate of the BX-102 overfill event fluids was drilling the combined vadose zone borehole and groundwater monitoring well 299-E33-343 (location shown in Figure 3.47. Table 3.19 shows the vertical distribution of selected potentially mobile constituents (in 1:1 sediment to water-extractable concentrations unless specified otherwise) in the sediments from well 299E33-343. Sediments were collected from 60 to $257 \mathrm{ft}$ bgs at new well 299-E33-343, but the shallowest sediments were not characterized once it was evident from processing other boreholes distal from inactive disposal facilities that there was no observed contamination in the shallow Hanford sediments. Sediment samples from 80 to $215 \mathrm{ft}$ bgs in 299-E33-343 did not show any evidence of contamination. As found at 
other recent 200-BP-5 vadose zone boreholes 299-E33-205, 299-E33-344, and 299-E33-345 contamination is found in the $\mathrm{CCU}_{z}$ stratum. In fact, borehole 299-E33-343 has the highest concentrations of acid- and water-extractable uranium compared to all the new 200-BP-5 boreholes that show significant uranium contamination in the $\mathrm{CCU}_{\mathrm{z}}$ strata. The acid-extractable uranium concentrations in the sediments in the $\mathrm{CCU}_{\mathrm{z}}$ unit at 299-E33-343 are about 10 times larger than at the two new wells (299-E33-344 and E33-345) near 299-E33-18. The water-extractable uranium in the sediments in the $\mathrm{CCU}_{\mathrm{z}}$ unit at 299-E33-343 ranges from about 5 to 10 times larger than at 299-E33-344 and -345. This trend fits the hypothesis that uranium from the BX-102 overfill event has migrated in a northeasterly direction and descended through the Hanford formation at about a ratio of $1.3 \mathrm{ft}$ lateral for every $1 \mathrm{ft}$ vertical (high uranium was found at 299-E33-45 in Hanford formation but not $\mathrm{CCU}_{\mathrm{z}}$ unit) and reached the $\mathrm{CCU}_{z}$ unit somewhere in the vicinity of the old well 299-E33-41 and/or the new well 299-E33-343. Once the high uranium concentration fluids reached the $\mathrm{CCU}_{\mathrm{z}}$ they continued nearly exclusive lateral migration east to wells 299-E33-18, E33-344, and E33-345.

Unlike the spectral gamma logging data at 299-E33-41, which showed some Hanford processed uranium in the Hanford H2 unit, SGLS field logging at 299-E33-343 shows no sign of elevated uranium in the Hanford formation. Identical SGLS results, showing no Hanford processed uranium in the Hanford $\mathrm{H} 2$ unit are found at the more distant pair of new boreholes 299-E33-344 and 299-E33-345. At all three of these new boreholes actual sediment characterization also shows there is Hanford processed uranium only in the $\mathrm{CCU}_{\mathrm{z}}$ unit sediments.

Table 3.19. Vertical Distribution of Selected Constituents in Sediments from 299-E33-343

\begin{tabular}{|c|c|c|c|c|c|c|c|c|c|c|}
\hline \multicolumn{11}{|c|}{ 299-E33-343 } \\
\hline $\begin{array}{c}\text { Depth } \\
\text { (ft bgs) }\end{array}$ & $\begin{array}{c}\mathrm{Na}(\mathrm{WE}) \\
\mu \mathrm{g} / \mathrm{g}\end{array}$ & $\begin{array}{c}\mathrm{Ca}(\mathrm{WE}) \\
\mu \mathrm{g} / \mathrm{g}\end{array}$ & $\begin{array}{c}\mathrm{F} \\
\mu \mathrm{g} / \mathrm{g}\end{array}$ & $\begin{array}{c}\text { Nitrate } \\
\mu \mathrm{g} / \mathrm{g}\end{array}$ & $\begin{array}{c}\text { Nitrite } \\
\mu \mathrm{g} / \mathrm{g}\end{array}$ & $\begin{array}{c}\text { Sulfate } \\
\mu \mathrm{g} / \mathrm{g}\end{array}$ & $\begin{array}{c}\mathrm{Tc} \\
\mathrm{pCi} / \mathrm{g}\end{array}$ & $\begin{array}{c}\mathrm{U}(\mathrm{AE}) \\
\mu \mathrm{g} / \mathrm{g}\end{array}$ & $\begin{array}{c}\mathrm{U}(\mathrm{WE}) \\
\mu \mathrm{g} / \mathrm{g}\end{array}$ & $\begin{array}{c}\mathrm{Cr}(\mathrm{WE}) \\
(\mu \mathrm{g} / \mathrm{g})\end{array}$ \\
\hline 80 & 11.2 & 8.11 & 0.36 & 1.60 & $<1.01$ & 15.5 & $<0.114$ & 0.349 & $<3.10 \mathrm{E}-04$ & $<2.07 \mathrm{E}-03$ \\
\hline 100 & 12 & 15.9 & 0.32 & 3.76 & $<0.99$ & 48.0 & $<0.128$ & 0.336 & $<5.22 \mathrm{E}-04$ & $<2.04 \mathrm{E}-03$ \\
\hline 123 & 21.3 & 21.5 & $<2.00$ & $<10$ & $<10$ & 55.5 & $<0.123$ & 0.417 & $3.02 \mathrm{E}-03$ & $<2.06 \mathrm{E}-03$ \\
\hline 125 & 16.4 & 8.96 & 0.34 & 2.75 & $<0.988$ & 17.1 & $<0.146$ & 0.433 & $2.51 \mathrm{E}-03$ & $<2.03 \mathrm{E}-03$ \\
\hline 163 & 8.94 & 8.32 & 0.23 & 3.92 & $<0.998$ & 16.7 & $<0.106$ & 0.328 & $<3.50 \mathrm{E}-04$ & $<2.05 \mathrm{E}-03$ \\
\hline 190 & 13.7 & 10.6 & 0.34 & 4.33 & $<1$ & 23.2 & $<0.158$ & 0.452 & $1.55 \mathrm{E}-03$ & $<2.06 \mathrm{E}-03$ \\
\hline 215 & 9.17 & 10 & 0.27 & 6.32 & $<1$ & 21.3 & $<0.164$ & 0.239 & $1.38 \mathrm{E}-03$ & $<6.42 \mathrm{E}-03$ \\
\hline 218 & 25.9 & 37.5 & 0.41 & 18.6 & $<1$ & 99.2 & $<0.147$ & 0.699 & $1.16 \mathrm{E}-02$ & $<2.06 \mathrm{E}-03$ \\
\hline 225 & 28 & 30.8 & 0.43 & 26.6 & $<1$ & 102 & $<0.280$ & 4.01 & $1.75 \mathrm{E}-01$ & $<2.06 \mathrm{E}-03$ \\
\hline 230 & 100 & 72 & $<2.00$ & 283 & $<9.99$ & 187 & 23.7 & 82.1 & 19.6 & $<2.05 \mathrm{E}-03$ \\
\hline 233 & 133 & 91.6 & $<2.00$ & 348 & 10.0 & 253 & 6.3 & 87.3 & 32.9 & $<2.04 \mathrm{E}-03$ \\
\hline 235 & 146 & 162 & $<20.0$ & 458 & 49.3 & 363 & 37.2 & 228 & 94.6 & $<2.06 \mathrm{E}-03$ \\
\hline 238 & 86.2 & 160 & $<2.00$ & 600 & $<10$ & 401 & 60.1 & 103 & 39.5 & $<2.06 \mathrm{E}-03$ \\
\hline \multicolumn{6}{|c|}{ water table $251.75 \mathrm{ft}$ bgs } & \multicolumn{4}{|c|}{ water table $251.75 \mathrm{ft}$ bgs } & \\
\hline 253 & 10.7 & 9.57 & $<2.00$ & $<10$ & $<10$ & 17.77 & $<0.231$ & 1.55 & $1.90 \mathrm{E}-02$ & $<2.09 \mathrm{E}-03$ \\
\hline
\end{tabular}




\subsubsection{U Isotope Signature Measurements for New Boreholes 299-E33-205 and 299-E33-343}

The final information that is available to interpret the vadose zone sediment distribution of contaminants below and proximal to the B-7-A crib is the precise uranium isotopic ratio measurements on vadose zone sediment water extracts and the direct measurement of the perched water sample. Appendix E lists all the available uranium isotopic ratio data collected, identifies which samples represent the various waste sources and which samples were used to create the clean end members for vadose zone pore waters and groundwater.

Figure 3.58 is a plot of the uranium isotopic ratios for pore water and groundwater samples from borehole 299-E33-205 located between the BX and BY tank farms. Uranium isotopic data for three pore waters from the $\mathrm{CCU}_{\mathrm{z}}$ strata and two groundwater samples were characterized. Groundwater samples are discussed in Section 5. Two of the vadose zone pore waters in the $\mathrm{CCU}_{\mathrm{z}}$ unit from borehole 299-E33-205 plot near a mixing line between BX-102 source signature and uncontaminated Cold Creek Unit pore waters. The third pore water from near the top of the $\mathrm{CCU}_{z}$ unit is essentially uncontaminated and plots between the uranium signatures for uncontaminated $\mathrm{H} 2$ and $\mathrm{CCU}_{\mathrm{z}}$ (see green and blue hash marks along bottom axis). This suggests the pore water is a mix of both strata's pore waters, likely pore water from the $\mathrm{H} 2$ unit that has descended into the $\mathrm{CCU}_{z}$ unit and not fully re-equilibrated. All the other vadose zone 299-E33-205 pore-water samples from shallower in the H2 unit, did not contain elevated concentrations of uranium or any other constituents suggesting that there was no contamination shallower than that found in the $\mathrm{CCU}_{z}$ unit. In summary, the vadose zone pore waters, which contain less than one-tenth the total uranium concentration found in this borehole's groundwater, appears to be a mixture of a very small amount of BX-102 waste fluids and uncontaminated vadose zone pore water.

Figure 3.59 shows the data for pore water and groundwater from well 299-E33-343. This well was drilled (see Figure 2.1) in between existing wells (299-E33-41 and 299-E33-18) that spectral gamma logging has shown contain vadose zone Hanford processed uranium. Appendix $\mathrm{H}$ shows details on the sample HEIS identification numbers, depths and total pore water uranium concentrations. There were six pore water samples (one from deep in the $\mathrm{H} 2$ unit and 5 from the Cold Creek unit) from between 190 and $253 \mathrm{ft}$ bgs and two groundwater samples that had uranium isotopic ratios determined. Groundwater samples are discussed in Section 5. Three of the pore waters from the Cold Creek unit with total uranium concentrations ranging from 323 to $435,000 \mu \mathrm{g} / \mathrm{L}$ plot in the upper left hand corner of the figure amongst the BX-102 source data (see insert). The shallowest pore water within the $\mathrm{CCU}_{\mathrm{z}}$ from $218 \mathrm{ft}$ bgs with only $41 \mu \mathrm{g} / \mathrm{L}$ total uranium and the pore water from the $\mathrm{H} 2$ unit (from $190 \mathrm{ft} \mathrm{bgs}$ ) with a total uranium concentration of $26 \mu \mathrm{g} / \mathrm{L}$ both plot along the mixing line between BX-102 source signature and uncontaminated $\mathrm{H} 2$ pore water.

Based on the water extracts of 299-E33-343 sediments in the deep H2 unit, it is concluded that there was no waste shallower than the contact with the $\mathrm{CCU}_{\mathrm{z}}$ unit, but the ultra-sensitive and precise uranium isotopic analyses confirm very low proportions of waste are present as shallow as $190 \mathrm{ft}$ bgs. Thus, the ultra-sensitive and precise uranium isotopic analyses confirm very low proportions of BX-102 waste in the deep $\mathrm{H} 2$ unit whereas water extract total uranium concentrations from these same samples were not elevated to the point that there would no debate that Hanford wastes were present. 
PNNL-19277

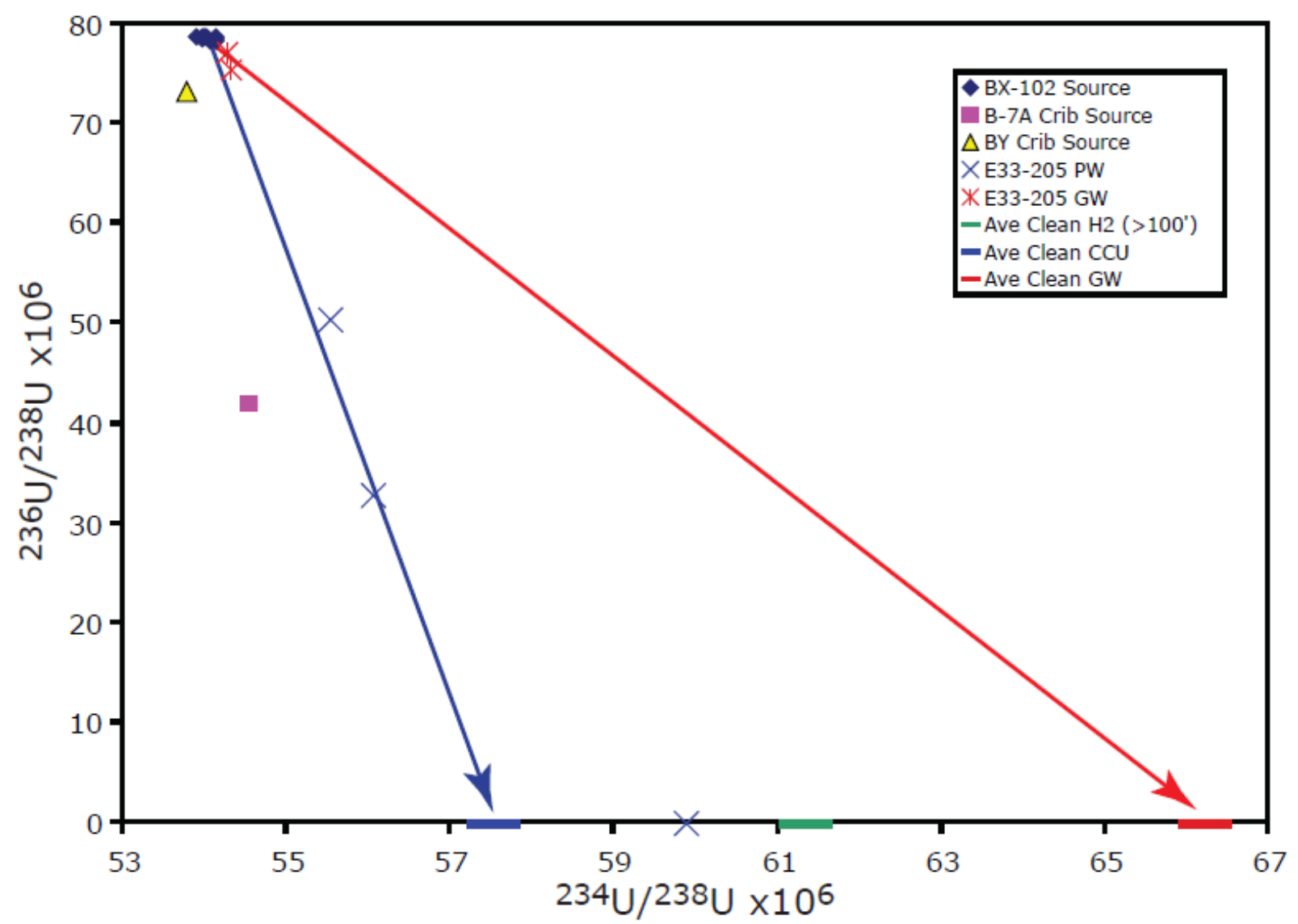

Figure 3.58. Uranium Isotopic Signature Data for Samples from Borehole 299-E33-205

Based on the U-236 content, the pore water at this depth is estimated to contain a uranium signature with $33 \% \mathrm{BX}-102$ waste and $67 \%$ uncontaminated $\mathrm{H} 2$ pore water. The pore water sample at the top of the $\mathrm{CCU}_{\mathrm{z}}$ unit, $218 \mathrm{ft}$ bgs, is estimated to have a uranium signature of $84 \% \mathrm{BX}-102$ waste with $16 \%$ uncontaminated pore water. The uncontaminated pore water resembles more so $\mathrm{H} 2$ than $\mathrm{CCU}_{\mathrm{z}}$ uncontaminated pore water. The other pore waters from deeper in the $\mathrm{CCU}_{\mathrm{z}}$ and $\mathrm{CCU}_{\mathrm{g}}$ units have much higher total uranium concentrations and have an estimated uranium signature that is 96 to $99 \% \mathrm{BX}-102$ source. Therefore, the Cold Creek unit sediments from this borehole have been interpreted to contain uranium from BX-102 fluids that have travelled horizontally mostly through the bottom $\sim 10 \mathrm{ft}$ of the $\mathrm{CCU}_{\mathrm{z}}$ strata. Further, at this location high concentrations of mobile uranium are found in the underlying $\mathrm{CCU}_{\mathrm{g}}$ strata in which the water table is found. Uranium from the BX-102 source appears to reach the groundwater very near the location of this borehole. 
PNNL-19277

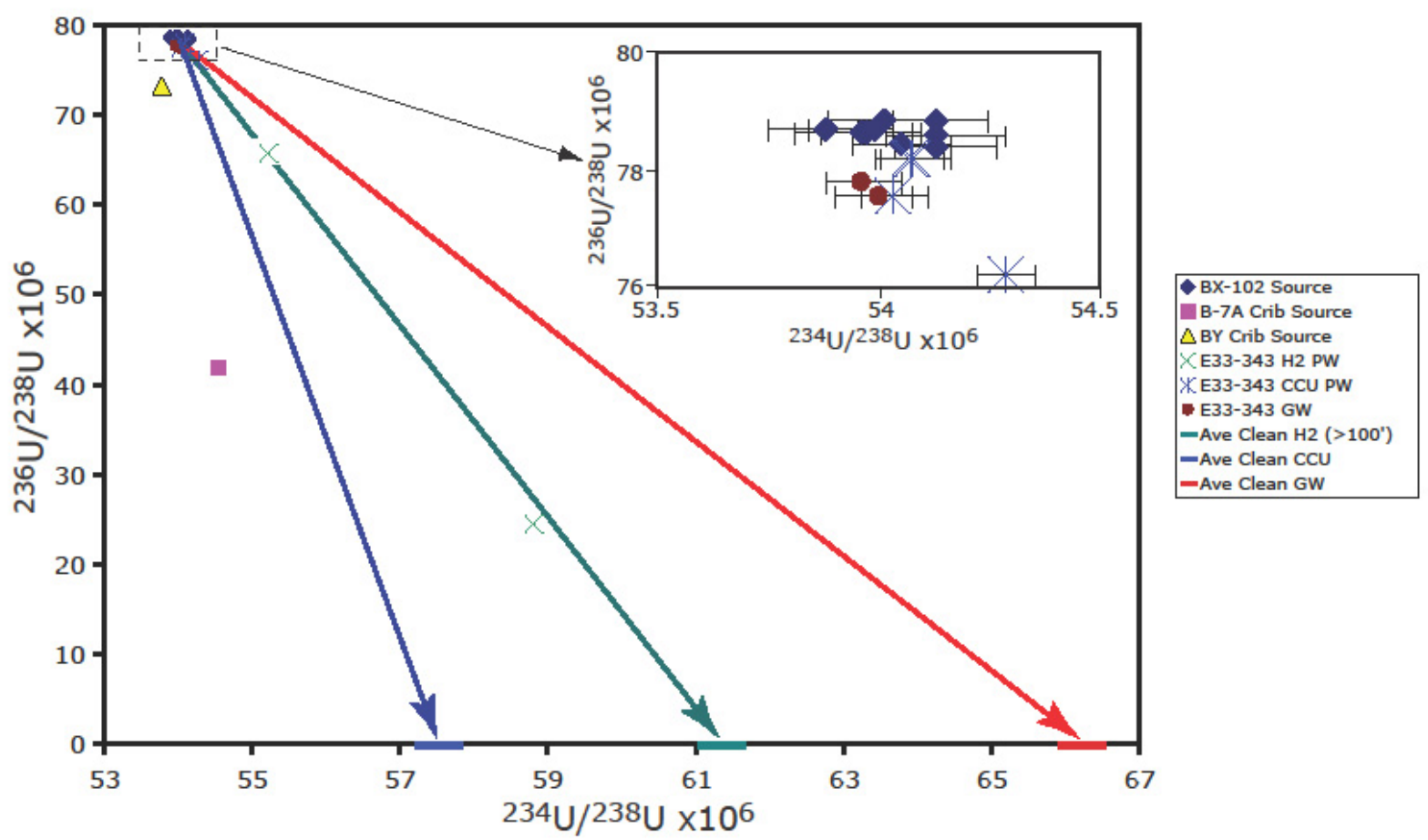

Figure 3.59. Uranium Isotopic Signature Results for Pore Waters and Groundwater from 299-E33-343 To illustrate the high precision in these measurements, the \pm 2 sigma uncertainty bars for both ratios (uranium-236/238 and uranium-234/238) are shown in the expanded figure. The uncertainty bars for the ratio uranium-236/238 are so small that for most data, the bars are no larger than the symbol itself.

It has been concluded that the source of the uranium in the vadose zone at borehole 299-E33-343 is BX-102 waste fluid. The two pore waters with lower uranium-236 and total uranium contents are found at the top of the $\mathrm{CCU}_{\mathrm{z}}$ fine-grained strata and appear to a mixture of BX-102 fluids and uncontaminated vadose zone pore water. The pore fluids in the lower portion of the $\mathrm{CCU}_{z}$ layer contain much higher total uranium concentrations $\left(>10^{+05} \mu \mathrm{g} / \mathrm{L}\right.$ ) with uranium isotope signatures nearly identical to the $\mathrm{BX}-102$ source. It is also concluded that highly uranium contaminated fluids from the $\mathrm{CCU}_{\mathrm{z}}$ strata are descending through the $\mathrm{CCU}_{\mathrm{g}}$ gravel to the water table nearer to 299-E33-343 than any other location where uranium isotopic measurements are available.

The cumulative data (sediment analyses from 299-E33-45, E33-205, E33-343, E33-344, and E33-345 and shallow direct pushes, spectral gamma logs from the same boreholes as well as 299-E33-41 and E33-18 as well as historical gross gamma logs of boreholes shown in Figure 3.49 top panel and Figure 3.50 presented in this section provide the framework to create a robust vadose zone model of the uranium contaminant migration associated with the Tank BX-102 release. It is concluded that Hanford processed uranium from the BX-102 overfill event in 1951 has migrated to the northeast following the stratigraphic dip in the Hanford formation and ultimately into the $\mathrm{CCU}_{\mathrm{z}}$ unit. In addition, it is clear that somewhere near borehole 299-E33-343 the waste enters the groundwater. Horizontal spreading is particularly evident along the thin H2F2 layer, which is found $\sim 120$ to $125 \mathrm{ft} \mathrm{bgs}$ throughout most of the region. The bulk of the waste fluid has descended out of the $\mathrm{H} 2$ unit into the $\mathrm{CCU}_{\mathrm{z}}$ unit by the time it reaches boreholes 299-E33-41 and -E33-343, where it migrates in an easterly direction reaching at least the three boreholes 299-E33-18, E33-344, and E33-345. 
Repeated spectral gamma logging has confirmed since 1991 that boreholes 299-E33-41 and 299-E3318 contain Hanford processed uranium in the $\mathrm{CCU}_{\mathrm{z}}$ unit. In addition, the 2002 logging at E33-41 quantifies that detectable Hanford processed uranium in the $\mathrm{H} 2$ unit occurs as shallow as $123 \mathrm{ft}$ bgs in the thin fine-grained H2F2 layer. The uranium was present at borehole E33-41 in the Hanford formation at the time of drilling (1991) but access to the detailed data to discuss concentrations was only available for 2002 (Figure 3.51). Also as shown in Figure 3.49 top panel, historical gamma logging observed Hanford processed uranium was present in 1971 at least as deep as $137.5 \mathrm{ft}$ bgs in the Hanford formation in an area to the northeast of BX-102 (Womack and Larkin 1971). Most of these boreholes were installed in 1971 and the uranium was already present. The uranium appears to have reached the location of well E33-18 between 1992 and 1997 (see Table 3.17).

There is a small amount of the BX-102 waste fluids in the vadose zone (deep $\mathrm{H} 2$ and $\mathrm{CCU}_{Z}$ units as far north and a bit to the west at the new borehole 299-E33-205. Strong support for significant lateral spreading is evidenced at borehole $299-E 33-45$, located $\sim 70 \mathrm{ft}$ to the east of the tank BX-102. However, only a small amount of the BX-102 waste fluid was present in the $\mathrm{CCU}_{\mathrm{z}}$ unit at borehole 299-E33-45 in 2001. The vast majority of the waste fluid was in the shallower $\mathrm{H} 2$ unit especially in and on top of the thin fine-grained H2F2 layer. Figure 3.60 and Figure 3.61 show cross-sections for the total or acidextractable uranium and water extractable uranium, respectively.

The technetium-99 in the BX-102 waste fluids likely follows the same migration path as the uranium however the distribution of technetium-99 is much less clearly defined because the data set does not benefit from the spectral gamma and historical gross gamma field logs. Figure 3.62 shows a cross section using available vadose zone depth discrete sediment data assuming that technetium-99 migrated along the same pathway as shown for the uranium. Further, based solely on the direct measurements of technetium99 in boreholes E33-45, E33-205, E33-343, E33-344, and E33-345, the technetium-99 may have descended into the $\mathrm{CCU}_{z}$ unit closer to tank BX-102 than the uranium.

It is also possible that some of the observed technetium-99 present in the $\mathrm{CCU}_{Z}$ unit is from other sources. In comparison, the technetium-99 inventory for wastes discharged to B-7-A\&B and B-8 Cribs is approximately 25 times less than the inventory associated with BX-102 thus it is assumed that these waste cribs have not contribute appreciable technetium-99 into the $\mathrm{CCU}_{z}$ unit. However, the presence of elevated fluoride and slightly elevated chromium in the vadose zone pore waters at boreholes E33-344, and E33-345 indicate waste fluids from B-7-A\&B and/or B-8 Cribs are present in the $\mathrm{CCU}_{\mathrm{z}}$ unit at this location. The other sources may be from the B or BY Tank Farms but without direct sediment measurements this possibility cannot be assessed. 
PNNL-19277

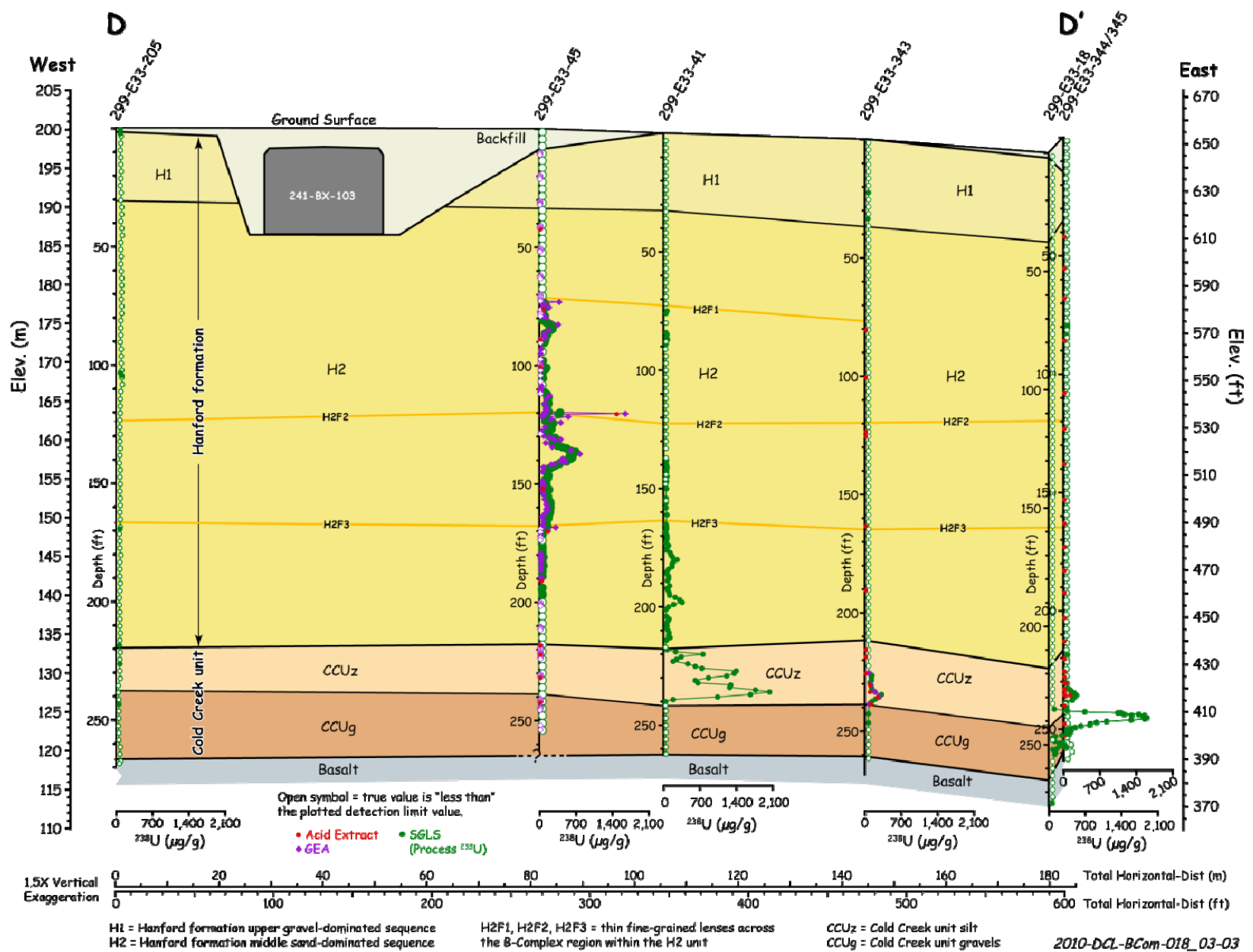

Figure 3.60. Cross Section of Boreholes That Contain Elevated Hanford Processed Uranium (total or acid extractable) 
PNNL-19277

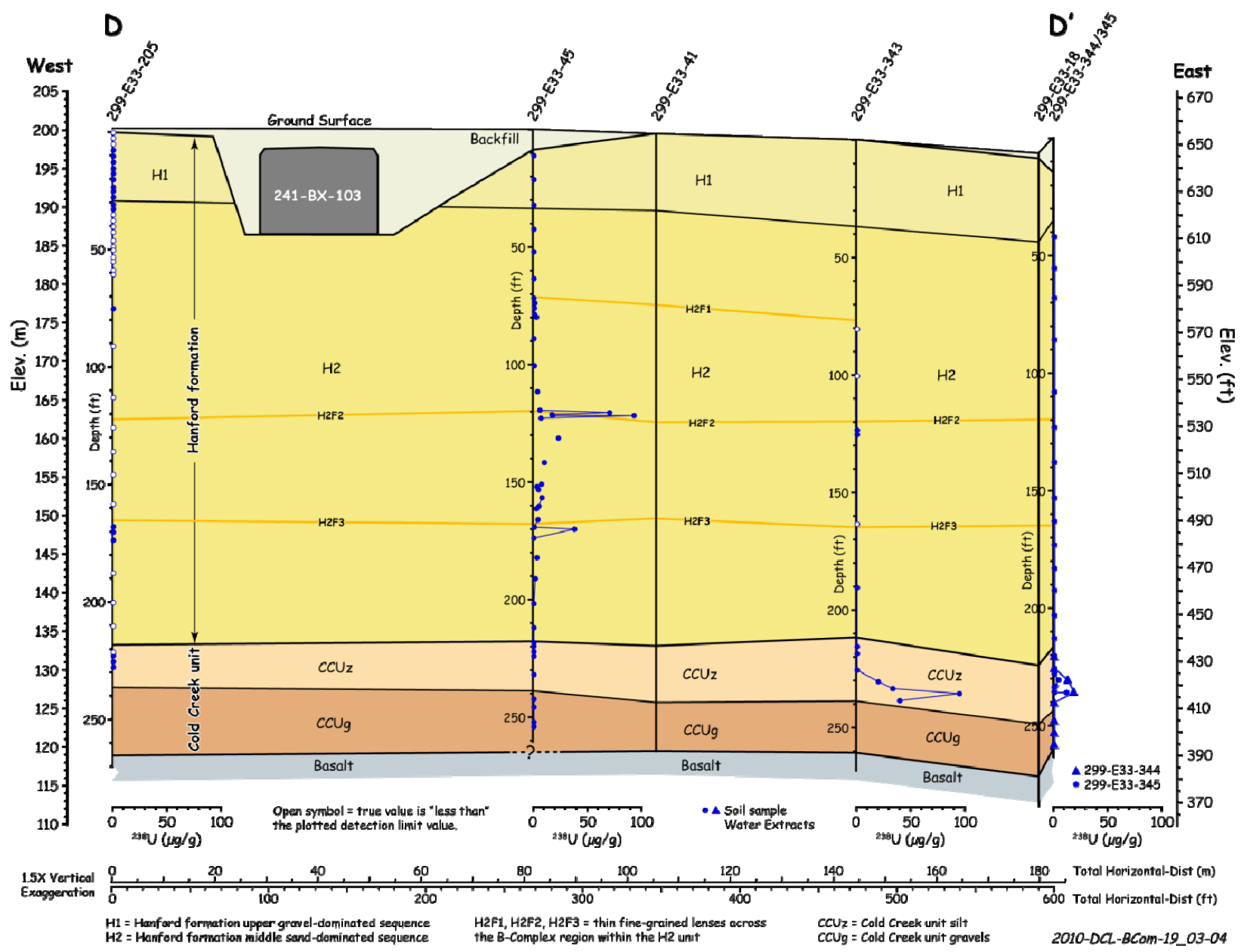

Figure 3.61. Cross Section of Boreholes That Contain Elevated Hanford Processed Uranium (water extractable or "mobile") 


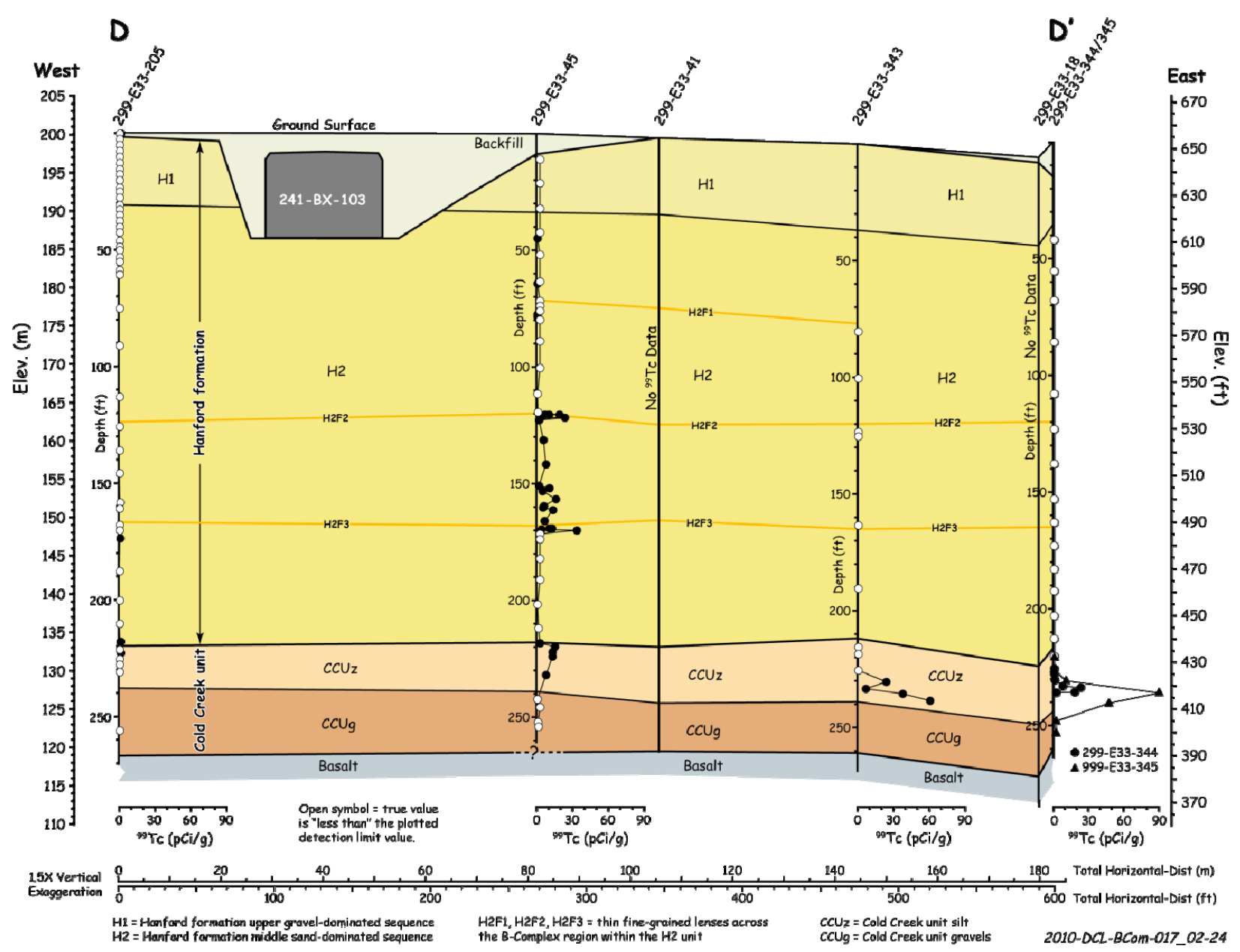

Figure 3.62. Cross Section Showing Distribution of Technetium-99 in Boreholes Associated with the Hanford Processed Uranium Plume

\subsubsection{Vadose Zone Mass Inventory from the BX-102 Overfill Event}

To estimate the masses of technetium-99 and uranium northeast of BX-102, the region east and northeast of tank BX-102 was broken into three areas (delineated by the areas outlined in green, black, and orange) noted in Figure 3.63. The green (cone-shaped region) represents the area formed by connecting the area of known vadose sediment uranium contamination in the Hanford formation (as shown in Figure 3.49 top panel) with boreholes 299-E33-41 (known to include traces of Hanford processed uranium in the deep H2 unit) to the northeast and to 299-E33-343 on the northwest (where little Hanford processed uranium is present in the Hanford formation). This "near-field" region of contamination has been extended to these two wells so that there is a connection between the region of Hanford formation contamination to the region in the $\mathrm{CCU}_{z}$ stratum with known uranium contamination. Based on ArcGIS ${ }^{\circledR}$ (ESRI, Redlands, California) calculations, the area within the green shape is $\sim 1464$ $\mathrm{m}^{2}$. It has been assumed that the sediment vertical distribution of technetium-99 and uranium in this "near BX-102" region has the concentrations found at borehole 299-E33-45. The second region used, shown as the black triangle on Figure 3.63, represents the region of the Cold Creek formation sediments where very high 


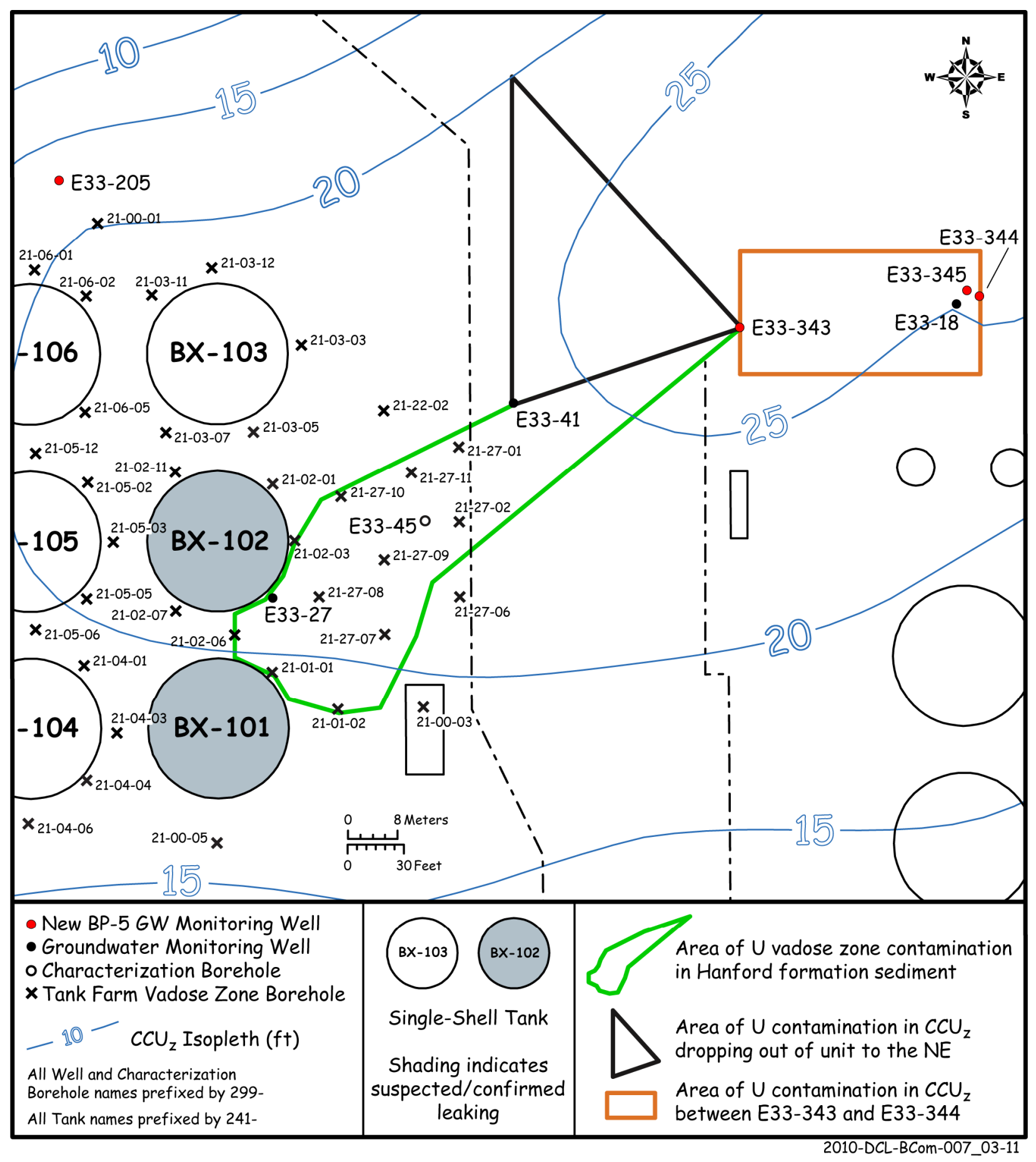

Figure 3.63. Close Up Map for the Near Tank BX-102 Region

contamination was found in the $\mathrm{CCU}_{z}$ sediments and groundwater. It has been assumed that the entire triangular region has the same contaminant vertical contaminant concentration profile as found in the $\mathrm{CCU}_{\mathrm{z}}$ unit at borehole 299-E33-343 and that the unit has a constant thickness of $21 \mathrm{ft}$. Using the coordinates for well 299-E33-41, 299-E33-343 and this point on the 20-ft thick isopach., the calculated area 
of the black triangle is $993 \mathrm{~m}^{2}$. As mentioned, it is hypothesized that waste liquids at this location are leaking through the $\mathrm{CCU}_{z}$ silt into the underlying $\mathrm{CCU}_{\mathrm{g}}$ and entering the groundwater somewhere in this region. For illustration only, the entry point where the waste fluids drop into the water table has been chosen to the north-northwest of borehole 299-E33-343 at a point on the 20-ft isopach for the $\mathrm{CCU}_{\mathrm{z}}$ (see Figure 3.63).

The third region for which mass balance calculations have been developed is the orange colored rectangle in Figure 3.63 that connects borehole 299-E33-343 with the three closely placed boreholes 299E33-18, E33-344, and E33-345. A rectangular shape with a width arbitrarily set at $20 \mathrm{~m}$ was chosen to represent this region. This area calculates to be $778 \mathrm{~m}^{2}$. The thickness of the $\mathrm{CCU}_{\mathrm{z}}$ within the orange rectangle was set at $21 \mathrm{ft}$. The concentrations of contaminants at the two new closely spaced boreholes (299-E33-344,-345) are quite variable as a function of depth within the $\mathrm{CCU}_{z}$ unit so two end member uranium concentrations were chosen to represent the entire volume, thus two calculations labeled " $\mathrm{CCU}_{z^{-}}$

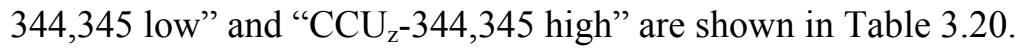

Table 3.20 shows the pertinent details for concentrations and calculated masses for each of the regions and conceptual models. It is acknowledged that the shapes and especially the choice of the outer edges and the vertical concentration profiles are somewhat arbitrary and thus the calculated masses are subject to unspecified uncertainty. Figure 3.60 through Figure 3.62 are provided to help clarify the conceptual models used to estimate the residual masses of uranium and technetium-99 in the vadose zone below and proximal to the BX-102 tank.

These vadose zone mass estimates suggest that a significant portion of the total mass of technetium-99 and uranium released from the entire BX Tank Farm (for the uranium completely dominated by the BX-102 overfill event) could still reside in the vadose zone. Table 3.20 shows that the green "near tank" area might contain, within solely the Hanford formation, $41 \%$ of the estimated mass of uranium released from BX-102. Further, only two of the near tank boreholes (299-E33-27 [also known as 21-02-04] and 299-E33-45 penetrated below $150 \mathrm{ft}$. At 299-E33-27, identification of Hanford processed uranium is complicated by high cesium-137 gamma activity making it difficult to measure uranium. At 299-E33-45, the bulk of the uranium was found above $150 \mathrm{ft}$ bgs but there is some measurable Hanford processed uranium as deep as the $\mathrm{CCU}_{\mathrm{z}}$ unit at $\sim 220 \mathrm{ft}$ bgs. At this time there is no way to be certain that nearer to tank BX-102 significant quantities of uranium have not descended deeper than the Hanford formation. The conceptual model and the available SGLS logs for 299-E33-41 and 299-E33-18 and sediment samples from 299-E33-343, 299-E33-344 and -345 show that up to an additional $20 \%$ of the uranium released from BX-102 currently could reside in the $\mathrm{CCU}_{\mathrm{z}}$. These new boreholes are relatively far from the original estimate of the extent to which the BX-102 vadose zone plume reached (shown in Figure 3.49 top panel) by Knepp (2002) based on historical gross gamma logs. The new boreholes are down dip of tank BX-102 based on the stratigraphy model such that there could be continued horizontal spreading along with further vertical descent of the waste fluids. The uranium isotopic signature measurements (discussed in Section 3.4.3) also strongly support the hypothesis that most of the uranium found in the $\mathrm{CCU}_{z}$ unit migrated to the northeast of $\mathrm{BX}-102$ overfill 
Table 3.20. Inventory Calculations for 3 Hypothetical Regions Hypothesized to Contain BX-102 Waste Fluids

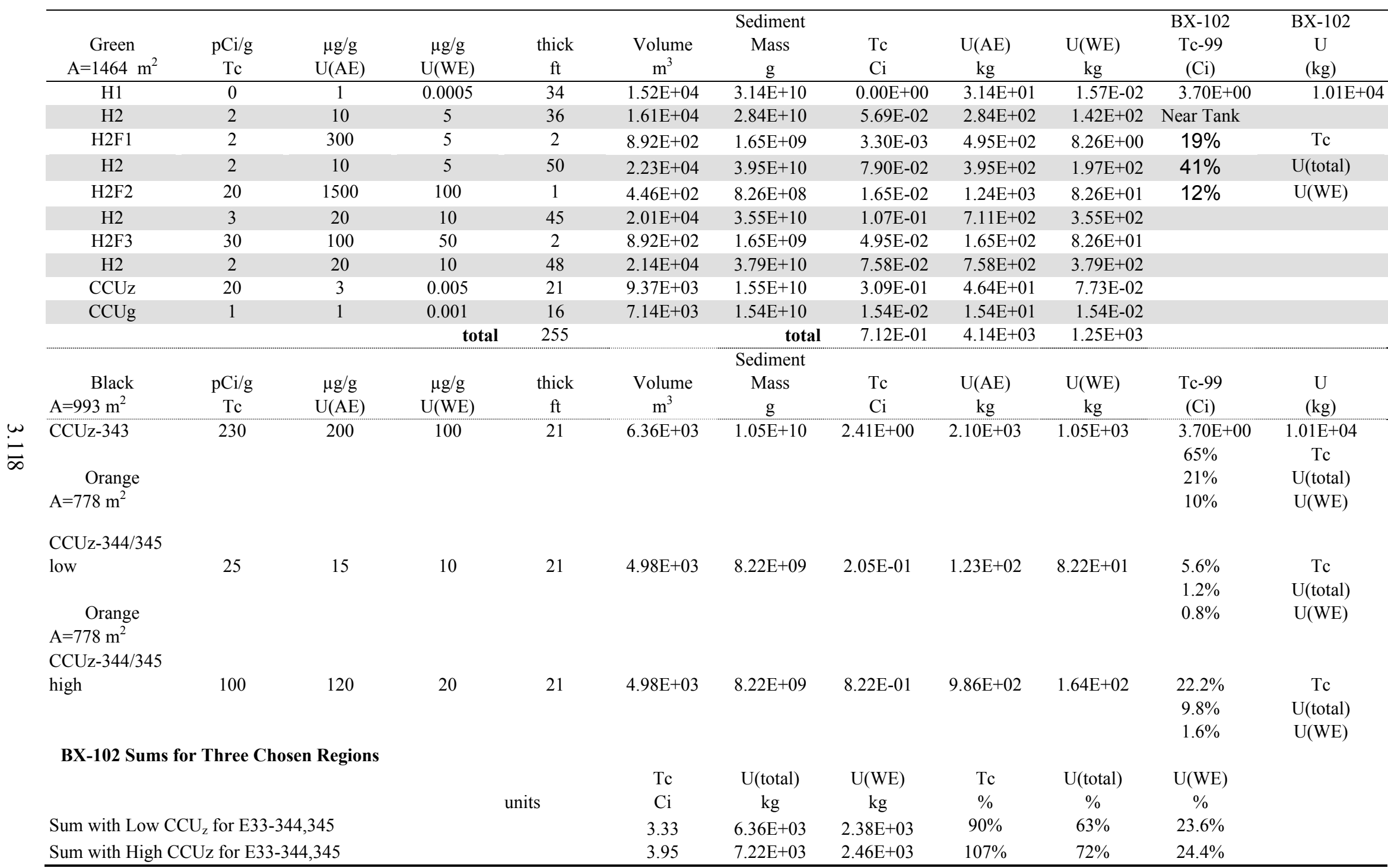


event. The total calculated mass of uranium (6360 to $7220 \mathrm{~kg}$ ) still residing in the vadose zone within the three regions delineated in Figure 3.63 represents between 63 and $72 \%$ of the total uranium released from the BX tank farm. However as shown in Table 3.20, only about 2380 to $2460 \mathrm{~kg}(\sim 24 \%$ of the total released to the vadose zone from the BX-102 overfill event) of uranium is readily extracted by water. Other details shown in Appendix H lead to an estimate that between 1520 and $1600 \mathrm{~kg}$ of waterextractable uranium remain in deep vadose zone (within $\sim 90 \mathrm{ft}$ of the water table).

The mass calculations suggest that the "green" region near the BX-102 tank may still retain $\sim 20 \%$ of the technetium-99 released during the 1951 overfill event resulting in the bulk of the released technetium99 being farther away in the $\mathrm{CCU}_{z}$ unit in the black and orange regions shown in Figure 3.63. The proportion of technetium-99 from the BX-102 tank overfill event reaching the $\mathrm{CCU}_{\mathrm{z}}$ strata in the "near tank" region (based on assuming the vertical distribution found at borehole E33-45 represents the vertical distribution throughout the region delineated by the green shape) is larger than the proportion of waterextractable uranium found in the "green region" $\mathrm{CCU}_{\mathrm{z}}$ sediments $(8 \% \mathrm{vs} .0 .5 \%)$ as one might expect based on the lack of adsorption of technetium. Farther to the northeast, based on these same assumptions, the technetium-99 mass calculated to be in the $\mathrm{CCU}_{\mathrm{z}}$ unit (sum for the black and orange regions shown in Figure 3.63 is between 71 and $87 \%$ of the technetium- 99 released from Tank BX-102. When the technetium-99 that is still present in the vadose zone within all three regions is summed, one can account for between 90 and $107 \%$ of the total technetium-99 released from Tank BX-102. These region calculations ignore the fact that some of the technetium-99 found in the $\mathrm{CCU}_{z}$ unit to the northeast of BX102 tank could be from another technetium-99 source. The presence of technetium-99 from another source is supported by the fact that the concentrations of technetium-99 found in the $\mathrm{CCU}_{\mathrm{z}}$ sediments at 299-E33-343, E33-344, and E33-345 are larger than the technetium-99 concentrations in the $\mathrm{CCU}_{z}$ sediments at 299-E33-45, which is much closer to the BX-102 Tank contrary to the generally observed trend where plumes dilute with distance from a source.

In conclusion, it has been calculated that about $70 \%$ (up to $\sim 7200 \mathrm{~kg}$ ) of the estimated 10 metric tons of uranium released from the 1951 overfill event at Tank BX-102 still resides in the vadose zone, and between 2220 and $3100 \mathrm{~kg}$ of the $7200 \mathrm{~kg}$ is found in the wet silts in the CCUz unit far to the northeast of the BX Tank Farm. Based on water extract and direct measurement of vadose zone pore waters, it is estimated that $2400 \mathrm{~kg}$ of the $7200 \mathrm{~kg}$ of uranium is in a mobile state with the majority of the mobile mass $(\sim 1520$ to $\sim 1600 \mathrm{~kg})$ within $90 \mathrm{ft}$ of the water table. Of the $2400 \mathrm{~kg}$ considered readily mobile $\sim 1050 \mathrm{~kg}$ is in the $\mathrm{CCU}_{\mathrm{z}}$ unit in close proximity to borehole 299-E33-343 where the groundwater concentrations of uranium have surpassed $5550 \mu \mathrm{g} / \mathrm{L}$ in mid-calendar year 2009. These calculated masses of uranium in the vadose zone dwarf the calculations of the mass of uranium in the current groundwater plume as will be discussed in Section 5.

\subsubsection{BY Tank Farm Description and Inventory Released}

Table 3.21 lists the release status of the twelve BY tanks. Of the three tank farms, BY is estimated to have released the least volume of liquids, $1.56 \times 10^{+05} \mathrm{~L}$. BY tanks that are suspected to have released fluids, based on Hanlon (2006) interpretations, in order of the volumes released to the subsurface, are BY107, -BY-105, -BY-106, -BY-103 and -BY-108. Field and Jones (2006) indicate that there is no technical basis for a leak inventory for tanks BY-105 and -BY-106. The values in Table 3.21 in blue and red type 
Table 3.21. BY Tank Integrity Status, Volumes Released and Masses Released

\begin{tabular}{|c|c|c|c|c|c|c|}
\hline Tank & Group & Date of & $\begin{array}{l}\text { Dimensions } \\
(\mathrm{ft})\end{array}$ & $\begin{array}{l}\text { Major } \\
\text { Waste }\end{array}$ & $\begin{array}{l}\text { Volume } \\
\text { Released } \\
\text { (ML) }\end{array}$ & \\
\hline & & Release & $\begin{array}{c}\text { Dia } \times \mathrm{Ht} \times \\
\text { Bottom }(\mathrm{ft} \\
\text { bgs })\end{array}$ & \multicolumn{2}{|c|}{ Type (for Leakers) } & Comments \\
\hline BY-101 & I & & $\begin{array}{c}75 \times 38 \times \\
45\end{array}$ & & & \\
\hline BY-102 & I & & $\begin{array}{l}75 \times 38 \times \\
45\end{array}$ & & & \\
\hline BY-103 & $\mathrm{R}$ & 1973 & $\begin{array}{l}75 \times 38 \times \\
45\end{array}$ & $\begin{array}{l}\text { BYSLT } \\
\text { (BT2) }\end{array}$ & $1.89 \mathrm{E}-02$ & $\begin{array}{l}\text { UPR-200-E-133; Field and Jones claim leak estimate in Hanlon \& WIDS too high; more realistic } \\
\text { TBD; WIDS says UPR is E-134 }\end{array}$ \\
\hline BY-104 & I & & $\begin{array}{l}75 \times 38 \times \\
45\end{array}$ & & & \\
\hline BY-105 & $\mathrm{R}$ & 1984 & $\begin{array}{l}75 \times 38 \times \\
45\end{array}$ & NA & 3.03E-02 & Hanlon \& WIDS estimate; in 197763 tons of cement put in tank \\
\hline BY-106 & $\mathrm{R}$ & 1972 & $\begin{array}{c}75 \times 38 \times \\
45\end{array}$ & NA & 3.03E-02 & Hanlon \& WIDS estimate; WIDS suggests dry well gamma drove leak designation \\
\hline BY-107 & $\mathrm{R}$ & 1974 & $\begin{array}{l}75 \times 38 \times \\
45\end{array}$ & $\begin{array}{l}\text { BYSLT } \\
\text { (BT2) }\end{array}$ & $5.72 \mathrm{E}-02$ & $\begin{array}{l}\text { Field and Jones claim leak estimate in Hanlon \& WIDS too high; more realistic value TBD; } \\
\text { WIDS says leak assigned UPR-200-E-135 }\end{array}$ \\
\hline BY-108 & $\mathrm{R}$ & 1972 & $\begin{array}{l}75 \times 38 \times \\
45\end{array}$ & $\begin{array}{l}\text { BYSLT } \\
\text { (BT2) }\end{array}$ & $1.89 \mathrm{E}-02$ & Field and Jones claim leak estimate in Hanlon \& WIDS too high; more realistic value TBD \\
\hline BY-109 & I & & $\begin{array}{l}75 \times 38 \times \\
45\end{array}$ & & & \\
\hline BY-110 & I & & $\begin{array}{l}75 \times 38 \times \\
45\end{array}$ & & & \\
\hline BY-111 & I & & $\begin{array}{l}75 \times 38 \times \\
45\end{array}$ & & & \\
\hline BY-112 & I & & $\begin{array}{l}75 \times 38 \times \\
45\end{array}$ & & & \\
\hline
\end{tabular}


Table 3.21 (contd)

\begin{tabular}{|c|c|c|c|c|c|c|c|c|c|c|c|c|c|c|c|c|}
\hline \multirow[b]{2}{*}{ Facility } & \multirow[b]{2}{*}{ Date } & \multirow[b]{2}{*}{$\mathrm{Na}$} & \multirow[b]{2}{*}{$\mathrm{Ca}$} & \multirow[b]{2}{*}{$\mathrm{NO}_{3}$} & \multicolumn{3}{|c|}{ Inventory (kg) } & \multirow[b]{2}{*}{$\mathrm{PO}_{4}$} & \multirow[b]{2}{*}{$\mathrm{F}$} & \multirow[b]{2}{*}{$\mathrm{Fe}(\mathrm{CN})_{6}$} & \multirow[b]{2}{*}{$\mathrm{U}$} & \multirow[b]{2}{*}{$\mathrm{Cr}$} & \multicolumn{4}{|c|}{ Inventory $\mathrm{Ci}$} \\
\hline & & & & & $\mathrm{NO}_{2}$ & $\mathrm{SO}_{4}$ & $\mathrm{CO}_{3}$ & & & & & & Co- 60 & $\mathrm{I}-129$ & Tc-99 & $\mathrm{H}-3$ \\
\hline \multicolumn{17}{|c|}{ BY Tank Farm } \\
\hline$\overline{B Y}-103$ & 1973 & $3.87 \mathrm{E}+02$ & $2.27 \mathrm{E}-01$ & $3.27 \mathrm{E}+02$ & $1.77 \mathrm{E}+02$ & $1.80 \mathrm{E}+01$ & $4.78 \mathrm{E}+01$ & $8.96 \mathrm{E}+00$ & $3.07 \mathrm{E}+00$ & 0 & $4.70 \mathrm{E}-02$ & $4.36 \mathrm{E}+00$ & $3.63 \mathrm{E}-02$ & $4.24 \mathrm{E}-04$ & $2.99 \mathrm{E}-01$ & $1.17 \mathrm{E}-01$ \\
\hline BY-105 & 1984 & NA & NA & NA & NA & NA & NA & NA & NA & NA & NA & NA & NA & NA & NA & NA \\
\hline BY-106 & 1972 & NA & NA & NA & NA & NA & NA & NA & NA & NA & NA & NA & NA & NA & NA & NA \\
\hline BY-107 & 1974 & $1.16 \mathrm{E}+03$ & $6.81 \mathrm{E}-01$ & $9.80 \mathrm{E}+02$ & $5.32 \mathrm{E}+02$ & $5.41 \mathrm{E}+01$ & $1.43 \mathrm{E}+02$ & $2.69 \mathrm{E}+01$ & $9.22 \mathrm{E}+00$ & 0 & $1.41 \mathrm{E}-01$ & $1.31 \mathrm{E}+01$ & $1.09 \mathrm{E}-01$ & $1.27 \mathrm{E}-03$ & $8.98 \mathrm{E}-01$ & $3.51 \mathrm{E}-01$ \\
\hline \multirow[t]{2}{*}{ BY-108 } & 1972 & $3.87 \mathrm{E}+02$ & $2.27 \mathrm{E}-01$ & $3.27 \mathrm{E}+02$ & $1.77 \mathrm{E}+02$ & $1.80 \mathrm{E}+01$ & $4.78 \mathrm{E}+01$ & $8.96 \mathrm{E}+00$ & $3.07 \mathrm{E}+00$ & 0 & $4.70 \mathrm{E}-02$ & $4.36 \mathrm{E}+00$ & $3.63 \mathrm{E}-02$ & 4.24E-04 & $2.99 \mathrm{E}-01$ & $1.17 \mathrm{E}-01$ \\
\hline & Sum & $1.93 \mathrm{E}+03$ & $1.14 \mathrm{E}+00$ & $1.63 \mathrm{E}+03$ & $8.86 \mathrm{E}+02$ & $9.01 \mathrm{E}+01$ & $2.39 \mathrm{E}+02$ & $4.48 \mathrm{E}+01$ & $1.54 \mathrm{E}+01$ & 0 & $2.35 \mathrm{E}-01$ & $2.18 \mathrm{E}+01$ & $1.82 \mathrm{E}-01$ & $2.12 \mathrm{E}-03$ & $1.5 \mathrm{E}+00$ & $5.85 \mathrm{E}-01$ \\
\hline
\end{tabular}

$\stackrel{w}{\sim}$ 
come from a combination of WIDS and the Hanlon periodic reports. In general, WIDS has the same values as reported in the Hanlon status reports. All of the most recent entries to WIDS for the BY Tank Farm are dated 1996.

Sobczyk (2004a, b) has reviewed all the gamma logging data performed within the BY tank farm during the baseline monitoring activities that are documented in detail in individual tank logging reports and summarized in a BY Tank Farm "roll up" report, DOE/GJO (1997). Figure 3.64 shows the location of many of the dry wells around the BY tanks that show elevated gamma activity. Sobczyk (2004a, b) suggests that two boreholes around the BY-102 Tank showed gamma activity between depths of 35 and $55 \mathrm{ft}$ bgs, which might be indicative that this tank released wastes. However, Sobczyk could not rule out the fact that the contamination might be related to waste fluid releases from tank BY-103, a suspected leaker. At least 5 monitoring dry wells near the BY-103 tank show gamma activity, one down to $77 \mathrm{ft}$ bgs. Based on observing gamma activity in dry well 22-05-09 at $60 \mathrm{ft}$ bgs, Sobczyk (2004a, b) concludes that the BY-105 Tank did release fluids in agreement with the Hanlon designation. At least three drywells surrounding the BY-106 Tank contain measureable manmade gamma emitters with one drywell, 22-06-07, showing cesium-137 down to a depth of $131 \mathrm{ft}$ bgs. Six dry wells surrounding the BY-107 Tank contain manmade gamma activity with cobalt-60 extending at least as deep as the bottom of the dry wells ( $\sim 130 \mathrm{ft}$ bgs). As shown in Table 3.21, the fluid lost from the BY-107 Tank might be the largest volume released of all the BY tanks. Thus having six nearby drywells showing gamma activity would make sense.

At least four dry wells associated with Tank BY-108 show gamma activity but the depths are quite shallow (23 to $26 \mathrm{ft}$ bgs) suggesting fluid release was from either ancillary piping or the top of the steel liner. Thus Sobczyk agrees that tanks BY-105, BY-106, BY-107 and BY-108 should remain on the suspected leakers list. Sobczyk (2004a) suggests that three dry wells on the west side of the BY-109 tank that show man-made gamma activity are proof that this tank did also release fluids despite current classification as sound (Hanlon 2006). At least 5 dry wells surrounding the BY-110 Tank contain manmade gamma emitters (mostly cobalt-60). The fact that two of them show the cobalt at $\sim 48 \mathrm{ft}$ bgs ( $3 \mathrm{ft}$ below the tank bottom) lead Sobczyk (2004) to conclude that the source was Tank BY-110 and not Tank BY-107 waste, which is found at deeper depths around Tank BY-107. The vertical extent of cobalt-60 below the BY-110 tank can't be determined because none of the drywells are deep enough to identify the leading edge. Numerous dry wells surrounding the BY-111 Tank show near-surface contamination and some show deeper contamination including Hanford processed uranium in dry well 22-11-08 at $62 \mathrm{ft}$ bgs. Cobalt-60 contamination on the west side of Tank BY-111 indicates that this tank has leaked in the past (DOE/GJO 1997). Historical documentation records liquid-level decreases coincident with increases in gamma-ray intensities in dry wells around the west side of this tank. Therefore, on the basis of these data, DOE/GJO 1997 recommended that this tank be reclassified as a leaker. Although not explicitly stated, it is assumed that Sobczyk (2004a) also believes that the BY-111 Tank released fluids in contrast to the current classification as intact in Hanlon (2006). Sobczyk (2004a) also concluded that the man-made gamma in dry wells on the south and east side of the BY-112 Tank likely are associated with fluids released from the BY-109 Tank. Thus Sobczyk (2004a) argues that three more tanks, BY-109, BY-110, and BY-111 should be added to the list of tanks that released wastes to the subsurface and that Tank BY102 might have also released waste. Additional discussion on the BY Tank Farm is found in Wood et al. (2000) and Knepp (2002). 


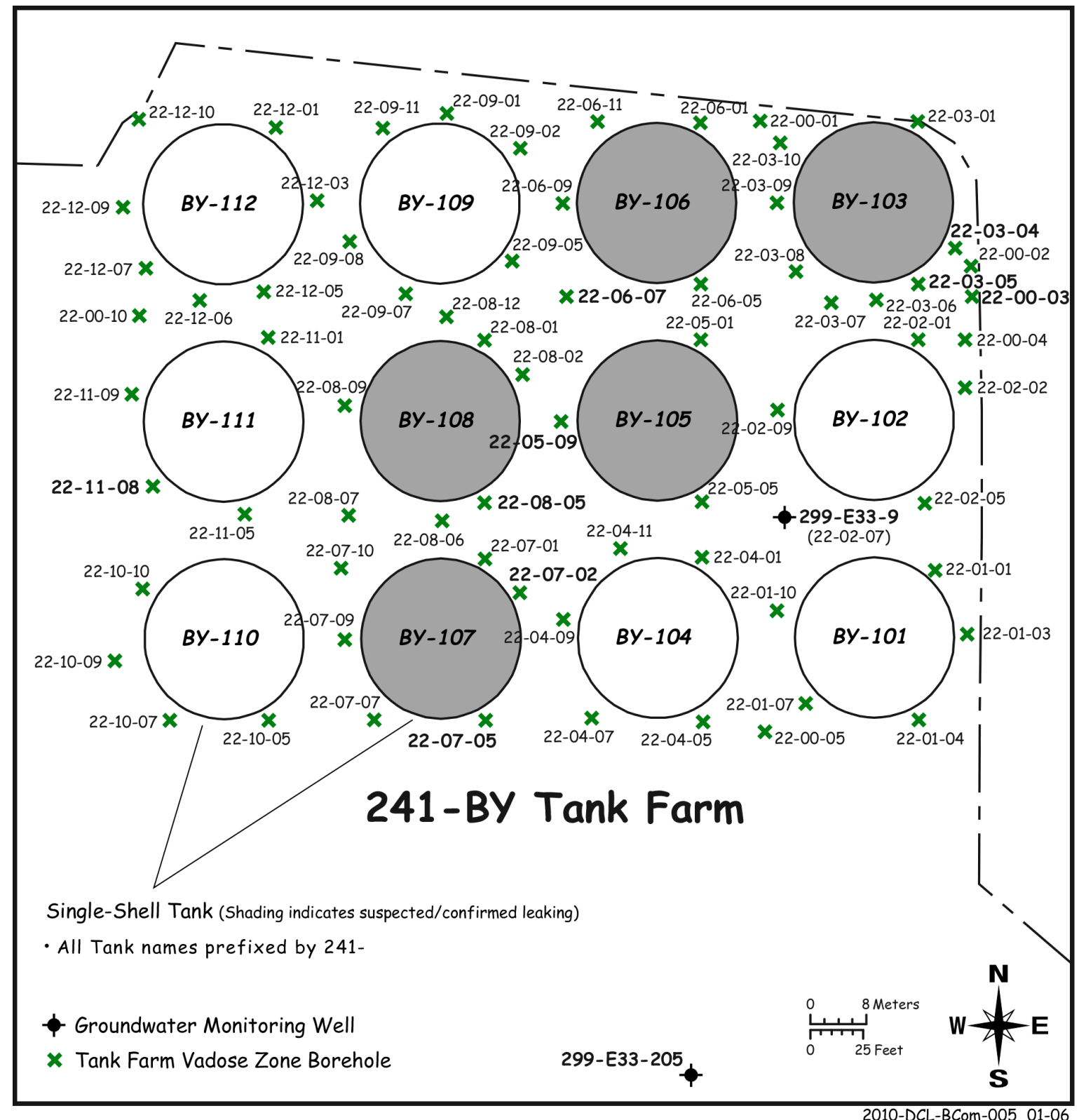

Figure 3.64. Location of Dry Wells and Groundwater Wells in BY Tank Farm

\subsubsection{BY Tanks Vadose Zone}

There has been only one borehole drilled and no direct push activities in the vadose zone in the BY Tank Farm region in the last twenty years. The only historical borehole that is deeper than the vadose zone dry wells that monitor the BY Tanks is E33-9 drilled in 1949. No vadose zone sediment characterization is available from E33-9 but gamma logging data is available that does not show any detectable Hanford processed uranium. The closest borehole for which actual sediment samples have been characterized is the new 200-BP5 characterization borehole, 299-E33-205, which was drilled north of Tank BX-106 and south of the BY Tank Farm (see Figure 1.2 or Figure 3.64). The sediment characterization data (Table 3.18) for 299-E33-205 was discussed in Section 3.4.3 along with other 
activities related to the BX Tank Farm. As discussed the vadose zone sediments in the Hanford formation from 299-E33-205 borehole were not significantly contaminated; however ultra sensitive uranium isotopic analysis show the presence of traces of uranium-236 (manmade) in pore water from 232-233 ft bgs (Figure 3.58). More importantly, the sediments from E33-205 in the $\mathrm{CCU}_{Z}$ unit showed slightly more contamination that appears to be a mixture of native uncontaminated vadose zone pore fluids with a small quantity of fluids from the BX-102 tank overfill event. The only available information on the horizontal and vertical distribution of subsurface contamination below the BY Tank Farm are the field gamma logs of dry wells and nearby groundwater wells and a field electrical resistivity survey. The depth of the dry wells that surround the individual SSTs is limited in general to the top 75 to $125 \mathrm{ft}$ of the vadose zone and only one groundwater well, 299-E33-9, is close enough to yield relevant gamma data for the deep vadose zone down to the water table. However, the borehole is double cased and has either bentonite-grout or grout emplaced between the dual casings such that no useful spectral gamma measurements can be made. (DOE/GJO 1996).

Before developing the conceptual model for the distribution of contaminants in the vadose zone below and proximal to the BY tank farm, all available spectral gamma and gross gamma logging results for the dry wells around the BY tanks and at wells 299-E33-9 and E33-205 were summarized. Dry well and groundwater monitoring well locations are shown in Figure 3.64. Concluding statements on gamma logging from Sobczyk (2004a, b) show that the highest cesium-137 concentrations in the BY Tank Farm boreholes were detected on the southeast side of tank BY-103, supporting the designation of this tank as an assumed leaker. Both cesium-137 and cobalt-60 were detected in borehole 22-03-05 with concentrations high enough to saturate the detector. Several other high cesium-137 concentrations were detected in the BY Tank Farm boreholes; however, these concentrations were associated with near surface contamination resulting from surface spills or pipe leaks or nearby pipes known to contain cesium-137 at the time of the dry well logging. Cesium-137 concentrations were usually less than 10 $\mathrm{pCi} / \mathrm{g}$; however, the vertical distributions were extensive.

Cobalt-60 contamination was detected around all the tanks in the BY Tank Farm that are known to have leaked (DOE/GJO 1997). Cobalt-60 contamination was often detected above the bases of the tanks and near the ground surface. Cobalt- 60 contamination was often detected alone below the base of the tank farm excavation within fine-grained sediments of the Hanford formation. A majority of the dry wells in the BY Tank Farm extend only to a depth of about $100 \mathrm{ft}$, and the log data from several of the boreholes indicated significant cobalt-60 contamination at total depth (DOE/GJO 1997). In borehole 22-00-03, cobalt- 60 was detected at a $\log$ depth of $145 \mathrm{ft}$, at the bottom of the borehole. The maximum depth extent of the BY Tank Farm cobalt- 60 contamination plumes is not known; therefore, any impacts of the vadose zone contamination on the groundwater cannot be directly determined. The depth to groundwater beneath the BY Tank Farm is about $250 \mathrm{ft}$, which is significantly deeper than all but 299-E33-9. There is a commitment to review the BY Tank Farm status in the future for each tank using the protocol described in Field et al. (2007). ${ }^{(a)}$

DOE/GJO (2000a) reported that the cesium-137 and cobalt-60, detected at borehole 22-02-07 (299-E33-9), just northwest of Tank BY-101 and $18 \mathrm{ft}$ southwest of Tank BY-102, in the sediments below the water table, may have affected the groundwater quality beneath the BY Tank Farm in the past. Groundwater samples collected from this well in December 1999 confirmed the presence of cobalt-60. These groundwater samples suggest that BY tank waste may have affected groundwater at

(a) Personal communication from JG Field (WRPS) September 2009. 
this location (Luttrell 2000). Cobalt-60 was also identified in borehole 299-E33-9 above the current water table from a 175 to $195 \mathrm{ft} \log$ depth and from 208 to $213 \mathrm{ft}$. However, due to the limited depths of other boreholes within the BY Tank Farm, the source of the cobalt-60 could not be positively identified. Analysis of historical gross gamma logging data by Randall and Price (1998) provided evidence of past and/or present unstable (i.e., migrating) contaminant zones in 26 boreholes in the BY Tank Farm. Subsequent routine monitoring suggests that vadose zone cobalt- 60 migration may be continuing in four dry wells (22-03-04, 22-07-02, 22-07-05 and 22-08-05). The spectral gamma log obtained from the new borehole 299-E33-205, showed no signs of manmade gamma or Hanford processed uranium in the vadose zone sediments. Albeit the new borehole is more distant from the BY Tank Farm and the vadose zone strata dip to the northeast such that placement of borehole 299E33-205 is not optimum for investigating low volume leaks from tanks in the BY Tank Farm.

A recent soil resistivity survey also identified a low resistivity (high conductivity region) anomaly south of Tank BY-107. However, because there are no direct measurements of the distribution of mobile contaminants from vadose zone sediments within any of the low resistivity field locations discussed as being contaminated at this time it is difficult to construct a conceptual model. Based on the low volumes of tank liquids listed as being released and low mass and activity inventories, the BX-102 Tank overfill is more likely the contributor to the current growing groundwater plume below the BY-Tank Farm. Because only one borehole (299-E33-9) penetrates the full vadose zone thickness and only gamma logging information are available, no estimates can be generated on the inventories or locations of residual contamination below the BY Tank Farm at this time.

In summary, it cannot be stated with certainty using actual sediment characterization data that the vadose zone below the BY Tank Farm has impacted groundwater in the past or that the deep vadose zone contains significant concentrations of potentially mobile contaminants that could reach the water table in the future. At borehole 299-E33-205 there is some indication of slightly elevated water extractable uranium in the $\mathrm{CCU}_{\mathrm{z}}$ sediments between 222 and $230 \mathrm{ft}$ bgs and one sediment sample at 225.5 $\mathrm{ft}$ bgs had $1 \mathrm{pCi} / \mathrm{g}$ water extractable technetium-99, but both likely came from the BX-102 Tank overfill fluids. Based on the low volumes of waste liquids released and the low masses of potentially mobile contaminants in the released fluids from the BY Tank Farm, it does not appear that the BY Tank Farm is currently or in the future will be a significant a contributor to the groundwater plumes.

\subsection{B Tank Farm Subregion}

In this subsection, the available borehole sediment characterization data, field gamma logging and electrical resistivity data are tabulated and compared with the known volumes and masses of waste chemicals and radionuclides released to the subsurface. Subsequently, a conceptual model is constructed for key waste constituents remaining in the vadose zone sediments.

The key facilities and key boreholes that were evaluated for the B Tank Farm subregion is shown in Figure 3.65. The reader should refer back to this figure to aid in understanding the following the discussion. Figure 3.65 also emphasizes in blue color the locations of boreholes and direct push holes from which sediment samples have been characterized to provide quantitative estimates of contaminant concentrations at these locations. 


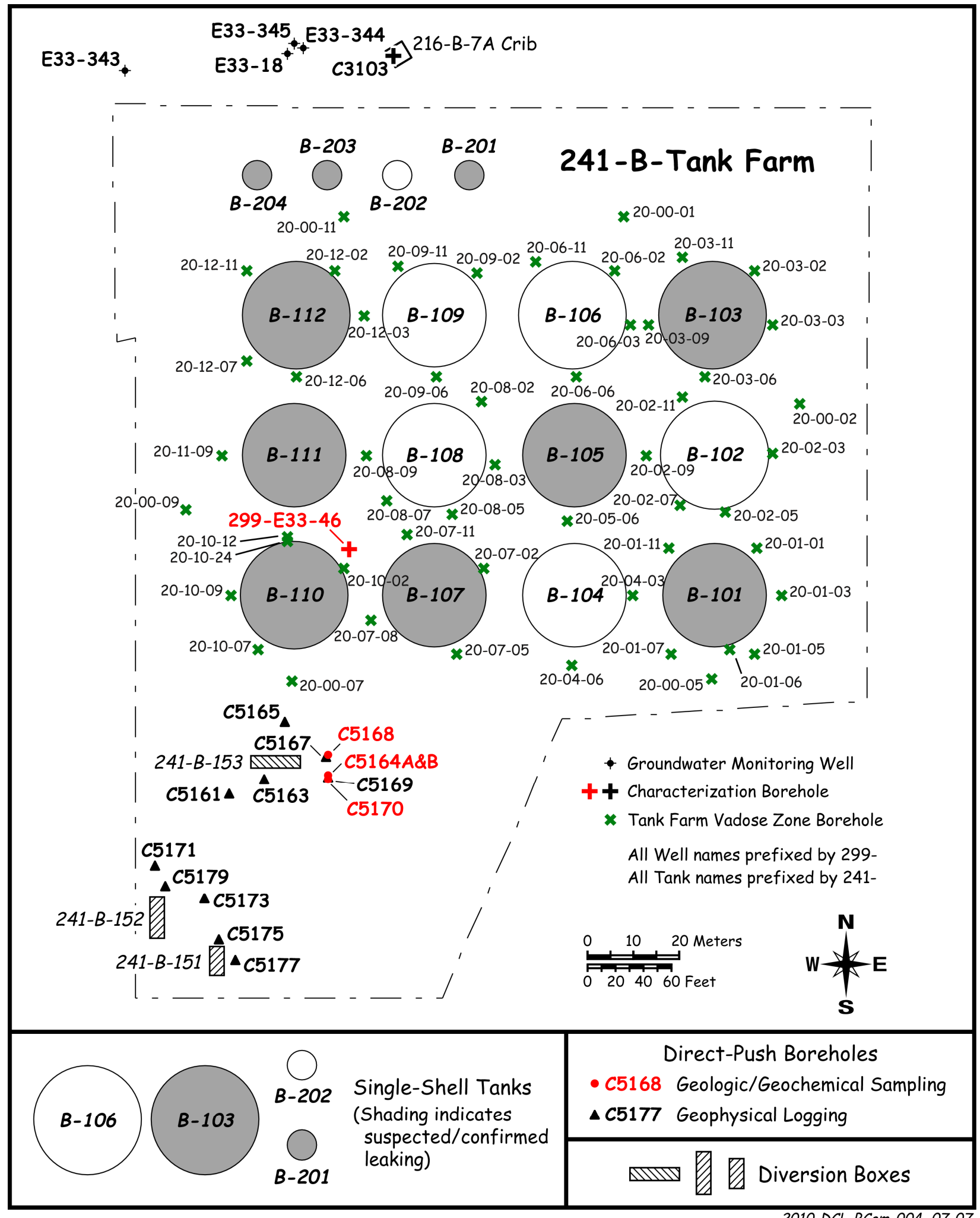

Figure 3.65. Location of Boreholes and Direct Pushes and Leak Status for B Tank Farm 


\subsubsection{B Tank Farm Description and Inventory Released}

The status of the tanks within the B Tank Farm is shown on Figure 3.65 and estimated volumes of waste and masses of selected constituents released to the vadose zone sediments are found in Table 3.22. The leak status of tanks in the B Tank Farm is not well established. There are at least four tanks (B-101, B-103, B-105, and B-111) shown in Table 3.22 for which no date for the listed release or an objective estimate of volume released has been established Tanks B-107, B-110, B-112, B-201, B-203, and B-204 have been designated currently as "confirmed leakers The estimated volume released from each of these "confirmed leakers" is relatively small and ranges from 1,140 to 37,900 L. Based on the grand totals of waste disposed and inventories of chemicals and radionuclides released to the sub-surface of the entire BComplex (see Table 3.24 and Table 3.25 for overall B-Complex "wrap up" details) release from the B Tank Farm is a small contributor. Only about $0.1 \%$ of the total volume of waste liquids disposed to the entire B-Complex occurred in the B Tank Farm. The estimated percentage of the total inventory of chemicals and radionuclides released to the entire B-Complex that were released to the environment within the B Tank Farm range from less than $0.1 \%$ up to $8.3 \%$ (cobalt-60). The two key constituents, uranium and technetium-99, and their release totals from the B Tank Farm are less than $0.1 \%$ and $1.3 \%$, respectively. Within the B Tank Farm, the largest mass contributor to the underlying vadose zone is Tank B-107 for uranium and Tank B-112 for technetium-99, each with low quantities of $1.5 \mathrm{~kg}$ and 1.0 curies, respectively. These are very small masses compared to the releases at several of the other B-Complex facilities. Of particular note in the B Tank Farm is the 1969 liquid release from Tank B-110 piping, which was characterized in 2002 by drilling vadose borehole, 299-E33-46. The vadose zone sediment characterization information for 299-E33-46 is summarized in the next subsection. However, as noted the Tank B-110 leak did not contain significant amounts of any of the key contaminants of interest to this document. Further, it does not appear that any of the contaminants or the fluid released by this leak has reached the groundwater. No boreholes have been drilled near any of the other tanks that may have released liquids to the vadose zone, and dry wells are lacking around the smaller 200-series tanks.

\subsubsection{B Tank Farms Vadose Zone}

Two characterization activities have been completed in the B Tank Farm that provided vadose zone sediment samples to measure the distribution of constituents in the vadose zone. The first activity was drilling borehole 299-E33-46, located about $15 \mathrm{ft}$ northeast from the B-110 tank wall (see Figure 3.65), down to groundwater. The primary purpose of the borehole was to investigate the vertical extent of strontium-90, uranium, technetium-99, and other mobile contaminants at a spot known to contain high strontium-90 contents based on the occurrence of highly elevated bremmstrahlung signal in the spectral gamma logging of nearby dry wells. Vadose zone characterization results for borehole 299-E33-46 along with detailed geologic interpretations are found in Serne et al. (2002a). The Serne et al. (2002a) vadose zone study showed conclusively that tank-related fluids are present in the vadose zone sediments at borehole 299-E33-46 to a depth of $52 \mathrm{~m}$ (170 ft) bgs, within the Hanford H2 unit. Below this depth, the concentration of nitrate still appears to be slightly elevated above natural background levels for deep vadose zone sediment based on a limited data set informally tabulated. There is also elevated technetium99 between 68 and $69 \mathrm{~m}$ (222 and $226 \mathrm{ft}$ ) bgs in the Cold Creek silt-dominated layer $\left(\mathrm{CCU}_{\mathrm{z}}\right)$, but Serne et al. (2002a) 
Table 3.22. B Tank Farm Leak Status and Leak Inventories

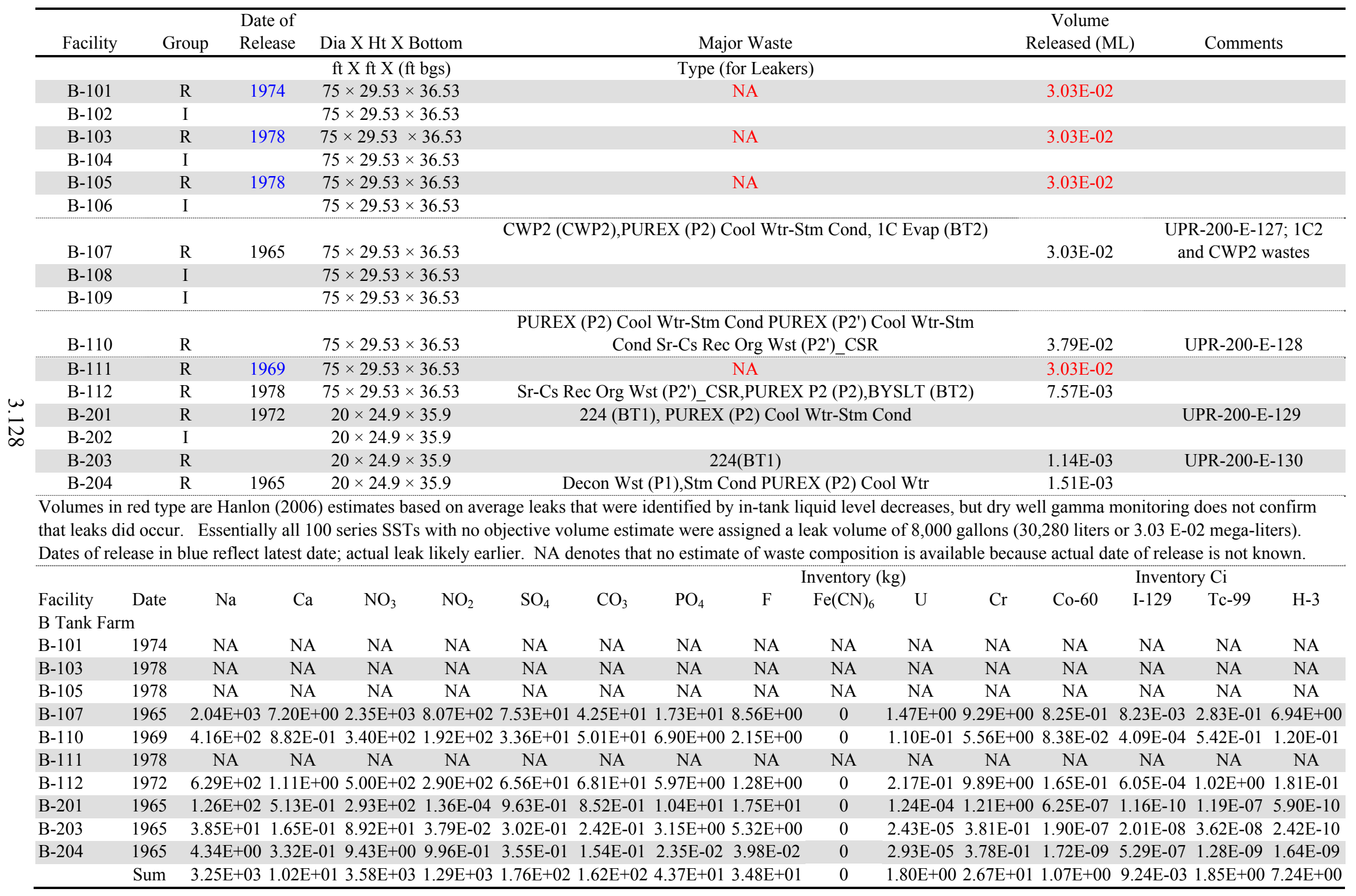


were unable to show that the technetium-99 traveled vertically through the entire Hanford formation to reach the $\mathrm{CCU}_{\mathrm{z}}$ unit at this borehole. In fact, the staff hypothesized that the contamination in the $\mathrm{CCU}_{z}$ unit likely has migrated horizontally from other sources to the location of the borehole.

At borehole 299-E33-46, there are several fine-grained layers within the H2 unit, at 26, 41, and $57 \mathrm{~m}$ $(85,168$, and $186 \mathrm{ft}) \mathrm{bgs}$ that promote horizontal spreading of percolating fluids. The depths of these fine-grained layers correspond to the three rather contiguous layers identified as the H2F1, H2F2, and $\mathrm{H} 2 \mathrm{~F} 3$ and described in Section 2.4. The 12.7-ft thick $\mathrm{CCU}_{\mathrm{z}}$ found between 215 and $227.7 \mathrm{ft}$ bgs is also an important stratigraphic controller of horizontal flow.

Pore-water electrical conductivity shows a two-lobed elevated high conductivity plume in the vadose zone at 299-E33-46. The shallower but more concentrated lobe, between 50.6 and $85 \mathrm{ft}$ bgs, resides within the middle sand sequence in the Hanford $\mathrm{H} 2$ unit. The shallow lobe appears to pond on top of the fine-grained H2F1 layer at $85 \mathrm{ft}$ bgs. The slightly less concentrated deeper lobe resides between 90.6 and $140 \mathrm{ft}$ bgs within the Hanford $\mathrm{H} 2$ unit. The leading edge of the vadose zone contaminant plume, based on the pore-water conductivity, appears to reside $78.0 \mathrm{~m}(255.8 \mathrm{ft}) \mathrm{bgs}$ well above the water table. Table 3.23 shows the vertical distribution of selected mobile constituents in the vadose zone sediments from 299-E33-46.

The other characterization activity in the B Tank Farm used three shallow (no deeper than $23 \mathrm{ft}$ bgs) direct push boreholes (C5168, C5170, and C5164A\&B)south of Tank B-110 and just east of diversion box B-153 (see Figure 3.65). Sediment samples were collected in a 1.5-in. outer diameter (OD), 6-in.long direct-push core barrel with stainless steel liners. Pertinent chemical data are shown at the bottom of Table 3.23. Recovery of sediment from direct push C5170 was poor and the mass collected was not adequate to perform detailed chemical analyses.

The data in Table 3.23 show that sediments in 299-E33-46 have elevated water-extractable sodium and lower-than-normal water-extractable calcium over the depth range $\sim 50$ to $130 \mathrm{ft}$ bgs. Two of the shallow direct-push boreholes show the same trend, which is indicative of high-concentration sodium wastes percolating through the sediments and stripping native calcium off the sediments' exchange sites. This ion exchange signature suggests that tank fluids descended vertically through the region penetrated by the boreholes. The profile of other mobile contaminants, such as fluoride, nitrate, and technetium-99 at borehole 299-E33-46, were also measured. The 299-E33-46 sediments show mildly elevated concentrations of fluoride between 55 and $85 \mathrm{ft}$ bgs, slightly elevated water-extractable uranium between 55 and $83 \mathrm{ft}$ bgs. The sediment nitrate concentrations at 299-E33-46 shows slightly elevated (above $10 \mu \mathrm{g} / \mathrm{g}$ ) nitrate sporadically at $84.6,131.8$ to 168.45 and 222 to $225 \mathrm{ft}$ bgs. If one uses the Hanford background sediment values found in DOE/RL (1995), which predominately used near ground surface sediment the average nitrate concentration in background sediments is $30.1 \mu \mathrm{g} / \mathrm{g}$. The highest sediment nitrate concentration observed in borehole $299-\mathrm{E} 33-46$ was $45.3 \mu \mathrm{g} / \mathrm{g}$ at $131.85 \mathrm{ft}$, near where the H2F2 lateral spreading layer is found. The most consistent region with slightly elevated ( 15 to $45 \mu \mathrm{g} / \mathrm{g}$ ) sediment nitrate concentration is between 131.8 to $168.45 \mathrm{ft}$, which is a region sandwiched between the $\mathrm{H} 2 \mathrm{~F} 2$ and $\mathrm{H} 2 \mathrm{~F} 3$ fine grained layers. The other depth that has similar slightly elevated sediment nitrate concentrations is between 222 to $225 \mathrm{ft}$ bgs, within the $\mathrm{CCU}_{\mathrm{z}}$ unit. 
PNNL-19277

Table 3.23. Vertical Distribution of Selected Chemicals and Radionuclides in Sediments Within B Tank Farm

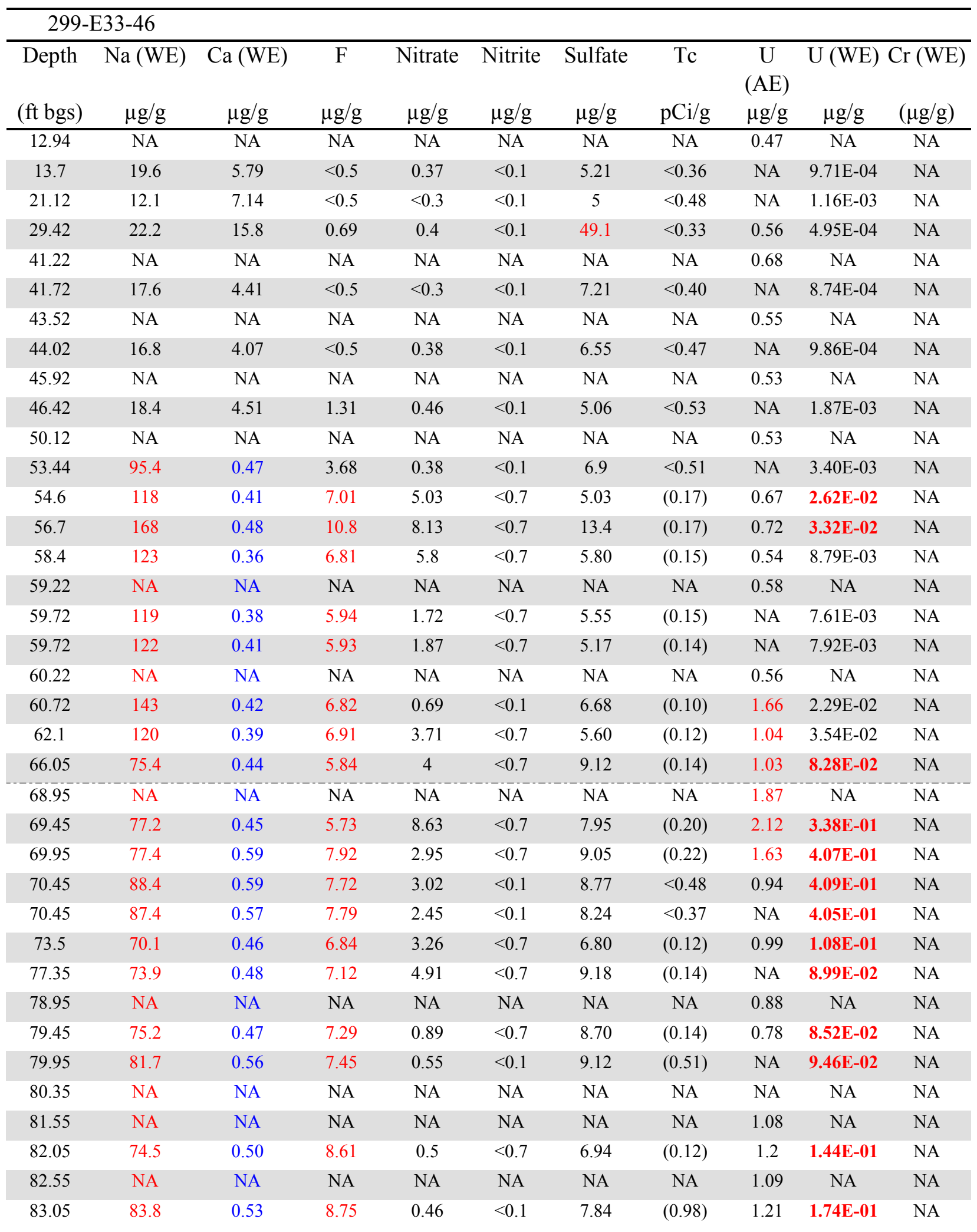


Table 3.23 (cont).

\begin{tabular}{|c|c|c|c|c|c|c|c|c|c|c|}
\hline \multicolumn{2}{|c|}{ 299-E33-46 } & \multirow[b]{2}{*}{$\mathrm{Ca}(\mathrm{WE})$} & \multirow[b]{2}{*}{$\mathrm{F}$} & \multirow[b]{2}{*}{ Nitrate } & \multirow[b]{2}{*}{ Nitrite } & \multirow[b]{2}{*}{ Sulfate } & \multirow[b]{2}{*}{$\mathrm{Tc}$} & \multirow[b]{2}{*}{$\begin{array}{c}\mathrm{U} \\
(\mathrm{AE})\end{array}$} & \multirow[b]{2}{*}{$\mathrm{U}(\mathrm{WE})$} & \multirow[b]{2}{*}{$\mathrm{Cr}(\mathrm{WE})$} \\
\hline Depth & $\mathrm{Na}(\mathrm{WE})$ & & & & & & & & & \\
\hline (ft bgs) & $\mu g / g$ & $\mu g / g$ & $\mu g / g$ & $\mu g / g$ & $\mu \mathrm{g} / \mathrm{g}$ & $\mu g / g$ & $\mathrm{pCi} / \mathrm{g}$ & $\mu \mathrm{g} / \mathrm{g}$ & $\mu \mathrm{g} / \mathrm{g}$ & $(\mu \mathrm{g} / \mathrm{g})$ \\
\hline 84.55 & 69.6 & 2.09 & 6.29 & 33.9 & $<0.7$ & 18.5 & $(0.25)$ & NA & $6.03 \mathrm{E}-02$ & NA \\
\hline 84.55 & 69.5 & 1.98 & 6.20 & 34.4 & $<0.7$ & 18.7 & $(0.27)$ & NA & 4.99E-02 & NA \\
\hline 87.85 & 29.1 & 1.65 & 1.06 & 14.0 & $<0.7$ & 5.03 & $(0.15)$ & 0.52 & $1.43 \mathrm{E}-03$ & NA \\
\hline 90.12 & NA & NA & NA & NA & NA & NA & NA & 0.59 & NA & NA \\
\hline 90.62 & 38.2 & 1.81 & 1.41 & 5.68 & $<0.1$ & 6.27 & $<0.28$ & 0.58 & $4.54 \mathrm{E}-03$ & NA \\
\hline 96.8 & 58.5 & 0.51 & 1.81 & 4.11 & $<0.7$ & 3.64 & $(0.12)$ & NA & $2.62 \mathrm{E}-02$ & NA \\
\hline 98.62 & 52.0 & 0.71 & 1.31 & 0.32 & $<0.1$ & 5.45 & $<0.22$ & NA & $1.26 \mathrm{E}-02$ & NA \\
\hline 98.62 & NA & NA & NA & NA & NA & NA & NA & 0.46 & NA & NA \\
\hline 109 & 62.1 & 0.55 & 1.03 & 16.7 & $<0.7$ & 7.91 & $(0.31)$ & NA & $3.45 \mathrm{E}-03$ & NA \\
\hline 110.92 & NA & NA & NA & NA & NA & NA & NA & 0.46 & NA & NA \\
\hline 111.42 & 75.2 & 0.52 & 1.02 & 5.51 & $<0.1$ & 6.9 & $(0.02)$ & 0.47 & $3.87 \mathrm{E}-03$ & NA \\
\hline 119.92 & 47.2 & 0.65 & 0.51 & 5.05 & $<0.1$ & 6.1 & $<0.21$ & NA & $2.94 \mathrm{E}-03$ & NA \\
\hline 126.75 & NA & NA & NA & NA & NA & NA & NA & 0.5 & NA & NA \\
\hline 131.85 & 37.7 & 7.79 & $<0.5$ & 45.3 & $<0.1$ & 12.6 & $(2.83)$ & 0.43 & $9.64 \mathrm{E}-04$ & NA \\
\hline 140.05 & 24.7 & 4.79 & $<0.5$ & 8.85 & $<0.1$ & 8.2 & $(0.78)$ & 0.49 & 8.31E-04 & NA \\
\hline 150.15 & 29.8 & 3.71 & $<0.5$ & 11.7 & $<0.1$ & 8.56 & $(0.64)$ & 0.45 & $1.37 \mathrm{E}-03$ & NA \\
\hline 160.15 & 29.0 & 4.15 & $<0.5$ & 15.2 & $<0.1$ & 10.1 & $(0.80)$ & 0.34 & $1.33 \mathrm{E}-03$ & NA \\
\hline 164.55 & 26.6 & 5.50 & $<0.5$ & 17.4 & $<0.1$ & 8.56 & $(1.24)$ & 0.42 & $1.47 \mathrm{E}-03$ & NA \\
\hline 166.85 & 23.9 & 4.88 & 0.5 & 16.0 & $<0.1$ & 8.2 & $(1.35)$ & 0.45 & $1.14 \mathrm{E}-03$ & NA \\
\hline 168.45 & 28.4 & 6.53 & 0.401 & 35.4 & $<0.7$ & 12.2 & 2.75 & NA & $1.57 \mathrm{E}-03$ & NA \\
\hline 171.15 & 34.9 & 3.94 & $<0.5$ & 6.99 & $<0.1$ & 9.17 & $(1.22)$ & 0.43 & $1.75 \mathrm{E}-03$ & NA \\
\hline 179.85 & 19.0 & 5.11 & $<0.5$ & 1.29 & $<0.1$ & 8.51 & (1.07) & 0.62 & $1.18 \mathrm{E}-03$ & NA \\
\hline 190.8 & 9.71 & 7.44 & 0.62 & 5.03 & $<0.1$ & 7.52 & (3.14) & 0.42 & $5.81 \mathrm{E}-04$ & NA \\
\hline 200.95 & 14.2 & 6.29 & $<0.5$ & 5.73 & $<0.1$ & 6.66 & $(4.82)$ & 0.44 & $5.58 \mathrm{E}-04$ & NA \\
\hline 209.95 & 15.7 & 5.70 & 0.82 & 3.14 & $<0.1$ & 8.04 & $(2.07)$ & 0.47 & $6.33 \mathrm{E}-04$ & NA \\
\hline 219.45 & 16.0 & 8.92 & 0.71 & 2.27 & $<0.1$ & 8.95 & $(3.90)$ & 1.12 & 7.39E-04 & NA \\
\hline 222.05 & 35.3 & 24.4 & 0.66 & 33.3 & $<0.1$ & 38.2 & 23.3 & NA & $1.30 \mathrm{E}-03$ & NA \\
\hline 222.05 & 33.0 & 22.3 & 0.69 & 33.5 & $<0.1$ & 34.8 & 22.0 & NA & $1.04 \mathrm{E}-03$ & NA \\
\hline 225.9 & 20.5 & 15.2 & 0.57 & 19.4 & $<0.7$ & 27.7 & 5.97 & 0.41 & $7.50 \mathrm{E}-04$ & NA \\
\hline 230.75 & 12.6 & 9.78 & 0.94 & 0.48 & $<0.1$ & 9.87 & $(0.80)$ & 0.34 & 4.42E-04 & NA \\
\hline 240.95 & 17.9 & 7.21 & 0.548 & $<0.012$ & $<0.7$ & 17.333 & $(0.39)$ & NA & $4.53 \mathrm{E}-04$ & NA \\
\hline 241.45 & 19.5 & 7.78 & 1.05 & 0.44 & $<0.1$ & 13.83 & $<0.25$ & 0.33 & $5.01 \mathrm{E}-04$ & NA \\
\hline 245.75 & 13.4 & 7.24 & $<0.5$ & 1.57 & $<0.1$ & 13.93 & $(0.70)$ & 2.48 & $3.33 \mathrm{E}-04$ & NA \\
\hline 253.15 & 16.8 & 7.69 & $<0.5$ & 1.52 & $<0.1$ & 7.87 & $<0.32$ & NA & $3.80 \mathrm{E}-04$ & NA \\
\hline C5164B & $\begin{array}{l}\text { Sodium } \\
(\mu \mathrm{g} / \mathrm{g})\end{array}$ & $\begin{array}{l}\text { Calcium } \\
(\mu \mathrm{g} / \mathrm{g})\end{array}$ & $\begin{array}{c}\text { Fluoride } \\
(\mu \mathrm{g} / \mathrm{g})\end{array}$ & $\begin{array}{l}\text { Nitrate } \\
(\mu \mathrm{g} / \mathrm{g})\end{array}$ & $\begin{array}{c}\text { Nitrite } \\
\mu \mathrm{g} / \mathrm{g}\end{array}$ & $\begin{array}{l}\text { Sulfate } \\
(\mu \mathrm{g} / \mathrm{g})\end{array}$ & $\begin{array}{l}{ }^{99} \mathrm{Tc} \\
(\mathrm{pCi} / \mathrm{g})\end{array}$ & $\begin{array}{l}\mathrm{UAE} \\
\mu \mathrm{g} / \mathrm{g})\end{array}$ & $\begin{array}{l}\text { U WE } \\
(\mu \mathrm{g} / \mathrm{g})\end{array}$ & $\begin{array}{c}\mathrm{Cr}(\mathrm{WE}) \\
(\mu \mathrm{g} / \mathrm{g})\end{array}$ \\
\hline 21.25 & $8.40 \mathrm{E}+01$ & $1.65 \mathrm{E}+00$ & 2.15 & 2.8 & $\mathrm{NA}$ & 12.6 & $(3.44 \mathrm{E}-02)$ & 0.52 & $7.79 \mathrm{E}-03$ & $(2.49 \mathrm{E}-03)$ \\
\hline 21.75 & $1.03 E+02$ & $(6.31 \mathrm{E}-01)$ & NA & 2.8 & NA & 4.2 & $<1.70 \mathrm{E}-01$ & 0.61 & $2.03 \mathrm{E}-02$ & $(1.24 \mathrm{E}-03)$ \\
\hline 21.75 & $1.26 \mathrm{E}+02$ & $(8.66 \mathrm{E}-01)$ & NA & 4.2 & NA & 6.9 & $<1.51 \mathrm{E}-01$ & 0.52 & $3.02 \mathrm{E}-02$ & (1.54E-03) \\
\hline 22.25 & $1.62 E+02$ & $(8.31 \mathrm{E}-01)$ & NA & 12.5 & NA & 4.5 & $<1.71 \mathrm{E}-01$ & 0.71 & $1.47 \mathrm{E}-01$ & $2.87 \mathrm{E}-03$ \\
\hline
\end{tabular}


PNNL-19277

Table 3.23 (cont)

\begin{tabular}{|c|c|c|c|c|c|c|c|c|c|c|}
\hline & Sodium & \multicolumn{2}{|c|}{ Calcium Fluoride } & Nitrate & Nitrite & Sulfate & ${ }^{9} \mathrm{Tc}$ & $\overline{\mathrm{UAE}}$ & $\overline{\mathrm{UWE}}$ & $\overline{C r}(\mathrm{WE})$ \\
\hline C5164A & $(\mu \mathrm{g} / \mathrm{g})$ & \multicolumn{2}{|c|}{$(\mu \mathrm{g} / \mathrm{g})(\mu \mathrm{g} / \mathrm{g})$} & $(\mu \mathrm{g} / \mathrm{g})$ & $\mu \mathrm{g} / \mathrm{g}$ & $(\mu \mathrm{g} / \mathrm{g})$ & $(\mathrm{pCi} / \mathrm{g})$ & $\mu \mathrm{g} / \mathrm{g})$ & $(\mu \mathrm{g} / \mathrm{g})$ & $(\mu \mathrm{g} / \mathrm{g})$ \\
\hline 17.25 & $1.88 \mathrm{E}+01$ & $5.43 \mathrm{E}+00$ & 0.50 & 1.8 & $\mathrm{NA}$ & 3.5 & $<1.70 \mathrm{E}-01$ & 0.41 & $1.48 \mathrm{E}-03$ & $4.75 \mathrm{E}-03$ \\
\hline 17.75 & $2.00 \mathrm{E}+01$ & $4.88 \mathrm{E}+00$ & 0.69 & 1.2 & $\mathrm{NA}$ & 9.2 & $<1.77 \mathrm{E}-01$ & 0.37 & $9.38 \mathrm{E}-04$ & $6.05 \mathrm{E}-03$ \\
\hline 18.25 & $1.77 \mathrm{E}+01$ & $3.94 \mathrm{E}+00$ & 0 . & 1.3 & NA & 5.1 & $<1.70 \mathrm{E}-01$ & 0.44 & 7.97E-04 & (2.08E-03) \\
\hline \multicolumn{11}{|l|}{ C5168 } \\
\hline 17.25 & $1.63 \mathrm{E}+02$ & $(6.79 \mathrm{E}-01)$ & 1.13 & 1.6 & $\mathrm{NA}$ & 12.3 & $<1.73 \mathrm{E}-01$ & 0.61 & $4.37 \mathrm{E}-02$ & $(1.65 \mathrm{E}-03)$ \\
\hline 17.25 & $2.01 \mathrm{E}+02$ & (9.70E-01) & 1.33 & 6.8 & NA & 9.7 & $<1.78 \mathrm{E}-01$ & 0.72 & 8.36E-02 & (1.35E-03) \\
\hline 17.75 & $1.70 \mathrm{E}+02$ & (9.16E-01) & 0.77 & 4.5 & NA & 2.7 & $<1.70 \mathrm{E}-01$ & 0.58 & $5.62 \mathrm{E}-02$ & 2.89E-03 \\
\hline 18.25 & $1.69 \mathrm{E}+02$ & (6.47E-01) & NA & 3.2 & NA & 2.3 & $<1.72 \mathrm{E}-01$ & 0.68 & $7.11 \mathrm{E}-02$ & $(1.65 \mathrm{E}-03)$ \\
\hline
\end{tabular}

$\mathrm{NA}=$ not analyzed Bold type $=$ elevated above natural background concentrations . Red type $=$ elevated concentrations indicative of the presence of some type of waste Blue Type $=$ concentrations less than normal for uncontaminated sediments caused by ion exchange reactions

There is one isolated detection $(2.75 \mathrm{pCi} / \mathrm{g})$ of technetium-99 in the 299-E33-46 sediment profile at the $\mathrm{H} 2 \mathrm{~F} 3$ fine grained layer at $168 \mathrm{ft}$ bgs and more elevated ( 6 to $23 \mathrm{pCi} / \mathrm{g}$ ) concentrations of sediment technetium-99 in the $\mathrm{CCU}_{z}$, suggesting that the waste stream released from tank B-110 did not contain high concentrations of technetium-99. The technetium-99 in the $\mathrm{CCU}_{\mathrm{z}}$ strata may have entered via lateral spreading from another source, perhaps BX-102 waste fluids.

Two of the shallow direct-push sediments (see Figure 3.65) show elevated water-extractable uranium, but none of the three shows any elevated acid-extractable uranium, technetium-99, nitrate, or fluoride. The main purpose of the direct push campaign within the B Tank Farm was to investigate vadose zone contamination associated with potential leaks from diversion boxes (B-151, B-152, and B-153). The B diversion boxes were reported to have leaked metal waste in 1951 (Wood et al. 2000). Metal waste is considered to be the most contaminated waste stream leaked in WMA B and could have contaminated the vadose zone with tank waste contaminants, including uranium and technetium-99. The data for the shallow direct push samples, shown at the bottom of Table 3.23, suggest that the waste liquids that percolated through the sediments east of diversion box B-153 did not contain significantly high concentrations of uranium or technetium-99, or that mobile contaminants have been flushed deeper than the $\sim 23$-ft maximum depth interrogated. The latter hypothesis was favored by Brown et al. (2007), in which more details of the direct-push activities can be found.

Because of the limited nature of the two vadose zone sediment characterization studies at the B Tank Farm no generalizations on potential horizontal spreading of waste fluids and mobile contaminants below the B Tank Farm can be made. Gamma logging of the numerous dry wells around the larger 100-series SSTs were reviewed to make some estimates of the continuity of vadose zone plumes and lateral spreading. A detailed review of gamma logging data was performed by Sobczyk (2004a, b) and discussed in Section 3.5.1. His review suggested that there are several contiguous vadose zone plumes below the B Tank Farm. Based on the borehole gamma logging results, the vadose zone plume in the vicinity of B110 has spread at least $80 \mathrm{ft}$ to the northeast of the tank's outer circumference and $40 \mathrm{ft}$ to the southwest. The transfer line that might have leaked connects Tanks B-110 to Tank B-111. Because gamma logging of this plume appears to be measuring strontium-90, a moderately sorbing contaminant, the true distances of lateral spread might be considerably larger for the $\sim 37,900 \mathrm{~L}$ release. 
Sobczyk (2004a, b) agrees that there is little indication that fluids lost below the B Tank Farm have reached groundwater but suggests that additional boreholes are needed in the region. Also, besides the tanks noted in Table 3.22, Tank B-106 shows gamma activity in several dry wells near its base tank that might indicate a release of tank fluids. Sobczyk (2004a, b) also points out that dry wells and deeper monitoring boreholes around the 200-series tanks, B-201 through B-204, are too sparse to determine the vadose zone status in this location.

The available sediment data from below the B Tank Farm do not suggest that Tank B-110 has contributed significant amounts of mobile contaminants to the groundwater. Rather, it appears that the $\mathrm{CCU}_{\mathrm{z}}$ unit is acting as a horizontal spreading layer and contains waste fluids from a different source than Tank B-110. As discussed in Christensen et al. (2004), the uranium isotopic ratios for water extracts from contaminated sediments from borehole 299-E33-46 are distinctly different than those from water extracts taken from borehole 299-E33-45, which is known to have fluids from the BX-102 tank overfill event (refer to Section 3.4.2). Further, none of the groundwater samples that have been measured for precise uranium isotopic ratios appear to be a mixture of pore waters from the Tank B-110 waste with uncontaminated groundwater. Therefore, there is no indication that significant volumes of waste fluids from the release near Tank B-110 have reached the groundwater. The fluids released from the transfer line at Tank B-110 also appear not to contain significant concentrations of nitrate or technetium-99 compared to other waste streams. The low concentrations of mobile contaminants found in the Hanford formation sediments below the B Tank Farm do not appear to be a significant future source of groundwater contamination in comparison to the deep vadose zone under the BY Cribs and the larger area of very moist $\mathrm{CCU}_{z}$ sediments to the north and west of the B Tank Farm that currently contain high concentrations of uranium, technetium-99, fluoride, and nitrate from the BX-102 tank overfill event.

\subsubsection{Mass Inventory Calculation of B Tank Farm}

Because there is no indication, based on the available borehole and direct push sediments and uranium isotopic ratio measurements, that waste fluids from the B Tank Farm have reached the groundwater below the region and the fact that the total mass of wastes that were released from tanks in the B Tank Farm is quite low, calculations to estimate the residual mass and distribution of contaminants below the B Tank Farm were not performed. Besides the data for 299-E33-46 and the shallow direct-push samples, no other boreholes are available to make vadose zone inventory calculations at other tanks in the B Tank Farm.

\subsection{B-Complex Total Mass of Chemicals and Key Radionuclides Released to the Vadose Zone}

In this subsection, the estimates of total mass/activity of major chemicals and key stable and radioactive constituents that were released to the subsurface in the cribs, trenches, French drains, and from the SSTs and their ancillary infrastructure have been tabulated. The values used come solely from the SIM information found in the electronic appendices within Corbin et al. (2005), excepting ferrocyanide data, for which the mass estimate source is discussed below. The Corbin et al. (2005) mass/activity estimates for each facility were based on a thorough review of historical information and model development to "standardize" the methodology for waste inventory estimates at cribs, trenches, ponds, etc. and unintentional releases from SSTs. The methodology was based on knowledge of the processes used to reprocess irradiated fuel and to recover specific radionuclides, the masses of starting 
chemicals procured, waste volumes produced, and direct measurements of a few of the waste streams. The process knowledge, chemical inventory, and waste volumes produced were based on technical manuals, process flow sheets, and radiological source-term reports. Model results for fission and activation products from fuel irradiation were combined with all the other Hanford Site historical information on the various processes to determine radionuclide and chemical partitioning. The reader needs to keep in mind that the SIM values for masses of chemicals and radionuclides used herein are predominately estimates as opposed to direct measurements. Hanford records provide documentation of routine sample results for a few of the key constituents in a few of the waste streams, but more often, the tabulated values are estimates. Many constituents had either limited or no actual measurements to ascertain the validity or the inventory estimates. More details on how the inventory estimates were produced and SIM model limitations can be found in Corbin et al. (2005) and the HDW documentation (most recent version is Rev 5; Higley and Place 2004).

Table 3.24 presents the total mass released to the subsurface at each facility (grouped into the six localized subregions). One striking observation during construction of Table 3.24 was that only one facility, the B-45 Crib in the BY Cribs subregion, showed ferrocyanide released to the subsurface. The SIM document does not explain why the ferrocyanide used during the scavenging process to precipitate cesium-137 only reached the B-45 crib. However, this cyanide inventory discrepancy has been realized (see Section 7.2.11 in Higby and Place (2004)). They attribute identification of this HDW and SIM model "logic" error to Lilga et al. (1996). Given the discovery that the electronic appendices in SIM do not adequately address the cyanide inventory, a review of historical documents, found that one (DOE/RL 1993a) does have inventories for ferrocyanide released to the BY Cribs. DOE/RL (1993a) cites the ferrocyanide values as being from DOE/RL (1992), which attributes the values as coming from the current (at that time) version of WIDS. Therefore, the cyanide inventory values from DOE/RL (1993a) are used in Table 3.24. Further, direct sediment measurements (Section 3.1.2) confirm that the two BY cribs characterized (B-43 and B-49) received waste fluids containing ferrocyanide. Further, no measurable cyanide was detected in any of the sediments from boreholes in other B-Complex facility footprints or in sediments from boreholes proximal to the other B-Complex facilities.

The SIM model also asserts that some of the SSTs that released fluids to the subsurface sediments had very low volumes $(<0.1 \%$ of total released) of waste that contained ferrocyanide at the time of the leak event. Tanks B-107, B-112, BX-101, and BX-108 were noted as such by the SIM model. There are no boreholes directly adjacent to these tanks. Therefore, it cannot be ruled out that these tanks could have released miniscule amounts of ferrocyanide. But because the detection limit for cyanide extracted from sediments is rather high, the probability of detecting low-mass releases of cyanide from these tanks is very low.

Table 3.25 sums the masses/activities released to the subsurface by subregion and also provides the percentages of the total volume and masses/activities released to the vadose zone for each of the subregions. In the case of the BY Crib subregion, two cribs (B-50 and B-57) received much larger 
Table 3.24. Total Mass/Activity of Constituents Released from Each Facility to the Subsurface by Localized Regions

\begin{tabular}{|c|c|c|c|c|c|c|c|c|c|c|c|c|c|c|c|c|}
\hline \multirow[b]{2}{*}{ Facility } & \multirow[b]{2}{*}{ Date } & \multicolumn{11}{|c|}{ Inventory $(\mathrm{kg})$} & \multicolumn{4}{|c|}{ Inventory $\mathrm{Ci}$} \\
\hline & & $\mathrm{Na}$ & $\mathrm{Ca}$ & $\mathrm{NO}_{3}$ & $\mathrm{NO}_{2}$ & $\mathrm{SO}_{4}$ & $\mathrm{CO}_{3}$ & $\mathrm{PO}_{4}$ & $\mathrm{~F}$ & $\mathrm{Fe}(\mathrm{CN})_{6}$ & $\mathrm{U}$ & $\mathrm{Cr}$ & Co-60 & I-129 & Tc-99 & $\mathrm{H}-3$ \\
\hline \multicolumn{17}{|c|}{ BY Cribs\& Vicinity } \\
\hline B-43 & 1954 & $1.89 \mathrm{E}+05$ & $3.13 \mathrm{E}+02$ & $4.21 \mathrm{E}+05$ & $2.01 \mathrm{E}+02$ & $2.49 \mathrm{E}+04$ & $4.68 \mathrm{E}+02$ & $1.42 \mathrm{E}+04$ & $8.59 \mathrm{E}+03$ & 1100 & $6.58 \mathrm{E}+01$ & $3.65 \mathrm{E}+02$ & $3.98 \mathrm{E}-01$ & $1.03 \mathrm{E}-02$ & $8.05 \mathrm{E}+00$ & $1.32 \mathrm{E}+01$ \\
\hline B44 & $1954 / 55$ & $4.99 \mathrm{E}+05$ & $8.27 \mathrm{E}+02$ & $1.11 \mathrm{E}+06$ & $5.30 \mathrm{E}+02$ & $6.59 \mathrm{E}+04$ & $1.24 \mathrm{E}+03$ & $3.75 \mathrm{E}+04$ & $2.27 \mathrm{E}+04$ & 3000 & $1.74 \mathrm{E}+02$ & $9.63 \mathrm{E}+02$ & $1.05 \mathrm{E}+00$ & $2.73 \mathrm{E}-02$ & $2.13 \mathrm{E}+01$ & $3.49 \mathrm{E}+01$ \\
\hline B-45 & 1955 & $4.39 \mathrm{E}+05$ & $7.48 \mathrm{E}+02$ & $9.77 \mathrm{E}+05$ & $5.13 \mathrm{E}+02$ & $5.81 \mathrm{E}+04$ & $1.12 \mathrm{E}+03$ & $3.32 \mathrm{E}+04$ & $1.99 \mathrm{E}+04$ & 2600 & $1.65 \mathrm{E}+02$ & $8.46 \mathrm{E}+02$ & $9.24 \mathrm{E}-01$ & $2.40 \mathrm{E}-02$ & $1.87 \mathrm{E}+01$ & $3.07 \mathrm{E}+01$ \\
\hline B-46 & 1955 & $5.97 \mathrm{E}+05$ & $9.89 \mathrm{E}+02$ & $1.33 \mathrm{E}+06$ & $6.34 \mathrm{E}+02$ & $7.88 \mathrm{E}+04$ & $1.48 \mathrm{E}+03$ & $4.49 \mathrm{E}+04$ & $2.71 \mathrm{E}+04$ & 4000 & $2.08 \mathrm{E}+02$ & $1.15 \mathrm{E}+03$ & $1.26 \mathrm{E}+00$ & $3.26 \mathrm{E}-02$ & $2.55 \mathrm{E}+01$ & $4.18 \mathrm{E}+01$ \\
\hline B-47 & 1955 & $3.30 \mathrm{E}+05$ & $5.43 \mathrm{E}+02$ & $7.32 \mathrm{E}+05$ & $2.53 \mathrm{E}+02$ & $4.33 \mathrm{E}+04$ & $8.13 \mathrm{E}+02$ & $2.47 \mathrm{E}+04$ & $1.49 \mathrm{E}+04$ & 2000 & $1.14 \mathrm{E}+02$ & $6.33 \mathrm{E}+02$ & $6.92 \mathrm{E}-01$ & $1.79 \mathrm{E}-02$ & $1.40 \mathrm{E}+01$ & $2.29 \mathrm{E}+01$ \\
\hline B-48 & 1955 & $3.65 \mathrm{E}+05$ & $6.03 \mathrm{E}+02$ & $8.12 \mathrm{E}+05$ & $3.87 \mathrm{E}+02$ & $4.81 \mathrm{E}+04$ & $9.04 \mathrm{E}+02$ & $2.74 \mathrm{E}+04$ & $1.66 \mathrm{E}+04$ & 2200 & $1.27 \mathrm{E}+02$ & $7.03 \mathrm{E}+02$ & 7.69E-01 & $1.99 \mathrm{E}-02$ & $1.55 \mathrm{E}+01$ & $2.55 \mathrm{E}+01$ \\
\hline B-49 & 1955 & $5.98 \mathrm{E}+05$ & $9.89 \mathrm{E}+02$ & $1.33 \mathrm{E}+06$ & $6.35 \mathrm{E}+02$ & $7.88 \mathrm{E}+04$ & $1.48 \mathrm{E}+03$ & $4.49 \mathrm{E}+04$ & $2.71 \mathrm{E}+04$ & 4000 & $2.08 \mathrm{E}+02$ & $1.15 \mathrm{E}+03$ & $1.26 \mathrm{E}+00$ & $3.27 \mathrm{E}-02$ & $2.55 \mathrm{E}+01$ & $4.18 \mathrm{E}+01$ \\
\hline B50 & $1965-74$ & $1.57 \mathrm{E}+02$ & $7.22 \mathrm{E}+02$ & $1.11 \mathrm{E}+02$ & $3.90 \mathrm{E}+01$ & $4.20 \mathrm{E}+02$ & $1.05 \mathrm{E}+01$ & $1.97 \mathrm{E}+00$ & $7.59 \mathrm{E}+00$ & 0 & $2.88 \mathrm{E}-02$ & $1.48 \mathrm{E}+01$ & $8.01 \mathrm{E}-03$ & $9.34 \mathrm{E}-05$ & $6.60 \mathrm{E}-02$ & $1.26 \mathrm{E}+02$ \\
\hline B-57 & $1968-73$ & $3.66 \mathrm{E}+02$ & $1.11 \mathrm{E}+03$ & $2.76 \mathrm{E}+02$ & $1.17 \mathrm{E}+02$ & $6.53 \mathrm{E}+02$ & $3.16 \mathrm{E}+01$ & $5.91 \mathrm{E}+00$ & $1.27 \mathrm{E}+01$ & 0 & 5.94E-02 & $2.42 \mathrm{E}+01$ & $2.40 \mathrm{E}-02$ & $2.80 \mathrm{E}-04$ & $1.97 \mathrm{E}-01$ & $1.95 \mathrm{E}+02$ \\
\hline $\begin{array}{l}\text { BY-201 } \\
\text { Settling } \\
\text { Tank }\end{array}$ & $1954 / 55$ & $3.71 \mathrm{E}+03$ & $6.14 \mathrm{E}+00$ & $8.27 \mathrm{E}+03$ & $3.94 \mathrm{E}+00$ & $4.90 \mathrm{E}+02$ & $9.19 \mathrm{E}+00$ & $2.79 \mathrm{E}+02$ & $1.69 \mathrm{E}+02$ & 0 & $1.29 \mathrm{E}+00$ & $7.16 \mathrm{E}+00$ & $7.83 \mathrm{E}-03$ & $2.03 \mathrm{E}-04$ & $1.58 \mathrm{E}-01$ & $2.59 \mathrm{E}-01$ \\
\hline & Sum & $3.02 \mathrm{E}+06$ & $6.85 \mathrm{E}+03$ & $6.72 \mathrm{E}+06$ & $3.31 \mathrm{E}+03$ & $3.99 \mathrm{E}+05$ & $7.56 \mathrm{E}+03$ & $2.27 \mathrm{E}+05$ & $1.37 \mathrm{E}+05$ & $.89 E+04$ & $1.06 \mathrm{E}+03$ & $5.86 \mathrm{E}+03$ & $6.39 \mathrm{E}+00$ & $1.65 \mathrm{E}-01$ & $1.29 \mathrm{E}+02$ & $5.32 \mathrm{E}+02$ \\
\hline
\end{tabular}
B-7-A\&B/B-8 Cribs Subregion

i. B-51

w French $\quad 1956-58 \quad 9.05 \mathrm{E}+01 \quad 1.48 \mathrm{E}-01 \quad 1.99 \mathrm{E}+02 \quad 3.20 \mathrm{E}-02 \quad 1.18 \mathrm{E}+01 \quad 2.21 \mathrm{E}-01 \quad 6.70 \mathrm{E}+00 \quad 4.05 \mathrm{E}+00$ Drain

B-7A\&B $\quad 1946-\quad 1.18 \mathrm{E}+06 \quad 5.12 \mathrm{E}+03 \quad 2.71 \mathrm{E}+06 \quad 1.48 \mathrm{E}+03 \quad 1.16 \mathrm{E}+04 \quad 7.31 \mathrm{E}+03 \quad 9.77 \mathrm{E}+04 \quad 1.62 \mathrm{E}+05$ $54 ; 1966-$

67

$\begin{array}{llllllllll}\mathrm{B}-8 & 1948-53 & 1.06 \mathrm{E}+06 & 3.65 \mathrm{E}+03 & 1.94 \mathrm{E}+06 & 9.12 \mathrm{E}+01 & 1.18 \mathrm{E}+05 & 5.46 \mathrm{E}+03 & 1.62 \mathrm{E}+05 & 1.05 \mathrm{E}+05\end{array}$ $\begin{array}{llllllllll}\text { B- } & 1952-54 & 1.25 \mathrm{E}+02 & 1.87 \mathrm{E}+02 & 2.45 \mathrm{E}+02 & 8.54 \mathrm{E}+00 & 3.72 \mathrm{E}+01 & 9.17 \mathrm{E}+00 & 6.73 \mathrm{E}+00 & 3.60 \mathrm{E}+00\end{array}$

$11 \mathrm{~A} \& \mathrm{~B}$

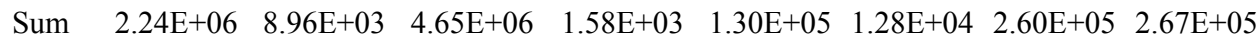
BX Trenches

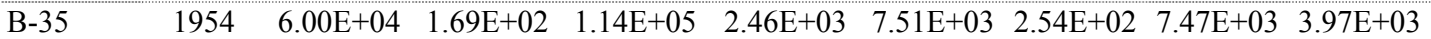
$\begin{array}{llllllllll}\mathrm{B}-36 & 1954 & 1.10 \mathrm{E}+05 & 3.10 \mathrm{E}+02 & 2.08 \mathrm{E}+05 & 4.50 \mathrm{E}+03 & 1.37 \mathrm{E}+04 & 4.64 \mathrm{E}+02 & 1.37 \mathrm{E}+04 & 7.27 \mathrm{E}+03\end{array}$

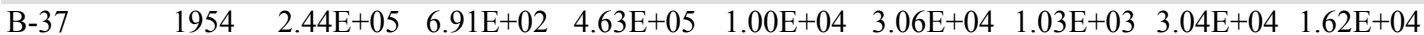
$\begin{array}{llllllllll}\mathrm{B}-38 & 1954 & 8.09 \mathrm{E}+04 & 2.29 \mathrm{E}+02 & 1.53 \mathrm{E}+05 & 3.31 \mathrm{E}+03 & 1.01 \mathrm{E}+04 & 3.42 \mathrm{E}+02 & 1.01 \mathrm{E}+04 & 5.36 \mathrm{E}+03\end{array}$ $\begin{array}{lllllllllll}\text { B-39 } & 1953 / 54 & 8.71 \mathrm{E}+04 & 2.46 \mathrm{E}+02 & 1.65 \mathrm{E}+05 & 3.57 \mathrm{E}+03 & 1.09 \mathrm{E}+04 & 3.69 \mathrm{E}+02 & 1.09 \mathrm{E}+04 & 5.77 \mathrm{E}+03\end{array}$

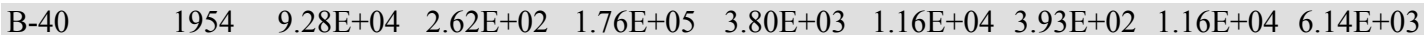
$\begin{array}{lllllllllll}\mathrm{B}-41 & 1954 & 8.15 \mathrm{E}+04 & 2.30 \mathrm{E}+02 & 1.54 \mathrm{E}+05 & 3.34 \mathrm{E}+03 & 1.02 \mathrm{E}+04 & 3.45 \mathrm{E}+02 & 1.01 \mathrm{E}+04 & 5.39 \mathrm{E}+03\end{array}$

$\begin{array}{llllllllll}\mathrm{B}-42 & 1954 & 1.34 \mathrm{E}+05 & 2.21 \mathrm{E}+02 & 2.98 \mathrm{E}+05 & 1.42 \mathrm{E}+02 & 1.76 \mathrm{E}+04 & 3.31 \mathrm{E}+02 & 1.00 \mathrm{E}+04 & 6.08 \mathrm{E}+03\end{array}$ $\begin{array}{lllllllll}\text { Sum } & 8.90 \mathrm{E}+05 & 2.36 \mathrm{E}+03 & 1.73 \mathrm{E}+06 & 3.11 \mathrm{E}+04 & 1.12 \mathrm{E}+05 & 3.53 \mathrm{E}+03 & 1.04 \mathrm{E}+05 & 5.62 \mathrm{E}+04\end{array}$

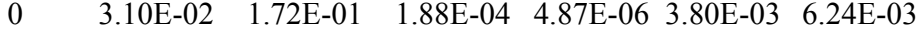

$1.97 \mathrm{E}+02 \quad 1.16 \mathrm{E}+04 \quad 3.61 \mathrm{E}-01 \quad 6.67 \mathrm{E}-04 \quad 9.47 \mathrm{E}-02 \quad 7.81 \mathrm{E}-03$

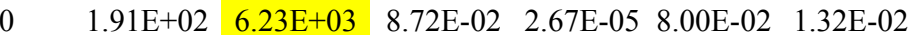

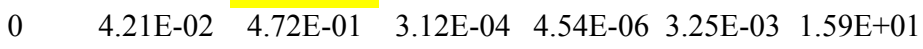

$0 \quad 3.88 \mathrm{E}+02 \quad 1.78 \mathrm{E}+04 \quad 4.49 \mathrm{E}-01 \quad 7.03 \mathrm{E}-04 \quad 1.82 \mathrm{E}-01 \quad 1.59 \mathrm{E}+01$

$\begin{array}{lllllll}0 & 3.63 \mathrm{E}+01 & 3.80 \mathrm{E}+02 & 3.37 \mathrm{E}-01 & 1.87 \mathrm{E}-03 & 2.14 \mathrm{E}-01 & 6.46 \mathrm{E}+00\end{array}$ $\begin{array}{lllllll}6.64 \mathrm{E}+01 & 6.95 \mathrm{E}+02 & 6.16 \mathrm{E}-01 & 3.42 \mathrm{E}-03 & 3.92 \mathrm{E}-01 & 1.18 \mathrm{E}+01\end{array}$ $\begin{array}{llllll}1.48 \mathrm{E}+02 & 1.55 \mathrm{E}+03 & 1.37 \mathrm{E}+00 & 7.62 \mathrm{E}-03 & 8.73 \mathrm{E}-01 & 2.63 \mathrm{E}+01\end{array}$ $\begin{array}{lllllll}4.90 \mathrm{E}+01 & 5.12 \mathrm{E}+02 & 4.54 \mathrm{E}-01 & 2.52 \mathrm{E}-03 & 2.89 \mathrm{E}-01 & 8.72 \mathrm{E}+00\end{array}$ $\begin{array}{lllllll}5.27 \mathrm{E}+01 & 5.52 \mathrm{E}+02 & 4.89 \mathrm{E}-01 & 2.72 \mathrm{E}-03 & 3.11 \mathrm{E}-01 & 9.39 \mathrm{E}+00\end{array}$ $\begin{array}{llllll}5.62 \mathrm{E}+01 & 5.87 \mathrm{E}+02 & 5.21 \mathrm{E}-01 & 2.89 \mathrm{E}-03 & 3.32 \mathrm{E}-01 & 1.00 \mathrm{E}+01\end{array}$ $\begin{array}{llllll}4.93 \mathrm{E}+01 & 5.16 \mathrm{E}+02 & 4.57 \mathrm{E}-01 & 2.54 \mathrm{E}-03 & 2.91 \mathrm{E}-01 & 8.78 \mathrm{E}+00\end{array}$ $\begin{array}{llllll}4.65 \mathrm{E}+01 & 2.58 \mathrm{E}+02 & 2.82 \mathrm{E}-01 & 7.31 \mathrm{E}-03 & 5.70 \mathrm{E}+00 & 9.35 \mathrm{E}+00\end{array}$ $\begin{array}{lllllll}5.04 \mathrm{E}+02 & 5.05 \mathrm{E}+03 & 4.53 \mathrm{E}+00 & 3.09 \mathrm{E}-02 & 8.40 \mathrm{E}+00 & 9.08 \mathrm{E}+01\end{array}$ 
Table 3.24. Total Mass/Activity of Constituents Released from Each Facility to the Subsurface by Localized Regions

\begin{tabular}{|c|c|c|c|c|c|c|c|c|c|c|c|c|c|c|c|c|}
\hline \multirow[b]{2}{*}{ Facility } & \multirow[b]{2}{*}{ Date } & \multicolumn{11}{|c|}{ Inventory (kg) } & \multicolumn{4}{|c|}{ Inventory $\mathrm{Ci}$} \\
\hline & & $\mathrm{Na}$ & $\mathrm{Ca}$ & $\mathrm{NO}_{3}$ & $\mathrm{NO}_{2}$ & $\mathrm{SO}_{4}$ & $\mathrm{CO}_{3}$ & $\mathrm{PO}_{4}$ & $\mathrm{~F}$ & $\mathrm{Fe}(\mathrm{CN})_{6}$ & $\mathrm{U}$ & $\mathrm{Cr}$ & Co-60 & I-129 & Tc-99 & H-3 \\
\hline \multicolumn{17}{|c|}{ BX Tank Farm } \\
\hline BX-101 & 1972 & $1.23 \mathrm{E}+03$ & $5.82 \mathrm{E}+00$ & $7.24 \mathrm{E}+02$ & $1.09 \mathrm{E}+02$ & $6.58 \mathrm{E}+01$ & $2.31 \mathrm{E}+02$ & $1.35 \mathrm{E}+01$ & $3.66 \mathrm{E}-02$ & 0 & 4.54E-01 & $1.50 \mathrm{E}+00$ & $1.16 \mathrm{E}-01$ & $9.06 \mathrm{E}-05$ & $2.48 \mathrm{E}-01$ & $4.81 \mathrm{E}-02$ \\
\hline BX-102 & 1951 & $1.68 \mathrm{E}+04$ & $1.51 \mathrm{E}+02$ & $3.80 \mathrm{E}+03$ & $2.70 \mathrm{E}+02$ & $5.59 \mathrm{E}+03$ & $1.27 \mathrm{E}+04$ & $4.13 E+03$ & $1.31 \mathrm{E}-05$ & 0 & $1.01 \mathrm{E}+04$ & $6.05 \mathrm{E}+01$ & 4.99E-02 & $1.01 \mathrm{E}-03$ & $2.27 \mathrm{E}+00$ & $3.85 \mathrm{E}+00$ \\
\hline BX-108 & 1972 & $8.37 \mathrm{E}+02$ & $1.39 \mathrm{E}+00$ & $6.98 \mathrm{E}+02$ & $3.45 \mathrm{E}+02$ & $7.58 \mathrm{E}+01$ & $9.23 \mathrm{E}+01$ & $5.76 \mathrm{E}+00$ & $4.45 \mathrm{E}-01$ & 0 & 2.87E-01 & $1.37 \mathrm{E}+01$ & $2.17 \mathrm{E}-01$ & $8.88 \mathrm{E}-04$ & $1.18 \mathrm{E}+00$ & $3.32 \mathrm{E}-01$ \\
\hline BX-110 & 1976 & NA & NA & NA & NA & NA & NA & NA & NA & NA & NA & NA & NA & NA & NA & NA \\
\hline \multirow[t]{2}{*}{ BX-111 } & 1984 & NA & NA & NA & NA & NA & NA & NA & NA & NA & NA & NA & NA & NA & NA & NA \\
\hline & Sum & $1.89 \mathrm{E}+04$ & $1.58 \mathrm{E}+02$ & $5.22 \mathrm{E}+03$ & $7.24 \mathrm{E}+02$ & $5.73 \mathrm{E}+03$ & $1.30 \mathrm{E}+04$ & $4.15 \mathrm{E}+03$ & $4.82 \mathrm{E}-01$ & 0 & $1.01 \mathrm{E}+04$ & $7.57 \mathrm{E}+01$ & $3.83 \mathrm{E}-01$ & $1.99 \mathrm{E}-03$ & $3.70 \mathrm{E}+00$ & $4.23 \mathrm{E}+00$ \\
\hline \multicolumn{17}{|c|}{ BY Tank Farm } \\
\hline BY-103 & 1973 & $3.87 \mathrm{E}+02$ & $2.27 \mathrm{E}-01$ & $3.27 \mathrm{E}+02$ & $1.77 \mathrm{E}+02$ & $1.80 \mathrm{E}+01$ & $4.78 \mathrm{E}+01$ & $8.96 \mathrm{E}+00$ & $3.07 \mathrm{E}+00$ & 0 & $4.70 \mathrm{E}-02$ & $4.36 \mathrm{E}+00$ & $3.63 \mathrm{E}-02$ & 4.24E-04 & 2.99E-01 & 1.17E-01 \\
\hline BY-105 & 1984 & NA & NA & NA & NA & NA & NA & NA & NA & NA & NA & NA & NA & NA & NA & NA \\
\hline BY-106 & 1972 & NA & NA & NA & NA & NA & NA & NA & NA & NA & NA & NA & NA & NA & NA & NA \\
\hline BY-107 & 1974 & $1.16 \mathrm{E}+03$ & $6.81 \mathrm{E}-01$ & $9.80 \mathrm{E}+02$ & $5.32 \mathrm{E}+02$ & $5.41 \mathrm{E}+01$ & $1.43 \mathrm{E}+02$ & $2.69 \mathrm{E}+01$ & $9.22 \mathrm{E}+00$ & 0 & $1.41 \mathrm{E}-01$ & $1.31 \mathrm{E}+01$ & $1.09 \mathrm{E}-01$ & $1.27 \mathrm{E}-03$ & 8.98E-01 & $3.51 \mathrm{E}-01$ \\
\hline \multirow[t]{2}{*}{ BY -108} & 1972 & $3.87 \mathrm{E}+02$ & $2.27 \mathrm{E}-01$ & $3.27 \mathrm{E}+02$ & $1.77 \mathrm{E}+02$ & $1.80 \mathrm{E}+01$ & $4.78 \mathrm{E}+01$ & $8.96 \mathrm{E}+00$ & $3.07 \mathrm{E}+00$ & 0 & 4.70E-02 & $4.36 \mathrm{E}+00$ & $3.63 \mathrm{E}-02$ & 4.24E-04 & 2.99E-01 & 1.17E-01 \\
\hline & Sum & $1.93 \mathrm{E}+03$ & $1.14 \mathrm{E}+00$ & $1.63 \mathrm{E}+03$ & $8.86 \mathrm{E}+02$ & $9.01 \mathrm{E}+01$ & $2.39 \mathrm{E}+02$ & $4.48 \mathrm{E}+01$ & $1.54 \mathrm{E}+01$ & 0 & $2.35 \mathrm{E}-01$ & $2.18 \mathrm{E}+01$ & $1.82 \mathrm{E}-01$ & 2.12E-03 & $1.50 \mathrm{E}+00$ & $5.85 \mathrm{E}-01$ \\
\hline \multicolumn{17}{|c|}{ 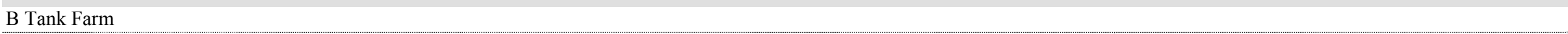 } \\
\hline B-101 & 1974 & NA & NA & NA & NA & NA & NA & NA & NA & NA & NA & NA & NA & NA & NA & NA \\
\hline B-103 & 1978 & NA & NA & NA & NA & NA & NA & NA & NA & NA & NA & NA & NA & NA & NA & NA \\
\hline B-105 & 1978 & NA & NA & NA & NA & NA & NA & NA & NA & NA & NA & NA & NA & NA & NA & NA \\
\hline B-107 & 1965 & $2.04 \mathrm{E}+03$ & $7.20 \mathrm{E}+00$ & $2.35 \mathrm{E}+03$ & $8.07 \mathrm{E}+02$ & $7.53 \mathrm{E}+01$ & $4.25 \mathrm{E}+01$ & $1.73 \mathrm{E}+01$ & $8.56 \mathrm{E}+00$ & 0 & $1.47 \mathrm{E}+00$ & $9.29 \mathrm{E}+00$ & $8.25 \mathrm{E}-01$ & $8.23 \mathrm{E}-03$ & 2.83E-01 & $6.94 \mathrm{E}+00$ \\
\hline B-110 & 1969 & $4.16 \mathrm{E}+02$ & 8.82E-01 & $3.40 \mathrm{E}+02$ & $1.92 \mathrm{E}+02$ & $3.36 \mathrm{E}+01$ & $5.01 \mathrm{E}+01$ & $6.90 \mathrm{E}+00$ & $2.15 \mathrm{E}+00$ & 0 & $1.10 \mathrm{E}-01$ & $5.56 \mathrm{E}+00$ & $8.38 \mathrm{E}-02$ & 4.09E-04 & $5.42 \mathrm{E}-01$ & $1.20 \mathrm{E}-01$ \\
\hline B-111 & 1978 & NA & NA & NA & NA & NA & NA & NA & NA & NA & NA & NA & NA & NA & NA & NA \\
\hline B-112 & 1972 & $6.29 \mathrm{E}+02$ & $1.11 \mathrm{E}+00$ & $5.00 \mathrm{E}+02$ & $2.90 \mathrm{E}+02$ & $6.56 \mathrm{E}+01$ & $6.81 \mathrm{E}+01$ & $5.97 \mathrm{E}+00$ & $1.28 \mathrm{E}+00$ & 0 & 2.17E-01 & $9.89 \mathrm{E}+00$ & $1.65 \mathrm{E}-01$ & $6.05 \mathrm{E}-04$ & $1.02 \mathrm{E}+00$ & $1.81 \mathrm{E}-01$ \\
\hline B-201 & 1965 & $1.26 \mathrm{E}+02$ & $5.13 \mathrm{E}-01$ & $2.93 \mathrm{E}+02$ & $1.36 \mathrm{E}-04$ & $9.63 \mathrm{E}-01$ & $8.52 \mathrm{E}-01$ & $1.04 \mathrm{E}+01$ & $1.75 \mathrm{E}+01$ & 0 & $1.24 \mathrm{E}-04$ & $1.21 \mathrm{E}+00$ & $6.25 \mathrm{E}-07$ & $1.16 \mathrm{E}-10$ & $1.19 \mathrm{E}-07$ & $5.90 \mathrm{E}-10$ \\
\hline B-203 & 1965 & $3.85 \mathrm{E}+01$ & $1.65 \mathrm{E}-01$ & $8.92 \mathrm{E}+01$ & 3.79E-02 & $3.02 \mathrm{E}-01$ & $2.42 \mathrm{E}-01$ & $3.15 \mathrm{E}+00$ & $5.32 \mathrm{E}+00$ & 0 & $2.43 \mathrm{E}-05$ & $3.81 \mathrm{E}-01$ & $1.90 \mathrm{E}-07$ & $2.01 \mathrm{E}-08$ & 3.62E-08 & $2.42 \mathrm{E}-10$ \\
\hline \multirow{2}{*}{ B-204 } & 1965 & $4.34 \mathrm{E}+00$ & $3.32 \mathrm{E}-01$ & $9.43 \mathrm{E}+00$ & $9.96 \mathrm{E}-01$ & $3.55 \mathrm{E}-01$ & $1.54 \mathrm{E}-01$ & $2.35 \mathrm{E}-02$ & $3.98 \mathrm{E}-02$ & 0 & $2.93 \mathrm{E}-05$ & $3.78 \mathrm{E}-01$ & $1.72 \mathrm{E}-09$ & 5.29E-07 & $1.28 \mathrm{E}-09$ & $1.64 \mathrm{E}-09$ \\
\hline & Sum & $3.25 \mathrm{E}+03$ & $1.02 \mathrm{E}+01$ & $3.58 \mathrm{E}+03$ & $1.29 \mathrm{E}+03$ & $1.76 \mathrm{E}+02$ & $1.62 \mathrm{E}+02$ & $4.37 \mathrm{E}+01$ & $3.48 \mathrm{E}+01$ & 0 & $1.80 \mathrm{E}+00$ & $2.67 \mathrm{E}+01$ & $1.07 \mathrm{E}+00$ & $9.24 \mathrm{E}-03$ & $1.85 \mathrm{E}+00$ & $7.24 \mathrm{E}+00$ \\
\hline
\end{tabular}


Table 3.25. Summary Information on Volumes Disposed of and Masses/Activities Released to the Vadose Zone for Subregions of B-Complex

\begin{tabular}{|c|c|c|c|c|c|c|c|c|c|c|c|c|c|c|c|}
\hline $\begin{array}{l}\text { Sub-region } \\
\text { units }\end{array}$ & $\begin{array}{l}\text { Vol Disposed } \\
\text { (ML) }\end{array}$ & $\begin{array}{l}\mathrm{Na} \\
(\mathrm{kg})\end{array}$ & $\begin{array}{l}\mathrm{Ca} \\
(\mathrm{kg})\end{array}$ & $\begin{array}{l}\mathrm{NO} 3 \\
(\mathrm{~kg})\end{array}$ & $\begin{array}{l}\mathrm{NO} 2 \\
(\mathrm{~kg})\end{array}$ & $\begin{array}{l}\mathrm{SO} 4 \\
(\mathrm{~kg})\end{array}$ & $\begin{array}{l}\mathrm{PO} 4 \\
(\mathrm{~kg})\end{array}$ & $\begin{array}{c}\mathrm{F} \\
(\mathrm{kg})\end{array}$ & $\begin{array}{c}\mathrm{Fe}(\mathrm{CN}) 6 \\
(\mathrm{~kg})\end{array}$ & $\begin{array}{c}\mathrm{U} \\
(\mathrm{kg})\end{array}$ & $\begin{array}{c}\mathrm{Cr} \\
(\mathrm{kg}) \\
\end{array}$ & $\begin{array}{c}\text { Co-60 } \\
\text { (Ci) }\end{array}$ & $\begin{array}{c}\mathrm{I}-129 \\
(\mathrm{Ci}) \\
\end{array}$ & $\begin{array}{l}\text { Tc-99 } \\
\text { (Ci) }\end{array}$ & $\begin{array}{l}\mathrm{H}-3 \\
(\mathrm{Ci})\end{array}$ \\
\hline BY Cribs (TBP) & $3.38 \mathrm{E}+01$ & $3.02 \mathrm{E}+06$ & $5.02 \mathrm{E}+03$ & $6.72 \mathrm{E}+06$ & $3.16 \mathrm{E}+03$ & $3.98 \mathrm{E}+05$ & $2.27 \mathrm{E}+05$ & $1.37 \mathrm{E}+05$ & $1.89 \mathrm{E}+04$ & $1.06 \mathrm{E}+03$ & $5.82 \mathrm{E}+03$ & $6.36 \mathrm{E}+00$ & $1.65 \mathrm{E}-01$ & $1.29 \mathrm{E}+02$ & $2.11 \mathrm{E}+02$ \\
\hline $\begin{array}{l}\text { BY Cribs Vicinity } \\
\text { (ITS) }\end{array}$ & $1.39 \mathrm{E}+02$ & $5.22 \mathrm{E}+02$ & $1.83 \mathrm{E}+03$ & $3.87 \mathrm{E}+02$ & $1.56 \mathrm{E}+02$ & $1.07 \mathrm{E}+03$ & $7.89 \mathrm{E}+00$ & $2.03 \mathrm{E}+01$ & $0.00 \mathrm{E}+00$ & 8.82E-02 & $3.90 \mathrm{E}+01$ & $3.20 \mathrm{E}-02$ & $3.73 \mathrm{E}-04$ & $2.63 \mathrm{E}-01$ & $3.21 \mathrm{E}+02$ \\
\hline $\begin{array}{l}\text { B-7-A\&B/B-8 } \\
\text { Cribs }\end{array}$ & $1.10 \mathrm{E}+02$ & $2.24 \mathrm{E}+06$ & $8.96 \mathrm{E}+03$ & $4.65 \mathrm{E}+06$ & $1.58 \mathrm{E}+03$ & $1.30 \mathrm{E}+05$ & $2.60 \mathrm{E}+05$ & $2.67 \mathrm{E}+05$ & $0.00 \mathrm{E}+00$ & $3.88 \mathrm{E}+02$ & $1.78 \mathrm{E}+04$ & 4.49E-01 & $7.03 \mathrm{E}-04$ & $1.82 \mathrm{E}-01$ & $1.59 \mathrm{E}+01$ \\
\hline BX Trenches & $1.49 \mathrm{E}+01$ & $8.90 \mathrm{E}+05$ & $2.36 \mathrm{E}+03$ & $1.73 \mathrm{E}+06$ & $3.11 \mathrm{E}+04$ & $1.12 \mathrm{E}+05$ & $1.04 \mathrm{E}+05$ & $5.62 \mathrm{E}+04$ & $0.00 \mathrm{E}+00$ & $5.04 \mathrm{E}+02$ & $5.05 \mathrm{E}+03$ & $4.53 \mathrm{E}+00$ & $3.09 \mathrm{E}-02$ & $8.40 \mathrm{E}+00$ & $9.08 \mathrm{E}+01$ \\
\hline BX Tank Farm & 4.32E-01 & $1.89 \mathrm{E}+04$ & $1.58 \mathrm{E}+02$ & $5.22 \mathrm{E}+03$ & $7.24 \mathrm{E}+02$ & $5.73 \mathrm{E}+03$ & $4.15 \mathrm{E}+03$ & $4.82 \mathrm{E}-01$ & $0.00 \mathrm{E}+00$ & $1.01 \mathrm{E}+04$ & $7.57 \mathrm{E}+01$ & $3.83 \mathrm{E}-01$ & $1.99 \mathrm{E}-03$ & $3.70 \mathrm{E}+00$ & $4.23 \mathrm{E}+00$ \\
\hline BY Tank Farm & $1.56 \mathrm{E}-01$ & $1.93 \mathrm{E}+03$ & $1.14 \mathrm{E}+00$ & $1.63 \mathrm{E}+03$ & $8.86 \mathrm{E}+02$ & $9.01 \mathrm{E}+01$ & $4.48 \mathrm{E}+01$ & $1.54 \mathrm{E}+01$ & $0.00 \mathrm{E}+00$ & $2.35 \mathrm{E}-01$ & $2.18 \mathrm{E}+01$ & $1.82 \mathrm{E}-01$ & $2.12 \mathrm{E}-03$ & $1.50 \mathrm{E}+00$ & $5.85 \mathrm{E}-01$ \\
\hline Tank Farm & $2.28 \mathrm{E}-01$ & $3.25 \mathrm{E}+03$ & $1.02 \mathrm{E}+01$ & $3.58 \mathrm{E}+03$ & $1.29 \mathrm{E}+03$ & $1.76 \mathrm{E}+02$ & $4.37 \mathrm{E}+01$ & $3.48 \mathrm{E}+01$ & $0.00 \mathrm{E}+00$ & $1.80 \mathrm{E}+00$ & $2.67 \mathrm{E}+01$ & $1.07 \mathrm{E}+00$ & $9.24 \mathrm{E}-03$ & $1.85 \mathrm{E}+00$ & $7.24 \mathrm{E}+00$ \\
\hline $\begin{array}{c}\text { B Complex Grand } \\
\text { Total }\end{array}$ & $2.98 \mathrm{E}+02$ & $6.18 \mathrm{E}+06$ & $1.83 \mathrm{E}+04$ & $1.31 \mathrm{E}+07$ & $3.89 \mathrm{E}+04$ & $6.47 \mathrm{E}+05$ & $5.95 \mathrm{E}+05$ & ${ }_{4} \cdot 60_{\mathrm{E}}+05$ & $1.8{ }_{9} \mathrm{E}+04$ & $1.21_{\mathrm{E}}+04$ & $2.89 \mathrm{E}+04$ & $1.30 \mathrm{E}+01$ & $2.10 \mathrm{E}-01$ & $1.44 \mathrm{E}+02$ & $6.51 \mathrm{E}+02$ \\
\hline Sub-region & $\begin{array}{c}\text { Vol Disposed } \\
(\%)\end{array}$ & $\begin{array}{l}\mathrm{Na} \\
(\%)\end{array}$ & $\begin{array}{l}\mathrm{Ca} \\
(\%)\end{array}$ & $\begin{array}{l}\text { NO3 } \\
(\%)\end{array}$ & $\begin{array}{l}\mathrm{NO} 2 \\
(\%)\end{array}$ & $\begin{array}{l}\mathrm{SO} 4 \\
(\%)\end{array}$ & $\begin{array}{l}\mathrm{PO} 4 \\
(\%)\end{array}$ & $\begin{array}{l}F \\
(\%)\end{array}$ & $\begin{array}{l}\mathrm{Fe}(\mathrm{CN}) 6 \\
(\%)\end{array}$ & $\begin{array}{c}\mathrm{U} \\
(\%)\end{array}$ & $\begin{array}{l}\mathrm{Cr} \\
(\%)\end{array}$ & $\begin{array}{c}\text { Co-60 } \\
(\%)\end{array}$ & $\begin{array}{c}\mathrm{I}-129 \\
(\%)\end{array}$ & $\begin{array}{c}\text { Tc-99 } \\
(\%)\end{array}$ & $\begin{array}{l}\mathrm{H}-3 \\
(\%)\end{array}$ \\
\hline BY Cribs (TBP) & $11.30 \%$ & $48.9 \%$ & $27.4 \%$ & $51.3 \%$ & $8.10 \%$ & $61.5 \%$ & $38.1 \%$ & $29.8 \%$ & $100 \%$ & $8.80 \%$ & $20.2 \%$ & $48.9 \%$ & $78.4 \%$ & $89.0 \%$ & $32.4 \%$ \\
\hline $\begin{array}{l}\text { BY Cribs Vicinity } \\
\text { (ITS) }\end{array}$ & $46.7 \%$ & $0.00 \%$ & $10.0 \%$ & $0.00 \%$ & $0.40 \%$ & $0.20 \%$ & $0.00 \%$ & $0.00 \%$ & $0.00 \%$ & $0.00 \%$ & $0.10 \%$ & $0.20 \%$ & $0.20 \%$ & $0.20 \%$ & $49.3 \%$ \\
\hline $\begin{array}{l}\text { B-7-A\&B/B-8 } \\
\text { Cribs Farm }\end{array}$ & $36.7 \%$ & $36.3 \%$ & $48.8 \%$ & $35.5 \%$ & $4.10 \%$ & $20.0 \%$ & $43.6 \%$ & $58.0 \%$ & $0.00 \%$ & $3.20 \%$ & $61.8 \%$ & $3.40 \%$ & $0.30 \%$ & $0.10 \%$ & $2.40 \%$ \\
\hline BX Trenches & $5.00 \%$ & $14.4 \%$ & $12.9 \%$ & $13.2 \%$ & $80.0 \%$ & $17.3 \%$ & $17.5 \%$ & $12.2 \%$ & $0.00 \%$ & $4.20 \%$ & $17.5 \%$ & $34.8 \%$ & $14.7 \%$ & $5.80 \%$ & $14.0 \%$ \\
\hline BX Tank Farm & $0.15 \%$ & $0.30 \%$ & $0.90 \%$ & $0.00 \%$ & $1.90 \%$ & $0.90 \%$ & $0.70 \%$ & $0.00 \%$ & $0.00 \%$ & $83.8 \%$ & $0.30 \%$ & $2.90 \%$ & $0.90 \%$ & $2.60 \%$ & $0.70 \%$ \\
\hline BY Tank Farm & $0.05 \%$ & $0.00 \%$ & $0.00 \%$ & $0.00 \%$ & $2.30 \%$ & $0.00 \%$ & $0.00 \%$ & $0.00 \%$ & $0.00 \%$ & $0.00 \%$ & $0.10 \%$ & $1.40 \%$ & $1.00 \%$ & $1.00 \%$ & $0.10 \%$ \\
\hline B Tank Farm & $0.08 \%$ & $0.10 \%$ & $0.10 \%$ & $0.00 \%$ & $3.30 \%$ & $0.00 \%$ & $0.00 \%$ & $0.00 \%$ & $0.00 \%$ & $0.00 \%$ & $0.10 \%$ & $8.30 \%$ & $4.40 \%$ & $1.30 \%$ & $1.10 \%$ \\
\hline $\begin{array}{l}\text { B Complex Grand } \\
\text { Total }\end{array}$ & $100 \%$ & $100 \%$ & $100 \%$ & $100 \%$ & $100 \%$ & $100 \%$ & $100 \%$ & $100 \%$ & $100 \%$ & $100 \%$ & $100 \%$ & $100 \%$ & $100 \%$ & $100 \%$ & $100 \%$ \\
\hline
\end{tabular}


volumes of liquids, but the wastes were very dilute. Thus, the BY Cribs subregion tables are split into two parts to reflect the differences in masses of constituents released to the subsurface for the concentrated scavenged wastes versus the dilute wastes. For several of the SSTs, there are no data on the masses or activities released (those designated NA in Table 3.15, Table 3.21, and Table 3.22) because the time of the release is not available, and whether any volume actually was released is questionable. In the future should the formalized process of revisiting releases from these SSTs (see Field et al. 2007) decide that releases did occur, the data in Table 3.24 and Table 3.25 will be revised to update the release estimates of constituents and waste liquid volumes from SSTs to the vadose zone below the B Complex.

Some general observations with implications to the conceptual model for contaminant distributions below the B-Complex that can be gleaned from these two summary tables and historical documents follow. The two localized regions with the largest volumes of waste released are the BY Cribs subregion and the B-7-A\&B Cribs subregion. These two subregions account for almost $96 \%$ of the waste volume released to the B-Complex. In terms of volume of fluids released per square meter of facility footprints, the BY Cribs (with a total area of $672 \mathrm{~m}^{2}$ ) received a total of 33.8 million-liters of scavenged waste liquids or the equivalent of a water column $30 \mathrm{ft}$ square and $50 \mathrm{~m}$ high. This waste volume when added to the vadose zone $\mathrm{H} 2$ sand unit, with a total porosity of 0.25 , would fill a sediment column $200 \mathrm{~m}$ thick or ( $\sim 660 \mathrm{ft})$. With the water table being $\sim 230 \mathrm{ft}$ bgs, it is calculated that the waste disposed of to the BY Cribs would have to spread out over an area more than three times larger than the footprint of the excavation (or $2016 \mathrm{~m}^{2}$ ) to not reach $230 \mathrm{ft}$ bgs. If the cribs had been used with the specific retention concept where only $10 \%$ of the volume of the facility cross section would have been used, the area to avoid contacting the water table would need to be increased by another factor of 2.5 (total porosity $0.25 / 0.1$ ) or a total area of $\sim 7.5$ times larger than the BY cribs excavation footprint $\left(4704 \mathrm{~m}^{2}\right)$.

For comparison, the BX Trenches that were operated using the specific retention concept received on average $7.9 \mathrm{~m}$ of liquid to their footprints. This column of water would fill all the pores (again assuming a porosity of 0.25$)$ to a depth of $31.8 \mathrm{~m}(104 \mathrm{ft})$. Given a depth to water of $\sim 230 \mathrm{ft}$ and the fact that the trench bottoms are $\sim 20 \mathrm{ft}$ below ground, the total volume of fluid disposed of to the BX Trenches would fill all the pores below the footprint to a depth of about $124 \mathrm{ft}$ bgs, leaving $\sim 105 \mathrm{ft}$ of deep vadose zone with unfilled pores. Of course, the vadose zone sediments do not saturate uniformly or retain all the waste liquids when fluids are discharge to them, but this simple concept illustrates that much of the waste fluids disposed of to the BY Cribs likely reached the groundwater during the active disposal period while little of the waste fluids disposed of to the BX Trenches likely reached the groundwater.

The B-7-A\&B cribs and B-11-A\&B French Drains received the most liquid to their actual footprints in the B-Complex based on the total volumes disposed of and the cross sectional areas of these facilities. The waste liquids disposed of to these two facilities' footprints would represent water columns that are 1,670 and 12,680 m tall, respectively. When added to the vadose zone $\mathrm{H} 2$ sediments these water columns would saturate the pores in a sediment column four times thicker than these two very large numbers. If it is assumed that the liquids percolated vertically only below the footprint of the facilities, then most of the waste liquids would certainly have reached groundwater during their period of operation because the water table is only about $260 \mathrm{ft}$ bgs. Early groundwater monitoring status reports (listed in Table 1.2 and discussed in Section 5) show that the water table below the BY Cribs, B-7-A\&B Cribs, and B-11-A\&B French Drains was quickly penetrated by 
wastes within a few months of disposal site operation. A large groundwater plume of gross beta was monitored below these two facilities beginning in the mid 1950s through the mid 1960s. The groundwater plumes from these two facilities were fully commingled by the time that groundwater monitoring reports were published in 1956. These early monitoring reports portray the gross beta groundwater data as one cohesive plume.

In terms of masses of contaminants released, the two subregions (BY Cribs and B-7-A \&B/B-8 Cribs) account for $87 \%$ of the nitrate (with the BY cribs contributing $49 \%$ ), $88 \%$ of the fluoride (the B-7-A\&B and B-8 Cribs contributing 58\%), 100\% of the ferrocyanide (BY Cribs exclusively), $82 \%$ of the chromium (B-7-A\&B/B-8 Cribs at $62 \%$ ), $89 \%$ of the technetium-99 (BY Cribs exclusively), and $84 \%$ of the tritium (BY Cribs with $81.7 \%$ ). It is important to note that only $12 \%$ of the total uranium came from these three facilities, as the remaining $84 \%$ of the total mass of uranium released in the B-Complex area came from the BX-102 Tank overfill event. Other chemicals released are also concentrated in three subregions, with the BY Cribs and the B-7-A\&B/B-8 Cribs regions generally receiving the bulk. The details on percentages of the total mass/activity released to the B-Complex follow: sodium, $86 \%, 49 \%$ to the BY Cribs and $37 \%$ to the B-7-A\&B/B-8 Cribs ; sulfate, $99 \%(62 \%$ to the BY cribs, $20 \%$ to the B-7$\mathrm{A} \& \mathrm{~B}$ and $\mathrm{B}-8 \mathrm{Cribs}$, and $17 \%$ to the $\mathrm{BX}$ Trenches). The breakdown of where the other two mobile radionuclides, iodine-129 and cobalt -60 were released also shows the BY Cribs and BX Trenches dominate. For iodine-129, 94\% was released to these two subregions (with $79 \%$ to the BY Cribs and $14.7 \%$ to the BX Trenches). For cobalt- $60,92 \%$ of the total activity was released to three subregions ( $49 \%$ to the BY Cribs, 35\% to the BX Trenches, and $8 \%$ to the B Tank Farm. All of these estimates were used in developing the conceptual model on how the contaminants reached the groundwater and dispersed to generate the groundwater plume(s) observed today. 



\subsection{Hydraulic Properties of the Vadose Zone and Unconfined Aquifer}

This section summarizes hydraulic and transport parameter values for both the vadose zone and the unconfined aquifer in the vicinity of the B-Complex. Parameter values estimated from laboratory tests of sediment samples are provided for the four stratigraphic facies presented in Figure $2.5\left(\mathrm{H} 1, \mathrm{H} 2, \mathrm{CCU}_{\mathrm{z}}\right.$, $\left.\mathrm{CCU}_{\mathrm{g}}\right)$ in addition to the fine-grained layers $(\mathrm{H} 2 \mathrm{~F} 1, \mathrm{H} 2 \mathrm{~F} 2$, and H2F3) and backfill material. Saturated hydraulic conductivity values for the aquifer are also provided from in situ pumping tests, slug tests, and analysis of well development pumping at wells in and near the B-Complex. Hydraulic and transport parameters required for predictive modeling are dependent on the code to be used. Currently, the code or set of codes to be used for subsurface flow and contaminant transport in the B-Complex have not been defined.

This section also defines best estimates of recharge rates for near-surface soil types and vegetated conditions existing within the B-Complex to serve as a model for upper boundary conditions for future flow and contaminant transport modeling.

\subsection{Methodology}

\subsubsection{Laboratory Methods}

Laboratory-scale measurements were made on intact cores (dimensions 4-in. dia. by 6 in. long) or aliquots of the sediments from the cores after dismantling the cores. Numerous measurements summarized below and described in more detail in Appendix $C$ were performed to augment the available data sets on hydrologic and physical parameters on sediments from the B-Complex region. Before this work, the data set for sediments from the B-Complex was very sparse.

\subsubsection{Field-Scale Methods}

Field-scale saturated hydraulic conductivity values for the unconfined aquifer sediments were derived from in situ pumping tests, slug tests, and analysis of well development pumping at wells in and near the B-Complex using methods described in Moench (1997), Thorne et al. (2006), and Newcomer (2008).

\subsection{Laboratory-Scale Results}

Hydraulic and physical analysis methods and results for the 200-BP-5 RI/FS cores are provided in Appendix C. Samples were assigned to a stratigraphic unit based on geologic interpretation and comparing sample depth to the formation contours in Appendix B. A total of 30 samples representing the $\mathrm{H} 1$ unit $(\mathrm{n}=7), \mathrm{H} 2$ unit $(\mathrm{n}=10), \mathrm{H} 2 \mathrm{~F}$ fine-grained layers $(\mathrm{n}=2), \mathrm{CCU}_{\mathrm{z}}(\mathrm{n}=2)$, and $\mathrm{CCU}_{\mathrm{g}}(\mathrm{n}=9)$ were used to develop the parameter dataset. A review of published hydraulic parameter datasets did not reveal any samples identified as being backfill material. As an alternative, parameters generated for $\mathrm{CCU}_{\mathrm{g}}$ unit material are also assigned to backfill material as suggested by Khaleel (2007). Arithmetic and geometric mean parameter values were calculated for normal and log normal distributed data, respectively. Maximum and minimum ranges were calculated as being \pm one standard deviation from the mean 
parameter. For stratigraphic units in which the sample size was insufficient to calculate standard deviation, the maximum and minimum reported parameter values were used.

Published hydraulic parameter datasets (see Khaleel 2007, Last et al. 2006) overwhelmingly use the van Genuchten (1980) parametric model to describe the soil-water/matric potential relationship (i.e., soilwater retention characteristics). The van Genucthen (1980) model is of the form:

$$
\theta=\theta_{r}+\frac{\left(\theta_{s}-\theta_{r}\right)}{\left[1+(\alpha \varphi)^{n}\right]^{m}}
$$

where $\theta=$ water content $\left(\mathrm{cm}^{3} / \mathrm{cm}^{3}\right)$

$\theta_{\mathrm{s}}=$ saturated water content $\left(\mathrm{cm}^{3} / \mathrm{cm}^{3}\right)$

$\theta_{\mathrm{r}}=$ residual water content $\left(\mathrm{cm}^{3} / \mathrm{cm}^{3}\right)$

$\alpha=$ curve-fitting parameter $(1 / \mathrm{cm})$

$\varphi=$ matric potential $(-\mathrm{cm})$

$\mathrm{n}=$ curve-fitting parameter $(-)$

$\mathrm{m}=1-(1 / \mathrm{n})$.

The van Genuchten model is used in this report because of its prevalence of use and its flexibility in describing measured water-retention data. However, some codes use a different water-retention model based on Campbell (1974). RESRAD is one such code and uses the Campbell empirical parameter b as follows to calculate the hydraulic conductivity for unsaturated sediments from water retention data (see http://web.ead.anl.gov/resrad/documents/data_collection.pdf) for more details: :

$$
\frac{K}{K_{s a t}}=\left\langle\frac{\theta}{\theta_{s}}\right\rangle^{(2 b+3)}
$$

where $\theta=$ water content $\left(\mathrm{cm}^{3} / \mathrm{cm}^{3}\right)$

$\theta_{\mathrm{s}}=$ saturated water content $\left(\mathrm{cm}^{3} / \mathrm{cm}^{3}\right)$

$\mathrm{K}=$ hydraulic conductivity at unsaturated water content $\left(\mathrm{cm}^{3} / \mathrm{cm}^{3}\right)$

$\mathrm{K}_{\mathrm{s}}=$ Hydraulic conductivity at saturation $(1 / \mathrm{cm})$

$\mathrm{b}=$ Campbell empirical parameter (unitless)

In addition to these parameters, other hydraulic and transport parameters for numerical modeling are:

- total porosity $\left(\mathrm{p}_{\mathrm{t}}\right)$

- effective porosity $\left(\mathrm{p}_{\mathrm{e}}\right)$

- field capacity $\left(\mathrm{q}_{\mathrm{fc}}\right)$.

- particle density $\left(\rho_{\mathrm{p}}\right)$

- saturated hydraulic conductivity $\left(\mathrm{K}_{\mathrm{s}}\right)$

- dispersivity (A). 


\subsubsection{Van Genuchten Water-Retention Parameters and $\mathrm{K}_{\mathrm{s}}$}

Various efforts have tabulated datasets containing van Genuchten parameters and measured $\mathrm{K}_{\mathrm{s}}$ for the different stratigraphic units identified at Hanford (Connelly et al. 1992, Khaleel 2007, Khaleel and Freeman 1995, Last et al. 2006). Connelly et al. (1992) tabulated van Genuchten parameters and $\mathrm{K}_{\mathrm{s}}$ measurements for 60 cores collected throughout the 200 East Area in support of the 200 East Ground Water Aggregate Area Management Study. Khaleel and Freeman (1995) cataloged moisture retention data and $\mathrm{K}_{\mathrm{s}}$ measurements for 183 samples in the 200 East and West Areas, including the samples presented in Connelly et al. (1992). Mean van Genuchten parameters and $\mathrm{K}_{\mathrm{s}}$ were developed for six soil categories. Last et al. (2006) compiled van Genuchten parameters and $\mathrm{K}_{\mathrm{s}}$ datasets, including those in Khaleel and Freeman (1995), for over 250 samples and calculated statistics for 10 soil classes, grouping datasets by several categories, including site-wide, $200 \mathrm{West}$, and various WMAs. However, their analysis did not generate parameters specific to the 200 East Area or the B-Complex area. Khaleel (2007) includes the tabulated hydraulic data from Khaleel and Freeman (1995) as well as datasets used in past tank farm assessments. The data provided in Khaleel (2007) are the primary source for data used in developing the water retention and $\mathrm{K}_{\mathrm{s}}$ recommendations in this report because of the detail in hydraulic and physical property information and uniformity in analysis methods for the cores that were characterized.

Mean and maximum /minimum ranges of van Genuchten parameters and $\mathrm{K}_{\mathrm{s}}$ for the B-Complex were derived from measurements performed on cores recently collected within and adjacent to the B-Complex area. This includes cores described in Khaleel (2007) as being from the 200-BP-1 OU and cores collected as part of the 200-BP-5 RI/FS characterization program (Appendix C). In total, 26 water-retention samples and $30 \mathrm{~K}_{\mathrm{s}}$ measurements were used for this analysis. Sample and borehole ID as well as fitted van Genuchten parameters and measured $\mathrm{K}_{\mathrm{s}}$ values for samples selected for this analysis are presented at the end of Appendix C. Parameter statistics were generated with $\theta_{\mathrm{r}}, \theta_{\mathrm{s}}$, and $\mathrm{n}$ assumed as having normal Gaussian distributions while $\alpha$ and $\mathrm{K}_{\mathrm{s}}$ are treated as having lognormal distributions (Khaleel and Freeman 1995). The mean and maximum and minimum ranges for van Genuchten parameters and $\mathrm{K}_{\mathrm{s}}$ are presented in Table 4.1. Mean soil-water retention curves for each stratigraphic unit are presented in Figure 4.1. Predicted unsaturated hydraulic conductivity relationships calculated from the mean water-retention parameters using the van Genuchten (1980)-derived solution to the Mualem (1976) model are shown in Figure 4.2.

\subsubsection{Particle Density}

Particle density is defined as the ratio of the total mass of soil to the total volume of solids. Particle densities for Hanford soils typically range from 2.65 to $2.78 \mathrm{~g} / \mathrm{cm}^{3}$; however, a value of $2.65 \mathrm{~g} / \mathrm{cm}^{3}$ is often assumed, this being the specific gravity of quartz, which is the predominant mineral in Hanford soils. Particle density is not reported for the water retention and $\mathrm{K}_{\mathrm{s}}$ samples in Khaleel (2007); however, given the relatively small variation in particle density for the vadose zone and upper aquifer cores collected as part of the 200-BP-5 RI/FS characterization program (Appendix C), an average particle density was calculated from the $\mathrm{H} 2$ and $\mathrm{CCU}_{\mathrm{g}}$ cores in Appendix $\mathrm{C}$ and assumed to apply to all stratigraphic units. This approach produced an average particle density of $2.70 \mathrm{~g} / \mathrm{cm}^{3}$. 
Table 4.1. B-Complex Mean and Maximum/Minimum Ranges for van Genuchten Parameters and $\mathrm{K}_{\mathrm{s}}$

\begin{tabular}{ccccccc}
\hline \multicolumn{2}{c}{ Stratigraphic Unit } & $\mathrm{a}(1 / \mathrm{cm})$ & $\mathrm{n}(-)$ & $\theta_{\mathrm{r}}\left(\mathrm{cm}^{3} / \mathrm{cm}^{3}\right)$ & $\theta_{\mathrm{s}}\left(\mathrm{cm}^{3} / \mathrm{cm}^{3}\right)$ & $\mathrm{K}_{\mathrm{s}}(\mathrm{cm} / \mathrm{s})$ \\
\hline \multirow{3}{*}{$\mathrm{H} 1$} & Mean & 0.0073 & 1.5877 & 0.0180 & 0.1207 & $2.20 \mathrm{E}-04$ \\
& + SD & 0.0177 & 1.7487 & 0.0278 & 0.1728 & $1.77 \mathrm{E}-03$ \\
& - SD & 0.0030 & 1.4267 & 0.0082 & 0.0686 & $2.73 \mathrm{E}-05$ \\
$\mathrm{H} 2$ & Mean & 0.0157 & 1.8882 & 0.0309 & 0.2515 & $1.18 \mathrm{E}-04$ \\
& + SD & 0.0315 & 2.2995 & 0.0431 & 0.3565 & $4.04 \mathrm{E}-04$ \\
& - SD & 0.0078 & 1.4769 & 0.0187 & 0.1466 & $3.44 \mathrm{E}-05$ \\
\hline \multirow{3}{*}{${\mathrm{H} 2 \mathrm{~F}^{(\mathrm{a})}}$} & Mean & 0.0068 & 1.7865 & 0.0233 & 0.3345 & $9.31 \mathrm{E}-05$ \\
& Max & 0.0146 & 1.9371 & 0.0314 & 0.3904 & $1.35 \mathrm{E}-04$ \\
& Min & 0.0032 & 1.6359 & 0.0151 & 0.2786 & $6.43 \mathrm{E}-05$ \\
$\mathrm{CCUz}^{(\text {a) }}$ & Mean & 0.0046 & 1.7669 & 0.0249 & 0.3763 & $1.22 \mathrm{E}-05$ \\
& Max & 0.0185 & 1.8757 & 0.0463 & 0.5319 & $1.47 \mathrm{E}-04$ \\
& Min & 0.0011 & 1.6580 & 0.0035 & 0.2207 & $1.01 \mathrm{E}-06$ \\
\hline \multirow{3}{*}{ Backfill / CCUg-0 } & Mean & 0.0061 & 1.5709 & 0.0103 & 0.1212 & $3.08 \mathrm{E}-04$ \\
& + SD & 0.0116 & 1.7471 & 0.0191 & 0.1838 & $2.00 \mathrm{E}-03$ \\
& $-\mathrm{SD}$ & 0.0033 & 1.3947 & 0.0015 & 0.0586 & $4.75 \mathrm{E}-05$ \\
\hline
\end{tabular}

(a) Sample size insufficient to calculate standard deviation; values should be used for all three fine-grained layers in $\mathrm{H} 2$ sediments described in Section 3.

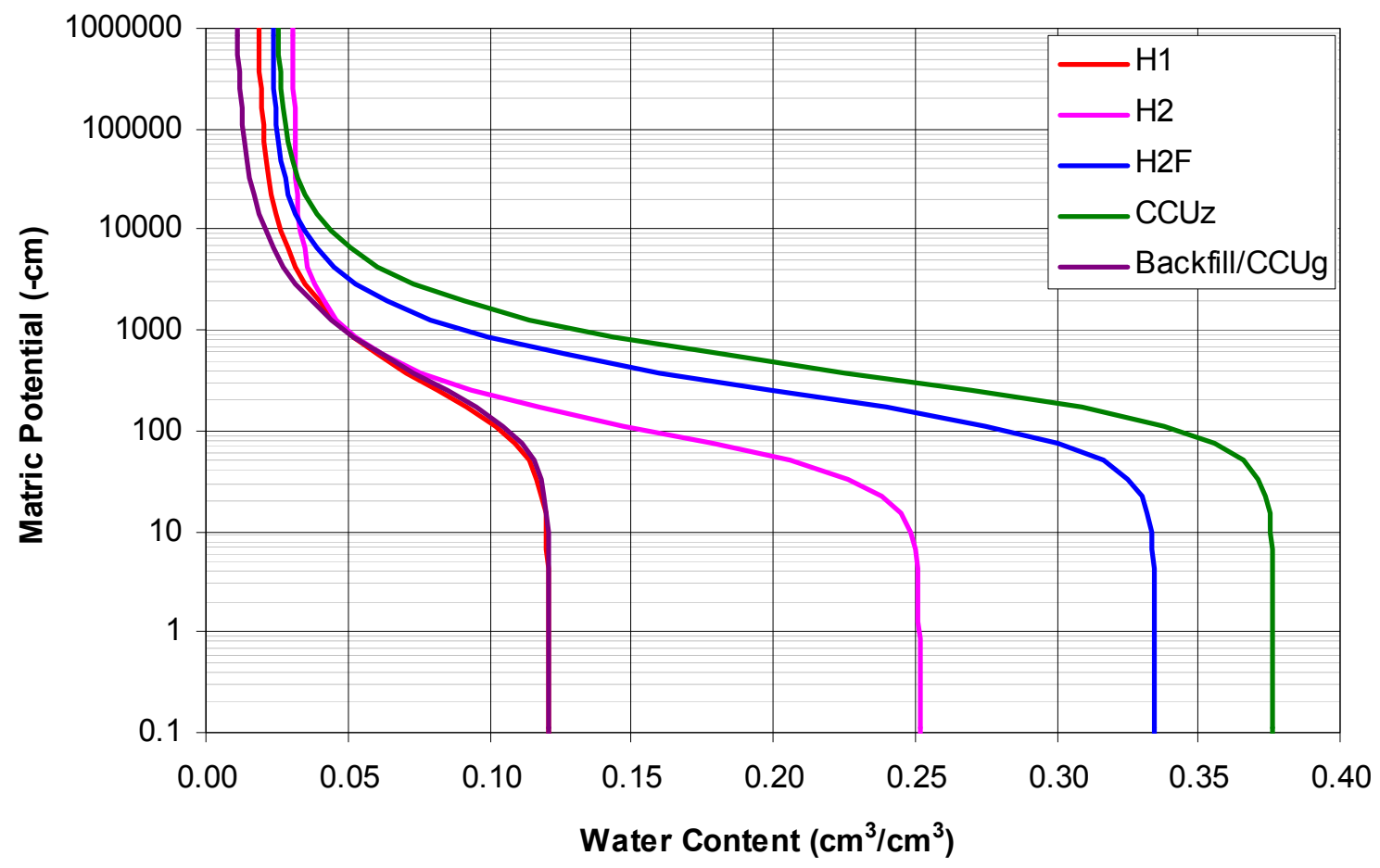

Figure 4.1. Mean van Genuchten Parameter Soil-Water Retention Characteristics for each Stratigraphic Unit 


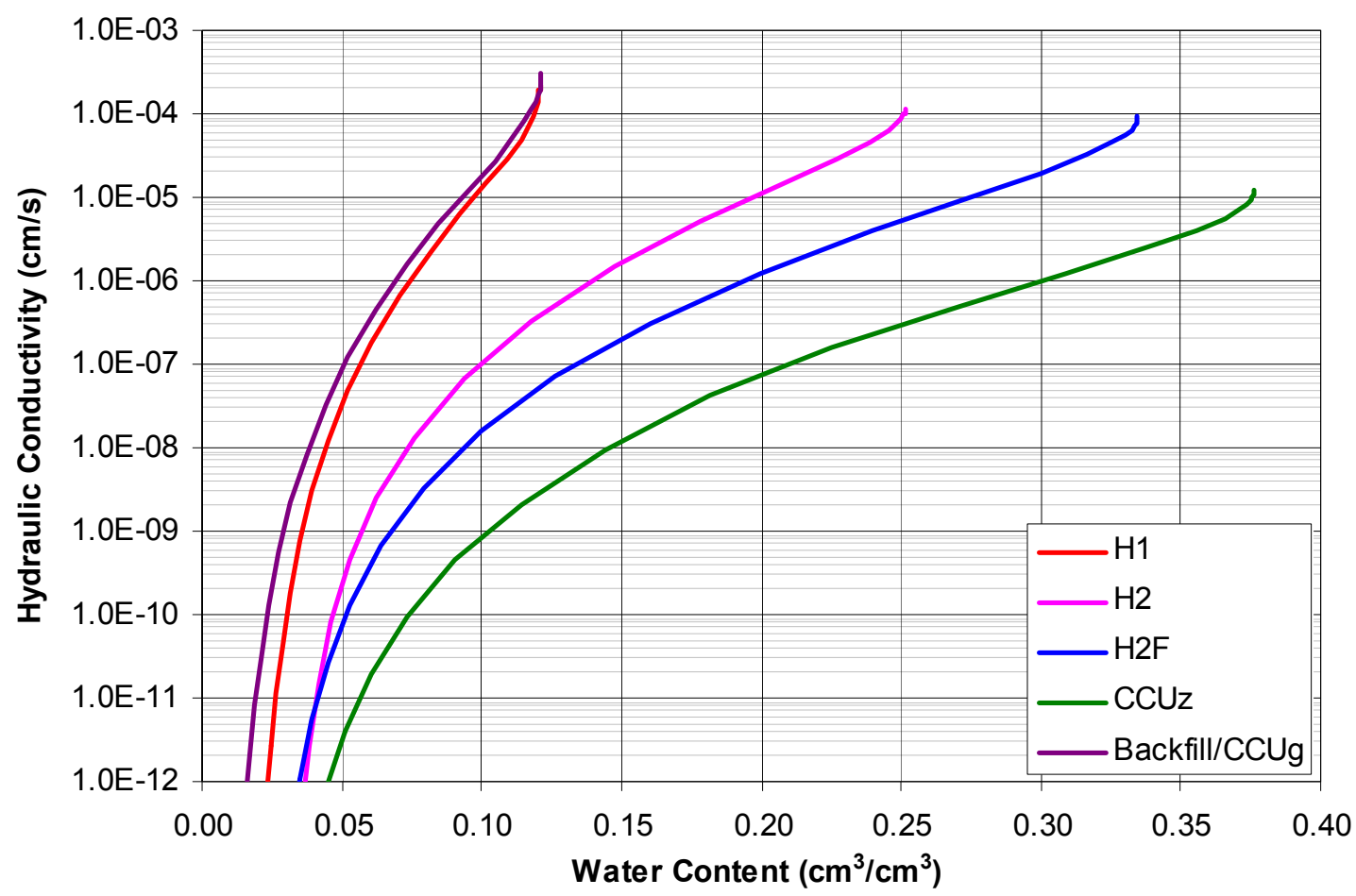

Figure 4.2. Predicted Unsaturated Hydraulic Conductivity Relationships Calculated from the Mean Water-Retention Parameters

\subsubsection{Bulk Density}

Bulk density is defined as the ratio of the total mass of dry soil to the total soil volume (solids and pores). Bulk density typically varies with soil texture, with coarser textured soils having a higher bulk density than finer textured soils. In situ bulk density values are not reported for the water retention and $\mathrm{K}_{\mathrm{s}}$ samples in Khaleel (2007); however, he does tabulate and classify based on stratigraphic unit bulk density values for a subset of samples collected throughout the 200 East and 200 West Areas. These bulk density data have been used in previous tank farm assessment data packages (Khaleel et al. 2001; Khaleel et al. 2006) and for this reason are deemed suitable for the B-Complex area. The Khaleel (2007) bulk density data were combined with the measured bulk density for the $\mathrm{H} 2$ and $\mathrm{CCU}_{\mathrm{g}}$ cores collected as part of the 200-BP-5 RI/FS characterization program (Appendix C) to derive mean and maximum/minimum ranges of the bulk density for each stratigraphic unit. Sample and borehole IDs as well as bulk densities for samples used to calculate bulk density statistics are presented in Appendix D. Bulk-density statistics were calculated assuming a normal Gaussian distribution (Khaleel and Freeman 1995). Table 4.2 lists the mean and maximum/minimum ranges of bulk density.

\subsubsection{Total and Effective Porosity}

Total porosity is the ratio of the volume of soil voids (pores) to the total soil volume (solids and pores). Total porosity is equivalent to: 


$$
p_{t}=1-\frac{\rho_{b}}{\rho_{s}}
$$

The total porosity of coarser textured soils is typically less than that of finer textured soils. Calculated total porosities using Equation (4.2) and the bulk density data in Table 4.2 do not always correspond, likely because the dataset used to develop bulk density estimates differs from the water-retention dataset. To provide consistency with the van Genuchten data set used in this report, the total porosity is defined as being equal to the saturated water-content values reported in Table 4.1. Others (e.g., Last et al. 2009) do not ascribe to this definition. Rather they state that "Most assessment data packages use $\theta_{\mathrm{s}}$ as an estimate of total porosity because that is the most complete data set available. Using $\theta_{\mathrm{s}}$ as an estimate for $\mathrm{p}_{\mathrm{t}}$ generally is not recommended because in many cases this may be a fitted parameter representing an unconstrained fit of water retention data (Schaap et al. 2003)." Klute (1986) states that $\theta_{\mathrm{s}}$ is typically $80 \%$ to $90 \%$ of the total porosity because of entrapped or encapsulated air, but this is soil-dependent.

Table 4.2. B-Complex Mean and Maximum/Minimum Ranges of Bulk Density $\left(\rho_{\mathrm{b}}\right)$

\begin{tabular}{ccc}
\hline Stratigraphic Unit & & $\rho_{\mathrm{b}}\left(\mathrm{g} / \mathrm{cm}^{3}\right)$ \\
\hline \multirow{2}{*}{$\mathrm{H} 1$} & Mean & 2.07 \\
& $+\mathrm{SD}$ & 2.18 \\
& $-\mathrm{SD}$ & 1.95 \\
\hline \multirow{2}{*}{$\mathrm{H} 2$} & Mean & 1.77 \\
& $+\mathrm{SD}$ & 1.89 \\
& $-\mathrm{SD}$ & 1.65 \\
\hline \multirow{2}{*}{$\mathrm{H}^{2} \mathrm{~F}^{(\mathrm{a})}$} & Mean & 1.85 \\
& Max & 1.91 \\
& Min & 1.79 \\
\hline \multirow{2}{*}{$\mathrm{CCUz}$} & Mean & 1.65 \\
& $+\mathrm{SD}$ & 1.71 \\
& $-\mathrm{SD}$ & 1.60 \\
\hline \multirow{2}{*}{ Backfill/CCUg } & Mean & 2.15 \\
& $+\mathrm{SD}$ & 2.27 \\
& $-\mathrm{SD}$ & 2.03 \\
\hline
\end{tabular}

(a) Sample size insufficient to calculate standard deviation; values should be used for all three fine-grained layers in $\mathrm{H} 2$ sediments described in Section 3.

Effective porosity refers to the pore volume that actively conveys water. Effective porosity is typically less than saturated porosity because of discontinuous pores. Effective porosity data for Hanford sediments are limited and generally not specified in assessment data packages. DOE/RL (2007b) specified an effective porosity value for the 200-CS-1 OU feasibility study as being equal to the total porosity. However, this most likely overestimates the actual effective porosity, which would lead to overestimating transport times. Instead, the relationship that effective porosity is equivalent to the total porosity minus the residual water content (Stephens et al. 1998) was used. Table 4.3 lists the mean and maximum and minimum ranges of total and effective porosity for each stratigraphic unit based on the laboratory measurements. 


\subsubsection{Field Capacity}

Field capacity is the water content at which soil water drainage becomes negligible. Measurements of field capacity for Hanford sediments are sparse. As an alternative to measured field capacity, Last et al. (2009) estimated field capacity using three different methods: 1 ) assuming field capacity to be equivalent to the water content at a soil matric potential of $1 / 3$ bar $(340 \mathrm{~cm}), 2)$ assuming field capacity to be the water content at which the unsaturated hydraulic conductivity equals $10^{-8} \mathrm{~cm} / \mathrm{s}$, and 3 ) assuming that field capacity is equal to residual water content. Last et al. (2009) observed that for conservative transport calculations, the estimation method providing the largest field capacity should be used; they found that the largest field capacity was estimated when using the $1 / 3$ bar method in all but two of their cases.

Following the recommendation by Last et al. (2009), the field capacity for each van Genuchten parameter sample in Appendix D was estimated by calculating the water content at $1 / 3$ bar. Sample and borehole ID as well as estimated field capacities used to calculate field capacity statistics are presented in Appendix D. Field capacity statistics were calculated assuming a normal Gaussian distribution. Table 4.4 lists the mean and maximum/minimum ranges of field capacity.

Table 4.3. B-Complex Mean and Maximum/Minimum Ranges of Total Porosity $\left(\mathrm{p}_{\mathrm{t}}\right)$ and Effective Porosity $\left(\mathrm{p}_{\mathrm{e}}\right)$

\begin{tabular}{|c|c|c|c|}
\hline \multicolumn{2}{|c|}{ Stratigraphic Unit } & $\mathrm{p}_{\mathrm{t}}\left(\mathrm{cm}^{3} / \mathrm{cm}^{3}\right)$ & $\mathrm{p}_{\mathrm{e}}\left(\mathrm{cm}^{3} / \mathrm{cm}^{3}\right)$ \\
\hline \multirow{3}{*}{$\mathrm{H} 1$} & Mean & 0.1207 & 0.1027 \\
\hline & $+\mathrm{SD}$ & 0.1728 & 0.1451 \\
\hline & - SD & 0.0686 & 0.0603 \\
\hline \multirow{3}{*}{$\mathrm{H} 2$} & Mean & 0.2515 & 0.2207 \\
\hline & $+\mathrm{SD}$ & 0.3565 & 0.3134 \\
\hline & - SD & 0.1466 & 0.1279 \\
\hline \multirow{3}{*}{$\mathrm{H} 2 \mathrm{~F}^{(\mathrm{a})}$} & Mean & 0.3345 & 0.3113 \\
\hline & Max & 0.3904 & 0.3590 \\
\hline & Min & 0.2786 & 0.2635 \\
\hline \multirow{3}{*}{$\mathrm{CCUz}^{(\mathrm{a})}$} & Mean & 0.3763 & 0.3514 \\
\hline & Max & 0.5319 & 0.4856 \\
\hline & Min & 0.2207 & 0.2172 \\
\hline \multirow{3}{*}{ Backfill / CCUg } & Mean & 0.1212 & 0.1109 \\
\hline & $+\mathrm{SD}$ & 0.1838 & 0.1647 \\
\hline & $-\mathrm{SD}$ & 0.0586 & 0.0571 \\
\hline
\end{tabular}

(a) Sample size insufficient to calculate standard deviation; values should be used for all three fine-grained layers in $\mathrm{H} 2$ sediments described in Section 3. 
PNNL-19277

Table 4.4. B-Complex Mean and Maximum/Minimum Ranges of Field Capacity $\left(\theta_{\mathrm{fc}}\right)$ and Campbell $\mathrm{b}$ Parameter

\begin{tabular}{|c|c|c|c|}
\hline \multicolumn{2}{|c|}{ Stratigraphic Unit } & $\theta_{\mathrm{fc}}\left(\mathrm{cm}^{3} / \mathrm{cm}^{3}\right)$ & $\mathrm{b}(-)$ \\
\hline \multirow{3}{*}{ H1 } & Mean & 0.0741 & 3.15 \\
\hline & $+\mathrm{SD}$ & 0.1007 & 3.88 \\
\hline & $-\mathrm{SD}$ & 0.0476 & 2.56 \\
\hline \multirow{3}{*}{$\mathrm{H} 2$} & Mean & 0.0842 & 2.29 \\
\hline & $+\mathrm{SD}$ & 0.1135 & 3.06 \\
\hline & $-\mathrm{SD}$ & 0.0549 & 1.72 \\
\hline \multirow{3}{*}{$\mathrm{H} 2 \mathrm{~F}^{(\mathrm{a})}$} & Mean & 0.1627 & 2.00 \\
\hline & Max & 0.1180 & 1.70 \\
\hline & Min & 0.2074 & 2.36 \\
\hline \multirow{3}{*}{$\mathrm{CCUz}^{(\mathrm{a})}$} & Mean & 0.2644 & 1.94 \\
\hline & Max & 0.1019 & 1.90 \\
\hline & Min & 0.4269 & 1.99 \\
\hline \multirow{3}{*}{ Backfill / CCUg } & Mean & 0.0775 & 2.62 \\
\hline & $+\mathrm{SD}$ & 0.0452 & 3.17 \\
\hline & $-\mathrm{SD}$ & 0.1227 & 2.16 \\
\hline
\end{tabular}

(a) Sample size insufficient to calculate standard deviation; values should be used for all three fine-grained layers in $\mathrm{H} 2$ sediments described in Section 3.

\subsubsection{Campbell b Parameter}

Some codes use the b parameter in the Campbell (1974) power function model to describe waterretention characteristics. The $\mathrm{b}$ parameter is the slope of the soil-water retention curve plotted as $\log$ matric potential versus log water content. To date, there has been little effort to determine the Campbell $\mathrm{b}$ parameter from raw water-retention data sets, and instead, estimates of $b$ are calculated using published pedotransfer functions, hydrogeologic parameter conversion formulas, or fitting the Campbell model to van Genuchten-generated water-retention points. Assuming the fitted van Genuchten parameters accurately represent the measured water-retention data, fitting the Campbell model to discrete waterretention data points generated by the van Genuchten model is the preferred approach. This approach was applied to obtain a fitted value for the $b$ parameters using the van Genuchten parameter samples in Appendix D. Sample and borehole ID as well as the fitted $b$ parameter are presented at the end of Appendix C. Statistics for the $\mathrm{b}$ parameter were calculated assuming a lognormal distribution (Meyer and Gee 1999). Table 4.4 lists the mean and maximum/minimum ranges of the $b$ parameter.

\subsubsection{Dispersivity}

Dispersivity, a transport parameter used to relate hydraulic and transport parameters for numerical modeling, relates pore-water velocity to mechanical dispersion (i.e., mixing and spreading of solutes caused by variations in water velocity). Dispersivity is scale dependent (Gelhar 1986) with mechanical dispersion at the core scale reflecting variation in water velocities in pores whereas at larger scales (e.g., field scale) mechanical dispersion increases because of additional variations in water velocities associated 
with hydraulic heterogeneities. It is the large-scale dispersivities that are most appropriate for predictive modeling of contaminant transport beneath the B-Complex because of the likely large grid scale that will be used. Dispersivity is dependent on the direction of flow with transverse dispersivity (dispersion orthogonal to the direction of flow) generally assumed to be 0.1 times longitudinal dispersivity (dispersion in the direction of flow) (Gelhar et al. 1992).

No measured data exist on large-scale dispersivities in Hanford sediments; however, Khaleel et al. (2001, 2006, Khaleel 2007) developed large-scale dispersivity estimates for Hanford sediments based on stochastic models that relate dispersive spreading to the spatial variability of saturated hydraulic conductivity. For this report, dispersivity estimates from Khaleel et al. (2001) and Khaleel et al. (2006) are used, and because of the lack of available data, estimates are limited to mean dispersivity values only. Dispersivity assignment for the H2-fine-grained layers are assumed to be equivalent to the CCUz unit based on their similarity in hydraulic properties. Longitudinal and transverse dispersivity estimates for each stratigraphic unit are presented in Table 4.5.

Table 4.5. Longitudinal $\left(A_{L}\right)$ and Transverse $\left(A_{T}\right)$ Dispersivity Estimates

\begin{tabular}{ccc}
\hline Stratigraphic Unit & $\mathrm{A}_{\mathrm{L}}(\mathrm{cm})$ & $\mathrm{A}_{\mathrm{T}}(\mathrm{cm})$ \\
\hline $\mathrm{H} 1$ & 100 & 10 \\
$\mathrm{H} 2$ & 150 & 15 \\
$\mathrm{H} 2 \mathrm{~F}^{(\mathrm{a})} / \mathrm{CCUz}$ & 50 & 5 \\
Backfill / CCUg & 150 & 15 \\
\hline
\end{tabular}

(a) Values should be used for all three fine-grained layers in $\mathrm{H} 2$ sediments described in Section 3.

\subsubsection{Recharge}

Recharge, defined as vadose zone water that reaches the water table, is vitally important at the Hanford Site because of its potential to transport contaminants located in the unsaturated zone to groundwater. Recharge may originate from artificial sources, such as leaking water lines, or from natural sources, such as rainfall and snowmelt. Recharge values typically serve as the upper model boundary conditions for flow and contaminant transport modeling, necessitating that a technically defensible recharge rate is chosen to perform groundwater risk and remediation alternative calculations at Hanford.

Four main variables are highly influential in controlling recharge at the Hanford Site: soil conditions, vegetation, land use, and climate. The greater capability of finer textured soils to store water allows for more water to remain nearer the soil surface where it is available for extraction by plants through transpiration processes or evaporation. The opposite is true for coarser textured soils. The presence of vegetation reduces recharge by providing a mechanism to remove soil water through plant transpiration. The degree of influence a plant has on recharge depends on many factors, including plant phenology, root density, and rooting depth. With this in mind, it is clear that land uses that alter vegetation or surface soils will ultimately impact recharge rates. Finally, climatic conditions in the form of precipitation, wind, humidity, and solar radiation all act to influence recharge. Wind, humidity, and solar radiation all affect evaporation and plant transpiration rates. Precipitation strongly influences recharge rates, with winter precipitation (November through March) controlling recharge at Hanford (Gee et al. 1992) due to the greater amounts of precipitation and lower evaporation and plant transpiration rates experienced during the winter months. 
Numerous efforts have estimated recharge at the Hanford site for various locations, vegetation, landuse conditions, and soil types (Last et al. 2006; Fayer and Walter 1995; Fayer and Szecsody 2004, Fayer and Keller 2007). Most recently, Fayer and Keller (2007) published a recharge data package that considered areas in and around SST WMAs. Recharge estimates were developed for different soil types and for conditions with and without vegetation. The Fayer and Keller (2007) data package relied on recharge estimates in Last et al. (2006), but where appropriate, these estimates were updated to include new recharge estimates from chloride mass balance and numerical simulations.

The variability of soil conditions, plant, and land use throughout the B-Complex necessitates multiple recharge values. Based on soil survey work by Hajek (1966), Fayer and Keller (2007) described the near surface of the B-Complex area to be Ephrata sandy loam. Unvegetated gravel-rich surfaces, such as those that exist at B-BX-BY tank farms, also exist in other parts of the B-Complex area. In addition, it is possible that future management decisions will include the placement of surface barriers over portions of the B-Complex. Table 4.6 presents Fayer and Keller (2007)-estimated mean natural recharge rates for present and anticipated future B-Complex surface conditions. Fayer and Keller (2007) do not present maximum and minimum ranges of recharge. Traditional statistical calculations are not possible because of the paucity of recharge data. Last et al. (2006) analyzed the distribution of winter precipitation records from the Hanford Meteorological Station (HMS), on the basis that recharge is controlled by winter precipitation. The standard deviation for estimated recharge is defined as being equal to half the mean recharge rate, and the maximum estimated recharge is limited to be no greater than the 58-year average HMS winter precipitation rate of $101 \mathrm{~mm} / \mathrm{yr}$. This approach was applied to assign maximum and minimum ranges of recharge in Table 4.6.

Table 4.6. B-Complex Estimated Mean and Maximum/Minimum Ranges of Recharge

\begin{tabular}{cccc}
\hline & \multicolumn{3}{c}{ Estimated Recharge Rate (mm/yr) } \\
Soil Type & & Shrub & No Plants \\
\hline \multirow{3}{*}{ Ephrata sandy loam } & Mean & 2.8 & 23.0 \\
& + SD & 4.2 & 34.5 \\
& - SD & 1.4 & 11.5 \\
\multirow{3}{*}{ Graveled surface } & Mean & NM & 92.0 \\
& + SD & NM & 101.0 \\
& - SD & NM & 46.0 \\
Modified RCRA C barrier & Mean & 0.10 & 0.10 \\
& + SD & 0.15 & 0.15 \\
& - SD & 0.05 & 0.05 \\
\hline \multirow{3}{*}{ Gravel side slope on surface barrier } & Mean & 1.9 & 33.0 \\
& + SD & 2.9 & 49.5 \\
\cline { 2 - 4 } & - SD & 1.0 & 16.5 \\
\hline NM-estimated recharge rates have not been developed. \\
\hline
\end{tabular}

\subsection{Field Scale Results (Aquifer Hydraulic Properties from In Situ Tests)}

The $\mathrm{CCU}_{\mathrm{g}}$ sediments found below the water table in the B-Complex area are generally less permeable than the Hanford formation gravel and sand facies that are found below the water table south and west of 
the B-Complex. Hanford formation gravel and sand is also likely to exist below the water table to the northwest of the B-Complex area in the direction of apparent historical groundwater plume movement. However, as discussed in Chapter 2 and Appendix B, the extent of the $\mathrm{CCU}_{\mathrm{g}}$ sediments to the northwest is uncertain. A limited number of aquifer tests conducted in this area are listed in Table 4.7 and shown on the map in Figure 4.3. The field-scale aquifer test results indicate that the saturated hydraulic conductivity $\left(\mathrm{K}_{\text {sat }}\right)$ of the $\mathrm{CCU}_{\mathrm{g}}$ in this area ranges from about 5 to $100 \mathrm{~m} / \mathrm{d}$. Where the aquifer consists of Hanford formation sand and gravel, $\mathrm{K}_{\text {sat }}$ values range from about 100 up to more than 5,000 m/d. However, it is difficult to accurately determine the upper limit of $\mathrm{K}_{\text {sat }}$ for the extremely permeable Hanford formation sediments. Some results are, therefore, shown as "greater than" $(>)$ values in Table 4.7.

Table 4.7. Aquifer Field Test with $\mathrm{K}_{\text {sat }}$ Results in the Vicinity of the B-Complex Area

\begin{tabular}{|c|c|c|c|c|c|}
\hline Well & $\overline{\mathrm{K}_{\text {sat }}}$ & Test Type & Test & Source & Comment \\
\hline 299-E28-27 & 150 & Constant rate & $9 / 29 / 1987$ & PNL-6820 & \\
\hline 299-E32-4 & $>264$ & Constant rate & 9/21/1987 & PNL-6820 & \\
\hline 299-E32-5 & 175 & Slug & $8 / 13 / 1990$ & PNL-7333 & \\
\hline 299-E33-28 & $>1500$ & Constant rate & $10 / 21 / 1987$ & PNL-6820 & \\
\hline 299-E33-29 & $>1400$ & Constant rate & 9/17/1987 & PNL-6820 & \\
\hline 299-E33-30 & $>1500$ & Constant rate & 9/24/1987 & PNL-6820 & \\
\hline 299-E33-33 & 98 & Slug & 9/27/1987 & PNL-7330 & \\
\hline 299-E33-334 & 42 & Slug & $2 / 1 / 2000$ & PNNL-13514 & \\
\hline 299-E33-335 & 50 & Slug & $3 / 28 / 2000$ & PNNL-13514 & \\
\hline 299-E33-338 & 89 & Slug & $10 / 22 / 2001$ & PNNL-14186 & \\
\hline 299-E33-44 & 24 & Slug & $10 / 13 / 1998$ & PNNL-13378 & \\
\hline 299-E33-12 & 12 & Constant rate & $5 / 11 / 1982$ & RHO-RE-ST-12P & \\
\hline 299-E33-36 & 220 & Slug & 2/26/1990 & Unpublished & \\
\hline 299-E33-37 & 230 & Slug & $2 / 26 / 1990$ & Unpublished & \\
\hline 299-E34-8 & 180 & Slug & $4 / 11 / 1990$ & Unpublished & \\
\hline 299-E33-49 & 97 & Slug & $9 / 20 / 2005$ & PNNL-17348 & \\
\hline 299-E34-2 & 3180 & Constant rate & 8/7/1987 & PNL-6820 & East of mapped area in Figure 4.3 \\
\hline 299-E34-3 & 390 & Constant rate & $8 / 5 / 1987$ & PNL-6820 & East of mapped area in Figure 4.3 \\
\hline 299-E34-7 & 24 & Constant rate & 10/5/1989 & PNL-7333 & East of mapped area in Figure 4.3 \\
\hline 299-E35-2 & 6 & Slug & $11 / 3 / 1989$ & Unpublished & East of mapped area in Figure 4.3 \\
\hline $699-52-55 \mathrm{~A}$ & 0.2 & Slug & $4 / 22 / 2008$ & PNNL-17675 & North of mapped area in Figure 4.3 \\
\hline
\end{tabular}

Test Documentation References:

PNL-6820 Last et al. 1989. Hydrogeology for the 200 Areas Low-Level Burial Grounds - An Interim Report.

PNL-7330 Newcomer et al. 1990. Hydrologic Testing at the Single-Shell Tanks, 1989.

PNL-7333 Borghese and Goodwin. 1989. Hydrologic Testing at the Low-Level Burial Grounds, 1989.

PNNL-13378 Spane et al. 2001. Results of Detailed Hydrologic Characterization Tests - Fiscal Year 1999.

PNNL-13514 Spane et al. 2001. Results of Detailed Hydrologic Characterization Tests - Fiscal Year 2000.

PNNL-14186 Spane et al. 2003. Results of Detailed Hydrologic Characterization Tests - Fiscal Year 2002.

PNNL-17348 Spane and Newcomer. 2008. Results of Detailed Hydrologic Characterization Tests-Fiscal and Calendar Year 2005.

PNNL-17675 Newcomer. 2008. BP-5 Remedial Investigation Slug-Test Characterization Results for Well 699-52-55A

RHO-RE-ST-12P Graham et al. 1984. An Assessment of Aquifer Intercommunication in the B Pond, Gable Mountain Pond Area. 


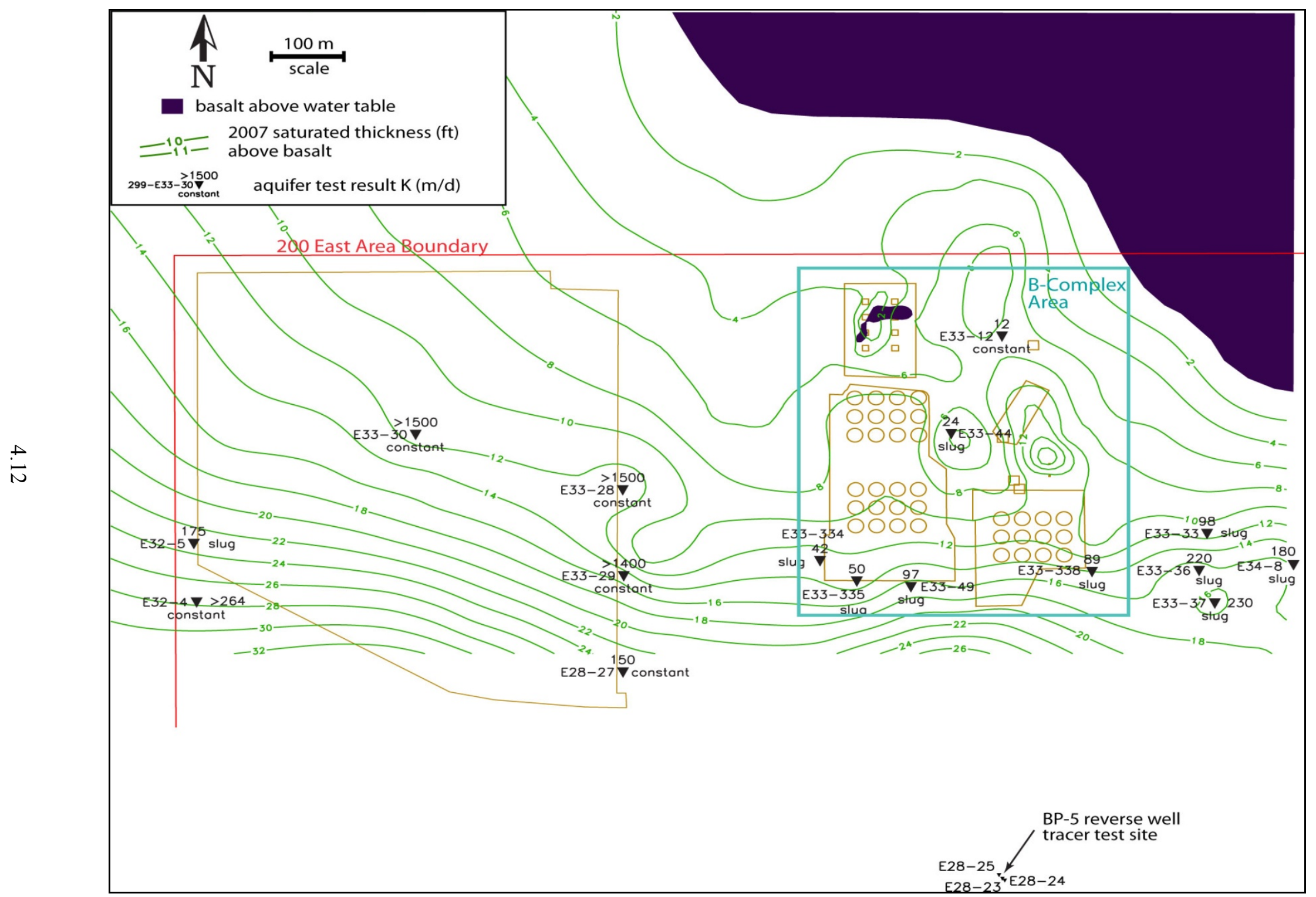

Figure 4.3. Hydraulic Conductivity (m/d) Determined from Constant-Rate Pumping and Slug Tests in Vicinity of the B-Complex 
Nearly all of the aquifer tests performed in the B-Complex area have been slug tests. One exception is the constant-rate pumping test performed at 299-E33-12. The results of this constant-rate pumping test indicated a relatively low $\mathrm{K}_{\mathrm{sat}}$ of $12 \mathrm{~m} / \mathrm{d}$. Pumping tests have generally not been performed in the B-Complex area because of the difficulty in handling and disposing of the contaminated groundwater pumped to the ground surface during the test. Slug tests do not require the removal of groundwater from the aquifer. However, because of the small displacement volumes employed during slug tests, hydraulic properties determined using this characterization method are representative of conditions relatively close to the well.

As shown on Figure 4.3, additional constant-rate pumping tests have been conducted on wells to the west of the B-Complex. The $\mathrm{K}_{\text {sat }}$ results derived from the constant rate pump tests are generally higher than those estimated from slug tests. However, this trend may be related to the location of the tests rather than to the method. The tests indicating high $\mathrm{K}_{\text {sat }}$ to the west are at wells tapping the Hanford formation. It appears that a few of the tested wells that were open to a thin zone of saturated Hanford formation sediments at the time of testing may now be in an area where the water table has fallen below the Hanford formation/Cold Creek unit contact. Relatively low $\mathrm{K}_{\text {sat }}$ values were determined from constant-rate tests at 299-E33-12 (located on the northern edge of Figure 4.3) and 699-52-55A (located to the north of the area mapped in Figure 4.3). At these two wells, the saturated sediments are relatively thin and located where the depositional environment may have resulted in finer grained sediments being deposited at and below the depth of the current water table.

To supplement the available aquifer test data, results of well development pumping were also examined. In many cases, the flow rates and drawdown during well development were monitored, allowing for the calculation of a specific capacity for the well. The specific capacity is calculated by dividing the pumping rate by the measured drawdown and reflects the capability of the well and aquifer to produce water. Figure 4.4 shows the values of specific capacity calculated for wells in the vicinity of the 200-BP-5 OU source area. Methods have been developed to estimate aquifer transmissivity $(\mathrm{T})\left(\mathrm{K}_{\mathrm{sat}}\right.$ multiplied by aquifer thickness) from specific capacity values. However, drawdown in a pumping well is determined by both aquifer hydraulic properties and the efficiency of the well completion. If the well is only $75 \%$ efficient, then the $\mathrm{T}$ estimated from the specific capacity will be $75 \%$ of the actual $\mathrm{T}$ value for the aquifer.

The published methods for estimating $\mathrm{T}$ from specific capacity also assume that the well has been pumped long enough to establish a steady-state drawdown level. In the case of the 200-BP-5 OU well development, pumping was performed for an average of only about $1 \mathrm{hr}$, and significant additional drawdown to reach a steady state was expected for most of the wells. The time required for near steadystate conditions is also greater for unconfined aquifers. Therefore, a site-specific estimation technique for T was developed for the 200-BP-5 OU wells. Drawdown type-curves (drawdown vs. pumping time) were calculated for each well based on the analytical solution of drawdown for a pumped well fully or partially penetrating an unconfined aquifer (Moench 1997). Simulated drawdown curves were generated for each well based on the pumping rate and aquifer penetration of the well. A range of values for vertical anisotropy $\left(\mathrm{K}_{\text {sat- } \mathrm{v}} / \mathrm{K}_{\text {sat-h }}\right)$ of 0.1 to 0.5 and a range of values for aquifer specific yield of 0.1 to 0.3 were applied to generate two drawdown curves for each well. T was then estimated for each well from the simulated curves, resulting in a range of values reflecting the uncertainty in assumed specific yield and anisotropy. Results of the T estimation from specific capacity and supporting information are given in Table 4.8. The well-development data included wells where no measureable drawdown was observed. It 


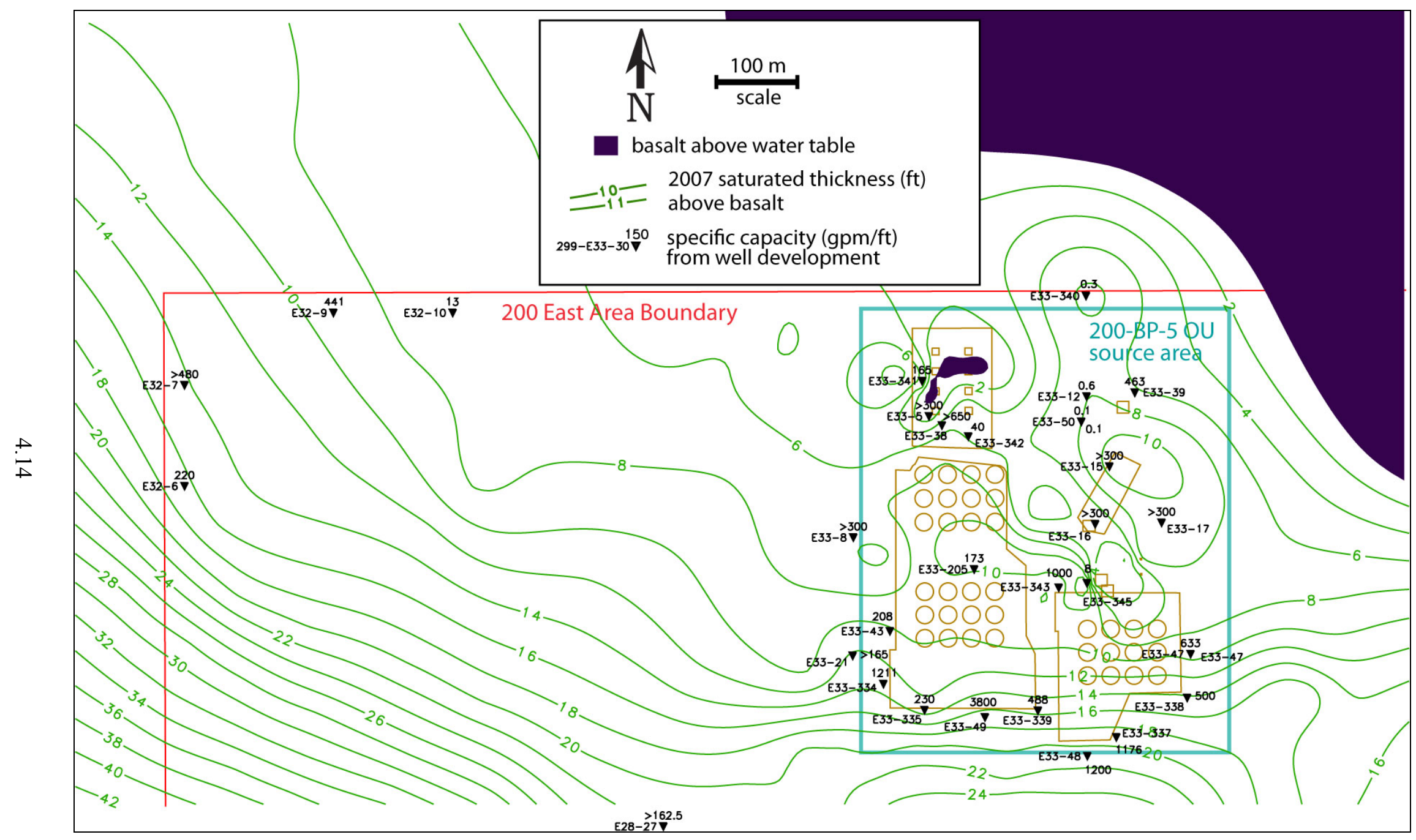

Figure 4.4. Specific Capacity (gal/min/ft) from Development Pumping of Wells in the Vicinity of the 200-BP-5 Source Area 
Table 4.8. Transmissivity Estimated from Development Pumping of Wells in the Vicinity of the B-Complex Area

\begin{tabular}{|c|c|c|c|c|c|c|c|c|c|c|}
\hline well & test data & $\begin{array}{c}\text { saturated } \\
\text { thickness } \\
(\mathrm{ft})\end{array}$ & $\begin{array}{l}\text { top of screen } \\
\text { above WT (tt) }\end{array}$ & $\begin{array}{l}\text { bottom of } \\
\text { screen below } \\
\text { WT (ft) }\end{array}$ & $\begin{array}{c}\text { well } \\
\text { diameter } \\
\text { (inches) }\end{array}$ & $\begin{array}{l}\text { pumping rate } \\
\text { (gpm) }\end{array}$ & Drawdown (ft) & $\begin{array}{l}\text { pumping } \\
\text { duration } \\
\text { (minutes) }\end{array}$ & $\begin{array}{c}\text { specific } \\
\text { capacity } \\
(\mathrm{gpm} / \mathrm{ft})\end{array}$ & $\begin{array}{l}\mathrm{T}(\mathrm{m} 2 / \mathrm{d}) \\
\text { estimated } \\
\text { from } \\
\text { drawdown }\end{array}$ \\
\hline 299-E32-9 & $10 / 1 / 1991$ & 8.6 & -12.4 & 8.2 & 4 & 8.82 & 0.02 & 42 & $>441$ & $>2000$ \\
\hline 299-E33-15 & $10 / 21 / 1997$ & 10.4 & $\cdot 6.1$ & 8.9 & 8 & 9 & 0.08 & 10 & 113 & 2800 \\
\hline 299-E33-205 & $8 / 21 / 2008$ & 9.7 & 0.3 & 10.3 & 4 & 19 & 0.09 & 45 & 211 & $>1300$ \\
\hline 299-E33-3 & $9 / 7 / 1990$ & 5.3 & -11.5 & 0.5 & 6 & 9.3 & 0.15 & 100 & 62 & 5000 \\
\hline 299-E33-334 & $1 / 5 / 2000$ & 13 & -9.3 & 15.8 & 4 & 23 & 0.019 & 103 & 1210 & $>5000$ \\
\hline 299-E33-335 & $2 / 10 / 2000$ & 13.1 & $\cdot 7.4$ & 12.7 & 4 & 23 & 0.1 & 59 & 230 & 2400 \\
\hline 299-E33-337 & $8 / 22 / 2001$ & 18.3 & -7.3 & 17.7 & 4 & 20 & 0.017 & 24 & 1175 & $>5000$ \\
\hline 299-E33-338 & $9 / 4 / 2001$ & 14 & -6.1 & 13.9 & 4 & 20 & 0.04 & 119 & 500 & $>5000$ \\
\hline 299-E33-339 & $8 / 21 / 2001$ & 15.3 & -4.3 & 15.6 & 4 & 20 & 0.04 & 120 & 500 & $>5000$ \\
\hline 299-E33-341 & $6 / 10 / 2008$ & 5 & -4.5 & 5.5 & 4 & 27.3 & 0.03 & 45 & 910 & 1900 \\
\hline 299-E33-342 & $6 / 9 / 2008$ & 5.5 & -4.3 & 5.7 & 4 & 27 & 0.05 & 23 & 540 & $>5000$ \\
\hline 299-E33-343 & $3 / 10 / 2008$ & 7.7 & $\cdot 2.4$ & 7.6 & 4 & 20 & 0.02 & 59 & 1000 & 4800 \\
\hline 299-E33-38 & 2/25/1991 & 4.7 & -14.7 & 6.3 & 4 & 13 & 0.02 & 33 & $>650$ & $>3000$ \\
\hline 299-E33-39 & $2 / 12 / 1991$ & 5.7 & -15.6 & 5.4 & 4 & 13.9 & 0.03 & 13 & 463 & $>3000$ \\
\hline 299-E33-43 & $11 / 13 / 199$ & 9.9 & -12.3 & 8.8 & 4 & 10.4 & 0.01 & 45 & $>1040$ & $>3000$ \\
\hline 299-E33-47 & $9 / 1 / 2004$ & 9.2 & -4.7 & 15.3 & 4 & 19 & 0.03 & 36 & 633 & $>5000$ \\
\hline 299-E33-48 & $9 / 10 / 2004$ & 20.8 & -4.5 & 20.5 & 4 & 18 & 0.02 & 48 & $>900$ & $>5000$ \\
\hline 299-E33-49 & $9 / 3 / 2004$ & 16.7 & -3.3 & 16.7 & 4 & 19 & 0.02 & 48 & $>950$ & $>5000$ \\
\hline 299-E33-7 & $9 / 17 / 1990$ & 4.3 & -12.2 & 2.9 & 4 & 8.5 & 0.14 & 45 & 61 & 400 \\
\hline
\end{tabular}

appeared that a drawdown of more than $0.02 \mathrm{ft}$ could be reliably measured. Therefore, the wells that showed less than or $0.02 \mathrm{ft}$ drawdown were assigned T estimates with "greater than" $(>)$ values.

Laboratory-scale analyses of the sediment samples discussed herein and in Appendix $\mathrm{C}$ indicate an average $\mathrm{K}_{\text {sat }}$ of $0.3 \mathrm{~m} / \mathrm{d}$ for the $\mathrm{CCU}_{\mathrm{g}}$. This was based on testing nine samples from six boreholes. The values are much lower than those from field-scale aquifer tests, which ranged from about 1 to $100 \mathrm{~m} / \mathrm{d}$ in the 200-BP-5 OU source area. This difference may result from the fact that these tests were performed on small "intact" core samples that did not include the more permeable portion (i.e., gravel fraction) of a heterogeneous formation. The laboratory tests also measure the vertical $\mathrm{K}_{\text {sat }}$ of the sample $\left(\mathrm{K}_{\text {sat-v }}\right)$, which is usually lower than the horizontal $\mathrm{K}_{\text {sat }}(\mathrm{Ksat}-\mathrm{h})$ by a factor of ten or more. The sediment permeability in the core samples may also have been altered in the process of split-spoon core collection, which is known to cause some compaction.

Calibration of a 3D finite-element groundwater flow model of the Hanford site resulted in hydraulic conductivities of 2500 to $5000 \mathrm{~m} / \mathrm{d}$ for the vicinity of the 200-BP-5 OU waste sites and approximately $10,000 \mathrm{~m} / \mathrm{d}$ for the area northwest of the 200 East Area (Thorne et al. 2006). However, because this model defined the sediments above the basalt in the 200-BP-5 OU area as only Hanford formation and did not recognize the existence of the lower permeability Cold Creek unit sediments, the cited calibration estimate for the B-Complex area is not considered reliable because the bulk of the aquifer is composed of $\mathrm{CCUg}$ and not Hanford formation sediments.

Effective porosity of the aquifer is important in determining the volume of contaminated groundwater and associated contaminant inventory for a plume. Effective porosity is also inversely proportional to the 
average groundwater velocity in the saturated zone. Porosity has been measured through laboratory analysis of a limited number of core samples from boreholes in the 200-BP-5 OU source area. These laboratory tests resulted in a mean effective porosity of 0.11 for the $\mathrm{CCU}_{\mathrm{g}}$ unit (see Table 4.3). Aquifer effective porosity and dispersivity (longitudinal) were also assessed during a treatability study focused on the BP-5 reverse well (DOE/RL 1996a) by conducting two tracer tests. The tracer test site is about $300 \mathrm{~m}$ south of the 200-BP-5 OU source area (Figure 4.3) in an area where Hanford formation sediments are found below the water table. Well 299-E28-23 was used as the discharge well in both tests. Wells 299-E28-7 and 299-E28-25 were used as recharge wells in the first and second tests, respectively. The tracer tests resulted in a porosity estimate of 0.22 and 0.30 and a dispersivity estimate from 12 and $22 \mathrm{ft}$, respectively. The results were affected to some degree by a change in flow rate after the tracer injection, which leads to additional uncertainty in the analytical curve-matching analysis. The laboratory porosity values reported in Table 4.3 differ from results of the tracer tests because of the difference in location and also because the relatively small core samples may not have included the higher porosity sediments of a heterogeneous formation. Based on other measurements of porosity for Hanford formation and $\mathrm{CCU}_{\mathrm{g}}$ sediments, the effective porosity is likely to fall in the range of 0.1 to 0.3 .

\subsection{Additional Remarks Pertinent to the B-Complex Hydrogeologic Model}

The hydrogeologic structure of the vadose zone beneath the B-Complex area is observed to be complex. Thin lenses of texturally contrasting material, such as those identified in the $\mathrm{H} 2$ unit (Section 2.4) and interfaces at formation contacts (e.g., between the $\mathrm{CCU}_{\mathrm{z}}$ and $\mathrm{CCU}_{\mathrm{g}}$ ) can dominate flow processes by impeding downward flow of water and promoting lateral spreading. For example, the occurrence of significant lateral flow within the vadose zone is supported by the presence of waste stream fluids from various B-Complex sources in vadose zone pore-water collected at locations laterally distant from the source (see Section 3).

Future predictive fate and transport modeling of the B-Complex area vadose zone should accommodate the influence of stratigraphic controlling layers and lateral flow resulting from these layers, as developed in the conceptual model for uranium. While not located in the B-Complex area, contaminant distributions beneath the $\mathrm{BC}$ cribs illustrate the complexity and variability of Hanford subsurface conditions and their influence on contaminant transport. At the $\mathrm{BC}$ cribs, characterization studies (Serne et al. 2009) have detected much of the contaminant mass in the vadose zone and little evidence of the mobile contaminant technetium-99 reaching the groundwater; however 1D simulations that did not incorporate the influence of inter- and intra-stratigraphic layering incorrectly predicted that technetium-99 reached the groundwater beneath this location (Ward et al. 2006). The concentration and distribution of technetium-99 was accurately predicted with the inclusion of an appropriate multidimensional model that incorporated observed fine textured lenses within primary stratigraphic units (Ward et al. 2006).

The hydrogeology of the saturated aquifer is also quite variable/heterogeneous in and around the B-Complex. The aquifer is thin and pinches out to the north where basalt rises above the water table. There may also be localized (small areas) places where basalt is above the water table within the B-Complex. The saturated zone in the regions where high-concentration groundwater plumes exist appears to be dominated by the $\mathrm{CCU}_{\mathrm{g}}$ unit. However, large areas of the groundwater plume are in saturated Hanford formation sand and gravel sediments to the west of the B-Complex. As discussed in 
the geology section (Section 2.5), the water table is very flat, and groundwater flow directions are difficult to determine. The water table and flow directions may also be affected by changes in the level of the Columbia River. Water levels in the region north of the B-Complex are especially influenced by Columbia River stages (personal communication John McDonald CHPRC; January 2010; with some discussion in PNNL (2006) and DOE/RL (2008b). 



\subsection{Status of Selected Mobile Contaminants in Groundwater Below the B Complex}

In this section five potentially mobile contaminants found in the groundwater below the B-Complex are discussed in subsections for each contaminant. First a historical summary of the status of the mobile contaminant plume in the groundwater below the B-Complex is presented that relies heavily on plume maps taken from other sources. Next mass estimates and how the estimates have evolved in the last decade for three key contaminants (technetium-99, uranium, and cyanide) in the groundwater are presented in their respective subsections. The mass estimates were generated for the years 2000, 2003, 2006, and 2009 for two key reasons. First the database for most constituents increased significantly in the late 1990s as more monitoring wells were completed and analytical methods for most constituents improved thus allowing for more defensible mass estimates. Second a key objective was to evaluate whether the masses in the groundwater below the B-Complex were changing in the recent past long after active disposals had ceased and the water table was returning towards its natural steady state. The last topic in each subsection is a discussion on what direction each of the contaminant groundwater plumes has been migrating over the last decade. For uranium the isotope ratio fingerprinting results for groundwater samples are discussed.

Following in Section 6, the conceptual models for the key mobile contaminant distributions in each of the five vadose zone subregions discussed in Section 3 are integrated with the conceptual model for the groundwater contaminant plumes below the B-Complex developed in this section to attempt to establish which facilities appear to be currently contributing contamination to the groundwater. Using the integrated conceptual models for the groundwater and vadose zone, a discussion of potential impacts to the groundwater is provided in Section 7, and observations pertinent to both deep vadose zone and groundwater remediation are made.

\subsection{Status of Groundwater Plumes in the B-Complex}

As a prelude to developing the historical discussion on the selected mobile contaminants and the mass estimates for technetium-99, cyanide and uranium a literature search was performed looking for systematic groundwater monitoring information. In addition inquiries were made to the current groundwater monitoring staff to find what historical documents they were aware of. The outcome of these efforts found that organized groundwater monitoring status reports were not started until the mid 1950s (see Table 1.2 for a listing of all the historical and recent groundwater monitoring reports that were found and reviewed). Because most all the facilities (including the SSTs) in the B-Complex region were actively being used to dispose of or store liquid wastes years before the groundwater monitoring data appear to be available, there is no possible way to discuss the origination and extent of the groundwater plumes or the concentrations of individual mobile constituents within the plumes during and right after the active disposal period. With essentially only gross beta, cobalt-60, and nitrate (and very limited uranium) data available between 1955 and 1987, this time period is also difficult to assess for the status of key mobile contaminants. There also seems to be a gap between 1965 and 1995 over which time there are no systematic (i.e., yearly) Hanford Site groundwater monitoring reports available that map the regional groundwater plumes. During this time period, there were two independent groundwater monitoring reports; the first discussed findings inside the active facilities fence lines, and a second discussed 
groundwater monitoring results in the outlying "600 Area" regions. It is also not clear from the literature searches that between 1965 and 1995 that these dual set of monitoring reports was continuous.

It is clear that over the time interval from 1956 through at least the mid 1960s, there was a large and high-concentration groundwater plume below the B-Complex that contained mobile fission products, such as ruthenium-106, mobile activation products such as cobalt-60, and chemicals such as nitrate, cyanide, and sodium. The early plume must have contained tritium and technetium-99 given their presence in the waste, along with the contaminants that were measured and reported, and their known mobility attributes. Because the gross beta (mainly ruthenium-106 and cobalt-60) species have relatively short half lives (i.e., $1 \mathrm{yr}$ and $5.7 \mathrm{y}$, respectively), they are no longer useful for tracking the migration of the original groundwater plumes that were present near the end of the active disposal period. The only two species that do not rapidly decay that were sometimes measured in the mid-1950s to mid-1960s are nitrate and uranium.

A location map for most of the key groundwater wells is shown in Figure 5.1, and the year that each of the wells was drilled is found in Table 5.1. The Environmental Dashboard Application $<$ http://environet.hanford.gov/eda/ $>$ contains a publicly available database with the groundwater monitoring results tabulated in great detail for all monitoring wells essentially from the time that they were first sampled to either the time the well was abandoned (usually when water table dropped below the depth of the casing) or to the current date. 
PNNL-19277

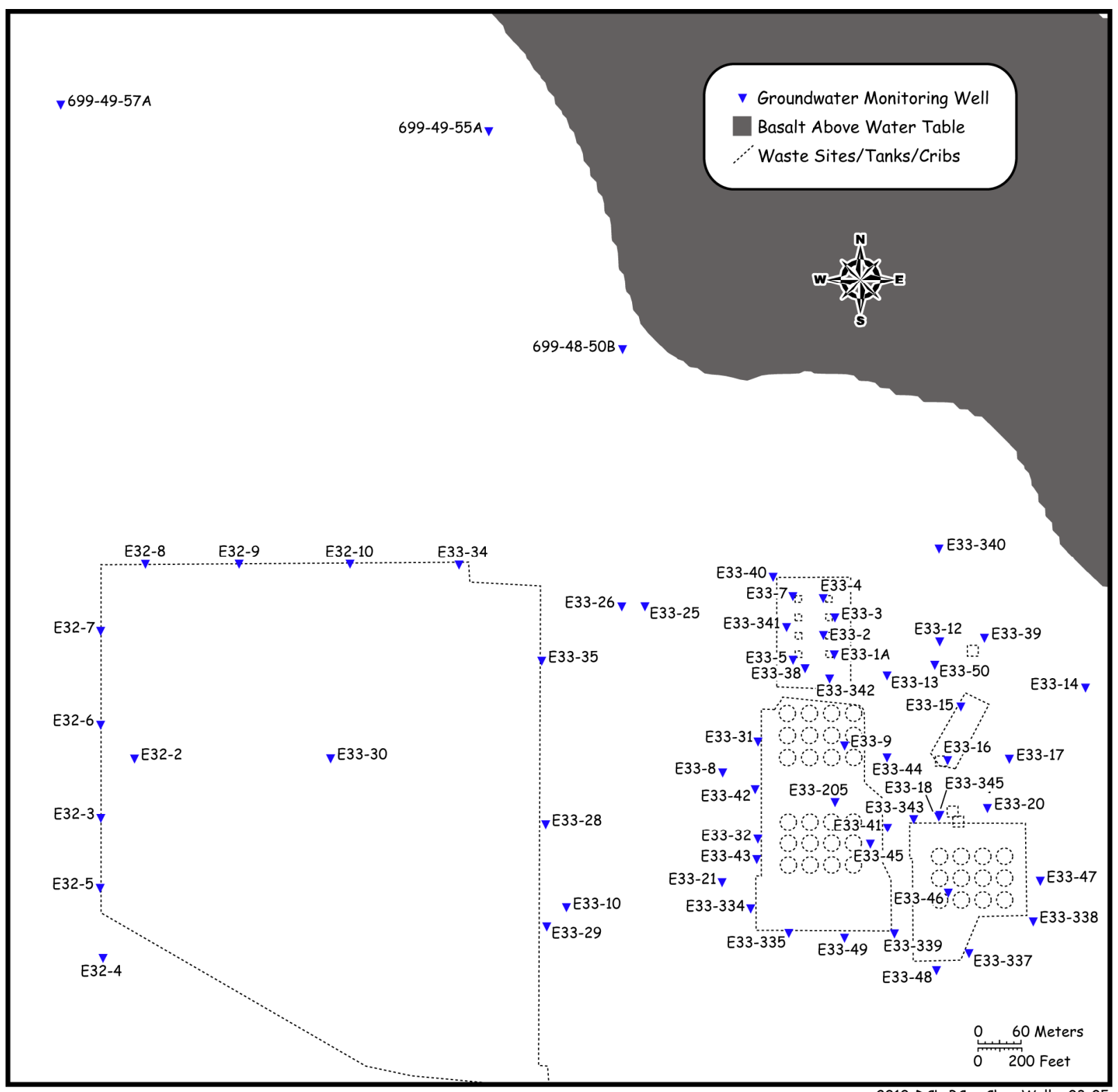

2010-DCL-BComChemWells_03-05

Figure 5.1. Location of Groundwater Monitoring Wells in B-Complex Area 
PNNL-19277

Table 5.1. Details for B-Complex Groundwater Monitoring Wells

\begin{tabular}{|c|c|c|c|c|c|}
\hline Well Name & Well ID & $\begin{array}{l}\text { Easting } \\
(\mathrm{m})\end{array}$ & $\begin{array}{l}\text { Northing } \\
\text { (m) }\end{array}$ & $\begin{array}{c}\text { Ground } \\
\text { Surface } \\
\text { Elev. (ft)* }\end{array}$ & $\begin{array}{c}\text { Drilling } \\
\text { Completed } \\
\text { Date } \\
\end{array}$ \\
\hline 299-E27-16 & A4814 & 574179.2 & 137164.9 & 652.8 & 1990 \\
\hline 299-E28-8 & A6788 & 573698.1 & 137074.3 & 670.1 & 1957 \\
\hline 299-E33-1A & A4838 & 573632.3 & 137614 & 632.9 & 1954 \\
\hline 299-E33-2 & A4846 & 573617 & 137641.3 & 630.7 & 1954 \\
\hline 299-E33-3 & A4854 & 573633.1 & 137666 & 623.6 & 1954 \\
\hline 299-E33-4 & A4865 & 573616.8 & 137693.1 & 628.7 & 1954 \\
\hline 299-E33-5 & A4870 & 573574.2 & 137606.4 & 632.3 & 1955 \\
\hline 299-E33-6 & A6852 & 573574.4 & 137652.9 & 631.3 & 1955 \\
\hline 299-E33-7 & A4871 & 573574 & 137696 & 625.7 & 1955 \\
\hline 299-E33-8 & A4872 & 573475.3 & 137447.9 & 650.8 & 1953 \\
\hline 299-E33-9 & A4873 & 573646.8 & 137485.9 & 653.5 & 1949 \\
\hline 299-E33-10 & A6853 & 573255.5 & 137258.2 & 674.2 & 1955 \\
\hline 299-E33-11 & A6854 & 573901.3 & 137635.8 & 622.2 & 1954 \\
\hline 299-E33-12 & A4839 & 573780.5 & 137632.2 & 624.3 & 1953 \\
\hline 299-E33-13 & A4840 & 573706.5 & 137584.4 & 629.5 & 1953 \\
\hline 299-E33-14 & A4841 & 573985.6 & 137567.2 & 623.4 & 1953 \\
\hline 299-E33-15 & A4842 & 573810.3 & 137540.7 & 628.1 & 1953 \\
\hline 299-E33-16 & A6855 & 573791.7 & 137465.3 & 637.6 & 1953 \\
\hline 299-E33-17 & A4843 & 573878.5 & 137467.2 & 635.4 & 1953 \\
\hline 299-E33-18 & A4844 & 573779.2 & 137386.1 & 646.6 & 1947 \\
\hline 299-E33-19 & A4845 & 573847.6 & 137422.7 & 640.3 & 1956 \\
\hline 299-E33-20 & A4847 & 573847.6 & 137397.9 & 642.4 & 1956 \\
\hline 299-E33-21 & A4848 & 573474.5 & 137293.2 & 667.4 & 1957 \\
\hline 299-E33-22 & A6856 & 573624.8 & 137660.8 & 631.1 & 1965 \\
\hline 299-E33-23 & A6857 & 573617.1 & 137695.1 & 629.2 & 1965 \\
\hline 299-E33-24 & A4849 & 573493.5 & 137578.5 & 638.3 & 1967 \\
\hline 299-E33-25 & A6858 & 573365.2 & 137681.6 & 631.1 & 1969 \\
\hline 299-E33-26 & A4850 & 573333.4 & 137681.5 & 633.7 & 1969 \\
\hline 299-E33-27 & A4851 & 573668.1 & 137338.2 & 659.4 & 1970 \\
\hline 299-E33-31 & A4856 & 573525 & 137491.4 & 647.7 & 1989 \\
\hline 299-E33-32 & A4857 & 573524.8 & 137354 & 660.2 & 1989 \\
\hline 299-E33-33 & A4858 & 574080.1 & 137301.9 & 640.7 & 1989 \\
\hline 299-E33-36 & A4861 & 574068.5 & 137240 & 647.2 & 1990 \\
\hline 299-E33-37 & A4862 & 574091.5 & 137185.4 & 653.5 & 1990 \\
\hline 299-E33-38 & A4863 & 573591.2 & 137594.5 & 633.3 & 1990 \\
\hline 299-E33-39 & A4864 & 573843.5 & 137637.4 & 623.8 & 1991 \\
\hline 299-E33-40 & A4866 & 573546.2 & 137723.1 & 624.6 & 1991 \\
\hline 299-E33-41 & A4867 & 573707.2 & 137369.9 & 654.8 & 1991 \\
\hline 299-E33-42 & A4868 & 573521 & 137424.4 & 654.2 & 1991 \\
\hline 299-E33-43 & A4869 & 573523.2 & 137325.4 & 662.5 & 1991 \\
\hline 299-E33-44 & B8554 & 573706.4 & 137469.2 & 643.1 & 1998 \\
\hline 299-E33-47 & C4259 & 573916.5 & 137295.5 & 648.8 & 2004 \\
\hline 299-E33-48 & $\mathrm{C} 4260$ & 573781.5 & 137162.1 & 664.7 & 2004 \\
\hline 299-E33-49 & C4261 & 573647.5 & 137212.8 & 666.8 & 2004 \\
\hline
\end{tabular}


PNNL-19277

Table 5.1. Details for B-Complex Groundwater Monitoring Wells

\begin{tabular}{|c|c|c|c|c|c|}
\hline Well Name & Well ID & $\begin{array}{l}\text { Easting } \\
(\mathrm{m})\end{array}$ & $\begin{array}{l}\text { Northing } \\
(\mathrm{m})\end{array}$ & $\begin{array}{c}\text { Ground } \\
\text { Surface } \\
\text { Elev. (ft)* }\end{array}$ & $\begin{array}{c}\text { Drilling } \\
\text { Completed } \\
\text { Date } \\
\end{array}$ \\
\hline 299-E33-50 & C5195 & 573773.6 & 137599.3 & 625.8 & 2006 \\
\hline 299-E33-205 & C5989 & 573633.4 & 137406.2 & 657.2 & 2008 \\
\hline 299-E33-296 & A7092 & 573628.1 & 137613.9 & 632.4 & 1992 \\
\hline 299-E33-302 & A7098 & 573579.9 & 137665.7 & 628.8 & 1992 \\
\hline 299-E33-304 & A7100 & 573496.6 & 137563.3 & 640.3 & 1991 \\
\hline 299-E33-333 & B8079 & 574086.4 & 137181.3 & 653.4 & 1998 \\
\hline 299-E33-334 & B8810 & 573514.7 & 137256.4 & 667.0 & 1999 \\
\hline 299-E33-335 & B8811 & 573568.4 & 137222.2 & 667.4 & 2000 \\
\hline 299-E33-337 & C3390 & 573821.8 & 137193.9 & 662.7 & 2001 \\
\hline 299-E33-338 & C3391 & 573912.1 & 137238.2 & 657.0 & 2001 \\
\hline 299-E33-339 & C3392 & 573716.9 & 137221.5 & 663.7 & 2001 \\
\hline 299-E33-340 & C5853 & 573779.6 & 137763.8 & 617.9 & 2008 \\
\hline 299-E33-341 & C5856 & 573565.2 & 137652.5 & 627.5 & 2008 \\
\hline 299-E33-342 & C5857 & 573625.7 & 137580 & 636.9 & 2008 \\
\hline 299-E33-343 & C5858 & 573744 & 137382.3 & 652.3 & 2008 \\
\hline 299-E33-345 & C6226 & 573780.9 & 137388.2 & 653.2 & 2008 \\
\hline \multicolumn{6}{|c|}{${ }^{*}$ Ground Surface Elevation (ft) at time of drilling. } \\
\hline \multicolumn{6}{|c|}{$=$ Disc $\_Z$ value in HEIS } \\
\hline \multicolumn{6}{|c|}{$\begin{array}{l}\text { = Calculated from most recent TOC survey and adjusted stick-up since time of } \\
\text { drilling }\end{array}$} \\
\hline \multicolumn{6}{|c|}{$\mathrm{TOC}=$ top of casing } \\
\hline
\end{tabular}

\subsection{Nitrate}

With significant gaps in data collection for nitrate from 1959 to 1962 and again from 1964 to either 1981 or 1991, it is difficult to determine whether the groundwater nitrate plume was growing in specific areas or generally dissipating. These data are discussed without visual representation (excepting the 1958 plume graphic in Figure 5.2) herein. By 1957, the groundwater below almost the entire B-Complex had nitrate concentrations that ranged from $>500$ to $\sim 10,000 \mathrm{mg} / \mathrm{L}$, suggesting that during and right after the active disposal of liquids ceased, there was a large and highly concentrated nitrate groundwater plume below, north, and east of the major B-Complex facilities. Nitrate data suggest that the 1958 groundwater in the B-Complex area contained concentrations on the order of several thousand $\mathrm{mg} / \mathrm{L}$ in many wells and up to 10,000 to $13,000 \mathrm{mg} / \mathrm{L}$ in a few select wells located in the BY Cribs area (e.g., 299-E33-4 and E333) (see Figure 5.2). By 1987, the groundwater below the B-Complex showed only one well (299-E33-3) with nitrate values greater than $45 \mathrm{mg} / \mathrm{L}$, the drinking water standard. From 1988 to 1989, nitrate concentrations to the north of the BY Cribs were increasing up to $100 \mathrm{mg} / \mathrm{L}$. The nitrate concentrations at well 699-49-55A, about 0.5 miles northwest of the BY Cribs, peaked at about $250 \mathrm{mg} / \mathrm{L}$ in 1987 and dropped to less than 100 in 1989. 

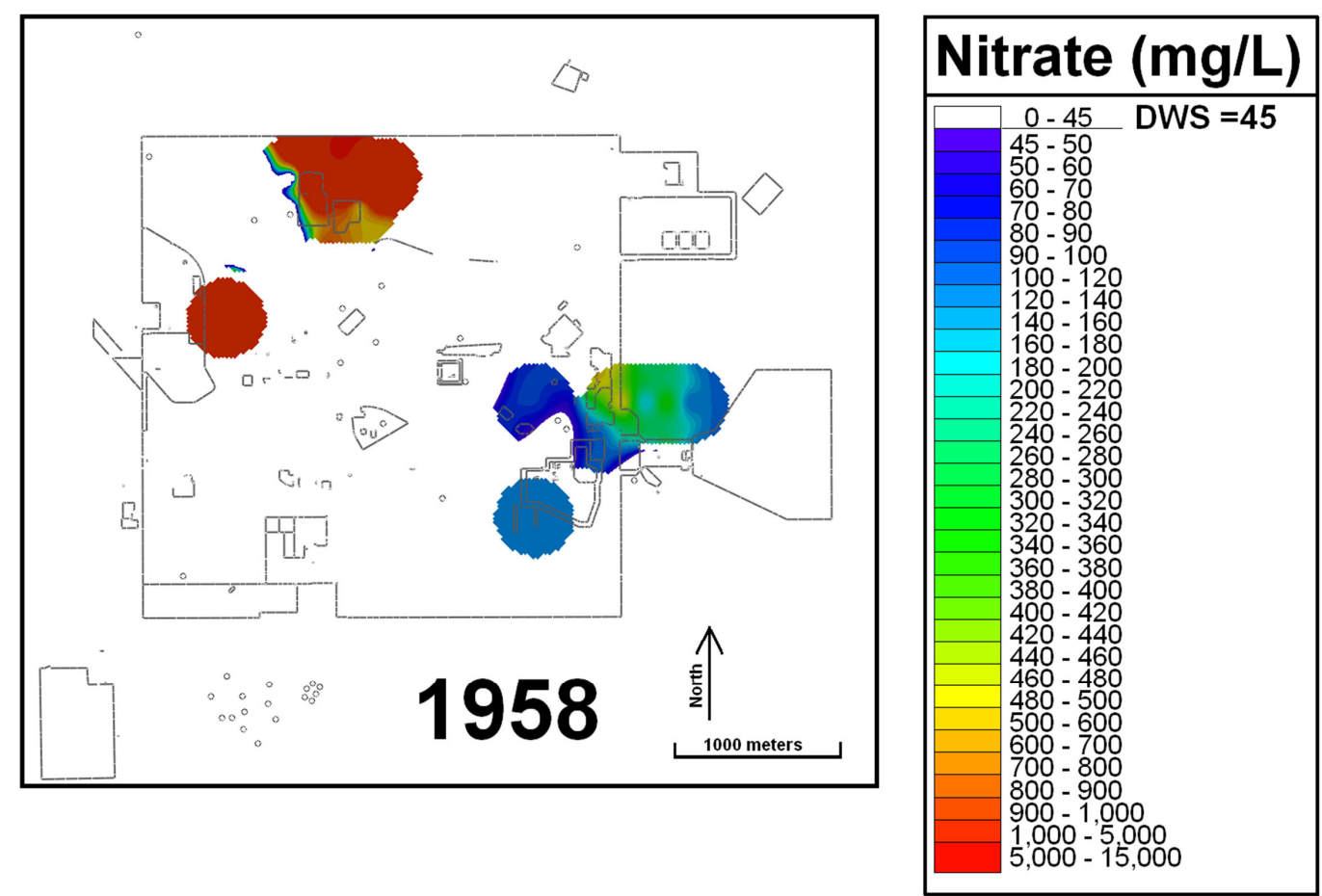

Figure 5.2. Nitrate Groundwater Plumes below the Entire 200-E Area (based on much fewer wells than available today)

In 1990, only 14 groundwater nitrate measurements were reported for the region below the BComplex. Three wells within the BY Cribs region had nitrate concentrations that ranged from 9 to 41.4 $\mathrm{mg} / \mathrm{L}$ but the two wells E33-3 and E33-4 that showed the high nitrate concentrations in previous years were not sampled in 1990. Since 1991, the well coverage and consistency in sampling has been much better in the B-Complex. It is apparent that nitrate concentrations increased in 1991 in BY Cribs and B7A\&B and B-8 Cribs regions. In 1992 through 1993, the BY Cribs had nitrate groundwater concentration highs between 65 to $83 \mathrm{mg} / \mathrm{L}$ and the region around 299-E33-18 (near the B-7A Crib) showed nitrate between 50 and $62 \mathrm{mg} / \mathrm{L}$. Figure 5.3, taken from DOE/RL (2007c), shows a time series map of the nitrate groundwater plume below the B-Complex from 1995 to 2007. These plume maps did not consider the nitrate found northwest of the BY Cribs at wells 699-49-55A and 699-49-57A. Therefore, the higher concentration areas should be extended to the northwest and off the maps. In general between 1994 and 1999, nitrate groundwater concentrations below the BY Cribs and the B-7-A\&B/B-8 subregions were slowly increasing from between 60 to 100 and 60 to $70 \mathrm{mg} / \mathrm{L}$ to 60 to 410 and 125 to $540 \mathrm{mg} / \mathrm{L}$, respectively. By 2001, the nitrate plume had expanded areally in these two regions, and nitrate concentrations increased to between 380 to 750 and 130 to $640 \mathrm{mg} / \mathrm{L}$ below the BY Cribs and B7A\&B/B-8 Cribs subregions. By 2004, the nitrate plume had increased in size and a localized hot spot (with a nitrate concentration $>1000 \mathrm{mg} / \mathrm{L}$ ) developed in the northeast corner of the BY Cribs area at well 299-E33-4. By 2007, the $1000 \mathrm{mg} / \mathrm{L}$ nitrate concentration included most of the BY Cribs footprint area and extended east to well 299-E33-13. By this time at the original hotspot at well 299-E33-4, the groundwater nitrate concentration reached almost $5000 \mathrm{mg} / \mathrm{L}$, similar to the nitrate groundwater concentrations observed in 1958. The $>1000 \mathrm{mg} / \mathrm{L}$ isopleths covered the entire BY Cribs footprint as well as the northeast tip of the BY Tank Farm. In 2007, the $>100 \mathrm{mg} / \mathrm{L}$ isopleth (tan color in Figure 5.3) extended under the entire BY Tank Farm all the way south to cover all but the bottom third of the BX 

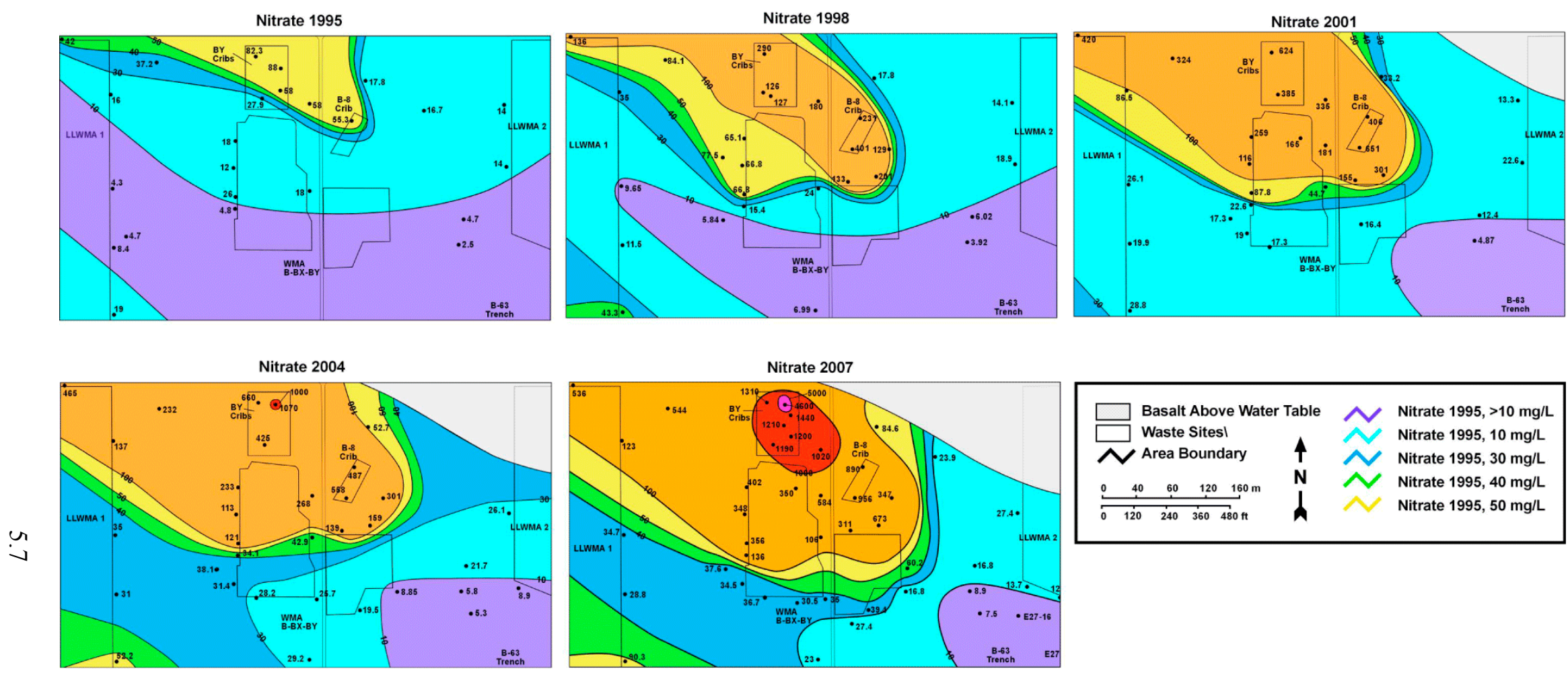

Figure 5.3. Time Series (1995 to 2007) Plume Maps for Nitrate in the B-Complex Region (taken from DOE/RL 2007c) 
Tank Farm to the east to cover the northern one-third of the B Tank Farm and the entire B-7-A\&B/B-8 Cribs subregion. In fact the nitrate concentrations below the northern half of BY Tank Farm and below the B-8 Crib and Tile Field area were approaching 500 and $1000 \mathrm{mg} / \mathrm{L}$ in 2007, respectively. By July of 2008, the nitrate concentration in well 299-E33-4 was $17,800 \mathrm{mg} / \mathrm{L}$ and was $1030 \mathrm{mg} / \mathrm{L}$ at 299-E33-16 below the B-8 Crib. As shown in Figure 5.3 around 2003, and certainly by 2007, groundwater nitrate concentrations below the BY Cribs increased, suggesting that the BY Cribs vadose zone started to resupply high concentrations of nitrate to the water table.

Recent groundwater nitrate plume data over the last several years based on plots of only samples collected in the spring and fall were made available for this report by CHPRC staff associated with the Site Wide Groundwater Monitoring Program. These plots, Figure 5.4 through Figure 5.7, differ from most of the historical groundwater plume plots and those generated for this report that used yearly averages of the groundwater data. Most wells in the B-Complex are now sampled quarterly, some semiannually, and fewer annually. The key finding from the spring and fall groundwater nitrate plume plots is the appearance of episodic "pulses" of contaminants infiltrating into the groundwater with variable groundwater flow velocities in a generally northwest direction. Note that the concentrations of nitrate in Figure 5.4 through Figure 5.7 have units of $\mu \mathrm{g} / \mathrm{L}$ instead of $\mathrm{mg} / \mathrm{L}$ as most of the other figures used in this report. One needs to mentally reduce the values in the legends of Figure 5.4 through Figure 5.7 by a factor of 1000 to compare nitrate values between these and the other nitrate graphics. Several points can be made from these seasonal figures. In the spring 2008 (Figure 5.4), the center of mass of the high nitrate concentrations (between 1000 and $1500 \mathrm{mg} / \mathrm{L}$ ) was located below the BY Cribs. By the fall of 2008 (Figure 5.5), the groundwater nitrate concentrations below the BY Cribs had increased such that the high isopleth was 1500 to $2000 \mathrm{mg} / \mathrm{L}$. Also during this time frame the nitrate plume appeared to migrate to the southeast causing significant increases in well 299-E33-13. This migration was concurrent with the first recorded groundwater gradient reversal in this area. The flow direction reversal was attributed to high spring Columbia River stages (DOE/RL-2008b). In the spring of 2009 (Figure 5.6), the area under the BY Cribs within the highest isopleth (red color) increased in size and shifted its center of mass towards the northwest. The 1000 to $1500 \mathrm{mg} / \mathrm{L}$ isopleth (orange color) continued to grow especially towards the southeast to now fall directly below the B-8 Crib and the southern end of the B-8 Tile Field. Figure 5.7 (Fall 2009) shows that the center of mass of both of these high-nitrate isopleths has migrated significantly towards the northwest looking more like the Fall 2008 configuration. These four figures suggest a conceptual model wherein the groundwater flow direction below the B-Complex is primarily towards the northwest, but that for part of the time, the flow appears to have reversed. During this year and half period of time the nitrate concentrations have trended up primarily within the BY Crib Region and the below the B-8 Crib strongly suggesting infiltration into the groundwater. When the groundwater flow returned to the northwest as it appears to have done between spring and fall 2009, the observed nitrate concentrations drop slightly in wells in the central core region of the B-Complex.

These observations on nitrate in the groundwater below the B-Complex lead to the following conclusions. There appears to be a period of time over which the groundwater nitrate plume from the 1954 to 1956 active disposal period dissipated based on finding very few measurements in groundwater below the BY Cribs and B-7A Crib above $45 \mathrm{mg} / \mathrm{L}$ in 1984 through 1990 in wells in the B-Complex; however the number of wells sampled during this time period was small in comparison to later dates. From 1990 through 1993, localized inputs of nitrate were observed close to the BY Cribs and the B-7A\&B and B-8 Cribs. Based on Figure 5.3, there appears to be a more recent period of time (2006 through 


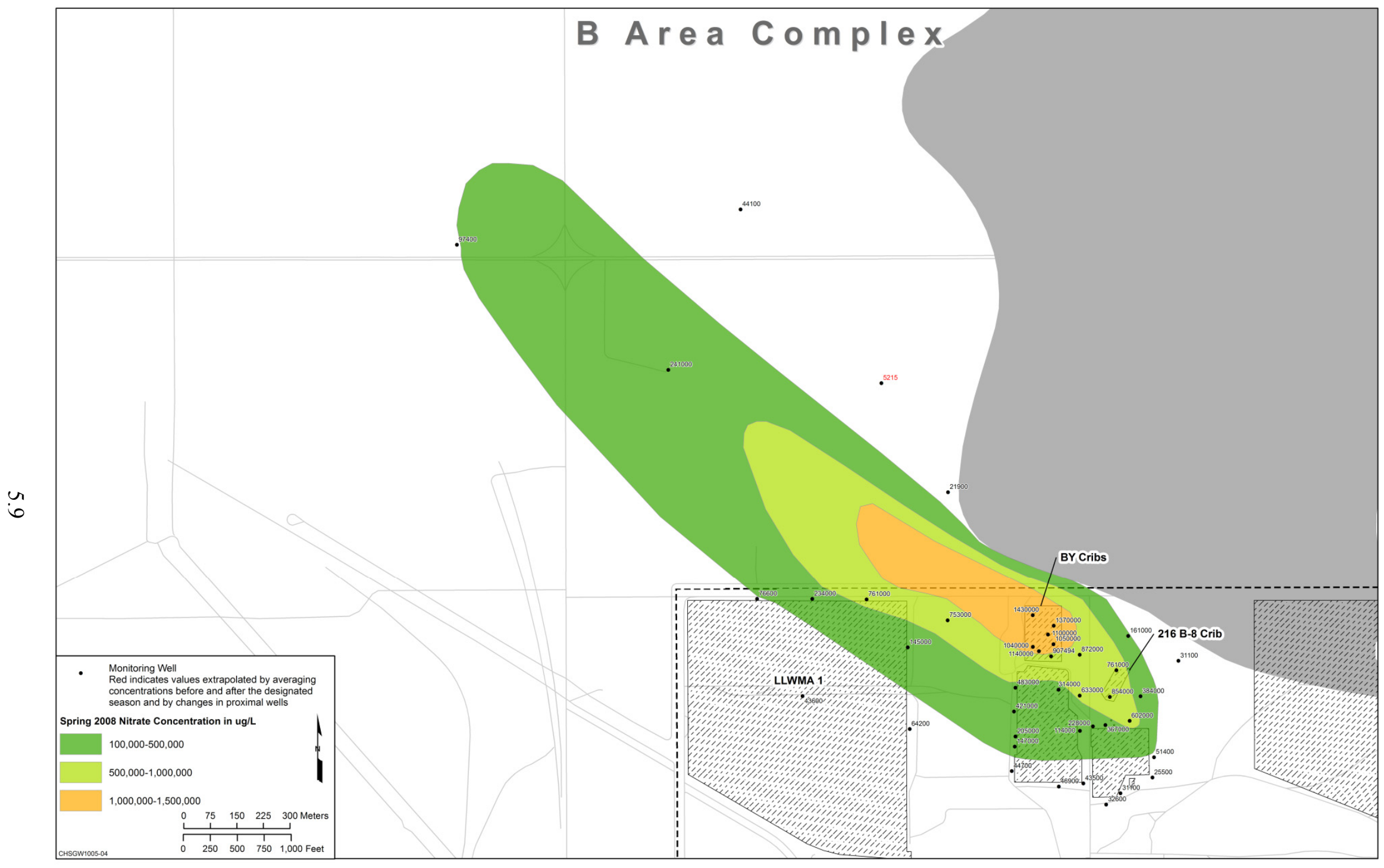

Figure 5.4. Groundwater Nitrate Plume Map for Samples Collected in Spring 2008 


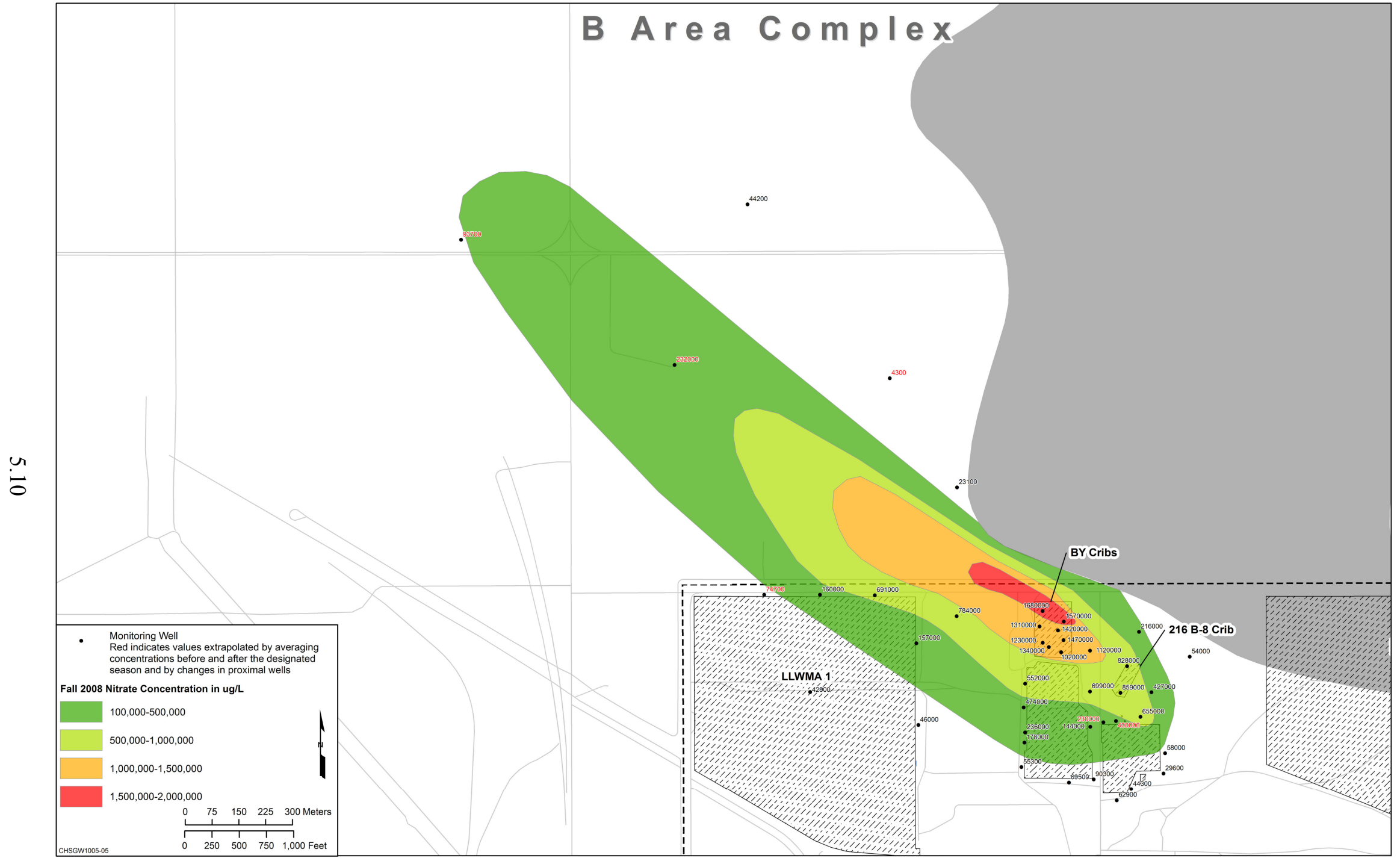

Figure 5.5. Groundwater Nitrate Plume Map for Samples Collected in Fall 2008 


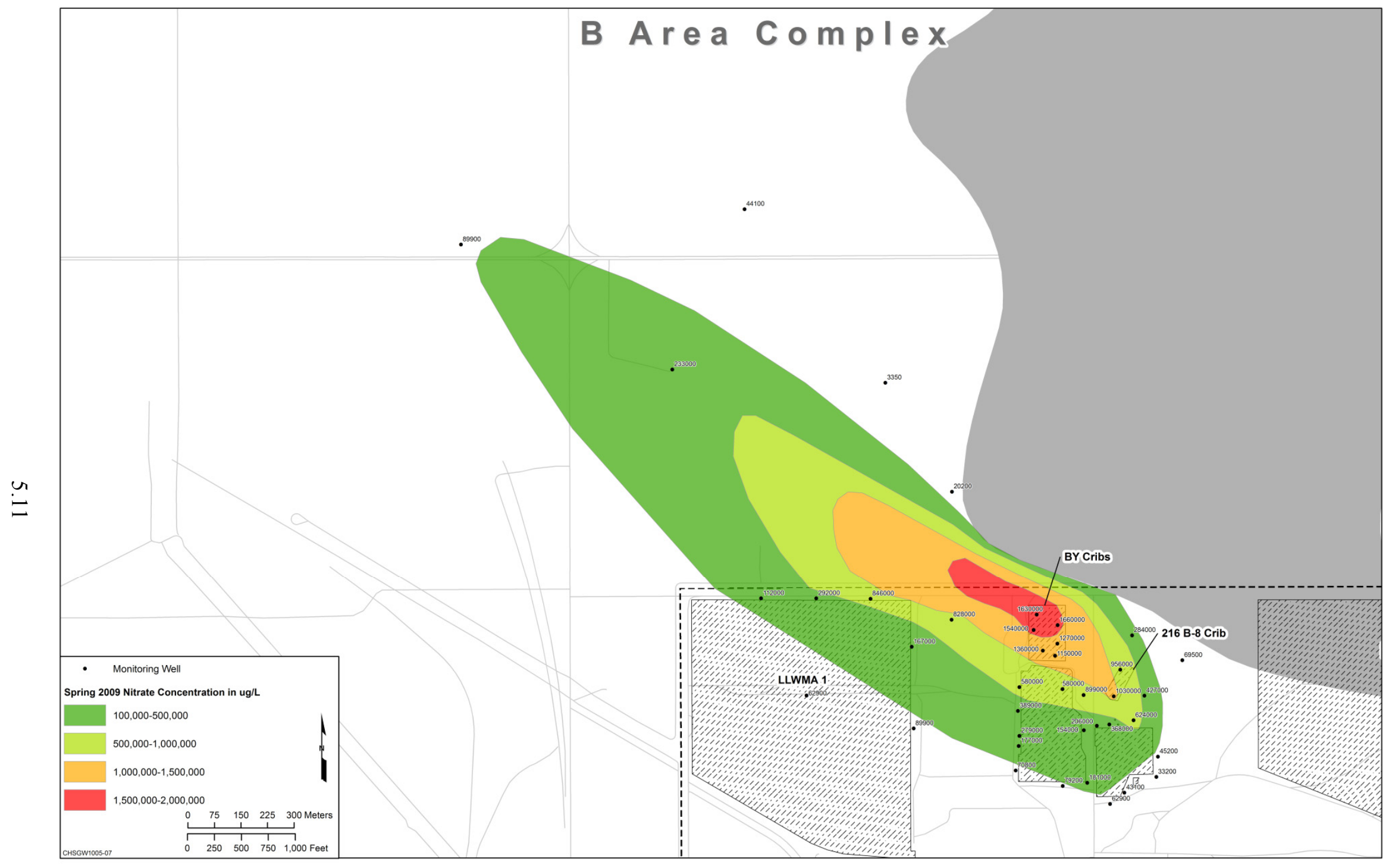

Figure 5.6. Groundwater Nitrate Plume Map for Samples Collected in Spring 2009 


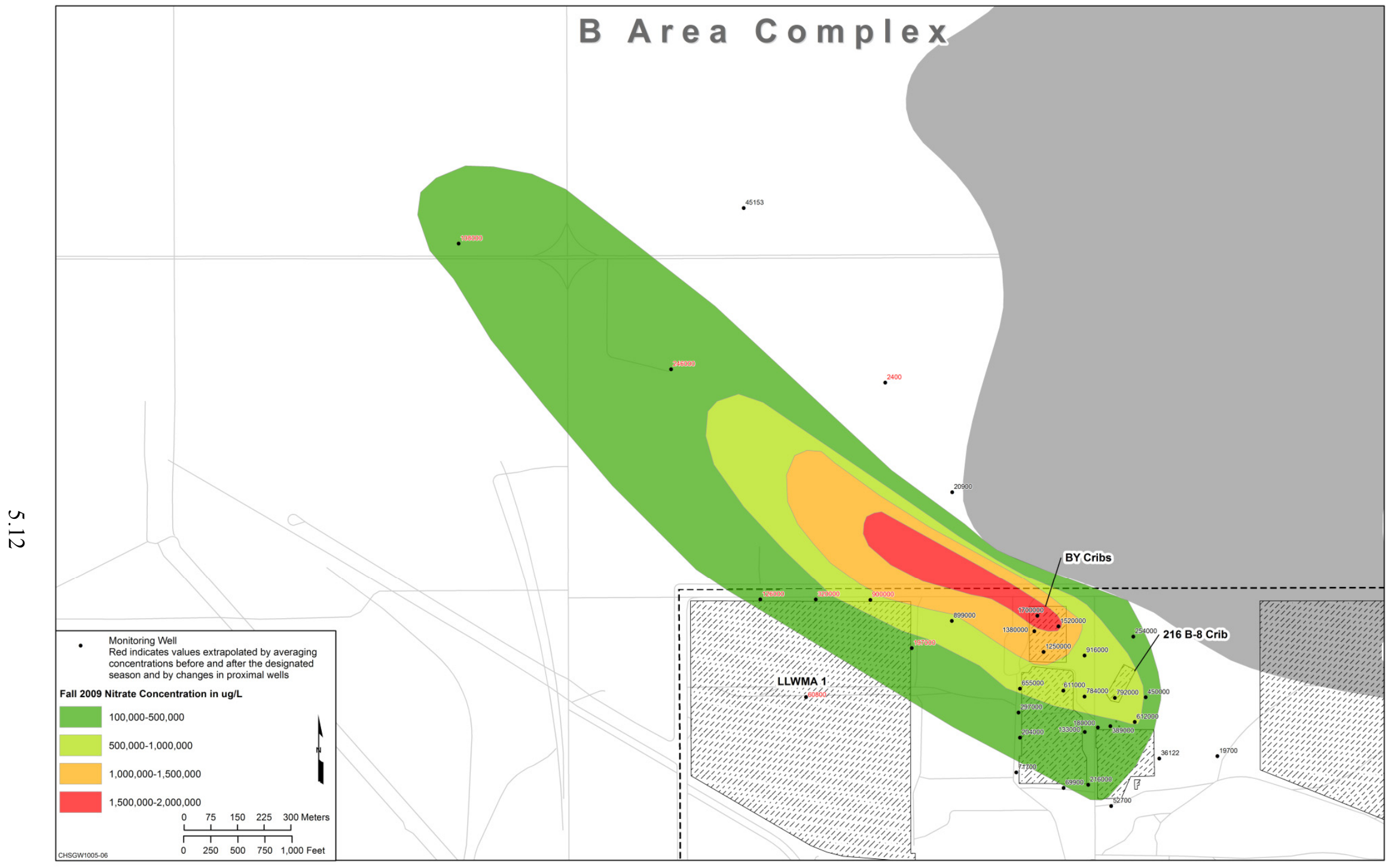

Figure 5.7. Groundwater Nitrate Plume Map for Samples Collected in Fall 2009 
the present) with more rapidly increasing concentrations of nitrate observed in the groundwater below the B-Complex, mainly sourced from the BY Cribs but with some contribution from the B-8 Crib and Tile Field. Along with the supporting data on the liquid release volumes, large nitrate inventories disposed, and vadose zone depth discrete sediment measurements below the BY Cribs it is concluded that the entire area below the BY cribs is currently draining nitrate into the water table. Nitrate also is infiltrating into the water table beneath the B-7-A\&B/B-8 Cribs subregion based on the groundwater data with support of the liquid release volumes, large nitrate inventories disposed to these two cribs, and soil electrical resistivity survey results. Since less is understood about the vadose zone beneath the B-8 and to some extent the B-7A\&B Cribs versus the BY Cribs determining the residual mass of nitrate still available for infiltration into the aquifer is not known to some quantitative certainty. Appendix G contains similar fall-spring seasonal groundwater plume maps for sodium from 2000 through 2008. Sodium is the typical cation in the high nitrate waste streams, and its migration tendencies are correlated with nitrate. Thus, one can use the sodium time series plume maps to generalize on the behavior of nitrate over this longer time period.

\subsection{Technetium-99}

The first groundwater measurements of technetium-99 in the B-Complex that are in the HEIS database are from late 1986 for well 299-E33-7 in the northwest corner of the BY Cribs subregion. Between 1987 and 1989, technetium-99 was reported for a few wells in the B-Complex (e.g., 299-E331A, -E33-7, -E33-8, -E33-9, -E33-12, -E33-20, -E33-21, and -E33-24). In 1991, several more groundwater monitoring wells were drilled, and technetium- 99 groundwater data became more systematically available and continues to the present time. Because of the lack of early technetium-99 data, it is not possible to develop a technetium-99 groundwater plume map for the B-Complex before 1991. A time series technetium-99 plume map for the entire 200-East Area for selected years between 1992 and 2001 is shown in Figure 5.8. A second time series technetium-99 plume map is presented in DOE/RL-(2007c) and reproduced herein as Figure 5.9. As mentioned, no technetium-99 groundwater data could be found for years before 1986, but it is inferred that, based on the relationship of technetium99 and nitrate, the high nitrate concentrations would also indicate high concentrations of technetium-99 were also present during the years of active disposal to facilities in the B-Complex and into the 1960s when the gross beta and nitrate plumes started to dissipate. If one assumes that the ratio of technetium-99 to nitrate is a constant, then estimates of the technetium- 99 concentration in the groundwater could be made for the early years even though no technetium-99 measurements were being made. Because neither technetium-99 nor nitrate interact significantly with sediments, they should remain in the waste fluid at an equal ratio as they migrate and dilute with native pore water during its descent towards the water table. The ratio of technetium-99 to nitrate in the waste disposed of to the seven BY Cribs that contained scavenged waste, based on SIM model estimates, is $0.019 \mathrm{pCi} / \mu \mathrm{g}$ (see Table 3.24). A second estimation method is to use the ratio of technetium-99 to nitrate in the water extracts in the deep vadose zone from the two boreholes drilled through the BY Crib footprints (E33-296 and E33-302). The water extract technetium-99 to nitrate ratios are $0.049 \pm 0.009$ and $0.031 \pm 0.005 \mathrm{pCi} / \mu \mathrm{g}$, respectively (data from Table 3.2 and Table 3.3). By these methods the concentration of technetium-99 in the groundwater during the early years, before technetium-99 measurements were available, was likely within these ratio 


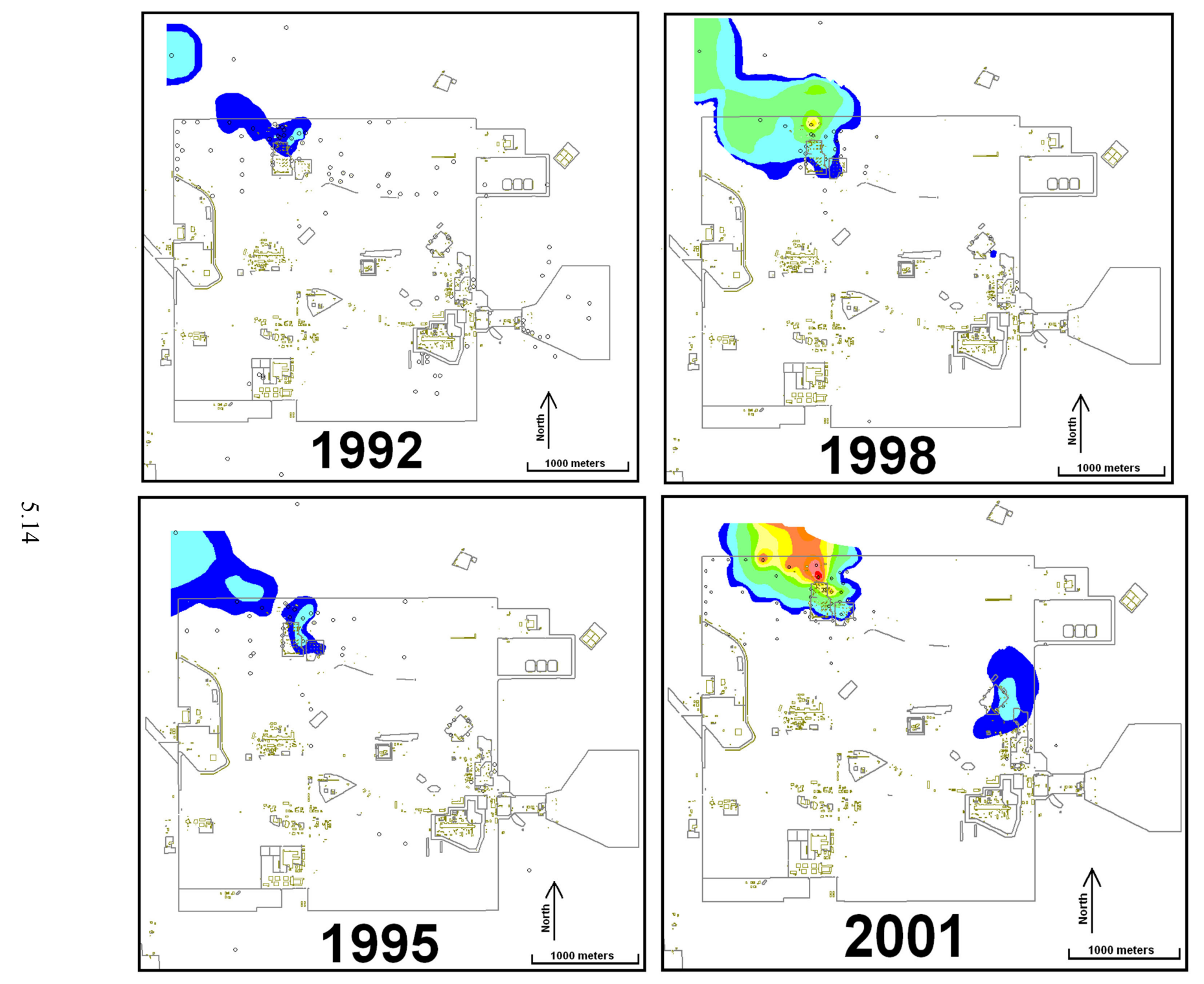

\begin{tabular}{|c|}
\hline $\begin{array}{l}\text { Technetium-99 } \\
\text { (pCi/L) }\end{array}$ \\
\hline $\begin{array}{l}0-450 \\
450-900 \quad \text { DWS }=900 \\
900-2,000 \\
2,000-3,000 \\
3,000-4,000 \\
4,000-5,000 \\
5,000-6,000 \\
6,000-7,000 \\
7,000-8,000 \\
8,000-9,000 \\
9,000-10,000 \\
10,000-50,000\end{array}$ \\
\hline
\end{tabular}

Figure 5.8. Times Series Technetium- 99 Groundwater Plume Maps for 200-E Area 
Technetium 2002

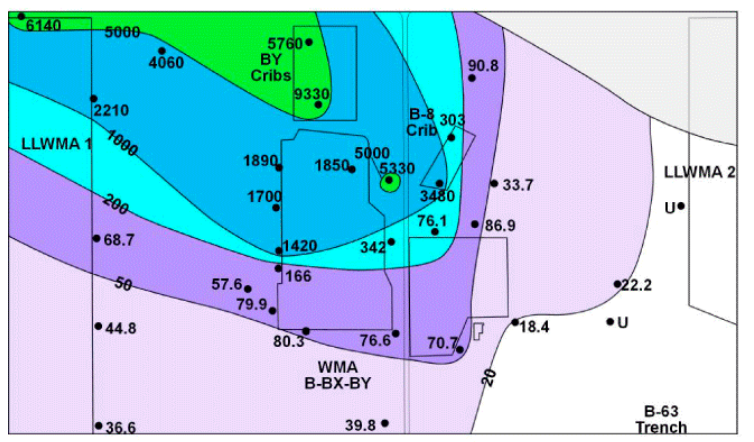

Technetium 2006

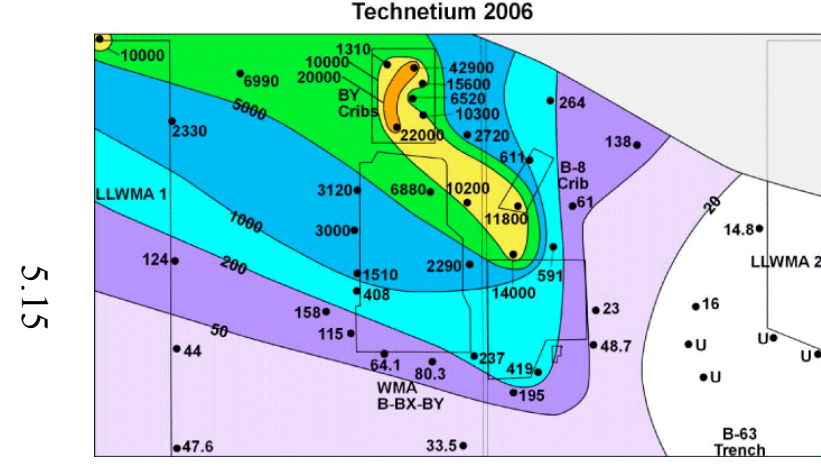

Technetium 2004

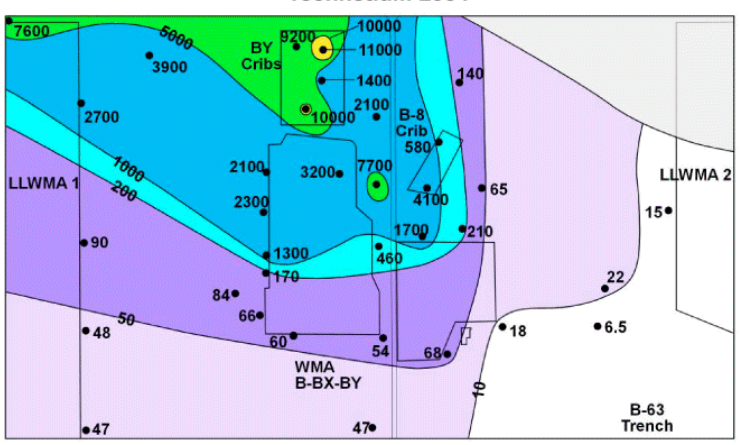

Technetium 2007

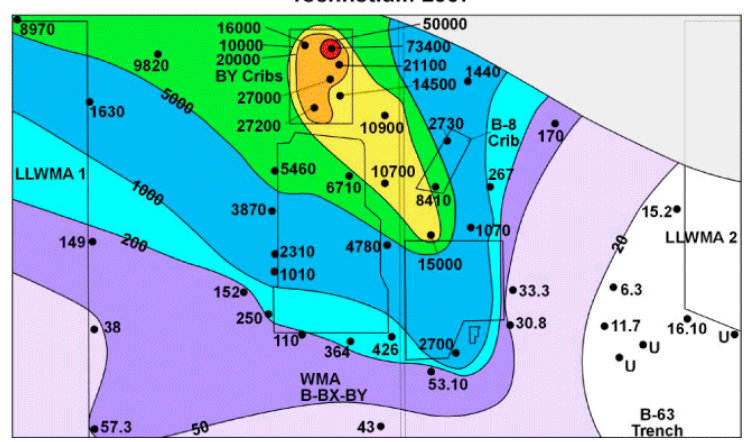

Technetium 2005

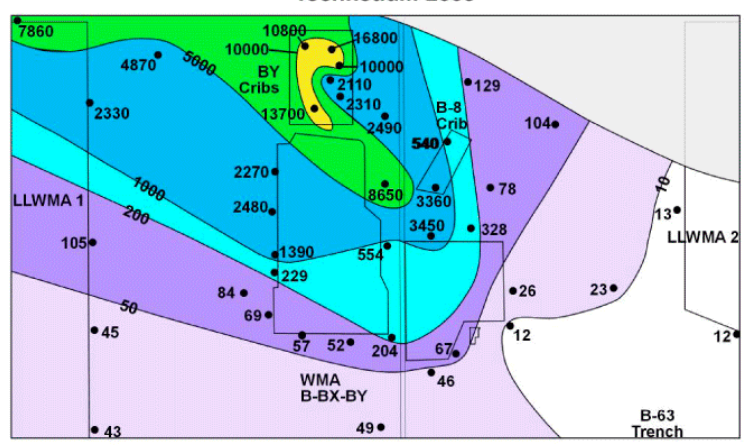

49.

Figure 5.9. Time Series (2002 to 2007) Plume Maps for Technetium- 99 in the B-Complex Region

Taken from DOE/RL-(2007c) 
ranges multiplied by the measured nitrate concentrations. As mentioned in subsection 5.2 , the groundwater nitrate concentration in well 299-E33-4 in 1958 reached $10,000 \mathrm{mg} / \mathrm{L}$. The equivalent estimated technetium-99 concentration at this well at this time likely ranged from $1.92 \mathrm{E}+05$ to $4.9 \mathrm{E}+05$ $\mathrm{pCi} / \mathrm{L}$. Recently, the technetium-99 concentration in this location has been $1.0 \mathrm{E}+05$, about the same as during the past active disposal era. This suggests that residual waste held up, possibly by significant horizontal spreading in the vadose zone during the active liquid disposal period, has recently descended down to the water table.

As shown in Figure 5.8 from 1992 through 1995, a technetium-99 plume close to or slightly above the drinking water standard of $900 \mathrm{pCi} / \mathrm{L}$ was seen in the northern half of the $\mathrm{BY}$ Cribs region. Between 1992 and 1995 the technetium-99 plume appears to spread to the northwest and north beyond the BY Cribs. By 1998, some wells north of the BY Cribs had technetium-99 concentrations greater than 5,000 pCi/L. By 2001, some wells northwest and within the northern half of the BY Cribs had technetium-99 concentrations greater than $10,000 \mathrm{pCi} / \mathrm{L}$. The technetium-99 plume maps shown in Figure 5.9 (taken from DOE/RL-2007c) cover a smaller region, centered on the B-BX-BY Tank Farms. The figure generally shows the technetium-99 plume evolution, but does not show the development of high concentrations to the northwest of the BY cribs because they did not consider well 699-49-57A, located off the map to the northwest. As shown in Figure 5.9, a region with $\sim 10,000 \mathrm{pCi} / \mathrm{L}$ technetium- 99 was present within the BY Cribs footprint in 2004 and grew in size in 2005. In the 2004 to 2005 time frame, a small localized technetium-99 hot spot ( $7000 \mathrm{pCi} / \mathrm{L})$ also appeared east of the BY Tank Farm at well 299-E33-44. By 2006, there was a significant in-growth of technetium-99 with the greater than 10,000 $\mathrm{pCi} / \mathrm{L}$ isopach extending from below the BY Cribs region to near the northeast corner of the B Tank Farm. The 2006 plume map also shows that the technetium-99 in the BY Cribs footprint increased to at least $20,000 \mathrm{pCi} / \mathrm{L}$. In 2007, the technetium-99 groundwater concentrations below the entire BY Cribs area were between 10,000 and $20,000 \mathrm{pCi} / \mathrm{L}$ with the initial hot spot in the northern edge at $50,000 \mathrm{pCi} / \mathrm{L}$. The $10,000 \mathrm{pCi} / \mathrm{L}$ isopleth also appears to have grown in a southeastern direction to extend down to 299-E33-18. This could be interpreted as groundwater from below the BY Cribs flowing towards the southeast; however, with the drilling of 299-E33-343 in January 2008, it is now apparent that high concentrations of technetium-99 are entering the groundwater near this location. This new discovery means high technetium-99 in the groundwater was feeding mass near the location of 299-E33-343 and causing the $10,000 \mathrm{pCi} / \mathrm{L}$ isopleth to shift to the southeast. This new source of technetium-99 along with the seasonal Columbia River impacts of the regional hydraulic gradient causes the appearance of southeasterly flow. In reality, the net long-term groundwater flow from the BY Cribs continues moving in the northwest direction over at least the last decade.

A third time series of technetium-99 plume maps were generated to investigate seasonal changes in plume concentrations and locations in a similar fashion as done for the nitrate groundwater plume. The data for individual quarters (spring and fall) were prepared for the years 2008 and 2009. Figure 5.10 through Figure 5.13 show the seasonal plumes of only samples collected in the spring and fall. Most other groundwater plume graphics in this document average the measurements by sampling year.

Several points can be made from these seasonal figures. In the spring of 2008 (Figure 5.10), the center of mass of the high technetium-99 concentrations $(>25,000 \mathrm{pCi} / \mathrm{L})$ was located below the northwestern portion of the BY Cribs. By the fall of 2008, Figure 5.11, technetium-99 groundwater concentrations below the BY Cribs increased such that the maximum isopleth was now 35,000 to 45,000 pCi/L, and the 


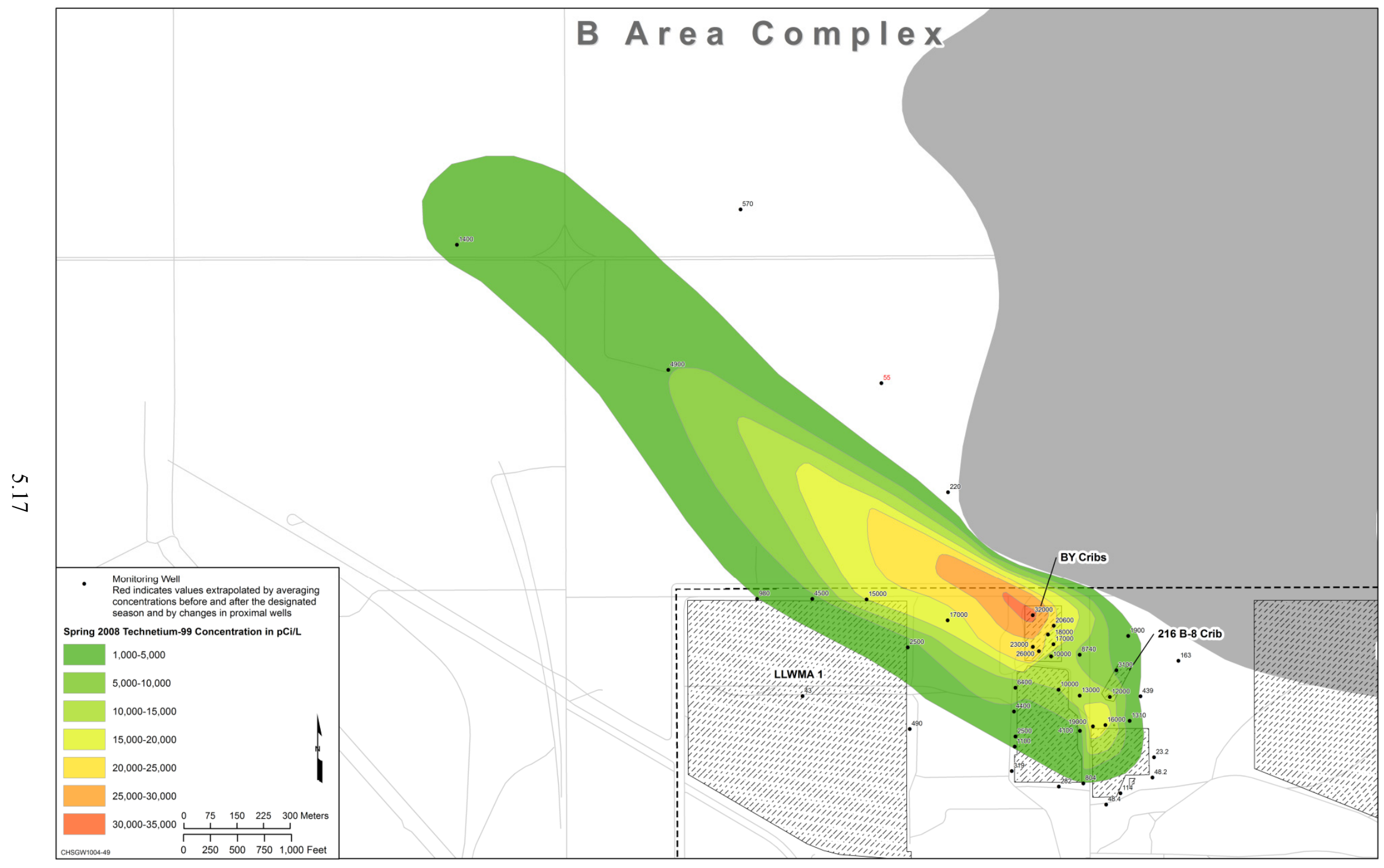

Figure 5.10. Groundwater Technetium-99 Plume Map for Samples Collected in Spring 2008 


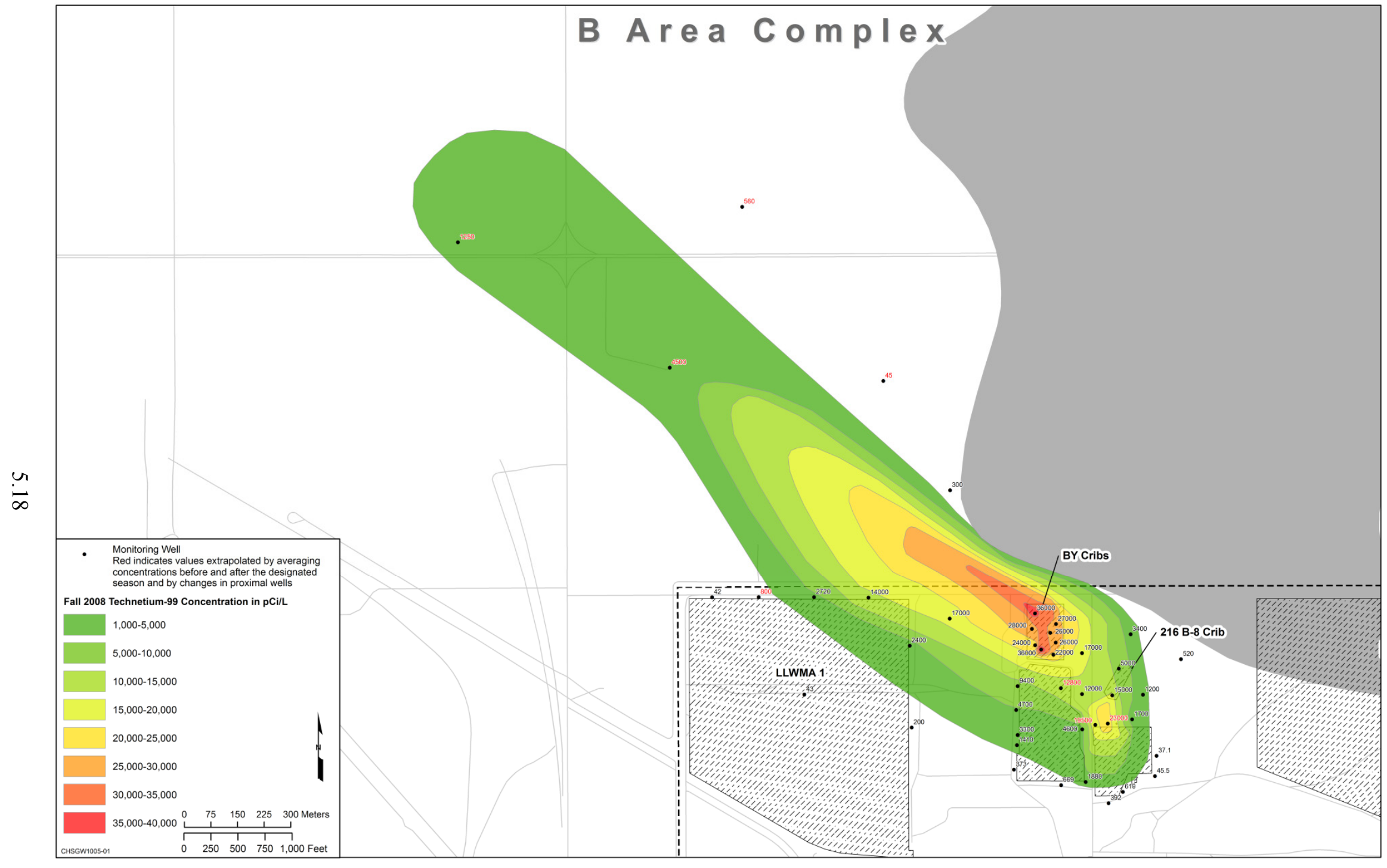

Figure 5.11. Groundwater Technetium-99 Plume Map for Samples Collected in Fall 2008 


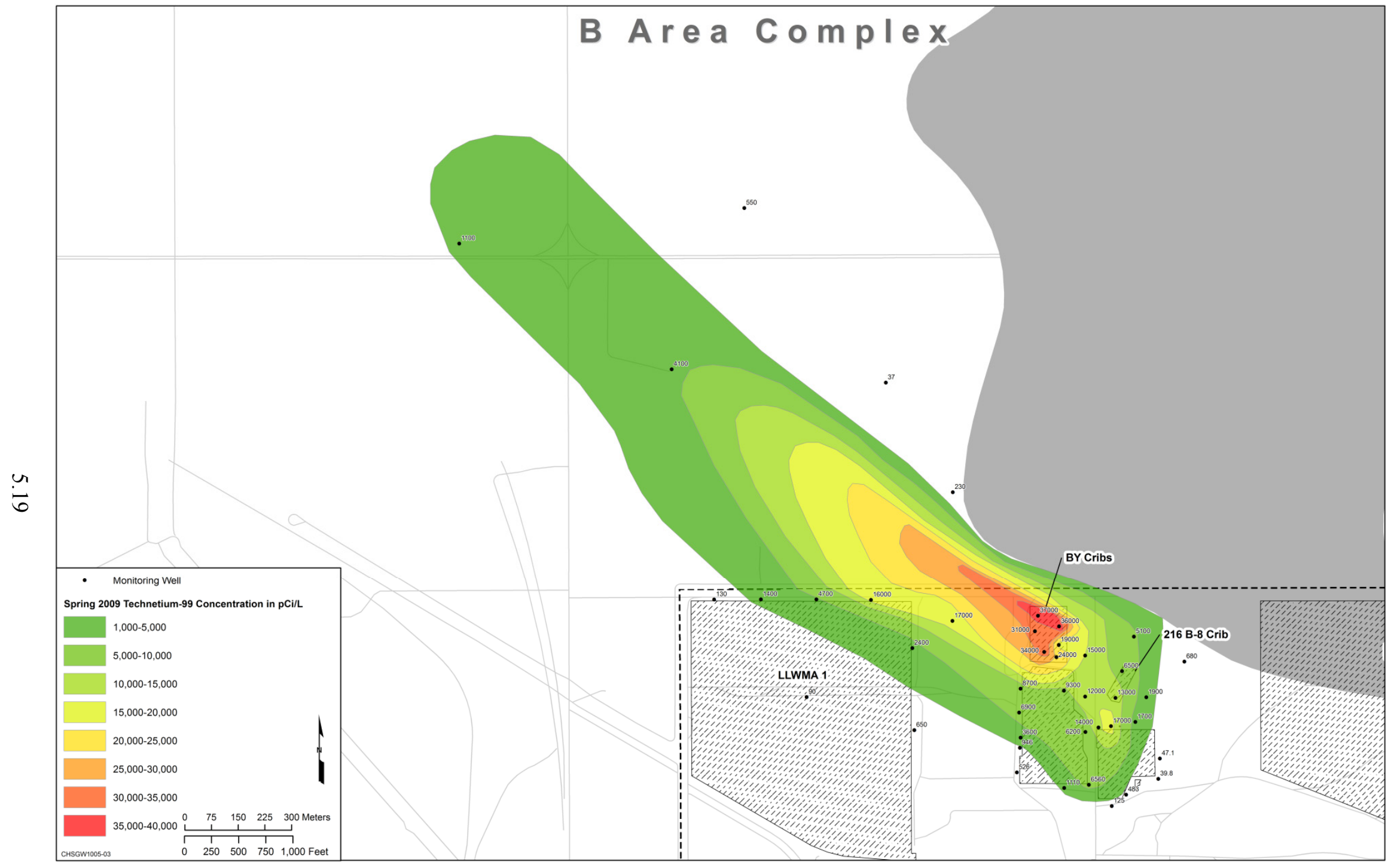

Figure 5.12. Groundwater Nitrate Plume Map for Samples Collected in Spring 2009 


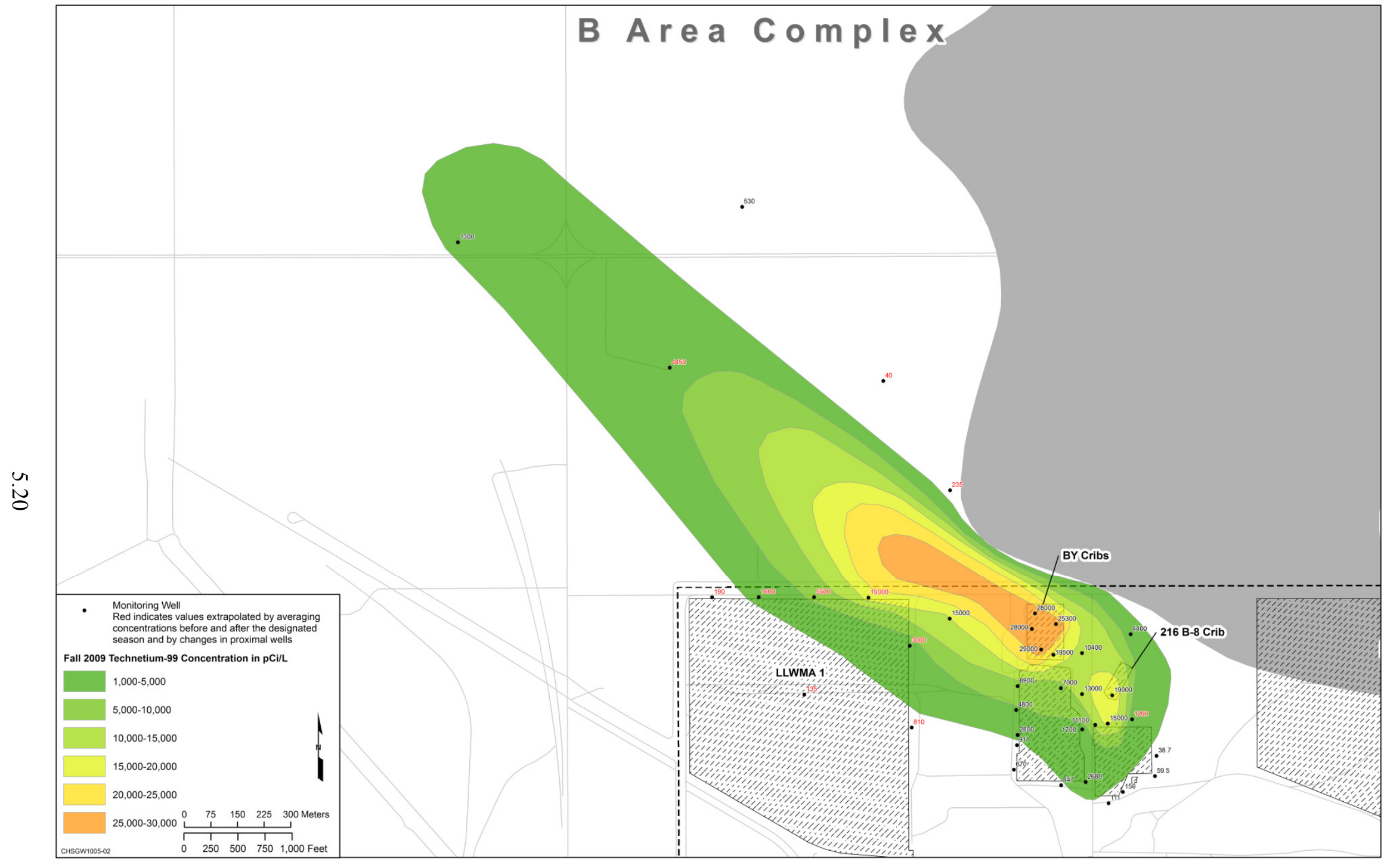

Figure 5.13. Groundwater Technetium-99 Plume Map for Samples Collected in Fall 2009 
higher concentration isopleths seem to have moved to the southeast. The apparent southeast movement was likely caused by a combination of a reversal of the groundwater gradient resulting from a relatively high Columbia River stage in the spring of 2008 (DOE/RL-2008b) and the influx of high technetium-99 water from the secondary vadose zone source near 299-E33-343. Figure 5.11 shows that the secondary localized plume of relatively high technetium-99 occurred in the vicinity of the future borehole 299-E33343 (not yet drilled at this time).

In the spring of 2009 (Figure 5.12), the area under the BY Cribs within the highest isopleth (red color) had shifted its center of mass towards the northwest, and the secondary localized hot spot near 299E33-343 had decreased in concentration. Figure 5.13 (Fall 2009) shows that the concentrations of technetium-99 in general were decreasing. These four figures suggest a conceptual model wherein the groundwater flow direction below the B-Complex was predominantly towards the northwest, but that during times of high Columbia River stage, the groundwater flow gradient appeared to decrease and even reversed between the spring and fall of 2008 (see DOE/RL-2008b). During these times, increasing groundwater concentrations because of less advection in the aquifer and an apparent movement of the plume to the southeast were observed. When the groundwater flow velocity to the northwest resumed between the spring and fall 2009, the observed technetium-99 concentrations dropped slightly in wells in the central core region of the B-Complex. This is the same conceptual model as described by the nitrate groundwater data seasonal evolution over the 2008 to 2009 time period.

During times of reduced groundwater gradient, contaminants originating below the BY Cribs and below the northwest corner of the B Tank Farm migrate to the aquifer and increase groundwater concentrations. The increased concentrations also give the appearance of net groundwater flow to the southeast. As mentioned there is temporary reversal of groundwater flow for a few months in some years, but it is believed that the greater cause of the apparent southeasterly movement of groundwater contaminant isopleths is the lower flux of water in the B-Complex during these times that does not sweep away the influx from the vadose zone as quickly thus giving the appearance of higher groundwater concentrations.

A final activity performed on technetium-99 groundwater data was to plot the yearly average concentrations for the years 2000, 2003, 2006, and 2009 to allow the inventory of technetium in the unconfined aquifer to be estimated. Inventories of technetium- 99 for the groundwater plume underneath the B-Complex were estimated using the conceptual model for aquifer thickness discussed in Section 2 and Appendix B and the technetium groundwater monitoring data and water table elevations available in the EDA database. When data existed for several sampling intervals within the same calendar year, the reported technetium-99 concentrations were averaged to obtain the average value for technetium- 99 for the years chosen to produce plume maps and total mass estimates within the plume. Care was taken to exclude groundwater data that were qualified with "Lab Qualifier" designations of E (reported value estimated because of interference), $U$ (not detected above specified criteria; generally the detection limit), $\mathrm{X}, \mathrm{Y}$, or $\mathrm{Z}$ (codes that required review of the hard copy data forms to determine why the data were flagged as not reliable or inaccurate). The process was as follows: EarthVision ${ }^{\circledR}$, a 3D geosciences computer code, was used to create $10-\mathrm{m}$ by $10-\mathrm{m}$ grids of the area encompassing the technetium- 99 plume. The elevations of the water table for each year and the top of basalt elevation from the conceptual geologic model described in Section 2 were used to determine the aquifer thickness. The average groundwater contaminant concentrations were then gridded in EarthVision ${ }^{\circledR}$ using information from handdrawn isopleths for additional control. Because the technetium-99 detection limit was usually equal to or 
below $10 \mathrm{pCi} / \mathrm{L}$, this concentration value was used as the cutoff value. Measurements with a U laboratory-qualifier (meaning non-detects) helped define the extent of the technetium-99 plume. Computer generated interpretations of the interpolated groundwater contaminant isopleths and aquifer thickness were revised based on review by a team of hydrogeologists.

As shown in the following figures, the technetium-99 plume extends far to the north and northwest beyond the B-Complex. For the region far to the north of the 200 East Area fence line and beyond Gable Gap, the aquifer thickness increases significantly compared to the relatively thin aquifer currently found below the B-Complex. Concerns were raised that contaminants and water migrating from the B-Complex into the thicker aquifer might not thoroughly mix over the entire depth to the basalt bedrock. However; in at least one well suite (699-53-55B and 53-55C; screened at different elevations) the technetium-99 groundwater concentration appears to be constant with depth. Therefore it was decided to assume that the entire aquifer thickness contained the same concentration of technetium measured in the groundwater samples obtained in only the screened region. As shown in the bottom row of Table 5.2, the mass estimates remain low compared to the mass disposed of to the BY Cribs (192 Ci). The mass estimates shown in Table 5.2 should overestimate the inventory in the aquifer plume if the contaminants remain closer to the top of the water table where most screens reside instead of mixing throughout the entire aquifer thickness. Conversely if the technetium-99 laden wastewater sinks after leaving the shallow aquifer below the B-Complex as it migrates towards and through Gable Gap, then the measured groundwater technetium concentrations might underestimate the mass of technetium in subregions north and northwest of the B-Complex.

The contaminant mass within each $10 \mathrm{~m} \times 10 \mathrm{~m}$ cell was calculated by multiplying the aquifer thickness at the cell location, by the cell area $\left(100 \mathrm{~m}^{2}\right)$, by the aquifer porosity, and by the groundwater concentration at the cell location. This resulted in a mass (activity) being assigned to each grid cell. The total mass was then determined by summing the mass of all cells in the grid. Porosity was used in the mass calculation because groundwater does not fill the entire volume of the cells, but rather only fills the void space (porosity) of the cell. The masses were calculated based on an average aquifer porosity of 0.121. This porosity value represents the recommended value for the $\mathrm{CCU}_{\mathrm{g}}$ unit (see Table 4.3), which is the strata in which almost all of the unconfined aquifer resides below the B-Complex.

The calculated masses only include technetium-99 dissolved in the groundwater and do not include any technetium sorbed onto the aquifer sediments. Other tacit assumptions in the calculation include that each sample and its measured value in any calendar year was equally weighted and that the measured concentration represented the concentration over the entire calculated thickness of the aquifer at the cell containing the contaminant. The validity of this uniform concentration from the top to bottom of the aquifer is questionable. Very little depth-discrete sampling has been performed in Hanford monitoring wells, and the data that have been collected do not show a consistent pattern from well to well or from one time period to another at a given well. However, as mentioned one pertinent well (699-53-55B and C) does have a nearly uniform groundwater technetium-99 concentration vertical profile.

The aquifer thickness below the B-Complex (see Figure 2.27 and Figure 2.28) thins to the north such that below much of the BY Cribs subregion, the current aquifer is less than $4 \mathrm{ft}$ thick. There also is a localized "high" spot of basalt that causes the aquifer to be as thin as $4 \mathrm{ft}$ at a well east of the B-7-A\&B Cribs. In the southernmost portion of the B-Complex, the aquifer is currently as thick as $24 \mathrm{ft}$, but in the region of most interest to the groundwater "hot spots" of technetium-99, the aquifer is thin, ranging in thickness from the 0 to $6 \mathrm{ft}$. The aquifer thickness in 1987 (see Figure 2.27) was used to represent the 
high water table and shows a thickness of $\sim 12 \mathrm{ft}$ in the northern portion of the B-Complex and $\sim 26 \mathrm{ft}$ in the southern portion. Thus, by 2009 (Figure 2.28), the aquifer below the B-Complex had dropped about $10 \mathrm{ft}$ throughout the region. A slow decline continues and more study on the depth distribution of contaminants in such thin aquifers is underway so that the impacts of the thin aquifer on potential pump and treat remediation efficacy will be considered in the planning stages of such remediation.

Figure 5.14 through Figure 5.17 show the entire technetium-99 groundwater plume for the 4 years chosen $(2000,2003,2006$, and 2009) to make mass estimates. Figure 5.18 through Figure 5.21 show the technetium-99 plume maps for only the B-Complex itself to allow more detail to be seen. In all the figures, the current basalt above the water table is shown in gray shading, and the isopleth contours and individual well technetium-99 values are presented in $\mathrm{nCi} / \mathrm{L}$ instead of $\mathrm{pCi} / \mathrm{L}$ to facilitate the labeling. (Recall that a nanocurie is 1000 picocuries; so when comparing Figure 5.14 through Figure 5.21 to earlier technetium-99 plume maps, one must multiply the values by 1000.) Table 5.2 contains the masses calculated to be present in the unconfined aquifer for each of the 4 years.

The technetium groundwater plume mass estimates were subdivided into 3 subregions to allow more detail in the mass estimates. The areas covered by each groundwater plume subsection are shown in Figure 5.14 through Figure 5.17. Subregion \#1 includes the area within the 200 East fence line and the BComplex. Subregion \#2 includes the area beyond the 200 East fence line out to the northwest to a line drawn parallel to the $0.45 \mathrm{nCi} / \mathrm{L}$ isopleth just north of Gable Gap. The third subregion, subregion \#3, encompasses the secondary technetium-99 groundwater plume to the north beyond Gable Gap.

The large area technetium-99 plume maps (Figure 5.14 through Figure 5.17) show two lobes: one north of the Gable Gap (the narrow region between the Gable Butte [western] and Gable Mountain [eastern] basalt outcrops designated as subregion \#3 in Table 5.2 and the large-area figures) and a higher concentration lobe within designated subregion \#2 in Table 5.2 and the large-area figures that follows the southern flank of Gable Mountain towards the source below the BY Cribs subregion. The estimated mass of technetium99 in subregion \#3 is larger than the sum of the other two subregions because the area covered and the aquifer thickness are larger than for the other two subregions. Most of the technetium-99 in subregion \#3 is likely remnant technetium from the early period after the active disposal when concentrations were high, and the water table was higher. The high water table allowed groundwater to travel in the past in a northeasterly direction over some of the Gable Mountain basalt region now above the water table. Currently, it is believed that this remnant water is draining from the northern and eastern flanks of the Gable Mountain basalt to feed this lobe of the technetium-99 plume. The mass estimates between year 2000 and 2003 increase for subregions \#2 and \#3, but remain constant for subregion \#1. The mass increase for subregion \#2 was from 0.40 to $0.64 \mathrm{Ci}(60 \%$ increase) and for subregion \#3 was from 3.67 to $4.98 \mathrm{Ci}(35 \%$ increase). Despite the high Tc concentrations in the groundwater below the B-Complex (subregion \#1) because of the very shallow aquifer and smaller area in comparison to the other two plume subregions, subregion \#1 has the smallest technetium-99 mass estimate. Between 2000 and 2003, there was some growth in the 5-nCi/L technetium-99 isopleth to the northwest from the main lobe in subregion \#2 that is being sourced the BY Cribs, and the secondary lobe in subregion \#3 develops a 2-nCi/L localized region.

In 2006 within plume subregion \#1, a 10-nCi/L isopleth grew to the northwest (into subregion \#2) with the apparent source being the BY Cribs. The 2-nCi/L isopleth in the secondary lobe of the technetium-99 (plume subregion \#3) diminished in area between 2003 and 2006 as reflected in a decrease 


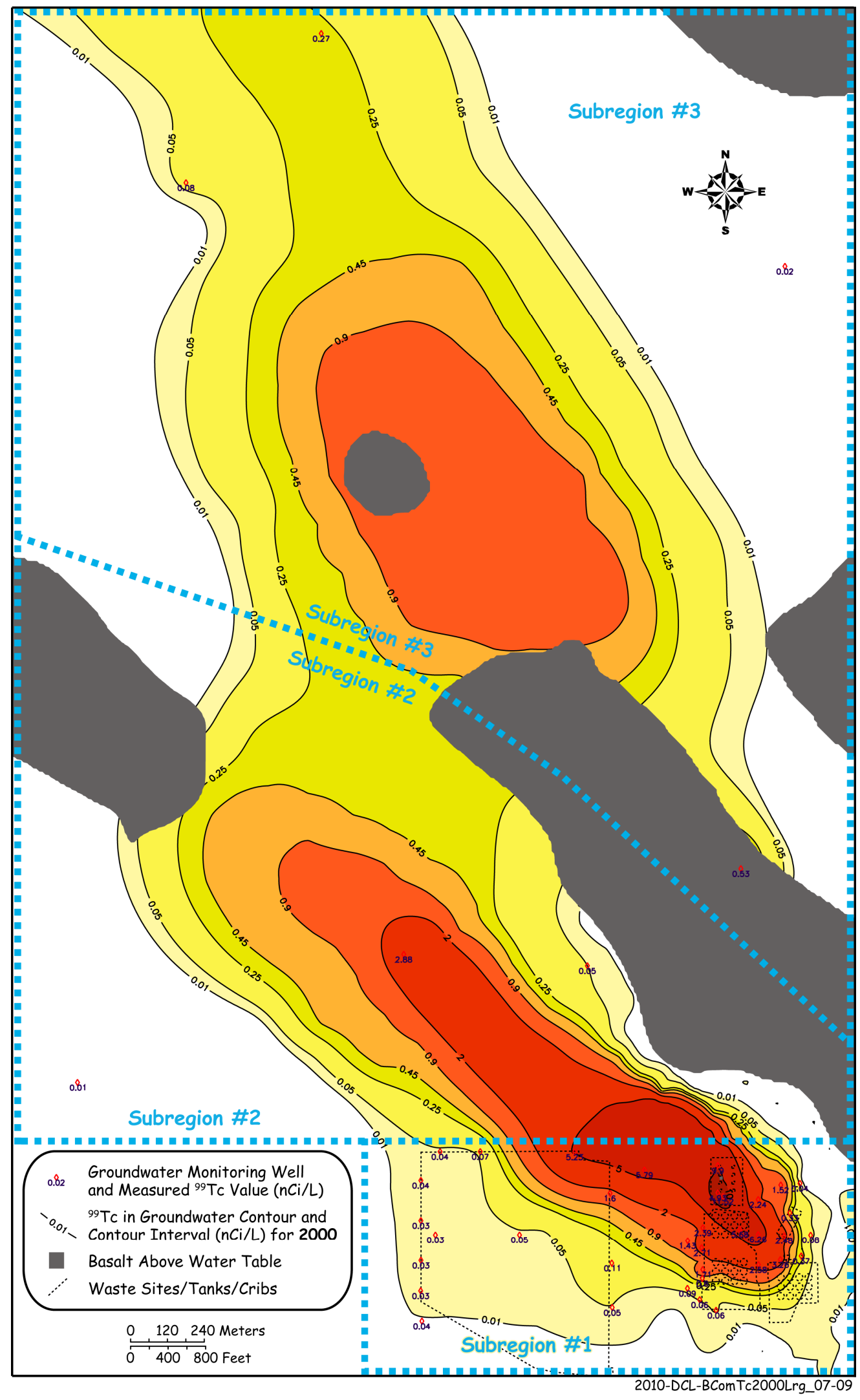

Figure 5.14. Technetium-99 (nCi/L) Groundwater Plume for 2000 


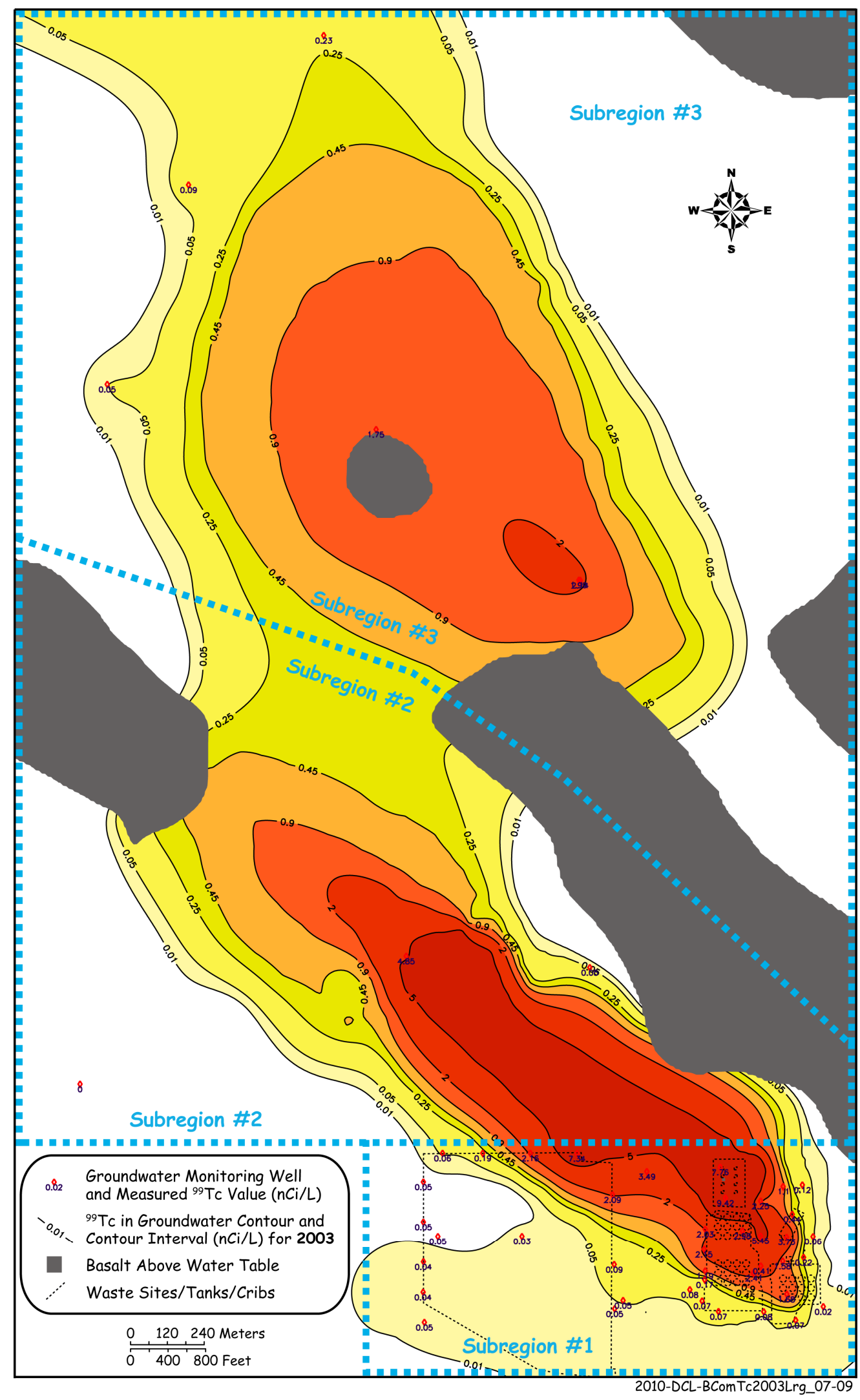

Figure 5.15. Technetium-99 (nCi/L) Groundwater Plume for 2003 


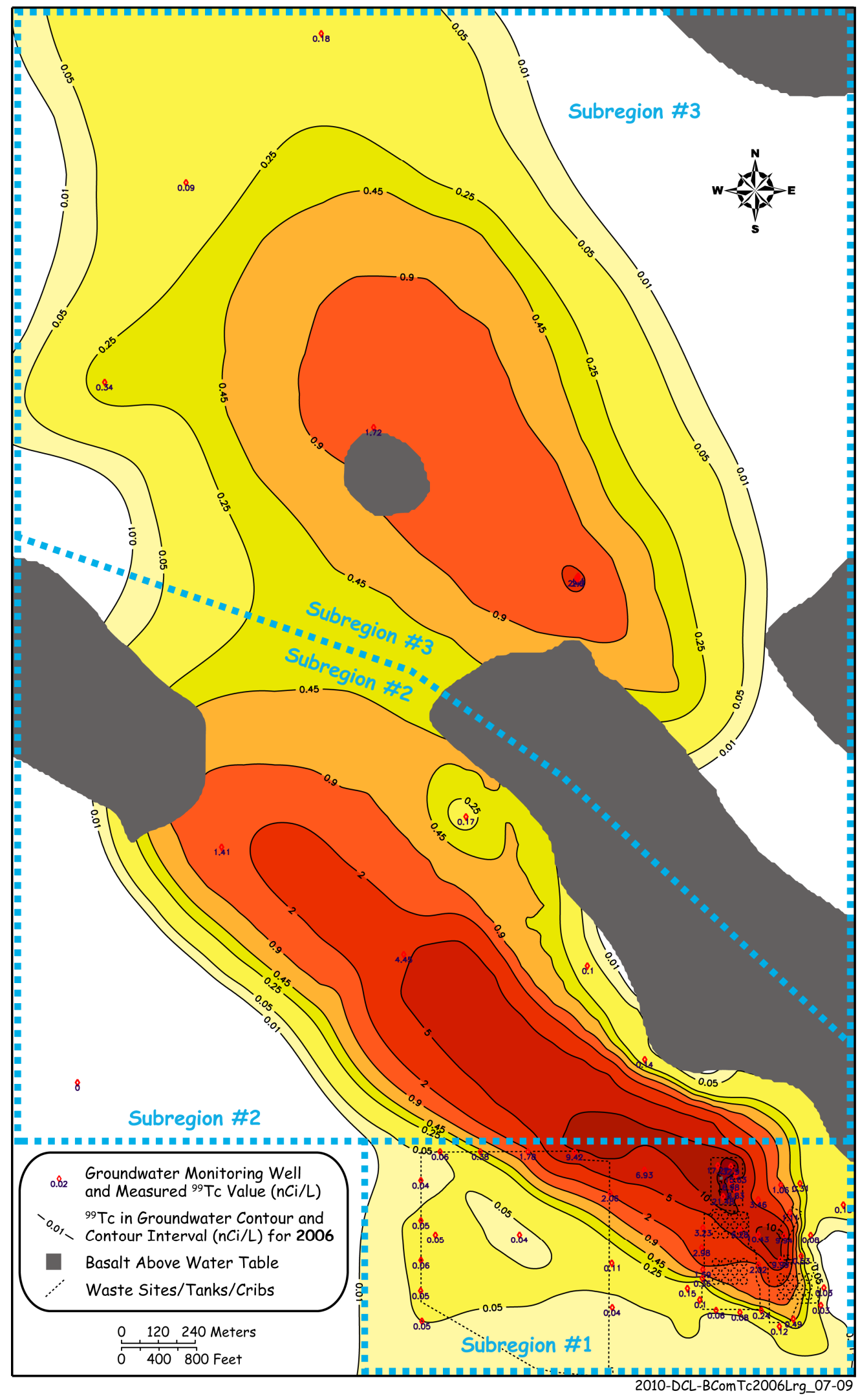

Figure 5.16. Technetium-99 (nCi/L) Groundwater Plume for 2006 


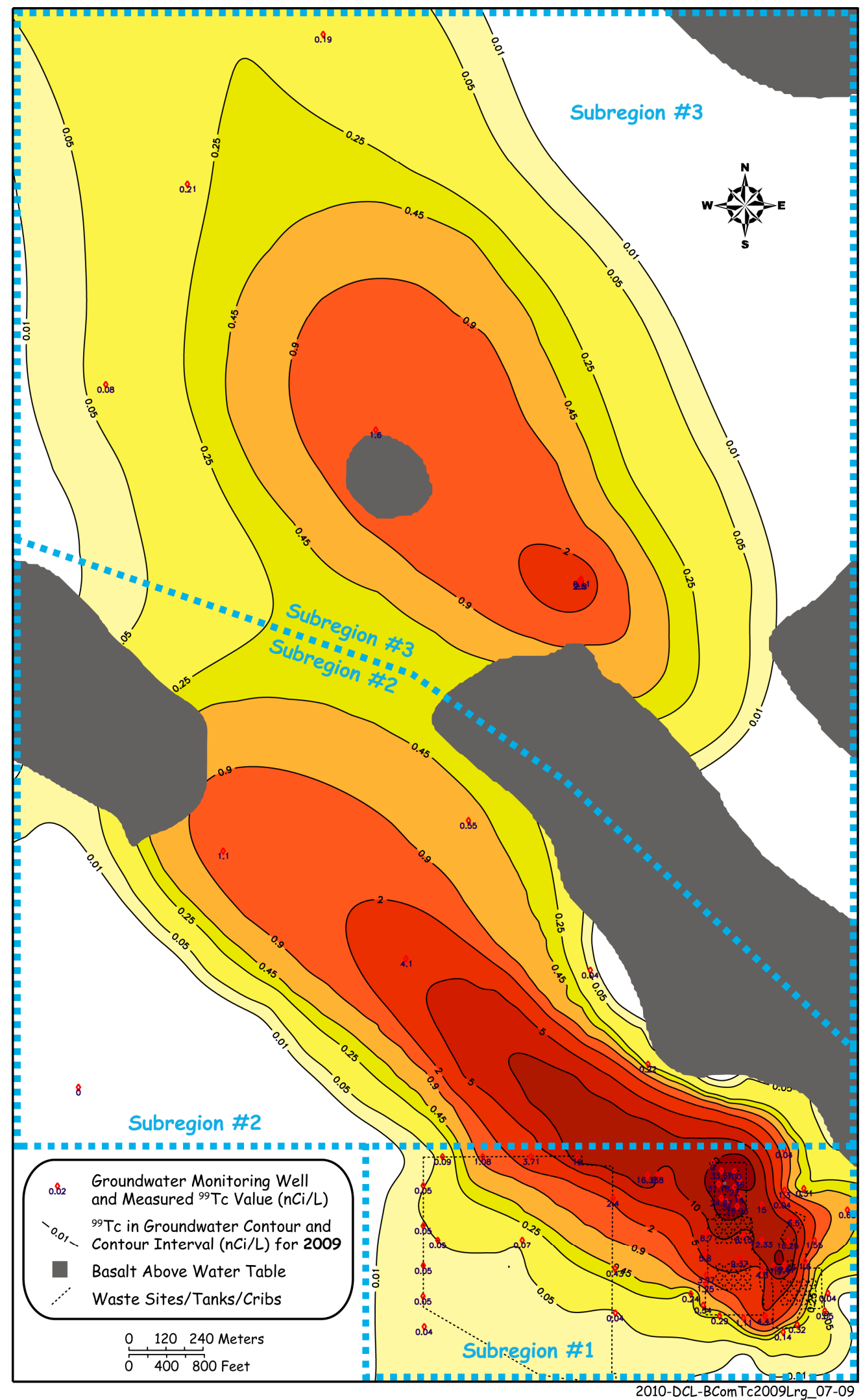

Figure 5.17. Technetium-99 (nCi/L) Groundwater Plume for 2009 


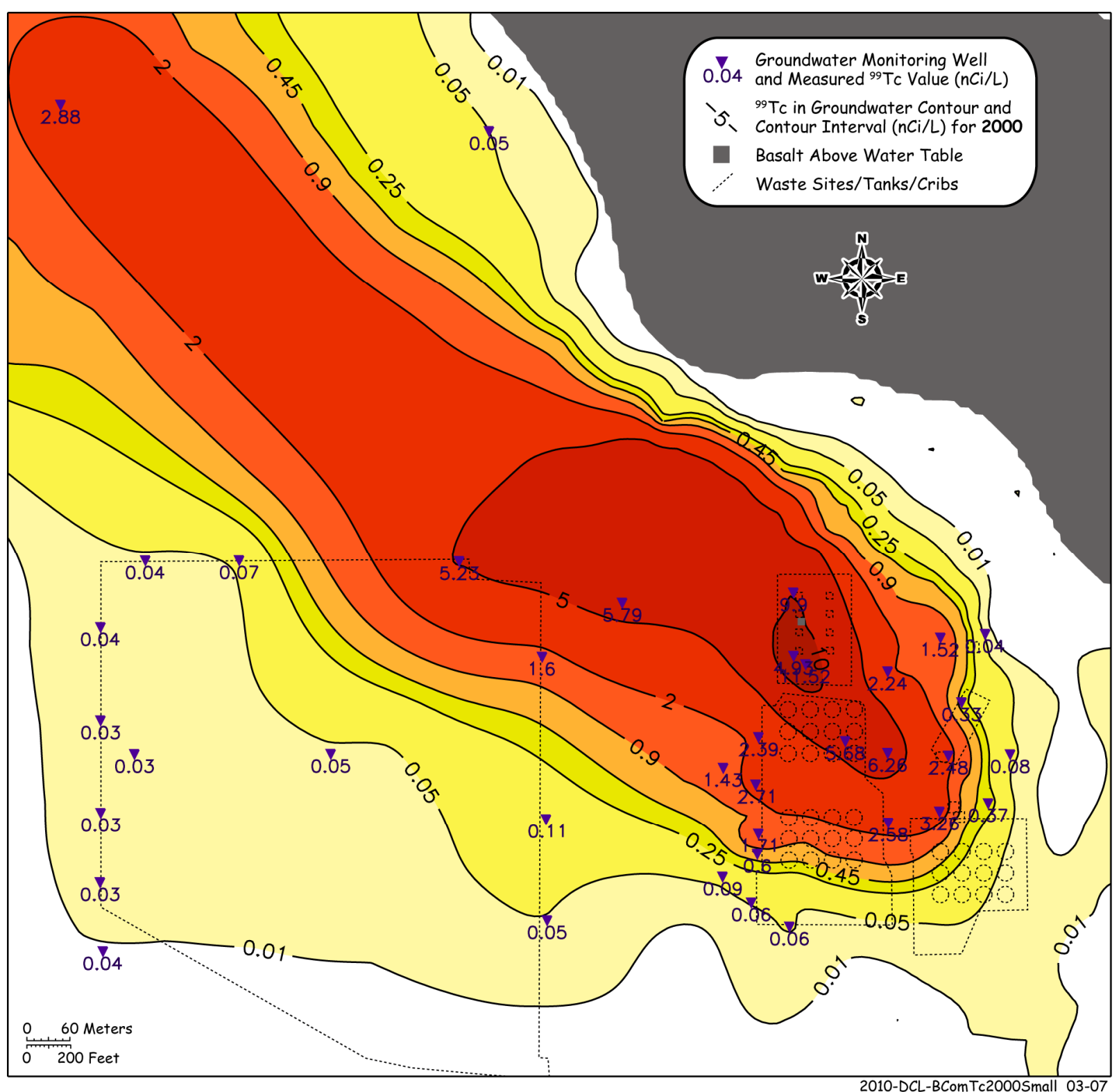

Figure 5.18. Technetium-99 (nCi/L) Groundwater Plume Below B-Complex for 2000 


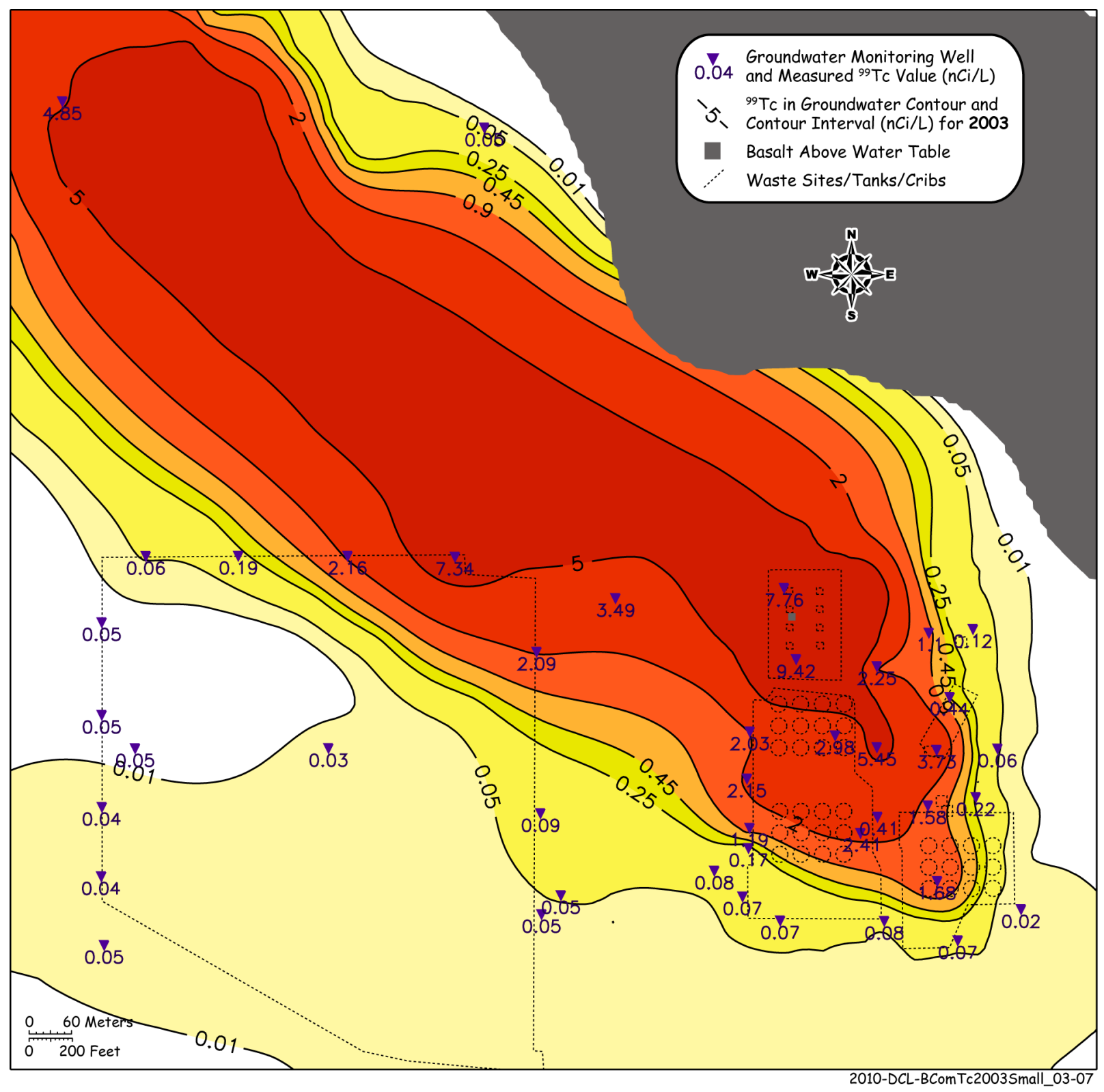

Figure 5.19. Technetium- 99 (nCi/L) Groundwater Plume Below B-Complex for 2003 


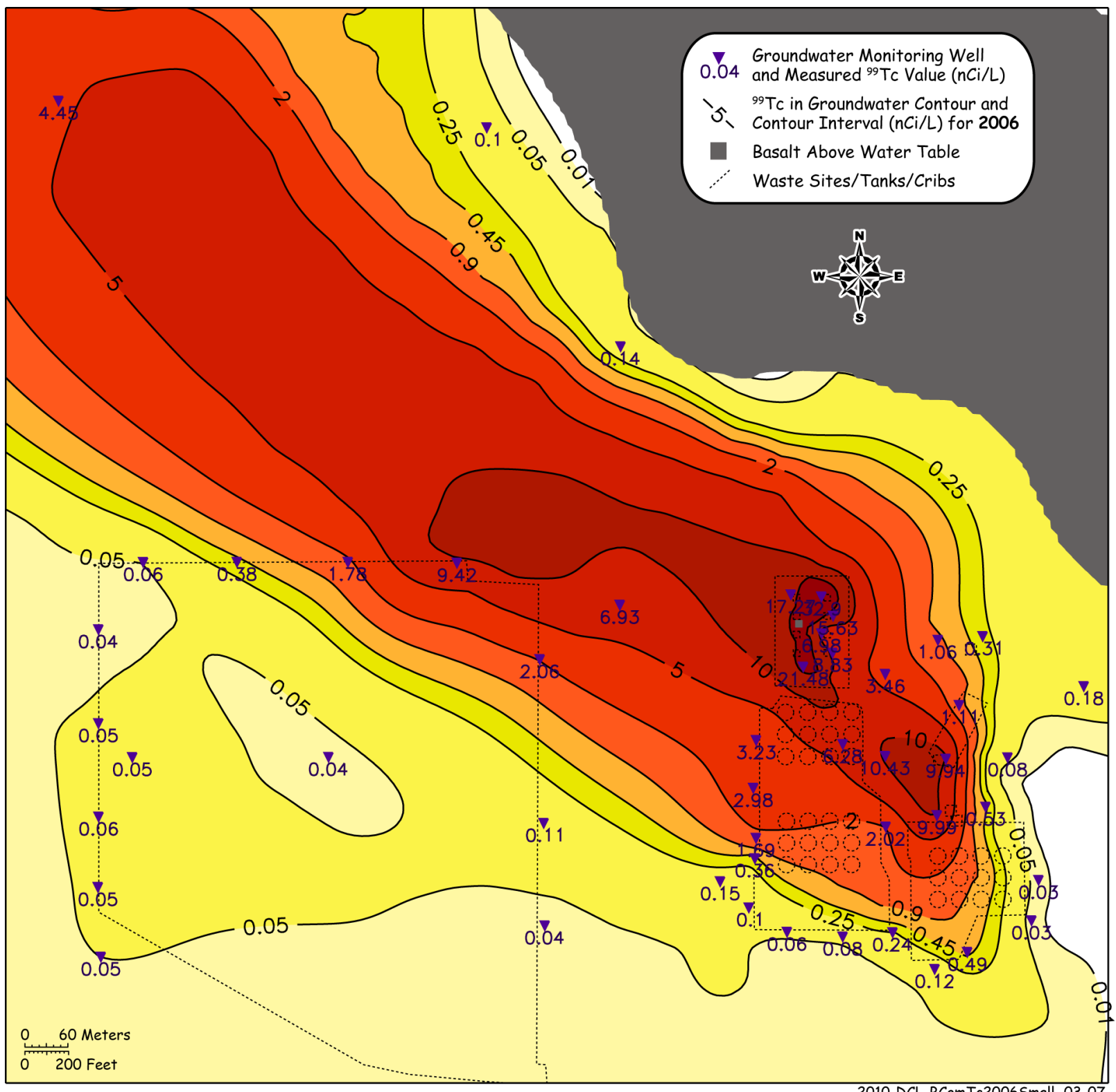

Figure 5.20. Technetium- 99 (nCi/L) Groundwater Plume Below B-Complex for 2006 


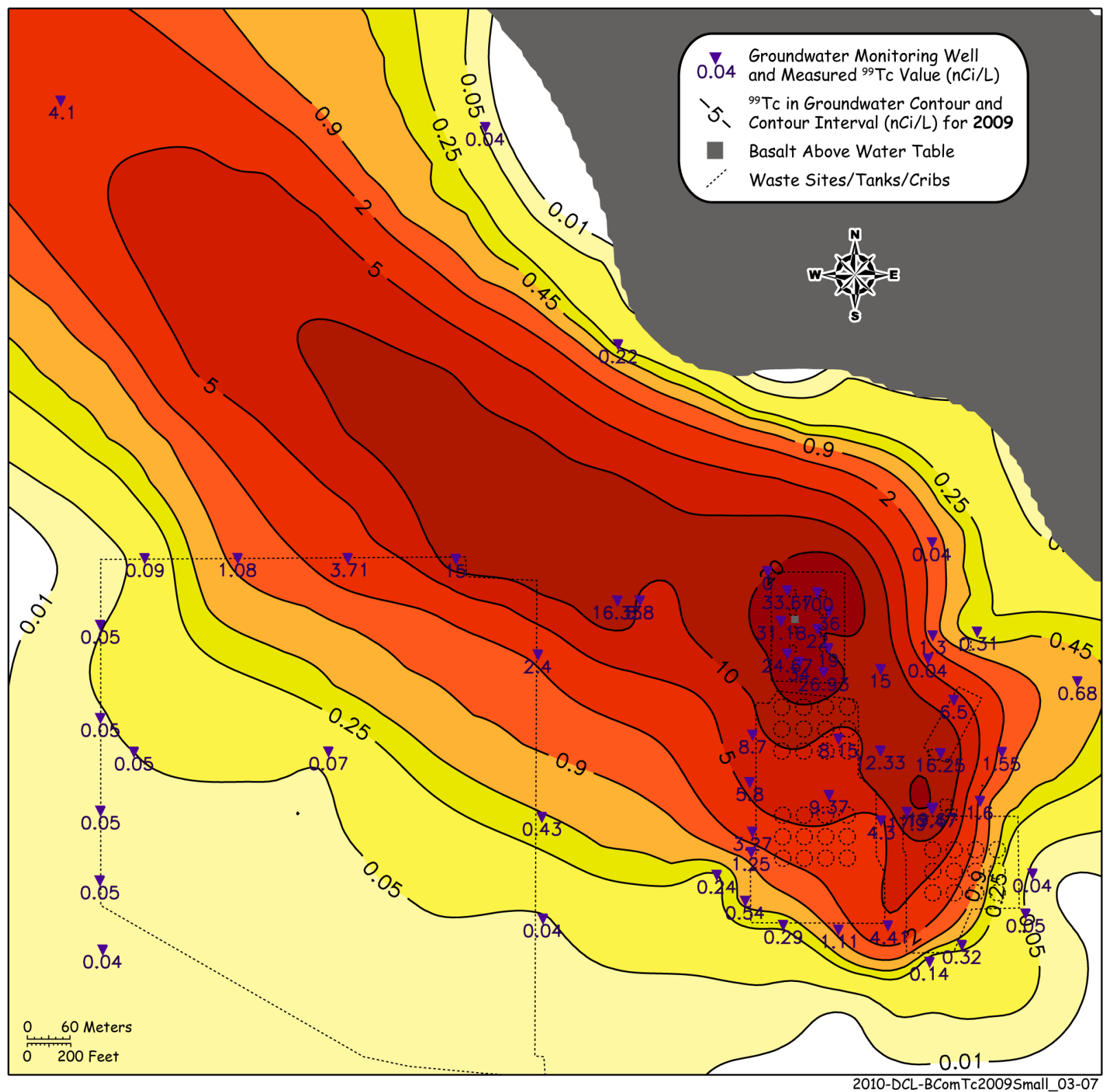

Figure 5.21. Technetium-99 (nCi/L) Groundwater Plume Below B-Complex for 2009

in overall mass in subregion \#3 (see Table 5.2). The estimated mass in plume subregion $\# 2$ increased from 0.64 to $0.77 \mathrm{Ci}$ between 2003 and 2006 (20\% increase). Increased technetium-99 mass within plume subregion \#1 also occurred between 2003 and 2006 ( 0.29 increasing to $0.42 \mathrm{Ci}$ ). By 2009, the higher valued isopleths in the main technetium-99 lobe (in plume subregions \#1 and \#2) increased in area with movement towards the northwest. Between 2006 and 2009, the largest percentage increase in technetium-99 occurred in subregion \#1 (within the B-Complex proper) with the mass increasing from 0.42 to $0.76 \mathrm{Ci}$. The technetium-99 estimated mass in region \#2 dropped ( 8\%) between 2006 and 2009, and the estimated mass in subregion \#3 increased slightly (3\%). It is not clear that the losses in estimated mass in subregion \#2 between 2006 and 2009 and subregion \#3 between 2003 and 2006 are indicative of a flux out of these subregions. It does appear that since 2003, there have been consistent increases in the mass of technetium-99 entering the groundwater in plume subregion \#1 (below the B-Complex). Oddly, 
the lower valued isopleths $(<2 \mathrm{nCi} / \mathrm{L})$ in the leading edges of both technetium-99 lobes did not substantially change position or area over the entire time period covered in the maps, suggesting that the technetium plumes are attenuating to below detection limits as the water travels through Gable Gap and on towards the Columbia River to the north.

The smaller area plume maps shown in Figure 5.18 through Figure 5.21 allow the BY crib source to be seen more easily, as well as the northwesterly spread of the $5 \mathrm{nCi} / \mathrm{L}$ isopleth between 2000 and 2003 . There was an ingrowth of both $10-$ and $20-\mathrm{nCi} / \mathrm{L}$ isopleths below the $\mathrm{BY}$ Cribs region and an occurrence of a 10-nCi/L region north of B Tank Farm and west of B-8 Crib in 2006. Figure 5.21 shows the continued growth of the $20-\mathrm{nCi} / \mathrm{L}$ isopleth's area and its movement to the northwest as well as the occurrence of a small area of the $20 \mathrm{nCi} / \mathrm{L}$ technetium- 99 isopleth within the $10-\mathrm{nCi} / \mathrm{L}$ isopleth in the region north of B Tank Farm in the vicinity of the new borehole 299-E33-343. As shown in Table 5.2, the mass of technetium-99 in the entire groundwater plume increased from 4.37 to 6.06 curies between 2000 and 2009. The 2009 mass estimate represents a small fraction (5\%) of the total technetium-99 released from the seven BY cribs $(129 \mathrm{Ci})$ that disposed of high-salt scavenged waste. More discussion and comparisons to estimates of residual technetium-99 mass left in the vadose zone are found in Section 6.

Table 5.2. Estimates of Mass of Technetium-99 in Aquifer for Selected Years and \% Change Between Successive Time Periods by Plume Subregion

\begin{tabular}{|c|c|c|c|c|c|c|c|c|c|}
\hline Plume Cutoff & \multicolumn{4}{|c|}{$10 \mathrm{pCi} / \mathrm{L}$} & & & & & \\
\hline Mass Units & $\mathrm{Ci}$ & $\mathrm{Ci}$ & $\mathrm{Ci}$ & $\mathrm{Ci}$ & \multicolumn{5}{|c|}{ Percentage Change Between Time Periods } \\
\hline Year & 2000 & 2003 & 2006 & 2009 & Year & 2000 & 2003 & 2006 & 2009 \\
\hline Subregion & & & & & Subregion & & & & \\
\hline 1 & 0.29 & 0.29 & 0.42 & 0.76 & 1 & & $0.02 \%$ & $44.77 \%$ & $80.67 \%$ \\
\hline 2 & 0.40 & 0.64 & 0.77 & 0.71 & 2 & & $60.43 \%$ & $19.82 \%$ & $-8.07 \%$ \\
\hline 3 & 3.67 & 4.98 & 4.46 & 4.59 & 3 & & $35.49 \%$ & $-10.32 \%$ & $2.90 \%$ \\
\hline Total & 4.37 & 5.91 & 5.66 & 6.06 & Total & & $35.43 \%$ & $-4.33 \%$ & $7.17 \%$ \\
\hline
\end{tabular}

In conclusion, the technetium-99 in the groundwater below the B-Complex is sourced mainly from below the BY Cribs, and the plume over the last decade has primarily migrated to the northwest. A secondary source in the vicinity of the new borehole 299-E33-343 (near the northwest corner of the B Tank Farm) has also been supplying technetium-99 to the overall plume at least since 2003 (assuming that the technetium-99 arrived at the water table at this location at the same time as uranium). A definitive hypothesis has not been generated on which facility has contributed the technetium-99 that is entering the water table in the vicinity of borehole 299-E33-343. Some of the technetium-99 is from the BX-102 overfill event, but other sources, such as fluids from the BY or B Tank Farms, or less likely the B-7-A\&B and B-8 Crib and Tile Field or fluids from BY Cribs that migrated within horizontal spreading layers all the way to the $\mathrm{CCU}$ unit near borehole E33-343 are possibilities. The vadose zone data for sediments within and around the B-7-A\&B Cribs, B-8 Crib and Tile Field, and BY and B Tank Farms are not adequate to develop conceptual models of technetium-99 migration down to the water table from these potential sources.

Most of the technetium-99 in the groundwater plume north of Gable Gap is likely residual contaminated water from earlier periods. Recall that before 1991, only a handful of technetium-99 
groundwater measurements were available. The well coverage was for only a few wells in or near the BY Cribs so that no technetium-99 groundwater plume time series is available to follow the migration of this mobile contaminant from the time of active disposal through 1991. The technetium-99 groundwater concentrations during the 1950 s could have been as high as 200,000 to $500,000 \mathrm{pCi} / \mathrm{L}$. This is based on ratioing technetium-99 to nitrate in the waste stream disposed of to the BY Cribs or currently found in the deep vadose zone below the BY Cribs and using measured nitrate groundwater values in the mid 1950s. There was a 200-East Area wide drop in the gross beta and nitrate groundwater concentrations in the 1960s, so it is suspected that technetium-99 values also dropped and perhaps started increasing in the B-Complex region, again between 1998 and 2001 (see Figure 5.8).

Based on Figure 5.10 through Figure 5.13, there also appears to be seasonal impacts on the rate of flow of the groundwater below the B-Complex that causes some of the increased concentrations in contaminants, assuming that the influx of contaminated pore water from the deep vadose into the aquifer is occurring at the identified locations at a constant rate. That is, if the groundwater flow rate slows down, stops, or reverses for a period of time, but the flux out of the vadose zone remains fixed, then groundwater samples taken during the low flow or stopped-flow conditions will be more concentrated. It is highly likely that the flux out of the deep vadose zone is also transient, thus adding to the variation in groundwater concentrations observed at wells, especially those close to the regions where vadose zone pore water contains high concentrations of contaminants. The seasonal (transient) nature to the groundwater flow and identification of at least two localized regions of higher technetium-99 concentrations in vadose zone pore water entering the water table cause the groundwater plume maps for contaminants below the B-Complex to appear to migrate in several directions from one time period to another. It is now believed that the groundwater flow below the B-Complex has a net northwesterly direction out through the Gable Gap that occasionally reverses for brief periods when high Columbia River stage influences are transmitted to the northern portion of the B-Complex.

\subsection{Cyanide}

The first cyanide measurements of groundwater in the B-Complex that are in the HEIS database were measured in 1987. In 1991, several more wells were drilled, and cyanide groundwater data became more systematically available. Cyanide measurements in groundwater using a more robust number of wells continue to the present time. Because of the lack of early data, it is not possible to develop a cyanide groundwater plume map for B-Complex before 1987. In the April to June 1957 quarterly (Brown 1957d), there is mention that total cyanide had been found as high as $230 \mathrm{mg} / \mathrm{L}$ in groundwater near the BY Cribs; however, a specific measurement documented in this quarterly monitoring report for free cyanide in groundwater from well 299-E33-4 (just west of crib B-46 [see Figure 5.1]) was $<0.5 \mathrm{mg} / \mathrm{L}$. A preponderance of complexed cyanide over free cyanide was also observed in the 1991 vadose zone sediment studies at the BY Cribs described in Section 3.1.2 so that it is difficult to decide whether the statement in Brown et al. (1957d) that total cyanide values are as high as $230 \mathrm{mg} / \mathrm{L}$ is accurate.

Cyanide groundwater time series plumes covering the years from 1992 through 2008 were made available from Dr. Stan Sobczyk (Nez Perce Indian Tribe consultant). The time series plumes were constructed from the HEIS database (available in EDA) for the entire 200-E Area using Rockware ${ }^{\circledR}$ software to generate the contouring. Selected time series plots for the yearly averaged groundwater data are shown in Figure 5.22 and Figure 5.23. The yearly time series plots chosen for inclusion in this report were those with adequate data or those that showed discernable changes in the isopleths between the years 
tabulated (either increases in concentration or movement in location). In 1992, there was a small lowconcentration cyanide plume centered under the BY Tank Farm that soon changed location to be below the BY Cribs. The cyanide plume has remained anchored beneath the BY Cribs from 1993 through today. The cyanide groundwater plume below the BY Cribs remained below the drinking water standard of $200 \mu \mathrm{g} / \mathrm{L}$ up to 1997 and showed a slow drift towards the northwest. Between 1997 and 1998, the maximum cyanide concentrations beneath the BY Cribs increased from 100 to $300 \mu \mathrm{g} / \mathrm{L}$. There was continued slow growth in both the area and concentration of the cyanide plume between 2000 and 2002 . The cyanide concentrations have increased faster beginning in 2004 through the present as shown in Figure 5.23. By 2006, cyanide groundwater concentrations in the range of 500 to $700 \mu \mathrm{g} / \mathrm{L}$ were observed below the BY Cribs.

Another independent assessment of the cyanide groundwater plume was developed as part of the 2007 site-wide groundwater monitoring report (DOE/RL-2007c). Figure 5.24 is taken from the cited report and covers fiscal year 2007. Figure 5.24 shows that by 2007, cyanide groundwater concentrations below the BY Cribs area reached $>1000 \mu \mathrm{g} / \mathrm{L}$.

For this report, another more quantitative estimate of the mass of cyanide in the groundwater plume was generated using EarthVision $\mathbb{R}$ software and the geologic conceptual model using the same methodology described for the technetium-99 mass estimates. Again, plume maps and mass estimates were generated for the four years 2000, 2003, 2006, and 2009. The plume maps for the B-Complex and the area just to the north are shown in Figure 5.25 through Figure 5.28; however the plume was not followed all the way north to its leading edge because well coverage with cyanide measurements were quite sparse to the north of the 200 East Area. These time series maps show the same groundwater cyanide trends as shown in Figure 5.24. That is; the origin of the cyanide is found below the BY Cribs, the leading edge of the plume extends well to the north of Gable Gap similar to technetium-99, the cyanide groundwater plume migrated to the northwest with time, and the concentrations in the heart of the plume have increased with time at least since 1998. Table 5.3 presents the mass balance estimates for a portion of the groundwater cyanide plume centered below the B-Complex from 2000 through 2009. The estimates show an increase from $15.1 \mathrm{~kg}$ in 2000 to $38.5 \mathrm{~kg}$ in 2009 . Based on the sparse cyanide data to the north of Gable Gap and the aquifer thickness, the authors estimate that the plume contains $\sim 30$ more $\mathrm{kg}$ of cyanide not accounted for in these calculations. The combined masses ( $\sim 68$ to $70 \mathrm{~kg}$ ) from the region shown in Figure 5.25 through Figure 5.28 and the mass farther to the north represents about $1 \%$ of the total mass of cyanide disposed of to the BY Cribs. 

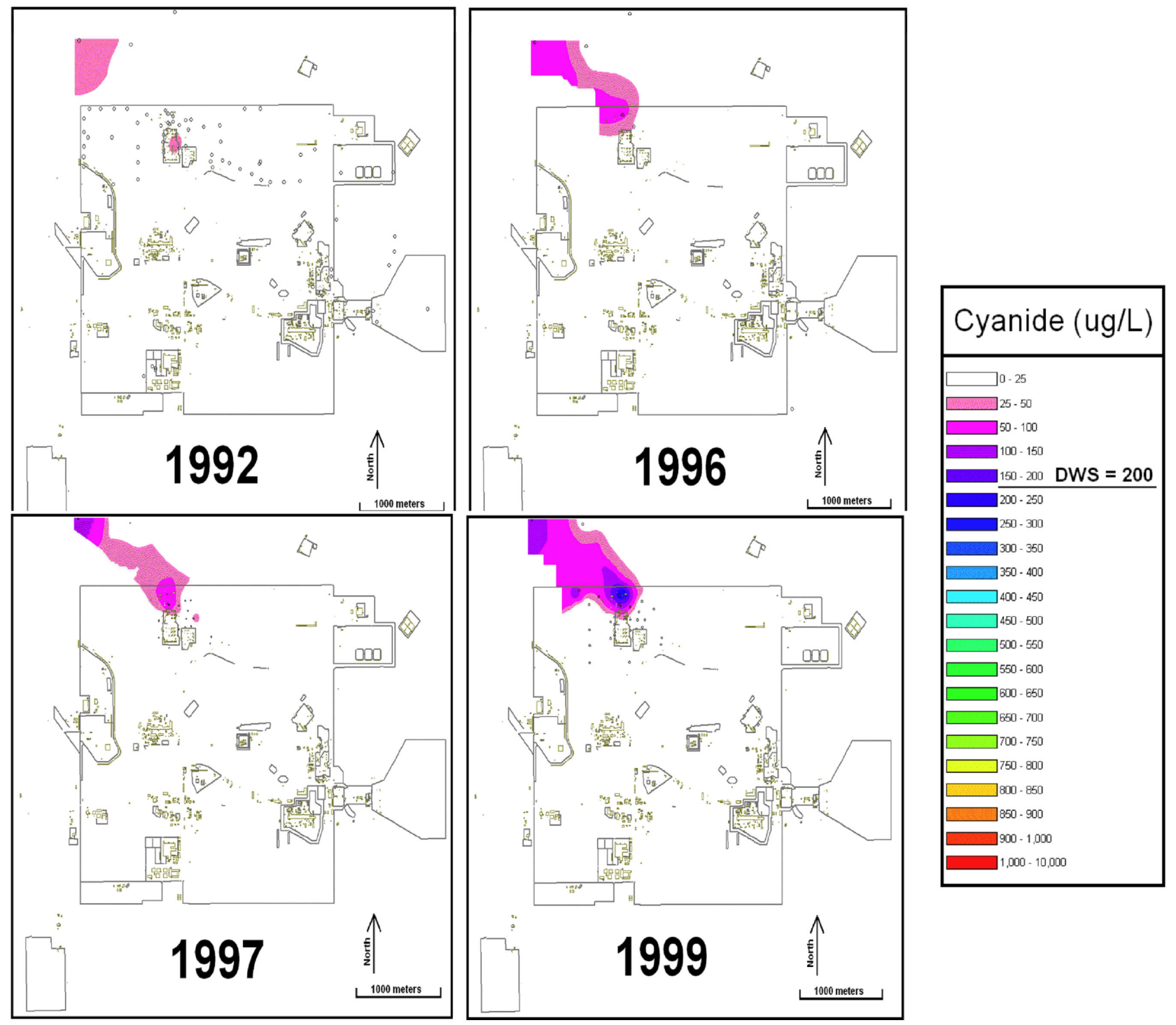

Figure 5.22. Cyanide ( $\mu \mathrm{g} / \mathrm{L})$ Groundwater Plume Time Series for 200-E Area (1992-1999) 


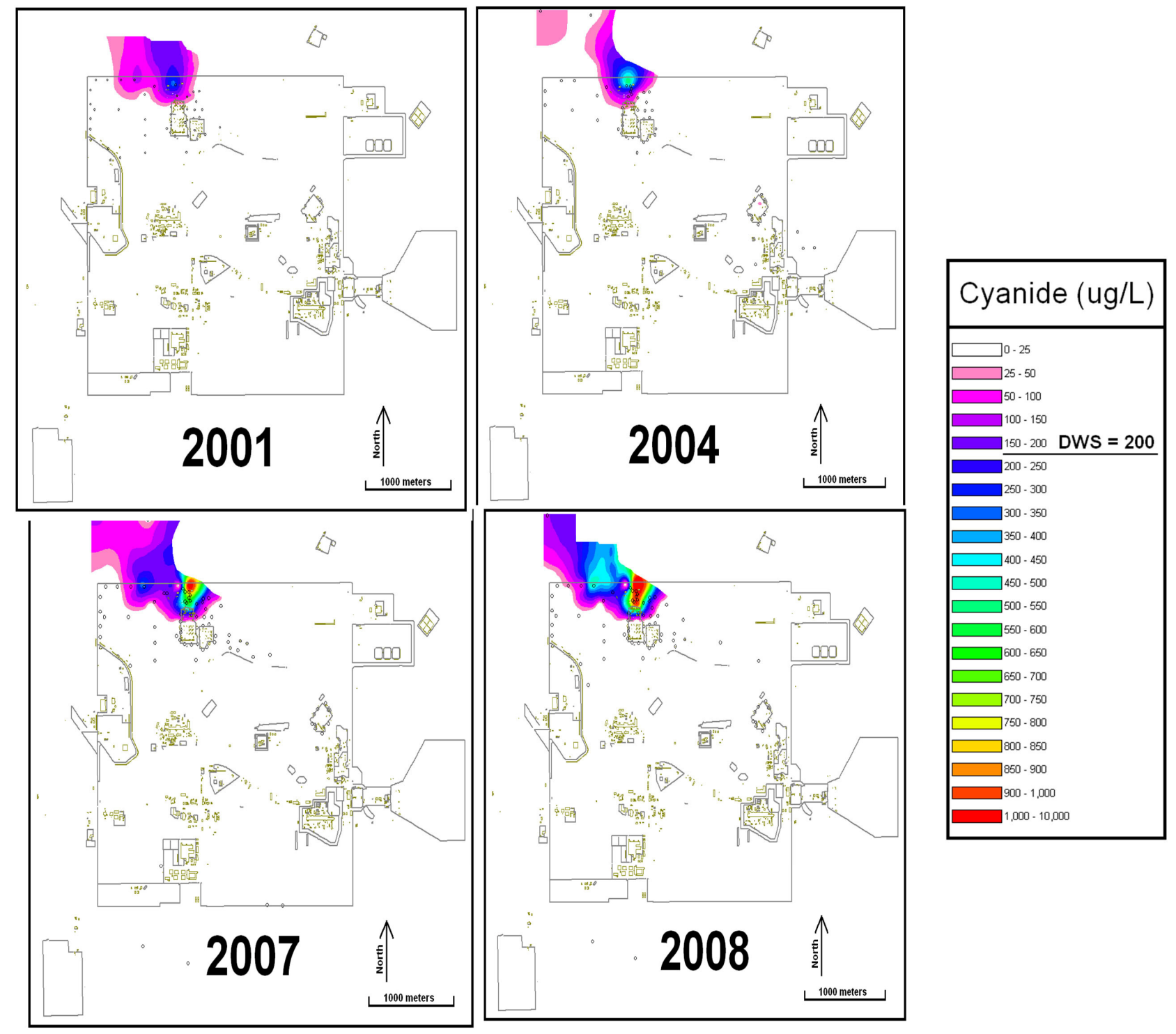

Figure 5.23. Cyanide ( $\mu \mathrm{g} / \mathrm{L})$ Groundwater Plume Time Series for 200-E Area (2001-2008) 
PNNL-19277

Table 5.3. Estimates of Cyanide $(\mathrm{CN})$ Mass $(\mathrm{kg})$ in Groundwater Plume Below B-Complex

\begin{tabular}{c:cccc:ccccc}
\hline $\begin{array}{c}\text { Contaminant } \\
\text { Plume Cutoff }\end{array}$ & $\mathrm{CN}$ & $\mathrm{CN}$ & $\mathrm{CN}$ & $\mathrm{CN}$ & & $\mathrm{CN}$ & $\mathrm{CN}$ & $\mathrm{CN}$ & $\mathrm{CN}$ \\
\hline $\begin{array}{c}\text { Mass Units } \\
\text { Year }\end{array}$ & $\mathrm{kg}$ & $\mathrm{kg}$ & $\mathrm{kg}$ & $\mathrm{kg}$ & \multicolumn{3}{|c}{ Percentage Change Between Time Periods } \\
$\begin{array}{c}\text { Total in Area Mapped } \\
\text { Estimate of Mass }\end{array}$ & 15.1 & 9.0 & 22.0 & 38.5 & & & $-40.4 \%$ & $144.4 \%$ & $75.0 \%$ \\
Farther to the North & $\sim 30$ & $\sim 30$ & $\sim 30$ & $\sim 30$ & & NA & NA & NA & NA \\
\hline
\end{tabular}

There is a systematic drop in all the groundwater cyanide values for calendar year 2003 in the EDA database in comparison to earlier and later years. There was no change in analytical methods or in the analytical laboratory used to perform the measurements during 2003 that might explain the reporting of cyanide values systematically lower in all wells in the B-Complex region. Changes in the cyanide analysis procedure and the analytical laboratory used to perform the measurements did occur in late 2006 through early 2007 as documented in the EDA database. However, no changes or explanation for the apparent systematically low cyanide values for 2003 are found in the EDA database. The only "physical" or hydrologic explanation would be a rapid speeding up in the groundwater flow below the BY Cribs in 2003 that would have flushed the high cyanide water from the region. Because there do not appear to be changes in the trends of other constituents in the groundwater plume below the B-Complex during 2003, it is doubtful that this hydrologic hypothesis is valid.

As mentioned in Section 3.1.2, the available data for determining the mass of cyanide still residing in the vadose zone sediments is insufficient to attempt calculations. Therefore, mass balance estimates on the fate of the cyanide cannot be made. If the mention in the 1957 groundwater quarterly (Brown et al. $1957 \mathrm{~d}$ ) that groundwater cyanide was as high as $230,000 \mu \mathrm{g} / \mathrm{L}$ in the $1950 \mathrm{~s}$, then a large percentage of the cyanide has migrated out of the BY Cribs subregion and been diluted far downstream to concentrations that were not detectable before the more recent monitoring period (post 1991). The maximum cyanide concentration observed in groundwater near the BY Cribs in the last decade was a recent measurement at $7,180 \mu \mathrm{g} / \mathrm{L}$ in well $299-\mathrm{E} 33-4$. This value is $\sim 30$ times lower than the maximum cyanide groundwater concentrations that Brown et al. (1957d) suggest were present in the mid 1950s. 
PNNL-19277

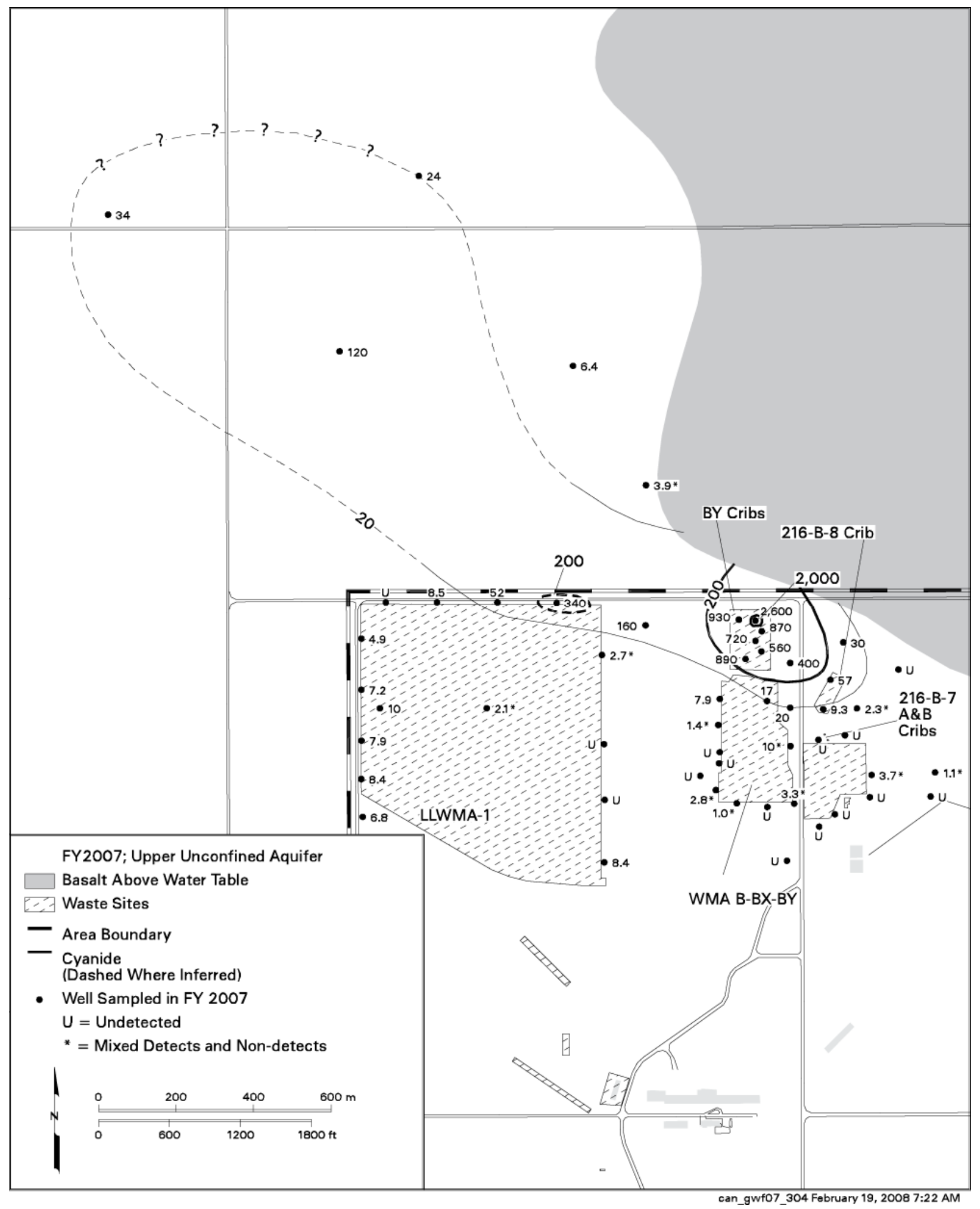

Figure 5.24. Cyanide Groundwater Plume Map for the B-Complex for 2007 (from DOE/RL-2007c) 


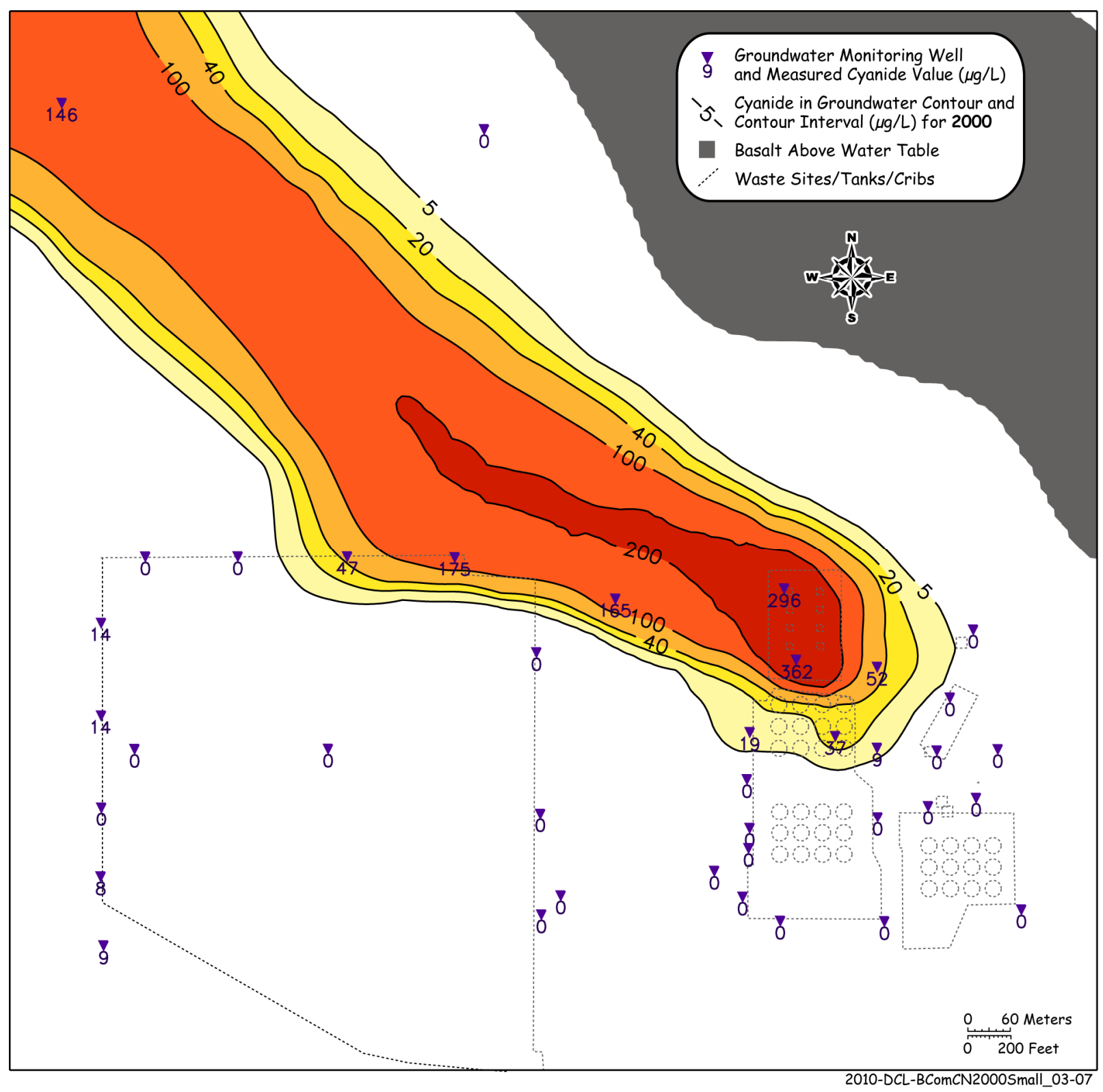

Figure 5.25. Cyanide $(\mu \mathrm{g} / \mathrm{L})$ Groundwater Plume for B-Complex and to the North for Year 2000 


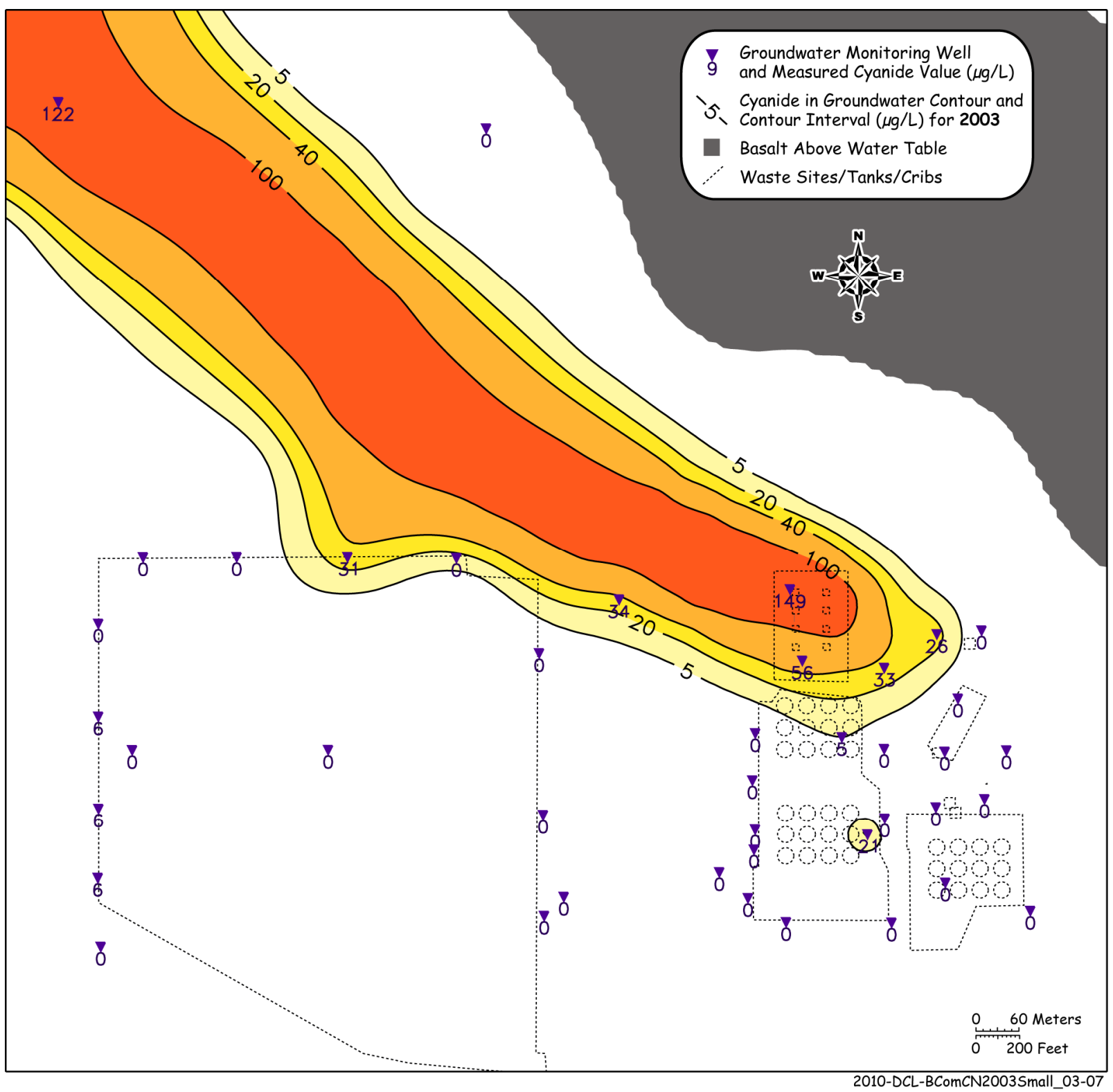

Figure 5.26. Cyanide ( $\mu \mathrm{g} / \mathrm{L})$ Groundwater Plume for B-Complex and to the North for Year 2003 


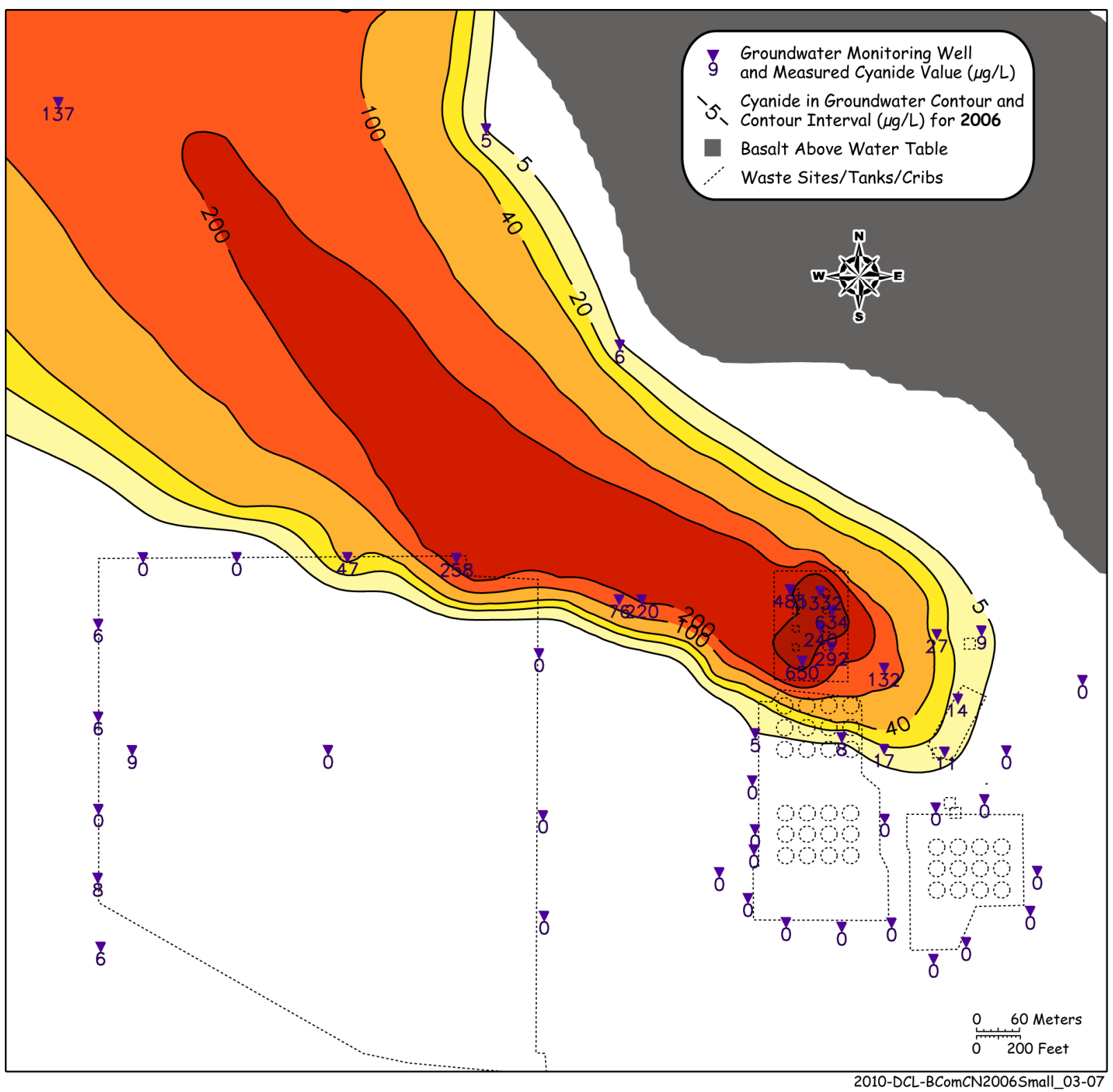

Figure 5.27. Cyanide $(\mu \mathrm{g} / \mathrm{L})$ Groundwater Plume for B-Complex and to the North for Year 2006 


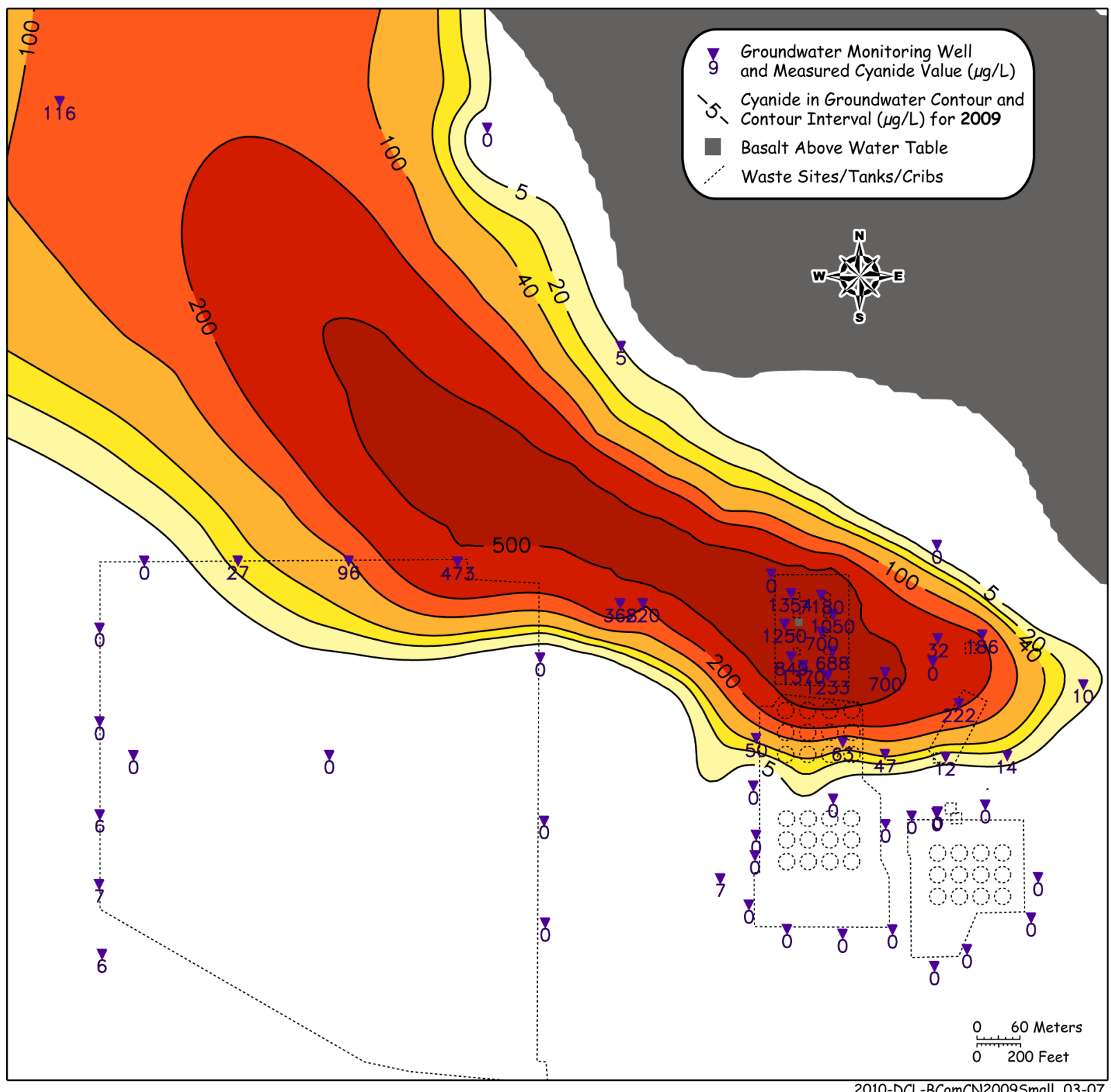

Figure 5.28. Cyanide ( $\mu \mathrm{g} / \mathrm{L})$ Groundwater Plume for B-Complex and to the North for Year 2009 
There is little doubt that cyanide has been reaching the groundwater at increasing concentrations in the last decade in the region below the BY Cribs. Ignoring the 2003 year's cyanide data, Table 5.3 shows that the mass estimate for cyanide in the groundwater plume increases from 15.1 to 22 to $38.5 \mathrm{~kg}$ between 2000 to 2006 to 2009 . Along with technetium-99 and nitrate, the likely source of the cyanide is the deep vadose zone sediments below the BY Cribs. As mentioned in Section 3.1.2 and shown in Table 3.2 and Table 3.3, the sediments in the two boreholes placed in the footprint of the B-43 and B-49 cribs in 1991 and in the two new boreholes, 299-E33-341 and -E33-342 do show elevated cyanide, technetium-99, nitrate, and sulfate concentrations. Thus, the deep vadose zone sediments below the BY Cribs are a major source that is feeding these contaminants to the B-Complex groundwater. No other facility in the BComplex received significant masses of cyanide so that the available vadose zone sediment and groundwater cyanide data in fact are consistent in pointing to the BY Cribs as the primary (and most likely sole) source of the cyanide in the groundwater below and to the north of the B-Complex.

\subsection{Chromium}

Groundwater time series maps were generated for chromium as part of the effort to understand the seasonal fluctuations in groundwater plumes and in an attempt to ascertain the source facilities that are contributing chromium to the aquifer throughout the past decade. Figure 5.29 through Figure 5.34 show the chromium groundwater plume for selected wells associated with the B-Complex during the spring and fall seasons for some of the years between 2001 and 2009. Plots for other year's can be found in Appendix G. The chromium plumes for the spring and fall of 2001, 2004, and 2008 do not show as clearly the apparent concentration build up trend observed for nitrate and technetium-99 plumes. However, the figures might support the seasonal groundwater flow fluctuation and flow reversal hypothesis in a more subdued fashion. More importantly, the figures do support other significant hypotheses, first the source of chromium in the groundwater appears to be the B-8 Crib and Tile Field with perhaps some contribution from the B-7-A\&B Cribs and second the general direction of groundwater flow is to the northwest. The chromium plume maps also show that the concentration of chromium in the groundwater in 2001 and 2008 was significantly larger than in 2004. Therefore, a transient influx of contamination from the deep vadose zone below the B-8 Crib and Tile Field and perhaps B-7-A\&B/B-8 Cribs subregion needs to be factored in to the overall integrated vadose zone-groundwater conceptual model. The rise and fall of total chromium concentrations appears to be occurring on a slower frequency (over several years) compared to the seasonal (spring-fall) trends observed for nitrate and technetium-99. However, the spring-fall plume maps also could be interpreted as showing that the B-8 Crib and Tile Field is the sole source of chromium (i.e., excluding B-7-A\&B Cribs source) with an apparent southerly migration of the chromium plume towards the B-7-A\&B Cribs location when there is reduced groundwater flow to the northwest. Without more vadose zone sediment characterization in the region, it is difficult to assess whether both crib facilities are contributing the chromium. Both B-7-A\&B and B-8 Cribs had significant quantities of chromium disposed of within them, and both facilities had large enough overall volumes of waste disposed to push contaminants deep into the vadose zone and reach the aquifer. 


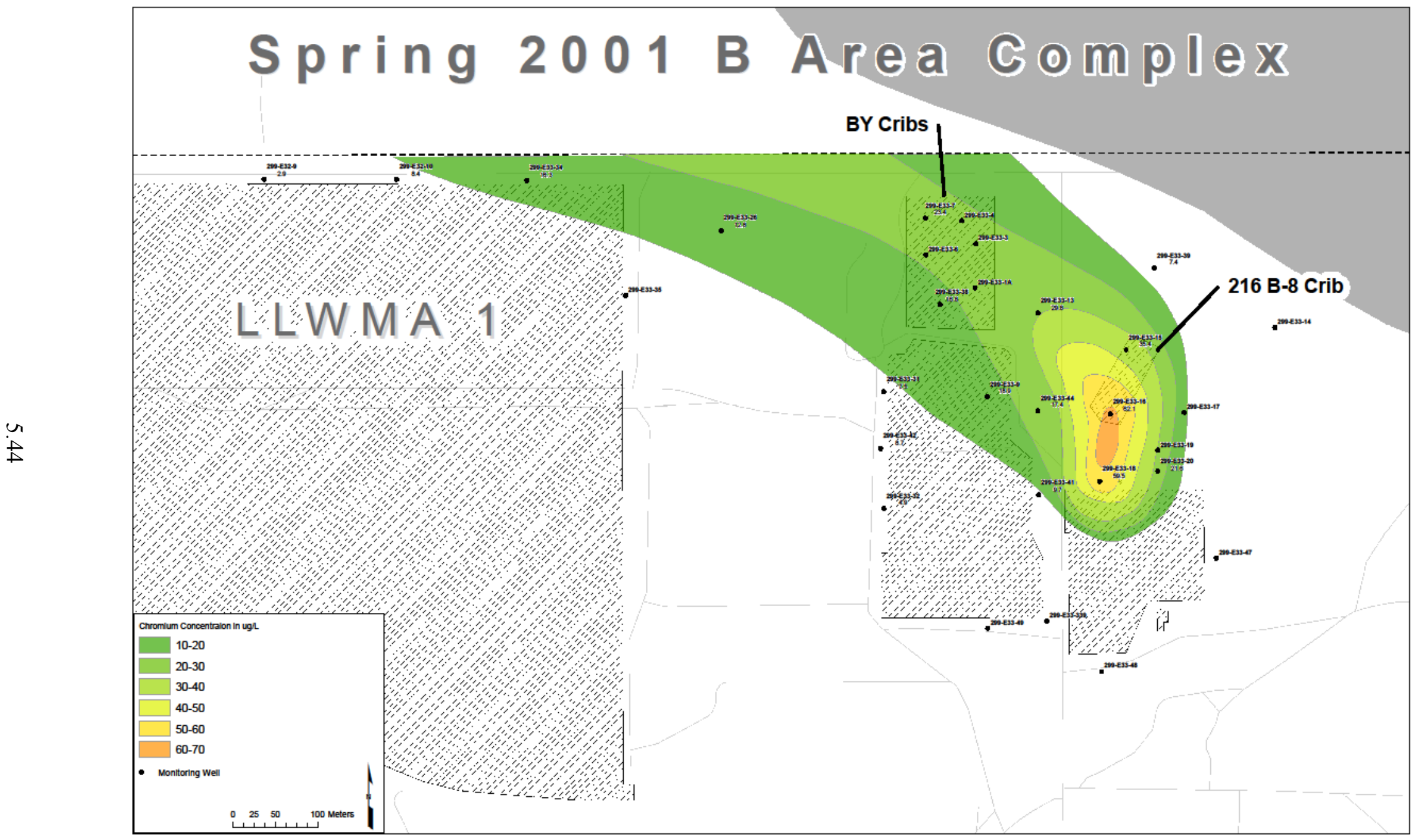

Figure 5.29. Chromium Groundwater Plume for Spring 2001 


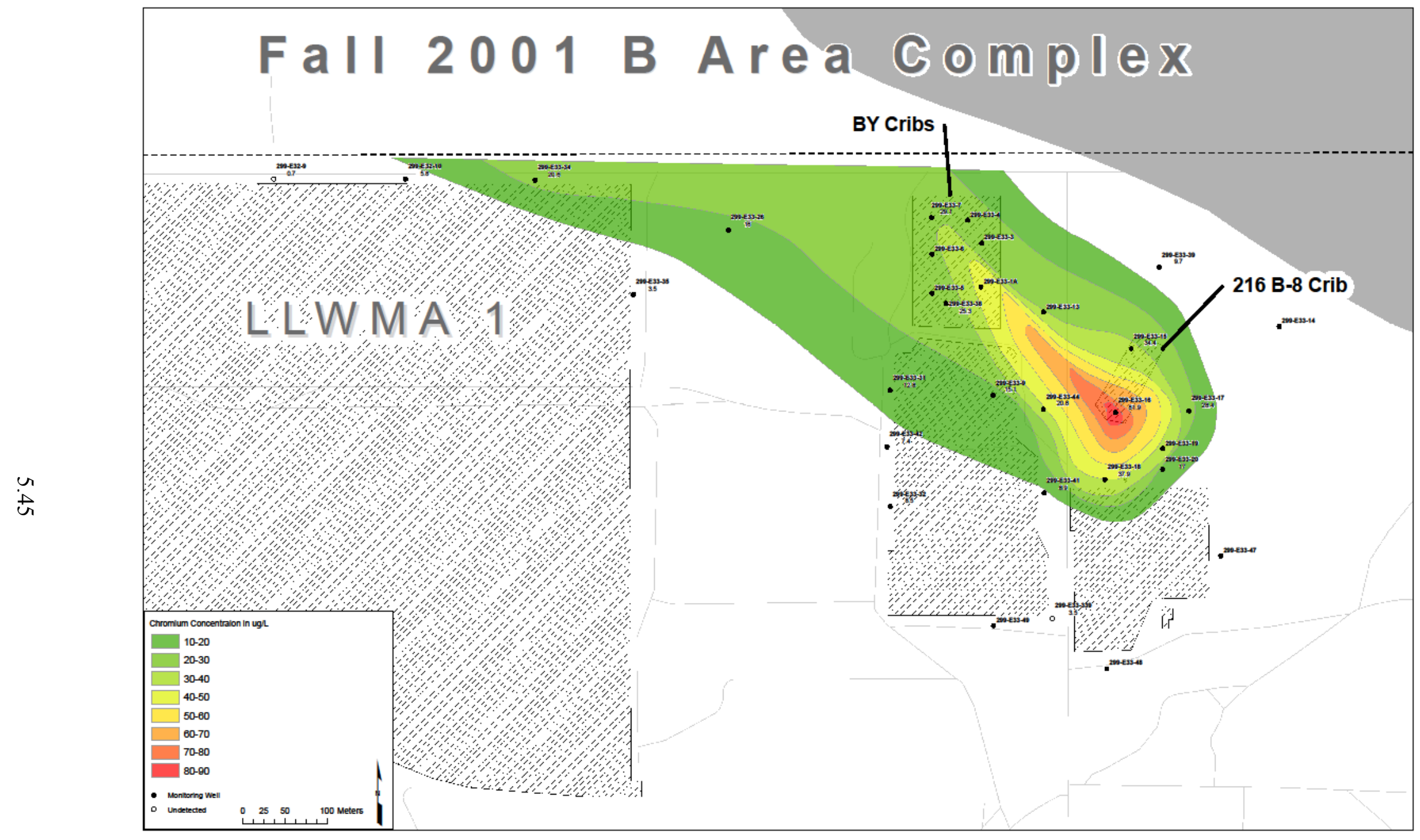

Figure 5.30. Chromium Groundwater Plume for Fall 2001 


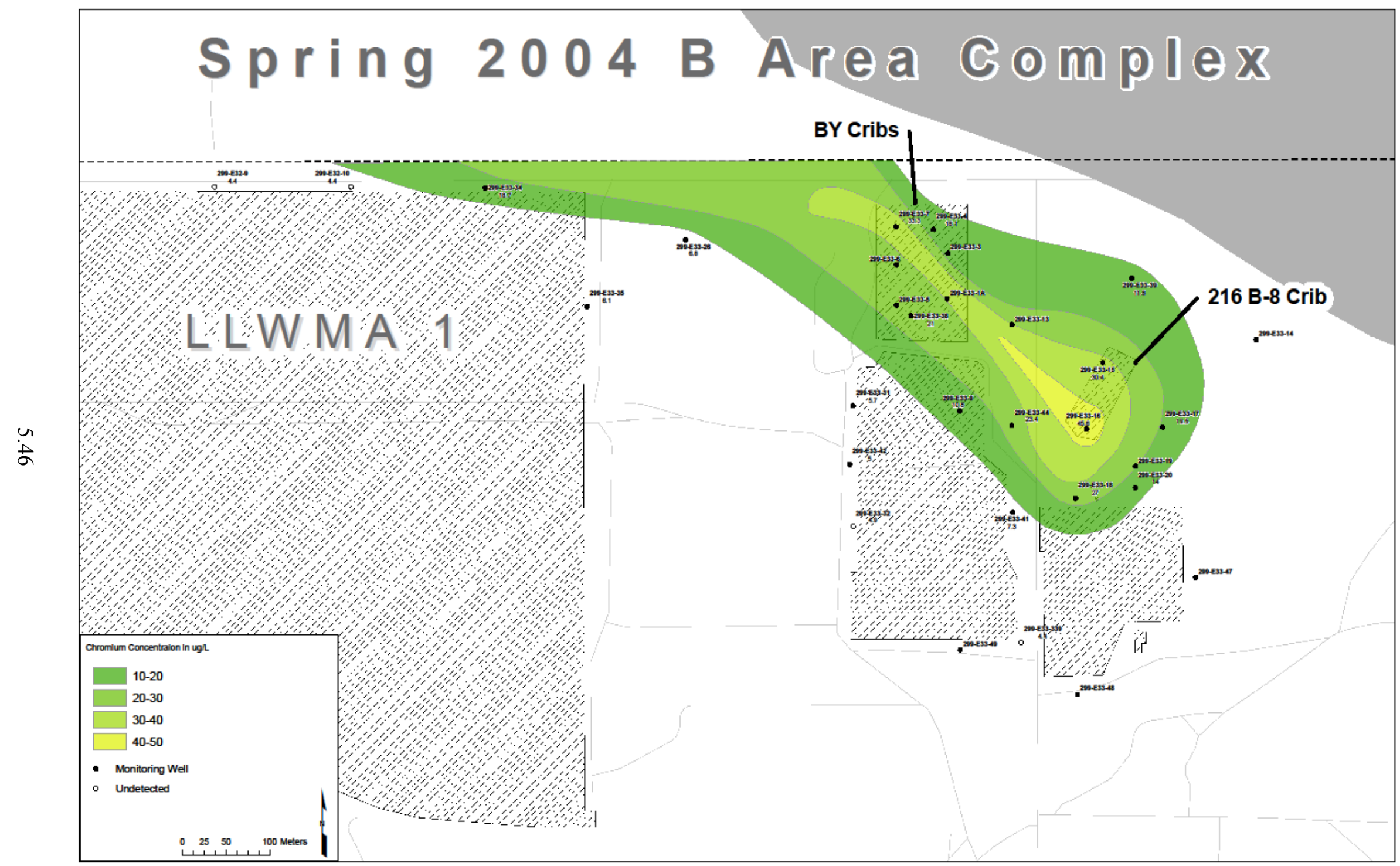

Figure 5.31. Chromium Groundwater Plume for Spring 2004 


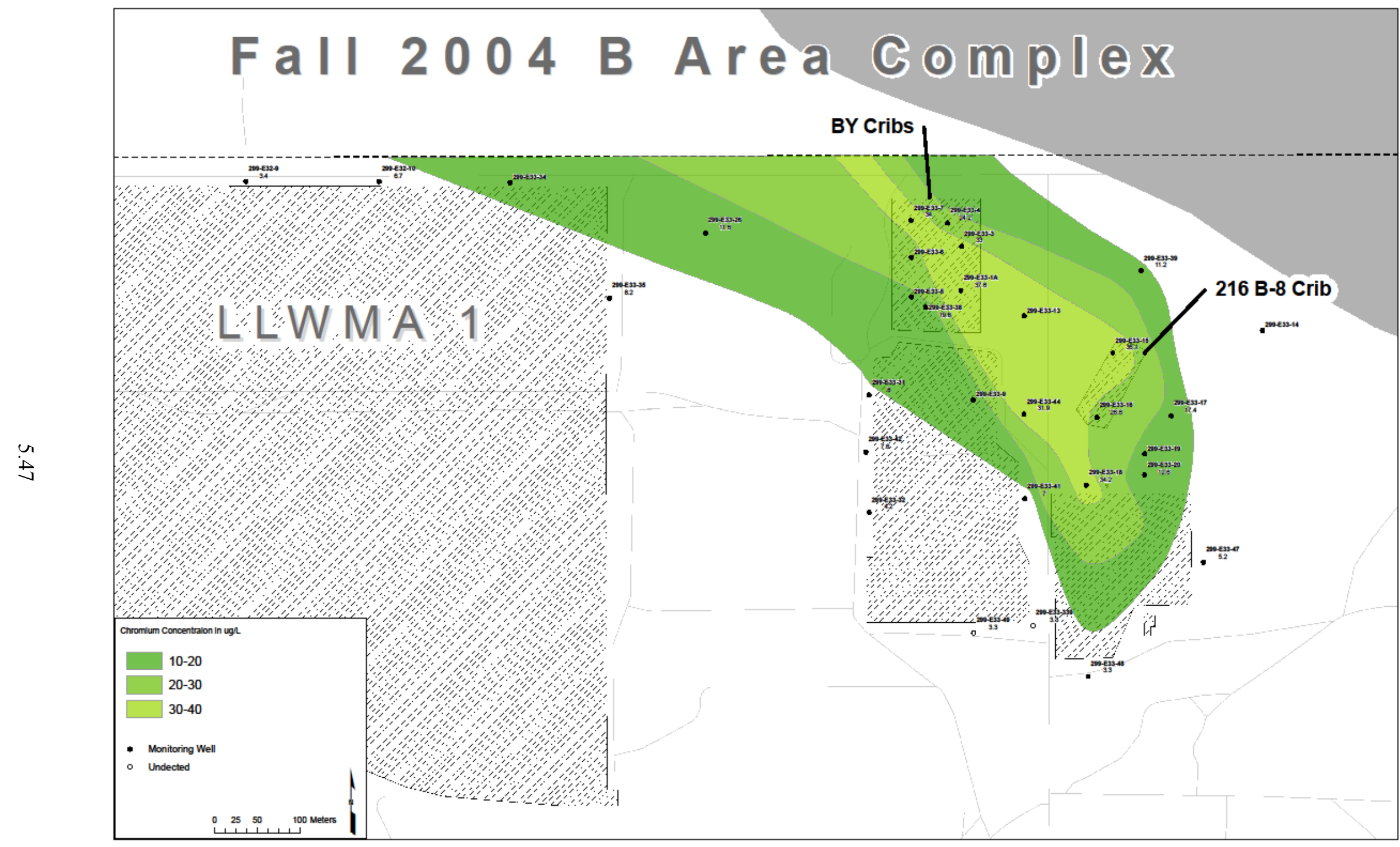

Figure 5.32. Chromium Groundwater Plume for Fall 2004 


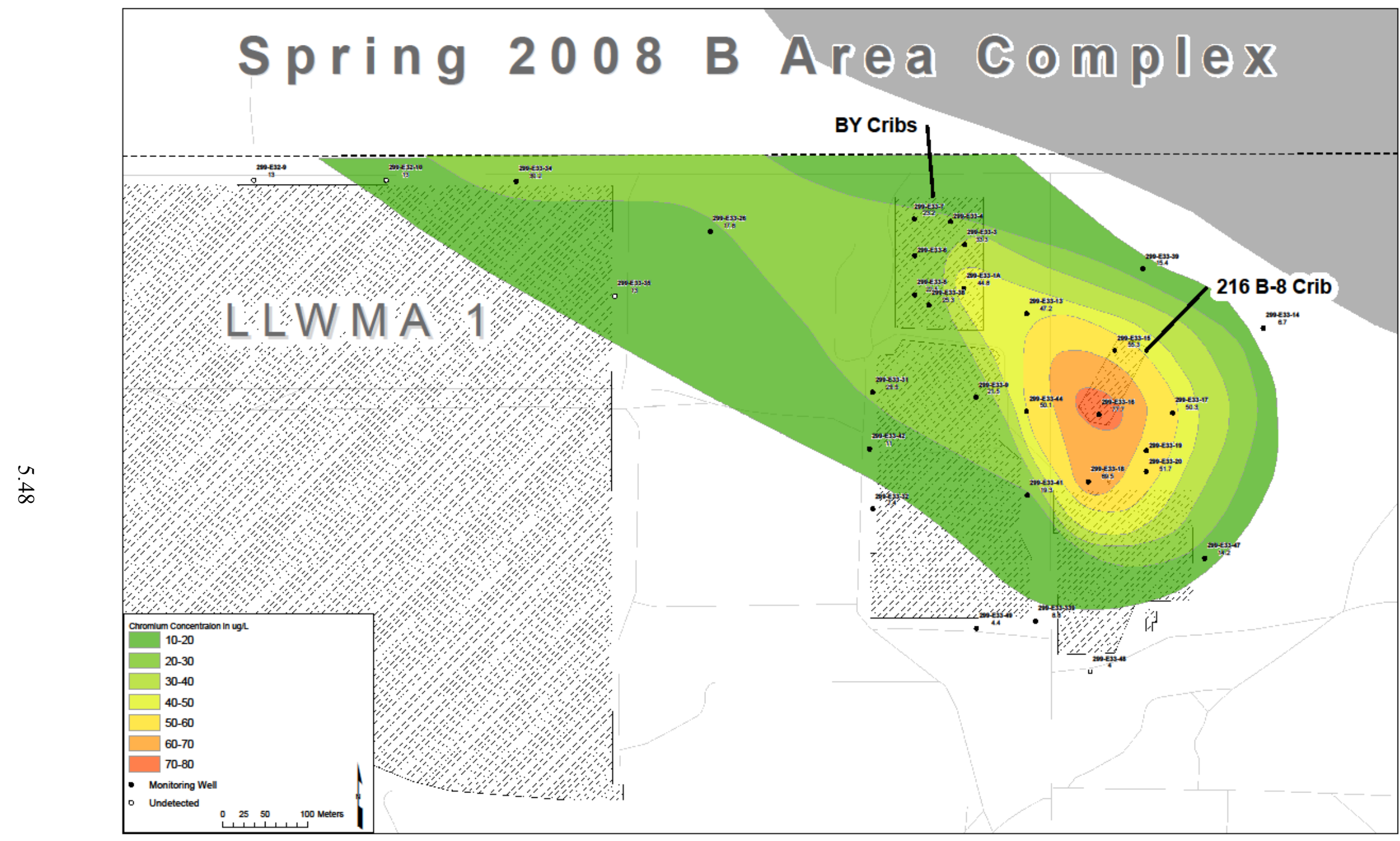

Figure 5.33. Chromium Groundwater Plume for Spring 2008 


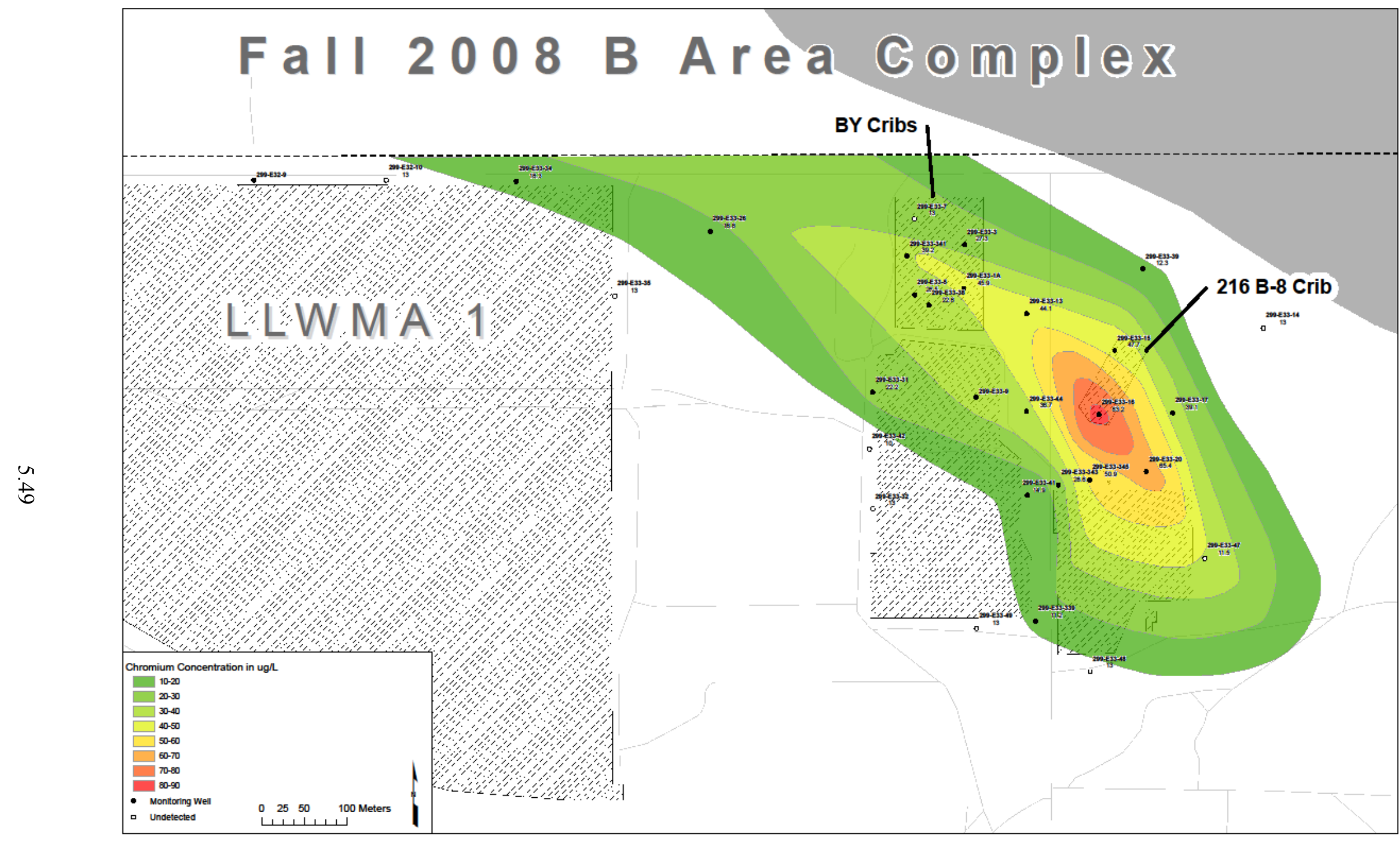

Figure 5.34. Chromium Groundwater Plume for Fall 2008 


\subsection{Uranium}

Uranium concentrations in the groundwater have been increasing below the B-Complex for several years, and its source has been vigorously debated since 2002. The first data available in the EDA database for groundwater uranium concentrations are for existing wells near the BY Cribs and B-7-A\&B/B-8 subregions. The historical uranium data were obtained using a liquid scintillation radio counting method in the 1955 to 1958 time frame, but in general, no elevated uranium concentrations were found. Some of this early uranium data for a particular date $(02 / 12 / 1957)$ for several wells appears to have some less-than values missing from the EDA database or some other peculiar data entry because the numerical value reported is constant at $220 \mathrm{pCi} / \mathrm{L}$. More variation in the numerical values would be expected if they were actual measurements. The authors therefore did not use these potentially "missentered" uranium data in their critical review. More wells started to have uranium measurements performed around the 1987 to 1988 time period, but then uranium measurements were stopped again until 1991. After 1991, most of the wells in the B-Complex were placed on a set schedule for uranium analyses as were new wells drilled after 1991. For the wells sampled between 1985 and 1993, there were no uranium concentrations above the drinking water standard of $30 \mu \mathrm{g} / \mathrm{L}$ below the B-Complex. In 1994, a small region of slightly elevated uranium in the groundwater was found at well 299-E33-18 near the B-7-A Crib.

In 1996, there was a large ingrowth of relatively low uranium concentrations in the groundwater beneath much of the BY Crib region and the eastern portion of the BY Tank Farm centered between wells E33-13 to the north and E33-44 to the south. Between 1998 and 2000, this plume remained at about the same concentration $(<300 \mu \mathrm{g} / \mathrm{L})$ and did not move far areally. The uranium plume appears to have two localized higher concentration zones at this time period, the first associated with the northern portion of the BY Tank Farm and a second smaller hot spot at 299-E33-18, near the B-7-A Crib. Between 2001 and 2004, the cores of the two localized uranium plumes increased in concentration to between 300 to 500 $\mu \mathrm{g} / \mathrm{L}$, and the plumes appeared to be dispersing/migrating towards the northwest. In 2006, the core of the plume showed increased concentrations above $800 \mu \mathrm{g} / \mathrm{L}$ at wells 299-E33-9 and 299-E33-18. Figure 5.35 shows time series uranium groundwater plume maps for the entire 200-E Area for selected years during this time period to illustrate the uranium plume increases in size and concentration.

There was a time series uranium plume assessment performed as part of the 2007 Site-wide Groundwater Monitoring report (DOE/RL 2007c). Figure 5.36 shows the plume evolution for the BComplex region for the years 2003, 2006, and 2007. The core of the uranium plume (with a concentration of $\sim 500 \mu \mathrm{g} / \mathrm{L}$ ) in 2003 occurred at well 299-E33-9 within the BY Tank Farm with the second highest concentration found to the southeast at well 299-E33-44. The shape of the uranium groundwater plume suggests migration towards the northwest. In 2006, the core of the uranium groundwater plume remained at well 299-E33-9, and the concentration increased to $\sim 800 \mu \mathrm{g} / \mathrm{L}$. However, the second highest concentration occurred far to the southeast centered on well 299-E33-18 near the B-7-A Crib. The uranium groundwater plume also widened in the north and south directions but continued to appear to be migrating towards the northwest. In 2007, the main portion of the uranium groundwater plume within the B-Complex was still centered at well 299-E33-9, and it did not change much in location or concentration from 2006, but the small "hot spot" centered at well 299-E33-18 was growing in both concentration and areal extent. By the end of 2007 through the first half of 2008, the concentration of uranium at well 299-E33-18 had increased to $\sim 1250 \mu \mathrm{g} / \mathrm{L}$, but dropped slightly in late 
2008 through the middle of 2009 to slightly below $1000 \mu \mathrm{g} / \mathrm{L}$. The uranium concentration in the 299-E33-9 well also increased to $\sim 1300 \mu \mathrm{g} / \mathrm{L}$ in 2008 . In May 2009 , the uranium concentration in well 299-E33-41 west and slightly south of well 299-E33-18 also sharply increased from 300 to $450 \mu \mathrm{g} / \mathrm{L}$ up to $1100 \mu \mathrm{g} / \mathrm{L}$. The uranium concentration in well 299-E33-44 between wells 299-E33-9 and -E33-18 (300 ft north of 299-E33-41) did not show a dramatic rise in uranium concentrations and has had concentrations ranging between 200 and $350 \mu \mathrm{g} / \mathrm{L}$ since 2003. The new well 299-E33-343, which is $\sim 130 \mathrm{ft}$ northeast of 299-E33-41 and 120 ft west of 299-E33-18, was first sampled in March 2008, and between then and now has shown very high uranium concentrations ranging from 3900 to $4850 \mu \mathrm{g} / \mathrm{L}$.

The center of mass or the location where the concentration of uranium is greatest is difficult to pinpoint and is highly influenced by which wells are sampled and the date that the samples were taken. With the drilling of the new boreholes 299-E33-205, E33-343, and E33-345, a better conceptual model of where the uranium groundwater hot spot (highest concentration) is possible. Groundwater plume maps for 2008 and 2009, which include these new boreholes, show the hot spot to be pinpointed near 299-E33343. It appears that, based on the very high concentrations of uranium in the 299-E33-343 vadose zone pore waters extracted from the sediments in the $\mathrm{CCU}_{\mathrm{z}}$ layer, uranium from this silt-dominated layer is migrating down through the gravel-dominated $\mathrm{CCU}_{\mathrm{g}}$ into the water table very near to this well. There is little doubt that the overall uranium plume below the B-Complex has been increasing since 1996 with rapid increases in some years (2006) and localized rapid increases in the vicinity just north of the northwest corner of the B Tank Farm fence (the location of 299-E33-343).

Seasonal (spring versus fall) uranium groundwater plume maps help refine the conceptual model on where the uranium is entering the water table as well as clarifying some of the movement of the plume's isopleths. Figure 5.37 and Figure 5.38 are used to generate the following conceptual model to identify the source(s) of uranium, the seasonal evolution of the plume, the net overall regional groundwater flow direction, and a qualitative statement on whether the mass of uranium has been increasing over the last three years. A second more quantitative estimate of the mass of uranium in the aquifer as a function of time is discussed later.

Figure 5.37 shows that the highest uranium in the groundwater in the fall of 2007 is found near where the new borehole 299-E33-343 would be drilled in early 2008. The 1000- $\mu \mathrm{g} / \mathrm{L}$ isopleth does not extend to the northwest as far as well 299-E33-9, and the general shape of the plume suggests northwesterly groundwater movement. In all the seasonal groundwater figures, there appears to be a low or depressed uranium groundwater concentration at well 299-E33-44, as signified by the hatches on the isopleths. Figure 5.38, representing the spring of 2008, shows that a new higher concentration region was found at 299-E33-343, and the 1000- to 2500- $\mathrm{gg} / \mathrm{L}$ isopleth migrated as far as 299-E33-9. The more dilute uranium isopleths did not show as much migration to the northwest as the higher concentration isopleths. In the fall of 2008 (Figure 5.39), the highest uranium isopleth narrowed in shape, and the low surrounding 299-E33-44 became more pronounced. The 500 - to $1000-\mu \mathrm{g} / \mathrm{L}$ isopleth has moved in a northwesterly direction since the spring of 2008. 


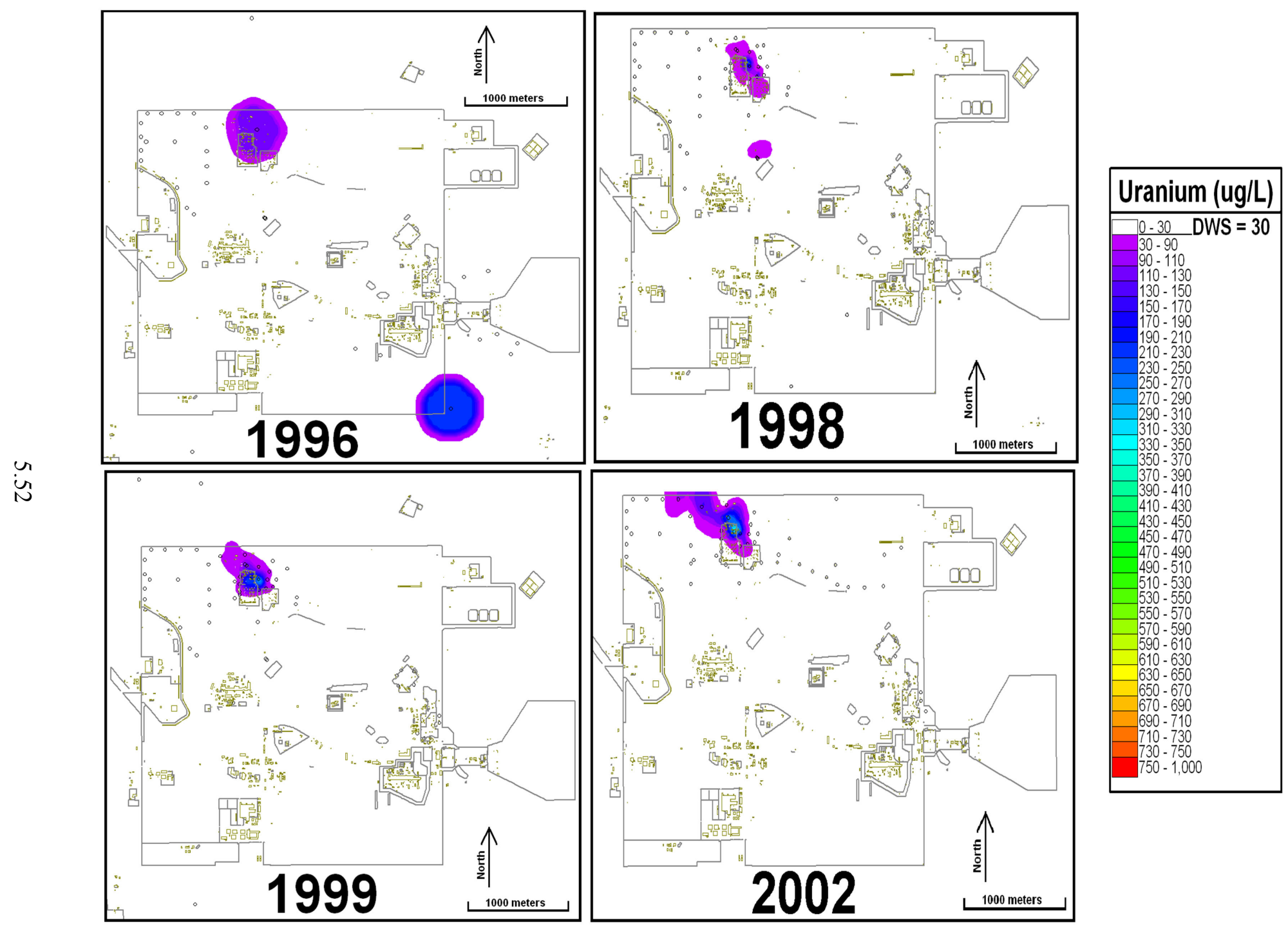

Figure 5.35. Uranium Groundwater Plume Maps for Entire 200-East Area for Early Years 
PNNL-19277
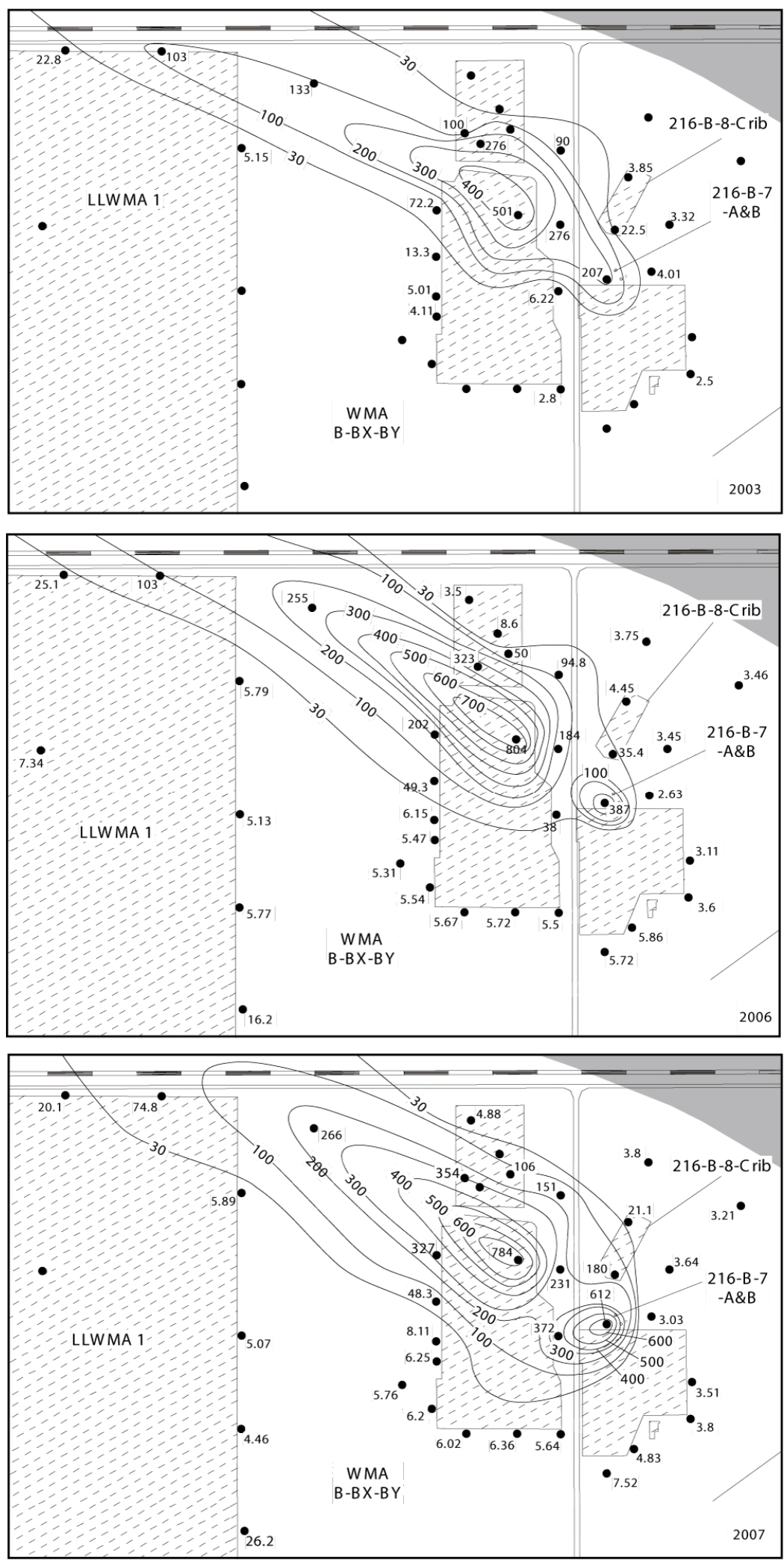

Figure 5.36. Time Series Groundwater Plume Maps for U in B-Complex (2003, 2006, and 2007) taken from DOE/RL (2007c) 


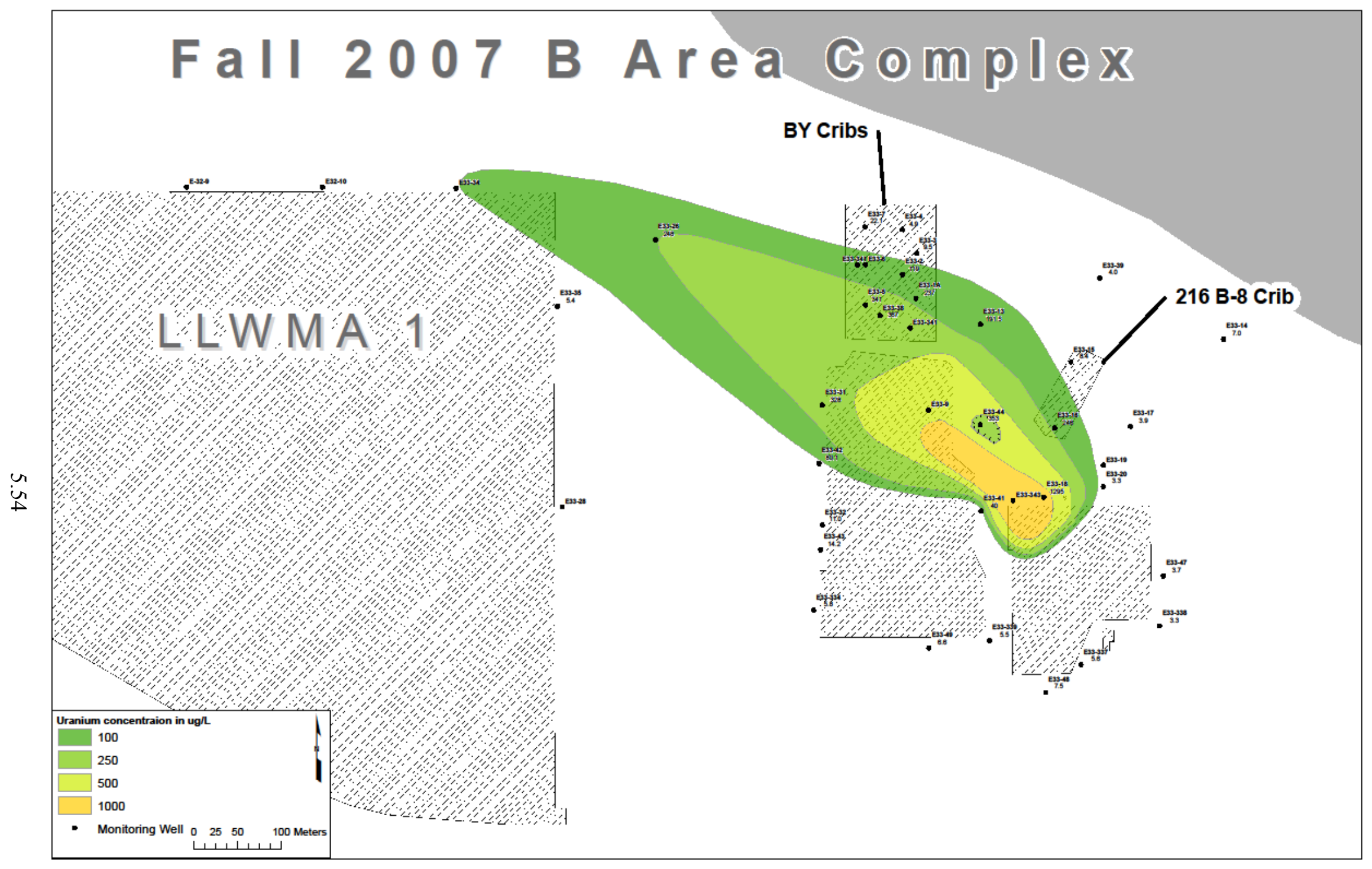

Figure 5.37. Uranium Groundwater Plume for Fall 2007 


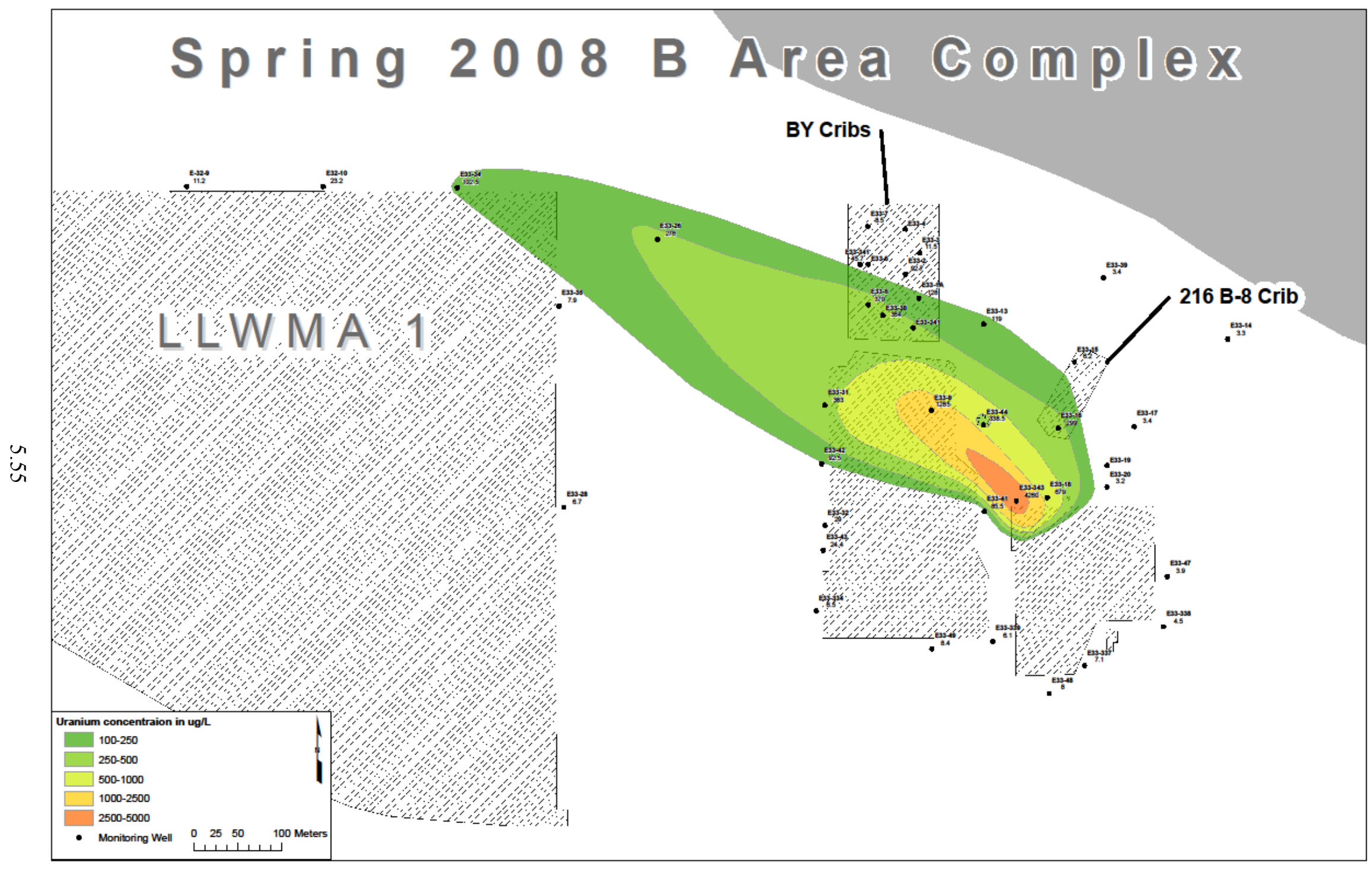

Figure 5.38. Uranium Groundwater Plume for Spring 2008 
In the spring of 2009, Figure 5.40, the uranium groundwater concentration around 299-E33-343 increased to form a $>50000-\mu \mathrm{g} / \mathrm{L}$ region, the low surrounding 299-E33-44 became even more pronounced, and the 500 to $1000 \mu \mathrm{g} / \mathrm{L}$ isopleth narrowed, with the northern edge moving eastward. Most noteworthy was the appearance of a new minor "hot spot" around well 299-E33-339 at the southeast corner of the BX Tank Farm fenceline. One explanation of the apparent southern migration of some of the uranium isopleths and the formation of the secondary hot spot around 299-E33-339 could be the same phenomenon discussed in the seasonal trends for nitrate and technetium-99. If the northwesterly regional groundwater flow is diminished, stopped or even reversed, but uranium is continuing to enter the water table in the region around E33-343, then concentrations would increase at E33-343, and the isopleths surrounding this region would increase in a radial fashion that would project as some movement of the plume towards the south. This also could be misconstrued as forming a secondary new source at 299E33-339. It will require future monitoring of both the groundwater uranium and the proposed subtle water level changes caused by the impacts of Columbia River stage through the Gable Gap region to better understand the seasonal uranium trends. The seasonal uranium plumes do support localized groundwater flow to the northwest, the influx of uranium from the vadose zone around the 299-E33-343 location, and an overall increase in the mass of uranium within the plume. The localized depression in the groundwater uranium concentration at E33-44 is more speculative and requires some uranium input from the B-8 Crib and Tile Field or some localized lower permeability zone in the aquifer that diverts the groundwater laden with uranium from flowing directly through this localized region.

Using the geologic conceptual model, the average yearly groundwater uranium concentration and water table elevations from the EDA database beneath the B-Complex, the estimated mass of uranium in the groundwater was calculated for the years 2000, 2003, 2006, and 2009. The data were entered into the 3D EarthVision ${ }^{\circledR}$ model for the B-Complex and as described for the technetium-99 and cyanide mass calculations were generated for uranium within the total volume contained within the $5-\mu \mathrm{g} / \mathrm{L}$ uranium isopleth. That is, the uranium groundwater concentration for each $10-\mathrm{m}$ by $10-\mathrm{m}$ grid cell in the 3D visualization was multiplied by the calculated aquifer thickness for the year chosen, and the mass estimate from each cell was summed out to the areal boundaries delineated by the outer edge of the $5-\mu \mathrm{g} / \mathrm{L}$ isopleth. Table 5.4 shows the estimated mass of uranium within the uranium plume for the calendar years 2000, 2003, 2006, and 2009. Figure 5.41 through Figure 5.44 show the uranium groundwater plumes for each year. In this uranium plume conceptualization, the lower uranium concentration in the localized region around well E33-44 was not considered; rather, the contouring was performed assuming one uranium plume with the source from the vadose zone located near well E33-343. The uranium plumes generated by the EarthVision ${ }^{\circledR}$ software are quite similar to those shown for the entire 200-E Area in Figure 5.35 and Figure 5.36 and Figure 5.37 through Figure 5.40, with the exception of the localized low surrounding well E33-44. All the plume renditions suggest that the local groundwater flow direction is to the northwest, and the smaller scale plume maps show that the hot spot from which the uranium is entering the water table is in the vicinity of new borehole E33-343, near the northwest corner of the BTank Farm. As shown quantitatively in Table 5.4, the various groundwater plume maps suggest an increasing mass of uranium over at least the last decade. 


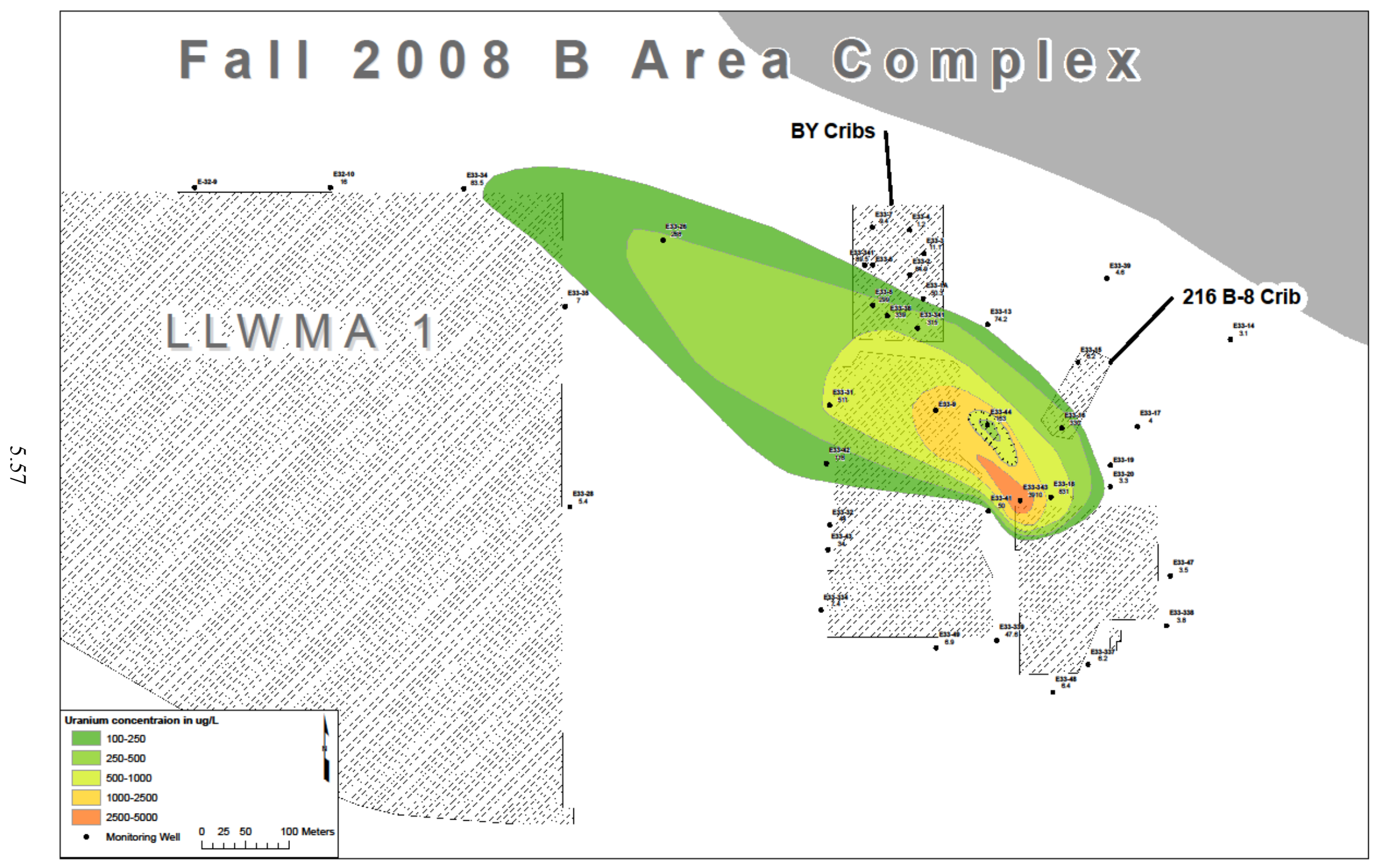

Figure 5.39. Uranium Groundwater Plume for Fall 2008 


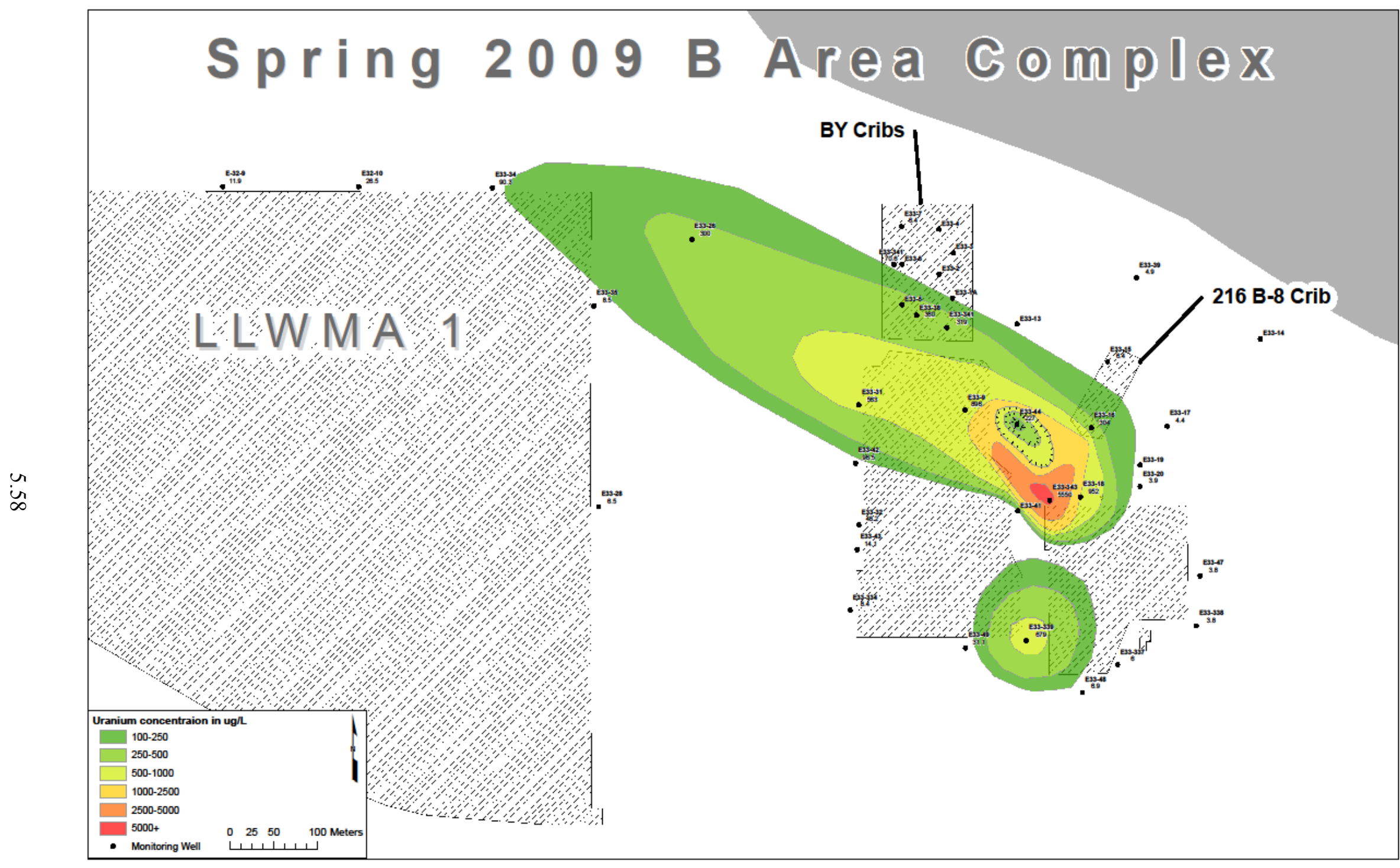

Figure 5.40. Uranium Groundwater Plume for Spring 2009 
PNNL-19277

Table 5.4. Estimated Mass (kg) of Uranium Contained in Groundwater Plume for Selected Years

\begin{tabular}{|c|c|c|c|c|c|c|c|c|c|}
\hline Contaminant & $\overline{\mathrm{U}}$ & $\mathrm{U}$ & $\mathrm{U}$ & $\mathrm{U}$ & & $\mathrm{U}$ & $\mathrm{U}$ & $\mathrm{U}$ & $\mathrm{U}$ \\
\hline Plume Cutoff & \multicolumn{4}{|c|}{$5 \mu \mathrm{g} / \mathrm{L}$} & & & & & \\
\hline Mass Units & $\mathrm{kg}$ & $\mathrm{kg}$ & $\mathrm{kg}$ & $\mathrm{kg}$ & Perce & tage $\mathrm{Ch}$ & nge Bety & een Tims & Periods \\
\hline Year & 2000 & 2003 & 2006 & 2009 & Year & 2000 & 2003 & 2006 & 2009 \\
\hline Total & 3.4 & 5.8 & 11.4 & 22.3 & & & $70.6 \%$ & $96.6 \%$ & $95.6 \%$ \\
\hline
\end{tabular}

Based on the conceptual model the mass of uranium present in the groundwater plume below the BComplex has steadily increased over the last decade from 3.4 to $22.3 \mathrm{~kg}$ as shown in Table 5.4. This mass is a very small fraction of the uranium estimated to have been released $(10,100 \mathrm{~kg})$ in the 1951 overfill event at BX-102. As will be discussed in Section 6 , the $\sim 22 \mathrm{~kg}$ currently in the groundwater is also a very small fraction of the uranium that is estimated to still be present in the vadose zone between tank BX-102 and the region to the northeast encompassing boreholes 299-E33-45, E33-41, E33-343, E3318, and E33-345. Residual mass estimates for uranium in the vadose zone were discussed in Section 3.4.4.

In summary, since perhaps 1996, the groundwater uranium concentrations have been increasing steadily below much of the B-Complex region. In 2006, concentrations dramatically increased and appear to continue to date at a relatively high rate. As with the nitrate and technetium-99, seasonal groundwater plume mapping suggests that there is a transient nature to the evolution (areal movement) of the plume isopleths. However, the overall local groundwater flow direction is towards the northwest. The outer reaches of the uranium plume are well to the northwest of the B-Complex boundaries but not as far north as the technetium-99 or cyanide, which is what one might expect for the slightly chemically interacting uranium contaminant. 


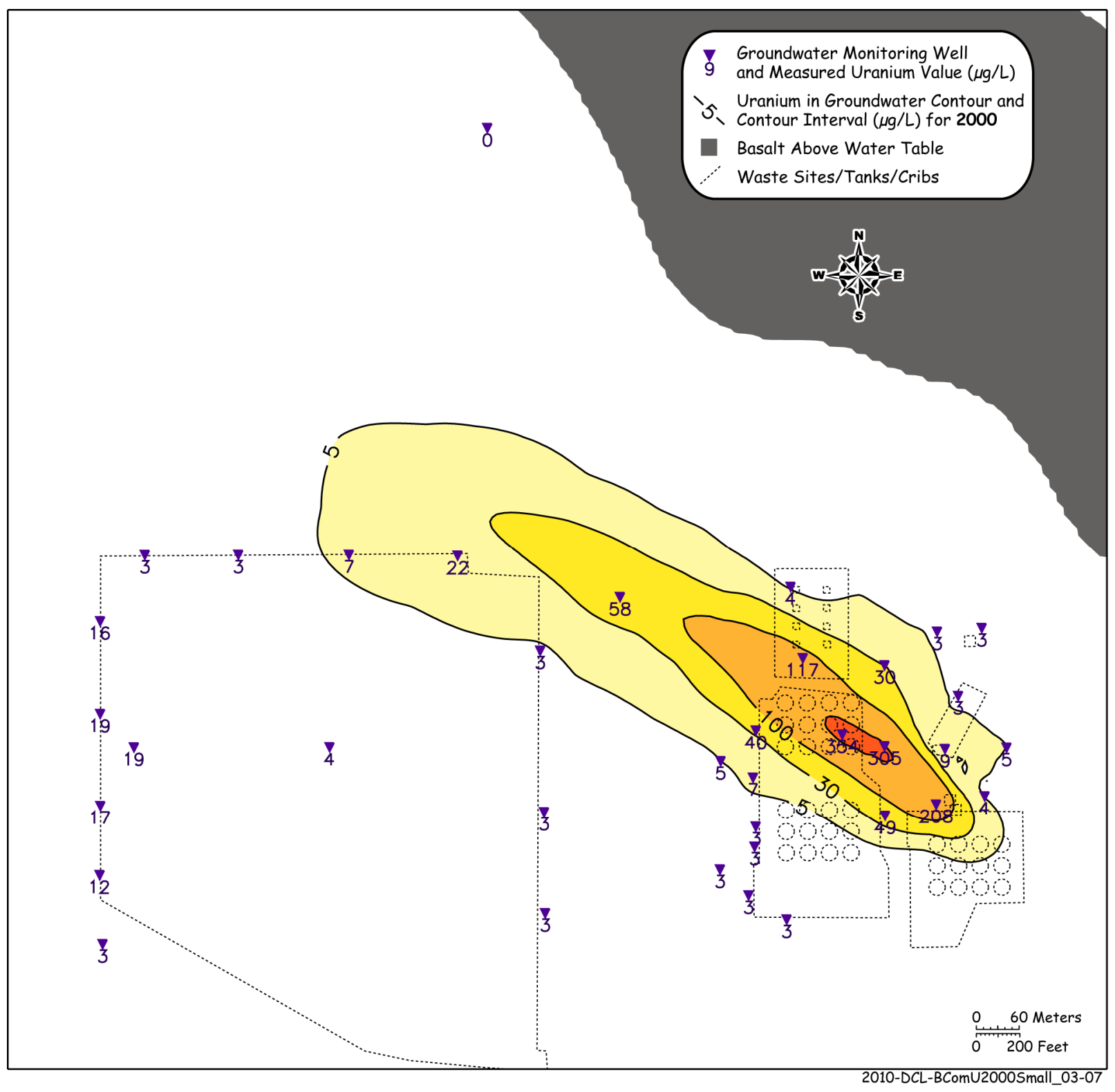

Figure 5.41. Groundwater Uranium ( $\mu \mathrm{g} / \mathrm{L}$ ) Plume Map for Year 2000 


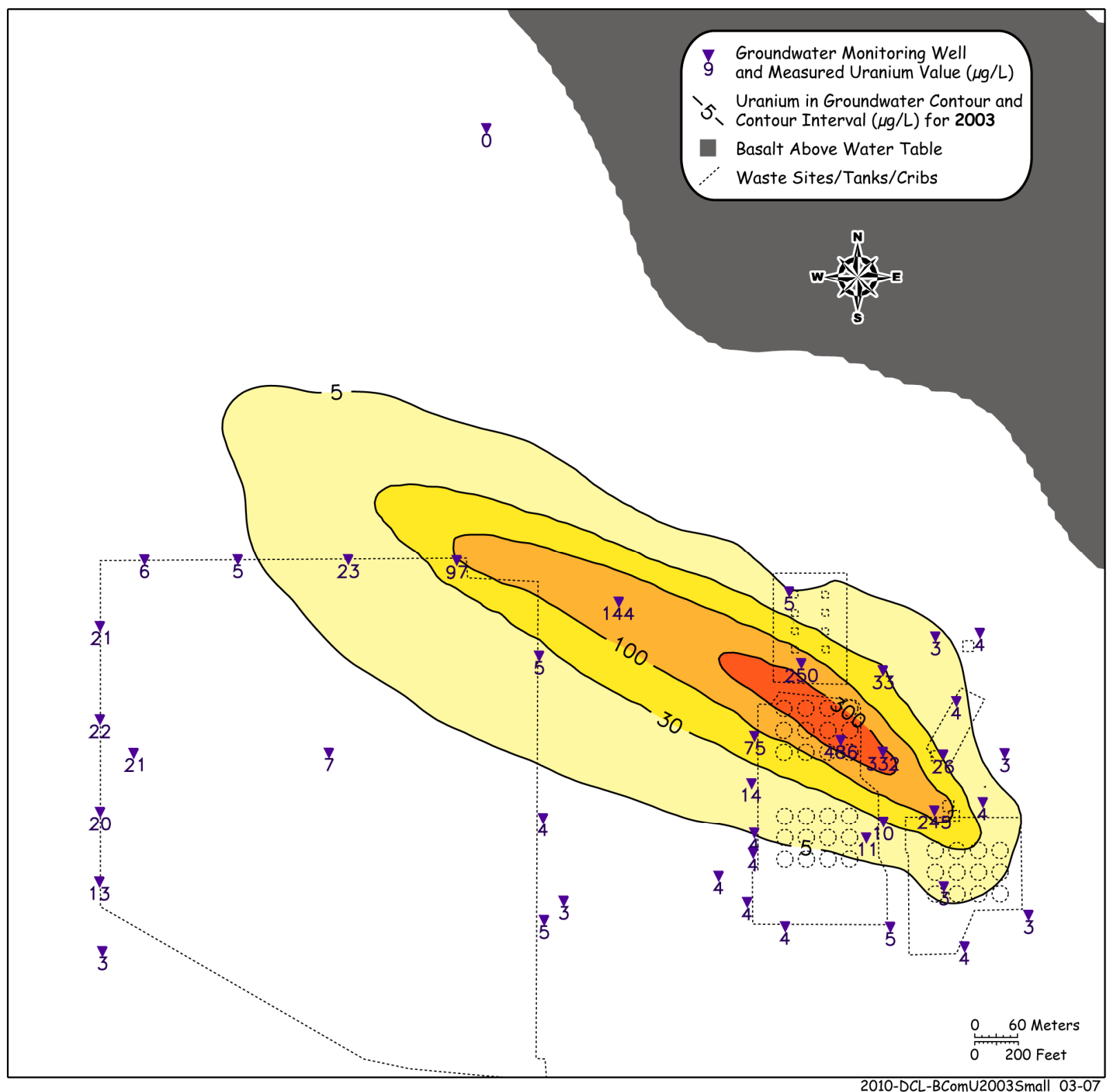

Figure 5.42. Groundwater Uranium $(\mu \mathrm{g} / \mathrm{L})$ Plume Map for Year 2003 


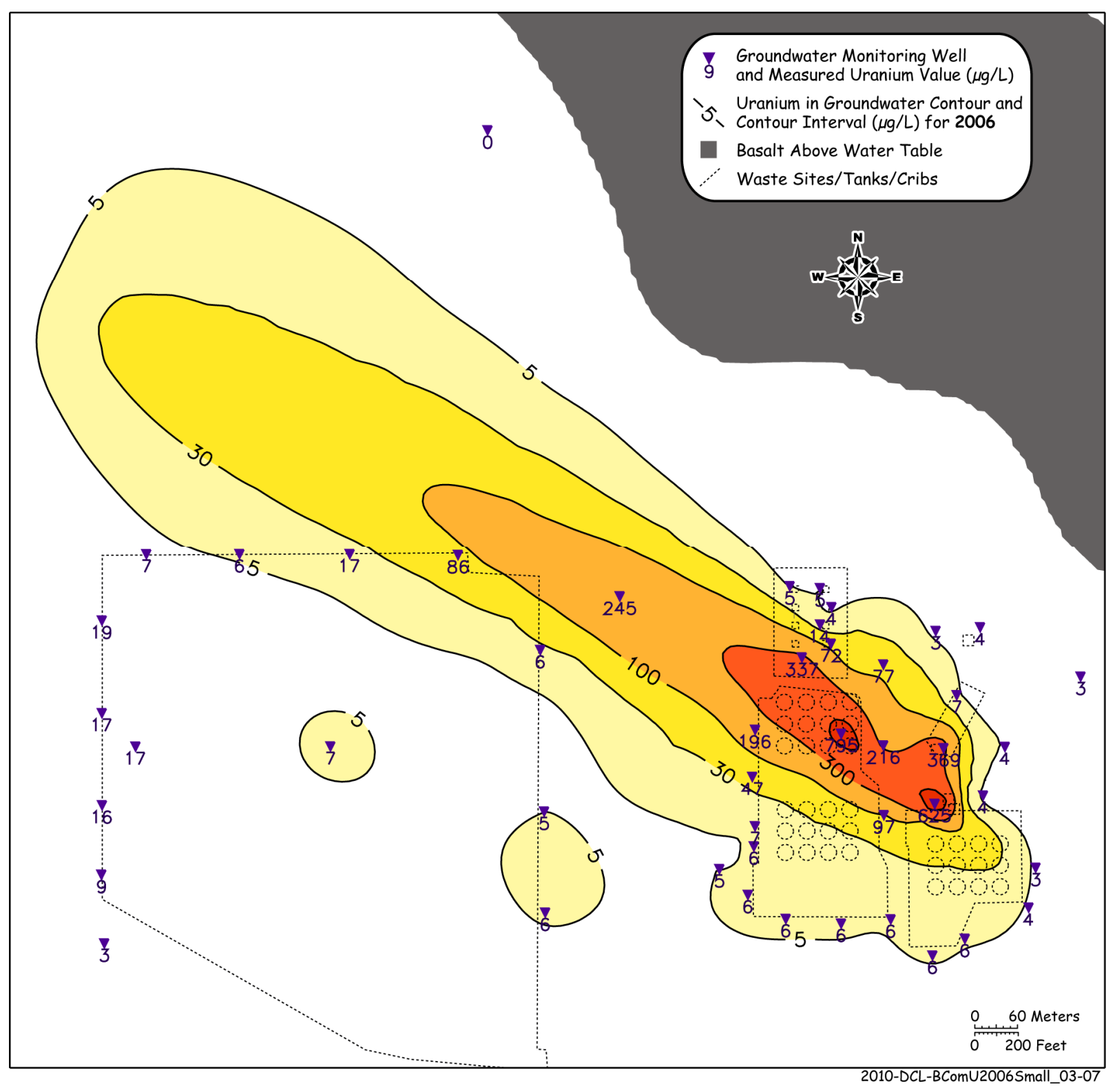

Figure 5.43. Groundwater Uranium ( $\mu \mathrm{g} / \mathrm{L}$ ) Plume Map for Year 2006 


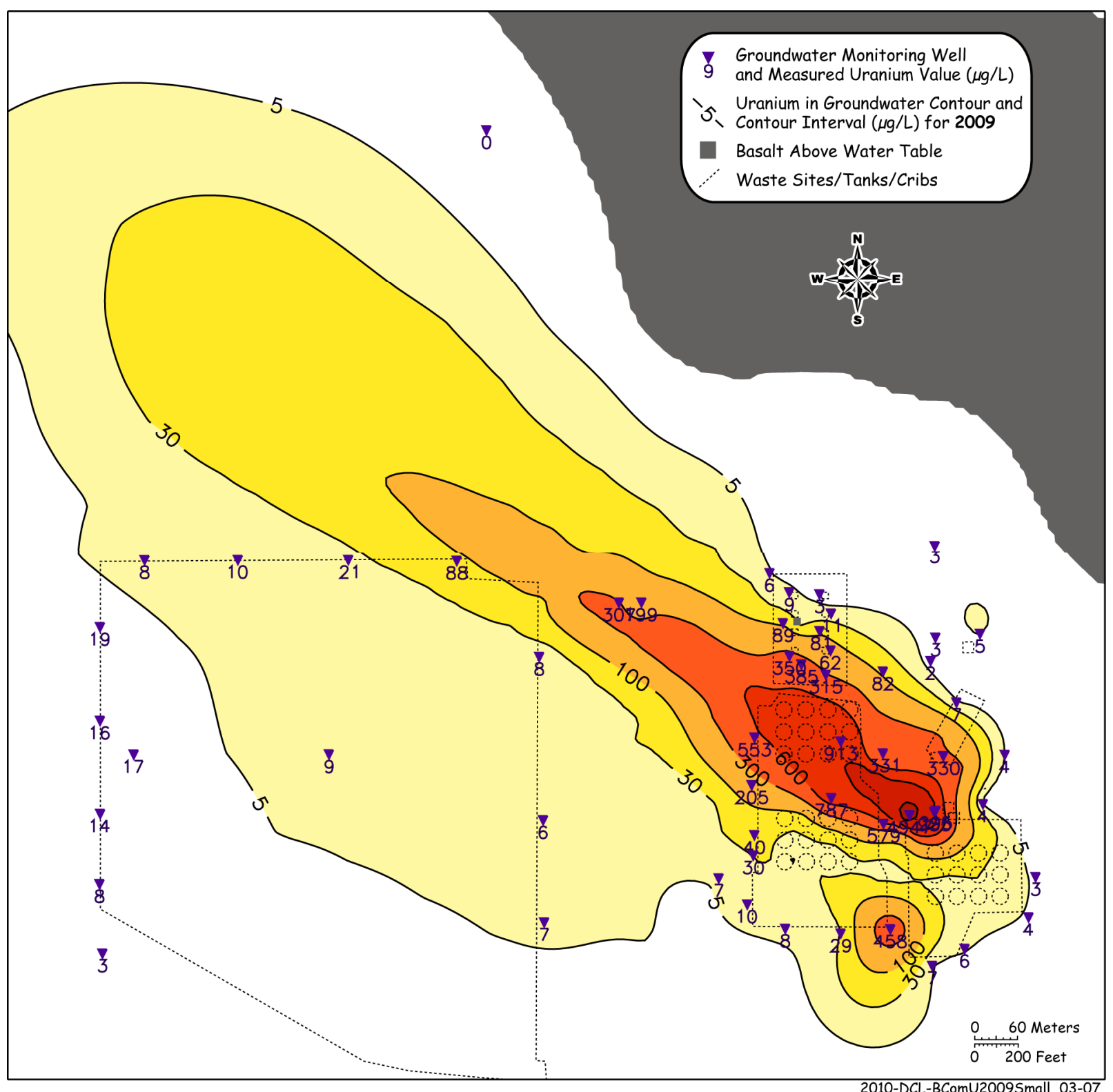

Figure 5.44. Groundwater Uranium $(\mu \mathrm{g} / \mathrm{L})$ Plume Map for Year 2009 


\subsection{Uranium Isotopic Signatures in B-Complex Groundwater}

The final information germane to groundwater uranium in the B-Complex was to conduct precise uranium isotopic signature measurements of groundwater samples obtained during the drilling of new boreholes and selected measurements of archived groundwater samples of nearby wells. All the new and key pertinent data from nearby well 299-E33-18 are plotted in Figure 5.45. Because many of the data plot in a tight cluster in the upper left hand portion of the figure, an expanded plot of this area, which includes the Tank BX-102 source signature values, is plotted in Figure 5.46. To illustrate the high precision in these measurements, the \pm 2 sigma uncertainty bars for both ratios (uranium-236/238 and uranium234/238) are shown in the expanded figure. The uncertainty bars for the ratio uranium-236/238 are so small that for most data, the bars are no larger than the symbol itself.

Interpretation of the groundwater and perched water results follows. The perched water from within the $\mathrm{CCU}_{\mathrm{z}}$ silt unit at borehole 299-E33-344 is a mixture of water with a BX-102 source signature and uncontaminated vadose pore waters from $\mathrm{CCU}_{\mathrm{z}}$ sediments with some $\mathrm{H} 2$ pore water, as discussed previously in Section 3.4.3. All of the groundwater samples from the unconfined aquifer in the BComplex that have been analyzed exhibit a uranium signature almost identical to the BX-102 source (Figure 5.45) or a mixture of BX-102 waste water with uncontaminated groundwater. The groundwater samples with the highest uranium-236 content are best seen on Figure 5.46. The groundwater samples that plot the closest to the BX-102 source signature are the two from well 299-E33-343, which appears to be closest to where uranium is descending into the water table, the groundwater sample from well 299E33-345, and the 2007 sample from 299-E33-18. Remarkably, all three of these boreholes are many hundreds of feet northeast of Tank BX-102. Based on the uranium-236/uranium-238 ratio in these groundwater samples with signatures very close to the BX-102 source, the percentage of BX-102 sourced uranium in the groundwaters ranges from 98.6 to $100.3 \%$. The groundwater sample from 299-E33-341, which is located in the BY Cribs region and hundreds of feet down-gradient from 299-E33-343, has a uranium isotope signature that is a mixture of $87.5 \%$ uranium from BX-102 and $13.5 \%$ uncontaminated groundwater uranium. The groundwater uranium isotope signatures for waters to the northwest of 299E33-343, namely 299-E33-205, -E33-342, and -E33-341, show a monotonic decrease in the percentage of BX-102 source signature at the expense of increasing proportions of the signature for uncontaminated groundwater. This is the progression one would expect for a uranium plume that is migrating from a source region towards the northwest as was inferred from the data presented in Section 5 for each contaminant discussed. Interestingly, the 2001 groundwater at well 299-E33-18 contained a total concentration of uranium of $123 \mu \mathrm{g} / \mathrm{L}$, and in 2007, the total uranium increased to $1330 \mu \mathrm{g} / \mathrm{L}$. Over this 6-year time span, the isotope signature for the uranium increased from 95.5 to $99.0 \% \mathrm{BX}-102$ sourced uranium, which again supports the hypothesis that the BX-102 overfill event is the predominant if not sole source of contaminant uranium currently residing below the B-Complex.

It is comforting that the groundwater samples from 299-E33-345 and -E33-18 have essentially the same uranium isotope signature considering that the two boreholes are within $10 \mathrm{ft}$ of each other. Further, the fact that the total uranium in the groundwater at 299-E33-18 over the 6-year period has increased by an order of magnitude and the isotope signature has moved closer to the BX-102 source signature suggests that the source of the uranium remains the same as opposed to suggesting that mixtures of two or more uranium sources have occurred. 


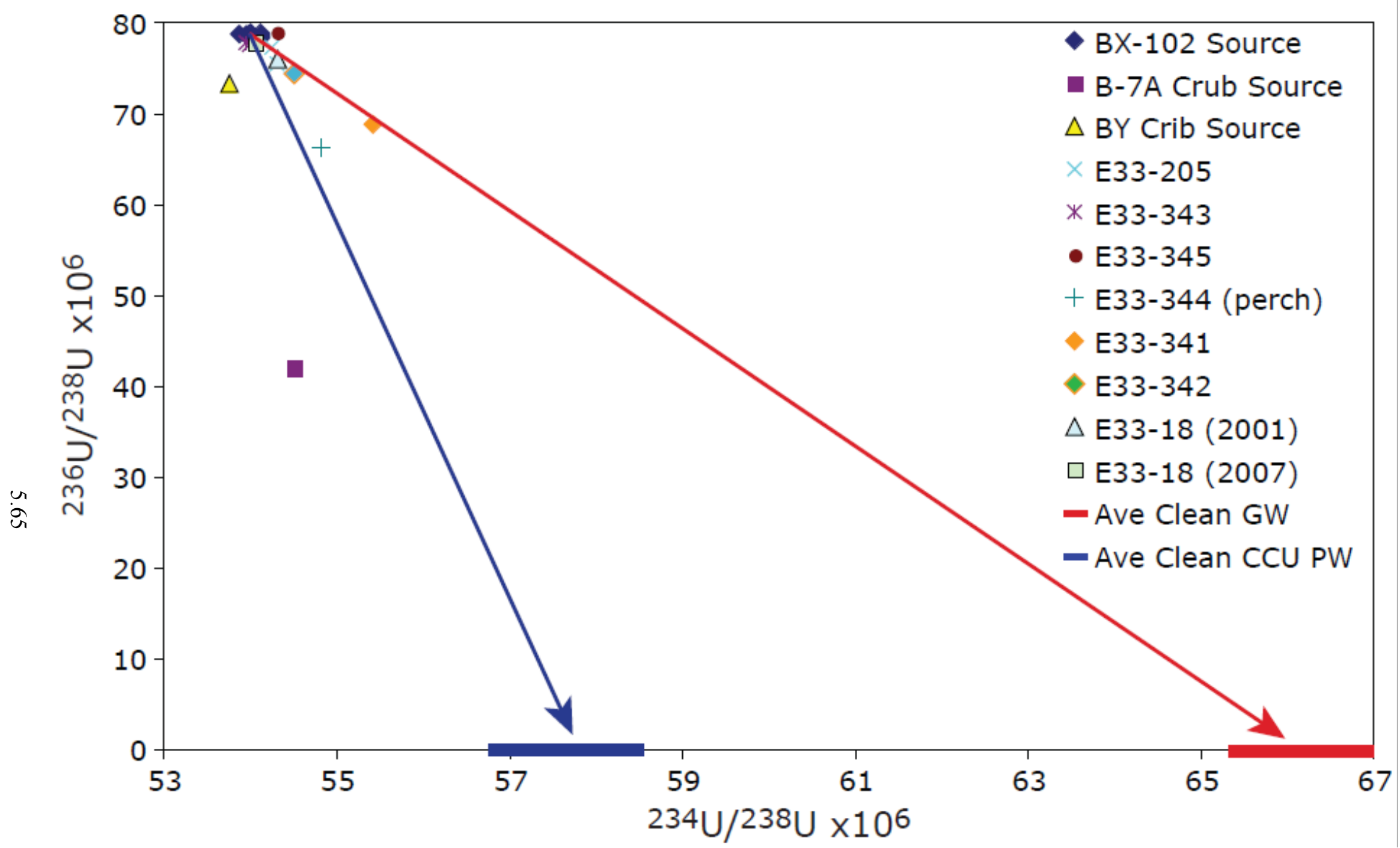

Figure 5.45. Uranium Signature for Groundwater and Perched Water from Wells 299-E33-205, E33-341, E33-342, E33-343, E33-344, E33-345 and E33-18 


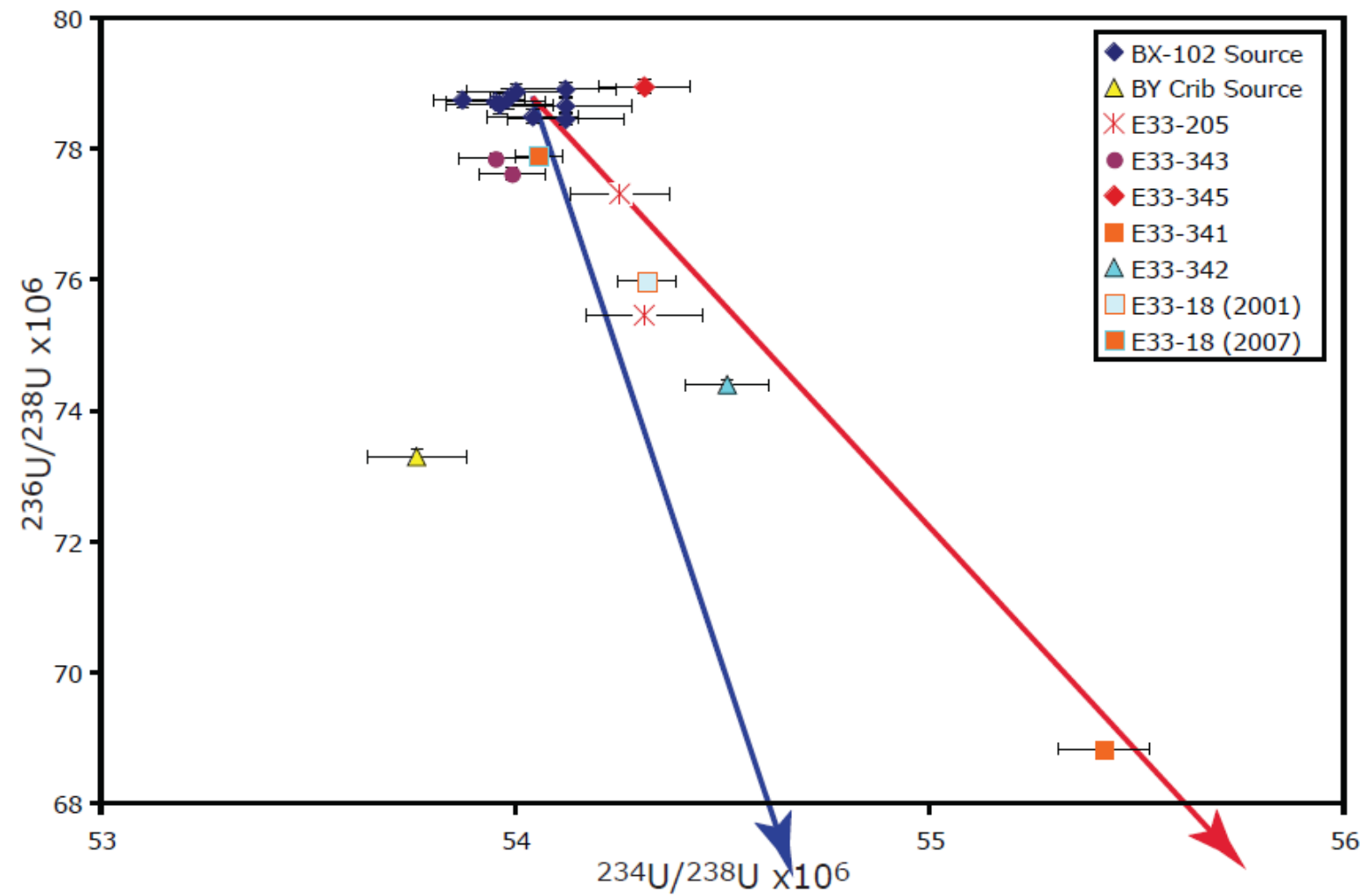

Figure 5.46. Expanded Scale Uranium Signatures for Groundwater from Wells 299-E33-205, E33-341, E33-342, E33-343, E33-344, E33-345 and E33-18

To illustrate the high precision in these measurements, the \pm 2 sigma uncertainty bars for both ratios (uranium-236/238 and uranium-234/238) are shown in the expanded figure. The uncertainty bars for the ratio uranium-236/238 are so small that for most data, the bars are no larger than the symbol itself.

In summary, both the vadose zone (see Sections 3.1.3, 3.3.3, and 3.4.3) and the groundwater uranium isotopic ratio signature data suggest the following conceptual model for sources of uranium below the B-Complex. Because all the uranium in wastes disposed of to the BY Cribs, BX Trenches, B-8 Crib and Tile Field, and many of the B-BX-BY tanks at the time of their leaks came from un-enriched natural abundance fuel, the uranium-235/238 ratio provides little or no source discrimination potential. One exception is the unique 1966-67 disposal of PUREX-derived wastes to the B-7-A\&B Cribs, which was of short duration and relatively low volume compared to the volumes released in the 1950s. The estimated uranium mass disposed of at B-7A\&B Cribs was also very low in comparison to the release from BX102. As shown in Figure 1.3, there is an indication that enriched uranium-235 may be in the groundwater sample from well 299-E33-345 indicative of a small amount of enriched uranium from the 1966-67 disposal to the B-7A\&B Cribs.

Earlier work on nine vadose zone pore waters from different depths in borehole 299-E33-45 showed that these nine uranium isotope signatures cluster very tightly together (see Figure 5.46) for uranium ratios measured (uranium-234/238 and uranium-236/238 shown and uranium-235/238 not used herein but available in Appendix H), which supports the assumption that the uranium in the 299-E33-45 borehole 
pore water is from one source, the BX-102 overfill event in 1951. More discussion on this topic can be found in Christensen et al. (2004).

Based on the shallow depth of the elevated total uranium concentration at 299-E33-46 (not discussed in any detail in this report, but adequately shown and discussed in Christensen et al. 2004), the lowvolume estimate for the B-110 tank leak and its pore-water showing a significantly different uranium236/238 and uranium-234/238 ratios (see Figure 1.4) than groundwater samples below the B-Complex, it has been concluded that the slightly elevated uranium below Tank B-110 is not contributing significantly or, more likely, not contributing at all to the B-Complex groundwater plume.

Only one sample each was obtained for the B-7-A Crib and BY Cribs footprints because the available sediment samples in regions where high concentrations of total uranium might have been present were limited. To get precise isotopic ratio data, one must have high concentrations of total uranium in the pore water or large volumes of pore water available to collect an adequate mass (30 to $100 \mathrm{ng}$ ) of total uranium. The very dry vadose zone sediments do not contain large volumes of pore water so that the attempt to gather more of the precise uranium isotope ratios needed to have high confidence that their unique source signatures have been identified was thwarted. However, if one assumes that the uranium isotopic signatures for the four source facilities (BY Cribs, BX-102 Tank, B-7-A\&B Cribs, and B-110 Tank) have been reasonably captured, they are distinct enough from each other to allow evaluation and assignment of sources to contaminated vadose zone pore waters and groundwaters in the B-Complex region. The one key facility that lacks a source uranium isotopic signature is the B-8 Crib and Tile Field for which no boreholes have been drilled. By assuming that the B-8 Crib and Tile Field uranium source signature would be distinctly different from the other four sources, or at least not too similar to the $\mathrm{BX}-102$ source signature, one can form hypotheses on the origin of uranium in the groundwater below the B-Complex.

The authors conclude that the source of the uranium from borehole 299-E33-343 is almost "fullstrength" BX-102 fluid for three of the vadose pore waters and the two groundwater samples. The two pore waters with lower uranium-236/uranium-238 ratios are found at the top of the $\mathrm{CCU}_{z}$ fine-grained stratum and appear to be a mixture of BX-102 fluids and uncontaminated vadose zone pore water. The authors also conclude that fluids containing high uranium concentrations (from the BX-102 release) within the $\mathrm{CCU}_{\mathrm{z}}$ stratum are descending out of this unit and through the $\mathrm{CCU}_{\mathrm{g}}$ gravel to the water table nearer to 299-E33-343 than any other location for which uranium isotopic measurements are available. The total uranium time series groundwater plume maps also suggest this location as the entry of uranium into the water table.

The uranium isotope signature data for groundwater from 299-E33-205 appears to be a mixture of mostly BX-102 tank fluid diluted with uncontaminated groundwater. The 299-E33-205 groundwater samples do not fall near the mixing lines with either the BY or B-7-A Cribs. If groundwater from 299E33-343 is very near the location where uranium-contaminated water enters the aquifer and the local flow direction is to the northwest as is believed, then it would be diluted somewhat by the time it reached 299-E33-205 as the uranium isotopic signature data for 299-E33-205 groundwater suggest. 
PNNL-19277

\subsection{B-Complex Groundwater Conclusions}

\subsubsection{Groundwater Contaminant Concentration Trends (Masses Increasing)}

All of the mobile contaminants that were discussed in this report appear to be increasing in concentrations in groundwater in the B-Complex region over the last decade, and the rate of increase for many has risen since 2006. For technetium-99, cyanide, and uranium, quantitative estimates are presented whereas for nitrate and chromium, only increasing concentrations via isopleths with greater values in the time series plume plots are shown. However, for any given 3-year sequence, over the last two decades, based on the season-by-season time series plume maps, there also appears to be years when the groundwater concentrations of mobile constituents have increased or decreased in episodic fashion. This suggests either a dynamic (transient) flux of constituents into the water table (e.g., from the deep vadose zone) or transient groundwater flux.

The nitrate concentrations today are only about one-fifth as high as during the active disposal period in the mid 1950s and after active disposal in the late 1950s through early 1960s. Because very few longlived radionuclides that exhibit high-to-moderate mobility (technetium-99, iodine-129, and uranium) were measured in the groundwater in the 1950s and 1960s, it is not possible to determine what the highest concentrations in groundwater below the B-Complex might have been for these constituents. However, one telling fact needs to be acknowledged for the current groundwater conditions. As stated in DOE/RL (2007c) "The highest concentrations of technetium-99, uranium, cobalt-60, cyanide, and nitrate on the Hanford Site in fiscal year 2008 were in wells in the 200-BP-5 Operable Unit."

\subsubsection{Direction of Groundwater Plume Migration}

As aptly stated in the last several site-wide groundwater monitoring reports "The water table in the northern 200 East Area is virtually flat, making it difficult to determine current directions of groundwater flow." The water table below the B-Complex is in the heart of this very flat water table gradient where the water levels across the entire region vary by no more than $4 \mathrm{~cm}$, which is well within the uncertainty of current measuring devices. Complicating any evaluation of the regional groundwater flow direction is the fact that the water table in the 200-BP-5 region fluctuated during and after the time of active liquid disposal to the facilities described in this report. More importantly, even larger volumes of dilute and oftentimes uncontaminated water was disposed of to the ponds and "swamps" to the north, east, and far to the west in the 200 West Area. The water table in the 200-BP-5 area continues to drop slowly towards the pre-Hanford Site levels.

The new analyses of groundwater flow that combine the uranium isotopic ratio measurements with the time series plume maps shown herein (including those for the overall 200 East Area, the seasonal spring and fall and the yearly 2000, 2003, 2006, and 2009) all support current net groundwater flow to the northwest through the B-Complex region. It is acknowledged that much of the available data and past interpretations that hypothesize groundwater flow in the opposite direction (to southeast) had merit at the time. This was especially the case in the more localized area between the southeastern corner of the BY Cribs through the northwestern corner of the B Tank Farm. However, the spring and fall seasonal observations appear to explain the intermittent movement of contaminant isopleths to the south or southeast from one seasonal groundwater map to another. The key hypotheses that coalesce into a consistent conceptual model for the current groundwater plumes include 
1) Columbia River stage influences are present within the B-Complex leading to both seasonally reduced or infrequently reversed localized groundwater flow

2) the presence of three or more sources of contaminated water entering this B-Complex local region (BY Cribs subregion, near 299-E33-343, and near B-8 Crib and Tile Field); and

3) fairly contiguous thin fine-grained layers $\left(\mathrm{H} 2 \mathrm{~F} 1, \mathrm{H} 2 \mathrm{~F} 2\right.$, and $\mathrm{H} 2 \mathrm{~F} 3$ and most importantly the $\mathrm{CCU}_{\mathrm{z}}$ unit) appear to have allowed residual waste fluids to migrate large distances in horizontal directions from B-Complex disposal facilities and to have delayed the descent of these residual waste fluids to the water table.

In the last decade, there has been an increase in the mass of the residual mobile contaminants reaching the water table. The moderately adsorbing uranium contaminant has only recently begun to breakthrough to the water table.

It appears that there is a transient (non-uniform) nature to the flux out of the deep vadose zone that helps confound simple interpretation of the evolution of the groundwater plumes. The $\mathrm{CCU}_{\mathrm{z}}$ (shown in Figure 2.20) is not continuous below the B-Complex; it varies in thickness and particle size (permeability) in both areal and vertical directions based on visual inspection of the sediments (both grab and core samples) from the new characterization boreholes and archived samples from older boreholes. The migration of residual fluids through the heterogeneous and variably thick $\mathrm{CCU}_{\mathrm{z}}$ unit, in both the horizontal and vertical directions, likely promotes transient fluxes of contaminants into the water table. 



\subsection{Integrated Conceptual Models for Key Contaminants}

In this section, the information used to develop vadose zone conceptual models for the distribution of key mobile contaminants has been combined with the observed groundwater plumes for each of the five subregions discussed in Section 3: 1) BY and B-57 Cribs, 2) BX Trenches, 3) B-7-A\&B/B-8 Cribs, 4) BX and BY Tank Farms (WMA BX-BY), and 5) B Tank Farm (WMA B). A discussion on the strengths and weaknesses of the integrated conceptual models and key data gaps that would need to be addressed to further develop the proposed models is also provided. The section ends with a discussion on the estimates of mass for key risk drivers remaining in the vadose zone below each subregion in relationship to the present groundwater plumes and what the future groundwater risks might be should the residual masses reach the groundwater.

\subsection{BY and B-57 Cribs}

Based on the review of available data, both the new information developed from the past 3 years on the 200-BP-5 Operable Unit RI/FS project and historical data, the following conceptual models for the distribution of technetium-99, uranium, cyanide, and nitrate below the BY Cribs are developed. As discussed in Section 3.1.4, the B-57 and B-61 cribs did not have large enough volumes of waste fluids disposed to impact the deep vadose zone or groundwater and thus are not considered in the BY Cribs conceptual model. Depth-discrete concentrations in the vadose zone sediment below BY Cribs (found in Table 3.2 and Table 3.3) suggest that there is a considerable mass of these mobile contaminants (and others) in the deep vadose zone. Most noteworthy, at the B-49 crib, elevated technetium-99 concentrations are located from $70 \mathrm{ft}$ bgs to close to the water table at $\sim 236 \mathrm{ft}$ bgs, and below B-43 crib, elevated technetium- 99 concentrations are found from $150 \mathrm{ft}$ bgs to the water table.

The geologic stratigraphy model for the BY Cribs local region shows that the fine textured $\mathrm{CCU}_{\mathrm{z}}$ silt layer is either absent or very thin below much of the BY Cribs area (see cross sections of the four boreholes for which sediment characterization data exist in Figure 3.17 through Figure 3.20). Thus, there is a potential for relatively rapid descent to groundwater for residual waste fluids that remain in the sediment profile. Available historical gross and spectral gamma logs of the subsurface surrounding the BY Cribs (example shown in Figure 3.3) and the soil electrical resistivity survey (shown in Figure 3.4 through Figure 3.6) both suggest that there was widespread lateral migration as well as vertical descent of contaminants all the way to the water table. The volume of waste liquid disposed to the BY Cribs was also large ( $\sim 88$ million liters) in relation to the cross sectional area of the gravel-filled excavations for each of the eight cribs. In section 3.6, it was calculated that the volume of waste liquids would have filled the pore space below the footprint of the BY Cribs' excavations to a depth of $200 \mathrm{~m}(660 \mathrm{ft})$, which is much larger than the $\sim 71.6 \mathrm{~m}(235 \mathrm{ft})$ distance to groundwater. Given the field indications of significant lateral spreading, much of the waste fluids must have remained within the vadose zone after active disposal ceased. This residual fluid has been descending towards the water table and appears to have supplied mobile contaminants such as nitrate, cyanide and technetium-99 to the water table sporadically between 1988 and 1996 and in a continual fashion since 1997, (see Figure 5.3 through Figure 5.7).

Groundwater trends for nitrate and technetium-99 in monitoring wells (such as 299-E33-7) below the BY Cribs are quite similar suggesting a common source (see Figure 6.1). 
PNNL-19277

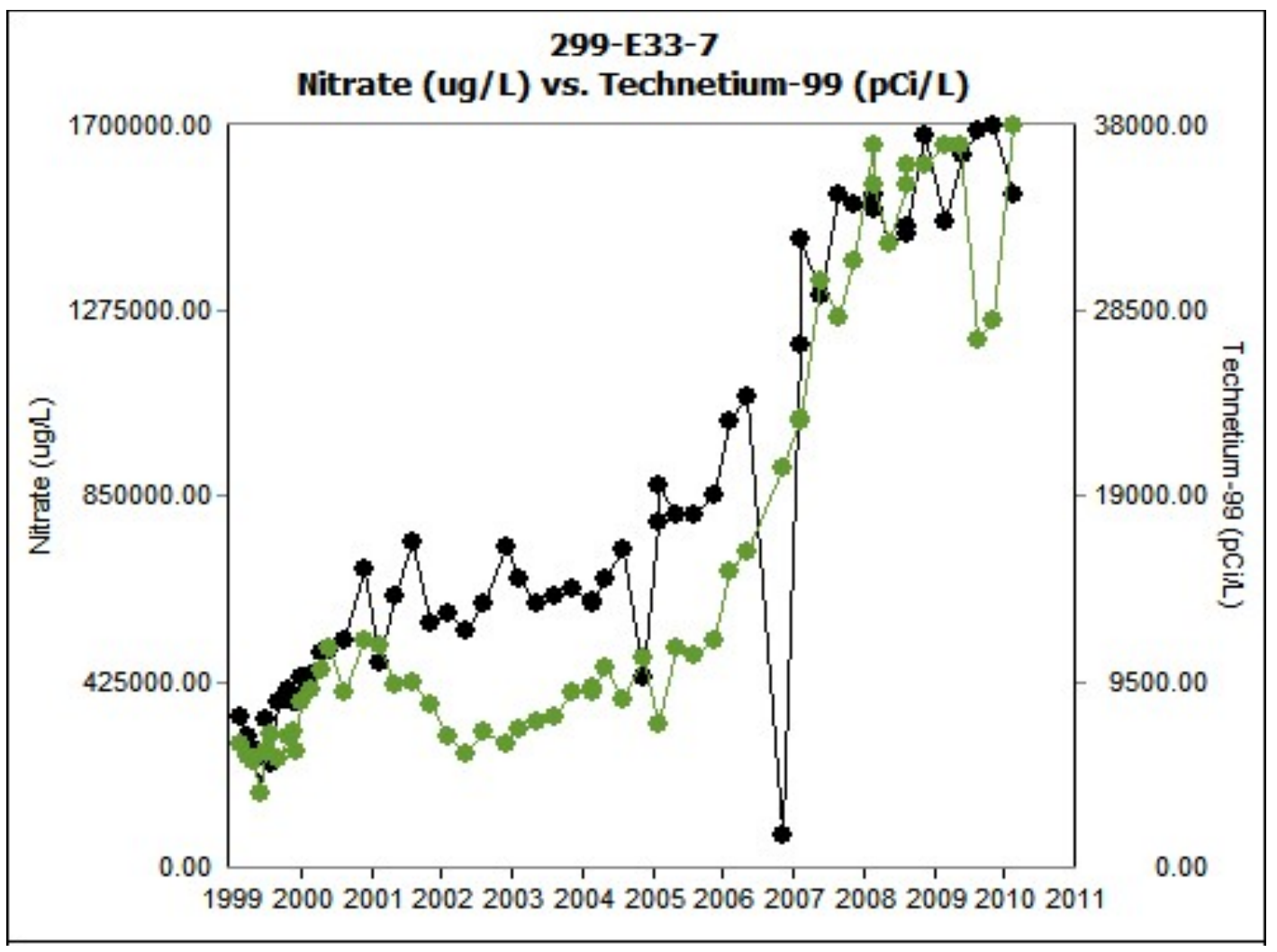

Figure 6.1. Groundwater Nitrate (black symbols) and Technetium-99 (green symbols) at E33-7 Over the Last 10 Years

The most compelling point is that the BY Cribs received $89 \%$ of the total mass of technetium-99 disposed of in the entire B-Complex (see Table 3.25). Further, the time series groundwater plume maps shown in Figure 5.9 through Figure 5.21 clearly show that the BY Cribs are the major source of the technetium-99 entering the water table below the B-Complex over the last two decades. It is acknowledged that other facilities or locations may have contributed additional technetium-99 mass to the groundwater at localized "hot spots" in the past. Other facilities with deep vadose zone technetium-99 may also be contributing some technetium-99 currently (see Figure 3.41 and Figure 3.55) and could contribute to the groundwater mass in the future. However, these other sources are likely small in comparison to the BY Cribs source. As there are no direct measurements of the vertical and horizontal extent of contaminants in the vadose zone sediments at facilities such as the B-8 Crib and Tile Field, the B-11-A\&B French Drains, and the BY Tank Farm these "poorly" characterized facilities cannot be fully dismissed from the list of sources. It is clear that the former two facilities had adequate volumes of waste disposed to have readily reached groundwater if lateral spreading was not significant. In addition, other indirect techniques to ascertain the extent of technetium-99 vadose zone contamination are very qualitative (field electrical resistivity surveys for high conductivity plumes and using cobalt-60 gamma logs as a surrogate for technetium-99 spread). Still, as shown in Table 3.25, these "poorly" characterized facilities had low masses of technetium-99 disposed of within them, so it is proposed that they can be dismissed as significant contributors to the current technetium-99 groundwater plume.

In summary, facts that support the hypothesis that the BY Cribs are the current major source of technetium-99, nitrate, and cyanide include the observed high concentrations of technetium-99 in the 
borehole sediments below the footprints of cribs B-43 and B-49 ( $200 \mathrm{pCi} / \mathrm{g}$ and $160 \mathrm{pCi} / \mathrm{g}$, respectively) as well as in borehole 299-E33-341 (180 pCi/g) to the west, the large mass of technetium-99 and large volume of fluids disposed to the BY Cribs, and the field gamma and soil electrical resistivity surveys indicating that there was significant spreading and deep penetration of wastes. As mentioned, at the B-49 crib, the elevated technetium-99 concentrations are located from $70 \mathrm{ft}$ bgs to close to the water table at $\sim 236 \mathrm{ft}$ bgs, and for B-43, the elevated technetium-99 concentrations are found from $150 \mathrm{ft}$ bgs to the water table.

Table 6.1 provides a comparison of the estimates of residual masses of technetium-99 in the entire vadose zone and the deep vadose zone (within $\sim 90 \mathrm{ft}$ of the water table) with the estimates for technetium-99 currently in the groundwater plume and the total amount of technetium-99 disposed of to the BY Cribs subregion. The details on the vadose zone conceptual model used to estimate masses of residual technetium-99 were presented in Section 3.1.9, and the groundwater mass estimates for technetium-99 are found in Section 5.3. Appendix I contains the spreadsheets with equations and logic used to create the values found in Sections 3 and 6. The estimates suggest that between 30 and 53 curies of technetium-99 still reside in the vadose sediments below the BY Cribs, and of this mass, between 3 and 20 curies are in the deep vadose zone. These estimates are large in comparison to the estimated range of technetium-99 in the current groundwater plume (6.1 curies). The various summed estimates for the mass of technetium-99 that are found in the BY Cribs subregion today represent from 28 to $46 \%$ of the total technetium-99 disposed of. The percentage of technetium-99 that resides deep in the vadose zone or is already in the current groundwater plume ranges from $\sim 7$ to $20 \%$ of the total mass disposed of to the BY Cribs. The estimated mass of technetium- 99 residing in the deep vadose zone is from 0.5 to 3.3 times the mass in the current groundwater plume. Thus, removal of technetium-99 from the existing groundwater plume may only be a temporary fix should the deep vadose zone sediments continue to dispense the residual technetium-99 to the water table.

It is also hypothesized that the cyanide currently observed in the groundwater (Figure 5.22 through Figure 5.28) originates from the waste disposed of to the BY Cribs. Facts that support this hypothesis include the SIM model estimates that suggest that no other facility in the B-Complex received cyanide waste to any significant extent, all the cited cyanide time series groundwater plume maps show the influx coming from below the BY Cribs subregion, and the only vadose zone sediment samples that contained detectable cyanide were from the two boreholes emplaced within the BY Cribs' footprints (299-E33-296 and -E33-302) and the nearby new borehole 299-E33-341. The cyanide distribution in the vadose zone sediments is not well characterized because the analytical technique used to process the sediments is not very sensitive such that few samples yielded values above the detection limit. Those sediments that did (see Table 3.2 and Table 3.3) contain detectable cyanide were associated with finer grained sediments found throughout the profile, or were near the crib bottom or were deep in the sediments, suggesting that most of the disposed cyanide has migrated throughout the vadose zone below the BY Cribs. However, the residual mass of cyanide for the vadose zone cannot be estimated from the sparse data. The mass of cyanide currently in the groundwater plume below the B-Complex is $38.5 \mathrm{~kg}$ as cyanide. Out to the north and through the Gable Gap groundwater cyanide data are sparse but in several wells that also delineate the extent of the technetium-99 plume suggest there may be an equivalent mass of cyanide. Assuming that the entire cyanide groundwater plume is $\sim 80 \mathrm{~kg}$, this represents only $1 \%$ of the total $\mathrm{Fe}(\mathrm{CN})_{6}$ that Table 3.24 estimates was disposed of into the BY Cribs. This calculation suggests that either most of the cyanide has been flushed out of the system or that the vadose zone sediments still contain a large mass of 
Table 6.1. Mass Balance for Technetium- 99 in the BY Cribs Sub-Region

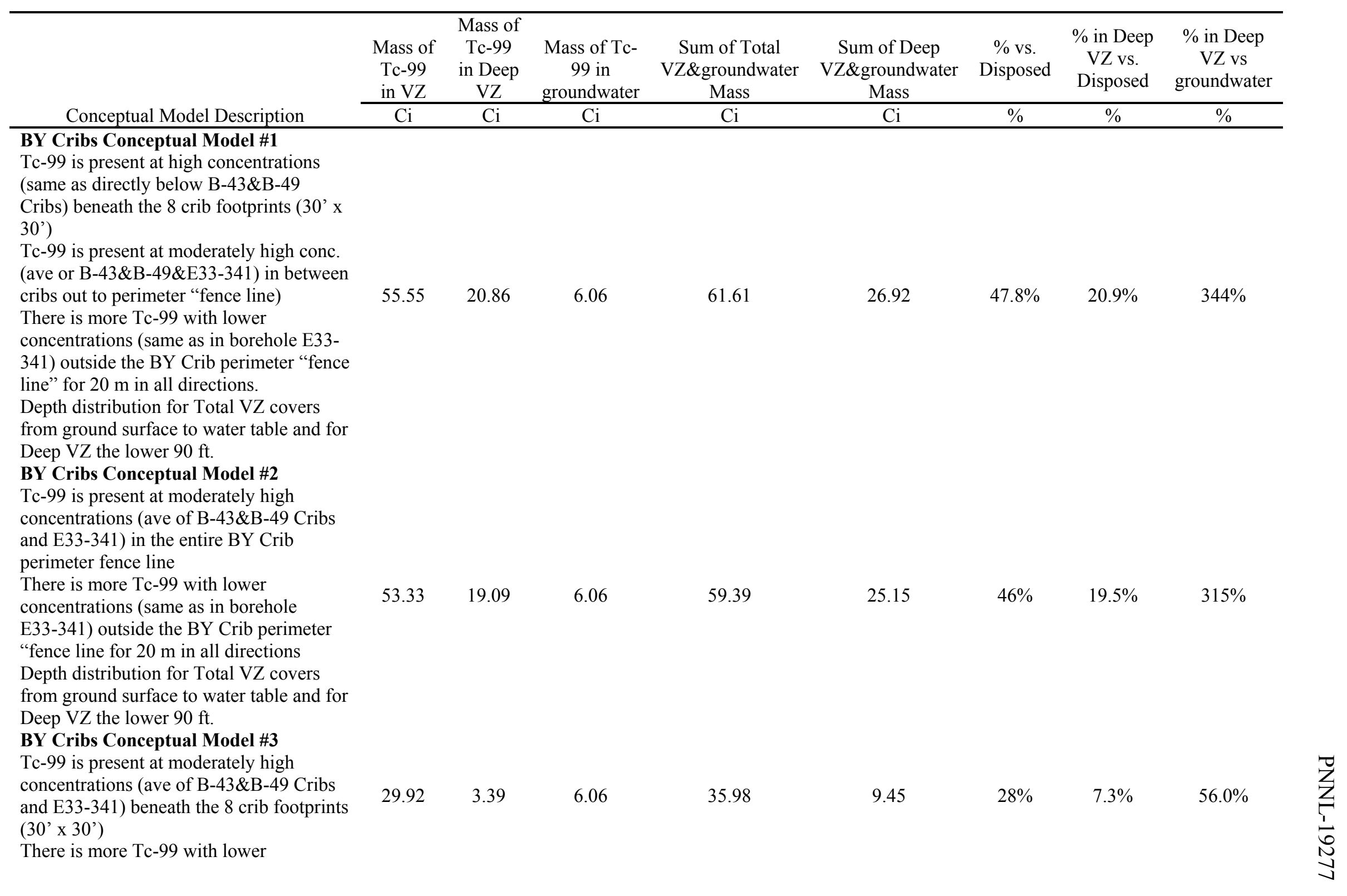


Table 6.1. Mass Balance for Technetium- 99 in the BY Cribs Sub-Region

\begin{tabular}{|c|c|c|c|c|c|c|c|c|}
\hline & $\begin{array}{l}\text { Mass of } \\
\text { Tc-99 } \\
\text { in VZ }\end{array}$ & $\begin{array}{c}\text { Mass of } \\
\text { Tc-99 } \\
\text { in Deep } \\
\text { VZ }\end{array}$ & $\begin{array}{l}\text { Mass of Tc- } \\
99 \text { in } \\
\text { groundwater }\end{array}$ & $\begin{array}{c}\text { Sum of Total } \\
\text { VZ\&groundwater } \\
\text { Mass }\end{array}$ & $\begin{array}{c}\text { Sum of Deep } \\
\text { VZ\&groundwater } \\
\text { Mass }\end{array}$ & $\begin{array}{c}\% \text { vs. } \\
\text { Disposed }\end{array}$ & $\begin{array}{c}\% \text { in Deep } \\
\text { VZ vs. } \\
\text { Disposed }\end{array}$ & $\begin{array}{l}\% \text { in Deep } \\
\text { VZ vs } \\
\text { groundwater }\end{array}$ \\
\hline Conceptual Model Description & $\mathrm{Ci}$ & $\mathrm{Ci}$ & $\mathrm{Ci}$ & $\mathrm{Ci}$ & $\mathrm{Ci}$ & $\%$ & $\%$ & $\%$ \\
\hline $\begin{array}{l}\text { concentrations (same as in borehole } \\
\text { E33-341) Between the cribs and outside } \\
\text { the BY Crib perimeter "fence line for } 20 \\
\mathrm{~m} \text { in all directions. } \\
\text { Depth distribution for Total VZ covers } \\
\text { from ground surface to water table and for } \\
\text { Deep VZ the lower } 90 \mathrm{ft} \text {. } \\
\text { BY Cribs Total Technetium-99 } \\
\text { Disposed: }\end{array}$ & 129 & $\mathbf{C i}$ & & & & & & \\
\hline
\end{tabular}

in 
cyanide that could continue to migrate down to the water table. As an aside, it also appears that the BY Cribs subregion has been a source of sodium to the groundwater plume below the B-Complex as evidenced by seasonal plume maps for groundwater sodium shown in Appendix $G$

It is not believed that the uranium present in the groundwater below the B-Complex comes from the disposal of wastes to the BY Cribs. This is based on the evolution of the time series groundwater plumes that show a clear flux of uranium into the water table near the 299-E33-343 borehole with later migration towards the northwest, traveling below the southeastern portion of the BY Cribs subregion. The uranium isotopic signature measurements and the distribution of elevated uranium concentrations in the vadose zone to the northeast of Tank BX-102 also suggests that BY Cribs is not the source of uranium in the groundwater in the last few decades. However, there are some Hanford staff who are not convinced that the BY Cribs is not a secondary source of uranium in the existing groundwater plume because $1063 \mathrm{~kg}$ of uranium was estimated to have been disposed of in the BY Cribs. Table 6.2 provides points on why it has been interpreted that uranium disposed of to the BY Cribs has reached the water table in amounts that would be measurable as a secondary source. The salient point from Table 6.2 is the fact that the three conceptual models for the mass distribution of total uranium in the vadose zone sediments below the BY Cribs can account for 87 to $110 \%$ of the total mass disposed of into the cribs; that is, all the uranium disposed into the BY Cribs is likely still present in the vadose zone below the cribs.

The second key point is that the fraction of the uranium in the BY Cribs' sediments that is mobile is much lower than the total uranium, which is another indication that the speciation of uranium disposed of to the BY Cribs promotes sequestration (see Table 3.2, Table 3.3, and Table 3.8 as well as Figure 3.19 and Figure 3.20). Table 6.2 estimates suggest that throughout the entire BY Cribs' vadose zone sediment profile, only 6 to $10 \mathrm{~kg}$ of uranium is present in a form that is readily mobilized. Further, only 0.2 to $0.5 \mathrm{~kg}$ of the mobile uranium is found in the lower $90 \mathrm{ft}$ of the BY Cribs profile (the deep vadose zone). This is an inconsequential amount compared to the $22.3 \mathrm{~kg}$ of uranium present in the groundwater today. It is therefore hypothesized that although the BY Cribs received the second largest inventory of uranium disposed of to the entire B-Complex region, it remains strongly sequestered in the shallow vadose zone sediments and has not in the past reached groundwater and should not be a significant contributor in the future under current conditions. The speciation of the uranium sequestered in the shallow BY Crib sediments has not been characterized to date, but is likely a relatively insoluble co-precipitate with other components in the waste stream and with secondary minerals formed when the liquid wastes interacted with the native Hanford formation sediments. Similar sequestering reactions between uranium in Hanford wastes and Hanford formation sediments have been identified (see Catalano et al. 2004; Ilton et al. 2008; Liu et al. 2004 and 2006; McKinley et al. 2006; Qafoku et al. 2005; Reeder et al. 2000, 2001; Wang et al. 2005; Zachara et al. 2007a,b; and Wan et al. 2009).

As mentioned in Section 3.1 although sediments below and proximal to the B-61 Crib, and BY-201 Settling Tank (included in BY Cribs sub-region) have not been characterized, there are no indications that liquids disposed of or released from these two facilities have impacted either the deep vadose zone or groundwater. Based on the inventory estimates for the B-57 Crib, shown in Table 3.1 and the fact that sediments under the -B-57 Crib footprint do not contain cyanide, contain only minor amounts of uranium, and only about $0.1 \%$ of the total technetium- 99 mass in the BY crib region, this facility has not contaminated groundwater and is unlikely to be a significant contributor to groundwater contamination in 
Table 6.2. Estimated Mass of Uranium Below BY Cribs and Comparison to Current Mass of Uranium in Groundwater and Mass Disposed to BY Cribs

\begin{tabular}{|c|c|c|c|c|c|c|c|c|}
\hline Conceptual Model Description & Total $\mathrm{U}$ in $\mathrm{VZ}$ & $\begin{array}{c}\text { Mobile U in } \\
\text { VZ } \\
\text { kg }\end{array}$ & $\begin{array}{l}\text { U in } \\
\text { groundwater } \\
\qquad \mathrm{kg}\end{array}$ & $\begin{array}{c}\text { Sum of Total } \\
\text { U Mass } \\
\text { kg }\end{array}$ & $\begin{array}{l}\text { Sum of } \\
\text { Mobile U } \\
\text { Mass } \\
\quad \text { kg }\end{array}$ & $\begin{array}{l}\% \text { total U } \\
\text { vs. } \\
\text { Disposed } \\
\%\end{array}$ & $\begin{array}{l}\text { \% mobile } \\
\text { U vs. } \\
\text { Disposed } \\
\%\end{array}$ & $\begin{array}{l}\text { \% in Deep } \\
\text { VZ vs. } \\
\text { groundwater } \\
\quad \%\end{array}$ \\
\hline $\begin{array}{l}\text { BY Cribs Conceptual Model \#1 } \\
\text { - U is present at high concentrations (same as } \\
\text { directly below B-43\&B-49 Cribs) beneath } \\
\text { the } 8 \text { crib footprints (30' x 30') } \\
\text { - U is present at moderately high conc. (ave or } \\
\text { B-43\&B-49\&E33-341) in between cribs out } \\
\text { to perimeter "fence line) } \\
\text { - There is more U with lower concentrations } \\
\text { (same as in borehole E33-341) outside the } \\
\text { BY Crib perimeter "fence line" for } 20 \mathrm{~m} \text { in } \\
\text { all directions. } \\
\text { Depth distribution covers from ground } \\
\text { surface to water table. }\end{array}$ & 1143 & 10.1 & 22.3 & 1165.3 & 32.4 & $110 \%$ & $3.0 \%$ & NA \\
\hline $\begin{array}{l}\text { BY Cribs Conceptual Model \#2 } \\
\text { - U is present at moderately high } \\
\text { concentrations (ave of B-43\&B-49 Cribs and } \\
\text { E33-341) in the entire BY Crib perimeter } \\
\text { fence line, } \\
\text { - There is more U with lower concentrations } \\
\text { (same as in borehole E33-341) outside the } \\
\text { BY Crib perimeter "fence line for } 20 \mathrm{~m} \text { in all } \\
\text { directions } \\
\text { Depth distribution covers from ground } \\
\text { surface to water table. }\end{array}$ & 1009 & 6.5 & 22.3 & 1031.3 & 28.8 & $97 \%$ & $2.7 \%$ & NA \\
\hline $\begin{array}{l}\text { BY Cribs Conceptual Model \#3 } \\
\text { - U is present at moderately high } \\
\text { concentrations (ave of B-43\&B-49 Cribs and } \\
\text { E33-341) beneath the } 8 \text { crib footprints (30’ } \mathrm{x} \\
30^{\prime} \text { ) } \\
\text { - There is more U with lower concentrations } \\
\text { (same as in borehole E33-341) Between the } \\
\text { cribs and outside the BY Crib perimeter }\end{array}$ & 901 & 5.7 & 22.3 & 923.3 & 28 & $87 \%$ & $2.6 \%$ & NA \\
\hline
\end{tabular}


Table 6.2. Estimated Mass of Uranium Below BY Cribs and Comparison to Current Mass of Uranium in Groundwater and Mass Disposed to BY Cribs

\begin{tabular}{|c|c|c|c|c|c|c|c|c|}
\hline & Total U in VZ & $\begin{array}{c}\text { Mobile U in } \\
\text { VZ }\end{array}$ & $\begin{array}{l}\mathrm{U} \text { in } \\
\text { groundwater }\end{array}$ & $\begin{array}{l}\text { Sum of Total } \\
\text { U Mass }\end{array}$ & $\begin{array}{l}\text { Sum of } \\
\text { Mobile U } \\
\text { Mass }\end{array}$ & $\begin{array}{l}\text { \% total U } \\
\text { vs. } \\
\text { Disposed }\end{array}$ & $\begin{array}{l}\text { \% mobile } \\
\text { U vs. } \\
\text { Disposed }\end{array}$ & $\begin{array}{l}\text { \% in Deep } \\
\text { VZ vs. } \\
\text { groundwater }\end{array}$ \\
\hline Conceptual Model Description & $\mathrm{kg}$ & $\mathrm{kg}$ & $\mathrm{kg}$ & $\mathrm{kg}$ & $\mathrm{kg}$ & $\%$ & $\%$ & $\%$ \\
\hline
\end{tabular}

"fence line for $20 \mathrm{~m}$ in all directions.

Depth distribution covers from ground surface to

water table.

BY Cribs Conceptual Model \#1 U Deep Vadose

Zone only.

- Depth distribution covers deepest $90 \mathrm{ft}$ down

203

0.48

22.3

225.3

22.78

$21 \%$

$2.1 \%$

$2 \%$

BY Cribs Conceptual Model \#2 U Deep Vadose

Zone only.

- Depth distribution covers deepest $90 \mathrm{ft}$ down

202

0.23

22.3

224.3

22.53

$21 \% \quad 2.1 \%$

$1 \%$ to water table.

\section{BY Cribs Conceptual Model \#3 U Deep Vadose} Zone only.

- Depth distribution covers deepest $90 \mathrm{ft}$ down

0.23

22.3

221.3

22.53

$21 \%$

$2.1 \%$

$1 \%$ to water table.

BY Cribs Total U Disposed:

$1063 \mathrm{~kg}$

$\mathrm{NA}=$ not applicable 
the future because it has a surface barrier in place, and mobile contaminants do not appear to have descended more than $\sim 60 \mathrm{ft}$ below the ground surface.

\subsection{BX Trench Sub-region}

As discussed in Section 3.2, there are no indications that wastes disposed of to the BX Trenches have been a significant source of mobile contaminants to the groundwater below the B-Complex, especially over the last two decades. There has been only one detailed vadose zone sediment characterization study, borehole $\mathrm{C} 3104$ through the footprint of trench B-36, in the region. The concentrations of mobile contaminants and their vertical distribution (see Table 3.10) are very low and shallow, respectively. Historical gross gamma logs question whether trench B-37 might have had adequate volumes of fluids released to have reached the groundwater soon after active disposal ceased. A field investigation and historical groundwater data are not conclusive, and it is as likely that the historical data showing the occurrence of elevated gamma deep in nearby boreholes and some contamination in the groundwater originated from the BY Cribs subregion. The BX Trenches were used in the specific retention mode where the volume of fluids disposed of was limited to prevent breakthrough to the water table. Therefore, it is proposed that residual waste below the BX Trenches is of such low mass and at shallow depth as to not be a current or future threat to groundwater under current conditions compared to other facilities in the B-Complex.

\subsection{B-7-A\&B/B-8 Cribs Subregion (includes B-8 Tile Field, B-11-A\&B and B-51 French Drains}

The combined conceptual model for the vadose zone and groundwater below this sub-region is not well developed because of a lack of good coverage on vadose zone sediment distributions of contaminants below the individual disposal facilities footprints. Therefore it is uncertain how some of the vadose zone contaminants found in new boreholes 299-E33-344 and E33-345 reached their locations. Further, the concentrations of some of the contaminants in the depth-discrete samples from these two boreholes show widely varying concentrations within the $\mathrm{CCU}_{\mathrm{z}}$ silt unit. Thus both challenges (lack of boreholes through footprints and highly variable concentrations as a function of depth in the $\mathrm{CCU}_{\mathrm{z}}$ unit) hinder development of defensible conceptual models and residual mass estimates for this subregion. Regardless the following discussion is offered.

The volume of liquid disposed of to the B-7-A\&B Cribs, B-8 Crib and Tile Field, and B-11-A\&B French Drains was large enough, in comparison to their respective footprints, to have reached groundwater. Thus, it is quite likely that waste fluids did break through to groundwater at these facilities unless there was significant lateral spreading in the vadose zone profile such that waste fluids did not totally saturate the $\mathrm{CCU}_{Z}$ unit and allow gravity drainage to the water table.

The $\mathrm{CCU}_{z}$ unit is present in parts of this sub-region with thicknesses as large as 26 to $27 \mathrm{ft}$ (299-33345 and E33-16), but thins quickly to the north (is not present at E33-15) and to the east is $5 \mathrm{ft}$ thick at E33-17. At the well closest to B-11-A, 299-E33-20, the thickness of the $\mathrm{CCU}_{z}$ unit is uncertain. The B-7 and B-8 Cribs and the B-11-B French Drain are situated above the rather thick portion of the $\mathrm{CCU}_{\mathrm{z}}$ unit, but some of the B-8 tile field has no $\mathrm{CCU}_{z}$ silt below. Unfortunately, the data for well E33-20 is not of adequate quality to defensibly choose a thickness below B-11-A. With no other additional boreholes or 
wells in the region to better define the $\mathrm{CCU}_{\mathrm{z}}$ unit's thickness and exact locations where it pinches out, the horizontal spreading tendencies over this sub-region cannot be accurately assessed. The historical gamma logging analyses are also not definitive for this region but appear to show gaps between the plumes of waste between these three facilities, suggesting no commingling of plumes within the vadose zone (see discussion in Section 3.3.2, 3.3.5 and 3.3.9 and Figure 3.30). In addition, the spectral gamma logging contractor concluded that there was not sufficient evidence to state that wastes from the B-7-A\&B/ B-8 Cribs subregion had reached groundwater. On the other hand, the soil resistivity field survey does indicate commingling of the vadose zone plumes and suggests that waste liquids have reached the groundwater (see Figure 3.31 through Figure 3.33). The soil resistivity survey report (Rucker et al. 2007) did remark that the B-8 Tile Field seemed to be the location where more waste had penetrated deeper into the profile.

The only direct sediment sampling for this subregion was borehole C3103 through the B-7-A Crib footprint, however, drilling was stopped right at the top of the $\mathrm{CCU}_{\mathrm{z}}$ unit when high moisture was observed. The vertical profiles of select contaminants from this borehole are presented in Table 3.12 and Figure 3.35 through Figure 3.42. The interpretation of the contaminant profiles, based solely on C3103 results, were that mobile contaminants could be traced from the crib bottoms to midway through the Hanford formation sediments at elevated concentrations, but the deeper Hanford formation sediments did not show any noteworthy elevated concentrations. However, at $218 \mathrm{ft} \mathrm{bgs}$, at the top of the $\mathrm{CCU}_{\mathrm{z}}$ where drilling stopped, the concentrations of mobile contaminants were again elevated. It is clear that wastes from B-7-A\&B Cribs and perhaps B-8 Crib and Tile Field did migrate down to the $\mathrm{CCU}_{\mathrm{z}}$ unit and apparently found a pathway to the water table. Data from the two new boreholes (E33-344, E33-345) 75 $\mathrm{ft}$ to the southwest of $\mathrm{C} 3103$, had elevated fluoride and chromium contamination in the $\mathrm{CCU}_{\mathrm{z}}$ unit. This led to the conclusion that wastes from the B-7-A\&B and perhaps B-8 Crib facilities migrated along the top or within the $\mathrm{CCU}_{z}$ unit to the location of the new boreholes. Finding highly elevated fluoride and moderately elevated water extractable chromium in the pore waters from the $\mathrm{CCU}_{\mathrm{z}}$ unit at the two new boreholes points to the B-7 and B- 8 facilities as the source because these two facilities received the highest masses of these two species in the entire B-Complex. There were some inconsistencies in the composition of the pore waters from the two new boreholes, however, in that they showed much higher uranium and technetium-99 concentrations than would appear to be sourced from fluids from the B-7-A Crib. There was very low technetium- 99 found in the $\mathrm{C} 3103$ sediment profile, and elevated total and measureable water-extractable uranium was only found in the very shallow sediments and not down at the $\mathrm{CCU}_{\mathrm{z}}$ unit. When the precise uranium isotopic measurements of the $\mathrm{CCU}_{\mathrm{z}}$ sediments from the two new boreholes showed the same signature as BX-102 waste, it was realized that wastes from two subregions likely are present at the location of the two new boreholes. However, the groundwater data for the new well E33-345 and the nearby old well 299-E33-18 do not conclusively show that waste water with high fluoride or chromium is entering the water table close by. One could speculate that wastes in the $\mathrm{CCU}_{\mathrm{z}}$ unit right at boreholes E33-18, E33-344, and E33-345 (all within $\sim 10 \mathrm{ft}$ of each other) are not breaking through to the water table at this locale.

The spring and fall seasonal groundwater plume maps for chromium (shown in Figure 5.29 through Figure 5.34 and others shown in Appendix G) and seasonal plume maps for sodium (Appendix G) show that the source of chromium and one of the sources of sodium over the last decade appears to be the B- 8 Crib. Thus, there is not a clear understanding of exactly where the waste fluids with a definite B-7-A\&B/B-8 Cribs source signature (elevated chromium and fluoride) have migrated down through the Hanford formation sediments into and through the $\mathrm{CCU}_{\mathrm{z}}$ unit and reached the groundwater. The well 
coverage and vadose zone characterization of wastes below these facility's footprints are too sparse to determine the fate of the wastes disposed of. The stratigraphy below this region is also not adequately resolved because of the sparse borehole coverage down at the depths of the Cold Creek Units.

An estimate for the masses of technetium-99 and uranium remaining in the vadose zone between borehole C3103 and the two new boreholes (E33-344 and E33-345) was made and compared to the estimates with the current masses in their respective groundwater plumes. Even though it is not believed that the B-7-A\&B Cribs and B-8 Crib and Tile Field are sources for these two contaminants, they are the source for the chromium. However, adequate vadose zone sediment-water extract data are not available to estimate how much mobile chromium remains above the water table, and a mass estimate for chromium in the groundwater plume was not made. Due to this lack of data, a mass balance calculation cannot be performed to estimate how much of the chromium mass disposed of in this subregion has been located. Alternative data collection using strong acid extracts do not give a reasonable estimate of Hanford waste chromium because there is a significant amount of native chromium in sediments that also dissolves and masks the portion that might be derived from Hanford waste. The results of the mass estimates between borehole $\mathrm{C} 3103$ and the two new boreholes for technetium- 99 and uranium are found in Table 6.3 and Table 6.4., respectively. As mentioned, there is insufficient vadose zone data to include residual masses for contaminants below the B-8 Crib and Tile Field and B-11-A\&B French Drain facilities in the conceptual model.

The mass estimates for technetium-99 for three conceptual models for the vadose zone below the B-7-A Crib are compared to the mass of technetium-99 found in the groundwater plume attributed to disposals below the B-Complex and with the total mass of technetium-99 disposed of to the B-7-A\&B Crib, B-8 Crib and Tile Field, and B-11-A\&B French Drains (see Section 3.3.10 for detailed discussion). Model 1 assumes that the waste fluids percolated directly below the individual B-7-A\&B Crib footprints all the way to the water table. Model 2 assumes vertical percolation down a footprint formed by drawing a rectangular box around both cribs, essentially including the area of the cribs' perimeters and the area below the piping connecting the two cribs all the way to the water table. Model 3 assumes that the waste fluids filled the same area below the cribs as Model 2 in the Hanford formation as well as migrating horizontally in all four directions through the $\mathrm{CCU}_{z}$ unit another $20 \mathrm{~m}$. Conceptual Model 3 allows the waste to reach locations within the Cold Creek units at boreholes E33-344 and E33-345 as found, based on the fluoride and chromium occurrences. The conceptual vertical distribution of contaminants uses the data from C3103 down through the Hanford formation sediments and then the data from boreholes 299E33-344 and -E33-345 for the Cold Creek Units.

The technetium-99 mass balance (Table 6.3 ) shows that there is very small masses $(<0.3 \mathrm{Ci})$ of technetium-99 in the vadose zone profile below the crib's summed footprints (Model 1) and the crib's collective perimeter footprint (Model 2). However, these small masses exceed the total mass of technetium-99 disposed of to the B-7A\&B Cribs. Conceptual model 3 that allows disposed waste to spread laterally in the Cold Creek Units, the estimated technetium-99 mass reaches 1.6 Ci. Essentially, all the mass of technetium-99 resides in the $\mathrm{CCU}_{z}$ unit based on elevated concentrations found in boreholes 299-E33-344 and -E33-345. Again it needs to be stated that the 1.6 Ci estimate far exceeds the total mass of technetium-99 disposed to the B-7-A\&B Cribs. As discussed earlier in this section technetium-99 is likely not from the facilities in this subregion. There is not much difference between the residual technetium-99 mass estimates for the entire vadose zone and the deepest $90 \mathrm{ft}$ because there is insignificant mass found in the shallow Hanford formation sediments. The residual mass below the crib's 
Table 6.3. Mass Balance Estimates for Tc-99 Below B-7-A\&B Cribs in Comparison to Current Groundwater Plume and Mass Disposed to B-7-A\&B/B-8 Cribs Subregion

\begin{tabular}{|c|c|c|c|c|c|c|c|}
\hline $\begin{array}{r}\text { Concept } \\
\text { Mode }\end{array}$ & $\begin{array}{l}\text { Unal } \\
\text { Units }\end{array}$ & $\begin{array}{c}\text { Tc Mass } \\
\text { in } \mathrm{VZ} \\
\mathrm{Ci} \\
\end{array}$ & $\begin{array}{c}\text { Tc Mass in } \\
\text { groundwater } \\
\mathrm{Ci}\end{array}$ & $\begin{array}{c}\text { Sum Tc } \\
\text { Mass } \\
\text { Ci }\end{array}$ & $\begin{array}{c}\text { Sum } \\
\text { VZ\&groundwater } \\
\text { vs. Disposed } \\
\% \\
\end{array}$ & $\begin{array}{c}\text { VZ vs. } \\
\text { Disposed } \\
\% \\
\end{array}$ & $\begin{array}{c}\mathrm{VZ} \text { vs } \\
\text { groundwater } \\
\% \\
\end{array}$ \\
\hline $\begin{array}{l}1 \text { (vertical } \\
\text { down crib } \\
\text { footprint }\end{array}$ & $\begin{array}{l}\text { All } \\
\text { VZ }\end{array}$ & $1.54 \mathrm{E}-02$ & 6.06 & $6.08 \mathrm{E}+00$ & $3375 \%$ & $8.54 \%$ & $0.3 \%$ \\
\hline $\begin{array}{l}2 \text { (vertical } \\
\text { down crib } \\
\text { perimeter) }\end{array}$ & $\begin{array}{l}\text { All } \\
\text { VZ }\end{array}$ & $2.19 \mathrm{E}-01$ & 6.06 & $6.28 \mathrm{E}+00$ & $3488 \%$ & $121.39 \%$ & $3.6 \%$ \\
\hline $\begin{array}{l}3 \text { (vertical } \\
\text { through } \\
\text { crib } \\
\text { perimeter } \\
\text { plus } \\
\text { horizontal } \\
\text { in } \mathrm{CCU}_{\mathrm{z}} \\
\text { to E33- } \\
345\end{array}$ & $\begin{array}{l}\text { All } \\
\text { VZ }\end{array}$ & $1.64 \mathrm{E}+00$ & 6.06 & $7.70 \mathrm{E}+00$ & $4279 \%$ & $912.03 \%$ & $27.1 \%$ \\
\hline $\begin{array}{l}1 \text { (vertical } \\
\text { down crib } \\
\text { footprint }\end{array}$ & $\begin{array}{c}\text { Deep } \\
\text { VZ }\end{array}$ & $1.26 \mathrm{E}-02$ & 6.06 & $6.07 \mathrm{E}+00$ & $3374 \%$ & $7.00 \%$ & $0.2 \%$ \\
\hline $\begin{array}{l}2 \text { (vertical } \\
\text { down crib } \\
\text { perimeter) }\end{array}$ & $\begin{array}{c}\text { Deep } \\
\text { VZ }\end{array}$ & $1.79 \mathrm{E}-01$ & 6.06 & $6.24 \mathrm{E}+00$ & $3466 \%$ & $99.55 \%$ & $3.0 \%$ \\
\hline $\begin{array}{l}3 \text { (vertical } \\
\text { through } \\
\text { crib } \\
\text { perimeter } \\
\text { plus } \\
\text { horizontal } \\
\text { in } \mathrm{CCU}_{z} \\
\text { to E33- } \\
345\end{array}$ & $\begin{array}{c}\text { Deep } \\
\text { VZ }\end{array}$ & $1.60 \mathrm{E}+00$ & 6.06 & $7.66 \mathrm{E}+00$ & $4257 \%$ & $890.19 \%$ & $26.4 \%$ \\
\hline $\begin{array}{l}\text { Total Tc-99 } \\
\text { Cribs Sub-re }\end{array}$ & $\begin{array}{l}\text { dispos } \\
\text { egion }\end{array}$ & of to the $\mathrm{F}$ & $\mathrm{A} \& \mathrm{~B} / \mathrm{B}-8$ & & 0.18 & $\mathrm{Ci}$ & \\
\hline
\end{tabular}

literal and perimeter footprints is small compared to the $6.06 \mathrm{Ci}$ of technetium- 99 already in the groundwater below the B-Complex and extending out beyond Gable Gap. The sum of estimated residual technetium-99 in the vadose zone for all three B-7-A\&B Cribs conceptual models and groundwater far exceeds the mass of technetium-99 disposed of to the sub-region. This supports the hypothesis that the bulk of technetium-99 observed in the $\mathrm{CCU}_{z}$ unit at the new boreholes 299-E33-344 and -E33-345 did not originate from the B-7-A\&B Cribs. Summing the mass of residual technetium-99 with the estimate of technetium-99 in the groundwater in 2009 is not realistic because it is known that the technetium-99 in the groundwater is dominated by BY Crib-sourced waste. Even if one considers only the groundwater technetium found directly below the B-Complex in 2009 (0.76 Ci; see Table 5.2), the mass balance of technetium-99 remaining below the B-7-A\&B Cribs in the vadose zone sediments and groundwater below the B-Complex far exceeds the estimated mass disposed of in the B-7-A\&B Cribs. Based on the SIM inventory estimates, B-8 Crib and Tile Field and B-11-A\&B French Drains also are not likely sources of 
deep vadose zone or groundwater technetium-99 because they also received insignificant amounts of technetium-99. Rather, the source of the technetium-99 in the $\mathrm{CCU}_{\mathrm{z}}$ unit throughout its occurrence below the B-Complex likely is a combination of mostly BY Cribs, with minor masses from BX-102, and perhaps similarly small contributions from other unidentified sources (such as the 200-series B Tanks or the BY Tank Farm).

Table 6.4. shows that it could be conceivable that the $388 \mathrm{~kg}$ of uranium disposed of in the B-7-A\&B/B-8 Cribs subregion could still be sequestered in the vadose zone below the B-7-A\&B Cribs literal or perimeter footprints, but when the hypothesized mass of uranium in the Cold Creek Units is

Table 6.4. Mass Balance Estimates for Uranium Below B-7-A\&B Cribs in Comparison to Current Groundwater Plume and Mass Disposed to B-7-A Sub-Region

\begin{tabular}{|c|c|c|c|c|c|c|}
\hline Conceptual Model & & U Mass in VZ & $\begin{array}{l}\text { U Mass in } \\
\text { groundwater }\end{array}$ & Sum U Mass & $\begin{array}{c}\text { Sum } \\
\text { VZ\&groundwater } \\
\text { vs. Disposed }\end{array}$ & $\begin{array}{c}\text { VZ vs. } \\
\text { Disposed }\end{array}$ \\
\hline \multirow[b]{2}{*}{$\begin{array}{l}1 \text { (vertical down crib } \\
\text { footprint }\end{array}$} & Units & $\mathrm{kg}$ & $\mathrm{kg}$ & $\mathrm{kg}$ & $\%$ & $\%$ \\
\hline & All VZ & 41 & 22.3 & 63.3 & $16 \%$ & $10.6 \%$ \\
\hline $\begin{array}{l}2 \text { (vertical down crib } \\
\text { perimeter) }\end{array}$ & All VZ & 580 & 22.3 & 605.3 & $156 \%$ & $150.3 \%$ \\
\hline $\begin{array}{l}3 \text { (vertical through crib } \\
\text { perimeter plus } \\
\text { horizontal in } \mathrm{CCU}_{\mathrm{z}} \text { to } \\
\mathrm{E} 33-345\end{array}$ & All VZ & 1000 & 22.3 & 1032.3 & $266 \%$ & $260.3 \%$ \\
\hline $\begin{array}{l}1 \text { (vertical down crib } \\
\text { footprint }\end{array}$ & Deep VZ & 4 & 22.3 & 26.5 & $7 \%$ & $1.1 \%$ \\
\hline $\begin{array}{c}2 \text { (vertical down crib } \\
\text { perimeter) }\end{array}$ & Deep VZ & 60 & 22.3 & 82.1 & $21 \%$ & $15.4 \%$ \\
\hline $\begin{array}{l}3 \text { (vertical through crib } \\
\text { perimeter plus } \\
\text { horizontal in } \mathrm{CCU}_{\mathrm{z}} \text { to } \\
\text { E33-345 }\end{array}$ & Deep VZ & 485 & 22.3 & 507.3 & $131 \%$ & $125.0 \%$ \\
\hline Total U disposed to B-7 & $3-8, \mathrm{~B}-11 \mathrm{~S}$ & bregion & & & 388 & \\
\hline
\end{tabular}

included, the residual mass of uranium in the vadose zone exceeds the total disposed of in the entire subregion. In all but one of the conceptual models created for the B-7-A\&B Cribs, the residual uranium mass in the vadose zone is larger than the current estimate of uranium in the groundwater plume below the B-Complex suggesting that most of the uranium disposed of to this crib remains sequestered and rather immobile. It is believed that this uranium mass balance exercise further supports the contention that uranium present in the groundwater today and within the $\mathrm{CCU}_{z}$ unit, does not include any significant amount of uranium disposed of to the B-7-A\&B Cribs, and by analogy the B-8 Crib and Tile Field, or B11-A\&B French Drains. Further, a close inspection of Table 3.14 indicates that even less of the total uranium present below the B-7-A Crib footprint is water extractable, so the probability of uranium disposed of to the B-7-A\&B Cribs reaching the $\mathrm{CCU}_{z}$ unit and spreading laterally to boreholes 299-E33344 and -E33-345 seems remote. One difficult-to-explain observation regarding uranium in the B-7 A\&B/B-8 Cribs subregion is the apparent slight enrichment in uranium-235 found in the groundwater sample taken right at the end of drilling well 299-E33-345. Based on the disposal history tabulated in the SIM model, there was some dilute PUREX waste disposed of to the B-7-A\&B Cribs between 1966 and May 1967; however, no waste streams that should have contained enriched uranium were disposed of into the B-8 Crib and Tile Field. It was asserted above that it is not believed that significant amounts of 
uranium from the B-7-A\&B Crib facility has reached groundwater, so this observation of an enriched uranium-235 signature in the groundwater sample from 299-E33-345 conflicts with this hypothesis. Possible explanations are that the isotope signature measurements are remarkably sensitive such that a very small mass of uranium from the B-7-A\&B Cribs did reach the groundwater without being detected by the total uranium analyses in vadose zone pore waters. Second, it is possible that the groundwater sample was contaminated either in the field or in the PNNL laboratory during the process of aliquoting a small volume to send to Lawrence Berkeley National Laboratory, where the measurements are performed. The PNNL laboratory does not have clean-room provisions that would make it possible to treat samples with great care to avoid inadvertent minor contamination. Hundreds of sediment and groundwater samples have been processed ranging from highly contaminated as well as uncontaminated regions of the Hanford Site so that a minute amount of uranium-236 from a highly contaminated sample could have conceivably been introduced to the E33-345 groundwater.

As discussed at the beginning of this subsection, the integrated conceptual model for the vadose zone and groundwater below the B-7-A\&B/B-8 Cribs subregion is more tenuous than for other subregions. However, the consensus "best" model indicates that the majority of the uranium in the pore fluids in the sediments within the $\mathrm{CCU}_{\mathrm{z}}$ unit at 299-E33-344 and -E33-345 comes from the BX-102 overfill event. This is based on the field spectral gamma logging, the uranium isotopic signature measurements, and the direct measurement of total and water-extractable uranium from vadose zone sediments from available boreholes in this sub-region. Because the technetium-99 inventory from the three facilities in this subregion are very small and no continuous migratory pathway from the B-7A Crib bottom to the deep vadose zone is observed, the high concentrations of technetium-99 found in the 299-E33-344 and -E33345 sediments in the $\mathrm{CCU}_{z}$ unit and the mass estimate results shown in Table 6.3 support the presence of additional technetium-99 from other sources. The only sediment samples from C3103, within the B-7A Crib footprint with detectable technetium-99 were those very shallow in the sediment profile.

Based on the available technetium-99 sediment distribution versus depth, the low SIM inventory estimate and the uranium isotopic signature results, the additional source for the technetium- 99 is likely the BX-102 overfill event despite some previous concerns about the observed technetium-99 vadose zone pore water concentrations not monotonically decreasing from the values at 299-E33-45 to 299-E33-343 and east to 299-E33-344 and E33-345. Other plausible sources of the "excess" technetium-99 in the CCU sediments near E33-344 and E33-345, are unstudied leaks from the B-Tank Farm 200 series tanks or the BY Tank Farm or least probable from the BY Cribs. However, waste fluids and some mobile contaminants from this sub-region have definitely reached the $\mathrm{CCU}_{\mathrm{z}}$ unit based on elevated fluoride and chromium measurements. The B-7-A\&B/B-8 Cribs received the majority of these two constituents in comparison to all other B-Complex facilities. Thus the conceptual model for technetium-99 in the B-7-A\&B Crib subregion is not without some apparent inconsistency that would require additional boreholes down through facility footprints to provide more data.

\subsection{BX and BY Tank Farms (WMA BX-BY) Sub-region}

The combined conceptual model for the vadose zone and groundwater below this subregion was developed from several sources of information for uranium including field logging results from 13 historical boreholes, the more recent SGLS data for E33-41, E33-45, and E33-18 that contain Hanford processed uranium (see Figure 3.49 bottom panel) and the detailed characterization of sediments from borehole E33-45 and the new BP-5 RI boreholes E33-205, E33-343, E33-344, and E33-345. Correlation 
of the geologic stratigraphy, spectral gamma logging results and uranium isotopic ratio signatures portray a large area and deep vertical penetration of Hanford processed uranium into the vadose zone east and northeast of tank BX-102 (see Figure 3.60 and Figure 3.61). However, as noted previously, the absolute concentration of uranium in the sediments can be significantly overestimated when logging through old steel casings because uranium accumulates on the outside and perhaps inside the steel casing controlled by sorption/co-precipitation reactions with corrosion products (e.g., rust). The difference between actual sediment uranium concentrations in the two new boreholes 299-E33-344 and E33-345 with SGLS logging estimates in the older borehole 299-E33-18 is shown in Figure 3.60. But the main point is that the SGLS logging does indicate where Hanford processed uranium resides and if adequate time series logging is available when the Hanford processed uranium arrived at the location.

Table 6.5 combines the vadose zone mass estimate, found in Table 3.20, with the estimate of uranium mass currently in the groundwater plume below the B-Complex (see Table 5.4) to allow an overall mass balance estimate for uranium in the subregion versus the estimated mass lost from the 1951 overfill event at Tank BX-102. The mass-balance estimates for uranium show that the total uranium currently found in the vadose zone sediments to the northeast of Tank BX-102 ranges from $\sim 6400$ to $\sim 7200 \mathrm{~kg}$ and that $\sim 24 \%$ of this mass is readily mobilized by water. Further, the estimated mass of total uranium within 90 $\mathrm{ft}$ of the water table is substantial (3050 to $3910 \mathrm{~kg}$ ), and about $45 \%$ of this mass is readily mobilized by water (i.e., is water extractable at 1:1 solid to deionized water within 16 hours). These mass estimates for residual uranium within the vadose zone sediments dwarf the total uranium $(22.3 \mathrm{~kg})$ currently in the groundwater plume, which is mainly below the B-Complex with a leading edge north of the 200 East Area fenceline. The sum of total uranium that can be accounted for in the vadose zone plus groundwater plume varies from 63 to $72 \%$ of the mass released from the BX-102 overfill. It is hypothesized that the uranium from the 1951 overfill event required about 40 to 45 years to reach the water table. This hypothesis is based on the lack of elevated uranium concentrations in the groundwater until 1994 when concentrations were reported at $63.9 \mathrm{ug} / \mathrm{L}$ at well 299-E33-18, followed by a large influx to groundwater below the B-Complex in 1996.

Hanford processed uranium was first noted in the deep vadose zone within the $\mathrm{CCU}_{\mathrm{z}}$ unit in borehole 299-E33-18 in 1997. Before 1997, there was no detectable Hanford-process uranium in this borehole based on logging results in 1992. Therefore, the first occurrence of significantly elevated uranium in the vadose zone sediments at this location occurred between 1992 and 1997. This time frame is consistent with the influx of uranium to the groundwater in 1994 at this same well and a larger influx to groundwater in the region in 1996. Since it is estimated that only 63 to $72 \%$ of the uranium released during the BX-102 overfill event is still in the vadose zone and only $22.3 \mathrm{~kg}$ is in the groundwater, the areas and volume of sediment northeast of the Tank BX-102 that is contaminated appears to slightly underestimate the conceptual models of the vadose zone, or the uranium concentration distribution within the chosen contaminated vadose zone region has been slightly underestimated. Otherwise, the mass balance estimate should be closer to $100 \%$, given the fact that all the uranium from the overfill event is still present within the designated vadose zone region and groundwater plume. 
Table 6.5. Mass Balance Estimates for Uranium Below BX-102 Subregion in Comparison to Current Groundwater Plume and Mass Lost from BX-102

\begin{tabular}{|c|c|c|c|c|c|c|c|c|c|c|c|}
\hline Conceptual Model & Units & $\begin{array}{c}\text { Total U } \\
\text { Mass in } \\
\text { VZ } \\
\text { kg }\end{array}$ & $\begin{array}{c}\text { Mobile U } \\
\text { Mass in } \\
\text { VZ } \\
\text { kg }\end{array}$ & $\begin{array}{l}\text { U Mass } \\
\text { in } \\
\text { groundw } \\
\text { ater } \\
\mathrm{kg}\end{array}$ & $\begin{array}{c}\text { Sum } \\
\text { Total U } \\
\text { Mass } \\
\text { kg }\end{array}$ & $\begin{array}{l}\text { Sum } \\
\text { Mobile U } \\
\text { Mass } \\
\text { kg }\end{array}$ & $\begin{array}{c}\text { Sum of } \\
\text { Total U in } \\
\text { VZ\&groun } \\
\text { dwater vs. } \\
\text { Disposed } \\
\%\end{array}$ & $\begin{array}{c}\text { Sum } \\
\text { Mobile U } \\
\text { in } \\
\text { VZ\&grou } \\
\text { ndwater } \\
\text { vs. } \\
\text { Disposed } \\
\%\end{array}$ & $\begin{array}{c}\text { Total U in } \\
\text { VZ vs. } \\
\text { Disposed } \\
\%\end{array}$ & $\begin{array}{c}\text { Mobile U } \\
\text { in VZ vs. } \\
\text { Disposed } \\
\%\end{array}$ & $\begin{array}{l}\text { Mobile U } \\
\text { in VZ vs. } \\
\text { groundw } \\
\text { ater } \\
\text { fraction }\end{array}$ \\
\hline $\begin{array}{l}\text { Uranium spread through } \\
\text { Hanford formation to E33- } \\
343 \text { and then spread through } \\
\text { CCUz to groundwater and } \\
\text { to E33-345 (high estimate). }\end{array}$ & All VZ & 7224 & 2461 & 22.3 & 7246 & 2483 & $72 \%$ & $24.6 \%$ & $72 \%$ & $24.4 \%$ & 110 \\
\hline $\begin{array}{l}\text { Uranium spread through } \\
\text { Hanford formation to E33- } \\
343 \text { and then spread through } \\
\text { CCUz to groundwater and } \\
\text { to E33-345 (low estimate). }\end{array}$ & All VZ & 6361 & 2379 & 22.3 & 6383 & 2401 & $63 \%$ & $23.8 \%$ & $63 \%$ & $23.5 \%$ & 107 \\
\hline $\begin{array}{l}\text { Uranium spread through } \\
\text { Hanford formation to E33- } \\
343 \text { and then spread through } \\
\text { CCUz to groundwater and } \\
\text { to E33-345 (high estimate). }\end{array}$ & Deep VZ & 3914 & 1598 & 22.3 & 3937 & 1620 & $39 \%$ & $16.0 \%$ & $39 \%$ & $15.8 \%$ & 72 \\
\hline $\begin{array}{l}\text { Uranium spread through } \\
\text { Hanford formation to E33- } \\
343 \text { and then spread through } \\
\text { CCUz to groundwater and } \\
\text { to E33-345 (low estimate). }\end{array}$ & Deep VZ & 3052 & 1516 & 22.3 & 3074 & 1538 & $30 \%$ & $15.2 \%$ & $30 \%$ & $15.0 \%$ & 68 \\
\hline $\begin{array}{l}\text { Total Uranium released } \\
\text { from } \mathrm{BX}-102 \text { sub-region. }\end{array}$ & & & & & & & & & $1.01 \mathrm{E}+04$ & $\mathrm{~kg}$ & Z \\
\hline
\end{tabular}


Table 5.4 shows that the mass of uranium in the groundwater below the B-Complex has increased over the last 9 years from 3.4 to $22.3 \mathrm{~kg}$. Sourcing this groundwater increase is the estimated 1600 to $1700 \mathrm{~kg}$ of mobile uranium still residing in the vadose zone within $90 \mathrm{ft}$ of the water table (see Table 6.5). Furthermore, approximately 1100 to $1200 \mathrm{~kg}$ (see Table 3.20) of mobile uranium is estimated to be contained within the $\mathrm{CCU}_{\mathrm{z}}$ unit whose bottom is $\sim 20 \mathrm{ft}$ above the water table in the region where the uranium appears to be entering the water table (near 299-E33-343). It is concluded from these estimates that considerable mass of uranium will reach the water table in the future. This is a key prediction that must be factored into the remedy selection criteria for the BP-5 operable unit.

The conceptual model mass estimate for technetium-99 in this subregion is not as well developed as the uranium model because technetium-99 can only be determined by direct analysis of borehole sediments and groundwater; (i.e., spectral gamma logging data can not directly aid in locating where technetium-99 resides). Based on technetium-99 measurements from depth-discrete sediment samples at boreholes 299E33-45, E33-205, E33-343, E33-344, and E33-345, the vertical distributions of technetium-99 were estimated at each of these boreholes. The same areas as chosen for the uranium conceptual model were used to estimate the vadose zone residual mass of technetium-99 (see Section 3.4.4). The technetium-99 estimated inventory in the groundwater is shown in Table 5.2. The mass balance calculations for the BXBY Tank Farm sub-region are shown in Table 6.6. The mass balance estimates show that between 3.1 and $4 \mathrm{Ci}$ of technetium-99 remain in the vadose zone sediments with 92 to $93 \%$ of the total found in the deep vadose zone almost entirely in the $\mathrm{CCU}_{Z}$ unit near boreholes E33-343 and E33-344/E33-345. Because the major contributor to the technetium-99 groundwater plume is the BY Cribs the correct mass balance calculation (amount of residual technetium-99 in the vadose zone plus in the groundwater compared to amount released) is not useful. The second to last column on the right in Table 6.6 shows the mass balance if one assumes that all the technetium-99 released in the subregion still remains in the vadose zone sediment volume considered in the conceptual models. A second calculation where it is assumed that only the technetium-99 released in the BX-102 overfill event $(2.27 \mathrm{Ci})$ still resides in the vadose zone area considered is shown in the last column of Table 6.6. As can be seen the mass balances, assuming that all the technetium-99 released in the subregion still resides in the vadose zone sediments, range from 82 to $107 \%$. For the assumption that only technetium-99 from the BX-102 overfill event is present in the vadose zone the mass balance estimates range from 133 to $174 \%$. In both cases the vast majority of the technetium-99 in the vadose zone resides deep. It is known from figures in Section 5 that technetium-99 from this deep vadose zone region has been infiltrating into the water table such that the mass balance estimates assuming all of the technetium-99 still resides in the vadose zone are not realistic. The mass balances would be even more biased above $100 \%$ if only a localized groundwater technetium-99 contribution was included in the calculation. The technetium-99 conceptual model for the BX-BY Tank Farm subregion over-estimates either the volume of technetium-99 contaminated soils or the technetium-99 concentration distribution within the region chosen. 
Table 6.6. Mass Balance Estimates for Technetium-99 Below BX-102 Subregion in Comparison to Current Groundwater Plume and Mass Lost from BX-102

\begin{tabular}{|c|c|c|c|c|c|c|c|}
\hline Conceptual Model & Units & $\begin{array}{c}\text { Total } \\
\text { Tc } \\
\text { Mass in } \\
\text { VZ } \\
\mathrm{Ci} \\
\end{array}$ & $\begin{array}{c}\text { Tc Mass in } \\
\text { groundwater }^{(a)} \\
\mathrm{Ci}\end{array}$ & $\begin{array}{c}\text { Sum } \\
\text { Total } \\
\text { Tc } \\
\text { Mass } \\
\text { Ci } \\
\end{array}$ & $\begin{array}{c}\text { Sum of Total Tc } \\
\text { in } \\
\text { VZ\&groundwater } \\
\text { vs. Disposed to } \\
\text { Subregion } \\
\% \\
\end{array}$ & $\begin{array}{c}\text { Total Tc in } \\
\text { VZ vs. } \\
\text { Disposed to } \\
\text { Subregion } \\
\% \\
\end{array}$ & $\begin{array}{c}\text { Total Tc in VZ } \\
\text { vs. Disposed } \\
\text { During Overfill } \\
\text { Event } \\
\% \\
\end{array}$ \\
\hline $\begin{array}{l}\text { Tc spread through } \\
\text { Hanford formation to } \\
\text { E33-343 and then } \\
\text { spread through } \mathrm{CCU}_{\mathrm{z}} \text { to } \\
\text { groundwater and to } \\
\text { E33-345 (high } \\
\text { estimate). }\end{array}$ & All VZ & 3.95 & 6.06 & 10.01 & $270 \%$ & $107 \%$ & $174 \%$ \\
\hline $\begin{array}{l}\text { Tc spread through } \\
\text { Hanford formation to } \\
\text { E33-343 and then } \\
\text { spread through } \mathrm{CCU}_{\mathrm{z}} \text { to } \\
\text { groundwater and to } \\
\text { E33-345 (low estimate). }\end{array}$ & All VZ & 3.33 & 6.06 & 9.39 & $254 \%$ & $90 \%$ & $147 \%$ \\
\hline $\begin{array}{l}\text { Tc spread through } \\
\text { Hanford formation to } \\
\text { E33-343 and then } \\
\text { spread through } \mathrm{CCU}_{\mathrm{z}} \text { to } \\
\text { groundwater and to } \\
\text { E33-345 (high } \\
\text { estimate). }\end{array}$ & $\begin{array}{c}\text { Deep } \\
\text { VZ }\end{array}$ & 3.64 & 6.06 & 9.70 & $262 \%$ & $98 \%$ & $160 \%$ \\
\hline $\begin{array}{l}\text { Tc spread through } \\
\text { Hanford formation to } \\
\text { E33-343 and then } \\
\text { spread through } \mathrm{CCU}_{\mathrm{z}} \text { to } \\
\text { groundwater and to } \\
\text { E33-345 (low estimate). }\end{array}$ & $\begin{array}{c}\text { Deep } \\
\text { VZ }\end{array}$ & 3.02 & 6.06 & 9.08 & $245 \%$ & $82 \%$ & $133 \%$ \\
\hline $\begin{array}{l}\text { Total Tc released from } \\
\text { BX-102 sub-region. } \\
\text { Note that Tank BX- } \\
\mathbf{1 0 2} \text { itself released only } \\
\mathbf{2 . 2 7} \text { Ci. } \\
\text { (a) Tc-99 in groundwater }\end{array}$ & 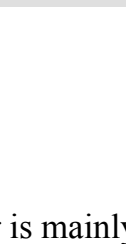 & - & .1 & 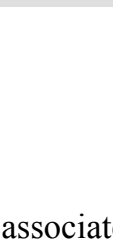 & 3.7 & $\mathrm{Ci}$ & \\
\hline
\end{tabular}

Another possibility is the observed technetium-99 in the vadose zone sediments and groundwater within this subregion includes another source for the technetium-99. This possibility might be supported by the fact that the concentration of technetium-99 in the $\mathrm{CCU}_{\mathrm{z}}$ unit at borehole 299-E33-45 (closer to Tank BX-102) is lower than concentrations at boreholes E33-343 and beyond at E33-344 and E33-345. It does not seem logical for concentrations of an un-reactive species to be higher at locations longer distances from a source than closer to a source. Generally as contaminated water moves through porous media it mixes with native (uncontaminated) pore waters and dispersion/diffusion processes cause dilution as the water moves to distant locations. Alternatively, it is possible that the technetium-99 concentrations measured in $\mathrm{CCU}_{\mathrm{z}}$ unit sediments at the location of borehole 299-E33-45 are lower than found in other nearby sediments containing the BX-102 overfill fluids. There is little doubt that the 
source of the uranium in the vadose zone sediments northeast of Tank BX-102 all the way to 299-E343 and E33-344 and E33-345 is from the BX-102 overfill event thus the observed technetium-99 in the vadose zone sediments at E33-343 and E33-344/345 may also be exclusively from the overfill event.

Should interest continue to evaluate whether there are two (or more) sources for the technetium-99 in this subregion, isotopic signature measurements of stable (as opposed to radioactive) ruthenium fission isotopes in a similar fashion as used for uranium signatures could be used. Ruthenium as the ruthenate anion $\left(\mathrm{RuO}_{4}{ }^{2-}\right)$ has mobility attributes quite similar to technetium as pertechnetate $\left(\mathrm{TcO}_{4}{ }^{-}\right)$and background concentrations of natural ruthenium in sediments and their pore waters are very low in comparison to fission product stable ruthenium concentrations. Further, the isotope ratios of stable ruthenium produced during fission are significantly different than the ratios of background ruthenium making it possible to distinguish stable fission and natural ruthenium contributions.

The technetium-99 groundwater plume, sourced from under the B-Complex, has spread out towards and well beyond the gap between Gable Butte and Gable Mountain (see Figure 5.17). As discussed in Section 5 the plume contains $\sim 6.06$ curies of technetium- 99 and is sourced from the BY Cribs. The total mass of technetium-99 released from the BX Tank Farm is 3.7 curies and from Tank BX-102 itself is 2.27 curies. Therefore the calculations in Table 6.6 showing the sum of residual technetium- 99 masses in the subregion vadose zone sediments with the mass in the groundwater plume are not useful because the groundwater mass is not related to releases to this subregion. There is some technetium-99 entering the water table along with the uranium from BX-102 close to well 299-E33-343 as shown in recent groundwater plume maps (see Figure 5.21). As mentioned above there may be another source of technetium-99 in the vadose zone sediments of this subregion or alternatively the mass balance estimates for technetium-99 remaining below the subregion may suffer from the small data set of available boreholes and direct sediment measurements.

No technetium-99 borehole sediment data are available close to the BY tanks, excepting the new borehole E33-205, which did not show detectable concentrations of technetium-99 in any vadose zone sediments. Technetium-99, at concentrations ranging from 1 to $4 \mathrm{pCi} / \mathrm{g}$, was measured in the E33-205 sediments below the water table, and the groundwater sample taken during drilling contained $9400 \mathrm{pCi} / \mathrm{L}$, but it is suspected that this technetium-99 entered the water table close to E33-343 and moved to the northwest to intercept well 299-E33-205. The uranium isotopic ratio signature data for the groundwater at 299-E33-205 also supports the source of uranium as being from the BX-102 overfill so that the observed technetium-99 in the groundwater likely traveled together.

The mass of uranium and activity of technetium-99 released by tanks in the BY Tank Farm is shown in Table 3.21. Compared to the BX Tank Farm, the BY Tank Farm released less (technetium-99 activity of $1.5 \mathrm{vs}$. $3.7 \mathrm{Ci}$ and uranium mass of 0.24 vs. $10,100 \mathrm{~kg}$ ). Further, the BY Tank Farm is estimated to have released about one-third the volume of liquid wastes as the BX Tank Farm (see Table 3.15 and Table 3.21). As mentioned in Section 3.4.5, there is uncertainty in how many and which tanks in the BY Tank Farm actually released fluid to the subsurface, so all of these estimates are subject to some debate. However, based on the available information, it is hypothesized that the BY Tank Farm is not a significant contributor to deep vadose zone contamination or the groundwater plumes under the B-Complex under current conditions. 


\subsection{B Tank Farm Sub-region}

As discussed in Section 3.5, it has been concluded, based on sediment characterization around Tank B-110, the estimates of volumes of waste released, the estimated masses of mobile contaminants present in the released wastes, the available spectral gamma logs of dry wells within the B Tank Farm, and the groundwater plume maps that this tank farm has not been a significant contributor to deep vadose zone contamination or a significant source of mobile contaminants to the groundwater under current conditions. Therefore, mass balance estimates for this sub-region were not generated.

\subsection{Contaminant Mobility Once in the Aquifer}

The conceptual models for technetium-99, cyanide and nitrate once they reach the water table are that they will migrate at the same velocity as the groundwater (i.e., retardation factor equals 1 and $\mathrm{K}_{\mathrm{d}}$ equals 0 $\mathrm{mL} / \mathrm{g})$. Although not discussed in much detail, chromium (VI) as chromate $\left(\mathrm{CrO}_{4}{ }^{2-}\right)$, also is mobile and relatively non-sorbing under most Hanford disposal conditions, especially for the types of waste streams released in the B Complex. All of these contaminants are anions in the geochemical conditions of the Hanford groundwater. Anions rarely exhibit retardation caused by chemical bonding with the sediments at the Hanford Site as long as the typical oxidizing and near-neutral $\mathrm{pH}$ conditions are present. In addition, the aquifer sediments are coarse-grained and thus not generally considered good adsorbents for most contaminants.

The conceptual model for uranium once it reaches the water table is that it will interact slightly with the aquifer sediments and travel somewhat more slowly than the groundwater itself. One estimate of the retardation was made by Christensen et al. (2004) based on monitoring the increase in the uranium-236/238 ratio of the total uranium in selected groundwater wells in the northwestern portion of the B-Complex. The time evolution of the groundwater plume using the flux of the elevated uranium-236/238 ratio suggests an average uranium migration rate of $\sim 0.7-0.8 \mathrm{~m} /$ day and showing slight retardation relative to the groundwater flow of $\sim 1 \mathrm{~m} /$ day. This yields a retardation factor $\left(\mathrm{V}_{\text {groundwater }} / \mathrm{V}_{\text {contaminant }}\right)$ of 1.25 to 1.43 .

The $\mathrm{K}_{\mathrm{d}}$ can be calculated from the equation

$$
R=1+\frac{\rho_{b d}}{\theta_{e f f}} * K_{d}
$$

where $\mathrm{R}$ is the retardation factor, $\rho_{\mathrm{bd}}$ is the dry bulk density (for $\mathrm{CCU}_{\mathrm{g}}$ unit the value is $2.15 \mathrm{~g} / \mathrm{cm}^{3}$ ), and $\theta_{\text {eff }}$ is the effective porosity (for $\mathrm{CCU}_{\mathrm{g}}$ unit the value is $0.112 \mathrm{~cm}^{3} / \mathrm{cm}^{3}$ ). The bulk density and effective porosity for the $\mathrm{CCU}_{\mathrm{g}}$ unit are found in Section 4. The calculated uranium $\mathrm{K}_{\mathrm{d}}$ values for this range in the retardation factor are 0.013 to $0.022 \mathrm{~mL} / \mathrm{g}$.

\subsection{Summary of Key Integrated Conceptual Models}

The key sources of deep vadose zone contamination and groundwater contamination below the B-Complex are listed in Table 6.7. The table gives a qualitative description of how consistent the various data sets are that support the conceptual models for the various sources and some comments on additional 
Table 6.7. Qualitative Description of Strength and Weakness of Integrated VZ/groundwater Models Used to Identify Sources of groundwater Contamination

\begin{tabular}{|c|c|c|c|c|c|c|c|c|c|}
\hline Source & $\begin{array}{c}\text { Vadose Zone } \\
\text { Sediment } \\
\text { Characterization } \\
\text { Details }\end{array}$ & $\begin{array}{c}\text { Vadose Zone } \\
\text { Sediment } \\
\text { Quality }\end{array}$ & $\begin{array}{l}\text { Gamma Field } \\
\text { Survey }\end{array}$ & $\begin{array}{c}\text { Soil } \\
\text { Resistivity }\end{array}$ & $\begin{array}{c}\text { Vadose Zone } \\
\text { Data } \\
\text { Consistency }\end{array}$ & $\begin{array}{l}\text { Groundwater } \\
\text { Plume Details }\end{array}$ & $\begin{array}{l}\text { Groundwater/VZ } \\
\text { Consistency }\end{array}$ & Overall Rating & Comments \\
\hline $\begin{array}{c}\text { BY } \\
\text { Cribs }\end{array}$ & $\begin{array}{c}3 \text { shallow } \\
\text { boreholes in } \\
\text { each crib \& } 5 \\
\text { deep boreholes } \\
\text { with } 3 \text { inside } \\
\text { footprints } \\
\text { (B-43, B-49, } \\
\text { B-57) and } 2 \\
\text { proximal to } \\
\text { cribs }\end{array}$ & $\begin{array}{l}\text { Areal coverage } \\
\text { adequate; } \\
\text { contaminant } \\
\text { vertical } \\
\text { distribution } \\
\text { coverage in } \\
\text { deep vadose } \\
\text { marginal. }\end{array}$ & $\begin{array}{c}\text { Good coverage } \\
\text { both areally and } \\
\text { vertically; } \\
\text { suggests } \\
\text { widespread lateral } \\
\text { and deep } \\
\text { contamination. }\end{array}$ & $\begin{array}{c}\text { Good } \\
\text { coverage } \\
\text { suggests } \\
\text { widespread } \\
\text { salt plume } \\
\text { that likely } \\
\text { reaches water } \\
\text { table. }\end{array}$ & $\begin{array}{l}\text { All three } \\
\text { "tools" } \\
\text { agree. }\end{array}$ & $\begin{array}{l}\text { Over last } 20 \\
\text { years, } \\
\text { groundwater } \\
\text { plots suggest } \\
\mathrm{BY} \text { cribs is } \\
\text { source of } \mathrm{Tc} \text {, } \\
\text { cyanide, } \mathrm{NO}_{3} \text {, } \\
\mathrm{Na} \text {, but not } \mathrm{U} \text {. }\end{array}$ & $\begin{array}{l}\text { Good agreement. } \\
\text { Deep vadose zone } \\
\text { sediment has high } \\
\text { concentrations of } \\
\text { same species found in } \\
\text { groundwater hot spots } \\
\text { below Cribs; plumes } \\
\text { migrate to NW. }\end{array}$ & $\begin{array}{l}\text { Very Good; VZ; } \\
\text { groundwater, and } \\
\text { Facility Masses } \\
\text { and Volumes } \\
\text { disposed of yield } \\
\text { a coherent model. }\end{array}$ & $\begin{array}{l}\text { BY cribs is sole source of } \\
\text { cyanide, major source of } \\
\text { Tc, and large contributor of } \\
\mathrm{NO}_{3} \text { and } \mathrm{Na} \text { to } \\
\text { groundwater. }\end{array}$ \\
\hline $\begin{array}{l}\text { B-7- } \\
\text { A\&B } \\
\text {-B-8 } \\
\text { Cribs }\end{array}$ & $\begin{array}{c}4 \text { boreholes } \\
1 \text { inside B-7A } \\
\text { crib, } 3 \text { proximal } \\
\text { to B-7-A) }\end{array}$ & $\begin{array}{c}\text { Areal coverage } \\
\text { poor; } \\
3 \text { proximal } \\
\text { boreholes } \\
\text { clustered } \\
\text { together; } \\
\text { vertical } \\
\text { distribution } \\
\text { coverage in } \\
\text { deep vadose in } \\
\text { footprint poor. }\end{array}$ & $\begin{array}{c}\text { Mediocre areal } \\
\text { coverage suggests } \\
\text { facility plumes } \\
\text { have not } \\
\text { commingled, and } \\
\text { waste may not } \\
\text { have reached } \\
\text { water table. }\end{array}$ & $\begin{array}{l}\text { Good } \\
\text { coverage } \\
\text { suggests } \\
\text { widespread } \\
\text { salt plume } \\
\text { that likely } \\
\text { reaches water } \\
\text { table. }\end{array}$ & $\begin{array}{l}\text { All three } \\
\text { tools do not } \\
\text { give a } \\
\text { consistent } \\
\text { "picture." }\end{array}$ & $\begin{array}{c}\text { Over last } 20 \\
\text { years, } \\
\text { groundwater } \\
\text { plots suggest } \mathrm{B}- \\
8 \text { crib is source } \\
\text { of } \mathrm{Cr}, \mathrm{Na} \text {, and } \\
\mathrm{NO}_{3} .\end{array}$ & $\begin{array}{l}\text { Some inconsistencies } \\
\text { attributed mostly to } \\
\text { lack of } \mathrm{VZ} \text { data and } \\
\text { groundwater well } \\
\text { coverage; } \mathrm{F} \text { and } \mathrm{Cr} \text { in } \\
\mathrm{CCU}_{\mathrm{z}} \text { pore waters and } \\
\mathrm{Cr} \text { in groundwater } \\
\text { must be from these } \\
\text { facilities. }\end{array}$ & $\begin{array}{l}\text { Poor. Some of } \\
\text { the VZ; } \\
\text { groundwater, and } \\
\text { facility masses } \\
\text { and volumes } \\
\text { disposed of hint } \\
\text { at a coherent } \\
\text { model, but VZ } \\
\text { data too sparse to } \\
\text { be defensible. }\end{array}$ & $\begin{array}{c}\text { Need additional } \\
\text { borehole/groundwater } \\
\text { monitoring well through B- } \\
8 \text { and deeper borehole/well } \\
\text { at B-7-A; need more deep } \\
\text { VZ borehole coverage to } \\
\text { define extent and thickness } \\
\text { of } \mathrm{CCU}_{\mathrm{z}} \text { unit. }\end{array}$ \\
\hline
\end{tabular}


Table 6.7 (contd)

\begin{tabular}{|c|c|c|c|c|c|c|c|c|c|}
\hline Source & $\begin{array}{c}\text { Vadose Zone } \\
\text { Sediment } \\
\text { Characterization } \\
\text { Details }\end{array}$ & $\begin{array}{l}\text { Vadose Zone } \\
\text { Sediment } \\
\text { Quality }\end{array}$ & $\begin{array}{l}\text { Gamma Field } \\
\text { Survey }\end{array}$ & Soil Resistivity & $\begin{array}{c}\text { Vadose Zone } \\
\text { Data Consistency }\end{array}$ & $\begin{array}{l}\text { Groundwater } \\
\text { Plume Details }\end{array}$ & $\begin{array}{c}\text { Groundwater/VZ } \\
\text { Consistency }\end{array}$ & Overall Rating & Comments \\
\hline $\begin{array}{l}\text { BX-102 } \\
\text { Overfill }\end{array}$ & $\begin{array}{l}5 \text { boreholes, } \\
3 \text { direct push, } \\
\sim 20 \text { Gamma } \\
\text { Logs identified } \\
\text { location of } U \text {. }\end{array}$ & $\begin{array}{c}\text { Very good } \\
\text { vertical } \\
\text { distribution of } \\
\text { contaminants } \\
\text { and adequate } \\
\text { areal coverage } \\
\text { for order of } \\
\text { magnitude U } \\
\text { mass estimates. }\end{array}$ & $\begin{array}{l}\text { Very good data } \\
\text { set for locating } \\
\text { presence of } \\
\text { Hanford } \\
\text { processed U; old } \\
\text { casing attract U } \\
\text { and bias absolute } \\
\text { concentrations. }\end{array}$ & $\begin{array}{l}\text { Resistivity near } \\
\text { tank } \\
\text { infrastructure is } \\
\text { not reliable; } \\
\text { results to NE of } \\
\text { BX tanks } \\
\text { questionable } \\
\text { (some } \\
\text { inversions did } \\
\text { not see known } \\
\text { VZ plume). }\end{array}$ & $\begin{array}{l}\text { Sediment } \\
\text { characterization } \\
\text { and gamma logs } \\
\text { very consistent; } \\
\text { Resistivity data } \\
\text { were "ignored." }\end{array}$ & $\begin{array}{l}\text { Plumes in last } \\
10 \text { years are } \\
\text { consistent that } \\
\text { there is } \\
\text { increasing } U \\
\text { masses entering } \\
\text { groundwater in } \\
\text { vicinity of new } \\
\text { well E33-343. }\end{array}$ & $\begin{array}{c}\text { Good agreement } \\
\text { between sediment } \\
\text { characterization, } \\
\text { gamma logging, and } \\
\text { groundwater plume } \\
\text { evolution; U isotopic } \\
\text { signatures of VZ pore } \\
\text { waters and } \\
\text { groundwater also } \\
\text { identify BX-102 as } \\
\text { source. }\end{array}$ & $\begin{array}{l}\text { Very good } \\
\text { agreement } \\
\text { between most } \\
\text { "tools"; Soil } \\
\text { resistivity info } \\
\text { not } \\
\text { inconsistent } \\
\text { but not of } \\
\text { much value in } \\
\mathrm{CCU}_{\mathrm{z}} \text { region } \\
\text { of interest. }\end{array}$ & $\begin{array}{l}\text { Need detailed 3D } \\
\text { VZ hydrologic } \\
\text { modeling of tank } \\
\text { overfill volumes } \\
\text { and sensitivity } \\
\text { analysis of other } \\
\text { water sources to } \\
\text { show plausibility } \\
\text { of the great } \\
\text { distances that it is } \\
\text { hypothesized that } \\
\text { the BX-102 U has } \\
\text { travelled. }\end{array}$ \\
\hline $\begin{array}{l}\text { Tc-99 at } \\
\text { E33-343 } \\
\text { location }\end{array}$ & $\begin{array}{c}3 \text { boreholes } \\
\text { (E33-343, -344, } \\
\text {-345) have } \\
\text { elevated Tc } \\
\text { concentration in } \\
\mathrm{CCU}_{\mathrm{z}} .\end{array}$ & $\begin{array}{l}\text { Adequate areal } \\
\text { and vertical } \\
\text { coverage. }\end{array}$ & $\begin{array}{l}\text { Gamma tool not } \\
\text { capable of } \\
\text { detecting Tc. }\end{array}$ & $\begin{array}{l}\text { Soil Resistivity } \\
\text { not capable of } \\
\text { identifying Tc. }\end{array}$ & $\begin{array}{l}\text { Only data useful } \\
\text { are from direct } \\
\text { measurement of } \\
\text { sediments. }\end{array}$ & $\begin{array}{l}\text { Recent plume } \\
\text { maps show } \\
\text { influx of Tc at } \\
\text { same location } \\
\text { as U (near E33- } \\
\text { 343). }\end{array}$ & $\begin{array}{l}\text { High } \mathrm{Tc} \text { in } \mathrm{CCU}_{\mathrm{z}} \text { and } \\
\text { location of secondary } \\
\text { groundwater hot spot } \\
\text { very consistent. }\end{array}$ & $\begin{array}{l}\text { Fair, some } \\
\text { question on } \\
\text { potential for } \\
\text { unidentified } \\
\text { source for } \\
\text { some of Tc } \\
\text { observed in } \\
\text { VZ. }\end{array}$ & $\begin{array}{l}\text { Could investigate } \\
\text { Ru isotopic } \\
\text { signature tool to } \\
\text { source the Tc or } \\
\text { need more VZ } \\
\text { boreholes between } \\
\text { BY cribs and } \\
\text { E33-343 or near } \\
\text { potential SST } \\
\text { sources. }\end{array}$ \\
\hline
\end{tabular}


Table 6.7 (contd)

\begin{tabular}{|c|c|c|c|c|c|c|c|c|c|}
\hline & & Vadose & & & & & & & \\
\hline $\begin{array}{l}\text { Sub- } \\
\text { region }\end{array}$ & $\begin{array}{l}\text { VZ Sediment } \\
\text { Characterization } \\
\text { Details }\end{array}$ & $\begin{array}{l}\text { Zone } \\
\text { Sediment } \\
\text { Quality }\end{array}$ & $\begin{array}{l}\text { Gamma Field } \\
\text { Survey }\end{array}$ & $\begin{array}{c}\text { Soil } \\
\text { Resistivity }\end{array}$ & $\begin{array}{l}\text { Vadose Zone } \\
\text { Data } \\
\text { Consistency }\end{array}$ & $\begin{array}{l}\text { Groundwater } \\
\text { Plume Details }\end{array}$ & $\begin{array}{c}\text { Groundwater/VZ } \\
\text { Consistency }\end{array}$ & Overall Rating & Comments \\
\hline $\begin{array}{l}\text { BX } \\
\text { Trenches }\end{array}$ & $\begin{array}{l}1 \text { borehole in B- } \\
36 \text { footprint. }\end{array}$ & $\begin{array}{l}\text { Mediocre; in } \\
\text { deep vadose } \\
\text { zone } \\
\text { sampled } \\
\text { every } 50 \mathrm{ft} .\end{array}$ & $\begin{array}{l}\text { Mediocre; } \\
\text { Historical } \\
\text { gamma has not } \\
\text { penetrated full } \\
\text { extent of VZ. }\end{array}$ & $\begin{array}{l}\text { Good; High } \\
\text { salt plume has } \\
\text { not reached } \\
\text { water table. }\end{array}$ & $\begin{array}{l}\text { Reasonable } \\
\text { consistency }\end{array}$ & $\begin{array}{l}\text { No current elevated } \\
\text { concentrations of } \\
\text { key risk drivers. }\end{array}$ & Acceptable & Adequate & $\begin{array}{l}\text { Trench with highest } \\
\text { volume release B-37 } \\
\text { could be drilled to show } \\
\text { that specific retention } \\
\text { concept worked. }\end{array}$ \\
\hline $\begin{array}{l}\text { BY Tank } \\
\text { Farm }\end{array}$ & No boreholes & No data & $\begin{array}{l}\text { Sobczyk } \\
\text { suggest more } \\
\text { leakers than } \\
\text { Hanlon; some } \\
\text { Cobalt-60 is } \\
\text { migrating year } \\
\text { to year. }\end{array}$ & $\begin{array}{l}\text { Suggests high } \\
\text { salt plume } \\
\text { south of } \\
\text { BY-107. }\end{array}$ & $\begin{array}{l}\text { Data are too } \\
\text { sparse to } \\
\text { evaluate. }\end{array}$ & $\begin{array}{l}\text { Only one well, and } \\
\text { it appears to be } \\
\text { influenced by } \\
\text { plumes migrating } \\
\text { from influx near } \\
\text { E33-343. }\end{array}$ & $\begin{array}{l}\text { Data too sparse to } \\
\text { evaluate. }\end{array}$ & $\begin{array}{l}\text { Dismissed BY } \\
\text { TF solely } \\
\text { based on low } \\
\text { release } \\
\text { volumes and } \\
\text { inventories. }\end{array}$ & $\begin{array}{l}\text { If investigated BY-107, } \\
\text { had highest volume and } \\
\text { mass released in tank } \\
\text { farm. }\end{array}$ \\
\hline $\begin{array}{l}\text { B Tank } \\
\text { Farm }\end{array}$ & $\begin{array}{l}1 \text { borehole, } 3 \\
\text { very shallow } \\
\text { direct pushes }\end{array}$ & $\begin{array}{l}\text { Adequate } \\
\text { for B-110 } \\
\text { tank }\end{array}$ & $\begin{array}{l}\text { Sobczyk } \\
\text { suggest more } \\
\text { leakers than } \\
\text { Hanlon. }\end{array}$ & $\begin{array}{l}\text { No definitive } \\
\text { suggestions } \\
\text { from } \\
\text { contractor on } \\
\text { interesting } \\
\text { tanks. }\end{array}$ & $\begin{array}{l}\text { Aside from B- } \\
110 ; \text { Data are } \\
\text { too sparse to } \\
\text { evaluate. }\end{array}$ & $\begin{array}{l}\text { Water sample at } \\
\text { bottom of E33-46 } \\
\text { was not } \\
\text { contaminated; no } \\
\text { monitoring wells in } \\
\text { side fence line. }\end{array}$ & $\begin{array}{l}\text { Overall tank farm data } \\
\text { too sparse to evaluate; } \\
\text { but B-110 release is } \\
\text { not impacting deep } \\
\text { VZ or groundwater. }\end{array}$ & $\begin{array}{l}\text { Dismissed B } \\
\text { TF solely } \\
\text { based on low } \\
\text { release } \\
\text { volumes and } \\
\text { inventories. }\end{array}$ & $\begin{array}{l}\text { If investigated, locations } \\
\text { north of B-106 and B- } \\
200 \text { series tanks are } \\
\text { priority. Might help } \\
\text { interpretation of mixed } \\
\text { fluids in } \mathrm{CCU}_{\mathrm{z}} \text { unit near } \\
\text { E33-345 or source of } \\
\text { elevated Tc-99 near } \\
\text { E33-343. }\end{array}$ \\
\hline
\end{tabular}


activities that would be needed to improve or disprove the hypotheses. Table 6.7 also lists subregions within the B-Complex for which the conclusion is made that they are not impacting the deep vadose zone or groundwater. Abbreviated reasons that led to the conclusion to dismiss the facilities as causing current or future impacts have been provided. More details were presented in Section 3 during the discussion on vadose zone findings.

It is hypothesized that the BY Cribs are the source of all of the cyanide, most of the technetium-99, the largest portion of nitrate and sodium, and none, or at most an insignificant amount, of the uranium currently found in the groundwater below the B-Complex and the plumes' leading edges that are travelling north through the Gable Gap. An evaluation as to whether the BY Cribs have contributed chromium to the groundwater below the B-Complex was not possible because the only chromium data for vadose zone sediments directly below BY Crib footprints is total chromium, which is not useful for differentiating natural from Hanford contributions in most cases. The SIM mass estimates suggest that $20 \%$ of the total chromium disposed of within the B-Complex was disposed of to the BY Cribs. Based on the SIM estimates, the BY Cribs received $100 \%$ of the cyanide, $89 \%$ of the technetium- $99,51 \%$ of the nitrate, and $49 \%$ of the sodium, but only $9 \%$ of the uranium that was disposed of in the entire B-Complex. There is a fairly direct correlation between the percentages of total B-Complex mass estimates disposed of to the BY Cribs and the qualitative estimates of how much of the current groundwater mass estimates are attributed to the BY Cribs as the source. This simple correlation is encouraging and supports the mass-balance exercise performed in this section.

The BY Cribs received 58\% of the total volume of waste liquids disposed of or released to the B-Complex; however, most ( $\sim 80 \%)$ of this volume was dilute waste water that was disposed to the B-50 Crib 10 to 20 years after the more concentrated wastes were disposed of. Assuming that lateral spreading along fine-grained layers has occurred during and after active waste disposal, the dilute waters could have pushed the earlier more concentrated wastes further distances and deeper within the vadose zone. The $\mathrm{CCU}_{z}$ unit, which is a very effective lateral spreading stratum, is not present below most of the eastern half of the BY Cribs footprint and is thin below the western half. This geologic setting likely promoted a stronger vertical component for the waste liquids during the active disposal at the depth of the $\mathrm{CCU}_{\mathrm{z}}$. However, there are strong indications that thin fine-grained layers in the Hanford formation, especially the H2F2 lens, have been effective at spreading the waste liquid and contaminants laterally for distances of tens of meters from the BY Cribs' footprints. Spectral gamma logging and sediment characterization from borehole E33-341 support this conclusion. Further, a soil resistivity field survey concludes that lateral spreading was widespread, and breakthrough to the groundwater likely occurred below the BY Cribs. The characterization data for the retrieved sediments from the four available boreholes in the BY Cribs subregion show the highest concentrations of residual technetium-99, nitrate, cyanide, sulfate, and sodium in the deep vadose zone of all the B Complex regions studied. The time series groundwater plume maps from the entire time period between the mid 1950s through the present also suggest that the BY Cribs have been, and continue to be, a major source of these contaminants found in the groundwater below the B-Complex.

The source contributing likely all, or the vast majority, of the uranium to the groundwater plume below the B-Complex is from the BX-102 tank overfill event in 1951. The conceptual model has the uranium from this release spreading laterally in a northeasterly direction along the thin fine-grained layers in the Hanford formation as well as descending into the $\mathrm{CCU}_{\mathrm{z}}$ unit somewhere in the vicinity of boreholes 
E33-41 and E33-343. Once in the very moist $\mathrm{CCU}_{z}$ stratum, the $\mathrm{BX}-102$ waste fluids have migrated as far east as the location of boreholes 299-E33-18, E33-344, and E33-345. The conceptual model suggests that somewhere near borehole E33-343, the BX-102 uranium is breaking through the $\mathrm{CCU}_{z}$ unit and descending relatively quickly through the $\sim 15$ - to 20 -ft-thick gravel-dominated $\mathrm{CCU}_{\mathrm{g}}$ unit to the water table. Once in the groundwater, the uranium migrates towards the northwest. The highest concentration portion of the uranium plume travels below the northeastern portion of the BY Tank Farm and southwestern portion of the BY Cribs area and is heading towards the northeast corner of the 218-E-10 Burial Ground (Low-Level WMA-1).

The spectral gamma and historical gross gamma field logs for 20 boreholes (13 historical and 7 newer boreholes), the vadose zone sediment characterization at E33-45 and four of the new boreholes (299-E33205, E33-343, E33-344, and E33-345), the precise uranium isotopic signature measurements of vadose zone pore waters and groundwater, and the time series groundwater plume maps all support this uranium conceptual model. Further, $88 \%$ of the uranium released to the entire B-Complex comes from the BX102 overfill event and as has been found for the other waste sources, the facilities that received the largest masses of each contaminant do in fact correlate with the occurrence of groundwater contamination.

The one remaining issue regarding the $\mathrm{BX}-102$ overfill event is how did the uranium present in a relatively low volume (347,000 liters), relative to the several million-liter disposals to the BY Cribs and B-7-A\&B/B-8 Cribs subregions, migrate so far from the source. It was not within the scope of this report to assess the details on vadose zone flow and sources of water to the vadose zone. There have been numerous reports of substantial water sources to the vadose zone including: 1) prolonged potable water line leaks; 2) large snow melt events that flooded tank farms and inactive disposal facilities; 3) enhanced recharge within the tank farm boundaries caused by the gravel covers to prevent spread of surface contamination; and 4) perhaps surface runoff into low lying topography (see Figure 6.2; taken from DOE/RL (2007c) or from covers placed over facilities such as the B-57 Crib barrier. In addition, the $\mathrm{CCU}_{z}$ unit 1) has been found to be contiguous over most of the central portion of the B-Complex, 2) has very high moisture contents (there have been at least three instances of perched or free flowing water extracted from this unit during borehole drilling), and 3) has produced water from the perched well 299E33-344 when sampled (at least eight times through calendar year 2009). Assuming that the waste liquids lost during the $1951 \mathrm{BX}-102$ overfill event migrated down the stratigraphic gradient (units dip to the northeast) along the fine-grain layers and reached the wet $\mathrm{CCU}_{\mathrm{z}}$ unit, there appears to be adequate moisture in this unit to allow migration of contaminants for hundreds of meters. It was also observed that the sediments within the $\mathrm{CCU}_{\mathrm{z}}$ unit vary in particle size and thus there are apparent areas of higher permeability. Therefore, it is speculated that lateral water flow in the $\mathrm{CCU}_{\mathrm{z}}$ unit is quite variable, allowing some flow paths to move water faster than others. At selected locations in the $\mathrm{CCU}_{\mathrm{z}}$ unit, the sediments become saturated with water, and the capillary break process breaks down, allowing contaminated fluids to descend into the coarser grained $\mathrm{CCU}_{\mathrm{g}}$ stratum in which the aquifer resides. Further, at the edges of the $\mathrm{CCU}_{\mathrm{z}}$ unit where the silt layer thins and pinches out, it is suspected that contaminated and commingled liquids from several of the sources discussed escapes and rapidly descends through the $\mathrm{CCU}_{\mathrm{g}}$ into the water table. The conceptual model for uranium entering the water table near borehole E33-343 is discussed in detail in Section 3.4.

The groundwater time series plume maps and the analysis of the vadose zone sediment concentrations of technetium-99 suggest that some technetium-99 is also entering the water table near E33-343. Because the available technetium-99 data set for the region northeast of the BX-102 is much less robust than the 


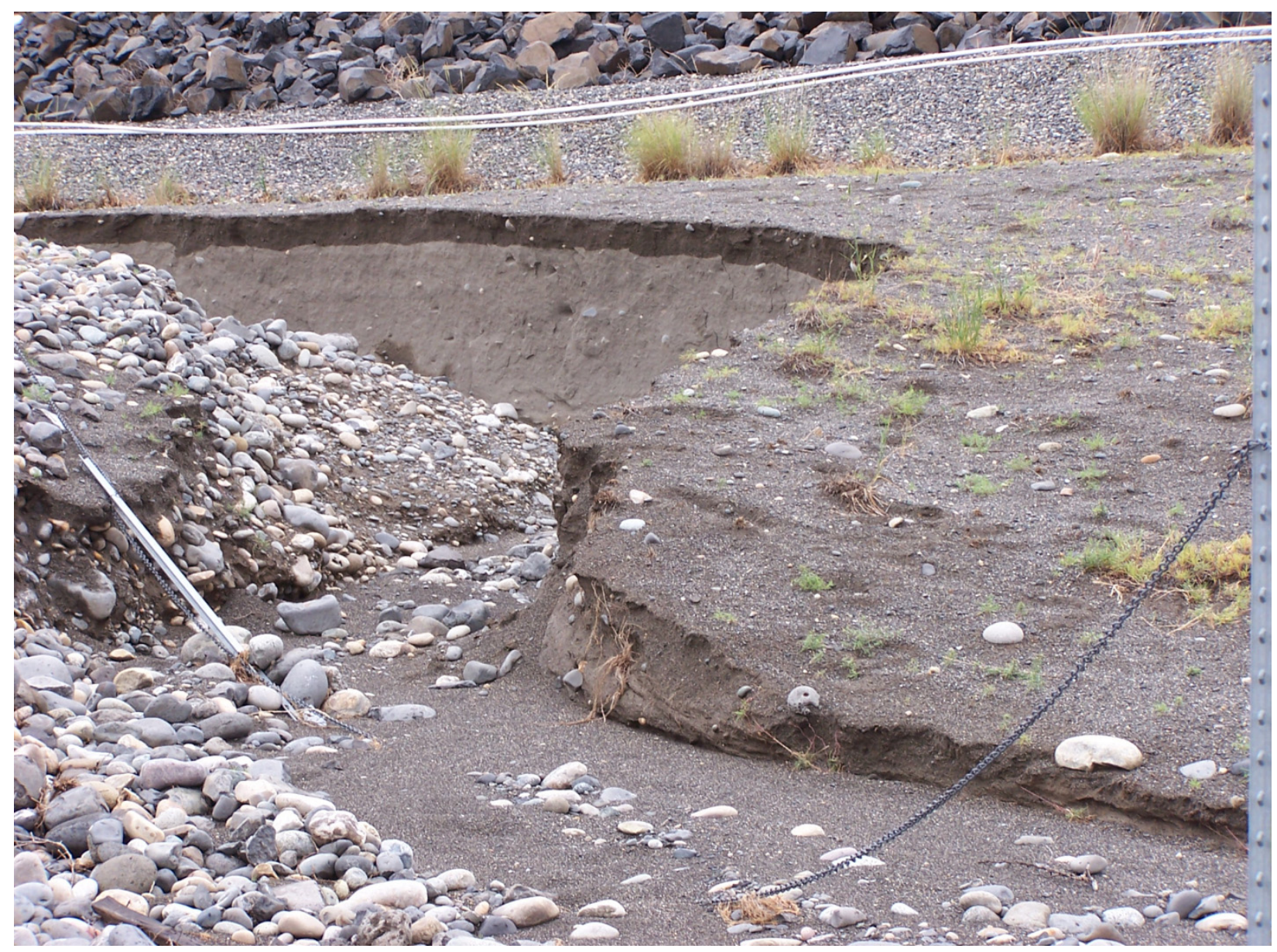

Figure 6.2. Erosional Feature Formed after Heavy Rain Event Between East Side of B-57 Crib Barrier and Southwest Corner of BY Tank Farm (taken from DOE/RL 2007c; Figure 2.10-23); see footnote below. ${ }^{\text {(a) }}$

uranium data set, it is not completely clear whether this technetium-99 is solely from the BX-102 overfill event. The overfill event's estimated mass of technetium-99 and sediment data at E33-45 (within $70 \mathrm{ft}$ of BX-102) suggest that technetium-99 concentrations in the $\mathrm{CCU}_{z}$ unit at E33-343 may be higher than supported by pore waters closer to the source if the BX-102 overfill event was the sole technetium-99 source. Based on similar high technetium-99 concentrations in the $\mathrm{CCU}_{\mathrm{z}}$ unit to the east farther away from BX-102 (i.e., at 299-E33-344/345) one can question whether there is another unidentified source for some of the technetium-99. There is no question, in the opinion of the authors, that the $\mathrm{CCU}_{\mathrm{z}}$ below the B-Complex contains waste fluids from at least two sources based on the chemical composition of sediment water extracts obtained by ultracentrifugation, and the perched water from E33-344. It cannot be determined whether the source of the elevated technetium-99 entering the groundwater near E33-343 is

(a) This event depicted in the photograph happened in the spring of 2003; there was 2 inches of rain in one afternoon, and the north end of the BY Tank Farm flooded the east side of the B-57 crib barrier creating a gully that was at least 4 feet deep before percolating "tons" of water into the ground near the BY cribs (personal communication March 2010 from Dr. Glendon Gee, PNNL Emeritus Fellow and former B-57 barrier principle investigator). Discussion in DOE/RL (2007d) Section 2.10, pages 2-18, implies that this location had flooded before and that water lines north of the barrier were left open to water deciduous trees for long periods of time. 
solely from the BX-102 overfill event or partially from an identified source such as another SST. Based on technetium-99 mass estimates disposed of to the B-7-A\&B/B-8 Cribs subregion and the sparse data available from $\mathrm{C} 3103$ (through the footprint of the B-7-A Crib), it is doubtful that these cribs are the source of elevated technetium-99 in the CCUz unit.

The third significant source of the contaminants in the B-Complex groundwater is the B-7-A\&B/B-8 Cribs subregion. It appears that the deep vadose zone of one or both of these facilities is supplying most of the chromium, some of the sodium, and likely some of the nitrate, that has been entering the groundwater over the last two decades. It is also likely that these two facilities contributed the same contaminants in the mid 1950s through 1960s. Sufficient data to separate the individual impacts of each of these facilities is lacking. No sediment characterization data are available for the B-8 Crib and Tile Field, and the sediment data for the B-7-A Crib footprint stopped at the top of the CCUz unit. The spectral gamma and historical gross-gamma field surveys are also inconclusive on definitively addressing the extent of lateral spreading, and whether wastes from these two facilities reached groundwater and when. The soil electrical resistivity field survey results seem to conflict with some of the gamma logging interpretations by suggesting commingling of the vadose zone waste plumes from all the facilities in this subregion (B-7-A\&B Cribs, B-8 Crib and Tile Field, and B-11-A\&B and B-51 French Drains). The soil electrical resistivity field survey interpretation was that the commingled plumes did reach groundwater. The CCUz unit is very thick below much of this region but does thin and pinch out to the north and east. For example, the entire B-7-A\&B Crib footprint has thick CCUz sediments as does the B-11-B French drain, but much of the B-8 Tile Field appears to have no CCUz sediments below. Thickness of the CCUz unit below the B-11-A French Drain is not established because of poor sampling and records. Because this stratum is highly effective at promoting lateral spreading, which can restrict contaminants from reaching the water table, more vadose zone characterization of the stratigraphy and contaminant distribution would be required to create a more defensible conceptual model. The groundwater plume time series plots do suggest strongly that that one or both of these two facilities (B-7-A\&B and B-8 Cribs) are contributing chromium and sodium (and although not presented in plume maps; nitrate) to the groundwater in the last two decades. The SIM estimates (see Table 3.25) of the masses of chromium, sodium, and nitrate disposed of to these cribs and the volumes of waste disposed of are significant such that they likely are contributing sources for these contaminants to the groundwater plume. 



\subsection{Description of Potential for Future Groundwater Impacts}

Based on the inventory estimates for technetium-99 and uranium currently residing in the vadose zone, especially the deep vadose zone, there is a high potential for continued and future undesirable impacts to the groundwater below the B-Complex, as well as to regions to the northwest where the current groundwater plumes are migrating.

The vadose zone estimates of residual technetium-99 and uranium in subregions that appear to be providing these two contaminants (along with nitrate, cyanide, chromium, sodium, and sulfate) are provided in Sections 3.1.9 (for the BY Cribs subregion); 3.3.10 (for the B-7-A\&B/B-8 sub-region); and 3.4.4 (for the BX-BY WMA subregion). These vadose zone residual mass estimates were also compared with the mass estimates for the entire B-Complex groundwater plume in Sections 6.1, 6.3 and 6.4. The mass-estimate comparisons in Section 6 also discussed mass-balance calculations where the sum of estimates of residual mass in the vadose zone and groundwater were compared to the total mass estimates disposed to each subregion. These mass-balance calculations allow for the evaluation of whether the estimate is good (close agreement and all mass accounted for) or whether significant mass is unaccounted for. When significantly more mass is found in the summed estimate than the SIM inventory for disposal to a subregion, the mass balance estimate is considered an over estimate of the residual mass in the vadose zone because the authors of this report believe that the SIM estimates of mass disposed are more accurate than the mass calculated from available vadose zone and groundwater data sets.

For technetium-99 that was present in the groundwater prior to 1993, when groundwater technetium99 measurements began, there was no objective way to calculate the mass that left the B-Complex. Thus, having mass of technetium-99 unaccounted for in the current mass balances can either be attributed to mass that escaped in pre-1993 groundwater or to inaccurate estimates in the vadose zone residual models. It would take more vadose zone borehole drilling and sampling to improve the residual mass estimates. The same issue arises for the related contaminants (cyanide, nitrate, and chromium) that were not measured in the groundwater samples taken in the mid 1940s through early 1990s. Well coverage was also an issue before the early 1990s, even when specific contaminants were being measured in the wells sampled. As mentioned, the uranium from the 1951 BX-102 tank overfill event probably did not start entering the groundwater below the B-Complex before the early 1990s such that no uranium mass likely escaped the region before the groundwater monitoring network and regular sample measurement activities were in place. Thus, any mass-balance imbalances in the cited uranium estimates are believed to be caused by inaccurate residual vadose zone conceptual models.

Although the degree of lateral spreading of contaminants in the vadose zone sediments, especially within the deep vadose zone (within 90 feet of the water table), is the most tenuous piece of the mass balance, there is direct evidence that contamination has reached the deep vadose zone and has been entering the water table near the three sources noted above. As discussed in Section 6, the mass balance estimates show that the sum of the technetium-99 mass deep below the BY Cribs and in the $\mathrm{CCU}_{\mathrm{z}}$ sediments below 299-E33-343 to 299-E33-345 are larger (3 to $20 \mathrm{Ci}$ ) than the estimated mass of technetium-99 currently in the groundwater plume below the entire B-Complex and its extension out beyond Gable Gap $(6.06 \mathrm{Ci})$. The same can be stated for the mass of water extractable (mobile) uranium below the region northeast of Tank BX-102. The estimate of mobile uranium deep in the vadose zone in this region is 1620 to $1700 \mathrm{~kg}$ versus $22.3 \mathrm{~kg}$ currently in the groundwater plume. Succinctly, Section 6 shows there may be up to 3 times more technetium-99 in the deep vadose sediments than is currently 
present in the technetium-99 groundwater plume and $\sim 75$ times as much mobile uranium in the deep vadose zone than is present in the current uranium groundwater plume. These mass estimates suggest that, in the future, there is potential for continued replenishment and perhaps increasing rates of mass flux of these two contaminants to the water table if no actions are taken.

An estimate of the time it will take for the contaminants in the deep vadose zone to reach the water table was not within the scope of this report. Impacts to groundwater for the continued movement of vadose zone contamination into the groundwater can be assessed using multidimensional reactive transport codes that can accommodate highly anisotropic unsaturated water flow through the deep vadose zone. For uranium modeling, the transport code should also have capabilities to describe kinetically controlled uranium release from several types of subsurface sediments. Provided in this document (see Section 8 and Appendix C) are recommended values for some of the input parameters and boundary conditions to support site-specific computer-based transport analyses. 


\subsection{Tables Listing Recommended Values and Ranges}

\subsection{Geology (thicknesses and areal extent of each layer)}

The contact elevations between each stratigraphic layer and the thicknesses of each layer are shown pictorially in Appendix B. The wells used and elevations (in $\mathrm{ft}$ ) for the contacts between strata chosen to represent the geology and to construct the 3D visualization are found in Table 8.1. To access the 3D visualization information that is stored in the EarthVision ${ }^{\circledR}$ software package, contact Paul Thorne at (509) 371-7220 or by email at paul.thorne@pnl.gov.

Table 8.1. Details on Geologic Contacts

\begin{tabular}{|c|c|c|c|c|c|c|c|c|c|c|c|}
\hline \multirow[b]{2}{*}{ Well Name } & \multirow[b]{2}{*}{$\begin{array}{l}\text { Ground } \\
\text { Surface } \\
\text { Elev. (ft) }\end{array}$} & \multicolumn{10}{|c|}{ Depth (ft) Below Ground Surface at Time of Drilling } \\
\hline & & Backfill & $\mathrm{H} 1$ & $\mathrm{H} 2$ & $\mathrm{H} 3$ & $\begin{array}{l}\mathrm{H} 2 \mathrm{~F} 1 \\
\left(\sim 70^{\prime}\right)\end{array}$ & $\begin{array}{c}\mathrm{H} 2 \mathrm{~F} 2 \\
\left(\sim 120^{\prime}\right)\end{array}$ & $\begin{array}{c}\text { H2F3 } \\
\left(\sim 170^{\prime}\right) \\
\end{array}$ & $\mathrm{CCUz}$ & $\mathrm{CCUg}$ & Basalt \\
\hline 299-E27-16 & 652.8 & $\mathrm{np}$ & 0 & & & & & 174 & $\mathrm{np}$ & 205 & 269 \\
\hline 299-E28-8 & 670.1 & 0 & 3 & 17 & 223 & & & & 301 & 301 & 301 \\
\hline 299-E33-1A & 632.9 & np & 0 & 23 & $\mathrm{np}$ & & 110 & & $\mathrm{np}$ & 212 & NDE \\
\hline 299-E33-2 & 630.7 & 0 & $\mathrm{np}$ & 18 & $\mathrm{np}$ & & & 145 & np & 185 & 234.5 \\
\hline 299-E33-3 & 623.6 & $\mathrm{U}$ & & & $\mathrm{np}$ & & & & $\mathrm{U}$ & 188 & 231 \\
\hline 299-E33-4 & 628.7 & $\mathrm{U}$ & & & $\mathrm{np}$ & & & & np & 190 & 231 \\
\hline 299-E33-5 & 632.3 & 0 & 25 & 50 & $\mathrm{np}$ & & & & $\mathrm{U}$ & 185 & 236 \\
\hline 299-E33-6 & 631.3 & 0 & 10 & 20 & $\mathrm{np}$ & & & & U & 193 & 229 \\
\hline 299-E33-7 & 625.7 & 0 & 15 & 50 & $\mathrm{np}$ & & & & $\mathrm{U}$ & 192 & 230 \\
\hline 299-E33-8 & 650.8 & np & 0 & 25 & $\mathrm{np}$ & & 124 & & np & 224 & 257 \\
\hline 299-E33-9 & 653.5 & 0 & 35 & 53 & $\mathrm{np}$ & & & 170 & np & 200 & 263 \\
\hline 299-E33-10 & 674.2 & np & 0 & 57 & $\mathrm{np}$ & & & & np & 206 & 287 \\
\hline 299-E33-11 & 622.2 & np & 0 & 9 & $\mathrm{np}$ & & & 166 & np & 195 & 226.5 \\
\hline 299-E33-12 & 624.3 & np & 0 & 20 & $\mathrm{np}$ & & & 150 & np & 185 & 232 \\
\hline 299-E33-13 & 629.5 & np & 0 & 17 & $\mathrm{np}$ & 85 & & 150 & $\mathrm{U}$ & 185 & 235 \\
\hline 299-E33-14 & 623.4 & np & 0 & 20 & $\mathrm{np}$ & & & & 166 & 169 & 228 \\
\hline 299-E33-15 & 628.1 & 0 & np & 19 & np & & & & np & 170 & 238.5 \\
\hline 299-E33-16 & 637.6 & 0 & np & 24 & $\mathrm{np}$ & & & & 203 & 229 & 246.5 \\
\hline 299-E33-17 & 635.4 & np & 0 & 20 & $\mathrm{np}$ & & & & 200 & 205 & 242.5 \\
\hline 299-E33-18 & 646.6 & 0 & 2.5 & 38 & $\mathrm{np}$ & & & & 218 & 243 & 265.3 \\
\hline 299-E33-19 & 640.3 & np & 0 & 31 & $\mathrm{np}$ & & & & 216 & 232 & 257 \\
\hline 299-E33-20 & 642.4 & np & 0 & 33 & $\mathrm{np}$ & 90 & & & $\mathrm{U}$ & 219 & 254 \\
\hline 299-E33-21 & 667.4 & np & 0 & 42 & $\mathrm{np}$ & & & & np & 220 & 279 \\
\hline 299-E33-22 & 631.1 & 0 & np & 20 & $\mathrm{np}$ & & & & np & 198 & NDE \\
\hline 299-E33-23 & 629.2 & 0 & 15 & 17 & $\mathrm{np}$ & & 110 & & np & 192 & NDE \\
\hline 299-E33-24 & 638.3 & np & 0 & 30 & $\mathrm{np}$ & & & & np & 197 & 244 \\
\hline 299-E33-25 & 631.1 & np & 0 & 20 & $\mathrm{np}$ & & & & np & & 235 \\
\hline 299-E33-26 & 633.7 & $\mathrm{np}$ & 0 & 20 & $\mathrm{np}$ & & & & np & 230 & 239 \\
\hline 299-E33-27 & 659.4 & $\mathrm{U}$ & & 44 & $\mathrm{np}$ & & & & $\mathrm{U}$ & 242 & NDE \\
\hline 299-E33-31 & 647.7 & $\mathrm{np}$ & 0 & 50 & $\mathrm{np}$ & 85 & & & 202 & 205 & 255.6 \\
\hline 299-E33-32 & 660.2 & np & 0 & 33 & $\mathrm{np}$ & 75 & 117 & & 220 & 230 & 269 \\
\hline 299-E33-33 & 640.7 & $\mathrm{np}$ & 0 & 37 & $\mathrm{np}$ & & & 157 & 202 & 216 & 252 \\
\hline 299-E33-36 & 647.2 & np & 0 & 28 & $\mathrm{np}$ & & & & 203 & 204 & 263.8 \\
\hline 299-E33-37 & 653.5 & np & 0 & 26 & $\mathrm{np}$ & & & 177 & $\mathrm{np}$ & 197 & 267.5 \\
\hline 299-E33-38 & 633.3 & np & 0 & 13 & $\mathrm{np}$ & & & & 189 & 189.5 & 238 \\
\hline 299-E33-39 & 623.8 & np & 0 & 8 & $\mathrm{np}$ & & & 157 & np & 187 & 229.5 \\
\hline 299-E33-40 & 624.6 & np & 0 & 49 & $\mathrm{np}$ & & & & 190 & 195 & 228 \\
\hline 299-E33-41 & 654.8 & np & 0 & 33 & $\mathrm{np}$ & 73 & 123 & 164 & 218 & 242 & 262.7 \\
\hline
\end{tabular}


Table 8.1. Details on Geologic Contacts

\begin{tabular}{|c|c|c|c|c|c|c|c|c|c|c|c|}
\hline \multirow[b]{2}{*}{ Well Name } & \multirow[b]{2}{*}{$\begin{array}{l}\text { Ground } \\
\text { Surface } \\
\text { Elev. }(\mathrm{ft})\end{array}$} & \multicolumn{10}{|c|}{ Depth (ft) Below Ground Surface at Time of Drilling } \\
\hline & & Backfill & H1 & $\mathrm{H} 2$ & H3 & $\begin{array}{l}\mathrm{H} 2 \mathrm{~F} 1 \\
\left(\sim 70^{\prime}\right)\end{array}$ & $\begin{array}{l}\text { H2F2 } \\
\left(\sim 120^{\prime}\right)\end{array}$ & $\begin{array}{l}\text { H2F3 } \\
\left(\sim 170^{\prime}\right)\end{array}$ & $\mathrm{CCUz}$ & CCUg & Basalt \\
\hline 299-E33-42 & 654.2 & np & 0 & 28 & $\mathrm{np}$ & 92 & & 147 & np & 238 & 260 \\
\hline 299-E33-43 & 662.5 & np & 0 & 42 & $\mathrm{np}$ & & & & 210 & 225 & NDE \\
\hline 299-E33-44 & 643.1 & 0 & 9 & 23 & $\mathrm{np}$ & 69 & 121 & 165 & 204 & 210 & 247.5 \\
\hline 299-E33-45 & 656.8 & 0 & 9 & 34 & $\mathrm{np}$ & 72 & 120 & 168 & 218 & 239 & NDE \\
\hline 299-E33-46 & 657.3 & 0 & 10 & 38.5 & $\mathrm{np}$ & 69.7 & 129 & 168 & 215 & 228 & NDE \\
\hline 299-E33-47 & 648.8 & 0 & $\mathrm{np}$ & 47 & $\mathrm{np}$ & & & 164 & 209 & 221 & 258 \\
\hline 299-E33-48 & 664.7 & 0 & 16 & 36 & $\mathrm{np}$ & 75 & 128 & & 211 & 212 & 285.5 \\
\hline 299-E33-49 & 666.8 & 0 & & 49 & $\mathrm{np}$ & 70 & & 165 & np & 217 & 283.5 \\
\hline 299-E33-50 (F) & 625.8 & $\mathrm{np}$ & 0 & 11 & $\mathrm{np}$ & 82 & 120 & 149 & $\mathrm{U}$ & 187.5 & 233.6 \\
\hline 299-E33-205 (C) & 657.2 & 0 & 2 & 31 & $\mathrm{np}$ & & 124 & 167 & 220 & 238 & 267 \\
\hline 299-E33-296 & 632.4 & 0 & 17.5 & 19 & $\mathrm{np}$ & & 116 & & 190 & 191.5 & NDE \\
\hline 299-E33-302 & 628.8 & 0 & 17 & 18 & $\mathrm{np}$ & & & & 190 & 191 & NDE \\
\hline 299-E33-304 & 640.3 & 0 & 16.5 & 26 & $\mathrm{np}$ & & & & 197.3 & 198 & NDE \\
\hline 299-E33-333 & 653.4 & 0 & 11 & 30 & $\mathrm{np}$ & & & 174 & $\mathrm{np}$ & 212 & NDE \\
\hline 299-E33-334 & 667.0 & $\mathrm{np}$ & 0 & 51 & $\mathrm{np}$ & 61.5 & 121 & 151 & 220 & 221 & 280 \\
\hline 299-E33-335 & 667.4 & np & 0 & 52 & $\mathrm{np}$ & 73 & 124 & 160 & 215 & 224 & 280.5 \\
\hline 299-E33-337 & 662.7 & np & 0 & 55 & $\mathrm{np}$ & 71 & 120 & & np & 215 & 281 \\
\hline 299-E33-338 & 657.0 & np & 0 & 51 & $\mathrm{np}$ & & 106 & 170 & 213 & 222 & 271 \\
\hline 299-E33-339 & 663.7 & 0 & 6 & 54 & $\mathrm{np}$ & & & 169 & $\mathrm{np}$ & 222 & 279 \\
\hline 299-E33-340 (G) & 617.9 & np & 0 & 33 & $\mathrm{np}$ & 95 & 131 & & 210 & 211 & 226.1 \\
\hline 299-E33-341 (D) & 627.5 & np & 0 & 40 & $\mathrm{np}$ & 83 & 105 & & 187 & 191 & 232.5 \\
\hline 299-E33-342 (E) & 636.9 & 0 & 7 & 13 & $\mathrm{np}$ & & 116 & 142 & $\mathrm{np}$ & 190 & 242.4 \\
\hline 299-E33-343 (A) & 652.3 & np & 0 & 37 & $\mathrm{np}$ & 77 & 120 & 165 & 212 & 239 & 260.9 \\
\hline 299-E33-345 (Br) & 653.2 & 0 & 15 & 36 & $\mathrm{np}$ & & 120 & 165 & 217 & 244 & 260.3 \\
\hline C3103 & 652.8 & 0 & 23 & 35 & $\mathrm{np}$ & & & 168 & 217 & NDE & NDE \\
\hline C3104 & 662.7 & 0 & 1 & 30.5 & $\mathrm{np}$ & 71 & 110 & & 216 & 220 & NDE \\
\hline \multicolumn{12}{|c|}{$\begin{array}{l}\text { Letter in "( )" is original temporary well designation in planning documents. } \\
\mathrm{NDE}=\text { Not deep enough } \\
\mathrm{np}=\text { not present } \\
\mathrm{U}=\text { uncertain }\end{array}$} \\
\hline
\end{tabular}

\subsection{Hydrologic Parameters (by Geologic Layer) and Recharge}

The recommended values for hydrologic parameters and recharge for future B-Complex fate and transport modeling activities using the RESRAD code are found in Table 8.2. For modeling activities using a more robust and/or a multidimensional code, such as STOMP, additional useful information can be found in Section 4 and Appendix C.

Table 8.2. Hydrologic Parameters for RESRAD

\begin{tabular}{ccccccccccc}
\hline $\begin{array}{c}\text { Stratigraphic } \\
\text { Unit }\end{array}$ & $\mathrm{a}(1 / \mathrm{cm})$ & $\mathrm{n}(-)$ & $\begin{array}{c}\theta_{\mathrm{r}} \\
\left(\mathrm{cm}^{3} / \mathrm{cm}^{3}\right)\end{array}$ & $\begin{array}{c}\theta_{\mathrm{s}} \\
\left(\mathrm{cm}^{3} / \mathrm{cm}^{3}\right)\end{array}$ & $\begin{array}{c}\mathrm{K}_{\mathrm{s}} \\
(\mathrm{cm} / \mathrm{s})\end{array}$ & $\begin{array}{c}\rho_{\mathrm{b}} \\
\left(\mathrm{g} / \mathrm{cm}^{3}\right)\end{array}$ & $\begin{array}{c}\theta_{\mathrm{fc}} \\
\left(\mathrm{cm}^{3} / \mathrm{cm}^{3}\right)\end{array}$ & $\mathrm{b}(-)$ & $\mathrm{A}_{\mathrm{L}}(\mathrm{cm})$ & $\mathrm{A}_{\mathrm{T}}(\mathrm{cm})$ \\
\hline Backfill & 0.0061 & 1.571 & 0.01 & 0.121 & $3.08 \mathrm{E}-04$ & 2.15 & 0.0775 & 2.62 & 150 & 15 \\
H1 & 0.0073 & 1.597 & 0.018 & 0.121 & $2.20 \mathrm{E}-04$ & 2.07 & 0.0741 & 3.15 & 100 & 10 \\
H2 & 0.0157 & 1.888 & 0.031 & 0.252 & $1.18 \mathrm{E}-04$ & 1.77 & 0.0842 & 2.29 & 150 & 15 \\
all H2F lenses & 0.0068 & 1.786 & 0.023 & 0.334 & $9.31 \mathrm{E}-05$ & 1.85 & 0.1627 & 2.00 & 50 & 5 \\
CCUz & 0.0046 & 1.767 & 0.025 & 0.376 & $1.22 \mathrm{E}-05$ & 1.65 & 0.2644 & 1.94 & 50 & 5 \\
CCUg & 0.0061 & 1.571 & 0.01 & 0.121 & $3.08 \mathrm{E}-04$ & 2.15 & 0.0775 & 2.62 & 150 \\
\hline
\end{tabular}




\section{3 $\mathrm{K}_{\mathrm{d}}$ Values and Ranges (by Geologic Layer)}

The traditional method used to represent the interactions of dissolved contaminants (solutes) present in waste fluids disposed of to the subsurface with soils and sediments is the $\mathrm{K}_{\mathrm{d}}$ construct. The proper use of the $\mathrm{K}_{\mathrm{d}}$ construct requires adherence to several key geochemical restrictions (see discussions in EPA 1999a; Cantrell et al. 2002, 2007). It is beyond the scope of this conceptual model report to instruct potential end users in the proper use of the $\mathrm{K}_{\mathrm{d}}$ construct; however, the following quote from a recent report, Last et al. (2009), that assembles Hanford specific data to use in the RESRAD code to replace the generic default values is presented as a useful caveat.

"It should be noted that defining the $\mathrm{K}_{\mathrm{d}}$ value as the mass of solute adsorbed or precipitated on the soil (per unit of dry mass) to the solute concentration in the liquid, as done in the RESRAD model (Yu et al. 2001), is a simplification of the geochemical transport process. Under certain specific conditions, the linear sorption model $\left(\mathrm{K}_{\mathrm{d}}\right)$ can provide an accurate representation of adsorption (Cantrell et al. 2002). However, if precipitation has occurred during the measurement of the $K_{d}$ value, or if a $K_{d}$ value measured in the absence of precipitation is used to represent a situation in which precipitation has occurred, the model results will be highly uncertain. This is because precipitation and dissolution are not linear processes as required by the assumptions inherent in the linear distribution coefficient $\left(\mathrm{K}_{\mathrm{d}}\right)$ model."

Despite the limitations of the $\mathrm{K}_{\mathrm{d}}$ construct to evaluate near-field waste disposal conditions in environments that exhibit contaminant precipitation, such as the vadose zone sediment-pore water northeast of the BX-102 tank, it is common to continue to use the $\mathrm{K}_{\mathrm{d}}$ construct in scoping calculations. With this "reality" in mind, the following B-Complex site-specific $\mathrm{K}_{\mathrm{d}}$ values for each geologic strata identified in the geological conceptual model are found in Table 8.3. In general, the $\mathrm{K}_{\mathrm{d}}$ values presented in Table 8.3 agree with the Hanford specific values presented in Table 6.9 in Last et al. (2009), which also provides adequate instructions for performing scoping calculations for contaminant transport using RESRAD.

Also included in Table 8.3 are values for cyanide because this constituent was not covered in Last et al. (2009. Some new site-specific sediment-pore water interaction information (Brown et al. 2007) on uranium from the metal waste stream that was released from Tank BX-102 is provided. The Table 8.3 uranium $\mathrm{K}_{\mathrm{d}}$ also places more weight on past efforts to calculate in situ $\mathrm{K}_{\mathrm{d}}$ values directly from characterization of sediments from near the BX-102 Tank that are found in Table 4.17 in Serne et al. (2002b).

The values listed in Table 8.3 attempt to follow the guidance given by DOE/RL (2007b) that was intended to assist operable unit managers in choosing contaminant-partitioning coefficients. The gist of their guidance follows. DOE/RL (2007a, p. 4-17) suggested that parameters used for base-case flow and transport modeling should represent best-estimate values for the actual site conditions and properties and, if possible, should incorporate a moderate bias toward the conservative side of site-specific "bestestimate" values such that the assessment models would then yield conservative and/or upper-bounding estimates of risk. Conservative values are those that increase potential groundwater contamination estimates relative to similar estimates resulting from the selection of different but plausible values.

The user community is cautioned that a conservative $\mathrm{K}_{\mathrm{d}}$ for groundwater protection would be the selection of a lower value from the available choices. However, when using the $\mathrm{K}_{\mathrm{d}}$ construct to evaluate 
release of contaminants from contaminated sediments for remediation purposes that rely on flushing the contaminant out of the sediment, a conservative $\mathrm{K}_{\mathrm{d}}$ would be the selection of a higher value from the available choices. This reversal is caused by the equilibrium relationship that defines the $\mathrm{K}_{\mathrm{d}}$. With a high $\mathrm{K}_{\mathrm{d}}$, more of the contaminant in a representative volume of sediment and pore water remains associated with the sediment. This is good for slowing the migration of the contaminant out of the representative volume towards a receptor. For remediation, one wishes just the opposite and desires that the contaminant be removed from the sediment into a solution that is then extracted from the subsurface and treated. If one chooses a low $\mathrm{K}_{\mathrm{d}}$ value, the efficacy of water extraction-based remediations will be unrealistically predicted to be more effective than they will be in reality. If the remediation technique relies on promoting additional sequestration of the contaminant in place on the sediment, such as promoting uranium precipitation as an insoluble phosphate solid phase, then the conservative approach is to use the lower $K_{d}$ value or better yet a solubility activity product.

Another caution regarding the use of solubility constructs to predict fate and transport is that choosing a constant concentration value for the contaminant is not always appropriate. Thermodynamic solubility products $\left(\mathrm{K}_{\mathrm{sp}}\right)$ are in fact constant, but they do not equate to a constant concentration for each species that constitutes the solubility product. Simple fate and transport modelers at times mistakenly use a constant concentration for a contaminant to predict fate and transport for situations where the chemical environment is changing such that the concentration of the contaminant can increase significantly while the chosen solid phase bearing the contaminant remains present. However, other ligands in the solubility product drop in concentration such that the contaminant's concentration will increase driven by the requirement to keep the $\mathrm{K}_{\mathrm{sp}}$ constant.

A significant portion of the uranium present in the vadose zone sediments surrounding Tank BX-102 is found as discrete uranium precipitates such as alkali and alkaline-earth uranyl silicates and coprecipitates (Catalano et al. 2004; Ilton et al. 2008; Liu et al. 2004 and 2006; McKinley et al. 2006; Reeder et al. 2000, 2001; Wang et al. 2005; Zachara et al. 2007a,b; and Wan et al. 2009). These discrete uranium solid phases dissolve relatively slowly when waters with lower dissolved uranium, sodium, calcium, sulfate, and carbonate flow by the precipitated solids. Simple fate and transport models cannot easily address the dynamic coupled chemical equations that are needed to properly predict the resultant uranium concentration in solution. Even thermodynamically based equilibrium ion-speciation codes that can accommodate solubility-precipitation, oxidation-reduction, classical ion-exchange, and surface complexation reactions explicitly, often fail to give accurate predictions because they ignore the slow kinetics. Technically defensible predictions of the fate of the uranium in the vadose zone sediments below the B-Complex proximal and northeast of Tank BX-102 will be a challenge. 
Table 8.3. Recommended Values and Ranges for Mobile Contaminants in Vadose Zone for B-Complex

\begin{tabular}{|c|c|c|c|c|c|c|c|c|c|c|c|c|}
\hline \multicolumn{13}{|c|}{ Vadose Zone Sediments } \\
\hline & & & & $2 \mathrm{~F} 1, \mathrm{H} 2 \mathrm{~F}$ & & & & & & $\mathrm{H} 2 \mathrm{~F} 1, \mathrm{H} 2 \mathrm{~F}$ & & \\
\hline Strata & Back-fill & $\mathrm{H} 1$ & $\mathrm{H} 2$ & , H2F3 & $\mathrm{CCU}_{\mathrm{z}}$ & $\mathrm{CCU}_{\mathrm{g}}$ & Back-fill & $\mathrm{H} 1$ & $\mathrm{H} 2$ & 2, H2F3 & $\mathrm{CCU}_{\mathrm{z}}$ & $\mathrm{CCU}_{\mathrm{g}}$ \\
\hline Constituent & \multicolumn{6}{|c|}{ Best Estimate $(\mathrm{mL} / \mathrm{g})$} & \multicolumn{6}{|c|}{ Range $(\mathrm{mL} / \mathrm{g})$} \\
\hline $\mathrm{NO}_{3}, \mathrm{NO}_{2}$ & 0 & 0 & 0 & 0 & 0 & 0 & 0 to 0.01 & 0 to 0.01 & 0 to 0.01 & 0 to 0.02 & 0 to 0.02 & 0 to 0.01 \\
\hline Cyanide $^{(a)}$ & 0 & 0 & 0 & 0 & 0 & 0 & 0 to 0.1 & 0 to 0.1 & 0 to 0.1 & 0 to 0.2 & 0 to 0.2 & 0 to 0.1 \\
\hline $\mathrm{F}$ & 0 & 0 & 0 & 0 & 0 & 0 & 0 to 0.03 & 0 to 0.05 & 0 to 0.1 & 0 to 0.2 & 0 to 0.2 & 0 to 0.05 \\
\hline $\mathrm{Cr}(\mathrm{VI})$ & 0 & 0 & 0 & 0 & 0 & 0 & 0 to 0.1 & 0 to 0.1 & 0 to 0.1 & 0 to 0.2 & 0 to 0.2 & 0 to 0.1 \\
\hline $\mathrm{Co}-60^{(\mathrm{a})}$ & 0 & 0 & 0 & 0 & 0 & 0 & 0 to 0.1 & 0 to 0.2 & 0 to 0.2 & 0 to 0.3 & 0 to 0.3 & 0 to 0.1 \\
\hline Tc-99 & 0 & 0 & 0 & 0 & 0 & 0 & 0 to 0.01 & 0 to 0.01 & 0 to 0.03 & 0 to 0.1 & 0 to 0.1 & 0 to 0.01 \\
\hline I-129 & 0 & 0.01 & 0.02 & 0.02 & 0.02 & 0.01 & 0 to 0.05 & 0 to 0.1 & 0 to 0.2 & 0 to 0.2 & 0 to 0.2 & 0 to 0.1 \\
\hline $\mathrm{U}^{(\mathrm{b})}$ & 0 & 0.5 & 1 & 100 & 100 & 1 & 0 to 10 & 0 to 2 & 0 to 5 & 0 to 200 & 0 to 200 & 0 to 2 \\
\hline $\mathrm{U}^{(\mathrm{c})}$ & 0 & 0.3 & 0.8 & 1.5 & 1.5 & 0.26 & 0 to 3 & 0 to 3 & 0 to 10 & 0 to 10 & 0 to 10 & 0 to 2 \\
\hline
\end{tabular}

Aquifer sediments are in general gravel dominated $\mathrm{CCU}_{\mathrm{g}}$ solids and the groundwater composition is more dilute than vadose zone pore water. Strata

\begin{tabular}{|c|c|c|}
\hline $\mathrm{NO}_{3}, \mathrm{NO}_{2}$ & $0^{\text {(d) }}$ & 0 to 0.01 \\
\hline Cyanide $^{(a)}$ & 0 & 0 to $0.1^{(\mathrm{e})}$ \\
\hline $\mathrm{F}$ & 0 & 0 to 0.05 \\
\hline $\mathrm{Cr}(\mathrm{VI})$ & $0^{(\mathrm{d})}$ & 0 to 0.1 \\
\hline $\mathrm{Co}-60^{(\mathrm{a})}$ & 0 & 0 to 0.1 \\
\hline Tc-99 & $0^{(\mathrm{d})}$ & 0 to 0.01 \\
\hline $\mathrm{I}-129$ & 0.01 & 0 to $0.1^{(\mathrm{e})}$ \\
\hline $\mathrm{U}^{(\mathrm{b})}$ & 0.015 & 0 to $0.025^{(\mathrm{f})}$ \\
\hline $\mathrm{U}^{(\mathrm{c})}$ & $0.26^{(\mathrm{d})}$ & 0 to 2 \\
\hline \multicolumn{3}{|c|}{ (a) values for cyanide and cobalt-60 assume that they are complexed as follows: $\mathrm{Fe}(\mathrm{CN})_{6}^{4-}$ and some cobalt-ferrocyanide complex not specified/identified. } \\
\hline \multicolumn{3}{|c|}{ (c) values for uranium are for all the other types of uranium-bearing waste streams disposed of in the B-Complex. } \\
\hline \multicolumn{3}{|c|}{ (d) Same value as Last et al. (2009) recommends for gravel-dominated aquifer sediments and groundwater (see Table 6.9 in Last et al.). } \\
\hline \multicolumn{3}{|c|}{ (e) Includes value recommended by Last et al. (2009) in the range. } \\
\hline \\
\hline
\end{tabular}





\subsection{Summary}

This report offers conceptual models for the distribution of two key risk-driver groundwater contaminants, technetium-99 and uranium, within the B-Complex region in the vadose zone down to the water table. It also presents information on where the plumes migrate. In addition, the report provides estimates for the mass of technetium-99 and uranium that remain in the vadose zone sediments and within the current groundwater plumes. The mass of cyanide in groundwater was also estimated, but the cyanide remaining in the vadose zone sediment could not be evaluated because the data are too sparse. The estimated masses remaining in the vadose zone and currently present in the groundwater plumes originating below the B-Complex are compared to the estimates of the total masses disposed of or released to the B-Complex subsurface since the beginning of the waste disposal activities. These massbalance estimates provide baseline information on two key issues:

1) How well has the mass (and thus distribution in the vadose zone and aquifer) of the contaminant been identified?

2) Can the contaminant mass distribution in the deep vadose zone and aquifer be used to project future risks and guide the selection of remediation alternatives?

In addition, a current geologic stratigraphy conceptual model and hydrologic and geochemical input parameters needed for fate and transport predictive modeling are provided. The hydrologic and geochemical values (most plausible and $\mathrm{min} / \mathrm{max}$ ranges) provided can be used as input to various fate and transport codes.

The methodology used to create the conceptual models started with review and assembly of pertinent background information on the facilities that received the wastes. Key background information includes location of the facilities, period of operation, volumes of waste disposed, types of waste streams disposed, and total masses of constituents released to the vadose zone sediments. The second step was to assemble the available data on the distribution (vertical and lateral) in the vadose zone sediments of the key contaminants and species that control the mobility of the contaminants. Emphasis was placed on evaluating the distribution of technetium-99 and uranium. Distributions for chromium, cyanide, and nitrate were also evaluated. Plots of the available data for five subregions below the B-Complex were superimposed on cross sections of the stratigraphy, and available field surveys (gamma logs and soil resistivity) were used to aid in constructing models of the lateral and vertical extent of the key contaminants within the vadose zone. A similar effort was performed using the available groundwater monitoring data, with emphasis on the last decade, to develop time-series contaminant plume maps. Using a 3D aquifer conceptual model with $10 \mathrm{~m}$ by $10 \mathrm{~m}$ grid cells and the aquifer thicknesses from the geologic conceptual model, the mass of selected contaminants was calculated for the years 2000, 2003, 2006, and 2009. The masses within the groundwater plumes could then be calculated and compared to evaluate whether mass was increasing or decreasing over the last decade and where the mass appears to be entering the water table. The shapes of the groundwater plumes also revealed the net direction of flow of the groundwater. The vadose zone contaminant distribution data and groundwater data were then combined to create integrated conceptual models on where the bulk of the contaminants remain, where they enter the water table and how the plumes have migrated over the last decade. 
Some of the strengths and weaknesses or inconsistencies in the mass-balance estimates for the key contaminants for the conceptual models for each subregion are presented. Recommendations on additional activities that could be performed to resolve inconsistencies and to fill data gaps are also provided. The report includes a brief discussion of the potential for future groundwater impacts.

\subsection{Facilities Summary}

The key points from the review of facility history follow. A total of approximately 300 million liters of waste was released, either intentionally or unintentionally, into the subsurface below the B-Complex. Further, the groundwater underlying the B-Complex has been influenced by dilute wastewaters from the billions of liters disposed of to the B Pond and Gable Mountain Pond. There is little information on the volumes and timing for water lost from water-line leaks, and the volume of enhanced recharge from denuding the ground surface or from the use of gravel covers over the tank farms. All of these water sources likely promoted contaminant migration within the vadose zone.

The largest volumes of waste fluids that were disposed of to the B-Complex occurred at the BY Cribs; however, the timing and types of waste disposed of to the BY Cribs had two distinct histories. In the 13-month time period between November 1954 and December 1955, seven of the BY Cribs received 33.8 million liters of fairly concentrated wastes from scavenging uranium and cesium-137 out of metal waste originally stored in SSTs. Then from January 1964 to January 1974, another 139 million liters of rather dilute waste from in-tank stabilization (ITS) processes was disposed of to two cribs in the BY Crib region. The chemical content of the ITS waste was insignificant compared to the wastes disposed of earlier, but the volume accounts for $80 \%$ of the total volume of liquid discharged to the BY Cribs. The substantial volume of ITS liquid wastes likely helped flush contaminants from the original scavenged wastes deeper into the vadose zone, with some mobile contaminants reaching the groundwater. The BY Cribs subregion received about $66 \%$ of the total volume of wastes disposed of to the entire BComplex; however, only $13 \%$ of the total volume disposed of to the B-Complex was the more concentrated scavenged waste type.

The B-7-A\&B/B-8 Cribs sub-region, which consists of the B-7-A\&B Cribs, B-8 Crib and Tile Field, and B-11-A\&B French Drains received 110 million liters of liquid waste over the period September 1946 to May 1967, with the most intense disposal occurring between 1948 and 1953. The only other two subregions that contributed more than $0.1 \%$ of the total waste volume disposed to the B-Complex are the BX Trenches with 14.9 million liters and the BX Tank Farm with 0.43 million liters. Table 9.1 shows the percentages of the total volume of waste disposed and the percent of mobile contaminants released to each subregion. The BY Cribs subregion received the most sodium (49\%), nitrate (51\%), sulfate (62\%), ferrocyanide (100\%), cobalt-60 (49\%), iodine-129 (79\%), and technetium-99 (89\%). The BY Cribs subregion contributed only $\sim 9 \%$ of the total uranium released in the B-Complex. The B-7-A\&B/B-8 Cribs subregion received $36 \%$ of the total sodium, $36 \%$ of the nitrate, $44 \%$ of the phosphate, $58 \%$ of the fluoride, and $62 \%$ of the chromium, but only $3.2 \%$ of the uranium and $0.1 \%$ of the technetium- 99 . The BX Tank Farm subregion accounts for $84 \%$ of the uranium, almost all contributed by the 1951 overfill event at Tank BX-102. In total, the three tank farms (B, BX, and BY) contributed less than $5 \%$ of the technetium-99 and insignificant percentages of the other mobile contaminants. The BX Trenches subregion received $80 \%$ of the nitrite disposed of in the B-Complex and about $15 \%$ of the sodium, nitrate, sulfate, fluoride, chromium, iodine-129, and tritium as well as $6 \%$ of the technetium- 99 . 
Table 9.1. Summary by Region of the Percentage Volume and Mass of Contaminants Disposed of

\begin{tabular}{|c|c|c|c|c|c|c|c|c|c|c|}
\hline Sub-region & $\begin{array}{c}\text { Vol Disposed } \\
(\%)\end{array}$ & $\begin{array}{l}\mathrm{NO}_{3} \\
(\%)\end{array}$ & $\begin{array}{l}\mathrm{F} \\
(\%)\end{array}$ & $\begin{array}{c}\mathrm{Fe}(\mathrm{CN})_{6} \\
(\%)\end{array}$ & $\begin{array}{l}\mathrm{U} \\
(\%)\end{array}$ & $\begin{array}{l}\mathrm{Cr} \\
(\%)\end{array}$ & $\begin{array}{c}\text { Co-60 } \\
(\%)\end{array}$ & $\begin{array}{r}\mathrm{I}-129 \\
(\%)\end{array}$ & $\begin{array}{c}\text { Tc-99 } \\
(\%)\end{array}$ & $\begin{array}{r}\mathrm{H}-3 \\
(\%)\end{array}$ \\
\hline BY Cribs (TBP) & $11.30 \%$ & $50 \%$ & $30 \%$ & $100 \%$ & $9 \%$ & $20 \%$ & $50 \%$ & $80 \%$ & $90 \%$ & $30 \%$ \\
\hline BY Cribs & $46.70 \%$ & $0 \%$ & $0 \%$ & $0 \%$ & $0 \%$ & $0.1 \%$ & $0.2 \%$ & $0.2 \%$ & $0.2 \%$ & $50 \%$ \\
\hline B-7-A\&B & $6.70 \%$ & $36 \%$ & $58 \%$ & $0 . \%$ & $3 \%$ & $62 \%$ & $3.4 \%$ & $0.3 \%$ & $0.1 \%$ & $2.4 \%$ \\
\hline BX Tr & $5.00 \%$ & $13 \%$ & $12 \%$ & $0 \%$ & $4.2 \%$ & $18 \%$ & $35 \%$ & $15 \%$ & $6 \%$ & $14 \%$ \\
\hline BX Tank Farm & $0.15 \%$ & $0 \%$ & $0 \%$ & $0 \%$ & $84 \%$ & $0.3 \%$ & $3 \%$ & $1 \%$ & $3 \%$ & $1 \%$ \\
\hline BY Tank Farm & $0.05 \%$ & $0 \%$ & $0 \%$ & $0 \%$ & $0 \%$ & $0.1 \%$ & $1.4 \%$ & $1 \%$ & $1.0 \%$ & $0.1 \%$ \\
\hline B Tank Farm & $0.08 \%$ & $0 \%$ & $0 \%$ & $0 \%$ & $0 \%$ & $0.1 \%$ & $8.3 \%$ & $4 \%$ & $1 \%$ & $1.1 \%$ \\
\hline
\end{tabular}

Red type delineates the major contributor for each constituent, and bold type delineates other significant contributors.

Based solely on volumes and percentages of the waste constituent inventory disposed of to each subregion, one would expect that the BY Cribs waste stream would be the major contributor to groundwater contamination for ferrocyanide, iodine-129, and technetium-99. If a significant portion of the large volume of more dilute wastewater that was disposed of in the mid 1960s to mid 1970s to two of the cribs in the BY region migrated laterally, it might have flushed residual fluids deeper and perhaps out of the vadose zone below the other seven cribs that received the concentrated waste. Based on the percentages of mass disposed of to the B-7 A\&B Cribs and the B-8 Crib and Tile Field, they would be the key contributors of fluoride, chromium, and some of the nitrate to the groundwater contamination below the B-Complex. If the relatively low volume (compared to the cribs and trenches) of the BX-102 tank overfill liquid was assisted in its migration down to groundwater, it would be considered the major contributor to B-Complex groundwater uranium contamination and a minor contributor to the groundwater technetium-99 contamination.

\subsection{Conceptual Model for Technetium-99 in the B-Complex}

The available sediment characterization data show that high concentrations of technetium reside deep in the vadose zone below the BY Cribs within both the Hanford formation $\mathrm{H} 2$ and the Cold Creek coarsegrained $\left(\mathrm{CCU}_{\mathrm{g}}\right)$ sediments. In the region of the BY Cribs, the fine-grained $\mathrm{CCU}_{\mathrm{z}}$ unit is absent to very thin (1 to $1.5 \mathrm{ft}$ thick). It appears that water (steady-state natural recharge or transient natural or maninduced) that is fluxing through these deep sediments is carrying the technetium-99 down to the water table. Concentrations of technetium-99 ranged from 120 to $200 \mathrm{pCi} / \mathrm{g}$ in the sediments within 90 feet of the water table (the deep vadose zone) under the BY Cribs subregion. Residual technetium-99 concentrations in deep vadose zone sediments at all other boreholes within or proximal to other inactive disposal facilities in the B-Complex in the same geologic units are at least one order of magnitude lower. However, at two new boreholes (299-E33-343 and -345) far from the footprints of B-Complex waste facilities, water extractable technetium-99 also reaches concentrations of $230 \mathrm{pCi} / \mathrm{g}$ in the $\mathrm{CCU}_{\mathrm{z}}$ unit. Based on the deep vadose zone sediment samples from below the BY Cribs' footprint and the assumption that the areas under all eight BY Cribs have similar concentrations of technetium-99, the deep vadose zone inventory is estimated to be between 3 and 20 curies. No other deep vadose zone regions below facility footprints, for which sediment data are available, calculate to have technetium- 99 masses greater than 1 curie. The $\mathrm{CCU}_{z}$ unit between boreholes 299-E33-343 and 299-E33-345 is estimated to contain $\sim 3.0$ to 3.5 curies of technetium-99. 
The BY Cribs are considered to be the most important source for the technetium-99 currently observed in the B-Complex groundwater, based on the high volume of waste disposed of at the BY cribs compared to any other facility, the lack of or thin manifestation of the $\mathrm{CCU}_{z}$ unit, and the observed high concentrations of technetium-99 in the deep vadose zone sediments. The time series groundwater plumes also show that the BY Cribs are the location where the high groundwater technetium-99 concentrations originate. The recent time series groundwater plume maps also show a second location near the new borehole 299-E33-343 where a small "hot spot" (high technetium-99 concentrations) has formed. This coincides with the occurrence of high concentrations of uranium in the $\mathrm{CCU}_{z}$ sediments at 299-E33-343. The source of this secondary elevated technetium-99 mass has not been determined absolutely. The simplest hypothesis is that the technetium-99 originated from the Tank BX-102 overfill and spread laterally with a vertical component driven by gravity. The vadose zone geology and gravity have facilitated technetium-99 transport into the very moist $\mathrm{CCU}_{\mathrm{z}}$ sediments, where it and uranium from Tank BX-102 migrate east all the way to 299-E33-345. It is also possible that technetium-99 from other SSTs in the B and BY Tank Farms may have reached the $\mathrm{CCU}_{z}$ unit to mix with the Tank BX-102 fluids near 299-E33-343.

Once the technetium-99 enters the water table at the two designated locations, it appears to be migrating towards the northwest and out of the B-Complex into the Gable Gap region. Given the fact that technetium-99 exhibits little to no sorptive tendencies with all Hanford Site sediments, its ultimate fate will be continued migration with the groundwater to the northwest out of the B-Complex with little to no retardation.

\subsection{Conceptual Model for the Uranium in the B-Complex}

The available sediment characterization data from borehole 299-E33-45 and spectral gamma logs from nearby dry wells show that high concentrations of Hanford processed uranium reside in the Hanford formation $\mathrm{H} 2$ unit from about 70 to $140 \mathrm{ft}$ to the east and northeast of the BX-102 tank. The vertical and lateral distribution of uranium south, east, and northeast of the tank was delineated with gamma logging surveys starting in the 1970 s on about 20 boreholes (see Figure 3.49 top panel). Farther to the north and northeast, a combination of new boreholes with multiple sediment analyses versus depth and field gamma logs show that high concentrations of Hanford processed uranium reside in the thick $\mathrm{CCU}_{\mathrm{z}}$ unit (total spread is depicted in Figure 3.49 bottom panel). The progression of the uranium down through the Hanford formation sediments to the $\mathrm{CCU}_{\mathrm{z}}$ unit follows the dip of the vadose zone sediments. Many of the sediment water extracts, pore waters obtained by ultracentrifugation, one perched water sample, and about a dozen groundwater samples taken from B-Complex monitoring wells as a function of time have been analyzed for uranium isotopic signatures. Using sediment samples obtained from near several other BComplex facilities, it has been determined that the uranium-236/238 and uranium-234/238 ratios for samples representing each facility's "source" or fingerprint are unique and distinguishable from each other. Assuming that other waste streams from other facilities for which no samples are available would have unique uranium isotope signatures, just as the four facilities that have been studied, one can hypothesize that the available data have conclusively identified the source of the deep vadose zone uranium. The fact that the highest concentrations of water-extractable uranium in the $\mathrm{CCU}_{\mathrm{z}}$ sediments occurs at borehole 299-E33-343 and that groundwater at this well has the highest concentration of uranium found below the entire B-Complex, the point of entry of the uranium into the aquifer is close by. It is hypothesized that the $\mathrm{CCU}_{z}$ fine-grained sediments in this region have become nearly saturated and thus the capillary break process that generally forces water to remain in the finer-grained unsaturated 
sediments and not to enter underlying much drier coarse-grained sediments has broken down at this location. Once the finer grained sediments saturate, water from them can descend into the coarser $\mathrm{CCU}_{\mathrm{g}}$ sediments below. The descending water can then easily reach the water table that resides $\sim 16 \mathrm{ft}$ below. Therefore, the pathway followed by the highly uranium-laden waste from Tank BX-102 was to travel laterally along fine-grained layers in the Hanford formation sediments with vertical descent by gravity and the natural stratigraphic dip to the northeast until the fluids reached the $\mathrm{CCU}_{\mathrm{z}}$ unit. Once within the $\mathrm{CCU}_{\mathrm{z}}$ unit, moisture content increased leading to lateral spreading towards the east. With the installation of well 299-E33-343 it appears that some of the high-uranium waste fluids have broken through the bottom of the $\mathrm{CCU}_{\mathrm{z}}$ unit, or exited out the edge on the northern flank, to quickly travel to the water table. Once in the unconfined aquifer, the uranium is moving to the northwest at a speed slightly slower than the groundwater itself. Using the uranium isotopic signature measurements on several groundwater samples taken over several years from wells in the uranium plume, Christensen et al. (2004) estimated the uranium migration rate at $\sim 0.7$ to $0.8 \mathrm{~m} /$ day compared to the apparent groundwater flow rate of $\sim 1 \mathrm{~m} /$ day.

The interaction of uranium with Hanford Site sediments has been studied intensely for the past 10 years and has been found to be quite complex. Recent findings are summarized in Cantrell et al. (2007), Zachara et al. (2007a,b), Wan et al. (2008), and tens of references cited therein. To accurately determine the rate and masses of uranium that will transport out of the deep vadose zone and into the aquifer to continue to supply more uranium into the groundwater plume would benefit from the use of sophisticated kinetically controlled algorithms. More discussion on transport modeling is found in Section 8 .

The following subsections summarize the key findings used to support the geologic, hydrologic, vadose zone contaminant distributions and residual mass estimates, uranium isotopic fingerprinting, and groundwater plume time series and mass estimates, all which were used to generate the conceptual models for technetium-99 and uranium just described in subsections 9.2 and 9.3. Each of these efforts was necessary to winnow the possible interpretations down to the most consistent and hopefully technically defensible conceptual models.

\subsection{Geology Model and Description}

The process of building the geologic conceptual model followed a series of investigative steps that were designed to honor and give preferential treatment to higher quality boreholes. First, the main stratigraphic units and contacts were identified in boreholes ranked as high quality. Elevations and thicknesses of the major stratigraphic contacts were then calculated from the depths. The next step was to plot the elevations and thicknesses of the major units onto structure-contour and isopach maps, respectively. The computer-generated structure-contour and isopach maps were reviewed by geologists and hydrologists and "manually" altered to yield the "best" interpretations. As a final step, the "best" interpretations were used with a 3D visualization computer program, EarthVision ${ }^{\circledR}$, to create an electronic version of the conceptual model.

The B-Complex lies along the northern flank of Cold Creek bar, a large compound flood bar formed during Pleistocene Ice-Age floods. The upper surface of the bar in the 200 East Area forms a broad plain at about $700 \mathrm{ft}(210 \mathrm{~m})$ elevation. The bar extends westward for several miles; the northern boundary of the bar is defined by a series of northwest-southeast trending flood channels. The B-Complex is located 
on a grade that slopes gently $(\sim 0.026 \mathrm{ft} / \mathrm{ft}[0.085 \mathrm{~m} / \mathrm{m}])$ to the northeast from the top of Cold Creek bar into the western most flood channel. Six stratigraphic units are recognized in the B-Complex area:

- Recent backfill material

- Hanford formation-gravel-dominated sequence (H1 unit)

- Hanford formation-sand-dominated sequence (H2 unit)

- Cold Creek unit-fine grained $\left(\mathrm{CCU}_{\mathrm{z}}\right)$

- Cold Creek unit - coarse grained $\left(\mathrm{CCU}_{\mathrm{g}}\right)$

- Columbia River Basalt Group.

The fluvial-lacustrine Ringold Formation, which overlies basalt over most of the Hanford Site, does not appear to be present beneath the B-Complex. It likely was completely eroded away in the Pleistocene floods. The vadose zone beneath the B-Complex is as much as $83 \mathrm{~m}(273 \mathrm{ft})$ thick and consists of the Pleistocene-aged Hanford formation and the Cold Creek unit. The unconfined aquifer beneath the BComplex is generally only a few to a approximately ten feet thick. Along the southern portion of the B and BX Tank farms, the aquifer thickens to nearly 20 feet thick. In localized places, the top of basalt extends above the water table. The saturated zone lies mostly within the coarse-grained Cold Creek Unit $\left(\mathrm{CCU}_{\mathrm{g}}\right)$.

The Hanford formation makes up the majority of the suprabasalt sedimentary sequence beneath the B-Complex, ranging in thickness from 43 to $73 \mathrm{~m}$ (140 to $240 \mathrm{ft}$ ). Based on lithologies observed at the B-Complex, the Hanford formation can be divided into two informal units ( $\mathrm{H} 1$ and $\mathrm{H} 2)$. The $\mathrm{H} 1$ unit consist of mostly coarse-grained gravel or sandy gravel; the $\mathrm{H} 2$ unit is predominantly sand or gravelly sand, with occasional beds of sandy gravel. The Hanford formation $\mathrm{H} 2$ unit is ubiquitous beneath B-Complex. Three rather continuous thin fine-grained layers across the B-Complex region were identified within the $\mathrm{H} 2$ unit; H2F1 (at $70 \mathrm{ft}$ bgs), H2F2 (at $~ 120 \mathrm{ft}$ bgs), and H2F3 (at about $170 \mathrm{ft}$ bgs). Because these fine-grained layers have lower permeability and retain more moisture, they can laterally divert wastewater moving downward through the vadose zone and cause significant horizontal spreading far from the disposal facility footprints.

A geologic unit of late Pliocene to early Pleistocene age appears to be present beneath the Hanford formation over a localized region of the B-Complex area. This is indicated by a thick (up to 25 to 27 feet in wells 299-E33-16, E33-18, E33-343, and F33-345) layer of silt and/or fine sand $\left(\mathrm{CCU}_{\mathrm{z}}\right)$ that lays several tens of feet above the top of basalt. Cataclysmic-flood deposits of the Hanford formation typically do not contain silt beds more than a few feet thick; therefore, this silt layer is believed to be a pre-Missoula flood deposit. The silt layer is present only locally in an area centered over the northwestern portion of the B Tank Farm. Elsewhere, it was either subsequently eroded or not deposited. The top of the $\mathrm{CCU}_{\mathrm{z}}$ silt layer dips slightly toward the northeast, where the $\mathrm{CCU}_{\mathrm{z}}$ layer is missing. In the extreme northern, western, and eastern edges of the B-Complex area, it is often difficult to distinguish between the $\mathrm{CCU}_{\mathrm{g}}$ and the overlying Hanford formation $\mathrm{H} 2$ unit. The upper surface of the $\mathrm{CCU}_{\mathrm{g}}$ shows about $10 \mathrm{~m}(30 \mathrm{ft})$ of relief. A depression exists at the top of this unit centered over the northwest corner of the B Tank Farm, which is filled with the overlying $\mathrm{CCU}_{z}$ silt. The thickness of the $\mathrm{CCU}_{\mathrm{g}}$ ranges from 5 to $15 \mathrm{~m}(20$ to $50 \mathrm{ft})$. The $\mathrm{CCU}_{\mathrm{g}}$ unit is thinnest and structurally low near the same locations where the $\mathrm{CCU}_{\mathrm{z}}$ unit is thickest, suggesting that erosion of the gravel took place before being backfilled with silt.

The surface of the Columbia River Basalt Group forms the bedrock base of the unconfined aquifer under the B-Complex. The top of the basalt also dips northeast in the eastern half of the B-Complex area, 
but dips to the southwest in the western half of the B-Complex. Up to $8 \mathrm{~m}$ of topographic relief exists on the basalt surface as a result of tectonic deformation and/or erosion that occurred in this area before cataclysmic flooding. A northwest-southeast trending basalt high lies just north of the B and BY Tank Farms, which is consistent with the trend of other eroded and/or deformed basalt highs in the region.

\subsection{Hydraulic and Recharge Parameters}

Section 4 summarizes suggested hydraulic and transport parameter values to be used for predictive modeling of the vadose zone portion of subsurface flow and contaminant transport near the B-Complex. Parameter values needed for the six stratigraphic units in addition to the fine-grained layers $(\mathrm{H} 2 \mathrm{~F} 1, \mathrm{H} 2 \mathrm{~F} 2$, and $\mathrm{H} 2 \mathrm{~F} 3$ ) and backfill material are provided. Best estimate and ranges for the following hydraulic and transport parameters are presented: particle density, total porosity, effective porosity, saturated hydraulic conductivity, van Genuchten parameters, the field capacity, saturated water content, the Campbell b parameter, and dispersivity. Best estimates of recharge rates for near-surface soil types for non-vegetated and vegetated conditions existing within the B-Complex are also provided and serve as model upperboundary conditions for future flow and contaminant transport modeling.

\subsection{Nature and Extent of Contaminants in Vadose Zone Sediments}

The extent of contamination in the subsurface below each of the subregions was used to develop conceptual models of the current nature and extent of contamination for each facility or localized region (the term subregion is used throughout the report). At the BY Cribs, three boreholes were drilled down to near the water table in the individual crib footprints in the early 1990s. Sediment samples, constituting only $14 \%$ of the vadose zone profile, were collected and analyzed for selected chemicals. Only total concentrations of key contaminants in the sediments were sought by the investigators. More recently, two boreholes (299-E33-341 and E33-342) were placed outside the BY Cribs' footprint, and hundreds of sediment samples were collected. Besides measuring the total concentration of key constituents, 1:1 water to sediment extraction was used to better estimate the portions of key constituents that are readily mobilized by water, such as natural recharge. Combining the data set from within the BY Cribs' footprints with the new data from the two nearby boreholes, it was concluded that mobile contaminants such as nitrate, technetium-99, cyanide, sodium, and sulfate have reached the groundwater. Further, the deep vadose zone pore waters below the BY Cribs from $\sim 50 \mathrm{ft}$ bgs to the water table, at $\sim 230 \mathrm{ft}$ bgs, still contain elevated concentrations of these mobile species. To the west of the B-49 crib, the new borehole 299-E33-341 shows that lateral spreading of the fluids disposed of to the BY Cribs has occurred.

Elevated concentrations ( $\max \sim 200 \mathrm{pCi} / \mathrm{g}$ ) of technetium-99 are found at the top of a fine-grained layer at $\sim 40 \mathrm{ft}$ bgs. Lower but still elevated concentrations of technetium-99 are found deeper from 85 (H2F1 layer) to $100 \mathrm{ft}$ bgs. At another fine-grained layer at $105 \mathrm{ft}$ bgs (H2F2), the technetium- 99 sediment concentration again reaches $\sim 200 \mathrm{pCi} / \mathrm{g}$. There is a third deeper lobe of technetium-99 at about 130 to $140 \mathrm{ft}$ bgs, again associated with a fine-grained layer (H2F3) within the $\mathrm{H} 2$ formation and the sands immediately below the layer. Elevated nitrate concentrations are found in the same three locations as the technetium-99 in about the same relative abundances. That is, where the technetium- 99 sediment concentrations are elevated to $\sim 200 \mathrm{pCi} / \mathrm{g}$, the nitrate concentrations are elevated to $\sim 7000 \mu \mathrm{g} / \mathrm{g}$. Given the fact that technetium-99 does not adsorb to any significant degree and thus remains in the pore water, finding similar concentrations in the sediment about fifty feet laterally from the crib footprint fortifies the conclusion that waste fluids disposed of in the BY Cribs did spread horizontally along fine-grained layers. There is no indication of major lateral spreading of disposed waste fluids along the contact between the 
Hanford formation and the Cold Creek unit at borehole 299-E33-341, likely because the fine-grained $\mathrm{CCU}_{z}$ stratum is very thin at this location. However, at borehole 299-E33-342, several hundred feet to the southeast, there is evidence of horizontal spreading of nitrate at the contact between the Hanford formation and the $\mathrm{CCU}_{z}$.

Based on spectral gamma logging of cobalt-60, known to be mobile in the BY Cribs region, lateral migration around the BY Cribs region appears to be extensive. Cobalt- 60 was detected laterally $220 \mathrm{ft}$ northwest of the B-50 crib and $286 \mathrm{ft}$ southeast of the B-43 crib. Contaminant distributions in regions north, west, and south of the BY Cribs cannot be quantitatively assessed because these regions have few boreholes. Based on the vadose zone stratigraphic dip to the northeast, it is likely that extensive lateral spreading would be detected north of the BY Cribs. Comparison of individual borehole logs acquired in 1992 and 2002 indicates continuing migration of cobalt-60 (and by inference other mobile contaminants) in the vadose zone in the area of the BY Cribs since the early 1990s.

When coupled with the groundwater plume time series maps, it becomes clear that the deep vadose zone below the BY Cribs is currently contributing technetium-99, cyanide, nitrate, and perhaps cobalt-60 to the groundwater. However, it does not appear that the deep vadose zone below the BY Cribs is contributing much, if any, uranium to the groundwater at this time, and water-extractable uranium in the vadose zone sediment below the BY Cribs is found only in shallow sediments far from the water table. It would take detailed predictive modeling to assess whether this shallow uranium might percolate down to the water table in the distant future. The B-57 Crib and the BY-102 Settling Tank, both located in the BY Cribs subregion, have sparse vadose zone sediment contaminant data, but what are available from the B57 Crib suggest comparatively low concentrations and relatively shallow distributions for all constituents. Under current conditions these two facilities appear not to be past, present, or significant future contributors to groundwater risk.

Waste liquids disposed of to the B-7-A\&B Cribs did reach the groundwater soon after the start of disposal in 1946. Data from gross gamma logging in nearby boreholes, some installed in 1947-48, represent the most compelling defense of this conclusion. Documents published in 1963 and 1976 (see DOE/GJO 2002a), suggest that significant gamma-emitting contamination was observed at or below groundwater level as early as 1959 but that most of the dry well monitoring around the B-7-A\&B Cribs today show significant gross gamma signals down to depths of only 50 to $100 \mathrm{ft}$ bgs. However, none of the long-lived gamma emitters present in the waste streams are highly mobile so that gamma logging today is not as valuable a method to assess whether mobile contaminants are migrating through the vadose zone and affecting groundwater. The exception is Hanford-processed uranium, for which the spectral gamma tool can be a valuable method for locating it in vadose zone and aquifer sediments if present above activities of $\sim 10$ to $15 \mathrm{pCi}$ uranium per gram of sediment.

The vertical distribution of species in the $\mathrm{C} 3103$ borehole through the B-7-A Crib footprint in general show elevated concentrations of total and water-extractable uranium in the shallow sediments and then much lower concentrations in the deeper Hanford formation sediments. Unfortunately, the C3103 borehole was stopped just below the contact between the Hanford $\mathrm{H} 2$ and $\mathrm{CCU}_{z}$ unit, so a full vadose zone vertical profile for the B-7-A Crib is not available. Elevated concentrations of nitrate and fluoride are present within the Hanford formation below the B-7-A Crib footprint to 160 and $95 \mathrm{ft}$ bgs, respectively. Both constituents also show a sharp increase in concentration at $218 \mathrm{ft}$ bgs, in the $\mathrm{CCU}_{z}$ unit, just where the borehole was terminated. Somewhere in the vadose zone proximal to the B-7-A\&B 
Cribs, there must be a continuous trail of these two constituents through the Hanford formation into the $\mathrm{CCU}_{\mathrm{z}}$ unit and likely down to the water table.

The B-7-A\&B Cribs and B-8 Crib and Tile Field received about three times as much fluoride and chromium as the BY Cribs subregion. Thus, elevated fluoride and chromium concentrations are good indicators of B-7-A\&B and/or B-8 Crib and Tile Field waste fluids breaking through to groundwater. Elevated water-extractable fluoride is present at extremely high concentrations in the $\mathrm{CCU}_{\mathrm{z}}$ sediments from new boreholes 299-E33-344 and E33-345. It is also noteworthy that there is little to no detectable technetium-99 in the sediments below the B-7-A Crib footprint (C3103 borehole), although the borehole does not penetrate the $\mathrm{CCU}_{\mathrm{z}}$ strata where elevated concentrations of technetium-99 are found in the nearby 299-E33-344 and E33-345 $\mathrm{CCU}_{\mathrm{z}}$ sediments.

Both new boreholes are southwest of the B-7-A\&B Cribs and show no signs of elevated concentrations of major chemical constituents or typical waste constituents from ground surface all the way through the Hanford formation. However, once the $\mathrm{CCU}_{\mathrm{z}}$ unit is reached, sediments and accompanying pore waters show significant signs of waste fluid impacts, such as elevated $\mathrm{pH}$ and elevated concentrations of water-extractable sodium, chromium, fluoride, nitrate, sulfate, carbonate, technetium-99, and uranium. The total uranium concentration in the $\mathrm{CCU}_{\mathrm{z}}$ sediments at the two new boreholes (299-E33-344 and E33-345) is also elevated. The two new boreholes were placed within $10 \mathrm{ft}$ of the existing groundwater monitoring well 299-E33-18, which monitors the B Tank Farm and B-7-A Crib. Most of the constituents measured in the water extracts of sediments within the $\mathrm{CCU}_{\mathrm{z}}$ unit show a complicated vertical distribution. The technetium-99 is highest from 230 to $240 \mathrm{ft}$ bgs, and the waterextractable uranium is highest from $\sim 228$ to $235 \mathrm{ft} \mathrm{bgs,} \mathrm{which} \mathrm{is} \mathrm{in} \mathrm{about} \mathrm{the} \mathrm{middle} \mathrm{of} \mathrm{the} \mathrm{rather} \mathrm{thick}$ $(\sim 27.5 \mathrm{ft}) \mathrm{CCU}_{\mathrm{z}}$ unit. The uranium isotope ratios vary for the perched water, groundwater, and vadose zone pore waters from the two new boreholes, but most suggest that the BX-102-sourced uranium dominates and that the variations are caused by mixing with pore waters (natural or other contaminated waters not containing uranium at elevated concentrations). However, much more analysis and perhaps another borehole through the B-7-A Crib would be needed to strengthen the conceptual model.

In summary, the vadose zone sediment profiles of constituents below the B-7-A\&B Cribs yield conflicting data for answering the question about waste fluid penetration all the way to the groundwater. After weighing all the available vadose zone data, it has been concluded that the B-7-A\&B Cribs did breakthrough to groundwater during its active period and at present is a source for some of the contamination found in the $\mathrm{CCU}_{\mathrm{z}}$ unit. The observed water-extractable fluoride and chromium in the $\mathrm{CCU}_{\mathrm{z}}$ pore waters and chromium in groundwater in nearby wells support the conclusion that water from B-7-A\&B Cribs and/or B-8 Crib and Tile Field is present in the pore waters in the $\mathrm{CCU}_{\mathrm{z}}$ unit. However, uranium isotopic signature data suggest that fluids from the B-7-A Crib are not a significant contributor to the uranium found in the groundwater at 299-E33-18, E33-344, and E33-345.

There are no sediment samples from within the footprints of the B-8 Crib and Tile Field or B-11-A\&B French Drains. Thus, only gross- and spectral-gamma log results for nearby boreholes and the soil resistivity survey results are available. Using the gamma logging data, the fact that large volumes of liquids were disposed of to the B-8 Crib, and historical groundwater data, it has been concluded that liquids disposed of to the B-8 Crib likely did reach groundwater no later than 1959 . The time series groundwater plume maps show that the B-8 Crib is a continuing source of chromium, sodium, and likely nitrate contamination to the groundwater today. There has been no vadose zone sediment characterization within or close to the B-51 French Drain disposal facility. Further, there is such sparse dry well and 
groundwater monitoring well coverage at this location that historical and spectral gamma logging data are inadequate to make any statements about the vertical extent and lateral spreading potential for fluids, chemicals, and radionuclides disposed of to this facility. However, based on the low volume of liquid disposed of and low total inventories of key risk-driving constituents (see Table 3.11, Table 3.24 and Table 3.25), the B-51 French Drain is not considered a significant contributor of contamination to the deep vadose zone or the unconfined aquifer.

The only mobile constituent that is present in the borehole through the B-38 Trench (BX Trenches subregion) at large enough concentrations to develop a good vertical distribution is nitrate, and the bulk of the nitrate is found above $150 \mathrm{ft}$ bgs, well above the water table at $\sim 265 \mathrm{ft}$ bgs. The concentrations of other potentially mobile constituents such as cyanide, fluoride, nitrite, and technetium-99 are so small in the vadose zone sediments that most of the samples analyzed have no detectable amounts. The uranium concentrations in the $\mathrm{C} 3104$ (within the B-38 Trench footprint) sediments are within the range for uncontaminated sediments. Therefore, it was concluded that waste liquids disposed of to the B-38 Trench likely have not reached the groundwater. Based on this observation, it was concluded that the entire BX Trench subregion also has not impacted the groundwater to any significant extent.

The largest release of uranium in the B-Complex occurred from Tank BX-102 in 1951. Field gamma logs show that the uranium appears to have migrated at least $300 \mathrm{ft}$ laterally towards the northeast as well as vertically about $180 \mathrm{ft}$ into the $\mathrm{CCU}_{\mathrm{z}}$ unit. Hanford-processed uranium has been identified in the vadose zone using gamma logging through borehole casings. Sobczyk (2004a, b) found that the most extensive area of uranium-235/238 contamination is located northeast of Tank BX-102. The area northeast of the BX-102 Tank contains most of the boreholes where Hanford-processed uranium has been detected. Concentrations of acid-extractable uranium in the Hanford formation at borehole 299-E33-45 (70 ft east of BX-102) and other nearby shallow direct push boreholes range from 60 to $1500 \mu \mathrm{g} / \mathrm{g}$. More importantly, the water-extractable uranium in these same samples range from 1 to $100 \mu \mathrm{g} / \mathrm{g}$. The highest acid-extractable uranium concentrations near Tank BX-102 are found in silt-enriched Hanford formation sediments, especially the thin $\mathrm{H} 2 \mathrm{~F} 2$ layer. The same association of high acid-extractable uranium concentrations with fine-grained sediments (but within the $\mathrm{CCU}_{\mathrm{z}}$ unit) is found in the more distant new boreholes, 299-E33-343, E33-344, and E33-345. Most striking was the fact that boreholes 299-E33-18 and 299-E33-41 (also located northeast of Tank BX-102) showed, by time series gamma logging, an influx of uranium contamination within the $\mathrm{CCU}_{\mathrm{z}}$ unit ( 220 to $245 \mathrm{ft}$ bgs) between 1991 and 1997. Figure 9.1 (taken from Sobzyck 2004b) shows the Hanford processed uranium versus depth (as delineated by SGLS) in the vadose zone on a transect from BX-102 towards borehole 299-E33-345 to the northeast.

Uranium observed in the $\mathrm{CCU}_{\mathrm{z}}$ unit at borehole 299-E33-45 is at much lower concentrations than found shallower in the Hanford formation. This suggests that the bulk of the uranium lost during the overfill event has not descended as deep as the $\mathrm{CCU}_{\mathrm{z}}$ unit at borehole 299-E33-45. The precise uranium isotope signature measurements on the $299-\mathrm{E} 33-45 \mathrm{CCU}_{\mathrm{z}}$ pore water suggest that this pore water is $90 \%$ native and only $10 \%$ from the BX-102 waste fluids. This fact further corroborates a conceptual model where the BX-102 fluids were mainly diverted in a horizontal direction right near the tank towards the northeast.

The distribution of the uranium from the BX-102 overfill event between sediment and pore water is highly variable and strongly dependent on the sediment particle size. Solid-phase testing using micro-X-ray fluorescence, XANES, and time-resolved laser-induced fluorescence spectroscopy suggest 
that the uranium in the most highly contaminated sediments is predominately a calcium uranyl silicate, such as uranophane $\left[\mathrm{Ca}\left(\mathrm{UO}_{2}\right)_{2}\left(\mathrm{SiO}_{3} \mathrm{OH}\right)_{2}\left(\mathrm{H}_{2} \mathrm{O}\right)_{5}\right]$. The detailed sediment characterization shows that

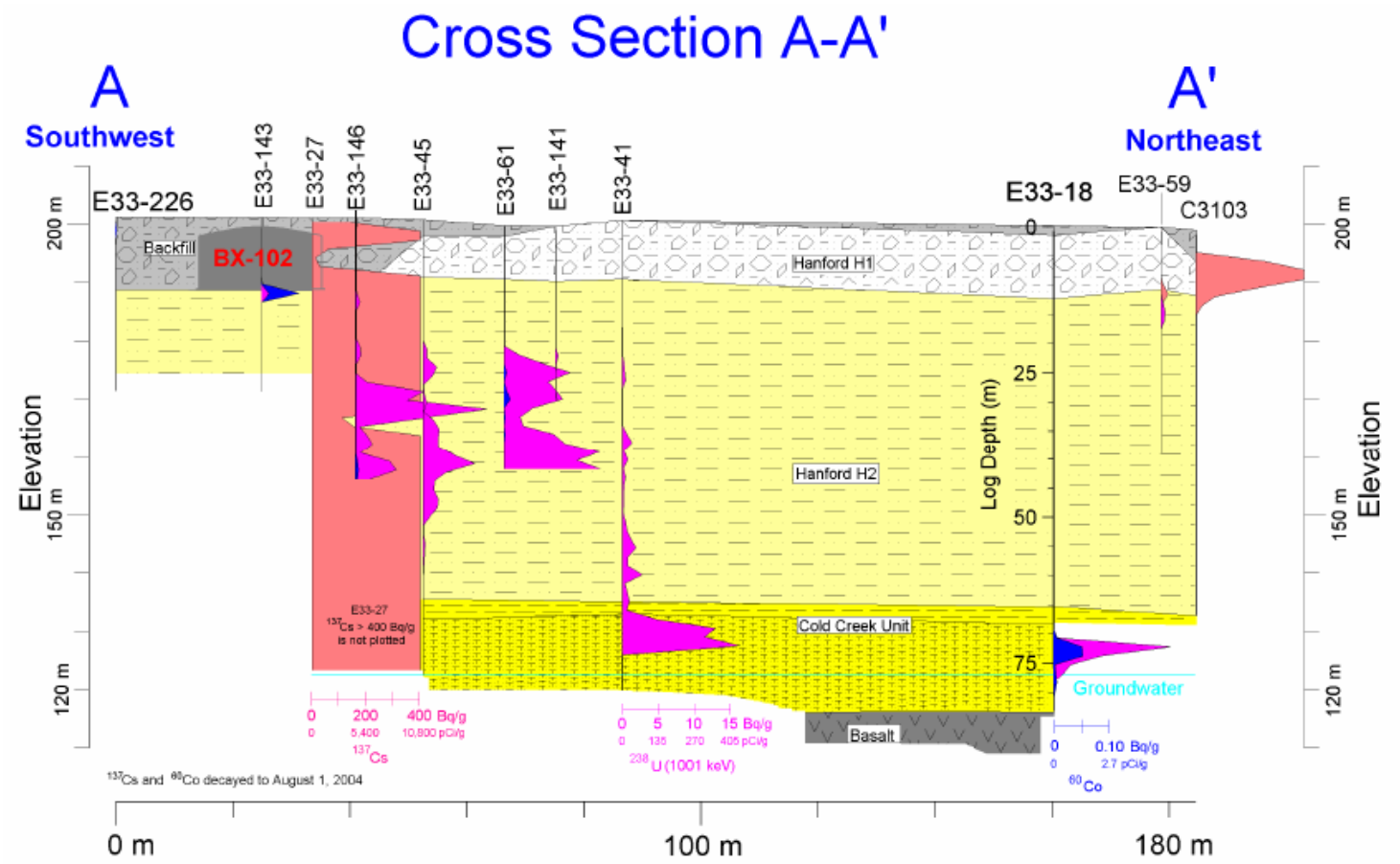

Figure 9.1. Conceptual Model for U Descent and Lateral Spreading from BX-102 (based on SGLS) (taken from Sobzyck 2004b)

uranium sequestration occurs by formation of micro-precipitates within small pores in the sediment particles and that greater amounts of these precipitates are present in the finer-grained layers that are interspersed throughout the Hanford formation. The significance of this detailed characterization of the more highly uranium-contaminated sediments from the Hanford formation near Tank BX-102 is that a significant percentage of the uranium is not readily mobilized by water and that the uranium associates more so with the fine-grained portions of the heterogeneous Hanford formation sediments, which are predominately sand. This conclusion would also hold for the fine-grained $\mathrm{CCU}_{\mathrm{z}}$ sediments.

Despite the fact that much of the uranium associated with the fine-grained sediments near Tank BX102 does not leach into water quickly or completely over time periods of a few months to perhaps years, the concentrations of dissolved uranium in vadose zone pore waters can reach dramatically high concentrations. Pore waters obtained by ultracentrifugation of vadose zone sediment from 299-E33-45 and 299-E33-343 contain from 3,000 to 2,500,000 and 110,000 to 435,000 $\mu \mathrm{g} / \mathrm{L}$ of uranium in Hanford formation and $\mathrm{CCU}_{\mathrm{z}}$ unit sediments, respectively.

The vadose zone sediment study at 299-E33-46 near Tank B-110 also showed conclusively that tankrelated fluids, likely from a transfer line leak, are present in the vadose zone sediments to a depth of $170 \mathrm{ft}$ bgs, within the Hanford $\mathrm{H} 2$ sand unit. There is also elevated technetium-99 between 222 and $226 \mathrm{ft}$ bgs in the $\mathrm{CCU}_{z}$ unit, but there is no measureable technetium-99 shallower in the Hanford formation sediments at this borehole. Again, it appears that the $\mathrm{CCU}_{\mathrm{z}}$ unit below Tank B-110 is acting as a lateral spreading layer, but contains waste fluids from a different source than the Tank B-110 leak event, likely BX-102 overfill fluid. The available sediment data from below the B Tank Farm do not suggest that Tank 
B-110 has contributed significant amounts of mobile contaminants to the groundwater. Further, the low concentrations of mobile contaminants found in the Hanford formation sediments from borehole 299E33-46 do not appear to be a significant future source of groundwater contamination. Spectral gamma logging experts agree that there is little indication that fluids lost below the B Tank Farm have reached groundwater. However, they suggest that additional boreholes may be useful in the region, especially around the 200-series tanks B-201 through B-204.

There have been no vadose zone sediments taken from the BY Tank Farm, so there are no direct measurements of the vertical distribution of chemicals or radionuclides in the vadose zone profile at this location. The closest borehole for which sediments were collected is the new borehole, 299-E33-205, which was drilled north of Tank BX-106 and south of the BY Tank Farm. There were no significantly elevated concentrations of any chemicals or radionuclides in the vadose zone at this new borehole. The groundwater samples at 299-E33-205, however, do contain signs of contamination that appear to have come from the west to southwest from the location of borehole 299-E33-343, based on both uranium isotopic ratio measurements and time series groundwater plume maps. Based solely on the low volumes of liquids released and the low masses of potentially mobile contaminants in the released fluids from the BY Tank Farm, it has been hypothesized that the BY Tank Farm is not a significant contributor to the existing groundwater contamination under current conditions. However, the BY Tank Farm vadose zone has not been characterized and the leak estimates (see Table 3.21) have been questioned such that further vadose zone borehole drilling and sediment characterization is recommended.

\subsection{Vadose Zone Residual Inventories for Technetium-99 and Uranium}

Estimates for residual masses of technetium-99 and uranium in the vadose zone (see Sections 3 and 6) suggest that significant percentages of the total masses disposed of to the cribs and trenches and released from SSTs remain in the vadose zone. The ability to estimate the degree of lateral spreading (distance) and the variation of contaminant concentrations laterally away from facility footprints as a function of distance is limited. However, using the various types of data and critical synthesis, what seems to be reasonable residual mass estimates for these two contaminants were generated for the three subregions of the B-Complex that show strong indications of being sources to the groundwater plumes (BY Cribs, B-7A\&B/B-8 Cribs and Tank BX-102).

As discussed in Section 6, it is hypothesized that 33 to 57 curies of technetium-99 remain in the vadose zone below the B-Complex in two distinct locations. The vast majority of the residual technetium-99 is below the BY Cribs where between 30 and 53 curies are estimated. This represents between 23 and $41 \%$ of the technetium-99 disposed of to the BY Cribs. The mass of technetium-99 estimated to be in the deep vadose zone (lower $90 \mathrm{ft}$ ) at the BY Cribs is between 3.4 and 20 curies. The other location within the B-Complex that contains a noteworthy mass of technetium-99 is the $\mathrm{CCU}_{\mathrm{z}}$ unit from northeast of the BX Tank Farm to borehole E33-343 and to the east as far as E33-345. In this location, it is hypothesized that $\sim 3$ to 4 curies resides in the vadose zone of which nearly all resides within 20 to $40 \mathrm{ft}$ of the water table.

In a similar fashion, the inventory calculations for uranium residing in the vadose zone suggest that the BX Tank Farm subregion dominates with $\sim 2400 \mathrm{~kg}$ of water-leachable uranium present above the water table. Of this estimate, $\sim 1650 \mathrm{~kg}$ is found in the $\mathrm{CCU}_{\mathrm{z}}$ unit northeast of Tank BX-102 with the 
majority located between the new boreholes 299-E33-343 and 299-E33-345. The estimate for waterleachable uranium in the deep vadose zone below the BY Cribs is less 0.2 to $0.5 \mathrm{~kg}$. Below the B-7-A\&B Cribs and B-8 Crib and Tile Field footprints, an estimate for deep vadose zone water leachable uranium is difficult to generate because little data are available and it appears using the hypothetical vadose zone models shown in Figure 3.46 and Table 3.14 that the bulk of the uranium is in the $\mathrm{CCU}_{\mathrm{z}}$ and not "sourced" from these cribs.

\subsection{Uranium Isotopic Ratio Signature Results}

The results of the precise uranium isotopic ratio measurements suggest that cross plots of the ratios of uranium-236/238 versus uranium-234/238 can differentiate fluids disposed of or released to BY Cribs, the B-7-A Crib, BX-102 Tank, and B-110 Tank from each other. Unfortunately, the isotopic signatures for the B-7-A Crib and BY Cribs must rely on one sample each. Thus, confidence that unique signatures can be obtained for these two facilities is tentative. Assuming that each facility does have a unique signature, uranium isotopic ratios are an excellent tool for differentiating sources. The conceptual model described in this report for sources of uranium in the vadose zone and groundwater below the central portion of the B-Complex was aided greatly by such measurements.

Because all the uranium in wastes disposed of to the BY Cribs, BX Trenches, B-8 Crib and Tile Field as well as many of the B-BX-BY tanks at the time of their leaks came from un-enriched (natural abundance) fuel, the uranium-235/238 ratio provides little or no source discrimination potential. One exception is the unique PUREX-derived wastes disposed of to the B-7-A\&B Cribs in 1966-67, which was of short duration and low total volume relative to the earlier disposal volumes. Earlier work on nine pore waters from different depths in borehole 299-E33-45 showed that these nine uranium isotope signatures cluster very tightly together for all three uranium ratios measured (uranium-234/238, uranium-235/238, and uranium-236/238). The tight clustering of the measurement corroborates the assumption that the uranium in the 299-E33-45 borehole pore water is from one source. In a similar vein, the Tank B-110 unique isotopic signature is not manifested anywhere else but in the relatively shallow region around borehole 299-E33-46. This leads to the conclusion that the slightly elevated uranium below Tank B-110 is not contributing significantly or, more likely, not contributing at all to the B-Complex groundwater uranium plume. A summary figure showing the cross plots for uranium-236/238 versus uranium-234/238 for all the vadose zone pore waters is shown in Figure 9.2. A similar plot with all the groundwater samples is found in Figure 5.45 and with an expanded scale for those samples clustered around the BX102 "full strength" signature in Figure 5.46.

The source of the uranium in the vadose zone at borehole 299-E33-343 has nearly the same isotopic composition as BX-102 waste fluid for three of the pore waters and the two available groundwater samples. Two additional E33-343 pore waters with lower uranium-236 contents, found at the top of the $\mathrm{CCU}_{\mathrm{z}}$ strata, appear to be a mixture of BX-102 fluids and uncontaminated vadose zone pore water. This observation corroborates the hypothesis that uranium-contaminated fluids in the $\mathrm{CCU}_{\mathrm{z}}$ strata are descending through the $\mathrm{CCU}_{\mathrm{g}}$ gravel to the water table nearer to 299-E33-343 than any other location that has uranium isotopic measurements available. The time series groundwater maps for the last decade also indicate this location as the major source of uranium for the B-Complex groundwater plume.

The uranium isotopic ratio signatures for water extracts of $\mathrm{CCU}_{z}$ sediments from boreholes 299-E33344 and E33-345, the perched water from 299-E33-344, and groundwater from 299-E33-345 and 299- 
E33-18 suggest that the $\mathrm{CCU}_{\mathrm{z}}$ unit has a complicated vertical distribution of water-leachable uranium. The 299-E33-344 and E33-345 vadose zone pore water results suggest that the deeper portion of the $\mathrm{CCU}_{\mathrm{z}}$ strata in this region contains fluids from the BX-102 overfill event diluted with other pore waters either uncontaminated (native) or from a waste source not containing much uranium (such as water from the deep vadose zone below B-7-A Crib) while the pore waters in the upper portion of the $\mathrm{CCU}_{\mathrm{z}}$ sediments contain fluids dominated solely by the BX-102 source. The perched water obtained from 299E33-344 from a depth of $225 \mathrm{ft}$ bgs, has a different uranium isotopic signature than the nearby groundwaters, collected from $\sim 258 \mathrm{ft}$ bgs. The uranium isotopic ratio for the perched water falls very close to a mixing line for the BX-102 source fluids with uncontaminated vadose zone pore fluids from both the Hanford formation and Cold Creek unit and is not close to the mixing line for B-7-A Crib waste with uncontaminated vadose zone pore water. This observation is consistent with the conclusion that the shallower portion ( $<235 \mathrm{ft}$ bgs) of the $\mathrm{CCU}_{\mathrm{z}}$ sediments is dominated by BX-102 source fluids at the location of the borehole. The groundwaters from new well 299-E33-345 and 299-E33-18 (2007 sampling date) have a tightly clustered uranium isotope signature that is very close to the BX-102 source uranium isotopic signature (see Figure 5.46). There is a small change in the uranium isotopic ratio for the groundwater at 299-E33-18 over 6 years. The signature is moving closer to the BX-102 source suggesting that the source of uranium remains the same and the new water contains even more BX-102 sourced fluid with high concentrations of total uranium. Finally, the isotopic signature measurements for the $\mathrm{CCU}_{\mathrm{z}}$ pore waters and perched water suggest that fluids in the localized region bounded by the three boreholes (299-E33-18, E33-344, and E33-345) likely are not the point of entry for the uranium to the water table. This is because the pore waters from the deepest part of the $\mathrm{CCU}_{z}$ unit at E33-344 and E33-345 have less BX-102 source signature(19 to 23\%) than the groundwater samples from 299-E33-18 and -E33-345 (99 to 100\%). Therefore, the vadose zone pore waters in the local region are not communicating substantially with the groundwater, or else the vadose zone pore waters have their mixed (BX-102 source with uncontaminated water or low-uranium contaminated water) uranium isotopic signal overwhelmed by the BX-102 "full strength" signature once the water enters the groundwater.

\subsection{Groundwater Plume Inventories for Technetium-99 and Uranium and Groundwater Flow}

Three activities that focused on the unconfined aquifer aided development of the overall conceptual model of the B-Complex subsurface. The first activity was to study time series groundwater plume plots of the entire 200-East Area to ascertain what direction the mobile contaminants in the groundwater appear to be going. This approach, which relied more so on observing the whole plume evolution as opposed to looking at trend plots for contaminant concentrations at a few wells, leads to the conclusion that since about 1991, the overall groundwater flow direction under the B-Complex has been from the southeast towards the northwest. In localized regions at several time periods, there appears to be flow to the south or southeast, but through the use of a second activity where seasonal trends were based on spring and fall groundwater measurement only, a hypothesis explaining the apparent flow reversal was developed. It appears that fluctuations in the Columbia River stage impact the water levels and the hydraulic gradients in wells at the northwest end of the B-Complex and up through Gable Gap. In essence, during some time periods, the gradient that allows flow towards the northwest below the B-Complex is diminished such that flow either slows down or even infrequently reverses direction. During these periods as new influxes of contaminants out of the deep vadose zone into the aquifer continue, the concentration isopleths for key contaminants appear to migrate in directions different from the overall trend to the northwest. By observing the overall 200-East and regional B-Complex groundwater plume trend plots in increments of 


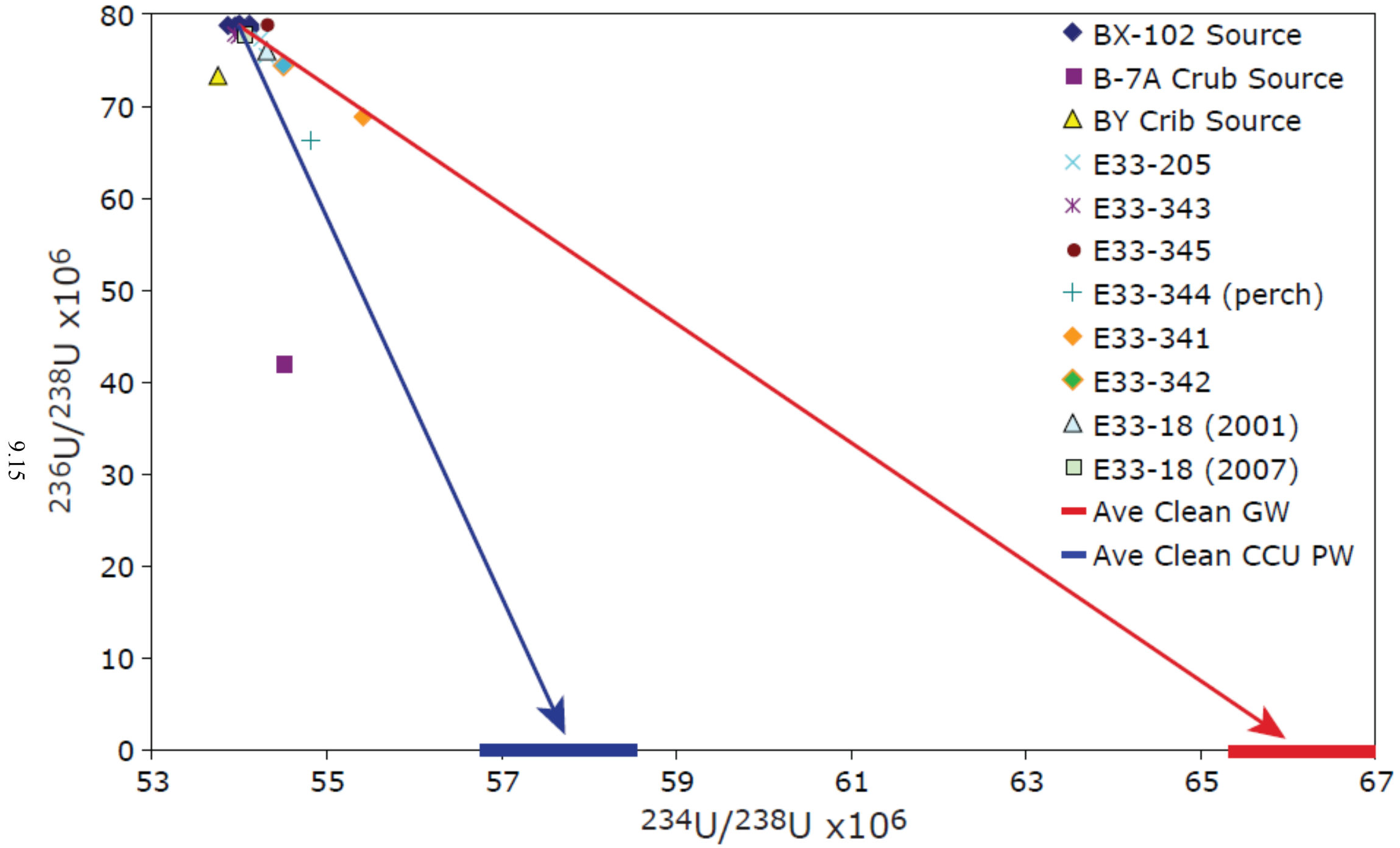

Figure 9.2. Uranium Isotope Signature Results for all Recent Vadose Zone Pore Waters 
several years, the concentration isopleths do expand towards the northwest in a continuous fashion. Time series groundwater plots of nitrate, technetium-99, cyanide, sodium, chromium, and uranium all show this trend (see Section 5 and Appendix G). Further, the time-series plots appear to suggest that concentrations, and more importantly, the masses of contaminants in the groundwater plumes below the B-Complex are increasing with time. To quantify whether the total mass of key contaminants is increasing, detailed mass estimates were made for technetium-99, cyanide, and uranium for the years 2000, 2003, 2006, and 2009 using the detailed 3D EarthVision ${ }^{\circledR}$ software tool. Results show generally consistent increases in the masses within the groundwater plume over each 3-year interval, with the exception of cyanide. For some inexplicable reason, all the cyanide measurements for calendar year 2003 are considerably lower than values for years just before and right after 2003 in the EDA database. Assuming that this is an artifact, the other mass comparisons show increasing masses in the groundwater plumes below the localized B-Complex area (see Table 5.2 through Table 5.4). This supports the hypothesis that contamination is entering the aquifer below the B-Complex. Another striking observation is that the masses estimated to be in the aquifer in the last decade are relatively small compared to the masses estimated to reside in the deep vadose zone sediments. The masses currently in the groundwater are also small compared to the masses disposed or released to the subsurface below the B-Complex, suggesting that with time, significantly more contamination may enter the groundwater.

The total activity of technetium-99 currently in the groundwater plume is estimated to be 6.06 curies throughout the entire B-Complex and Gable Gap regions but only $0.76 \mathrm{Ci}$ below the B-Complex area (see Table 5.2), which represents less than $5 \%$ and less than $1 \%$, respectively of the total activity of technetium-99 released (145 curies) to the subsurface below the B-Complex. The comparable statistic (see Table 5.4) for uranium mass in the B Complex groundwater plume $(22.3 \mathrm{~kg})$ is $<1 \%$ of the uranium released $(12,000 \mathrm{~kg})$ to the subsurface below the B-Complex.

The estimated mass of technetium-99 and uranium in the vadose zone, is significantly larger than the mass currently in the groundwater directly below the B-Complex. More importantly, the mass estimates of technetium-99 and mobile uranium in the deep vadose zone are up to 8 to 30 and 70 to 76 times larger than the current groundwater masses in the plumes below the B-Complex. For technetium-99 the majority of the mass in the current groundwater plume is outside the 200-East fence line north through Gable Gap and beyond. This technetium-99 likely represents mass that was released earlier than the last ten years, which is the time frame for which most of the groundwater analysis has emphasized. The increase in technetium-99 mass in the groundwater plume directly below the B-Complex has been increasing at the fastest rate amongst the three groundwater plume subregions (see Table 5.2).

Summary statistics for the estimated masses remaining in the vadose near the three locations where the largest amounts of wastes are either intercepting the water table or where there is potential in the near future are shown in Table 9.2. The three subregions are the BY Cribs, the B-7-A\&B/B-8 Cribs, and the BX-BY Tanks. For the BY Cribs subregion, the more realistic conceptual model for uranium allows significant interaction with the sediments such that the lateral spread and vertical penetration of the high uranium concentrations are limited to the contiguous facility footprint and only low concentrations of uranium are assigned to areas outside the BY Cribs' contiguous footprint. The BY Crib values in Table 9.2 for uranium are based on conceptual model \#2 (see Table 3.8). For the B-7\&B/B-8 Cribs subregion the most realistic total uranium conceptual model that allows significant sediment interaction is model \#2 (see Table 3.14) for the B-7-A\&B/B-8 Cribs subregion. For mobile uranium at the B-7A\&B/B8 Cribs subregion the more realistic conceptual model is Model \#1 that assumes the smaller crib footprint 
to avoid including mobile uranium deep in the vadose zone that appears to be from the BX-102 source. For technetium-99, which does not interact appreciably with sediments, the mass balance values in Table 9.2 for all three subregions include the entire range from all the plausible conceptual models that vary the lateral spreading and to lesser extents the vertical distribution of technetium-99.

Fate and transport modeling is needed to assess how much of the mass of technetium-99, uranium, and others contaminants, in the deep vadose zone will reach the water table and the timing of their arrival. Section 8 summarizes most of the necessary information that in combination with the geological model presented in Section 2 and Appendix B may be used to support future fate and transport modeling activities. 
Table 9.2. Summary Estimates of Mass in Vadose Zone, Deep Vadose, and groundwater by Subregion for Most Realistic Conceptual Models and Comparison to Entire B-Complex Masses Released

\begin{tabular}{|c|c|c|c|c|c|c|c|c|c|c|}
\hline & Tc-99 (Ci) & & & & Total U (kg) & & $\begin{array}{l}\text { Mobile U } \\
\quad(\mathrm{kg})\end{array}$ & & & \\
\hline Subregion & Entire VZ & Deep VZ & groundwater & $\begin{array}{c}\text { Tc-99 Disposed } \\
\text { of }(\mathrm{Ci})\end{array}$ & Entire VZ & Deep VZ & Entire VZ & Deep VZ & groundwater & $\begin{array}{r}\text { U Disposed of } \\
(\mathrm{kg})\end{array}$ \\
\hline BY Cribs & 30 to 55.53 & 3.4 to 20.9 & & 129 & 1009 & 202 & 6.5 & 0.23 & & 1063 \\
\hline $\begin{array}{c}\text { B-7-A\&B/B-8 } \\
\text { Cribs }\end{array}$ & 0.02 to 1.64 & 0.01 to 1.6 & & 0.018 & 583 & 59.8 & 4.3 & 2.6 & & 388 \\
\hline BX-102 Overfill & 3.3 to 4.0 & 3.0 to 3.6 & & 3.7 & 6360 to 7220 & 3050 to 3910 & 2380 to 2460 & 1520 to 1600 & & 10,100 \\
\hline Sum of these 3 & 33.3 to 58.9 & 6.5 to 24.4 & & 133 & 7950 to 8810 & 3310 to 4170 & 2390 to 2470 & 1520 to 1600 & & 11,550 \\
\hline B-Complex (All) & & & $\begin{array}{c}6.06 \\
\text { (0.76 below } \\
\text { B-Complex) } \\
\end{array}$ & 145 & & & & & 22.3 & 12,000 \\
\hline
\end{tabular}

$i_{\infty}^{\infty}$ 
PNNL-19277

\subsection{Recommendations Based on B-Complex Conceptual Model Findings}

After collating and critically assessing available historical and new characterization data provided by the recent 200-BP5-OU boreholes within the B-Complex, the following suggestions and recommendations are offered. First, there are some general remarks pertaining to vadose zone sediment sampling and characterization protocols, then some potential programmatic interactions that could lead to additional research funds being devoted to the Hanford cleanup effort are covered, and finally, specific recommendations are offered for drilling new vadose zone boreholes for further characterization of the nature and extent of deep vadose zone contamination. Despite the efforts over the last 20 years to characterize vadose zone sediments, the biggest data gap to accurately assess the potential current and future impacts to groundwater from past waste disposals and unplanned releases in the B-Complex remains characterization of the vertical and lateral extent of mobile contaminants in the vadose zone. Two regions are especially in need of further drilling, sediment collection, and analysis. Most important is characterization of the deep vadose zone below inactive facility footprints and secondly, characterization of deep vadose zone locations dominated by the $\mathrm{CCU}_{z}$ silt and the nearly water-saturated unit outside the facility footprints. Both the western and northeastern areal extent of the $\mathrm{CCU}_{\mathrm{z}}$ is not well known because no boreholes have been placed in key locations (see Figure 10.1). The $\mathrm{CCU}_{\mathrm{z}}$ unit appears to be a significant mixing zone for wastes from past disposals and periodic extreme natural recharge and man-induced recharge to the deep vadose zone.

\subsection{Vadose Zone Sediment Sampling Protocol}

Past drilling activities through inactive facility footprints emphasized sediment sampling at the facility bottoms and tens of feet below the facility bottoms. The sampling density to investigate the extent of contamination in the deep vadose zone was too sparse, most commonly one sediment sample taken at best every 30 to often only every $50 \mathrm{ft}$ down to the water table or first signs of elevated moisture deep in the profile. None of the pre-200-BP5-OU DQO (Thomas 2008) sediment sampling campaigns at the BY Cribs, BX Trenches, or B-7-A Crib obtained more than 20 depth-discrete samples to cover the entire vadose zone profile from the bottom of the facility to the water table (see Sections 3.1.2, 3.2.2, and 3.3.2 for details.). This sampling density yields samples that cover $\sim 15 \%$ of the vadose profile between the facility bottoms and the water table. Because the standard technique used to drill boreholes at Hanford is the drive barrel method, sediments from the entire vadose zone profile are brought to the surface in incremental lifts that would allow a much higher sampling density to be performed as a function of depth. Grab samples could be readily collected on a frequency of one per every few feet. The size of the grab samples could be a small as $\sim 500 \mathrm{~g}$ to $1000 \mathrm{~g}\left(\sim 300\right.$ to $\left.750 \mathrm{~cm}^{3}\right)$ to allow for detailed characterization if protocols developed at PNNL are used. During the grab sample collection, the field geologist would also be recording geologic descriptor information, and if interesting changes in moisture or particle size texture were noted or an obvious contact between strata was observed, additional samples should be collected at these depths. Observing changes in moisture content/particle size or contacts between two strata generally correlate strongly with changes in constituent concentrations. Thus, collecting samples for future characterization at these depths is important to develop a good profile of the extent of contamination as a function of depth in the vadose zone. 


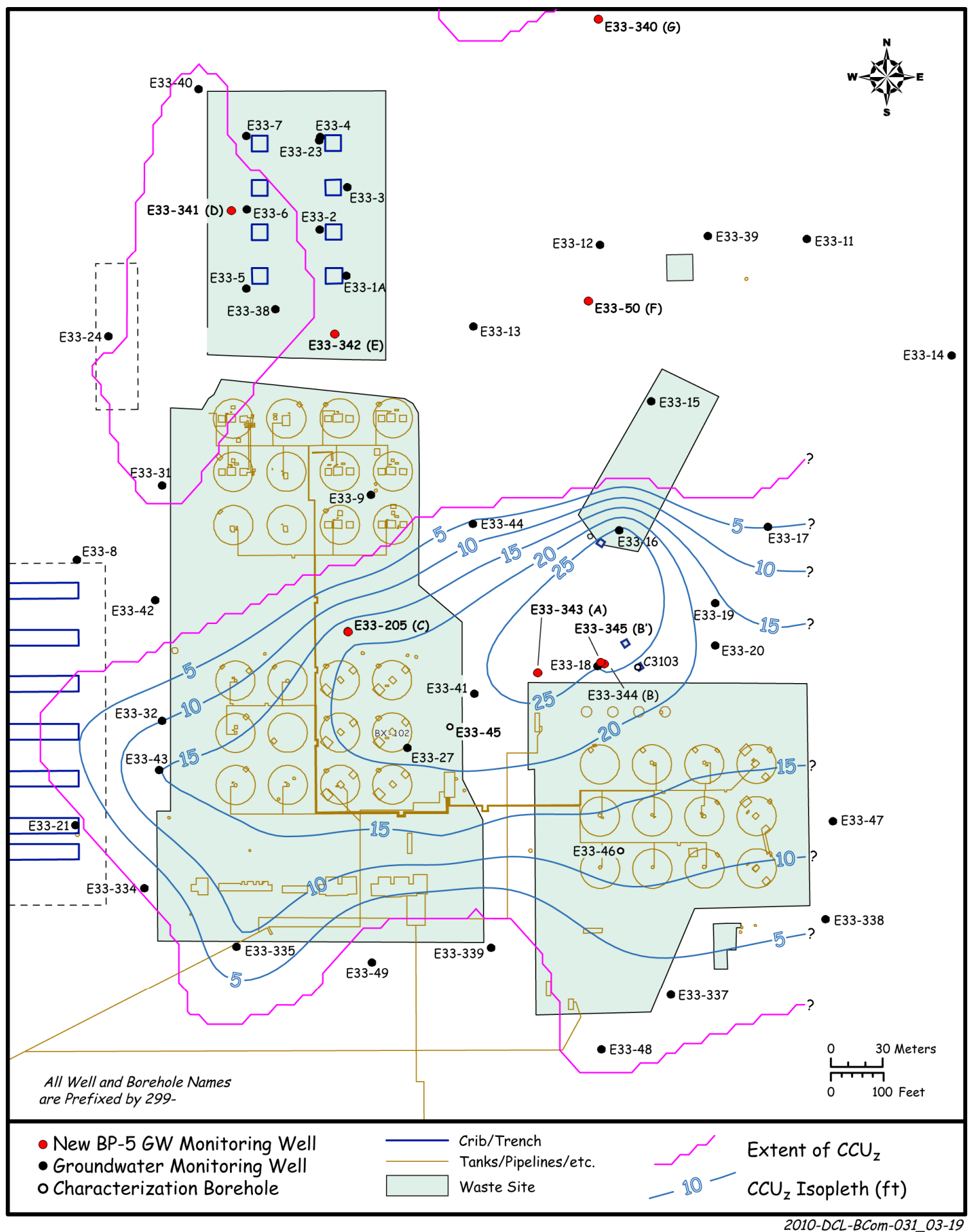

Figure 10.1. Location Map for Extent of $\mathrm{CCU}_{\mathrm{z}}$ Below B-Complex 
This recommendation to collect grab samples from sediment, which is already being brought to the surface, visually inspected, and for the most part placed in waste drums, does not add significant cost to the drilling campaign. Furthermore, not every grab sample would need to be characterized; see discussion below. This recommendation also does not interfere with the collection of intact cores at specific depths that are used to collect hydrologic data. The key point is that collecting the grab samples at the time of drilling allows characterization staff to "fill in" vertical profiles of key constituents and contaminants using a tiered or iterative characterization approach, which is discussed below. This recommendation - to collect grab samples at a high density of one per every few feet (and when the field geologist notices a change in moisture or particle size etc.) - is equally if not even more important for boreholes drilled outside inactive facility footprints because it is now understood that thin finer grained lenses act as lateral spreading planes for disposed fluids and mobile contaminants.

\subsection{Vadose Zone Sediment Characterization Protocol}

Over the past 10 years, it has been found that the most economical and technically defensible protocol to determine the vertical extent of contamination in the vadose zone profile is to use a tiered or iterative approach. The recommended characterization protocol is to have a team, led by an experienced geologist who has reviewed the field driller's and geologist's notes/logs, open the samples in the laboratory, digitally photograph them, and visually estimate the particle size distribution and particle types (basalt or granite etc. using color/shape). At the same time, an aliquot of sediment is quickly prepped to determine moisture content and often other inexpensive screening parameters (qualitative carbonate content, gamma energy analysis). Within a day or so, the screening information becomes available and is used to select the first tier of samples for additional characterization. The first tier analyses are chosen using knowledge on the types of waste and contaminants of concern assumed to be present in the vadose zone sediments. In general, for mobile contaminants, either a 1:1 water extract or direct ultracentrifugation of some of the sediment to obtain pore water directly is most productive to identify the extent and concentration of mobile contaminants. Once the first tier data are collected for key mobile contaminants from the grab samples, which are chosen with coarse sample density over the entire profile, and the outline of the vertical location of plume(s) has been delineated, a second tier of samples is characterized to fill in more details on the vertical extent and concentrations of mobile contaminants. The iterative approach continues until the vadose zone plume of key contaminants and/or other constituents is fully developed so mass inventories can be adequately estimated at the borehole. A key shortcoming of past Central Plateau contractor analytical protocols is that they only measured total concentrations of contaminants generally using a strong acid and heat extraction. To adequately determine the extent and more importantly the mass of mobile contaminants in the vadose zone, it would work better to have a much less vigorous extraction process. Because there is generally a significant mass of natural occurring RCRA metals and uranium in Hanford Site sediments, the strong acid extract yields little information on the amounts caused by the Hanford wastes, unless the waste disposal was highly concentrated. That is, the amount of natural RCRA metals and uranium present in the strong acid extracts often dwarfs the mass of Hanford added contaminant so the two sources cannot be differentiated. Most importantly, the speciation of the RCRA metals and uranium added via Hanford activities is generally very different than the natural masses and much more mobile. For example, in the 300 Area vadose zone sediments, it has been found that the total uranium content of sediments with values ranging from 3 to $5 \mathrm{ppm}$, well within the range of natural sediment abundances, can still cause groundwater uranium concentrations to remain well above the $30 \mu \mathrm{g} / \mathrm{L}$ drinking water limit. By extracting the 300 Area sediments with either distilled water or a 
sodium-bicarbonate-carbonate extractant instead of the strong acid, one can readily differentiate sediments with Hanford-processed uranium from natural sediments that have similar total uranium concentrations. The same need for a less vigorous sediment extraction process is required in the B-Complex, especially for uranium, chromium, and other RCRA metals. The strong acid extract results used to measure total concentrations is a poor predictor of mobile fractions that can percolate down to the water table and enter the aquifer. To reiterate, one must extract the sediments with a milder lixiviant than concentrated acids. More details on the vadose zone characterization protocol can be found in the RFICMS document (editor Mann 2008) at URL:

http://wrpstoc.com.s59537.gridserver.com/uploads/files/tier1/Chapter_5_Major_Accomplishments.pdf.

One problem with the tiered approach has been identified. For some constituents, there are short "hold times" allowed before measurements need to be performed to meet regulatory requirements. From a scientific standpoint, past experience working with Hanford Site vadose zone sediments over the past 10 years indicates that as long as the sediments are stored in air tight containers so that moisture is not lost to evaporation, the vast majority of inorganic and radionuclide constituents yield the same values after up to 6 months to perhaps a few years after sample collection, including those constituents with regulatory-mandated shorter hold times. The Hanford vadose zone environment has very low microbiological activity and remains in a fairly oxidizing redox state (most all the pore space in the sediments are air-filled in the natural state as well as the stored conditions in the laboratory). There is little opportunity for the inorganic and radionuclide constituents in vadose zone sediments stored in the laboratory to degrade or change in chemical composition in ways different than what is naturally occurring in the field where the sediments exist in relatively low moisture content conditions in a relatively uniform temperature regime slightly lower that laboratory conditions and in the absence of light. The sediment samples stored in the laboratory are kept at fairly uniform temperatures (either refrigerated or at ambient dependent on refrigerator space) and in the absence of light. It is recommended that a discussion be held with regulators to address this hold-time issue versus the economic benefits of using the tiered approach to vadose zone sediment sampling. There are data showing no impact on measured concentrations of key contaminants and constituents after several months of storage. If necessary, more formalized testing could be performed with regulatory participation on how the storage issue to allow the tiered characterization approach vs. hold time testing should be conducted.

\subsection{Sediment Archive Facility and Ultimate Disposition}

Currently, few of the Hanford Reservation operating contractors make provisions to store contaminated sediments beyond the time necessary to perform prescribed measurements. Generally, all unused sediment is deemed to be waste and disposed of as quickly as possible. This is a very unfortunate protocol in that hundreds of thousands to millions of dollars per year are expended at the Hanford Reservation to drill boreholes and obtain sediment samples. The protocol to as quickly as possible send all unused sediment to waste precludes further opportunities to study in more detail the mechanisms that control the interaction of contaminants with the sediments. As discussed next, there are opportunities to procure funds outside the traditional Hanford clean-up budgets to perform basic and applied research on particularly interesting sediments containing contamination. Many researchers at Hanford and other national laboratories and universities have over the last 10 years attempted to obtain relevant contaminated and uncontaminated sediments to perform studies. It is a disheartening situation to not be in a position to share relevant contaminated sediments when requests occur and to incur an added (mostly 
unfunded) expense to go out in the field to attempt to find out-crop uncontaminated sediments that can act as surrogates for the deep-vadose zone sediments. If there was a facility to store contaminated sediments for adequate periods of time ( $\sim 10$ years) and if the existing uncontaminated sediment facility (near FFTF) were made more readily available to researchers at the time of their requests, much would be gained.

Similarly, the current protocol for either field screening sediments obtained at the boreholes to determine their "contamination" status or just assuming that they are "contaminated" or "listed" (F-listed if from within tank farm fence lines) as a conservative approach leads to inefficient decisions on how to store, handle, and ultimately dispose of the sediments. In the former case (field screening), hard-to-detect beta emitters, such as technetium-99, iodine-129, and tritium, are often present in the vadose zone sediments at concentrations that would impact groundwater quality should the pore water reach the water table, and yet the samples are labeled "non-rad." On the other hand, many sediment samples are labeled "rad" or F-listed that after rather thorough characterization are found to be uncontaminated. These sediment samples cannot be sent to the uncontaminated storage facility for future use and are required to be disposed of as low-level or mixed waste at great expense. These issues - the need to have facilities to store samples for future use in studies focused on basic, applied, and laboratory remedial investigation studies and ultimate sediment disposal in an economically responsible fashion-would benefit from contractor and DOE attention.

\subsection{Synergistic Ties to Other Basic and Applied Research Opportunities}

Starting in 1997, there was a strong mandate to focus national resources in DOE-headquarters programs called EMSP and later ERSP on the Hanford Site. Numerous national laboratories and universities, engaged both in collaboration with Hanford scientists and independently, have been addressing subsurface contaminant fate and transport and remediation alternatives. It appears that these activities have waned considerably in the last several years, and it would be very useful for efforts to be expended to rejuvenate these valuable efforts. More details on how valuable such ties to these programs have been to the Hanford Site cleanup efforts are found in the RFI-CMS document (editor Mann 2008) at URL:

http://wrpstoc.com.s59537.gridserver.com/uploads/files/tier1/Chapter_13 Associated_Science_Activities. pdf.

It is not clear to the project scientists working on this task how best to approach a funding source to promote this "rejuvenation" recommendation. To get such science and technology activities activated in the past, staff at PNNL (Tom Brouns, Mark Freshley, John Zachara) and at DOE/RL (Mike Thompson, John Morse) should be valuable resources/contacts to provide the guidance or to become the lead "lobbyists."

In 2009, a DOE-headquarters initiative focused on using state-of-the-art fate and transport codes to model complex subsurface systems was started. The DOE-headquarters points of contact in late 2009 were Vince Adams and Ming Zhu. It is believed that all the data collated in this B-Complex conceptual model report and other historical and new data not yet collated for the rest of the 200-BP5-OU would provide an excellent data set to be used in these initiatives. It is suggested that this data set be brought to Vince Adams' and Ming Zhu's attention. 
An accurate model for quantifying the degree of interaction for uranium between sediments and pore waters at the Hanford Site has been actively pursued, and it is well known that the interaction cannot be reduced to a constant $K_{d}$. Brown et al. (2007) discuss one direct-push sediment sample that contained a contact between typical Hanford formation $\mathrm{H} 2$ sand and a fine-grained thin layer. Using two different leach tests and an isotope exchange test where pore water was inoculated with an exotic uranium isotope not found in nature, they determined that if the interaction was to be quantified as $\mathrm{K}_{\mathrm{d}}$ values that the coarser sand manifested a $\mathrm{K}_{\mathrm{d}}$ of $\sim 1.5 \mathrm{~mL} / \mathrm{g}$ and the finer grained, silt-rich sediment manifested a $\mathrm{K}_{\mathrm{d}}$ $\sim 900 \mathrm{~mL} / \mathrm{g}$. These sediments were located within several inches of each other. Thus, the challenge will be to determine which approach to use to predict the fate of the uranium present in the vadose zone sediments northeast of Tank BX-102. For now, it is only possible to describe the vertical and lateral spread of the uranium in the vadose zone, which is known in this region with defensible confidence. The state-of-the-art computer codes have the necessary algorithms to model the complex interactions (when appropriate data are available) that have been identified as operative in the contaminated sediments below and surrounding the BX tank farm.

As a corollary, the uranium in the deep vadose zone lateral spreading unit $\mathrm{CCU}_{z}$ east and north of the BX-102 tank would benefit from more mechanistic studies on its solid-phase composition and its leaching and desorption attributes. Significant work has been done on the contaminated Hanford formation sediments closer to the BX-102 tank that have provided detailed information needed to understand the fate of uranium released by the 1951 overfill event. Results have been summarized in Zachara et al. (2007a, b) and Brown et al. (2007). It is quite possible that uranium interactions with the $\mathrm{CCU}_{\mathrm{z}}$ and $\mathrm{CCU}_{\mathrm{g}}$ sediments and other Hanford formation sediments at locations more distal from the overfill event would be different than the understanding of uranium interactions developed to date from the Hanford formation sediment samples studied to date. Thus, it would be helpful for similar solid phase and leach testing as described in the cited references to be funded to complete the data set for the CCU sediments, which also will be needed along with the already characterized $\mathrm{H} 2$ unit sediments to model accurately the complex interactions of uranium with the vadose and aquifer sediments below the B-Complex.

Several years ago, DOE-EM started at least three 5-yr long IFC projects (Integrated Field Challenges) to tackle complicated scientific issues on the field scale. If there is opportunity to start new IFC programs, the B-Complex would be an ideal site to expend resources to evaluate the interconnection between the deep vadose zone technetium-99 and uranium inventories and the increasing groundwater plumes.

In a similar vein, there is currently a "Deep-Vadose Zone Demonstration" project ongoing at the Hanford Site in the BC Crib and Trenches Area. The same wastes that were disposed of to the BY cribs were disposed of at $\mathrm{BC}$ Cribs and Trenches. It is now clear that the deep vadose zone technetium-99 below the BY Cribs is currently supplying much more technetium-99 to the groundwater than is the deep vadose zone at the $\mathrm{BC}$ Cribs and Trenches area. The reason is perhaps the added $\sim 100 \mathrm{ft}$ of vadose zone sediment thickness below the $\mathrm{BC}$ Cribs and Trenches area. It is recommended that the findings and remedial alternatives demonstrations that are ongoing and planned at BC Cribs and Trenches be similarly considered at the BY Cribs or that resources and activities be shifted from BC Cribs and Trenches area to the BY Cribs region, where groundwater is being impacted now. 


\subsection{Highest Priority Boreholes to Address Deep Vadose Zone Technetium-99 and Uranium Connection to the Water Table}

Table 1.3 lists the boreholes from which directly measured concentrations of key contaminants are available for the B-Complex as well as some of boreholes in which indirect measurements of Hanford processed uranium can be estimated. The number of boreholes (a few dozen at most) and the number of depth-discrete samples analyzed are very small in comparison to the area and volume that constitutes the B-Complex vadose zone. Compared to the number of groundwater monitoring wells in the region, the vadose zone is disproportionately under characterized. Therefore, it is suggested that more vadose zone characterization boreholes be drilled and sediments characterized using the protocols described above to develop a more accurate understanding of the vertical and horizontal extent of contamination of key contaminants in the vadose zone. It would be helpful for newly initiated program for the deep vadose zone to be the focus of the characterization efforts but that the shallower sediments also be retained for future study, as needed, to improve the estimates of mass remaining in the entire vadose zone. The following locations should be considered as higher priorities for new boreholes based on the apparent location where the bulk of the technetium-99 and uranium in the deep vadose zone is entering the water table. For the technetium-99, the most important location is to the east of the BY Tank Farm and out to the new borehole 299-E33-343. Additional boreholes in the northern end of the BY Crib facility would also be beneficial to investigate the lateral spreading in the deep vadose zone of the technetium-99. For improving the understanding of uranium in the deep vadose zone, the prime locations are more boreholes surrounding 299-E33-343 and a borehole through the B-8 Crib or inlet to the tile field.

Boreholes through crib/trench footprints could be drilled using closed-end, direct-push techniques to get below the zone of high contamination generally found with several meters of the facility bottom and then reverting to telescoped (narrower diameter drill string) cable tool techniques to collect the deeper and less radioactive sediments. The key interest is measuring the vertical distribution of technetium-99 and other mobile contaminants in the deep vadose zone down to the water table so that not having to bring to the surface and handle the most potentially high dose sediments near the crib bottom is acceptable. The recommendations to collect grab samples about every 2 feet and to perform the tiered characterization approach as described above still hold.

The WRPS contractor has funded a vendor to optimize a detector that can specifically measure technetium-99 in situ with borehole or direct-push technology. Should the technique work and be available in time, it would be very useful in shallow direct pushes to locate specific co-ordinates for future boreholes. The technique requires that the probe be inserted into an empty hole as the drive barrel or direct casing is back-pulled incrementally. Therefore, direct push technology would be preferred to allow for many X-Y locations near the BY Tank Farm and BY Crib footprints to be interrogated before choosing locations to drill the traditional drive barrel boreholes with sediment collection and characterization. Sample collection using the direct-push technology as the casing is back pulled and after the technetium-99 detector results have been recorded would also be possible.

Boreholes placed to the east of the BY Tank Farm on a transect towards 299-E33-343 would be useful to investigate whether releases from BY Tanks are the source of the secondary hot spot of technetium-99 entering the water table near the new well. Additional boreholes north and northeast of B-46 (in BY Cribs) that follow the vadose zone stratigraphic dip would be useful to evaluate horizontal spreading beyond the BY Cribs' footprint. Drilling within and outside the BY Cribs' footprint in the 
vicinity of the location that appears to be the link between the deep vadose zone technetium-99 contamination and the water table would improve the ability of the researchers to estimate the inventory of technetium-99 remaining in the vadose zone at the facility considered to be the largest source.

To gain more data on the location where uranium from the BX-102 overfill event appears to be reaching the water table, several more boreholes in the vicinity of 299-E33-343 could be drilled. It may be possible to use direct-push technology coupled with spectral gamma logging through the direct-push casing to probe more of the area around 299-E33-343 if the $\mathrm{CCU}_{z}$ unit can be reached and penetrated (depth required is 220 to $240 \mathrm{ft}$ bgs). It is not clear that direct push can reach this depth and penetrate the $\mathrm{CCU}_{z}$ strata. Because there is no indication (aside from the ultra-sensitive uranium isotopic signature measurements) of Hanford processed uranium being present shallower in the Hanford formation around 299-E33-343, there is nothing to be gained probing only the Hanford formation in this region with directpush or SGLS logging.

Drilling several more boreholes in the region of 299-E33-343 would allow a much better mass inventory estimate for deep vadose zone uranium and the secondary technetium-99 hot spot to be developed as well as to better locate the areal extent of where the uranium and technetium-99 are entering the water table at this location. If no scouting, direct-push information can be used to locate where to put boreholes, one suggestion is to use the isopach map for the $\mathrm{CCU}_{\mathrm{z}}$ lens and move to the north and perhaps west of 299-E33-343 because the layer thins in these directions (see Figure 10.1). The top elevation of the $\mathrm{CCU}_{\mathrm{z}}$ lens is fairly flat such that the thinning of the lens is more a function of the finer grained sediments filling an irregular trough present in the underlying coarser-grained $\mathrm{CCU}_{\mathrm{g}}$ strata. Thus, the high-uranium-laden pore water from the $\mathrm{CCU}_{z}$ sediments might reach the coarser grained underlying sediments and descend to the water table by horizontally moving out the bottom of the lateral spreading layer as opposed to dropping out of the edges where the whole unit pinches out. This conceptual model makes it difficult to guess where the $\mathrm{CCU}_{\mathrm{z}}$ uranium-laden pore water reached the more permeable $\mathrm{CCU}_{\mathrm{g}}$ sediments and descended into the water table.

At 299-E33-343, none of the deeper $\mathrm{CCU}_{\mathrm{g}}$ samples were characterized in detail before they were disposed of as waste, so more attention should be placed on measuring Hanford-processed uranium in this coarser sediment in which the groundwater resides. Many of the grab and core samples of $\mathrm{CCU}_{\mathrm{z}}$ sediments from the boreholes discussed in the B-Complex conceptual report have been retained in spite of the push to close out the project and cost all disposal in FY09. However, all of the samples from the $\mathrm{CCU}_{\mathrm{g}}$ were disposed of, and consequently, neither the concentrations of uranium in the vadose zone sediments right above the water table nor the interactions of pore water from the $\mathrm{CCU}_{\mathrm{z}}$ sediments can be investigated. Particular attention should be placed on determining whether there is "perched" or freestanding water within the $\mathrm{CCU}_{z}$ lens at each of the new proposed boreholes. If there is free standing water, a "perched" well similar to that completed at 299-E33-344 should be installed for future monitoring and pumping.

It would also be informative to locate better where the Hanford processed uranium from the BX-102 overfill event descends out of the Hanford formation into the $\mathrm{CCU}_{\mathrm{z}}$ horizontal spreading unit. A borehole or direct-push campaign would be useful southwest of 299-E33-343 along the B Tank Farm fence line along a transect between 299-E33-343 and borehole 299-E33-45. This would allow better estimates of the Hanford formation $\mathrm{H} 2$ unit mass of uranium and location where the uranium is descending into the $\mathrm{CCU}_{\mathrm{z}}$ horizontal spreading unit to be developed. The high-sample-density grab sampling and tiered characterization protocols would be preferred. 
It would help if a borehole to the water table with high-density grab sampling and characterization were drilled near 21-02-04 (299-E33-27) to evaluate the vertical extent of uranium penetration right near the assumed location of the BX-102 overfill event. The SGLS logs for this borehole are confounded by the presence of high cesium-137 that precludes determination of the vertical distribution of Hanford processed uranium near the source of the overfill event.

If the boreholes (drilled by Womack and Larkin 1971) known as the "27 series boreholes (shown in Figure 3.49) are accessible and suitable for spectral gamma logging, their re-logging to obtain a current estimate of Hanford processed uranium would be quite valuable. The data from re-logging with the current SGLS system would help determine the horizontal and vertical extent of the uranium from BX102 overfill event. This re-logging could be performed before the drilling and direct-push activities suggested above.

\subsection{Other Locations Where Additional Vadose Zone Boreholes or Direct Push with Sediment Sampling are Needed}

The following are other locations where data on vadose zone distributions of mobile contaminants are non-existent or sparse. Priorities have not been established as to which of these recommended additional boreholes are more important than others.

At the BX trenches, a borehole through the trench with the largest volume of waste and largest mass of contaminants disposed of would be prudent. The trench would be B-37 as evidenced by data in Appendix A.

Another borehole either through the B-7A Crib or just to the northeast of the footprint (the direction that vadose zone strata dip) would be most useful. The higher density grab sampling and the tiered characterization approach described above would be ideal to better ascertain the deep vadose zone distribution of mobile contaminants from this facility, which received high volumes of water that surely reached the water table. The same recommendation has already been made for a borehole through the B-8 Crib footprint or its connection to the tile field.

Some direct-push probe activity would be useful with SGLS and the technetium-99 in situ detector funded by WRPS (should the detector be viable) within the BY Tank Farm and surrounding the three 200-series B Tanks, which are designated as potential leakers. The direct-push field surveys should attempt to reach the top of the $\mathrm{CCU}_{\mathrm{z}}$ unit to evaluate whether this stratigraphic unit could be a significant source of mobile contaminants in the vicinity of the three wells (299-E33-18, E33-344, and E33-345) that show complicated and highly variable pore-water compositions as a function of depth. If there is indication that the BY Tank Farm or 200-series B Tanks are contributing mobile contaminants to the deep vadose zone, traditional boreholes down to the water table with high density grab sampling and characterization would be warranted. If there is indication that fluids released from the BY Tanks have impacted the vadose zone, more traditional boreholes with the recommended sample collection and characterization could be performed to better estimate the inventory of mobile contaminants attributable to the BY tank farm. Most all of the scavenged TBP waste that went to the BY Cribs that contained the high concentrations of cyanide, nitrate, and technetium-99 were cascaded through BY Tanks and then to the BY-201 Settling Tank before reaching the BY Cribs. Thus, leaks or releases from 
the BY Tanks could be the source of the secondary technetium-99 hot spot occurring at the water table near 299-E33-343.

During SGLS studies and historical gross gamma logging reviews in the vicinity of the BY Cribs, the BX Trenches, the B-7-A\&B, B-8, B-11-A\&B, and the B, BX, and BY Tank Farms, the Stoller Company provided several recommendations on regions that did not have adequate borehole coverage to allow determination of the horizontal and vertical extent of contamination. It is also recommended that these reports be re-visited to determine additional locations that would benefit from additional vadose zone characterization (see DOE/GJO 2003, DOE/GJO 2002a, DOE/GJO 2002b, and Sobczyk 2004a, b).

\subsection{Improvement Needed in Cyanide Method for Sediments}

The available data for total cyanide content in the vadose zone and aquifer sediments obtained during the drilling of the boreholes show that low to non-detectable amounts of cyanide are present. However, after reviewing the data and making calculations on what the detection limits would be for cyanide in vadose zone pore waters, it was discovered that the current detection limit for measuring the cyanide content of sediments is woefully insensitive. Because the detection limit for cyanide in Hanford vadose zone sediments has ranged from 0.2 to $1 \mu \mathrm{g} / \mathrm{g}$ over the last 20 years, it is difficult to show where cyanide is present and not present at environmentally important concentrations in sediments. That is, if one assumes that all the cyanide extracted from the sediment was present in the pore water, then at the typical moisture contents of Hanford formation $\mathrm{H} 2$ sand ( 3 to $5 \% \mathrm{wt}$ ), the detection limit is equivalent to porewater concentrations of between 4,000 and 33,000 $\mu \mathrm{g} / \mathrm{L}$ cyanide. These pore-water detection limits are much too insensitive to be very useful at discerning the presence or absence of cyanide in vadose zone pore water excepting in situations with very high cyanide concentrations. Cyanide concentrations found in Hanford Site groundwater plumes rarely exceed $1,000 \mu \mathrm{g} / \mathrm{L}$ such that relying on the current analytical procedures for determining cyanide concentrations in moist vadose zone sediments is a rather insensitive protocol that is likely only identifying the most highly cyanide-contaminated locations. Concentrations in the groundwater below the B-Complex are increasing over the last decade, so it would be useful to expend more effort on improving the measurement and detection limit for cyanide in sediments.

\subsection{Isotope Signature Activities}

As discussed in the B-Complex Conceptual Model Report (see Sections 1.7, 3.1.3, 3.3.3, 3.4.3, 5.7, and 9.8) high-precision uranium isotopic ratio measurements offer a unique methodology to discriminate between various sources of Hanford processed uranium. When adequate amounts of uranium are present in pore waters or water extracts, this technique can differentiate one source from another. Good signatures are available for the BX-102 overfill event, the B-110 tank release, the natural uncontaminated vadose zone pore water from each vadose zone unit, and uncontaminated groundwater. One datum for the each of the BY Cribs and B-7-A Crib sources are available, but it would be beneficial to obtain more data for these two facilities as well as new ones for new boreholes for B-37 (BX Trenches), B-8 Crib, 200-Series B Tanks, and BY Tanks.

Also at the T Tank Farm, precise isotope signature studies on the nitrogen and oxygen isotope ratios have suggested that tank waste can be differentiated from "low activity" trench and crib wastes. Water extracts, pore waters, and groundwaters from the recent 200-BP-5 boreholes described in the B-Complex Conceptual Model Report have been made available to staff at the Center for Isotope Studies at Lawrence 
Berkeley National Laboratory, but no funding has been allocated to perform the nitrogen and oxygen in nitrate analyses. It would be very helpful for funds to be made available such that some of the samples can be processed to ascertain whether nitrate nitrogen and oxygen isotopes from samples from the B-Complex can be used as a second source discriminator, and more importantly, if the nitrate signatures corroborate the same sources as the dominant sources of the fluids and dissolved uranium in the vadose zone. Similar isotope fingerprints using the stable ruthenium fission product isotopes could prove valuable as an analogue to technetium-99, such that the sources of technetium-99 might be differentiable.

\subsection{Deep Vadose Zone Uranium Remediation}

It is recommended that the CHPRC staff consider pumping the "perched" water well 299-E33-344 for extended periods of time with flow rate, water chemical composition monitoring, and water-level impacts near the two aquifer wells 299-E33-18 and 299-E33-345. If the volume of water that can be pumped from the perched well is quite limited and there is no impact on the levels and chemical composition of the water in the two aquifer wells, then after suitable time to allow the perched water to re-equilibrate, then injections of uranium sequestering agents (such as phosphate, ammonia gas, or reductants) could be performed with subsequent water withdrawal versus time field tests to evaluate the efficacy of deep vadose zone remediation techniques that rely on in situ sequestration. Similar deep vadose zone uranium testing could be performed at the new boreholes that are recommended near 299-E33-343 should similar perched or free-standing water be found. 

PNNL-19277

\subsection{References}

Baker VR. 1978. "Large-Scale Erosional and Depositional Features of the Channeled Scabland." In The Channeled Scabland. VR Baker and D Nummedal, eds. National Aeronautics and Space Administration, Washington D.C., p. 81-115.

Baker VR, BN Bjornstad, AJ Busacca, KR Fecht, EP Kiver, UL Moody, JG Rigby, DF Stradling, and AM Tallman. 1991. "Quaternary Geology of the Columbia Plateau." In Quaternary Nonglacial Geology; Conterminous U.S.: Boulder, Colorado. RB Morrison, ed., Geological Society of America, The Geology of North America, v. K-2.

Bierschenk WH (editor). 1958a. Chemical Effluents Technology Waste Disposal Investigations October, November December 1976. HW-54848, Hanford Atomic Products Operation, Richland, Washington.

Bierschenk WH (editor). 1958b. Chemical Effluents Technology Waste Disposal Investigations January, February, March 1958. HW-55841 RD, Hanford Atomic Products Operation, Richland, Washington.

Bierschenk WH (editor). 1958c. Chemical Effluents Technology Waste Disposal Investigations April, May, June 1958. HW-57002 RD, Hanford Atomic Products Operation, Richland, Washington.

Bierschenk WH (editor). 1958d. Chemical Effluents Technology Waste Disposal Investigations July, August, September 1958. HW-58023, Hanford Atomic Products Operation, Richland, Washington.

Bierschenk WH (editor). 1959a. Chemical Effluents Technology Waste Disposal Investigations October, November December 1958. HW-58811 RD, Hanford Atomic Products Operation, Richland, Washington.

Bierschenk WH (editor). 1959b. Chemical Effluents Technology Waste Disposal Investigations January, February, March 1959. HW-60163, Hanford Atomic Products Operation, Richland, Washington.

Bierschenk WH (editor). 1959c. Chemical Effluents Technology Waste Disposal Investigations April, May, June 1959. HW-61197 RD, Hanford Atomic Products Operation, Richland, Washington.

Bjornstad BN. 2006. On the Trail of the Ice Age Floods: A Geological Field Guide to the Mid-Columbia Basin. Keokee Co. Publishing, Inc., Sandpoint, Idaho.

Brodeur JR, RK Price, RD Wilson, and CJ Koizumi. 1993. Results for Spectral Gamma-Ray Logging of Selected Boreholes for the 200 Aggregate Area Management Study. WHC-SD-EN-TI-021, Westinghouse Hanford Company, Richland, Washington.

Brown DJ (editor). 1957a. Chemical Effluents Technology Waste Disposal Investigations July, August, September 1956. HW-49465, Hanford Atomic Products Operation, Richland, Washington.

Brown DJ (editor). 1957b. Chemical Effluents Technology Waste Disposal Investigations October, November December 1956. HW-50186, Hanford Atomic Products Operation, Richland, Washington.

Brown DJ (editor). 1957c. Chemical Effluents Technology Waste Disposal Investigations January, February, March 1957. HW-51095, Hanford Atomic Products Operation, Richland, Washington. 
Brown DJ (editor). 1957d. Chemical Effluents Technology Waste Disposal Investigations April, May, June 1957. HW-53225, Hanford Atomic Products Operation, Richland, Washington.

Brown DJ (editor). 1957e. Chemical Effluents Technology Waste Disposal Investigations July, August, September 1957. HW-54655, Hanford Atomic Products Operation, Richland, Washington.

Brown DJ (editor). 1962a. Chemical Effluents Technology Waste Disposal Investigations-JulyDecember, 1961. HW-72645-RD, Hanford Atomic Products Operation, Richland, Washington.

Brown DJ (editor). 1962b. Chemical Effluents Technology Waste Disposal Investigations-JanuaryJune 1962. HW-74915-RD, Hanford Atomic Products Operation, Richland, Washington.

Brown DJ (editor). 1963. Chemical Effluents Technology Waste Disposal Investigations-July December 1962. HW-76120-RD, Hanford Atomic Products Operation, Richland, Washington.

Brown DJ (editor). 1964. Chemical Effluents Technology Waste Disposal Investigations-January December 1964. HW-84549, Hanford Atomic Products Operation, Richland, Washington.

Brown DJ (editor). 1965. Chemical Effluents Technology Waste Disposal Investigation, January -June 1965. BNWL-CC-285, Battelle-Northwest Laboratory, Richland, Washington.

Brown DJ and WA Haney. 1964. Chemical Effluents Technology Waste Disposal Investigations—July December, 1963. HW-80909, Hanford Atomic Products Operation, Richland, Washington.

Brown CF, JP Icenhower, W Um, BN Bjornstad, MM Valenta, C Iovin, DC Lanigan, IV Kutnyakov, SR Baum, MJ Lindberg, and RD Orr. 2007. Characterization of Direct-Push Vadose Zone Sediments from the B and BX Tank Farms. PNNL-17162, Pacific Northwest National Laboratory, Richland, Washington.

Campbell GS. 1974. "A Simple Method for Determining Unsaturated Conductivity from Moisture Retention Data." Soil Science 117:311-314.

Cantrell KJ, RJ Serne, and GV Last. 2002. Applicability of the Linear Sorption Isotherm Model to Represent Contaminant Transport Processes in Site-Wide Performance Assessments. CP-17089 Revision 0, Fluor Hanford, Inc., Richland, Washington.

Cantrell KJ, RJ Serne, and GV Last. 2003. Hanford Contaminant Distribution Coefficient Database and Users Guide. PNNL-13895, Rev. 1, Pacific Northwest National Laboratory, Richland, Washington.

Cantrell .J, JM Zachara, PE Dresel, KM Krupka, and RJ Serne. 2007. Geochemical Processes Data Package for the Vadose Zone in the Single-Shell Tank Waste Management Areas at the Hanford Site. PNNL-16663, Pacific Northwest National Laboratory, Richland, Washington.

Cantrell KJ, CF Brown, RJ Serne, and KM Krupka. 2008. Geochemical Characterization Data Package for the Vadose Zone in the Single-Shell Tank Waste Management Areas at the Hanford Site. PNNL17154, Pacific Northwest National Laboratory, Richland, Washington. 
Catalano GJ, SM Heald, JM Zachara, and GEJ Brown. 2004. "Spectroscopic and Diffraction Study of Uranium Speciation in Contaminated Vadose Zone Sediments from the Hanford Site, Washington State." Environmental Science \& Technology 38:2822-2828.

Christensen JN, PE Dresel, PG Conrad, K Maher, and DJ DePaolo. 2004. "Identifying the Sources of Subsurface Contamination at the Hanford Site in Washington Using High-Precision Uranium Isotopic Measurements." Environmental Science \& Technology 38:3330-3337.

Clukey, HV. 1956. Tabulation of Radioactive Liquid Waste Disposal Facilities. HW-43121, General Electric Hanford Works, Richland, Washington

Connelly MP, JV Borghese, CD Delaney, BH Ford, JW Lindberg, and SJ Trent. 1992. Hydrogeologic Model for the 200 East Groundwater Aggregate Area. WHC-SD-EN-TI-019, Westinghouse Hanford Company, Richland, Washington.

Corbin RA, BC Simpson, MJ Anderson, WF Danielson III, JG Field, TE Jones, and CT Kincaid. 2005. Hanford Soil Inventory Model, Rev 1. RPP-26744, CH2M-Hill Hanford Group, Inc., Richland, Washington. This document was also released at the same time as PNNL-15367 by Pacific Northwest National Laboratory, Richland, Washington.

DOE_U.S. Department of Energy. 1988. Consultation Draft Site Characterization Plan. DOE/RW-0164, 9 volumes, Office of Civilian Radioactive Waste Management, U.S. Department of Energy, Washington, D.C.

DOE/GJO-U.S. Department of Energy/Grand Junction Office. 1996. Vadose Zone Characterization Project at the Hanford Tank Farms, Tank Summary Data Report for Tank BY-102. GJO-96-2-TAR/GJOHAN-19, DOE Grand Junction Office, Grand Junction, Colorado.

DOE/GJO-U.S. Department of Energy/Grand Junction Office. 1997. Vadose Zone Characterization Project at the Hanford Tank Farm, BY Tank Farm Report. GJO-96-2-TAR/GJO-HAN-6, DOE Grand Junction Office, Grand Junction, Colorado.

DOE/GJO_U.S. Department of Energy/Grand Junction Office. 1998. Hanford Tank Farms Vadose Zone: BX Tank Farm Report. GJO-98-40-TAR/GJO-HAN-19, DOE Grand Junction Office, Grand Junction, Colorado.

DOE/GJO_U.S. Department of Energy/Grand Junction Office. 1999. Hanford Tank Farms Vadose Zone: B Tank Farm Report. GJO-99-113/GJO-HAN-19, DOE Grand Junction Office, Grand Junction, Colorado.

DOE/GJO-U.S. Department of Energy/Grand Junction Office. 2000a. Hanford Tank Farms Vadose Zone, Addendum to the BY Tank Farm Report. GJO-HAN-6, DOE Grand Junction Office, Grand Junction, Colorado.

DOE/GJO_U.S. Department of Energy/Grand Junction Office. 2000b. Hanford Tank Farms Vadose Zone, B Tank Farm Report. GJO-HAN-28, DOE Grand Junction Office, Grand Junction, Colorado. 
DOE/GJO-U.S. Department of Energy/Grand Junction Office. 2002a. Hanford 200 Areas Spectral Gamma Baseline Characterization Project, B-8 Crib and Adjacent Sites Waste Site Summary Report. GJO-2002-343-TAR, DOE Grand Junction Office, Grand Junction, Colorado.

DOE/GJO-U.S. Department of Energy/Grand Junction Office. 2002b. Hanford 200 Areas Spectral Gamma Baseline Characterization Project, B-35 to -42 Trenches Waste Site Summary Report. GJO2002-322-TAR, DOE Grand Junction Office, Grand Junction, Colorado.

DOE/GJO_U.S. Department of Energy/Grand Junction Office. 2003. Hanford 200 Areas Spectral Gamma Baseline Characterization Project B-43 to -50, -57, and -61 Cribs and Adjacent Sites Waste Site Summary Report. GJO-2003-458-TAC, DOE Grand Junction Office, Grand Junction, Colorado.

DOE/ORP-U.S. Department of Energy-Office of River Protection. 2008. RCRA Facility Investigation Report for Hanford Single-Shell Tank Waste Management Areas. DOE/ORP-2008-01, U.S. Department of Energy, Office of River Protection, Richland, Washington.

DOE/RL-U.S. Department of Energy, Richland Operations. 1992. Hanford Site Waste Management Units Report. DOE-RL 88-30, U.S. Department of Energy, Richland Operations Office, Richland, Washington.

DOE/RL-U.S. Department of Energy, Richland Operations. 1993a. Phase I Remedial Investigation Report for 200-BP-1 Operable Unit. DOE/RL-92-70, Rev. 0, U.S. Department of Energy, Richland Operations Office, Richland, Washington.

DOE/RL-U.S. Department of Energy-Richland Operations. 1993b. B Plant Source Aggregate Area Management Study Report, DOE/RL-92-05, Rev. 0, U.S. Department of Energy, Richland Operations Office. Richland, Washington.

DOE/RL-U.S. Department of Energy-Richland Operations. 1995. Hanford Site Background: Part 1, Soil Background for Nonradioactive Analytes. DOE/RL-92-24 Rev. 3, U.S. Department of Energy, Richland Operations Office, Richland, Washington.

DOE/RL-U.S. Department of Energy-Richland Operations. 1996a. 200-BP-5 OU Treatability Test Report, DOE/RL-95-59, Rev. 0, U.S. Department of Energy, Richland Operations Office. Richland, Washington.

DOE/RL-U.S. Department of Energy-Richland Operations. 1996b. Annual Report for RCRA Groundwater Monitoring Projects at Hanford Site Facilities for 1995. DOE/RL-96-01, Rev. 0, U.S. Department of Energy, Richland Operations Office, Richland, Washington.

DOE/RL. 2002. Standardized Stratigraphic Nomenclature for the Post-Ringold-Formation Sediments Within the Central Pasco Basin. DOE/RL-2002-39, Rev. 0, U.S. Department of Energy, Richland, Washington.

DOE/RL-U.S. Department of Energy-Richland Operations. 2003. Remedial Investigation Report for the 200-TW-1 Scavenged Waste Group, the 200-TW-2 Tank Waste Group, and the 200-PW-5 FissionProduct Rich Waste Group Operable Units. DOE/RL-2003-64, U.S. Department of Energy, Richland Operations Office, Richland, Washington. 
DOE/RL-U.S. Department of Energy-Richland Operations. 2007a. 200-UW-1 Operable Unit Remedial Action Goals for Removal/Treatment/Disposal Waste Sites. DOE/RL-2007-35, Rev. 0, Richland, Washington.

DOE/RL-U.S. Department of Energy-Richland Operations. 2007b. Regulatory Criteria for the Selection of Vadose Zone Modeling in Support of the 200-UW-1 Operable Unit. DOE/RL-2007-34, Rev. 0, U.S. Department of Energy, Richland Operations Office, Richland, Washington.

DOE/RL-U.S. Department of Energy-Richland Operations. 2007c. Hanford Site Groundwater Monitoring for Fiscal Year 2007. DOE/RL-2008-01, U.S. Department of Energy, Richland Operations Office, Richland, Washington. Available at: http://www.hanford.gov/cp/gpp/library/gwrep07/html/start07.htm.

DOE/RL-U.S. Department of Energy-Richland Operations. 2008a. Remedial Investigation/Feasibility Study Work Plan for the 200-BP-5 Groundwater Operable Unit. U.S. Department of Energy, Richland Operations Office, Richland, Washington.

DOE/RL - U.S. Department of Energy-Richland Operations. 2008b. Hanford Site Groundwater Monitoring for Fiscal Year 2008. DOE/RL-2008-66, U.S. Department of Energy, Richland Operations Office, Richland, Washington. Available at: http://www.hanford.gov/cp/gpp/library/gwrep08/html/start08.htm.

Eliason JR. 1966a. Earth Sciences Waste Disposal Investigations July-December, 1965. BNWL-CC574, Battelle-Northwest Laboratory, Richland, Washington.

Eliason JR. 1966b. Earth Sciences Waste Disposal Investigations January - June, 1966. BNWL-CC887, Battelle-Northwest Laboratory, Richland, Washington.

EPA-U.S. Environmental Protection Agency. 1999a. Understanding Variation in Partition Coefficient, $K_{d}$, Values: Volume I. The $K_{d}$ Model, Methods of Measurement, and Application of Chemical Reaction Codes. EPA 402-R-99-004A, prepared for the U.S. Environmental Protection Agency, Washington, D.C. by Pacific Northwest National Laboratory, Richland, Washington.

EPA-U.S. Environmental Protection Agency. 1999b. Understanding Variation in Partition Coefficient, $K_{d}$,Values: Volume II. Review of Geochemistry and Available $K_{d}$ Values for Cadmium, Cesium, Chromium, Lead, Plutonium, Radon, Strontium, Thorium, Tritium $\left({ }^{3} H\right)$, and Uranium. EPA 402-R-99004B, prepared for the U.S. Environmental Protection Agency, Washington, D.C. by Pacific Northwest National Laboratory, Richland, Washington.

EPA-U.S. Environmental Protection Agency. 2004. Understanding Variation in Partition Coefficient, $K_{d}$,Values: Volume III. Review of Geochemistry and Available $K_{d}$ Values for Americium, Arsenic, Curium, Iodine, Neptunium, Radium, and Technetium. EPA 402-R-04-002C, prepared for the U.S. Environmental Protection Agency, Washington, D.C. by Pacific Northwest National Laboratory, Richland, Washington.

Evans JC, RW Bryce, and DR Sherwood. 1989. Hanford Site Ground-Water Monitoring for January Through June 1988. PNL-6886, Pacific Northwest Laboratory, Richland, Washington. 
Fayer MJ and JM Keller. 2007. Recharge Data Package for Hanford Single-Shell Tank Waste Management Areas. PNNL-16688, Pacific Northwest National Laboratory, Richland, Washington.

Fayer MJ and TB Walter. 1995. Estimated Recharge Rates at the Hanford Site. PNL-10285, Pacific Northwest National Laboratory, Richland, Washington.

Fayer MJ and JE Szecsody. 2004. Recharge Data Package for the 2005 Integrated Disposal Facility Performance Assessment. PNNL-14744, Pacific Northwest National Laboratory, Richland, Washington.

Fecht KR, GV Last, and KR Price. 1977. Evaluation of Scintillation Probe Profiles from 200 Area Crib Monitoring Wells. ARH-ST-156, Atlantic Richfield Hanford Company, Richland, Washington.

Fecht KR, BN Bjornstad, DG Horton, GV Last, SP Reidel, and KA Lindsey. 1999. Clastic Injection Dikes of the Pasco Basin and Vicinity: Geologic Atlas Series. BHI-01103, Rev. 0, Bechtel Hanford Company, Richland, Washington.

Field JG and TE Jones. 2006. Tank Farm Vadose Zone Contamination Volume Estimates. RPP-23405 Rev. 2, CH2M-Hill Hanford Group, Inc., Richland, Washington.

Field JG, JP Harris, ME Johnson. 2007. Process to Assess Tank Farm Leaks in Support of Retrieval and Closure Planning. RPP-32681, Rev. 0, CH2M-Hill Hanford Group, Inc., Richland, Washington.

Gee GW, MJ Fayer, ML Rockhold, and MD Campbell. 1992. "Variations in Recharge at the Hanford Site." Northwest Science 66:237-250.

Gelhar LW. 1986. "Stochastic Subsurface Hydrology from Theory to Application." Water Resources Research 22(9):135S-145S.

Gelhar LW, C Welty, and KR Rehfeldt. 1992. "A Critical Review of Data on Field-Scale Dispersion in Aquifers." Water Resources Research 28:1955-1974.

Hajek BF. 1966. Soil Survey Hanford Project in Benton County, Washington. BNWL-243, BattelleNorthwest Laboratory, Richland, Washington.

Haney WA (editor). 1959. Chemical Effluents Technology Waste Disposal Investigations July, August, September 1959. HW-62692 RD, Hanford Atomic Products Operation, Richland, Washington.

Haney WA (editor). 1960a. Chemical Effluents Technology Waste Disposal Investigations October, November December 1959. HW-64094-RD, Hanford Atomic Products Operation, Richland, Washington.

Haney WA (editor). 1960b. Chemical Effluents Technology Waste Disposal Investigations January, February, March 1960. HW-65464-RD, Hanford Atomic Products Operation, Richland, Washington.

Haney WA (editor). 1960c. Chemical Effluents Technology Waste Disposal Investigations April, May, June 1960. HW-66859-RD, Hanford Atomic Products Operation, Richland, Washington. 
Haney WA (editor). 1960d. Chemical Effluents Technology Waste Disposal Investigations July, August, September 1960. HW-67753- RD, Hanford Atomic Products Operation, Richland, Washington.

Haney WA (editor). 1961a. Chemical Effluents Technology Waste Disposal Investigations October, November December 1960. HW-68543-RD, Hanford Atomic Products Operation, Richland, Washington.

Haney WA (editor). 1961b. Chemical Effluents Technology Waste Disposal Investigations-JanuaryJune, 1961. HW-70806-RD, Hanford Atomic Products Operation, Richland, Washington.

Haney WA (editor). 1963. Chemical Effluents Technology Waste Disposal Investigations-JanuaryJune, 1963. HW-78951, Hanford Atomic Products Operation, Richland, Washington.

Hanlon BM. 2006. Waste Tank Summary Report for Month Ending June 30, 2006. HNF-EP-0182Rev. 19, CH2M-Hill Hanford Group, Inc., Richland, Washington.

Hartman MJ, LF Morasch, and WD Webber (eds.). 2006. Hanford Site Groundwater Monitoring for Fiscal Year 2005. PNNL-15670, Pacific Northwest National Laboratory, Richland, Washington.

Higley BA and DE Place. 2004. Hanford Defined Waste Model-Revision 5.0. RPP-19822, Rev 0, CH2M-Hill Hanford Group, Inc., Richland, Washington.

Horton DG. 2007. Data Package for Past and Current Groundwater Flow and Contamination beneath Single-Shell Tank Waste Management Areas. PNNL-15837, Pacific Northwest National Laboratory, Richland, Washington.

Ilton ES, NP Qafoku, C Liu, DA Moore, and JM Zachara. 2008. “Advective Removal of Intraparticle Uranium from Contaminated Vadose Zone Sediments, Hanford, USA.” Environmental Science \& Technology 42:1565-1571. Johnson VG. 1993. Westinghouse Hanford Company Operational Groundwater Status Report 1990-1992. WHC-EP-0595, Westinghouse Hanford Company, Richland, Washington.

Khaleel R. 2007. Far-Field Hydrology Data Package for the RCRA Facility Investigation (RFI) Report. RPP-RPT-35222, Rev. 1, CH2M-Hill Hanford Group, Inc., Richland, Washington.

Khaleel R and EJ Freeman. 1995. Variability and Scaling of Hydraulic Properties for 200 Area Soils, Hanford Site. WHC-EP-0883, Westinghouse Hanford Company, Richland, Washington.

Khaleel R, TE Jones, AJ Knepp, FM Mann, DA Myers, and MI Wood. 2001. Modeling Data Package for B-BX-BY Field Investigation Report (FIR). RPP-9223, Rev. 0, CH2M-Hill Hanford Group, Inc., Richland, Washington.

Khaleel R, MP Connelly, and WJ McMahon. 2006. Modeling Data Package for an Initial Assessment of Closure of the C Tank Farm. RPP 13310, Rev. 1, CH2M-Hill Hanford Group, Inc., Richland, Washington. 
Klute A. 1986. Water retention: Laboratory methods. In A. Klute (ed). Methods of Soil Analysis. Part I. Physical and mineralogical methods. Second edition. American Society of Agronomy, Monograph No. 9, Madison, WI.

Knepp AJ. 2002. Field Investigation Report for Waste Management Area B-BX-BY. RPP-10098, CH2MHill Hanford Group, Inc., Richland, Washington.

Last GV, BN Bjornstad, MP Bergeron, DW Wallace, DR Newcomer, JA Schramke, MA Chamness, CS Cline, SP Airhart, and JS Wilbur. 1989. Hydrogeology of the 200 Areas Low-Level Burial Grounds - An Interim Report. PNL-6820, 2 volumes, Pacific Northwest Laboratory, Richland, Washington.

Last GV, GW Gee, EJ Freeman, WE Nichols, KJ Cantrell, BN Bjornstad, MJ Fayer, and DG Horton. 2006. Vadose Zone Hydrogeology Data Package for Hanford Assessments. PNNL-14702, Rev. 1, Pacific Northwest National Laboratory, Richland, Washington.

Last GV, ML Rockhold, CJ Murray, and KJ Cantrell. 2009. Selection and Traceability of Parameters to Support Hanford-Specific RESRAD Analyses. PNNL-18564, Pacific Northwest National Laboratory, Richland, Washington.

Lewis RE, BN Bjornstad, and SS Teel. 1993. "Buried Megaripples at the Hanford Site, Benton County, Washington." Geological Society of America Abstracts with Programs 25(6):A-67.

Lilga MA, DJ Kowalski, RT Hallen, GR. Lumetta, EV Alderson, WF Riemath, MO Hogan, RA Romine, L Hubler, GF Schiefelbein, GL Jones, and MR Telander. 1996. Ferrocyanide Safety Project: Ferrocyanide Aging Studies Final Report. PNNL-11211, Pacific Northwest National Laboratory, Richland, Washington.

Lindenmeier CW, RJ Serne, BN Bjornstad, GV Last, DC Lanigan, MJ Lindberg, RE Clayton, VL LeGore, IV Kutnyakov, SR Baum, KN Geiszler, MM Valenta, and TS Vickerman. 2002. Characterization of Vadose Zone Sediment: Borehole C3103 Located in the B-7A Crib Near the B Tank Farm. PNNL-14128, Pacific Northwest National Laboratory, Richland, Washington.

Lindsey KA. 1991. Revised Stratigraphy for the Ringold Formation, Hanford Site, South-Central Washington. WHC-SD-EN-EE-004, Rev. 0, Westinghouse Hanford Company, Richland, Washington.

Lindsey KA. 1995. Miocene-to Pliocene-Aged Suprabasalt Sediments of the Hanford Site, South-Central Washington. BHI-00184, Bechtel Hanford, Inc., Richland, Washington.

Lindsey KA. 1996. "The Miocene to Pliocene Ringold Formation and Associated Deposits of the Ancestral Columbia River System, South-Central Washington and North-Central Oregon.” Open File Report 96-8, Washington Division of Geology and Earth Resources, Olympia, Washington.

Lindsey KA, BN Bjornstad, JW Lindberg, and KM Hoffman. 1992. Geologic Setting of the 200 East Area: An Update. WHC-SD-EN-TI-012, Westinghouse Hanford Company, Richland, Washington.

Lindsey KA, SE Kos, and KD Reynolds. 2001. Vadose Zone Geology of Boreholes 299-E33-45 and 299-E33-46 B-BX-BY Waste Management Area, Hanford Site, South-Central Washington. RPP-8681, 
Rev. 0. Prepared for the Office of River Protection, CH2M-Hill Hanford Group, Inc., Richland, Washington.

Liu C, JM Zachara, OS Qafoku, JP McKinley, SM Heald, and Z Wang, Z. 2004. "Dissolution of Uranyl Microprecipitates in Subsurface Sediments at Hanford Site, USA." Geochimica et Cosmochimica Acta 68:4519-4537.

Liu CX, JM Zachara, W Yantasee, PD Majors, and JP McKinley. 2006. "Microscopic Reactive Diffusion of Uranium in the Contaminated Sediments at Hanford, United States." Water Resources Research 42: Art. No. W12420.

Luttrell SP. 2000. Letter Report to M.J. Thurman, U.S. Department of Energy, Richland Operations Office, Subject: "Quarterly Resource Conservation and Recovery Act Groundwater Monitoring Data for the Period October 1 through December 31, 1999." Pacific Northwest National Laboratory, Richland, Washington.

Maher K, DJ DePaulo, and JN Christensen. 2006. "U-Sr Isotopic Speedometer: Fluid Flow and Chemical Weathering Rates in Aquifers." Geochimica et Cosmochimica Acta 70:4417-4435.

Maxfield HL. 1979. Handbook - 200 Area Waste Sites (Volumes 1, 2 and 3). RHO-CD-673, Rockwell Hanford Operations, Richland, Washington.

McKee EH, DA Swanson, and TL Wright. 1977. "Duration and Volume of Columbia River Basalt Volcanism: Washington, Oregon, Idaho." Geological Society of America Abstracts with Programs, v. 9, no. 4, pp, 463-464.

McKinley JP, JM Zachara, C Liu, SC Heald, BI Prenitzer, and BW Kempshall. 2006. "Microscale Controls on the Fate of Contaminant Uranium in the Vadose Zone, Hanford Site, Washington." Geochimica et Cosmochimica Acta 70:1873-1887.

Meyer PD and GW Gee. 1999. Information on Hydrologic Conceptual Models, Parameters, Uncertainty Analysis, and Data Sources for Dose, Assessments at Decommissioning Sites. PNNL-13091, Pacific Northwest National Laboratory, Richland, Washington.

Moench AF. 1997. Flow to a Well of Finite Diameter in a Homogeneous, Anisotropic WaterTable Aquifer." Water Resources Research 33(6):1397-1407.

Mualem Y. 1976. "A New Model for Predicting the Hydraulic Conductivity of Unsaturated Porous Media." Water Resources Research 12:513-522.

Myers DA. 1978. Environmental Monitoring Report on Radiological Status of the Groundwater Beneath the Hanford Site, January-December 1977. PNL-2624, Pacific Northwest Laboratory, Richland, Washington.

Myers DA, JJ Fix, and JR Raymond. 1977. Environmental Monitoring Report on Radiological Status of the Groundwater Beneath the Hanford Site, January-December 1976. BNWL-2199, Battelle-Northwest Laboratory, Richland, Washington. 
Newcomer. 2008. BP-5 Remedial Investigation Slug-Test Characterization Results for Well 699-52-55A. PNNL-17675, Pacific Northwest National Laboratory, Richland, Washington.

PNNL_Pacific Northwest National Laboratory. 1996. Hanford Site Groundwater Monitoring for Fiscal Year 1996. PNNL-11470, Pacific Northwest National Laboratory, Richland, Washington. Available at: http://www2.hanford.gov/arpir/?content=findpage\&AKey=D199132964.

PNNL_Pacific Northwest National Laboratory. 1997. Hanford Site Groundwater Monitoring for Fiscal Year 1997. 1997. PNNL-11793, Pacific Northwest National Laboratory, Richland, Washington.

Available at:

http://www2.hanford.gov/arpir/?content=findpage\&AKey=D199132962.

PNNL_Pacific Northwest National Laboratory. 1998. Hanford Site Groundwater Monitoring for Fiscal Year 1998. PNNL-12086, Pacific Northwest National Laboratory, Richland, Washington. Available at: http://www2.hanford.gov/arpir/?content=findpage\&AKey=D199091099.

PNNL_Pacific Northwest National Laboratory. 1999a. Hanford Site Groundwater Monitoring for Fiscal Year 1998. PNNL-12086, Pacific Northwest National Laboratory for the U.S. Department of Energy, Richland Operations Office, Richland, Washington.

PNNL_Pacific Northwest National Laboratory. 1999b. Hanford Site Groundwater Monitoring for Fiscal Year 1999. PNNL-13116, Pacific Northwest National Laboratory, Richland, Washington.

Available at: http://www2.hanford.gov/arpir/?content=findpage\&AKey=D2736610 and http://www2.hanford.gov/arpir/?content=findpage\&AKey=D2736978.

PNNL_Pacific Northwest National Laboratory. 2000. Hanford Site Groundwater Monitoring for Fiscal Year 2000. PNNL-13404, Pacific Northwest National Laboratory, Richland, Washington. Available at: http://www.pnl.gov/main/publications/external/technical_reports/PNNL-13404.pdf.

PNNL_Pacific Northwest National Laboratory. 2001. Hanford Site Groundwater Monitoring for Fiscal Year 2001. PNNL-13788, Pacific Northwest National Laboratory, Richland, Washington. Available at: http://www.pnl.gov/main/publications/external/technical_reports/PNNL-13788.pdf.

PNNL_Pacific Northwest National Laboratory. 2002. Hanford Site Groundwater Monitoring for Fiscal Year 2002. PNNL-14187, Pacific Northwest National Laboratory, Richland, Washington. Available at: http://www.pnl.gov/main/publications/external/technical_reports/PNNL-14187.pdf.

PNNL_Pacific Northwest National Laboratory. 2003. Hanford Site Groundwater Monitoring for Fiscal Year 2003. PNNL-14548, Pacific Northwest National Laboratory, Richland, Washington. Available at: http://www.pnl.gov/main/publications/external/technical_reports/PNNL-14548.pdf.

PNNL-Pacific Northwest National Laboratory. 2004. Hanford Site Groundwater Monitoring for Fiscal Year 2004. PNNL-15070, Pacific Northwest National Laboratory, Richland, Washington. Available at: http://www.pnl.gov/main/publications/external/technical_reports/PNNL-15070.pdf.

PNNL_Pacific Northwest National Laboratory. 2005. Hanford Site Groundwater Monitoring for Fiscal Year 2005. PNNL-15670, Pacific Northwest National Laboratory, Richland, Washington. Available at: http://www.pnl.gov/main/publications/external/technical_reports/PNNL-15670.pdf. 
PNNL_Pacific Northwest National Laboratory. 2006. Hanford Site Groundwater Monitoring for Fiscal Year 2006. PNNL-16346, Pacific Northwest National Laboratory, Richland, Washington. Available at: http://www.pnl.gov/main/publications/external/technical_reports/PNNL-16346.pdf.

Price RK. 1992. Spectral Gamma-Ray Log Report for 200-BP-1. WHC-SD-EN-ES-029, Rev. 0, Westinghouse Hanford Company, Richland, Washington.

Price RK. 1998. In Situ Spectral Gamma-Ray Survey Results of Selected Boreholes Associated with the $B$-BX-BY Tank Farm Reassessment, WMNW-9759114, Rev. 0, Waste Management Federal Services, Inc., Richland, Washington.

Price WH and KR Fecht. 1976. Geology of the BX Tank Farm. ARH-LD-130, Atlantic Richfield Hanford Company, Richland, Washington.

PSPL—Puget Sound Power and Light Company. 1982. "Skagit/Hanford Nuclear Project, Preliminary Safety Analysis Report.” Vol. 4, App. 20, Amendment 23, Puget Sound Power and Light Company, Bellevue, Washington.

Qafoku NP, JM Zachara, X Liu, PL Gassman, OS Qafoku, and SC Smith. 2005. "Kinetic Desorption and Sorption of U(VI) During Reactive Transport in a Contaminated Hanford Sediment." Environmental Science \& Technology 39:3157-3165.

Randall RR and RK Price. 1998. Analysis of Historical Gross Gamma Logging Data from BY Tank Farm. HNF-3532, Rev. 0, prepared by Waste Management Northwest and Three Rivers Scientific for Lockheed Martin Hanford Corporation, Richland, Washington.

Raymond JR and VL McGhan. 1964. Scintillation Probe Results 200 Area Waste Disposal Site Monitoring Well. HW-84577, General Electric Hanford Atomic Products Operation, Richland, Washington.

Reeder RJ, M Nugent, GM Lamble, CD Tait, and DE Morris. 2000. "Uranyl Incorporation into Calcite and Aragonite: XAFS and Luminescence Studies.” Environmental Science \& Technology 34:638-644.

Reeder RJ, M Nugent, CD Tait, DE Morris, SM Heald, KM Beck, WP Hess, and A Lanzirotti. 2001. "Coprecipitation of Uranium(VI) with Calcite: XAFS, Micro-XAS, and Luminescence Characterization." Geochimica et Cosmochimica Acta 65:3491-3503.

Reidel SP and MA Chamness. 2007. Geology Data Package for the Single-Shell Tank Waste Management Areas at the Hanford Site. PNNL-15955, Pacific Northwest National Laboratory, Richland, Washington.

Reynolds KD. 2001. BX-102 Borehole Completion Report. RPP-7921, Rev. 0, Duratek Federal Services, Inc., Northwest Operations, Richland, Washington.

Rhoads K, BN Bjornstad, RE Lewis, SS Teel, KJ Cantrell, RJ Serne, JL Smoot, CT Kincaid, and SK Wurstner. 1994. Estimation of the Release and Migration of Lead Through Soils and Groundwater at the Hanford Site 218-E-12B Burial Ground. PNL-8356, Vol. 1, Pacific Northwest Laboratory, Richland, Washington. 
Rucker DF and JB Fink. 2007. "Inorganic Plume Delineation Using Surface High-Resolution Electrical Resistivity at the BC Cribs and Trenches Site, Hanford." Vadose Zone Journal 6(4):946-958.

Rucker D, M Levitt, M Bergeron, J Greenwood, G O’Brien, M McNeill, B Cubbage, R McGill, S Gerring, and C Henderson. 2007. Surface Geophysical Exploration of the B, BX, and BY Tank Farms at the Hanford Site. RPP-34690, Rev. 0, CH2M-Hill Hanford Group, Inc., Richland, Washington.

Schaap MG, PJ Shouse, and PD Meyer. 2003. Laboratory measurements of the unsaturated hydraulic properties at the Vadose Zone Transport Field Study Site. PNNL-14284, Pacific Northwest National Laboratory, Richland, Washington.

Serne RJ, BN Bjornstad, GW Gee, HT Schaef, DC Lanigan, CW Lindenmeier, RD Orr, VL LeGore, RE Clayton, MJ Lindberg, IV Kutnyakov, SR Baum, KN Geiszler, MM Valenta, TS Vickerman, and LJ Royack. 2002a. Characterization of Vadose Zone Sediment: Borehole 299-E33-46 Near B-110 in the $B-B X-B Y$ Waste Management Area. PNNL-14119, Pacific Northwest National Laboratory, Richland, Washington.

Serne RJ, GV Last, GW Gee, HT Schaef, DC Lanigan, CW Lindenmeier, MJ Lindberg, RE Clayton, VL LeGore, RD Orr, IV Kutnyakov, SR Baum, KN Geiszler, CF Brown, MM Valenta, and TS Vickerman. 2002b. Characterization of Vadose Zone Sediment: Borehole 299-E33-45 Near BX-102 in the B-BX-BY Waste Management Area. PNNL- 14083, Pacific Northwest National Laboratory, Richland, Washington.

Serne RJ, BN Bjornstad, DG Horton, DC Lanigan, CW Lindenmeier, MJ Lindberg, RE Clayton, VL LeGore, RD Orr, IV Kutnyakov, SR Baum, KN Geiszler, MM Valenta, and TS Vickerman. 2004a. Characterization of Vadose Zone Sediments Below the TX Tank Farm: Boreholes C3830, C3831, C3832 and RCRA Borehole 299- W10-2 7. PNNL-14594, Pacific Northwest National Laboratory, Richland, Washington.

Serne RJ, BN Bjornstad, DG Horton, DC Lanigan, HT Schaef, CW Lindenmeier, MJ Lindberg, RE Clayton, VL LeGore, KN Geiszler, SR Baum, MM Valenta, IV Kutnyakov, TS Vickerman, RD Orr, and CF Brown. 2004b. Characterization of Vadose Zone Sediments Below the T Tank Farm: Boreholes C4104, C4105, 299-W10-196, and RCRA Borehole 299-W11-39. PNNL-14849, Pacific Northwest National Laboratory, Richland, Washington.

Serne RJ, AL Ward, W Um, BN Bjornstad, DF Rucker, DC Lanigan and MW Benecke. 2009. Electrical Resistivity Correlation to Vadose Zone Sediment and Pore-Water Composition for the BC Cribs and Trenches Area. PNNL-17821, Pacific Northwest National Laboratory, Richland, WA.

Slate JL. 1996. "Buried Carbonate Paleosols Developed in Pliocene-Pleistocene Deposits of the Pasco Basin, South-Central Washington, USA.” Quaternary International. 34-36:191-196.

Sobczyk SM. 2004a. Hanford 200 Areas Spectral Gamma Baseline Characterization Project: B-BX-BY WMA and Adjacent Waste Sites Summary Report. GJO-2003-545-TAC, U.S. Department of Energy, Grand Junction, Colorado. 
Sobczyk SM. 2004b. Interpreted Extent of Subsurface Contamination Resulting from the 241-BX-102 Tank Leak, 200 East Area, Hanford Site, Washington. Confederated Tribes of the Umatilla Indian Reservation, Department of Science and Engineering, Mission, Oregon.

Stenner RD, KH Cramer, KA Higley, SJ Jette, DA Lamar, TJ McLaughlin, DR Sherwood, and NE Van Houten. 1988. Hazard Ranking System Evaluation of CERCLA Inactive Waste Sites at Hanford. PNL-6456, Volumes 1, 2, 3, Pacific Northwest Laboratory, Richland, Washington.

Stephens DB, K-C Hsu, MA Prieksat, MD Ankeny, N Blandford, TL Roth, JA Kelsey, and JR Whitworth. 1998. "A Comparison of Estimated and Calculated Effective Porosity." Hydrogeology Journal 6:156-165.

Tallman AM, KR Fecht, MJ Marratt, and GV Last. 1979. Geology of the Separation Areas, Hanford Site, South-central Washington. RHO-ST-23, Rockwell Hanford Operations, Richland, Washington.

Thomas GW. 2008. Data Quality Objectives Summary Report in Support of the 200-BP-5 Groundwater Operable Unit Remedial Investigation/Feasibility Study Process. WMP-28945, Rev 1, CH2M-Hill Central Plateau Remediation Company, Richland, Washington.

Thorne, PD, MP Bergeron, MD Williams and VL Freedman. 2006. Groundwater Data Package for Hanford Assessments. PNNL-14753 Rev 1, Pacific Northwest National Laboratory, Richland, Washington.

Todd ME and C Trice. 2002. Borehole Summary Report for Boreholes C3101, C3341, C3342, C3343, and C3344, in the B-38 Trench and B-7A Crib, 200-TW-2 Tank Waste Group Operable Unit. BHI01607, Rev. 0, Bechtel Hanford, Inc., Richland, Washington.

Tuli A, MA Denton, JW Hopmans, T Harter, and JL MacIntyre. 2001. Multi-Step Outflow Experiment: From Soil Preparation to Parameter Estimation. Land, Air, And Water Resources Publication 100037, University of California, Davis, Davis, California.

van Genuchten MT. 1980. "A Closed-Form Equation for Predicting the Hydraulic Conductivity of Unsaturated Soils.” Soil Science Society of America Journal 44:892-898.

Wan J, TK Tokunaga, Y Kim, Z Wang, A Lanzirotti, E Saiz, and RJ Serne. 2008. "Effect of Saline Waste Solution Infiltration Rates on Uranium Retention and Spatial Distribution in Hanford Sediments." Environmental Science and Technology 42:1973-1978.

Wan J, Y Kim, TK Tokunaga, Z Wang, S Dixit, CI Steefel, E Saiz, M Kunz, and N Tamura. 2009. "Spatially Resolved U(VI) Partitioning and Speciation: Implications for Plume Scale Behavior of Contaminant U in the Hanford Vadose Zone." Environmental Science and Technology, in press.

Wang Z, JM Zachara, JP McKinley, and SC Smith. 2005. “Cryogenic Laser-Induced U(VI) Fluorescence Studies of a U(VI) Substituted Natural Calcite: Implications to U(VI) Speciation in Contaminated Hanford Sediments.” Environmental Science \& Technology 38:2651-2659. 
Ward AL, GW Gee, ZF Zhang, and JM Keller. 2006. Vadose Zone Contaminant Fate-And-Transport Analysis for the B-26 Trench. PNNL-14907, Pacific Northwest National Laboratory, Richland, Washington.

Womack JC and DJ Larkin. 1971. Investigation and Evaluation of 102-BX Tank Leak. ARH-2035, Atlantic Richfield Hanford Company, Richland, Washington.

Wood MI, VG Johnson, SP Reidel, and TE Jones. 1999. Subsurface Conditions Description Report for the S-SX Waste Management Are. HNF-4936, Lockheed Martin Hanford Company, Richland, Washington.

Wood MI, TE Jones, R Schalla, BN Bjornstad, and SM Narbutovskih. 2000. Subsurface Conditions Description of the B-BX-BY Waste Management Area. HNF-5507, Rev. 0A, CH2M-Hill Hanford Group, Inc, Richland, Washington.

Yu C, AJ Zielen, JJ Cheng, DJ LePoire, E Gnanapragasam, S Kamboj, J Arnish, A Wallo III, WA Williams, and H Peterson. 2001. User's Manual for RESRAD Version 6. ANL/EAD-4, Argonne National Laboratory, Argonne, Illinois.

Zachara JM, CF Brown, J Christensen, JA Davis, PE Dresel, S Kelly, C. Liu, JP McKinley, RJ Serne, and W Um. 2007a. A Site-wide Perspective on Uranium Geochemistry at the Hanford Site. PNNL-17031. Pacific Northwest National Laboratory, Richland, Washington.

Zachara JM, J Serne, M Freshley, F Mann, F Anderson, M Wood, T Jones, and D Myers, 2007b. "Geochemical Processes Controlling Migration of Tank Wastes in Hanford's Vadose Zone." Vadose Zone Journal 6:985-1003. 


\section{Appendix A}

Waste Facility Dimensions, Waste Stream Definitions, Major Chemical Inventories Disposed by Year for Each Facility 



\section{Appendix A: Waste Facility Dimensions, Waste Stream Definitions, Major Chemical Inventories Disposed by Year for Each Facility}

Table A.1. Facility Dimensions

\begin{tabular}{|c|c|c|c|c|c|c|c|c|}
\hline Facility & $\begin{array}{c}\text { Length/diameter } \\
\mathrm{ft}\end{array}$ & $\begin{array}{c}\text { Width } \\
\mathrm{ft}\end{array}$ & $\begin{array}{c}\text { Height/ } \\
\text { Depth } \\
\mathrm{ft}\end{array}$ & $\begin{array}{c}\text { Overburden } \\
\mathrm{ft}\end{array}$ & $\begin{array}{c}\text { Footprint Area } \\
\mathrm{ft}^{2}\end{array}$ & $\begin{array}{l}\text { Footprint Area } \\
\mathrm{m}^{2}\end{array}$ & $\begin{array}{l}\text { Top } \\
\mathrm{ft} \text { bgs }\end{array}$ & $\begin{array}{c}\text { Bottom } \\
\mathrm{ft} \text { bgs }\end{array}$ \\
\hline B-7A\&B & 12 & 12 & 4 & $\sim 10$ & 288 (sum) & 26.76 & 10 & 14 \\
\hline B-8 & 12 & 12 & 7 & $\sim 7$ & 144 & 13.38 & 7 & 14 \\
\hline B-8 Tile Field & 300 & 100 & 4 & $\sim 10$ & 30000 & 2787 & 10 & 14 \\
\hline B-51 French Drain & 5 (diameter) & & 15 & -1 & 19.64 & 1.82 & -1 & 14 \\
\hline B-57 & 200 & 15 & 10 & $\begin{array}{l}\text { Barrier in } \\
\text { Place }\end{array}$ & 3000 & 278.71 & & \\
\hline B-11A\&B & 4 (diameter) & & 30 & 10 & 25.13 (sum) & 2.33 & 10 & 40 \\
\hline $\begin{array}{l}\text { BY-201 Settling } \\
\text { Tank }\end{array}$ & 41.33 & 6.33 & 9.1 & 5 & 261.62 & 24.31 & 5 & 14.1 \\
\hline \multicolumn{9}{|l|}{ BX Trenches } \\
\hline B-35 & 252 & 10 & 10 & 10 & 2520 & 234.12 & 10 & 20 \\
\hline B-36 & 252 & 10 & 10 & 10 & 2520 & 234.12 & 10 & 20 \\
\hline B-37 & 252 & 10 & 10 & 10 & 2520 & 234.12 & 10 & 20 \\
\hline B-38 & 252 & 10 & 10 & 10 & 2520 & 234.12 & 10 & 20 \\
\hline B-39 & 252 & 10 & 10 & 10 & 2520 & 234.12 & 10 & 20 \\
\hline B-39 & 252 & 10 & 10 & 10 & 2520 & 234.12 & 10 & 20 \\
\hline B-40 & 252 & 10 & 10 & 10 & 2520 & 234.12 & 10 & 20 \\
\hline B-41 & 252 & 10 & 10 & 10 & 2520 & 234.12 & 10 & 20 \\
\hline B-42 & 252 & 10 & 10 & 10 & 2520 & 234.12 & 10 & 20 \\
\hline BY Cribs & \multicolumn{2}{|c|}{$\begin{array}{l}\text { Bottom of Excavation } \\
\text { dimensions }\end{array}$} & \multicolumn{6}{|c|}{$\begin{array}{l}\text { Each crib consists of } 4-4 \mathrm{ft} \text { dia. by } 4 \mathrm{ft} \text { long concrete culverts on end } \\
\text { in a square pattern with centers } 15 \mathrm{ft} \text { apart }\end{array}$} \\
\hline B-43 & 30 & 30 & 8 & 7 & 900 & 83.61 & 7 & 15 \\
\hline B-44 & 30 & 30 & 8 & 7 & 900 & 83.61 & 7 & 15 \\
\hline B-45 & 30 & 30 & 8 & 7 & 900 & 83.61 & 7 & 15 \\
\hline B-46 & 30 & 30 & 8 & 7 & 900 & 83.61 & 7 & 15 \\
\hline B-47 & 30 & 30 & 8 & 7 & 900 & 83.61 & 7 & 15 \\
\hline B-48 & 30 & 30 & 8 & 7 & 900 & 83.61 & 7 & 15 \\
\hline B-49 & 30 & 30 & 8 & 7 & 900 & 83.61 & 7 & 15 \\
\hline B-50 & 30 & 30 & 8 & 7 & 900 & 83.61 & 7 & 15 \\
\hline \multicolumn{9}{|l|}{ B Tank Farm } \\
\hline B-101 & 75 (Dia) & & 29.75 & 7 & 4418 & 410.43 & 7 & 36.75 \\
\hline B-102 & 75 (Dia) & & 29.53 & 7 & 4418 & 410.43 & 7 & 36.53 \\
\hline B-103 & 75 (Dia) & & 29.53 & 7 & 4418 & 410.43 & 7 & 36.53 \\
\hline B-104 & 75 (Dia) & & 29.53 & 7 & 4418 & 410.43 & 7 & 36.53 \\
\hline B-105 & 75 (Dia) & & 29.53 & 7 & 4418 & 410.43 & 7 & 36.53 \\
\hline B-106 & 75 (Dia) & & 29.53 & 7 & 4418 & 410.43 & 7 & 36.53 \\
\hline B-107 & 75 (Dia) & & 29.53 & 7 & 4418 & 410.43 & 7 & 36.53 \\
\hline B-108 & 75 (Dia) & & 29.53 & 7 & 4418 & 410.43 & 7 & 36.53 \\
\hline B-109 & 75 (Dia) & & 29.53 & 7 & 4418 & 410.43 & 7 & 36.53 \\
\hline B-110 & 75 (Dia) & & 29.53 & 7 & 4418 & 410.43 & 7 & 36.53 \\
\hline
\end{tabular}


PNNL-19277

Table A.1. Facility Dimensions

\begin{tabular}{|c|c|c|c|c|c|c|c|c|}
\hline Facility & Length/diameter & Width & $\begin{array}{l}\text { Height/ } \\
\text { Depth }\end{array}$ & Overburden & Footprint Area & Footprint Area & Top & Bottom \\
\hline B-111 & 75 (Dia) & & 29.53 & 7 & 4418 & 410.43 & 7 & 36.53 \\
\hline B-112 & 75 (Dia) & & 29.53 & 7 & 4418 & 410.43 & 7 & 36.53 \\
\hline B-201 & 20(Dia) & & 24.9 & 11 & 314 & 29.19 & 11 & 35.9 \\
\hline B-202 & 20(Dia) & & 24.9 & 11 & 314 & 29.19 & 11 & 35.9 \\
\hline B-203 & 20(Dia) & & 24.9 & 11 & 314 & 29.19 & 11 & 35.9 \\
\hline B-204 & 20(Dia) & & 24.9 & 11 & 314 & 29.19 & 11 & 35.9 \\
\hline \multicolumn{9}{|l|}{ BX Tank Farm } \\
\hline BX-101 & 75 (Dia) & & 31.17 & 7.25 & 4418 & 410.43 & 7.25 & 38.42 \\
\hline BX-102 & 75 (Dia) & & 31.17 & 7.25 & 4418 & 410.43 & 7.25 & 38.42 \\
\hline BX-103 & 75 (Dia) & & 31.17 & 7.25 & 4418 & 410.43 & 7.25 & 38.42 \\
\hline BX-104 & 75 (Dia) & & 31.17 & 7.25 & 4418 & 410.43 & 7.25 & 38.42 \\
\hline BX-105 & 75 (Dia) & & 31.17 & 7.25 & 4418 & 410.43 & 7.25 & 38.42 \\
\hline BX-106 & 75 (Dia) & & 31.17 & 7.25 & 4418 & 410.43 & 7.25 & 38.42 \\
\hline BX-107 & 75 (Dia) & & 31.17 & 7.25 & 4418 & 410.43 & 7.25 & 38.42 \\
\hline BX-108 & 75 (Dia) & & 31.17 & 7.25 & 4418 & 410.43 & 7.25 & 38.42 \\
\hline BX-109 & 75 (Dia) & & 31.17 & 7.25 & 4418 & 410.43 & 7.25 & 38.42 \\
\hline BX-110 & 75 (Dia) & & 31.17 & 7.25 & 4418 & 410.43 & 7.25 & 38.42 \\
\hline BX-111 & 75 (Dia) & & 31.17 & 7.25 & 4418 & 410.43 & 7.25 & 38.42 \\
\hline BX-112 & 75 (Dia) & & 31.17 & 7.25 & 4418 & 410.43 & 7.25 & 38.42 \\
\hline \multicolumn{9}{|l|}{ BY Tank Farm } \\
\hline BY-101 & 75 (Dia) & & 37 & 8 & 4418 & 410.43 & 8 & 45 \\
\hline BY-102 & 75 (Dia) & & 37 & 8 & 4418 & 410.43 & 8 & 45 \\
\hline BY-103 & 75 (Dia) & & 37 & 8 & 4418 & 410.43 & 8 & 45 \\
\hline BY-104 & 75 (Dia) & & 37 & 8 & 4418 & 410.43 & 8 & 45 \\
\hline BY-105 & 75 (Dia) & & 37 & 8 & 4418 & 410.43 & 8 & 45 \\
\hline BY-106 & 75 (Dia) & & 37 & 8 & 4418 & 410.43 & 8 & 45 \\
\hline BY-107 & 75 (Dia) & & 37 & 8 & 4418 & 410.43 & 8 & 45 \\
\hline BY-108 & 75 (Dia) & & 37 & 8 & 4418 & 410.43 & 8 & 45 \\
\hline BY-109 & 75 (Dia) & & 37 & 8 & 4418 & 410.43 & 8 & 45 \\
\hline BY-110 & 75 (Dia) & & 37 & 8 & 4418 & 410.43 & 8 & 45 \\
\hline BY-111 & 75 (Dia) & & 37 & 8 & 4418 & 410.43 & 8 & 45 \\
\hline BY-112 & 75 (Dia) & & 37 & 8 & 4418 & 410.43 & 8 & 45 \\
\hline
\end{tabular}


Table A.2. Hanford Defined Waste Streams (after Higley and Place 2004)

\begin{tabular}{|c|c|}
\hline Waste Stream & Waste Type Description \\
\hline \multicolumn{2}{|c|}{ Bismuth Phosphate Process Waste (1944-1956) } \\
\hline MW1 & $\mathrm{BiPO}_{4}$ Metal Waste (1944-1949)-high fission product content \\
\hline MW2 & $\mathrm{BiPO}_{4}$ Metal Waste (1950-1956)-high fission product content \\
\hline $1 \mathrm{C} 1$ & $\mathrm{BiPO}_{4}$ First cycle decontamination waste and Al cladding (coating) waste (1944-1949) \\
\hline $1 \mathrm{C} 2$ & $\mathrm{BiPO}_{4}$ First cycle decontamination waste and Al cladding (coating) waste (1950-1956) \\
\hline $2 \mathrm{C} 1$ & $\mathrm{BiPO}_{4}$ Second cycle decontamination waste (1944-1949)-low fission product content \\
\hline $2 \mathrm{C} 2$ & $\begin{array}{l}\mathrm{BiPO}_{4} \text { Second cycle decontamination waste (1950-1956) and low activity cell 5-6 } \\
\text { drainage waste (June 1951-1956) } \\
\text { low activity cell 5-6 drainage waste (June 1951-1956) -all low fission product content }\end{array}$ \\
\hline $224-1$ & Lanthanum Fluoride process 224 Building waste (1944-1949) \\
\hline $224-2$ & Lanthanum Fluoride process 224 Building waste (1950-1956) \\
\hline \multicolumn{2}{|c|}{ Uranium Recovery And Scavenging Waste (1952-1958) } \\
\hline TBP (or UR) & Tributyl phosphate process waste (1952-1958), same as UR \\
\hline PFeCN1 & $\begin{array}{l}\text { Ferrocyanide sludge from TBP in-plant scavenged supernatant and co-disposed TBP } \\
\text { sludge (1954-1955). }\end{array}$ \\
\hline $\mathrm{PFeCN} 2$ & $\begin{array}{l}\text { Ferrocyanide sludge from TBP in-plant scavenged supernatant and co-disposed TBP } \\
\text { sludge (1955-1958). }\end{array}$ \\
\hline $\mathrm{TFeCN}$ & $\begin{array}{l}\text { Ferrocyanide sludge from supernatant scavenging in 244-CR Vault (1955-1958). } \\
\text { These supernatants consisted of TBP supernatant and the commingled supernatants } \\
\text { from other wastes stored in the same tanks. }\end{array}$ \\
\hline $1 \mathrm{CFeCN}$ & $\begin{array}{l}\text { Ferrocyanide sludge from in-plant scavenging of T-Plant 1C waste (without coating } \\
\text { waste). Transferred to TY-Farm (1955-1956). }\end{array}$ \\
\hline \multicolumn{2}{|c|}{ Reduction And Oxidation (REDOX)"Process Waste(1952-1966) } \\
\hline $\mathrm{R} 1$ & REDOX high-level waste (1952-1958) \\
\hline $\mathrm{R} 2$ & REDOX high-level waste (1959-1966) \\
\hline CWR1 & REDOX cladding waste, aluminum clad fuel (1952-1960) \\
\hline CWR2 & REDOX cladding waste, aluminum clad fuel (1961-1966) \\
\hline \multicolumn{2}{|c|}{ Plutonium-Uranium Extraction (PUREX) Process Waste Types (1956-1990) } \\
\hline $\mathrm{P} 1$ & PUREX high-activity waste (1956-1962) \\
\hline P2 & PUREX high-activity waste (1963-1967) \\
\hline P2' & PUREX acid waste to B-Plant (1964-1972) \\
\hline P3AZ1 & PUREX high-activity waste to AZ-101 (1983-March 13, 1986) \\
\hline P3AZ2 & PUREX high-activity waste to AZ-102 (March 13, 1986 to 1990) \\
\hline CWP1 & PUREX cladding waste, aluminum clad fuel (1956-1960) \\
\hline CWP2 & PUREX cladding waste, aluminum clad fuel (1961-1972) \\
\hline CWZr1 & PUREX (and REDOX) zirconium cladding waste, (1968-1972) \\
\hline CWZr2 & PUREX zirconium cladding waste (1983-1989) \\
\hline OWW1 & PUREX organic wash waste and non-boiling waste (1956-1962) \\
\hline OWW2 & PUREX organic wash waste and non-boiling waste (1963-1967) \\
\hline OWW3 & PUREX organic wash waste (1968-1972) \\
\hline PL1 & PUREX non-boiling waste (1968-1972) \\
\hline PL2 & PUREX organic wash waste and non-boiling waste (1983-1988) \\
\hline TH1 & Thoria process wastes (1966) \\
\hline TH2 & Thoria process wastes (1970) \\
\hline PASF & PUREX Ammonia Scrubber Feed \\
\hline \multicolumn{2}{|c|}{$\begin{array}{l}\text { Cesium And Strontium Recovery Waste Types (1961-1985) } \\
\text { HS } \quad \text { Hot Semiworks strontium purification waste (1961-1968) }\end{array}$} \\
\hline HS & Hot Semiworks strontium purification waste (1961-1968) \\
\hline
\end{tabular}


Table A.2. Hanford Defined Waste Streams (after Higley and Place 2004)

\begin{tabular}{|c|c|}
\hline Waste Stream & Waste Type Description \\
\hline$\overline{\mathrm{AR}}$ & $\begin{array}{l}\text { Water washed PUREX sludge entrained in decants of recovered sludge or the water } \\
\text { washes of this sludge and the solids remaining after acidification (1967-1976). }\end{array}$ \\
\hline $\mathrm{B}$ & $\begin{array}{l}\text { B-Plant high-activity waste - Rare earth (RE) fission products, recovered current acid } \\
\text { waste (CAW), solvent wash waste, and } \\
\text { any solution containing high activity (including cask station receipts, cell drainage } \\
\text { containing product spills) (1967-1972). }\end{array}$ \\
\hline BL & $\begin{array}{l}\text { B-Plant low-activity waste - } 1 \text { AW solvent extraction waste stream (includes } \\
\text { complexants added for solvent extraction), the } \\
\text { 1CP/organic wash waste during PAS processing, and insoluble solids remaining after } \\
\text { treatment of solids centrifuged from } \\
\text { CAW feed (i.e., acid leached and water washed PUREX high-level waste [HLW] } \\
\text { sludge). Cell drainage and Waste } \\
\text { Encapsulation Storage Facility (WESF) transfers with low radionuclide content (1967- } \\
\text { 1976). }\end{array}$ \\
\hline SRR & $\begin{array}{l}\text { High-activity waste from B-Plant processing of PUREX acidified sludge (PAS), solids } \\
\text { centrifuged from AR vault feed, strontium purification wastes after solvent extraction } \\
\text { (SX), RE or ion exchange (IX) rework, and other solutions containing activity } \\
\text { (including cask station receipts, cell drainage containing product spills, WESF returns } \\
\text { unsuitable for rework and crude product spills, WESF returns unsuitable for rework } \\
\text { and crude RE disposal). (1969-1985) }\end{array}$ \\
\hline CSR & $\begin{array}{l}\text { Supernatants from which the cesium has been removed by ion-exchange. C-801 cask } \\
\text { station (1962-1967). B-Plant Waste Fractionization (1967-1976). }\end{array}$ \\
\hline \multicolumn{2}{|c|}{ Other Process Facility Wastes } \\
\hline $\mathrm{Z}$ & Plutonium Finishing Plant waste (1974-1988) \\
\hline DW & Decontamination wastes, primarily from T Plant operations (1967-1976) \\
\hline $\mathrm{N}$ & N Reactor decontamination waste (1976-1990) \\
\hline \multicolumn{2}{|l|}{ Miscellaneous Wastes } \\
\hline CEM & Portland cement added to tank BY-105 \\
\hline $\mathrm{DE}$ & $\begin{array}{l}\text { Diatomaceous earth added to six tanks (BX-102, SX-113, TX-116, TX-117, TY-106, } \\
\text { and U-104) }\end{array}$ \\
\hline NIT & Partial neutralization feed for evaporator campaigns (1977-1981) \\
\hline \multicolumn{2}{|c|}{ Saltcakes And Salt Slurries } \\
\hline BT-SltCk & $\begin{array}{l}\text { Saltcake from 242-B Evaporator operation (1951-1953) and the 242-T Evaporator } \\
\text { operation (1951-1955). Formerly BSltCk and T1SltCk. }\end{array}$ \\
\hline BYSltCk & Saltcake from in-tank solidification (ITS) in BY-Farm (1965-1974) \\
\hline RSltCk & Saltcake from self-concentration in S- and SX-Farms (1952-1966) \\
\hline T2SltCk & Saltcake from the last 242-T Evaporator campaign (1965-1976) \\
\hline A1SltCk & $\begin{array}{l}\text { Saltcake from the first 242-A Evaporator campaign using A-102 feed tank (1977- } \\
\text { 1980) }\end{array}$ \\
\hline A2SltCk & $\begin{array}{l}\text { Saltcake form the second 242-Evaporator campaign using AW-102 feed tank (1981- } \\
\text { 1988) }\end{array}$ \\
\hline S1SltCk & Saltcake from the first 242-S Evaporator campaign using S-102 feed tank (1973-1976) \\
\hline S2SltCk & $\begin{array}{l}\text { Saltcake from the second 242-S Evaporator campaign using SY-102 feed tank (1977- } \\
\text { 1980) }\end{array}$ \\
\hline
\end{tabular}


Table A.3. Volumes and Mass of Constituents Disposed to Facilities each Year and Waste Types and Waste Densities

\begin{tabular}{|c|c|c|c|c|c|c|c|c|c|c|c|c|c|c|c|c|c|c|c|c|}
\hline \multirow[b]{2}{*}{ Facility } & \multirow[b]{2}{*}{$\begin{array}{c}\text { Date } \\
\text { Disposed }\end{array}$} & \multirow[b]{2}{*}{ Waste Type } & \multirow{2}{*}{$\begin{array}{c}\text { ML } \\
\text { Vol } \\
\text { Disposed } \\
\end{array}$} & \multirow{2}{*}{$\begin{array}{l}\mathrm{g} / \mathrm{cm}^{3} \\
\text { Density } \\
\end{array}$} & \multirow[b]{2}{*}{$\mathrm{pH}$} & \multicolumn{11}{|c|}{ Yearly Inventory (kg) } & \multicolumn{4}{|c|}{ Yearly Inventory $\mathrm{Ci}$} \\
\hline & & & & & & $\mathrm{Na}$ & $\mathrm{Ca}$ & $\mathrm{NO}_{3}$ & $\mathrm{NO}_{2}$ & $\mathrm{CO}_{3}$ & $\mathrm{PO}_{4}$ & $\mathrm{SO}_{4}$ & $\mathrm{~F}$ & U-Total & $\mathrm{Cr}$ & $\mathrm{Fe}(\mathrm{CN}) 6$ & Сo- 60 & $\mathrm{I}-129$ & Tc-99 & $\mathrm{H}-3$ \\
\hline \multirow[t]{13}{*}{ B-7A\&B } & 1946 & 224 (BT1) & $1.75 \mathrm{E}+00$ & 1.09 & NA & $6.52 \mathrm{E}+04$ & $2.59 \mathrm{E}+02$ & $1.51 \mathrm{E}+05$ & 7.01E-02 & $3.95 \mathrm{E}+02$ & $5.36 \mathrm{E}+03$ & $4.90 \mathrm{E}+02$ & $9.04 \mathrm{E}+03$ & $3.57 \mathrm{E}-02$ & $6.23 \mathrm{E}+02$ & $0.00 \mathrm{E}+00$ & $3.22 \mathrm{E}-04$ & $2.72 \mathrm{E}-08$ & $6.14 \mathrm{E}-05$ & $3.04 \mathrm{E}-07$ \\
\hline & 1947 & 224 (BT1) & $4.48 \mathrm{E}+00$ & 1.09 & NA & $1.66 \mathrm{E}+05$ & $6.60 \mathrm{E}+02$ & $3.86 \mathrm{E}+05$ & $1.79 \mathrm{E}-01$ & $1.01 \mathrm{E}+03$ & $1.37 \mathrm{E}+04$ & $1.25 \mathrm{E}+03$ & $2.31 \mathrm{E}+04$ & $9.12 \mathrm{E}-02$ & $1.59 \mathrm{E}+03$ & $0.00 \mathrm{E}+00$ & $8.22 \mathrm{E}-04$ & $6.95 \mathrm{E}-08$ & $1.57 \mathrm{E}-04$ & 7.77E- 07 \\
\hline & 1948 & 224 (BT1) & $5.22 \mathrm{E}+00$ & 1.09 & NA & $2.04 \mathrm{E}+05$ & $8.05 \mathrm{E}+02$ & $4.68 \mathrm{E}+05$ & $1.03 \mathrm{E}+00$ & $1.23 \mathrm{E}+03$ & $1.75 \mathrm{E}+04$ & $2.60 \mathrm{E}+03$ & $2.79 \mathrm{E}+04$ & $1.95 \mathrm{E}+00$ & $1.91 \mathrm{E}+03$ & $0.00 \mathrm{E}+00$ & $1.58 \mathrm{E}-03$ & $3.90 \mathrm{E}-07$ & $8.81 \mathrm{E}-04$ & $1.98 \mathrm{E}-05$ \\
\hline & 1948 & 5-6 (BT1) & $3.97 \mathrm{E}+00$ & 1.02 & NA & & & & & & & & & & & & & & & \\
\hline & 1949 & 224 (BT1) & $4.67 \mathrm{E}+00$ & 1.09 & NA & $1.74 \mathrm{E}+05$ & $6.89 \mathrm{E}+02$ & $4.03 \mathrm{E}+05$ & $1.87 \mathrm{E}-01$ & $1.05 \mathrm{E}+03$ & $1.43 \mathrm{E}+04$ & $1.31 \mathrm{E}+03$ & $2.41 \mathrm{E}+04$ & $9.52 \mathrm{E}-02$ & $1.66 \mathrm{E}+03$ & $0.00 \mathrm{E}+00$ & $8.58 \mathrm{E}-04$ & $7.24 \mathrm{E}-08$ & $1.64 \mathrm{E}-04$ & $8.11 \mathrm{E}-07$ \\
\hline & 1950 & 224 (BT2) & $6.16 \mathrm{E}+00$ & 1.09 & NA & $2.29 \mathrm{E}+05$ & $9.08 \mathrm{E}+02$ & $5.30 \mathrm{E}+05$ & $3.54 \mathrm{E}-01$ & $1.39 \mathrm{E}+03$ & $1.88 \mathrm{E}+04$ & $1.72 \mathrm{E}+03$ & $3.17 \mathrm{E}+04$ & $1.25 \mathrm{E}-01$ & $2.19 \mathrm{E}+03$ & $0.00 \mathrm{E}+00$ & 3.53E-03 & $0.00 \mathrm{E}+00$ & 3.53E-04 & $9.29 \mathrm{E}-05$ \\
\hline & 1951 & 224 (BT2) & $6.81 \mathrm{E}+00$ & 1.09 & NA & $2.53 \mathrm{E}+05$ & $1.00 \mathrm{E}+03$ & $5.86 \mathrm{E}+05$ & 3.91E-01 & $1.53 \mathrm{E}+03$ & $2.08 \mathrm{E}+04$ & $1.90 \mathrm{E}+03$ & $3.51 \mathrm{E}+04$ & $1.39 \mathrm{E}-01$ & $2.42 \mathrm{E}+03$ & $0.00 \mathrm{E}+00$ & 3.90E-03 & $0.00 \mathrm{E}+00$ & $3.91 \mathrm{E}-04$ & $1.03 \mathrm{E}-04$ \\
\hline & 1952 & 224 (BT2) & $1.58 \mathrm{E}+00$ & 1.09 & NA & $5.87 \mathrm{E}+04$ & $2.33 \mathrm{E}+02$ & $1.36 \mathrm{E}+05$ & $9.08 \mathrm{E}-02$ & $3.56 \mathrm{E}+02$ & $4.82 \mathrm{E}+03$ & $4.41 \mathrm{E}+02$ & $8.14 \mathrm{E}+03$ & $3.21 \mathrm{E}-02$ & $5.62 \mathrm{E}+02$ & $0.00 \mathrm{E}+00$ & $9.05 \mathrm{E}-04$ & $0.00 \mathrm{E}+00$ & $9.06 \mathrm{E}-05$ & $2.38 \mathrm{E}-05$ \\
\hline & 1953 & 5-6 (BT2) & $7.71 \mathrm{E}+00$ & 1.02 & NA & $1.84 \mathrm{E}+04$ & $6.74 \mathrm{E}+01$ & $3.72 \mathrm{E}+04$ & $1.16 \mathrm{E}+00$ & $1.01 \mathrm{E}+02$ & $2.20 \mathrm{E}+03$ & $1.17 \mathrm{E}+03$ & $2.13 \mathrm{E}+03$ & $1.79 \mathrm{E}+00$ & $1.69 \mathrm{E}+02$ & $0.00 \mathrm{E}+00$ & $2.00 \mathrm{E}-03$ & $0.00 \mathrm{E}+00$ & $1.12 \mathrm{E}-03$ & $6.51 \mathrm{E}-04$ \\
\hline & 1954 & 5-6 (BT2) & $1.11 \mathrm{E}+00$ & 1.02 & NA & $2.64 \mathrm{E}+03$ & $9.70 \mathrm{E}+00$ & $5.35 \mathrm{E}+03$ & 1.66E-01 & $1.45 \mathrm{E}+01$ & $3.16 \mathrm{E}+02$ & $1.68 \mathrm{E}+02$ & $3.06 \mathrm{E}+02$ & $2.58 \mathrm{E}-01$ & $2.43 \mathrm{E}+01$ & $0.00 \mathrm{E}+00$ & $2.88 \mathrm{E}-04$ & $0.00 \mathrm{E}+00$ & $1.61 \mathrm{E}-04$ & $9.37 \mathrm{E}-05$ \\
\hline & 1966 & Decon Wst (P2') & $9.30 \mathrm{E}-01$ & 1.01 & NA & $4.18 \mathrm{E}+03$ & $3.91 \mathrm{E}+02$ & $9.04 \mathrm{E}+03$ & $1.03 \mathrm{E}+03$ & $1.94 \mathrm{E}+02$ & $0.00 \mathrm{E}+00$ & $3.62 \mathrm{E}+02$ & $0.00 \mathrm{E}+00$ & $1.58 \mathrm{E}+02$ & $3.87 \mathrm{E}+02$ & $0.00 \mathrm{E}+00$ & 7.37E-05 & $5.44 \mathrm{E}-04$ & $1.95 \mathrm{E}-04$ & $1.14 \mathrm{E}-03$ \\
\hline & 1967 & Decon Wst (P2') & $2.00 \mathrm{E}-01$ & 1.01 & NA & $1.75 \mathrm{E}+03$ & $8.74 \mathrm{E}+01$ & $2.77 \mathrm{E}+03$ & $4.45 \mathrm{E}+02$ & $4.66 \mathrm{E}+01$ & $0.00 \mathrm{E}+00$ & $1.86 \mathrm{E}+02$ & $0.00 \mathrm{E}+00$ & $3.45 \mathrm{E}+01$ & $8.99 \mathrm{E}+01$ & $0.00 \mathrm{E}+00$ & $3.46 \mathrm{E}-01$ & $1.23 \mathrm{E}-04$ & $9.12 \mathrm{E}-02$ & $5.69 \mathrm{E}-03$ \\
\hline & 1967 & $\begin{array}{l}\text { Sr-Cs Rec Wst } \\
\text { (P1)_HS }\end{array}$ & $0.00 \mathrm{E}+00$ & 1.08 & NA & & & & & & & & & & & & & & & \\
\hline \multirow[t]{9}{*}{ B-8 } & 1948 & 2C1 (BT1) & $6.33 \mathrm{E}+00$ & 1.1 & NA & $2.75 \mathrm{E}+05$ & $9.52 \mathrm{E}+02$ & $5.05 \mathrm{E}+05$ & $2.25 \mathrm{E}+01$ & $1.42 \mathrm{E}+03$ & $4.25 \mathrm{E}+04$ & $3.13 \mathrm{E}+04$ & $2.74 \mathrm{E}+04$ & $5.07 \mathrm{E}+01$ & $1.43 \mathrm{E}+03$ & $0.00 \mathrm{E}+00$ & 1.70E-02 & 8.47E-06 & $1.91 \mathrm{E}-02$ & $5.18 \mathrm{E}-04$ \\
\hline & 1949 & 2C1 (BT1) & $6.77 \mathrm{E}+00$ & 1.1 & $\mathrm{NA}$ & $2.94 \mathrm{E}+05$ & $1.02 \mathrm{E}+03$ & $5.40 \mathrm{E}+05$ & $2.40 \mathrm{E}+01$ & $1.52 \mathrm{E}+03$ & $4.54 \mathrm{E}+04$ & $3.34 \mathrm{E}+04$ & $2.93 \mathrm{E}+04$ & $5.42 \mathrm{E}+01$ & $1.53 \mathrm{E}+03$ & $0.00 \mathrm{E}+00$ & $1.82 \mathrm{E}-02$ & $9.07 \mathrm{E}-06$ & $2.05 \mathrm{E}-02$ & $5.54 \mathrm{E}-04$ \\
\hline & 1950 & 2C1 (BT1) & $6.81 \mathrm{E}+00$ & 1.1 & NA & $3.81 \mathrm{E}+05$ & $1.31 \mathrm{E}+03$ & $6.96 \mathrm{E}+05$ & $3.39 \mathrm{E}+01$ & $1.96 \mathrm{E}+03$ & $5.85 \mathrm{E}+04$ & $4.31 \mathrm{E}+04$ & $3.78 \mathrm{E}+04$ & $6.98 \mathrm{E}+01$ & $2.30 \mathrm{E}+03$ & $0.00 \mathrm{E}+00$ & 3.43E-02 & $9.12 \mathrm{E}-06$ & $3.00 \mathrm{E}-02$ & $6.08 \mathrm{E}-03$ \\
\hline & 1950 & 2C2 (BT2) & $1.98 \mathrm{E}+00$ & 1.06 & NA & & & & & & & & & & & & & & & \\
\hline & 1951 & $2 \mathrm{C} 2$ (BT2) & $1.83 \mathrm{E}+00$ & 1.06 & NA & $9.11 \mathrm{E}+04$ & $3.10 \mathrm{E}+02$ & $1.66 \mathrm{E}+05$ & $9.77 \mathrm{E}+00$ & $4.64 \mathrm{E}+02$ & $1.33 \mathrm{E}+04$ & $9.49 \mathrm{E}+03$ & $9.06 \mathrm{E}+03$ & $1.53 \mathrm{E}+01$ & $8.16 \mathrm{E}+02$ & $0.00 \mathrm{E}+00$ & $1.61 \mathrm{E}-02$ & $0.00 \mathrm{E}+00$ & $9.47 \mathrm{E}-03$ & $5.54 \mathrm{E}-03$ \\
\hline & 1951 & 5-6 (BT2) & $5.17 \mathrm{E}+00$ & 1.02 & NA & & & & & & & & & & & & & & & \\
\hline & 1952 & 5-6 (BT2) & $4.42 \mathrm{E}+00$ & 1.02 & NA & $1.05 \mathrm{E}+04$ & $3.86 \mathrm{E}+01$ & $2.13 \mathrm{E}+04$ & 6.62E-01 & $5.78 \mathrm{E}+01$ & $1.26 \mathrm{E}+03$ & $6.70 \mathrm{E}+02$ & $1.22 \mathrm{E}+03$ & $1.03 \mathrm{E}+00$ & $9.69 \mathrm{E}+01$ & $0.00 \mathrm{E}+00$ & 1.15E-03 & $0.00 \mathrm{E}+00$ & 6.41E-04 & 3.73E-04 \\
\hline & 1953 & 5-6 (BT2) & $1.96 \mathrm{E}+00$ & 1.02 & NA & $4.66 \mathrm{E}+03$ & $1.71 \mathrm{E}+01$ & $9.45 \mathrm{E}+03$ & 2.94E-01 & $2.56 \mathrm{E}+01$ & $5.58 \mathrm{E}+02$ & $2.97 \mathrm{E}+02$ & $5.41 \mathrm{E}+02$ & 4.55E-01 & $4.30 \mathrm{E}+01$ & $0.00 \mathrm{E}+00$ & $5.08 \mathrm{E}-04$ & $0.00 \mathrm{E}+00$ & 2.84E-04 & $1.65 \mathrm{E}-04$ \\
\hline & $\begin{array}{l}\text { SIM has } \\
\text { no } \\
\text { disposal } \\
\text { in } 1954\end{array}$ & & & & & & & & & & & & & & & & & & & \\
\hline \multirow{3}{*}{$\begin{array}{l}\text { B-51 } \\
\text { French } \\
\text { Drain }\end{array}$} & 1956 & PFeCN2 (BT2) & 4.80E-04 & 1.21 & NA & $4.35 \mathrm{E}+01$ & 7.09E-02 & $9.56 \mathrm{E}+01$ & $1.54 \mathrm{E}-02$ & 1.06E-01 & $3.22 \mathrm{E}+00$ & $5.65 \mathrm{E}+00$ & $1.94 \mathrm{E}+00$ & $1.49 \mathrm{E}-02$ & $8.26 \mathrm{E}-02$ & $0.00 \mathrm{E}+00$ & 9.02E-05 & $2.34 \mathrm{E}-06$ & $1.82 \mathrm{E}-03$ & $2.99 \mathrm{E}-03$ \\
\hline & 1957 & PFeCN2 (BT2) & 4.80E-04 & 1.21 & NA & $4.35 \mathrm{E}+01$ & 7.09E-02 & $9.56 \mathrm{E}+01$ & $1.54 \mathrm{E}-02$ & $1.06 \mathrm{E}-01$ & $3.22 \mathrm{E}+00$ & $5.65 \mathrm{E}+00$ & $1.94 \mathrm{E}+00$ & $1.49 \mathrm{E}-02$ & $8.25 \mathrm{E}-02$ & $0.00 \mathrm{E}+00$ & $9.02 \mathrm{E}-05$ & $2.34 \mathrm{E}-06$ & $1.82 \mathrm{E}-03$ & $2.99 \mathrm{E}-03$ \\
\hline & 1958 & PFeCN2 (BT2) & 4.00E-05 & 1.21 & NA & $3.62 \mathrm{E}+00$ & $5.91 \mathrm{E}-03$ & $7.97 \mathrm{E}+00$ & $1.28 \mathrm{E}-03$ & 8.84E-03 & 2.68E-01 & 4.71E-01 & $1.62 \mathrm{E}-01$ & $1.24 \mathrm{E}-03$ & $6.88 \mathrm{E}-03$ & $0.00 \mathrm{E}+00$ & 7.52E-06 & $1.95 \mathrm{E}-07$ & $1.52 \mathrm{E}-04$ & $2.49 \mathrm{E}-04$ \\
\hline \multirow{3}{*}{$\begin{array}{l}\text { B- } \\
11 \mathrm{~A} \& \mathrm{~B}\end{array}$} & 1952 & 1C Evap (BT2) & $0.00 \mathrm{E}+00$ & 1.01 & NA & $4.35 \mathrm{E}+01$ & $9.04 \mathrm{E}+01$ & $8.55 \mathrm{E}+01$ & $2.85 \mathrm{E}+00$ & $3.06 \mathrm{E}+00$ & $2.25 \mathrm{E}+00$ & $1.62 \mathrm{E}+01$ & $1.20 \mathrm{E}+00$ & $1.57 \mathrm{E}-02$ & $1.57 \mathrm{E}-01$ & $0.00 \mathrm{E}+00$ & $1.04 \mathrm{E}-04$ & $1.51 \mathrm{E}-06$ & $1.09 \mathrm{E}-03$ & $7.69 \mathrm{E}+00$ \\
\hline & 1952 & $\begin{array}{c}\text { 242-B (BT2) Evap } \\
\text { Cond }\end{array}$ & $1.43 \mathrm{E}+01$ & 1.01 & NA & & & & & & & & & & & & & & & \\
\hline & 1953 & 1C Evap (BT2) & $0.00 \mathrm{E}+00$ & 1.26 & NA & 4.10E+01 & $5.07 \mathrm{E}+01$ & $7.99 \mathrm{E}+01$ & $2.85 \mathrm{E}+00$ & $3.06 \mathrm{E}+00$ & $2.24 \mathrm{E}+00$ & $1.08 \mathrm{E}+01$ & $1.20 \mathrm{E}+00$ & $1.33 \mathrm{E}-02$ & $1.57 \mathrm{E}-01$ & $0.00 \mathrm{E}+00$ & $1.04 \mathrm{E}-04$ & $1.52 \mathrm{E}-06$ & $1.08 \mathrm{E}-03$ & $4.31 \mathrm{E}+00$ \\
\hline
\end{tabular}


Table A.3. Volumes and Mass of Constituents Disposed to Facilities each Year and Waste Types and Waste Densities

\begin{tabular}{|c|c|c|c|c|c|c|c|c|c|c|c|c|c|c|c|c|c|c|c|c|}
\hline \multirow[b]{2}{*}{ Facility } & \multirow[b]{2}{*}{$\begin{array}{c}\text { Date } \\
\text { Disposed }\end{array}$} & \multirow[b]{2}{*}{ Waste Type } & \multirow{2}{*}{$\begin{array}{c}\text { ML } \\
\text { Vol } \\
\text { Disposed }\end{array}$} & \multirow{2}{*}{$\begin{array}{l}\mathrm{g} / \mathrm{cm}^{3} \\
\text { Density }\end{array}$} & \multirow[b]{2}{*}{$\mathrm{pH}$} & \multicolumn{11}{|c|}{ Yearly Inventory (kg) } & \multicolumn{4}{|c|}{ Yearly Inventory $\mathrm{Ci}$} \\
\hline & & & & & & $\mathrm{Na}$ & $\mathrm{Ca}$ & $\mathrm{NO}_{3}$ & $\mathrm{NO}_{2}$ & $\mathrm{CO}_{3}$ & $\mathrm{PO}_{4}$ & $\mathrm{SO}_{4}$ & $\mathrm{~F}$ & U-Total & $\mathrm{Cr}$ & $\mathrm{Fe}(\mathrm{CN}) 6$ & Сo-60 & I-129 & Tc-99 & $\mathrm{H}-3$ \\
\hline & 1953 & $\begin{array}{c}\text { 242-B (BT2) Evap } \\
\text { Cond }\end{array}$ & $8.01 \mathrm{E}+00$ & 1.01 & NA & & & & & & & & & & & & & & & \\
\hline & 1954 & 1C Evap (BT2) & $0.00 \mathrm{E}+00$ & 1.26 & NA & $4.07 \mathrm{E}+01$ & $4.62 \mathrm{E}+01$ & $7.93 \mathrm{E}+01$ & $2.85 \mathrm{E}+00$ & $3.06 \mathrm{E}+00$ & $2.24 \mathrm{E}+00$ & $1.02 \mathrm{E}+01 \quad 1$ & $1.20 \mathrm{E}+00$ & $1.31 \mathrm{E}-02$ & $1.57 \mathrm{E}-01$ & $0.00 \mathrm{E}+00$ & $1.04 \mathrm{E}-04$ & $1.51 \mathrm{E}-06$ & $1.08 \mathrm{E}-03$ & $3.94 \mathrm{E}+00$ \\
\hline & 1954 & $\begin{array}{l}\text { 242-B (BT2) Evap } \\
\text { Cond }\end{array}$ & $7.31 \mathrm{E}+00$ & 1.01 & NA & & & & & & & & & & & & & & & \\
\hline $\begin{array}{l}\text { BX } \\
\text { Trenches }\end{array}$ & & & & & & $\mathrm{Na}$ & $\mathrm{Ca}$ & NO3 & $\mathrm{NO} 2$ & $\mathrm{CO} 3$ & PO4 & $\mathrm{SO} 4$ & F & $\mathrm{U}$ & $\mathrm{Cr}$ & $\mathrm{CN}$ & Сo- 60 & I-129 & Tc-99 & $\mathrm{H}-3$ \\
\hline B-35 & Feb-54 & $1 \mathrm{C} 2(\mathrm{BT} 2)$ & $1.06 \mathrm{E}+00$ & 1.13 & 7.6 & $6.00 \mathrm{E}+04$ & $1.69 \mathrm{E}+02$ & $1.14 \mathrm{E}+05$ & $2.46 \mathrm{E}+03$ & $2.54 \mathrm{E}+02$ & $7.47 \mathrm{E}+03$ & $7.51 \mathrm{E}+033$ & $3.97 \mathrm{E}+03$ & $3.63 \mathrm{E}+01$ & $3.80 \mathrm{E}+02$ & $0.00 \mathrm{E}+00$ & $3.37 \mathrm{E}-01$ & $1.87 \mathrm{E}-03$ & $2.14 \mathrm{E}-01$ & $6.46 \mathrm{E}+00$ \\
\hline B-36 & Apr-54 & $1 \mathrm{C} 2$ (BT2) & $1.94 \mathrm{E}+00$ & 1.13 & 9.9 & $1.10 \mathrm{E}+05$ & $3.10 \mathrm{E}+02$ & $2.08 \mathrm{E}+05$ & $4.50 \mathrm{E}+03$ & $4.64 \mathrm{E}+02$ & $1.37 \mathrm{E}+04$ & $1.37 \mathrm{E}+047$ & $7.27 \mathrm{E}+03$ & $6.64 \mathrm{E}+01$ & $6.95 \mathrm{E}+02$ & $0.00 \mathrm{E}+00$ & $6.16 \mathrm{E}-01$ & $3.42 \mathrm{E}-03$ & $3.92 \mathrm{E}-01$ & $1.18 \mathrm{E}+01$ \\
\hline B-37 & $\begin{array}{l}\text { Aug to } \\
\text { Sep } 1954\end{array}$ & $1 \mathrm{C} 2(\mathrm{BT} 2)$ & $4.32 \mathrm{E}+00$ & 1.13 & 8 & $2.44 \mathrm{E}+05$ & $6.91 \mathrm{E}+02$ & $4.63 \mathrm{E}+05$ & $1.00 \mathrm{E}+04$ & $1.03 \mathrm{E}+03$ & $3.04 \mathrm{E}+04$ & $3.06 \mathrm{E}+04 \quad 1$ & $1.62 \mathrm{E}+04$ & $1.48 \mathrm{E}+02$ & $1.55 \mathrm{E}+03$ & 0 & $1.37 \mathrm{E}+00$ & 7.62E-03 & $8.73 \mathrm{E}-01$ & $2.63 \mathrm{E}+01$ \\
\hline B-38 & Jul-54 & $1 \mathrm{C} 2(\mathrm{BT} 2)$ & $1.43 \mathrm{E}+00$ & 1.13 & 7.2 & $8.09 \mathrm{E}+04$ & $2.29 \mathrm{E}+02$ & $1.53 \mathrm{E}+05$ & $3.31 \mathrm{E}+03$ & $3.42 \mathrm{E}+02$ & $1.01 \mathrm{E}+04$ & $1.01 \mathrm{E}+045$ & $5.36 \mathrm{E}+03$ & $4.90 \mathrm{E}+01$ & $5.12 \mathrm{E}+02$ & 0 & $4.54 \mathrm{E}-01$ & $2.52 \mathrm{E}-03$ & $2.89 \mathrm{E}-01$ & $8.72 \mathrm{E}+00$ \\
\hline B-39 & Dec-53 & $1 \mathrm{C} 2$ (BT2) & $7.80 \mathrm{E}-01$ & 1.13 & NA & $4.41 \mathrm{E}+04$ & $1.25 \mathrm{E}+02$ & $8.36 \mathrm{E}+04$ & $1.81 \mathrm{E}+03$ & $1.87 \mathrm{E}+02$ & $5.50 \mathrm{E}+03$ & $5.53 \mathrm{E}+032$ & $2.92 \mathrm{E}+03$ & $2.67 \mathrm{E}+01$ & $2.79 \mathrm{E}+02$ & $0.00 \mathrm{E}+00$ & $2.48 \mathrm{E}-01$ & $1.38 \mathrm{E}-03$ & $1.58 \mathrm{E}-01$ & $4.75 \mathrm{E}+00$ \\
\hline B-39 & $\begin{array}{l}\text { Jan-Nov- } \\
1954\end{array}$ & $1 \mathrm{C} 2$ (BT2) & $7.60 \mathrm{E}-01$ & 1.13 & NA & $4.30 \mathrm{E}+04$ & $1.22 \mathrm{E}+02$ & $8.14 \mathrm{E}+04$ & $1.76 \mathrm{E}+03$ & $1.82 \mathrm{E}+02$ & $5.35 \mathrm{E}+03$ & $5.39 \mathrm{E}+032$ & $2.85 \mathrm{E}+03$ & $2.60 \mathrm{E}+01$ & $2.72 \mathrm{E}+02$ & $0.00 \mathrm{E}+00$ & $2.41 \mathrm{E}-01$ & $1.34 \mathrm{E}-03$ & $1.54 \mathrm{E}-01$ & $4.63 \mathrm{E}+00$ \\
\hline B-40 & $\begin{array}{l}\text { Apr-Jul- } \\
1954\end{array}$ & $1 \mathrm{C} 2(\mathrm{BT} 2)$ & $1.64 \mathrm{E}+00$ & 1.13 & 7.4 & $9.28 \mathrm{E}+04$ & $2.62 \mathrm{E}+02$ & $1.76 \mathrm{E}+05$ & $3.80 \mathrm{E}+03$ & $3.93 \mathrm{E}+02$ & $1.16 \mathrm{E}+04$ & $1.16 \mathrm{E}+046$ & $6.14 \mathrm{E}+03$ & $5.62 \mathrm{E}+01$ & $5.87 \mathrm{E}+02$ & 0 & $5.21 \mathrm{E}-01$ & $2.89 \mathrm{E}-03$ & $3.32 \mathrm{E}-01$ & $1.00 \mathrm{E}+01$ \\
\hline B-41 & Nov-54 & 1C2 (BT2) & $1.44 \mathrm{E}+00$ & 1.13 & NA & $8.15 \mathrm{E}+04$ & $2.30 \mathrm{E}+02$ & $1.54 \mathrm{E}+05$ & $3.34 \mathrm{E}+03$ & $3.45 \mathrm{E}+02$ & $1.01 \mathrm{E}+04$ & $1.02 \mathrm{E}+045$ & $5.39 \mathrm{E}+03$ & $4.93 \mathrm{E}+01$ & $5.16 \mathrm{E}+02$ & 0 & $4.57 \mathrm{E}-01$ & $2.54 \mathrm{E}-03$ & $2.91 \mathrm{E}-01$ & $8.78 \mathrm{E}+00$ \\
\hline B-42 & 1954 & PFeCN1 (BT1) & $1.50 \mathrm{E}+00$ & 1.21 & NA & $1.34 \mathrm{E}+05$ & $2.21 \mathrm{E}+02$ & $2.98 \mathrm{E}+05$ & $1.42 \mathrm{E}+02$ & $3.31 \mathrm{E}+02$ & $1.00 \mathrm{E}+04$ & $1.76 \mathrm{E}+046$ & $6.08 \mathrm{E}+03$ & $4.65 \mathrm{E}+01$ & $2.58 \mathrm{E}+02$ & 0 & $2.82 \mathrm{E}-01$ & 7.31E-03 & $5.70 \mathrm{E}+00$ & $9.35 \mathrm{E}+00$ \\
\hline \multicolumn{21}{|l|}{ BY Cribs } \\
\hline B-43 & Nov-54 & PFeCN1 (BT1) & $2.12 \mathrm{E}+00$ & 1.21 & NA & $1.89 \mathrm{E}+05$ & $3.13 \mathrm{E}+02$ & $4.21 \mathrm{E}+05$ & $2.01 \mathrm{E}+02$ & $4.68 \mathrm{E}+02$ & $1.42 \mathrm{E}+04$ & $2.49 \mathrm{E}+048$ & $8.59 \mathrm{E}+03$ & $6.58 \mathrm{E}+01$ & $3.65 \mathrm{E}+02$ & $1.10 \mathrm{E}+03$ & $3.98 \mathrm{E}-01$ & $1.03 \mathrm{E}-02$ & $8.05 \mathrm{E}+00$ & $1.32 \mathrm{E}+01$ \\
\hline \multirow[t]{2}{*}{ B-44 } & Dec-54 & PFeCN1 (BT1) & $3.08 \mathrm{E}+00$ & 1.21 & NA & $2.75 \mathrm{E}+05$ & $4.55 \mathrm{E}+02$ & $6.12 \mathrm{E}+05$ & $2.92 \mathrm{E}+02$ & $6.80 \mathrm{E}+02$ & $2.06 \mathrm{E}+04$ & $3.62 \mathrm{E}+04$ & $1.25 \mathrm{E}+04$ & $9.55 \mathrm{E}+01$ & $5.30 \mathrm{E}+02$ & $1.22 \mathrm{E}+03$ & $5.79 \mathrm{E}-01$ & $1.50 \mathrm{E}-02$ & $1.17 \mathrm{E}+01$ & $1.92 \mathrm{E}+01$ \\
\hline & $\begin{array}{c}\text { Jan-Mar } \\
1955\end{array}$ & PFeCN1 (BT1) & $2.52 \mathrm{E}+00$ & 1.21 & NA & $2.25 \mathrm{E}+05$ & $3.72 \mathrm{E}+02$ & $5.00 \mathrm{E}+05$ & $2.39 \mathrm{E}+02$ & $5.57 \mathrm{E}+02$ & $1.69 \mathrm{E}+04$ & $2.96 \mathrm{E}+04 \quad 1$ & $1.02 \mathrm{E}+04$ & $7.81 \mathrm{E}+01$ & $4.33 \mathrm{E}+02$ & $1.78 \mathrm{E}+03$ & 4.74E-01 & $1.23 \mathrm{E}-02$ & $9.57 \mathrm{E}+00$ & $1.57 \mathrm{E}+01$ \\
\hline B-45 & $\begin{array}{l}\text { Apr-Jun- } \\
1955\end{array}$ & PFeCN1 (BT1) & $4.92 \mathrm{E}+00$ & 1.21 & NA & $4.39 \mathrm{E}+05$ & $7.48 \mathrm{E}+02$ & $9.77 \mathrm{E}+05$ & $5.13 \mathrm{E}+02$ & $1.12 \mathrm{E}+03$ & $3.32 \mathrm{E}+04$ & $5.81 \mathrm{E}+04$ & $1.99 \mathrm{E}+04$ & $1.65 \mathrm{E}+02$ & $8.46 \mathrm{E}+02$ & $2.60 \mathrm{E}+03$ & $9.24 \mathrm{E}-01$ & $2.40 \mathrm{E}-02$ & $1.87 \mathrm{E}+01$ & $3.07 \mathrm{E}+01$ \\
\hline B-46 & $\begin{array}{l}\text { Sep-Dec } \\
1955\end{array}$ & PFeCN1 (BT1) & $6.70 \mathrm{E}+00$ & 1.21 & NA & $5.97 \mathrm{E}+05$ & $9.89 \mathrm{E}+02$ & $1.33 \mathrm{E}+06$ & $6.34 \mathrm{E}+02$ & $1.48 \mathrm{E}+03$ & $4.49 \mathrm{E}+04$ & $7.88 \mathrm{E}+042$ & $2.71 \mathrm{E}+04$ & $2.08 \mathrm{E}+02$ & $1.15 \mathrm{E}+03$ & $4.00 \mathrm{E}+03$ & $1.26 \mathrm{E}+00$ & $3.26 \mathrm{E}-02$ & $2.55 \mathrm{E}+01$ & $4.18 \mathrm{E}+01$ \\
\hline \multirow[t]{2}{*}{ B-47 } & Sep-55 & PFeCN1 (BT1) & $2.15 \mathrm{E}+00$ & 1.21 & NA & $3.30 \mathrm{E}+05$ & $5.43 \mathrm{E}+02$ & $7.32 \mathrm{E}+05$ & $2.53 \mathrm{E}+02$ & $8.13 \mathrm{E}+02$ & $2.47 \mathrm{E}+04$ & $4.33 \mathrm{E}+04$ & $1.49 \mathrm{E}+04$ & $1.14 \mathrm{E}+02$ & $6.33 \mathrm{E}+02$ & $2.00 \mathrm{E}+03$ & $6.92 \mathrm{E}-01$ & $1.79 \mathrm{E}-02$ & $1.40 \mathrm{E}+01$ & $2.29 \mathrm{E}+01$ \\
\hline & Sep-55 & PFeCN2 (BT2) & $1.53 \mathrm{E}+00$ & 1.21 & NA & & & & & & & & & & & & & & & \\
\hline B-48 & Nov-55 & PFeCN1 (BT1) & $4.09 \mathrm{E}+00$ & 1.21 & NA & $3.65 \mathrm{E}+05$ & $6.03 \mathrm{E}+02$ & $8.12 \mathrm{E}+05$ & $3.87 \mathrm{E}+02$ & $9.04 \mathrm{E}+02$ & $2.74 \mathrm{E}+04$ & $4.81 \mathrm{E}+04$ & $1.66 \mathrm{E}+04$ & $1.27 \mathrm{E}+02$ & $7.03 \mathrm{E}+02$ & $2.20 \mathrm{E}+03$ & 7.69E-01 & $1.99 \mathrm{E}-02$ & $1.55 \mathrm{E}+01$ & $2.55 \mathrm{E}+01$ \\
\hline B-49 & $\begin{array}{l}\text { Nov- } \\
\text { Dec- } \\
1955\end{array}$ & PFeCN1 (BT1) & $6.70 \mathrm{E}+00$ & 1.21 & NA & $5.98 \mathrm{E}+05$ & $9.89 \mathrm{E}+02$ & $1.33 \mathrm{E}+06$ & $6.35 \mathrm{E}+02$ & $1.48 \mathrm{E}+03$ & $4.49 \mathrm{E}+04$ & $7.88 \mathrm{E}+042$ & $2.71 \mathrm{E}+04$ & $2.08 \mathrm{E}+02$ & $1.15 \mathrm{E}+03$ & $4.00 \mathrm{E}+03$ & $1.26 \mathrm{E}+00$ & $3.27 \mathrm{E}-02$ & $2.55 \mathrm{E}+01$ & $4.18 \mathrm{E}+01$ \\
\hline \multirow[t]{6}{*}{ B-50 } & 1965 & BYSLT (BT2) & $0.00 \mathrm{E}+00$ & 1.51 & NA & $1.58 \mathrm{E}+01$ & $7.33 \mathrm{E}+01$ & $1.12 \mathrm{E}+01$ & $3.90 \mathrm{E}+00$ & $1.05 \mathrm{E}+00$ & $1.97 \mathrm{E}-01$ & $4.26 \mathrm{E}+01$ & $7.69 \mathrm{E}-01$ & $2.90 \mathrm{E}-03$ & $1.50 \mathrm{E}+00$ & $0.00 \mathrm{E}+00$ & $8.03 \mathrm{E}-04$ & $9.37 \mathrm{E}-06$ & $6.60 \mathrm{E}-03$ & $1.28 \mathrm{E}+01$ \\
\hline & 1965 & $\begin{array}{l}\text { ITS Cool Wtr-Cond } \\
\text { (BT2) }\end{array}$ & $5.56 \mathrm{E}+00$ & 1.01 & NA & & & & & & & & & & & & & & & \\
\hline & 1966 & BYSLT (BT2) & $0.00 \mathrm{E}+00$ & 1.51 & NA & $1.54 \mathrm{E}+01$ & $6.99 \mathrm{E}+01$ & $1.10 \mathrm{E}+01$ & $3.90 \mathrm{E}+00$ & $1.05 \mathrm{E}+00$ & $1.97 \mathrm{E}-01$ & $4.07 \mathrm{E}+01$ & 7.37E-01 & $2.82 \mathrm{E}-03$ & $1.43 \mathrm{E}+00$ & $0.00 \mathrm{E}+00$ & $8.00 \mathrm{E}-04$ & $9.32 \mathrm{E}-06$ & $6.62 \mathrm{E}-03$ & $1.22 \mathrm{E}+01$ \\
\hline & 1966 & $\begin{array}{l}\text { ITS Cool Wtr-Cond } \\
\text { (BT2) }\end{array}$ & $5.30 \mathrm{E}+00$ & 1.01 & NA & & & & & & & & & & & & & & & \\
\hline & 1967 & BYSLT (BT2) & $0.00 \mathrm{E}+00$ & 1.51 & NA & $2.03 \mathrm{E}+01$ & $1.19 \mathrm{E}+02$ & $1.36 \mathrm{E}+01$ & $3.90 \mathrm{E}+00$ & $1.05 \mathrm{E}+00$ & $1.97 \mathrm{E}-01$ & $6.88 \mathrm{E}+01$ & $1.20 \mathrm{E}+00$ & 4.07E-03 & $2.37 \mathrm{E}+00$ & $0.00 \mathrm{E}+00$ & 8.06E-04 & $9.33 \mathrm{E}-06$ & $6.60 \mathrm{E}-03$ & $2.08 \mathrm{E}+01$ \\
\hline & 1967 & ITS Cool Wtr-Cond & $9.00 \mathrm{E}+00$ & 1.01 & NA & & & & & & & & & & & & & & & \\
\hline
\end{tabular}


Table A.3. Volumes and Mass of Constituents Disposed to Facilities each Year and Waste Types and Waste Densities

\begin{tabular}{|c|c|c|c|c|c|c|c|c|c|c|c|c|c|c|c|c|c|c|c|c|}
\hline \multirow[b]{2}{*}{ Facility } & \multirow[b]{2}{*}{$\begin{array}{c}\text { Date } \\
\text { Disposed }\end{array}$} & \multirow[b]{2}{*}{ Waste Type } & \multirow{2}{*}{$\begin{array}{c}\text { ML } \\
\text { Vol } \\
\text { Disposed } \\
\end{array}$} & \multirow{2}{*}{$\begin{array}{l}\mathrm{g} / \mathrm{cm}^{3} \\
\text { Density }\end{array}$} & \multirow[b]{2}{*}{$\mathrm{pH}$} & \multicolumn{11}{|c|}{ Yearly Inventory (kg) } & \multicolumn{4}{|c|}{ Yearly Inventory Ci } \\
\hline & & & & & & $\mathrm{Na}$ & $\mathrm{Ca}$ & $\mathrm{NO}_{3}$ & $\mathrm{NO}_{2}$ & $\mathrm{CO}_{3}$ & $\mathrm{PO}_{4}$ & $\mathrm{SO}_{4}$ & $\mathrm{~F}$ & U-Total & $\mathrm{Cr}$ & $\mathrm{Fe}(\mathrm{CN}) 6$ & Co-60 & $\mathrm{I}-129$ & Tc-99 & $\mathrm{H}-3$ \\
\hline & & (BT2) & & & & & & & & & & & & & & & & & & \\
\hline & 1968 & BYSLT (BT2) & $0.00 \mathrm{E}+00$ & 1.51 & NA & $1.79 \mathrm{E}+01$ & $9.44 \mathrm{E}+01$ & $1.23 \mathrm{E}+01$ & $3.90 \mathrm{E}+00$ & $1.05 \mathrm{E}+00$ & $1.98 \mathrm{E}-01$ & $5.48 \mathrm{E}+01$ & 9.72E-01 & $3.45 \mathrm{E}-03$ & $1.90 \mathrm{E}+00$ & $0.00 \mathrm{E}+00$ & 8.03E-04 & 9.31E-06 & $6.59 \mathrm{E}-03$ & $1.65 \mathrm{E}+01$ \\
\hline & 1968 & $\begin{array}{l}\text { ITS Cool Wtr-Cond } \\
\text { (BT2) }\end{array}$ & $7.16 \mathrm{E}+00$ & 1.01 & NA & & & & & & & & & & & & & & & \\
\hline & 1969 & BYSLT (BT2) & $0.00 \mathrm{E}+00$ & 1.51 & NA & $2.03 \mathrm{E}+01$ & $1.19 \mathrm{E}+02$ & $1.36 \mathrm{E}+01$ & $3.90 \mathrm{E}+00$ & $1.05 \mathrm{E}+00$ & $1.97 \mathrm{E}-01$ & $6.88 \mathrm{E}+01$ & $1.20 \mathrm{E}+00$ & 4.07E- 03 & $2.37 \mathrm{E}+00$ & $0.00 \mathrm{E}+00$ & 8.03E-04 & $9.33 \mathrm{E}-06$ & $6.56 \mathrm{E}-03$ & $2.08 \mathrm{E}+01$ \\
\hline & 1969 & $\begin{array}{l}\text { ITS Cool Wtr-Cond } \\
\text { (BT2) }\end{array}$ & $9.00 \mathrm{E}+00$ & 1.01 & NA & & & & & & & & & & & & & & & \\
\hline & 1970 & BYSLT (BT2) & $0.00 \mathrm{E}+00$ & 1.51 & NA & $1.96 \mathrm{E}+01$ & $1.12 \mathrm{E}+02$ & $1.33 \mathrm{E}+01$ & $3.90 \mathrm{E}+00$ & $1.05 \mathrm{E}+00$ & 1.97E-01 & $6.50 \mathrm{E}+01$ & $1.14 \mathrm{E}+00$ & $3.90 \mathrm{E}-03$ & $2.24 \mathrm{E}+00$ & $0.00 \mathrm{E}+00$ & 8.07E-04 & 9.33E-06 & $6.59 \mathrm{E}-03$ & $1.96 \mathrm{E}+01$ \\
\hline & 1970 & $\begin{array}{l}\text { ITS Cool Wtr-Cond } \\
\text { (BT2) }\end{array}$ & $8.50 \mathrm{E}+00$ & 1.01 & NA & & & & & & & & & & & & & & & \\
\hline & 1971 & BYSLT (BT2) & $0.00 \mathrm{E}+00$ & 1.51 & NA & $1.65 \mathrm{E}+01$ & $8.05 \mathrm{E}+01$ & $1.15 \mathrm{E}+01$ & $3.90 \mathrm{E}+00$ & $1.05 \mathrm{E}+00$ & 1.97E-01 & $4.68 \mathrm{E}+01$ & 8.38E-01 & 3.09E-03 & $1.64 \mathrm{E}+00$ & $0.00 \mathrm{E}+00$ & 7.94E-04 & 9.35E-06 & $6.62 \mathrm{E}-03$ & $1.41 \mathrm{E}+01$ \\
\hline & 1971 & $\begin{array}{c}\text { ITS Cool Wtr-Cond } \\
\text { (BT2) }\end{array}$ & $6.10 \mathrm{E}+00$ & 1.01 & NA & & & & & & & & & & & & & & & \\
\hline & 1972 & BYSLT (BT2) & $0.00 \mathrm{E}+00$ & 1.51 & NA & $1.24 \mathrm{E}+01$ & $3.94 \mathrm{E}+01$ & $9.30 \mathrm{E}+00$ & $3.90 \mathrm{E}+00$ & $1.05 \mathrm{E}+00$ & $1.98 \mathrm{E}-01$ & $2.31 \mathrm{E}+01$ & 4.45E-01 & $2.04 \mathrm{E}-03$ & 8.51E-01 & $0.00 \mathrm{E}+00$ & $8.02 \mathrm{E}-04$ & 9.36E-06 & $6.58 \mathrm{E}-03$ & $6.90 \mathrm{E}+00$ \\
\hline & 1972 & $\begin{array}{c}\text { ITS Cool Wtr-Cond } \\
\text { (BT2) }\end{array}$ & $2.99 \mathrm{E}+00$ & 1.01 & NA & & & & & & & & & & & & & & & \\
\hline & 1973 & BYSLT (BT2) & $0.00 \mathrm{E}+00$ & 1.51 & NA & $9.97 \mathrm{E}+00$ & $1.46 \mathrm{E}+01$ & $8.02 \mathrm{E}+00$ & $3.90 \mathrm{E}+00$ & $1.05 \mathrm{E}+00$ & 1.97E-01 & $8.83 \mathrm{E}+00$ & $2.08 \mathrm{E}-01$ & $1.41 \mathrm{E}-03$ & 3.76E-01 & $0.00 \mathrm{E}+00$ & 7.98E-04 & 9.35E-06 & $6.60 \mathrm{E}-03$ & $2.56 \mathrm{E}+00$ \\
\hline & 1973 & $\begin{array}{c}\text { ITS Cool Wtr-Cond } \\
\text { (BT2) }\end{array}$ & $1.11 \mathrm{E}+00$ & 1.01 & NA & & & & & & & & & & & & & & & \\
\hline & 1974 & BYSLT (BT2) & $0.00 \mathrm{E}+00$ & 1.51 & NA & $8.54 \mathrm{E}+00$ & $3.02 \mathrm{E}-01$ & $7.21 \mathrm{E}+00$ & $3.90 \mathrm{E}+00$ & $1.05 \mathrm{E}+00$ & 1.97E-01 & $5.68 \mathrm{E}-01$ & $7.05 \mathrm{E}-02$ & $1.04 \mathrm{E}-03$ & $1.02 \mathrm{E}-01$ & $0.00 \mathrm{E}+00$ & 7.97E-04 & $9.34 \mathrm{E}-06$ & $6.61 \mathrm{E}-03$ & $5.45 \mathrm{E}-02$ \\
\hline & 1974 & $\begin{array}{c}\text { ITS Cool Wtr-Cond } \\
\text { (BT2) }\end{array}$ & $2.25 \mathrm{E}-02$ & 1.01 & NA & & & & & & & & & & & & & & & \\
\hline \multirow[t]{11}{*}{ B-57 } & 1968 & $\begin{array}{c}\text { ITS Cool Wtr-Cond } \\
\text { (BT2) }\end{array}$ & $1.25 \mathrm{E}+01$ & 1.01 & NA & $5.89 \mathrm{E}+01$ & $1.65 \mathrm{E}+02$ & $4.49 \mathrm{E}+01$ & $1.95 \mathrm{E}+01$ & $5.26 \mathrm{E}+00$ & $9.85 \mathrm{E}-01$ & $9.70 \mathrm{E}+01$ & $1.92 \mathrm{E}+00$ & $9.39 \mathrm{E}-03$ & $3.64 \mathrm{E}+00$ & $0.00 \mathrm{E}+00$ & $4.01 \mathrm{E}-03$ & 4.68E-05 & $3.29 \mathrm{E}-02$ & $2.88 \mathrm{E}+01$ \\
\hline & 1969 & BYSLT (BT2) & $0.00 \mathrm{E}+00$ & 1.51 & NA & $6.88 \mathrm{E}+01$ & $2.64 \mathrm{E}+02$ & $5.04 \mathrm{E}+01$ & $1.95 \mathrm{E}+01$ & $5.26 \mathrm{E}+00$ & 9.86E-01 & $1.54 \mathrm{E}+02$ & $2.86 \mathrm{E}+00$ & $1.19 \mathrm{E}-02$ & $5.53 \mathrm{E}+00$ & $0.00 \mathrm{E}+00$ & 4.01E-03 & 4.68E-05 & $3.28 \mathrm{E}-02$ & $4.61 \mathrm{E}+01$ \\
\hline & 1969 & $\begin{array}{c}\text { ITS Cool Wtr-Cond } \\
\text { (BT2) }\end{array}$ & $2.00 \mathrm{E}+01$ & 1.01 & NA & & & & & & & & & & & & & & & \\
\hline & 1970 & BYSLT (BT2) & $0.00 \mathrm{E}+00$ & 1.51 & NA & $6.78 \mathrm{E}+01$ & $2.55 \mathrm{E}+02$ & $4.98 \mathrm{E}+01$ & $1.95 \mathrm{E}+01$ & $5.26 \mathrm{E}+00$ & 9.84E-01 & $1.49 \mathrm{E}+02$ & $2.77 \mathrm{E}+00$ & $1.17 \mathrm{E}-02$ & $5.35 \mathrm{E}+00$ & $0.00 \mathrm{E}+00$ & $3.99 \mathrm{E}-03$ & 4.65E-05 & $3.29 \mathrm{E}-02$ & $4.45 \mathrm{E}+01$ \\
\hline & 1970 & $\begin{array}{l}\text { ITS Cool Wtr-Cond } \\
\text { (BT2) }\end{array}$ & $1.93 \mathrm{E}+01$ & 1.01 & NA & & & & & & & & & & & & & & & \\
\hline & 1971 & BYSLT (BT2) & $0.00 \mathrm{E}+00$ & 1.51 & NA & $5.96 \mathrm{E}+01$ & $1.71 \mathrm{E}+02$ & $4.52 \mathrm{E}+01$ & $1.95 \mathrm{E}+01$ & $5.26 \mathrm{E}+00$ & $9.88 \mathrm{E}-01$ & $1.01 \mathrm{E}+02$ & $1.98 \mathrm{E}+00$ & $9.58 \mathrm{E}-03$ & $3.76 \mathrm{E}+00$ & $0.00 \mathrm{E}+00$ & 3.99E-03 & 4.66E-05 & $3.29 \mathrm{E}-02$ & $3.00 \mathrm{E}+01$ \\
\hline & 1971 & $\begin{array}{c}\text { ITS Cool Wtr-Cond } \\
\text { (BT2) }\end{array}$ & $1.30 \mathrm{E}+01$ & 1.01 & NA & & & & & & & & & & & & & & & \\
\hline & 1972 & BYSLT (BT2) & $0.00 \mathrm{E}+00$ & 1.51 & NA & $6.14 \mathrm{E}+01$ & $1.90 \mathrm{E}+02$ & $4.63 \mathrm{E}+01$ & $1.95 \mathrm{E}+01$ & $5.26 \mathrm{E}+00$ & 9.83E-01 & $1.11 \mathrm{E}+02$ & $2.16 \mathrm{E}+00$ & $1.00 \mathrm{E}-02$ & $4.12 \mathrm{E}+00$ & $0.00 \mathrm{E}+00$ & 4.00E-03 & 4.65E-05 & $3.30 \mathrm{E}-02$ & $3.32 \mathrm{E}+01$ \\
\hline & 1972 & $\begin{array}{c}\text { ITS Cool Wtr-Cond } \\
\text { (BT2) }\end{array}$ & $1.44 \mathrm{E}+01$ & 1.01 & NA & & & & & & & & & & & & & & & \\
\hline & 1973 & BYSLT (BT2) & $0.00 \mathrm{E}+00$ & 1.51 & NA & $4.93 \mathrm{E}+01$ & $6.77 \mathrm{E}+01$ & $3.96 \mathrm{E}+01$ & $1.95 \mathrm{E}+01$ & $5.26 \mathrm{E}+00$ & $9.88 \mathrm{E}-01$ & $4.10 \mathrm{E}+01$ & $9.86 \mathrm{E}-01$ & $6.86 \mathrm{E}-03$ & $1.78 \mathrm{E}+00$ & $0.00 \mathrm{E}+00$ & $4.01 \mathrm{E}-03$ & 4.67E-05 & $3.29 \mathrm{E}-02$ & $1.18 \mathrm{E}+01$ \\
\hline & 1973 & $\begin{array}{c}\text { ITS Cool Wtr-Cond } \\
\text { (BT2) }\end{array}$ & $5.13 \mathrm{E}+00$ & 1.01 & NA & & & & & & & & & & & & & & & \\
\hline \multirow{2}{*}{$\begin{array}{l}\text { BY-201 } \\
\text { Settling } \\
\text { Tank }\end{array}$} & 1954 & PFeCN1 (BT1) & $5.95 \mathrm{E}-03$ & 1.21 & NA & $5.31 \mathrm{E}+02$ & $8.78 \mathrm{E}-01$ & $1.18 \mathrm{E}+03$ & 5.63E-01 & $1.31 \mathrm{E}+00$ & $3.98 \mathrm{E}+01$ & $7.00 \mathrm{E}+01$ & $2.41 \mathrm{E}+01$ & $1.85 \mathrm{E}-01$ & $1.02 \mathrm{E}+00$ & $0.00 \mathrm{E}+00$ & $1.12 \mathrm{E}-03$ & $2.90 \mathrm{E}-05$ & $2.26 \mathrm{E}-02$ & $3.71 \mathrm{E}-02$ \\
\hline & 1955 & PFeCN1 (BT1) & 3.57E-02 & 1.21 & NA & $3.18 \mathrm{E}+03$ & $5.27 \mathrm{E}+00$ & $7.09 \mathrm{E}+03$ & $3.38 \mathrm{E}+00$ & $7.87 \mathrm{E}+00$ & $2.39 \mathrm{E}+02$ & $4.20 \mathrm{E}+02$ & $1.45 \mathrm{E}+02$ & $1.11 \mathrm{E}+00$ & $6.14 \mathrm{E}+00$ & $0.00 \mathrm{E}+00$ & $6.71 \mathrm{E}-03$ & $1.74 \mathrm{E}-04$ & $1.36 \mathrm{E}-01$ & $2.22 \mathrm{E}-01$ \\
\hline
\end{tabular}


Table A.3. Volumes and Mass of Constituents Disposed to Facilities each Year and Waste Types and Waste Densities

\begin{tabular}{|c|c|c|c|c|c|c|c|c|c|c|c|c|c|c|c|c|c|c|c|c|c|}
\hline \multirow[b]{2}{*}{ Facility } & \multirow{2}{*}{$\begin{array}{c}\text { Date } \\
\text { Disposed } \\
\end{array}$} & \multirow[b]{2}{*}{ Waste Type } & \multirow{2}{*}{$\begin{array}{c}\text { ML } \\
\text { Vol } \\
\text { Disposed } \\
\end{array}$} & \multirow{2}{*}{$\begin{array}{l}\mathrm{g} / \mathrm{cm}^{3} \\
\text { Density } \\
\end{array}$} & \multirow[b]{2}{*}{$\mathrm{pH}$} & \multirow[b]{2}{*}{$\mathrm{Na}$} & \multirow[b]{2}{*}{$\mathrm{Ca}$} & \multirow[b]{2}{*}{$\mathrm{NO}_{3}$} & \multirow[b]{2}{*}{$\mathrm{NO}_{2}$} & \multicolumn{3}{|c|}{ Yearly Inventory (kg) } & \multirow[b]{2}{*}{$\mathrm{F}$} & \multirow[b]{2}{*}{ U-Total } & \multirow[b]{2}{*}{$\mathrm{Cr}$} & \multirow[b]{2}{*}{$\mathrm{Fe}(\mathrm{CN}) 6$} & \multirow[b]{2}{*}{ Co-60 } & \multicolumn{2}{|c|}{ Yearly Inventory Ci } & \multirow[b]{2}{*}{$\mathrm{H}-3$} & \\
\hline & & & & & & & & & & $\mathrm{CO}_{3}$ & $\mathrm{PO}_{4}$ & $\mathrm{SO}_{4}$ & & & & & & $\mathrm{I}-129$ & Tc-99 & & \\
\hline $\begin{array}{l}\text { BX Tank } \\
\text { Farm }\end{array}$ & & & & & & $\mathrm{Na}$ & $\mathrm{Ca}$ & NO3 & NO2 & $\mathrm{CO} 3$ & PO4 & $\mathrm{SO} 4$ & F & $\mathrm{U}$ & $\mathrm{Cr}$ & $\mathrm{Fe}(\mathrm{CN}) 6$ & Co-60 & $\mathrm{I}-129$ & Tc-99 & H-3 & \\
\hline BX-101 & 1972 & $\begin{array}{l}\text { Sr-Cs Rec Org Wst } \\
\text { aq (P2)_BL }\end{array}$ & $1.51 \mathrm{E}-02$ & 1.09 & NA & $1.23 \mathrm{E}+03$ & $5.82 \mathrm{E}+00$ & $7.24 \mathrm{E}+02$ & $1.09 \mathrm{E}+02$ & $2.31 \mathrm{E}+02$ & $1.35 \mathrm{E}+01$ & $6.58 \mathrm{E}+01$ & $3.66 \mathrm{E}-02$ & 4.54E-01 & $1.50 \mathrm{E}+00$ & 0 & $1.16 \mathrm{E}-01$ & $9.06 \mathrm{E}-05$ & $2.48 \mathrm{E}-01$ & $4.81 \mathrm{E}-02$ & \\
\hline BX-102 & 1951 & MW1 (BT1) & $3.47 \mathrm{E}-01$ & 1.1 & NA & $1.68 \mathrm{E}+04$ & $1.51 \mathrm{E}+02$ & $3.80 \mathrm{E}+03$ & $2.70 \mathrm{E}+02$ & $1.27 \mathrm{E}+04$ & $4.13 \mathrm{E}+03$ & $5.59 \mathrm{E}+03$ & $1.31 \mathrm{E}-05$ & $1.01 \mathrm{E}+04$ & $46.05 \mathrm{E}+01$ & 0 & 4.99E-02 & $1.01 \mathrm{E}-03$ & $2.27 \mathrm{E}+00$ & $3.85 \mathrm{E}+00$ & \\
\hline BX-108 & 1972 & $\begin{array}{l}\text { Sr-Cs Rec Org Wst } \\
\text { (P2')_CSR;CWP2 } \\
\text { (CWP2) }\end{array}$ & $9.46 \mathrm{E}-03$ & $1.19,1.07$ & NA & $8.37 \mathrm{E}+02$ & $1.39 \mathrm{E}+00$ & $6.98 \mathrm{E}+02$ & $3.45 \mathrm{E}+02$ & $9.23 \mathrm{E}+01$ & $5.76 \mathrm{E}+00$ & $7.58 \mathrm{E}+01$ & 4.45E-01 & $2.87 \mathrm{E}-01$ & $1.37 \mathrm{E}+01$ & 0 & 2.17E-01 & $8.88 \mathrm{E}-04$ & $1.18 \mathrm{E}+00$ & 3.32E-01 & \\
\hline BX-110 & 1976 & NA & 3.03E-02 & NA & NA & NA & NA & NA & NA & NA & NA & NA & NA & NA & NA & NA & NA & NA & NA & NA & \\
\hline BX-111 & 1984 & NA & 3.03E-02 & NA & NA & NA & NA & NA & NA & NA & NA & NA & NA & NA & NA & NA & NA & NA & NA & NA & \\
\hline $\begin{array}{l}\text { BY Tank } \\
\text { Farm }\end{array}$ & & & & & & & & & & & & & & & & & & & & & \\
\hline BY-103 & 1973 & BYSLT (BT2) & $1.89 \mathrm{E}-02$ & 1.51 & NA & $3.87 \mathrm{E}+02$ & 2.27E-01 & $3.27 \mathrm{E}+02$ & $1.77 \mathrm{E}+02$ & $4.78 \mathrm{E}+01$ & $8.96 \mathrm{E}+00$ & $1.80 \mathrm{E}+01$ & $3.07 \mathrm{E}+00$ & $4.70 \mathrm{E}-02$ & $4.36 \mathrm{E}+00$ & 0 & 3.63E-02 & 4.24E-04 & 2.99E-01 & $1.17 \mathrm{E}-01$ & \\
\hline BY-105 & 1984 & NA & $3.03 \mathrm{E}-02$ & NA & NA & NA & NA & NA & NA & NA & NA & NA & NA & NA & NA & NA & NA & NA & NA & NA & \\
\hline BY-106 & 1972 & NA & 3.03E-02 & NA & NA & $\mathrm{NA}$ & $\mathrm{NA}$ & NA & NA & NA & NA & NA & NA & NA & NA & NA & NA & $\mathrm{NA}$ & NA & NA & \\
\hline BY-107 & 1974 & BYSLT (BT2) & $5.72 \mathrm{E}-02$ & 1.51 & NA & $1.16 \mathrm{E}+03$ & $6.81 \mathrm{E}-01$ & $9.80 \mathrm{E}+02$ & $5.32 \mathrm{E}+02$ & $1.43 \mathrm{E}+02$ & $2.69 \mathrm{E}+01$ & $5.41 \mathrm{E}+01$ & $9.22 \mathrm{E}+00$ & $1.41 \mathrm{E}-01$ & $1.31 \mathrm{E}+01$ & 0 & $1.09 \mathrm{E}-01$ & $1.27 \mathrm{E}-03$ & $8.98 \mathrm{E}-01$ & $3.51 \mathrm{E}-01$ & \\
\hline BY-108 & 1972 & BYSLT (BT2) & $1.89 \mathrm{E}-02$ & 1.51 & NA & $3.87 \mathrm{E}+02$ & 2.27E-01 & $3.27 \mathrm{E}+02$ & $1.77 \mathrm{E}+02$ & $4.78 \mathrm{E}+01$ & $8.96 \mathrm{E}+00$ & $1.80 \mathrm{E}+01$ & $3.07 \mathrm{E}+00$ & $4.70 \mathrm{E}-02$ & $4.36 \mathrm{E}+00$ & 0 & 3.63E-02 & $4.24 \mathrm{E}-04$ & $2.99 \mathrm{E}-01$ & $1.17 \mathrm{E}-01$ & \\
\hline $\begin{array}{l}\text { B Tank } \\
\text { Farm } \\
\text { B-101 }\end{array}$ & 1974 & NA & $3.03 \mathrm{E}-02$ & NA & NA & NA & NA & NA & NA & NA & NA & NA & NA & NA & NA & NA & NA & NA & NA & NA & \\
\hline B-103 & 1978 & NA & 3.03E-02 & NA & NA & NA & NA & NA & NA & NA & NA & NA & NA & NA & NA & NA & NA & NA & NA & NA & \\
\hline B-105 & 1978 & NA & 3.03E-02 & NA & NA & NA & NA & NA & NA & NA & NA & NA & NA & NA & NA & NA & NA & NA & NA & NA & \\
\hline B-107 & 1965 & $\begin{array}{l}\text { CWP2 } \\
\text { (CWP2),PUREX } \\
\text { (P2) Cool Wtr-Stm } \\
\text { Cond, 1C Evap } \\
\text { (BT2) }\end{array}$ & $3.03 \mathrm{E}-02$ & $1.07,1.01,1.26$ & $\mathrm{NA}$ & $2.04 \mathrm{E}+03$ & $7.20 \mathrm{E}+00$ & $2.35 \mathrm{E}+03$ & $8.07 \mathrm{E}+02$ & $4.25 \mathrm{E}+01$ & $1.73 \mathrm{E}+01$ & $17.53 \mathrm{E}+01$ & $8.56 \mathrm{E}+00$ & $1.47 \mathrm{E}+00$ & $9.29 \mathrm{E}+00$ & 0 & $8.25 \mathrm{E}-01$ & $8.23 \mathrm{E}-03$ & $2.83 \mathrm{E}-01$ & $6.94 \mathrm{E}+00$ & \\
\hline B-110 & 1969 & $\begin{array}{l}\text { PUREX (P2) Cool } \\
\text { Wtr-Stm Cond } \\
\text { PUREX (P2') Cool } \\
\text { Wtr-Stm Cond Sr- } \\
\text { Cs Rec Org Wst } \\
\text { (P2')_CSR }\end{array}$ & 3.79E-02 & $1.01,1.01,1.19$ & NA & $4.16 \mathrm{E}+02$ & 8.82E-01 & $3.40 \mathrm{E}+02$ & $1.92 \mathrm{E}+02$ & $5.01 \mathrm{E}+01$ & $6.90 \mathrm{E}+00$ & $3.36 \mathrm{E}+01$ & $2.15 \mathrm{E}+00$ & $1.10 \mathrm{E}-01$ & $5.56 \mathrm{E}+00$ & 0 & 8.38E-02 & 4.09E-04 & 5.42E-01 & $1.20 \mathrm{E}-01$ & \\
\hline B-111 & 1978 & NA & 3.03E-02 & NA & NA & NA & NA & NA & NA & NA & NA & NA & NA & NA & NA & NA & NA & NA & NA & NA & \\
\hline B-112 & 1972 & $\begin{array}{l}\text { Sr-Cs Rec Org Wst } \\
\text { (P2')_CSR,PUREX } \\
\text { P2 (P2),BYSLT } \\
\text { (BT2) }\end{array}$ & 7.57E-03 & $\begin{array}{c}1.19,1.05 \\
1.51\end{array}$ & NA & $6.29 \mathrm{E}+02$ & $1.11 \mathrm{E}+00$ & $5.00 \mathrm{E}+02$ & $2.90 \mathrm{E}+02$ & $6.81 \mathrm{E}+01$ & $5.97 \mathrm{E}+00$ & $6.56 \mathrm{E}+01$ & $1.28 \mathrm{E}+00$ & $2.17 \mathrm{E}-01$ & $9.89 \mathrm{E}+00$ & 0 & $1.65 \mathrm{E}-01$ & $6.05 \mathrm{E}-04$ & $1.02 \mathrm{E}+00$ & $1.81 \mathrm{E}-01$ & $\begin{array}{l}Z \\
Z \\
Z \\
\frac{1}{0} \\
\text { J }\end{array}$ \\
\hline
\end{tabular}


Table A.3. Volumes and Mass of Constituents Disposed to Facilities each Year and Waste Types and Waste Densities

\begin{tabular}{|c|c|c|c|c|c|c|c|c|c|c|c|c|c|c|c|c|c|c|c|c|}
\hline \multirow[b]{2}{*}{ Facility } & \multirow[b]{2}{*}{$\begin{array}{c}\text { Date } \\
\text { Disposed }\end{array}$} & \multirow[b]{2}{*}{ Waste Type } & \multirow{2}{*}{$\begin{array}{c}\text { ML } \\
\text { Vol } \\
\text { Disposed } \\
\end{array}$} & \multicolumn{2}{|l|}{$\mathrm{g} / \mathrm{cm}^{3}$} & \multicolumn{11}{|c|}{ 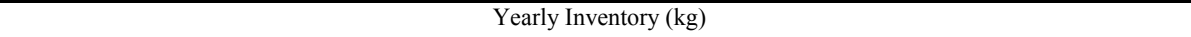 } & \multicolumn{4}{|c|}{ Yearly Inventory $\mathrm{Ci}$} \\
\hline & & & & Density & $\mathrm{pH}$ & $\mathrm{Na}$ & $\mathrm{Ca}$ & $\mathrm{NO}_{3}$ & $\mathrm{NO}_{2}$ & $\mathrm{CO}_{3}$ & $\mathrm{PO}_{4}$ & $\mathrm{SO}_{4}$ & $\mathrm{~F}$ & U-Total & $\mathrm{Cr}$ & $\mathrm{Fe}(\mathrm{CN}) 6$ & Co-60 & I-129 & Тc-99 & $\mathrm{H}-3$ \\
\hline B-201 & 1965 & $\begin{array}{l}224 \text { (BT1), PUREX } \\
\text { (P2) Cool Wtr-Stm } \\
\text { Cond }\end{array}$ & $3.03 \mathrm{E}-02$ & $1.09,1.01$ & NA & $1.26 \mathrm{E}+02$ & $5.13 \mathrm{E}-01$ & $2.93 \mathrm{E}+02$ & $1.36 \mathrm{E}-04$ & $8.52 \mathrm{E}-01$ & $1.04 \mathrm{E}+01$ & $9.63 \mathrm{E}-01$ & $1.75 \mathrm{E}+01$ & $1.24 \mathrm{E}-04$ & $1.21 \mathrm{E}+00$ & 0 & $6.25 \mathrm{E}-07$ & $1.16 \mathrm{E}-10$ & $1.19 \mathrm{E}-07$ & $5.90 \mathrm{E}-10$ \\
\hline B-203 & 1965 & $\begin{array}{l}224 \text { (BT1), Decon } \\
\text { Wst (P1), } \\
\text { PUREX (P2) Cool } \\
\text { Wtr-Stm Cond }\end{array}$ & $1.14 \mathrm{E}-03$ & $1.09,1.01,1.01$ & NA & $3.85 \mathrm{E}+01$ & $1.65 \mathrm{E}-01$ & $8.92 \mathrm{E}+01$ & $3.79 \mathrm{E}-02$ & 2.42E-01 & $3.15 \mathrm{E}+00$ & $3.02 \mathrm{E}-01$ & $5.32 \mathrm{E}+00$ & 2.43E-05 & 3.81E-01 & 0 & $1.90 \mathrm{E}-07$ & 2.01E-08 & $3.62 \mathrm{E}-08$ & $2.42 \mathrm{E}-10$ \\
\hline B-204 & 1965 & $\begin{array}{l}224 \text { (BT1),Decon } \\
\text { Wst (P1),PUREX } \\
\text { (P2) Cool Wtr-Stm } \\
\text { Cond }\end{array}$ & $1.51 \mathrm{E}-03$ & 1.09,1.01,1.01, & NA & $4.34 \mathrm{E}+00$ & $3.32 \mathrm{E}-01$ & $9.43 \mathrm{E}+00$ & $9.96 \mathrm{E}-01$ & $1.54 \mathrm{E}-01$ & $2.35 \mathrm{E}-02$ & 3.55E-01 & $3.98 \mathrm{E}-02$ & 2.93E-05 & 3.78E-01 & 0 & $1.72 \mathrm{E}-09$ & $5.29 \mathrm{E}-07$ & $1.28 \mathrm{E}-09$ & $1.64 \mathrm{E}-09$ \\
\hline
\end{tabular}





\section{Appendix B}

Geology Details (cross sections, contact elevations, isopachs or thicknesses of each stratum) 



\section{Appendix B: Geology Details (cross sections, fence diagrams, contact isopachs, thicknesses of each stratum)}

This appendix includes graphics showing the borehole locations, the tops of the chosen stratigraphic units, and the thicknesses of each of the chosen units that represent the geology beneath the B-Complex. Isopach (thickness) maps are also provided for the unconfined aquifer for 2 years that represent high water table elevations when the release of large volumes of water to the B-Pond and Gable Mountain Pond was causing artificial mounding of groundwater. These graphics should allow the creation of a detailed geologic framework for the B-Complex that can be used in detailed fate and transport modeling activities.

Electronic files for the various graphics and the underlying geologic data are available by contacting Paul Thorne, PNNL. Paul's phone number is (509) 371-7220 or by email at paul.thorne@pnl.gov. 


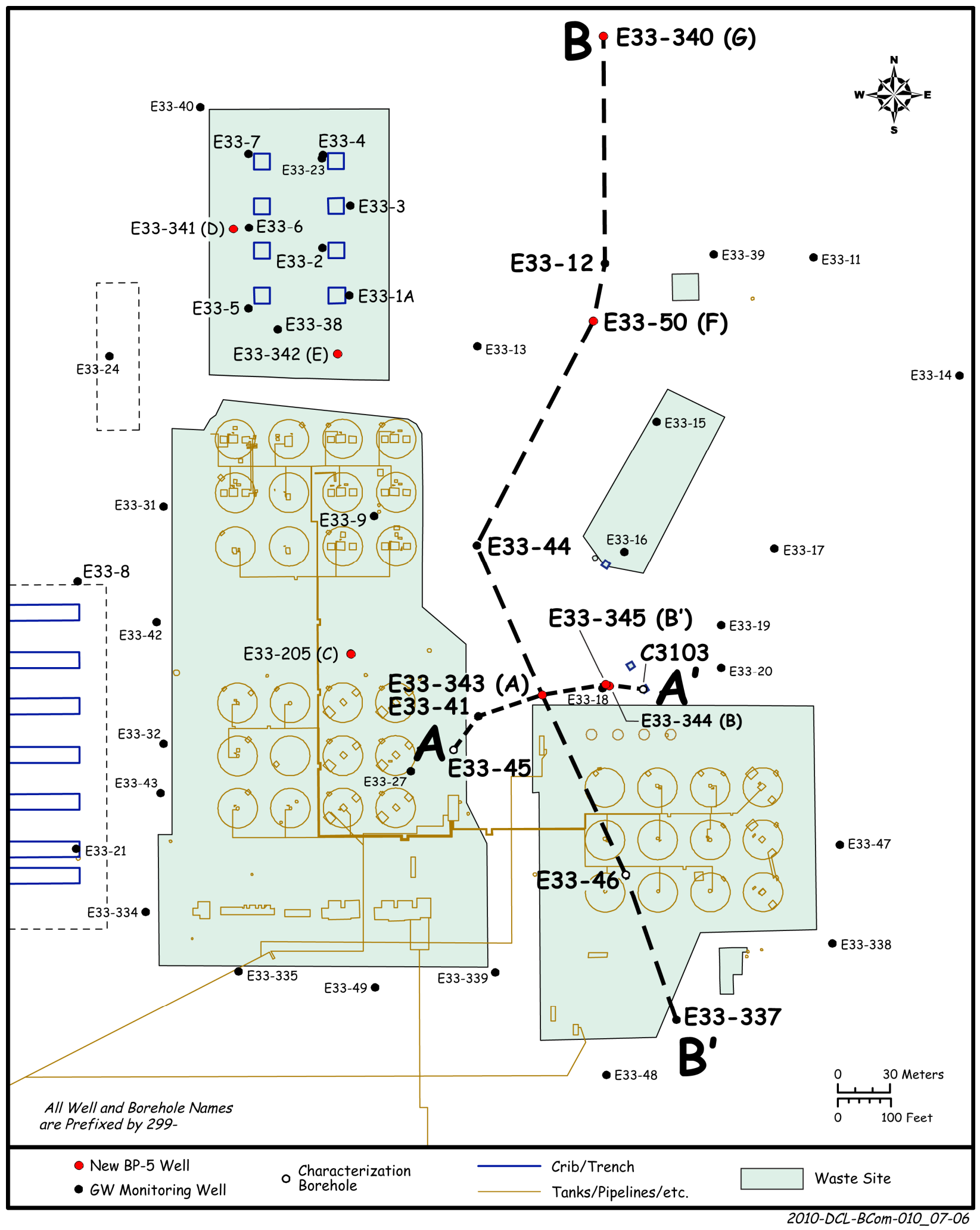

Figure B.1. Location of Wells Used to Make Cross-Sections 


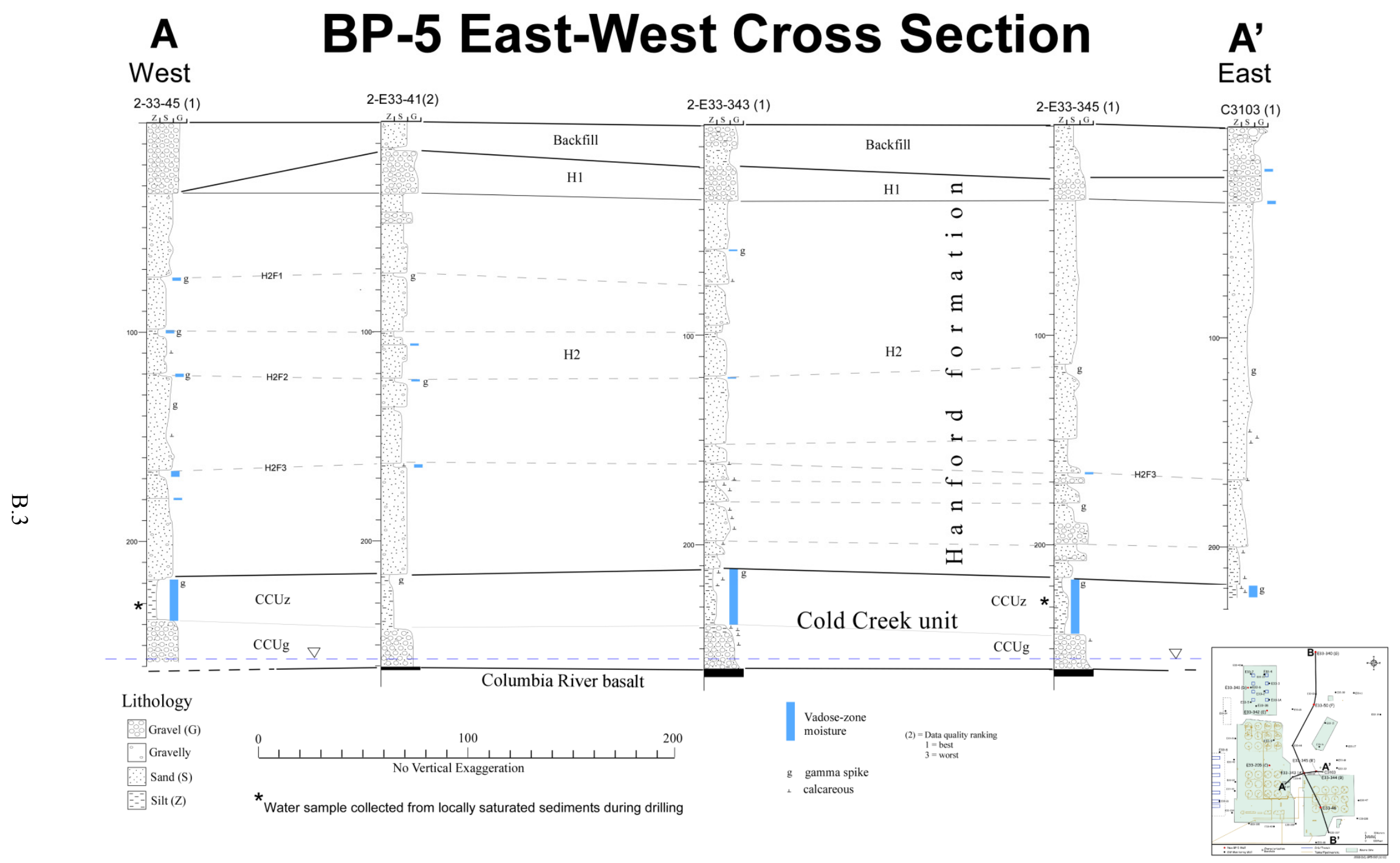

Figure B.2a. East-West Cross-Section 


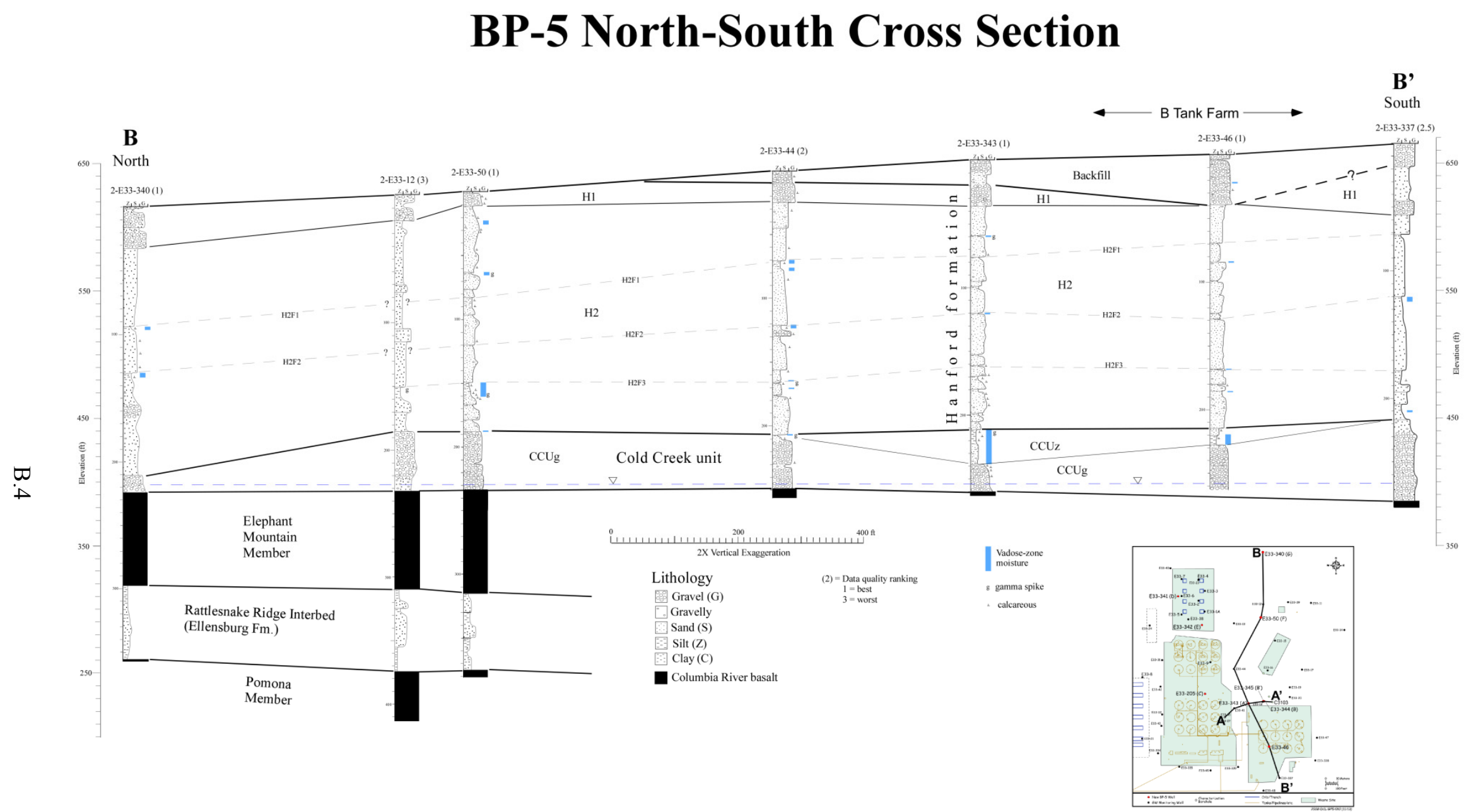

Figure B.2b. North-South Cross-Section 
PNNL-19277

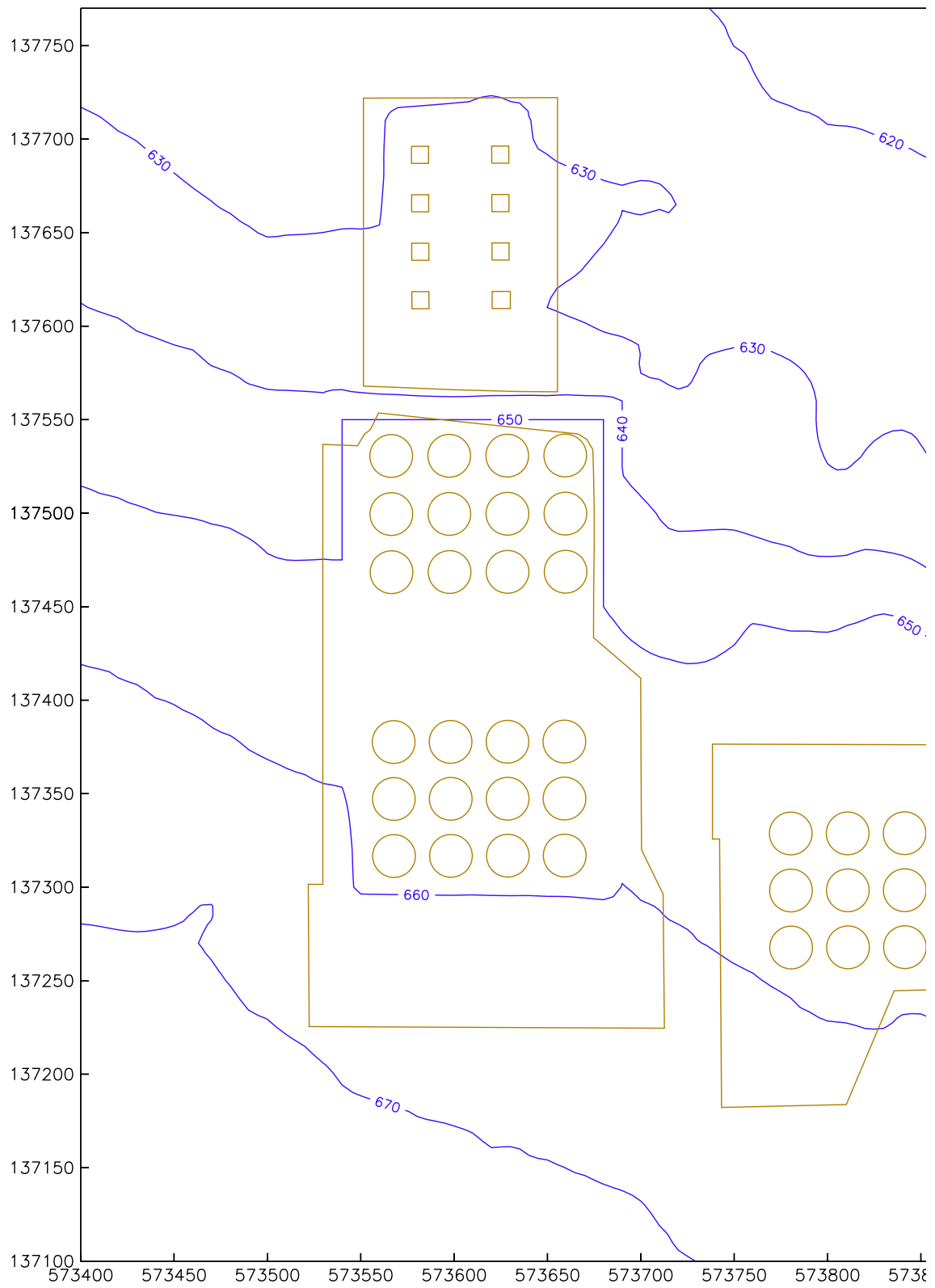

Figure B.3. Contour Map of Ground Surface at B-Complex (Elevation in $\mathrm{ft}$ ) 
PNNL-19277

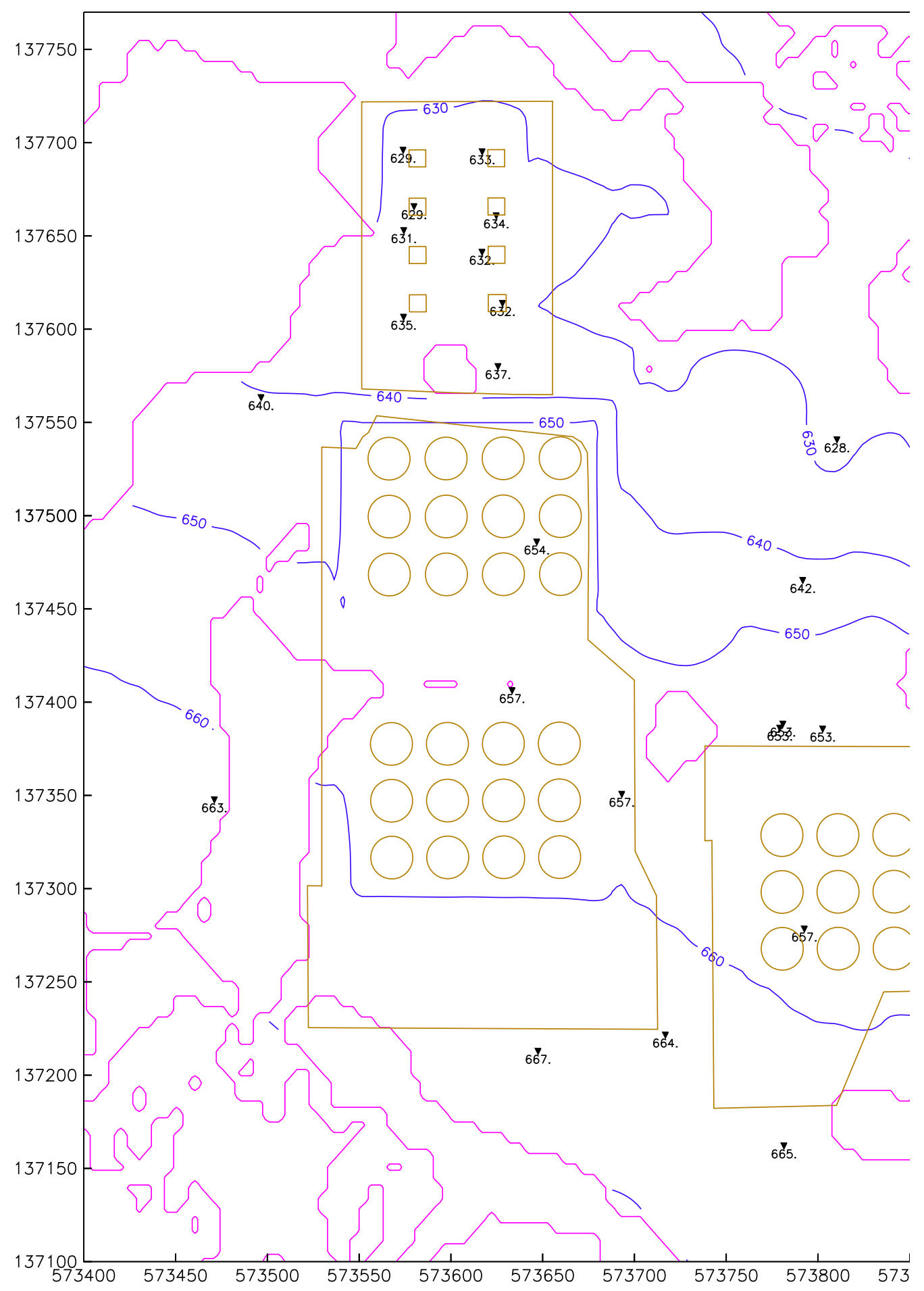

Figure B.4. Contour Map for Top of Backfill at B-Complex (Elevation in ft) 
PNNL-19277

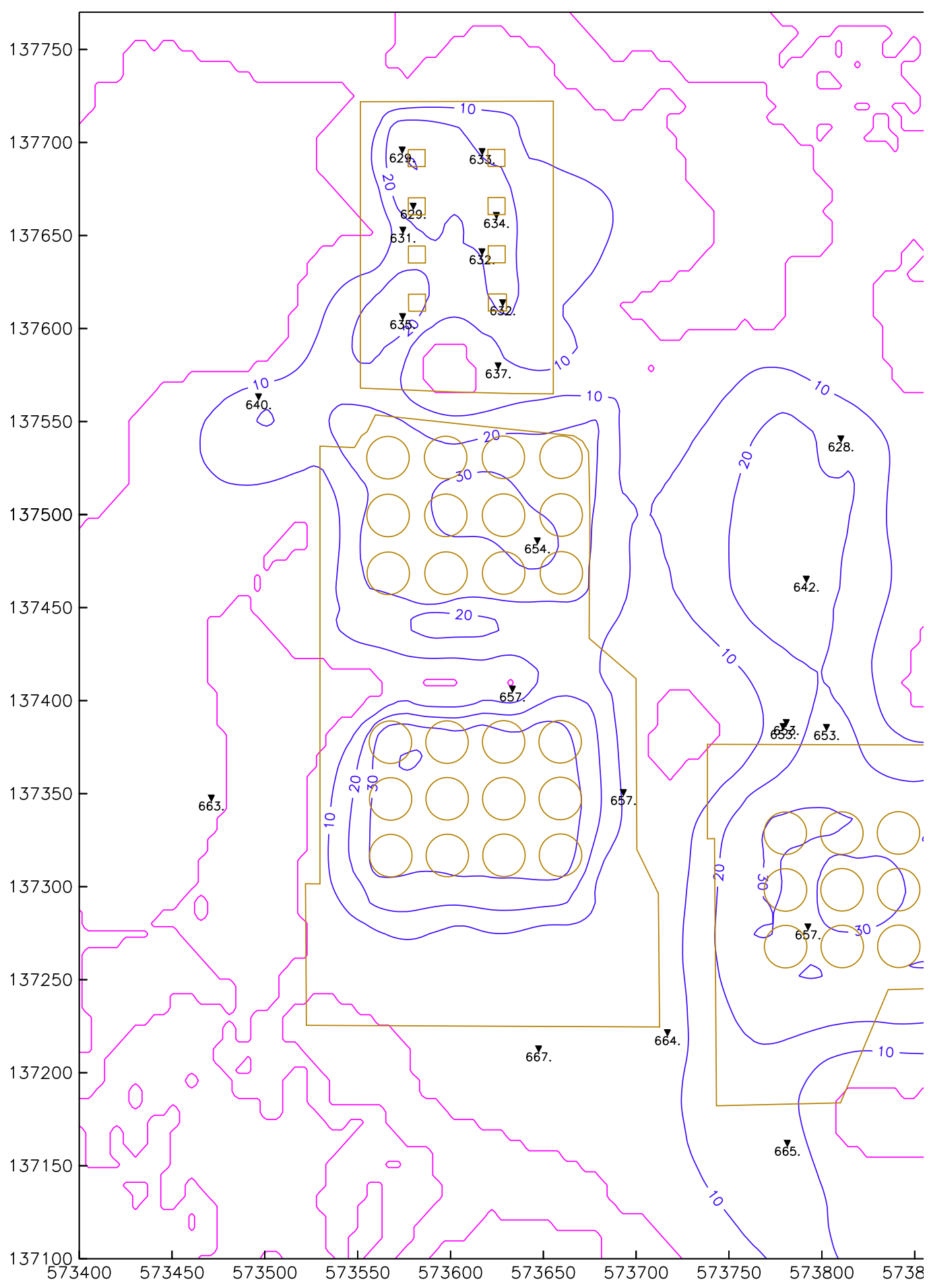

Figure B.5. Thickness Map for Backfill at B-Complex (ft) 
PNNL-19277

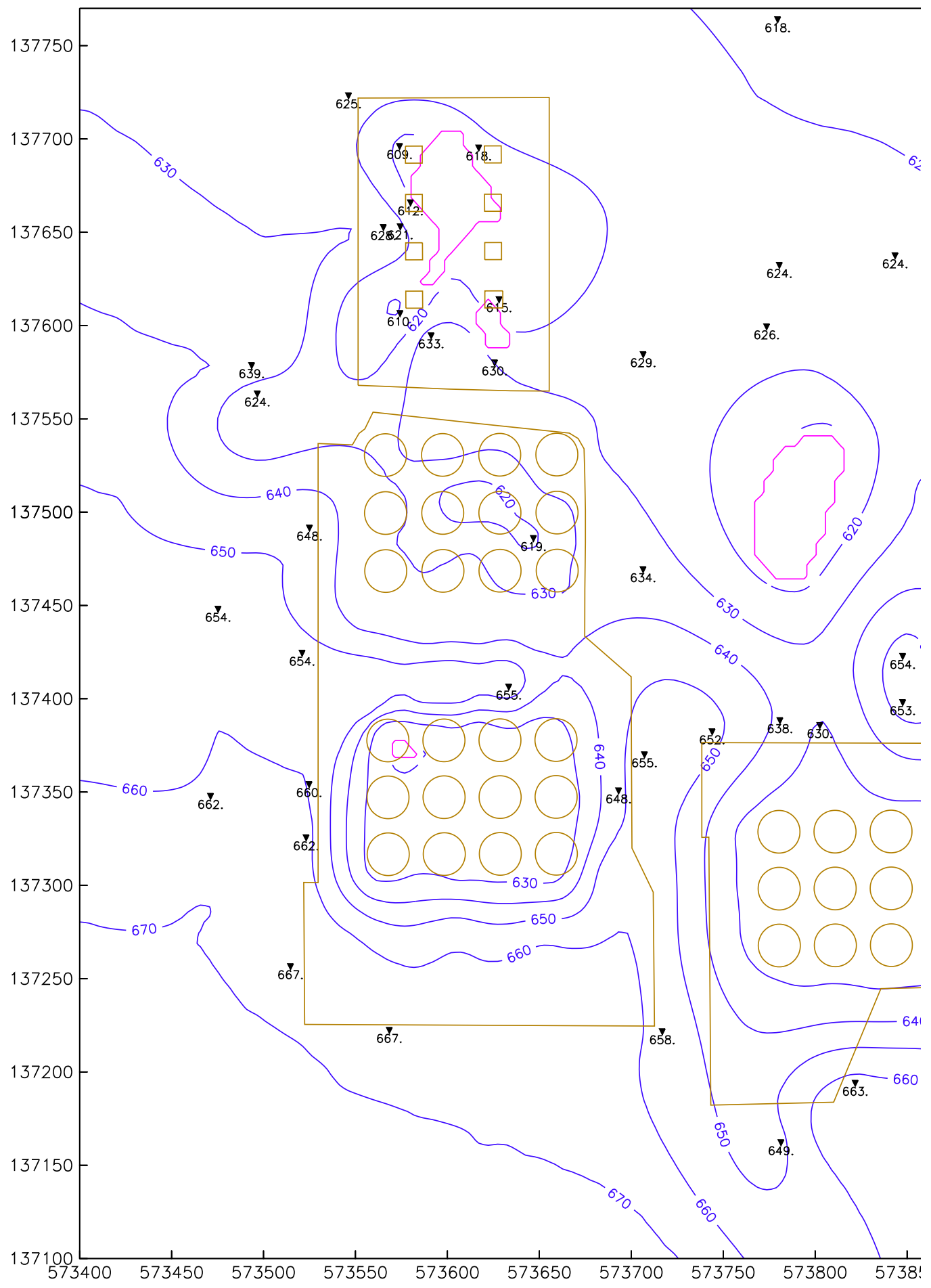

Figure B.6. Contour Map for Top of H1 Unit at B-Complex (Elevation in $\mathrm{ft}$ ) 


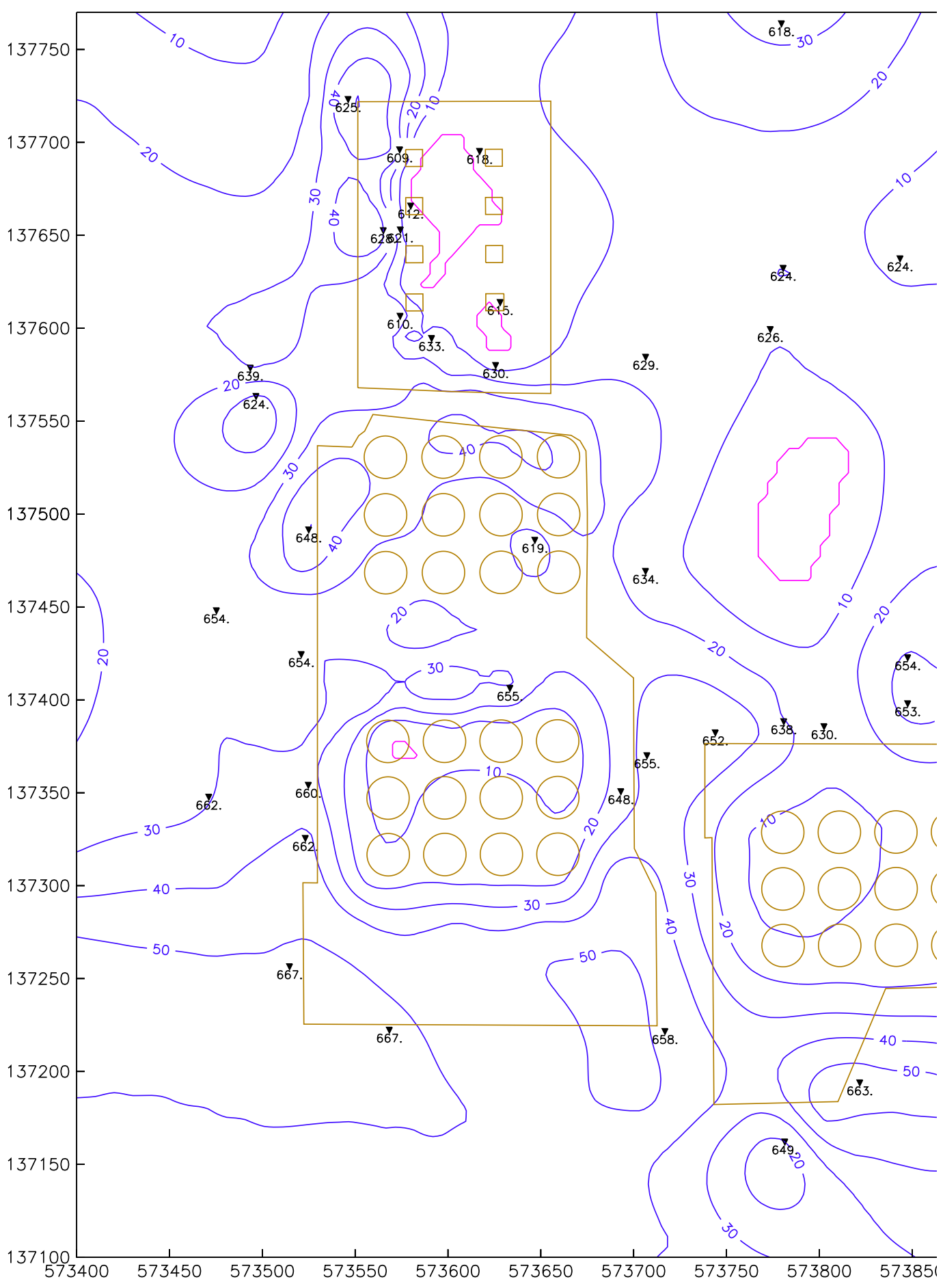

Figure B.7. Thickness Map for H1 Unit at B-Complex (ft) 
PNNL-19277

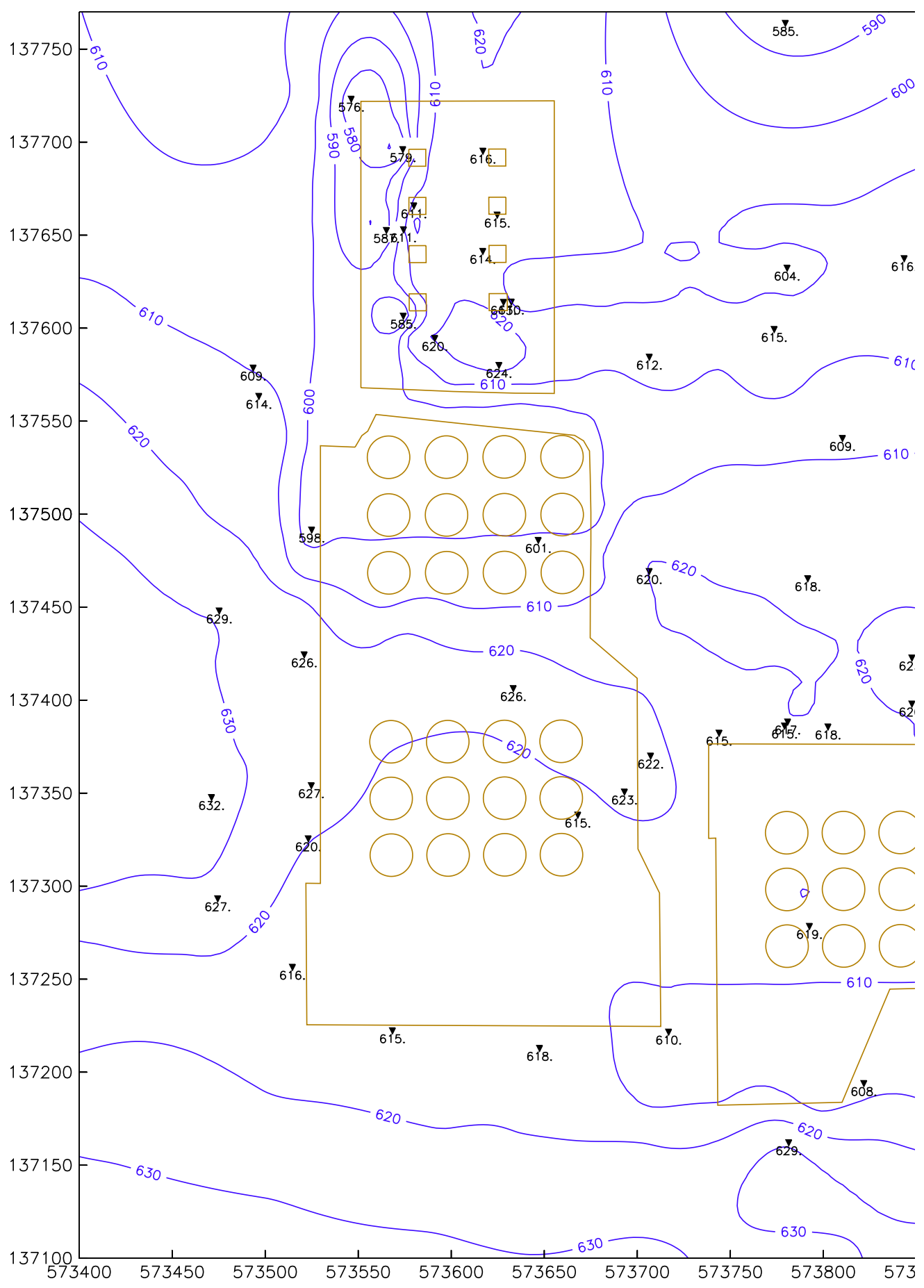

Figure B.8. Contour Map of $\mathrm{H} 2$ Unit at B-Complex (Elevation in $\mathrm{ft}$ ) 
PNNL-19277

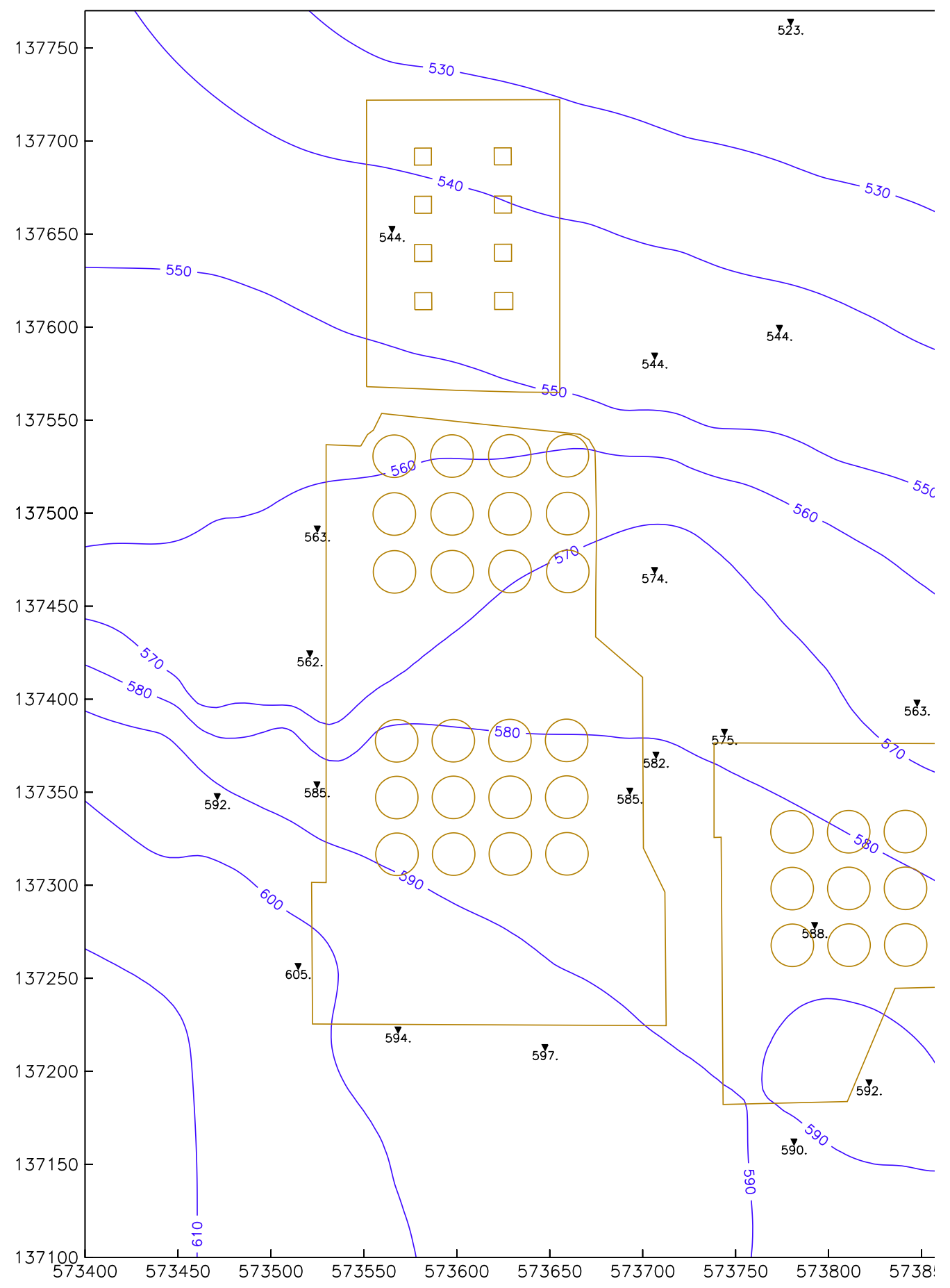

Figure B.9. Contour Map for Top of H2F1 Thin Fine-Grained Lens at B-Complex (Elevation in ft) 
PNNL-19277

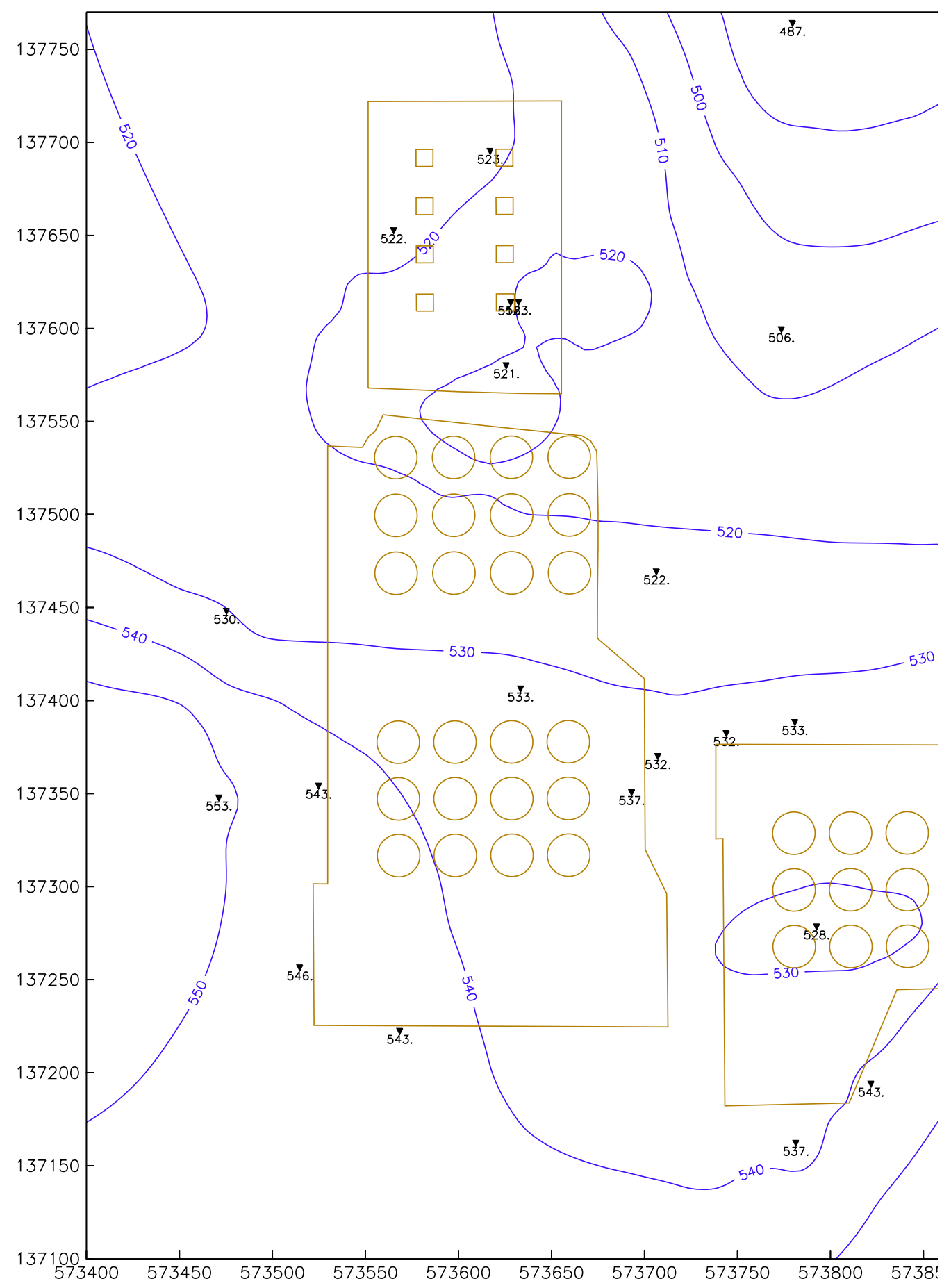

Figure B.10. Contour Map of H2F2 Thin Fine-Grained Lens at B-Complex (Elevation in ft) 
PNNL-19277

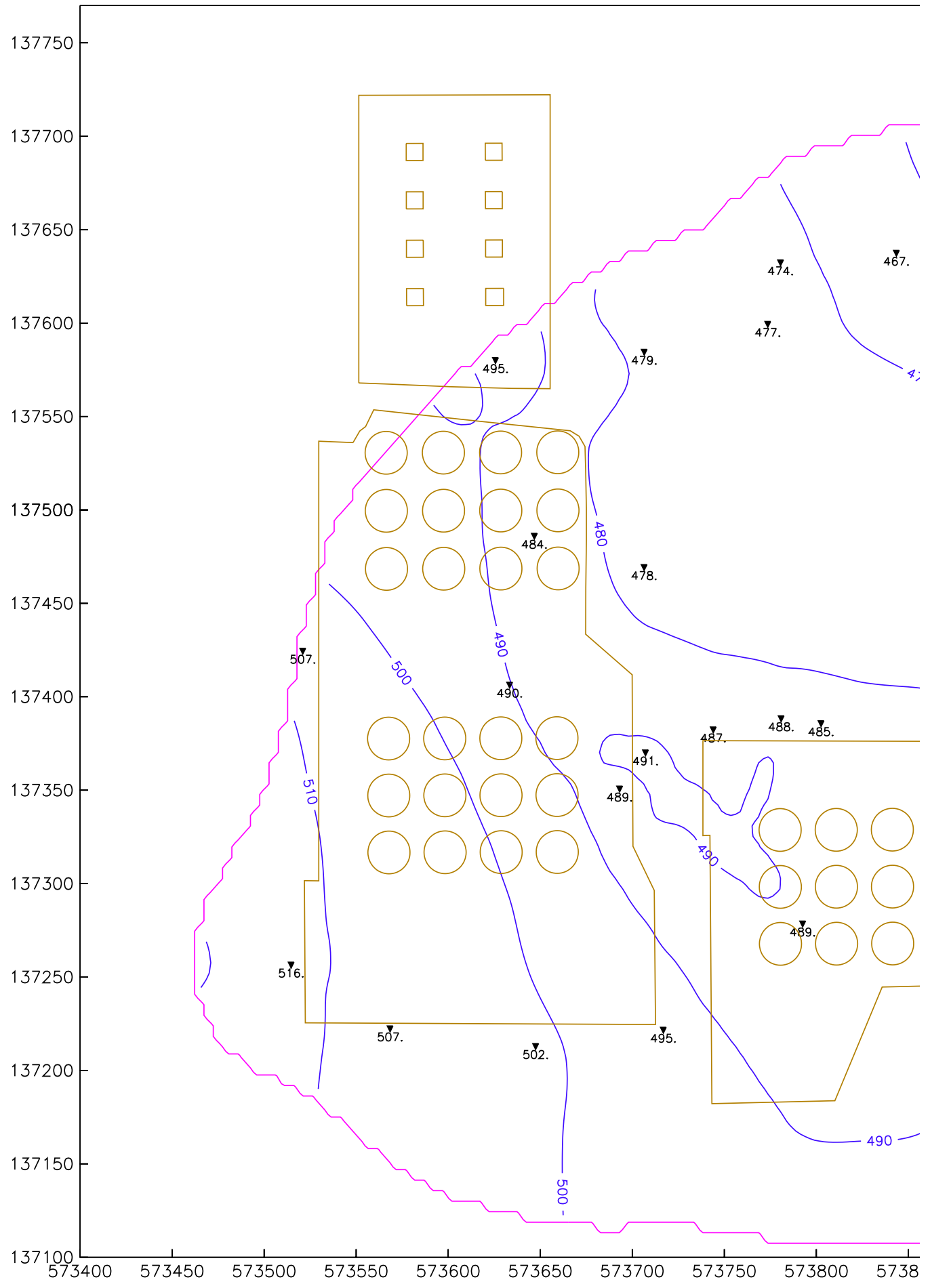

Figure B.11. Contour Map of Top of H2F3 Thin Fine-Grained Lens at B-Complex (ft) 
PNNL-19277

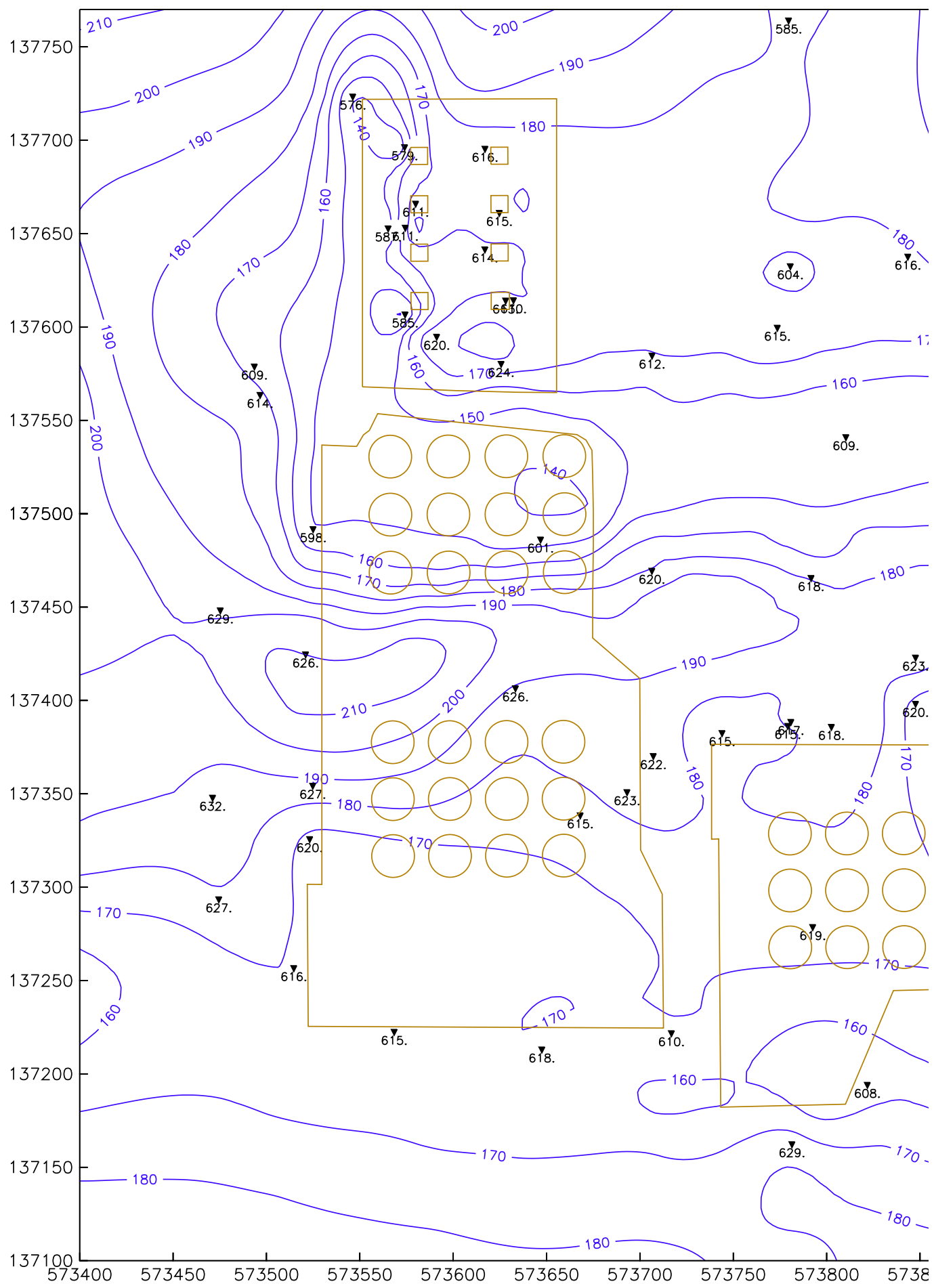

Figure B.12. Thickness Map for H2 Unit at B-Complex (ft) 
PNNL-19277

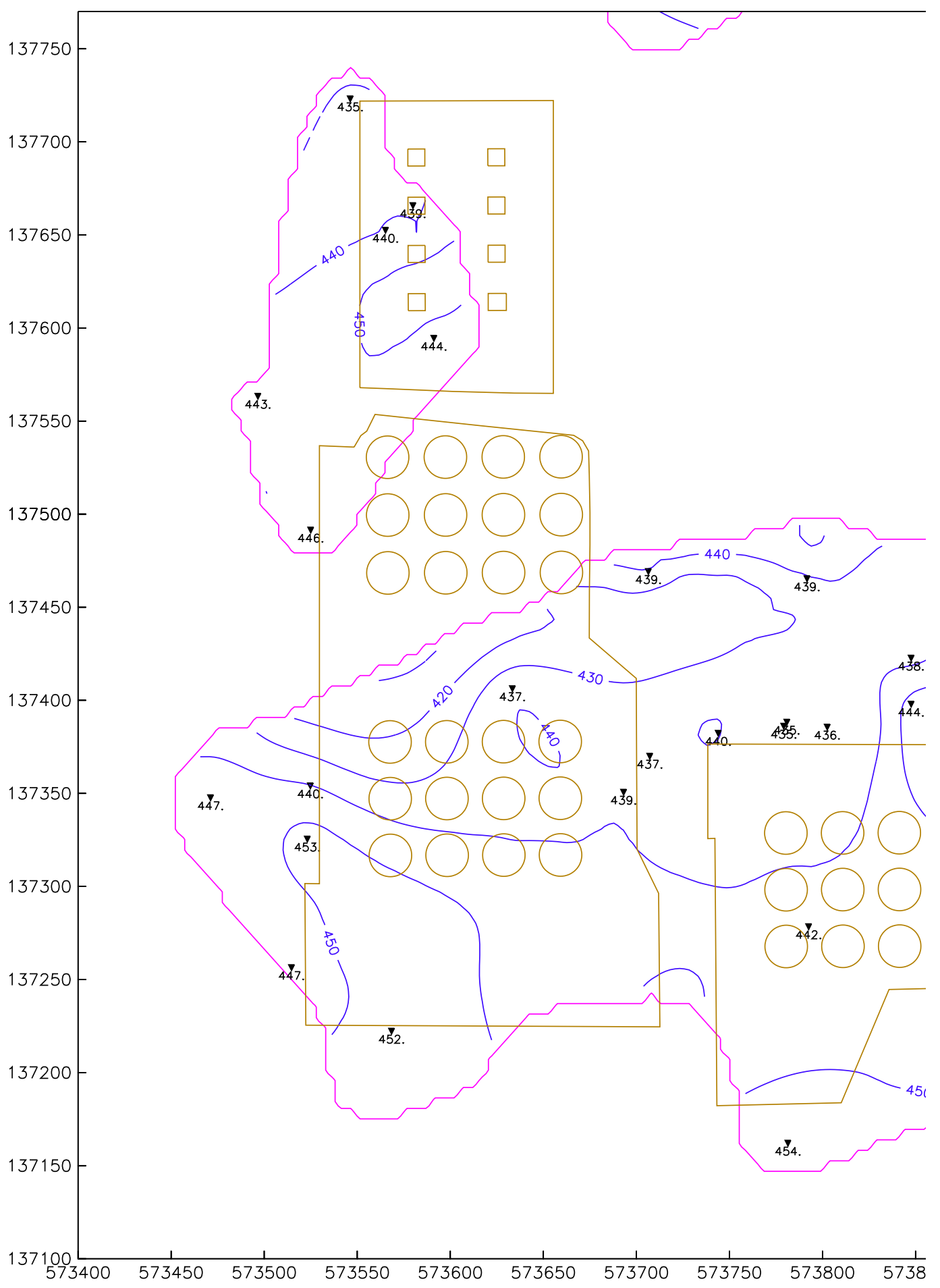

Figure B.13. Contour Map of Top of $\mathrm{CCU}_{\mathrm{z}}$ Unit at B-Complex (Elevation $\mathrm{ft}$ ) 
PNNL-19277

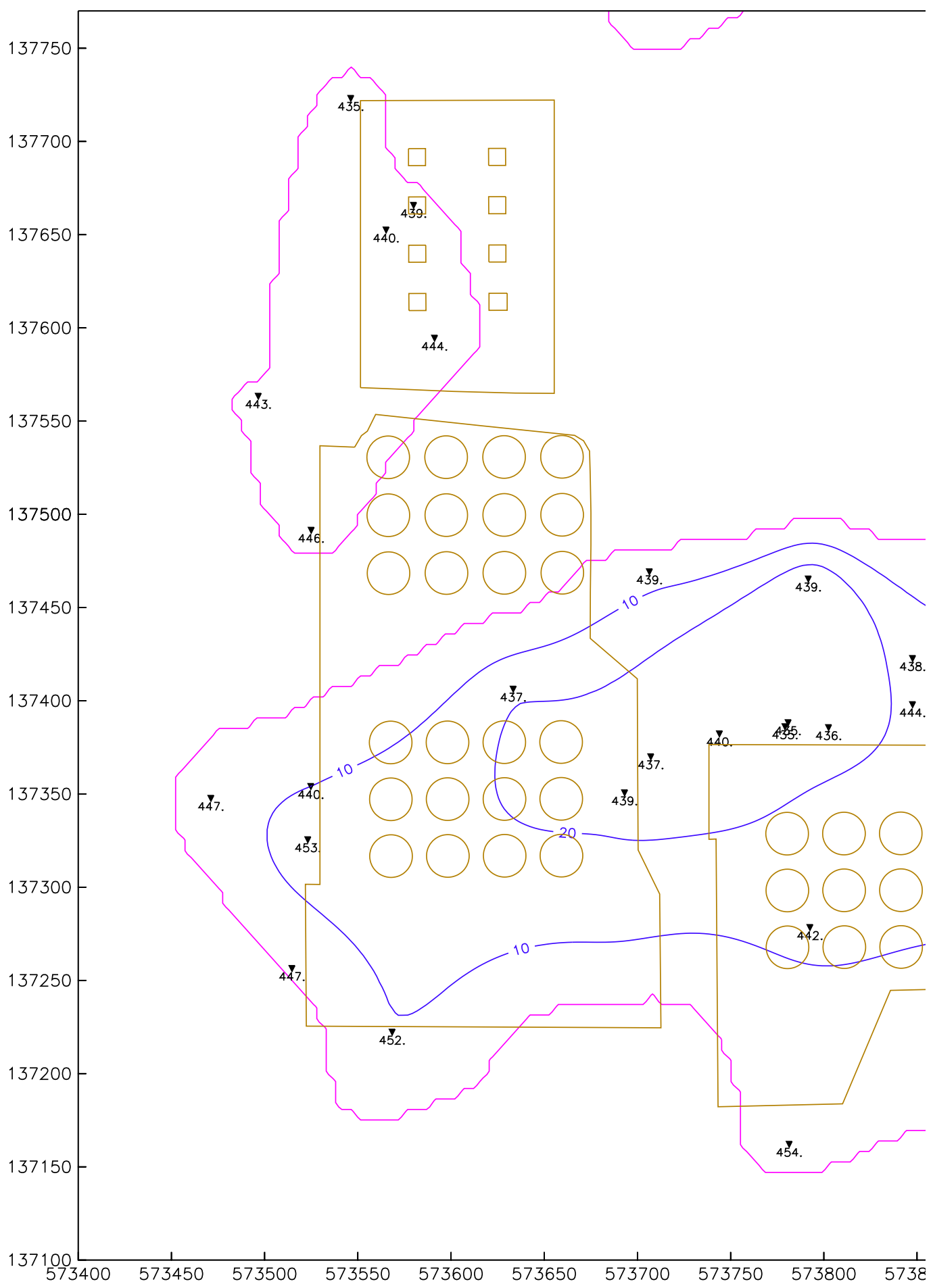

Figure B.14. Thickness Map for $\mathrm{CCU}_{z}$ at B-Complex (ft) 
PNNL-19277

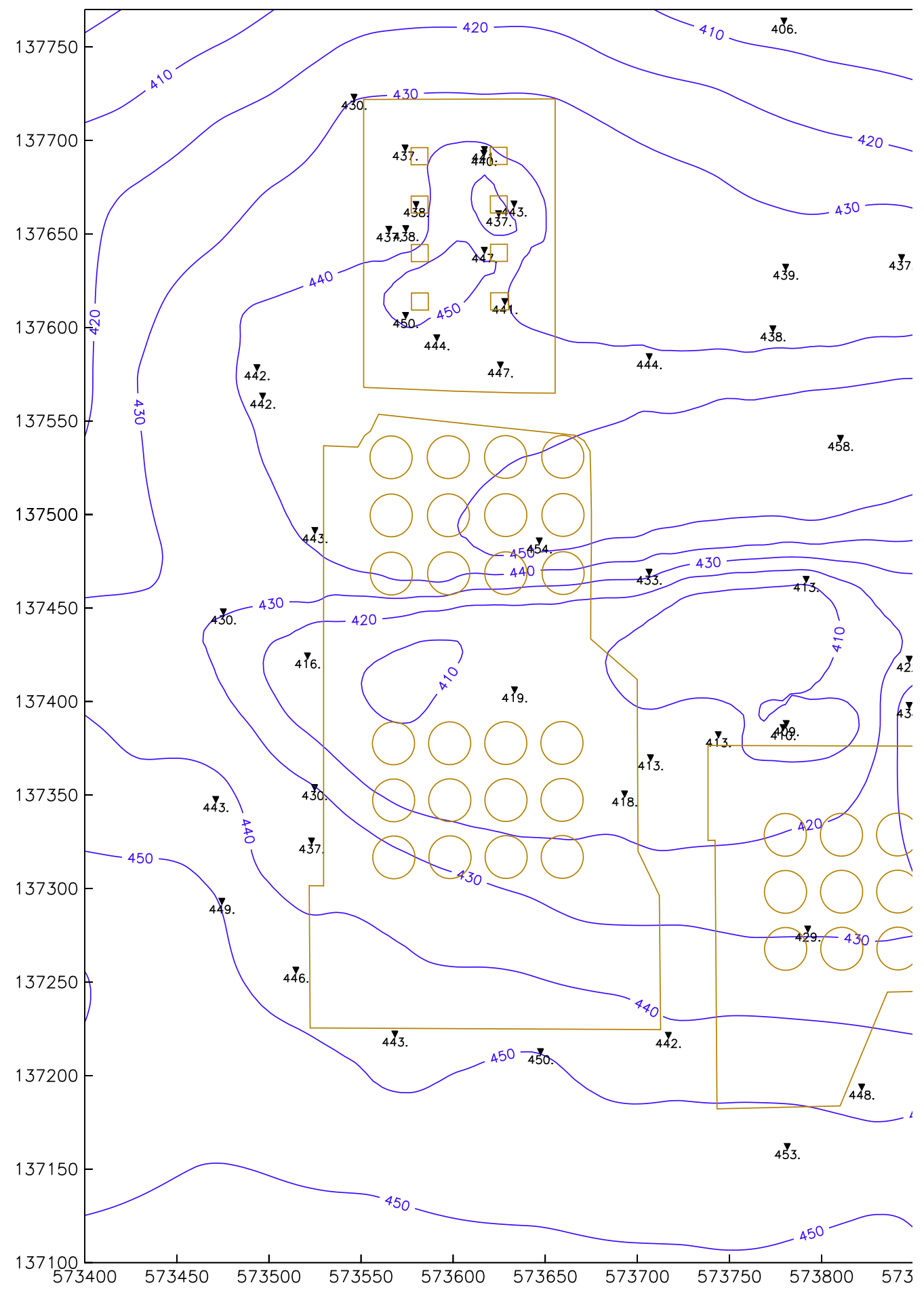

Figure B.15. Contour Map of Map for Top of $\mathrm{CCU}_{\mathrm{g}}$ at B-Complex (Elevation $\mathrm{ft}$ ) 
PNNL-19277

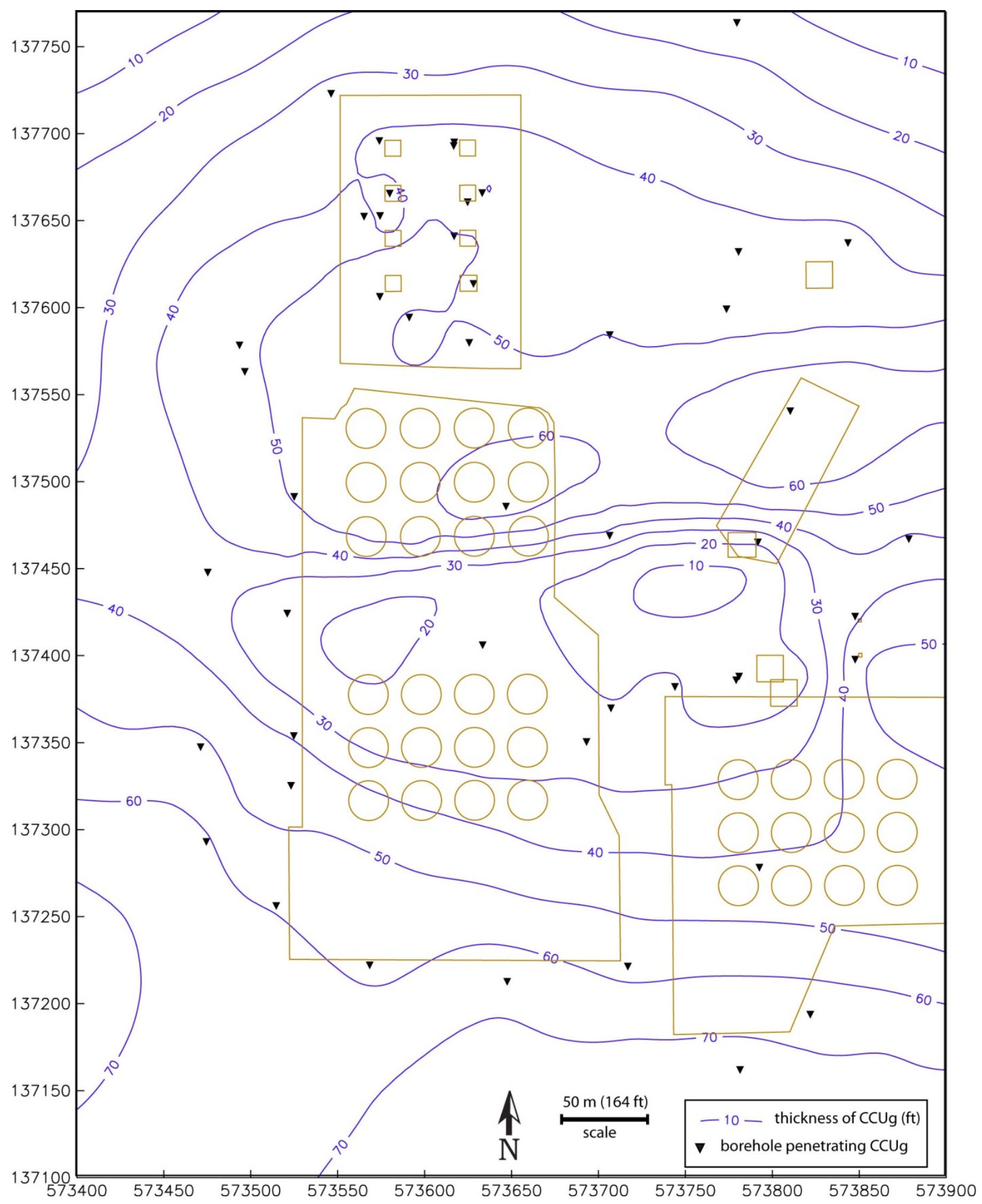

Figure B.16. Thickness Map for $\mathrm{CCU}_{\mathrm{g}}$ at B-Complex (ft) 
PNNL-19277

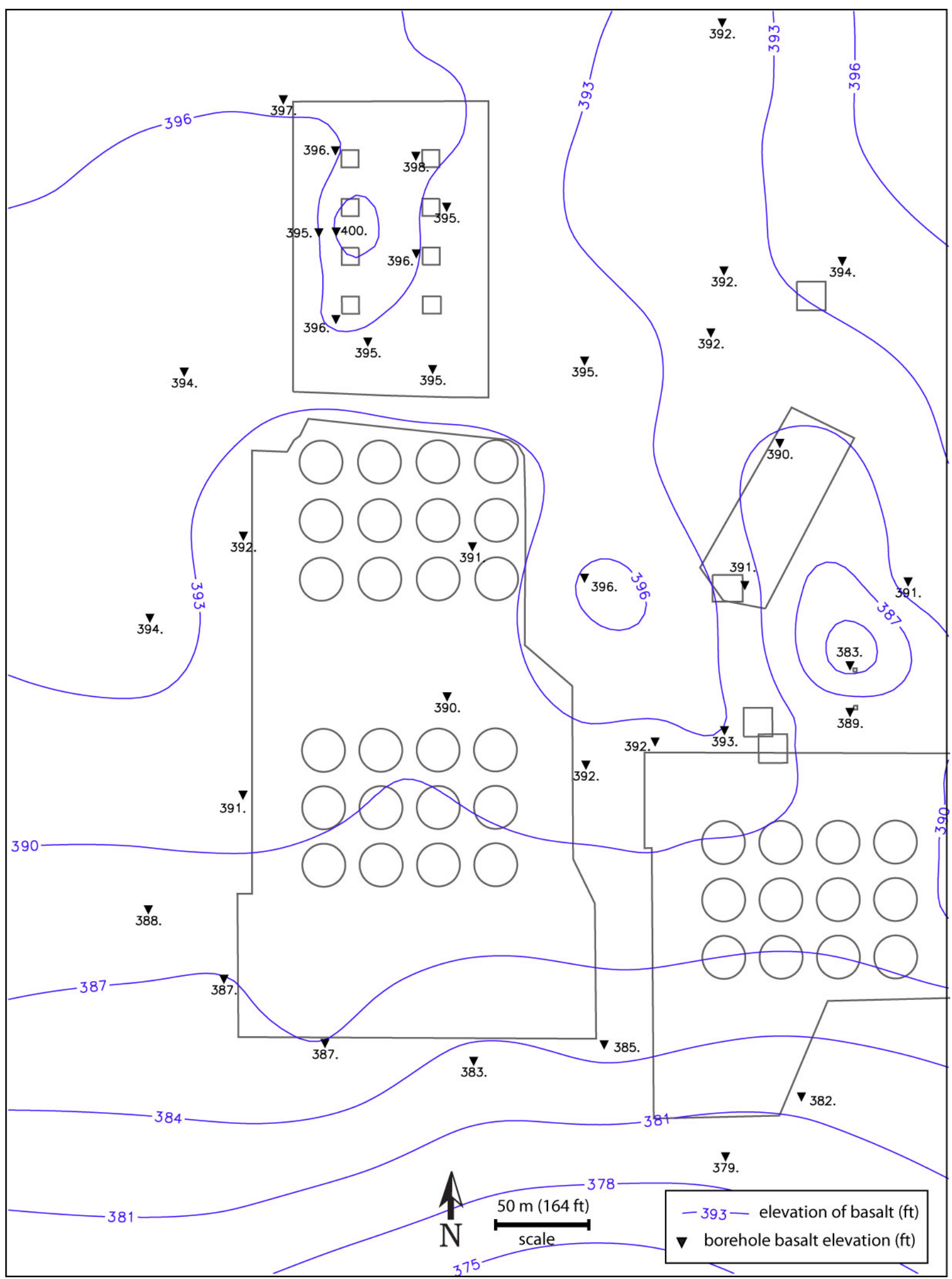

Figure B.17. Contour Map for Top of Basalt at B-Complex (Elevation in $\mathrm{ft}$ ) 


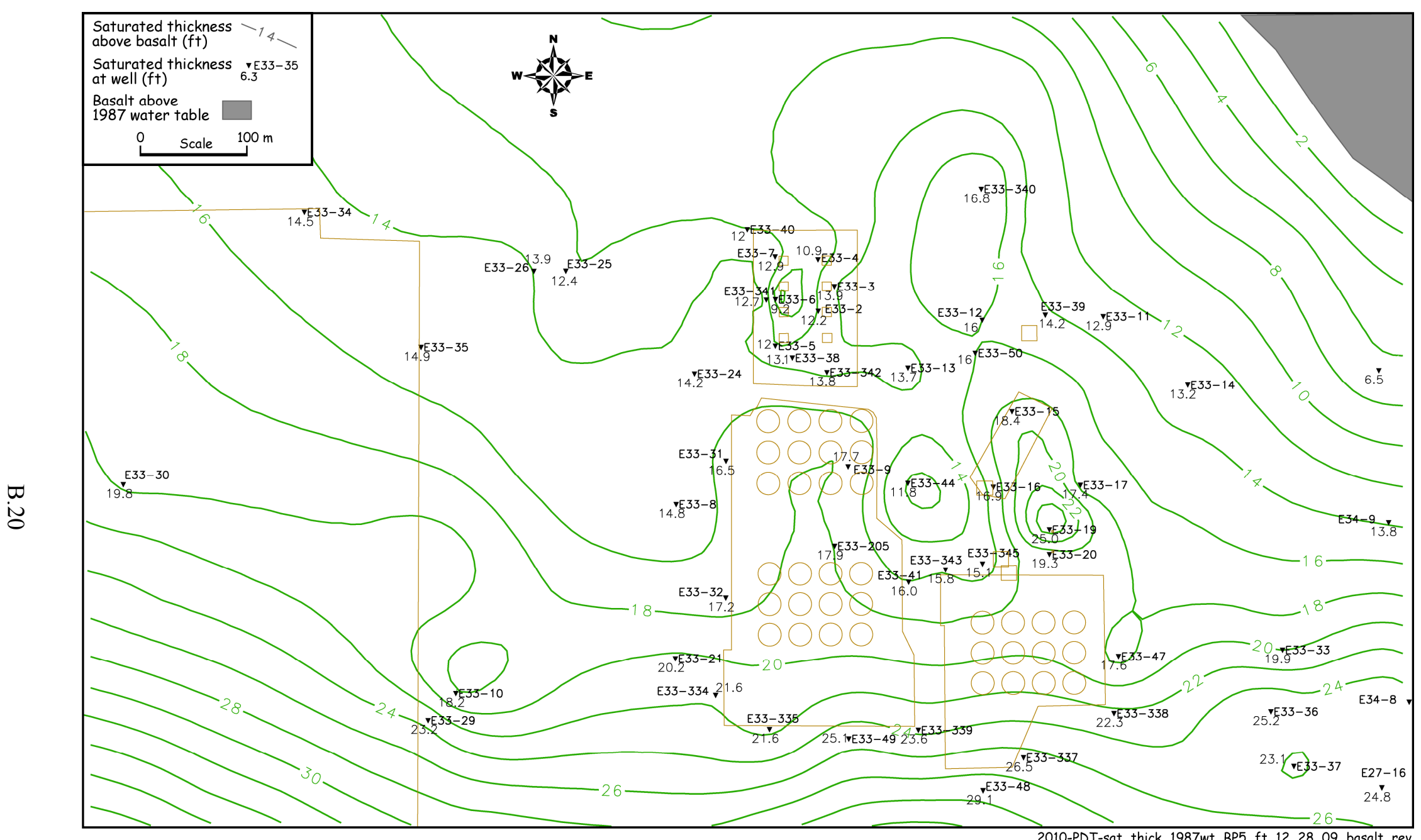

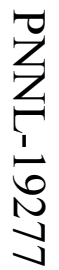

Figure B.18. Thickness Map for Unconfined Aquifer in 1987 (high water table) at B-Complex (ft) 


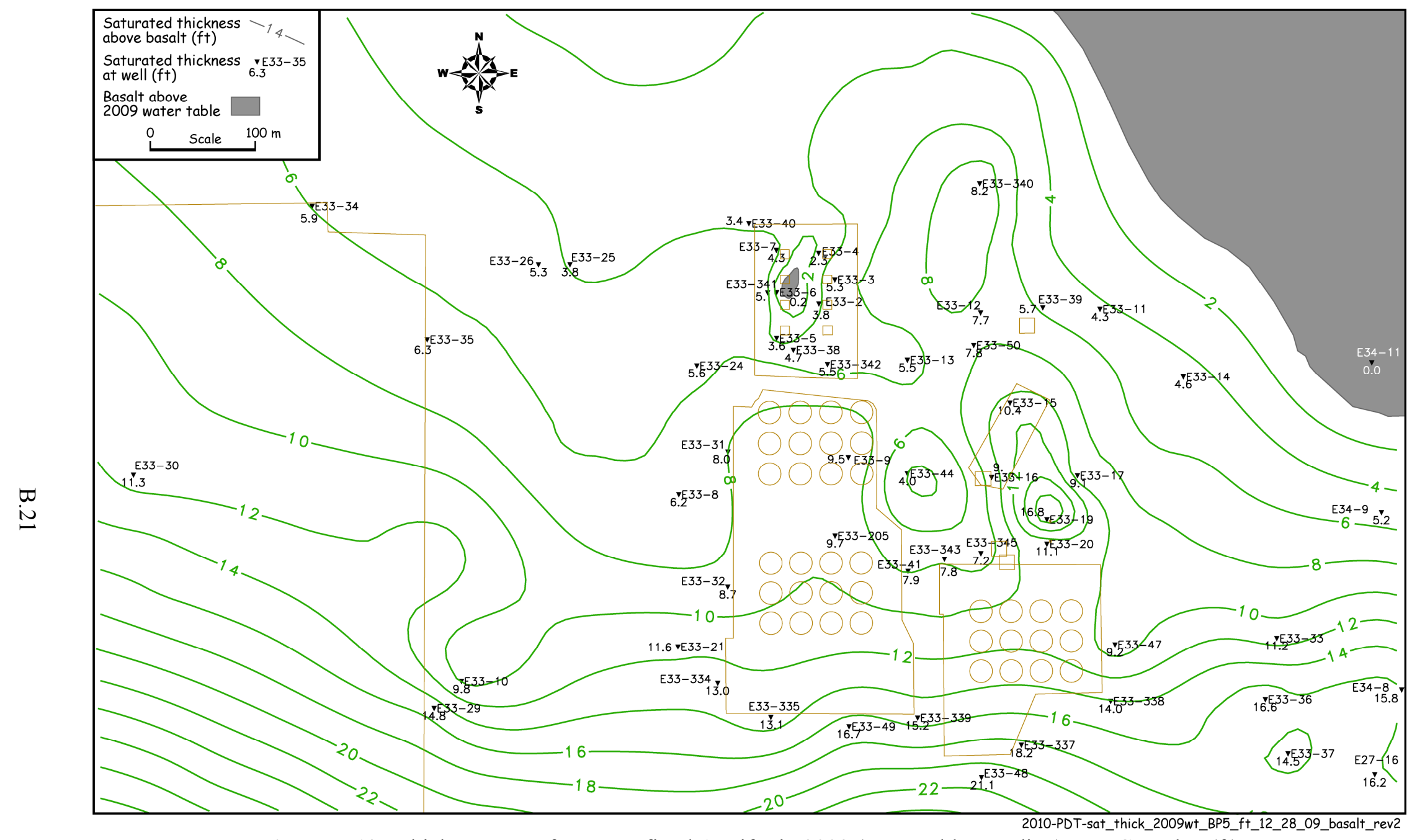

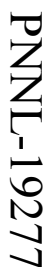

Figure B.19. Thickness Map for Unconfined Aquifer in 2009 (water table receding) at B-Complex (ft) 



\section{Appendix C}

\section{Hydrologic Parameter Details}



PNNL-19277

\section{Appendix C: Hydrologic Parameter Details}

\section{C.1 Introduction}

In support of the remedial investigation/feasibility study (RI/FS) for the 200-BP-5 groundwater Operable Unit (OU), cores were collected from cable-tool drilled boreholes 299-E33-50, 699-48-50B, 699-50-56, 299-E33-343, and 299-E33-345. Several 4-in.-diameter by 6-in.-long liners from the cores that were the most intact were used to measure grain size and hydraulic conductivity to support future numerical simulation assessments. This was based on the total weight of the core liners and visual inspection after carefully removing the top end cap to look for liner "fullness" and obvious signs of particle disturbance. Most of the cores collected below the water table suffered loss of sediment while pulling the sampler back to the surface so that the sediment in the core liners was disturbed, and core recovery was not adequate to attempt measurement of hydraulic conductivity. The gravel nature of the $\mathrm{CCU}_{\mathrm{g}}$ unit in which the water table resides at most boreholes in the B-Complex is very difficult to collect in the undisturbed state. This Appendix presents results of the physical and hydraulic property characterization efforts performed on the 16 intact cores collected. Figure C.1 presents the location of boreholes selected for hydraulic and physical analysis as well as neighboring wells. Tables C.13 and C.14 are details that support choices shown in Section 4 of the main text.

\section{C.2 Methods}

A brief synopsis is given of the methods performed for hydraulic and physical analysis of intact cores and core material from boreholes 299-E33-50, 699-48-50B, 699-50-56, 299-E33-343, and 299-E33-345.

\section{$\underline{\text { Filter Paper }}$}

Field matric potential was measured using the filter paper technique described in Scanlon et al. (2002). Whatman no. 42 filter paper was placed in contact with the core sediment, the core was resealed, and the sample allowed to equilibrate for several days before the water content of the filter paper was measured.

\section{$\underline{\text { Saturated Hydraulic Conductivity }}$}

Saturated hydraulic conductivity $\left(\mathrm{K}_{\mathrm{s}}\right)$ was measured on intact cores using the falling head method or the constant head method, both of which are described in Reynolds et al. (2002). The falling head method was performed on cores with $\mathrm{K}_{\mathrm{s}}$ less than $10^{-4} \mathrm{~cm} / \mathrm{s}$ and the constant head method on cores with $\mathrm{K}_{\mathrm{s}}$ greater than $10^{-4} \mathrm{~cm} / \mathrm{s}$.

\section{Unsaturated Hydraulic Conductivity}

Unsaturated hydraulic conductivity was measured on the intact core using the multistep method described by Hopmans et al. (2002) and Tuli et al. (2001). The multistep method provides matric potential and cumulative outflow data for a series of increasing pressure heads. These data were used in 
conjunction with the single fluid optimization program (SFOPT) (Tuli et al. 2001) to optimize the hydraulic parameters.

\section{$\underline{\text { Water Retention }}$}

Water retention was measured on the $<2 \mathrm{~mm}$ size fraction of the core samples using the pressure plate and dew point potentiometer methods. Measurement of matric potential using the pressure plate method followed the general procedure outlined in Dane and Hopmans (2002) and ASTM (2000). Measurements were made at pressures of $0.5,1,2,4$, and 15 bar. Core material was analyzed in triplicate using a sample ring $(1 \mathrm{~cm}$ in height, $5.1 \mathrm{~cm}$ inside diameter) packed with $25 \mathrm{~g}$ of oven dry soil. Measurement of water potential using the dew point potentiometer followed the procedure outlined in Scanlon et al. (2002). Consecutive measurements of water potential were made at decreasing water contents. In addition, water retention was measured on intact cores using the multistep method described by Hopmans et al. (2002) and Tuli et al. (2001). 


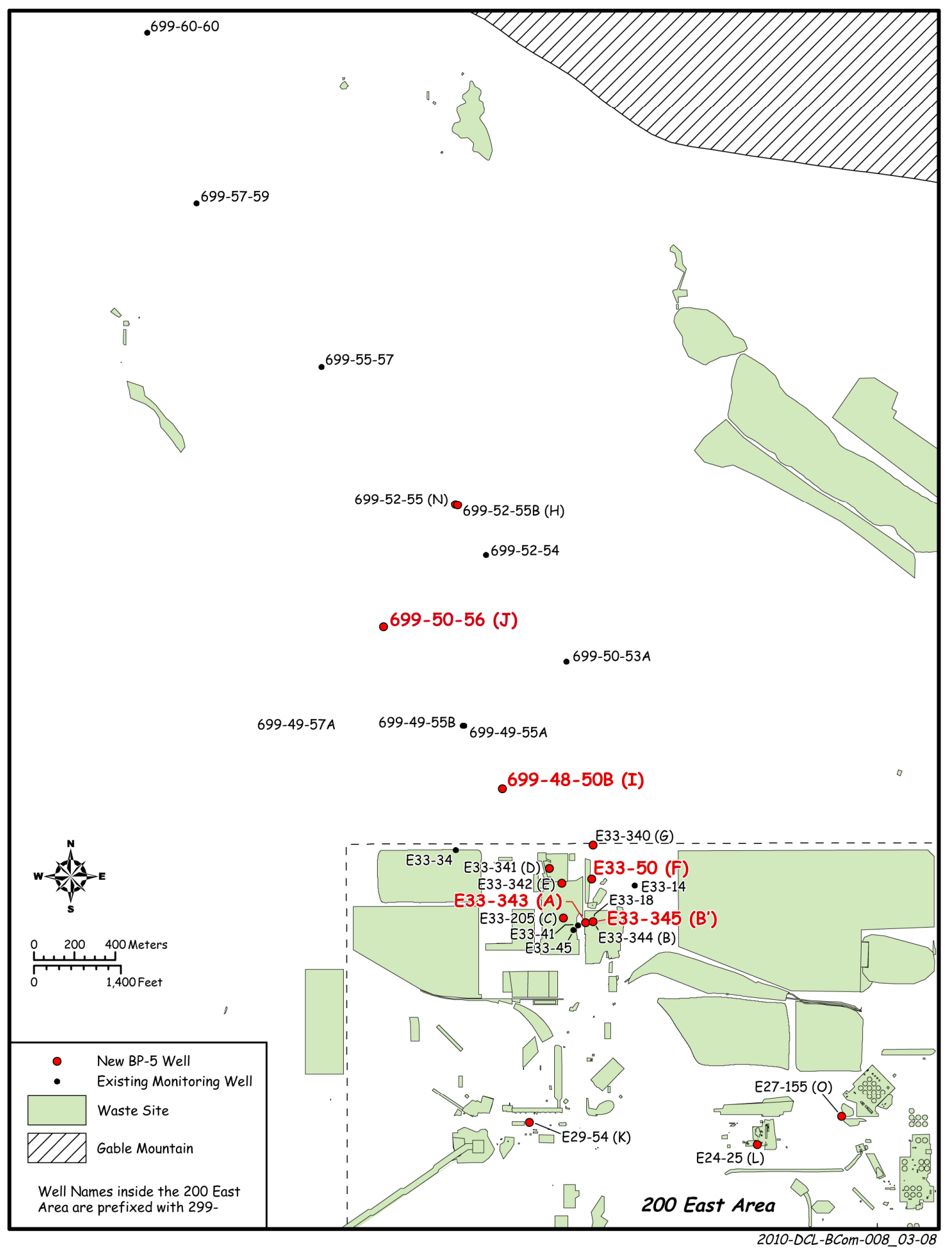

Figure C.1. Location of wells 299-E33-50, 699-48-50B, 699-50-56, 299-E33-343, and 299-E33-345 
PNNL-19277

\section{$\underline{\text { Particle Density }}$}

Particle density was performed on the $<2-\mathrm{mm}$ size fraction of the core material using the pycnometer method described by Flint and Flint (2002). Each core was run in triplicate using a 10-g aliquot of ovendry sediment.

\section{Bulk Density}

Dry bulk density was calculated from intact cores using the volume of the core, calculated from the length and inside diameter of the core liner, and the dry weight of the sediment within the core liner.

\section{$\underline{\text { Particle Size Analysis }}$}

Dry sieving and hydrometer methods were used to determine the particle-size distribution. For dry sieving, oven-dry core material was sieved through a sieve nest of 76.2, 50.8, 38.1, 25.4, 19.1, 12.7, 9.50, $4.75,2,1,0.5,0.25,0.106,0.075$, and $0.053 \mathrm{~mm}$ or $63.0,31.5,16.0,8.0,4.0,0.053,2,1,0.5,0.25,0.125$, and $0.053 \mathrm{~mm}$ using an auto shaker. Samples were shaken for approximately 1 hour. Hydrometer analysis followed the method described in Gee and Or (2002). Hydrometer analysis utilized approximately 50 -g aliquots of oven-dry core material with gravel $(>2 \mathrm{~mm})$ removed.

\section{Water Content}

Moisture content was measured gravimetrically using the convective oven-drying method of Topp and Ferré (2002). The starting weight of the core liner was recorded, and after performing the saturated hydraulic conductivity, the liner and all end caps and tape were weighed such that a field moist weight of the sediment itself could be calculated. The sediment was then placed in tared containers, weighed, and dried in an oven at $105^{\circ} \mathrm{C}$ until constant weight was achieved. At least two weightings, each after a 24-hour heating, were performed to make certain that all moisture was removed. The gravimetric water content was computed as percentage change in soil weight at field conditions (i.e., before hydraulic conductivity analysis performed seeing as the laboratory hydraulic conductivity tests necessitated saturating the cores) and after oven drying. The volumetric water content was computed by multiplying the gravimetric moisture content by the core bulk density.

Due to the number of different analysis performed on the core material and the need to keep the core intact for a portion of the analyses, the various analyses were performed in the following order:

1. Filter paper analysis.

2. Saturated hydraulic conductivity and unsaturated hydraulic conductivity (multistep analysis).

3. Field moisture content.

4. Dry bulk density.

5. Particle-size distribution, particle density, pressure plate, and dew point potentiometer. 


\section{C.3 Results}

This section reports the results of physical and hydraulic property characterization efforts performed on 16 intact cores collected from cable-tool drilled boreholes 299-E33-50, 299-E33-343, 299-E33-345, 699-48-50B, and 699-50-56 within the BP-5 Operable Unit. Physical property measurements included particle-size distribution, particle density, and bulk density. Hydraulic characterization included saturated hydraulic conductivity $\left(\mathrm{K}_{\mathrm{s}}\right)$ and water content. In addition, a subset of cores was analyzed for unsaturated hydraulic properties (e.g., water retention and unsaturated hydraulic conductivity). This additional hydraulic property analysis was restricted to cores collected from within the vadose (unsaturated) zone or near the water table where a decrease in water table elevation would result in de-saturation of the sediment. Physical and hydraulic analyses performed on each core sample are identified in Table C.1. The analyses listed in Table C.1 followed the methods described in Section C.2.0. Descriptive particlesize distribution information for the core samples is presented in Table C.3. Sieve and hydrometer analysis results are given in Tables C.4 through C.6.

Core selection was guided by geologist's logs and moisture content results from nearby grab samples. The aim was to choose cores that 1) have complete or near complete sample recovery, 2) do not contain slough material, and 3) represent hydraulically controlling layers. The cores were collected in Lexan liners with the exception of three cores from borehole 299-E33-50, which were collected in stainless steel liners. Sample IDs, collection depth interval, and sample volume are presented in Table C.2. Samples B1L9X3-2, B1L373-2, B1L7X9-1, B1TIJ5-1, B1T1J8-1, B1RLK4-3, and B1RLY0-4 were located in the unconfined aquifer. Samples B1LBC9-3, B1LBD0-1, and B1LBD1-3 were located in the confined aquifer underlying the Columbia River Basalt Group. The remaining samples were collected from unsaturated sediment above the unconfined aquifer.

For borehole 299-E33-50, the gravel content (material $>2 \mathrm{~mm}$ ) ranged from a high of 80.2 percent to zero percent. The United States Department of Agriculture (USDA) texture designation (Table C.3) for those samples within the Hanford formation, $\mathrm{H} 2$ stratigraphic unit is a loamy sand and sand. For the Hanford formation cores, the gravel content does not exceed 7 percent. Based on geologic log information, particle-size data, and hydraulic characteristics, samples B1L9T7-2 and B1L9V5-3 are believed to represent fine-textured lenses within the $\mathrm{H} 2$ unit; the latter core is from the areally extensive H2F1 lens. The core B1L9X3-2 from the borehole collected at $226 \mathrm{ft}$ bgs was from the underlying CCU gravel dominated sequence is classified as an extremely gravelly loamy sand, having a gravel content of 80.2 percent (see Table C.2). The three deepest cores, B1LBC9-3, B1LBD0-1 and B1LBD1-3 are from the Rattlesnake Ridge Interbed stratigraphic unit are classified as a sand or sandy loam soil with very little to no gravel.

Core samples from borehole 699-48-50B were all obtained from the stratigraphic unit classified as Ringold formation, yet all three samples were quite variable ranging from a very gravelly sand with a gravel content of 54.2 percent to a fine textured silt loam soil. Core samples analyzed from 699-50-56, 299-E33-343, and 299-E33-345 were all collected from the CCU gravel dominated sequence $\left(\mathrm{CCU}_{\mathrm{g}}\right)$. These samples are extremely coarse, having gravel contents ranging from 43.4 to 79.3 percent. Particlesize distribution curves for all samples are presented in Figures C.2 through C.6. The curves show the degree of variability between samples and the heterogeneous nature of the subsurface. 
Table C.1. Analysis associated with cores collected from boreholes 299-E33-50, 699-48-50B, 699-50-56, 299-E33-343, and 299-E33-345.

\begin{tabular}{|c|c|c|}
\hline Borehole & Sample ID & Measurements Performed \\
\hline \multirow{8}{*}{ 299-E33-50 } & B1L9T7-2 & $\begin{array}{l}\text { Saturated hydraulic conductivity, unsaturated hydraulic conductivity, water retention, } \\
\text { particle density, bulk density, particle size distribution, water content }\end{array}$ \\
\hline & B1L9V5-3 & $\begin{array}{l}\text { Saturated hydraulic conductivity, unsaturated hydraulic conductivity, water retention, } \\
\text { particle density, bulk density, particle size distribution, water content }\end{array}$ \\
\hline & B1L9W0-3 & $\begin{array}{l}\text { Saturated hydraulic conductivity, unsaturated hydraulic conductivity, water retention, } \\
\text { particle density, bulk density, particle size distribution, water content }\end{array}$ \\
\hline & B1L9W2-2 & $\begin{array}{l}\text { Saturated hydraulic conductivity, unsaturated hydraulic conductivity, water retention, } \\
\text { particle density, bulk density, particle size distribution, water content }\end{array}$ \\
\hline & B1L9X3-2 & $\begin{array}{l}\text { Saturated hydraulic conductivity, unsaturated hydraulic conductivity, water retention, } \\
\text { particle density, bulk density, particle size distribution, water content }\end{array}$ \\
\hline & B1LBC9-3 & $\begin{array}{l}\text { Saturated hydraulic conductivity, particle density, bulk density, particle size } \\
\text { distribution, water content }\end{array}$ \\
\hline & B1LBD0-1 & $\begin{array}{l}\text { Saturated hydraulic conductivity, particle density, bulk density, particle size } \\
\text { distribution, water content }\end{array}$ \\
\hline & B1LBD1-3 & $\begin{array}{l}\text { Saturated hydraulic conductivity, particle density, bulk density, particle size } \\
\text { distribution, water content }\end{array}$ \\
\hline \multirow{3}{*}{$699-48-50 \mathrm{~B}$} & B1L1T0-2 & $\begin{array}{l}\text { Saturated hydraulic conductivity, unsaturated hydraulic conductivity, water retention, } \\
\text { particle density, bulk density, particle size distribution, water content }\end{array}$ \\
\hline & B1L1T1-2 & $\begin{array}{l}\text { Saturated hydraulic conductivity, unsaturated hydraulic conductivity, water retention, } \\
\text { particle density, bulk density, particle size distribution, water content }\end{array}$ \\
\hline & B1L373-2 & $\begin{array}{l}\text { Saturated hydraulic conductivity, particle density, bulk density, particle size } \\
\text { distribution, water content }\end{array}$ \\
\hline $699-50-56$ & B1L7X9-1 & Particle density, particle size distribution, water content \\
\hline \multirow{2}{*}{ 299-E33-343 } & B1T1J5-1 & Saturated hydraulic conductivity, particle size distribution \\
\hline & B1T1J8-1 & Saturated hydraulic conductivity, particle size distribution \\
\hline \multirow{2}{*}{ 299-E33-345 } & B1RLK4-3 & Saturated hydraulic conductivity, particle size distribution \\
\hline & B1RLY0-4 & Saturated hydraulic conductivity, particle size distribution \\
\hline
\end{tabular}


PNNL-19277

Table C.2. Sample depth interval, liner material, and core dimensions for boreholes 299-E33-50, 699-4850B, 699-50-56, 299-E33-343, and 299-E33-345

\begin{tabular}{|c|c|c|c|c|c|c|c|}
\hline \multirow[b]{2}{*}{ Borehole } & \multirow[b]{2}{*}{ Sample ID } & \multicolumn{2}{|c|}{ Sample Depth Interval } & \multirow[b]{2}{*}{ Liner Material } & \multicolumn{2}{|c|}{ Core Dimensions } & \multirow[b]{2}{*}{$\begin{array}{c}\text { Core } \\
\text { Volume } \\
\left(\mathrm{cm}^{3}\right)\end{array}$} \\
\hline & & $\mathrm{m}$ bgs & $\mathrm{ft}$ bgs & & $\begin{array}{l}\text { Height } \\
(\mathrm{cm})\end{array}$ & $\begin{array}{l}\text { Inside } \\
\text { Diameter } \\
(\mathrm{cm})\end{array}$ & \\
\hline \multirow{8}{*}{ 299-E33-50 } & B1L9T7-2 & $19.21-19.36$ & $63.0-63.5$ & Lexan & 15.2 & 9.5 & 1077.4 \\
\hline & B1L9V5-3 & $25.30-25.46$ & $83.0-83.5$ & Lexan & 15.2 & 9.5 & 1077.4 \\
\hline & B1L9W0-3 & $35.21-35.37$ & $115.5-116.0$ & Lexan & 15.2 & 9.5 & 1077.4 \\
\hline & B1L9W2-2 & $49.09-49.24$ & $161.0-161.5$ & Lexan & 15.2 & 9.5 & 1077.4 \\
\hline & B1L9X3-2 & $68.90-69.05$ & $226.0-226.5$ & Lexan & 15.2 & 9.5 & 1077.4 \\
\hline & B1LBC9-3 & $97.10-97.26$ & $318.5-319.0$ & Stainless Steel & 15.2 & 9.9 & 1170.0 \\
\hline & B1LBD0-1 & $104.42-104.57$ & $342.5-343.0$ & Stainless Steel & 15.2 & 9.9 & 1170.0 \\
\hline & B1LBD1-3 & $110.64-110.79$ & $362.9-363.4$ & Stainless Steel & 15.2 & 9.9 & 1170.0 \\
\hline \multirow{3}{*}{ 699-48-50B } & B1L1T0-2 & $59.30-59.45$ & $194.5-195.0$ & Lexan & 15.2 & 9.5 & 1077.4 \\
\hline & B1L1T1-2 & $60.82-60.98$ & $199.5-200.0$ & Lexan & 15.2 & 9.5 & 1077.4 \\
\hline & B1L373-2 & $63.41-63.57$ & $208.0-208.5$ & Lexan & 15.2 & 9.5 & 1077.4 \\
\hline $699-50-56$ & B1L7X9-1 & $48.02-48.17$ & $157.5-158.0$ & Lexan & 15.2 & 9.5 & 1077.4 \\
\hline \multirow{2}{*}{ 299-E33-343 } & B1T1J5-1 & $76.29-76.44$ & $250.3-250.8$ & Lexan & 15.2 & 9.5 & 1077.4 \\
\hline & B1T1J8-1 & $77.57-77.72$ & $254.5-255.0$ & Lexan & 15.2 & 9.5 & 1077.4 \\
\hline \multirow{2}{*}{ 299-E33-345 } & B1RLK4-3 & $77.27-77.42$ & $253.5-254.0$ & Lexan & 15.2 & 9.5 & 1077.4 \\
\hline & B1RLY0-4 & $77.88-78.03$ & $255.5-256.0$ & Lexan & 15.2 & 9.5 & 1077.4 \\
\hline
\end{tabular}


Table C.3. Particle-Size Distribution Information and USDA Texture and Stratigraphic Unit Designations

\begin{tabular}{|c|c|c|c|c|c|c|c|c|c|}
\hline \multirow[b]{2}{*}{ Borehole } & \multirow[b]{2}{*}{ Sample ID } & \multicolumn{2}{|c|}{ Sample Depth Interval } & \multirow{2}{*}{$\begin{array}{c}\text { Gravel } \\
\text { Content (\%) } \\
>2.0 \mathrm{~mm}\end{array}$} & \multirow{2}{*}{$\begin{array}{c}\begin{array}{c}\text { Sand Content } \\
(\%)\end{array} \\
2.0 \mathrm{~mm}- \\
0.05 \mathrm{~mm}\end{array}$} & \multirow{2}{*}{$\begin{array}{c}\text { Silt Content } \\
(\%)\end{array}$} & \multirow{2}{*}{ 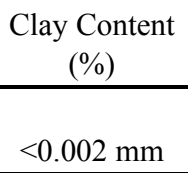 } & \multirow[b]{2}{*}{ USDA Texture } & \multirow[b]{2}{*}{ Stratigraphic Unit } \\
\hline & & $\mathrm{m}$ bgs & $\mathrm{ft}$ bgs & & & & & & \\
\hline \multirow[t]{8}{*}{ 299-E33-50 } & B1L9T7-2 & $19.21-19.36$ & $63.0-63.5$ & 2.3 & 75.3 & 18.7 & 3.7 & loamy sand & $\mathrm{H} 2 / \mathrm{H} 2 \mathrm{~F}$ \\
\hline & B1L9V5-3 & $25.30-25.46$ & $83.0-83.5$ & 0.3 & 81.8 & 15.6 & 2.4 & loamy sand & $\mathrm{H} 2$ / H2F1 \\
\hline & B1L9W0-3 & $35.21-35.37$ & $115.5-116.0$ & 7.0 & 78.3 & 13.3 & 1.4 & loamy sand & $\mathrm{H} 2$ \\
\hline & B1L9W2-2 & $49.09-49.24$ & $161.0-161.5$ & 0.2 & 88.5 & 9.2 & 2.0 & sand & $\mathrm{H} 2$ \\
\hline & B1L9X3-2 & $68.90-69.05$ & $226.0-226.5$ & 80.2 & 16.9 & 2.5 & 0.4 & $\begin{array}{l}\text { extremely gravelly } \\
\text { loamy sand }\end{array}$ & $\mathrm{CCUg}$ \\
\hline & B1LBC9-3 & $97.10-97.26$ & $318.5-319.0$ & 0.0 & 70.6 & 23.3 & 6.0 & sandy loam & Rattlesnake Ridge Interbed \\
\hline & B1LBD0-1 & $104.42-104.57$ & $342.5-343.0$ & 0.6 & 87.4 & 10.1 & 1.9 & sand & Rattlesnake Ridge Interbed \\
\hline & B1LBD1-3 & $110.64-110.79$ & $362.9-363.4$ & 0.0 & 67.2 & 23.7 & 9.1 & sandy loam & Rattlesnake Ridge Interbed \\
\hline \multicolumn{10}{|c|}{ bgs - below ground surface } \\
\hline \multicolumn{10}{|c|}{ USDA - United States Department of Agriculture } \\
\hline \multicolumn{10}{|c|}{$\mathrm{H} 2$ - Hanford formation sand dominated sequence } \\
\hline \multicolumn{10}{|c|}{$\begin{array}{l}\mathrm{H} 2 \mathrm{~F} \text { - Fine grained lens within } \mathrm{H} 2 \text { unit } \\
\mathrm{CCUg} \text { - CCU gravel dominated sequence }\end{array}$} \\
\hline
\end{tabular}


Table C.3 (contd)

\begin{tabular}{|c|c|c|c|c|c|c|c|c|c|}
\hline \multirow[b]{2}{*}{ Borehole } & \multirow[b]{2}{*}{ Sample ID } & \multicolumn{2}{|c|}{ Sample Depth Interval } & \multirow{2}{*}{$\begin{array}{c}\begin{array}{c}\text { Gravel Content } \\
(\%)\end{array} \\
>2.0 \mathrm{~mm}\end{array}$} & \multirow{2}{*}{$\begin{array}{c}\begin{array}{c}\text { Sand Content } \\
(\%)\end{array} \\
2.0 \mathrm{~mm}- \\
0.05 \mathrm{~mm}\end{array}$} & \multirow{2}{*}{$\begin{array}{c}\begin{array}{c}\text { Silt Content } \\
(\%)\end{array} \\
0.05 \mathrm{~mm}- \\
0.002 \mathrm{~mm}\end{array}$} & \multirow{2}{*}{$\begin{array}{c}\begin{array}{c}\text { Clay Content } \\
(\%)\end{array} \\
<0.002 \mathrm{~mm}\end{array}$} & \multirow[b]{2}{*}{ USDA Texture } & \multirow[b]{2}{*}{ Stratigraphic Unit } \\
\hline & & $\mathrm{m}$ bgs & $\mathrm{ft}$ bgs & & & & & & \\
\hline \multirow{3}{*}{$699-48-50 \mathrm{~B}$} & B1L1T0-2 & $59.30-59.45$ & $194.5-195.0$ & 0.0 & 91.5 & 6.5 & 2.0 & sand & Ringold formation \\
\hline & B1L1T1-2 & $60.82-60.98$ & $199.5-200.0$ & 0.0 & 28.7 & 58.4 & 12.9 & silt loam & Ringold formation \\
\hline & B1L373-2 & $63.41-63.57$ & $208.0-208.5$ & 54.2 & 41.1 & 3.4 & 1.3 & $\begin{array}{c}\text { very gravelly } \\
\text { sand }\end{array}$ & Ringold formation \\
\hline $699-50-56$ & B1L7X9-1 & $48.02-48.17$ & $157.5-158.0$ & 76.1 & 21.0 & 2.6 & 0.3 & extremely gravelly sand & CCUg \\
\hline \multirow[b]{2}{*}{ 299-E33-343 } & B1T1J5-1 & $76.29-76.44$ & $250.3-250.8$ & 43.4 & 49.3 & 5.8 & 1.5 & gravelly sand & $\mathrm{CCUg}$ \\
\hline & B1T1J8-1 & $77.57-77.72$ & $254.5-255.0$ & 79.3 & 17.2 & 2.8 & 0.7 & $\begin{array}{l}\text { extremely } \\
\text { gravelly } \\
\text { loamy sand }\end{array}$ & CCUg \\
\hline \multirow[t]{2}{*}{ 299-E33-345 } & B1RLK4-3 & $77.27-77.42$ & $253.5-254.0$ & 48.0 & 38.9 & 10.4 & 2.7 & $\begin{array}{l}\text { very gravelly } \\
\text { sandy loam }\end{array}$ & CCUg \\
\hline & B1RLY0-4 & $77.88-78.03$ & $255.5-256.0$ & 49.4 & 46.3 & 3.2 & 1.1 & $\begin{array}{l}\text { very gravelly } \\
\text { sand }\end{array}$ & CCUg \\
\hline $\begin{array}{l}\text { bgs - below g } \\
\text { USDA - Unit } \\
\text { H2 - Hanford } \\
\text { H2F - Fine g1 } \\
\text { CCUg - CCU }\end{array}$ & $\begin{array}{l}\text { und surface } \\
\text { States Depa } \\
\text { ormation san } \\
\text { ined lens with } \\
\text { ravel domina }\end{array}$ & $\begin{array}{l}\text { dment of Agricu } \\
\text { dominated seq } \\
\text { ed } 2 \text { unit } \\
\text { ed sequence }\end{array}$ & $\begin{array}{l}\text { ture } \\
\text { ence }\end{array}$ & & & & & & \\
\hline
\end{tabular}


PNNL-19277

Table C.4. Particle-Size Distribution Data for Borehole 299-E33-50 (1 of 2)

\begin{tabular}{|c|c|c|c|c|c|c|c|}
\hline \multicolumn{8}{|c|}{ 299-E33-50 } \\
\hline \multicolumn{2}{|c|}{ B1L9T7-2 } & \multicolumn{2}{|c|}{ B1L9V5-3 } & \multicolumn{2}{|c|}{ B1L9W0-3 } & \multicolumn{2}{|c|}{ B1L9W2-2 } \\
\hline Particle & Percent & Particle & Percent & Particle & Percent & Particle & Percent \\
\hline $\begin{array}{l}\text { Diameter } \\
(\mathrm{mm})\end{array}$ & $\begin{array}{c}\text { Particles }< \\
\text { Diameter }\end{array}$ & $\begin{array}{l}\text { Diameter } \\
(\mathrm{mm})\end{array}$ & $\begin{array}{c}\text { Particles }< \\
\text { Diameter }\end{array}$ & $\begin{array}{l}\text { Diameter } \\
(\mathrm{mm})\end{array}$ & $\begin{array}{c}\text { Particles }< \\
\text { Diameter }\end{array}$ & $\begin{array}{l}\text { Diameter } \\
(\mathrm{mm})\end{array}$ & $\begin{array}{c}\text { Particles }< \\
\text { Diameter }\end{array}$ \\
\hline 76.2 & 100.0 & 76.2 & 100.0 & 76.2 & 100.0 & 76.2 & 100.0 \\
\hline 50.8 & 100.0 & 50.8 & 100.0 & 50.8 & 100.0 & 50.8 & 100.0 \\
\hline 38.1 & 100.0 & 38.1 & 100.0 & 38.1 & 100.0 & 38.1 & 100.0 \\
\hline 25.4 & 100.0 & 25.4 & 100.0 & 25.4 & 100.0 & 25.4 & 100.0 \\
\hline 19.1 & 100.0 & 19.1 & 100.0 & 19.1 & 100.0 & 19.1 & 100.0 \\
\hline 12.7 & 100.0 & 12.7 & 100.0 & 12.7 & 100.0 & 12.7 & 100.0 \\
\hline 9.5 & 100.0 & 9.5 & 100.0 & 9.5 & 100.0 & 9.5 & 100.0 \\
\hline 4.750 & 100.0 & 4.750 & 100.0 & 4.750 & 99.2 & 4.750 & 100.0 \\
\hline 2.000 & 97.7 & 2.000 & 99.7 & 2.000 & 93.0 & 2.000 & 99.8 \\
\hline 1.000 & 80.4 & 1.000 & 99.6 & 1.000 & 81.0 & 1.000 & 84.2 \\
\hline 0.500 & 52.5 & 0.500 & 99.3 & 0.500 & 47.7 & 0.500 & 33.5 \\
\hline 0.250 & 43.4 & 0.250 & 95.7 & 0.250 & 31.1 & 0.250 & 24.1 \\
\hline 0.106 & 33.6 & 0.106 & 36.9 & 0.106 & 21.5 & 0.106 & 18.6 \\
\hline 0.075 & 28.2 & 0.075 & 24.4 & 0.075 & 18.1 & 0.075 & 15.9 \\
\hline 0.053 & 23.9 & 0.053 & 19.3 & 0.053 & 15.6 & 0.053 & 12.1 \\
\hline 0.035 & 15.1 & 0.034 & 10.5 & 0.034 & 10.4 & 0.033 & 6.2 \\
\hline 0.019 & 11.0 & 0.019 & 8.4 & 0.019 & 7.5 & 0.018 & 5.0 \\
\hline 0.011 & 8.3 & 0.011 & 6.3 & 0.011 & 5.8 & 0.010 & 4.4 \\
\hline 0.008 & 6.2 & 0.008 & 4.2 & 0.008 & 4.6 & 0.007 & 3.1 \\
\hline 0.006 & 5.5 & 0.006 & 4.2 & 0.006 & 3.5 & 0.006 & 3.1 \\
\hline 0.005 & 5.5 & 0.005 & 4.2 & 0.005 & 3.5 & 0.005 & 3.1 \\
\hline 0.002 & 3.4 & 0.002 & 2.1 & 0.002 & 1.2 & 0.001 & 1.9 \\
\hline
\end{tabular}


PNNL-19277

Table C.4. Particle Size Distribution Data for Borehole 299-E33-50 (2 of 2)

\begin{tabular}{|c|c|c|c|c|c|c|c|}
\hline \multicolumn{8}{|c|}{ 299-E33-50 } \\
\hline \multicolumn{2}{|c|}{ B1L9X3-2 } & \multicolumn{2}{|c|}{ B1LBC9-3 } & \multicolumn{2}{|c|}{ B1LBD0-1 } & \multicolumn{2}{|c|}{ B1LBD1-3 } \\
\hline Particle & Percent & Particle & Percent & Particle & Percent & Particle & Percent \\
\hline $\begin{array}{l}\text { Diameter } \\
(\mathrm{mm})\end{array}$ & $\begin{array}{c}\text { Particles }< \\
\text { Diameter }\end{array}$ & $\begin{array}{l}\text { Diameter } \\
(\mathrm{mm})\end{array}$ & $\begin{array}{c}\text { Particles }< \\
\text { Diameter }\end{array}$ & $\begin{array}{l}\text { Diameter } \\
(\mathrm{mm})\end{array}$ & $\begin{array}{c}\text { Particles }< \\
\text { Diameter }\end{array}$ & $\begin{array}{l}\text { Diameter } \\
(\mathrm{mm})\end{array}$ & $\begin{array}{c}\text { Particles }< \\
\text { Diameter }\end{array}$ \\
\hline 76.2 & 100.0 & 76.2 & 100.0 & 76.2 & 100.0 & 76.2 & 100.0 \\
\hline 50.8 & 100.0 & 50.8 & 100.0 & 50.8 & 100.0 & 50.8 & 100.0 \\
\hline 38.1 & 100.0 & 38.1 & 100.0 & 38.1 & 100.0 & 38.1 & 100.0 \\
\hline 25.4 & 74.0 & 25.4 & 100.0 & 25.4 & 100.0 & 25.4 & 100.0 \\
\hline 19.1 & 62.1 & 19.1 & 100.0 & 19.1 & 100.0 & 19.1 & 100.0 \\
\hline 12.7 & 54.1 & 12.7 & 100.0 & 12.7 & 100.0 & 12.7 & 100.0 \\
\hline 9.5 & 48.7 & 9.5 & 100.0 & 9.5 & 100.0 & 9.5 & 100.0 \\
\hline 4.750 & 36.3 & 4.750 & 100.0 & 4.750 & 100.0 & 4.750 & 100.0 \\
\hline 2.000 & 19.8 & 2.000 & 100.0 & 2.000 & 99.4 & 2.000 & 100.0 \\
\hline 1.000 & 14.2 & 1.000 & 88.9 & 1.000 & 85.8 & 1.000 & 92.7 \\
\hline 0.500 & 10.1 & 0.500 & 78.5 & 0.500 & 56.7 & 0.500 & 82.9 \\
\hline 0.250 & 7.2 & 0.250 & 70.2 & 0.250 & 28.7 & 0.250 & 70.2 \\
\hline 0.106 & 4.6 & 0.106 & 49.9 & 0.106 & 18.1 & 0.106 & 48.5 \\
\hline 0.075 & 3.6 & 0.075 & 40.0 & 0.075 & 14.5 & 0.075 & 41.2 \\
\hline 0.053 & 3.1 & 0.053 & 30.9 & 0.053 & 12.9 & 0.053 & 34.0 \\
\hline 0.034 & 1.7 & 0.036 & 22.3 & 0.036 & 7.6 & 0.036 & 27.8 \\
\hline 0.019 & 1.3 & 0.020 & 16.5 & 0.020 & 5.7 & 0.020 & 21.1 \\
\hline 0.011 & 0.9 & 0.011 & 11.6 & 0.011 & 4.8 & 0.011 & 15.3 \\
\hline 0.007 & 0.6 & 0.008 & 9.7 & 0.008 & 1.9 & 0.008 & 13.4 \\
\hline 0.006 & 0.5 & 0.006 & 9.7 & 0.007 & 1.9 & 0.006 & 13.4 \\
\hline 0.005 & 0.5 & 0.006 & 7.8 & 0.006 & 1.9 & 0.006 & 13.4 \\
\hline 0.002 & 0.4 & 0.002 & 5.8 & 0.002 & 1.9 & 0.002 & 8.6 \\
\hline
\end{tabular}


PNNL-19277

Table C.5. Particle Size Distribution Data for Boreholes 699-48-50B and 699-50-56

\begin{tabular}{|c|c|c|c|c|c|c|c|}
\hline \multicolumn{6}{|c|}{ 699-48-50B } & \multirow{2}{*}{\multicolumn{2}{|c|}{$\begin{array}{l}699-50-56 \\
\text { B1L7X9-1 }\end{array}$}} \\
\hline \multicolumn{2}{|c|}{ B1L1T0-2 } & \multicolumn{2}{|c|}{ B1L1T1-2 } & \multicolumn{2}{|c|}{ B1L373-2 } & & \\
\hline Particle & Percent & Particle & Percent & Particle & Percent & Particle & Percent \\
\hline $\begin{array}{l}\text { Diameter } \\
(\mathrm{mm})\end{array}$ & $\begin{array}{c}\text { Particles }< \\
\text { Diameter }\end{array}$ & $\begin{array}{l}\text { Diameter } \\
(\mathrm{mm})\end{array}$ & $\begin{array}{c}\text { Particles }< \\
\text { Diameter }\end{array}$ & $\begin{array}{l}\text { Diameter } \\
(\mathrm{mm})\end{array}$ & $\begin{array}{c}\text { Particles }< \\
\text { Diameter }\end{array}$ & $\begin{array}{l}\text { Diameter } \\
(\mathrm{mm})\end{array}$ & $\begin{array}{c}\text { Particles }< \\
\text { Diameter }\end{array}$ \\
\hline 76.2 & 100.0 & 76.2 & 100.0 & 76.2 & 100.0 & 76.2 & 100.0 \\
\hline 50.8 & 100.0 & 50.8 & 100.0 & 50.8 & 100.0 & 50.8 & 86.5 \\
\hline 38.1 & 100.0 & 38.1 & 100.0 & 38.1 & 100.0 & 38.1 & 70.1 \\
\hline 25.4 & 100.0 & 25.4 & 100.0 & 25.4 & 96.7 & 25.4 & 60.7 \\
\hline 19.1 & 100.0 & 19.1 & 100.0 & 19.1 & 93.6 & 19.1 & 51.1 \\
\hline 12.7 & 100.0 & 12.7 & 100.0 & 12.7 & 85.1 & 12.7 & 44.6 \\
\hline 9.5 & 100.0 & 9.5 & 100.0 & 9.5 & 79.4 & 9.5 & 41.7 \\
\hline 4.750 & 100.0 & 4.750 & 100.0 & 4.750 & 60.8 & 4.750 & 32.5 \\
\hline 2.000 & 100.0 & 2.000 & 100.0 & 2.000 & 45.8 & 2.000 & 23.9 \\
\hline 1.000 & 98.5 & 1.000 & 99.6 & 1.000 & 26.0 & 1.000 & 17.5 \\
\hline 0.500 & 98.1 & 0.500 & 99.5 & 0.500 & 13.0 & 0.500 & 11.2 \\
\hline 0.250 & 90.7 & 0.250 & 99.2 & 0.250 & 8.6 & 0.250 & 7.1 \\
\hline 0.106 & 17.3 & 0.106 & 97.1 & 0.106 & 6.2 & 0.106 & 4.4 \\
\hline 0.075 & 12.5 & 0.075 & 85.6 & 0.075 & 5.6 & 0.075 & 3.6 \\
\hline 0.053 & 9.1 & 0.053 & 75.4 & 0.053 & 4.9 & 0.053 & 3.1 \\
\hline 0.033 & 5.0 & 0.036 & 52.4 & 0.033 & 3.7 & 0.034 & 2.0 \\
\hline 0.018 & 4.0 & 0.020 & 39.3 & 0.018 & 3.2 & 0.019 & 1.4 \\
\hline 0.010 & 3.0 & 0.011 & 31.0 & 0.010 & 2.6 & 0.011 & 1.0 \\
\hline 0.007 & 2.0 & 0.008 & 25.0 & 0.007 & 1.7 & 0.007 & 0.8 \\
\hline 0.006 & 2.0 & 0.006 & 21.4 & 0.006 & 1.7 & 0.006 & 0.6 \\
\hline 0.005 & 2.0 & 0.005 & 20.2 & 0.005 & 1.4 & 0.005 & 0.6 \\
\hline 0.001 & 2.0 & 0.002 & 11.9 & 0.001 & 1.3 & 0.002 & 0.3 \\
\hline
\end{tabular}


PNNL-19277

Table C.6. Particle Size Distribution Data for Boreholes 299-E33-343 and 299-E33-345

\begin{tabular}{|c|c|c|c|c|c|c|c|}
\hline \multicolumn{4}{|c|}{ 299-E33-343 } & \multicolumn{4}{|c|}{ 299-E33-345 } \\
\hline \multicolumn{2}{|c|}{ B1T1J5-1 } & \multicolumn{2}{|c|}{ B1T1J8-1 } & \multicolumn{2}{|c|}{ B1RLK4-3 } & \multicolumn{2}{|c|}{ B1RLY0-4 } \\
\hline & Percent & & Percent & & Percent & & Percent \\
\hline Particle & Particles & Particle & Particles & Particle & Particles & Particle & Particles \\
\hline Diameter & $<$ & Diameter & $<$ & Diameter & $<$ & Diameter & $<$ \\
\hline (mm) & Diameter & $(\mathrm{mm})$ & Diameter & $(\mathrm{mm})$ & Diameter & (mm) & Diameter \\
\hline 63.0 & 100.0 & 63.0 & 100.0 & 63.0 & 100.0 & 63.0 & 100.0 \\
\hline 31.5 & 100.0 & 31.5 & 100.0 & 31.5 & 100.0 & 31.5 & 100.0 \\
\hline 16.0 & 86.6 & 16.0 & 95.8 & 16.0 & 89.7 & 16.0 & 96.6 \\
\hline 8.0 & 73.0 & 8.0 & 65.6 & 8.0 & 71.7 & 8.0 & 79.1 \\
\hline 4.000 & 64.8 & 4.000 & 35.6 & 4.000 & 59.8 & 4.000 & 64.0 \\
\hline 2.000 & 56.7 & 2.000 & 20.7 & 2.000 & 52.0 & 2.000 & 50.6 \\
\hline 1.000 & 42.4 & 1.000 & 13.3 & 1.000 & 42.1 & 1.000 & 35.3 \\
\hline 0.500 & 27.4 & 0.500 & 9.4 & 0.500 & 31.0 & 0.500 & 19.6 \\
\hline 0.250 & 17.8 & 0.250 & 7.0 & 0.250 & 18.3 & 0.250 & 11.0 \\
\hline 0.085 & 8.9 & 0.085 & 4.1 & 0.089 & 15.9 & 0.083 & 5.3 \\
\hline 0.059 & 7.7 & 0.060 & 3.7 & 0.062 & 14.3 & 0.058 & 4.6 \\
\hline 0.034 & 6.6 & 0.034 & 3.1 & 0.035 & 11.8 & 0.033 & 3.8 \\
\hline 0.018 & 5.5 & 0.018 & 2.4 & 0.019 & 9.3 & 0.018 & 3.3 \\
\hline 0.011 & 4.4 & 0.011 & 1.8 & 0.011 & 7.1 & 0.010 & 2.5 \\
\hline 0.007 & 3.6 & 0.007 & 1.6 & 0.008 & 6.0 & 0.007 & 2.0 \\
\hline 0.006 & 3.0 & 0.006 & 1.4 & 0.006 & 5.5 & 0.006 & 2.0 \\
\hline 0.005 & 2.5 & 0.005 & 1.2 & 0.005 & 4.9 & 0.005 & 1.5 \\
\hline 0.001 & 1.4 & 0.001 & 0.6 & 0.002 & 2.5 & 0.001 & 1.0 \\
\hline
\end{tabular}

The in situ physical properties of the soil cores, excluding cores from 299-E33-343 and 299-E33-345 that were not measured, are presented in Table C.7. Bulk density for the borehole samples range from $1.21 \mathrm{~g} / \mathrm{cm}^{3}$ to $2.34 \mathrm{~g} / \mathrm{cm}^{3}$. The highest bulk densities generally correspond with higher gravel contents. This comes about as a result of smaller particles filling the matrices formed by the gravel fraction. The lowest bulk densities correspond to the Rattlesnake Ridge Interbed stratigraphic unit, with the two lowest bulk density samples exhibiting poor sorting. Particle densities for cores collected from the Hanford formation, $\mathrm{H} 2$ stratigraphic unit, and Cold Creek gravel subunit vary from $2.67 \mathrm{~g} / \mathrm{cm}^{3}$ to $2.76 \mathrm{~g} / \mathrm{cm}^{3}$. Particle densities from the Rattlesnake Ridge Interbed stratigraphic unit cores are significantly lower, ranging from $2.49 \mathrm{~g} / \mathrm{cm}^{3}$ to $2.53 \mathrm{~g} / \mathrm{cm}^{3}$. The sediment in this formation is likely tuffaceous in origin and has a mineralogical composition that differs from the overlaying formations. Porosity $(\phi)$ was estimated from sample bulk density $\left(\rho_{b}\right)$ and particle density $\left(\rho_{s}\right)$ using the relationship: 


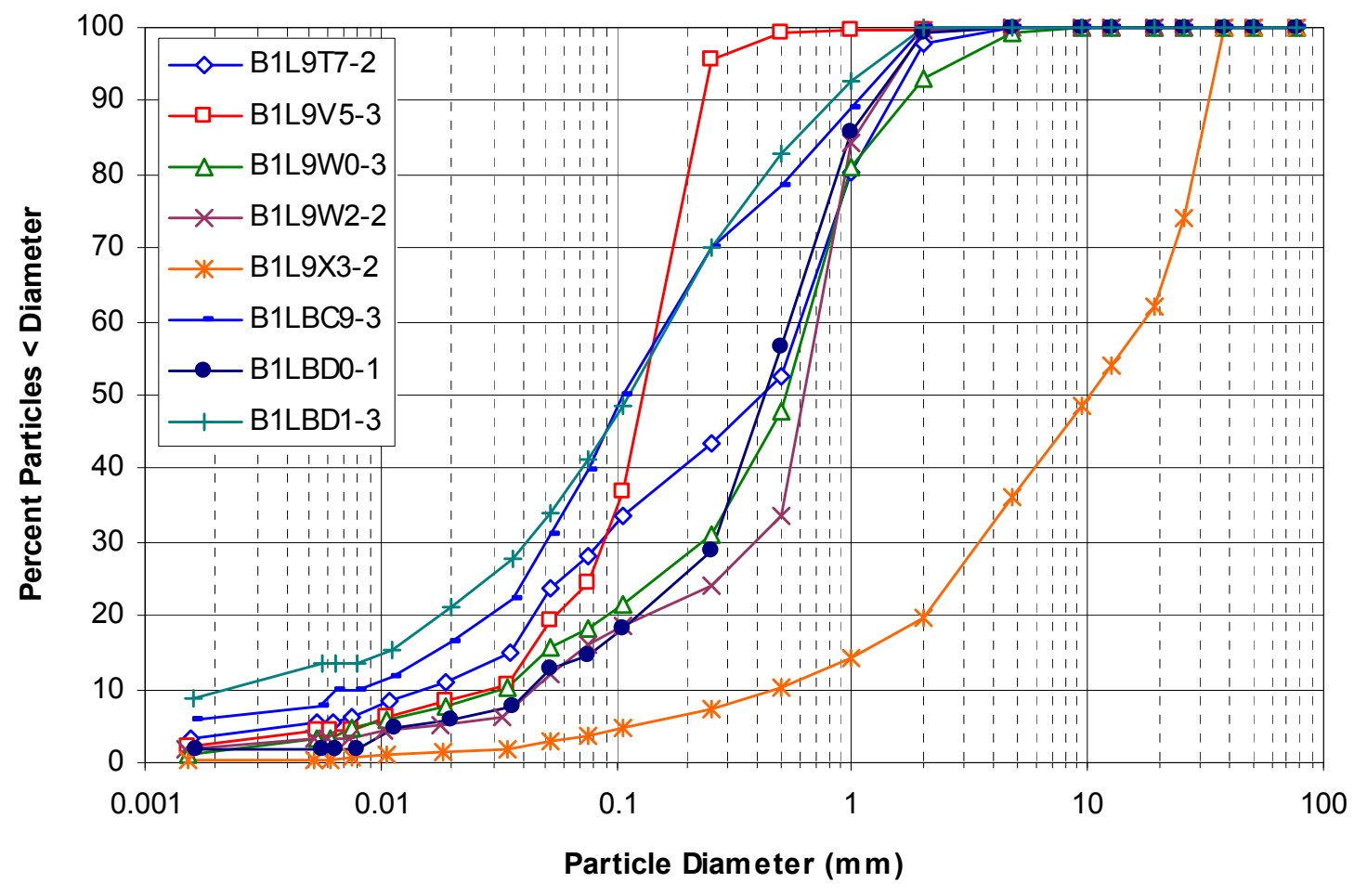

Figure C.2. Particle-Size Distribution for Borehole 299-E33-50 Samples

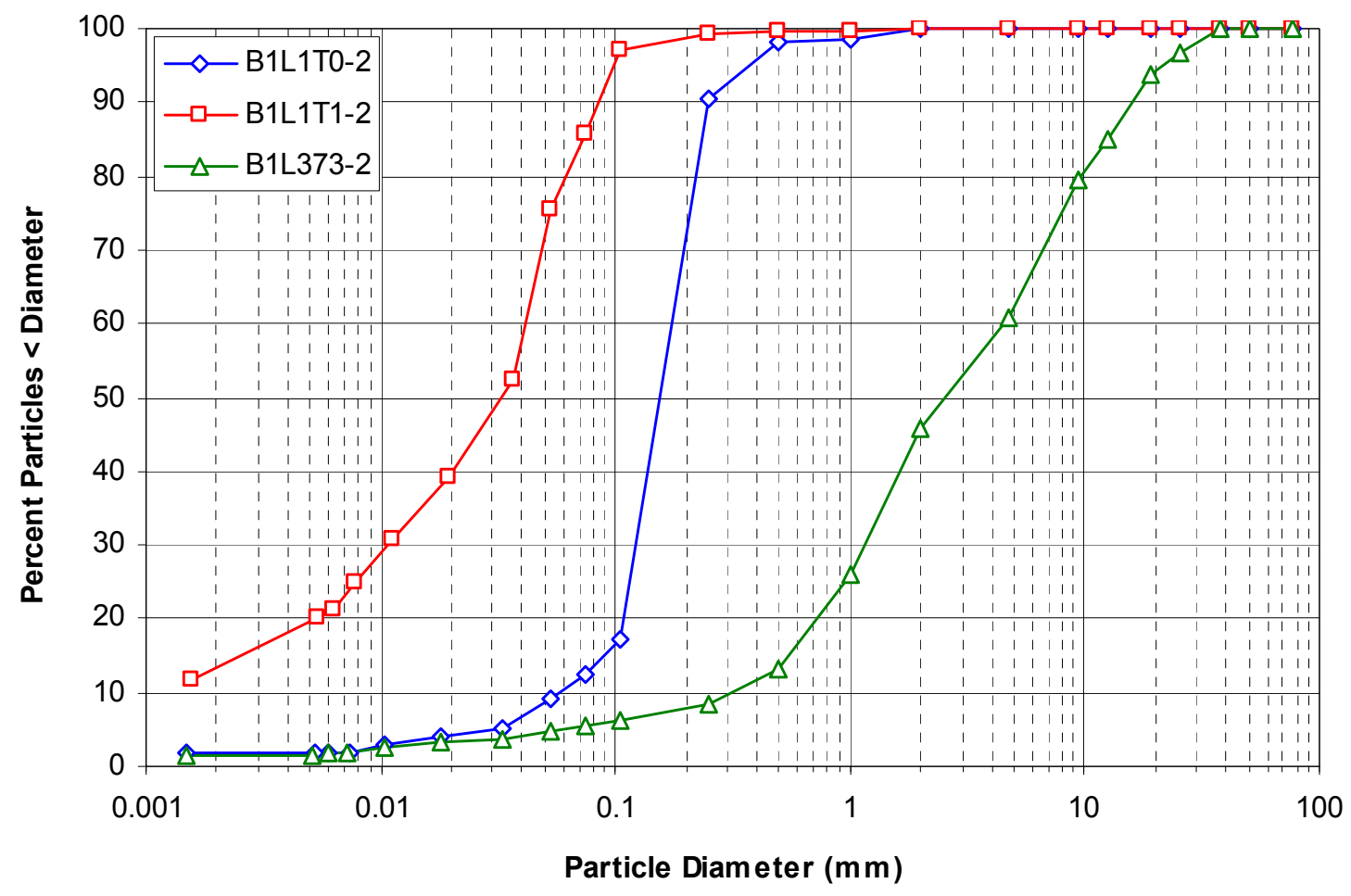

Figure C.3. Particle-Size Distribution for Borehole 699-48-50B Samples 


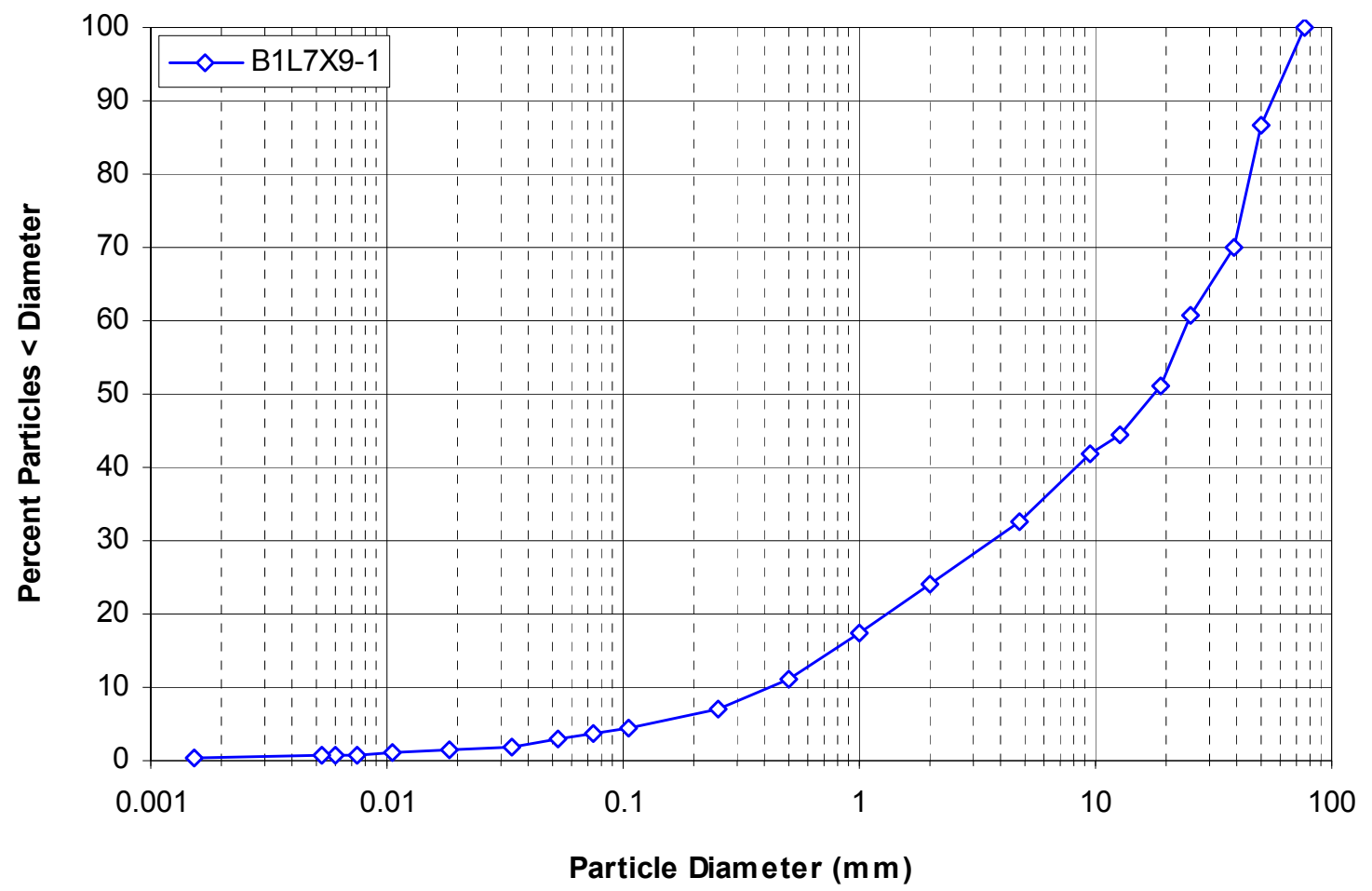

Figure C.4. Particle-Size Distribution for Borehole 699-50-56 Samples

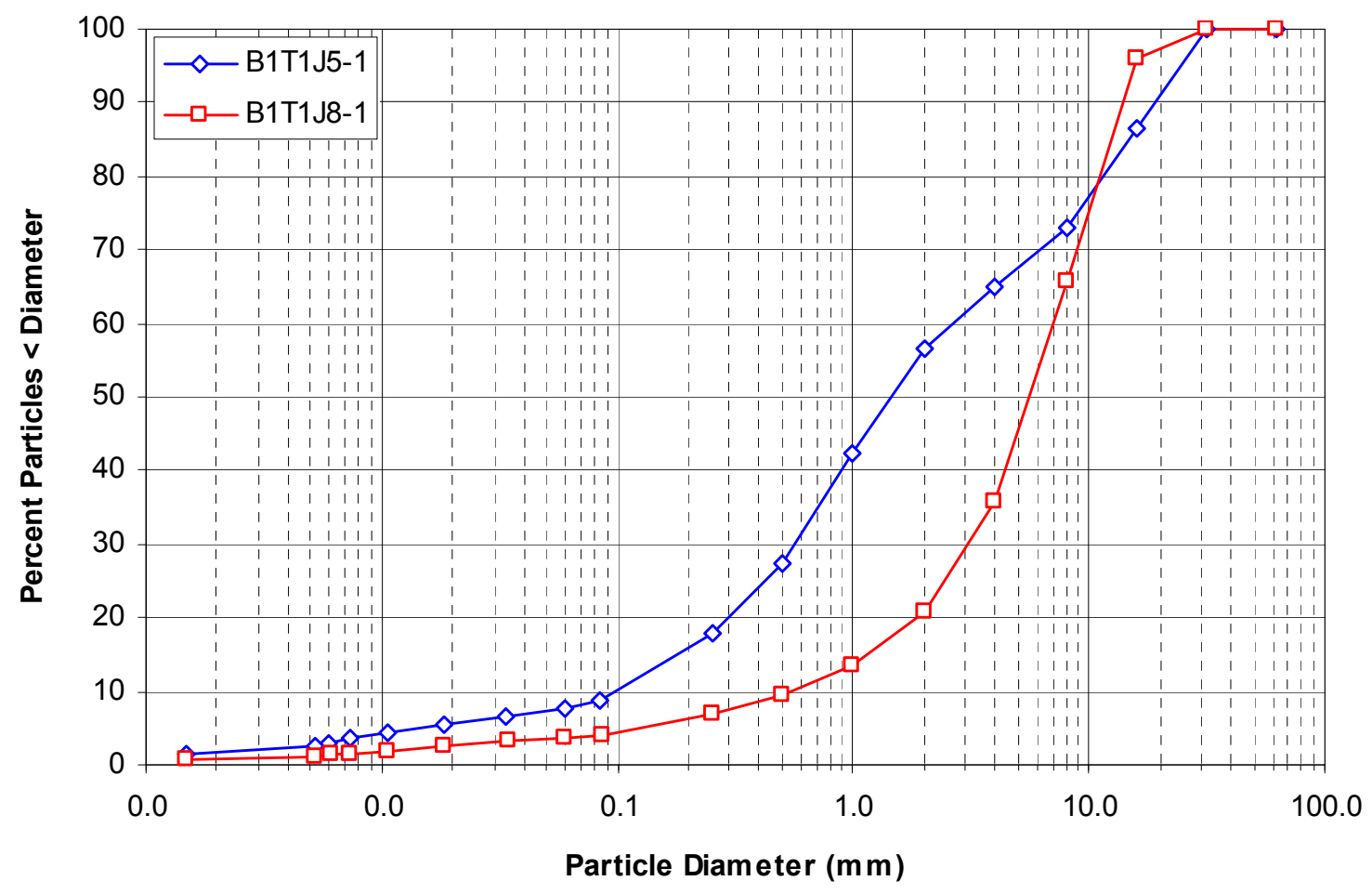

Figure C.5. Particle-Size Distribution for Borehole 299-E33-343 Samples 
PNNL-19277

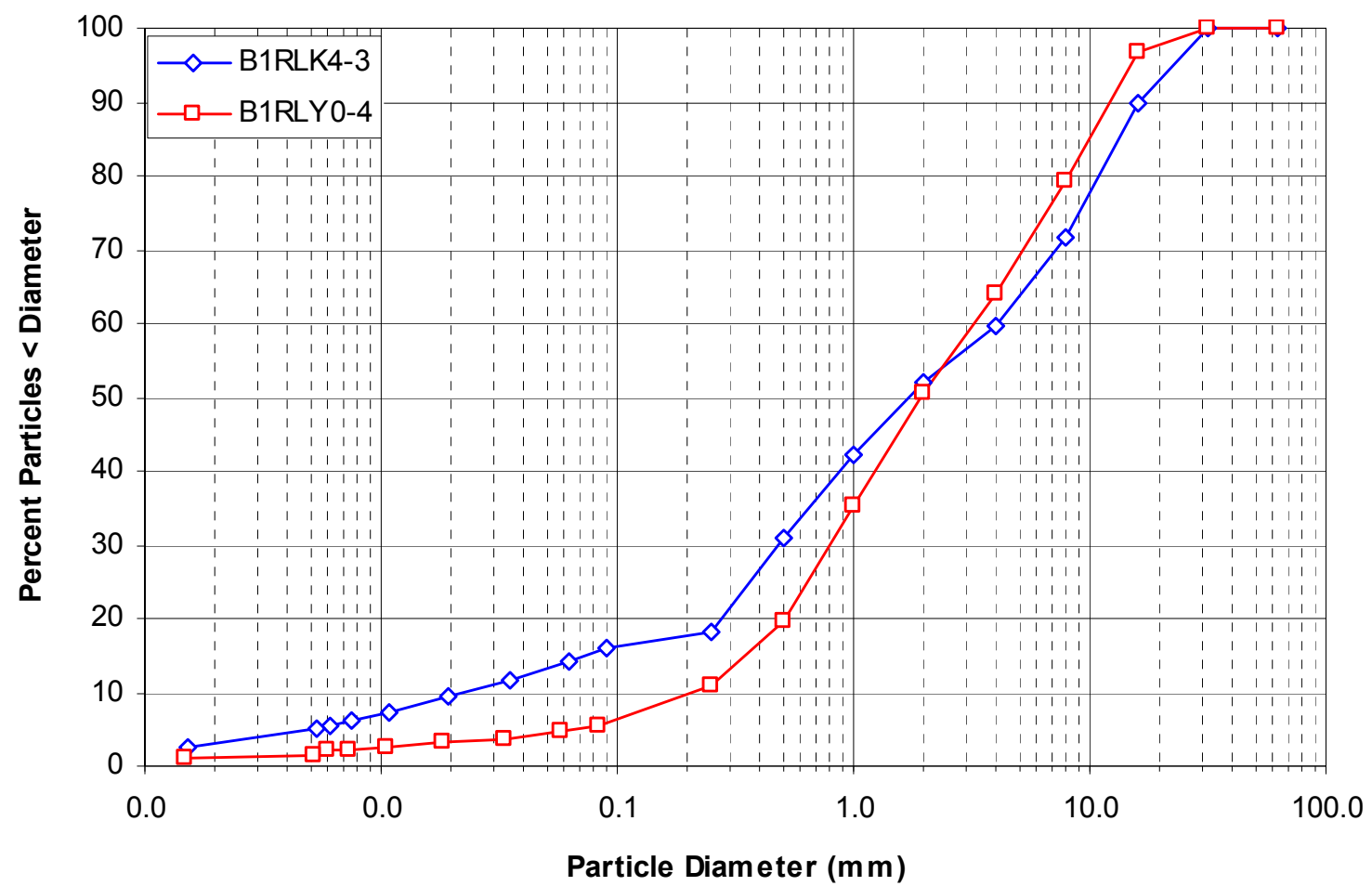

Figure C.6. Particle-Size Distribution for Borehole 299-E33-345 Samples

Table C.7. Field Water Content, Bulk Density, Particle Density, and Calculated Porosity

\begin{tabular}{ccccccc}
\hline & & \multicolumn{2}{c}{ Field Water Content } & Bulk Density & Particle Density & Porosity $^{\mathrm{a}}$ \\
\cline { 3 - 7 } Borehole & Sample ID & $(\mathrm{g} / \mathrm{g})$ & $\left(\mathrm{cm}^{3} / \mathrm{cm}^{3}\right)$ & $\left(\mathrm{g} / \mathrm{cm}^{3}\right)$ & $\left(\mathrm{g} / \mathrm{cm}^{3}\right)$ & $\left(\mathrm{cm}^{3} / \mathrm{cm}^{3}\right)$ \\
\hline \multirow{5}{*}{$299-$-E33-50 } & B1L9T7-2 & 0.086 & 0.164 & 1.91 & 2.67 & 0.285 \\
& B1L9V5-3 & 0.129 & 0.231 & 1.79 & 2.70 & 0.338 \\
& B1L9W0-3 & 0.022 & 0.040 & 1.86 & 2.71 & 0.314 \\
& B1L9W2-2 & 0.042 & 0.079 & 1.87 & 2.72 & 0.313 \\
& B1L9X3-2 & 0.034 & 0.079 & 2.34 & 2.71 & 0.135 \\
& B1LBC9-3 & 0.337 & 0.456 & 1.35 & 2.50 & 0.459 \\
& B1LBD0-1 & 0.262 & 0.394 & 1.50 & 2.49 & 0.395 \\
699-48-50B & B1LBD1-3 & 0.391 & 0.472 & 1.21 & 2.53 & 0.522 \\
& B1L1T0-2 & 0.018 & 0.028 & 1.61 & 2.68 & 0.399 \\
699-50-56 & B1L1T1-2 & 0.239 & 0.406 & 1.70 & 2.70 & 0.372 \\
\hline NM - not measured & B1L373-2 & 0.101 & 0.206 & 2.04 & 2.76 & 0.258 \\
a - calculated using the relationship porosity $=1$ - bulk density/particle density & \\
\hline
\end{tabular}




$$
\phi=1-\frac{\rho_{b}}{\rho_{s}}
$$

Porosity ranges from a low of $0.135 \mathrm{~cm}^{3} / \mathrm{cm}^{3}$ to a high of $0.522 \mathrm{~cm}^{3} / \mathrm{cm}^{3}$. Field-measured water contents for samples collected in the vadose zone generally trend with soil texture, with the finer textured samples having a higher water content. The field water content of the samples collected below the water table do not necessarily equal the estimated porosity possibly due to 1) small errors in the bulk density and particle density measurements, and more importantly, 2) water lost by drainage and evaporation during core recovery and handling at the ground surface before sealing of the core.

Saturated hydraulic conductivity measured using either the constant head method or the falling head method are presented in Table C.8. For borehole 299-E33-50 within the Hanford formation, the measured saturated hydraulic conductivities range from $7.17 \times 10^{-5} \mathrm{~cm} / \mathrm{sec}$ to $7.93 \times 10^{-4} \mathrm{~cm} / \mathrm{sec}$, with the lower saturated hydraulic conductivity value found in core B1L9V5-3 representing the fine-texture H2F1 lens. Within the Rattlesnake Ridge Interbed stratigraphic unit, the saturated hydraulic conductivity decreases to a minimum value of $2.38 \times 10^{-7} \mathrm{~cm} / \mathrm{sec}$. For borehole $699-48-50 \mathrm{~B}$, the saturated hydraulic conductivity is variable, ranging from a high of $2.91 \times 10^{-2} \mathrm{~cm} / \mathrm{sec}$ for the very gravelly sand textured core (B1L373-2) to a low of $8.12 \times 10^{-6} \mathrm{~cm} / \mathrm{sec}$ for the silt loam textured core (B1L1T1-2). Saturated hydraulic conductivity for cores from the $\mathrm{CCU}_{\mathrm{g}}$ were quite variable, ranging from $8.82 \times 10^{-5}$ to $2.99 \times 10^{-3} \mathrm{~cm} / \mathrm{sec}$. Driller's logs and field notes indicate that core B1RLK4-3 was collected from a highly calcareous zone, which, in addition to its finer texture, is likely to contribute to the low saturated hydraulic conductivity for this core by way of cementation of the soil matrix.

The water retention and unsaturated hydraulic conductivity characteristics of a soil are often described by mathematical functions. There are various expressions that can be used to describe soil hydraulic behavior. The most commonly used are those of van Genuchten (1980) for soil water retention and the Mualem - van Genuchten conductivity function for describing unsaturated hydraulic conductivity (van Genuchten 1980). The van Genuchten water retention function is given as:

$$
\theta=\theta_{r}+\left(\theta_{s}-\theta_{r}\right)\left[1+(\alpha \cdot h)^{n}\right]^{-m}
$$

where $\theta_{s}$ is the saturated water content $\left(\mathrm{cm}^{3} / \mathrm{cm}^{3}\right), \theta_{r}$ is the residual water content $\left(\mathrm{cm}^{3} / \mathrm{cm}^{3}\right), h$ is the matric potential $(-\mathrm{cm})$, and $\alpha(1 / \mathrm{cm})$, and $n, m$ are fitting parameters with $n$ and $m$ being dimensionless.

The van Genuchten - Mualem conductivity function follows:

$$
K=K_{s} \frac{\left\{1-(\alpha \cdot h)^{n-1}\left[1+(\alpha \cdot h)^{n}\right]^{-m}\right\}^{2}}{\left[1+(\alpha \cdot h)^{n}\right]^{1 \cdot m}}
$$

where $K_{s}$ is the saturated hydraulic conductivity, and $l$ is the pore connectivity parameter.

Table C.9 shows the van Genuchten parameter estimates determined using the SFOPT program in conjunction with the matric potential and drainage multistep data and the measured saturated hydraulic conductivity. The large gravel content of core B1L9X3-2 made it impossible to insert tensiometers in the 
core, necessitating that the parameter estimates rely only on the multistep drainage data and the measured saturated hydraulic conductivity and assumes that static conditions were achieved at each pressure step. Cores B1L9T7-2 and B1L1T1-2 experienced minimal drainage over the range of multistep pressures, making convergence of SFOPT-predicted van Genuchten parameters impossible. Instead, the water content at each multistep pressure was considered a point on the retention curve with the assumption that static conditions had been achieved, and, in combination with the pressure plate and potentiometric data, the van Genuchten parameters were estimated using the RETC program (van Genuchten 1991). All estimation procedures constrained the van Genuchten $m$ parameter to be equal to $1-1 / n$ and $\theta_{s}$ equal to the final water content of the core plus the volume of drainage water collected during the multistep test. $l$ of the Mualem - van Genuchten conductivity function was set equal to 0.5 .

Because the multistep method specifies that two tensiometers be installed within the core, in this case at a vertical distance of $10 \mathrm{~cm}$ apart, the SFOPT analysis produces two sets of estimated parameter values: one for the upper tensiometer and one for the lower tensiometer. Ideally, the estimated parameters from both tensiometers' data are identical, but commonly heterogeneities within the core produce different estimated parameter values. Such is the instance with core B1L9V5-3 where the upper and lower tensiometer estimates are significantly different.

For the entire data set, $\alpha$ ranges from $0.001 \mathrm{~cm}^{-1}$ to $0.017 \mathrm{~cm}^{-1}$. The parameter $n$ ranges from 1.559 to 3.546. The residual water content $\left(\theta_{r}\right)$ ranges from 0.001 to $0.039 \mathrm{~cm}^{3} / \mathrm{cm}^{3}$. The ranges of estimated parameters are typical for unconsolidated sediments at the Hanford site.

Pressure plate and dew point potentiometer data for boreholes 299-E33-50 and 699-48-50B are presented in Tables C.10 through C.13. Because pressure plate and dew point potentiometer measurements were restricted to the $<2$ - $\mathrm{mm}$ size fraction, water contents were corrected for gravel content by assuming that the gravel particles contributed no additional moisture content under the very low matric potential heads of these analyses. The water retention and hydraulic conductivity functions generated using the parameter estimates in Table C.9 are shown in Figures C.7 through C.10. In these figures, SFOPTpredicted retention functions are compared with the pressure plate and dew point potentiometer data. While there is some correspondence between the function and data, some of the samples show differences. This may be the result of the matric potential range of the multistep data being much lower than that of the pressure plate and dew point potentiometer data. Note that the SFOPT fitting procedure does not use the pressure plate and potentiometer data. A second reason may be because the van Genuchten retention model used here does not always accurately represent retention in the dry range. Finally, the differences may reflect heterogeneities within the sample, with the multistep test responding to the heterogeneities since it is measured on the entire core, but the pressure plate and potentiometer measurements are on discrete core subsamples.

Figure C.11 shows the filter paper method measured matric potentials for borehole 299-E33-50 and the gravity head expressed in pressure units (MPa). The gravity head is zero at the water table and increases linearly with height to the soil surface, representing the steady state unit gradient condition (i.e., neither draining nor drier than equilibrium). For borehole 299-E33-50, the water potentials are generally less than the gravity potential from 61 to $84 \mathrm{ft}(18.6$ to $25.6 \mathrm{~m})$, suggesting that drainage is occurring down to $84 \mathrm{ft}(25.6 \mathrm{~m})$. Below $84 \mathrm{ft}(25.6 \mathrm{~m})$ and to the water table at $\sim 224.6 \mathrm{ft}(\sim 68.5 \mathrm{~m})$, matric potential conditions are more sporadic. The matric potential profile suggests that deep drainage is occurring at this location and may represent enhanced drainage resulting from nonvegetated surface conditions that were created for operational purposes. As discussed in Gee et al. (1992), Fayer and 
Szecsody (2004), and Fayer and Keller (2007), removing plants enhances recharge by significantly reducing evapotranspiration and plant recycling of water from its roots up through the stems and leaves.

This matric potential profile is similar to that reported by Serne et al. (2002a) for borehole 299-E33338 (C3391) located outside the southeast corner of the B tank farm. At this location, like the location of borehole 299-E33-50, the presence of deep rooted ( $>3 \mathrm{~m}$ ) vegetation is minimal due to past surface disturbances, creating increased drainage deeper in the profile (e.g., $>20 \mathrm{~m}$ ) far below the variations caused by differences in yearly precipitation and evapotranspiration) relative to pre-disturbance conditions.

Table C.8. Measured Saturated Hydraulic Conductivity

\begin{tabular}{cccc}
\hline Borehole & Core & Test Method & Saturated Hydraulic Conductivity(cm/sec) \\
\hline & B1L9T7-2 & Falling Head & $1.21 \times 10^{-4}$ \\
& B1L9V5-3 & Falling Head & $7.17 \times 10^{-5}$ \\
& B1L9W0-3 & Falling Head & $3.75 \times 10^{-4}$ \\
\multirow{2}{*}{$299-E 33-50$} & B1L9W2-2 & Falling Head & $7.93 \times 10^{-4}$ \\
& B1L9X3-2 & Falling Head & $2.37 \times 10^{-4}$ \\
& B1LBC9-3 & Falling Head & $9.90 \times 10^{-6}$ \\
& B1LBD0-1 & Falling Head & $1.90 \times 10^{-5}$ \\
& B1LBD1-3 & Falling Head & $2.38 \times 10^{-7}$ \\
& B1L1T0-2 & Constant Head & $2.26 \times 10^{-3}$ \\
\hline \multirow{2}{*}{$699-48-50 B$} & B1L1T1-2 & Falling Head & $8.12 \times 10^{-6}$ \\
& B1L373-2 & Constant Head & $2.91 \times 10^{-2}$ \\
\hline $699-50-56$ & B1L7X9-1 & & $\mathrm{NM}$ \\
\hline \multirow{2}{*}{$299-E 33-343$} & B1T1J5-1 & Falling Head & $6.40 \times 10^{-4}$ \\
\hline \multirow{2}{*}{$299-E 33-345$} & B1T1J8-1 & Constant Head & $2.99 \times 10^{-3}$ \\
\hline NM - not measured & B1RLK4-3 & Falling Head & $8.82 \times 10^{-5}$ \\
\hline
\end{tabular}

Table C.9. van Genuchten Parameter Estimates

\begin{tabular}{|c|c|c|c|c|c|c|}
\hline Borehole & Core & $\begin{array}{c}\text { Tensiometer } \\
\text { Location }\end{array}$ & $\alpha(1 / \mathrm{cm})$ & $\mathrm{n}$ & $\theta_{\mathrm{r}}$ & $\theta_{\mathrm{s}}{ }^{\mathrm{a}}$ \\
\hline \multirow{8}{*}{ 299-E33-50 } & B1L9T7-2 & - & 0.004 & 1.680 & 0.029 & 0.295 \\
\hline & \multirow{2}{*}{ B1L9V5-3 } & Upper & 0.008 & 2.227 & 0.034 & 0.374 \\
\hline & & Lower & 0.017 & 1.559 & 0.001 & 0.374 \\
\hline & \multirow{2}{*}{ B1L9W0-3 } & Upper & 0.011 & 1.724 & 0.025 & 0.303 \\
\hline & & Lower & 0.013 & 1.642 & 0.020 & 0.303 \\
\hline & \multirow{2}{*}{ B1L9W2-2 } & Upper & 0.013 & 1.824 & 0.036 & 0.339 \\
\hline & & Lower & 0.013 & 1.819 & 0.036 & 0.339 \\
\hline & B1L9X3-2 & - & 0.015 & 1.624 & 0.023 & 0.122 \\
\hline \multirow{3}{*}{ 699-48-50B } & \multirow{2}{*}{ B1L1T0-2 } & Upper & 0.015 & 3.200 & 0.024 & 0.381 \\
\hline & & Lower & 0.014 & 3.546 & 0.025 & 0.381 \\
\hline & B1L1T1-2 & - & 0.001 & 1.636 & 0.039 & 0.400 \\
\hline
\end{tabular}

a $-\theta_{\mathrm{s}}$ set equal to the initial water content, calculated from the final water content and volume of water drained from the core. 
Table C.10. Borehole 299-E33-50 Pressure Plate Water Retention Data for the $<2 \mathrm{~mm}$ Fraction. Water content is corrected for bulk gravel fraction.

\begin{tabular}{|c|c|c|c|c|c|c|c|c|c|}
\hline \multicolumn{10}{|c|}{ 299-E33-50 } \\
\hline \multicolumn{2}{|c|}{ B1L9T7-2 } & \multicolumn{2}{|c|}{ B1L9V5-3 } & \multicolumn{2}{|c|}{ B1L9W0-3 } & \multicolumn{2}{|c|}{ B1L9W2-2 } & \multicolumn{2}{|c|}{ B1L9X3-2 } \\
\hline Matric & Water & Matric & Water & Matric & Water & Matric & Water & Matric & Water \\
\hline $\begin{array}{l}\text { Potential } \\
\quad(-\mathrm{cm})\end{array}$ & $\begin{array}{l}\text { Content } \\
\left(\mathrm{cm}^{3} / \mathrm{cm}^{3}\right)\end{array}$ & $\begin{array}{c}\text { Potential } \\
(-\mathrm{cm})\end{array}$ & $\begin{array}{c}\text { Content } \\
\left(\mathrm{cm}^{3} / \mathrm{cm}^{3}\right)\end{array}$ & $\begin{array}{c}\text { Potential } \\
(-\mathrm{cm})\end{array}$ & $\begin{array}{l}\text { Content } \\
\left(\mathrm{cm}^{3} / \mathrm{cm}^{3}\right)\end{array}$ & $\begin{array}{c}\text { Potential } \\
(-\mathrm{cm})\end{array}$ & $\begin{array}{l}\text { Content } \\
\left(\mathrm{cm}^{3} / \mathrm{cm}^{3}\right)\end{array}$ & $\begin{array}{c}\text { Potential } \\
(-\mathrm{cm})\end{array}$ & $\begin{array}{c}\text { Content } \\
\left(\mathrm{cm}^{3} / \mathrm{cm}^{3}\right)\end{array}$ \\
\hline 511 & 0.1522 & 511 & 0.1098 & 511 & 0.0928 & 511 & 0.0912 & 511 & 0.0349 \\
\hline 1023 & 0.1218 & 1023 & 0.0812 & 1023 & 0.0619 & 1023 & 0.0691 & 1023 & 0.0201 \\
\hline 2045 & 0.0954 & 2045 & 0.0582 & 2045 & 0.0535 & 2045 & 0.0610 & 2045 & 0.0150 \\
\hline 4091 & 0.0770 & 4091 & 0.0377 & 4091 & 0.0393 & 4091 & 0.0417 & 4091 & 0.0104 \\
\hline 15341 & NM & 15341 & 0.0244 & 15341 & 0.0260 & 15341 & 0.0282 & 15341 & NM \\
\hline
\end{tabular}

Table C.11. Borehole 699-48-50B Pressure Plate Water Retention Data for the $<2 \mathrm{~mm}$ Fraction. Water content is corrected for bulk gravel fraction.

\begin{tabular}{|c|c|c|c|}
\hline \multicolumn{4}{|c|}{ 699-48-50B } \\
\hline \multicolumn{2}{|c|}{ B1L1T0-2 } & \multicolumn{2}{|c|}{ B111T1-2 } \\
\hline Matric & Water & Matric & Water \\
\hline $\begin{array}{l}\text { Potential } \\
(-\mathrm{cm})\end{array}$ & $\begin{array}{c}\text { Content } \\
\left(\mathrm{cm}^{3} / \mathrm{cm}^{3}\right)\end{array}$ & $\begin{array}{c}\text { Potential } \\
(-\mathrm{cm})\end{array}$ & $\begin{array}{l}\text { Content } \\
\left(\mathrm{cm}^{3} / \mathrm{cm}^{3}\right)\end{array}$ \\
\hline 511 & 0.0673 & 511 & 0.3884 \\
\hline 1023 & 0.0448 & 1023 & 0.3004 \\
\hline 2045 & 0.0338 & 2045 & 0.2351 \\
\hline 4091 & 0.0269 & 4091 & 0.1903 \\
\hline 15341 & NM & 15341 & NM \\
\hline NM - not 1 & heasured & & \\
\hline
\end{tabular}


PNNL-19277
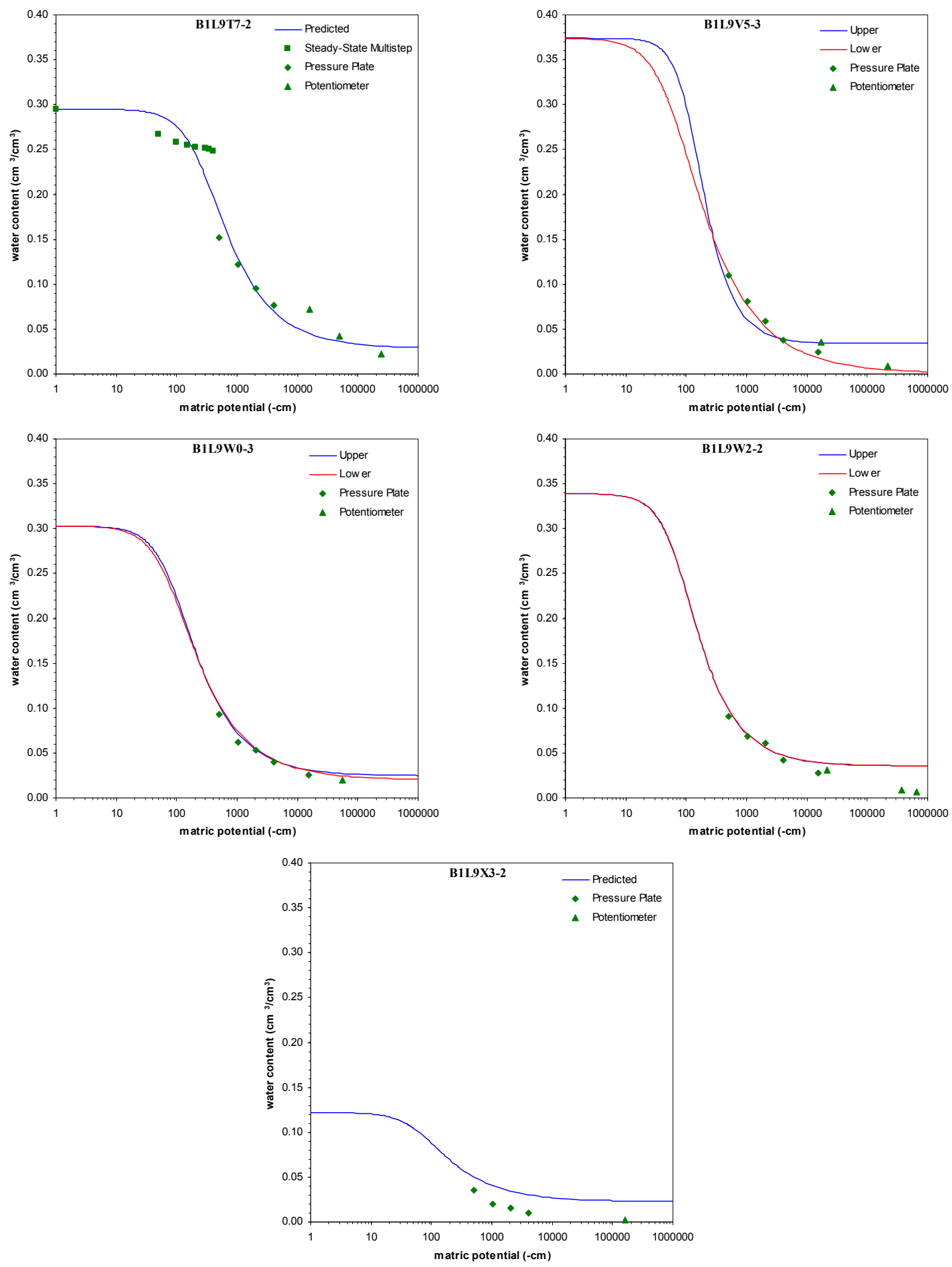

Figure C.7. Predicted Retention Functions and Data (pressure plate and dew point potentiometer) for borehole 299-E33-50

"Upper" fitted with drainage and upper tensiometer data; "Lower" fitted with drainage and lower tensiometer data. Core B1L9T7-2 fitted using multistep, pressure plate, and potentiometer data. Core B1L9X3-2 fitted with drainage data only. 
PNNL-19277
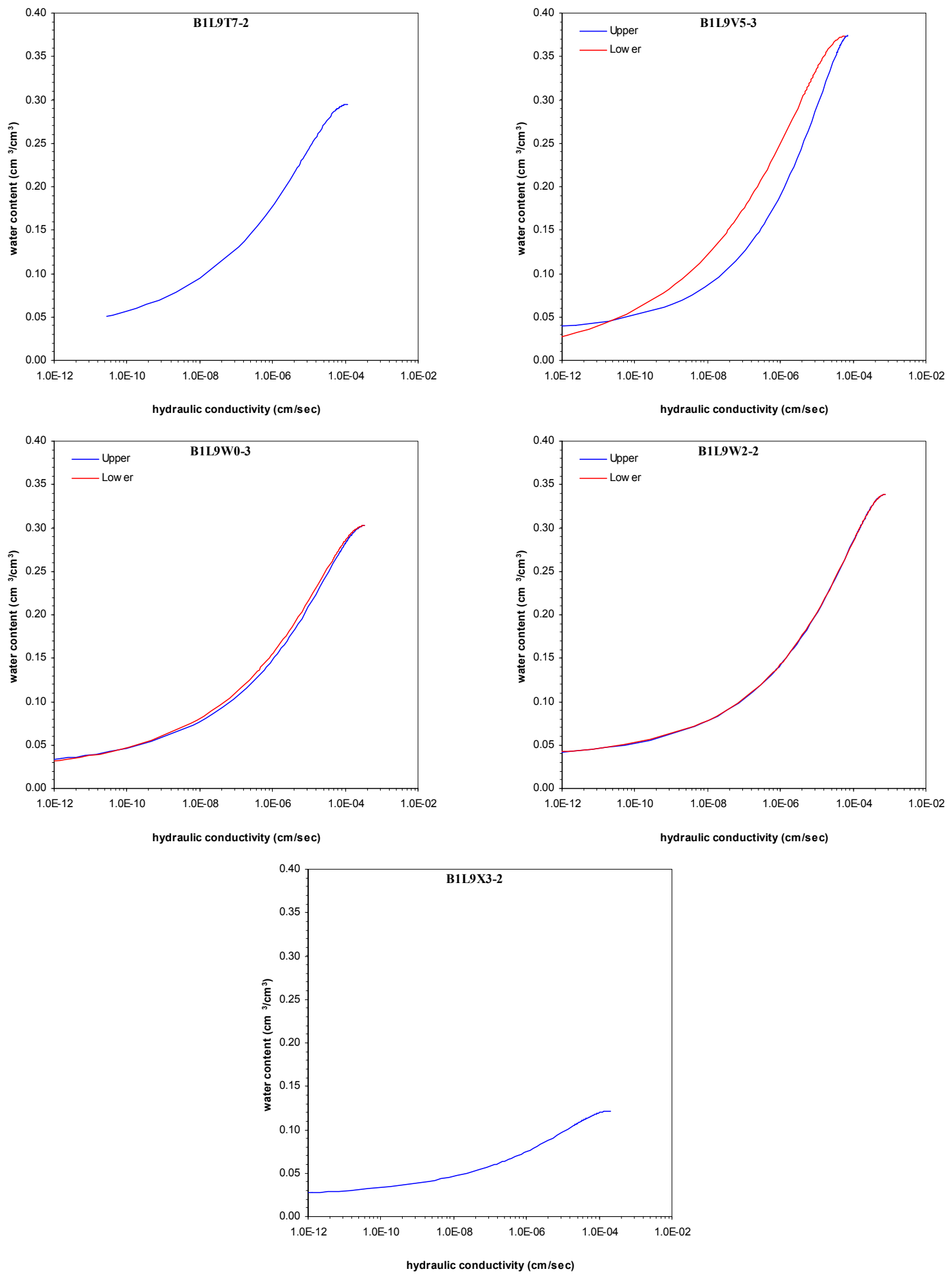

Figure C.8. Predicted Hydraulic Conductivity Functions for Borehole 299-E33-50 "Upper" fitted with drainage and upper tensiometer data; "Lower" fitted with drainage and lower tensiometer data. Core B1L9T7-2 fitted using multistep, pressure plate, and potentiometer data. Core B1L9X3-2 fitted with drainage data only. 
PNNL-19277
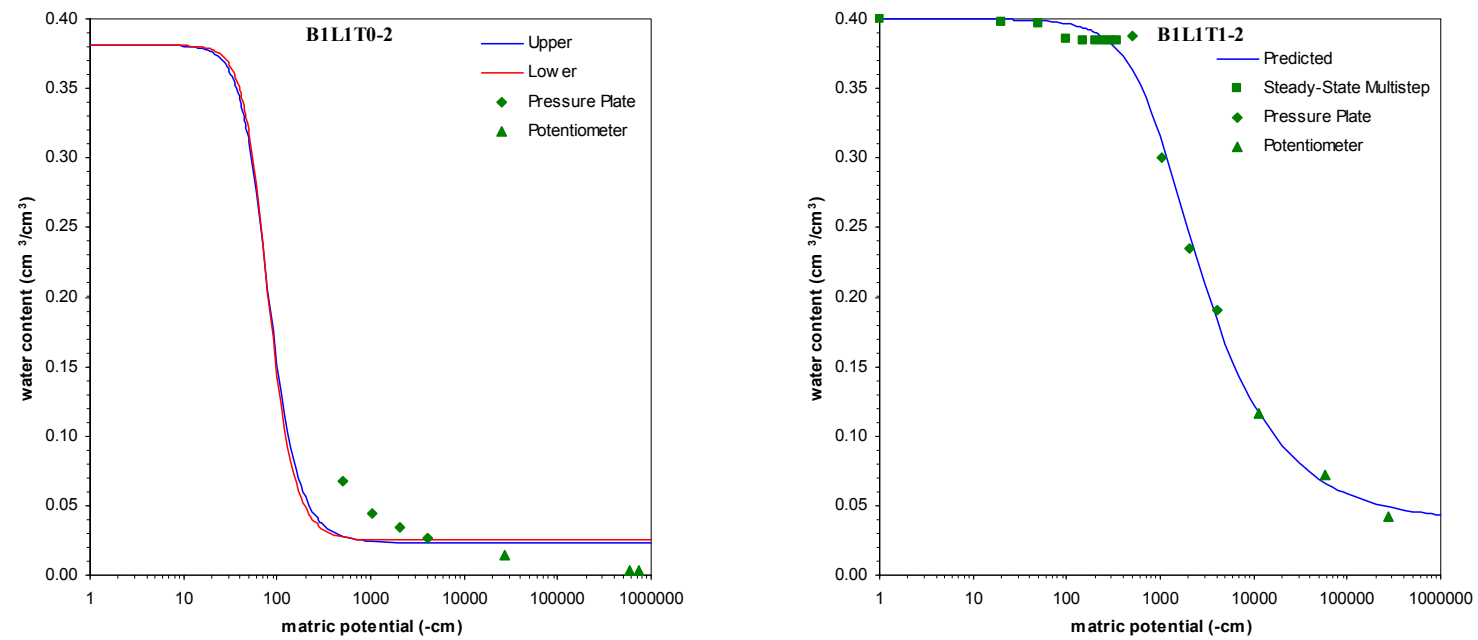

Figure C.9. Predicted Retention Functions and Data (pressure plate and dew point potentiometer) for Borehole 699-48-50B

"Upper" fitted with drainage and upper tensiometer data; "Lower" fitted with drainage and lower tensiometer data. Core B1L1T1-2 fitted using multistep, pressure plate, and potentiometer data.
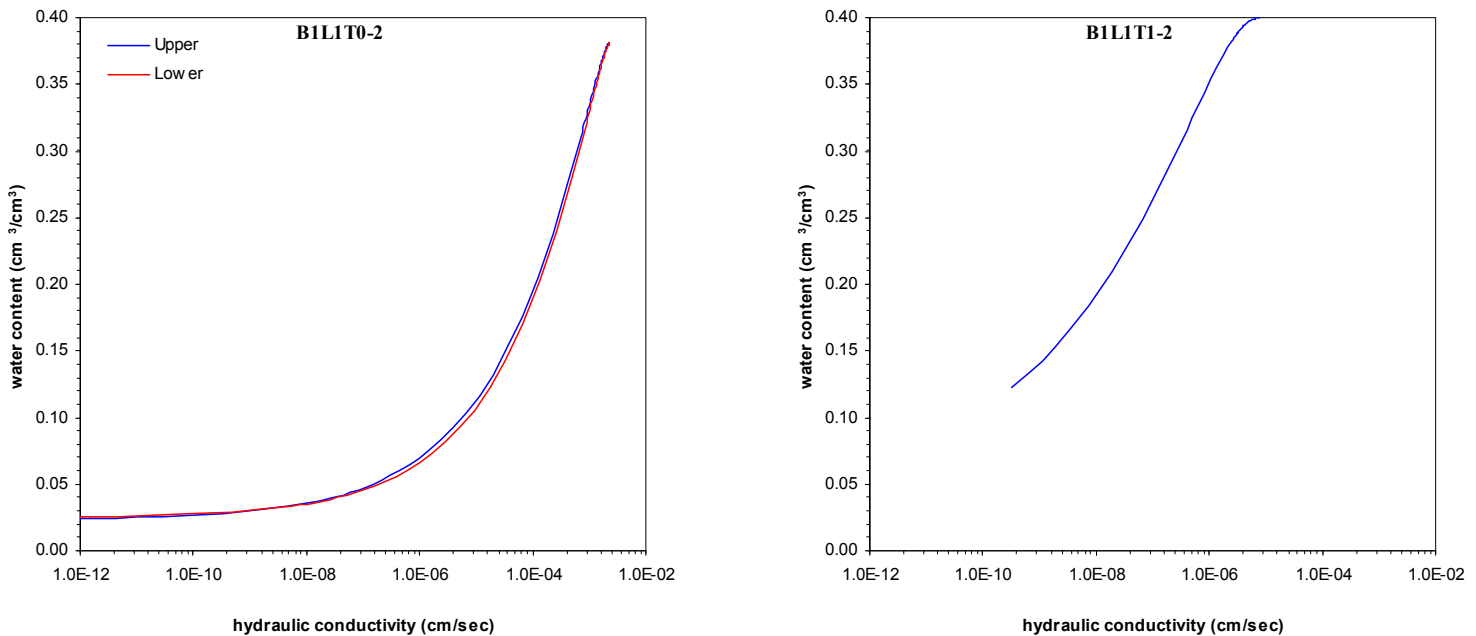

Figure C.10. Predicted Hydraulic Conductivity Functions for Borehole 699-48-50B "Upper" fitted with drainage and upper tensiometer data; "Lower" fitted with drainage and lower tensiometer data. Core B1L1T1-2 fitted using multistep, pressure plate, and potentiometer data. 
Table C.12. Borehole 299-E33-50 Dew Point Potentiometer Retention Data for the $<2-\mathrm{mm}$ Fraction. Water content is corrected for bulk gravel fraction.

\begin{tabular}{|c|c|c|c|c|c|c|c|c|c|}
\hline \multicolumn{10}{|c|}{ 299-E33-50 } \\
\hline \multicolumn{2}{|c|}{ B1L9T7-2 } & \multicolumn{2}{|c|}{ B1L9V5-3 } & \multicolumn{2}{|c|}{ B1L9W0-3 } & \multicolumn{2}{|c|}{ B1L9W2-2 } & \multicolumn{2}{|c|}{ B1L9X3-2 } \\
\hline $\begin{array}{c}\text { Matric } \\
\text { Potential }\end{array}$ & $\begin{array}{c}\text { Water } \\
\text { Content }\end{array}$ & $\begin{array}{c}\text { Matric } \\
\text { Potential }\end{array}$ & $\begin{array}{c}\text { Water } \\
\text { Content }\end{array}$ & $\begin{array}{c}\text { Matric } \\
\text { Potential }\end{array}$ & $\begin{array}{c}\text { Water } \\
\text { Content }\end{array}$ & $\begin{array}{c}\text { Matric } \\
\text { Potential }\end{array}$ & $\begin{array}{c}\text { Water } \\
\text { Content }\end{array}$ & $\begin{array}{c}\text { Matric } \\
\text { Potential }\end{array}$ & $\begin{array}{c}\text { Water } \\
\text { Content }\end{array}$ \\
\hline$(-\mathrm{cm})$ & $\left(\mathrm{cm}^{3} / \mathrm{cm}^{3}\right)$ & $(-\mathrm{cm})$ & $\left(\mathrm{cm}^{3} / \mathrm{cm}^{3}\right)$ & $(-\mathrm{cm})$ & $\left(\mathrm{cm}^{3} / \mathrm{cm}^{3}\right)$ & $(-\mathrm{cm})$ & $\left(\mathrm{cm}^{3} / \mathrm{cm}^{3}\right)$ & $(-\mathrm{cm})$ & $\left(\mathrm{cm}^{3} / \mathrm{cm}^{3}\right)$ \\
\hline 15852 & 0.0716 & 17523 & 0.0352 & 56012 & 0.0196 & 21273 & 0.0306 & 159888 & 0.0024 \\
\hline 49841 & 0.0418 & 217502 & 0.0087 & - & - & 374321 & 0.0091 & - & - \\
\hline 243752 & 0.0223 & - & - & - & - & 657960 & 0.0064 & - & - \\
\hline
\end{tabular}

Table C.13. Borehole 699-48-50B Dew Point Potentiometer Retention Data for the $<2$-mm Fraction. Water content is corrected for bulk gravel fraction.

\begin{tabular}{|c|c|c|c|}
\hline \multicolumn{4}{|c|}{ 699-48-50B } \\
\hline \multicolumn{2}{|c|}{ B1L1T0-2 } & \multicolumn{2}{|c|}{ B111T1-2 } \\
\hline Matric & Water & Matric & Water \\
\hline $\begin{array}{l}\text { Potential } \\
(-\mathrm{cm})\end{array}$ & $\begin{array}{c}\text { Content } \\
\left(\mathrm{cm}^{3} / \mathrm{cm}^{3}\right)\end{array}$ & $\begin{array}{c}\text { Potential } \\
(-\mathrm{cm})\end{array}$ & $\begin{array}{c}\text { Content } \\
\left(\mathrm{cm}^{3} / \mathrm{cm}^{3}\right)\end{array}$ \\
\hline 27409 & 0.0147 & 57785 & 0.0725 \\
\hline 596937 & 0.0036 & 272048 & 0.0422 \\
\hline 743188 & 0.0031 & - & - \\
\hline
\end{tabular}


PNNL-19277

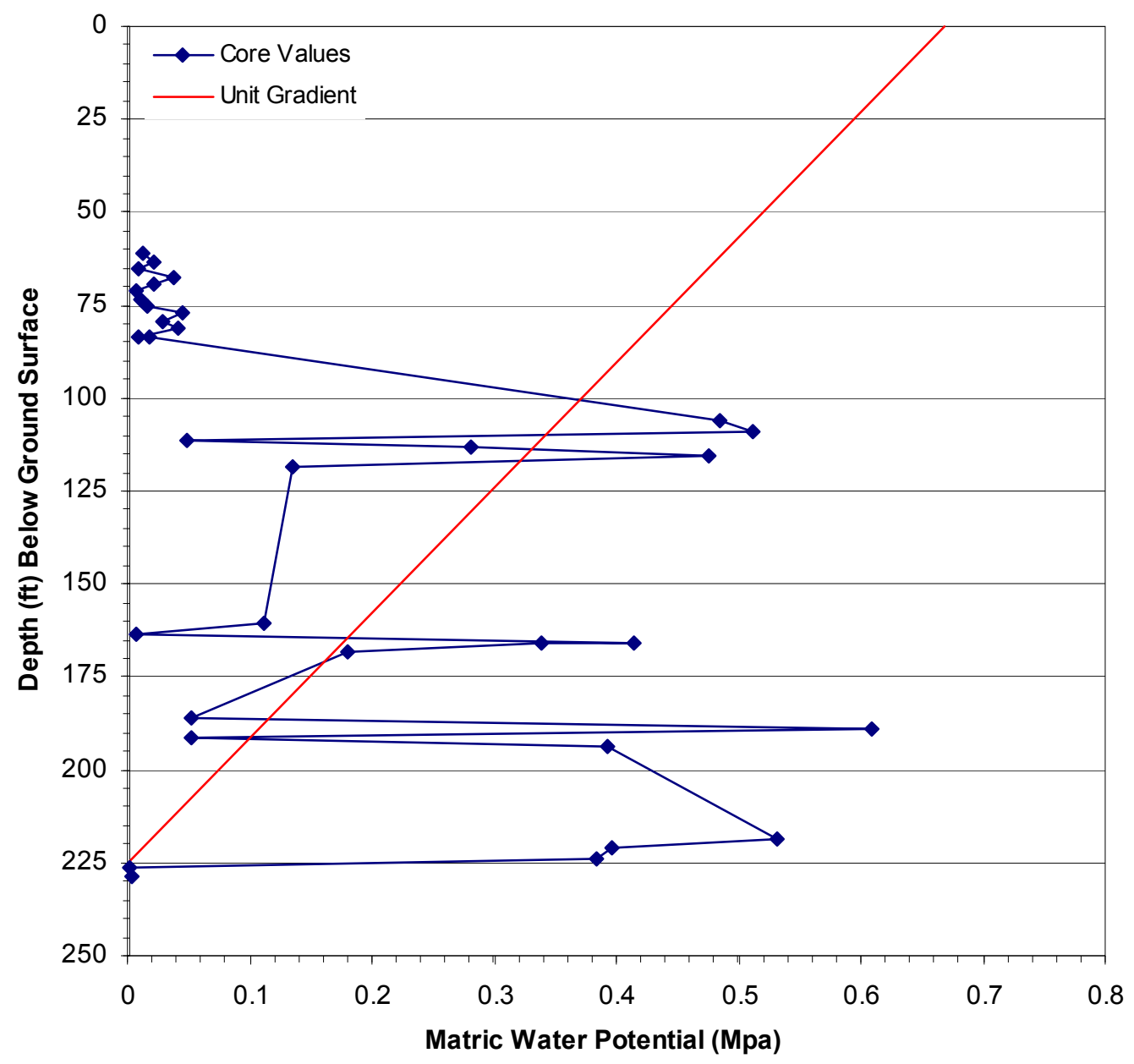

Figure C.11. Matric Water Potential Measured by Filter Paper Technique on Core Samples from Borehole 299-E33-50 
Table C.14. Sample ID, Borehole, Assigned Stratigraphic Unit, Fitted van Genuchten Parameters, and Measured Saturated Hydraulic Conductivity $\left(\mathrm{K}_{\mathrm{s}}\right)$ Used to Calculate van Genuchten Parameter and $\mathrm{K}_{\mathrm{s}}$ Statistics (1 of 2)

\begin{tabular}{|c|c|c|c|c|c|c|c|c|}
\hline & & Stratigraphic & $\mathrm{a}$ & & II & 15 & $\mathrm{~K}_{\mathrm{s}}$ & \\
\hline Sample ID & Borehole & Unit & $(1 / \mathrm{cm})$ & $\mathrm{n}(-)$ & $\left(\mathrm{cm}^{3} / \mathrm{cm}^{3}\right)$ & $\left(\mathrm{cm}^{3} / \mathrm{cm}^{3}\right)$ & $(\mathrm{cm} / \mathrm{s})$ & Source \\
\hline $1-0526$ & 299-E33-38 & H1 & 0.0164 & 1.5448 & 0.0229 & 0.2144 & $2.00 \mathrm{E}-05$ & Kahleel, 2007 \\
\hline $1-0527$ & 299-E33-38 & H1 & 0.0255 & 1.6222 & 0.015 & 0.0773 & $5.70 \mathrm{E}-05$ & Kahleel, 2007 \\
\hline $1-0550$ & 299-E33-40 & H1 & 0.0037 & 1.4567 & 0.0000 & 0.0757 & $6.00 \mathrm{E}-04$ & Kahleel, 2007 \\
\hline $1-1133$ & B-61A & H1 & 0.0028 & 1.8847 & 0.0162 & 0.0781 & $1.80 \mathrm{E}-03$ & Kahleel, 2007 \\
\hline $1-1134$ & B-61A & H1 & 0.0034 & 1.6905 & 0.0322 & 0.1409 & $2.80 \mathrm{E}-03$ & Kahleel, 2007 \\
\hline $1-1136$ & B-61A & H1 & 0.0056 & 1.4945 & 0.0187 & 0.1043 & $4.00 \mathrm{E}-04$ & Kahleel, 2007 \\
\hline $1-1137$ & B-61A & H1 & 0.0139 & 1.4207 & 0.0210 & 0.1542 & $1.80 \mathrm{E}-05$ & Kahleel, 2007 \\
\hline $1-0528$ & 299-E33-38 & $\mathrm{H} 2$ & 0.0045 & 1.8509 & 0.0105 & 0.0746 & $5.00 \mathrm{E}-04$ & Kahleel, 2007 \\
\hline $2-2244$ & B-49A & $\mathrm{H} 2$ & 0.0135 & 2.0185 & 0.0270 & 0.2687 & $4.60 \mathrm{E}-05$ & Kahleel, 2007 \\
\hline $2-2253$ & B-49A & $\mathrm{H} 2$ & 0.0205 & 1.7138 & 0.0308 & 0.2284 & $8.80 \mathrm{E}-05$ & Kahleel, 2007 \\
\hline $2-2258$ & B-43A & $\mathrm{H} 2$ & 0.0373 & 1.7815 & 0.0271 & 0.2306 & $2.80 \mathrm{E}-05$ & Kahleel, 2007 \\
\hline $2-2261$ & B-49A & $\mathrm{H} 2$ & 0.0410 & 1.6885 & 0.0303 & 0.2026 & $1.80 \mathrm{E}-04$ & Kahleel, 2007 \\
\hline $2-2283$ & B-57A & $\mathrm{H} 2$ & 0.0298 & 1.6757 & 0.0269 & 0.2005 & $2.10 \mathrm{E}-05$ & Kahleel, 2007 \\
\hline $2-2286$ & B-49A & $\mathrm{H} 2$ & 0.0077 & 3.0137 & 0.0569 & 0.4712 & $6.30 \mathrm{E}-05$ & Kahleel, 2007 \\
\hline $2-2289$ & B-43A & $\mathrm{H} 2$ & 0.0131 & 1.6351 & 0.0409 & 0.1968 & $1.30 \mathrm{E}-04$ & Kahleel, 2007 \\
\hline B1L9W0-3 & 299-E33-50 & $\mathrm{H} 2$ & 0.0120 & 1.6830 & 0.0225 & 0.3030 & $3.75 \mathrm{E}-04$ & Appendix C \\
\hline B1L9W2-2 & 299-E33-50 & $\mathrm{H} 2$ & 0.0130 & 1.8215 & 0.0360 & 0.3390 & 7.93E-04 & Appendix C \\
\hline B1L9T7-2 & 299-E33-50 & $\mathrm{H} 2 \mathrm{~F}$ & 0.0040 & 1.6800 & 0.0290 & 0.2950 & $1.21 \mathrm{E}-04$ & Appendix C \\
\hline B1L9V5-3 & 299-E33-50 & $\mathrm{H} 2 \mathrm{~F}$ & 0.0117 & 1.8930 & 0.0175 & 0.3740 & 7.17E-05 & Appendix C \\
\hline $1-0530$ & 299-E33-38 & $\mathrm{CCUz}$ & 0.0123 & 1.6899 & 0.0098 & 0.2663 & $7.10 \mathrm{E}-05$ & Kahleel, 2007 \\
\hline $1-0531$ & 299-E33-38 & $\mathrm{CCUz}$ & 0.0017 & 1.8438 & 0.0400 & 0.4863 & $2.10 \mathrm{E}-06$ & Kahleel, 2007 \\
\hline
\end{tabular}

Table C.14. Sample ID, Borehole, Assigned Stratigraphic Unit, Fitted van Genuchten Parameters, and Measured Saturated Hydraulic Conductivity $\left(\mathrm{K}_{\mathrm{s}}\right)$ Used to Calculate van Genuchten Parameter and $\mathrm{K}_{\mathrm{s}}$ Statistics (2 of 2)

\begin{tabular}{|c|c|c|c|c|c|c|c|c|}
\hline Sample ID & Borehole & Stratigraphic Unit & $\mathrm{a}(1 / \mathrm{cm})$ & $n(-)$ & $\mathrm{q}_{\mathrm{r}}\left(\mathrm{cm}^{3} / \mathrm{cm}^{3}\right)$ & $\mathrm{q}_{\mathrm{s}}\left(\mathrm{cm}^{3} / \mathrm{cm}^{3}\right)$ & $\mathrm{K}_{\mathrm{s}}(\mathrm{cm} / \mathrm{s})$ & Source \\
\hline $1-0529$ & 299-E33-38 & CCUg / Backfill & 0.0026 & 1.4909 & 0.0000 & 0.0557 & $4.20 \mathrm{E}-03$ & Kahleel, 2007 \\
\hline $2-2271$ & B-57A & CCUg / Backfill & 0.0074 & 1.4319 & 0.0145 & 0.1636 & $1.40 \mathrm{E}-05$ & Kahleel, 2007 \\
\hline $2-2294$ & B-43A & CCUg / Backfill & 0.0051 & 1.4514 & 0.0066 & 0.2006 & $4.40 \mathrm{E}-05$ & Kahleel, 2007 \\
\hline $2-2297$ & B-57A & CCUg / Backfill & 0.0059 & 1.8562 & 0.0074 & 0.0641 & $4.10 \mathrm{E}-04$ & Kahleel, 2007 \\
\hline B1L9X3-2 & 299-E33-50 & CCUg / Backfill & 0.0150 & 1.6240 & 0.0230 & 0.1220 & $2.37 \mathrm{E}-04$ & herein \\
\hline B1RLK4-3 & 299-E33-345 & CCUg / Backfill & NA & NA & NA & NA & $8.82 \mathrm{E}-05$ & herein \\
\hline B1RLY0-4 & 299-E33-345 & CCUg / Backfill & NA & NA & NA & NA & 5.93E-04 & herein \\
\hline B1T1J5-1 & 299-E33-343 & CCUg / Backfill & NA & NA & NA & NA & $6.40 \mathrm{E}-04$ & herein \\
\hline B1T1J8-1 & 299-E33-343 & CCUg / Backfill & NA & NA & NA & NA & $2.99 \mathrm{E}-03$ & herein \\
\hline
\end{tabular}


PNNL-19277

Table C.15. Sample ID, Borehole, Assigned Stratigraphic Unit, and Measured Bulk Density $\left(\rho_{b}\right)$ Used to Calculate $\rho_{\mathrm{b}}$ Statistics (1 of 2)

\begin{tabular}{|c|c|c|c|c|}
\hline Sample ID & Borehole & Stratigraphic Unit & $\rho_{\mathrm{b}}\left(\mathrm{g} / \mathrm{cm}^{3}\right)$ & Source \\
\hline $3-0210$ & 299-W10-196 & H1 & 2.11 & Kahleel, 2007 \\
\hline $3-0572-2$ & $199-F 5-48$ & H1 & 2.03 & Kahleel, 2007 \\
\hline $3-0576$ & 199-F5-43B & H1 & 1.95 & Kahleel, 2007 \\
\hline $3-0668$ & 299-W10-196 & H1 & 2.13 & Kahleel, 2007 \\
\hline $3-0682$ & 299-W10-196 & $\mathrm{H} 1$ & 2.14 & Kahleel, 2007 \\
\hline $3-0688$ & 299-W10-196 & $\mathrm{H} 1$ & 2.17 & Kahleel, 2007 \\
\hline $3-0689$ & 299-W10-196 & $\mathrm{H} 1$ & 1.93 & Kahleel, 2007 \\
\hline $3-0690$ & 299-W10-196 & H1 & 2.19 & Kahleel, 2007 \\
\hline $5-0152$ & 299-E34-1 & H1 & 1.85 & Kahleel, 2007 \\
\hline $5-0153$ & 299-E32-4 & $\mathrm{H} 1$ & 2.08 & Kahleel, 2007 \\
\hline $5-0158$ & 299-E32-4 & H1 & 2.15 & Kahleel, 2007 \\
\hline 3-0589 & 299-W10-196 & $\mathrm{H} 2$ & 1.86 & Kahleel, 2007 \\
\hline $3-1707$ & 299-W19-95 & $\mathrm{H} 2$ & 1.86 & Kahleel, 2007 \\
\hline $3-1712$ & 299-W19-95 & $\mathrm{H} 2$ & 1.71 & Kahleel, 2007 \\
\hline $3-1713$ & 299-W19-95 & $\mathrm{H} 2$ & 1.72 & Kahleel, 2007 \\
\hline $3-1714$ & 299-W19-95 & $\mathrm{H} 2$ & 1.68 & Kahleel, 2007 \\
\hline $4-0637$ & 699-36-63A & $\mathrm{H} 2$ & 1.62 & Kahleel, 2007 \\
\hline $4-0642$ & 699-35-69A & $\mathrm{H} 2$ & 1.98 & Kahleel, 2007 \\
\hline $4-0644$ & 699-35-69A & $\mathrm{H} 2$ & 1.89 & Kahleel, 2007 \\
\hline 4-0791 & 699-35-65A & $\mathrm{H} 2$ & 1.6 & Kahleel, 2007 \\
\hline 4-1076 & 699-35-61A & $\mathrm{H} 2$ & 1.74 & Kahleel, 2007 \\
\hline
\end{tabular}


PNNL-19277

Table C.15 (contd)

\begin{tabular}{|c|c|c|c|c|}
\hline Sample ID & Borehole & Stratigraphic Unit & $\rho_{\mathrm{b}}\left(\mathrm{g} / \mathrm{cm}^{3}\right)$ & Source \\
\hline $4-1111$ & 699-38-68A & $\mathrm{H} 2$ & 1.69 & Kahleel, 2007 \\
\hline $4-1112$ & 699-38-68A & $\mathrm{H} 2$ & 1.73 & Kahleel, 2007 \\
\hline B1L9W0-3 & 299-E33-50 & $\mathrm{H} 2$ & 1.86 & herein \\
\hline B1L9W2-2 & 299-E33-50 & $\mathrm{H} 2$ & 1.87 & herein \\
\hline B1L9V5-3 & 299-E33-50 & $\mathrm{H} 2 \mathrm{~F}$ & 1.91 & herein \\
\hline B1L9W0-3 & 299-E33-50 & $\mathrm{H} 2 \mathrm{~F}$ & 1.79 & herein \\
\hline $4-1011$ & 699-35-69A & $\mathrm{CCUz}$ & 1.72 & Kahleel, 2001 \\
\hline $5-5001$ & 299-W7-9 & $\mathrm{CCUz}$ & 1.6 & Kahleel, 2001 \\
\hline $5-5002$ & 299-W7-9 & $\mathrm{CCUz}$ & 1.68 & Kahleel, 2001 \\
\hline $5-5005$ & 299-W7-9 & $\mathrm{CCUz}$ & 1.61 & Kahleel, 2001 \\
\hline 4-0792 & $699-35-65 A$ & CCUg / Backfill & 2.32 & Kahleel, 2007 \\
\hline $4-1012$ & $699-35-69 A$ & CCUg / Backfill & 2.19 & Kahleel, 2007 \\
\hline $4-1013$ & 699-35-69A & CCUg / Backfill & 2.2 & Kahleel, 2007 \\
\hline $4-1079$ & $699-35-61 \mathrm{~A}$ & CCUg / Backfill & 2.06 & Kahleel, 2007 \\
\hline $4-1080$ & 699-35-61A & CCUg / Backfill & 2 & Kahleel, 2007 \\
\hline $3-0668$ & 299-W10-196 & CCUg / Backfill & 2.13 & Kahleel, 2007 \\
\hline $3-0682$ & 299-W10-196 & CCUg / Backfill & 2.14 & Kahleel, 2007 \\
\hline $3-0688$ & 299-W10-196 & CCUg / Backfill & 2.17 & Kahleel, 2007 \\
\hline $3-0689$ & 299-W10-196 & CCUg / Backfill & 1.93 & Kahleel, 2007 \\
\hline $3-0690$ & 299-W10-196 & CCUg / Backfill & 2.19 & Kahleel, 2007 \\
\hline B1L9X3-2 & 299-E33-50 & CCUg / Backfill & 2.34 & herein \\
\hline
\end{tabular}


Table C.16. Sample ID, Borehole, Assigned Stratigraphic Unit, Estimated Field Capacity $\left(\theta_{\mathrm{fc}}\right)$ and Fitted Campbell b Parameter Used to Calculate $\theta_{\mathrm{fc}}$ and $\mathrm{b}$ Statistics

\begin{tabular}{|c|c|c|c|c|}
\hline Sample ID & Borehole & Stratigraphic Unit & $\mathrm{q}_{\mathrm{fc}}$ & b \\
\hline $1-0526$ & 299-E33-38 & H1 & 0.0961 & 3.02 \\
\hline $1-0527$ & 299-E33-38 & H1 & 0.0310 & 3.55 \\
\hline $1-0550$ & 299-E33-40 & H1 & 0.0575 & 2.35 \\
\hline $1-1133$ & B-61A & H1 & 0.0618 & 2.46 \\
\hline $1-1134$ & B-61A & H1 & 0.1098 & 3.22 \\
\hline $1-1136$ & B-61A & H1 & 0.0746 & 3.73 \\
\hline $1-1137$ & B-61A & H1 & 0.0881 & 4.09 \\
\hline $1-0528$ & 299-E33-38 & $\mathrm{H} 2$ & 0.0480 & 2.32 \\
\hline $2-2244$ & B-49A & $\mathrm{H} 2$ & 0.0769 & 1.94 \\
\hline $2-2253$ & B-49A & $\mathrm{H} 2$ & 0.0794 & 2.56 \\
\hline $2-2258$ & B-43A & $\mathrm{H} 2$ & 0.0549 & 2.38 \\
\hline $2-2261$ & B-49A & $\mathrm{H} 2$ & 0.0582 & 2.41 \\
\hline $2-2283$ & B-57A & $\mathrm{H} 2$ & 0.0628 & 2.75 \\
\hline $2-2286$ & B-49A & $\mathrm{H} 2$ & 0.1141 & 1.18 \\
\hline $2-2289$ & B-43A & $\mathrm{H} 2$ & 0.0992 & 3.68 \\
\hline B1L9W0-3 & 299-E33-50 & $\mathrm{H} 2$ & 0.1261 & 2.28 \\
\hline B1L9W2-2 & 299-E33-50 & $\mathrm{H} 2$ & 0.1226 & 2.23 \\
\hline B1L9T7-2 & 299-E33-50 & $\mathrm{H} 2 \mathrm{~F}$ & 0.2074 & 2.36 \\
\hline B1L9V5-3 & 299-E33-50 & $\mathrm{H} 2 \mathrm{~F}$ & 0.1180 & 1.70 \\
\hline $1-0530$ & 299-E33-38 & $\mathrm{CCUz}$ & 0.1019 & 1.99 \\
\hline $1-0531$ & 299-E33-38 & CCUz & 0.4269 & 1.90 \\
\hline $1-0529$ & 299-E33-38 & CCUg / Backfill & 0.0456 & 2.20 \\
\hline $2-2271$ & B-57A & CCUg / Backfill & 0.1076 & 3.26 \\
\hline $2-2294$ & B-43A & CCUg / Backfill & 0.1413 & 2.81 \\
\hline $2-2297$ & B-57A & CCUg / Backfill & 0.0353 & 2.08 \\
\hline B1L9X3-2 & 299-E33-50 & CCUg / Backfill & 0.0578 & 2.92 \\
\hline
\end{tabular}

\section{C.4 References}

American Society for Testing and Materials (ASTM). 2000. "Standard test method for capillary-moisture relationships for coarse- and medium- textured soils by porous-plate apparatus." D 2325-68 (1968). 2000 Annual book of ASTM Standards 04.08. ASTM, Philadelphia, PA.

Dane, J.H. and J.W. Hopmans. 2002. "Pressure Plate Extractor". pp. 688-690, In JH Dane and GC Topp (ed.) Methods of Soil Analysis. Part 4. SSSA Book Series No. 5. SSSA, Madison, WI.

Fayer MJ and JM Keller. 2007. Recharge Data Package for Hanford Single-Shell Tank Waste Management Areas. PNNL-16688, Pacific Northwest National Laboratory, Richland, Washington.

Fayer MJ and JE Szecsody. 2004. Recharge Data Package for the 2005 Integrated Disposal Facility Performance Assessment. PNNL-14744, Pacific Northwest National Laboratory, Richland, Washington. Fayer and Szecsody 2004 
Flint, A.L. and L.E. Flint. 2002. "Particle Density." pp. 229-240, In JH Dane and GC Topp (ed.) Methods of Soil Analysis. Part 4. SSSA Book Series No. 5. SSSA, Madison, WI.

Gee groundwater, MJ Fayer, ML Rockhold, and MD Campbell. 1992. "Variations in Recharge at the Hanford Site." Northwest Sci. 66:237-250.

Gee, G.W. and D. Or. 2002. "Particle-size analysis.” Pp. 255-293, In JH Dane and GC Topp (ed.) Methods of Soil Analysis. Part 4. SSSA Book Series No. 5. SSSA, Madison, WI.

Hopmans, J.W., J. Šimůnek, N. Romano, and W. Durner. 2002. “Inverse Methods.” pp. 963-1008, In JH Dane and GC Topp (ed.) Methods of Soil Analysis. Part 4. SSSA Book Series No. 5. SSSA, Madison, WI.

Reynolds, W.D., D.E. Elrick, E.G. Youngs, H.W.G. Booltink, and J. Bouma. 2002. "Saturated and Field-Saturated Water Flow Parameters, Laboratory Methods." pp. 802-814, In JH Dane and GC Topp (ed.) Methods of Soil Analysis. Part 4. SSSA Book Series No. 5. SSSA, Madison, WI.

Scanlon, B.R., B.J. Andraski, and J. Bilskie. 2002. "Miscellaneous Methods for Measuring Matric or Water Potential." pp. 643-670, In JH Dane and GC Topp (ed.) Methods of Soil Analysis. Part 4. SSSA Book Series No. 5. SSSA, Madison, WI.

Serne, R.J., G.V. Last, G.W. Gee, H.T. Schaef, D.C. Lanigan, C.W. Lindenmeier, M.J. Lindberg, R.E. Clayton, V.L. LeGore, R.D. Orr, I.V. Kutnyakov, S.R. Baum, K.N. Geiszler, C.F. Brown, M.M. Valenta, T.S. Vickerman. 2002. Characterization of Vadose Zone Sediment: Borehole 299-E33-45 Near BX-102 in the B-BX-BY Waste Management Area. PNNL-14083. Pacific Northwest National Laboratory, Richland, Washington.

Topp, G.C. and P.A. Ferré. 2002. “Water Content.” pp. 422-424, In JH Dane and GC Topp (ed.) Methods of Soil Analysis. Part 4. SSSA Book Series No. 5. SSSA, Madison, WI.

Tuli, A., M.A. Denton, J.W. Hopmans, T. Harter, J.L. Mac Intyre. 2001. Multi-step outflow experiment: From soil preparation to parameter estimation. Land, Air, and Water Resources Document 100037 , University of California, Davis.

van Genuchten, M.Th. 1980. "A closed-form equations for predicting the hydraulic conductivity of unsaturated soils.” Soil Sci. Soc. Am. J. 44:892-898.

van Genuchten, M. Th., F.J. Leij, and S.R. Yates. 1991. The RETC Code for Quantifying the Hydraulic Functions of Unsaturated Soils, Version 1.0. EPA Report 600/2-91/065, U.S. Salinity Laboratory, USDA, ARS, Riverside, California. 


\section{Appendix D}

Geochemical Parameter Discussions: Electronic Files for New Boreholes (Excel Data Dumps, Digital Photos, Logs) 



\section{Appendix D: Electronic Files for New Boreholes (Excel Data Dumps, Digital Photos, Logs)}

These files are too large to put into Word Table formats and will be on CD or DVD attached to the report in a similar fashion to Site-Wide Groundwater Annual Reports where the executive summary and table of contents are printed, and the rest of the report is found on the CD or DVD in a sleeve attached to the hard copy executive summary document. 

PNNL-19277

\section{Appendix E}

\section{Sobcyzk Reports}

This electronic appendix contains two pdf files of reports by Dr. Stan Sobczyk that are difficult to access and are made available with permission from DOE/RL, CHPRC, and the author for the convenience of those wishing to study the B-Complex issues in detail. 



\section{Appendix E: Sobcyzk Reports}



PNNL-19277

\section{Appendix F}

\section{Spectral Gamma Logging System Logs for Key Boreholes}

This appendix contains the SGLS and in a few instances Neutron Moisture Logs and Summary Reports for as Many of the Boreholes in the B-Complex as could be reasonable obtained. 



\section{Appendix F: Spectral Gamma Logging System Logs for Key Boreholes}



PNNL-19277

\section{Appendix G}

\section{Additional Groundwater Fall and Spring Plume Maps}

This appendix contains Powerpoint Slideshow files for $\mathrm{Na}, \mathrm{Cr}$, and combined $\mathrm{Cr}$ and $\mathrm{U}$ that were generated and offered by CHPRC groundwater staff. 



\section{Appendix G: Additional Groundwater Fall and Spring Plume Maps}



PNNL-19277

\section{Appendix H}

\section{Uranium Isotope Signatures}

This electronic appendix contains a large $\mathrm{EXCEL}^{\circledR}$ with all the uranium isotopic ratio results, standard deviations, total uranium concentrations, sample ID, descriptions of the sample type and other pertinent information that can be used to verify interpretations discussed in the main text. 



\section{Appendix H: Uranium Isotope Signatures}



PNNL-19277

\section{Appendix I}

\section{Mass Balance}

This electronic appendix contains a large $\mathrm{EXCEL}^{\circledR}$ with all calculations (including equations) used to construct the residual vadose zone mass estimates for technetium-99, total uranium and water extractable uranium in the sediments below key facilities discussed in Section 3 and the mass balance estimates discussed in Section 6. 



\section{Appendix I: Mass Balance}








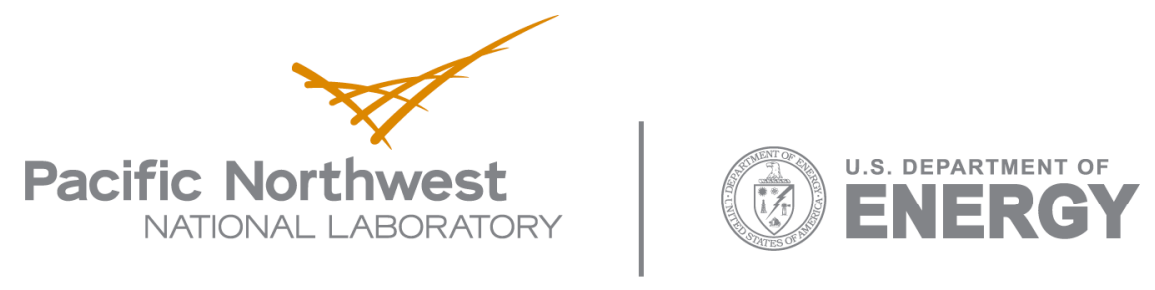

902 Battelle Boulevard

P.O. Box 999

Richland, WA 99352

1-888-375-PNNL (7665)

www.pnl.gov 